UNIVERSIDADE DE SÃO PAULO

FACULDADE DE FILOSOFIA, LETRAS E CIÊNCIAS HUMANAS

DEPARTAMENTO DE HISTÓRIA

PROGRAMA DE PÓS-GRADUAÇÃO EM HISTÓRIA SOCIAL

FERNANDO PRESTES DE SOUZA

Pardos livres em um campo de tensões:

milícia, trabalho e poder (São Paulo, 1797-1831)

(Versão corrigida)

São Paulo

2018 
FERNANDO PRESTES DE SOUZA

\title{
Pardos livres em um campo de tensões: milícia, trabalho e poder (São Paulo, 1797-1831)
}

\author{
Tese apresentada ao Programa de Pós- \\ Graduação em História Social do \\ Departamento de História da Faculdade de \\ Filosofia, Letras e Ciências Humanas da \\ Universidade de São Paulo para obtenção do \\ título de Doutor em História.
}

Orientador: Prof. Dr. Pedro Puntoni

De acordo.

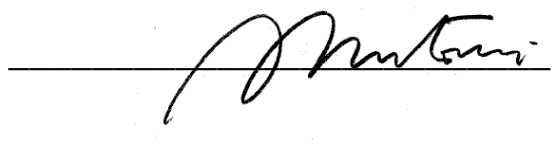

(Versão corrigida)

São Paulo 
Autorizo a reprodução e divulgação total ou parcial deste trabalho, por qualquer meio convencional ou eletrônico, para fins de estudo e pesquisa, desde que citada a fonte.

Catalogação na Publicação

Serviço de Biblioteca e Documentação

Faculdade de Filosofia, Letras e Ciências Humanas da Universidade de São Paulo

Souza, Fernando Prestes de

Pardos livres em um campo de tensões: milícia, trabalho e poder (São Paulo, 1797-1831) / Fernando Prestes de Souza ; orientador Pedro Puntoni. - São Paulo, 2018.

$520 \mathrm{f}$.

Tese (Doutorado)- Faculdade de Filosofia, Letras e Ciências Humanas da Universidade de São Paulo. Departamento de História. Área de concentração: História Social.

1. Pardos livres. 2. Milícias. 3. Regimento dos Úteis. 4. Equilíbrios de poder. 5. São Paulo. I. Puntoni, Pedro, orient. II. Título. 


\section{Agradecimentos}

Ao professor Pedro Puntoni, pela orientação, apoio e inspiração ao longo desses anos.

À Fundação da Universidade de São Paulo (FUSP), pela concessão de uma bolsa de estudos durante o primeiro ano do curso.

À Fundação de Amparo à Pesquisa de São Paulo (FAPESP), pela bolsa concedida ao longo de três anos (Processo 2013/22236-6) e pelo apoio financeiro por ocasião do Estágio de Pesquisa no Exterior (Bolsa BEPE, Processo 2014/24482-7).

Às várias instituições onde realizei atividades de pesquisa em fontes primárias e de consulta a material bibliográfico e aos seus prestativos funcionários: Archivo General de Índias (AGI), Archivo General de Simancas (AGS), Archivo General de la Nación México (AGN-Mx), Arquivo da Cúria Metropolitana de São Paulo (ACMSP), Arquivo Histórico do Exército (AHEx), Arquivo Histórico Municipal de São Paulo (AHM), Arquivo Nacional (AN), Arquivo Público do Estado de São Paulo (APESP), Biblioteca Francisco de Vitoria (BFV/USAL), Biblioteca Nacional (BN), Cátedra Jaime Cortesão - FFLCH/USP (CJC), Centro de Memória - Unicamp (CMU), Centro de Documentação e Pesquisa em História (CEDOPE), Escuela de Estudios HispanoAmericanos - Sevilla-ES (EEHA), Museu Republicano "Convenção de Itu” (MRCI).

Ao professor José Manuel Santos Pérez, pela orientação durante a realização do estágio de pesquisa na Universidade de Salamanca.

Às professoras Wilma Peres Costa e Miriam Dolhnikoff e aos professores Luiz Geraldo Silva e Rafael de Bivar Marquese, membros integrantes da banca examinadora, pela leitura crítica a este trabalho, por oferecerem inúmeras sugestões e por proporcionarem a mim uma grande oportunidade de aprendizado através de suas arguições.

Aos historiadores e amigos Francielly Giachini, Daniele Santos e Leandro Francisco de Paula, pela interlocução constante e pela revisão de partes do trabalho.

Aos vários amigos, familiares, professores e funcionários de instituições científicas que forneceram, de diversos modos, suporte à realização deste trabalho. Em especial Ana Paula Prestes de Souza, Anicleide Zequini, Angelita Bossi de Souza, Breno Aparecido Servidone Moreno, Deolinda Ferreira, Irio Ferreira, Jair Mongelli Júnior, Jessica Manfrim Oliveira, Luiz Alexandre Prestes de Souza, Maria Luiza Andreazza, Sergio Paolo Solano de las Aguas, Sonia Pérez Toledo.

Por fim, agradeço à Priscila de Lima Souza, por ser minha parceira de vida e de profissão. 


\section{Resumo}

Esta tese versa sobre os milicianos pardos de São Paulo que atuaram no Regimento dos Úteis entre os anos 1797-1831. As milícias de pardos e de pretos remontam ao século XVII e se caracterizaram como uma força militar fundamental para a monarquia e um canal de expressão social e política para os seus integrantes até serem extintas, em 1831. Os problemas investigados se desdobram em três eixos articulados entre si, a saber, a história militar, social e política. No primeiro deles, se examina a milícia parda de São Paulo em meio à estrutura militar colonial e à trajetória das milícias de cor lusobrasileiras. Ademais, aborda-se a sua estrutura de funcionamento e o seu papel nas atividades militares paulistas. $\mathrm{O}$ segundo eixo explora a origem e a condição social dos milicianos pardos, com destaque para as questões da formação do grupo de pardos livres e libertos, a vinculação dos milicianos a formas de trabalho compulsório e aos universos indígena, africano e mestiço, e a formação de famílias. Trata, igualmente, da condição socioeconômica dos milicianos, atentando para seu perfil ocupacional, níveis de riqueza e posse de escravos. Finalmente, o terceiro eixo considera a articulação da milícia com a política e encara o universo militar como um campo de tensões. Nele, os problemas da oficialidade de cor e da existência dos seus corpos militares, fundamentais para a compreensão da atuação da milícia parda na conjuntura da independência em São Paulo, são examinados a partir das dimensões entrelaçadas do Estado, das autoridades militares locais, da competição entre oficiais brancos e pardos, e das relações de poder internas à milícia parda. A sociologia eliasiana constitui o principal referencial teórico e a tese se ampara em farta e diversificada documentação primária, com destaque para as listas nominativas, fontes paroquiais e especialmente os registros produzidos a partir das atividades cotidianas da milícia, tais como os requerimentos e o livro de matrícula dos milicianos pardos de São Paulo.

Palavras-chave: pardos livres; milícias; trabalho; configurações sociais; equilíbrios de poder. 


\begin{abstract}
This doctoral thesis is about the Pardo militiamen of São Paulo who acted in the Regimento dos Úteis (1797-1831). That Pardo and Black militias dates back to the seventeenth century and were characterized as a fundamental military force for the State. Moreover, they were a sort of a canal of social and political expression for its members until they were extinguished in 1831. The problems in question unfold in three articulated issues: military, social and political history. In the first one, the Pardo militia is examined in the midst of the colonial military structure and the trajectory of the LusoBrazilian militias. In addition, its operational structure and its role in the military activities of São Paulo are discussed. In the second one, it will be explored the origin of the Pardo and they social status as militiamen. This aspect emphasis the formation of the group of free and liberated Pardo, also the linking of militiamen to forms of compulsory labor and the Indigene, African and Mestizo universes, and formation of families. It also deals with the socioeconomic condition of the militiamen, considering their occupational profile, levels of wealth and the possession of slaves. Finally, the last aspect considers the articulation of the militia with politics and regards the military universe as a field of tensions. The problems of color officers and the existence of their military corps, which are fundamental to understanding the actions of the Free Colored militia in the context of independence in Sao Paulo, are examined from the intertwined dimensions of the State, the local military authorities, the competition between White and Free Colored officers, and from internal power relations to the brown militia. Eliasian sociology is the main theoretical reference, and the thesis is based on a large and diversified primary documentation, with special emphasis on the nominative lists, parish sources and especially the records produced from the daily activities of the militia, such as the requirements and the book of Registration of the Pardo militiamen of São Paulo.
\end{abstract}

Keywords: Free Pardo; militia; labor; social configurations; balance of power. 


\section{Lista de Abreviaturas}

Instituições

ACMSP - Arquivo da Cúria Metropolitana de São Paulo

AGI - Archivo General de Indias, Espanha

AGN-Mx - Archivo General de la Nación, México

AGS - Archivo General de Simancas, Espanha

AHEx - Arquivo Histórico do Exército, Brasil

AHU - Arquivo Histórico Ultramarino, Portugal

AN - Arquivo Nacional, Brasil

APESP - Arquivo Público do Estado de São Paulo

BN/dm - Biblioteca Nacional (Brasil)/divisão de manuscritos

TJESP - Tribunal de Justiça do Estado de São Paulo

Coleções e fundos documentais

DMC - Dispensa Matrimonial e Casamento

DH - Documentos Históricos

DI - Documentos Interessantes para a História e Costumes de São Paulo

RIHGB - Revista do Instituto Histórico e Geográfico Brasileiro

Bairros e Companhias de Ordenanças nos Maços de População

Atibaia

B.V. - Boa Vista

C.L.,C. - Campo Largo e Caetetuba

C.,V. - Caetetuba e Vila

I.,R.Ac. - Itapetinga e Rio Acima

M.D. - Mato Dentro

M.D.,I. - Mato Dentro e Itajoapira

M.D.,B.V. - Mato Dentro e Boa Vista

R.Ab. - Rio Abaixo

V.,C.,C. - Vila, Caioçara e Caetetuba

V.,C. - Vila e Caioçara

Cidade de São Paulo

S.Ef. - Santa Efigênia

N.S.Ó - Nossa Senhora do Ó

Sé D.N. - Sé Distrito Norte

Sé D.S.: Sé Distrito Sul 


\section{Lista de tabelas, gráficos, diagramas, figuras e quadros}

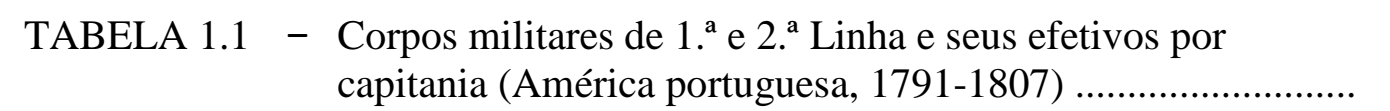

TABELA 1.2 - Contingente militar de 1. ${ }^{\mathrm{a}}$ e 2. ${ }^{\mathrm{a}}$ Linha do Brasil, por

TABELA 2.1 - Desembarque de escravos africanos no Brasil por período e

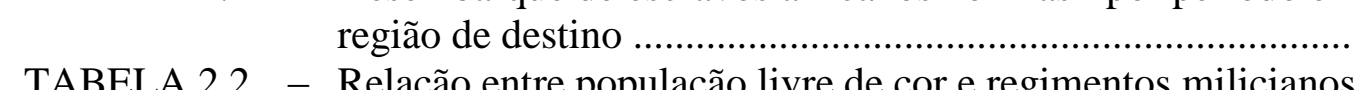
de pardos e de pretos por capitanias (1803-1815)

TABELA 2.3 - Relação entre regimentos milicianos por cor e população por cor (1800-1811)

TABELA 2.4 - População por cor e condição (São Paulo, 1811, 1815 e 1836)

TABELA 3.1 - Períodos de mais intenso recrutamento de soldados (18021827)

TABELA 3.2 - Baixas e razões para a saída de milicianos do Regimento ...

TABELA 3.3 - Destacamento miliciano mensal na cidade de São Paulo (1824-1829)

TABELA 4.1 - Tipo e cor de cabelo de oficiais e soldados pardos (18101831)

TABELA 4.2 - Tipos de cabelo dos milicianos pardos por posição hierárquica (1810-1831)

TABELA 4.3 - Tipo de cabelo de soldados por Companhia (em n. ${ }^{\text {s }}$ absolutos) e área citadina ou interiorana (em percentagem), $1810-1831$

TABELA 4.4 - Cores dos milicianos pardos das cinco companhias da cidade de São Paulo nas listas nominativas (em números absolutos), 1798-1836

TABELA 4.5 - Cores dos milicianos pardos da Companhia de Atibaia nas listas nominativas (em números absolutos), 1798-1830

TABELA 4.6 - Cores dos milicianos pardos da Companhia de Santana de Parnaíba nas listas nominativas (em números absolutos), 1806-1828

TABELA 4.7 - Condição dos milicianos pardos ao serem batizados, 17521808

TABELA 4.8 - Filiação dos milicianos pardos ...

TABELA 4.9 - Estrutura familiar de acordo com a condição de nascimento/batismo de pais e mães de milicianos dos Úteis, c. 1730 - c. 1800

TABELA 4.10 - Estado civil dos milicianos e condição das esposas no batismo

TABELA 5.1 - Milicianos pardos por ofício e companhias, 1811-1831 ..........

TABELA 5.2 - Artesãos de diferentes ofícios pertencentes ao Regimento dos Úteis (1810-1831) e habitantes da província de São Paulo (1836)

TABELA 5.3 - Oficiais milicianos por batalhão e área profissional (18261830) 
TABELA 5.4 - Riqueza de oficiais milicianos de diferentes batalhões (São Paulo, 1828-1830)

TABELA 5.5 - Modalidade de posse de escravos entre soldados e oficiais milicianos pardos (em percentuais e números absolutos de proprietários), 1798-1836

TABELA 5.6 - Tamanho de plantéis de escravos entre oficiais e soldados milicianos pardos (em percentuais e números absolutos de proprietários), 1798-1836

TABELA 5.7 - Posse de escravos por faixas de quantidade e atividades econômicas dos milicianos pardos (1798-1836)

GRÁFICO 3.1 - Faixas etárias de ingresso no Regimento dos Úteis, por companhias e postos (1802-1827)

GRÁFICO 4.1 - População das freguesias Penha de França e São Miguel por cor e condição jurídica (em números absolutos), 1804-1827

GRÁFICO 4.2 - População da freguesia Santana por cor e condição jurídica (em números absolutos), 1805-1829.

GRÁFICO 4.3 - População da vila de Santana de Parnaíba por cor e condição jurídica (em números absolutos), 1806-1822

GRÁFICO 4.4 - População da vila de Atibaia por cor e condição jurídica (em números absolutos), 1805-1828

DIAGRAMA - Genealogia de Amador da Rocha Lima, Silvestre de Lima e

4.1 Pedro Domingues

DIAGRAMA - Genealogia de Jacinto Leite Pedroso ......

4.2

DIAGRAMA - Genealogia de Gregório Rodrigues e José Rodrigues

DIAGRAMA - Genealogia de José Rodrigues Batista, Joaquim Rodrigues

4.4 Batista, Manoel de Amorim e Antonio Francisco de Amorim

FIGURA 1.1 - Regimentos milicianos de Pardos e de Pretos na América portuguesa $(\sim 1800)$

FIGURA 1.2 - Localização das Companhias do Regimento dos Úteis (18011831) .

FIGURA 5.1 - Proporções de ocupações entre soldados e oficiais pardos .....

QUADRO 1.1 - Cronologia da formação de terços auxiliares e de regimentos milicianos de pardos e de pretos (1633-1824) ......

QUADRO 3.1 - Calendário das atividades milicianas (1826-1827) ..................
QUADRO 6.1 - Militares brancos oriundos da $1 .^{a}$ linha que pleitearam postos no estado-maior do Regimento dos Úteis (1803-1828)

QUADRO 6.2 - Milicianos pardos que pleitearam postos no estado-maior do Regimento dos Úteis (1798-1830)

QUADRO 6.3 - Coronéis e tenentes-coronéis do Regimento dos Úteis (17971831) 


\section{SUMÁRIO}

Introdução

\section{PARTE I}

\section{Capítulo 1}

Milícias de pardos e de pretos na América portuguesa: guerra, Estado e a construção da estrutura militar moderna (séculos XVI a XIX) .

1.1. Estrutura militar colonial nos quadros da formação do exército moderno: tropas regulares e milicianas

1.2. As milícias de pardos e de pretos na América portuguesa (séculos XVII a XIX)

1.3. Milicianos de cor em São Paulo: das primeiras companhias de pardos e de pretos ao Regimento dos Úteis

\section{Capítulo 2}

As milícias de pardos e de pretos nos quadros econômicos e demográficos da América portuguesa

2.1. População e milícia (I) - América portuguesa

2.2. População e milícia (II) - São Paulo

\section{Capítulo 3}

Os pardos e o delineamento de seus corpos milicianos: formação, estrutura e funções das milícias de cor

3.1. O papel de pardos e de pretos livres na formação de suas corporações militares. Modelos institucionais, identidades e demandas

3.2. Fazer e desfazer-se miliciano pardo: recrutamento, licenças, ausências e baixas

3.3. As funções militares dos milicianos pardos

\section{PARTE II}

\section{Capítulo 4}

Origem social dos milicianos pardos de São Paulo. Condição social, cor e família

4.1. A cor parda dos milicianos: reiteração e transformação

4.1.1. Os debates sobre a cor e sobre os pardos na historiografia

4.1.2. Origem social e cor dos integrantes das companhias setecentistas de pardos e de pretos em São Paulo 
4.1.3. Origem social dos milicianos pardos a partir da cor e tipo de cabelo (1810-1831)

4.1.4. A cor dos milicianos pardos nos recenseamentos: atribuição, mudança, branqueamento e mobilidade social

4.2. Origem social dos milicianos pardos de São Paulo: escravidão negra, administração indígena e mestiçagens na formação familiar (século XVIII e primeira metade do século XIX)

4.2.1. Condição social e jurídica dos milicianos pardos no batismo e no casamento

4.2.2. Famílias pardas: condição social e jurídica dos pais e das mães de milicianos pardos

4.2.3. A reprodução das famílias pardas: milicianos pardos, noivas e matrimônio

\section{Capítulo 5}

Condição socioeconômica dos milicianos pardos de São Paulo: trabalho, riqueza e posse de escravos

5.1. Composição socioprofissional dos milicianos pardos de São Paulo

5.2. Diversidade ocupacional, mudança de ofício e riqueza

5.3. Milicianos pardos e a posse de escravos

\section{PARTE III}

\section{Capítulo 6}

Milicianos pardos em um campo de tensões (I): monarquia, reformadores, oficiais de linha e soldados pardos

6.1. Introdução

6.2. A legislação referente à existência das milícias de pardos e de pretos na América portuguesa e a regulamentação da oficialidade desses corpos militares

6.3. Milícias de pardos e de pretos e o reformismo ilustrado: projetos e embates

6.3.1. América espanhola: Vice-reinado de Nueva España

6.3.2. América portuguesa: Pernambuco, Rio de Janeiro e Bahia

6.3.3. São Paulo

6.3.4. Um balanço dos projetos de reforma para as milícias pardas e pretas na América Ibérica (segunda metade do século XVIII e primeiras décadas do XIX)

6.4. Disputa pelo comando da milícia parda: competição aberta entre pardos e brancos (São Paulo, 1797-1831)

6.5 Equilíbrio de poder interno ao grupo dos pardos livres: entre a milícia e o artesanato (São Paulo, 1810-1831) 


\section{Capítulo 7}

Milicianos pardos em um campo de tensões (II): a independência do Brasil e a nobilitação de oficiais

7.1. O Regimento dos Úteis e seus integrantes pardos na independência do Brasil

7.2. Guerras, milícia, ofícios mecânicos e a nobilitação de uma família parda: estratégias e tensões vividas pelos Ribeiros (São Paulo, c. 1750 - c. 1830) ... 463

Considerações finais

Fontes

Bibliografia 502 


\section{INTRODUÇÃO}

Esta tese tem como objeto os milicianos pardos da capitania e depois província de São Paulo, com especial ênfase para os integrantes do Regimento dos Úteis que permaneceram alistados entre os anos 1797 e 1831. Trata-se de homens que eram identificados socialmente tanto pela baixa origem social quanto pelas funções militares que desempenhavam. $\mathrm{O}$ entrelaçamento desses aspectos contraditórios, isto é, a importância dos pardos como força armada e a baixa reputação social imposta a descendentes de escravos e de livres pobres, deu margem ao estabelecimento de um complexo quadro de tensões em todas as configurações sociais em que esses corpos militares existiam. Objetiva-se, assim, compreender a experiência social dos milicianos pardos de São Paulo colocando-a em perspectiva relativamente a configurações sociais luso e hispano-americanas e considerando a sua inserção em um contexto histórico específico, marcado por intensas mobilizações militares, pelas reformas ilustradas, pelo constitucionalismo vintista e pela independência do Brasil. Analiticamente, o exame à milícia parda e aos seus integrantes se estrutura em três eixos interdependentes, a saber, a história militar, a história social e a história política.

Ao focalizar a milícia parda, este estudo visa igualmente a fornecer uma contribuição para o campo da história social dos grupos populares do Brasil colonial e escravista, constituído pelas pessoas livres pobres, pelas pessoas de cor e pelos mestiços em geral. ${ }^{1}$ É pertinente

\footnotetext{
${ }^{1}$ Objeto deste estudo, os "milicianos pardos" eram referidos tanto pela função social e institucional que desempenhavam na estrutura militar quanto pela sua posição no repertório de cores que pautava a organização de instituições e práticas de governo durante o período compreendido entre as décadas finais da Colônia e a primeira década do Brasil independente. Nessa época, era comum que os corpos militares e as irmandades religiosas distinguissem pessoas "brancas", "pardas" e "pretas", assim como o era o emprego dessa tríade de cores em registros paroquiais, nos recenseamentos e em processos jurídicos. Isso não significa que as pessoas necessariamente se identificassem a uma dessas três cores ou que reconhecessem a cor atribuída por autoridades. Ora, tais categorias de cor haviam se consolidado no bojo de um processo de homogeneização da sociedade promovido pelas reformas ilustradas e evidentemente conviviam com diversificados e complexos repertórios regionais de identidades e estigmas sociais. Desse modo, homens referidos na documentação relativa à milícia como "pardos" poderiam, em outras fontes, ser notados como "mulatos", "bastardos", "brancos", "forros", "libertos" e daí por diante. Nesta tese, emprega-se preferencialmente o termo "pardo" definido pela instituição miliciana e reiterado em outros registros; as demais categorias, quando ocorrem, são mencionadas sempre que se considerou pertinente. Além da terminologia coeva, a literatura se vale de uma extensa e diversificada gama de categorias analíticas para se referir às populações que fazem parte deste estudo. Apenas para citar as categorias abrangentes e mais recorrentes que incluem os "pardos", há, em primeiro lugar, a dos "homens livres pobres", presente em abordagens que enfatizam as relações classistas; em segundo lugar, a dos "homens livres de cor" - ou a variante "pessoas livres de cor" - é frequente em obras que privilegiam as "relações raciais" vigentes na sociedade escravista e a permanência das marcas do cativeiro durante várias gerações após a conquista da liberdade. Tais expressões são utilizadas nesta tese sempre que houver referência aos autores que as empregam tipicamente e também nas situações em que, circunstancialmente, se objetivar ressaltar a proximidade social dos "pardos" em relação ao conjunto das pessoas comuns e pobres, em um caso, ou em relação aos demais grupos estigmatizados através de referências à cor e à origem escrava, em outro. Por fim, cumpre esclarecer que a pertinência da noção raça, tanto como categoria histórica quanto como analítica, é foco de intensos debates. Aqui ela será empregada somente quando estiver presente em fontes primárias ou secundárias.
} 
retomar algumas das mais influentes interpretações historiográficas do século XX acerca desse grupo social heterogêneo a fim de deslindar a recorrência, em obras de diferentes matrizes teóricas, de um argumento que encarou a sua posição social e a sua história de modo marcadamente determinista e pessimista. Em certo sentido, tais perspectivas desestimularam, por longo tempo, o estudo da atuação social e política das populações de cor livres ou libertas. Interessa, ainda, perceber eventuais resquícios dessas interpretações na historiografia mais recente.

Foi nas obras clássicas de Gilberto Freyre, datadas de 1933 e 1936, que se propôs de forma contundente uma interpretação para o papel dos homens de cor livres na sociedade colonial. Seu modelo acerca da formação e desestruturação da sociedade patriarcal brasileira tomou como atores sociais basilares, em um primeiro momento, senhores e escravos, para, em seguida, especialmente na obra Sobrados \& mucambos, explorar o lugar social dos "mulatos". Esses seriam, a um só tempo, signos e agentes da transformação seguida pela derrocada da harmoniosa formação social erigida sob a égide do patriarcado rural. Um tipo social caracterizado ora como insubmisso, no caso das pessoas sem senhor, desvinculadas das relações patronais, e ora como deferente, no caso dos mulatos que se valiam da flexibilidade social brasileira para ascenderem socialmente e que aspiravam a "embranquecer". Numa e noutra situação, o mulato, situado entre brancos e pretos e entre senhores e escravos, é definido como "socialmente incompleto" e "desajustado". 2

De outro lado, Caio Prado Jr. sugeriu os traços gerais da estrutura social brasileira a partir de sua natureza escravista, ela própria vinculada à empresa colonial que lhe conferia sentido. Conforme Prado Jr., havia "um vácuo imenso entre os extremos da escala social: os senhores e os escravos". Ressaltando a importância da posição e da função dos grupos no sistema produtivo, considerou que "aqueles dois grupos são os dos bem classificados na hierarquia e na estrutura social da colônia”, já que uns dirigiam aquela empresa e outros compunham a massa trabalhadora. Precisamente entre essas duas categorias é que se localizaria o vasto contingente de homens de cor livres, parte de um conjunto maior, o dos "desclassificados, inúteis e inadaptados". 3

Freyre e Prado Jr. forneceram as principais bases interpretativas para o modo como o “mulato" ou os "homens livres pobres” seriam encarados daí por diante. Já na década de 1960,

\footnotetext{
${ }^{2}$ FREYRE, Gilberto. Sobrados e mucambos: decadência do patriarcado rural e desenvolvimento do urbano. São Paulo: Global, 15a ed., 2004 ( $1^{\mathrm{a}}$ ed. 1936), p. 472-548 e 710-815. Ver também FREYRE, Gilberto. Casa-grande \& senzala. (12 ${ }^{\mathrm{a}}$ ed.). Brasília: Editora Universidade de Brasília, 1963.

3 PRADO JÚNIOR, Caio. Formação do Brasil contemporâneo. 23 a ed. (1. a ed. 1942). São Paulo: Editora Brasiliense, 1994, p. 269-297, especialmente p. 281.
} 
em abordagem inspirada nos referenciais weberiano e pradiano, Maria Sylvia de Carvalho Franco construiu uma definição do "tipo humano" identificado como "homens livres pobres" ou "expropriados" correspondente a todo o período de vigência da escravidão. É fundamental a consideração de que a "produção para o mercado", sendo "o objetivo para o qual esteve basicamente orientada a sociedade brasileira", localizou os "homens livres e pobres" na "estrutura social e definiu o seu destino". Significa dizer que a incapacidade daquele segmento em ter acesso a terras, escravos e crédito, e, portanto, à propriedade dos fatores de produção, situava-os numa posição intermediária entre senhores e escravos e atribuía-lhes funções sociais secundárias naquela estrutura. Tratar-se-ia de "um conjunto de homens livres e expropriados que não conheceram os rigores do trabalho forçado e não se proletarizaram". Nada mais que "uma 'ralé' que cresceu e vagou ao longo de quatro séculos: homens a rigor dispensáveis, desvinculados dos processos essenciais à sociedade". ${ }^{4}$ Pela mesma época, e fundamentado em Franco, Roberto Schwartz esquematizou as três classes de população produzidas pela colonização "com base no monopólio da terra": "o latifundiário, o escravo e o "homem livre"”. Formariam o último grupo aqueles que, "nem proprietários nem proletários", dependiam do favor "de um grande" para lograrem "acesso à vida social e a seus bens". 5

A discussão em torno do caráter benevolente ou não do escravismo brasileiro suscitada por Freyre, passou rapidamente a integrar as preocupações de pesquisadores brasileiros e brasilianistas. No Brasil, Florestan Fernandes e Roger Bastide foram os primeiros a apresentar crítica incisiva ao que eles denominaram "mito da democracia racial" brasileira. ${ }^{6}$ Após a reiteração da interpretação freyreana por parte de Donald Pierson ${ }^{7}$ e Frank Tannenbaum ${ }^{8}$, na década de 1940, outros pesquisadores estrangeiros integraram esse debate nos anos seguintes. Refere-se aqui aos estudos de Charles R. Boxer referentes às relações raciais no âmbito do

\footnotetext{
${ }^{4}$ FRANCO, Maria Sylvia de Carvalho. Homens livres na ordem escravocrata. $4^{\mathrm{a}}$ ed. São Paulo: Fundação Editora da UNESP, 1997, p. 14-15.

${ }^{5}$ SCHWARZ, Roberto. As idéias fora do lugar. Estudos CEBRAP, São Paulo, n. 3, p. 149-161, jan. 1973, p. 153.

${ }^{6}$ BASTIDE, Roger; FERNANDES, Florestan. Brancos e negros em São Paulo: ensaio sociológico sobre aspectos da formação, manifestações atuais e efeitos do preconceito de cor na sociedade paulistana. [1955]. (4. ${ }^{\mathrm{a}}$ ed.). São Paulo: Global, 2008.

${ }^{7}$ PIERSON, Donald. Ascenção social do mulato brasileiro. Revista do Arquivo Municipal, São Paulo, ano 7, v. 87, p. 107-119, dez. 1942.

${ }^{8}$ TANNENBAUM, Frank. El negro en las Americas: esclavo e ciudadano. (1. ${ }^{a}$ ed. 1944). Buenos Aires: Paidos, 1968.
} 
império colonial português ${ }^{9}$ e aos trabalhos de Herbert S. Klein ${ }^{10}$ e A. J. R. Russell-Wood ${ }^{11}$, esses relativos exclusivamente à presença de "homens livres de cor" e "escravos e libertos" na sociedade escravista brasileira. Enquanto Boxer procurou demonstrar a vigência de preconceito "racial” em todas as partes dos territórios lusitanos, Klein optou por salientar as oportunidades de mobilidade social aos homens livres de cor como um distintivo daquela sociedade em relação ao escravismo norte-americano. Dos três, foi Russell-Wood, através de estudo denso e pioneiro, quem ofereceu considerações mais expressivas acerca do lugar social dos libertos e livres de cor da América portuguesa. Embora reconhecesse que a flexibilidade daquela configuração social a distinguia das colônias inglesas, esse historiador foi enfático quanto à magnitude do preconceito "racial" existente na América portuguesa, o qual era alimentado por uma política pouco definida da Coroa diante da questão: essa atitude "tornaria ambígua a posição do indivíduo de ascendência africana", especialmente a dos libertos ou livres. Ora, esses "não eram uma coisa nem outra e permaneciam pouco à vontade entre os escravos e senhores, entre os predominantemente negros e os predominantemente brancos". ${ }^{12}$

Em 1982, mesmo ano em que Russell-Wood publicou Escravos e libertos no Brasil colonial, veio a lume Desclassificados do ouro, de Laura de Mello e Souza. Com a proposta de privilegiar aquele segmento até então evitado por sociólogos e historiadores, por ser "a parte difícil de classificar" da sociedade colonial, Souza examinou os "desclassificados". Conforme seus termos, a formação social mineira do Setecentos "se apresentava definida nos extremos, rigidamente hierarquizada na sua porção superior e fluida na camada que avizinhava com os cativos". Ademais, a sociedade colonial "reteve a imagem mais nítida dos senhores e dos escravos e jogou fora a camada intermediária", constituída pelo "homem livre pobre" ou simplesmente pelos "mestiços pobres". Como se vê, Souza retomou o modelo de Prado Jr. e a tradição historiográfica e sociológica que lhe sucedeu, mas foi adiante ao desenvolver aspecto relegado a um segundo plano. Entendendo os desclassificados como produto do processo de formação do capitalismo, defendeu a particularidade do marginalizado colonial: visto pelas autoridades inicialmente apenas como "inimigo em potencial", a incidência de mecanismos de controle por parte do Estado foi capaz de transformar o desclassificado em "um auxiliar

\footnotetext{
${ }^{9}$ BOXER, Charles R. Relações raciais no império colonial português, 1415-1825. (1. a ed. 1963). Porto: Edições Afrontamento, 1988.

${ }^{10}$ KLEIN, Herbert S. Os homens livres de cor na sociedade escravista brasileira. Dados - Revista de Ciências Sociais, n. 17, p. 3-27, 1978.

${ }^{11}$ RUSSELL-WOOD, A. J. R. Escravos e libertos no Brasil colonial. Trad. Maria Beatriz de Medina. Rio de Janeiro: Civilização Brasileira, 2005. Essa é uma versão traduzida e ampliada de The Black man in slavery and freedom in colonial Brazil. New York: St. Martins Press, 1982.

${ }^{12}$ RUSSELL-WOOD, A. J. R. Escravos e libertos..., p. 285-292. Ver também p. 83-104.
} 
valioso" na defesa das fronteiras e em uma "válvula de escape" que "justificava o sistema escravista". ${ }^{13}$

Por sua vez, Silva H. Lara reexaminou a construção do lugar social ocupado por negros e mulatos livres e libertos na sociedade colonial em Fragmentos setecentistas, de 2007. Apesar de se propor a superar a perspectiva inaugurada por Caio Prado Jr., que, de acordo com Lara, concebia-os quase como "uma excrescência na estrutura social da colônia", em sua conclusão a historiadora reiterou o argumento da presença "desestruturante dos negros e mulatos libertos" na sociedade colonial. Esses, "cada vez mais numerosos e escapando do domínio senhorial, [...] apareciam como um corpo estranho", razão pela qual passaram a ser alvo de medidas enérgicas de controle social impostas por representantes da monarquia entre finais do século XVIII e começo do XIX, as quais se inscrevem em um "processo crescente de racialização das relações sociais". ${ }^{14}$

Destaca-se aqui a permanência, enraizamento e compartilhamento, em diferentes modelos analíticos, de uma interpretação geral acerca do vasto grupo dos pardos livres e libertos que lhe atribui um não lugar ou lugar indefinido na sociedade colonial e escravista. ${ }^{15}$ Comumente, os integrantes do grupo em questão são associados a um lugar social definido apenas pela posição intermediária ocupada entre o grupo de cima, identificado a senhores, brancos e proprietários dos bens de produção, e o grupo de baixo, formado por escravos, pretos, a massa trabalhadora. Adiante são abordadas algumas das principais decorrências dessa modalidade de interpretação que, de acordo com os pressupostos que norteiam a tese, configuram-se em obstáculos para a investigação da ação social e política de pardos livres e libertos, bem como as dificuldades encontradas pela literatura contemporânea, ela própria não imune à força da noção do lugar social intermediário ou indefinido, para a abordagem do grupo em questão. Antes, porém, cumpre indicar que a renovação vivida pela história social ao longo dos anos de 1980 foi decisiva na formulação de questionamentos e na demonstração dos limites inerentes ao emprego dessas polaridades como matrizes explicativas da sociedade lusobrasileira. Como resultado, muitos estudos recentes têm adotado uma postura crítica em relação a esse problema e observado, com maior ou menor precisão, a necessidade de superação das

\footnotetext{
13 SOUZA, Laura de Mello e. Desclassificados do ouro: a pobreza mineira no século XVIII. Rio de Janeiro: Edições Graal, 1990, especialmente p. 215-222.

${ }^{14}$ LARA, Silva Hunold. Fragmentos setecentistas..., p. 272-285.

${ }^{15}$ Nesta tese, confere-se destaque para os pardos livres e libertos. No entanto, como está claro, a bibliografia examinada não tratou com exclusividade os pardos. Antes, houve o emprego de diferentes termos para se referir aos grupos sociais aos quais os pardos pertenciam ou até mesmo englobavam. Portanto, em maior ou menor medida, os pardos livres e libertos abrangem ou se incluem entre os "mulatos", "homens livres de cor", "homens livres pobres" e daí por diante.
} 
dicotomias senhor/escravo e branco/preto para a compreensão do(s) lugar(es) ocupado(s) pelos pardos livres e libertos naquele universo. ${ }^{16}$

A abordagem freyreana sugere que as tensões vivenciadas nas esferas individual e coletiva pelos mulatos, desajustados em função da indefinição de sua cor e de sua classe, teriam sido direcionadas, em um sentido, para o radicalismo social que se revestiu de radicalismo político no contexto independentista; e, em outro sentido, para uma atitude de deferência em relação aos brancos, isto é, adoção de comportamentos que traduziam o respeito pela posição superior daqueles, mostravam adequação às normas sociais vigentes e compensariam o “defeito" da cor ou nascimento, os quais, em última análise, eram guiados pelo anseio dos mulatos em embranquecerem. A ação social desses indivíduos é entendida em extremos: ou se trata de completa insubmissão e rebeldia política da parte do mulato rancoroso ${ }^{17}$, ou de total submissão à ordem dominante por parte do mulato arrivista ${ }^{18}$.

Caio Prado Jr., em Evolução política do Brasil, de 1933, atribuiu às “camadas inferiores da população brasileira", as quais, mais tarde, definiu como "desclassificados, inúteis e inadaptados", as características de "ineficiência política" e "atitude revolucionária inconsequente", especialmente em referência à conjuntura da regência (1831-1840). ${ }^{19}$ Prado Jr. preocupara-se com o processamento da "revolução burguesa" no Brasil. Ora, uma vez consumada a "revolução da independência", estava em jogo o modelo político a ser adotado pelo país - se uma "monarquia burguesa" conservadora, gestada pelas elites, ou uma configuração política “democrática radical”, obra das camadas médias e inferiores da população brasileira. Com efeito, é nos quadros da derrota da "democracia radical" que ele avaliou o papel político desempenhado por essa população livre. Fosse em função da manipulação das "classes populares" pelas "classes abastadas" ou fosse pela falta de "coesão" e de "ideologia claramente definida", os homens livres pobres teriam apresentado "atitude revolucionária inconsequente". ${ }^{20}$

\footnotetext{
${ }^{16}$ COSTA, Iraci del Nero da. Arraia-miúda: um estudo sobre os não-proprietários de escravos no Brasil. São Paulo: MGSP Editores, 1992, especialmente o capítulo 1; LARA, S. H. Fragmentos setecentistas..., p. 284-285; BONNET, Márcia C. Leão. Entre o artifício e a arte: pintores e entalhadores no Rio de Janeiro setecentista. Rio de Janeiro: Secretaria Municipal de Cultura: Arquivo Geral da Cidade do Rio de Janeiro, 2009, p. 95-98; GUEDES, Roberto. Egressos do cativeiro: trabalho, família, aliança e mobilidade social (Porto Feliz, São Paulo, c. 1798-c. 1850). Rio de Janeiro: Mauad X: FAPERJ, 2008, p. 17-28; VIANA, Larissa. O idioma da mestiçagem: as irmandades de pardos na América portuguesa. Campinas: Editora da UNICAMP, 2007, p. 21-45.

${ }^{17}$ FREYRE, Gilberto. Sobrados e mucambos..., p. 710-775.

${ }^{18}$ FREYRE, Gilberto. Sobrados e mucambos..., p. 776-815.

${ }^{19}$ PRADO Jr., Caio. Evolução política do Brasil. Colônia e Império. 15ª ed. São Paulo: Editora Brasiliense, 1986. p. 65-68.

${ }^{20}$ PRADO Jr., Caio. Evolução política..., p. 65-68.
} 
Outra perspectiva clássica no tocante à agência dos homens livres pobres e libertos se deve a Homens livres na ordem escravocrata (1960), de Maria Sylvia de C. Franco. Abordando uma configuração social agrária da segunda metade do século XIX, interessou-lhe examinar os laços sociais de dominação exercidos por ricos proprietários sobre clientes/dependentes livres pobres. Nesse sentido, esses últimos estabeleciam relações verticais com grandes proprietários - e raramente horizontais entre si - das quais resultavam os diferentes níveis de dominação e de reduzida autonomia que os caracterizavam. Aqui se está diante de um modelo que argumenta que a "dominação pessoal" gerava "asfixia da consciência política", "incapacidade das camadas dominadas de se integrarem aos mecanismos de participação na vida política", "insuficiência para o exercício dos mais elementares direitos do cidadão" e, por fim, "sua inexistência como ser social". 21

Para Laura de Mello e Souza, a sociedade colonial, que produzira um tipo específico de desclassificados, lograra igualmente, através da dialética entre o "inimigo em potencial" e o "auxiliar valioso" que o conformava, inibir a "formação de uma consciência de grupo entre esses elementos". 22 Mais recentemente, o modelo de Silvia H. Lara não previu meios de integração harmoniosos para o "corpo estranho" formado pelos libertos naquela sociedade. Antes, esse contingente populacional “era desestruturador”, pois constituído por pessoas sem senhor e que não eram vassalos. Em poucas palavras, a sua presença apresentava "um potencial político eminentemente disruptivo". ${ }^{23}$ Por fim, Hendrik Kraay empreendeu exame às relações pessoais, socioeconômicas e culturais dos oficiais milicianos brancos, pardos e pretos de Salvador. Admitindo uma correlação entre "raça" e "classe" na organização social lusobrasileira, argumentou que os milicianos brancos e pretos formavam grupos delineados e coesos, capazes de se expressarem politicamente. Já os pardos, nem pretos nem brancos, nem ricos nem miseráveis, ocupariam na sociedade uma posição "ambígua", o que impossibilitaria a constituição de um grupo organizado politicamente. A expressão mais nítida dessa fragilidade coletiva, no universo miliciano, teria sido a incapacidade dos pardos em enfrentarem os efeitos calamitosos das reformas ilustradas em sua corporação militar, uma vez que, ao contrário dos brancos e pretos, eles viram o seu estado-maior ser completamente destituído e substituído por oficiais brancos. $^{24}$

\footnotetext{
${ }^{21}$ FRANCO, Maria S. de Carvalho. Homens livres na ordem escravocrata..., p. 65-114.

22 SOUZA, Laura de Mello e. Desclassificados do ouro..., p. 217.

${ }^{23}$ LARA, Silvia Hunold. Fragmentos setecentistas..., p. 277-279.

${ }^{24}$ KRAAY, Hendrik. Política racial, Estado e Forças Armadas na época da independência: Bahia, 1790-1850.

Trad. Magda Lopes. São Paulo: Hucitec, 2011, p. 133-164.
} 
Como se vê, a historiografia construiu e reproduziu narrativas bastante similares acerca da posição social dos mulatos, homens livres pobres, mestiços, negros livres e libertos do Brasil colonial e escravista. Nessas, os pares antagônicos senhor/escravo, branco/preto, proprietário/proletário foram encarados como os elementos estruturantes da sociedade, havendo, entre eles, uma camada intermediária tipicamente encarada como desestruturante, inorgânica, indefinida e ambígua. Essa camada, ademais, foi comumente descrita 'na negativa', isto é, a partir do que ela não era, do que lhe faltava e do que era incapaz de realizar. Algumas das interpretações referidas chegaram a subordinar a ação e o comportamento social dos grupos sociais nos quais se inserem os pardos forros e livres, objetos da tese, a perspectivas teleológicas, deterministas e funcionalistas. Em quase todas, porém, pouco se atentou para a capacidade de ação social dos pardos, mulatos, libertos ou dos homens livres pobres em geral. Sua expressão sociopolítica - ou a falta dela - decorria, fundamentalmente, de conflitos sociais e psicológicos, da dominação exercida por intermédio das relações clientelares, da ingerência estatal ou do temor "racializado" assimilado pela elite branca. Trata-se, evidentemente, de obras clássicas, complexas e densas, inseridas em contextos históricos e intelectuais específicos, devendo-se ainda esclarecer que algumas das quais sequer elegeram como o seu foco principal o grupo social heterogêneo aqui em destaque. Mas, exatamente pelo reconhecimento de sua relevância e influência no campo historiográfico, mereceram ser revisitadas. Não se pretendeu aqui, portanto, estabelecer críticas generalizadas às obras em questão e tampouco questionar o emprego da noção de grupo social intermediário, mas, antes, buscou-se demonstrar como determinadas formulações frequentemente constituíram uma espécie de beco sem saída no que diz respeito à história das populações pobres e de cor.

Vai daí a pertinência de se atentar para a experiência social efetiva dessas populações, de se investir em detalhamento empírico e de se testar perspectivas teóricas mais adequadas ao objeto. Tendo-se em vista as interpretações mencionadas acima, o exame às condições materiais, à inserção no mundo do trabalho, aos níveis de coesão social, à formação de identidades coletivas, ao estabelecimento de relações sociais alternativas às clientelares e ao comportamento social e político dos pardos forros e livres ganham significados ainda mais expressivos. Uma das formas mais fecundas para se abordar tais aspectos é justamente por meio de análise à participação daqueles homens nos corpos militares.

A história militar obviamente não ficou imune às transformações paradigmáticas no campo da história e das ciências sociais. Para além das suas tradicionais abordagens, de natureza hermética, cujas narrativas se caracterizavam pela ênfase na descrição de batalhas, personalidades, uniformes e consideração de aspectos estritamente institucionais, propôs-se que 
"los determinantes de la institución [militar] fueron, pues, los mismos factores que afectaron y conformaron el orden [social] en sî'. Logo, "estudiar lo militar es estudiar a la realidad del período en multitud de aspectos". ${ }^{25}$ Sendo impossível conceber indivíduos ou grupos como entes estáticos e cerrados a unidades ou funções sociais particulares - sob pena de simplificar a compreensão do mundo social - considera-se apropriado contemplar a experiência de soldados e oficiais, tais como os pardos de São Paulo, articuladamente à sua vida social e política. É nesse sentido que Castro, Izecksohn e Kraay afirmaram que “os militares brasileiros não se encontram isolados da sociedade abrangente, embora possam guardar uma relativa autonomia em alguns aspectos e épocas específicas”. Essa postura é indicativa de uma aproximação da história militar à história social, decorrendo daí um interesse particular em torno da "interação entre forças armadas e a sociedade". ${ }^{26}$ Passou-se a reconhecer que a vida externa aos quartéis era fundamental para a compreensão dos comportamentos e das atitudes de oficiais e soldados, de modo que as suas relações familiares, econômicas e culturais tornaram-se objeto de vívido interesse.

A renovação da história militar também instigou vários historiadores a sugerirem "uma integração do militar e do político" mediante uma aproximação efetiva entre a "nueva historia militar y la nueva historia política". ${ }^{27}$ Trata-se, no caso da historiografia ocupada com o período moderno, de explorar as relações existentes entre a formação histórica dos estados e a atividade das forças militares. As milícias, em particular, são encaradas como um meio de integração dos indivíduos ao universo político, uma vez que a prestação de serviço militar implicava a incorporação de identidades políticas específicas, variáveis de acordo com o espaço e o tempo, tais como as de cidadão, vecino e súdito.

No que se refere à historiografia dedicada ao estudo das milícias de cor, há um bom tempo que essas inquietações figuram em trabalhos atinentes aos espaços hispano-americanos, nos quais, conjuntamente às capitanias luso-americanas, os corpos militares em questão foram mais numerosos e atuantes. A partir de finais dos anos 1950, um grupo de historiadores norteamericanos encabeçado por Lyle N. McAlister se interessou pelo fenômeno por eles denominado de militarismo latino-americano. Focando no período colonial, eles examinaram

\footnotetext{
${ }^{25}$ MARCHENA FERNÁNDEZ, Juan. Ejército y milicias en el mundo colonial americano. Madrid: MAPFRE, 1992 , p. 9.

${ }^{26}$ CASTRO, Celso; IZECKSOHN, Vitor; KRAAY, Hendrik (Orgs.). Nova história militar brasileira. Rio de Janeiro: Editora FGV, 2004, p. 12.

27 GOUVEIA, António Camões; MONTEIRO, Nuno G. A milícia. In: MATTOSO, José (Dir.). História de Portugal. Vol. 4. Lisboa: Ed. Estampa, 1998, p. 197; RUIZ IBÁÑEZ, José Javier. Introducción: las milicias y el Rey de España. In: RUIZ IBÁÑEZ, José Javier (Coord.). Las milicias del Rey de España. Sociedad, política e identidad en las Monarquías Ibéricas. Madrid: Red Columnaria; Fondo de Cultura Económica, 2009, p. 9-21.
} 
os processos interdependentes de transformação do aparato estatal e de formação da estrutura militar em diferentes espaços, notadamente Nueva España, Peru, Cuba e Nueva Granada. ${ }^{28}$ Embora contemplassem os sistemas defensivos como um todo, as milícias de pardos e de morenos receberam atenção especial em todos esses trabalhos. Em um artigo de $1971^{29}$, Allan J. Kuethe indagou sobre como se relacionavam a hierarquia militar e a hierarquia da sociedade mais ampla: afinal, até que ponto o acesso dos pardos a posições elevadas em seus corpos militares, as quais eram concebidas como equivalentes às dos brancos, seria capaz de transformar as bases daquilo que ele chamou de desigualdade "racial" em um universo colonial e escravista? Essa problematização exemplifica a importância conferida ao estudo dos corpos militares formados pela gente de cor e, ao mesmo tempo, a percepção de uma história militar integrada à política e à sociedade. Mais do que a resposta, interessa notar que a questão da transformação do status dos descendentes de escravos a partir da milícia e da relação com o estado norteou os trabalhos precursores e abriu um caminho fértil para o estudo dos milicianos de cor da América espanhola nas décadas seguintes. Alguns temas frequentes dessa historiografia mais atual são: a vinculação dos milicianos pardos e morenos ao universo do artesanato urbano; o papel da milícia, de seus privilégios e do foro militar como meio de melhoramento de vida mediante a isenção de tributos e a conquista de relativa autonomia em relação às autoridades civis; as redes de sociabilidade e a formação de identidades entre tais milicianos; a atuação dos milicianos de cor nas independências e no contexto de formação dos estados nacionais. ${ }^{30}$

\footnotetext{
${ }^{28}$ McALISTER, Lyle N. The "fuero militar" in New Spain (1764-1800). Gainesville: University of Florida Press, 1957; KUETHE, Allan J. The military reform in the Viceroyalty of New Granada, 1773-1796. Tese de doutorado. Flórida: Universidade da Flórida, 1967; KUETHE, Allan J. The status of the free pardo in the disciplined militia of New Granada. The Journal of Negro History, v. 56, n. 2, p. 105-117, apr./1971; KUETHE, Allan J. Cuba, 1753 1815: Crown, military, and society. Knoxville: University of Tennessee Press, 1986; CAMPBELL, Leon G. Black power in colonial Peru: the 1779 tax rebellion of Lambayeque. Phylon, v. 33, n. 2, p. 140-152, 1972; CAMPBELL, Leon G. The changing racial and administrative structure of the peruvian military under the later bourbons. The Americas, v. 32, n. 1, p. 117-133, 1975; ARCHER, Christon I. Pardos, Indians, and the Army of New Spain. Interrelationships and conflicts. Journal of Latin American Studies, Vol. 6, No. 2, p. 231-255, nov. 1974; ARCHER, Christon I. The Army in Bourbon Mexico, 1760-1810. Albuquerque: University of New Mexico, 1977. Da mesma época, o artigo de KLEIN, Herbert S. The colored militia of Cuba: 1568-1868. Caribbean Studies, v. 6, n. 2, p. 17-27, 1969, e o ensaio do intelectual cubano DESCHAMPS CHAPEAUX, Pedro. Los batallones de pardos y morenos libres. La Habana: Instituto Cubano del Libro, 1976.

${ }^{29}$ KUETHE, Allan J. The status of the free pardo...

${ }^{30}$ Cumpre mencionar alguns dos principais estudos: SUAREZ, Santiago-Gerardo. Las milicias. Instituciones militares hispanoamericanas. Caracas: Academia Nacional de la Historia, 1984; VINSON III, Ben. Bearing arms for his majesty: the free-colored militia in colonial Mexico. Stanford: Stanford University Press, 2001; WOOD, James A. The burden of citizenship: artisans, elections, and the fuero militar in Santiago de Chile, 1822-1851. The Americas, v. 58, n. 3, p. 443-469, jan./2002; SERNA H., Juan M. de la. Integración e identidad, pardos y morenos en las milicias y cuerpo de lanceros de Veracruz en el siglo XVIII. In: ESCAMILLA, Juan Ortiz (Coord.). Fuerzas militares en Iberoamérica, siglos XVIII y XIX. México: El Colegio de México, Centro de Estudios Historicos; Zamora, Michoacán, México, El Colegio de Michoacán; Veracruz, México: Universidad Veracruzana, 2005. p. 61-74; BELMONTE POSTIGO, José Luís. El color de los fusiles. Las milicias de pardos en Santiago de Cuba en
} 
Apesar da propagação dos corpos militares constituídos por pardos e por pretos na América portuguesa, a historiografia sobre o tema se encontra em estágio incipiente. A primeira abordagem mais sistemática, que circunscreveu as milícias de cor e os seus integrantes como objeto de pesquisa, se deve a um capítulo de livro de autoria de A. J. R. Russell-Wood, datado de 1982, o qual, conforme ele próprio reconheceu, se tratou de "um exame preliminar". ${ }^{31}$ Até então, as interpretações restringiam-se a estudos acerca da biografia de Henrique Dias, o herói preto das guerras do açúcar, e a menções tangenciais às atividades militares dos pretos pernambucanos em obras mais gerais. ${ }^{32} \mathrm{O}$ pequeno capítulo que Russell-Wood dedicou às milícias formadas por negros livres e libertos contribuiu para alterar esse panorama historiográfico ao inserir outros espaços no campo de observação (as capitanias de Minas Gerais e Bahia) e ao examinar três questões fundamentais: a criação e estruturação das milícias de pardos e de pretos; as suas funções militares; e o seu papel de "porta-vozes das aspirações e reivindicações dos negros e mulatos livres". ${ }^{33}$ Ainda assim, em meio a um contexto de renovação historiográfica, os historiadores brasileiros estiveram inicialmente mais atentos aos temas da agência escrava e da experiência social dos negros - fossem eles cativos, libertos ou livres - através das irmandades religiosas, pouco se interessando pelo âmbito militar.

A passagem do século XX para o XXI representa um marco em termos da ampliação do interesse dos historiadores brasileiros no tema das milícias de cor coloniais, de modo semelhante ao que se processou relativamente aos corpos militares hispano-americanos. Vivese uma etapa de desbravamento em termos tanto da pesquisa em arquivos quanto da formulação de problemas e do emprego de metodologias, sendo que uma parte considerável dos trabalhos produzidos no período decorre de pesquisas desenvolvidas no universo da pós-graduação. ${ }^{34}$

los albores de la Revolución Haitiana. In: CHUST, Manuel; MARCHENA, Juan (Eds.). Las armas de la nación. Independencia y ciudadanía en Hispanoamérica (1750-1850). Madrid: Iberoamericana/Vervuert, 2007, p. 37-51; MÚNERA, Alfonso. El fracaso de la nación. Región, clase y raza en el Caribe colombiano (1717-1821). Bogotá: Editorial Planeta Colombiana, 2008; CRUCES, Hugo Contreras. Artesanos mulatos y soldados beneméritos. El Batallón de Infantes de la Patria en la Guerra de Independencia de Chile, 1795-1820. Historia, Santiago, v. 44, n. 1, p. 51-89, ene./jun. 2011; SOLANO D., Sergio Paolo; BOLÍVAR, Roicer Flórez. "Artilleros pardos y morenos artistas": artesanos, raza, milicias y reconocimiento social en el Nuevo Reino de Granada, 1770-1812. Historia critica, Bogotá, n. 48, p. 11-37, sep./dic. 2012; CRUCES, Hugo Contreras. Oficios, milicias y cofradías. Éxito económico, prestigio y redes sociales afromestizas en Santiago de Chile, 1780-1820. Revista de Historia Social y de las Mentalidades, Santiago de Chile, v. 17, n. 2, 2013, p. 43-74.

${ }^{31}$ RUSSELL-WOOD, A. J. R. Escravos e libertos..., p. 129.

${ }^{32}$ As biografias de Henrique Dias são PINHEIRO, J. C. Fernandes. Henrique Dias. Biographia dos brasileiros illustres, por armas, virtudes, etc. RIHGB, Rio de Janeiro, Tomo XXI, Parte 1, p. 365-383, 1868; MELLO, José Antônio Gonsalves de. Henrique Dias: governador dos pretos, crioulos e mulatos do Estado do Brasil. Recife (PE): Universidade do Recife, 1954. Alguns trabalhos abordaram as milícias de pardos e de pretos e os seus integrantes com interesses diversos. Ver, por exemplo, FREYRE, Gilberto. Sobrados e mucambos...; MELLO, Evaldo C. de. Olinda restaurada: guerra e açúcar no Nordeste, 1630-1654. $2^{\text {a }}$ ed. Rio de Janeiro: Topbooks, 1998. ${ }^{33}$ RUSSELL-WOOD, A. J. R. Escravos e libertos..., p. 142.

${ }^{34}$ As teses e dissertações que abordam os corpos militares de pardos e pretos são: KRAAY, Hendrik. Política racial, Estado e Forças Armadas...; SILVA, Kalina Vanderlei Paiva da. 'Nas solidões vastas e assustadoras'. Os 
Após o breve e precursor capítulo de Russell-Wood, poucos estudos têm sugerido perspectivas globais acerca dos processos de formação de companhias, terços e regimentos de pardos e de pretos, de um lado, e de suas funções elementares, tais como a mobilização para a guerra e para a defesa interna das capitanias/ províncias, de outro. ${ }^{35}$

As investigações em torno dos corpos militares de pardos e de pretos recuperaram a temática da ascensão social, que já estava presente nos estudos relativos às irmandades formadas por escravos, libertos e seus descendentes livres, e agregaram a ela novos elementos. ${ }^{36}$ Uma particularidade dos corpos militares é o fato de que as patentes militares concediam aos seus portadores privilégios e graus de nobreza reconhecíveis para além do universo corporativo e local, constituindo, portanto, uma das principais fontes de ascensão social aos homens de cor livres. Outro dado fundamental é a formalidade inerente a essa modalidade de ascensão social, o que a diferencia dos mecanismos de distinção informais e mais acessíveis a essa população dependentes da estima social individual, familiar ou comunitária, e mais suscetíveis a desgastes. As patentes, ao contrário, deviam ser registradas nas secretarias de governo das capitanias/províncias e até mesmo na Corte, e tanto as diferentes graduações como o que delas decorria eram aceitos em todo o território da monarquia. Isso evidentemente produzia atritos entre os grupos sociais, pois as elites locais e os brancos em geral, que deveriam reconhecer a

pobres do açúcar e a conquista do sertão de Pernambuco nos séculos XVII e XVIII. Tese (doutorado em História). Recife: CFCH, Universidade Federal de Pernambuco, 2003; MOTA, Celio de Souza. A face parda da "Conspiração dos Alfaiates": homens de cor, corporações militares e ascensão social em Salvador no final do século XVIII. Dissertação (mestrado em História). Feira de Santana: Universidade Estadual de Feira de Santana, 2010; COTTA, Francis Albert. Negros e mestiços nas milícias da América portuguesa. Belo Horizonte: Crisálida, 2010; CRISPIN, Ana Carolina Teixeira. Além do acidente pardo: os oficiais das milícias pardas de Pernambuco e Minas Gerais (1766-1807). Dissertação (mestrado em História). Niterói: ICHF, Universidade Federal Fluminense, 2011; SOUZA, Fernando Prestes de. Milicianos pardos em São Paulo. Cor, identidade e política (1765-1831). Dissertação (mestrado em História). Curitiba: SCHLA, Universidade Federal do Paraná, 2011; PAULA, Leandro Francisco de. Negros no campo das armas: homens de cor nos corpos militares das minas setecentistas. Dissertação (mestrado em História). Curitiba: SCHLA, Universidade Federal do Paraná, 2012; MARTA, Michel Mendes. Em busca de honras, isenções e liberdades: as milícias de homens pretos forros na cidade do Rio de Janeiro (meados do século XVIII e início do XIX). Dissertação (mestrado em História). Niterói: ICHF, Universidade Federal Fluminense, 2013.

${ }^{35}$ SILVA, Luiz Geraldo; SOUZA, Fernando Prestes de; PAULA, Leandro Francisco de. A guerra luso-castelhana e o recrutamento de pardos e pretos: uma análise comparativa (Minas Gerais, São Paulo e Pernambuco, 17751777). In: SANTOS, A. C. de A.; DORÉ, A. (Orgs.). Temas setecentistas: governos e populações no império português. Curitiba: UFPR-SCHLA/Fundação Araucária, 2008, p. 67-83; COTTA, Francis Albert. Negros e mestiços nas milícias da América portuguesa. Belo Horizonte: Crisálida, 2010; SILVA, Luiz Geraldo. Gênese das milícias de pardos e pretos na América portuguesa: Pernambuco e Minas Gerais, séculos XVII e XVIII. Revista de História, São Paulo, n. 169, p. 112-144, jul./dez. 2013.

${ }^{36}$ Além das dissertações e teses supracitadas, vide MALAQUIAS, Carlos de Oliveira. Militares negros e pardos na freguesia de São José do Rio das Mortes em fins do século XVIII. Temporalidades. Revista Discente do Programa de Pós-Graduação em História da UFMG, v. 2, n. 1, jan./jul. 2010, p. 130-137 e MOTA, Celio de Souza. Os Regimentos de Milícias de pretos e pardos em Salvador: trajetórias e mobilidade social em sociedade do Antigo Regime no final do século XVIII. In: CHAMBOULEYRON, R.; ARENZ, K.-H. (Orgs.). Anais do IV Encontro Internacional de História Colonial. Dinâmica imperial no Antigo Regime português: séculos XVI-XVIII. Belém: Editora Açaí, volume 6, 2014, p. 57-71. 
elevação social de descendentes de escravos, se mostraram reticentes a fazê-lo em inúmeras situações.

O modo como o serviço militar era utilizado pelos pretos e pardos como estratégia visando à aquisição de mercês junto à Coroa, tais como os hábitos militares, também tem sido explorado por alguns historiadores. De um modo geral, esses estudos revelaram que os feitos extraordinários em batalhas eram bem quistos pelo rei, mas que, ao mesmo tempo, outras instituições centrais da monarquia impunham restrições à nobilitação de descendentes de escravos e oficiais mecânicos. ${ }^{37}$ De se notar que o período priorizado diz respeito ao século XVII e às primeiras décadas do XVIII, o que sugere a pertinência de se examinar tais processos de nobilitação em conjunturas históricas posteriores, marcadas pelas reformas pombalinas, pela centralização monárquica e por uma nova onda de mobilizações militares ocorridas a partir da segunda metade do Setecentos. Entre os milicianos pardos paulistas, três homens obtiveram o hábito da Ordem de Cristo entre os anos 1810 e 1828, o que, de partida, revela tanto o peso da prestação de serviços na milícia na consideração régia quanto a diferença na receptividade às demandas desses homens em distintos contextos históricos.

Um desenvolvimento diferente da temática referente à elevação social de descendentes de escravos é proposto por historiadores que, sem desconsiderarem os indivíduos, atentam para as lutas e os processos de elevação de status em termos das coletividades. ${ }^{38}$ Nesse terreno, explora-se a centralidade que os corpos militares assumiam na formação de alianças, identidades e de grupos coesos, e como bases de atuação de pardos e pretos nas competições e tensões vivenciadas em meio à sociedade escravista.

Finalmente, um dos tópicos melhor examinados por essa historiografia recente é a participação dos milicianos de cor nas mobilizações militares da independência e no contexto de emergência da cidadania liberal. Abordou-se a atuação dos negros livres como homens

\footnotetext{
${ }^{37}$ DUTRA, Francis A. A hard-fought struggle for recognition: Manuel Gonçalves Dória, first Afro-Brazilian to become a Knight of Santiago. The Americas, v. 56, n. 1, p. 92-113, 1999; SILVA, Maria Beatriz Nizza da. Ser nobre na Colônia. São Paulo: Ed. UNESP, 2005, p. 96-122; MATTOS, Hebe. "Black Troops" and hierarchies of color in the Portuguese Atlantic World: The case of Henrique Dias and his Black Regiment. Luso-Brazilian Review, v. 45, n.1, p. 6-29, 2008; RAMINELLI, Ronald. Privilegios y malogros de la familia Camarão. Nuevo Mundo Mundos Nuevos [Online], Colóquios, posto online no dia 17 de março de 2008. URL: http://nuevomundo.revues.org/27802; RAMINELLI, Ronald. Élite negra en sociedad esclavista: Recife (Brasil) $c$. 1654-1744. Nuevo Mundo Mundos Nuevos [Online], Debates, posto online no dia 30 de novembro de 2011, consultado em 30 de maio de 2013. URL: http://nuevomundo.revues.org/6221.

${ }^{38}$ SILVEIRA, Marco Antonio. Narrativas de contestação. Os Capítulos do crioulo José Inácio Marçal Coutinho (Minas Gerais, 1755-1765). História social, n. 17, p. 285-307, 2009; SILVA, Luiz Geraldo. Sobre a "etnia crioula": o Terço dos Henriques e seus critérios de exclusão na América portuguesa do século XVIII. In: VENÂNCIO, R. P.; GONÇALVES, Andréa L.; CHAVES, Cláudia M. das G. (Orgs.). Administrando impérios. Portugal e Brasil nos séculos XVIII e XIX. Belo Horizonte: Fino Traço, 2012, p. 71-96; LIMA, Priscila de. De libertos a habilitados. Interpretações populares dos alvarás anti-escravistas na América portuguesa (1761-1810). Dissertação (mestrado em História). Curitiba: SCHLA, Universidade Federal do Paraná, 2011, p. 81-128.
} 
armados mediante o seu vínculo a redes clientelares que os conectavam às elites locais e lhes propiciavam "experiências transformadoras" em termos de aprendizado de técnicas militares e percepções políticas. ${ }^{39}$ De modo ainda mais instigante, também se procurou explicar a lógica da participação dessas milícias no processo histórico em questão a partir da percepção específica dos pardos e pretos como milicianos e como um segmento social estigmatizado. ${ }^{40}$

Não se pode deixar de notar duas características adicionais dessa historiografia. Os trabalhos produzidos de finais do século $\mathrm{XX}$ em diante priorizaram as realidades pernambucana, mineira e baiana, de modo que, afora um menor número de estudos relativos à São Paulo e ao Rio de Janeiro e de outros que propuseram comparações entre algumas dessas cinco configurações sociais, a vida social dos milicianos pardos das outras capitanias ou províncias luso-brasileiras ainda permanece pouquíssimo explorada. Há, igualmente, um descompasso entre o maior interesse na investigação dos corpos militares constituídos pelos homens pretos, também denominados terços e regimentos de Henriques, e uma atenção menor aos formados por pardos. Portanto, ao privilegiar um conjunto de milicianos pardos de São Paulo, a tese contempla um grupo social e um espaço até agora escassamente examinados.

Os corpos militares abordados na tese eram instituições vinculadas às unidades políticoadministrativas das capitanias e depois províncias, aspecto que justifica o fato de a delimitação espacial da tese recair sobre uma dessas unidades, a capitania/província de São Paulo. Uma das razões para essa escolha se deve à escassez de estudos sobre os corpos militares formados por pardos paulistas. Essa realidade evidencia-se facilmente quando se considera a produção historiográfica referente às atividades e à organização militar de São Paulo, que priorizou os temas da epopeia bandeirante ${ }^{41}$ e da militarização paulista em função das guerras no Sul da

\footnotetext{
${ }^{39}$ CARVALHO, Marcus J. M. de. Os negros armados pelos brancos e suas independências no Nordeste (18171848). In: JANCSÓ, István (Org.). Independência: história e historiografia. São Paulo: Hucitec, 2005, p. 881914.

${ }^{40}$ KRAAY, Hendrik. Política racial, Estado e Forças Armadas...; KRAAY, Hendrik. Identidade racial na política, Bahia, 1790-1840: o caso dos Henriques. In: JANCSÓ, István (Org.). Brasil: formação do Estado e da nação. São Paulo/Ijuí: Hucitec/Unijuí/FAPESP, 2003, p. 521-546; SILVA, Luiz Geraldo. Negros patriotas. Raça e identidade social na formação do Estado-nação (Pernambuco, 1770-1830). In: JANCSÓ, István (Org.). Brasil: formação do Estado e da nação. São Paulo: Hucitec; Ijuí: Unijuí, 2003; SILVA, Luiz Geraldo. Aspirações barrocas e radicalismo ilustrado. Raça e nação em Pernambuco no tempo da independência (1817-1823). In: JANCSÓ, István (Org.). Independência: história e historiografia. São Paulo: Hucitec, 2005, p. 915-934; SILVA, Luiz Geraldo. O avesso da independência: Pernambuco (1817-24). In: MALERBA, Jurandir (Org.). A independência brasileira: novas dimensões. Rio de Janeiro: Editora FGV, 2006, p. 343-384; SILVA, Luiz Geraldo. Negros de Cartagena y Pernambuco en la era de las revoluciones atlánticas: trayectorias y estructuras (1750-1840). Anuário Colombiano de Historia Social y de la Cultura, vol. 40, n. ${ }^{\circ}$ 2, p. 211-240, jul./dez. 2013; SILVA, Luiz Geraldo; SOUZA, Fernando Prestes de. Negros apoyos. Milicianos afrodescendientes, transición política y cambio de estatus en la era de las independencias (capitanías de São Paulo y Pernambuco, Brasil, 1790-1830). Nuevo Mundo Mundos Nuevos [Online], Debates, posto online no dia 14 Dezembro 2014, consultado em 29 Julho 2017. URL: http://nuevomundo.revues.org/67529; DOI: 10.4000/nuevomundo.67529.

${ }^{41}$ ORLANDO, Arthur. S. Paulo versus Alexandre VI. Rio de Janeiro: Typ. do Jornal do Commercio, 1910. Consulta online em: URL: http://www.brasiliana.usp.br/handle/1918/01969480; CAMPOS, Pedro Dias. O
} 
América portuguesa ${ }^{42}$, tendo passado ao largo dos soldados e oficiais pardos. De modo semelhante, a presença rarefeita dos milicianos pardos paulistas nas obras de história contrasta com uma já consolidada produção historiográfica atinente aos corpos militares de pardos e de pretos das capitanias economicamente mais dinâmicas e que se constituíram nas maiores concentrações de escravos negros, tais como Pernambuco, Bahia e Minas Gerais. ${ }^{43}$

Para além disso, o caso dos pardos de São Paulo apresenta particularidades históricas que suscitam problemas específicos, por um lado, e recorrências em relação aos seus pares de outros espaços, por outro, aspectos que tornam o seu estudo extremamente instigante. Entretanto, colocá-lo em perspectiva impõe ponderar outras realidades ou configurações sociais com as quais a capitania/província em questão mantinha relações de interdependência ou fazia parte - tanto as demais capitanias e províncias luso-americanas cuja natureza era semelhante à sua, como até mesmo as monarquias portuguesa e espanhola, consideravelmente mais

Espírito Militar Paulista. Revista do Instituto Histórico e Geográfico de São Paulo, v. 22, 1923, p. 129-175; RICARDO, Cassiano. Marcha para Oeste: A Influência da Bandeira na Formação Social e Política do Brasil. Rio de Janeiro: Livraria José Olympio Editora, 1940. As obras mais recentes sobre o tema, evidentemente, operam conforme os atuais marcos epistemológicos. Ver MONTEIRO, John Manuel. Negros da terra: índios e bandeirantes nas origens de São Paulo. São Paulo: Companhia das Letras, 1994; KOK, Maria da G. Porto. O sertão itinerante: expedições da capitania de São Paulo no século XVIII. Tese (doutorado em História). São Paulo: FFLCH, Universidade de São Paulo, 1998.

${ }^{42}$ RODRIGUES, José Wasth. Tropas paulistas de outrora. São Paulo: Governo do Estado, 1978; LEONZO, Nanci. As companhias de ordenanças na capitania de São Paulo. Das origens ao governo do Morgado de Mateus. Dissertação (mestrado em História). São Paulo: FFLCH, Universidade de São Paulo, 1975; LINS, Maria de L. Ferreira. A Legião de São Paulo no Rio Grande do Sul. Tese (doutorado em História). São Paulo: FFLCH, Universidade de São Paulo, 1976; LEONZO, Nanci. Defesa militar e controle social na capitania de São Paulo: as milícias. Tese (doutorado em História). São Paulo: FFLCH, Universidade de São Paulo, 1979; BELLOTTO, Heloísa Liberalli. Autoridade e conflito no Brasil colonial: o governo do Morgado de Mateus em São Paulo (17651775). São Paulo: Conselho Estadual de Artes e Ciências Humanas, 1979; LINS, Maria de L. Ferreira. Martim Lopes Lobo de Saldanha: a presença de São Paulo nas guerras do Sul. In: Anais do simpósio comemorativo do bicentenário da restauração do Rio Grande (1776-1976). (vol. 1). RJ: Instituto Histórico e Geográfico Brasileiro, 1979; MELO, Edilberto de Oliveira. Raízes do militarismo paulista. São Paulo: Imprensa Oficial do Estado, 1982; PEREGALLI, Enrique. Recrutamento militar no Brasil colonial. Campinas: Editora da UNICAMP, 1986; MELLO, Christiane F. Pagano de. Forças militares no Brasil colonial: corpos de Auxiliares e de Ordenanças na Segunda Metade do Século XVIII. Rio de Janeiro: E-Papers, 2009; SILVA, Karina da. Os recrutamentos militares e as relações sociedade-Estado na capitania/província de São Paulo (1765-1828). Dissertação (mestrado em História). Franca: FHDSS, Universidade Estadual Paulista, 2006.

${ }^{43}$ MELLO, José Antônio Gonsalves de. Henrique Dias: governador dos pretos, crioulos e mulatos do Estado do Brasil. Recife (PE): Universidade do Recife, 1954; KRAAY, Hendrik. Política racial, Estado e Forças Armadas...; KRAAY, Hendrik. Identidade racial na política...; SILVA, Luiz Geraldo. Negros patriotas...; SILVA, Luiz Geraldo. Aspirações barrocas e radicalismo ilustrado...; SILVA, Luiz Geraldo. O avesso da independência...; SILVA, Luiz Geraldo. Negros de Cartagena y Pernambuco...; SILVA, Luiz Geraldo. Sobre a "etnia crioula"...; SILVA, Luiz Geraldo; SOUZA, Fernando Prestes de. Negros apoyos...; PUNTONI, Pedro. A guerra dos bárbaros. Povos indígenas e a colonização do Sertão do Nordeste do Brasil, 1650-1720. São Paulo: Hucitec, 2002; CARVALHO, Marcus J. M. de. Os negros armados pelos brancos...; MALAQUIAS, Carlos de Oliveira. Militares negros e pardos...; MOTA, Celio de Souza. Os Regimentos de Milícias de pretos e pardos...; SILVA, Kalina Vanderlei Paiva da. 'Nas solidões vastas e assustadoras'. Os pobres do açúcar e a conquista do sertão de Pernambuco nos séculos XVII e XVIII. Tese (doutorado em História). Recife: CFCH, Universidade Federal de Pernambuco, 2003; MOTA, Celio de Souza. A face parda da "Conspiração dos Alfaiates"...; COTTA, Francis Albert. Negros e mestiços nas milícias...; CRISPIN, Ana Carolina Teixeira. Além do acidente pardo...; PAULA, Leandro Francisco de. Negros no campo das armas... 
abrangentes. Sob um ponto de vista mais geral, São Paulo pode ser caracterizada como uma configuração social periférica durante quase todo o período colonial, escassamente vinculada ao tráfico de escravos africanos até meados do Setecentos, composta por população majoritariamente indígena e mestiça, e permanentemente envolvida em mobilizações militares. Além de uma dezena de companhias de pardos e de pretos atuantes durante o século XVIII, São Paulo abrigou apenas um regimento miliciano de pardos livres, o último composto por esses homens a ser formado no Brasil colonial. Ao longo do período de existência desse corpo militar, a capitania paulista passava por profundas transformações: a população crescia enormemente, a economia ganhava impulso com a cultura da cana-de-açúcar movida através do trabalho de escravos africanos e crioulos e com a demanda crescente do Rio de Janeiro por gêneros alimentícios, seus habitantes atuavam decisivamente nas guerras travadas contra os espanhóis na fronteira sulina e, por fim, crescia a sua influência política junto à capital da América portuguesa, a qual em pouco tempo se transformaria em corte monárquica. Todo esse enquadramento impôs contornos específicos à atuação social dos pardos de São Paulo. Ao mesmo tempo, elementos estruturantes da realidade colonial e escravista tornaram a sua experiência muito próxima à de milicianos de cor de configurações sociais tão diversas quanto Pernambuco, Cuba e Nueva España. Tais elementos são a estigmatização lançada aos descendentes de escravos, as suas oportunidades de inserção no mundo do trabalho e os dilemas enfrentados por todos eles na Era das Revoluções, momento em que, apesar de extensamente requisitados como força armada, os seus corpos militares e as respectivas posições de autoridade e prestígio estavam sob forte ameaça.

O período de existência do Regimento dos Úteis fornece as balizas temporais da tese. Em 1797, quando a corporação foi formada, a capitania paulista assistia a uma significativa reforma e ampliação de sua estrutura militar, cujo fenômeno se vinculava tanto à sua dinâmica interna quanto ao quadro mais amplo de tensões atlânticas desencadeadas pela Revolução Francesa. Por sua parte, o ano de 1831 marca o fim das atividades daquele Regimento em decorrência da abolição das instituições militares imperiais que representavam tipicamente o período colonial - as milícias e as ordenanças - e da sua substituição pela Guarda Nacional, essa reputada uma instituição mais adequada ao Estado que, conforme a perspectiva política dominante, consolidava a sua independência após a abdicação de D. Pedro I. Entretanto, assim como o recorte espacial, a delimitação temporal da tese deve ser estirada para comportar a perspectiva processual. De modo que serão comuns as referências a períodos recuados dos séculos XVII e sobretudo do XVIII ao se examinar a formação da estrutura militar lusitana, dos corpos militares de pardos e de pretos na América portuguesa e particularmente em São Paulo, 
da camada social de pardos livres e forros paulista, e igualmente ao abordar a sua relação com a monarquia por intermédio das corporações militares.

Outro aspecto central concernente às temporalidades diz respeito ao fato de que o período em tela era especificamente um momento de transição: ele é configurado pelo fim do período colonial, pela posterior elevação do Brasil a reino no seio da monarquia portuguesa e finalmente pela independência e construção do império brasileiro; simultaneamente, o período foi atravessado pela transição dos modelos a partir dos quais se pensava e estruturava a sociedade e o poder, nomeadamente a ilustração que paulatinamente cedia espaço ao liberalismo. Foi nessa vaga que o centralismo monárquico referendado pelo iluminismo lusitano se chocou com o constitucionalismo liberal.

O referencial teórico-metodológico empregado na tese provém da sociologia de Norbert Elias. Nessa, são centrais as noções de processo, configuração social, interdependência, equilíbrios de poder e habitus. Elias construiu seu modelo ao longo de boa parte do século XX discutindo sobretudo com o pensamento e as teorias de Karl Marx, Émile Durkheim e Max Weber. Intrigava-o o antagonismo presente nas formulações teóricas que, de um lado, concebiam a sociedade como um organismo funcional autônomo e supraindividual, e, de outro, priorizavam a racionalidade estratégica presente na ação individual em menoscabo dos constrangimentos e processos sociais. Para Elias, a noção de configuração social se apresenta como uma alternativa ao binômio indivíduo/sociedade, na medida em que ela não prioriza nem um e nem outro, mas as relações e as redes relacionais estabelecidas entre os indivíduos. ${ }^{44} \mathrm{Se}$ considera que todas as interações sociais formam as configurações sociais nas quais ocorrem, sejam elas, sob qualquer critério, pouco ou bastante abrangentes. Assim, tomando os milicianos pardos como exemplo, entende-se que eles formavam configurações sociais com os integrantes das suas famílias, com os seus vizinhos, com os companheiros da milícia, com militares de diferentes corpos militares, com funcionários do governo e também com os representantes centrais da monarquia. As suas relações sociais ocorriam, portanto, em inúmeras dimensões, de modo que o regimento miliciano dos pardos, a capitania/província de São Paulo e a monarquia portuguesa e depois império do Brasil são, para além de instituições ou espaços políticoadministrativos, configurações sociais.

Um dado fundamental das configurações sociais é a noção de que elas se pautam no estabelecimento de cadeias de interdependência entre os seus integrantes. Significa dizer que

\footnotetext{
${ }^{44}$ Definições para o conceito configuração social e aplicações estão diluídos como elemento estruturante da obra eliasiana. Reflexões sintéticas podem ser encontradas, por exemplo, em ELIAS, Norbert. Introdução à sociologia. Lisboa: Edições 70, 2008, p. 77-112 e 133-145.
} 
não há atores sociais isolados, e que, ao contrário, as ações sociais de indivíduos, grupos, instituições ou estados influenciam os demais componentes com os quais estão entrelaçados assim como sofrem contínua coerção imposta por eles. Essa perspectiva é especialmente útil para se refletir, por exemplo, acerca dos processos de formação e transformação das milícias pardas e pretas bem como para a definiç̧ão de suas funções militares, fenômenos que se davam a partir da interdependência estabelecida com os demais corpos militares. A ideia de que no centro de toda configuração social existe um equilíbrio instável, móvel ou pendular de poder é outro elemento fundamental a se levar em conta. Ela pressupõe que as medições de forças fazem parte de todas as interações humanas, de modo que é possível identificar a posição dos indivíduos e de seus grupos em termos do poder que eles retêm em relação a outros indivíduos e grupos no interior de quaisquer configurações sociais. Poder, portanto, é tomada como uma categoria relacional. Indivíduos e grupos sociais que manejam e concentram níveis elevados de recursos materiais ou simbólicos - ou, em uma palavra, poder - em relação a outros e numa dada configuração, podem ter a sua proporção de poder significativamente reduzida quando considerados em meio a diferentes configurações sociais das quais também fazem parte. Tal é o caso dos oficiais pardos, que, ao mesmo tempo em que exerciam enorme poder e influência sobre os subordinados no interior da configuração social formada pelos integrantes do Regimento dos Úteis, tinham seu prestígio e sua estima social relativizados nas interações sociais que se davam em meio a configurações sociais mais abrangentes, como a formada pelo conjunto dos corpos militares de São Paulo.

Para melhor examinar a desigualdade das posições ocupadas pelos indivíduos e pelos grupos sociais, decorrente dos diferenciais de poder, no interior das configurações sociais e também entre diferentes configurações, Elias formulou o modelo de estabelecidos/outsiders. ${ }^{45}$ Por estabelecidos se entende o conjunto de indivíduos ou grupos que concentram as maiores parcelas de poder e que apresentam graus mais elevados de coesão no interior de uma configuração social particular. Em virtude de sua posição, eles detêm recursos mais abundantes que os demais integrantes e empregam instrumentos mais eficazes para manterem a situação favorável aos seus interesses. Um desses recursos é a estigmatização social, imposta pelos estabelecidos aos outsiders - esses os detentores de reduzidas parcelas de poder e de níveis de coesão relativamente baixos - como forma de legitimar a posição de superioridade de uns e a de inferioridade social de outros. Entretanto, como a interação social se dá no espaço e no tempo, incidindo sobre uma sucessão de entrelaçamentos, está sujeita a mudanças. Por isso,

\footnotetext{
${ }^{45}$ ELIAS, Norbert; SCOTSON, John L. Os estabelecidos e os outsiders. Sociologia das relações de poder a partir de uma pequena comunidade. Trad. Vera Ribeiro. Rio de Janeiro: Jorge Zahar Editor, 2000, p. 19-50.
} 
Elias enfatiza que as configurações sociais conformam equilíbrios de poder pendulares ou móveis: embora os estabelecidos detenham níveis mais elevados de poder em relação aos outsiders, esses também manejam os recursos disponíveis, podendo inclusive ampliar as concentrações de poder e assim alterar e até mesmo inverter o equilíbrio interno da configuração social. Nesses termos é que é analisada, na tese, uma parte substancial das relações que a milícia parda mantinha com corpos militares identificados a homens brancos.

As tensões inerentes às configurações sociais, no mais das vezes atreladas às competições pelas oportunidades de poder, também foram pensadas por Elias mediante os modelos de jogos. ${ }^{46}$ Nesses, se concebe os vários indivíduos e/ou grupos sociais como jogadores, decorrendo daí a necessidade de se indagar quais são os objetivos e as regras do jogo, quais as características dos jogadores, quais as estratégias empregadas por eles visando o sucesso na competição e, dentre outras questões, quais os comportamentos adotados pelos jogadores na medida em que o jogo vai transcorrendo e se estruturando. Nenhum movimento, de qualquer um dos participantes dos jogos que se processavam em circunstâncias tão complexas como a que se examina na tese, tinha resultados plenamente controlados, pois esses dependiam igualmente das jogadas dos demais competidores e dos rumos que o jogo assumiria. Portanto, os jogos sociais aqui considerados são vistos como processos sociais não planejados. Como se nota, a sociologia eliasiana reitera a noção de que o poder é relacional e repisa a interdependência dos indivíduos entre si e também entre grupos sociais. Tal perspectiva é extremamente pertinente para se refletir sobre a atuação da milícia parda, seja em situações corriqueiras seja nos fenômenos políticos mais diretamente associados à independência do Brasil, e entender tanto a lógica que norteava as ações dos seus integrantes quanto os limites impostos às suas estratégias de melhoramento de status.

Assim como a perspectiva teórica eliasiana considera os limites à racionalidade das estratégias e das ações individuais - uma vez que os entrelaçamentos e as coerções sociais são inescapáveis aos indivíduos, cuja perspectiva acerca do conjunto da configuração é sempre parcial e incompleta - ela também busca evitar a reificação da sociedade. Um dos meios empregados para tanto é adoção de abordagem processual, a qual, evidentemente, confere centralidade à tensão entre continuidade e ruptura histórica ${ }^{47}$ Nesse sentido, a estabilidade ou

\footnotetext{
${ }^{46}$ ELIAS, Norbert. Introdução à sociologia. Lisboa: Edições 70, 2008, p. 77-112.

47 A obra $O$ processo civilizador é o exemplo maior da dedicação eliasiana aos temas da transformação e da estabilidade das configurações sociais: ELIAS, Norbert. O processo civilizador. Uma história dos costumes. (v. 1). Trad. Ruy Jungmann. Rio de Janeiro: Jorge Zahar Editor, 1990; ELIAS, Norbert. O processo civilizador. Formação do Estado e Civilização. (v. 2). Trad. Ruy Jungmann. Rio de Janeiro: Jorge Zahar Editor, 1993. Ver também o ensaio "O problema da 'inevitabilidade' da evolução social” em ELIAS, Norbert. Introdução à sociologia. Lisboa: Edições 70, 2008, p. 173-191.
} 
instabilidade das configurações sociais depende dos equilíbrios de força internos a elas próprias e igualmente das suas relações interdependentes com outras configurações, tanto as congêneres como com as mais englobantes. Na tese, são examinados processos históricos tais como os de formação das milícias de cor na América portuguesa e na capitania de São Paulo, e o de formação do grupo social dos pardos livres e forros paulistas. Ademais, é notavelmente instigante abordar o entrelaçamento entre as transformações amplas desse período de transição estrutural - marcado pelo fim do período colonial e pelo advento do Estado brasileiro, assim como pela passagem da ilustração para o liberalismo - e as vividas na configuração social particular do Regimento dos Úteis de São Paulo. Vai daí a opção em examinar os objetos deste estudo como imersos em um "campo de tensões".

Um conjunto bastante amplo e diversificado de fontes primárias embasa a tese. Não é novidade na historiografia a dificuldade com a qual se deparam os pesquisadores interessados na história social das populações pobres, e notadamente dos descendentes de escravos, de indígenas e de mestiços, de um modo geral, no Brasil escravista. Ela decorre do fato de que a atuação social de tais pessoas escassamente redundava na produção de registros escritos, produzindo-se aí um contraste com a realidade das elites, devendo-se considerar, ainda, a diminuição no volume dos manuscritos preservados ocasionada por perdas e deteriorações. São Paulo, por outro lado, se revelou um oásis para o estudo dos milicianos pardos do Regimento dos Úteis - embora nem tanto para os seus pares que serviram em períodos recuados do Setecentos. Além das coleções de cartas, ofícios e demais documentação emitida ou recebida pelos gabinetes dos governadores e capitães-generais - guardadas no Arquivo Histórico Ultramarino (AHU), em Portugal, e disponibilizadas através do Projeto Resgate, bem como as custodiadas pelo Arquivo Público do Estado de São Paulo (APESP), e parcialmente publicadas nos Documentos Interessantes para a História e Costumes de São Paulo -, o pesquisador dispõe das fabulosas listas nominativas de habitantes (APESP) e dos bastante completos e bem preservados registros paroquiais, que abrangem o recorte temporal da tese.

O que mais chama a atenção, porém, é a abundância de registros referentes à milícia parda e aos seus integrantes, sobretudo para as décadas de 1810 e 1820 . Uma boa parte deles consiste em requerimentos encaminhados por oficiais pardos, ordens e reflexões atinentes ao funcionamento da corporação, e "mapas" resultantes de inspeções periódicas aos oficiais milicianos. Em meio a esse conjunto documental, se destaca o Livro Mestre do Regimento dos Úteis, uma peça de fundamental importância para a abordagem dos problemas atinentes à atividade militar e à vida social dos milicianos pardos entre 1811 e 1831 . Trata-se de um livro de matrícula no qual se registravam os dados de todos os integrantes da corporação, tais como 
nome e sobrenome, idade, filiação, altura, cor de olhos e cabelo, ofício, local de nascimento e residência, estado civil, ausências ou licenças do Regimento, e toda a trajetória individual na hierarquia miliciana. O Livro Mestre fornece a base das informações quantitativas referentes à totalidade da corporação e serve igualmente como ponto de partida para a abordagem da atuação social de indivíduos fora do âmbito da milícia. Assim como os livros mestres dos corpos militares existentes até 1831 são raros, também o são os estudos que empregam essas fontes. ${ }^{48}$ Tratando-se especificamente dos corpos militares de pardos e pretos, se constata que a utilização de documentação dessa natureza é ainda mais escassa, mesmo levando em conta a literatura concernente às milícias de cor hispano-americanas. ${ }^{49}$

Se a grande quantidade de dados empíricos referentes à atividade dos milicianos pardos de São Paulo chama a atenção, ela exigiu, por outro lado, um trabalho árduo e sistemático de coleta, tratamento e cruzamento dessas informações. Ficará claro, ao longo da tese, que a compreensão do modo como os pardos de São Paulo se inserem na história das milícias de cor luso-americanas, das funções militares por eles desempenhadas, das suas origens sociais e dos desafios políticos que enfrentavam nas décadas de 1810 e 1820 passou necessariamente pelo acúmulo de dados, pela investigação minuciosa de pistas dispersas e pelo estabelecimento de relações que custaram a se revelar. Como forma de organizar e exercer um controle sobre essa massa de dados múltiplos e heterogêneos, trabalhou-se com um banco de dados que abrangeu os 1.107 milicianos matriculados no Livro Mestre entre os anos de 1811 a 1831 . Complementam o corpus documental diretamente ligado ao Regimento dos Úteis a legislação militar, tabulações estatísticas e requerimentos referentes às milícias congêneres de diversos espaços luso e hispano-americanos, inventários e testamentos, autos cíveis, atas e registros de câmaras municipais paulistas, e relatos de viajantes.

A historiografia reconhece o protagonismo das forças militares não profissionais na defesa dos territórios coloniais e pós-coloniais americanos diante de ataques estrangeiros e também em termos da manutenção da ordem interna, bem como a atuação dos corpos militares de pardos e de pretos em tais circunstâncias. A primeira parte da tese aborda o Regimento dos Úteis paulista em meio aos universos mais amplos das milícias luso-americanas e da trajetória histórica das tropas de pardos e de pretos. Examina o processo de formação dos corpos militares

\footnotetext{
${ }^{48}$ Refiro-me a PUNTONI, Pedro. A guerra dos bárbaros. Povos indígenas e a colonização do Sertão do Nordeste do Brasil, 1650-1720. São Paulo: Hucitec, 2002, p. 192-223, e WESTPHALEN, Cecília M. A milícia na comarca de Paranaguá e Curitiba: a vila de Nossa Senhora da Luz dos Pinhais. Revista da SBPH, n. 16, p. 31-49, 1999.

${ }^{49} \mathrm{O}$ trabalho de VINSON III, referente às milícias de pardos do vice-reino de Nueva España, é uma exceção. Ver VINSON III, Ben. Bearing arms for his majesty: the free-colored militia in colonial Mexico. Stanford: Stanford University Press, 2001.
} 
de segunda linha no seio da monarquia portuguesa, atentando particularmente para a criação dos Auxiliares, em meados do século XVII, e a sua transformação em Milícias, em fins do século XVIII. Insere as tropas de pardos e de pretos de São Paulo na história mais abrangente dos corpos militares formados por homens de cor na América portuguesa, e, convergindo para o regimento dos pardos, investiga o seu funcionamento interno e as funções militares desempenhadas ao longo de sua existência.

O estudo de um corpo miliciano formado por homens pardos impõe que se interrogue sobre quem eram os pardos de São Paulo e o que essa identificação significava em termos da sua vivência social, e, analogamente, sobre o que era a milícia e o que implicava ser miliciano. A segunda parte da tese trata dessas questões mais gerais. Nela são abordados aspectos referentes à formação do grupo de pardos forros e livres em São Paulo ao longo do século XVIII, à identificação e à estigmatização social imposta aos pardos, à configuração familiar dos milicianos e as suas origens sociais relativamente à escravidão africana e à administração indígena. Igualmente, se examinam questões referentes à ocupação e à situação socioeconômica dos milicianos pardos, os quais intercalavam as atividades militares com as profissões habituais que lhes forneciam o sustento material. Além de uma caracterização ocupacional dos milicianos pardos comparativamente aos milicianos brancos de São Paulo e aos pardos e pretos de espaços luso e hispano-americanos, investiga-se o fenômeno da mudança ocupacional e a sua relação com processos de ascensão social, bem como a posse de escravos entre os soldados e os oficiais milicianos paulistas.

Finalmente, considerar a história das milícias de pardos e de pretos em meio a uma ordem social dominada por brancos implica levar em conta as múltiplas relações de poder que configuravam a atuação social daquelas corporações e de seus integrantes. Do mesmo modo, examiná-la no período compreendido entre os anos 1797 e 1831 impõe que se problematize a participação das milícias nos fenômenos e processos políticos que conduziram e compuseram a independência do Brasil. Tais são as questões estruturantes da terceira parte da tese, que encara os milicianos pardos como competidores no jogo que se desenrolava em meio ao universo militar. Nela são abordadas as relações entre os corpos militares de pardos e pretos e a monarquia portuguesa durante o século XVIII e as primeiras décadas do XIX, o impacto das reformas ilustradas para as milícias de cor, a competição entre brancos e pardos pelos postos de comando, a atuação dos pardos paulistas nos fenômenos políticos dos anos 1820 e a atividade militar como a principal fonte de remuneração simbólica e de ascensão social disponível aos pardos livres e forros. 
PARTE 1 


\section{CAPÍtulo 1 - Milícias de pardos e de pretos na AMÉrica portuguesa: guerra, ESTADO E A CONSTRUÇÃo DA ESTRUTURA MILITAR MODERNA (SÉCUlOS XVI A XIX)}

\subsection{Estrutura militar colonial nos quadros da formação do exército moderno: tropas regulares e milicianas}

Alguns estrangeiros que visitaram o Brasil nos primeiros anos do século XIX se surpreenderam com o elevado grau de participação da população masculina nos corpos militares. Gustavo Beyer fez questão de relatar, em suas Ligeiras notas de viagem, que "os homens, ainda que tenham empregos civis, são todos militares”. Por sua vez, Henry Koster observou que "o conjunto da administração do Brasil é militar". Ambos revelaram grande interesse em compreender aquela estrutura militar, em vários sentidos distinta das quais estavam habituados. Chamou-lhes a atenção especialmente a incorporação, nas forças militares terrestres, da totalidade dos homens livres capazes de portar armas, os quais eram enquadrados nas três linhas ou categorias de prestação de serviço: a tropa regular, as milícias e as ordenanças. ${ }^{1}$ A primeira linha era composta pelos corpos regulares, também denominados como de linha ou pagos, que eram os que mais se aproximavam do ideal de profissionalização. Eles deveriam ser a tropa melhor preparada para as ações bélicas e demais funções atribuídas aos corpos militares, cabendo-lhes igualmente permanecer instruídos e permanentemente mobilizados, razão pela qual eram pagos. A segunda linha era formada pelos corpos de auxiliares que posteriormente foram denominados milícia. Trata-se de corpos militares integrados por homens robustos e aptos para o serviço militar, mas que cotidianamente exerciam ocupações civis. Como um de seus nomes sugere, eram destinados a auxiliar a tropa regular e recebiam soldo apenas quando efetivamente mobilizados. Por fim, as ordenanças correspondiam à terceira linha. Seus integrantes eram os homens não incluídos na tropa regular ou nas milícias e, além de realizarem atividades militares mais ligadas à dinâmica das localidades, a terceira linha era encarada como um vasto contingente de reserva à tropa paga.

\footnotetext{
${ }^{1} C f$ : : BEYER, Gustavo. Ligeiras notas de viagem do Rio de Janeiro à capitania de São Paulo, no Brasil, no verão de 1813, com algumas notícias sobre a cidade de Bahia e a ilha Tristão da Cunha, entre o Cabo e o Brasil e que há pouco foi ocupada. In: Revista do Instituto Histórico e Geográfico de São Paulo (RIHGSP), v. 12. São Paulo: Typografia do Diario Official, 1907, p. 288; FREIREYSS, G. W. Viagem ao interior do Brasil nos anos de 18141815. In: RIHGSP, v. 11. São Paulo: Typographia do Diario Official, 1907, p. 215; KOSTER, Henry. Viagens ao Nordeste do Brasil. Trad. Luiz da Camara Cascudo. São Paulo: Companhia Editora Nacional, 1942. Kraay verificou semelhante interesse por parte de outros observadores estrangeiros do período. KRAAY, Hendrik. Política racial, Estado e Forças Armadas na época da independência: Bahia, 1790-1850. Trad. Magda Lopes. São Paulo: Hucitec, 2011, p. 29-30.
} 
Essa descrição tipológica auxilia o leitor pouco familiarizado com o universo militar colonial e imperial do Brasil, mas, em contrapartida, oculta aspectos fundamentais de seu processo histórico de constituição. Objetiva-se aqui, portanto, traçar as linhas gerais da construção da estrutura militar portuguesa, entre os séculos XVI e XIX, nos quadros da formação dos estados modernos e da prática da guerra na Europa e no ultramar. Examina-se igualmente a constituição das forças militares na América portuguesa, conferindo ênfase aos efetivos e à relação de interdependência estabelecida entre os corpos militares regulares e milicianos. Finalmente, investiga-se as modalidades de remuneração e de incentivo que a Coroa ofertava aos militares da segunda linha - um claro indicativo de sua posição como sustentáculo da Monarquia, na Europa e na América.

A guerra fez os estados, e vice-versa. Essa instigante afirmação de Charles Tilly introduz sua abordagem a respeito da conexão entre o processo europeu de formação dos estados modernos e depois nacionais, a expansão do capitalismo, e as múltiplas transformações ocorridas no universo militar e na prática da guerra. ${ }^{2}$ Com efeito, constata-se que "a guerra foi a atividade dominante dos estados europeus" ao longo de todo o último milênio, a qual induziuos a esforços cada vez mais enérgicos em busca da captação dos recursos que a subsidiassem bem como, e em decorrência, a um movimento de "expansão contínua do aparelho central do estado" ${ }^{3}$ Os estados comportaram-se como verdadeiras 'máquinas de guerra', desarmando progressivamente suas populações civis e seus concorrentes internos, ampliando sua concentração dos meios de coerção e travando disputas armadas com estados concorrentes. Foi no curso desse macroprocesso, e como parte de estruturas militares abrangentes e em transformação, que emergiram os corpos militares milicianos destinados a coadjuvar e até mesmo a preencher as lacunas das forças terrestres profissionais.

É a partir do século XVI, mas especialmente em meados do XVII, que se assistirá em Portugal e, por extensão, nos seus domínios ultramarinos, aos primeiros esforços no sentido da construção daquilo que se tem convencionado denominar exército moderno, isto é, um conjunto de forças militares segmentadas funcionalmente, treinadas, equipadas, disciplinadas e de caráter permanente. Cabe notar que a formação dos exércitos modernos configurava-se, em boa medida, como processo social não planejado. ${ }^{4}$ Conforme Tilly, o fenômeno se insere em um período de transição estrutural marcado pela superação das modalidades de guerra tardo-

\footnotetext{
2 TILLY, Charles. Coerção, Capital e Estados Europeus (990-1992). Trad. Geraldo Gerson de Souza. São Paulo: Edusp, 1996. Ver especialmente os capítulos 2 e 3.

${ }^{3}$ TILLY, Charles. Coerção, Capital e Estados Europeus..., p. 131, 149-150.

${ }^{4}$ Sobre a noção de processo social não planejado e sua importância para o exame de fenômenos de longa duração, ver ELIAS, Norbert. Introdução à sociologia. Trad. Maria Luísa Ribeiro Ferreira. Lisboa: Edições 70, p. 147-172.
} 
medievais. ${ }^{5}$ Essas, no caso ibérico, referem-se às ações militares da reconquista do território peninsular frente aos muçulmanos, em geral movimentos efêmeros e de pequena monta, coordenados pelos nobres e seus séquitos e também pelos poderes municipais. Ao longo do Quinhentos, esse processo afetou não somente a minguada tropa paga de que dispunha a Coroa lusitana, como também remodelou o serviço militar prestado pelo conjunto dos moradores das vilas e cidades - aspecto que particularmente interessa aqui. As matrizes institucionais que serviram de base às alterações na estrutura militar lusitana podem ser diversas e até suscitarem controvérsias na historiografia ${ }^{6}$, mas certamente há consenso em torno dos significados sociais mais amplos associados àquela transformação. As alterações nas modalidades de emprego das forças militares não profissionais apresentaram clara "tendencia a emancipar el ejército de su dependencia de las tropas señoriales, reforzando su control por el rey". ${ }^{7}$ Vai daí o declínio do monopólio da nobreza como classe guerreira e a decorrente inclusão de segmentos plebeus nos corpos militares; paralelamente, em termos táticos, assiste-se ao gradual esfacelamento da hegemonia da cavalaria, que então cede espaço à infantaria. ${ }^{8}$ Ao longo dessa transição os exércitos se expandiram, incorporaram novas tecnologias e táticas, e a prática da guerra atingiu dimensões cada vez mais amplas. ${ }^{9}$

Dentre as principais intervenções da Coroa portuguesa que deram início ao quadro de mudanças aludido acima, figuram duas determinações referentes a todos os súditos do sexo masculino compreendidos na faixa etária entre 18 e 60 anos, não alistados em tropa paga, que fossem capazes de defender o território. De um lado, a obrigatoriedade de disporem à sua própria custa de armamento adequado à condição social de cada um (Lei das Armas, de 1549 e 1569) e, de outro, o enquadramento em companhias militares organizadas territorialmente pelas municipalidades, a partir das quais seriam submetidos à prática regular de exercícios militares

\footnotetext{
5 TILLY, Charles. Coerção, Capital e Estados Europeus..., p. 133-143.

${ }^{6}$ De acordo com Leonzo, as alterações no enquadramento militar do conjunto dos habitantes de Portugal foram diretamente instigadas pelas transformações que incidiram sobre as forças militares não profissionais francesas entre os séculos XV e XVI. Por outro lado, Costa frisa a importância da reestruturação militar espanhola de fins do século XV. Ver LEONZO, Nanci. As Companhias de Ordenanças na capitania de São Paulo. Das origens ao governo do Morgado de Matheus. Dissertação (mestrado em História). São Paulo: FFLCH, Universidade de São Paulo, 1975, p. 1-4; COSTA, André Alexandre da Silva. La milicia, el Rey y la guerra: la corona de Portugal y el caso del Brasil meridional (siglos XVI-XVIII). In: RUIZ IBÁÑEZ, José Javier (Coord.). Las milicias del rey de España. Sociedad, política e identidad en las Monarquías Ibéricas. Madrid: FCE, Red Columnaria, 2009, p. 166167.

${ }^{7}$ COSTA, André Alexandre da Silva. La milicia, el Rey y la guerra..., p. 166-167.

${ }^{8}$ LEONZO, Nanci. As Companhias de Ordenanças..., p. 1-4.

${ }^{9}$ COSTA, André Alexandre da Silva. La milicia, el Rey y la guerra..., p. 166-167; TILLY, C. Coerção, Capital..., p. 89-156; MARCHENA FERNÁNDEZ, Juan. Ejército y milicias en el mundo colonial americano. Madrid: MAPFRE, 1992, p. 13-35.
} 
(Regimento das Ordenanças, de 1570). ${ }^{10}$ Essas reformas militares eram consoantes ao processo mais amplo vivenciado em diversas partes da Europa e, no caso particular de Portugal, atendiam às necessidades emergenciais da segunda metade do século XVI. Essas diziam respeito ao assédio de corsários mouros, franceses e ingleses à costa litorânea do reino, aos boatos acerca da possível extensão das guerras religiosas para o território peninsular, às investidas francesas e inglesas aos domínios ultramarinos portugueses e, finalmente, à continuidade das ações militares no norte da África. ${ }^{11}$ Os corpos militares de ordenanças funcionariam como complemento ao limitado contingente de tropa paga. Além disso, serviriam para robustecer os vínculos entre o rei e seus súditos, na medida em que permitiriam maior controle ao papel intermediador exercido pelos senhores locais. ${ }^{12}$ Longe de constituir um fenômeno histórico simplório, a arregimentação da população masculina em companhias de ordenança perenes e padronizadas tensionou aspectos fundamentais da organização social ibérica, gerando reações as mais diversas e especialmente por parte dos senhores locais que se percebiam invadidos em seus domínios e privilégios pela ingerência do Estado. As tensões entre poderes centrais e locais instigadas pelo advento das ordenanças perduraram por todo o período da União Ibérica (15801640). Se, de uma parte, a Coroa reconhecia a proeminência local dos senhores de terras e dos antigos castelos ao garantir a eles a preferência ao posto de capitães de ordenança, de outra, circunscrevia e padronizava o raio de ação e influência desses patronos regionais.

Como ocorreu a instauração das ordenanças no Ultramar? Como se sabe, os espaços coloniais lusitanos configuravam-se para a Coroa numa hierarquia de importância e prestígio, para a qual os fatores de ordem econômica eram centrais. No século XVI, à frente dessa hierarquia estava a Índia, que era seguida pelos entrepostos situados na África, e por último vinham as capitanias da América. Essa ordem se inverteu completamente apenas no século XVIII, embora já se verificasse tal tendência no decorrer do Seiscentos. ${ }^{13}$ Apesar de sua posição como o mais importante espaço colonial português, o Estado da Índia enfrentou dificuldades generalizadas para a formalização das companhias de ordenança até, pelo menos, meados do século XVII. Como resultado, houve a reprodução e manutenção de estrutura militar

\footnotetext{
${ }^{10}$ Excelente análise da legislação em questão em COSTA, André Alexandre da Silva. La milicia, el Rey y la guerra..., p. 166-175.

${ }^{11}$ LEONZO, Nanci. As Companhias de Ordenanças..., p. 4-8.

${ }^{12}$ COSTA, André Alexandre da Silva. La milicia, el Rey y la guerra..., p. 168-169.

${ }^{13}$ A hierarquia de prestígio desses espaços imperiais pode ser exemplificada a partir do diferencial de prestígio vigente no exercício dos cargos burocráticos e nas proporções desiguais de concessão de honrarias a indivíduos e a corporações inscritos nessas mesmas regiões. Ver BETHENCOURT, Francisco. A administração da coroa. In: BETHENCOURT, Francisco \& CHAUDHURI, Kirti (Orgs.). História da Expansão Portuguesa. Lisboa: Círculo de Leitores, 1998, vol. 1, p. 401-406; e SILVA, Maria Beatriz Nizza da. Ser nobre na Colônia. São Paulo: Ed. UNESP, 2005, p. 113.
} 
tradicional, ou seja, assentada sobremaneira nos vínculos clientelares e "caracterizada pela inexistência de qualquer estrutura permanente de enquadramento dos homens de armas" no Oriente. $^{14}$

Já a conquista e colonização da América, tanto para espanhóis quanto para portugueses, envolveu uma simbiose entre a coordenação militar estatal e a iniciativa dos próprios conquistadores e colonizadores. ${ }^{15}$ Esses últimos sustentaram grande parte do peso das atividades militares no caso da América portuguesa, cujo território apresentava poucos atrativos à Coroa comparativamente aos outros espaços ultramarinos, e onde amplos poderes administrativos foram delegados aos donatários, automaticamente declarados capitães das capitanias. A contribuição estatal para a construção de uma estrutura militar colonial, nos dois primeiros séculos, girou em torno da regulação legal das atividades bélicas (por meio de regimentos, decretos, provisões e alvarás) e mediante o apoio às armadas, fornecimento de alguma tropa de linha, suporte para a construção de fortes e fortalezas, e armamento para artilharia e infantaria. Desse modo, conforme Sodré, formou-se uma divisão funcional entre metrópole e os coloniais: enquanto aquela se responsabilizava pelas atividades militares marítimas e costeiras, os moradores eram incumbidos da obrigação de defenderem o território situado em terra firme. ${ }^{16}$ É de se notar que esse quadro pouco se alterou com a instauração de um governo-geral, em Salvador, em 1548, e sua decorrente ingerência na organização militar das capitanias donatariais. O Regimento passado a Tomé de Sousa, na ocasião, determinou a obrigatoriedade de todos os moradores possuírem armas destinadas à defesa do território face às ameaças externas e internas, por sua própria conta e sob pena de multa aos infratores. Recomendou também a associação militar entre portugueses e os indígenas em processo de cristianização sempre que se fizesse necessária na guerra contra tribos resistentes à presença europeia. ${ }^{17}$ De acordo com Leonzo, referências expressas à aplicação do Regimento das

\footnotetext{
${ }^{14}$ RODRIGUES, Vitor Luís Gaspar. A Acção reformadora dos filipes no seio da estrutura militar do Estado da Índia: a persistência do modelo tradicional de organização dos homens de armas (1584-1622). In: Separata das Actas do IX Colóquio «Os militares na sociedade portuguesa». Lisboa: Comissão Portuguesa de História Militar, 1999, p. 65; Ver também VEIGA, A. Botelho da Costa. Organização militar do Oriente. In: BAIÃO, António; CIDADE, Hernani; MÚRIAS, Manoel. História da expansão portuguesa no mundo. Lisboa: Editorial Ática, 1939, p. 85-92.

${ }^{15}$ SODRÉ, Nelson Werneck. História militar do Brasil. Rio de Janeiro: Civilização Brasileira, 1979, p. 16-33; LEONZO, Nanci. As Companhias de Ordenanças..., p. 9-13; PUNTONI, Pedro. A guerra dos bárbaros. Povos indígenas e a colonização do Sertão do Nordeste do Brasil, 1650-1720. São Paulo: Hucitec, 2002, p. 181-186; MARCHENA FERNÁNDEZ, J. Ejército y milicias..., p. 13-46.

${ }^{16}$ SODRÉ, Nelson Werneck. História militar do Brasil..., p. 26-32.

${ }^{17}$ PUNTONI, Pedro. A guerra dos bárbaros..., p. 181-186.
} 
Ordenanças (de 1570) na América portuguesa surgem apenas em 1612, no Regimento do governador-geral Gaspar de Sousa. ${ }^{18}$

Para além das determinações formais, conhece-se pouco acerca do processo de execução dessas medidas entre os séculos XVI e XVII na América portuguesa, notadamente no que diz respeito à disponibilidade de tropas pagas nas várias capitanias, aos diferentes ritmos regionais de formação dos terços e companhias de ordenanças, à composição social da oficialidade militar e aos quantitativos globais de soldados e armas. Por outro lado, há evidências significativas em torno do emprego de contingentes escravos de origem africana e de grupos indígenas ao lado dos conquistadores e colonizadores portugueses por todo o período. Para citar alguns exemplos, isso é válido tanto para as mobilizações militares destinadas a conter as investidas de tribos autóctones hostis à sociedade açucareira em construção, como às batalhas para a retomada do Rio de Janeiro frente aos franceses. ${ }^{19}$ Ademais, em várias referências a menção às estimativas parciais de homens armados mobilizados pela aristocracia guerreira parece obter primazia em relação à da quantidade de corpos militares existentes. Homem "de grande séquito" ou “opulento em arcos" eram expressões comuns para se referir aos capitães e outros oficiais das companhias de ordenanças nos primeiros tempos da colonização. ${ }^{20}$ Essa característica dos relatos sugere a permeabilidade das ordenanças aos modelos militares tradicionais, vinculados diretamente à capacidade de arregimentação de clientes oferecida pelos potentados locais. Igualmente, a inserção dos grupos africanos, indígenas e mestiços na estrutura militar indica desde muito cedo a vigência de processos de adaptação das referências militares europeias, e particularmente lusitanas, ao universo colonial. ${ }^{21}$ Os significados de tal formatação assumida pelas ordenanças foram de mão dupla para a Coroa: por uma via, esse foi o modo mais econômico de manter as atividades militares essenciais na colônia; por outra, a possibilidade de conversão das ordenanças - idealmente corpos militares institucionalizados e estáveis - em séquitos particulares representa a permanência dos modelos tradicionais e personalistas de arregimentação que a muito custo o Estado buscava controlar na Europa.

Fosse como fosse, a defesa das cidades e estabelecimentos coloniais dependia em grande medida dos contingentes armados formados por seus próprios habitantes, tendência que se acentuava tanto em função da escassez crônica de tropas profissionais como da intensificação

\footnotetext{
${ }^{18}$ LEONZO, Nanci. As Companhias de Ordenanças..., p. 12.

${ }^{19}$ LIMA, Carlos A. M. Escravos de peleja: a instrumentalização da violência escrava na América portuguesa (1580-1850). Revista de Sociologia e Política, Curitiba, n. 18, p. 131-152, jun. 2002, p. 134-136.

${ }^{20}$ SODRÉ, Nelson Werneck. História militar do Brasil..., p. 26.

${ }^{21}$ PUNTONI, Pedro. A arte da guerra no Brasil. Tecnologia e estratégia militar na expansão da fronteira da América portuguesa, 1550-1700. Novos Estudos. CEBRAP, n. 53, pp. 189-204, 1999.
} 
dos assédios perpetrados por piratas e estados concorrentes. As tropas regulares em serviço na América portuguesa eram formadas por contingentes exíguos, efêmeros e cuja reposição era esporádica. Além dos militares que eventualmente acompanharam os donatários ou seus representantes, os governadores-gerais eram assistidos de alguma tropa, como a de 400 homens que dispôs Tomé de Sousa, em 1548, e os 150 soldados de reforço disponibilizados a Giraldes, em $1588 .{ }^{22}$ De acordo com Puntoni, o primeiro terço de tropas regulares foi criado em Portugal apenas em 1618. No Brasil, formou-se um terço pago em 1626, após a expulsão dos holandeses da Bahia, e outro em 1631, abrigando, cada um, cerca de 800 homens. ${ }^{23}$ Durante a década de 1631 e os anos que a seguiram, no bojo das guerras do açúcar travadas entre portugueses e holandeses, foram criados às pressas, ainda, alguns corpos militares formados por índios e negros escravos e libertos. Entretanto, esses não se incluíam no conjunto da tropa regular. Ao contrário, tais grupos estavam previamente inseridos na estrutura militar colonial através das companhias de ordenança ou de séquitos particulares, como indicado anteriormente. O que se altera nesse contexto, no qual ficara patente a vulnerabilidade defensiva da América portuguesa em função da escassez de tropas profisssionais, é a constituição de corpos militares privativos a pretos e índios, cujo fenômeno, notadamente em relação aos pardos e morenos, já vinha ocorrendo em espaços da América espanhola. ${ }^{24}$ De se notar a natureza relativamente espontânea do fenômeno para o caso luso-brasileiro, que se configurou inicialmente como uma solução colonial isenta da gestão metropolitana direta.

Uma ideia acerca do estado das forças militares luso-americanas nesse período pode ser extraída do relato anônimo de um padre que testemunhara a conquista de Olinda e Recife por parte dos holandeses em 1630. Conforme o religioso, "a verdade é que gente que não é exercitada na milícia, nem paga, como naquela capitania [Pernambuco] a não havia [...], de ordinário perde o passo no primeiro encontro". Algumas das razões apontadas para a perda do território estariam vinculadas, portanto, à ausência de tropa paga suficiente bem como ao

\footnotetext{
22 SODRÉ, Nelson Werneck. História militar do Brasil..., p. 21-22.

${ }^{23}$ PUNTONI, Pedro. A guerra dos bárbaros..., p. 186. Os terços eram unidades militares amplas, as quais, assim como os regimentos e batalhões, englobavam várias companhias. Detalhes acerca das origens e significados desse termo e instituição em LEONZO, Nanci. Defesa militar e controle social na capitania de São Paulo: as milícias. Tese (doutorado em História). São Paulo: FFLCH, Universidade de São Paulo, 1979, p. 20-22.

${ }^{24}$ Sobre as guerras do açúcar, consultar MELLO, Evaldo Cabral de. Olinda restaurada: guerra e açúcar no Nordeste, 1630-1654. São Paulo: Ed. 34, 2007. Sobre a formação das companhias de pardos e morenos em espaços hispano-americanos, ver KLEIN, Herbert S. The colored militia of Cuba: 1568-1868. Caribbean Studies, v. 6, n. 2, p. 17-27, 1969; DESCHAMPS CHAPEAUX, Pedro. Los batallones de pardos y morenos libres. La Habana: Instituto Cubano del Libro, 1976, p. 17-33; SUAREZ, Santiago-Gerardo. Las milicias. Instituciones militares hispanoamericanas. Caracas: Academia Nacional de la Historia, 1984, p. 90-95 e 124-134; VINSON III, Ben. Articular el espacio: el establecimiento militar de gente de color libre en el México colonial de la conquista hasta la independencia. Callaloo, v. 27, n. 1, p. 331-354, 2004.
} 
despreparo das demais forças militares locais, quiçá ainda mal adaptadas ao modelo das ordenanças. Por intermédio da comparação entre as forças militares luso-americanas e a dos rivais, a testemunha anônima reitera o quadro de fragilidade estrutural do sistema defensivo colonial:

\begin{abstract}
A armada do inimigo holandês [...] fazia o número de setenta e tantas velas, com muita artilharia [...]: nela, fora a gente do mar, que também era mui luzida, vinham mais de seis mil infantes, toda gente mui exercitada, interessada e bem paga. Para lhe resistir, nem havia cidade murada, nem gente disciplinada, nem fortes reais aonde pudessem aturar o cerco e aguardar bataria dos canhões inimigos: e assim não há que pôr tamanha culpa aos moradores de Pernambuco. ${ }^{25}$
\end{abstract}

A influência que a momentânea derrota militar lusitana exerceu na avaliação de sua estrutura militar, a qual, por sua vez, foi contrastada com a dos vencedores, é notória no relato. Apesar de todo o envolvimento presente àquela perspectiva, sua caracterização dos traços gerais dos dois modelos distintos de organização bélica tem sido aceita pelos cientistas sociais. De um lado as forças militares coloniais luso-americanas, desfalcadas de contingentes profissionais e marcadas pela debilidade de seus contingentes milicianos; localizadas na periferia do sistema militar português, o qual há mais de meio século deixara de figurar na linha de frente entre as demais potências bélicas europeias, e manter-se-ia sob o domínio espanhol até 1640. De outro as poderosas armadas holandesas, bem equipadas e pagas, mantidas mediante a associação entre Estado e investidores capitalistas, que compunham a maior potência marítima à época. ${ }^{26} \mathrm{O}$ que não se sabia, por volta de 1630, é a extrema eficácia que a "guerra brasílica" desempenharia na expulsão dos batavos. Sem contar com o adequado auxílio ibérico, até 1640, e português, a partir de então, a resistência luso-americana fundou-se em um "sistema misto", no qual as tropas regulares desempenhavam os preceitos da guerra europeia enquanto as tropas irregulares, formadas por indígenas, negros e mestiços, empreendiam emboscadas, assaltos e movimentações de toda a sorte. ${ }^{27} \mathrm{O}$ certo é que, cada vez mais visados economicamente, os espaços da América portuguesa elevaram sua posição na hierarquia dos espaços de guerra ao

\footnotetext{
${ }^{25} C f$ :: "Relaçam verdadeira e breve da tomada da Villa de Olinda, e lugar do Recife na costa do Brazil pellos rebeldes de Olanda, tirada de uma carta que escreveo hum Religioso de muyta authoridade, \& que foy testemunha de vista de quase todo o socedido: \& assi o affirma, \& jura; \& do mais que depois disso socedeo te os dezoito de Abril deste prezente, \& fatal anno de 1630”. Anais da Biblioteca Nacional. (vol. 20). Rio de Janeiro: Typografia Leuzinger, 1899, p. 130. Estimativas semelhantes encontram-se em BARRIGA, Luis Alvares. "Propuesta de las advertencias, que de necessidad forçada, se deven justamente descursar, sobre la seguridad y certeza con que se deve recuperar el puerto de Pernambuco, defenderse y conservarse el Estado del Brasil". ABN. (vol. 69). Rio de Janeiro: Departamento de Imprensa Nacional, 1950, p. 258.

${ }^{26}$ TILLY, C. Coerção, Capital..., p. 150.

${ }^{27}$ PUNTONI, Pedro. A guerra dos bárbaros..., p. 186-192.
} 
longo do século XVII. A partir de então a frágil estrutura militar luso-americana passaria por transformações incisivas, decorrentes tanto da revolução militar que se processava na Europa como das adaptações e rearranjos próprios do mundo colonial.

Conforme Gouveia e Monteiro, "é à guerra que temos de recorrer, se queremos atentar na criação progressiva do aparelho militar"; afinal, ela induz a emergência de "surtos legislativos e organizacionais". ${ }^{28}$ Tais historiadores sugerem que a participação lusitana em quatro grandes confrontos bélicos na Europa entre 1640 e 1807 (a Guerra de Restauração contra a Espanha, entre 1640 a 1668; a Guerra de Sucessão de Espanha, entre 1701 a 1715; a Guerra dos Sete Anos, entre 1756-1763; e a resistência à invasão francesa, de 1807 em diante), intercalados com refluxos ao estado de paz, definiu o processo de construção de sua estrutura militar. ${ }^{29}$ Essa perspectiva é igualmente pertinente para a compreensão da organização militar na América desde que se leve em conta a importância dos confrontos e atividades militares coloniais, cujo peso para a conformação das atividades militares reinóis, aliás, ainda não foi devidamente avaliado.

E, com efeito, foi nos marcos da Guerra de Restauração e em meio a uma série de medidas direcionadas a reestruturar as forças armadas portuguesas que se criou os "Soldados Auxiliares", uma linha militar intermediária entre a tropa profissional, paga e disciplinada, e as ordenanças. ${ }^{30}$ A carta régia que a instituiu, em 1645, considerou a medida como um "remédio" à vexação causada aos integrantes das ordenanças "mais desamparados", os quais, em situação de guerra, eram irregularmente enviados às fronteiras de guerra viva. Trata-se de uma clara referência à vigência de práticas locais de suborno, proteção e isenção que beneficiavam aos comissários regionais e aos indivíduos e famílias capazes de pagar para eximirem-se das obrigações militares. Em sentido contrário, objetivava-se a alistar na tropa auxiliar a todos os "homens desobrigados", isto é, sem maiores empecilhos para se ausentarem de suas casas, bem como aqueles que, "a título de serem nobres e honrados, não costumam sair nas Companhias".31 A investida da Monarquia portuguesa, recém-restaurada e nas mãos da nova dinastia de Bragança, significou uma maior ingerência no funcionamento dos poderes locais e, ao mesmo tempo, um aumento em sua concentração dos meios de fazer a guerra.

\footnotetext{
${ }^{28}$ GOUVEIA, António Camões; MONTEIRO, Nuno G. A milícia. In: MATTOSO, José (Dir.). História de Portugal. Lisboa: Ed. Estampa, 1998, v. 4, p. 197.

${ }^{29}$ GOUVEIA, A. C.; MONTEIRO, N. G. A milícia...

${ }^{30}$ COSTA, André Alexandre da Silva. La milicia, el Rey y la guerra..., p. 171-178.

${ }^{31}$ Cf:: "Carta Régia de 7 de janeiro de 1645. Criação de Soldados Auxiliares". In: SILVA, José Justino de Andrade e. Collecção Chronologica da legislação portugueza (1640-1647). Lisboa: Impensa de F. X. de Souza, 1856, p. 271-272.
} 
Finalmente, com o estabelecimento dos soldados auxiliares, veio a lume a estrutura militar tripartite lusitana: a primeira linha, composta pelas tropas profissionais, em tese pagas, armadas e disciplinadas, aptas para a guerra; a segunda linha, constituída pelos auxiliares, isto é, corpos militares razoavelmente preparados para coadjuvar as tropas pagas em caso de necessidade e, por essa razão, comandados por oficiais provenientes da primeira linha e integrados por homens dotados de plena capacidade física; a terceira linha, formada pelas ordenanças, em cujos terços ou companhias permaneciam alistados os homens inaptos para a guerra, por condições físicas ou idade, bem como aqueles que, pelos motivos os mais diversos, não estavam disponíveis a se ausentarem de suas casas, famílias e localidades.

O sistema defensivo da América portuguesa e do Brasil imperial fundou-se igualmente nessas três linhas, sendo alterado tão somente com o advento das reformas liberais de 1831 que extinguiram as milícias (os já antigos corpos auxiliares) e as ordenanças, instituindo em seu lugar a Guarda Nacional. ${ }^{32}$ Contudo, como no caso das ordenanças, são escassos os estudos relativos à formação dos corpos militares auxiliares ou de segunda linha nas capitanias lusoamericanas, especialmente nos períodos mais recuados correspondentes à segunda metade do Seiscentos e primeira parte do Setecentos. ${ }^{33}$ Provavelmente tais corpos militares foram erigidos primeiramente, mas não sem dificuldades, nas capitanias economicamente mais dinâmicas, como é o caso da Bahia, onde se localizava a capital do Estado do Brasil, e Pernambuco. O fenômeno certamente estava conectado ao fato de que as invasões holandesas revelaram-nas capitanias extremamente suscetíveis a ataques pela costa marítima, bem como atendeu às

\footnotetext{
32 Vários trabalhos produziram mapeamento da legislação militar e forneceram interpretação ao processo de constituição do sistema tripartite lusitano, tais como LEONZO, Nanci. Defesa militar e controle social..., p. 2022; PUNTONI, Pedro. A guerra dos bárbaros..., p. 181-192; MELLO, Christiane F. Pagano de. Os Corpos de Auxiliares e de Ordenanças na Segunda Metade do Século XVIII. As Capitanias do Rio de Janeiro, São Paulo e Minas Gerais e a Manutenção do Império Português no Centro Sul América. Tese (doutorado em História). Niterói: ICHF, Universidade Federal Fluminense, 2002, p. 19-42; SILVA, Kalina Vanderlei Paiva da. 'Nas solidões vastas e assustadoras'. Os pobres do açúcar e a conquista do sertão de Pernambuco nos séculos XVII e XVIII. Tese (doutorado em História). Recife: CFCH, Universidade Federal de Pernambuco, 2003, p. 142-156; COSTA, A. A. da Silva. La milicia, el Rey y la guerra..., p. 166-178.

${ }^{33}$ E, nesse sentido, replica-se aqui a constatação de Leonzo, efetuada em 1979. LEONZO, N. Defesa militar..., p. 22. É verdade que há estudos específicos, relativos a determinadas capitanias - com predileção a Pernambuco - e corpos militares - como é o caso do terço de Henrique Dias. Há também estudos sobre guerras específicas. Porém, não há sínteses ou abordagens mais densas e abrangentes. Sobre Pernambuco e o terço de Henrique Dias, vide MELLO, José Antônio Gonsalves de. Henrique Dias: governador dos pretos, crioulos e mulatos do Estado do Brasil. Recife (PE): Universidade do Recife, 1954; MELLO, Evaldo C. de. Olinda restaurada: guerra e açúcar no Nordeste, 1630-1654. $2^{\mathrm{a}}$ ed. Rio de Janeiro: Topbooks, 1998; SILVA, Kalina V. P. da. 'Nas solidões vastas e assustadoras'...; MATTOS, Hebe. "Black Troops" and hierarchies of color in the Portuguese Atlantic World: The case of Henrique Dias and his Black Regiment. Luso-Brazilian Review, v. 45, n.1, p. 6-29, 2008. Um esforço recente no sentido de analisar a constituição das milícias de pretos e pardos a partir de uma perspectiva processual pode ser consultado em SILVA, Luiz Geraldo. Gênese das milícias de pardos e pretos na América portuguesa: Pernambuco e Minas Gerais, séculos XVII e XVIII. Revista de História, São Paulo, n. 169, p. 112-144, jul./dez. 2013.
} 
necessidades das sangrentas campanhas militares promovidas contra a presença de grupos indígenas e quilombolas no entorno da sociedade açucareira ao longo da segunda metade do século XVII. ${ }^{34}$ A descoberta do ouro, em fins daquele século, estimulou de imediato a criação de companhias e terços auxiliares nas capitanias do Centro-Sul do Brasil. Essas tropas, conjuntamente às ordenanças e à restrita tropa paga, atuariam na prevenção a desvios e desmandos internos assim como a possíveis assédios estrangeiros às regiões de extração e escoamento do metal. Não por acaso, o provimento dos primeiros postos de auxiliares em São Vicente - a capitania donatarial que, na primeira metade do século XVIII originaria as capitanias régias de São Paulo, Minas Gerais, Goiás e Mato Grosso - ocorreu entre 1697 e 1698. ${ }^{35}$ Já na capitania do Rio de Janeiro, a partir do mesmo período, teria vigorado um arranjo peculiar, mais tarde reputado "confuso" por um governador colonial, que consistia na sobreposição dos terços de auxiliares aos terços de ordenanças, os quais eram frequentemente referidos como terços ou companhias de "ordenanças auxiliares". ${ }^{36}$

$\mathrm{Na}$ ausência de qualquer estimativa abrangente aos vários espaços luso-americanos, pode-se deduzir que tais corpos militares experimentaram ampliação numérica e difusão espacial não mais que moderados ao longo da primeira metade do século XVIII. Vai daí que a provisão régia de 1739 , a primeira disposição legal dedicada especificamente aos corpos militares da América portuguesa ${ }^{37}$, tenha objetivado, em relação à terceira linha, controlar a expansão desenfreada da oficialidade das ordenanças e a consequente desordem proveniente da multiplicidade dos postos e de requerimentos, e ao mesmo tempo estimular a segunda linha ao “determinar que, nas terras deste Estado em que houver portos de mar, se criem Terços de Auxiliares". 38

\footnotetext{
${ }^{34} \mathrm{Em} 1663$, os conselheiros do Conselho Ultramarino requereram que o governador de Pernambuco informasse se os terços ali existentes estavam regulados como os auxiliares do reino ou se sob outra base. $C f:$ : AHU_ACL_CU, Consultas mistas, Cód. 16, fls. 89-89v. Ver igualmente SILVA, K. V. P. da. 'Nas solidões vastas e assustadoras'..., p. 146, 151-152.

${ }^{35}$ LEONZO, N. Defesa militar..., p. 23-27.

${ }^{36}$ MELLO, C. F. P. de. Os Corpos de Auxiliares e de Ordenanças..., p. 111-114. Essa especificidade fluminense possivelmente decorra de um arranjo institucional firmado na virada do século XVII para o XVIII, quando as ordenanças locais obtiveram a mercê régia de dispor dos privilégios das tropas auxiliares. Cf:: Documentos Históricos, v. 93, p. 70-71; DIHCSP, vol. 14, p. 80-84.

${ }^{37}$ CABRAL, Dilma (Org.). Dicionário da Administração Pública brasileira Online-Período colonial. Verbete "Companhia de Ordenanças". Disponível em: $<$ http://linux.an.gov.br/mapa/?p=4768>.

${ }^{38}$ Cf:: "Provisão de 21 de abril de 1739", anexa ao "Regimento das Ordenanças do Brasil de 21 de abril de 1739". In: SOUSA, José Roberto de Campos Coelho e. Sistema, ou Coleção dos Regimentos Reais, Tomo IV, Lisboa: Officina de Simão Thaddeo Ferreira, 1785, p. 516-527. Sobre o processo de diferenciação entre auxiliares e ordenanças em Pernambuco e Rio Grande do Norte, consultar SILVA, K. V. P. da. 'Nas solidões vastas e assustadoras'..., p. 149-150. Ver também a interpretação de N. W. Sodré, conforme a qual se operará uma transição das ordenanças para as milícias no que diz respeito à força militar predominante no Brasil colonial a partir do fim das guerras luso-holandesas de meados do século XVII e especialmente com a descoberta e exploração do ouro em Minas Gerais. As crescentes contradições no universo colonial entre os poderes locais e centrais
} 
A Guerra dos Sete Anos (1756-1763) catalisou o paulatino e desigual processo de formação da moderna estrutura militar tanto em Portugal como na América portuguesa. Essa guerra mobilizou toda a Europa e teve motivações e reflexos em territórios coloniais asiáticos e americanos. Seus principais protagonistas foram Inglaterra, de um lado, e França, de outro. Já Portugal e Espanha participaram do confronto em sua fase tardia. Enquanto os espanhóis mantinham relações de aliança historicamente construídas com a França, portugueses vinculavam-se mais estreitamente à Inglaterra. A pressão francesa que visava minar a hegemonia comercial inglesa em dimensão mundial instou os reinos ibéricos a assinarem um pacto de família, entre Bourbons, destinado à defesa mútua e ao estabelecimento de restrições à Inglaterra. A Espanha entrou na guerra em 1761, como aliada à França, ao passo que Portugal tentara permanecer relativamente neutro sem integrar aquela aliança. No ano seguinte, parte do reino português foi ocupado por uma coalizão franco-espanhola que objetivava fragilizar as relações entre lusitanos e ingleses. Dada a notável debilidade do sistema defensivo, o primeiro ministro português solicitou o imediato auxílio militar inglês para repelir a invasão, selando assim o vínculo anglo-lusitano. Atendido em seu pedido, Pombal negociou ainda, após o confronto, a permanência de oficiais militares que prestavam serviço à Inglaterra, os quais, a exemplo do general conde de Lippe, seriam elementos centrais na completa reestruturação militar planejada para Portugal. ${ }^{39}$ Enquanto isso, a Inglaterra executou ações militares agressivas a territórios coloniais espanhóis e franceses, levando a guerra concretamente para além da Europa. ${ }^{40}$

Para essa campanha, Portugal encontrava-se desprevenido. Além de requerer apoio do exército e marinha ingleses, viu-se obrigado a contratar dois batalhões de mercenários suíços e a adquirir armamento por meio de compra junto à Inglaterra. Ademais, a fim de ampliar os efetivos disponíveis, recorreu-se, como era comum, às levas que incidiam sobre a população comum, especialmente aos jovens adultos das ordenanças. ${ }^{41}$ Os efetivos totais estimados por Gouveia Pinto e reproduzidos por A. C. Gouveia e N. G. Monteiro apontam para um alargamento considerável na tropa regular: dos 33.200 homens distribuídos pelos corpos Guarda R. dos Archeiros, Infantaria, Cavalaria e Artilharia em 1735, passou-se a dispor, em

\footnotetext{
desembocariam, no plano militar, na conversão das milícias em instrumento da dominação e controle metropolitanos. SODRÉ, N. W. História militar do Brasil..., p. 50.

${ }^{39}$ MAXWELL, Kenneth. Marquês de Pombal: paradoxo do iluminismo. Rio de Janeiro: Paz e Terra, 1997, p. 119139.

${ }^{40}$ Sobre as tensões militares envolvendo os reinos europeus ao longo do século XVIII e, sobretudo, durante a Guerra dos Sete Anos, ver: NOVAIS, Fernando A. Portugal e Brasil na crise do Antigo Sistema Colonial (17771808). São Paulo: Editora HUCITEC, $5^{\text {a }}$ edição, 1989, pp. 32-56.

41 TAVEIRA, Alfredo Pereira. A defeza de Portugal. Summario histórico (1640-1815). Lisboa: Typ. Da Cooperativa Militar, 1906, p. 42-43.
} 
1762, de aproximadamente 48.240 homens entre oficiais e soldados. Com a desmobilização posterior aos confrontos, os efetivos estimados daqueles mesmos corpos militares reduziramse a 29.606 homens já em 1764, mas tenderiam a experimentar uma ampliação significativa entre fins do século XVIII e começo do XIX. ${ }^{42}$ A partir de meados do Setecentos, os gastos militares com o Exército e a Marinha se converteram na principal despesa da Coroa portuguesa. Mas talvez o maior legado de sua participação na Guerra dos Sete Anos, no tocante à reformulação da estrutura militar reinol, se relacione às reformas introduzidas pelo conde de Lippe durante e após as batalhas. Sob seu comando se processou a melhoria das fortificações, o estudo estratégico dos palcos da guerra e a "introdução de novas regras de recrutamento, aprendizagem, fardamento e disciplina". O estabelecimento de um regulamento militar, ao determinar padrões de conduta e regras atinentes às promoções, punições e demais circunstâncias da atividade marcial, representou um esforço modernizante além de um passo largo no sentido da relativa autonomização do universo militar em relação à sociedade civil. ${ }^{43}$

Do outro lado do Atlântico, na América portuguesa, os efeitos das tensões europeias de meados do século XVIII seriam sentidos com igual intensidade, mas obteriam direcionamento distinto daquele verificado em Portugal. Evidentemente, o universo colonial se inseria no equilíbrio instável de poder mais amplo do qual as metrópoles faziam parte, de modo que as diferentes colônias assimilaram parte das tensões decorrentes das alianças entre os estados europeus. Exemplo notável é a intensificação imediata das ações militares inglesas sobre espaços econômica e militarmente estratégicos das colônias espanholas desde a formalização do alinhamento franco-espanhol. Se o imenso império colonial hispânico experimentava as reformas bourbônicas desde a primeira metade do século XVIII, foi somente a partir de 1762, com a queda de Havana diante dos ingleses, que as reformas militares tiveram curso. Como demonstra a extensa bibliografia sobre o tema, além de arcar com parte substancial da manutenção dos exércitos peninsulares, os espaços hispano-americanos tiveram que sustentar a montagem de sua própria infraestrutura militar bem como os soldos das tropas veteranas e da plana maior das milícias. Estas, cumpre salientar, perceberam transformações quantitativas e qualitativas sem precedentes. ${ }^{44}$

\footnotetext{
42 GOUVEIA, A. C.; MONTEIRO, N. G. A milícia..., p. 201.

${ }^{43}$ GOUVEIA, A. C.; MONTEIRO, N. G. A milícia..., p. 202-203.

${ }^{44}$ MARCHENA FERNÁNDEZ, J. Ejército y milícias...; KLEIN, Herbert S. The colored militia of Cuba...; KUETHE, Allan J. The military reform in the viceroyalty of New Granada, 1773-1796. Tese de doutorado. Flórida: Universidade da Flórida, 1967; CAMPBELL, Leon G. The changing racial and administrative structure of the peruvian military under the later bourbons. The Americas, v. 32, n. 1, p. 117-133, 1975; SUAREZ, SantiagoGerardo. Las milicias...
} 
Assim como o ultramar espanhol, o Estado do Brasil não ficou imune aos desdobramentos da Guerra dos Sete Anos. Ali os confrontos europeus deram vazão a antigas rivalidades e disputas: nomeadamente, à competição entre Portugal e Espanha pelos territórios localizados na bacia do Prata, a qual remonta à fundação dos povoados portugueses Colônia do Sacramento (1680), Laguna (1684) e capitania do Rio Grande de São Pedro (1713). ${ }^{45}$ Situada defronte a Buenos Aires, desde então Sacramento tornou-se alvo de investidas castelhanas, que ora se constituíam em pequenos assaltos às roças de portugueses, ora tomavam a forma de cercos. A Colônia foi tomada pelos espanhóis já em 1680, o que se repetiu em 1704-1705. Entre 1735-1737 foi novamente sitiada. ${ }^{46}$ Evidentemente, a legitimidade da presença portuguesa na região era questionada pela Coroa espanhola de forma que, para além das incursões militares, tentou-se solucionar a questão pela via diplomática através dos tratados de Madri (1750) e de El Pardo (1761). ${ }^{47}$

No interior desse equilíbrio tenso e instável, os conflitos locais preexistentes se acentuaram em decorrência das posições opostas tomadas por Portugal e Espanha na Guerra dos Sete Anos. Paralelamente à invasão espanhola a Portugal, do outro lado do Atlântico, em fins de 1762, as forças hispano-americanas comandadas por D. Pedro de Cevallos ocuparam a Colônia do Sacramento, os fortes de São Miguel e de Santa Tereza, e, finalmente, penetraram na vila de São Pedro em maio de 1763. Iniciou-se, pois, o período da dominação espanhola no Sul da América portuguesa que duraria de 1762 a 1777. As ações militares se concentraram na conquista e avanço espanhol, entre 1762-1763, na contraofensiva portuguesa, de 1774 a 1776, a qual resultou na reconquista da capitania do Rio Grande de São Pedro, e, por fim, na resposta espanhola de 1777, com a conquista da ilha de Santa Catarina e do presídio do Iguatemi, situado no extremo oeste da América portuguesa. ${ }^{48}$

Essa guerra representou, certamente, a maior ação militar luso-americana do século XVIII. A transferência da capital do Estado do Brasil, de Salvador para o Rio de Janeiro, em 1763, e a criação do vice-reino do Rio da Prada, na América espanhola, em 1776, são exemplos

\footnotetext{
${ }^{45}$ CUNHA, P. O. Carneiro da. Política e administração de 1640 a 1763. In: HOLANDA, S. B. de (Dir.). História geral da civilização brasileira. (v. 2, t. 1). São Paulo: Difel, 1985, p. 19-41; HOLANDA, S. B. de. A Colônia do Sacramento e a expansão no extremo sul. In: HOLANDA, S. B. de (Dir.). História geral da civilização brasileira. (v. 1, t. 1). São Paulo: Difel, 1972, p. 322-363.

${ }^{46}$ HOLANDA, S. B. de. A Colônia do Sacramento...

${ }^{47}$ REICHEL, H. J.; GUTFREIND, I. Fronteiras e guerras no Prata. São Paulo: Atual, 1995, p. 23.

48 LEONZO, Nanci. As companhias de ordenanças na capitania de São Paulo. Das origens ao governo do Morgado de Mateus. Dissertação (mestrado em História). São Paulo: FFLCH, Universidade de São Paulo, 1975, p. 60; KÜHN, F. A fronteira em movimento: relações luso-castelhanas na segunda metade do século XVIII. Estudos Ibero-Americanos, v. 25, n.2, p. 91-112, dez./1999, p. 91; BELLOTTO, Heloísa Liberalli. Autoridade e conflito no Brasil colonial: o governo do Morgado de Mateus em São Paulo (1765-1775). São Paulo: Conselho Estadual de Artes e Ciências Humanas, 1979, p. 308.
} 
contundentes de seu impacto geopolítico. ${ }^{49}$ Vários generais e oficiais militares de alto escalão e com experiência recente na guerra europeia foram enviados para a América portuguesa para chefiar e reorganizar as tropas, assim como se efetuou uma grande reviravolta em seu tabuleiro político mediante a substituição dos governadores coloniais empossados por outros melhor instruídos nas estratégias militares em curso. ${ }^{50}$

As grandes dimensões desta guerra também se expressam no contingente de soldados mobilizados. Lins estimou que as forças militares portuguesas reunidas nas regiões fronteiriças da bacia do Prata e sob a denominação de Exército do Sul, quase que integralmente constituídas por tropas de linha, eram superiores a seis mil e trezentos homens, o que as tornava "o maior [exército luso-brasileiro] até então organizado em território americano". ${ }^{51}$ Elas eram integradas pelos regimentos de Moura, Bragança, Extremoz e artilheiros de Lagos, provenientes de Portugal (que perfaziam cerca de $31,8 \%$ do total de soldados presentes no palco da guerra entre 1775-1776), e principalmente por soldados das capitanias da América portuguesa, como São Paulo (que forneceu 38,3\% dos praças), Rio de Janeiro (15,1\%), Santa Catarina $(8,7 \%)$ e Rio Grande de São Pedro (5,9\%). ${ }^{52} \mathrm{O}$ quadro não era diferente do lado espanhol. Mesmo que se desconsidere o peso das forças militares hispano-americanas reunidas no recém-criado vicereino do Prata, a armada espanhola destinada à América, por si só, foi capaz de produzir um sentimento de terror pânico no vice-rei do Brasil, marquês do Lavradio. Ele obtivera notícia, em fins de 1776, que a Espanha organizara uma "expedição de 8 mil homens para mandar à América, supõe-se que a visitar primeiro algum dos 3 portos, Pernambuco, Bahia e Rio de Janeiro, e depois passarem a Santa Catarina e Rio Grande”. Porém, em fevereiro de 1777, a invasão espanhola à ilha de Santa Catarina revelou um poder de mobilização castelhano ainda

\footnotetext{
${ }^{49}$ Para o caso da América portuguesa ver MAXWELL, K. Marquês de Pombal..., p. 126. Em relação à América espanhola, consultar BRADING, D. A. A Espanha dos Bourbons e seu império americano. In: BETHELL, L. (Org.). História da América Latina. São Paulo: Edusp; Brasília: Fundação Alexandre Gusmão, 1997, p. 405-406. ${ }^{50}$ Cf:: "Carta de D. José I para o marquês do Lavradio". Palácio de Nossa Senhora da Ajuda, 9 de julho de 1774. In: MENDONÇA, M. C. de. Século XVIII, século pombalino no Brasil. Rio de Janeiro: Xerox do Brasil, 1989, p. 607-608; "Carta do marquês de Pombal para o marquês do Lavradio". Lisboa, 15 de julho de 1774. In: MENDONÇA, M. C. de. Século XVIII..., p. 608-610. Ver também MAXWELL, K. Marquês de Pombal..., p. 126; SILVA, L. G.; SOUZA, F. P. de; PAULA, L. F. de. A guerra luso-castelhana e o recrutamento de pardos e pretos: uma análise comparativa (Minas Gerais, São Paulo e Pernambuco, 1775-1777). In: SANTOS, A. C. de A.; DORÉ, A. (Orgs.). Temas setecentistas: governos e populações no império português. Curitiba: UFPR-SCHLA/Fundação Araucária, 2008, p. 67-83.

${ }^{51}$ LINS, Maria de L. Ferreira. Martim Lopes Lobo de Saldanha: a presença de São Paulo nas guerras do Sul. In: Anais do simpósio comemorativo do bicentenário da restauração do Rio Grande (1776-1976). (vol. 1). RJ: Instituto Histórico e Geográfico Brasileiro (IHGB), 1979, p. 315.

${ }^{52}$ LINS, Maria de L. Ferreira. A Legião de São Paulo no Rio Grande do Sul. Tese (doutorado em História). São Paulo: FFLCH, Universidade de São Paulo, 1976, p. 167-169.
} 
maior do que o previsto, pois se calculou que fora levada a efeito por 117 embarcações que abrigavam 12 batalhões e aproximadamente 10 mil homens. ${ }^{53}$

Uma vez que as tropas regulares ou de primeira linha disponíveis para a defesa da América portuguesa tenderam a se concentrar prioritariamente nas capitanias de Santa Catarina e Rio Grande de São Pedro no decorrer da guerra de 1762-1777, a situação dos demais espaços luso-americanos tornou-se temerária nesse contexto. Como o próprio vice-rei reconheceu, esse era o caso das capitanias desfalcadas de corpos militares em função do envio de alguns deles para os palcos da guerra, como as do Rio de Janeiro e São Paulo, ou mesmo daquelas cujos efetivos eram previamente considerados insuficientes, a exemplo de Pernambuco e Bahia ${ }^{54}$, as quais abrigavam cidades e portos marítimos dos mais importantes no conjunto da colônia. Vai daí a atribuição de papel central às forças militares não profissionais, formadas pelos próprios habitantes da colônia, para a defesa de suas próprias capitanias, cidades, vilas, casas e famílias. Essa condição mais geral tornou-se consensual entre os governadores coloniais desde que passou a ser regularmente transmitida aos capitães-generais e vice-reis em suas instruções de governo. Tais diretrizes atestavam três "princípios invariáveis":

Primeiro: que o pequeno continente de Portugal, tendo braços muito extensos, muito distantes e muito separados uns dos outros, quais são os seus domínios ultramarinos nas quatro partes do mundo, não pode ter meios nem forças com que se defenda a si próprio e acuda ao mesmo tempo à preservação e segurança de cada um deles; Segundo: que nenhuma potência do universo, por mais formidável que seja, pode nem intentou até agora defender as suas colônias com as únicas forças do seu próprio continente; Terceiro: que o único meio que até hoje se tem descoberto e praticado para acorrer à sobredita impossibilidade, foi o de fazer servir as mesmas colônias

\footnotetext{
${ }^{53}$ Cf:: "Carta escrita ao governador da Praça da Colônia". Rio de Janeiro, 30 de outubro de 1776; "Carta escrita ao governador da capitania de São Paulo". Rio de Janeiro, 13 de março de 1777. In: Biblioteca Nacional de Portugal (Digital). Cartas do 2.o Marquês do Lavradio, 11o Vice-Rei do Brasil, para os governadores de várias capitanias do Brasil sobre assuntos respeitantes ao governo e defesa das mesmas, p. 9-12, p. 79v-81v. Para outras estimativas coevas, referentes a 1774, vide "Orçamento das forças terrestres e navais que verossimilmente se pode julgar que os castelhanos tenham no Rio da Prata e sul do Brasil, depois que chegar a Buenos Aires a última expedição que partiu de Cádiz no mês de agosto deste presente ano de 1774, e combinação delas com as forças de Sua Majestade naquelas fronteiras". RIHGB, vol. 31, parte 1, 1868, p. 311-316; "Resumo das forças que se acham no Rio de Janeiro e nos distritos de sua dependência, socorros e outras providências, com que Sua Majestade tem mandado assistir à dita capitania". RIHGB, vol. 31, parte 1, 1868, p. 344-346.

${ }^{54} \mathrm{Na}$ realidade, Pernambuco e Bahia também enviaram tropas de linha para Rio de Janeiro para, se necessário, serem conduzidas a Santa Catarina naquele contexto. Ver a ordem para envio de um regimento pernambucano e dois baianos ao Rio de Janeiro, datada de 15 de julho de 1774, em RIHGB, vol. 31, parte 1, p. 303-307. Essas não devem ser confundidas com os terços de Henriques e Pardos pernambucanos mencionados em estratégia não concretizada. Ver RIHGB, vol. 31, parte 1, p. 331, 340, 342-343 e SILVA, L. G.; SOUZA, F. P. de; PAULA, L. F. de. A guerra luso-castelhana e o recrutamento de pardos e pretos... O impacto da mobilização dessa tropa foi sentido na capitania de Sergipe, subordinada à da Bahia, até pelo menos fins do século XVIII, e ganhou expressão nas palavras do ouvidor da cidade de São Cristóvão, o qual via com preocupação a falta de tropa regular para guarnecer a localidade desde o envio daquela unidade militar para o Sul, na década de 1770. $C f$.: AHU_ACL_CU_005, Cx. 218, D. 15290.
} 
para a própria e natural defesa delas: e na inteligência deste inalterável princípio, as principais forças que hão de defender o Brasil, são as do mesmo Brasil. ${ }^{55}$

Os itens acima deveriam ser encarados como axiomas direcionados a guiar a atuação dos governadores e capitães-generais responsáveis pelas capitanias luso-americanas. Em realidade, eles configuram um atestado honesto acerca das parcas condições dispostas pela metrópole para prover a defesa de suas colônias, ela própria, recorde-se, dependente de mercenários e forças militares estrangeiras. Quando as autoridades de Lisboa reconheceram a responsabilidade do Brasil por sua própria defesa militar, não se referiam exclusivamente à restrita tropa de linha que guarnecia as capitanias. Pelo contrário, esse momento foi marcado pela recorrência a narrativas épicas atinentes ao passado e a projeções de futuro de certo modo fantasiosas referentes às ações militares dos súditos luso-americanos inseridos em corpos militares auxiliares, de ordenanças ou mesmo em bandos irregulares. Entre as décadas de 1760 e 1770, houve, pois, uma expressiva retomada da memória das ações dos pretos e pardos comandados, respectivamente, por Henrique Dias e D. Felipe Antonio Camarão nas guerras luso-holandesas assim como se exaltou abundantemente o potencial dos sertanistas paulistas

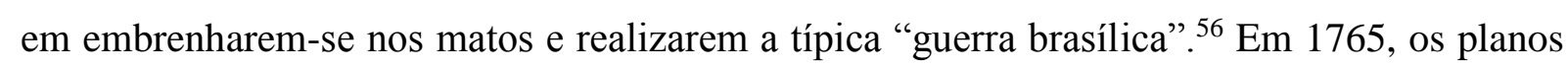
de Pombal incluíam igualmente a atuação de negros, livres ou cativos, da capitania de Minas Gerais. Ele era capaz de visualizar facilmente "vinte ou trinta mil a caírem de repente sobre os castelhanos", destruindo-os e reavendo o território que se estendia até a margem setentrional do Rio da Prata. ${ }^{57}$

Na prática, porém, a preparação das populações locais para a defesa territorial em tempos de guerra exigia a formação do máximo possível de unidades militares organizadas. É nesse sentido que se expediu a Carta Régia de 22 de março de 1766 a todas as capitanias da América portuguesa, na qual consta a disposição, amplamente difundida na historiografia, conforme a qual os governadores e capitães-generais deveriam "alistar todos os moradores [...] que se acharem em estado de poderem servir nas tropas auxiliares, sem exceção de nobres, plebeus, brancos, mestiços, pretos, ingênuos e libertos; e à proporção dos que tiver cada uma

\footnotetext{
${ }^{55}$ Cf:: "Instrução de Martinho de Melo e Castro para Luis de Vasconcelos". Salvaterra de Magos, 27 de janeiro de 1779. In: MENDONÇA, M. C. de. Século XVIII..., p. 753-754.

56 Cf: "Ofício do Marquês de Pombal para o Marquês do Lavradio". Lisboa, 8 de agosto de 1774. In: MENDONÇA, M. C. de. Século XVIII..., p. 613-615; "Carta do marquês de Pombal ao marquês do Lavradio". Lisboa, 9 de maio de 1775. In: MENDONÇA, M. C. de. Século XVIII..., p. 635-639.

${ }^{57}$ Cf: "Artigos (cópias) das Instruções dadas pelo conde de Oeiras ao General da capitania de São Paulo, D. Luis António de Sousa em ofício de 26 de janeiro de 1765". Palácio de Nossa Senhora da Ajuda, 26 de janeiro de 1765. AHU_CU_023-01, Cx. 23, D. 2221.
} 
das referidas classes, formeis terços de auxiliares e ordenanças, assim de cavalaria como de infantaria". ${ }^{58}$ De fato, ainda que se refira também às ordenanças, esta carta régia marcou definitivamente a emergência dos auxiliares, a segunda linha, como esteio do sistema militar colonial. Esses corpos militares deixaram de ser exclusivos das localidades em que havia portos marítimos $^{59}$ e foram criados até mesmo nas capitanias mais longínquas, como Mato Grosso e Goiás. Além disso, a urgência era tal que a recomendação para o alistamento de todos os homens capazes, independentemente das diferenças de estamento (se nobres ou plebeus), cor/qualidade (brancos, mestiços ou pretos) e condição jurídica (ingênuos ou libertos), se sobrepôs e descaracterizou momentaneamente o problema da existência de corpos militares segregados para brancos, pardos e pretos que havia aflorado na década de $1730 .{ }^{60} \mathrm{O}$ documento não detalhou se os membros de todas as classes deveriam e/ou poderiam ser incluídos nos auxiliares e ordenanças, na infantaria e cavalaria: urgia arregimentar tantos homens quanto a colônia dispusesse. Por outro lado, determinou que os terços de auxiliares e ordenanças devessem ser disciplinados por sargentos-mores retirados das tropas regulares e pagos através dos rendimentos das câmaras das vilas e cidades situadas nos distritos dos corpos militares em questão. Buscava-se, pois, elevar os níveis de organização e eficácia das tropas não profissionais. De acordo com Izecksohn, um dos significados dessa medida foi o afastamento do "senhoriato local" em relação àqueles postos superiores. Consequentemente, alargar-se-ia um campo de tensões preexistente entre os poderes centrais e locais, de forma que a Coroa sentiria uma forte imposição de limites a seu "poder de extração" - na prática, dificuldades em lograr apoio efetivo das milícias - sempre que esse interviesse nos equilíbrios regionais. ${ }^{61}$ Fosse como fosse, a partir de então se verificaria uma expansão e difusão dos terços auxiliares sem

\footnotetext{
${ }^{58}$ Cf:: "Carta de D. José I ao governador e capitão-general de São Paulo, morgado de Mateus". Palácio de Nossa Senhora da Ajuda, 22 de março de 1766. AHU_CU_023-01, Cx. 24, D. 2354.

${ }^{59}$ Conforme um observador coevo muito bem informado, as disposições de 1739 foram recebidas na Bahia no sentido de que "se suprimissem os Regimentos da Ordenança, e se criassem de novo os [...] Terços de Auxiliares". $C f:$ MIRALES, José de. Historia militar do Brazil. Desde o anno de mil quinhentos quarenta e nove, em q' teve principio a fund. ${ }^{\mathrm{am}}$ da Cid. ${ }^{\mathrm{e}}$ de S. Salv. ${ }^{\text {or }}$ Bahia de todos os Santos até o de 1762. In: Anais da Biblioteca Nacional. (vol. 22). Rio de Janeiro: Typographia Leuzinger, 1900, p. 79. Já para uma historiadora, tais medidas tanto recomendavam a formação de terços auxiliares para a guarnição dos portos marítimos quanto restringiam sua existência àqueles sítios. LEONZO, N. Defesa militar..., p. 27.

${ }^{60}$ Sobre as reformas militares que incidiram nos terços e companhias de ordenanças na década de 1730, ver SILVA, Luiz Geraldo. Gênese das milícias de pardos e pretos na América portuguesa: Pernambuco e Minas Gerais, séculos XVII e XVIII. Revista de História, São Paulo, n. 169, p. 112-144, jul./dez. 2013, p. 130-136; RAMINELLI, Ronald. Élite negra en sociedad esclavista: Recife (Brasil) c. 1654-1744. Nuevo Mundo Mundos Nuevos [Online], Debates, posto online no dia 30 Novembro 2011, consultado em 30 de maio de 2013. URL: http://nuevomundo.revues.org/62216; SOUZA, Fernando Prestes de. Milicianos pardos em São Paulo: cor, identidade e política (1765-1831). Dissertação (mestrado em História). Curitiba: SCHLA, Universidade Federal do Paraná, 2011, p. 45-47. Ver também o capítulo 6, item 6.2, desta tese.

${ }^{61}$ IZECKSOHN, Vitor. Milícias. In: Anais do XXVI Simpósio Nacional de História - ANPUH. São Paulo, jul. 2011, p. 5. A abordagem de Sodré, apesar de fundada em paradigma teórico-metodológico distinto, chega a resultados semelhantes a esse respeito. SODRÉ, N. W. História militar do Brasil..., p. 45-50.
} 
precedentes, de modo análogo ao que se processou na América espanhola. A obra iniciada em 1766 não seria concluída até a década final daquele século, período em que os governadores coloniais ainda se remetiam aos termos da carta régia em questão para justificar a formação de novos terços auxiliares. ${ }^{62}$

No império português, os corpos militares de 2. ${ }^{a}$ linha se converteram, a partir de 1796, em regimentos milicianos. ${ }^{63}$ Formalizava-se, assim, o emprego de uma categoria que no mundo lusitano designava genericamente as forças militares não profissionais, isto é, constituídas pelos moradores locais que se dedicavam regularmente a tarefas civis, mas que já era institucionalizada em outros estados. ${ }^{64}$ A alteração de nomenclatura também abarcou os postos do estado-maior - a exemplo dos mestres-de-campo, que passaram a ser identificados como coronéis - bem como veio acompanhada da reafirmação de privilégios e de estímulos para que as milícias fossem conduzidas por oficiais com experiência e treinamento, provenientes das tropas de linha. Tais medidas foram justificadas no Decreto de 7 de agosto daquele ano, que as instituiu, como parte de um conjunto de "provas manifestas da [...] Real Satisfação, e do muito que elas [, as antigas Tropas Auxiliares, agora Regimentos de Milícias,] merecem”. Esse reconhecimento régio seria mera retórica? Qual o peso das milícias no conjunto do sistema militar português durante o século XVIII e as primeiras décadas do século XIX? Havia diferenças entre o reino de Portugal e o Estado do Brasil quanto ao papel e importância daquelas forças militares?

Ao perscrutar essas questões, um aspecto fundamental é a compreensão das relações de interdependência entre as tropas regulares e os corpos milicianos. No reino de Portugal, como visto anteriormente, houve grande variação no contingente de tropas regulares ao longo do século XVIII. Os dados disponíveis referem-se ao total de praças projetado pelos generais e demais autoridades militares e não aos homens efetivamente mobilizados. Contudo, apesar de tais cifras superestimarem os fenômenos concretos de arregimentação, elas permitem entrever tendências e objetivos perseguidos pela Monarquia, como sugerem Gouveia e Monteiro. ${ }^{65}$ Assim, a tropa de linha reinol deveria constar de 32.200 homens no ano de 1735, em período de relativa paz; teria ascendido a 48.240 praças em 1762, no contexto da Guerra dos Sete Anos;

\footnotetext{
${ }^{62}$ Cf:: AHU_ACL_CU_008,Cx. 38, D. 2358. Vila Boa, 19 de outubro de 1790; AHU_CU_011, Cx. 173, D. 12930. Vila Rica, 31 de dezembro de 1804.

${ }^{63} C f$.: "Decreto de 7 de Agosto de 1796. Regulando os Corpos Auxiliares do Exército, denominando-os para os futuros Regimentos de Milícias”. In: SILVA, António Delgado da. Collecção da Legislação Portugueza Legislação de 1791 a 1801. Lisboa: Typografia Maigrense, 1828, p. 295-297.

${ }^{64}$ LEONZO, N. Defesa militar..., p. 171-172.

${ }^{65}$ GOUVEIA, A. C.; MONTEIRO, N. G. A milícia..., p. 201. É daí, igualmente, que foram retirados os números apresentados adiante.
} 
e reduzido drasticamente os efetivos para 29.606 homens em 1764, no pós-guerra. Quanto às tropas auxiliares, sabe-se apenas que formavam aproximadamente 40 terços durante o período compreendido entre 1707 e 1796 . Nesse ano, o estado completo das milícias previa um total de 34.400 homens, contingente bastante inferior aos 50.756 homens que então deveriam formar a totalidade prevista das tropas regulares. Em 1800, para um total previsto de 38.638 praças de 1. ${ }^{\mathrm{a}}$ linha, deveria haver nos corpos milicianos de Portugal um total de 34.400 homens. O evidente predomínio das tropas regulares em relação à 2. ${ }^{a}$ Linha foi recuando gradualmente ao longo do século XVIII, mas sem chegar a produzir uma inversão no peso daquelas forças. Em 1812, no contexto da resistência à ocupação do reino empreendida por Napoleão, o estado completo das tropas de linha portuguesas deveria constar de 57.254 praças, ao passo que se projetava dispor de um total de 53.310 milicianos. Embora se tenha verificado oscilações significativas nas tropas regulares reinóis, de um lado, e se reconheça que os dados referentes à milícia sejam escassos para o período anterior a 1796, de outro, pode-se sugerir que o contingente miliciano idealizado pela burocracia não tenha jamais ultrapassado o da tropa regular. Já os dados atinentes ao período 1796-1812, mais completos, indicam uma ampliação da milícia tendente a nivelar seu peso ao dos militares profissionais. Na configuração social metropolitana, para cada miliciano haveria ao menos um militar de linha. 
TABELA 1.1 - Corpos militares de $10^{\mathrm{a}}$ e 2. ${ }^{\mathrm{a}}$ Linha e seus efetivos por capitania (América portuguesa, 1791-1807)

\begin{tabular}{|c|c|c|c|c|c|c|}
\hline \multirow[t]{2}{*}{ Capitania } & \multicolumn{3}{|c|}{$\begin{array}{l}\text { Regimentos Regulares, Pagos ou } \\
\text { de } 1 .^{\text {a }} \text { Linha }\end{array}$} & \multicolumn{3}{|c|}{$\begin{array}{l}\text { Regimentos Milicianos ou de } 2 .^{a} \\
\text { Linha }\end{array}$} \\
\hline & Ano & Quantidade & $\begin{array}{l}\text { Estado } \\
\text { efetivo }\end{array}$ & Ano & Quantidade & $\begin{array}{l}\text { Estado } \\
\text { efetivo }\end{array}$ \\
\hline Rio Grande do Sul & 1806 & 3 & 925 & 1806 & 1 & 2.976 \\
\hline Santa Catarina & 1807 & 1 & 671 & 1805 & 1 & 2.824 \\
\hline São Paulo & 1807 & 2 & 1.875 & 1802 & 11 & 7.063 \\
\hline Rio de Janeiro & 1800 & $\begin{array}{c}4 \mathrm{e} \\
1 \text { esquadrão }\end{array}$ & 2.398 & 1800 & 18 & 12.254 \\
\hline Minas Gerais & 1801 & $\begin{array}{c}1 \mathrm{e} \\
1 \text { companhia }\end{array}$ & 681 & 1804 & $\begin{array}{c}22 \mathrm{e} \\
4 \text { companhias }\end{array}$ & 10.793 \\
\hline Goiás & 1806 & 2 companhias & 160 & 1806 & $\begin{array}{c}4 \mathrm{e} \\
2 \text { companhias }\end{array}$ & 4.810 \\
\hline Mato Grosso & 1804 & 2 companhias & 531 & 1804 & 2 & 1.177 \\
\hline Espírito Santo & 1804 & 1 companhia & 117 & 1804 & $\begin{array}{c}1 \mathrm{e} \\
2 \text { companhias }\end{array}$ & 896 \\
\hline Bahia & 1804 & $\begin{array}{c}3 \mathrm{e} \\
2 \text { companhias }\end{array}$ & 2.032 & 1804 & 10 & 6.670 \\
\hline Sergipe & 1798 & 0 & 0 & 1805 & 2 & {$[1.300]^{\mathrm{a}}$} \\
\hline Pernambuco ${ }^{b}$ & 1804 & 2 & 1.357 & 1806 & 19 & [12.350] \\
\hline Paraíba & 1806 & $\begin{array}{l}1 \text { tropa de } \\
\text { linha }^{c}\end{array}$ & 155 & 1806 & 4 & 2.614 \\
\hline Rio Grande do Norte & 1791 & 1 companhia & 87 & 1791 & 4 & 1.809 \\
\hline Ceará & 1805 & 2 companhias & 191 & 1805 & 9 & 5.678 \\
\hline Piauí $^{\mathrm{d}}$ & 1804 & 0 & 0 & 1797 & $\begin{array}{c}2 \mathrm{e} \\
1 \text { companhia }\end{array}$ & 3.207 \\
\hline Maranhão & 1803 & 1 & 1.202 & 1797 & $\begin{array}{c}7 \mathrm{e} \\
2 \text { companhias }\end{array}$ & 8.893 \\
\hline Pará & 1807 & 4 & 1.845 & 1807 & 5 & 4.020 \\
\hline Rio Negro ${ }^{\mathrm{e}}$ & -- & -- & - & 1806 & $\begin{array}{c}2 \mathrm{e} \\
4 \text { companhias }\end{array}$ & [1.400] \\
\hline TOTAL & $\begin{array}{r}22 \\
1 \\
11 \mathrm{col}\end{array}$ & $\begin{array}{l}\text { egimentos }{ }^{\mathrm{f}} \\
\text { squadrão e } \\
\text { panhias avulsas }\end{array}$ & 14.227 & $\begin{array}{r}12 \\
15 \mathrm{col}\end{array}$ & $\begin{array}{l}\text { regimentos e } \\
\text { panhias avulsas }\end{array}$ & 90.734 \\
\hline
\end{tabular}


${ }^{\text {a }}$ Quando não dispus de mapas referentes aos contingentes efetivos dos regimentos, procedi a cálculos hipotéticos. Em tais casos, considerei vigente as diretrizes do alvará de 1796 que previam que cada corpo militar fosse constituído por 800 homens, mas, a fim de calcular em números aproximados e sem superestimar o estado efetivo, descontei 150 homens do estado completo previsto. Desse modo, tomei por estado efetivo de cada um dos regimentos o número de 650 praças. Analogamente, considerei que as companhias avulsas contavam efetivamente com 65 praças. Os colchetes - “[ ]" - indicam as ocasiões em que esse procedimento foi adotado.

${ }^{\mathbf{b}}$ Inclui a comarca de Alagoas.

${ }^{\mathbf{c}}$ Constituída por estado-maior e três companhias. Considerada como corpo militar.

d A tropa de linha que guarnecia o Piauí era proveniente do regimento de linha do Maranhão e era provida por destacamento. Foi contabilizada na tropa de linha maranhense.

e Não foram encontrados dados referentes às tropas regulares desta capitania.

f Incluindo-se no conjunto 2 legiões, 1 batalhão e 1 "tropa de linha".

Fontes: [Rio Grande do Sul] AHU_CU_019, Cx. 11, D. 669; AHU_CU_019, Cx. 11, D. 670; AHU_CU_019, Cx. 12, D. 726; [Santa Catarina] AHU_CU_021, Cx. 9, D. 523; AHU_CU_019, Cx. 12, D. 745; [São Paulo] AHU_ACL_CU_023, Cx. 29, D. 1299; AHU_ACL_CU_023, Cx. 19, D. 950; [Rio de Janeiro] AHU_ACL_CU_017, Cx. 181, D. 13282; [Minas Gerais] AHU_CU_011, Cx. 167, D. 12483; AHU_CU_011, Cx. 173, D. 12930; [Goiás] AHU_ACL_CU_008, Cx. 51, D. 2892; AHU_ACL_CU_008, Cx. 52, D. 2924; AHU_ACL_CU_008, Cx. 51, D. 2859; [Mato Grosso] AHU_CU_010, Cx. 43, D. 2097; [Espírito Santo] AHU_CU_005-01, Cx. 132, D. 26.047; [Bahia] AHU_CU_005-01, Cx. 132, D. 26.047; [Sergipe] AHU_ACL_CU_005, Cx. 218, D. 15290; AHU_CU_005-01, Cx. 132, D. 26.282-26.290; [Pernambuco] AHU_CU_015, Cx. 251, D. 16819; AHU_CU_015, Cx. 259, D. 17405; [Paraíba] AHU_CU_014, Cx. 47, D. 3316; [Rio Grande do Norte] AHU_CU_018, Cx. 8, D. 483; [Ceará] AHU_CU_006, Cx. 19, D. 1080; [Piauí] AHU_ACL_CU_009, Cx. 97, D. 7922; [Maranhão] AHU_ACL_CU_009, Cx. 130, D. 9718; AHU_ACL_CU_009, Cx. 97, D. 7922; [Pará] AHU_ACL_CU_013, Cx. 140, D. 10624; [Rio Negro] AHU_ACL_CU_013, Cx. 134, D. 10231.

No universo colonial, a realidade era radicalmente distinta. O Estado do Brasil estava longe de poder fazer repousar seu sistema defensivo prioritariamente em corpos militares regulares, como, aliás, admitiam explicitamente as altas instâncias de poder metropolitanas. Conforme uma compilação de dados extraídos de mapas informativos do estado militar das capitanias, enviados pelos governadores coloniais a Lisboa desde fins do Setecentos até o começo do século XIX, se verifica uma enorme desproporção entre a disponibilidade de tropas regulares e de milícias (Tabela 1.1). Afortunadamente, aquelas tabulações revelam o estado efetivo dos corpos militares, de modo que constituem aferições mais precisas comparativamente aos números relativos a Portugal. Em primeiro lugar, o imenso território da América portuguesa dispunha para sua defesa de apenas 22 regimentos de linha distribuídos em uma dezena de capitanias, os quais eram complementados por um esquadrão e 11 companhias avulsas, sendo essas presentes tipicamente nas unidades político-administrativas onde não havia aqueles regimentos. A expressividade da milícia na sociedade colonial salta aos olhos, uma vez que seu contingente se compunha de 122 regimentos e 15 companhias avulsas. O número de regimentos milicianos excedia o total dos corpos regulares em uma centena. Proporcionalmente, para cada regimento de linha haveria no Brasil 5,5 regimentos milicianos. Em segundo lugar, um exame aos números de praças efetivamente mobilizadas revela um 
desequilíbrio entre a $1 .^{a}$ e $2 .^{a}$ linha semelhante ao verificado quando da comparação do total de corpos militares. Ora, no período considerado, havia aproximadamente 14.227 militares pagos guarnecendo fortalezas, presídios, cidades, prédios administrativos, quartéis, estradas e registros da América portuguesa. Nada que se aproximasse aos seus 90.734 oficiais e soldados milicianos. Isso significa que para cada militar pago, haveria ao menos seis milicianos.

Toda essa sequência de números pode confundir ou até mesmo perder-se facilmente ao longo da leitura. Entretanto, ela coloca em perspectiva de modo contundente o peso da milícia colonial no interior da estrutura militar imperial portuguesa e, em particular, da do Estado do Brasil. Um primeiro aspecto a ser ter em vista é a diferença entre metrópole e colônia no tocante à disponibilidade de corpos regulares. Em 1800, o pequeno reino de Portugal projetou contar com 38.638 homens, ao passo que a América portuguesa, no mesmo período, podia dispor concretamente de pouco mais de 14 mil praças - o que representava um efetivo duas ou quase três vezes menor em relação ao reinol. De certo modo, essa discrepância deveria ser aceita e até compreensível, uma vez que Portugal abrigava a sede da Monarquia e o núcleo de poder que controlava as colônias ultramarinas. Além disso, a fragilidade defensiva lusitana na Europa era amplamente conhecida desde o século XVII, período ao longo do qual se processava uma verdadeira revolução militar bem como, correlatamente, a concorrência entre os estados se refinava e acirrava. ${ }^{66}$ Uma conjunção de fatores deve ter atuado de modo a manter um equilíbrio entre as forças militares profissionais e as milicianas no reino: a razoável disponibilidade de tropas regulares, as características demográficas portuguesas e as exigências de mão de obra agrícola e artesanal possivelmente tenderam a impor limites à formação de mais corpos milicianos.

Desse diferencial entre um e outro lado do Atlântico no tocante às tropas regulares, decorre um segundo aspecto a ser notado: a diferença entre o peso exercido pela milícia no reino e na colônia. Como se viu, a burocracia militar reinol previa contar com pouco mais de 34 mil praças de segunda linha no ano de 1800, cujo total se estiraria após uma década para cerca de 53 mil homens, em contexto turbulento e dramático para a Monarquia portuguesa. No Brasil, os milicianos ultrapassavam os 89 mil homens, formando um conjunto duas vezes maior. Em realidade, a comparação entre a massa de soldados milicianos nos dois espaços objetiva apenas sublinhar a robustez que esse grupo funcional adquirira na colônia, pois as condições para a inteligibilidade do fenômeno estão assentadas em outros aspectos. Nomeadamente, na trajetória das relações historicamente mantidas entre tais forças militares e a Coroa portuguesa

${ }^{66}$ TILLY, C. Coerção, Capital..., p. 89-156. 
- já abordada parcialmente nas páginas anteriores e objeto de exame em capítulos posteriores no tocante às milícias de pardos e pretos - assim como no quadro da carência de efetivos militares em função da reduzida tropa de linha que operava no Brasil - a terceira variável a ser aqui considerada.

\section{TABELA 1.2 - Contingente militar de $10^{\mathrm{a}}$ e $2 .^{\mathrm{a}}$ Linha do Brasil, por província (década de 1820)}

\begin{tabular}{|c|c|c|c|c|c|c|}
\hline \multirow[b]{2}{*}{ Províncias } & \multicolumn{2}{|c|}{ 1. ${ }^{a} \operatorname{Linha}$} & \multicolumn{2}{|c|}{$2 .^{a} \operatorname{Linha}$} & \multicolumn{2}{|c|}{ Totais } \\
\hline & $\begin{array}{l}\text { Estado } \\
\text { efetivo }\end{array}$ & $\begin{array}{c}\text { Estado } \\
\text { completo }\end{array}$ & $\begin{array}{l}\text { Estado } \\
\text { efetivo }\end{array}$ & $\begin{array}{c}\text { Estado } \\
\text { completo }\end{array}$ & $\begin{array}{l}\text { Total } \\
\text { efetivo }\end{array}$ & $\begin{array}{c}\text { Total } \\
\text { completo }\end{array}$ \\
\hline Rio de Janeiro & 10.106 & 11.661 & 15.015 & 18.673 & 25.121 & 30.334 \\
\hline Cisplatina & 2.725 & - - - & 514 & - - - & - - - & - - - \\
\hline Rio Grande do Sul & 1.021 & - & 4.556 & -- & -- & -- \\
\hline São Paulo & 388 & 1.112 & 6.228 & 8.229 & 6.616 & 9.341 \\
\hline Santa Catarina & 629 & 997 & 3.154 & 5.420 & 3.783 & 6.417 \\
\hline Minas Gerais & 1.001 & 1.026 & 10.153 & 13.152 & 11.154 & 14.580 \\
\hline Goiás & 169 & 179 & 4.095 & 4.172 & 4.264 & 4.351 \\
\hline Mato Grosso & 817 & 1.007 & 2.229 & 2.708 & 3.046 & 3.715 \\
\hline Espírito Santo & 446 & 489 & 1.571 & 1.589 & 2.017 & 2.078 \\
\hline Bahia & 1.349 & - & 18.402 & -- & 19.751 & -- \\
\hline Sergipe & 343 & 484 & 5.003 & 7.295 & 5.346 & 7.779 \\
\hline Alagoas & 522 & 667 & 2.566 & 3.205 & 3.088 & 3.882 \\
\hline Pernambuco & 2.329 & 4.082 & 8.602 & 11.374 & -- & -- \\
\hline Paraíba & 850 & -- & 4.500 & -- & -- & - - - \\
\hline Rio Grande do Norte & 231 & 377 & 2.861 & 3.022 & 3.092 & 3.399 \\
\hline Ceará & 962 & -- & 6.998 & 7.071 & 7.960 & - - - \\
\hline Piauí & 223 & 864 & 4.500 & 6.761 & - - - & 7.625 \\
\hline Maranhão & 969 & -- & 3.750 & - - - & 1.724 & 1.984 \\
\hline Pará & 1.124 & 3.037 & 4.220 & - - - & - - - & - - - \\
\hline SOMA & 26.204 & $-\cdots$ & 108.967 & $-\cdots$ & -- & -- \\
\hline
\end{tabular}

"Nota [do original]: As províncias que levam este sinal “. _ _" não apresentaram Mapas ou apresentam em tal estado que não se pode conhecer com exatidão o contingente de sua força militar. É pois fundado em cálculos hipotéticos que são cheias algumas das casas que lhe são relativas; todavia são essas hipóteses mui bem fundamentadas.

As demais casas que não vão preenchidas também o não são por falta dos Mapas respectivos."

Fonte: "Mapa de força militar do Brasil em 182[...]”. BN, s.m., doc. II-30,28,1. 
De fato, a milícia superava quantitativamente os corpos regulares, e com larga distância, tanto em termos do total de corporações como dos efetivos. As proporções anteriormente referidas seriam mantidas no essencial durante a década de 1821, período em que um informante não identificado, mas provavelmente a serviço do nascente império brasileiro, calculou os contingentes efetivos e completos da 1. ${ }^{\mathrm{a}}$ e 2. ${ }^{\mathrm{a}}$ linhas (Tabela 1.2). Conforme suas advertências, teve-se como base os mapas enviados pelas antigas capitanias que passaram a ser denominadas províncias, e, nos casos de ausência dos mapas ou de informações imprecisas ou ilegíveis, procedeu-se a "cálculos hipotéticos [...]; todavia são essas hipóteses mui bem fundamentadas". ${ }^{67}$ Como resultado desse esforço, aferiu-se existir no Brasil aproximadamente 26.204 militares de linha e 108.907 milicianos, ou seja, a proporção de um para quatro. Embora não leve em conta os corpos militares em si, mas apenas os totais de homens em armas em cada província, os dados dos efetivos são extremamente relevantes. Eles não apenas demonstram a continuidade da desproporção entre uma e outra linha da estrutura militar - se bem que tenha havido uma diminuição da diferença, de 1/6 para 1/4 - mas sugerem que mesmo a instalação da Corte portuguesa no Brasil, as guerras e mobilizações militares na bacia do Prata e na Guiana francesa, as lutas da independência e a formação de um novo império não foram suficientes para alterar, no essencial, o sistema militar vigente. ${ }^{68}$ A supremacia e peso inigualável das milícias revelam tratar-se, pois, de um componente estrutural da sociedade colonial e imperial. Tanto quanto no século XVIII, sabia-se que "as principais forças que hão de defender o Brasil, são as do mesmo Brasil". ${ }^{69}$ E mais: que elas se comporiam principalmente de corpos milicianos.

As tabelas 1.1 e 1.2 permitem igualmente que se visualize a distribuição dos corpos militares e de seus efetivos pelas capitanias e províncias do Brasil. Durante a primeira década do Oitocentos, verifica-se uma concentração de regimentos e companhias regulares, em ordem decrescente, nas capitanias do Rio de Janeiro (4 regimentos e uma companhia avulsa), Pará (4 regimentos), Bahia (3 regimentos e 2 companhias avulsas), Rio Grande do Sul (3 regimentos), São Paulo e Pernambuco (2 regimentos cada), Minas Gerais (1 regimento e uma companhia avulsa) e Santa Catarina, Paraíba e Maranhão (com apenas 1 regimento). Goiás, Mato Grosso, Ceará, Espírito Santo e Rio Grande do Norte contavam com apenas uma ou duas companhias regulares, ao passo que Sergipe e Piauí não dispunham de tropa de linha fixa em seu território, mas recebiam destacamentos intermitentes de tropas provenientes de outras capitanias. A

\footnotetext{
${ }^{67} C f$.: "Mapa de força militar do Brasil em 182[...]". BN/dm, doc. ii-30,28,1.

${ }^{68}$ Os fenômenos históricos em questão são examinados nesta tese mais detidamente no capítulo 3 da parte 1 e ao longo da parte 3 .

${ }^{69} C f$ : "Instrução de Martinho de Melo e Castro para Luis de Vasconcelos". Salvaterra de Magos, 27 de janeiro de 1779. In: MENDONÇA, M. C. de. Século XVIII..., p. 753-754.
} 
ausência de dados relativos ao Rio Negro pode indicar a inserção da capitania no conjunto das regiões com pouca ou nenhuma tropa de linha. Percebe-se nitidamente a tendência de profusão de tais corpos militares sob certas condições não excludentes entre si: nas regiões de maior peso político e econômico, a exemplo do Rio de Janeiro e Bahia, capital e antiga capital do Estado do Brasil, e Pernambuco, grande produtora de açúcar e algodão; nas capitanias fronteiriças relativamente a outros estados ou colônias, como Pará e Rio Grande do Sul; e igualmente nas capitanias situadas da costa marítima. Inversamente, nota-se que as regiões interioranas da colônia tenderam a demandar menor participação das tropas regulares.

Os índices de concentração de corpos milicianos nas diferentes capitanias, sem destoarem dos padrões atinentes à tropa de linha, conferem destaque para a mais importante capitania interiorana. Com efeito, com seus 22 regimentos e 4 companhias avulsas, Minas Gerais abrigava o maior número de regimentos milicianos da América portuguesa. De acordo com Nelson Werneck Sodré, essa superabundância de corpos milicianos em Minas Gerais atendia ao objetivo metropolitano de assegurar o controle das populações locais que cresceram vertiginosamente ao longo do Setecentos e, sobretudo, a cobrança de impostos e a inibição do contrabando de metais e pedras preciosas. ${ }^{70}$ Seguiam-se as capitanias de Pernambuco, com 19 regimentos, Rio de Janeiro, com 18, São Paulo, com 11, e Bahia com 9 - para mencionar apenas as cinco maiores concentrações de corporações. Os milicianos efetivamente alistados em Pernambuco e Rio de Janeiro ultrapassavam, em cada um desses espaços, os 12 mil homens. Minas Gerais contava com quase 11 mil. Em seguida, a capitania do Maranhão, que dispunha de cerca de 9 mil soldados em seus 7 regimentos e duas companhias avulsas. Por fim, São Paulo arregimentara 7 mil homens nas milícias.

Pode-se deduzir que a relação de interdependência estabelecida entre corpos regulares e milicianos formava um arranjo coerente, por assim dizer, na estrutura militar colonial. A capital do Estado do Brasil aglutinava o maior número de corpos militares de ambas as linhas. Já a Bahia dispunha de um número razoável de tropa regular, talvez uma herança do passado como sede dos vice-reis e fruto da persistência de sua proeminência político-econômica, mas relativamente pouca milícia. Na vizinha Pernambuco o inverso, muita milícia e poucas forças militares profissionais. O mesmo se passa entre o Pará, responsável por assegurar a fronteira com a Guiana francesa e por isso dotado de um contingente significativo de tropa de linha ${ }^{71}$, e

\footnotetext{
${ }^{70}$ SODRÉ, N. W. História militar do Brasil..., p. 47.

${ }^{71}$ REIS, A. C. Ferreira. A ocupação de Caiena. In: HOLANDA, S. B. de (Dir.). História geral da civilização brasileira. Tomo II, 1. o vol. São Paulo: Difusão Européia do Livro, 1962.
} 
a capitania vizinha do Maranhão, cuja força miliciana era muito superior à paraense, mas a tropa regular era consideravelmente inferior.

Estabeleciam e atualizavam-se relações de complementaridade e interdependência recíproca construídas historicamente entre tais capitanias. Esse aspecto ficou muito claro no decorrer da guerra luso-espanhola em solo americano na segunda metade do século XVIII, quando a estratégia defensiva luso-americana previa o auxílio mútuo entre as capitanias. Rio Grande do Sul e Santa Catarina receberiam reforços do Rio de Janeiro, São Paulo, Minas Gerais e até mesmo da Bahia e Pernambuco. São Paulo era considerada uma barreira que isolava o território aurífero e diamantino dos palcos da guerra, de forma que deveria prover sua própria defesa e auxiliar diretamente a feitura da guerra. Minas Gerais teve igualmente que enviar corpos militares para o Rio de Janeiro a fim de incrementar o potencial defensivo da capital da América portuguesa e, ao mesmo tempo, contribuir para bloquear o acesso estrangeiro ao seu território. ${ }^{72} \mathrm{Na}$ realidade, Minas Gerais apresentava uma força regular pífia comparativamente à importância assumida por seus corpos militares de segunda linha. A configuração militar mineira e, guardadas as proporções, sua réplica nas demais capitanias do ouro, Goiás e Mato Grosso, revela uma diferenciação fundamental entre a $1 .^{a}$ e $2 .^{a}$ linha no que se refere às funções militares. Ora, distante dos portos marítimos e de aglomerações urbanas hispano-americanas que oferecessem risco ao domínio luso-americano, a necessidade de tropa de linha não era, ali, tão urgente. Antes, confiava-se às milícias o papel de assegurar a ordem interna, conter eventuais revoltas de escravos e fazer avançar os limites da sociedade colonial frente a grupos de indígenas não assimilados e quilombolas.

Em resumo, as capitanias luso-americanas e posteriormente províncias do império do Brasil diferiam entre si quanto à distribuição e concentração dos corpos militares de primeira e segunda linha. Contudo, ainda que relativamente autônomas umas em relação às outras, elas permaneciam vinculadas e interdependentes de modo a que se remediasse eventuais desequilíbrios e se atendesse a demandas emergenciais no terreno militar. ${ }^{73} \mathrm{O}$ mais importante, porém, é sublinhar o papel central assumido pelas milícias na estrutura militar do Brasil, até 1831, diante da incapacidade de manutenção de tropas regulares em níveis mais adequados. Ora, o alto custo dos exércitos profissionais demandava esforços colossais por parte dos estados. Tais mobilizações, em geral, produziam tensões e conflitos sociais cujo impacto

\footnotetext{
${ }^{72}$ Sobre a estratégia de guerra luso-americana nas décadas de 1760 e 1770, ver: SILVA, L. G.; SOUZA, F. P. de; PAULA, L. F. de. A guerra luso-castelhana e o recrutamento de pardos e pretos...; MELLO, C. F. Pagano de. Os Corpos de Auxiliares e de Ordenanças...; COTTA, Francis Albert. Negros e mestiços nas milícias da América portuguesa. Belo Horizonte: Crisálida, 2010, p. 35-59.

${ }^{73}$ SILVA, Luiz Geraldo. Gênese das milícias de pardos e pretos...
} 
variava desde a fuga ao recrutamento e ao pagamento de impostos até a eclosão de movimentos sociais de contestação e revolta mais amplos por parte dos grupos, comunidades e regiões inteiras que sofriam a coerção. ${ }^{74}$ Vai daí as milícias serem consideradas a mais viável alternativa à carência dos corpos regulares. No entanto, ficam as questões: como era remunerado o serviço militar prestado por homens que abandonavam temporariamente o trabalho habitual com o qual sustentavam suas famílias para empunhar armas em nome do monarca? O que os estados faziam, a partir de seus limitados recursos, para lograrem a lealdade e eficiência desses corpos militares não profissionais?

Em realidade, soldados auxiliares e milicianos eram compelidos a participar de exercícios militares de instrução, treinamento, mostras gerais e ritos cerimoniais regularmente algumas vezes ao ano. Em tais circunstâncias não havia pagamento de soldo. Apenas os oficiais do estado-maior das corporações, como sargentos-mores (ou majores) e ajudantes, responsáveis pela instrução dos subordinados, percebiam soldo mensal. De resto, apenas quando efetivamente mobilizados para a guerra ou para o serviço militar ordinário via destacamentos é que os milicianos, desde capitães até soldados, eram pagos. ${ }^{75}$ Ainda assim, a folha mensal de pagamento aos oficiais maiores e oficiais reformados ${ }^{76}$ era extremamente onerosa às capitanias e províncias a ponto de esse aspecto embasar projetos para a desativação de alguns regimentos milicianos entre fins do século XVIII e primeiras décadas do XIX, inclusive na América espanhola. ${ }^{77}$ A literatura que se ocupa com o tema da fiscalidade no universo colonial fornece vários exemplos das dificuldades enfrentadas por governadores: mesmo com a ampliação das fontes de receita e eficácia no recolhimento de impostos os recursos pareciam sempre insuficientes para o pagamento do soldo dos militares. ${ }^{78} \mathrm{Em} \mathrm{1807,} \mathrm{um} \mathrm{governador} \mathrm{e} \mathrm{capitão-}$ general de São Paulo viu-se em um dilema: se mantivesse a tropa de linha incompleta, o pagamento estaria em dia; mas, se completasse as vagas nos dois regimentos, "se lhes deixam de pagar três ou quatro meses no ano, como sucedeu em todos os governos anteriores". ${ }^{79}$ Desse

\footnotetext{
74 TILLY, Charles. Coerção, Capital e Estados Europeus..., capítulos 2 e 3; PEREGALLI, Enrique. Recrutamento militar no Brasil colonial. Campinas: Editora da UNICAMP, 1986; MELLO, C. F. Pagano de. Os Corpos de Auxiliares e de Ordenanças...

${ }^{75} C f$ :: "Carta Régia de 7 de janeiro de 1645. Criação de Soldados Auxiliares"...; para uma exemplificação mais detalhada e referenciada, ver, adiante, a seção "As funções militares dos milicianos pardos".

${ }^{76}$ A reforma era uma espécie de aposentadoria e levava em conta o período e qualidade dos serviços bem como os merecimentos ou justificativas do oficial postulante.

${ }^{77}$ Ver o item 6.3.1 desta tese.

78 ARAUJO, L. A. S. Contratos, comércio e fiscalidade na América portuguesa (1641-1730). In: CARRARA, A. A.; SANTIRÓ, E. S. (Coords). Guerra e fiscalidade na Ibero-América colonial (séculos XVII-XIX). Juiz de Fora: Ed. UFJF, 2012, p. 249-263; AIDAR, B. Novo imposto, nova ordem: poderes locais e fiscalidade na capitania de São Paulo, 1765-1775. In: CARRARA, A. A.; SANTIRÓ, E. S. (Coords). Guerra e fiscalidade..., p. 301-333.

${ }^{79}$ Cf:: AHU_ACL_CU_023, Cx. 29, D. 1299. São Paulo, 12 de fevereiro de 1807.
} 
modo, cabia ao Estado português lançar mão de recursos alternativos à moeda corrente a fim de remunerar o serviço miliciano prestado no reino e notadamente em sua colônia americana, bem como lograr avanços em termos de eficácia por parte desse setor do exército.

Não é por outra razão que a Coroa acenou para a concessão de privilégios, isenções e honrarias aos integrantes dos corpos auxiliares, desde o ato de sua criação, em 1645. A diferenciação dos auxiliares em relação às ordenanças era promovida do ponto de vista funcional e do estatutário. É significativo que no curto texto da carta régia em questão haja quatro menções à possibilidade de concessão/obtenção de "privilégio(s)", três para "mercê(s)", uma referência a "preeminências" e outra a "acrescentamento". Resumidamente, ofertou-se a todos os soldados auxiliares "o privilégio de que gozam os pagos, e outros que parecer mais conveniente". Aos capitães, "pessoas de experiência e valor", o monarca garantia que, "além de gozarem de todas as honras e preeminências de capitães pagos, lhes terei por particular serviço o que nesta forma me fizerem, para as ocasiões de sua honra e acrescentamento". Especial consideração régia obteria igualmente o sargento-mor designado para a formação dos corpos militares auxiliares e a generalidade da gente reputada como "nobres e honrados", aos quais "se deve esperar que, por serem de qualidade e afazendados, acudam com maior vontade à defesa da sua pátria e meu serviço" e também "por assentarem melhor [neles] as mercês que espero fazer aos que assim me servirem". Desse grupo é que, provavelmente, se comporiam as companhias de cavalaria dotadas de "maiores privilégios e honras". 80

No mesmo ano, expediu-se um alvará detalhando-se outras modalidades de privilégios ofertados aos auxiliares. Objetivava-se fazer com que os alistados nas "companhias dos Soldados Auxiliares o façam de melhor vontade e se animem a me servir com mais gosto daqui por diante". Segue-se uma lista dos privilégios mencionados na ocasião: isenção de contribuições (em dinheiro, gêneros, animais de carga ou empréstimo de imóveis); privilégios do Estanco do Tabaco; preferência no provimento de propriedades e serventias de ofícios aos indivíduos de qualidade e merecimentos; "que gozem dos mesmos privilégios dos Soldados pagos todo o tempo que estiverem alistados, e posto que deixem de ir às fronteiras, por não ser necessário, se lhes terá respeito como se servissem na guerra"; isenção opcional aos que servirem um ano nas fronteiras; "que os capitães e oficiais, enquanto o forem, [...] gozarão dos mesmos privilégios da gente paga e se lhes passarão patentes assinadas por mim, [...] reputandose-lhes o tal serviço como se fora feito nas fronteiras do Reino, em viva guerra"; isenção dos alardes das ordenanças; privilégios específicos aos bagageiros e gastadores; finalmente,

\footnotetext{
${ }^{80} C f$ : “Carta Régia de 7 de janeiro de 1645. Criação de Soldados Auxiliares”...
} 
delimitação do serviço dos auxiliares ao espaço das províncias referentes ao distrito das companhias e nas fronteiras sujeitas ao seu governador das armas. ${ }^{81}$ Esse conjunto de promessas destinadas aos auxiliares coloca em evidência o peso assumido pelo capital simbólico na sociedade de Antigo Regime assim como formaliza uma série de vantagens materiais e institucionais aos soldados de segunda linha. Elaborados sob a atmosfera da guerra da restauração frente à Espanha, tais documentos manifestam a preocupação fundamental em equiparar as novatas tropas auxiliares à tropa paga. Explicitamente, os privilégios se equivalem a partir de então; implicitamente, as obrigações deveriam seguir o mesmo rumo.

As concessões régias aos auxiliares seguirão ao longo do ministério pombalino (17501777), mas com caráter predominantemente simbólico. Em 1754, permitiu-se aos oficiais dos terços auxiliares e das ordenanças "que rodam com os oficiais dos regimentos pagos" que usassem "de galão de ouro ou prata nos seus chapéus", isto é, enfeites que desempenhavam a função de distintivos militares. ${ }^{82}$ Por outro lado, a conjuntura emergencial da guerra lusoespanhola que envolveu as colônias ibéricas na América provocou a reorganização e mesmo a formação e difusão dos corpos militares de segunda linha, como visto anteriormente. Na América portuguesa, a carta régia de 22 de março de 1766, que foi o principal instrumento legislativo de sua reestruturação militar, coroou a relação estabelecida há mais de um século entre o serviço militar de segunda linha e o acesso a privilégios, honras e isenções. De acordo com seu texto, esperando-se a fidelidade e bons serviços de oficiais e soldados, o rei concedeu que "os serviços que fizerem os mesmos oficiais, desde o posto de alferes até o de mestre-decampo [...], sejam despachados como os dos oficiais das Tropas Pagas [...]; e que possam usar, assim os ditos oficiais como os soldados, de uniformes, divisas e cairéis no chapéu, somente com a diferença de que as divisas e cairéis dos oficiais podem ser de ouro ou de prata, e as dos soldados não passarão de lã". Em contrapartida, "serão obrigados todos os oficiais e soldados a terem, à sua custa, espadas e armas do mesmo adarme, e os da cavalaria a terem e sustentarem à sua custa um cavalo e um escravo para cuidar nele, sem que nas ditas armas, cavalos e escravos se lhes possa fazer penhora, embargo ou execução alguma". ${ }^{83}$

\footnotetext{
${ }^{81}$ Cf:: “Alvará sobre os privilégios dos Auxiliares". Monte Mór o Novo, 24 de novembro de 1645. In: Systema, ou collecçaõ dos regimentos reaes. (tomo 5). Lisboa: Officina Patriarcal de Francisco Luiz Ameno, 1789, p. $228-229$.

${ }^{82} C f$.: "Aviso em que se permite que os oficiais dos Terços Auxiliares e Ordenanças possam trazer galão de ouro ou prata nos seus chapéus”. Paço de Belém, 4 de julho de 1754. In: Collecção Chronologica de leis extravagantes, posteriores a' nova compilação das Ordenações do Reino, publicadas em 1603. (tomo 2). Coimbra: Real Imprensa da Universidade, 1819 , p. 32.

${ }^{83} C f$ : : "Carta de D. José I ao governador e capitão-general de São Paulo, morgado de Mateus". AHU_CU_02301, Cx. 24, D. 2354. Palácio de Nossa Senhora da Ajuda, 22 de março de 1766.
} 
A equiparação dos oficiais milicianos aos oficiais das tropas pagas, mencionada nesses vários textos de legislação militar, implica o oferecimento de vantagens significativas aos primeiros. Em primeiro lugar, garante o desfrute do foro militar aos oficiais de segunda linha aplicável nos casos em que estes cometessem infrações ou crimes durante a execução das tarefas militares. Em tais circunstâncias, os milicianos deveriam ser julgados exclusivamente por um tribunal militar. Por questões específicas ao universo hispano-americano, a exemplo da tributação das castas, lá as disputas em torno do fuero militar tornaram-se uma das grandes questões sociopolíticas no decorrer do século XVIII. Em segundo lugar, consideravam-se equivalentes os postos regulares e milicianos em termos de graduação e técnica militar, honras e privilégios. Complementarmente, em terceiro lugar, isso significou que os corpos militares auxiliares e milicianos eram reconhecidos como fonte de nobilitação tal como o eram os militares de carreira. "É notório a todo o mundo que os postos militares enobrecem os sujeitos a quem forem conferidos", afirmou, no começo do Oitocentos, o autor de Privilégios da nobreza e fidalguia de Portugal ao abrir o capítulo intitulado "Da nobreza civil proveniente dos postos da milícia". ${ }^{84}$ Ainda segundo o especialista,

os guerreiros [...] têm direito e talvez preferência aos prêmios de honra, de glória e de estima com que o Estado favorece aos que se distinguem na causa pública: prêmios que as mais das vezes são pagos com a moeda de um grau de nobreza, inventada pelos soberanos para remunerarem grandes serviços sem exaurirem seus tesouros $\left[\ldots . .{ }^{85}\right.$

Entretanto, essa modalidade específica de nobreza, diferente da nobreza de corte, "não se ganha por via das armas sem se obter algum posto de milícia; o de capitão é suficiente para nobilitar" ${ }^{86}$

Como se vê, a Coroa portuguesa valeu-se de um vasto leque de privilégios, isenções e promessas de mercês a fim de garantir a lealdade e bons serviços dos soldados auxiliares e depois milicianos. É o que se nota particularmente em relação aos momentos dramáticos da guerra, tanto no reino como na realidade colonial, nos quais se revelava a debilidade da estrutura militar portuguesa, a escassez de tropas regulares e de recursos para propiciar oportunidades adequadas de defesa. O Estado compartilhava com a população local as responsabilidades militares e, em função de sua posição de dependência, se obrigava a reservar um papel central

\footnotetext{
${ }^{84}$ Cf:: OLIVEIRA, Luiz da Silva Pereira. Privilegios da nobreza, e fidalguia de Portugal. Lisboa: Oficina de João Rodrigues Neves, 1806, p. 41.

${ }^{85}$ Cf:: OLIVEIRA, Luiz da Silva Pereira. Privilegios da nobreza, e fidalguia de Portugal..., p. 41-42.

${ }^{86}$ Cf: : OLIVEIRA, Luiz da Silva Pereira. Privilegios da nobreza, e fidalguia de Portugal..., p. 44; ver também GOUVEIA, A. C.; MONTEIRO, N. G. A milícia..., p. 201-203.
} 
às milícias e aos milicianos, sobretudo nas colônias, cuja realidade manteve-se com D. João VI e foi herdada pelo primeiro reinado do império do Brasil.

Vai daí que o processo que se encaminhava no sentido da obtenção, jamais lograda, do monopólio do emprego da força e da violência pelo Estado e na direção da construção do exército moderno ocorria em ritmo e intensidade mais elevados na Europa em relação à periferia ultramarina dos impérios coloniais, mesmo porque a concorrência internacional em solo europeu manteve-se mais acirrada e exigente em termos de recursos em relação aos demais espaços mencionados. De qualquer modo, como afirmam Tilly e Gouveia e Monteiro, os estados que experimentaram o paulatino processo de construção do exército moderno conviveram e até mesmo dependeram, por toda a modernidade, de formas militares não profissionais. ${ }^{87}$ Assim, o fenômeno da concentração dos meios de coerção por parte dos estados europeus (incluindo-se seus governos coloniais) em relação às forças sociais centrífugas não pôde prescindir jamais da colaboração dos poderes locais, de modo que o sentido mais geral das disposições contidas na Lei das Armas, de meados do século XVI, teve que ser mantido até bem avançado o século XVIII. Ao invés de desarmar seus súditos, Portugal estimulava a que estes dispusessem de seu próprio armamento, desde que inseridos em corpos militares de auxiliares, milícias ou ordenanças. Conclusivamente, pode-se sugerir que a Coroa portuguesa promoveu um equilíbrio entre forças regulares e de segunda linha no reino em troca de uma “milicianização" do mundo colonial - o mesmo deve ter se passado no mundo hispânico ${ }^{88}$. Isto é, havia a opção deliberada de investir os limitados recursos financeiros prioritariamente na estrutura militar europeia, cuja estratégia era complementada pela delegação de amplas funções e responsabilidades militares ao conjunto dos habitantes da América portuguesa.

\subsection{As milícias de pardos e de pretos na América portuguesa (séculos XVII a XIX)}

Em 1797, quando enfim formou-se um regimento miliciano composto por homens pardos livres na capitania de São Paulo, corpos militares dessa natureza já vivenciavam uma trajetória secular na América portuguesa. A despeito de ser amplamente referida na historiografia, a noção conforme a qual os corpos militares compostos por pardos e pretos

\footnotetext{
${ }^{87}$ TILLY, C. Coerção, Capital e Estados Europeus..., p. 125-127; GOUVEIA, A. C.; MONTEIRO, N. G. A milícia..., p. 199.

${ }^{88}$ MARCHENA FERNÁNDEZ, J. Ejército y milicias..., p. 91-160.
} 
sofreram multiplicação vertiginosa na América portuguesa ao longo do século XVIII carece quase que completamente de detalhamento empírico. ${ }^{89}$ Há uma evidente escassez de dados sobre a quantidade e disposição espacial dos corpos militares exclusivos a pretos e pardos existentes na América portuguesa. Essa ausência revela ao menos dois aspectos centrais a respeito dos trabalhos até então desenvolvidos por parte da historiografia brasileira: 1) a preferência em examinar casos de capitanias ou vilas e cidades isoladamente e a correlata dificuldade em transcender desses âmbitos regionais em função de perspectiva mais ampla. Esse aspecto é evidente inclusive em estudos que se propuseram expressamente a examinar as milícias em toda a América portuguesa ${ }^{90} ; 2$ ) a pequena ocorrência de trabalhos dedicados a essa temática ou que apresentem pontos de convergência entre a história militar e a história social dos homens livres de cor luso-americanos.

Na discussão que se segue, será apresentado um quadro histórico concernente à formação e distribuição espacial dos corpos militares integrados por pretos e por pardos na América portuguesa entre os anos 1633 e 1831, ou seja, desde a criação das primeiras corporações até a extinção das milícias, já no contexto do Brasil imperial. Além de objetivar dimensionar o peso dessas instituições no conjunto da América portuguesa, esse exame consiste em etapa fundamental para que se possa inserir o caso particular da capitania de São Paulo em um processo histórico mais amplo, do qual ele efetivamente fez parte. Cabe esclarecer que, embora os terços de ordenanças e as companhias avulsas sejam considerados elementos integrantes do longo processo de formação das corporações exclusivas a pretos e pardos, o levantamento quantitativo exposto adiante privilegia os corpos militares de segunda linha que atingiram a formatação de terço, regimento ou batalhão. Além da inviabilidade em mapear e trabalhar com tantas e díspares corporações militares distribuídas pelos vários recantos da colônia, há razões de ordem conceitual para conferir destaque às tropas de segunda linha arregimentadas.

Em primeiro lugar, auxiliares e depois milícias distinguiam-se das ordenanças, ou terceira linha, tanto por suas funções militares quanto por seus privilégios. Pelo menos da segunda metade do século XVIII em diante, é possível afirmar que os corpos militares de

\footnotetext{
${ }^{89}$ Para citar alguns exemplos da menção à multiplicação e difusão das milícias de pardos e de pretos ocorrida no século XVIII, veja-se KLEIN, Herbert S. Os homens livres de cor na sociedade escravista brasileira. Dados Revista de Ciências Sociais, n. 17, p. 3-27, 1978, p. 4; RUSSELL-WOOD, A. J. R. Escravos e libertos no Brasil colonial. Trad. Maria Beatriz de Medina. Rio de Janeiro: Civilização Brasileira, 2005, p. 131 e 133; LARA, Silvia Hunold. Fragmentos Setecentistas: escravidão, cultura e poder na América portuguesa. São Paulo: Companhia das Letras, 2007, p. 142, 167; KRAAY, Hendrik. Política racial, Estado e Forças Armadas na época da independência: Bahia, 1790-1850. Trad. Magda Lopes. São Paulo: Hucitec Editora, 2011, p. 133-134.

${ }^{90}$ COTTA, Francis Albert. Negros e mestiços nas milícias da América portuguesa...
} 
segunda linha passaram por processo de relativa profissionalização militar. Na realidade da América espanhola o fenômeno está muito bem demarcado por ocasião da transformação das milícias provinciais ou tradicionais em milícias disciplinadas, isto é, padronizadas, adestradas, equipadas e efetivamente conectadas aos poderes centrais. ${ }^{91}$ Já no caso luso-brasileiro os indícios mais incisivos da tendência a se ampliar a diferença existente entre auxiliares e ordenanças estão presentes em um alvará de 1796, o qual primava que aqueles, dali em diante denominados milícias, estivessem "em tudo conformes [às] tropas regulares [...] na sua organização e formatura". ${ }^{92}$ A aproximação entre milícia e corpos regulares indica a importância militar assumida por aqueles corpos militares não profissionais, aspecto que se refletia nos privilégios concedidos à segunda linha já desde a criação dos auxiliares em Portugal. Ademais, a oficialidade dos terços, regimentos e batalhões milicianos de pardos e de pretos distinguia-se da oficialidade das ordenanças e das simples companhias avulsas de auxiliares não apenas pelo número, evidentemente mais avultado, de homens que a integravam, mas pela estima social atribuída àqueles postos. Por todos esses aspectos, sugere-se aqui que os corpos militares em tela constituíram a forma institucionalmente mais elevada de participação de egressos do cativeiro e seus descendentes imediatos na vida social e política da colônia e até mesmo do primeiro reinado.

Embora escravos africanos e crioulos - isto é, nascidos na América portuguesa -, indígenas em processo de assimilação à sociedade colonial, e pardos e pretos libertos ou nascidos livres estivessem envolvidos na defesa dos territórios luso-americanos desde o século $\mathrm{XVI}^{93}$, a incorporação formal de pardos e pretos em unidades militares identificadas como específicas a estes grupos remonta ao contexto das guerras luso-holandesas travadas em territórios então pertencentes às capitanias da Bahia (1624-1625) e de Pernambuco (1630-1635 e 1645-1654). ${ }^{94}$ Sabe-se que as ações militares do soldado e depois capitão mulato Manuel Gonçalves Dória no contexto da expulsão dos holandeses da cidade de Salvador tornaram-no o "primeiro afro-brasileiro" a receber o título de cavaleiro da Ordem de Santiago. ${ }^{95}$ Não há,

\footnotetext{
${ }^{91}$ MARCHENA FERNÁNDEZ, J. Ejército y milicias..., p. 91-210.

92 Cf:: Decreto de 7 de Agosto de 1796. Regulando os Corpos Auxiliares do Exército, denominando-os para osfuturos Regimentos de Milícias. In: SILVA, António Delgado da. Collecção da Legislação Portugueza Legislação de 1791 a 1801. Lisboa: Typografia Maigrense, 1828.

$93 \mathrm{O}$ fato de populações socialmente inferiorizadas - tais como índios, escravos africanos e crioulos, e mestiços livres ou libertos - cooperarem com as monarquias ibéricas desde o século XVI não permite pressupor a inexistência de comportamento diferente por parte dessas mesmas populações, as quais, aliás, em vários casos se voltaram contra os colonizadores e até mesmo se associaram a invasores estrangeiros.

${ }^{94}$ Sobre as guerras luso-holandesas ver MELLO, Evaldo C. de. Olinda restaurada: guerra e açúcar no Nordeste, 1630-1654. $2^{\mathrm{a}}$ ed. Rio de Janeiro: Topbooks, 1998.

95 DUTRA, Francis A. A hard-fought struggle for recognition: Manuel Gonçalves Dória, first Afro-Brazilian to become a Knight of Santiago. The Americas, v. 56, n. 1, p. 92-113, 1999.
} 
porém, evidências de que seus serviços militares tenham sido realizados em corporação militar privativa a homens de cor ou de que esta, no caso de ter existido, tenha sobrevivido à guerra. Por outro lado, dispõe-se de fragmentos documentais mais abundantes acerca do "bando de cativos e negros livres e libertos comandado por Henrique Dias nas guerras de Pernambuco", o qual provavelmente seja o primeiro corpo militar institucionalizado composto por africanos e seus descendentes na América portuguesa. ${ }^{96}$ Este corpo militar teria sido formado em Pernambuco, em 1633, ao calor das movimentações militares, com apenas algumas dezenas de soldados livres e cativos. A originalidade inscrita na composição de suas fileiras conferiu-lhe caráter provisório. Portanto, a confirmação da conservação do então "terço de homens pretos e pardos" no ano de 1657 - fruto em grande medida das pressões exercidas na Corte lisboeta por Henrique Dias, que havia algum tempo era "cabo e governador dos pretos e mulatos" - foi um fenômeno importante para seu processo de institucionalização. ${ }^{97}$ Em fins do Seiscentos, aquela corporação era composta por várias companhias de pretos forros distribuídas por diferentes vilas e freguesias da capitania pernambucana, as quais encontravam-se já agregadas sob a forma de terço - o Terço de Henrique Dias. Ainda no contexto da expulsão dos holandeses de Pernambuco, formaram-se na Bahia companhias militares com negros a partir de 1638, as quais foram inicialmente incorporadas ao terço do mestre-de-campo preto Henrique Dias e tenderam, ao fim das guerras luso-holandesas, a lograrem relativa autonomia em relação ao terço dos pretos de Pernambuco e a replicar a corporação em território baiano. ${ }^{98}$

\footnotetext{
${ }^{96}$ MELLO, José Antônio Gonsalves de. Henrique Dias: governador dos pretos, crioulos e mulatos do Estado do Brasil. Recife (PE): Universidade do Recife, 1954; SILVA, Luiz Geraldo. Gênese das milícias de pardos e pretos na América portuguesa: Pernambuco e Minas Gerais, séculos XVII e XVIII. Revista de História, São Paulo, n. 169, p. 112-144, jul./dez. 2013, p.122-126; PINHEIRO, J. C. Fernandes. Henrique Dias. Biographia dos brasileiros illustres, por armas, virtudes, etc. Revista do Instituto Histórico e Geográfico Brasileiro (RIHGB), Rio de Janeiro, tomo XXI, parte 1, p. 365-383, 1868; MATTOS, Hebe. "Black Troops" and hierarchies of color in the Portuguese Atlantic World: The case of Henrique Dias and his Black Regiment. Luso-Brazilian Review, v. 45, n.1, p. 6-29, 2008; SILVA, Kalina Vanderlei. Os Henriques nas Vilas Açucareiras do Estado do Brasil: Tropas de Homens Negros em Pernambuco, séculos XVII e XVIII. Estudos de História, Franca, v. 9, n.2, p. 145-194, 2002.

${ }^{97}$ Cf:: "Registro da patente de Henrique Dias, cabo e governador dos pretos e mulatos". Bahia, 4 de setembro de 1639. Documentos Históricos (doravante DH), v. 18, p. 95-96; "Ordem que se enviou ao Governador de Pernambuco acerca da conservação, preeminências e liberdades dos soldados do terço do Governador Henrique Dias". Bahia, 19 de agosto de 1658. DH, v. 4, p. 93-94.

${ }^{98} C f$ :: "Petição que fizeram os oficiais do terço da gente preta desta cidade ao excelentíssimo senhor conde vicerei”. Bahia, 18 de fevereiro de 1736. $D H$, v. 76 , p. 345-348. A afirmação de que o terço dos pretos baiano conquistou relativa - e não completa - autonomia frente ao terço pernambucano prende-se a indícios de que, até meados do século XVIII, os Henriques de Salvador continuavam consultando o mestre-de-campo da corporação pernambucana sobre certos assuntos ainda que estivessem alocados em um corpo militar separado daquele que the deu origem. Ver SILVA, Luiz Geraldo. Sobre a "etnia crioula": o Terço dos Henriques e seus critérios de exclusão na América portuguesa do século XVIII. In: VENÂNCIO, R. P.; GONÇALVES, Andréa L.; CHAVES, Cláudia M. das G. (Orgs.). Administrando impérios. Portugal e Brasil nos séculos XVIII e XIX. Belo Horizonte: Fino Traço, 2012, p. 71-96.
} 
A institucionalização destas tropas se efetivaria ao longo da segunda metade do século XVII e começo do XVIII, conforme sugere Silva, quando as ações militares deslocaram-se do combate aos inimigos externos para o enfrentamento a índios bravios e a comunidades quilombolas, os quais eram encarados como inimigos internos à dominação colonial portuguesa. ${ }^{99}$ Nessa conjuntura, os ainda recentes corpos militares de pretos e pardos perambularam em campanhas militares pelos vastos sertões compreendidos entre as capitanias da Bahia, Pernambuco, Sergipe d'El Rey, Paraíba, Rio Grande e Ceará, acompanhados, ocasionalmente, de alguns corpos militares compostos por brancos e índios. Vai daí a formalização, em 1674, de uma companhia de pardos livres previamente existente na cidade de São Cristóvão, capital do Sergipe, bem como é provável que se situem nesse contexto os germes das companhias de pardos e das de pretos atuantes já antes de 1757 nas vilas das Alagoas e do Penedo, comarca das Alagoas, todas pertencentes ao Terço de Henrique Dias e ao Regimento dos Pardos sediados em Pernambuco. ${ }^{100}$ Nesse momento de enraizamento dos terços constituídos por homens de cor na sociedade açucareira colonial, produziram-se importantes mutações na composição de suas fileiras, uma vez que passou-se a vetar o ingresso de homens cativos nos corpos militares que então se tornam privativos de pretos e de pardos livres ou libertos. Ademais, com a formalização dessas companhias e terços no mesmo período ${ }^{101}$, processou-se a clivagem entre as corporações militares de pretos e as de pardos livres que seria reiterada até a extinção das ordenanças e milícias no império do Brasil, em 1831. ${ }^{102}$

A formação de corpos militares congêneres nas demais regiões da América portuguesa se verificou em períodos históricos mais avançados, de modo que, efetivamente, o século XVIII assiste a uma extraordinária multiplicação e dispersão territorial de companhias, terços e, posteriormente, regimentos de pardos e de pretos forros e livres. O Rio de Janeiro e a porção litorânea do território em que se constituiu a capitania de São Paulo, com modesta produção

\footnotetext{
${ }^{99}$ Durante quase toda a segunda metade do século XVII a corporação militar em questão deu as costas para o mar e atuou nos sertões das capitanias da Bahia, Pernambuco, Rio Grande do Norte e Ceará tanto na "guerra dos bárbaros" quanto no combate ao quilombo dos Palmares. Ver PUNTONI, Pedro. A guerra dos bárbaros. Povos indígenas e a colonização do Sertão do Nordeste do Brasil, 1650-1720. São Paulo: Hucitec, 2002; e a sugestiva interpretação de SILVA, L. G. Gênese das milícias..., p. 122-126.

${ }^{100}$ Cf:: "Patente de capitão da Companhia dos Homens pardos da Capitania de Sergipe del-Rei provida na pessoa de Francisco de Barros". Bahia, 18 de dezembro de 1674. DH, v. 12, p. 342-344; "Ofício do governador da capitania de Pernambuco, Luís Diogo Lobo da Silva, ao secretário de Estado da Marinha e Ultramar, Tomé Joaquim da Costa Corte Real, remetendo os mapas demonstrativos das forças militares daquela capitania". AHU_CU_015, Cx. 88, D. 7184. Recife, 22 de fevereiro de 1759.

${ }^{101}$ Há referências à companhia específica dos "Homens Pardos" da Bahia para 1668. Ver "Portaria para o Capitão dos Homens Pardos cobrar a finta dos seus soldados". Bahia, 19 de abril de 1668. DH, v. 7, p. 359.

102 SILVA, Luiz Geraldo. Sobre a "etnia crioula": o Terço dos Henriques e seus critérios de exclusão na América portuguesa do século XVIII. In: VENÂNCIO, R. P.; GONÇALVES, Andréa L.; CHAVES, Cláudia M. das G. (Orgs.). Administrando impérios. Portugal e Brasil nos séculos XVIII e XIX. Belo Horizonte: Fino Traço, 2012, p. 71-96.
} 
açucareira e igualmente moderado acesso ao tráfico atlântico de escravos, ocupavam posição secundária na economia colonial até fins do século XVII. A partir daí, as descobertas de ouro e diamantes efetuadas sertão adentro alteraram profundamente o panorama local e mesmo o equilíbrio político e econômico da colônia. Com efeito, ao longo da primeira metade do Setecentos, e sob o influxo da atividade mineradora, ocupar-se-ão territórios formadores das capitanias de Minas Gerais, Goiás e Mato Grosso, bem como a cidade do Rio de Janeiro se converterá no principal porto de desembarque de escravos africanos na América portuguesa.

As referências mais recuadas relativas à existência de companhias de pardos e de pretos no Rio de Janeiro remontam exatamente à última década do século XVII e a primeira do XVIII. Sabe-se que, em 1703, havia uma companhia dos pardos agregada ao Terço da Ordenança da parte da cidade de São Sebastião do Rio de Janeiro, composta por 100 homens, e uma companhia de pretos forros, esta formada em 1698 e com um efetivo de 66 homens, a qual permanecia anexa ao Terço da Ordenança da banda d'além mar da parte de São Gonçalo. ${ }^{103}$ Por sua vez, a multiplicação daqueles corpos militares parece ter ocorrido já na década de 1710, e vincula-se a dois aspectos centrais. O primeiro deles seria o impacto das invasões francesas ao Rio de Janeiro, estas motivadas em grande medida pela opulência vivida regionalmente em função da circulação de ouro e de cativos; já o segundo se refere ao desenvolvimento de uma camada populacional composta por ex-escravos e seus descendentes, cada vez mais robusta e capaz de empunhar armas. ${ }^{104}$ No entanto, essa proliferação corporativa não ultrapassaria o patamar das companhias durante a primeira metade do século XVIII, de tal forma que o processo de constituição de terços ou regimentos semelhantes àqueles existentes nas capitanias do Nordeste açucareiro seria ali mais tortuoso, como mais adiante se verá. É o que se processa na costa litorânea de São Paulo. Em 1711, por ocasião da segunda invasão de corsários franceses à cidade do Rio de Janeiro, formou-se, às pressas, uma "Companhia de Infantaria de Ordenança de Homens Pardos Sujeitos" na vila de Santos. Tratava-se de uma companhia militar integrada por escravos, e é plausível que tenha sido o primeiro corpo militar destinado

\footnotetext{
${ }^{103}$ Cf:: "Mapa do Terço da Ordenança da parte da cidade de S. Sebastião do Rio de Janeiro, sob o comando do Coronel Chrispim da Cunha Tenreiro"; "Mapa do Terço da Ordenança da banda d'além mar, da parte de São Gonçalo, sob o comando do Coronel Balthazar de Abreu Cardoso". AHU_CU_017-01, Cx. 14, Docs. 2.768 e 2.769; MARTA, Michel Mendes. Em busca de honras, isenções e liberdades: as milícias de homens pretos forros na cidade do Rio de Janeiro (meados do século XVIII e início do XIX). Dissertação (mestrado em História). Niterói: ICHF, Universidade Federal Fluminense, 2013, p. 40-41.

104 Sobre a relação entre as invasões francesas e a reorganização do sistema defensivo do Rio de Janeiro, ver MELLO, Christiane F. Pagano de. Os Corpos de Auxiliares e de Ordenanças na Segunda Metade do Século XVIII. As Capitanias do Rio de Janeiro, São Paulo e Minas Gerais e a Manutenção do Império Português no Centro Sul América. Tese (doutorado em História). Niterói: ICHF, Universidade Federal Fluminense, 2002, p. 108-117.
} 
exclusivamente a homens de cor daquela capitania. ${ }^{105}$ A primeira referência a uma companhia de homens livres de cor naquela configuração social é ligeiramente posterior, de 1726, e reporta-se à "Companhia de Ordenança dos Homens Pardos Livres”, da vila de Santos. ${ }^{106}$

Cumpre notar, no caso das capitanias do ouro, ou seja, Minas Gerais, Goiás e Mato Grosso, que a emergência de tropas formadas por pardos e pretos ocorreu paralelamente à própria formação dos núcleos populacionais. O fenômeno é revelador da presença maciça de escravos, de egressos do cativeiro e de mestiços de toda sorte desde o nascimento daquelas formações sociais, além de sugerir a importância assumida por parte deste último contingente social na manutenção da ordem local e na conquista do território colonial frente aos grupos indígenas locais. ${ }^{107}$ É bem conhecido o séquito militar particular do mestre-de-campo Manuel Nunes Viana, formado em parte por escravos e atuante na Minas Gerais do começo do século XVIII, cuja fama imputava ao grupo o poder de manipular elementos mágicos em desfavor dos inimigos. ${ }^{108}$ Destaca-se aqui, contudo, a formação e a existência, nas vilas e freguesias de Minas Gerais, de companhias de pardos e de pretos relativamente autônomas frente aos poderes privados, ou, em termos talvez mais precisos, já que se tratava de uma formação social na qual os âmbitos público e privado não se encontravam plenamente dissociados ${ }^{109}$, de companhias formalizadas e fazendo parte do aparato estatal em instalação desde o começo do Setecentos. Parece se inserir nesse quadro a "companhia dos forros" da vila de São João del Rey, criada por volta de 1710-1713, e as inúmeras companhias, referidas por Russell-Wood, formadas sob os auspícios dos governadores mineiros entre os anos 1713 e $1732 .{ }^{110}$

Desafortunadamente, esta pesquisa não dispôs de referências documentais ou bibliográficas atinentes à organização militar do território que, em 1748, seria desmembrado da

\footnotetext{
${ }^{105}$ Cf:: "Requerimento do capitão Teodoro Gonçalves Santiago, homem pardo, morador na vila de Santos, escravo do sargento-mor Manuel Gonçalves de Aguiar, pedindo a D. João V que, por alvará, mande o suplicado aceitar ume escravo que lhe oferece em troca da sua liberdade". Santos, ant. 4 de maio de 1733. AHU_CU_023-01, Cx. 8, D. 898.

${ }^{106} C f$ : : Arquivo Público do Estado de São Paulo (APESP), ordem C00271, doc. 32.

${ }^{107}$ RUSSELL-WOOD, A. J. R. Autoridades ambivalentes: o Estado do Brasil e a contribuição africana para a "boa ordem na república". In: SILVA, Maria Beatriz Nizza da (Org.). Brasil: Colonização e Escravidão. Rio de Janeiro: Nova Fronteira, 2000, p. 105-123.

${ }^{108}$ PAIVA, Eduardo França. De corpo fechado: gênero masculino, milícias e trânsito de culturas entre a África dos mandingas e as Minas Gerais da América, no início do século XVIII. In: LIBBY, Douglas Cole; FURTADO, Júnia Ferreira. (Org.). Trabalho livre, trabalho escravo. Brasil e Europa, séculos XVIII e XIX. São Paulo/Belo Horizonte: Annablume/PPGH-UFMG, 2006, p. 113-129.

${ }^{109}$ NOVAIS, Fernando A. Condições da privacidade na Colônia. In: NOVAIS, Fernando A. (Org.). História da vida privada no Brasil [v. 1, SOUZA, Laura de Mello e (Org.). Cotidiano e vida privada na América portuguesa]. São Paulo: Companhia das Letras, 1997, p. 13-39.

${ }^{110}$ RUSSELL-WOOD, A. J. R. Escravos e libertos..., p. 132-133; SILVA, L. G. Gênese das milícias... p. $127-$ 129; SILVEIRA, Marco Antonio. Narrativas de contestação. Os Capítulos do crioulo José Inácio Marçal Coutinho (Minas Gerais, 1755-1765). História social, n. 17, p. 285-307, 2009, p. 303; COTTA, Francis Albert. Negros e mestiços nas milícias da América portuguesa. Belo Horizonte: Crisálida, 2010, p. 61-65.
} 
capitania de São Paulo e formaria a capitania de Goiás. Por outro lado, há um detalhamento mais preciso, sobre esse ponto, acerca da capitania de Mato Grosso, criada conjuntamente à de Goiás. Em memorial enviado à Coroa portuguesa, um governador informou que as ordenanças locais, cujas companhias desde o início se fundaram na separação entre brancos, pardos e pretos, tiveram origem por ocasião da elevação dos núcleos populacionais de Cuiabá e de Vila Bela à condição de vila, respectivamente em 1727 e 1752. ${ }^{111}$ Na região Norte da América portuguesa, nomeadamente nas capitanias do Maranhão, Pará e Rio Negro, o processo de formação de corpos militares de pardos e de pretos tomaria feição ainda mais tardia, localizando-se especificamente entre fins do século XVIII e inícios do XIX. Por isso, cabe agora interpor a essa perspectiva mais regional da gênese dos corpos militares em questão um conjunto de fenômenos específicos da segunda metade do Setecentos que impactaram de maneira integral às Américas portuguesa e espanhola relativamente ao processo em tela.

A extensão transoceânica das tensões europeias associadas à Guerra dos Sete Anos (1756-1763) impactou sensivelmente por toda a América espanhola. À perda - mesmo que momentânea - de importantes territórios nos campos militar e diplomático frente à Inglaterra somou-se a consciência de crise imperial, típica da ilustração ibérica. ${ }^{112}$ Portanto, a formação e expansão numérica das milícias disciplinadas em território hispano-americano - dentre as quais se incluíam, evidentemente, os corpos militares compostos por pardos e morenos - é expressão das necessidades urgentes de melhoria da estrutura defensiva e, ao mesmo tempo, de implementação de reformas visando à racionalização administrativa. ${ }^{113}$ Vai daí a existência de ao menos dezoito regimentos ou batalhões de pardos e morenos, além de outras tantas companhias soltas, espalhados por várias localidades do império espanhol, conforme levantamento realizado por Marchena Fernández referente ao período 1760-1810. ${ }^{114}$

No âmbito do império português, as suspeitas que assombravam os diplomatas lusitanos desde a primeira metade do século XVIII, de acordo com as quais quaisquer dos principais

\footnotetext{
${ }^{111}$ Cf:: Relação do estabelecimento dos Corpos das Ordenanças e dos Auxiliares da capitania de Mato Grosso... anexa à "Carta do governador e capitão general da capitania de Mato Grosso, Caetano Pinto de Miranda Montenegro, ao secretário de estado da Marinha e Ultramar, Rodrigo de Souza Coutinho, informando que tomou medidas para guarnecer a fronteira; das reformas feitas na Legião de Milícias; solicitando o envio de armas; sobre a criação de uma companhia militar com índios Bororo e apresentando mapas demonstrativos dos contingentes militares e armamentos existentes na Capitania". Vila Bela, 25 de outubro de 1799. AHU_CU_010, Cx. 37, D. 1879.

112 DONGHI, T. H. Reforma y disolución de los imperios ibéricos 1750-1850. Madrid: Alianza Editorial, 1985, p. 17-102; MAXWELL, Kenneth. Hegemonias antigas e novas: o Atlântico ibérico ao longo do século XVIII. In: MAXWELL, Kenneth. Chocolate, piratas e outros malandros: ensaios tropicais. São Paulo: Paz e Terra, 1999. ${ }^{113}$ MARCHENA FERNÁNDEZ, J. Ejército y milicias..., p. 91-210.

${ }^{114}$ MARCHENA FERNÁNDEZ, J. Ejército y milicias..., p. 119-124.
} 
portos da América portuguesa poderiam ser alvo de ataques por parte de reinos estrangeiros ${ }^{115}$, confirmaram-se, em parte, com a invasão à Colônia do Sacramento e a territórios pertencentes à capitania sulina do Rio Grande de São Pedro promovida em fins de 1762 por forças militares hispano-americanas. Inaugurava-se aí uma guerra que perduraria até 1777, em cujo período os espanhóis haviam conquistado a Ilha de Santa Catarina e, no extremo oeste, em território fronteiriço ao Paraguai, o presídio do Iguatemi. Essa guerra e a plausibilidade de mais ataques a qualquer parte de sua vasta costa litorânea ou a pontos específicos da imensa fronteira terrestre que separava as Américas portuguesa e espanhola produziram uma mobilização militar sem precedentes na história do Brasil colonial. É em função desse quadro histórico abrangente que, na América portuguesa, promoveram-se estímulos significativos para a formação e ampliação dos corpos de ordenanças e, principalmente, de auxiliares constituídos por pardos e pretos.

Embora contasse com uma abundante população de homens de cor disponíveis para o ingresso nos corpos militares, na capitania da Bahia houve acréscimo comedido às tropas de pardos e pretos existentes desde a segunda metade do século XVII e começo do XVIII. Em realidade, apenas manteve-se o terço auxiliar de Henriques e formalizou-se um terço auxiliar de pardos a partir da reunião das companhias de ordenança previamente existentes. ${ }^{116}$ Ao contrário de uma expansão mais significativa da segunda linha, optou-se por alocar nas ordenanças o vasto contingente de pardos e de pretos que não pertenciam àqueles dois terços de auxiliares. Assim, entre 1796 e 1804 foi possível localizar pelo menos 18 companhias de pardos e 12 companhias de pretos anexas a 15 terços de ordenança organizados sob o critério territorial, e não da cor, pertencentes às comarcas da Bahia, dos Ilhéus, da Jacobina e de Porto Seguro. Ademais, havia três companhias de ordenanças de pardos, no mesmo período, no Espírito Santo, além de cinco companhias de pardos e mais quatro de pretos incluídas nos terços de ordenanças de Sergipe d'El Rey, ambas as capitanias sob jurisdição da Bahia. Em nenhuma delas havia companhias ou regimentos de segunda linha de pardos e de pretos. ${ }^{117}$

A esse respeito, a moderação característica do caso baiano configurou-se dissonante em comparação à realidade das demais capitanias da América portuguesa, as quais perceberam um incremento mais substancial nos corpos auxiliares de pardos e de pretos. Esse é o caso do Rio de Janeiro, em cuja configuração social as companhias de ordenanças de pardos e de pretos,

\footnotetext{
115 MAXWELL, Kenneth. Marquês de Pombal: paradoxo do iluminismo. Rio de Janeiro: Paz e Terra, 1997, p. 119-139.

${ }^{116}$ MOTA, Celio de Souza. Os Regimentos de Milícias de pretos e pardos em Salvador: trajetórias e mobilidade social em sociedade do Antigo Regime no final do século XVIII. In: CHAMBOULEYRON, R.; ARENZ, K.-H. (Orgs.). Anais do IV Encontro Internacional de História Colonial. Dinâmica imperial no Antigo Regime português: séculos XVI-XVIII. Belém: Editora Açaí, volume 6, 2014, p. 57-71.

117 Cf:: AHU_CU_005-01, Cx. 132, Docs. 26.219-26.290.
} 
existentes desde a virada do século XVII para o XVIII, passaram por reestruturação e ampliação, chegando-se à composição de um terço auxiliar de pardos, em 1769, e de um terço de pretos denominado Henriques, entre 1771 e 1777, bem como à formação de mais quatro companhias auxiliares de pardos, as quais estavam incluídas, em 1786, no "Terço Auxiliar dos Campos". ${ }^{118}$ Já as companhias de pardos e de pretos da capitania de São Paulo experimentaram uma evolução modesta e em ritmo mais lento. Inicialmente, até 1765, o processo esteve restrito à região da costa marítima, mas, a partir daí, estendeu-se para o planalto paulista. Em função da mobilização associada à guerra, houve a reestruturação das companhias litorâneas e a formação de companhias na vila de São Paulo e nas regiões interioranas, e a reunião dessas unidades avulsas resultou na criação de um regimento miliciano de pardos em $1797 .{ }^{119}$

O processo de dispersão territorial e aumento dos efetivos nos corpos militares formados por homens de cor obteve ritmos diferentes entre as capitanias do ouro. Em Mato Grosso, pardos e pretos jamais constituíram terços ou regimentos específicos para si. Apesar disso, entre os anos 1758 e 1804, suas companhias, mais numerosas em relação ao período anterior, faziam parte tanto das duas Legiões Auxiliares, posteriormente convertidas em Regimentos Milicianos, quanto dos dois Terços de Ordenanças localizados nas vilas de Cuiabá e Vila Bela. Esse aspecto dotava aqueles corpos militares de uma composição mista em termos da identidade atrelada à cor assumida pelas companhias. Veja-se, por exemplo, a configuração do Regimento de Milícias dos Voluntários de Mato Grosso em 1799: de suas oito companhias, duas eram formadas exclusivamente por brancos, duas eram privativas a pardos, uma era composta por brancos e pardos e as três restantes por brancos e pretos Henriques, devendo-se notar, porém, que no caso das quatro últimas os brancos ocupavam os postos da oficialidade. ${ }^{120}$

Em Goiás os corpos militares de pardos e de pretos tomarão expressão mais significativa do que na vizinha Mato Grosso no período em questão. Entre 1779 a 1782 se processou ali a

\footnotetext{
$118 C f$ :: "Relatório do Marquês de Lavradio vice-rei do Rio de Janeiro, entregando o governo a Luiz de Vasconcellos e Sousa, que o sucedeu no vice-reinado". Rio de Janeiro, 19 de junho de 1779. RIHGB, Rio de Janeiro, tomo 4, p. 409-486, 1863; "Guarnição do Rio de Janeiro com seus uniformes e mapas do número de homens dos regimentos pagos e o mesmo dos auxiliares, feito por José Correa Rangel, ajudante de infantaria com exercício de engenheiro". BN/dm, doc. 9,1,3. Rio de Janeiro, 1786; MELLO, C. F. P. de. Os Corpos de Auxiliares e de Ordenanças..., p. 152-158; MARTA, M. M. Em busca de honras, isenções e liberdades..., p. 45-48.

${ }^{119} C f$ : " "Ofício n. ${ }^{\circ} 25$ do governador e capitão-general da capitania de São Paulo, Antonio Manuel de Melo Castro e Mendonça, para o ministro e secretário de Estado dos Negócios da Marinha e Domínios Ultramarinos, D. Rodrigo de Souza Coutinho, informando que, logo que tomou posse, cuidou de ver que medidas deveria tomar". AHU_CU_023-01, Cx. 44, D. 3507. São Paulo, 19 de novembro de 1797.

${ }^{120} C f:$ : "Carta do governador e capitão-general da capitania de Mato Grosso Caetano Pinto de Miranda Montenegro ao secretário de estado da Marinha e Ultramar Rodrigo de Sousa Coutinho, informando que tomou medidas para guarnecer a fronteira; das reformas feitas na Legião de Milícias; solicitando o envio de armas; sobre a criação de uma companhia militar com índios Bororo e apresentando mapas demonstrativos dos contingentes militares e armamentos existentes na capitania”. AHU_CU_010, Cx. 37, D. 1879. Vila Bela, 25 de outubro de 1799.
} 
formação de um Regimento de Infantaria Auxiliar de Homens Pardos e, em um período de tempo ligeiramente mais longo, entre 1780 e 1806, tomou forma um "Regimento de Artilharia de Milícias denominado de Henriques”, composto, evidentemente, por pretos. ${ }^{121}$ Tais regimentos obtiveram proporções colossais nas primeiras décadas do século XIX, uma vez que em 1824 o Regimento dos Pardos era formado por 10 companhias efetivas e 24 agregadas ao passo que o Regimento dos Pretos contava com 10 companhias efetivas e 7 agregadas. ${ }^{122}$ Esta formatação um tanto quanto inchada das corporações em questão reflete um crescimento populacional considerável experimentado pelas camadas formadas por ex-escravos e seus descendentes. Curiosamente, porém, e por razões que serão discutidas em outra seção, o número de corpos militares de segunda linha destinados a pardos e a pretos permaneceu limitado a dois.

O certo é que em nenhuma outra capitania os efeitos da reorganização militar promovida por ocasião da guerra luso-castelhana de 1762-1777 foram mais notórios, no tocante aos pardos e pretos, que em Minas Gerais. Ali, muitas das companhias de ordenanças preexistentes foram convertidas em companhias de auxiliares e agregadas a terços. Um informe de 1775 indicou a existência de apenas um terço de pardos, sediado em Vila Rica, e de mais 26 companhias de pardos e 13 de pretos, distribuídas por vilas das comarcas de Vila Rica e Rio das Mortes. ${ }^{123}$ Contudo, tais companhias tenderam a evoluir para a forma de terços auxiliares e, depois, regimentos milicianos, de forma que, em toda a América portuguesa, a capitania de Minas Gerais passou a ser aquela que abrigava o maior número de corporações de pardos e de pretos de segunda linha, prevalecendo quantitativamente as primeiras. Entre os anos 1799 e 1804, existiam ali seis Regimentos de Infantaria Miliciana de Pardos - as localidades de Mariana, Vila Rica, São João Del Rey, São José Del Rey, Sabará e Vila Nova da Rainha sediavam, cada qual, um regimento - e um Regimento de Infantaria Miliciana de Pretos, aquartelado na vila do Sabará, além de quatro companhias de pretos em Vila Rica. ${ }^{124}$

\footnotetext{
${ }^{121}$ A formação destas corporações pode ser acompanhada pela sequência de documentos referidos adiante. Por seu número elevado, optou-se por suprimir os textos de suas ementas: AHU_ACL_CU_008, Cx. 31, D. 1977; AHU_ACL_CU_008, Cx. 32, D. 2002; AHU_ACL_CU_008, Cx. 32, D. 2028; AHU_ACL_CU_008, Cx. 33, D. 2043; AHU_ACL_CU_008, Cx. 33, D. 2054; AHU_ACL_CU_008, Cx. 34, D. 2098; AHU_ACL_CU_008, Cx. 34, D. 2102; AHU_ACL_CU_008, Cx. 47, D. 2707.

${ }^{122}$ Cf: : MATTOS, Raymundo José da Cunha. Chorographia histórica da província de Goyaz. Arraial de Traíras, 31 de dezembro de 1824. RIHGB, Rio de Janeiro, tomo XXXVIII, volume 1, 1875, p. 51-56.

${ }^{123} C f$ :: "Carta de D. Antônio de Noronha, governador de Minas, informando Martinho de Melo e Castro sobre a sua chegada a Vila Rica, assim como sobre as medidas que tem tomado no sentido de reorganizar os corpos militares da referida capitania". AHU_CU_011, Cx. 108, D. 8594. Vila Rica, 14 de junho de 1775.

${ }^{124} C f$ : AHU_CU_011, Cx. 154, D. 11590 e AHU_CU_011, Cx. 173, D. 12930. Ver também COTTA, F. A. Negros e mestiços nas milícias da América portuguesa..., p. 68-70. Cotta deixou de computar o regimento dos pardos de Vila Rica, o mais antigo dentre os regimentos de pardos. Ver também PAULA, Leandro Francisco de. Negros no campo das armas: homens de cor nos corpos militares das minas setecentistas. Dissertação (mestrado em História). Curitiba: SCHLA, Universidade Federal do Paraná, 2012, p. 69-85, e CRISPIN, Ana Carolina
} 
Em Pernambuco, dispunha-se de apenas dois corpos militares de homens de cor em 1759. No entanto, eles aglutinavam uma multidão de homens que habitavam as diversas vilas pernambucanas, dentre as quais as vilas de Alagoas, Penedo e Porto Calvo que, em 1817, comporiam a capitania das Alagoas. O "Regimento de homens pardos", referido ocasionalmente como um corpo de ordenanças, possuía 31 companhias e contava com 1.401 pessoas; o "terço Henrique Dias" contava com 15 companhias formadas por 1.323 homens. ${ }^{125}$ Tais contingentes ampliaram-se consideravelmente entre 1766 e 1767, mediante o estabelecimento de três novos terços de homens de cor, bem como adquiriram a formatação de terços auxiliares. Ainda sob esse influxo, formou-se na comarca de Alagoas um terço auxiliar de pardos em 1772. ${ }^{126}$ No contexto da guerra, a capitania de Pernambuco passou a dispor, então, de quatro terços auxiliares de pardos e mais dois de pretos. ${ }^{127}$

As capitanias vizinhas e subordinadas à de Pernambuco apresentaram tendência análoga de expansão dos corpos de segunda linha compostos por pretos e pardos livres ao longo da segunda metade do século XVIII. Na capitania da Paraíba, onde já se encontrava estabelecido um terço de pretos Henriques anteriormente a 1757, criou-se um terço auxiliar de pardos entre os anos 1766 e $1770 .{ }^{128}$ Mais ao norte, no Ceará, um informe de 1768 revelou a existência de um terço auxiliar de pardos na localidade Ribeira do Icó, mas a formação desse regimento miliciano composto por homens de cor residentes nos sertões daquela capitania obteve bom termo apenas em 1800, ao findar-se o século em questão. ${ }^{129}$ Já a capitania do Piauí, situada

Teixeira. Além do acidente pardo: os oficiais das milícias pardas de Pernambuco e Minas Gerais (1766-1807). Dissertação (mestrado em História). Niterói: ICHF, Universidade Federal Fluminense, 2011.

${ }^{125} C f$ :: "Ofício do governador da capitania de Pernambuco, Luís Diogo Lobo da Silva, ao secretário de Estado do Reino e Mercês, Sebastião José de Carvalho e Melo, remetendo os mapas demonstrativos das forças militares daquela capitania". AHU_CU_015, Cx. 89, D. 7194. Recife, 2 de março de 1759.

${ }^{126} C f$ : : "Requerimento do coronel Martinho Pereira Álvares ao príncipe regente, D. João, a pedir confirmação da carta patente do posto de Mestre de campo do novo Terço das companhias de homens pardos das vilas e termos de Porto Calvo, Alagoas e Penedo". AHU_ACL_CU_004, Cx. 4, D. 332. Alagoas, ant. 18 de maio de 1802.

${ }^{127}$ SILVA, Luiz Geraldo; SOUZA, Fernando Prestes de; PAULA, Leandro Francisco de. A guerra luso-castelhana e o recrutamento de pardos e pretos: uma análise comparativa (Minas Gerais, São Paulo e Pernambuco, 17751777). In: SANTOS, A. C. de A.; DORÉ, A. (Orgs.). Temas setecentistas: governos e populações no império português. Curitiba: UFPR-SCHLA/Fundação Araucária, 2008, p. 67-83, p. 71.

${ }_{128} C f$ :: "Requerimento de António Soares Ramos, ao rei, D. José I, solicitando confirmação da carta patente, no posto de capitão de uma das Companhias do Terço dos Henriques, do distrito de Espírito Santo". AHU_CU_014, Cx. 20, D. 1575. Paraíba, ant. 3 de novembro de 1757; "Carta do governador da Paraíba, brigadeiro Jerónimo José de Melo e Castro, ao rei, D. José I, sobre estarem completos os dois regimentos de cavalaria auxiliar e os dois terços de brancos e pardos e quase completos o dos henriques, por falta de homens pretos; e reclamando do provimento de vários postos militares da capitania pelo governo de Pernambuco". AHU_CU_014, Cx. 24, D. 1872. Paraíba, 5 de fevereiro de 1770.

${ }^{129} C f$ : "Mapa dos regimentos de infantaria, corpo de artilharia, regimentos de auxiliares de Cavallo, $3 .^{\text {os }}$ de pé e ordenanças de todo o Continente de Pernambuco [...]". AHU, códice no 2164. Pernambuco, $1 .^{\circ}$ de abril de 1769; "Ofício do governador do Ceará, Bernardo Manuel de Vasconcelos, ao secretário de estado dos Negócios da Marinha e Ultramar, D. Rodrigo de Sousa Coutinho, sobre a criação do Corpo Miliciano composto por homens pardos e forros nos sertões do Ceará". AHU_CU_006, Cx. 14, D. 818. Fortaleza, 31 de dezembro de 1800; "Requerimento de Domingos Fernandes Moreira ao príncipe regente, D. João, a pedir confirmação da patente de 
entre o Norte e Nordeste da América portuguesa, apresentou uma distribuição constante de corpos militares compostos por homens de cor na segunda metade do Setecentos. Trata-se das oito “Companhias Francas de Pretos e Mestiços, Ingênuos e Libertos”, de ordenanças, formadas no contexto da guerra luso-castelhana e dispersas por todas as freguesias daquela capitania. ${ }^{130}$

Ademais, as estruturas militares do Ceará e do Piauí apresentavam um elemento típico - e, nesse momento histórico, quase exclusivo - das capitanias do Norte da América portuguesa: a presença notável dos corpos militares compostos e comandados por indígenas. ${ }^{131}$ Se no Piauí havia apenas duas companhias de ordenanças com esta composição ${ }^{132}$, no Ceará existiam nada mais e nada menos que 48 companhias de ordenanças, aparentemente avulsas, de índios. ${ }^{133}$ Nas capitanias do Pará, Maranhão e Rio Negro, os corpos militares formados por nativos da América haviam adquirido um peso social formidável. De acordo com um informe de 1773, no Rio Negro existia um "Terço de Infantaria Auxiliar de Índios" e um "Terço de Infantaria de Ordenança de Índios”. A capitania do Maranhão, por sua vez, contava com dois terços auxiliares de índios. Finalmente, a capitania do Pará notabilizava-se por abrigar nada menos que três terços auxiliares e dois terços de ordenanças formados exclusivamente por indígenas. ${ }^{134}$

A configuração destas mesmas capitanias revelou a tendência de que a presença de corpos militares compostos por pardos e pretos livres fosse inversamente proporcional à existência de corpos militares formados por índios. Ora, na capitania do Rio Negro provavelmente não havia corpos militares compostos por homens de cor livres para além das duas “Companhias Francas de Mulatos, Mestiços e Índios aldeados” existentes em 1788 na Ilha

capitão de uma das Companhias do Regimento de Milícias dos Homens Pardos da Ribeira do Icó". AHU_CU_006, Cx. 16, D. 919. Ant. 18 de maio de 1802.

${ }^{130} C f$.: "Ofício do governador do Piaú, João Pereira Caldas, ao secretário de estado da Marinha e Ultramar, Francisco Xavier de Mendonça Furtado, sobre a nova regulamentação dos Corpos de Milícias da capitania do Piauí". AHU_CU_016, Cx. 10, D. 616. Oeiras do Piauí, 1 de agosto de 1769.

${ }^{131}$ Sobre a desestruturação do poder político da tradicional família Camarão, de raízes indígenas, e a consequente desmobilização do corpo militar a ela vinculado, em Pernambuco, na primeira metade do século XVIII, ver: RAMINELLI, Ronald. Privilegios y malogros de la familia Camarão. Nuevo Mundo Mundos Nuevos [Online], Colóquios, março 2008. Ver o desenvolvimento da hipótese de que em Pernambuco os corpos militares de pardos e de pretos apresentavam tendência inversa aos formados por índios, os quais contavam com apenas duas companhias em 1759, em SILVA, L.G. Gênese das milícias..., p. 117-122.

${ }^{132} C f$.: "Ofício do governador do Piauí, João Pereira Caldas, ao secretário de estado da Marinha e Ultramar, Francisco Xavier de Mendonça Furtado, sobre a nova regulamentação dos Corpos de Milícias da capitania do Piauí'. AHU_CU_016, Cx. 10, D. 616. Oeiras do Piauí, 1 de agosto de 1769.

${ }^{133}$ Cf:: MENESES, Luiz Barba Alardo de. "Memória sobre a capitania do Ceará". Rio de Janeiro, 18 de abril de 1814. RIHGB, Rio de Janeiro, tomo XXXIV, parte 1, 1871, p. 278.

${ }^{134}$ Para as três capitanias em questão, a referência é "Ofício do governador e capitão general do Estado Pará e Rio Negro, João Pereira Caldas, para o secretário de estado da Marinha e Ultramar, Martinho de Melo e Castro, remetendo relação de todos os Corpos Militares de Ordenanças e Auxiliares daquele Estado criados pelo seu antecessor, Fernando da Costa de Ataíde Teive Sousa Coutinho, apresentando conjuntamente um plano de reforma e reorganização dos referidos Corpos”. AHU_ACL_CU_013, Cx. 70, D. 6003. Pará, 15 de maio de 1773. 
de Joanes, atual Ilha de Marajó. ${ }^{135}$ Na capitania do Maranhão formou-se um "Terço de Pedestres Auxiliares", compostos por "quatorze companhias soltas de homens pretos e pardos forros", tão somente em 1796. ${ }^{136}$ Já no Pará, data de 1808 a criação das duas primeiras companhias auxiliares de pardos e pretos. ${ }^{137}$ É evidente a predominância de corpos militares formados por indígenas nas capitanias do Norte em relação ao único terço e às parcas companhias de pardos e de pretos lá existentes a partir das décadas finais do século XVIII e começo do XIX. Por um lado, a reunião desses dados empíricos sugere a necessidade de matizar a noção, evidentemente plausível e pertinente para a maior parte das regiões coloniais americanas, de acordo com a qual as comunidades indígenas eram encaradas pelos poderes coloniais como potenciais "inimigos internos". Isso decorreria basicamente dos níveis elevados de enraizamento e coesão social dos grupos nativos, e teria como consequência a não atribuição, a eles, de funções militares no universo colonial. ${ }^{138}$ É significativo que, sozinhas, as capitanias do Rio Negro, Maranhão e Pará gestassem número de corpos militares auxiliares compostos por índios equivalente ou próximo ao total de terços compostos por pretos livres em toda a América portuguesa. Por outro lado, cumpre enfatizar o caráter tardio do processo de constituição dos corpos militares exclusivos aos pardos e pretos nas três capitanias em tela. Com efeito, o fenômeno guarda estreita relação com a trajetória econômica da região e com o aporte de cativos africanos para as capitanias do Norte. Sua posição absolutamente marginal em meio à economia da América portuguesa sofreria alguma alteração apenas com o limiar do século XVIII e especialmente em suas décadas finais, quando então, no contexto do renascimento agrícola luso-americano, os esforços na direção de instaurar atividades agroexportadoras surtiram resultado efetivo. A farta produção de algodão e arroz, somada à já tradicional extração do cacau, alavancou a economia do Pará e Maranhão e conectou a região ao tráfico de escravos africanos. ${ }^{139}$

\footnotetext{
${ }^{135} C f$ :: "Ofício do encarregado das demarcações do Rio Negro e capitão-general, João Pereira Caldas, ao secretário de estado da Marinha e Ultramar, Martinho de Melo e Castro, sobre a regulação e disciplina dos Corpos Auxiliares do Rio Negro e a necessidade da promoção a tenente-ajudante um alferes do Regimento para o ensino da Tropa Ligeira Auxiliar da ilha de Joanes. Pede a confirmação no cargo do referido oficial". AHU_ACL_CU_020, Cx. 14, D. 530. Vila de Barcelos, 30 de abril de 1788.

${ }^{136}$ Cf.: AHU_ACL_CU_009, Cx. 89, D. 7392. Maranhão, 10 de janeiro de 1796. Um informe de 1803 indica a existência de dois regimentos de pardos e não menciona os pedestres. Acredito que se referisse aos corpos militares de índios não citados. AHU_ACL_CU_009, Cx. 131, D. 9771.

${ }^{137}$ Cf:: "Cópia da ordem sobre a organização e formatura do corpo de milícias artilheiras desta cidade, constituído de pardos e pretos libertos". BN/dm, doc. 7,3,026. Pará, 2 de maio de 1808. Ver também breve abordagem acerca da formação de tais companhias em NOGUEIRA, Shirley Maria Silva. "A soldadesca desenfreada": politização militar no Grão-Pará da Era da Independência (1790-1850). Tese (doutorado em História). Salvador: FFCH, Universidade Federal de Salvador, 2009, p. 123 e 150-151.

${ }_{138}$ ALZATE, Jorge H. González. Las milicias y la preservación del dominio español en los altos de Guatemala, 1673-1821. Boletín de la Asociación para el Fomento de los Estudios Históricos en Centroamérica, n. 26, nov./2006, p. 5; SILVA, L. G. Gênese das milicias... p. 117-122.

${ }^{139}$ SCHWARTZ, Stuart B. Brasil colonial: plantaciones y periferias, 1580-1750. In: BETHELL, Leslie (Ed.). Historia de América Latina. (Vol. 3 - América Latina colonial: economía). Barcelona: Editorial Crítica, 1990, p.
} 
Adiante, são apresentados dados referentes à cronologia da formação dos terços auxiliares e dos regimentos milicianos de pardos e de pretos na América portuguesa bem como à sua localização espacial. De forma bastante resumida, cabe mencionar alguns aspectos que o Quadro 1.1 e a Figura $1.1^{140}$ revelam. Primeiramente, a dinâmica da constituição desses corpos militares. Até meados do século XVIII, havia apenas quatro terços auxiliares compostos por pardos e pretos, sendo a maior parte deles formada por pretos livres. Eles se localizavam exclusivamente em capitanias do Nordeste da América portuguesa, isto é, Pernambuco, Bahia e Paraíba - não por acaso, pois, nos arredores do principal núcleo político-administrativo colonial, nas regiões economicamente mais prósperas e efetivamente vinculadas ao tráfico transatlântico de escravos e, por conseguinte, mais visadas do ponto de vista militar. A segunda metade do século XVIII, por outro lado, foi o momento por excelência da expansão e difusão daqueles corpos militares arregimentados para as várias capitanias luso-americanas. Nota-se, então, uma inversão relevante: passam a predominar os terços e regimentos de pardos livres em relação aos de pretos Henriques. Isso se deu, em boa medida, como um efeito da economia mineradora, que alterou completamente o panorama político, econômico, social e militar da região Centro-Sul da colônia. Mas todas as regiões foram afetadas, em maior ou menor medida, pela dinâmica da escravidão e do processo de mudança de status dos escravizados, e pela consequente formação de uma vultosa população de pardos forros e livres.

Em segundo lugar, a inserção do Regimento dos Úteis na trajetória histórica das milícias de pardos e pretos da América portuguesa. Como se vê, o regimento dos pardos paulistas foi o último corpo miliciano de pardos a ser formado no período colonial, o que indica tanto sua existência em temporalidade tardia em relação aos demais corpos militares em questão quanto permite supor a existência de tradições e modelos institucionais referentes à inserção daquelas tropas no universo militar luso-americano plenamente consolidados quando de sua criação.

\footnotetext{
229-236; ALDEN, Dauril. El Brasil colonial tardío, 1750-1808. In: BETHELL, Leslie (Ed.) Historia de América Latina. (Vol. 3)..., p. 329-352. A ideia de que o Brasil vivera um processo de renascimento agrícola a partir da segunda metade do século XVIII, aplicada por Alden, foi desenvolvida anteriormente por Caio Prado Jr. em História econômica do Brasil. (1ª ed. 1945). São Paulo: Brasiliense, 1994, p. 79-93.

${ }^{140}$ As figuras 1.1 e 1.2 foram confeccionadas no software QGIS 2.18.9 e com o apoio de uma base cartográfica disponibilizada no site do IBGE que representa a divisão política do Brasil em 1872. Essa base georreferenciada é a que mais se aproxima à divisão político-territorial vigente no período focalizado nesta tese. Importa recordar que, durante o período de existência do Regimento dos Úteis, a capitania/província de São Paulo era constituída pelos atuais territórios dos estados de Paraná e de São Paulo. A base utilizada pode ser acessada em: ftp://geoftp.ibge.gov.br/organizacao_do territorio/malhas territoriais/municipios_1872_1991/divisao territorial $\underline{1872 \_1991 / 1872 /}$
} 
QUADRO 1.1 - Cronologia da formação de terços auxiliares e de regimentos milicianos de pardos e de pretos (1633-1824)

\begin{tabular}{|c|c|c|c|}
\hline Criação & Corpo militar & Cor & Capitania \\
\hline $1633-1657$ & $\begin{array}{l}\text { Terço de Homens Pretos e Pardos, posteriormente } \\
\text { convertido em Terço de Pretos de Henrique Dias }\end{array}$ & Pretos & Pernambuco \\
\hline $1638-\mathrm{a} .1736$ & Terço de Henrique Dias & Pretos & Bahia \\
\hline $1699-1703$ & $\begin{array}{l}\text { Terço de Pardos, derivado do Terço de Homens Pretos e } \\
\text { Pardos }\end{array}$ & Pardos & Pernambuco \\
\hline a.1757 & Terço de Henrique Dias & Pretos & Paraíba \\
\hline $1766-1767$ & Terço de Pardos & Pardos & Pernambuco \\
\hline $1766-1767$ & Terço de Pardos & Pardos & Pernambuco \\
\hline $1766-1767$ & Terço de Henrique Dias & Pretos & Pernambuco \\
\hline $1766-1770$ & Terço de Infantaria Auxiliar de Homens Pardos & Pardos & Paraíba \\
\hline $1768-1800$ & Terço Auxiliar de Pardos de Icó & Pardos & Ceará \\
\hline 1769 & Terço Auxiliar de Pardos & Pardos & Rio de Janeiro \\
\hline $1771-1777$ & Terço de Henrique Dias & Pretos & Rio de Janeiro \\
\hline 1772 & Terço de Pardos da vila de Penedo & Pardos & Pernambuco \\
\hline 1773 & Regimento de Artilharia Auxiliar dos Pardos da Bahia & Pardos & Bahia \\
\hline 1775 & Terço Auxiliar dos Pardos de Vila Rica & Pardos & Minas Gerais \\
\hline c. $1775-1799$ & Terço Auxiliar dos Pardos de Mariana & Pardos & Minas Gerais \\
\hline c. $1775-1799$ & Terço Auxiliar dos Pardos de São João Del Rey & Pardos & Minas Gerais \\
\hline c. $1775-1799$ & Terço Auxiliar dos Pardos de São José Del Rey & Pardos & Minas Gerais \\
\hline c. $1775-1799$ & Terço Auxiliar dos Pardos de Sabará & Pardos & Minas Gerais \\
\hline c. $1775-1799$ & Terço Auxiliar dos Pardos de Vila Nova da Rainha & Pardos & Minas Gerais \\
\hline c. $1775-1799$ & Terço Auxiliar dos Pretos de Sabará & Pretos & Minas Gerais \\
\hline $1779-1782$ & Regimento de Infantaria Auxiliar de Homens Pardos & Pardos & Goiás \\
\hline $1780-1806$ & $\begin{array}{l}\text { Regimento de Artilharia de Milícias denominado de } \\
\text { Henriques }\end{array}$ & Pretos & Goiás \\
\hline 1796 & Terço de Pedestres Auxiliares & Misto & Maranhão \\
\hline 1797 & $\begin{array}{l}\text { Regimento de Infantaria Miliciana dos Pardos denominado } \\
\text { dos Úteis }\end{array}$ & Pardos & São Paulo \\
\hline
\end{tabular}

Legenda: p. = posterior a; a. = anterior a; c. $=$ aproximadamente

Fontes: [Pernambuco] AHU_ACL_CU_015, Cx. 42, D. 3797 e AHU_ACL_CU_015, Cx. 259, D. 17405; [Bahia] AHU_CU_005-01, Cx. 132, Docs. 26.219-26.290; [Paraíba] AHU_CU_014, Cx. 20, D. 1575 e Cx. 24, D. 1872; [Ceará] AHU, códice no 2164 e AHU_CU_006, Cx. 14, D. 818; [Rio de Janeiro] BN,dm, doc. 9,1,3; [Minas Gerais] AHU_CU_011, Cx. 154, D. 11590 e Cx. 173, D. 12930; [Goiás] MATTOS, R. J. da C. Chorographia histórica..., p. 51-56; [Maranhão] AHU_ACL_CU_009, Cx. 131, D. 9771 (ver nota de rodapé n. 136); [São Paulo] AHU_CU_023-01, Cx. 44, D. 3507. 
FIGURA 1.1 - Regimentos milicianos de Pardos e de Pretos na América portuguesa ( 1800)

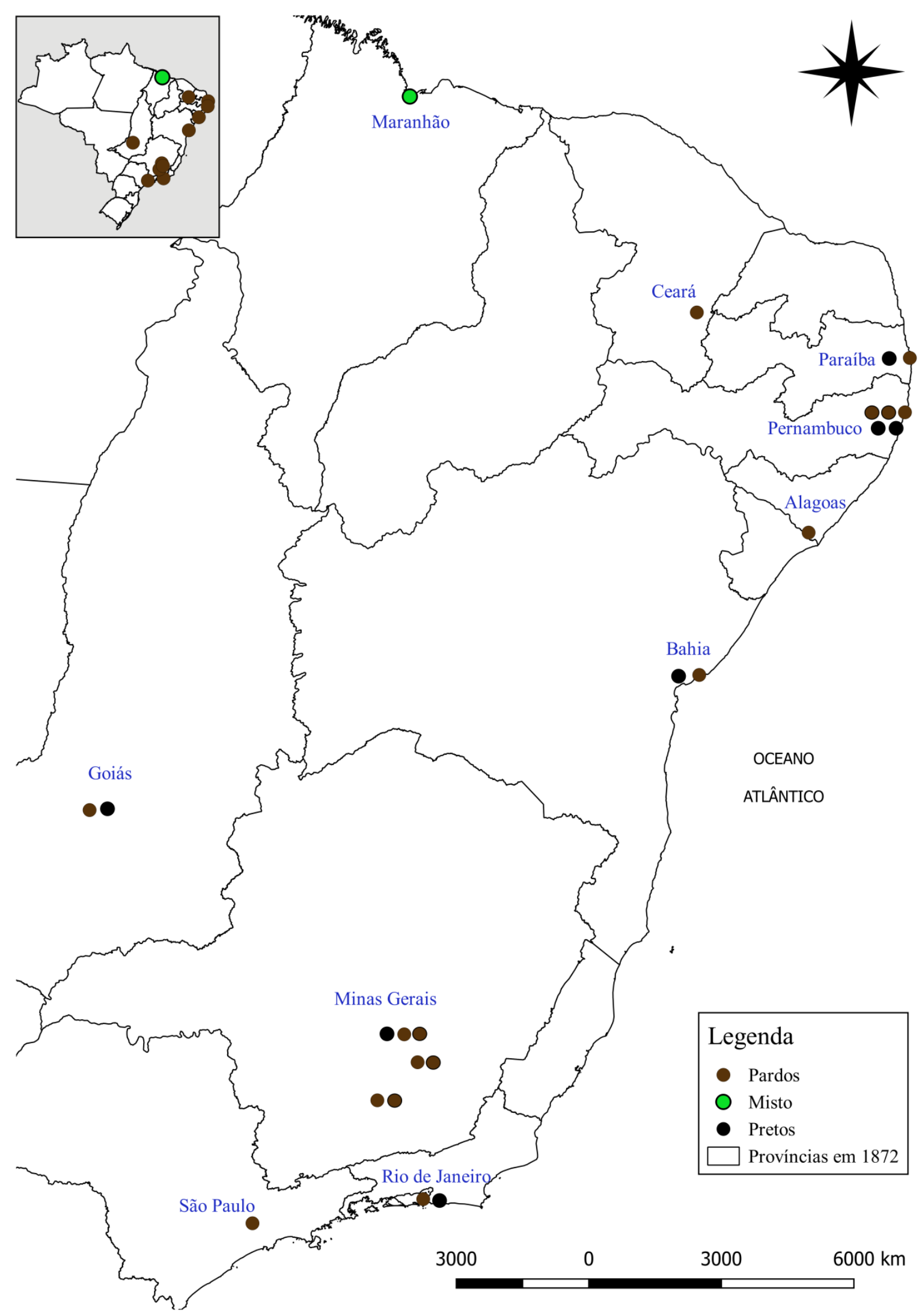




\subsection{Milicianos de cor em São Paulo: das primeiras companhias de pardos e de pretos ao Regimento dos Úteis}

Após essa visão panorâmica relativa à formação de corpos militares de pardos e de pretos nas diversas capitanias da América portuguesa, cabe um exame em pormenor ao caso que mais diretamente interessa aqui, o da capitania e depois província de São Paulo ${ }^{141}$. Como se viu preliminarmente, naquela configuração social a formação da única corporação militar composta por homens de cor livres no patamar de terço, regimento ou batalhão foi tributária de um processo de constituição de companhias de pretos e de pardos iniciado na capitania no começo do século XVIII e que se desenrolou até fins da mesma centúria. Em função dessa temporalidade, a criação do regimento dos pardos pode ser considerada tardia relativamente a outros espaços coloniais. Esse processo e sua localização na estrutura militar paulista mais ampla serão focalizados daqui por diante.

A capitania de São Paulo esteve situada na periferia da América portuguesa durante a maior parte do período colonial. Não apenas em termos de localização geográfica, mas sobretudo em virtude do enquadramento social, econômico e político das capitanias donatariais de Santo Amaro, São Vicente e Itanhaém, que deram origem a capitania régia de São Paulo e Minas do Ouro, em 1709, e, posteriormente, à capitania de São Paulo, separada da de Minas Gerais, em 1720. Ora, os empreendimentos voltados à produção de açúcar, que remontam à primeira metade do século XVI, não lograram, ali, resultados semelhantes aos das capitanias de Pernambuco e Bahia e foram rapidamente suprimidos. O insucesso daquela produção comercial gerou as condições para que os habitantes da costa marítima se deslocassem gradualmente para o planalto paulista, onde estabeleceram uma economia modesta movida pelo trabalho indígena. ${ }^{142} \mathrm{O}$ auge da escravidão dos nativos, em meados do Seiscentos, viabilizou a produção de trigo em escala suficiente para conectar a economia local ao comércio interno da América portuguesa. ${ }^{143}$ Em termos gerais, a história de São Paulo no século XVII pode ser entendida como sendo a da busca incessante no sertão por metais preciosos e por mão de obra para a agricultura. E, com efeito, é nesses marcos que se produziu a passagem do colonizador ao colono, do português ao paulista bandeirante.

\footnotetext{
141 Durante o período colonial, a composição territorial de São Paulo variou muito. Considera-se aqui como capitania/província de São Paulo o território compreendido pelos atuais estados de São Paulo e Paraná.

${ }^{142}$ SCHWARTZ, Stuart B. Brasil colonial: plantaciones y periferias, 1580-1750. In: BETHELL, Leslie (Ed.). Historia de América Latina. (Vol. 3 - América Latina colonial: economía). Barcelona: Editorial Crítica, 1990, p. 229-236.

${ }^{143}$ MONTEIRO, John Manuel. Negros da terra: índios e bandeirantes nas origens de São Paulo. São Paulo: Companhia das Letras, 1994, p. 57-128.
} 
Essa formação social refletiu-se na organização militar de São Paulo e em suas modalidades de atividades bélicas. Até 1592, o comando militar da capitania de São Vicente “cabia aos capitães-mores, loco-tenentes do donatário, que raramente o exerciam”. A nomeação de capitães "da gente de guerra" geralmente atendia à preparação de expedições e não, necessariamente, à formação de companhias estáveis. ${ }^{144}$ Desse ano em diante, a chefia militar da capitania donatarial passaria às mãos de um administrador das minas e capitão da vila de São Paulo, cargo vinculado ao governo-geral. Além do provimento de dois capitães naquela vila, sendo um de infantaria e outro de cavalaria, pouco se sabe sobre as atividades militares concretas levadas a efeito por tais oficiais, como reconhece Leonzo. Em 1610, a Câmara de São Paulo recebeu ordem para alistar "toda a gente de guerra", incluindo-se os índios, e arrolar o armamento que cada indivíduo possuía. Poucos anos depois, em 1615, havia na vila três companhias de infantaria. Mas há dúvidas quanto ao seu enquadramento institucional, já que as provisões passadas aos capitães das companhias não se referem a elas especificamente como sendo de ordenanças. Datam de 1620 as primeiras provisões de "capitães de infantaria da ordenança da vila de São Paulo". ${ }^{145}$

Leonzo atribui a formalização das companhias de Ordenanças em São Paulo à gestão de Martim Correa de Sá como "superintendente de todas as matérias de guerra da Costa Sul e capitanias dela" e "capitão-mor da capitania de São Vicente". Conforme a historiadora, esse oficial "alcançou grande destaque como sertanista, comerciante de pau-brasil e caçador de índios", além de estar envolvido nas questões de mineração. ${ }^{146}$ Vê-se, portanto, que a aplicação do Regimento das Ordenanças em São Paulo ocorreu associada às atividades do sertanismo e bandeirantismo, frequentemente tidas como antagônicas à gestão estatal. Em realidade, as expedições sertão adentro que partiam do planalto paulista na procura de jazidas auríferas foram estimuladas e avalizadas pela Coroa nos dois primeiros séculos de colonização. Os comandantes, eventualmente já providos em postos das ordenanças, recebiam patentes e deviam obedecer a regimentos específicos durante as jornadas. Contudo, em muitos casos essas campanhas militares eram concebidas e organizadas localmente pelos coloniais, e em tais circunstâncias assumiam a feição de empresas destinadas exclusivamente à captura e

\footnotetext{
${ }^{144}$ LEONZO, Nanci. As companhias de ordenanças na capitania de São Paulo. Das origens ao governo do Morgado de Mateus. Dissertação (mestrado em História). São Paulo: FFLCH, Universidade de São Paulo, 1975 , p. 14-15.

${ }^{145}$ LEONZO, Nanci. As companhias de ordenanças..., p. 14-19.

${ }^{146}$ LEONZO, Nanci. As companhias de ordenanças..., p. 17.
} 
escravização de indígenas. É nesse sentido que a maior parte das expedições organizadas pelos colonos operou. ${ }^{147}$

A crescente autonomia lograda pelos paulistas relativamente aos mecanismos formais de funcionamento do Estado tornou-se um problema ao poder central. Na resolução dessa questão, a Coroa e o governo-geral do Estado do Brasil buscaram aproveitar a aptidão sertanista e militar dos paulistas e ao mesmo tempo promover o estreitamento dos laços entre aqueles vassalos e o rei. ${ }^{148}$ É nesses termos que, na segunda metade do século XVII, ocorreu a contratação de chefes sertanistas paulistas e de índios sob seus domínios para atuarem nas margens da sociedade açucareira do Nordeste, nas campanhas militares da Guerra dos Bárbaros e no combate ao Quilombo de Palmares. O governador-geral Francisco Barreto de Meneses entendia que, em razão "do pouco uso que a infantaria aqui [na Bahia] tem de pelejar", apenas "a experiência dos sertanistas" paulistas seria capaz de promover o aniquilamento das aldeias visadas. ${ }^{149}$ Destaque-se o reconhecimento da diferença no enquadramento das tropas militares infantaria baiana e sertanistas paulistas. Como resultado da centralidade assumida pelas atividades militares sertanistas em São Paulo, o desenvolvimento das ordenanças naquele espaço foi obstaculizado pela dificuldade em dispor de homens fixados às vilas e povoações e pela sobreposição do modelo irregular de atividade militar das bandeiras.

A descoberta do ouro em Minas Gerais, por volta de 1690, alterou completamente a posição da vasta região compreendida pelas capitanias do Rio de Janeiro e de São Vicente e São Paulo, elevando-a, a partir de então, na hierarquia dos espaços coloniais. Com efeito, a ampliação da visibilidade desse espaço perante Portugal e os estados europeus concorrentes deve ser entendida como uma decorrência da dinamização econômica atrelada à extração de ouro e diamantes e às atividades associadas, como a produção e comércio de alimentos, gado, o tráfico de escravos africanos e o contrabando com a América espanhola. Esse momento histórico também marcou um ponto de inflexão no tocante à organização militar paulista. Em meio ao boom minerador, o governador da capitania do Rio de Janeiro, Artur de Sá e Menezes, foi designado para avaliar e aperfeiçoar as condições de defesa das capitanias donatariais vizinhas. Em 1698, ele informou ao rei que "em todas as vilas das capitanias do Sul não achei

\footnotetext{
${ }^{147}$ Sobre a organização das expedições bandeirantes, ver MONTEIRO, J. M. Negros da terra..., p. 57-98; KOK, Maria da Glória Porto. O sertão itinerante: expedições da capitania de São Paulo no século XVIII. Tese (doutorado em História). São Paulo: FFLCH, Universidade de São Paulo, 1998, p. 55-69.

${ }^{148}$ SOUZA, Laura de Mello e. O sol e a sombra: política e administração na América portuguesa do século XVIII. São Paulo: Companhia das Letras, 2006, 109-147.

${ }^{149} C f$ :: "Carta para o Capitão-mor da Capitania de São Vicente Manuel de Souza da Silva acerca dos Indios que se mandam vir daquella Capitania". Bahia, 21 de setembro de 1657. DH, vol. 3, p. 395-398. Esse documento assim como o contexto que o informa foram examinados em PUNTONI, P. A guerra dos bárbaros..., p. 102.
} 
nenhuma forma do exercício militar, tanto por não estarem alistados como por não terem capitães, nem os Terços coronéis ou outros oficiais a quem obedecessem e respeitassem". ${ }^{150}$ Descontando seus eventuais exageros, elementos típicos da retórica de governadores coloniais ciosos por expor o valor de seus serviços à Monarquia, Sá e Menezes revelou a debilidade do aparato militar da vila de Santos, na então capitania de São Vicente e São Paulo. A carência de corpos militares e de uma fortaleza expunha a vila a ataques de piratas e a Coroa aos descaminhos do ouro. Com esse argumento, o governador e capitão-general do Rio de Janeiro providenciou a criação da primeira companhia de infantaria paga de São Paulo e a destinou à vila e praça de Santos. A esse mesmo esforço se deve a formação de um terço de auxiliares e de um terço de ordenanças, sendo esses também os primeiros da capitania em questão. ${ }^{151}$

No começo do século XVIII, evidenciou-se uma vez mais a concomitante importância e fragilidade defensiva das capitanias do Centro-Sul da América portuguesa, mas agora por ocasião das invasões francesas à cidade do Rio de Janeiro, entre 1710-1711, ocorridas na esteira da guerra de sucessão espanhola (1701-1713). ${ }^{152}$ Embora a capitania de São Paulo fosse, à época, notabilizada pela destreza militar de seus habitantes, formando e até exportando corporações militares destinadas a lutar em guerras travadas contra nações indígenas e quilombos nas capitanias do Nordeste da América portuguesa ${ }^{153}$, viu-se desfalcada de homens aptos a defender seu principal porto marítimo diante do ataque francês de 1711. Nem mesmo os corpos militares recentemente erigidos foram suficientes. Uma solução emergencial foi não somente armar os escravos da vila e Praça de Santos, mas criar e formalizar uma companhia, dotada de oficialidade, composta pelos próprios escravos pardos. ${ }^{154}$ Trata-se da primeira companhia formada por homens de cor na capitania de São Paulo, onde havia pouco tempo garantiu-se um suprimento contínuo e modesto de cativos africanos. ${ }^{155}$ Cumpre recordar que é nesse mesmo pano de fundo que se insere a formação das primeiras companhias de pardos e pretos no Rio de Janeiro e em Minas Gerais. ${ }^{156}$

\footnotetext{
${ }^{150} C f$ : "Carta de Artur de Sá e Menezes ao Rei dando-lhe conta das nomeações que fizera de homens notáveis para os principais postos da milícia e da fazenda real da vila de São Paulo, de 27 de maio de 1698”. RIHGSP, vol. 18 , p. 342-343.

${ }^{151}$ LEONZO, Nanci. As companhias de ordenanças..., p. 19-23; LEONZO, Nanci. Defesa militar e controle social na capitania de São Paulo: as milícias. Tese (doutorado em História). São Paulo: FFLCH, Universidade de São Paulo, 1979, p. 23-26.

152 MELLO, C. F. P. de. Os Corpos de Auxiliares e de Ordenanças..., p. 108-117.

${ }^{153}$ MONTEIRO, J. M. Negros da terra...; PUNTONI, P. A guerra dos bárbaros...

${ }^{154}$ Cf.: AHU_CU_023-01, Cx. 8, D. 898.

${ }^{155}$ LUNA, Francisco Vidal; KLEIN, Herbert S. Evolução da sociedade e economia escravista de São Paulo, de 1750 a 1850. São Paulo: EDUSP, 2006, p. 28.

${ }^{156}$ MARTA, M. M. Em busca de honras, isenções e liberdades..., p. 36-48; SILVA, L. G. Gênese das milícias..., p. 127-129.
} 
Durante a primeira metade do século XVIII, foram criadas novas companhias de pardos e de pretos na capitania paulista, mas estas passaram a ser constituídas prioritariamente por homens livres ou forros. É significativo que a companhia de pardos escravos, ou "sujeitos", de 1712, que permaneceu ativa e chefiada por um capitão pardo e cativo, tendeu a uma evolução em sua composição ao longo do tempo, sendo reconhecida, em 1743, como Companhia de Homens Pretos Escravos e Libertos. ${ }^{157}$ Pelo menos desde 1726 havia uma Companhia de Ordenança de Homens Pardos Livres em atividade na vila de Santos, e, para 1744, há referências à Companhia de Mulatos da vila de São Vicente bem como, na mesma década, à Companhia dos Homens Pardos da vila da Conceição de Itanhaém. ${ }^{158}$ Essa última vivia, em 1748, a transição tendencial na composição de seus quadros, pois, naquela circunstância, deixava de ser comandada por capitão escravo mediante a nomeação de um pardo forro para o posto.

O que parece não ter sofrido alteração substancial no meio século que se seguiu à criação da primeira companhia de homens de cor na capitania foi a carência de homens para a sua defesa. Em 1735 um capitão pardo foi provido sob a justificativa de que sua companhia de ordenanças de Homens Pardos Obrigados era necessária "por não haver a gente branca que se precisa para a guarnição desta marinha quando por alguma ocasião a queira invadir o inimigo". ${ }^{159} \mathrm{Na}$ realidade, as descobertas de ouro em Minas Gerais, Cuiabá e Goiás atraíam vasto contingente populacional e não por acaso as autoridades paulistas tentaram de diversas maneiras, mas sem sucesso efetivo, conter a deserção de soldados da marinha para aquelas paragens. ${ }^{160}$ Os soldados da tropa regular chegaram até a promover um motim na vila de Santos, em 1718, reclamando o atraso de mais de um ano no pagamento de seus soldos e a ausência de condições mínimas para o exercício das funções militares. ${ }^{161}$ Nesse contexto e em tais circunstâncias, servir nas tropas devia ser pouco interessante para aqueles homens e suas famílias. Alguns oficiais e soldados pardos se incluíam, evidentemente, dentre os muitos homens que se ausentaram da costa litorânea paulista atraídos pelo ouro, diamantes e pelas oportunidades associadas à mineração - como atestam expressamente os provimentos de postos vagos daquelas companhias. ${ }^{162}$ Assim mesmo, os que permaneceram em seus postos assumiram papel de relevo na defesa territorial.

\footnotetext{
157 Cf:: APESP, ordem C00271, doc. 19.

${ }^{158} C f:$ : APESP, ordem C00271, docs. 32, 37 e 49.

${ }^{159}$ Cf:: APESP, ordem C00361, livro 5. Registro de uma patente de Bernardino Correa Pais de Santa Rita, de capitão de infantaria de Ordenança. Santos, 7 de outubro de 1735.

${ }^{160}$ Cf:: DIHCSP, vol. 12, p. 27-28; DIHCSP, vol. 49, p. 20-22.

${ }^{161} C f$ : : APESP, ordem C00379, Livro 51, fl. 245-245v.

${ }^{162} C f$ : APESP, ordem C00379, Livro 52, fl. 48; ordem C00271, doc. 49.
} 
As localidades auríferas do interior atraíram até mesmo os governadores e capitãesgenerais de São Paulo, que coordenaram pessoalmente a montagem das suas estruturas administrativas na primeira metade do Setecentos. ${ }^{163}$ Em 1748, já separada de Mato Grosso e de Goiás, a capitania de São Paulo perdeu sua autonomia político-administrativa e tornou-se subordinada à do Rio de Janeiro. ${ }^{164}$ Esses fatos, talvez, expliquem a escassez de dados detalhados acerca da composição e dos contingentes dos corpos militares de auxiliares e de ordenanças paulistas para o período. As tropas regulares, por outro lado, estão mais bem documentadas. O quartel militar da tropa paga ficava na vila de Santos sob o comando do governador da praça, cujo oficial, de tempos em tempos, enviava ao Conselho Ultramarino relatórios sobre o estado da tropa. A força militar em questão consistia de três companhias, em 1722, passando-se a cinco no ano de 1735. Dessas, quatro eram de infantaria e uma de artilharia. Para 1746 em diante, há menção aos efetivos das companhias, que se mantiveram no mesmo pé da década anterior: de um total de 288 militares pagos, 22 eram oficiais e 266 soldados. Nem todos os soldados serviam em Santos, localidade que contava efetivamente com 191 homens, além dos oficiais. Na ocasião, os 75 demais soldados estavam destacados. Já em 1759 o total de praças regulares fora ampliado para 314 homens, mas, desses, apenas 89 guarneciam o porto de Santos. O restante servia por destacamento em outras paragens da capitania ( 88 homens), atuando nas Campanhas sulinas (128 homens) e uma pequena parte permanecia afastada temporariamente por doença (nove homens). ${ }^{165}$ As deserções, destacamentos, campanhas militares externas à capitania e outras razões para o afastamento dos soldados pagos eram elementos perenes que comprometiam o potencial defensivo da costa litorânea paulista. Com efeito, para mencionar apenas as expedições de suas tropas para outros espaços coloniais, uma companhia regular foi destinada a Santa Catarina, em 1735, e outra para Goiás, onde forneceria o suporte à cobrança dos quintos do ouro. Duas companhias regulares de Santos e mais uma companhia de "aventureiros" da capitania foram direcionadas ao Rio Grande de São Pedro, em 1752, para acompanharem os trabalhos mais amplos de demarcação das fronteiras entre luso e hispano-americanos estabelecidas pelo Tratado de Madrid e que resultaram na Guerra

\footnotetext{
${ }^{163}$ CUNHA, Pedro Octávio Carneiro da. Política e administração de 1640 a 1763. In: HOLANDA, S. B. de (Dir.). História Geral da Civilização Brasileira. Vol. 2 - A época colonial: administração, economia e sociedade. Rio de Janeiro: Bertrand Brasil, 2003, p. 42-45.

${ }^{164}$ SILVA, Maria Beatriz Nizza da Silva (Org.). História de São Paulo colonial. São Paulo: Editora Unesp, 2009, p. 104-112; MARCÍLIO, Maria Luiza. Crescimento demográfico e evolução agrária paulista (1700-1836). São Paulo: Hucitec/EDUSP, 2000, p. 20.

${ }_{165} C f$ : AHU_CU_023-01, Cx. 11, D. 1079; AHU_CU_023-01, Cx. 15, D. 1492; AHU_CU_023-01, Cx. 22, D.

2117; LEONZO, Nanci. Defesa militar e controle social..., p. 10.
} 
Guaranítica (1754-1756). ${ }^{166}$ Partindo-se dessa perspectiva, as companhias de pardos existentes nas vilas de Santos, São Vicente e Itanhaém na primeira metade do século XVIII deixam de figurar apenas como complementares à tropa paga e tornam-se componentes fundamentais na estrutura militar paulista.

Em 1763, houve nova empreitada em termos de recomposição das tropas de cor situadas na vila de Santos e seus arredores, resultando no provimento de capitães para quatro companhias de pretos e de pretos crioulos, bem como de um capitão para a companhia de pardos. ${ }^{167}$ Como já visto, o fenômeno está relacionado diretamente às tensões que, a partir de 1762, deram início a uma guerra luso-castelhana nas partes meridionais da América portuguesa, a qual, por sua vez, era um reflexo da Guerra dos Sete Anos na Europa (1756-1763). ${ }^{168}$ Em virtude do acirramento dos confrontos no Sul, a Coroa decidiu restabelecer o governo da capitania, em 1765, e nomear para ela um governador e capitão-general. Embora o território de São Paulo não tenha sido palco direto das ações militares dessa guerra, a capitania enviou tropas para o Rio Grande do Sul e para a fronteira oeste nas proximidades do Paraguai, assim como proveu sua própria segurança diante da ameaça de ataques em sua costa marítima. ${ }^{169}$ Não por acaso, pois, as principais atividades dos governadores e capitães-generais Morgado de Mateus (1765-1775) e Martim Lopes Lobo de Saldanha (1775-1782) giraram em torno da completa reestruturação militar da capitania. Ao longo desse período, foram criados dois corpos militares regulares, sendo um deles formado a partir das companhias preexistentes da vila de Santos e outro por recrutas da região do planalto, os quais foram logo destinados à guerra no Sul. Ao mesmo tempo, auxiliares e ordenanças receberam nova organização. Os primeiros passaram a estar reunidos em seis regimentos. Em 1767, eles totalizavam 20 companhias de cavalaria e 40 de infantaria auxiliar, as quais compreendiam 4.004 homens. Já as ordenanças eram constituídas por 76 companhias que incluíam o restante da população masculina válida não alistada nas tropas regulares ou auxiliares. ${ }^{170}$

\footnotetext{
${ }^{166}$ RODRIGUES, J. Washt. Tropas paulistas de outrora. São Paulo: Governo do Estado, 1978, p. 10-12, 41; sobre a conjuntura político-administrativa do Centro-Sul da América portuguesa e ações militares em meados do Setecentos, ver MELLO, C. F. P. de. Os Corpos de Auxiliares e de Ordenanças..., p. 117-122.

${ }^{167} C f$ : APESP, C00379, Livro 52, fls. 37-48. Essas quatro companhias integradas por pretos forros parecem não ter vingado, já que não há qualquer menção a elas de 1765 em diante.

${ }^{168}$ SILVA, L. G.; SOUZA, F. P. de; PAULA, L. F. A guerra luso-castelhana e o recrutamento de pardos e pretos..., p. 67-83.

${ }^{169}$ BELLOTTO, Heloísa Liberalli. Autoridade e conflito no Brasil colonial: o governo do Morgado de Mateus em São Paulo (1765-1775). São Paulo: Conselho Estadual de Artes e Ciências Humanas, 1979, p. 69-83 e 117-169; LINS, Maria de L. Ferreira. A Legião de São Paulo no Rio Grande do Sul. Tese (doutorado em História). São Paulo: FFLCH, Universidade de São Paulo, 1976, p. 138-291.

${ }^{170}$ RODRIGUES, J. Washt. Tropas paulistas de outrora..., p. 56-86; LEONZO, Nanci. Defesa militar e controle social..., p. 28-64.
} 
Nessa conjuntura, foram criadas novas companhias de pardos nas vilas litorâneas mais importantes e mantiveram-se algumas das já existentes. As quatro companhias de pretos forros atuantes em 1763 se dispersaram rapidamente e, entre 1770 e 1771, foram convertidas a uma única companhia sediada em Santos. ${ }^{171}$ Ainda na região costeira, providenciou-se o alistamento dos cativos e a confecção de chuços para eles, os quais, no entanto, já não formavam companhias dotadas de oficialidade própria, como no começo daquele século. ${ }^{172}$ Por outro lado, deve-se destacar aqui que tão somente a partir de 1766 é que as companhias de pardos livres deixaram de ser exclusivamente litorâneas e começaram a ser criadas em áreas do planalto, notadamente na cidade de São Paulo e nas vilas de Pindamonhangaba, Taubaté, Jundiaí e Mogi Mirim. ${ }^{173}$ Nessas duas últimas vilas formou-se, em 1772, uma companhia com "mulatos, bastardos e carijós arranchados no sertão" ${ }^{174}$, cuja composição social expressa nitidamente traços característicos da população do planalto paulista no período: a camada de afrodescendentes livres em formação mesclava-se com a de índios remanescentes e desenraizados das aldeias e seus descendentes mestiços, sendo comum a todos um passado atrelado à escravidão ou a outras formas de exploração de trabalho compulsório. ${ }^{175}$ Apesar de possível o paralelo entre as capitanias de São Paulo e do Maranhão relativamente ao peso elevado da participação indígena na população em geral até a primeira parte do Setecentos ${ }^{176}$, elas diferiam substancialmente no tocante às formas de participação militar dos nativos da América. Enquanto no Maranhão abundavam os corpos de auxiliares e de ordenanças privativos aos indígenas, em São Paulo da segunda metade do século XVIII não existia nada semelhante, o que sugere que sua população de origem indígena se encontrava em estágio bastante avançado

${ }^{171} C f$ :: "Requerimento de Vicente Ferreira da Conceição ao governador e capitão-general da capitania de São Paulo, Martim Lopes Lobo de Saldanha”. Santos, anterior a 1. de setembro de 1770. APESP, Ordem C00273, doc. não catalogado.

${ }^{172} C f$ :: "Bando para que os senhores de escravos mandem fazer para cada um dos que tiverem, um chuço com haste de pau". DIHCSP, vol. 65, p. 17-18. Santos, 7 de setembro de 1765; "Para o conde da Cunha". DIHCSP, vol. 72, p. 113-114. Santos, 10 de novembro de 1765; BN/dm, doc. i-30,27,004. Ubatuba, 11 de março de 1766.

${ }^{173} C f$ :: "Patente a Narciso Rodrigues Lima, do posto de capitão dos Pardos forros da vila de Pindamonhangaba". São Paulo, 28 de agosto de 1766. APESP, Ordem C00366, Livro 17, fls. 18v-19v; "Carta de Bento Lopes de Leão, capitão-mor de Taubaté, ao governador Luís Antônio de Sousa Botelho Mourão, dando informações requeridas sobre as cinco companhias da ordenança existentes sob sua jurisdição". Taubaté, 05 de outubro de 1767. BN/dm, doc. i-30,13,12 n.16; "Ordem para se formar nesta cidade uma companhia de mulatos forros". DIHCSP, vol. 33, p. 180-181. São Paulo, 4 de janeiro de 1775.

${ }^{174} C f:$ : "Ordem que foi ao sargento-mor de Jundiaí para formar uma companhia de mulatos, bastardos e carijós". DIHCSP, vol. 33, p. 60. São Paulo, 11 de maio de 1772; "Para a câmara de Mogi Mirim”. DIHCSP, vol. 64, p. 5556. São Paulo, 17 agosto de 1772; "Carta ao governador dando parte das medidas tomadas para execução de ordem de formar companhia de pardos a fim de combater os ataques dos índios caiapó”. Mogi Mirim, 16 de outubro de 1772. BN/dm, doc. i-30,12,17 n. 40.

175 NAZZARI, M. Vanishing Indians: the social construction of race in colonial São Paulo. The Americas, v. 57, n. 4, p. 497-524, abr./2001.

176 SCHWARTZ, Stuart B. Brasil colonial: plantaciones y periferias, 1580-1750. In: BETHELL, Leslie (Ed.). Historia de América Latina. (Vol. 3)..., p. 229-236. 
de mestiçagem e ocupava as posições sociais menos valorizadas. Sobre essa questão, Luna e Klein argumentaram que "provavelmente em nenhuma outra região das Américas escravos índios e trabalhadores livres, fossem índios ou mestiços, integraram-se tão plenamente em um regime colonial dominado por brancos". ${ }^{177}$ Logo, a configuração assumida por esse contingente populacional na realidade paulista, entre outras variáveis, impediu a formação de terços e companhias indígenas e consequentemente inviabilizou o acesso dos mamelucos às funções sociais honorárias que estariam atreladas a esses corpos militares, ao contrário do que ocorreu nas capitanias do Norte. De qualquer modo, destinada inicialmente ao combate a índios caiapó que tangenciavam a rota entre São Paulo e Cuiabá, a tropa de mestiços paulistas mencionada acima foi obrigada a desviar-se da missão inicial e acabou marchando para uma fortaleza na fronteira oeste para fazer frente a eventuais ataques espanhóis via Paraguai. ${ }^{178}$

Em síntese, as companhias de pardos e pretos mantiveram-se na estrutura militar paulista reformada emergencialmente por ocasião da guerra e executaram funções relevantes na ocasião, tais como a vigia dos principais portos e povoados da costa marítima e a guarnição de posto avançado no sertão. No entanto, as companhias identificadas nas fontes primárias, que, apesar de ampliadas numericamente, não chegavam a uma dezena em toda a capitania, tinham um enquadramento institucional incerto, já que podiam ser referidas como sendo de auxiliares, de ordenanças ou mesmo sem esse tipo identificação. De certo modo, esse aspecto definiu sua posição secundária no interior da estrutura militar paulista, então composta por regimentos de linha e auxiliares e companhias de ordenanças. $\mathrm{O}$ exame às companhias avulsas de pardos e pretos da segunda metade do Setecentos, por outro lado, revela outros traços importantes dessa fase do processo histórico de constituição das milícias de cor em São Paulo. Ele marca a transposição do espaço litorâneo e a difusão das companhias por regiões do interior. Ao mesmo tempo, sinaliza para a perda de importância das companhias de escravos e também das de pretos forros e, comparativamente a elas, acena para a gradual consolidação das de pardos forros. ${ }^{179}$

A pacificação pós-guerra contribuiu para que a capitania vivesse uma nova etapa de crescimento econômico. $\mathrm{O}$ tema do atraso ou decadência das atividades produtivas foi corrente entre autoridades e memorialistas de São Paulo durante a segunda metade do século XVIII e as

\footnotetext{
177 Sobre essa questão, Luna e Klein argumentaram que "provavelmente em nenhuma outra região das Américas escravos índios e trabalhadores livres, fossem índios ou mestiços, integraram-se tão plenamente em um regime colonial dominado por brancos". LUNA, F. V.; KLEIN, H. S. Evolução da sociedade e economia..., p. 25.

178 Detalhes sobre os preparativos para as expedições destinadas ao Iguatemi, bem como do cotidiano no presídio: KOK, M. da G. P. O sertão itinerante: expedições da capitania de São Paulo no século XVIII. Tese (doutorado em História). São Paulo: FFLCH, Universidade de São Paulo, 1998, p. 294-332; BELLOTTO, H. L. Autoridade e conflito no Brasil colonial..., p. 117-169, 265-310.

${ }^{179}$ Mais detalhes em SOUZA, Fernando Prestes de. Milicianos pardos em São Paulo..., p. 64-81.
} 
primeiras décadas do XIX, como constatou Medicci. ${ }^{180}$ Esses homens indicaram diferentes causas para a estagnação diagnosticada, a qual remontaria aos primórdios da colonização e se acentuaria em meados do Setecentos: os métodos para preparação da terra e cultivo, as características dos trabalhadores, a participação paulista nas guerras e uma ineficiente gestão administrativa foram apenas alguns dos problemas elencados. Contudo, está claro que aqueles que refletiram sobre o atraso agrícola e comercial paulista focalizavam os grandes empreendimentos voltados à exportação, marginalizando, então, as pequenas roças, a criação doméstica de animais e as oficinas artesanais que bastavam para a subsistência e alimentavam o comércio miúdo local.

Há algum tempo que a historiografia tem revisado o tema da pobreza colonial paulista e demonstrado que havia processos de produção e acumulação vigentes em boa parte do período, apesar da frágil conexão de São Paulo à economia atlântica. John M. Monteiro revelou o advento da produção comercial de trigo no século XVII, numa conjuntura de disponibilidade abundante de mão de obra indígena escravizada ${ }^{181}$; Ilana Blaj e Maria A. M. Borrego sugeriram o curso de um processo de mercantilização da capitania e cidade de São Paulo entre fins do século XVII e a primeira metade do XVIII. ${ }^{182}$ Em trabalhos mais antigos, Alfredo Ellis Júnior e Mafalda Zemella indicaram a injeção econômica que a capitania recebeu, de fins do Seiscentos em diante, ao converter-se em centro abastecedor dos centros mineradores. ${ }^{183}$ Maria Luiza Marcílio demonstrou o curso de um processo de crescimento populacional de grandes proporções na São Paulo dos séculos XVIII e XIX, o qual estaria vinculado à sua "evolução agrária". ${ }^{184}$ Ademais, o tropeirismo dinamizou a economia por todo esse período. Maria T. S. Petrone examinou o desenvolvimento da cultura comercial da cana-de-açúcar a partir de meados do Setecentos, a qual engrenaria de vez em finais daquele século. ${ }^{185}$ É nesse período que se deu a ampliação do tráfico de escravos africanos para São Paulo, cuja mão de obra moveu a lavoura canavieira e depois cafeeira na capitania/província, conforme evidenciado por Luna

\footnotetext{
${ }^{180}$ MEDICCI, Ana Paula. De capitania a província: o lugar de São Paulo nos projetos de império, 1782-1822. In: COSTA, Wilma Peres; OLIVEIRA, Cecília Helena de Salles (Orgs.). De um império a outro: estudos sobre a formação do Brasil, séculos XVIII e XIX. São Paulo: Aderaldo \& Rothschild: Fapesp, 2007, p. 241-260.

${ }^{181}$ MONTEIRO, J. M. Negros da terra..., p. 99-128.

182 BLAJ, Ilana. A trama das tensões: o processo de mercantilização de São Paulo colonial (1681-1721). São Paulo: Humanitas/FFLCH/USP, 2002; BORREGO, Maria Aparecida de Menezes. A teia mercantil: negócios e poderes em São Paulo colonial (1711-1745). Tese (doutorado em História). São Paulo: FFLCH, Universidade de São Paulo, 2006.

${ }^{183}$ ELLIS JÚNIOR, Alfredo. O ouro e a Paulistânia. Boletim História da Civilização Brasileira, São Paulo, n. 8, 1948; ZEMELLA, Mafalda. O abastecimento da capitania de Minas Gerais. 2. ${ }^{a}$ ed. São Paulo: Hucitec/Edusp, 1990.

${ }^{184}$ MARCÍLIO, Maria Luiza. Crescimento demográfico...

185 PETRONE, Maria Thereza Schorer. A lavoura canavieira em São Paulo - expansão e declínio (1765-1815). São Paulo: Difel, 1968.
} 
e Klein. ${ }^{186}$ Em conjunto, esses trabalhos não negam a posição periférica da região paulista comparativamente à sociedade açucareira do Nordeste, aos centros de extração dos metais preciosos e à vultosa economia portuária do Rio de Janeiro. Antes, eles matizam a ideia de isolamento e estagnação, e a partir daí acenam para o estabelecimento de conexões entre as diferentes regiões da capitania, entre São Paulo e outros espaços do Brasil e do Atlântico, bem como permitem compreender o processo de crescimento econômico e de transformações sociais vivido pela capitania/província a partir de finais do século XVIII.

Luna e Klein fornecem um excelente panorama das atividades desenvolvidas nas diferentes regiões paulistas nesse momento de crescimento e aceleração econômica que merece ser aqui transcrito:

Ao iniciar-se o século XIX, a ocupação da Capitania concentrava-se nas áreas próximas ao litoral. A cidade de São Paulo, pelas funções de capital e localização privilegiada, representava o núcleo mais importante e densamente povoado; concentrava inúmeras atividades não agrícolas, ligadas ao comércio, ao artesanato e às profissões liberais. Ao seu redor espalhavam-se várias localidades, essencialmente agrícolas, cuja produção abastecia a capital. No planalto paulista, entre São Paulo e o Rio de Janeiro, estendia-se o Vale do Paraíba, com inúmeros povoamentos, alguns de porte como Lorena, Guaratinguetá e Taubaté; todos dedicados à agricultura e à pecuária. Sua posição facilitava o relacionamento comercial com Minas Gerais e o Rio de Janeiro, sendo uma das primeiras áreas integradas ao abastecimento do mercado mineiro. No litoral sul paulista, formaram-se vários núcleos de povoamento, alguns antigos como São Vicente, Iguape e Santos; este o principal porto da Capitania e ligação natural da cidade de São Paulo com o Rio de Janeiro e o exterior. No litoral norte estabeleceram-se também diversos povoados, cuja localização estimulava o relacionamento comercial com a cidade do Rio de Janeiro. São Sebastião, com sua produção de açúcar, era o centro mais importante do litoral norte. Pelo chamado Oeste Paulista, no caminho para o sertão, espalhavam-se algumas localidades, onde concentravase a maior parte da produção de açúcar da Capitania. Itu, Porto Feliz, Campinas e Jundiaí eram vilas importantes da região, todas produtoras de açúcar. Partindo do planalto paulista e estendendo-se para o sul da colônia, havia uma ampla e diversificada área, composta por vilas como Sorocaba, Itapetininga, Curitiba e Paranaguá. Por esse longo percurso, chamado Caminho do Sul, chegavam as mulas e movimentavam-se as tropas envolvidas no conflito com os espanhóis. [...]. ${ }^{187}$

Entre 1777 e 1797, aproximadamente, houve redução significativa das atividades militares na capitania e a estrutura montada para a guerra não foi ampliada. ${ }^{188}$ Entretanto, antes

\footnotetext{
${ }^{186}$ LUNA, F. V.; KLEIN, H. S. Evolução da sociedade e economia...

${ }^{187}$ LUNA, Francisco Vidal; KLEIN, Herbert S. Características da população em São Paulo no início do século XIX. In: LUNA, Francisco Vidal; COSTA, Iraci del Nero; KLEIN, Herbert S. Escravismo em São Paulo e Minas Gerais. São Paulo: Imprensa Oficial/Edusp, 2009, p. 165.

${ }^{188}$ LEONZO, N. Defesa militar..., p. 64-67.
} 
de iniciar o século XIX, São Paulo passou por uma nova reorganização conforme as disposições do decreto de 7 de agosto de 1796. Essas, como visto anteriormente, objetivaram aprimorar a qualidade do serviço prestado pela segunda linha aproximando-o ao da tropa regular. Por isso, o decreto estabeleceu o número de companhias e o contingente padrão de soldados e oficiais, assim como converteu os terços e regimentos auxiliares em regimentos de milícias. Essa reforma sugere a vinculação entre o desenvolvimento das instituições e do aparelho de estado e a prática da guerra, já que as tensões europeias e atlânticas decorrentes da Revolução Francesa certamente conformaram uma de suas principais motivações. Por essa razão, em São Paulo, ela resultou também no alargamento das forças militares, nomeadamente aos corpos milicianos: os seis já existentes foram mantidos e readequados, e cinco regimentos foram criados. ${ }^{189}$ Esses onze corpos milicianos é que compuseram as forças de segunda linha de São Paulo até 1831.

É nesse enquadramento histórico que, em 1797, se criou o Regimento dos Pardos, denominado Regimento dos Úteis, tendo-se como base a reunião das companhias de pardos existentes nas vilas litorâneas e na cidade de São Paulo. ${ }^{190}$ Assim, as antigas companhias de pardos evoluíram da incerteza quanto à sua natureza institucional, nas décadas de 1760 e 1770 , e da condição de companhias avulsas auxiliares, de fins dos anos 1780 e começos dos 1790, e tornaram-se regimento miliciano. Isso significou uma elevação em termos de status e importância na estrutura militar luso-brasileira, pois, além do reconhecimento da condição de milícia, ou segunda linha, as antigas companhias formariam a partir daí uma corporação coesa, melhor aparelhada e treinada, em função de contar com um estado-maior próprio. Por outro lado, no transcorrer da segunda metade do século XVIII as companhias de pretos forros e livres da capitania tomaram direção rigorosamente oposta às congêneres de pardos forros e livres, sendo extintas sem que tal processo sequer produzisse vestígios documentais. ${ }^{191}$ Já os escravos residentes nas localidades da costa marítima permaneceram alistados nos arrolamentos das

\footnotetext{
${ }^{189}$ Cf:: "Decreto de 7 de Agosto de 1796. Regulando os Corpos Auxiliares do Exército, denominando-os para os futuros Regimentos de Milícias”. In: SILVA, A. D. da. Collecção da Legislação Portugueza - Legislação de 1791 a 1801. Lisboa: Typografia Maigrense, 1828; CABRAL, José Antônio Teixeira. A estatística da Imperial Província de São Paulo: com várias anotações do tenente-coronel José Antônio Teixeira Cabral, membro da mesma estatística. Tomo I, 1827. Organização, transcrição e notas paleográficas Cristina Antunes. São Paulo: EDUSP, 2009, p. 123-126. LEONZO, N. Defesa militar..., p. 169-177.

${ }^{190} C f$. : "Ofício n. ${ }^{\circ} 25$ do governador e capitão-general da capitania de São Paulo, Antonio Manuel de Melo Castro e Mendonça, para o ministro e secretário de Estado dos Negócios da Marinha e Domínios Ultramarinos, D. Rodrigo de Souza Coutinho, informando que, logo que tomou posse, cuidou de ver que medidas deveria tomar". AHU_CU_023-01, Cx. 44, D. 3507. São Paulo, 19 de novembro de 1797.

191 Ao menos não há qualquer fragmento documental a esse respeito na coleção Documentos Interessantes e tampouco nos milhares de documentos referentes a São Paulo guardados no AHU ou nos fundos documentais investigados no APESP.
} 
ordenanças até as vésperas da independência do Brasil, mas completamente destituídos da oficialidade que chegara a existir no começo do século XVIII. ${ }^{192}$

FIGURA 1.2 - Localização das Companhias do Regimento dos Úteis (1801-1831)

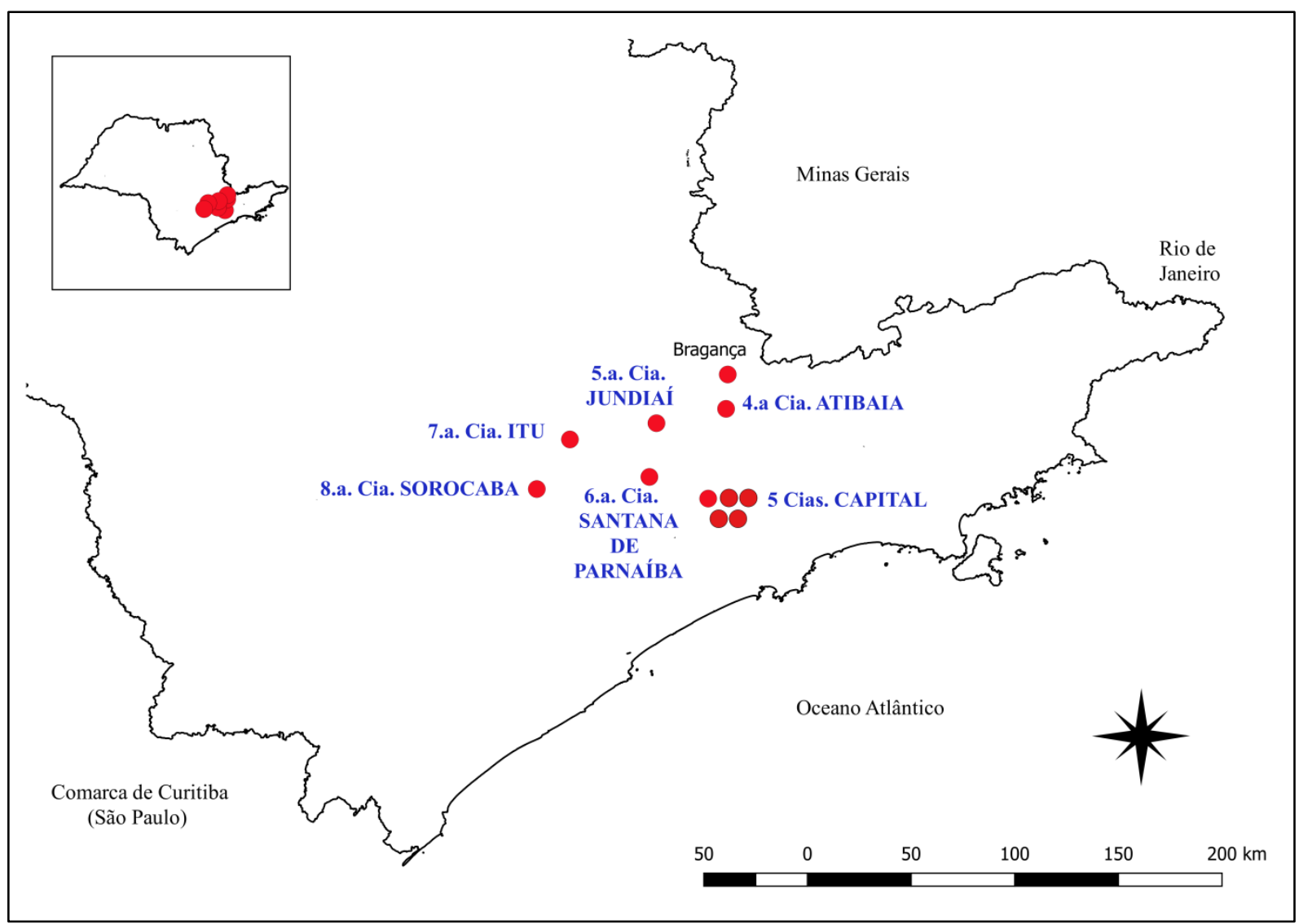

Por volta de 1801, os Úteis passaram por reorganização com a exclusão das companhias litorâneas e adição de companhias recém-formadas nas vilas interioranas da capitania, a saber, Atibaia, Jundiaí, Parnaíba, Itu e Sorocaba, como se vê na Figura 1.2. ${ }^{193}$ Com esta alteração, o Regimento praticamente foi desonerado da obrigação de guarnecer a costa marítima e suas funções passaram a estar diretamente associadas à manutenção da ordem interna à capitania e em particular à cidade de São Paulo. Apenas com a ascensão de um coronel pardo, em 1810, é que o processo de institucionalização da corporação parece chegar a um bom termo: daí em diante os postos da oficialidade seriam regularmente providos e o Regimento aparelhado, à

192 Cf:: APESP, ordem C00265, doc. 33-2-39.

193 Cf: AHU_ACL_CU_023, Cx. 29, D. 1286. No período em questão, o território paulista era formado pelos atuais estados de São Paulo e Paraná. 
custa de seus oficiais, com instrumentos e signos que sugerem a formalização da tropa, tais como o Livro Mestre, bandeira própria, instrumentos de música e instrução periódica. ${ }^{194}$

Em síntese, o processo de institucionalização do Regimento dos Pardos de São Paulo é tributário e de certa forma condensa o histórico das tropas formadas por homens de cor na capitania ao longo do século XVIII. As principais características desse processo são: a) exclusão dos escravos das companhias de pardos e de pretos, que se tornam privativas a forros e livres; b) atrofiamento das companhias de pretos e consolidação das companhias de pardos; c) deslocamento do eixo litoral/planalto em favor do último; d) deslocamento da função primordial desempenhada pelas companhias de pardos e pretos, antes voltada aos inimigos externos e posteriormente para a manutenção da ordem interna à capital e sede do governo; e) obtenção e solidificação do status de segunda linha às companhias avulsas; f) reunião das companhias avulsas de pardos e formação de um Regimento.

${ }^{194} C f$ :: APESP, ordem C00416, Livro 159, fls. 189-190. 


\section{CAPÍtUlo 2 - As Milícias de PARdos E de PRETOS NOS QUADROS ECONÔMicos E DEMográficos da AmÉrica Portuguesa}

\subsection{População e milícia (I) - América portuguesa}

Até aqui, demonstrou-se o elevado grau de dependência que a Monarquia portuguesa mantinha relativamente ao serviço militar prestado pelas populações locais e especialmente no universo colonial, onde, durante a segunda metade do século XVIII, os corpos de segunda linha predominavam em relação às tropas pagas e crescia a participação de pardos e de pretos como auxiliares e milicianos. O mapeamento da criação e difusão das companhias, terços e regimentos compostos por pardos e pretos forros e livres nas diversas capitanias e regiões da América portuguesa salientou, ainda que indiretamente, a influência exercida pela configuração macroeconômica das regiões, de um lado, e o fenômeno das ações bélicas frequentemente relacionadas aos quadros econômicos, de outro. Em resumo, verificou-se que o pontapé inicial ao processo de constituição dos corpos militares de homens de cor ocorreu nas capitanias do açúcar, principal polo econômico e escravista no século XVII e em decorrência das guerras luso-holandesas. Pouco tempo depois, a presença nas margens da sociedade açucareira de grupos indígenas e de escravos fugidos, esses últimos agrupados em quilombos, foi encarada como ameaça às populações luso-americanas e ao funcionamento das unidades agroexportadoras coloniais, decorrendo daí o emprego sistemático das tropas militares em tela. Estavam dadas as condições para sua manutenção, evolução e difusão. Já no começo do século XVIII, a região Centro-Sul da América portuguesa assistiria à formação de suas primeiras companhias de pardos e pretos. Ali esse fenômeno se vinculava ao boom econômico associado às descobertas de ouro e diamantes, bem como ao decorrente assédio estrangeiro àquelas riquezas - concretizado nas invasões à cidade do Rio de Janeiro promovidas por corsários franceses - e às necessidades de manutenção da ordem interna e de segurança frente a grupos indígenas hostis à dominação colonial.

Demonstrou-se uma fase de significativa expansão dos corpos militares compostos por pardos e pretos - nomeadamente companhias e terços auxiliares - ao longo da segunda metade do século XVIII. Na raiz desse quadro, o qual, aliás, foi extensivo às várias capitanias e regiões luso-americanas, estavam as tensões diplomáticas e bélicas existentes na Europa entre as décadas de 1750 e 1760 e os seus reflexos no universo colonial. Finalmente, a região Norte da 
América portuguesa gestou seus primeiros corpos militares compostos por pardos e pretos apenas entre fins do século XVIII e começos do seguinte, em meio a um contexto de crescimento econômico e expressão local do "renascimento agrícola" vivenciado por grande parte da colônia.

Entretanto, pouco se mencionou, até agora, o papel desempenhado por elementos mais diretamente vinculados aos grupos sociais formados por pardos e pretos livres e libertos na formação e conservação de seus próprios corpos militares. Refere-se, aqui, em primeiro lugar, às condições de emergência de tais grupos sociais nos quadros da dinâmica da escravidão no Brasil, isto é, na relação estabelecida entre atividades econômicas, tráfico de escravos, mecanismos de alforria e a consequente formação de conjuntos populacionais cuja origem situava-se na escravidão mas que a condição jurídica era forra ou livre. ${ }^{1}$ Em segundo lugar, pensa-se na atuação social de pardos e pretos livres exercendo pressão sobre a estrutura administrativa-militar no sentido da formação de seus corpos militares bem como, complementarmente, manipulando modelos institucionais e signos referentes ao universo militar colonial. Esses últimos elementos serão abordados em capítulo adiante. Objetiva-se, por ora, examinar as relações existentes entre a configuração populacional de pardos e pretos forros e livres e a existência das milícias de pardos e pretos nas diversas capitanias da América portuguesa entre o final do século XVIII e o início do XIX. Como se sabe, em um império em boa medida carente de recursos humanos para o preenchimento dos quadros administrativoburocrático, religioso e militar, como era o português, e especialmente tratando-se de suas unidades coloniais ultramarinas, o acesso a tais funções era relativamente comum a não europeus, ou melhor, aos colonizados e aos agentes colonizadores subordinados. ${ }^{2}$ Em que medida os corpos militares de pardos e pretos refletiam, em cada capitania, a disponibilidade numérica de pardos e pretos livres?

Um primeiro passo para a análise da constituição dos homens livres de cor enquanto grupo social é o exame de suas origens, as quais se vinculam diretamente ao tráfico de escravos e à dinâmica da escravidão no Brasil. Dentre os vários espaços coloniais americanos, a América portuguesa foi o que recebeu o maior volume de cativos africanos durante o período de vigência da escravidão moderna. Calcula-se que o Brasil tenha sido o destino de nada menos que 4.864.374 pessoas nesta condição, tornando-se responsável por quase metade do total de

\footnotetext{
${ }^{1}$ MARQUESE, Rafael de Bivar. A dinâmica da escravidão no Brasil. Resistência, tráfico negreiro e alforrias, séculos XVII a XIX. Novos Estudos, n. 74, p. 107-123, 2006.

${ }^{2}$ RUSSELL-WOOD, A. J. R. Autoridades ambivalentes...
} 
escravos desembarcados no continente americano entre os anos 1501-1866, ou seja, 10.538.227 homens e mulheres. ${ }^{3}$

\section{TABELA 2.1 - Desembarque de escravos africanos no Brasil por período e região de destino}

\begin{tabular}{lcccccr}
\hline \multirow{2}{*}{ Períodos } & \multicolumn{5}{c}{ Brasil } & Total \\
\cline { 2 - 6 } & Amazônia & Bahia & Pernambuco & $\begin{array}{c}\text { Sudeste do } \\
\text { Brasil }\end{array}$ & $\begin{array}{c}\text { Brasil não } \\
\text { especificado }\end{array}$ & \\
\hline $1561-1600$ & 0 & 5.647 & 18.571 & 3.955 & 0 & 28.173 \\
$1601-1650$ & 0 & 115.307 & 96.891 & 80.712 & 1.869 & 294.779 \\
$1651-1700$ & 1.096 & 196.889 & 123.446 & 140.003 & 0 & 461.434 \\
$1701-1750$ & 4.181 & 414.290 & 184.178 & 280.421 & 5.593 & 888.663 \\
$1751-1800$ & 67.100 & 399.859 & 144.885 & 474.833 & 9.493 & 1.096 .170 \\
$1801-1850$ & 69.397 & 412.034 & 255.990 & 1.274 .494 & 33.093 & 2.045 .008 \\
$1851-1856$ & 0 & 981 & 350 & 5.568 & 0 & 6.899 \\
\hline Total & 141.774 & 1.545 .006 & 824.312 & 2.259 .987 & 50.048 & 4.821 .127 \\
\hline
\end{tabular}

Fonte: The Trans-Atlantic Slave Trade Database. Endereço eletrônico: http://slavevoyages.org/tast/assessment/estimates.faces?yearFrom $=1501 \&$ yearTo $=1866 \&$ flag $=2 \&$ disembarkatio $\underline{\mathrm{n}=804.805 .801 .802 .803}$. Data de acesso: 2 de fevereiro de 2015.

Conforme os dados da Tabela 2.1, escravos africanos estavam sendo empregados na Bahia e Pernambuco desde o processo de montagem da economia canavieira, na segunda metade do século XVI. Com a transição operada no predomínio da mão de obra indígena para a de escravos africanos ${ }^{4}$, o volume desse contingente humano ampliou-se consideravelmente já na primeira parte do século XVII e apresentaria tendência similar na metade seguinte. Nesta mesma centúria um contingente expressivo de escravos desembarcou em portos da região Sudeste do Brasil, particularmente no Rio de Janeiro, o que denota um quadro de dinamismo econômico - que inclui a prática de contrabando para a região do Prata - suficiente para demandar um volume de mão de obra cativa próximo ao que se destinava a Pernambuco no

\footnotetext{
${ }^{3}$ As estimativas mais recentes, e que são incorporadas aqui, provêm do The Trans-Atlantic Slave Trade Database (www.slavevoyages.org). O link direto para os dados consultados é: http://slavevoyages.org/tast/assessment/estimates.faces?yearFrom $=1501 \&$ yearTo $=1866 \&$ disembarkation $=205.20$ 4.201.203.202.402.403.401.404.405.804.702.805.703.701.801.802.803.305.304.307.306.309.308.311.310.705.7 04.501.502.600.301.302.303 . Ver também a boa discussão de Klein acerca das linhas gerais do tráfico atlântico de escravos para o Brasil em KLEIN, Herbert S. A demografia do tráfico atlântico de escravos para o Brasil. Estudos econômicos, v. 17, n. 2, p. 129-149, 1987.

${ }^{4}$ SCHWARTZ, Stuart B. Segredos internos: engenhos e escravos na sociedade colonial, 1550-1835. São Paulo: Companhia das Letras, 1988, p. 57-73.
} 
mesmo período. O século XVIII, em sua primeira metade, assistiu ao ingresso tímido e modesto da região Norte da América portuguesa nos circuitos do tráfico atlântico de escravos bem como a uma formidável expansão da economia açucareira capitaneada, evidentemente, por Pernambuco e Bahia. Mas o que salta aos olhos, para esse mesmo período, é o impacto que a descoberta do ouro gerou na região Centro-Sul: esse fica nitidamente expresso no volume de escravos a ela destinados, que duplicou em relação ao período anterior. Pernambuco e Bahia apresentaram uma leve queda no volume de cativos aportados na segunda metade do Setecentos, mas tenderam a se recuperar e até a ampliar seu contingente de mão de obra escrava a partir das décadas finais daquele século. Por sua vez, as regiões Norte e Centro-Sul praticamente não viveram oscilações decrescentes no abastecimento de escravos durante os anos 1751-1800. Antes, elas encorparam ainda mais seus contingentes de pessoas escravizadas, cujo fenômeno se conecta, do ponto de vista da demanda por mão de obra, ao renascimento agrícola da América portuguesa. Embora a extração de ouro tenha declinado paulatinamente em Minas Gerais a partir de meados do século XVIII, Rio de Janeiro e, depois, São Paulo dinamizariam suas economias mediante o cultivo da cana-de-açúcar e, já no século XIX, do café. Nesse mesmo contex to é que as capitanias do norte, nomeadamente Maranhão e Pará, se conectaram efetivamente ao tráfico de escravos, na esteira da economia exportadora de algodão, arroz e cacau. ${ }^{5}$

Fica evidenciado que o tráfico de escravos africanos é uma variável plenamente compatível com a relação estabelecida anteriormente entre os contextos econômicos e as ações militares que caracterizaram as diferentes regiões da América portuguesa, de um lado, e a formação dos corpos militares compostos por pardos e pretos livres nas mesmas localidades, de outro. Em outros termos, a dinâmica da construção e dispersão daqueles corpos militares está intimamente vinculada às variáveis interdependentes em questão - atividades econômicas, tráfico de escravos e a posição das regiões na hierarquia da guerra. Não é por acaso, portanto, que as companhias e terços de pardos e pretos tenham se originado na região Nordeste, difundindo-se posteriormente pelas capitanias do Centro-Sul e mais tardiamente nas capitanias do Norte da América portuguesa. Ainda assim, o elo entre a presença de escravos e a existência de corpos militares destinados aos seus descendentes livres surge com feição frágil enquanto não se empreende um exame à formação e às características da camada de homens livres provenientes direta ou indiretamente da escravidão.

\footnotetext{
${ }^{5}$ ALDEN, Dauril. El Brasil colonial tardio, 1750-1808..., p. 329-352.
} 
Além de ser a maior importadora de escravos africanos, a sociedade escravista brasileira também foi marcada pela abrangência das oportunidades e mecanismos nela gestados para a manumissão escrava. Este último aspecto, que era compartilhado com várias regiões escravistas da América espanhola, revela-se com maior clareza quando comparado com a sociedade escravista norte-americana, por exemplo, a qual apresentava sérias restrições a qualquer modalidade de manumissão escrava. ${ }^{6} \mathrm{Na}$ longa duração, as relativamente elevadas taxas de alforria podem ser tomadas como elemento de primeira ordem na natureza e mecânica da escravidão no Brasil, sendo cabível sugerir que os descendentes livres de escravos se comportariam como uma "válvula de escape", amenizando as tensões mais profundas daquela sociedade escravista. ${ }^{7}$ Conforme Marquese, "a partir de fim do século XVII, o sistema escravista brasileiro passou a escorar-se em uma estreita articulação entre tráfico transatlântico de escravos bastante volumoso e número constante de alforrias". ${ }^{8}$ Com efeito, com base em modelos teóricos que questionam a definição de escravo como coisa e "encaram a escravização, a situação de escravidão e a manumissão como partes de um mesmo processo institucional" de transformação de status, pode-se ter uma visão mais complexa, e menos estática, do fenômeno da formação das camadas sociais compostas por homens e mulheres de cor livres. ${ }^{9}$ Junto das alforrias, a miscigenação entre escravizados, negros livres e libertos, índios, mestiços e brancos também está na raiz do grupo social em questão.

Infelizmente, as informações estatísticas relativas à população colonial são extremamente precárias considerando-se o período que vai até meados do século XVIII, de tal forma que o acompanhamento da evolução e dinâmica demográfica do segmento composto por egressos do cativeiro e seus descendentes se torna inviável ou até mesmo impossível. ${ }^{10}$ No entanto, a existência de estimativas atinentes a quase todas as capitanias para as décadas de 1800 e 1810 permite um retrato global da presença dos homens livres de cor nas diversas regiões do Brasil. Esses dados constam da Tabela 2.2, por meio da qual é possível igualmente estabelecer relações entre o contingente absoluto da população livre de cor em cada capitania e

\footnotetext{
${ }^{6}$ KLEIN, Herbert S. Os homens livres de cor...; LUNA, F. V.; KLEIN, H. S. Evolução da sociedade e economia ..., p. 197-199.

${ }^{7}$ DEGLER, Carl N. Nem preto nem branco: escravidão e relações raciais no Brasil e nos Estados Unidos. Rio de Janeiro: Labor do Brasil, 1976.

${ }^{8}$ MARQUESE, R. de B. A dinâmica da escravidão no Brasil..., p. 109.

9 KOPYTOFF, Igor. Slavery...; PATTERSON, Orlando. A condição social das pessoas libertadas. In: PATTERSON, O. Escravidão e morte social. São Paulo: Edusp, 2008, p. 341-368.

${ }^{10}$ Sobre a precariedade dos dados censitários para a América portuguesa, ver MARCÍlIO, Maria Luiza. A população do Brasil colonial. In: BETHELL, Leslie (Org.). História da América Latina: A América Latina Colonial. (vol. 2). São Paulo: EDUSP; Brasília, DF: Fundação Alexandre de Gusmão, 1999, p. 311-338.
} 
a existência de regimentos milicianos integrados exclusivamente por pardos e pretos livres. Estes corpos militares são, por ora, considerados conjuntamente.

TABELA 2.2 - Relação entre população livre de cor e regimentos milicianos de pardos e de pretos por capitanias $(\mathbf{1 8 0 3 - 1 8 1 5 )}$

\begin{tabular}{lccc}
\hline \multicolumn{1}{c}{ Capitania } & Ano & $\begin{array}{c}\text { População de cor } \\
\text { livre }\end{array}$ & $\begin{array}{c}\text { Regimentos Milicianos } \\
\text { de pardos e pretos }\end{array}$ \\
\hline Pernambuco & 1810 & 164.634 & 6 \\
Minas Gerais & 1814 & 143.080 & 7 \\
Bahia & 1810 & 113.582 & 2 \\
Paraíba & 1811 & 56.161 & 2 \\
São Paulo & 1811 & 48.004 & 1 \\
Rio de Janeiro & 1803 & 42.243 & 2 \\
Goiás & 1810 & 20.063 & 2 \\
Maranhão & 1810 & 13.643 & 1 \\
Mato Grosso & 1815 & 10.564 & 1 \\
Ceará & --- & ---- & 0 \\
\hline
\end{tabular}

Fonte: para a população de cor livre de Pernambuco, Bahia, Rio de Janeiro, Goiás e Maranhão, ver ALDEN, D. El Brasil colonial tardío, 1750-1808..., p. 313; para Minas Gerais, Paraíba, São Paulo e Mato Grosso, consultar KLEIN, H. S. Os homens livres de cor..., p. 6-9. Quanto aos regimentos milicianos, consultar o Quadro 1.1.

Em primeiro lugar, cumpre destacar que as capitanias onde havia maior número de homens livres de cor durante as duas primeiras décadas do século XIX eram justamente aquelas que se caracterizaram por dinamismo econômico já no século anterior. Exceção, talvez, para o caso do Rio de Janeiro, que, a despeito de se ter convertido, no Setecentos, no principal porto de desembarque de escravos e na capital da América portuguesa e sede do vice-rei, possuía menos homens de cor do que a capitania vizinha São Paulo, cujo crescimento econômico datava apenas de fins do século XVIII. ${ }^{11}$ Seja como for, as capitanias açucareiras se apresentavam ao

\footnotetext{
${ }^{11}$ Em função da rarefação de dados populacionais seguros para a capitania do Rio de Janeiro, atestada em KLEIN, Herbert S. Os homens livres de cor..., p. 8, e LARA, S. H. Fragmentos setecentistas..., p. 127, os quais restringiram suas amostras à cidade do Rio de Janeiro, incorporo aqui a estimativa de ALDEN, D. El Brasil colonial tardío, 1750-1808..., p. 313, referente à população de toda aquela capitania, mesmo suspeitando que nela tenha havido subestimação do contingente composto pelas pessoas de cor livres. Ao mesmo tempo, descartei a estimativa apresentada por Alden para São Paulo, a qual, comparada aos dados fornecidos por Klein, referentes a seis censos
} 
lado da mineradora como as que detinham os contingentes mais vultosos de pardos e pretos livres, o que certamente se vincula às características e ao histórico de sua inserção no tráfico transatlântico de escravos e ao processo de mudança de status característica daquele sistema escravista. No outro extremo, dentre as capitanias cuja quantidade de pessoas de cor livres era comparativamente menor, estavam aquelas secundárias em termos de extração de ouro, de povoamento recente, assim como outras economicamente periféricas e que experimentaram algum desenvolvimento socioeconômico para fins do período colonial.

Em segundo lugar, deve-se atentar para a relação que pode ser estabelecida entre a disponibilidade de homens livres de cor para as funções militares e a efetiva existência de milícias de pardos e pretos em cada capitania. Pernambuco e Minas Gerais eram as capitanias cujo grupo de homens livres de cor era mais avultado, e também foram as que mais regimentos milicianos exclusivos a pardos e pretos formaram. Inversamente, observa-se a tendência de que as regiões que apresentaram menor quantidade de milícias de pardos e de pretos fossem aquelas que dispunham de menores contingentes de pessoas de cor livres. Em geral, verifica-se que há correlação entre as variáveis examinadas. No entanto, há dois casos em que, nitidamente, o número elevado de homens de cor não reflete na quantidade de regimentos milicianos: o da Bahia, estimado em 113.582 homens livres de cor e apenas dois regimentos, sendo um de pardos e outro de pretos, e o de São Paulo, que contava com cerca de 48.004 homens livres de cor, mas apenas um regimento miliciano de pardos e nenhum de pretos livres. O contingente de afrodescendentes e mestiços livres no caso baiano até se aproximava do existente em Pernambuco e Minas Gerais, mas seus dois regimentos milicianos estavam distantes dos seis e sete daquelas capitanias, respectivamente. O caso de São Paulo é igualmente interessante para se refletir, uma vez que lá havia maior número de homens livres de cor do que nas capitanias do Rio de Janeiro e de Goiás e, no entanto, essas contavam, cada qual, com um regimento miliciano de pardos e outro de pretos. Ora, enquanto em São Paulo predominavam os pardos entre as pessoas de cor livres, na capital e principal porto da América portuguesa e em uma das capitanias onde se realizaram as maiores extrações auríferas da colônia, havia grande concentração de escravos pretos na virada do século XVIII para o XIX, o que sugere a presença de um contingente de pretos libertos igualmente pujante. Em parte, adviria daí a formação dos dois regimentos compostos por esses libertos e livres, corpos militares inexistentes na capitania paulista.

entre 1800 e 1836, subestima consideravelmente a participação da camada de escravos no conjunto da população total. Vê-los em KLEIN, H. S. Os homens livres de cor..., p. 8. 
Esse exercício permite que se enunciem algumas hipóteses: a) havia estreita relação entre a formação e existência de terços ou regimentos de pardos e pretos livres e as variáveis crescimento econômico, posição regional na hierarquia de guerra imperial, vinculação ao tráfico de escravos africanos e formação de uma camada social composta por homens livres de cor; b) contudo, tais variáveis não explicam satisfatoriamente algumas variantes, como parecem ser o caso da Bahia e de São Paulo, os quais se caracterizaram por elevado número de homens de cor livres e reduzido efetivo miliciano; c) como decorrência, se sugere que a atenção ao histórico dos equilíbrios de poder internos às capitanias, mormente as relações de interdependência estabelecidas entre os grupos formados por indivíduos identificados como brancos, pardos e pretos livres e, finalmente, escravos, contribua para a compreensão do fenômeno da formação e existência das milícias de pardos e de pretos. Inicialmente, propõe-se aqui expandir os termos da comparação efetuada anteriormente, de forma a tornar possível o estabelecimento de relações e comparações envolvendo o peso demográfico de brancos, homens de cor livres e de escravos e o peso dos regimentos milicianos de brancos ${ }^{12}$, pardos, pretos e índios. Aqui se adotou o procedimento de agregar em um mesmo conjunto os corpos militares de pardos e de pretos, em primeiro lugar, para viabilizar a comparação com os dados demográficos disponíveis, nos quais pardos e pretos são incluídos em um mesmo grupo e, em segundo lugar, para delinear mais claramente o contraste entre a proporção dos regimentos compostos por brancos e a dos de pardos e pretos. Não se quer, claro está, negligenciar as distinções existentes entre tais grupos.

Um aspecto que de imediato se faz notar dentre os dados da Tabela 2.3 é a predominância absoluta dos regimentos milicianos identificados a homens brancos em fins do período colonial nas capitanias examinadas. Em média, para cada corpo militar constituído por pardos, pretos ou índios, havia três de brancos. Ademais, em vários casos a proporção das milícias de brancos foi ainda maior. Na Bahia, tais regimentos perfaziam $80 \%$ de todo o corpo miliciano, e tanto no Rio de Janeiro como no Ceará esse índice chegou a 89\%. O caso mais desigual foi exatamente o de São Paulo, no qual 91\% dos regimentos de segunda linha eram identificados aos homens brancos. Algumas capitanias permaneceram com percentuais equivalentes entre regimentos de brancos e regimentos de pardos e pretos, e, no caso

\footnotetext{
${ }^{12}$ Uma vez que os regimentos milicianos exclusivos a pardos, pretos e índios eram explicitamente identificados como tais, considera-se aqui que todos os demais regimentos milicianos eram identificados a homens brancos, mesmo quando os epítetos corporativos remetessem para armas militares específicas, como a cavalaria, para posições sociais elevadas, como os "regimentos da nobreza", ou simplesmente às localidades sede. Evidentemente, havia homens livres de cor alistados nos regimentos de brancos, mas nestes eles vivenciavam inúmeras restrições, tal como a impossibilidade de ascender aos postos do oficialato.
} 
maranhense, também regimentos de índios. Entretanto, é significativo que em nenhuma configuração social o equilíbrio dos contingentes militares foi desfavorável aos brancos. Em Goiás e na Paraíba, as capitanias onde os regimentos de homens de cor representavam 50\% das forças milicianas, havia dois regimentos de brancos e um de pardos e outro de pretos. No Maranhão, existiam três corpos de segunda linha formados por brancos, dois por índios e um por afrodescendentes e mestiços. Jamais, portanto, os grupos de pardos ou pretos obtiveram, isoladamente, o mesmo peso dos brancos na estrutura militar colonial - não obstante o fato de que em várias capitanias as pessoas de cor livres eram maioria em relação às brancas.

TABELA 2.3 - Relação entre regimentos milicianos por cor e população por cor (1800-1811)

\begin{tabular}{|c|c|c|c|c|c|c|c|c|c|}
\hline \multirow[b]{2}{*}{ Capitania } & \multicolumn{4}{|c|}{ Regimentos Milicianos por cor $(\%)$} & \multicolumn{5}{|c|}{ População por cor e condição (\%) } \\
\hline & Ano & $\mathrm{BCO}$ & $\begin{array}{c}\text { PARD e } \\
\text { PRET }\end{array}$ & ÍND & Ano & $\mathrm{BCO}$ & $\begin{array}{r}\text { COR } \\
\text { LIVR }\end{array}$ & ESCR & ÍND \\
\hline $\begin{array}{l}\text { Minas } \\
\text { Gerais }\end{array}$ & 1804 & 68 & 32 & -- & 1810 & 23,6 & 33,7 & 40,9 & 1,8 \\
\hline Pernambuco $^{\mathrm{a}}$ & 1806 & 68,5 & 31,5 & - & 1810 & 28,5 & 42 & 26,2 & 3,2 \\
\hline Bahia $^{b}$ & 1800 & 80 & 20 & - & 1810 & 19,8 & 31,6 & 47 & 1,5 \\
\hline $\begin{array}{l}\text { Rio de } \\
\text { Janeiro }\end{array}$ & 1800 & 89 & 11 & -- & 1810 & 33,6 & 18,4 & 45,9 & 2 \\
\hline Goiás & 1806 & 50 & 50 & -- & 1810 & 12,5 & 36,2 & 46,2 & 5,2 \\
\hline Paraíba & 1800 & 50 & 50 & -- & 1811 & 38 & 47,2 & 14,8 & - \\
\hline Maranhão & 1803 & 50 & 16,7 & 33,3 & 1810 & 31 & 17,3 & 46 & 5 \\
\hline São Paulo & 1807 & 91 & 9 & - & 1811 & 54 & 23 & 23 & -- \\
\hline Ceará & 1805 & 89 & 11 & -- & 1808 & 34,5 & & $5,7^{\mathrm{c}}$ & 9,8 \\
\hline TOTAL $\left(\right.$ n. $^{\circ}$ & abs.) & 77 & 24 & 2 & & & & & \\
\hline
\end{tabular}

${ }^{a}$ Incluída a comarca de Alagoas e excluídas as capitanias anexas.

${ }^{\mathrm{b}}$ Excluídas as capitanias anexas de Sergipe d'El Rey e Espírito Santo.

${ }^{\mathrm{c}}$ Incluídos indistintamente pessoas de cor livres e escravos.

Legenda: $\mathrm{BCO}=$ brancos; PARD e PRET = pardos e pretos; ÍND = índios; COR LIVR = pessoas de cor livres; ESCR = escravos

Fontes: (dos regimentos milicianos) [Minas Gerais] AHU_CU_011, Cx. 173, D. 12930; [Pernambuco] AHU_ACL_CU_015, Cx. 259, D. 17405; [Bahia] AHU_ACL_CU_005, Cx. 216, D. 15168; [Rio de Janeiro] AHU_ACL_CU_017, Cx. 181, D. 13282; [Goiás] AHU_ACL_CU_008, Cx. 51, D. 2892; [Paraíba] AHU_CU_014, Cx. 36, D. 2588; [Maranhão] AHU_CU_009, Cx. 131, D. 9771; [São Paulo] AHU_ACL_CU_023, Cx. 29, D. 1299; [Ceará] AHU_CU_006, Cx. 19, D. 1080; [Rio Negro] AHU_ACL_CU_013, Cx. 70, D. 6003; (da população das capitanias) para a Paraíba e São Paulo, KLEIN, H. S. Os homens livres de cor..., p. 7 e 8; para o Ceará, MENEZES, Luiz B. A. de. Memoria sobre a capitania do Ceará. Rio de Janeiro, 18 de abril de 1814. RIHGB, tomo XXXIV, parte 1, 1871, p. 276; para todas as demais capitanias, ALDEN, D. El Brasil colonial tardío, 1750-1808..., p. 313. 
De fato, por volta de 1810, a preponderância de descendentes de escravos e de indígenas no conjunto da população livre do Brasil - incorporados às categorias "preto" e "pardo" ocorria em Minas Gerais, Pernambuco, Bahia, Goiás, Paraíba e, talvez, no Ceará, cuja população livre de cor fora computada juntamente à escrava. No conjunto das capitanias examinadas, Maranhão, Rio de Janeiro e São Paulo possuíam população branca numericamente superior ao conjunto das pessoas de cor livres. Esse dado explica parcialmente a razão pela qual as duas últimas contavam com as maiores desproporções entre regimentos milicianos e população total dividida por cores. Minas Gerais e Pernambuco eram as capitanias com maior contingente de homens de cor livres do Brasil e nelas essa camada populacional era significativamente superior à formada por brancos. Embora tais localidades também fossem as que abrigavam a maior parte das milícias de pardos e de pretos luso-americanas, o que de certa forma refletia a superabundância de homens disponíveis para o serviço militar, nelas as unidades milicianas correspondentes aos brancos equivaliam ao dobro do total das milícias de pardos e pretos. Do mesmo modo, nota-se que, dentre as capitanias em tela, a do Maranhão era a única a contar com unidades milicianas compostas por indígenas. O contingente nativo perfazia $5 \%$ de toda a população maranhense e parte dele era alocado nos dois regimentos milicianos privativos a índios. No entanto, as capitanias do Ceará e Goiás superavam-na em termos do percentual da população indígena face ao contingente humano total, mas tal supremacia não se expressou nos corpos militares de índios. Revela-se, desse modo, as noções, quase óbvias, mas essenciais para a argumentação que se segue, de acordo com as quais, de um lado, havia uma tendência a que as capitanias com maior contingente de homens de cor livres também obtivessem maior número de regimentos milicianos de pardos e de pretos e, inversamente, que as regiões onde aqueles corpos militares eram escassos fossem as caracterizadas pelas menores quantidades de egressos do cativeiro e seus descendentes. De outro lado, o exame comparativo entre os percentuais de população identificada como brancos, homens livres de cor e índios indica que não há, necessariamente, correlação entre a proporção de população disponível para o ingresso nas milícias e a proporção de corpos militares de segunda linha separados por cor.

Não há como ser diferente em se tratando de processos históricos e configurações sociais. Como advertiu Norbert Elias, ao teorizar sobre a dinâmica social no tempo a partir dos modelos de jogos, o entendimento de quaisquer formações sociais, e especialmente das mais complexas, de modo algum é redutível à consideração da soma de seus indivíduos e tampouco à ideia de que possuem existência metafísica. Antes, as configurações sociais e as suas transformações se devem ao entrelaçamento permanente existente entre os seus integrantes, que 
é o que lhes proporcionam dinâmicas próprias, nunca plenamente previsíveis ou controláveis por parte daqueles que delas fazem parte. ${ }^{13}$ Isso significa que as dezenas e, não raro, centenas de milhares de pessoas que viviam nas capitanias luso-americanas formavam configurações sociais extremamente complexas a partir dos seus infinitos entrelaçamentos e relações de interdependência. A disposição quantitativa dos grupos sociais uns em relação aos outros (ou as suas proporções) fornece parâmetros relevantes para a compreensão daquelas sociedades, como bem se vê para o caso da existência e manutenção das milícias de pretos e de pardos, mas, isoladamente, não dá conta de explicar integralmente os fenômenos históricos e sociais. É preciso atentar também para as relações entre os indivíduos e grupos que constituíam cada capitania ou província em um equilíbrio de poder específico. Não cabe, no espaço deste trabalho, um exame às diversas configurações sociais luso-americanas; contudo, esse tema será retomado minuciosamente em relação a São Paulo na parte 3 desta tese.

Outra dimensão extremamente relevante para a compreensão da existência das milícias de cor transcende ao âmbito mais restrito das capitanias e diz respeito às relações estabelecidas entre os diversos grupos sociais e o Estado e também à questão primordial, para este, da manutenção do equilíbrio social. Portanto, para além da carência colonial de homens para empunhar armas e da influência dos elementos de natureza demográfica que indubitavelmente estavam na raiz da existência das milícias de pardos e de pretos, o fenômeno em questão deve ser lido também - e, para o período colonial tardio, com muita ênfase - como sendo de ordem política. De acordo com a definição setecentista de Raphael Bluteau, "na sua mais ampla significação, Politica, é a que às cidades, repúblicas, reinos e impérios dá os preceitos do bom governo, assim para o bem dos que mandam, como dos que obedecem”. ${ }^{14}$ A acepção empregada por Bluteau, em um sentido próximo a "arte ou ciência do Governo", remete às reflexões típicas da filosofia clássica grega, origem desse conceito. ${ }^{15}$ Ela está intimamente atrelada a uma noção vigente nas sociedades do Antigo Regime por meio da qual se esperava que os governantes, entendidos fundamentalmente como árbitros da justiça, cumprissem o papel de manter as sociedades e grupos em um justo equilíbrio. Esse consistia, para citar uma definição axiomática de justiça, derivada igualmente do mundo greco-romano, em "dar a cada um o que lhe

\footnotetext{
${ }^{13}$ ELIAS, Norbert. Introdução à sociologia. Lisboa: Edições 70, 2008, p. 77-112, mas, especialmente, as p. 107108.

${ }^{14}$ Cf:: BLUTEAU, Raphael. Vocabulário portuguez \& latino: aulico, anatômico, architectonico [...]. Coimbra: Collegio das Artes da Companhia de Jesus, 1712-1728. 8 v. Verbete "Polîtica". Vol. 6, p. 576-577.

15 BOBBIO, Norberto; MATTEUCCI, Nicola; PASQUINO, Gianfranco. Dicionário de política. (1.a Ed.). Brasília: Editora Universidade de Brasília, 1998, v. 2, p. 954.
} 
corresponde" ${ }^{16}$ respeitando-se os estatutos e privilégios de indivíduos e grupos. No entanto, a sociologia dos séculos XIX e XX demonstrou que, para além do âmbito da jurisprudência, o monopólio da violência ou do uso da força militar consistia no principal requisito para o estabelecimento ou funcionamento do poder político, cuja finalidade mínima seria manter suas próprias condições de existência mediante o controle das tensões internas e da precaução a ameaças externas ${ }^{17}$, o que, em linguagem de Antigo Regime, pode ser lido como um dos significados da expressão "bom governo" aplicada por Bluteau. ${ }^{18}$

Portanto, há vários elementos a se considerar a partir do entendimento de que as milícias eram, entre outras coisas, um fenômeno político. Primeiramente, que essa definição não significa que os corpos militares de pardos e pretos estivessem, em fins do período colonial, destituídos de suas funções militares. Como visto em capítulos anteriores, a maior parte deles foi formada ou reformada em função da guerra luso-espanhola da segunda metade do século XVIII e se manteve durante o período das guerras promovidas por D. João VI e por D. Pedro I no Sul e no Norte. Em segundo lugar, quando se pensa na sociedade da América portuguesa, cumpre recordar que se tratava de uma sociedade escravista, ou melhor, da configuração social americana com maior participação de escravos e de seus descendentes livres no conjunto da população total. Dentre as capitanias que abrigavam corpos militares de homens de cor estavam, sem dúvida, as mais importantes para a colônia sob qualquer ponto de vista. Entre 1808 e 1811, em muitas delas, a camada composta por pessoas identificadas como brancas era minoritária em relação às pessoas de cor livres e em outras ocasiões ao grupo dos escravos. No caso de Minas Gerais, Bahia e Goiás, tanto as pessoas de cor livres como as escravas faziam-se majoritárias comparativamente aos brancos. Exceto São Paulo, em todas as demais configurações sociais os negros livres e escravos, se considerados em um mesmo conjunto, eram maioria em relação aos brancos. ${ }^{19}$ Foi a partir de semelhante constatação para a capitania de Pernambuco que seu então governador e capitão-general, Caetano Pinto de Miranda Montenegro, expressou, em 1806, essa configuração populacional como problema político. Conforme suas palavras,

\footnotetext{
${ }^{16}$ BARZOTTO, Luis Fernando. Justiça Social - Gênese, estrutura e aplicação de um conceito. Revista Jurídica Virtual, Brasília, v. 5, n. 48, maio/2003.

${ }^{17}$ BOBBIO, N.; MATTEUCCI, N.; PASQUINO, G. Dicionário de política..., v. 2, p. 955-959.

${ }^{18}$ Ver também SILVEIRA, Marco Antônio. O universo do indistinto. Estado e sociedade nas Minas setecentistas (1735-1808). São Paulo: Editora Hucitec, 1997, p. 78 e ss.

${ }^{19} \mathrm{O}$ predomínio dos brancos em relação à população de cor, livre e escrava, paulista foi constante por todo o século XIX. Ver MARCÍLIO, Maria Luiza. Crescimento demográfico e evolução agrária paulista: 1700-1836. São Paulo: Hucitec, Edusp, 2000, p. 118-119.
} 
Os brancos são os possuidores das terras e das riquezas. Os pardos e pretos em geral são pobres e vivem do seu trabalho e indústria: sendo, porém, em muito maior número e mais robustos nestes climas, têm a força física da sua parte.

Por consequência, a força moral e de opinião deve estar a favor dos brancos, quando não, dirão os outros, "ide-vos embora, também queremos possuir: já basta de obedecer, também queremos mandar". ${ }^{20}$

Essa argumentação expressa bem o fato de que o "bom governo" na sociedade da América portuguesa passava, como requisito ao funcionamento estável da justiça distributiva, por um esforço de manutenção daquilo que ela efetivamente era, ou seja, um sistema de dominação assentado na escravidão e na estigmatização de amplos setores da população. Para o governador colonial, as milícias de pardos e pretos eram instituições de extrema importância política, pois elas funcionariam perigosamente ao longo do tempo como veículos para a ampliação da "força física" e da "força moral e de opinião" dos descendentes de escravos razão pela qual deviam ser controladas.

Reflexões dessa natureza são recorrentes entre fins do século XVIII e as primeiras décadas do XIX, aqui e acolá, nas penas de governadores de capitanias, elites locais e também de observadores e viajantes europeus. É também desse ponto de vista que se pensou, na atmosfera constitucionalista dos anos de 1820, as "circunstâncias estatísticas" ao lado "dos costumes e territórios" como variáveis a se levar em conta ao se promover a "igualdade de direitos políticos e dos civis" entre os integrantes da nação portuguesa. Tais reflexões diziam respeito notadamente à "diversidade de circunstâncias do clima e estado de povoação, composta no Brasil de classes de diversas cores e pessoas umas livres e outras escravas, pois estas considerações e circunstâncias exigem uma legislação civil particular", como defendia a bancada de deputados paulistas entre 1821 e $1822 .{ }^{21}$ De sua parte, a historiografia abordou essa discussão mais geral sugerindo que elementos tão antagônicos como a necessidade de armar negros livres e ocasionalmente escravos, de um lado, e os temores, reais e ideológicos, quanto a possíveis revoltas de um ou outro grupo ou a união de ambos contra os brancos, de outro,

\footnotetext{
${ }^{20} C f:$ : AHU_CU_015, Cx. 259, D. 17405. Recife, 24 de março de 1806.

${ }^{21} C f:$ : "Lembranças e apontamentos do Governo Provisório de São Paulo para os deputados da província (9 e 10 outubro e 3 novembro 1821)". In: BONAVIDES, Paulo; AMARAL, Roberto (Orgs.). Textos políticos da história do Brasil. Brasília: Senado Federal, Conselho Editorial, 2002, p. 503-510. Ver também JANCSÓ, István; PIMENTA, João Paulo Garrido. Peças de um mosaico (ou apontamentos para o estudo da emergência da identidade nacional brasileira). In: MOTA, Carlos Guilherme (Org.). Viagem incompleta 1500-2000 - A experiência brasileira. (Vol. 1). São Paulo: Senac São Paulo Editora, 2000, p. 162-174; SILVA, Ana Rosa Cloclet da. Apropriações do Constitucionalismo nas Minas Gerais (1820-22). In: BERBEL, Márcia; OLIVEIRA, Cecília Helena de Salles (Orgs.). A experiência constitucional de Cádis: Espanha, Portugal e Brasil. São Paulo: Alameda, 2012, p. 137-166.
} 
teriam propiciado a eclosão de um "partido negro" na conjuntura revolucionária da década de $1820^{22}$ e gerado "atitude confusa" por parte da Coroa portuguesa quanto às milícias negras ${ }^{23}$.

Mesmo sem entrar de fato nos termos específicos propostos em tais estudos, é plausível sugerir que, do ponto de vista dos administradores coloniais e imperiais, a distribuição da população por cor e por condição jurídica fosse convertida em cálculo político. Muitos deles encaravam a prestação de serviço militar fornecida pelos corpos de pardos e pretos como um mal necessário. Tais corporações contribuíam com o policiamento local e também em eventuais mobilizações para as fronteiras; eram, igualmente, importantes instrumentos de controle social, pois, por um lado, cooptavam as elites pretas e pardas por meio da concessão de privilégios aos milicianos e, por outro lado, estimulavam as divisões entre a população livre egressa do cativeiro. Não obstante o papel desempenhado pelas milícias de pretos e pardos, deve-se ter em vista que a sua existência obrigava ao estabelecimento de uma vigilância permanente à atividade dos milicianos de cor. Não é por acaso que o número desses terços, regimentos e depois batalhões jamais excedeu ao dos corpos de brancos. Esse desequilíbrio provavelmente era um mecanismo de segurança e justificava parcialmente o predomínio absoluto das milícias brancas.

Os significados políticos atrelados à existência de ampla camada de pretos e pardos livres na América portuguesa e no Brasil imperial vêm sendo problematizados pela historiografia. Sob o risco da generalização, pode-se afirmar que existem duas correntes interpretativas preponderantes; uma que salienta o potencial desestruturador desse segmento social e a outra que destaca seu papel fundamental na manutenção da ordem vigente. No primeiro caso, sustenta-se que a ampla camada social em questão aparecia "como um corpo estranho, que precisava ser domado e disciplinado para não colocar em risco o bem comum". Longe de ser um esteio da ordem escravista, ele representaria uma espécie de fissura do sistema social, pois constituído basicamente de homens sem senhores que não estavam integrados em funções úteis ao Estado. ${ }^{24}$ No segundo modelo, lê-se o elevado percentual da população preta e parda livre e liberta como um traço diferenciador da sociedade do Brasil colonial e imperial, sendo uma peça fundamental da engrenagem voltada à manutenção e reprodução de uma de suas instituições basilares, a escravidão. Ao ser incorporada ao sistema social e partilhar de seus valores mais elementares - honra, ideal de nobreza e a própria legitimidade da escravidão - tal

\footnotetext{
22 REIS, João José. O jogo duro do Dois de Julho: o "partido negro" na independência da Bahia. In: REIS, João José; SILVA, Eduardo. Negociação e conflito: a resistência negra no Brasil escravista. São Paulo: Companhia das Letras, 1989. p. 79-98.

${ }^{23}$ RUSSELL-WOOD, A. J. R. Escravos e libertos no Brasil colonial..., p. 129-142.

${ }^{24}$ LARA, S. H. Fragmentos setecentistas..., p. 272-285.
} 
população converteu-se em esteio da ordem e contribuiu, a seu modo, para a sua estabilidade. ${ }^{25}$ A atuação das milícias como instrumentos de controle social não deixa dúvidas quanto à pertinência dessa interpretação.

Por sua vez, a perspectiva desenvolvida nesta tese é a de que o potencial político desses grupos sociais guarda a maior relação com a capacidade demonstrada por setores específicos do vasto grupo dos homens de cor livres de agirem dentro dos parâmetros da ordem de Antigo Regime, dominando sua linguagem e seus trâmites e tensionando seus limites desde dentro. ${ }^{26}$ A esse respeito, faz-se necessário utilizar o termo "política" a partir de uma definição menos restritiva, nas palavras de Bobbio, ou, ainda, que não se limite a contemplar a ação dos agentes ocupantes de cargos na governança. A concepção mais ampla aqui empregada se pauta na ideia de que política e sociedade de certa forma se confundem. ${ }^{27}$ Política se refere ao próprio relacionamento cotidiano dos atores sociais com o Estado, mas contempla, outrossim, as interações entre indivíduos e grupos medindo forças, exercendo pressões e mobilizando recursos visando à consecução de seus anseios e a preservação de seus bens. Em virtude da abrangência e relevância desse quadro de problemas, ele será examinado com mais vagar ao longo de toda esta tese. Por ora, antes de investigar em pormenor a configuração populacional da capitania de São Paulo e sua relação com a distribuição das milícias por cor, cabe uma menção sumária a dois casos nos quais, claramente, as milícias de pardos e de pretos permaneciam sub-representadas relativamente à população total de pessoas livres de cor, o que se dava parcialmente em função de tensões políticas locais.

O primeiro deles é o da capitania de Goiás. Como visto anteriormente, a população de livres de cor goiana foi estimada em cerca de 20 mil pessoas no ano de 1810, um contingente três vezes maior que o de pessoas brancas. Não obstante o domínio populacional dos de cor, os brancos ocupavam dois regimentos milicianos, ao passo que pardos e pretos dividiam-se nos

\footnotetext{
${ }^{25}$ MARQUESE, Rafael de Bivar. A Dinâmica da Escravidão no Brasil: resistência, tráfico negreiro e alforrias, séculos XVII a XIX. Novos Estudos. São Paulo, n. 74, 2006; SILVA, Luiz Geraldo. Negros de Cartagena y Pernambuco en la era de las revoluciones atlánticas: trayectorias y estructuras (1750-1840). Anuario Colombiano de Historia Social y de la Cultura, v. 40, n. 2, pp. 211-240, 2013, p. 222. Estando de acordo com as implicações macroscópicas dessa perspectiva, mas ao mesmo tempo matizando-a a partir de um foco mais restrito - condizente à capitania de Minas Gerais -, Marco Antonio Silveira argumenta que os mecanismos sofisticados de reprodução e de assimilação à ordem social vigente coexistiram com a "guerra molecular" e também com processos que acenam para a transformação dessa mesma ordem. SILVEIRA, Marco Antonio. Acumulando forças: luta pela alforria e demandas políticas na capitania de Minas Gerais (1750-1808). Revista de História, São Paulo, n. 158, p. 131-156, 2008. p. 133-134.

${ }^{26}$ Kuethe examina o potencial da milícia colonial do vice-reino espanhol de Nova Granada, separada por cores da mesma forma que na América portuguesa, em reproduzir as desigualdades sociais e "raciais", de um lado, e de provocar abalos nas "relações raciais" em função de igualdade dos postos militares, de outro. KUETHE, Allan J. The status of the free pardo...

${ }^{27}$ BOBBIO, N.; MATTEUCCI, N.; PASQUINO, G. Dicionário de política..., v. 2, p. 960.
} 
dois corpos de segunda linha restantes. O que mais chama a atenção, no entanto, é o fato de que essa configuração se manteve pelo menos até 1824, quando o regimento dos pretos Henriques contava com dez companhias fixas e mais sete agregadas, e o de pardos era formado por não menos que 24 companhias anexas às dez regulamentares. Mais ainda: no caso dos Henriques, informava Raymundo Mattos, “o estado maior acha-se vago inteiramente, e o Regimento é comandado pelo chefe da infantaria dos Pardos". ${ }^{28}$ Esse quadro indica que aqueles corpos militares eram objeto de rigoroso controle por parte da administração local: de um lado, ela conteve a formação de novos regimentos de pardos e de pretos, desprezando o fato de que o contingente de companhias excedentes era suficiente para a composição de mais três regimentos milicianos; de outro lado, atrofiou a oficialidade preta e cerceou a expansão da oficialidade parda, consentindo na existência de apenas um estado-maior para tamanho grupamento miliciano. O processo de formação de tais corpos militares remonta aos anos de 1779 e 1780 e, no caso dos pretos Henriques, arrastou-se por algumas décadas, o que sugere uma relutância de governadores e elites brancas quanto à oficialidade preta. Por sua vez, um capítulo importantíssimo da trajetória da formação social do grupo de pardos livres goianos foi marcado pela pressão exercida por seus milicianos junto à câmara de Vila Boa a fim de que obtivessem acesso aos cargos republicanos. Presume-se que as tensões provocadas no equilíbrio social por ocasião daquela movimentação coletiva, nos anos 1800, contribuíram diretamente para que, daí em diante, as milícias de pardos e pretos permanecessem numérica e socialmente asfixiadas em Goiás. $^{29}$

O segundo caso é o da Bahia. De acordo com os dados apresentados anteriormente, a população livre de cor baiana chegava a 113 mil pessoas e era majoritária em relação à de brancos, mas esse predomínio se invertia completamente quando se considera a configuração de suas milícias dividas por cor. Ora, para oito regimentos identificados aos brancos, havia tão somente um de Henriques e um de pardos, esse formado apenas na década de 1770. Tal panorama certamente era resultante da conjugação de inúmeros fatores, dentre os quais a necessidade estatal de corpos militares, as pressões sociais de pardos e pretos livres, o relacionamento desses grupos com as elites baianas e, finalmente, as avaliações que

\footnotetext{
${ }^{28}$ MATTOS, Raymundo J. da C. Chorographia histórica..., p. 51-56.

${ }^{29}$ LOIOLA, Maria L. Defeito ou acidente? Mulatos e pardos na produção da hierarquia social em Goiás colonial. In: Anais do III Seminário de Pesquisa e Pós-graduação em História UFG/PUC Goiás, 2010; SOARES, Márcio de Souza. Pretos e pardos na fronteira do Império: hierarquias e mobilidade social de libertos na capitania de Goiás (século XVIII). In: Anais do IV Seminário de Pesquisa do ESR, 2011, Campos dos Goytacazes, 2011; LIMA, Priscila de. De libertos a habilitados. Interpretações populares dos alvarás anti-escravistas na América portuguesa (1761-1810). Dissertação (mestrado em História). Curitiba: SCHLA, Universidade Federal do Paraná, 2011, p. 112-126.
} 
governadores coloniais e a Coroa faziam acerca do impacto social e político das milícias de cor naquela configuração social. Uma vez que tanto a importância militar dessas corporações como os níveis elevados de pressão que seus integrantes exerciam sobre o Estado estão muito bem documentados pela historiografia ${ }^{30}$, a julgar pelas dimensões da desproporção entre população e milícias por cor supõe-se que a evolução dos corpos militares compostos por homens de cor na Bahia sofresse controle tão ou até mais enérgico que a dos pares de Goiás. Nesse sentido, pode-se dizer que a destituição da oficialidade miliciana parda, ocorrida em 1796, e o movimento social de 1798, conhecido como a Revolta dos Alfaiates, que tinha como uma de suas principais bandeiras o acesso de militares a todos os postos independentemente das diferenças de cor, foram momentos em que claramente vieram à superfície tensões e confrontos que permeavam aquele quadro social e que até então se mantinham em estado latente. ${ }^{31}$

\subsection{População e milícia (II) - São Paulo}

Parte de um universo colonial e escravista, a capitania/província de São Paulo apresentou aspectos semelhantes a outros espaços coloniais, fossem eles luso-americanos ou não, mas, em vários sentidos examinados anteriormente, sua realidade se revelou peculiar. Dentre as configurações sociais consideradas, São Paulo foi a única em que a camada populacional composta por brancos superou a de pessoas de cor livres e escravos conjuntamente. Embora obtivesse, em 1810, o quinto maior contingente de homens de cor livres na América portuguesa, esse índice não se refletiu na existência mais abundante de corpos militares para homens de cor. A despeito de o processo de constituição de companhias de pardos e pretos remontar ao começo do século XVIII, tão somente em fins daquela centúria é que se criou um regimento miliciano exclusivo aos pardos e, durante todo esse período, nenhum destinado aos pretos livres. Objetiva-se aqui, por meio de abordagem à configuração

\footnotetext{
${ }^{30}$ KRAAY, Hendrik. Política racial, Estado e Forças Armadas na época da independência: Bahia, 1790-1850. Trad. Magda Lopes. São Paulo: Hucitec, 2011.

${ }^{31}$ A deposição dos oficiais pardos do estado-maior de seu regimento foi interpretada por Kraay em sentido diverso. Para esse historiador, o fenômeno em questão estaria associado à incapacidade de coesão grupal bem como à fragilidade política dos pardos, reputados como grupo ambíguo e indefinido em comparação com os pretos e brancos. KRAAY, H. Política racial, Estado e Forças Armadas..., p. 133-164. Sobre a Revolta dos Alfaiates ou Conjuração Baiana, consultar: JANCSÓ, István. Na Bahia, contra o império: história do ensaio da sedição de 1798. São Paulo: Hucitec, 1996; ARAÚJO, U. de C.; TAVARES, L. H. D.; SILVA, M. B. N. da; et al. Segundo centenário da sedição de 1798 na Bahia. Salvador: Academia de Letras da Bahia; Secretaria da Cultura e Turismo, 1999. Tais fenômenos serão retomados mais detalhadamente no capítulo 6, item 6.3.2.
} 
populacional paulista dedicada especialmente à composição dos grupos formados por escravos e pelas pessoas de cor livres, agregar elementos para a interpretação do processo histórico de formação do Regimento dos Úteis bem como para a compreensão de características de seus integrantes.

A população de São Paulo apresentou taxas de crescimento contínuo, embora com variações em seus níveis, ao longo do tempo. Apesar de partes de seu território terem estado entre os núcleos mais antigos de colonização, estes foram habitados por "uma população rala e de crescimento moroso" até fins do século XVII. Conforme estimativas apresentadas por Marcílio, a população paulista sob domínio colonial era formada por 2.500 pessoas em 1592 , no ano 1600 por 6 mil pessoas e, em 1690, por 15 mil almas. O período subsequente, entre os anos 1690 e 1765, apresentaria taxas elevadíssimas de crescimento, chegando-se à ordem de $425 \%$, já que, nessa última data, contava-se com cerca de 78.855 habitantes na capitania. Esse contingente duplicaria até 1798, um ano após a criação do regimento dos pardos, momento em que foram contabilizados aproximadamente 162.345 indivíduos, e prosseguiria ampliando-se. Em 1836, quando as milícias já estavam extintas, havia por volta de 326 mil pessoas habitando o território de São Paulo. ${ }^{32}$ Como se deu, ao longo do tempo, a participação de escravos e pessoas de cor livres nesse conjunto populacional crescente?

Desde os períodos mais recuados da colonização, havia escravos de origem africana no território em foco. No entanto, os cativos trazidos na "bagagem" por seus povoadores, destinados ao trabalho nos poucos engenhos de açúcar de São Vicente, ou aqueles desembarcados em decorrência da tentativa de estabelecimento do tráfico diretamente com Angola, em fins do século XVI, seriam em reduzido número, haja vista o malogro do cultivo da cana-de-açúcar em larga escala e as características do tráfico, "intermitente e que não levaria ao estabelecimento de uma corrente regular e contínua" de escravos africanos. ${ }^{33}$ Esse quadro, caracterizado pela ausência de atividades econômicas voltadas à exportação em larga escala e pela não vinculação da região com o tráfico transatlântico de escravos, permaneceu vigente ao longo do século XVII. Em realidade, desenvolveu-se no planalto paulista mais comumente a agricultura de subsistência acompanhada de modesto artesanato. ${ }^{34}$ Houve, ademais, o cultivo do trigo em escala um pouco mais ampliada em períodos intermediários do Seiscentos, de modo

\footnotetext{
${ }^{32}$ MARCÍLIO, M. L. Crescimento demográfico..., p. 69-76; SILVA, M. B. N. da (Org.). História de São Paulo colonial. São Paulo: Editora UNESP, 2009, p. 157-164.

${ }^{33}$ BASTIDE, R.; FERNANDES, F. Brancos e negros em São Paulo..., p. 27-29; QUEIROZ, Suely Robles Reis de. Escravidão negra em São Paulo. Rio de Janeiro: José Olympio, 1977, 9-13.

${ }^{34}$ LUNA, F. V.; KLEIN, H. S. Evolução da sociedade e economia..., p. 25-53; QUEIROZ, S. R. R. de. Escravidão negra em São Paulo..., p. 9-21.
} 
que esse produto fora comercializado com outras capitanias, conectando o planalto paulista ao litoral e inserindo o que se tornaria a capitania de São Paulo em um circuito de cabotagem. ${ }^{35}$

Em virtude da pequena capacidade de acúmulo de capital devido à natureza das atividades econômicas desempenhadas em São Paulo, a aquisição generalizada de cativos africanos se viu impossibilitada. Por essa razão, desde fins do século XVI e por toda a centúria seguinte, os paulistas organizaram expedições destinadas ao apresamento de indígenas e à decorrente obtenção de mão de obra, cujos empreendimentos muitas vezes ocorriam sob a justificativa da guerra justa ou até mesmo da busca por ouro ou prata. Inicialmente, as bandeiras, como se tornaram conhecidas, deslocaram-se pelos territórios adjacentes à vila de São Paulo, mas, conforme o "ouro vermelho" ia escasseando, quer pelas capturas ou quer pelo afugentamento provocado nos nativos, os sertanistas passaram a explorar territórios cada vez mais longínquos, tais como as regiões do Sertão dos Patos, no atual estado de Santa Catarina, as missões jesuíticas, no Paraguai, e territórios ao norte e noroeste da vila de São Paulo. ${ }^{36} \mathrm{O}$ resultado foi o estabelecimento de mentalidade e relações escravistas assentadas quase que exclusivamente na exploração do trabalho indígena, o qual, a propósito, foi o responsável pela lavra dos trigais. ${ }^{37}$ Para se ter uma ideia das proporções concernentes aos habitantes do território da futura capitania de São Paulo divididos entre brancos, índios e negros, cabe referir-se a duas estimativas autorizadas: primeiro, a de S. B. de Holanda, conforme a qual, ao longo de todo o século XVII, haveria quatro índios para cada morador branco em condições de portar armas ${ }^{38}$; e, depois, a de Alfredo Ellis Júnior, para quem, mediante análise de mais de dois mil inventários dos séculos XVI e XVII, haveria em São Paulo a proporção de um africano para 34 índios. ${ }^{39}$ Essa larga predominância de indígenas e de sua descendência mestiça na população em questão decerto transpôs os limites do Seiscentos, uma vez que, sob o designativo "administrados", eles constituíam mais de $48 \%$ da população contabilizada da cidade de São Paulo no ano 1730. Pode-se crer que sua presença era ainda mais avultada nas demais vilas e localidades do planalto, e tanto mais quanto se aproximava da "boca do sertão". Conforme Holanda, "será mantida até o final do século a predominância quantitativa do contingente indígena, que ainda forma o grosso da população". ${ }^{40}$

\footnotetext{
${ }^{35}$ MONTEIRO, J. M. Negros da terra..., p. 99-128.

${ }^{36}$ MONTEIRO, J. M. Negros da terra..., p. 17-98. Consultar também o mapa da p. 13 da obra em questão.

${ }^{37}$ MONTEIRO, J. M. Negros da terra..., p. 99-128.

${ }^{38}$ HOLANDA, Sérgio Buarque de. Movimentos de população de São Paulo no século XVIII. Revista do Instituto de Estudos Brasileiros, n. 1, p. 55-111, 1966, p. 82-84.

${ }^{39}$ Citado por QUEIROZ, S. R. R. de. Escravidão negra em São Paulo..., p. 11. A obra em questão é: ELLIS JÚNIOR, Alfredo. O ouro e a paulistânia. Boletim da Faculdade de Filosofia, Ciências e Letras da Universidade de São Paulo, São Paulo, n. 96, 1948, p. 54.

${ }^{40}$ HOLANDA, S. B. de. Movimentos de população..., p. 110-111.
} 
Embora se considere, atualmente, que naquele período as pessoas de origem africana formassem uma minoria em relação à população total contabilizável, e mesmo no interior do contingente escravo paulista, promoveu-se um debate ao longo da primeira metade do século XX em torno do peso da participação dos negros africanos nas expedições bandeirantes. Entretanto, a argumentação que sustentava o relevo social dos pretos na São Paulo dos dois primeiros séculos de colonização foi desbaratada a partir do esclarecimento de que o termo "negro" era correntemente empregado para aludir às pessoas na condição de escravidão, de forma que as expressões "negro da terra" ou "negro oriundo" designavam especificamente pessoas de origem indígena. ${ }^{41}$ Apesar de um movimento significativo de escravos nos portos localizados na região Sudeste da América portuguesa durante o século XVII (ver Tabela 2.1), escravos africanos ou sua progênie crioula tornaram-se mais numerosos em São Paulo apenas ao longo do século XVIII. A presença de cativos africanos ocorreu de forma moderada em sua primeira metade, na esteira das transformações promovidas pela descoberta de ouro e diamantes em Minas Gerais, de ouro em Mato Grosso e Goiás, e, mais acentuadamente no último quartel do Setecentos, por ocasião do desenvolvimento da economia açucareira em solo paulista com vistas à exportação. O fenômeno acenaria, na longa duração, para o curso de um processo de transição na força de trabalho em São Paulo: a mão de obra indígena, gradativamente minguante e cuja escravidão encontrava óbices jurídicos, cedia lugar à africana, que era alimentada pelos tráficos transatlântico e interno à América portuguesa. ${ }^{42}$

Infelizmente, a precariedade das informações censitárias não permitiu aos historiadores o estabelecimento de estimativas para a população escrava de toda a capitania para o período anterior a 1765. Daí em diante, os dados tornam-se mais ricos e consistentes. Em 1768, o governador Morgado de Mateus informou haver algo em torno de 23.323 pessoas cativas na capitania de São Paulo. ${ }^{43}$ Com grande probabilidade, a larga maioria delas seria de origem africana e crioula, uma vez que estavam em vigor as leis que declaravam a total liberdade dos índios. ${ }^{44}$ Pouco tempo depois, em 1777 , esse número chegou a 25.248 escravos, representando

\footnotetext{
${ }^{41}$ Um tratamento mais global dos termos do debate e de seus participantes em QUEIROZ, S. R. R. de. Escravidão negra em São Paulo..., p. 9-15. A discussão referente aos significados do termo "negro" também está presente no prefácio de S. B. de Holanda a esse mesmo livro, p. x-xi. Ver o tratamento mais recente da questão em: MONTEIRO, J. M. Negros da terra...; BALHANA, Altiva P.; WESTPHALEN, Cecília M. Negros, gentios da terra, ou negros d'África? Revista da SBPH, Curitiba, n. 17, p. 17-23, 2000.

${ }^{42}$ MONTEIRO, J. M. Negros da terra..., p. 220-226; PORTELA, Bruna Marina. Gentio da terra, gentio da Guiné: a transição da mão de obra escrava e administrada indígena para escravidão africana (Capitania de São Paulo, 1697-1780). Tese (doutorado em História). Curitiba: SCHLA, Universidade Federal do Paraná, 2014.

${ }^{43} C f:$ : "Carta ao mesmo conde [de Oeiras] remetendo-lhe a lista dos escravos e rendimentos da capitania de S. Paulo". DIHCSP, vol. 19, p. 282-283. São Paulo, 22 de fevereiro de 1769.

${ }^{44}$ GOLDSCHMIDT, Eliana Rea. Casamentos mistos: liberdade e escravidão em São Paulo colonial. São Paulo: Annablume; Fapesp, 2004, p. 129-147.
} 
22,6\% de uma população estimada em 113.424 indivíduos. Essa camada social não apenas acompanhou o ritmo de crescimento da população total, mas superou-o, ao atingir em 1829 o número de 75 mil pessoas, ou $26 \%$ da população total. ${ }^{45}$ Alguns índices demográficos, tais como a idade média dos plantéis escravos e a razão de masculinidade daqueles contingentes, asseguram que, para o século XIX, já se tratava da importação de cativos africanos em larga escala, a qual, por sua vez, viria a alterar o quadro anterior caracterizado pela supremacia de grupos antigos de escravos dotados de capacidade positiva de reprodução natural. Os africanos recém-incorporados foram destinados especialmente ao trabalho agrícola, que consistia na lavoura de gêneros de subsistência e de abastecimento interno e, principalmente, nos canaviais que tomariam conta da paisagem agrária paulista já nos finais do século XVIII. ${ }^{46}$

São também escassos os dados demográficos relativos às pessoas de cor livres. Essa carência é notável principalmente para os períodos mais recuados do século XVIII, para os quais praticamente inexistem aferições à população, e mesmo para os anos imediatamente posteriores a 1765, em função das características dos seus recenseamentos. Ao menos é o que se depreende de um exame da bibliografia que perscrutou a presença de pardos e pretos, forros e nascidos livres, no interior da população paulista dos séculos XVIII e XIX: de 1765 em diante, existe clara diferenciação entre população livre e escrava, mas, no conjunto dos livres, não é possível distinguir com alguma precisão a participação de brancos, índios, africanos e mestiços. ${ }^{47}$ Para fins do Setecentos, ocorre refinamento e padronização nas informações constitutivas das listas de população, tornando-se, enfim, possível o acompanhamento do peso e de outros aspectos da dinâmica do segmento em questão. Além dos critérios etários, de gênero, estado civil e condição jurídica anteriormente aplicados, os habitantes passam a ser segmentados entre brancos, pardos e pretos. ${ }^{48}$

\footnotetext{
${ }^{45}$ LUNA, F. V.; KLEIN, H. S. Evolução da sociedade e economia..., p. 53 e 167.

${ }^{46}$ LUNA, F. V.; KLEIN, H. S. Evolução da sociedade e economia..., p. 55-79, 107-136, 167-196. Cumpre notar que em determinadas regiões da capitania, mormente aquelas definidas pela historiografia como regiões de fronteira e/ou não vinculadas efetivamente a uma economia de mercado, como era o caso de boa parte da comarca de Curitiba, a escravidão crioula permaneceu dominante bem como os resquícios do trabalho compulsório indígena eram notáveis ainda em fins do século XVIII e começos do XIX. Ver GUTIÉRREZ, Horacio. Crioulos e africanos no Paraná, 1798-1830. Revista Brasileira de História, v. 8, n. 16, p. 161-188, mar./ago. 2008; MACHADO, Cacilda da Silva. A Trama das Vontades. Negros, pardos e brancos na produção da hierarquia social (São José dos Pinhais - Pr, passagem do XVIII para o XIX). Tese (doutorado em História). Rio de Janeiro: IFCS, Universidade Federal do Rio de Janeiro, 2006.

${ }^{47}$ ALDEN, D. The population of Brazil in the late eighteenth century: a preliminary study. The Hispanic American Historical Review, v. 43, n. 2, maio/1963, p. 196; BASTIDE, R.; FERNANDES, F. Brancos e negros em São Paulo..., p. 38-39; MARCÍLIO, M. L. Crescimento demográfico..., p. 117-119. Luna e Klein, ao que parece, também encontraram dificuldade em precisar o contingente de pardos e pretos dentre a população livre de São Paulo ao longo da segunda metade do século XVIII. Ver LUNA, F. V.; KLEIN, H. S. Evolução da sociedade e economia..., p. 53 e 197-222.

${ }^{48}$ Detalhamento referente à evolução dos censos paulistas em MARCíLIO, M. L. Crescimento demográfico..., p. 27-65.
} 
TABELA 2.4 - População por cor e condição (São Paulo, 1811, 1815 e 1836)

\begin{tabular}{|c|c|c|c|c|}
\hline \multirow[t]{2}{*}{ ANO } & \multirow[t]{2}{*}{ COR } & \multicolumn{2}{|c|}{ CONDIÇÃO } & \multirow[t]{2}{*}{ TOTAL } \\
\hline & & Livre & Escrava & \\
\hline \multirow[t]{4}{*}{1811} & Branca & 112.965 & $-\ldots$ & 112.965 \\
\hline & Parda & 44.053 & 10.548 & 54.601 \\
\hline & Negra & 3.951 & 37.602 & 41.553 \\
\hline & Total & 160.969 & 48.150 & 209.119 \\
\hline \multirow[t]{4}{*}{1815} & Branca & 115.203 & $-\ldots$ & 115.203 \\
\hline & Parda & 44.289 & 11.043 & 55.332 \\
\hline & Negra & 4.966 & 40.229 & 45.195 \\
\hline & Total & 164.458 & 51.272 & 215.730 \\
\hline \multirow[t]{4}{*}{1836} & Branca & 172.879 & - - - - & 172.879 \\
\hline & Parda & 59.454 & 14.722 & 74.176 \\
\hline & Negra & 6.811 & 72.211 & 79.022 \\
\hline & Total & 239.144 & 86.933 & 326.077 \\
\hline
\end{tabular}

Fonte: BASTIDE, R.; FERNANDES, F. Brancos e negros em São Paulo..., p. 46-48.

Conforme os dados compilados por Bastide e Fernandes, reproduzidos aqui na íntegra ${ }^{49}$ (Tabela 2.4), vê-se uma ampliação paulatina do segmento de pessoas de cor livres agrupadas distintamente entre pardos e pretos. Uma informação pontual de Luna e Klein indica que, em 1803, foram contabilizadas 47 mil pessoas de cor livres na capitania ${ }^{50}$, passando-se a 48 mil no ano de 1811 e a 49.255 e 66.265 pessoas nos anos de 1815 e 1836, respectivamente, de acordo com a Tabela 2.4. Embora se verificasse equilíbrio numérico entre as pessoas livres de cor e os escravos nas décadas de 1800 e 1810, com leve predomínio dos últimos, os dados referentes a

\footnotetext{
${ }^{49}$ Os dados em questão se encontram em BASTIDE, R.; FERNANDES, F. Brancos e negros em São Paulo..., p. 47-48. Embora Klein forneça dados para os anos 1800 e 1803, eles não são aproveitados aqui em função da divisão, pouco clara em seus critérios, efetuada entre os territórios dos atuais estados do Paraná e São Paulo, os quais formavam juntos a capitania/província de São Paulo no período em questão. KLEIN, H. S. Os homens livres de cor..., p. 8. Embora não seja o caso de Klein, o procedimento que consiste em seccionar a antiga capitania em função da delimitação contemporânea dos estados foi bastante comum na historiografia paulista. Como exemplo, consultar RABELLO, Elisabeth Darwiche. As elites na sociedade paulista na segunda metade do século XVIII. São Paulo: Comercial Safady, 1980, p. 17-29. A adoção desse recorte acusa, evidentemente, níveis relativamente elevados de envolvimento do historiador com a região, o momento histórico e o lugar social de onde produz seu discurso, de resto verificáveis, em menor ou maior grau, em todos os trabalhos acadêmicos. Ver as discussões teóricas relacionadas em ELIAS, Norbert. Envolvimento e distanciamento. Estudos sobre sociologia do conhecimento. Trad. Maria Luísa Cabaços Mélico. Lisboa: Publicações Dom Quixote, 1997, e CERTEAU, Michel de. A escrita da história. Trad. Maria de Lourdes Menezes. Rio de Janeiro: Forense Universitária, 1982, p. 23119.

${ }^{50}$ LUNA, F. V.; KLEIN, H. S. Evolução da sociedade e economia..., p. 203, nota 14.
} 
1836 sugerem que, de 1815 até esse momento, o crescimento da camada de pardos e pretos livres deixou de ser equivalente ao de brancos e escravos.

Nota-se, igualmente, que o grupo das "pessoas de cor livres" na realidade apresentava em seu interior diferenciações significativas. Ora, os pardos exerciam amplo predomínio em relação aos pretos, cujo padrão se inverte completamente ao se examinar o contingente de escravos, no qual os pretos dilatam ao longo do tempo uma condição já notavelmente majoritária em comparação aos cativos pardos. Apesar de o exame da elevação do contingente de brancos não ter espaço aqui, algumas considerações sobre a ampliação efetivada no de escravos parece ser pertinente. A diferença substantiva existente entre escravos pardos e negros sugere, de imediato, que, nas primeiras décadas do século XIX, a manutenção e reprodução dos plantéis paulistas estava assentada em boa medida no aporte de africanos e, em níveis menos relevantes, na reprodução natural. ${ }^{51}$ É o que se infere, de um lado, a partir das proporções elevadas e crescentes de escravos negros, cujo cativeiro seria recente e atribuiria ao grupo, em termos gerais, uma posição incipiente no estágio de enraizamento social; de outro lado, as menores proporções verificados nos cativos pardos, além do seu parco aumento, revela a tendência de que esse contingente mestiço e mais antigo - possivelmente mais enraizado experimentasse maiores oportunidades de desvinculação da condição escrava, de modo que, mediante alforrias e crescimento natural, houvesse um fluxo contínuo de pessoas transitando socialmente do cativeiro para a liberdade.

Desafortunadamente, os recenseamentos em questão não revelam quais ou quantos pardos e pretos nasceram livres ou obtiveram alforria ao longo de suas vidas e, sendo escassos os estudos relativos às manumissões em São Paulo para o período em tela, perde-se de vista essa variável importantíssima para a compreensão da camada de pessoas de cor livres. Seja como for, a inversão proporcional existente entre pardos e pretos na condição de livres e em cativeiro parece atestar o padrão extensamente verificado pela historiografia e válido em termos gerais para toda a sociedade escravista brasileira, conforme o qual os escravos pardos contavam com chances mais elevadas de lograrem libertar-se em comparação com os cativos pretos. De acordo com o mesmo padrão, as mulheres conquistavam a alforria com maior recorrência do que os homens. Isso explica o fato de que, em uma população que contava, em 1836, com equilíbrio numérico de gênero entre os brancos e com crescente predomínio de homens sobre

\footnotetext{
${ }^{51}$ LUNA, F. V.; KLEIN, H. S. Evolução da sociedade e economia..., p. 45-47.
} 
as mulheres escravas, as pessoas de cor livres fossem caracterizadas por um desequilíbrio inverso ao existente no mundo do cativeiro, pois para 87 homens havia 100 mulheres. ${ }^{52}$

Tomando-se como exemplo o número de negros e/ou pretos livres contabilizados em 1811, que não chegava a quatro mil pessoas, e aplicando-se o diferencial na taxa de masculinidade verificada para o segmento de livres de cor, se conclui que o número dos homens negros ou pretos livres, de todas as idades, e que habitavam todo o território da capitania, giraria em torno de 1.850 pessoas. Essa ínfima participação dos homens pretos livres no conjunto da população e dispersos espacialmente é suficiente para se compreender o porquê da inexistência de terço auxiliar ou regimento miliciano exclusivo para tais indivíduos em São Paulo, e mesmo para a desmobilização das companhias existentes em períodos iniciais e intermediários do século XVIII. Dessa forma, a análise pode ser verticalizada para o conjunto dos pardos livres, o qual interessa aqui mais diretamente em virtude de abrigar os homens que encarnaram as companhias setecentistas e o Regimento dos Úteis.

A partir do cruzamento entre os dados demográficos e as tabulações atinentes aos corpos militares paulistas, alguns aspectos se evidenciam. Em primeiro lugar, a população de São Paulo transitou de uma maioria indígena e mestiça do começo do século XVIII para um amplo predomínio dos brancos em fins do mesmo século; nesse último período, metade da população era branca e a outra metade dividia-se entre pardos livres e pretos escravos. Em segundo lugar, viu-se que, desde fins do século XVIII, São Paulo contava com dez regimentos milicianos identificados ao mesmo tempo a localidades específicas e aos homens brancos e apenas um regimento de pardos, configurando, pois, uma grande desproporção quanto à relação entre as quantidades de corpos milicianos separados por cor e a população total disponível para a composição dos regimentos. Ao mesmo tempo, em terceiro lugar, a população de cor livre de São Paulo, predominantemente parda, era a quinta maior do Brasil, havendo capitanias cuja população livre de cor, mesmo sendo menor, formava número mais elevado de terços ou regimentos de pardos e de pretos - como o Rio de Janeiro e Goiás.

O primeiro conjunto de dados aponta para um processo de profundas transformações demográficas vivenciado na capitania e também para mudanças significativas na designação dos grupos. Considerando-se todo o século XVIII, nota-se um crescimento elevado da população branca, um decréscimo notável da população indígena e, a partir da segunda metade da centúria, uma ampliação dos pardos livres e dos pretos escravos. Interpreta-se o crescimento

\footnotetext{
52 LUNA, F. V.; KLEIN, H. S. Evolução da sociedade e economia..., p. 203-204, sobre o peso das mulheres no contingente das pessoas de cor livres e também para um arrolamento da literatura mais geral sobre manumissões no Brasil escravista.
} 
dos brancos como derivado da reprodução natural e imigração e também da incorporação constante de segmentos provenientes de outros grupos sociais - notavelmente os mestiços com origem indígena. Vai daí, em parte, que a vigorosa população mameluca de começos do século XVIII tenha se tornado minoritária ao final da centúria. Outro fator que concorreu para a diminuição do contingente indígena e mestiço foi o regime de trabalho forçado assentado na administração indígena, o qual elevou as taxas de mortalidade desse grupo, redundando em baixa expectativa de vida comparada aos brancos. ${ }^{53}$ Ademais, uma outra parcela desses mestiços tendeu a ser assimilada ao crescente grupo dos pardos livres, que também era formado por ex-escravos de origem africana e seus descendentes mestiços.

Cumpre indagar qual a relação desse cenário social com a configuração da estrutura militar paulista. A fama militar dos paulistas que atravessou fronteiras e oceanos pouco dizia respeito a tropas plenamente institucionalizadas, pois estava assentada, antes, em formações mais espontâneas e improvisadas. ${ }^{54}$ Ora, o componente formal das bandeiras estava situado tão somente na oficialidade desses bandos, constituída pelos empreendedores das expedições militares e por seus parentes, sócios e dependentes imediatos; já o grosso dessas tropas, ao contrário, era integrado por índios, administrados, bastardos e mamelucos que serviam às famílias tradicionais e mais abastadas e também por aqueles que, estando menos intensamente atados às elites, ainda assim atendiam ao chamado para o alistamento. ${ }^{55}$ Sobretudo nas localidades situadas no planalto paulista, o processo de formação e institucionalização dos corpos militares levado a efeito a partir do começo do século XVIII - incluindo-se as companhias de ordenança, companhias de aventureiros, companhias e terços de auxiliares reproduziu esse traço característico das bandeiras, qual seja, a convivência, em um mesmo corpo militar, de indivíduos bem situados socialmente e de grupos maiores formados por pessoas socialmente inferiorizadas. Como demonstrou Nazzari, tais corporações contavam com mecanismos internos de diferenciação capazes de preservar as posições de indivíduos e grupos e assim resguardar as hierarquias. No caso da ordenança da freguesia de Santana, vinculada à

\footnotetext{
${ }^{53}$ MONTEIRO, J. M. Negros da terra..., p. 156-159.

${ }^{54}$ BLAJ, Ilana. A trama das tensões: o processo de mercantilização de São Paulo colonial (1681-1721). São Paulo: Humanitas/FFLCH/USP, 2002, p. 41-85, 302-307; PUNTONI, Pedro. A guerra dos bárbaros. Povos indígenas e a colonização do Sertão do Nordeste do Brasil, 1650-1720. São Paulo: Hucitec, 2002; RODRIGUES, Maria Eugénia. Cipaios da Índia ou soldados da terra? Dilemas da naturalização do exército português em Moçambique no século XVIII. História Questões \& Debates, v. 24, n. 45, jul./dez. 2006, p. 65; SOUZA, Laura de Mello e. $O$ sol e a sombra: política e administração na América portuguesa do século XVIII. São Paulo: Companhia das Letras, 2006, p. 109-147.

${ }^{55}$ HOLANDA, Sérgio Buarque de. Caminhos e fronteiras. Rio de Janeiro: Livraria José Olympio Editora, 1957 , p. 144-147; KOK, Maria da Glória Porto. O sertão itinerante: expedições da capitania de São Paulo no século XVIII. Tese (doutorado em História). São Paulo: FFLCH, Universidade de São Paulo, 1998, p. 55-111.
} 
cidade de São Paulo, brancos, bastardos, carijós, pardos e pretos serviam em uma mesma companhia, mas permaneciam organizados em esquadras diferentes na década de $1760 .{ }^{56}$

Nas regiões litorâneas da capitania é que desde cedo se demarcou a diferença de cor entre os corpos militares. Presumivelmente, a configuração social dessas vilas portuárias bastante influenciadas pelas especificidades da dinâmica econômica local, com destaque para as atividades comerciais e de prestação de serviços que estimulavam o fluxo constante de pessoas, mercadorias e crédito - tenha gerado laços de dependência e clientelismo menos acentuados do que nas regiões agrícolas do planalto. Isso seria especialmente válido para os pardos e pretos, livres ou libertos, que habitavam as vilas de Santos, São Vicente e São Sebastião ao longo de toda a primeira metade do século XVIII, em um contraponto à realidade social dos pardos, bastardos, carijós e demais mestiços de Serra-acima. ${ }^{57}$ Isso explicaria parcialmente o fato de brancos, pardos e pretos servirem em corpos militares separados nas regiões costeiras de São Paulo.

No planalto paulista, como visto, as companhias de pretos jamais chegaram a se constituir, e tenderam a desaparecer rapidamente até mesmo no litoral, ao passo que as companhias de pardos passarão a existir a partir de 1765. A atuação dos governadores e capitães-generais na capitania restaurada, após um período de mais de meio século marcado pela presença inconstante desses funcionários, foi decisiva na formação desses corpos militares. Os pardos, que até então engrossavam as companhias comandadas por capitães-mores das vilas de Taubaté, Pindamonhangaba, Mogi Mirim, Jundiaí e da cidade de São Paulo, foram sendo paulatinamente incorporados em companhias avulsas específicas para homens dessa cor. Esse fenômeno pode ser lido como uma entre tantas intervenções do poder central na dinâmica local, uma vez que, ao criar oficialidades pardas e vincular essas tropas também aos seus gabinetes,

\footnotetext{
${ }^{56}$ NAZZARI, Muriel. Vanishing indians: the social construction of race in colonial São Paulo. The Americas, Vol. 57, No. 4, abr. 2001, p. 497-524, especialmente p. 505-509.

${ }^{57}$ A ideia de que a cidade engendra maiores opções e níveis mais elevados de liberdade de ação aos escravos e seus descendentes é antiga. Em Freyre, os mucambos urbanos conformariam o aspecto mais notável da desagregação da ordem patriarcal brasileira. FREYRE, Gilberto. Sobrados e mucambos: decadência do patriarcado rural e desenvolvimento do urbano. São Paulo: Global, 15 ${ }^{\mathrm{a}}$ ed., 2004 (1 ${ }^{\mathrm{a}}$ ed. 1936). O argumento da diferença de oportunidades entre a cidade e o campo permeia toda a obra de RUSSELL-WOOD, A. J. R. Escravos e libertos no Brasil colonial. Trad. Maria Beatriz de Medina. Rio de Janeiro: Civilização Brasileira, 2005. Por outro lado, as obras que mais exploram a dominação exercida pelos potentados locais às populações livres pobres - as relações patriarcais, clientelares e de dependência - focalizam sobretudo as regiões rurais. Veja-se, por exemplo, FRANCO, Maria S. de Carvalho. Homens livres na ordem escravocrata. $4^{\text {a }}$ ed. São Paulo: Fundação Editora da UNESP, 1997, p. 65-114; e GUEDES, Roberto. Egressos do cativeiro: trabalho, família, aliança e mobilidade social (Porto Feliz, São Paulo, c. 1798-c. 1850). Rio de Janeiro: Mauad X: FAPERJ, 2008. Para o caso da capitania de São Paulo, ao longo do século XVIII e do começo do XIX, deve-se considerar que se tratava de uma configuração social predominantemente rural, com poucos espaços efetivamente urbanizados - a exemplo dos seus principais portos, dos pequenos núcleos administrativos das vilas e, sobretudo, da cidade de São Paulo.
} 
os governadores de certo modo retiraram das mãos dos capitães-mores uma parte do controle exercido sobre os forros, livres e libertos. ${ }^{58}$

Igualmente essenciais para a criação dessas companhias no planalto foram os processos entrelaçados de mercantilização da cidade de São Paulo, que remonta às décadas finais do século XVII, e de formação da camada de pardos livres, crescentemente numerosa ao longo do Setecentos. ${ }^{59}$ Com efeito, a primeira companhia de pardos da capital paulista data de 1775 , um momento caracterizado por reformas administrativas, esforços de guerra e estímulos à agricultura. ${ }^{60} \mathrm{Na}$ década de 1790 , a cidade de São Paulo já estava consolidada como centro econômico dinâmico e a camada de pardos livres que nela viviam e orbitavam também ampliou as suas dimensões, entre outros fatores, mediante a incorporação de populações rurais pressionadas pelo avanço da agricultura comercial. ${ }^{61}$ Isso permitiu que as companhias de auxiliares pardos se proliferassem velozmente: de três, existentes no começo da década, passarse-á a cinco por ocasião da criação do Regimento dos Úteis, em 1797. A partir de então, concentrando o maior número de companhias pardas, a cidade se tornou o núcleo para onde as demais convergiram, sobrepujando definitivamente as zonas litorâneas a esse respeito.

No primeiro momento, de 1797 a 1801, as cinco companhias da cidade que compunham o Regimento dos Úteis eram complementadas por igual número de unidades situadas na região litorânea. Entretanto, em pouco tempo se constatou a imensa dificuldade que a Serra do Mar oferecia para as reuniões da corporação na capital, resultando daí a extinção das antigas companhias litorâneas e a sua substituição por novas companhias formadas nas vilas do planalto. Essa transformação também se relacionava com o fato de que as vilas costeiras já contavam com população parda significativamente menor que muitas vilas de Serra-acima. ${ }^{62}$ Em ambos os cenários, porém, a cidade de São Paulo manteve-se na posição de centro gravitacional da milícia parda e dependeu do aporte de outras vilas - algumas distantes em até

\footnotetext{
${ }^{58}$ Os inúmeros ofícios expedidos a funcionários e habitantes da capitania de São Paulo pelos governadores e capitães-generais de São Paulo no período de 1765-1777, marcado por intensa mobilização militar, revelam inúmeras facetas da imposição dos poderes centrais. Ver, por exemplo, os volumes n 62,63 a 70 e 72 a 80 dos Documentos Interessantes... Essa discussão está presente em vários trabalhos. Sobre a questão militar, recomendase consultar PEREGALLI, Enrique. Recrutamento militar no Brasil colonial. Campinas: Editora da UNICAMP, 1986; e MELlO, Christiane F. Pagano de. Os Corpos de Auxiliares e de Ordenanças na Segunda Metade do Século XVIII. As Capitanias do Rio de Janeiro, São Paulo e Minas Gerais e a Manutenção do Império Português no Centro Sul América. Tese (doutorado em História). Niterói: ICHF, Universidade Federal Fluminense, 2002.

${ }^{59}$ BLAJ, Ilana. A trama das tensões...; BORREGO, Maria A. de Menezes. A teia mercantil...

${ }^{60}$ BELLOTTO, Heloísa Liberalli. Autoridade e conflito no Brasil colonial: o governo do Morgado de Mateus em São Paulo (1765-1775). São Paulo: Conselho Estadual de Artes e Ciências Humanas, 1979.

${ }^{61}$ METCALF, Alida C. Family and frontier in colonial Brazil, Santana de Parnaíba, 1580-1822. Berkeley: University of California Press, 1992, p. 143 e ss.

62 Cf:: MÜELLER, Daniel Pedro. Ensaio d'um quadro estatístico da província de S. Paulo. São Paulo: Typographia de Costa Silveira, 1838, p. 154-173.
} 
cem quilômetros, como Sorocaba - para a composição de metade das companhias do Regimento dos Úteis. Nas localidades não tocadas pelos braços do Regimento, os homens pardos provavelmente permaneceram incorporados tanto aos regimentos milicianos identificados à região e aos homens brancos quanto às ordenanças, enquanto outros tantos eram recrutados para a tropa de linha. Em quaisquer dessas situações, eles ocupavam as posições hierárquicas mais baixas. Essa disposição que várias localidades apresentaram em alistar os homens pardos entre os soldados brancos, bem como a dispersão territorial do Regimento dos Úteis, de resto característica dos demais corpos milicianos paulistas, contribuíram para que ele continuasse a ser o único corpo militar específico para os pardos da capitania/província até 1831. 


\section{CAPÍTULO 3 - OS PARDOS E O DELINEAMENTO DE SEUS CORPOS MILICIANOS: FORMAÇÃO, ESTRUTURA E FUNÇÕES DAS MILÍCIAS DE COR}

\subsection{O papel de pardos e de pretos livres na formação de suas corporações militares. Modelos institucionais, identidades e demandas}

No capítulo anterior, argumentou-se que a criação e existência das milícias de pardos e de pretos devam ser encaradas também como fenômenos políticos. Na ocasião, foram estabelecidas relações entre o peso populacional dos homens de cor livres em cada capitania e a existência de tais corporações naqueles espaços. Também foi sugerido que as avaliações referentes a essa relação e a seu impacto para o equilíbrio social, efetuadas por governadores e demais administradores coloniais, jogavam um papel de relevo na determinação da natureza e das dimensões dos corpos militares de pardos e pretos. Cumpre, a partir desse momento, deslocar a investigação desse fenômeno político e social para o universo dos homens de cor livres, e em particular aos pardos de São Paulo. Afinal, qual o papel desses indivíduos na construção de suas próprias corporações militares?

Embora não seja tarefa fácil reconstruir o variado campo de interesses e os procedimentos inscritos na formação da milícia dos pardos de São Paulo, alguns raros fragmentos documentais permitem problematizar aquele fenômeno, ocorrido em 1797. A existência do Regimento dos Úteis foi noticiada em um ofício por intermédio do qual Antonio Manuel de Mello Castro e Mendonça, governador de São Paulo entre 1797-1802, informou ao ministro e secretário de Estado dos Negócios da Marinha e Domínios Ultramarinos, D. Rodrigo de Souza Coutinho, as medidas adotadas em relação aos corpos militares paulistas logo que assumira o cargo. Quanto aos pardos, o governador e capitão-general comunicou que

O Regimento dos Mulatos, que se intitula "Regimento dos Úteis", eu o julgo muito capaz de desempenhar bem o fim dos Pedestres, porque este é o gênio deles, e, além disto, são vivos e capazes de perceber, e ordinariamente temerários e muito entusiasmados; e lembrando-me que este nome de Pedestres não lhes é o mais agradável, e que eles de livre vontade querem marchar a pé descalço e fazer deste modo todas as diligências, lhes concedi esta liberdade, e deste modo viemos a ter, como temos, um Regimento de Mulatos, que estando disciplinado como tropa de linha faz as mesmas vezes de Pedestres quando for preciso, e como [este] é o maior uso na guerra e há 
deles um grande número na capitania, pretendo erigir outro corpo com as mesmas leis e regularidade. ${ }^{1}$

O recrutamento foi outra etapa decisiva no processo de formação daquele corpo militar. Fez-se necessário arrolar homens para o preenchimento das companhias de pardos preexistentes - as três da cidade de São Paulo e as de Santos e São Vicente, na região litorânea - bem como para erigir as cinco unidades restantes conforme a organização estipulada pelo decreto de 7 de agosto de 1796, o qual versava sobre a transformação dos terços auxiliares em regimentos milicianos padronizados e assemelhados às tropas regulares. ${ }^{2}$ Enquanto o governador nomeava oficiais brancos, em sua maioria provenientes dos corpos de linha, para o estado-maior do Regimento dos Úteis ${ }^{3}$, a incumbência do recrutamento recaiu sobre o pardo Manoel José Ribeiro. Tratava-se de um veterano da guerra luso-castelhana de 1762-1777 que na ocasião capitaneava uma das companhias auxiliares de pardos da capital. Ribeiro se deslocou para diferentes vilas da capitania a recrutar os homens precisos, "com o pleno poder de nomear oficiais para as ditas", de acordo com as palavras de um miliciano pardo, ou, em termos mais brandos, "com ordens de formar as companhias e nomear oficiais subalternos", em cuja diligência "gastou três meses e 19 dias, fazendo as despesas da sua pessoa e de dois oficiais inferiores e dois soldados que o acompanharam a custa de seus bens". ${ }^{4}$

Por fim, uma inserção na carta-patente pela qual o tenente-coronel reformado Modesto Antonio Coelho Neto foi provido no posto de coronel dos Úteis justificou a criação daquele corpo militar, a qual foi efetuada em conformidade às diretrizes contidas na carta regida de 22 de março de 1766 e no decreto de 7 de agosto de 1796 :

não havendo até o presente mais que três companhias avulsas de homens pardos nesta capital, quando nas vilas imediatas há um número de indivíduos assaz suficiente para se arregimentarem e disciplinarem e servirem assim mais utilmente ao Estado: hei por bem ordenar que dos ditos homens se forme um Regimento de Milícias de Infantaria, que se denominará "O Regimento dos Úteis". 5

\footnotetext{
${ }^{1}$ Cf:: AHU_CU_023-01, Cx. 44, D. 3507. Ofício n. ${ }^{\circ}$ 25. São Paulo, 19 de novembro de 1797.

${ }^{2} C f$ : Decreto de 7 de agosto de 1796. In: SILVA, A. D. da. Collecção da Legislação Portugueza - Legislação de 1791 a 1801. Lisboa: Typografia Maigrense, 1828.

${ }^{3}$ Cf: : APESP, ordem C00407, fls. 20v-21, 21v, 24-24v, 31v-32, 34, 47v-48. São Paulo, 15 de setembro de 1797 a 26 de janeiro 1798; AHU_CU_023-01, Cx. 44, D. 3507. Ofício n. ${ }^{\circ} 21$. São Paulo, 7 de novembro de 1797.

${ }^{4}$ Cf:: APESP, ordem C00276, doc. 40-3-101. São Paulo, 9 e 16 de novembro de 1798; "Para o capitão comandante dos homens pardos ir fazer recrutar nas vilas abaixo declaradas”. APESP, ordem C00407, fl. 7v. São Paulo, 16 de agosto de 1797; ordem C00446, Livro Mestre do Regimento dos Úteis (daqui em diante referido apenas como Livro Mestre), fl. 1-1v.

${ }^{5}$ Cf:: "Portaria a Modesto Antonio Coelho Neto para servir por comissão o posto de coronel do Regimento dos Úteis desta cidade”. APESP, ordem C00407, fls. 20v-21. São Paulo, 15 de setembro de 1797.
} 
Tais são, pois, os vestígios mais explícitos acerca do processo de formação do regimento dos Úteis. Eles serão tomados como ponto de partida para o exame do papel desempenhado pelos pardos de São Paulo para a criação de seu regimento miliciano, delimitação de suas funções e construção de identidade coletiva assentada no âmbito militar.

Um primeiro ponto que deve ser observado diz respeito à ação decisória dos pardos ou "mulatos" junto ao governador no processo de criação da corporação. Esse aspecto, aliás, foi narrado por Castro e Mendonça, que fez questão de expressar especificamente a opção dos pardos em relação ao nome do regimento e ao modo de execução das atividades militares. Além disso, ficou documentada a autoridade investida em um capitão pardo para proceder ao recrutamento e também para escolher e nomear a oficialidade das companhias. Mas é lícito supor, com base em outros casos, que a participação daqueles sujeitos de "baixa extração" na conformação da instituição fosse ainda mais ampla e decisiva.

A formação e organização das companhias de pardos na própria capitania de São Paulo o sugere. Em 1735, um pardo apresentou-se à autoridade máxima da capitania alegando que lhe havia chegado a notícia de que o governador e capitão-general "pretende fazer uma companhia de homens pardos obrigados", razão porque se ofereceu para o posto de capitão, o qual, a propósito, lhe foi concedido. ${ }^{6} \mathrm{Na}$ vila de São Vicente, em 1744, um grupo de homens pardos requereu à câmara local que nomeasse um dentre eles para capitão da "companhia dos mulatos" de forma a que pudessem solicitar o provimento do posto junto ao governador. ${ }^{7} \mathrm{O}$ exemplo mais difundido na literatura é o da negociação que o governador Morgado de Mateus estabeleceu com o capitão dos pardos de Santos, Caetano Francisco Santiago, referido como um dos homens pardos "de cabedal e de préstimo" da localidade, visando à reestruturação daquela companhia em 1765. Naquela circunstância, o Conde de Oeiras, futuro Marquês de Pombal, foi informado que o pardo em questão ficara "muito satisfeito" com a proposta de reunir e fardar uma centena de homens de sua cor em troca de uma "patente de capitão de auxiliares pardos com graduação de tenente de infantaria paga". ${ }^{8}$ Talvez a referência a Santiago como "homem de cabedal" tenha contribuído para que o caso obtivesse tratamento historiográfico de forma isolada e individualista, de modo que pouco se ressaltou do acordo

\footnotetext{
${ }^{6} C f:$ : APESP, ordem C00271, doc. sem identificação. Santos, $1 .^{\circ}$ e 26 de setembro de 1735.

${ }^{7}$ Cf:: APESP, ordem C00271, doc. sem identificação. São Vicente, 4 de abril de 1744.

${ }^{8} C f$ :: "Carta ao Conde de Oeyras, sobre fortaleza e estado militar da capitania". DIHCSP, vol. 72, p. 45-47. Santos,

2 de agosto de 1765; "Carta ao Conde de Oeyras sobre formação de companhias e diversos outros assuntos militares". DIHCSP, vol. 72, p. 51-52. Santos, 10 de setembro de 1765.
} 
com o governador a margem de poder, por menor que fosse, que aqueles indivíduos pardos mobilizavam, individual e coletivamente, em tais circunstâncias. ${ }^{9}$

Nesse sentido, os pardos de São Paulo parecem ter seguido um caminho típico ao traçado por homens de cor das Américas portuguesa e espanhola entre os séculos XVII e XIX. ${ }^{10}$ A descrição da formação do corpo militar que viria a se tornar o terço dos pretos de Henrique Dias dá conta que este "se ofereceu ao general com a [gente] que pudesse juntar da sua, para servirem como negros e pelejarem como brancos". ${ }^{11}$ Uma carta-patente de 1674 que formalizou a companhia dos pardos existente na capitania de Sergipe del Rey revelou que o capitão fora escolhido pelos próprios "mulatos forros dela". ${ }^{12}$ Em 1744 foi a vez dos pardos forros da cidade do Rio de Janeiro requererem ao rei a formação de um regimento de cavalaria privativo a eles. ${ }^{13}$ É bem conhecido o esforço empreendido junto ao rei pelos "crioulos pretos e mestiços forros" das Minas Gerais, em meados do século XVIII, visando, entre outras coisas, sua arregimentação em corpos auxiliares. ${ }^{14}$ É igualmente significativa a justificativa fornecida ao Conselho Ultramarino pelo governador de Goiás, no começo do século XIX, para a criação de companhias de pardos excedentes às dez previstas para um regimento: "os motivos que me obrigaram a criar a dita companhia e outras além das que ficam ponderadas, foram as representações que me fizeram os Povos de diversos Arraiais, desejando alistar-se e empregar-se no real serviço". ${ }^{15}$ Finalmente, verifica-se atitude semelhante por parte de homens pardos hispano-americanos. ${ }^{16}$

Os indícios acessados até aqui permitem concluir que se está diante de diferentes momentos e situações em que os homens de baixa extração apresentaram-se coesos e capazes de se organizarem de modo a terem participado ativamente na ereção de seus corpos militares. Com efeito, nos processos de formação de companhias, terços e regimentos eles se ofereceram, requereram e representaram, além de terem eleito e nomeado seus oficiais comandantes. Em

\footnotetext{
${ }^{9}$ RODRIGUES, José Washt. Tropas paulistas de outrora. São Paulo: Governo do Estado, 1978, p. 61-63; MELLO, C. F. P. de. Os Corpos de Auxiliares e de Ordenanças..., p. 156-158.

${ }^{10}$ Ver a análise de Silva acerca do "caráter integrado, articulado e conectado das experiências históricas" presentes à gênese das milícias de pardos e pretos em Pernambuco e Minas Gerais. SILVA, L. G. Gênese das milícias...

${ }^{11}$ Cf:: FREYRE, F. de B. Nova Lusitânia, história da guerra brasílica. Lisboa: Na Oficina de João Galram, 1675 , p. 254-255.

${ }^{12}$ Cf:: "Patente de capitão da Companhia dos Homens pardos da Capitania de Sergipe del-Rei provida na pessoa de Francisco de Barros". DH, v. 12, p. 342-344. Bahia, 18 de dezembro de 1674.

${ }^{13}$ Cf:: "Requerimentos dos Pardos forros da cidade do Rio de Janeiro e seu recôncavo, no Brazil, nos quaes pedem para formarem um novo regimento de tropas auxiliares de cavallo". AHU_CU_017-01, Cx. 55, Docs. 12.94512.949. Rio de Janeiro, 1744 a 1746.

${ }^{14}$ SILVEIRA, M. A. Narrativas de contestação...; SILVA, L. G. Gênese das milícias..., p. 136-138; COTTA, F. A. Negros e mestiços..., p. 91-105.

${ }^{15}$ Cf:: AHU_ACL_CU_008,CX. 47, D. 2707.

${ }^{16}$ CRUCES, H. C. Artesanos mulatos y soldados beneméritos. El Batallón de Infantes de la Patria en la Guerra de Independencia de Chile, 1795-1820. Historia, Santiago, v. 44, n. 1, p. 51-89, 2011; SOLANO D., S. P.; BOLÍVAR, R. F. "Artilleros pardos y morenos artistas": artesanos, raza, milicias y reconocimiento social en el Nuevo Reino de Granada, 1770-1812. Historia critica, Bogotá, n.48, p. 11-37, 2012.
} 
diversas ocasiões se manifestaram como atores corporativos antes mesmo da criação da instituição militar. ${ }^{17}$ Uma noção aplicada a fenômenos históricos e sociais mais recentes, a de grupos de pressão, isto é, "coligação, ocasional ou permanente, formada por atores sociais, que visa obter do poder político isenções e privilégios", permite uma aproximação ao fenômeno aqui examinado. ${ }^{18}$ Conforme sugestão de Russell-Wood, à qual vários historiadores têm aderido, as corporações militares e religiosas destinadas a pretos e pardos eram espaços privilegiados de atuação política no período em questão. Além da função organizadora e hierarquizante cumprida por tais instituições em âmbito comunitário ou local, a partir delas se encaminhava a luta em prol de prerrogativas, privilégios e quebra de impedimentos, a qual não raro extrapolava seus limites e problemas particulares para atingir vastas coletividades formadas por libertos e seus descendentes. ${ }^{19}$

Retornando aos pardos de São Paulo, nota-se, na narrativa da construção do Regimento dos Úteis, a ausência de referência direta à natureza auxiliar ou miliciana daquele corpo militar e, em contraste, a ênfase do governador e capitão-general em um modelo específico de corpos militares, os "Pedestres", referido em três ocasiões. Conforme a máxima autoridade militar da capitania, aqueles homens mulatos se enquadravam perfeitamente nas características dos pedestres e até se propuseram a realizar o serviço militar "a pé descalço". No entanto, não restam dúvidas quanto à recusa dos pardos ao modelo institucional proposto por Castro e Mendonça, pois “este nome de Pedestres não lhes é o mais agradável”. Qual os possíveis motivos?

\footnotetext{
${ }^{17}$ Guerra, do ponto de vista historiográfico, e Elias, do sociológico, demonstram a supremacia do "corporativo" em relação ao "individual" ou, o que é a mesma coisa, a balança pendente para o "nós" e a desvantagem do "eu" nas sociedades de Antigo Regime. GUERRA, François-Xavier. De la política antigua a la política moderna. La revolución de la soberanía. In: GUERRA, François-Xavier; LEMPÉRIÉRE, Annick (Coords.). Los espacios públicos en Iberoamérica: ambigüedades y problemas, siglos XVIII y XIX. México: Centro Francés de Estudios Mexicanos y Centroamericanos; Fondo de Cultura Económica, 1998; ELIAS, Norbert. A sociedade dos indivíduos. Trad. Mário Matos. Lisboa: Dom Quixote, 1993.

${ }^{18}$ BAECHLER, J. Grupos e sociabilidade. In: BOUDON, R. Tratado de sociologia. Rio de Janeiro: Jorge Zahar Ed., 1995, p. 65-106. Especialmente p. 70-72. Nesta obra, o conceito de "grupo de pressão" foi empregado para analisar a articulação política de grupos nas sociedades contemporâneas, firmadas em regimes democráticorepresentativos. Não obstante, sua definição mais elementar não é incoerente com fenômenos processados em sociedades de Antigo Regime. Pardos e pretos, a partir de suas corporações militares e religiosas, articulavam demandas coletivas que visavam obter do poder político - no caso o rei - isenções e privilégios.

${ }^{19}$ RUSSELL-WOOD, A. J. R. Escravos e libertos..., p. 127-142; SILVEIRA, M. A. Soberania e luta social: negros e mestiços libertos na Capitania de Minas Gerais (1709-1763). In: CHAVES, C. M. das G.; SILVEIRA, M. A. (Orgs.). Território, conflito e identidade. Belo Horizonte: Argumentum, 2007; SILVEIRA, M. A. Acumulando forças: luta pela alforria e demandas políticas na capitania de Minas Gerais (1750-1808). Revista de História, n. 158, p. 131-156, 2008; SILVEIRA, M. A. Narrativas de contestação...; VIANA, L. O idioma da mestiçagem...; LIMA, P. de. De libertos a habilitados...; SOUZA, P. de L. "Sem que lhes obste a diferença de cor": a habilitação dos pardos na América portuguesa e no Caribe espanhol (c. 1750-1808). Tese (doutorado em História). São Paulo: FFLCH, Universidade de São Paulo, 2017.
} 
Em realidade, a questão não se restringia à nomenclatura da corporação - por certo um signo que se revestia da maior importância na construção de uma identidade coletiva, como mais adiante se verá. Ora, as tropas de pedestres eram típicas das capitanias do ouro, tendo sido criadas em Minas Gerais ainda na primeira metade do século XVIII e logo se difundido para as capitanias de Goiás, por volta de 1743, e Mato Grosso, em $1755 .{ }^{20}$ Tratava-se de companhias anexas à tropa regular, e, diferentemente do que ocorria nas segunda e terceira linhas, seus integrantes estavam em serviço permanentemente, razão pela qual eram - ou deviam ser - pagos mensalmente. As despesas exigidas à Real Fazenda para a manutenção dessas tropas explica, em grande parte, o motivo de permanecerem organizadas em um número pequeno de companhias com exígua oficialidade. A configuração dos pedestres em Mato Grosso, bastante semelhante às demais capitanias que lhe serviram como modelo, consistia em dois cabos e 119 soldados, no ano de 1765, e em 415 soldados governados apenas por um capitão, um tenente e um alferes em 1828. ${ }^{21}$ Não obstante a subordinação dos pedestres aos oficiais das tropas de linha, seus soldos equivaliam à metade do valor percebido pelos Dragões. ${ }^{22}$ Ademais, tais companhias eram integradas majoritariamente por soldados cativos e, na pequena oficialidade, por "homens pardos de pé descalço e de conduta igual aos seus mesmos soldados, com exceção de serem forros", no caso mineiro. ${ }^{23}$ Em Goiás, os pedestres eram compostos por "índios, mestiços, mulatos e bastardos", e, na vizinha Mato Grosso, eram formados por "mulatos, caburés e vários outros mestiços". ${ }^{24}$ Esse tipo de tropa exercia múltiplas funções, destacandose a capacidade dos pedestres servirem de correios, remadores nas canoas, condutores de presos, auxiliares no combate ao contrabando de ouro e guias nas expedições para locais de difícil acesso. Por fim, de acordo com um governador mato-grossense, "fazem outros serviços trabalhosos, resistindo melhor que os brancos a todas as doenças". 25

Durante a segunda metade do século XVIII, e especialmente em seu período final, o modelo dos pedestres foi aplicado à capitania do Espírito Santo e nas capitanias do norte da América portuguesa, notadamente Pará, Piauí e Maranhão. ${ }^{26}$ Em sua versão maranhense, os

\footnotetext{
${ }^{20}$ Cf:: AHU_ACL_CU_008, Cx. 19, D. 1191 e Cx. 52, D. 2924, para Goiás; e, para Mato Grosso, AHU_CU_010, Cx. 9, D. 539 e D’ALINCOURT, Luiz. Resultado dos trabalhos e indagações estatísticas da província de Mato Grosso. Anais da Biblioteca Nacional, v. 8, 1880-1881, p. 110. Sobre os pedestres de Minas Gerais, ver COTTA, F. A. Negros e mestiços..., p. 74-82.

${ }^{21}$ Cf.: AHU_CU_010, Cx. 9, D. 539 e D’ALINCOURT, Luiz. Resultado dos trabalhos..., p. 110.

${ }^{22} C f .:$ AHU_ACL_CU_008, Cx. 27, D. 1718; AHU_CU_010, Cx. 35, D. 1799.

${ }^{23}$ COTTA, F. A. Negros e mestiços..., p. 76-77.

${ }^{24} C f:$ AHU_ACL_CU_008, Cx. 27, D. 1718; AHU_CU_010, Cx. 17, D. 1039.

${ }^{25}$ Cf: AHU_CU_010, Cx. 17, D. 1039.

${ }^{26} C f$ : AHU_CU_007, Cx. 06, D. 445; AHU_ACL_CU_013, Cx. 114, D. 8853; AHU_CU_016, Cx. 10, D. 599; AHU_CU_016, Cx. 22, D. 1138; AHU_ACL_CU_013, Cx. 70, D. 6003; AHU_ACL_CU_009, Cx. 51, D. 4918; AHU_ACL_CU_009, Cx. 89, D. 7392; AHU_ACL_CU_009, Cx. 123, D. 9326.
} 
pedestres obtiveram feição significativamente distinta. Embora a composição das quatro companhias soltas fosse semelhante à das capitanias do ouro, pois eram formadas "de índios, negros forros e mestiços, que andam descalços e se denominam Pedestres”, elas se enquadraram inicialmente no formato das ordenanças até que o crescente número de companhias fosse convertido em terço auxiliar de pedestres pardos em fins do século XVIII, como já visto. É provável que, em 1797, os pardos de São Paulo tivessem conseguido dissuadir parcialmente seu governador e capitão-general a formar o corpo de pedestres nos moldes dos existentes nas capitanias vizinhas - não obstante aquele ainda insistisse em elementos de pormenor que caracterizavam os pedestres, tal como o servir a pé descalço. É de se supor que eles desconhecessem a criação do terço auxiliar de pedestres no Maranhão ocorrida no ano anterior, o qual poderia ser encarado como um modelo alternativo ao proposto pelo governador. Seja como for, não apenas o nome, mas todo o formato institucional dos pedestres foi rechaçado quando da criação do Regimento de Infantaria Miliciana dos Úteis. Deve ter havido boas razões para isso e é possível deduzir algumas delas.

Em primeiro lugar, as condições de execução do serviço militar poderiam não ser atrativas para os pardos da cidade de São Paulo. Não é possível mensurar o quanto eles conheciam da realidade dos pedestres de Minas Gerais, Goiás e Mato Grosso, mas o certo é que aqueles corpos militares eram destinados permanentemente para o desempenho de tarefas árduas em regiões distantes e inóspitas, de forma que as tropas de brancos eram preservadas de sujeição a semelhantes funções e, ainda assim, quando a remuneração não atrasava, pagava-se aos negros e mestiços apenas meio soldo. Outro ponto essencial é que os pedestres inseriam-se tipicamente dentre os corpos militares regulares ou de linha. É possível que aos pardos paulistas não lhes agradasse a ideia de executar as duras funções de pedestres sem a previsão de remuneração, uma vez que não se trataria, ali, de tropa de linha. Um terceiro aspecto diz respeito à identificação dos pedestres mineiros ao universo da escravidão, do qual, certamente, muitos daqueles pardos ou mulatos de São Paulo viam-se na necessidade de se desvencilhar.

Por outro lado, em comparação com o modelo dos pedestres, parece que as características do enquadramento como regimento miliciano eram mais vantajosas e atrativas. Um fator de primeira ordem se relaciona às dimensões da oficialidade miliciana, extremamente avultada se contrastada com o comando dos pedestres. Enquanto esses se resumiam, na prática, a dois ou três homens, os regimentos milicianos contavam, de acordo com a regulamentação de 1796, com nada menos que 30 oficiais de patente no interior de suas dez companhias, bem como com um estado-maior. Haveria na milícia espaço suficiente para acomodar a elite dos pardos 
de São Paulo, que era efetivamente onde se localizavam os homens que negociaram com o governador e que concorriam entre si pelos postos.

As posições no oficialato miliciano tornavam seus ocupantes investidos de autoridade formal sobre uma vasta teia de subordinados e, para além disso, permitiam-lhes o desfrute dos privilégios dos auxiliares - o que não sucedia aos pedestres. A historiografia que se ocupa das milícias de pardos e morenos da América espanhola ressalta o impacto social e político da concessão do foro militar privilegiado àqueles homens, os quais passariam a estar livres de subordinação a autoridades civis e judiciárias locais, bem como, em certos casos, lograriam a isenção do pagamento de tributos a que eram obrigados índios e castas. ${ }^{27} \mathrm{Na}$ América portuguesa não havia imposição de encargos tributários aos pardos e pretos em função especificamente de sua condição social e, a despeito de eles usufruírem do foro especial por serem oficiais milicianos, esse problema nunca se tornou relevante, ou, ao menos, nos níveis assumidos na realidade hispano-americana. Antes, no Brasil, o que mais gerou atritos ao longo de todo o período de existência das milícias de pardos e pretos foi a extensão àquelas tropas dos privilégios dos auxiliares e sua equiparação aos demais corpos militares de segunda linha. Esses aspectos particulares serão abordados ao longo da tese. Importa aqui destacar que tais privilégios, honrarias e isenções foram estipulados para os auxiliares do reino já no momento de criação dessa modalidade de corpos militares, em 1645, e reiterados para a América portuguesa no texto da carta régia de 22 de março de $1766 .{ }^{28}$ Eles consistiam, resumidamente, na elevação dos privilégios dos auxiliares ou milícias à categoria dos usufruídos por integrantes das tropas regulares ou de linha, assim como na permissão do uso de determinados signos de distinção. Esse último aspecto obtinha especial significância para pardos e pretos, muitos dos quais forros, haja vista os impedimentos a que pessoas de baixa condição, como eram via de regra os negros livres, se apresentassem publicamente trajando-se de roupas, joias e adereços não condizentes com sua qualidade. ${ }^{29}$

\footnotetext{
${ }^{27}$ Para uma análise geral acerca do impacto da extensão do foro militar aos milicianos de cor, McALISTER, Lyle N. The "fuero militar" in New Spain (1764-1800). Gainesville: University of Florida Press, 1957. Vários autores exploraram a aplicação do foro ao nível de localidades específicas. Ver, por exemplo, KUETHE, A. J. The status of the free pardo..., e VINSON III, Ben. Articular el espacio: el establecimiento militar de gente de color libre en el México colonial de la conquista hasta la independencia. Callaloo, v. 27, n. 1, p. 331-354, 2004, que também aborda a questão da isenção fiscal.

${ }^{28}$ Cf:: "Carta Régia de 7 de Janeiro de 1645. Criação de Soldados Auxiliares". In: SILVA, José Justino de Andrade e. Collecção Chronologica da Legislação Portugueza. Lisboa: Imprensa de J. J. A. Silva, 1854; "Cópia do traslado do Alvará dos soldados Auxiliares porque gozam dos privilégios dele”. DIHCSP, vol. 14, p. 81-84. Monte Mor o Novo, 24 de novembro de 1645; "Carta de D. José I ao governador e capitão-general de São Paulo, morgado de Mateus”. AHU_CU_023-01, Cx. 24, D. 2354. Palácio de Nossa Senhora da Ajuda, 22 de março de 1766.

${ }^{29}$ RUSSELL-W̄OOD, A. J. R. Escravos e libertos..., p. 107-108; e, principalmente, LARA, S. H. Fragmentos setecentistas..., p. 79-125.
} 
Verificado o status político e militar relativamente elevado da segunda linha, é compreensível que os pardos de São Paulo rejeitassem o formato dos pedestres. O governador Castro e Mendonça prosseguiu insistindo, junto a outros "homens mestiços e libertos" da capitania, moradores na vila de Itu e seu distrito, na formação de regimento cuja natureza fosse semelhante aos pedestres. E, de fato, em 1798 informou a criação de um regimento de infantaria miliciana intitulado "Sertanejos", o qual se prestaria tanto a manter "em respeito os sertões daquela vizinhança [...] como para domesticar e fazer sociáveis estes homens, sujeitando-os à disciplina dos seus respectivos cabos, com o que serão de grande importância na ocasião de algum rompimento de guerra". ${ }^{30}$ Nota-se, pois, que a identificação, em parte recusada pelos Úteis, fora assumida por outro grupo militar composto inicialmente "por homens de toda a qualidade, capazes de entrarem no sertão por viverem em bastante proximidade dele". ${ }^{31}$ Embora a composição daquele corpo tenha sido alterada rapidamente, passando a ser identificado como um regimento de homens brancos, o nome Sertanejos permaneceu até a década de 1820. Não se sabe em que medida os Sertanejos de São Paulo, dada a similitude nos nomes, era tropa espelhada no "Terço dos Sertanistas e Índios Bororós", projeto malogrado estabelecido pela Coroa ao Mato Grosso entre 1758-1759, os quais deviam ser reduzidos à forma "dos cipais que servem nas tropas da nossa Índia Oriental”. ${ }^{32}$ Fica patente, porém, a circulação, desenvolvimento e manipulação de diferentes modelos de tropas de segunda linha no mundo colonial. Nesse sentido, cumpre indagar qual a relação estabelecida, na gênese dos Úteis, com as tradições, identidades coletivas e modelos de corpos militares tipicamente associados a pardos e pretos Henriques na América portuguesa.

É provável que aos pardos paulistas fosse estranho o projeto do terço de Sertanistas e Índios Bororós assim como a referência aos pedestres auxiliares maranhenses. Contudo, é impossível que ignorassem a fama e tradição dos terços ou regimentos de pardos e de pretos Henriques. Mesmo porque a própria Coroa tratava de difundir aspectos atinentes ao universo militar dos negros livres como forma de incentivá-los ao serviço militar e a reiterarem os laços de lealdade historicamente construídos com o rei. No contexto da guerra luso-castelhana de 1762-1777, quando se cogitou o emprego de pardos e pretos diretamente no campo de combate, Pombal advertiu ao vice-rei Lavradio quanto ao status diferenciado desfrutado por tais corpos militares, lembrando-lhe "que os referidos pretos e pardos são descendentes de dois heróis tão

\footnotetext{
${ }^{30} C f:$ : "N. ${ }^{\circ}$ 47. Para o mesmo [Secretário de Estado, D. Rodrigo de Souza Coutinho]". DIHCSP, vol. 29, p. 61. São Paulo, 26 de abril de 1798.

${ }^{31} C f$ :: "Para o mesmo sobre a dúvida que S. A. R. pôs em confirmar o Regimento de Sertanejos". DIHCSP, vol. 29, p. 160. São Paulo, 21 de janeiro de 1800.

${ }^{32}$ Cf: : AHU_CU_010, Cx. 37, D. 1879.
} 
grandes, como foram o preto Henrique Dias e o pardo Dom Antonio Felipe Camarão", atuantes nas guerras luso-holandesas do século XVII. E, a partir de termos incrivelmente significativos, o ministro de D. José I indicou que "sua majestade, por esta memória, estima tanto aqueles vassalos pretos e pardos" que "manda tratar nesta Corte os oficiais deles como os das outras tropas, sem diferença alguma", o que deveria suceder igualmente no Brasil. ${ }^{33}$

A referência à recepção gentil e atenciosa dispensada àqueles vassalos de cor na Corte não era fortuita: tais homens, especialmente os integrantes da oficialidade auxiliar e depois miliciana, partiam de suas capitanias e províncias em direção à Corte - atravessando o oceano rumo a Lisboa e, de 1808 em diante, se encaminhando ao Rio de Janeiro - com uma frequência ainda pouco notada. Crispin destacou esse investimento dos milicianos pardos e pretos, particularmente os das capitanias de Pernambuco e Minas Gerais na segunda metade do século XVIII, e o bom trânsito na relação estabelecida com as autoridades imperiais. ${ }^{34}$ Cumpre recordar que, ainda no Seiscentos, Henrique Dias se prestara a tal expediente a fim de lograr audiência com o rei ou com seus ministros. Os motivos que os levavam à Corte eram múltiplos, e diversos também eram os objetivos que tinham relação mais direta com o universo miliciano: provisão de postos, confirmação de patentes, requisição de soldos e honrarias e, dentre outros, requerimentos coletivos visando tanto à arregimentação e formação de corpos militares como a conquista de privilégios. É pertinente aclarar que, mesmo nas ocasiões em que as demandas obtinham feição individual, fazia-se menção invariavelmente ao âmbito corporativo e coletivo ao qual todas as individualidades tendiam a confluir. Ademais, cada concessão de mercê régia, independentemente de se destinar a indivíduos ou a grupos, abria precedentes e oportunizava a pressão, em mesmo sentido, por parte de outros atores sociais localizados na mesma configuração social ou até mesmo provenientes de outras capitanias. ${ }^{35}$

Dentro dessa lógica, os habitantes de qualquer região mantinham-se atentos não apenas aos equilíbrios de poder internos às configurações sociais que pertenciam, mas notavelmente ao que se passava em outras localidades no tocante aos diversos âmbitos de relação entre os vassalos e o rei - e isso não era diferente com os militares pretos e pardos. Os terços de auxiliares dos pardos e pretos Henriques pernambucanos constituíam o ponto de referência às demais corporações de homens de cor do Estado do Brasil. Suas prerrogativas e status,

\footnotetext{
${ }^{33} C f$ :: "Carta do marquês de Pombal ao marquês do Lavradio". In: MENDONÇA, M. C. de. Século XVIII, século pombalino no Brasil. Rio de Janeiro: Xeróx, 1989, p. 635-639. Lisboa, 9 de maio de 1775.

${ }^{34}$ CRISPIN, A. C. T. Além do acidente pardo..., p. 63-70.

${ }^{35}$ O que não significa o estabelecimento de "direitos". Antes, aponta-se para o papel desempenhado pela tradição, costume e precedente na lógica de Antigo Regime. Ver LIMA, Priscila de. De libertos a habilitados..., especialmente p. 100-128.
} 
reconhecidos e propagados pela Coroa, tornaram-se espelho para seus pares de cor das várias capitanias, os quais buscavam insistentemente elevar-se ao mesmo padrão institucional daqueles. Não é por outra razão que, dos sete terços de pretos existentes na América portuguesa no começo do século XIX, seis faziam referência e homenagem formal, por meio de seus nomes, a Henrique Dias, mesmo que suas trajetórias históricas tivessem origem distante das pelejas que resultaram na expulsão dos neerlandeses travadas no século XVII, como era o caso de goianos e fluminenses. ${ }^{36}$

Embora tais modelos fossem evocados reiteradamente pela Coroa, por governadores coloniais e pelos próprios homens de cor, como mostram abundantemente os fragmentos documentais coloniais, a formação daquelas milícias era resultante de inúmeras variáveis. E dentre elas, de acordo com o que se sugere aqui, a ação dos "grupos de pressão" conformados por pardos e pretos não era de somenos importância. O exame de casos específicos permite entrever alguns dos elementos empregados por aqueles indivíduos e seus grupos sociais no exercício de pressão política junto à Coroa bem como a capacidade de se apropriarem daqueles modelos e de elaborarem discursos sobre seu valor militar.

Entre os anos de 1755 e 1762, José Inácio Marçal Coutinho, um homem de cor, capitão de uma companhia dos pardos forros, se deslocou de Minas Gerais para Lisboa com o intuito de representar os "homens crioulos pretos e mestiços forros" daquela capitania. Durante esse tempo, como "agente e procurador" daqueles homens apresentou vários requerimentos e, em um deles, solicitava-se precisamente que o rei "os mande ali regimentar no mesmo modo, tratamento e honra que gozam os homens pretos de Pernambuco, Bahia e São Thomé, com companhias úteis e necessárias", uma vez que, até então, não havia terços auxiliares para pardos e pretos, como visto em outra seção. ${ }^{37}$ Por volta de 1801 , um capitão do Regimento dos Pardos da cidade da Paraíba viajou com familiares para a Corte a fim de apresentar ao rei "os importantes serviços que fizera à Coroa, e em benefício da mesma se servir, por sua fidelidade e amor, de lhe representar verbalmente a grande necessidade que no Brasil há de se levantar um novo Regimento de homens pardos”. Conforme seus termos, atendia-se à necessidade de defesa de pontos específicos da costa litorânea paraibana, bem como aos anseios de um milhar de

\footnotetext{
${ }^{36} \mathrm{Na}$ realidade, até mesmo o regimento dos pretos de Sabará, Minas Gerais, o único cuja nomenclatura formal não se referia expressamente à memória de Henrique Dias, era ocasionalmente chamado de "de Henriques". Veja-se a transcrição da assinatura de "João Geraldo Pereira dos Santos, Tenente de Henriques" em Diario do Governo Imperio do Brasil, Vol. 3, N. ${ }^{\circ}$ 19, 26 de janeiro de 1824, p. 86. Consultar, igualmente, APMG, SG-Cx. 88, doc. 31. Vila Nova da Rainha, 9 de setembro de 1813.

${ }^{37}$ Cf:: AHU_CU_011, Cx. 69, D. 5750. Esse caso foi abordado minuciosamente em SILVEIRA, M. A. Narrativas de contestação... Conferir também as interpretações de SILVA, L. G. Gênese das milícias..., p. 136-138 e COTTA, F. A. Negros e mestiços nas milícias..., p. 91-105.
} 
pardos não matriculados em "mostrar no serviço de V.A.R. aquela mesma fidelidade que em outro tempo os seus antepassados já o mostraram" - uma clara alusão às guerras lusoholandesas. ${ }^{38}$

Por fim, três capitães pardos de ordenanças, moradores na capitania de Sergipe del Rey, encabeçaram um requerimento com os "demais homens pardos com eles abaixo assinados" com o objetivo de que se erigisse ali um regimento miliciano de pardos. Mais do que a narrativa eloquente empregada, é significativo o modo como expressaram o papel das milícias de pardos e pretos no estabelecimento de diferenciação entre os indivíduos e igualmente entre as diversas capitanias ou configurações sociais luso-americanas. Dito de outro modo, eles revelam refinada capacidade de observação política e consciência de seu posicionamento coletivo em relação aos demais grupos de pardos e pretos junto à Coroa. Na ocasião, pediram ao rei

queira, com aquele amor paternal com que tanto tem engrandecido e felicitado toda esta América, engrandecer e felicitar também este continente [...], mandando [...] criar um Regimento de Milícia Auxiliar de homens pardos naquela mesma cidade e seu termo, honrando-os assim com a mesma liberalidade, graça e amor com que estão condecorados os vassalos da mesma qualidade das capitanias da Bahia e Pernambuco, para não se considerarem menos felizes ou amados de Vossa Real Alteza do que esses; já que a milícia é vida mui decente e mui própria para ganharem os homens merecimentos e honras, e para adiantarem as suas graduações e fortunas. ${ }^{39}$

Como se vê, havia um vasto campo de interesses que justificava a ação coletiva dos pardos e pretos de pleitearem junto à Coroa a formação de seus regimentos milicianos. Realmente, a milícia era uma das formas institucionalmente mais elevadas de vinculação entre os homens de cor e o rei. Ela chancelava as elites de cor como tais através de graduações e honras associadas às patentes. Além disso, produzia a hierarquização entre os grupos de "vassalos da mesma qualidade" das diversas configurações sociais, de modo que eles revelavam-se sensíveis aos equilíbrios de poder presentes a essa relação. Vai daí a observação cristalina e coeva de Henry Koster acerca de um processo paulatino de acúmulo de poder por parte das milícias de cor na América portuguesa: "Portugal continua, por política, o sistema que outrora lhe havia sido imposto pelas circunstâncias locais", isto é, pela carência de contingente

\footnotetext{
${ }^{38}$ Cf:: AHU_CU_014, Cx. 37, D. 2658. Paraíba, ant. 3 de fevereiro de 1801.

${ }^{39}$ Cf:: "Representação dos officiaes da Companhia dos homens pardos da cidade de São Christovão, Capitania de Sergipe d'Elrei, annexa ao Terço das Ordenanças do Capitão-mór Francisco Felix Barreto de Menezes, em que pedem para se crear naquella cidade um regimento de milícias e nelle serem incorporados". AHU_CU_005-01, Cx. 110, D. 21.594. Ant. 4 de setembro de 1800.
} 
humano para compor as forças defensivas. ${ }^{40}$ Fica claro que a manipulação dos modelos formais de corpos milicianos se insere nessa dinâmica de natureza politizada.

No caso dos milicianos pardos de São Paulo não foi diferente. Além dos modelos de corpos militares que o governador e capitão-general Castro e Mendonça tinha em mente, estavam na mesa os formatos específicos de corpos militares que eram da predileção daqueles homens de baixa extração. Em realidade, a formação do Regimento dos Úteis se processou a partir da replicação do modelo tradicional dos terços e regimentos de pardos, de um lado, e, de outro, pela criação de um signo identitário que diferenciava o último regimento miliciano de pardos livres a ser erigido no período colonial dos demais corpos militares análogos. Com efeito, o nome "Úteis" requer reflexão. O que, no fim das contas, ele revela sobre aqueles homens?

Em primeiro lugar, esse nome não era inédito entre as milícias da América portuguesa. Havia, com efeito, um “Terço dos Úteis" em Salvador, Bahia, de formação mais antiga. Mas aquele, ao contrário da corporação paulista, se compunha de comerciantes brancos com seus caixeiros e era conhecido também pelo "pomposo nome de Regimento da nobreza". ${ }^{41}$ É bastante provável que se soubesse da existência do homônimo quando da estruturação dos Úteis paulistas, mas, para aqueles pardos, o significado atribuído ao nome aparentemente era de natureza diversa do "pomposo" sentido vigente entre as elites baianas. A escolha dessa denominação significou que a tradicional designação de terço ou regimento "dos Pardos" ficaria em segundo plano, não obstante se mantivesse na essência da corporação paulista. Na verdade, a condição social dos seus integrantes era constantemente recordada pelas autoridades, que costumavam se referir àquele corpo militar como "Regimento de Milícias dos Pardos, denominado dos Úteis da cidade de São Paulo". ${ }^{42}$ Seja como for, parece clara a intenção de que a identificação do regimento dispusesse a utilidade e valor militar daqueles homens à frente da cor, que, embora jamais tenha sido negada, era correntemente empregada como signo

\footnotetext{
${ }^{40}$ Cf:: KOSTER, Henry. Viagens ao Nordeste do Brasil. Tradução e notas de Luiz da Camara Cascudo. São Paulo/Rio de Janeiro: Companhia Editora, 1942, p. 481.

${ }^{41} C f$ :: "Carta muito interessante do advogado da Bahia, Josá da Silva Lisboa, para o Dr. Domingos Vandelli, Director do Real Jardim Botânico de Lisboa, em que lhe dá notícia desenvolvida sobre a Bahia [...]”. Bahia, 18 de outubro de 1781. In. CASTRO E ALMEIDA, Eduardo de. Inventário dos documentos relativos ao Brasil existentes no Archivo de Marinha e Ultramar de Lisboa. Vol. 2 - Bahia (1763-1786). Rio de Janeiro: Officinas Graphicas da Biblioteca Nacional, 1914, p. 498. Grifos no original; PRADO JÚNIOR, C. Formação do Brasil contemporâneo..., p. 312.

${ }^{42} C f$ :: "Relação dos oficiais de Tropa de Linha, Milícias e Corpo de Ordenanças da capitania de São Paulo, promovidos e reformados por Decreto de 13 e 26 de maio do corrente ano". APESP, ordem C00417, doc. sem identificação. Rio de Janeiro, 10 de junho de 1815.
} 
estigmatizador, relegando seus portadores a uma condição social inferior aos brancos. ${ }^{43}$ Apenas essa inversão, por si só, já seria de extrema importância. Ora, sabe-se que já na primeira metade do século XVII o "mulatismo" fora incorporado aos estatutos de pureza de sangue lusitanos como condição maculada e "infecta". ${ }^{44}$ No mundo colonial, para além de se constituir alvo de preconceitos ordinários, a atribuição de sangue impuro aos mulatos foi institucionalizada nas Constituições primeiras do arcebispado da Bahia, de $1707 .{ }^{45}$ Ademais, a assimilação formal ou mesmo informal dessa referência estigmatizadora à estrutura governativa da América portuguesa significou que os homens de cor livres eram considerados inabilitados para ocuparem postos de relevo nas municipalidades, na carreira eclesiástica e em corpos militares que não fossem privativos à sua cor. ${ }^{46}$

A historiografia tem notado recentemente que, em função da construção e consolidação de um topos que associava elementos de caráter pejorativo aos mulatos, processou-se paulatinamente a positivação da categoria pardo, tida como sinônimo de mulato. Assim, ao passo que se fazia uso correntemente do termo mulato para referir-se a qualidades socialmente condenáveis atribuídas aos mestiços, esses optavam por utilizar o designativo pardo como forma de evitar alusão a toda a carga de preconceitos sintetizada na palavra mulato. ${ }^{47}$ Do mesmo modo, observou-se que em fins do período colonial as elites brancas costumavam referir-se à cor parda como um "defeito", ao passo que na argumentação dos pardos ela surgia como um “acidente". ${ }^{48}$ Possivelmente a inversão operada no regimento dos pardos de São Paulo, que consistiu em explicitar que seu valor militar superava em importância, na relação com o rei, qualquer elemento que pudesse ser associado à cor ou condição mulata ou parda, estivesse conectada de algum modo àquele macroprocesso de reação aos estigmas atribuídos aos mestiços e descendentes de escravos.

Sua utilidade era de natureza militar, como, aliás, referendava o próprio governador Castro e Mendonça ao afirmar que, ao "se arregimentarem e disciplinarem”, os pardos serviriam

\footnotetext{
${ }^{43}$ Sobre a importância e efeito da atribuição e assimilação dos estigmas sociais nas relações de poder, ver ELIAS, Norbert; SCOTSON, John L. Os estabelecidos e os outsiders. Sociologia das relações de poder a partir de uma pequena comunidade. Trad. Vera Ribeiro. Rio de Janeiro: Jorge Zahar Editor, 2000.

${ }^{44}$ VIANA, L. O idioma da mestiçagem..., p. 54.

45 VIANA, L. O idioma da mestiçagem..., p. 77-78.

${ }^{46}$ LIMA, Priscila de. De libertos a habilitados...

${ }^{47}$ PESSOA, Raimundo Agnelo Soares. Gente sem sorte: os mulatos no Brasil colonial. Tese (doutorado em História). Franca: FHDSS, Universidade Estadual Paulista "Júlio de Mesquita Filho", 2007; VIANA, L. O idioma da mestiçagem...

${ }^{48}$ LOIOLA, Maria L. Defeito ou acidente? Mulatos e pardos...; SOUZA, P. de L. "Sem que lhes obste a diferença de cor"...
} 
"mais utilmente ao Estado". ${ }^{49}$ Assim também insistiam os milicianos de outras paragens, como os homens de cor mineiros que, ao requererem arregimentação, argumentaram que suas companhias seriam "úteis e necessárias". ${ }^{50}$ Mas a utilidade expressa no epíteto da corporação transcendia a esse âmbito particular. Tal como concluíra o marquês do Lavradio ao deixar o posto de vice-rei, o mesmo governador paulista, referindo-se ao Regimento de Sertanejos, acreditava que ao lado da função estritamente militar das corporações milicianas elas seriam locus adequados para "domesticar e fazer sociáveis estes homens, sujeitando-os à disciplina dos seus respectivos cabos". ${ }^{51}$ Dito de outro modo, tais regimentos funcionariam como instrumentos de inserção das populações no processo civilizatório ${ }^{52}$ e do estabelecimento de laços de vassalagem entre aqueles e a Coroa. Aspecto de fundamental importância é o papel atribuído à própria oficialidade parda de exercício de controle social e disciplinarização sobre a vasta camada de subordinados na milícia, o qual, em seus meandros, será examinado em outra seção.

Cumpre aqui referir à oposição explícita entre a "utilidade" à qual os milicianos pardos passaram a se associar e a "inutilidade" recorrentemente imputada pelos administradores coloniais às populações situadas nos andares de baixo da sociedade. Como bem demonstrou Laura de Mello e Souza, na Europa, desde fins da Idade Média que as populações marginalizadas e desenraizadas eram vistas como "inúteis ao mundo". Na linguagem colonial, os termos "vadio" e "vagabundo" eram fluentemente empregados para aludir às pessoas sem domicílio ou ocupação certa, os inúteis. ${ }^{53}$ Não é difícil imaginar que os grupos preferencialmente indicados como tais fossem constituídos por mestiços de africanos, crioulos e indígenas, populações profundamente abaladas pelas formas de trabalho forçado a que eram costumeiramente submetidas, pelas dificuldades de acesso à terra e pela miséria. A referência "úteis", portanto, pode ser entendida de modo mais amplo como um esforço dos milicianos pardos para, a um só tempo, expressarem valor militar bem como diferenciação em relação ao restante da população formada por pessoas de cor livres ou de pessoas livres pobres, cujo empenho fora avalizado pelo governador e capitão-general de São Paulo.

\footnotetext{
${ }^{49}$ Cf: "Portaria a Modesto Antonio Coelho Neto para servir por comissão o posto de coronel do Regimento dos Úteis desta cidade”. APESP, ordem C00407, fls. 20v-21. São Paulo, 15 de setembro de 1797; AHU_CU_023-01, Cx. 44, D. 3507.

${ }^{50} C f:$ : AHU_CU_011, Cx. 69, D. 5750.

${ }^{51} C f$ : "Relatório do marquês de Lavradio, vice-rei do Rio de Janeiro, entregando o governo a Luiz de Vasconcelos e Souza, que o sucedeu no vice-reinado". RIHGB, t. 4, n. 16, p. 419-425 e 436; "N. ${ }^{\circ}$ 47. Para o mesmo [Secretário de Estado, D. Rodrigo de Souza Coutinho]". DIHCSP, vol. 29, p. 61. São Paulo, 26 de abril de 1798.

${ }^{52}$ ELIAS, Norbert. O processo civilizador. Uma história dos costumes. (v. 1). Trad. Ruy Jungmann. Rio de Janeiro: Jorge Zahar Editor, 1990; ELIAS, Norbert. O processo civilizador. Formação do Estado e Civilização. (v. 2). Trad. Ruy Jungmann. Rio de Janeiro: Jorge Zahar Editor, 1993.

${ }^{53}$ SOUZA, L. de M. e. Desclassificados do ouro..., especialmente p. 51-90 e 215-222.
} 
Este exame à gênese do Regimento dos Úteis surpreendeu o papel de relevo desempenhado por pardos livres ao lado do governador e capitão-general de São Paulo. Tratavase de protagonismo assumido por pardos e pretos em diferentes circunstâncias e em diversos espaços ibero-americanos. Em tais ocasiões, os homens de cor não apenas acordavam a construção de corpo militar, mas negociavam e decidiam, conjuntamente à máxima autoridade política e militar local, qual a formatação institucional da corporação, quais as funções militares seriam realizadas, a nomeação de oficiais inferiores e a conformação de identidades coletivas. No caso dos Úteis, a referência identitária fora forjada nitidamente tendo-se em vista o relacionamento dos pardos com o Estado e o rei. Era a esses níveis de poder elevados que cabia aos pardos demonstrar a viabilidade da associação entre sua cor, a utilidade militar e a fidelidade dos laços de vassalagem. E, sempre que o faziam, revelavam coesão grupal e consciência de que seu lugar social não era ambíguo, inadaptado ou desajustado.

\subsection{Fazer e desfazer-se miliciano pardo: recrutamento, licenças, ausências e baixas}

Uma vez abordadas as linhas gerais do processo de formação do Regimento dos Úteis e sua localização na trajetória histórica das milícias de pardos e pretos da América portuguesa, pode-se, enfim, dar início à averiguação de aspectos referentes à sua estrutura e funcionamento internos. Essa incursão será iniciada pelo exame ao recrutamento, fenômeno que tem sido contemplado pela historiografia com alguma constância, e seguirá com a investigação de outros aspectos igualmente essenciais para o funcionamento e organização dos corpos militares, tais como as ausências temporárias de milicianos e as saídas e baixas.

O estudo da conscrição no Brasil colonial e imperial, como de resto em todas as sociedades de Antigo Regime ${ }^{54}$, aponta quase que invariavelmente para o emprego da violência como o meio mais recorrente de obtenção de soldados. De fato, foi constatado em trabalho anterior que o recrutamento forçado dos homens pardos - assim como de outros grupos sociais - era prática comum em São Paulo na conjuntura da guerra luso-castelhana travada entre os

\footnotetext{
${ }^{54} \mathrm{Ou}$, ao menos, no mundo ibérico: HOLANDA, S. B. de. São Paulo. In: HOLANDA, S. B. de (Dir.). História geral da civilização brasileira. (t. II, $2^{\circ}$ vol.). São Paulo: Difusão Européia do Livro, 1967, p. 434; COSTA, Fernando D. Os problemas do recrutamento militar no final do século XVIII e as questões da construção do Estado e da nação. Análise social, v. 30 (130), p. 121-155, 1995; MARCHENA FERNÁNDEZ, J. Ejército y milícias..., p. 69-86.
} 
anos 1762-1777. ${ }^{55}$ Para além dos efeitos catastróficos do recrutamento, muito bem ilustrados pelas fugas em massa que esvaziavam vilarejos ou pelos prejuízos na lavoura e o decorrente encarecimento dos alimentos nas cidades ${ }^{56}$, os historiadores atualmente debatem o significado do recrutamento forçado para o entendimento do Estado colonial e imperial. Afinal, tais práticas revelariam uma estrutura de governo avassaladora e capaz de se impor sobre os indivíduos, ou, ao contrário, o uso da força demonstraria apenas a precariedade da organização estatal e de seu relacionamento com os grupos da sociedade? ${ }^{57}$ Uma alternativa à polaridade existente é o manejo de categorias mais dinâmicas e flexíveis, como é o caso de "campo de tensões". Tal expressão pressupõe a interação e a competição entre diferentes participantes e é afeita à contextualização e à consideração dos equilíbrios de poder e sua variação no tempo. Outro aspecto a se notar a respeito da historiografia em questão é que, independentemente das diferenças interpretativas, tais estudos concentram sua observação prioritariamente à prática do recrutamento em situação de guerra ou de mobilização militar em níveis intensos, assim como tendem a examinar predominantemente a produção de soldados destinados aos corpos militares regulares ou de linha mediante a captura aleatória de pessoas ou a intermediação das ordenanças. Não por acaso, subiste certa propensão a se generalizar o recrutamento para as tropas regulares como a prática padrão do recrutamento para a segunda linha. Em decorrência, as características efetivas da introdução regular de contingentes humanos nas milícias permanecem como um aspecto a se desvendar.

Em segundo lugar, o fenômeno das ausências ou das baixas motivadas por ausências merece ser revisto, uma vez que o sumiço dos soldados é mais comumente associado às movimentações da guerra. Entretanto, como se verá em outra seção, mesmo em uma conjuntura de intensa mobilização militar, o Regimento dos Úteis foi destinado para campanha militar pouquíssimas vezes ao longo de sua existência. Isso significou que a prestação de serviços militares ocorrera habitualmente no interior da capitania/província. Ao mesmo tempo, tratar-

\footnotetext{
55 SOUZA, Fernando Prestes de. Milicianos pardos em São Paulo. Cor, identidade e política (1765-1831). Dissertação (mestrado em História). Curitiba: SCHLA, Universidade Federal do Paraná, 2011, p. 64-81.

${ }^{56}$ PRADO JÚNIOR, Caio. Formação do Brasil contemporâneo..., p. 310-313; HOLANDA, S. B. de. São Paulo..., p. 432-440.

57 PEREGALLI, Enrique. Recrutamento militar no Brasil colonial. Campinas: Editora da UNICAMP, 1986, representa adequadamente a primeira postura; MENDES, Fábio Faria. Encargos, privilégios e direitos: o recrutamento militar no Brasil nos séculos XVIII e XIX. In: CASTRO, C.; IZECKSOHN, V.; KRAAY, H. (Orgs.). Nova história militar brasileira. Rio de Janeiro: Editora FGV, 2004, p. 111-138, se insere na segunda perspectiva. Entende-se aqui que a interpretação de Laura de Mello e Souza se situa em uma posição de equilíbrio entre esses polos. Para a historiadora em questão, a governança colonial, dependente de homens para a segurança e povoamento das fronteiras, encontrou solução no recrutamento forçado de grupos desenraizados e marginais, de modo que, a um só tempo, afastava-se das vilas e cidades os elementos socialmente incômodos e tornava-os úteis em outros espaços. SOUZA, Laura de Mello e. Desclassificados do ouro...
} 
se-ia de uma população materialmente rústica e pouco enraizada nos territórios, ou melhor, caracterizada por intensa mobilidade geográfica, a despeito de todo o esforço políticoadministrativo para contê-la em sujeição. Assim, o fenômeno da deserção não se reduz à fuga da guerra.

Finalmente, cumpre indicar que a ênfase historiográfica concedida às tensões e negociações envolvendo Estado, chefes locais e seus clientes/dependentes e que emergiriam por ocasião da conscrição não considera a presença de pardos e de pretos como agentes recrutadores. ${ }^{58}$ Isto é, tais indivíduos são implicitamente considerados como aqueles que comporiam o grosso das fileiras militares, posicionando-se exclusivamente nos níveis mais baixos. E, de fato, a imagem de pardos e pretos forros ou já nascidos livres parece não compor o tipo ideal referido como "chefes locais" ou "patronos", a quem se atribui a capacidade de exercer influência decisiva na vida de seus "bandos" ou subordinados - o que, no caso em questão, significaria a possibilidade de optar por oferecer proteção a seus homens diante do recrutamento ou entregá-los para as tropas a caminho da guerra. Em um ou outro caso, tratarse-ia tipicamente de exercício de poder em esfera local. No entanto, muitos dos terços, regimentos e batalhões de pardos e de pretos da América portuguesa contavam com oficialidade de alto escalão formada pelos próprios homens de cor. Todas as companhias eram encabeçadas por capitães, tenentes e alferes de sua própria cor. Se, do ponto de vista dos historiadores que examinaram o recrutamento para a tropa regular, essa prática - ou melhor, a isenção, proteção ou acoitamento ao alistamento - se revestia de um caráter reprodutor e reiterador das teias clientelares e de dependência previamente existentes, no caso dos pardos livres é cabível sugerir que o arrolamento na milícia funcionaria como a própria construção de um conjunto de subordinados aos oficiais pardos, os quais em geral não se caracterizaram como grandes proprietários de terras e de escravos - como será visto na parte 2 desta tese. O exame realizado adiante, relativo não apenas ao recrutamento, mas igualmente às saídas temporárias ou definitivas dos milicianos do regimento dos pardos de São Paulo, lança luz diretamente ao funcionamento da corporação e ao papel exercido pelos oficiais pardos na gestão miliciana.

A principal fonte de informações para essa investigação é o Livro Mestre do Regimento dos Úteis, um documento excepcional já descrito na introdução desta tese. Não obstante o fato

\footnotetext{
${ }^{58}$ PEREGALLI, E. Recrutamento militar no Brasil colonial..., p. 75; KRAAY, Hendrik. Race, state, and armed forces..., p. 55-61; MELLO, Christiane F. P. de. "Fazer soldados, poder tremendo! Não os fazer, maior ainda". In: SANTOS, A. C. de A.; DORÉ, A. (Orgs.). Temas setecentistas: governos e populações no império português. Curitiba: UFPR-SCHLA/Fundação Araucária, 2008, p. 37-43; COSTA, F. D. Os problemas do recrutamento..., p. 138-141, investiga o fenômeno, mas exclusivamente para as tropas de linha de Portugal, onde não havia, evidentemente, milícias ou participação efusiva de negros.
} 
de o corpo militar em questão ter sido formado por dez companhias, aqui se optou por delimitar a análise a duas delas: a de Granadeiros, com sede na cidade de São Paulo, e a 4. ${ }^{a}$ Companhia de Fuzileiros, sita na vila de Atibaia. Não era incomum que milicianos obtivessem transferência entre as companhias do Regimento, e, de modo ainda mais recorrente, que ocupassem diferentes postos ao longo da trajetória miliciana. Desse modo, a fim de evitar a repetição de registros e de indivíduos, o critério adotado para estabelecer a qual companhia pertencia cada indivíduo consistiu em considerar o seu último registro. Já a referência aos postos privilegiou a posição mais elevada ocupada por cada sujeito. ${ }^{59}$ No Livro Mestre há registro de 121 e 122 milicianos para cada companhia, respectivamente. Entre 1811 e 1831, a companhia de granadeiros registrou 25 oficiais e 96 soldados, e a de Atibaia 17 oficiais e 105 soldados.

TABELA 3.1 - Períodos de mais intenso recrutamento de soldados (1802-1827)

\begin{tabular}{|c|c|c|c|}
\hline \multicolumn{2}{|c|}{ Companhia de Granadeiros } & \multicolumn{2}{|c|}{ Companhia de Atibaia } \\
\hline Períodos & Soldados & Períodos & Soldados \\
\hline $24 / 07 / 1802$ a $20 / 11 / 1802$ & 5 & $20 / 08 / 1802$ a $28 / 08 / 1802$ & 12 \\
\hline 06/02/1808 a 01/12/1808 & 21 & $18 / 04 / 1808$ a $26 / 06 / 1808$ & 14 \\
\hline $13 / 12 / 1812$ a $02 / 03 / 1813$ & 19 & $11 / 12 / 1811$ a $30 / 12 / 1811$ & 23 \\
\hline $09 / 03 / 1815$ a $23 / 07 / 1815$ & 11 & $23 / 08 / 1815$ a $27 / 08 / 1815$ & 14 \\
\hline $16 / 05 / 1821$ a $02 / 08 / 1821$ & 12 & $15 / 09 / 1821$ a $10 / 12 / 1821$ & 9 \\
\hline \multirow[t]{3}{*}{$26 / 05 / 1822$ a $19 / 02 / 1823$} & 10 & $13 / 05 / 1822$ a $28 / 05 / 1822$ & 7 \\
\hline & & 02/02/1823 a 06/06/1823 & 7 \\
\hline & & $11 / 03 / 1827$ a $12 / 05 / 1827$ & 7 \\
\hline Totais & $78 / 96$ & & $93 / 105$ \\
\hline
\end{tabular}

Fonte: APESP, ordem C00446, Livro Mestre do Regimento de Infantaria Miliciana dos Úteis, fls. 11-54 e 221261.

Os dados acima se referem aos períodos de maior intensidade no recrutamento em cada companhia e se restringem àqueles indivíduos que, entre 1811 e 1831, não ultrapassaram a condição de soldados. Já em um primeiro olhar se vê que os momentos de realização dos recrutamentos ou alistamentos não eram ocasionais ou aleatórios. Os períodos de maior volume de alistamentos coincidem entre as duas companhias (anos 1802, 1808, fins de 1812 e começo

\footnotetext{
${ }^{59}$ Por exemplo, se um indivíduo iniciou sua carreira como soldado na companhia de Atibaia, onde ascendeu a cabo, e depois obteve transferência para a companhia de Granadeiros no posto de sargento, no qual permaneceu até a sua baixa, então, nas estatísticas, ele foi considerado como um sargento da companhia de Granadeiros.
} 
de 1813 em uma e fins de 1811 em outra, 1815, 1821, meados de 1822 a meados de 1823 em ambas). Provavelmente esse calendário se relacionasse diretamente ao estabelecimento de ordens superiores, emitidas pelo governador e capitão-general, autorizando o recrutamento. ${ }^{60}$ Ou seja, havia coordenação na tarefa do alistamento, de modo que aos oficiais milicianos não competia arrolar aleatoriamente ou a seu arbítrio. Ademais, visualiza-se que cada empreitada de recrutamento/alistamento poderia ser relativamente demorada: em alguns casos as levas duravam poucos dias, mas, em outros, passava-se meses ou quase um ano inteiro alistando os milicianos. Decorre daí que tais modalidades de alistamento dificilmente ocorriam sob a forma de violência ou recrutamento forçado, típicas de períodos de guerra. De modo geral, os habitantes de Atibaia e da vila de Bragança, que também fornecia homens para a companhia de Atibaia, eram recrutados após algumas semanas ou meses em relação aos habitantes da cidade de São Paulo e de seus bairros vizinhos, o que possibilitaria, se necessário fosse, a evasão - já que havia tempo e condições hábeis para que as notícias do alistamento se disseminassem. Por fim, as amostras acima, referentes aos períodos de mais intenso alistamento dão conta que 78 soldados granadeiros e 93 soldados de Atibaia inseriram-se nesse padrão. Inversamente, apenas 18 soldados da cidade e 12 de Atibaia foram alistados em outros períodos, talvez mais individualmente, fora, portanto, das grandes levas.

\section{GRÁFICO 3.1 - Faixas etárias de ingresso no Regimento dos Úteis, por companhias e postos (1802-1827)}

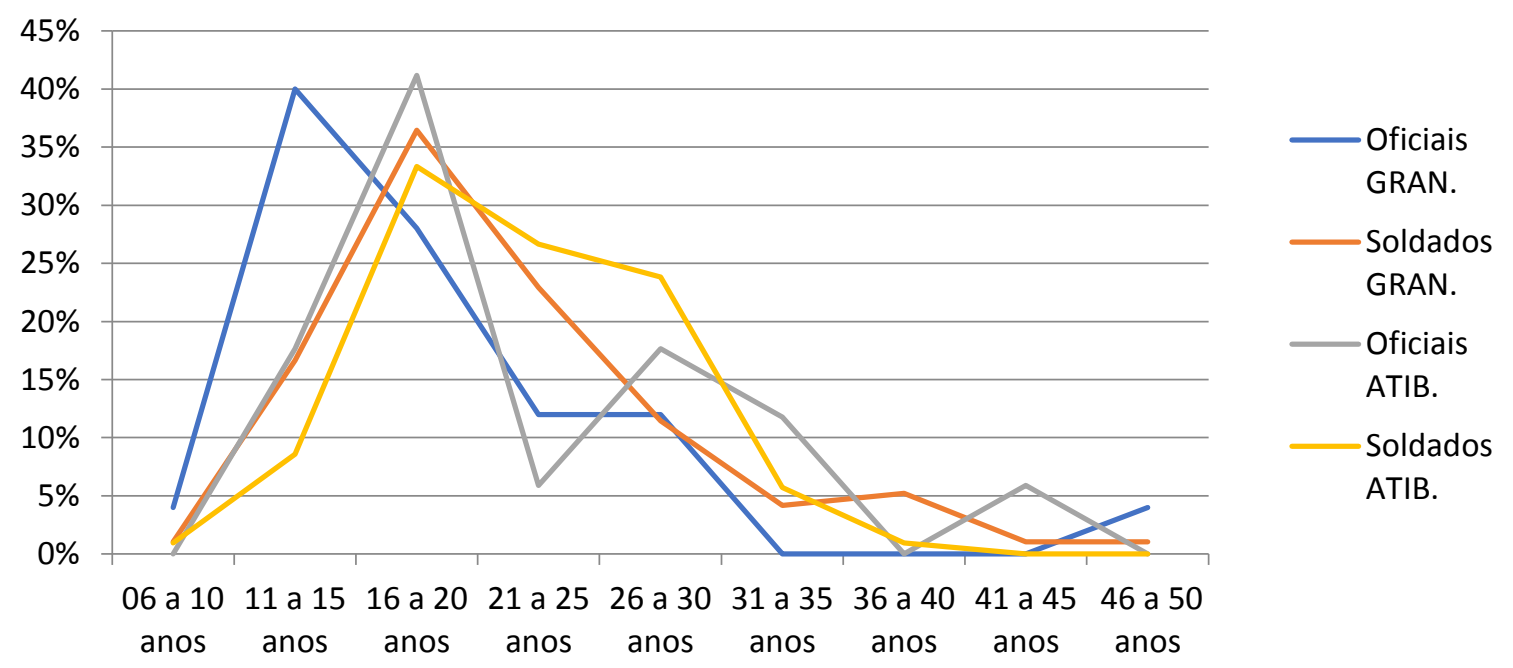

Fonte: APESP, ordem C00446, Livro Mestre..., fls. 11-54 e 221-261.

\footnotetext{
${ }^{60}$ Cf:: APESP, ordens C00265, doc. 33-1-34. São Paulo, 22 e 24 de agosto de 1816; e C07743, livro 198, fls. 143143v. Rio de Janeiro, 2 de janeiro de 1827.
} 
A idade média de alistamento dos milicianos pardos aqui em consideração variou entre os 19 e os 22 anos e meio. Enquanto a menor média corresponde àqueles homens que futuramente se converteriam em oficiais de Granadeiros, a mais elevada diz respeito aos alistados que se permaneceram como soldados em Atibaia (Gráfico 3.1). Embora não se tenha parâmetro de comparação, notadamente em relação a outros corpos milicianos de São Paulo ou mesmo em relação a corpos milicianos de pardos e de pretos de outros espaços, presume-se que essa margem esteja na média das demais corporações. Ora, considerando-se que nas sociedades pré-industriais a expectativa de vida era mais baixa que nas sociedades contemporâneas ${ }^{61} \mathrm{e}$ que a introdução das pessoas em práticas atualmente entendidas como constitutivas da vida adulta, tais como inserção no mundo do trabalho e formação de novas famílias via casamento e geração de filhos, se dava comumente já a partir dos 15 anos de idade, é plausível que a idade média de ingresso dos milicianos pardos paulistas não indique alistamento prematuro e tampouco tardio.

Mesmo que se considere a possibilidade ou a hipótese de a média de idade para ingresso na milícia entre os pardos ser sutilmente mais elevada que a de outros regimentos milicianos, ainda assim esse dado pode ser encarado como um indicativo de que a maioria dos milicianos pardos não vivenciou experiência individual direta com a escravidão. Antes, a constatação de que a faixa etária média de ingresso na milícia parda girava em torno dos vinte anos sugere que a maior parte de tais milicianos era constituída por nascidos livres, ou, quando muito, por libertos em pia batismal ou em tenra idade. É que os escravos que se obrigavam a comprar a sua própria alforria teriam necessidade de acumular um capital excedente aos eventuais gastos pessoais e que fosse suficiente para a aquisição de um escravo cujo valor correspondesse ao seu próprio, o que podia levar muito tempo. A ideia aqui não é subestimar as oportunidades de acúmulo em curto período de tempo ou mesmo as possibilidades de obtenção de alforria gratuita, mas sinalizar que a compra da liberdade não era algo factível à generalidade dos indivíduos escravizados na faixa etária de 22 anos ou menos, a idade média de ingresso no Regimento dos Úteis.

Em geral, para as duas companhias em questão, a idade típica de alistamento consistia no intervalo de 11 a 30 anos. No entanto, nota-se que há variações nessa tendência (vide o Gráfico 3.1), uma vez que a maioria dos oficiais das companhias de granadeiros e de Atibaia tinha entre 11 e 20 anos quando foram alistados, ao passo que o alistamento daqueles que não ultrapassaram a condição de soldados ocorreu tipicamente um pouco mais tarde, quando tinham entre 16 a 25 anos, no caso dos granadeiros, e entre 16 a 30 anos no caso dos milicianos pardos

${ }^{61}$ MARCÍLIO, Maria Luiza. Crescimento demográfico e evolução agrária paulista (1700-1836). São Paulo: Hucitec/EDUSP, 2000, p. 99. 
de Atibaia. Esses padrões diferenciados revelam aspectos cujas implicações ultrapassam o âmbito do recrutamento, e por essa razão são aqui abordados de forma sumária. São eles a tendência a que os alistados mais tardiamente obtivessem menores chances de alcançar elevação na hierarquia miliciana, de um lado, e a prática do alistamento precoce como estratégia familiar de ascensão nos postos, de outro. Conquanto esse último aspecto deva ser matizado, pois há vários casos como o do tambor Antonio Manoel e do soldado José Joaquim Vidal, alistados em Atibaia quando tinham 12 e 14 anos $^{62}$, respectivamente, e do soldado de granadeiros, José Benedito, de 11 anos, e o tambor Francisco das Chagas, que ingressou na milícia com apenas 8 anos de idade ${ }^{63}$, os quais jamais ascenderam na hierarquia miliciana, é de se notar que o capitão de granadeiros, Antonio Joaquim da Costa Ribeiro, neto do coronel dos Úteis, Manoel José Ribeiro, foi alistado na tenra idade de 9 anos. Ademais, é significativo que em ambas as companhias os oficiais de patente, isto é, capitães, tenentes e alferes, ingressaram na milícia tendo, no máximo, vinte anos. Exceção, e notória, foi um dos capitães da Companhia de Atibaia, que ingressou na milícia tendo a idade de 44 anos e prontamente ascendeu nos postos. ${ }^{64}$

A milícia poderia, sem equívoco, ser caracterizada como uma tropa anfíbia, como, aliás, o fez um militar de alto escalão a serviço da Coroa portuguesa. Não em termos táticos ou de técnica militar, mas em função da modalidade de prestação de serviço militar e da decorrente necessidade de conciliá-lo com as atividades cotidianamente desenvolvidas no âmbito civil por seus integrantes. Esses eram, conforme o Conde de Lippe, "meio paisanos, meio militares". ${ }^{65}$ Por essa razão se recomendou, por intermédio da carta régia de $1 .^{\circ}$ de setembro de 1808 , que o serviço miliciano não obstasse o desenvolvimento da agricultura e do comércio. ${ }^{66}$ Expressão disso seria a profusão de licenças e dispensas das funções nos corpos milicianos concedidas a seus soldados para que, isentos das obrigações da milícia, pudessem cuidar de seus negócios por um período de tempo justificado - que podia durar desde alguns meses até alguns anos, sendo, ainda, passível de prorrogação. Tais licenças faziam-se indispensáveis, uma vez que a circulação dos milicianos em localidades não compreendidas no distrito de suas companhias estava condicionada à autorização dos oficiais superiores. Uma vez concedidas, eram anotadas no livro de matrícula do regimento, bem como o eram todas as ocasiões em que os milicianos

\footnotetext{
${ }^{62}$ Cf:: Livro Mestre, fl. 228 e $246 \mathrm{v}$.

${ }^{63}$ Cf:: Livro Mestre, fl. 31v e 18.

${ }^{64}$ Para cada um dos oficiais de patente dos Granadeiros, ver Livro Mestre, fls. 11-11v, 12; 13, 183v; 12, 13, 14; 12 e 13. Para os oficiais de Atibaia, ver Livro Mestre, fl. 221, 222, 223; 223, 238v; 223, 224v; 221 e 222.

${ }^{65} C f$ :: "Observações militares dirigidas ao Conde de Oeiras pelo marechal general Conde de Lippe". 5 de setembro de 1764, Apud COTTA, F. A. Negros e mestiços..., p. 49.

${ }^{66}$ Em 1825 o governador das armas de São Paulo reiterava as diretrizes dessa carta régia. Cf.: APESP, ordem E00662, fls. 43-43v e 51-51v. São Paulo, 28 de junho de 1825.
} 
se ausentavam sem obterem licença. Nesse último caso, os registros figuravam como "nota" negativa e representativa do descaso e desobediência às normas instituídas.

No livro mestre dos Úteis, há registro de concessão de licenças ou dispensas para 6/25 oficiais e 19/96 soldados da companhia de granadeiros. Já para a companhia de Atibaia a quantia de licenças e dispensas diminui consideravelmente, referindo-se a apenas 2/17 oficiais e 3/105 soldados. Esse diferencial existente entre as regiões da cidade de São Paulo e da vila de Atibaia certamente guarda relações com as características urbana e economicamente mais dinâmica da capital da capitania/província em relação às vilas rurais do interior. Talvez resida aí uma explicação razoável para o que pode ser lido como uma maior necessidade por parte dos milicianos pardos da capital de se ausentarem do serviço militar e mesmo de suas casas. Entretanto, convém não subestimar o dinamismo existente nos níveis mais baixos da economia local e a circulação de pessoas nas vilas interioranas. Estudos recentes têm revelado, por exemplo, a onipresença do artesanato e de outras atividades econômicas não agrícolas em São Paulo. ${ }^{67}$ Além disso, as localidades para onde os milicianos se ausentavam, eventualmente referidas em seus registros, indicam níveis consideráveis de mobilidade: dentre os milicianos granadeiros, três viajaram para a capitania de Minas Gerais, dois para a Corte do Rio de Janeiro, um para Mato Grosso e cinco foram dispensados para que se dedicassem integralmente ao desempenho de outras funções sociais, mormente na Casa da Ópera da cidade de São Paulo; dos poucos milicianos de Atibaia que obtiveram licença do serviço militar, dois se dirigiram às Minas Gerais. ${ }^{68}$ Portanto, parece mais adequado sugerir que os milicianos residentes na capital e em seu entorno sofressem coerções por parte de seus superiores em níveis mais elevados que os de Atibaia, até mesmo pelo fato de estarem mais próximos dos núcleos de poder político e militar paulistas. Desse modo, os índices de afastamento consentido da milícia mais abundantes para os granadeiros indicariam menos a vigência de um quadro de estagnação ou imobilidade em Atibaia e mais o exercício de controle relativamente efetivo às atividades dos milicianos pardos da capital. Essa hipótese pode ser testada adiante a partir do confronto entre os dados referentes às licenças e dispensas autorizadas, de uma parte, e, de outra, os da evasão temporária ou definitiva não autorizada.

A realidade é que essa última modalidade de afastamento era não apenas recorrente, mas a mais praticada pelos milicianos: conforme os registros, 27/96 soldados granadeiros e 66/105 soldados das vilas de Atibaia e Bragança se ausentaram, ao menos uma vez ao longo de sua

\footnotetext{
${ }^{67}$ LUNA, F. V.; KLEIN, H. S. Evolução da sociedade e economia..., p. 223-245.

${ }^{68}$ Cf:: Livro Mestre, fls. 11-11v, 12, 13, 14, 14v, 17, 18v, 33v, 35v, 40, 40v, 47v, 49, 108v, 221, 222, 224v, 226v, 229v, 233, 257.
} 
trajetória na milícia, ignorando as normas que exigiam a obtenção de consentimento prévio junto aos superiores. Recurso adotado tipicamente por soldados, essa prática não estava ausente do grupo dos oficiais, especialmente da baixa oficialidade das companhias, já que 3/25 oficiais granadeiros e 7/17 oficiais de Atibaia/Bragança obtiveram essa nota negativa em seus registros. Ao passo que os soldados, quando recorriam à evasão não autorizada e consequentemente deixavam de atender às obrigações militares, poderiam ser presos e castigados, as penalidades para os oficiais resultavam quase sempre na destituição de seus postos atrelada à prisão militar. ${ }^{69}$ É de se notar que nesse quesito os oficiais de patente mostraram-se individualmente zelosos quanto ao respeito às normas que regiam sua corporação, condição essencial para a manutenção de sua posição no topo da hierarquia. Sua autoridade, porém, não era suficiente para manter os subordinados cumprindo rigorosamente os deveres da milícia, o que se depreende particularmente do exame ao caso da companhia de Atibaia. Ora, apenas um pequeno número de oficiais e soldados buscaram e obtiveram licença formal para se afastarem da corporação e mais da metade do total de soldados se ausentaram sem licença prévia. Assim, a análise às modalidades de licenciamento do corpo militar dos pardos resulta na ideia de que, quanto mais afastados estavam os milicianos do principal centro político e militar da capitania/província, mais comumente recorriam a expedientes informais e desautorizados.

As ausências não consentidas dos milicianos - que não são aqui denominadas como deserção, uma vez que essa noção traz consigo inevitavelmente a ideia de fuga de combate, a qual, por sua vez, dissonaria daquilo que caracterizava as funções milicianas executadas pelos pardos de São Paulo - eram em tão grande número e em muitos casos excessivamente duradouras a ponto de se tornarem o principal meio de evasão definitiva do Regimento dos Úteis. Ora, em um universo composto por 243 milicianos da cidade de São Paulo e das vilas de Atibaia e Bragança, 164 deles obtiveram baixa entre os anos 1810 e 1831, período compreendido na amostra, e, destes, nada menos que 39\% deixaram o Regimento por estarem ausentes por longo período ou por passarem a "residir fora do distrito da sua companhia e Regimento". Em seguida, as transferências para outros corpos militares resultaram em outro fator de destaque dentre os que agiam diminuindo os efetivos, notadamente os da companhia de granadeiros, que forneceu 15 homens para a tropa de linha e nove para outros regimentos milicianos. Ao passo que a transferência para diferentes corpos de segunda linha era quase sempre motivada por requerimento dos próprios milicianos, a passagem para a tropa de linha

\footnotetext{
${ }^{69}$ Os dados globais para as companhias se encontram em Livro Mestre, fls. 11-54 e 221-261. Os oficiais punidos com a baixa dos postos estão localizados na mesma fonte, em fls. 16v e 157v; 15, 16, 111v e 31v; $224 \mathrm{v} ; 226$ e $240 \mathrm{v}$.
} 
ocorria recorrentemente como punição aos milicianos insubordinados. ${ }^{70}$ Por sua vez, soldados músicos deixavam o Regimento com tal frequência que esse setor nos Úteis chegava a atrofiarse. ${ }^{71}$ Concorriam para isso o assédio da parte de outros coronéis milicianos ou a vontade dos jovens soldados de perceberem soldos mais elevados. ${ }^{72}$ Por fim, exerceu papel relevante para a baixa ou saída do Regimento o adoecimento crônico ou grave sofrido por muitos daqueles homens, uma circunstância que, em não raras vezes, foi seguida do falecimento. ${ }^{73}$ Mesmo em tais casos, para a obtenção de baixa por motivo de doença fazia-se necessário que o miliciano apresentasse aos superiores um atestado de cirurgiões-mores habilitados, que era pago com suas próprias economias, ou se apresentasse no hospital militar da cidade de São Paulo nas ocasiões de exames coletivos, tendo obrigatoriamente, por essa via, que se dirigir à capital. ${ }^{74}$

TABELA 3.2 - Baixas e razões para a saída de milicianos do Regimento

\begin{tabular}{|c|c|c|c|c|c|c|c|c|}
\hline & \multirow{2}{*}{\multicolumn{3}{|c|}{$\begin{array}{c}\text { Companhia de } \\
\text { GRANADEIROS }\end{array}$}} & \multirow{2}{*}{\multicolumn{3}{|c|}{$\begin{array}{c}\text { Companhia de } \\
\text { ATIBAIA }\end{array}$}} & \multirow{3}{*}{$\begin{array}{l}\mathrm{T} \\
\mathrm{O} \\
\mathrm{T} \\
\mathrm{A} \\
\mathrm{L}\end{array}$} \\
\hline & & & & & & & & \\
\hline & & Oficiais & Soldados & $\begin{array}{c}\text { Total } \\
\text { parcial }\end{array}$ & Oficiais & Soldados & $\begin{array}{l}\text { Total } \\
\text { parcial }\end{array}$ & \\
\hline \multirow{2}{*}{\multicolumn{2}{|c|}{$\begin{array}{l}\text { Número de milicianos } \\
\text { Milicianos que saíram antes } \\
\text { de 18/08/1831 }\end{array}$}} & 25 & 96 & 121 & 17 & 105 & 122 & 243 \\
\hline & & 15 & 69 & 84 & 10 & 70 & 80 & 164 \\
\hline $\begin{array}{ll}\mathbf{M} \\
0\end{array}$ & Falecimento & 4 & 7 & 11 & 2 & 10 & 12 & 23 \\
\hline $\mathbf{T}$ & Doença & 2 & 14 & 16 & 0 & 8 & 8 & 24 \\
\hline $\begin{array}{l}\mathbf{I} \\
\mathbf{V}\end{array}$ & Transferência & 3 & 21 & 24 & 1 & 6 & 7 & 31 \\
\hline o & Ausência & 2 & 11 & 13 & 1 & 24 & 25 & 38 \\
\hline S & Residir fora do distrito & 0 & 1 & 1 & 3 & 22 & 25 & 26 \\
\hline A & Motivo não detalhado & 2 & 13 & 15 & 1 & 0 & 1 & 16 \\
\hline $\begin{array}{l}\text { I } \\
\text { D }\end{array}$ & Reforma $^{\text {a }}$ & 1 & 0 & 1 & 2 & 0 & 2 & 3 \\
\hline $\mathbf{A}$ & Outros ${ }^{b}$ & 1 & 2 & 3 & 0 & 0 & 0 & 3 \\
\hline
\end{tabular}

${ }^{a}$ Inclui tempo de serviço e idade

b Um oficial teve baixa por Doença e "rebelde para o serviço e incorrigível”, um soldado para servir de carcereiro na cadeia da Cidade e outro por motivo de doença e "por fazer pouco serviço e por andar em um contínuo giro de comércio".

\footnotetext{
${ }^{70} C f$ : : APESP, ordens: C02385, doc. sem identificação. São Paulo, 10 de março de 1823; E00662, fl. 43. São Paulo, 28 de junho de 1825; C02366, doc. sem identificação. São Paulo, 19 de janeiro de 1826.

${ }^{71} C f$ : APESP, ordem C00270, doc. 37-2-43. São Paulo, 20 de setembro de 1820.

${ }^{72} C f$ : : APESP, ordem C00279, doc. 42a-4-103. São Paulo, 13 de novembro de 1820.

${ }^{73}$ Os dados globais para as companhias se encontram em Livro Mestre, fls. 11-54 e 221-261.

${ }^{74} C f$ :: "3. ${ }^{\circ}$ Regimento de Infantaria de 2. ${ }^{\text {a }}$ linha. Relação das praças doentes que se apresentaram neste hospital militar para serem examinadas”. APESP, C02366, documento não identificado. São Paulo, 3 de dezembro de 1824.
} 
Um caso que ilustra as agruras dos milicianos que se submetiam aos procedimentos necessários para a obtenção de baixas por doença ao mesmo tempo em que revela a margem de poder manipulado pelos oficiais pardos relativamente a seus subordinados decorre de um requerimento enviado ao governador da capitania pelo soldado Marcelino Antonio da Mota em maio de 1816. No documento em questão, ao qual fora anexado um atestado clínico, o soldado informou que há três anos estava "atacado de muito graves enfermidades que o tem impedido poder prestar seus respectivos deveres: e como seu estado se tem tornado valetudinário e o suplicante incapaz de serviço", requereu a baixa. No despacho inicial, datado do mesmo mês, o governador ordenou que os cirurgiões-mores da tropa paga examinassem atestando o estado de saúde do requerente, e, com efeito, ambos certificaram que o soldado era "valetudinário e incapaz de servir no posto que ocupa". Na sequência, os documentos foram enviados para que o capitão responsável pelo soldado em questão, Francisco de Paula Leite Prestes, informasse o que lhe constava. O fez em novembro de 1816. Na ocasião, o oficial argumentou que seu soldado alegava estar doente há vários anos e "incapaz de fazer o serviço", mas que incorria em contradição uma vez que trabalhava pelo seu ofício de carpinteiro. Apenas quando pressionado pelo capitão é que Mota teria apresentado o atestado. Colocando à prova o caráter do soldado, Prestes concluiu a informação da seguinte forma: "só posso dizer que para os seus interesses nunca teve impedimentos, e para o serviço militar no meu tempo nunca pôde fazer uma guarda".

Como o processo de investigação e a própria demanda estivessem, aparentemente, emperrados, Mota renovou seu requerimento e, em agosto de 1817, o coronel dos pardos conformou-se com a informação fornecida no ano anterior pelo capitão pardo. Por sua vez, o inspetor de milícias da capitania encerrou a série de informações, em outubro, cerca de um ano e meio após o primeiro requerimento de Mota, argumentando incisivamente que "não convém dar baixa a milicianos senão em ocasião oportuna, com os exames necessários". ${ }^{75} \mathrm{O}$ desfecho se deu em novembro de 1817 com o despacho do governador favorável à baixa do soldado enfermo. ${ }^{76} \mathrm{O}$ certo é que o caso em tela lança luz sobre a parcela, se não de controle, de influência que a oficialidade miliciana poderia exercer na decisão de causas vitais a seus subordinados. Fica detalhado, igualmente, as dificuldades enfrentadas pelos milicianos, principalmente os do baixo escalão, na resolução de seus problemas a partir dos procedimentos burocráticos padrão. Talvez a morosidade dos processos somada às opiniões contrárias dos

\footnotetext{
${ }^{75} C f:$ : APESP, C00278, docs. 42-1-30 e 42-1-31.

${ }^{76} C f$.: "Portaria para o coronel Manoel José Ribeiro para dar baixa a Marcelino Antonio da Motta". DIHCSP, vol. 90, p. 81-82. São Paulo, 16 de novembro de 1817.
} 
superiores fossem alguns dos motivos pelos quais os soldados optavam, por exemplo, por se ausentarem sem licença prévia.

Por fim, tanto o recrutamento como a transferência de milicianos para outros corpos militares, por se tratar de pessoas de cor, constituem situações especialmente interessantes para análise no caso aqui examinado. Ora, ser incorporado e permanecer vinculado a uma corporação militar privativa a pardos livres e libertos implicava, em tese, o reconhecimento do pertencimento àquela coletividade identificada pela cor e condição social. No entanto, ao longo de toda a existência do Regimento dos Úteis houve manifestações individuais de milicianos visando à transferência para corpos militares constituídos por brancos cujos termos e significados devem ser analisados.

A historiografia tem concedido relevo ao problema da mudança ou negociação da cor e, preferencialmente, aos processos de embranquecimento via ascensão social. Exemplar, nesse sentido, é a extensa reprodução, na literatura, do caso aludido pelo viajante Henry Koster em que um capitão-mor mulato passara a ser reputado homem branco ao ascender ao posto, pois, indagava um subordinado, “e pode lá um capitão-mor ser mulato?". ${ }^{77}$ Compondo essa vertente historiográfica, Roberto Guedes examinou fragmentos da trajetória de vida de um morador da vila paulista de Porto Feliz, entre fins do século XVIII e inícios do XIX, acompanhando várias etapas de sua ascensão social, a iniciar pela conquista da alforria materna. ${ }^{78}$ Joaquim Barbosa Neves, o sujeito em questão, se desvinculou do cativeiro e, ao fim de sua vida, havia se tornado senhor de um total de 41 escravos. Transitara, no mundo do trabalho, do universo artesanal para o da grande lavoura. Estabelecera sólidos laços familiares bem como mantivera bom relacionamento e atitude de deferência para com as elites locais e, finalmente, obteve uma patente militar. Em suma, conforme o historiador, Neves "ultrapassou a barreira da linha da cor" e ingressou "no clube dos brancos". Mas restava a questão: “por que não embranqueceu?". Admitindo permanecer "no campo da hipótese", Guedes sugeriu que o não embranquecimento em questão, verificável a partir dos recenseamentos paulistas, se devia ao fato de Neves compor “a primeira geração livre na família. [...] Talvez as gerações seguintes embranquecessem" ${ }^{79} \mathrm{O}$ estudo de Guedes é, com efeito, um belo ensaio no qual se aplica a perspectiva da escravidão

\footnotetext{
${ }^{77}$ Cf:: KOSTER, Henry. Viagens ao Nordeste do Brasil. Trad. Luiz da Camara Cascudo. São Paulo; Recife; Rio de Janeiro: Companhia Editora Nacional, 1942, p. 480; o trecho em questão foi citado, dentre outros, em FREYRE, G. Sobrados e mucambos..., p. 727; RUSSELL-WOOD, A. J. R. Escravos e libertos..., p. 113-114; COSTA, Emília Viotti da. Introdução ao estudo da emancipação política. In: MOTA, C. G. (Org.). Brasil em perspectiva. $18 .^{a}$ ed. Rio de Janeiro: Ed. Bertrand Brasil, 1988, p. 96; VINSON III, Ben. Bearing arms for his majesty: the free-colored militia in colonial Mexico. Standford: Standford University Press, 2001, p. 85; GUEDES, R. De ex-escravo a elite escravista..., p. 345; CRISPIN, A. C. T. Além do acidente pardo..., p. 44.

${ }^{78}$ Ver GUEDES, Roberto. De ex-escravo a elite escravista..., e GUEDES, R. Egressos do cativeiro...

${ }^{79}$ GUEDES, R. De ex-escravo a elite escravista..., especialmente p. 365 e 368. Mantive os grifos originais.
} 
como processo e os métodos da micro-história ao caso dos pardos forros. Contudo, a ênfase nas relações estabelecidas entre potentados locais e seus clientes tem como contrapartida a minimização de pertinentes aspectos constitutivos do relacionamento dos vassalos com o Estado. Isso vale, particularmente, para o caso da milícia separada por cor, uma instituição típica da sociedade colonial. Uma das razões pelas quais Neves não embranqueceu - e pode-se considerar que não havia qualquer relação determinista nesse sentido - foi certamente seu ingresso no Regimento dos Úteis, ou dos pardos. ${ }^{80}$ Essa, aliás, foi a condição essencial para que sua ascensão econômica e simbólica na esfera local obtivesse reconhecimento mais amplo, por intermédio da patente militar. Ora, antes de tornar-se sargento reformado com a graduação de tenente, Joaquim Barbosa Neves serviu como simples soldado por vários anos na tropa de linha da capitania do Mato Grosso e no regimento miliciano de Sorocaba, onde não pôde "ter aumento em razão da sua cor" ${ }^{81}$ Ao contrário de tornar-se branco, Neves reconheceu formalmente a condição de homem pardo e, daí em diante, em apenas sete meses, ascendeu do posto de soldado ao de sargento reformado em tenente do regimento dos pardos.

Uma vez que esse não é o momento mais adequado para discorrer sobre os critérios e processos inscritos na conformação da hierarquia miliciana e sua dinâmica, cabe apenas referir a dois elementos suscitados pelo caso em questão: em primeiro lugar, torna-se clara a necessidade de se compreender os vários nichos de atuação social dos pardos livres na sociedade colonial e imperial, tal como a milícia, e de se reconhecer sua importância na organização de inúmeros aspectos daquele mundo; em segundo lugar, e por decorrência, notase a carência de uma definição mais precisa à noção de embranquecimento por parte dos cientistas que os empregam. Um desafio encarado ao longo desta tese diz respeito a examinar, a partir das questões sociais ligadas à milícia dos pardos, as tensões propiciadas pela elevação daqueles sujeitos - muitos dos quais vinculados ao universo dos ofícios mecânicos, a um passado cativo e identificados ao grupo dos pardos - a posições de elite entre seus pares e, mais do que isso, a posições associadas à nobreza. ${ }^{82}$ De toda forma, fica dito que enobrecer ou elevarse à camada senhorial não era, necessariamente, sinônimo de embranquecer e vice-versa.

Alguns milicianos dos Úteis, porém, se manifestaram em relação à sua cor de um modo diferente de Neves, notadamente pelo fato de que não aceitaram a qualidade de pardos a que se

\footnotetext{
${ }^{80}$ Cf:: Livro Mestre, fl. 347.

${ }^{81}$ GUEDES, R. De ex-escravo a elite escravista..., p. 364.

${ }^{82}$ Cf:: OLIVEIRA, Luiz da Silva Pereira. Privilegios da nobreza, e fidalguia de Portugal. Lisboa: Na nova Officina de João Rodrigues Neves, 1806, p. 41-50, em que a autoridade no assunto reconhece as honras e privilégios atrelados às patentes militares como uma modalidade de desfrute da condição nobre, posto que seu portador não o seja.
} 
lhes queria imputar mediante o recrutamento àquele regimento. Dentre outras coisas, essa foi uma forma de reação à noção de que a cor parda expressava um defeito, estigma e sinal de desprestígio social. Como resultado, houve muitos requerimentos e processos judiciais através dos quais intentavam provar serem brancos. Em outros casos, milicianos apresentavam argumentos restritos à execução do serviço militar para sustentar a pretendida transferência para regimentos de brancos.

Os primeiros requerimentos de milicianos inconformados por terem que servir ao rei como se fossem homens pardos surgiram tão logo se formou o Regimento dos Úteis. Em agosto de 1797, o pardo Manoel José Ribeiro, como capitão-comandante dos homens pardos, recebeu ordem para partir "sem perda de tempo a recrutar a gente precisa para se completar um Regimento" no distrito da cidade de São Paulo e seu termo, nas vilas e termos de Mogi das Cruzes, Jacareí, Taubaté, São Luiz do Paraitinga, Cunha, Ubatuba, São Sebastião, Santos e São Vicente. Na mesma ocasião o governador de São Paulo determinou "aos capitães-mores e sargentos-mores das ordenanças façam extrair para isso as listas necessárias e lhe deem todo o auxílio que ele precisar". ${ }^{83}$ Um ano depois, em agosto de 1798, três homens da vila de São Luiz do Paraitinga requereram a dispensa do Regimento "da gente parda", onde se sentiam "vexados", alegando serem "brancos da terra". Conforme seus termos, "pessoas mal afetas e inimigas dos suplicantes foram as que deram [os nomes] dos suplicantes à lista". Além disso, um deles demonstrou, em contrapartida à mercê solicitada, estar "pronto para servir a Sua Majestade em outra companhia de gente branca ou em outro qualquer serviço". Finalmente, os pareceres dos capitães de ordenança e do capitão-mor da vila foram favoráveis aos solicitantes. ${ }^{84}$

Como se disse, tais esforços para a desvinculação do regimento dos pardos não se restringiram aos milicianos recém-recrutados. Em 1816, dois irmãos moradores na vila de Itu e milicianos dos Úteis desde 1803 e 1808 objetivaram provar serem brancos e "de sangue puro" mediante uma justificação cível em função da qual foram ouvidas cinco testemunhas. ${ }^{85} \mathrm{~A}$ despeito de essas declararem que os irmãos eram legitimamente brancos, a condição lhes foi negada pelo coronel pardo Manoel José Ribeiro que argumentou que o pai de ambos era um capitão do mato pardo. Ribeiro prosseguiu intentando descaracterizar a justificação cível, afirmando, a respeito das testemunhas e dos próprios milicianos, que "estes homens sempre

\footnotetext{
${ }^{83}$ Cf:: APESP, ordem C00407, fl. 7v. São Paulo, 16 de agosto de 1797.

${ }^{84} C f$ :: APESP, ordem C00276, doc. 40-3-86. São Luis do Paraitinga, agosto de 1798.

${ }^{85}$ Cf:: APESP, ordem C00265, doc. 33-1-57. Itu, agosto de 1816 e São Paulo, 9 de dezembro de 1816.
} 
estão prontos para darem juramentos falsos por qualquer interesse que se lhes faça". ${ }^{86} \mathrm{E}$ aparentemente logrou êxito, pois os irmãos conseguiram transferir-se para o Regimento de Sertanejos apenas em 1821 e 1823, momento em que o coronel pardo reformado fora sucedido no comando do Regimento por um oficial branco. ${ }^{87}$

Mais recorrentes eram as alegações que dissimulavam completamente a questão e o problema da cor. Observe-se o caso do cabo de esquadra Sabino José Ribeiro, que em 1821 empreendeu esforço para deixar o regimento dos pardos e "servir com praça no [...] 2. Regimento, por lhe ficar mais cômodo o serviço". A justificativa do requerente era servir ao rei em local mais próximo de sua residência. Contudo, a resposta de seu superior, o capitão Lourenço Miguel de Siqueira, igualmente homem pardo, fez convergir para o centro do debate o significado mais profundo da passagem pretendida pelo cabo pardo. O capitão desconhecia, pois, "a causa do suplicante querer passar para outro regimento aonde lhe não compete servir, por ser homem pardo, e sair do regimento de sua própria cor aonde lhe é destinado servir". Por fim, o capitão concluiu que "não parece justo a passagem que pretende, por que do contrário é abrir exemplo aos mais". Indignado, ao que parece, o cabo Sabino deixou de cumprir suas funções no regimento e acabou sendo preso por desobediência. ${ }^{88} \mathrm{Em}$ um caso semelhante, decidiu-se igualmente pela permanência do requerente no regimento dos Úteis, uma vez que ele próprio "reconhece que pela sua cor parda não deve misturar-se entre os brancos". ${ }^{89}$

Os casos examinados acima instilam algumas considerações. Primeiramente, os milicianos que intentaram passagem para regimentos de brancos eram exclusivamente soldados ou oficiais do mais diminuto escalão. Exceto os recém-recrutados, eles, provavelmente, previam dificuldades na competição com outros pardos pelos postos superiores do Regimento ou vivenciavam de modo insatisfatório o serviço miliciano e as relações no cotidiano daquele corpo militar. A partir dessas experiências é que julgavam ser preferível, em alguns casos, passarem-se por brancos, e, em outros, apenas servirem junto dos brancos. Ao mesmo tempo, era incomum que oficiais de patente, posicionados no topo da hierarquia dos pardos, movessem semelhante esforço. Vai daí que, por um lado, evidencia-se a existência de diferentes possibilidades ou caminhos para os sujeitos que buscavam se posicionar favoravelmente na teia social, cada qual com suas próprias coerções e pressões; e, de outro lado, revela-se o papel, praticamente desconsiderado pela historiografia, desempenhado pelos oficiais pardos na

\footnotetext{
${ }^{86} C f:$ : APESP, ordem C00265, doc. 33-1-57. São Paulo, 9 de dezembro de 1816.

${ }^{87}$ Cf:: Livro mestre, fls. 356 e 366.

${ }^{88}$ Cf:: APESP, ordem C00270, doc. 37-3-4. São Paulo, 25 de maio de 1821; e doc. 32-3-4. São Paulo, 4 de maio de 1821.

${ }^{89}$ Cf:: APESP, ordem C00265, doc. 33-1-7. São Paulo, 12 de fevereiro de 1816.
} 
atribuição e manutenção de cor ou condição a um vasto grupo de indivíduos, bem como na conservação das distinções sociais assentadas na origem e expressa na cor. Por fim, demonstrase que o problema inerente aos casos de transferência de pardos para regimentos de brancos está longe de se restringir à mera vacância nas fileiras da milícia. A preocupação manifestada por vários oficiais referia-se à possibilidade de perda de autoridade e controle sobre aquela corporação, e, principalmente, seu desmantelamento no caso de que tais transferências se tornassem habituais. Por essa razão, os informes dos capitães e do coronel pardo eram, quase sempre, contrários a tais demandas.

Já a perspectiva de José Arouche de Toledo Rendon, inspetor geral de milícias em 1816, era diametralmente oposta. Considerando o clamor de uma mãe para que o filho fosse desvinculado dos Úteis e assim servir em regimento de brancos, escreveu ao governo da capitania argumentando que

segundo o meu modo de pensar não deve a suplicante ser increpada de querer ser branca, e não parda: a opinião pública, opinião que sempre é mais poderosa do que as leis, tem feito desgraçada a raça africana: não deve portanto impedir-se ao vassalo o meio de livrar-se de uma injúria por meios que não são odiosos nem proibidos. Se Vossa Excelência mandasse que eu dissesse o meu parecer, ele seria que Vossa Excelência aceitasse a oferta que ela faz do filho para a Tropa de Linha; por que esse é o meio de cortar a questão [...]. ${ }^{90}$

Essa que aparenta ser uma mera informação, referente unicamente ao destino de um jovem soldado, na realidade compõe um quadro muito mais amplo marcado, no âmbito local, pela tensão existente entre a oficialidade parda e segmentos da elite branca da capitania/província de São Paulo, e, em esfera mais abrangente, pelo reformismo ilustrado e suas consequências para as milícias de pardos e pretos - temas que serão abordados em pormenor na parte 3 desta tese.

Para concluir, deve-se ressaltar que o serviço militar realizado pelos pardos localizavase em um continuum constituído, nos extremos, por imposição do Estado e por resistência das populações, e, mais ao centro, pela negociação entre as partes. Em outros termos, do recrutamento/alistamento até a ausência definitiva ou baixa por qualquer motivo, as relações entre a governança, a oficialidade parda e os soldados eram marcadas por intensa medição de forças. Nesse sentido, relativamente ao funcionamento do Regimento dos Úteis, tanto a atribuição de cor quanto a capacidade de evasão da milícia demonstrada por seus integrantes

${ }^{90}$ Cf:: APESP, ordem C00265, doc. 33-1-19. São Paulo, 10 de setembro de 1816. 
parecem ter tido impacto e/ou repercussão social maior do que a imposição de violência física, a qual nem sempre caracterizava o recrutamento/alistamento dos milicianos.

\title{
3.3. As funções militares dos milicianos pardos
}

\begin{abstract}
Destituída esta Província de Tropas de $1 .{ }^{a}$ Linha, desde as expedições da Legião de Tropas Ligeiras para as fronteiras do Rio da Prata e o Regimento de Caçadores para essa Corte, ficaram empregadas as Milícias, sofrendo todo o peso do serviço na Guarnição da Cidade e subúrbios há quase dois anos, com atraso considerável de suas casas e famílias, da agricultura, da província e do Império. ${ }^{91}$
\end{abstract}

No Brasil as milícias superavam numericamente os corpos regulares com enorme folga entre as décadas de 1791 e 1821, como visto anteriormente. Esse diferencial na disponibilidade de corpos militares profissionais, de um lado, e de milicianos, de outro, sugere antes de qualquer coisa a atribuição de papéis relevantes às tropas de segunda linha no conjunto da estrutura militar colonial e do primeiro reinado. Desde as clássicas interpretações do Brasil até as mais recentes pesquisas sobre o tema, reconhece-se que a milícia foi um pilar da organização social luso-brasileira até a sua extinção e substituição pela Guarda Nacional, em 1831. ${ }^{92}$ Em geral se enfatiza ora seu papel no exercício de controle social sobre as populações livres pobres, ora a função original de compor uma tropa auxiliar aos corpos militares regulares. No entanto, não há uma visão suficientemente clara acerca do tipo e frequência das obrigações impostas aos milicianos. Quais as funções militares efetivamente desempenhadas pelas milícias? Havia regulamentação em torno do período de prestação de trabalho miliciano? Quais os significados do serviço miliciano para quem o encarnava? $\mathrm{O}$ exame pormenorizado às atividades militares dos integrantes do Regimento dos Úteis durante as três primeiras décadas do século XIX permite que se problematize a questão das obrigações e tarefas estipuladas aos milicianos pardos a partir da perspectiva das diferenças de cor e qualidade cultivadas por aquela sociedade,

\footnotetext{
${ }^{91} C f$ :: Ofício do governador das armas da província de São Paulo ao ministro da Guerra. São Paulo, fevereiro de 1823. APESP, ordem E00716, fls. 3-3v.

92 PRADO JÚNIOR, Caio. Formação do Brasil contemporâneo. São Paulo: Editora Brasiliense, 1994, p. 323-328; FAORO, Raymundo. Os donos do poder. Formação do patronato político brasileiro. Rio de Janeiro: Globo, 2001, capítulo VI; LEONZO, Nanci. Defesa militar e controle social na capitania de São Paulo: as milícias. Tese (doutorado em História). São Paulo: FFLCH, Universidade de São Paulo, 1979; SILVA, Kalina Vanderlei Paiva da. 'Nas solidões vastas e assustadoras'. Os pobres do açúcar e a conquista do sertão de Pernambuco nos séculos XVII e XVIII. Tese (doutorado em História). Recife: CFCH, Universidade Federal de Pernambuco, 2003, p. 149.
} 
bem como possibilitam uma interpretação mais geral acerca do serviço prestado pelo conjunto das forças militares não profissionais.

O modo como as atividades militares da segunda linha foram interpretadas depende de inúmeras variáveis. Nos requerimentos de milicianos que buscavam a obtenção de mercês régias há uma quase ilimitada valorização das funções desempenhadas, aspecto que inegavelmente contrasta com as constantes queixas de governadores coloniais quanto à disciplina e aptidão das tropas locais. De modo análogo, a insolência ocasionalmente apresentada por soldados distanciados de suas casas, famílias e trabalho habitual para sofrerem os rigores dos destacamentos milicianos nas cidades coloniais é uma imagem diretamente oposta a dos milicianos que regressam como heróis de campanhas militares para as quais não havia alternativa ao emprego de não profissionais. ${ }^{93}$

A historiografia de certo modo ilustra a diversidade de perspectivas em torno da questão, e não poderia ser diferente, já que contempla diferentes espaços, contextos e problemas de análise. Assim, uma das principais ênfases foi direcionada ao papel da milícia como instrumento de controle e de dominação das populações, territórios e riquezas coloniais por parte da metrópole. Sodré notou a emergência dos auxiliares no século XVIII e a decorrente deposição da importância das ordenanças, encaradas como forças privadas, como uma faceta do processo de concentração dos meios de coerção em mãos régias. O conjunto da organização militar destinar-se-ia "a fiscalizar o povo, a vigiar as suas ações, a reprimir qualquer manifestação de rebeldia - é uma força contra o povo", conclui. Em sentido semelhante, Leonzo sugeriu que os corpos de segunda linha atendiam exclusivamente aos interesses de seus comandantes, recrutados entre as elites escravistas locais ou reinóis, e da Coroa, ao passo que a massa de soldados servia mediante "imposição". Conforme essa interpretação, "as Milícias eram, em síntese, um dos instrumentos de opressão do sistema colonial português". Finalmente, do exame de Peregalli aos esforços de guerra vividos pela capitania de São Paulo na segunda metade do século XVIII resulta uma perspectiva que reitera o peso da dominação colonial. De

\footnotetext{
${ }^{93}$ Em 1829 um miliciano pardo foi preso porque, estando de sentinela na cadeia da cidade de São Paulo, permitiu a entrada de "grande porção de aguardente, com a qual se embriagaram os presos". Consultar: APESP, ordem E00698, fls. 183. São Paulo, 15 de janeiro de 1829. Sobre a emotiva recepção aos milicianos - muitos dos quais pardos - que marcharam para a Corte do Rio de Janeiro atendendo à solicitação do então príncipe regente D. Pedro, ver: "120. . Sessão". DIHCSP, v. 2, p. 181. São Paulo, jun./ago. de 1822. Referências ao uso retórico dos serviços prestados na milícia em requerimentos de oficiais e soldados bem como às opiniões de governadores e autoridades coloniais/imperiais podem ser encontradas na literatura. Ver, por exemplo, RUSSELL-WOOD, A. J. R. Escravos e libertos no Brasil colonial. Trad. Maria Beatriz de Medina. Rio de Janeiro: Civilização Brasileira, 2005, p. 129142; KRAAY, Hendrik. Política racial, Estado e Forças Armadas na época da independência: Bahia, 1790-1850. Trad. Magda Lopes. São Paulo: Hucitec, 2011, p. 133-164; SILVA, Luiz Geraldo. Gênese das milícias de pardos e pretos na América portuguesa: Pernambuco e Minas Gerais, séculos XVII e XVIII. Revista de História, São Paulo, n. 169, p. 112-144, jul./dez. 2013, p. 117-122.
} 
um lado as elites locais, como que iludidas pelas promessas de mercês régias, de outro os homens livres pobres, aos quais recaíam, mediante o emprego da força e violência, o recrutamento, marchas e serviços subsidiários à estrutura bélica. ${ }^{94}$

Por outro lado, há um campo historiográfico, em realidade heterogêneo, constituído por pesquisadores que se dispõem a examinar o comprometimento dos milicianos com o poder régio sem necessariamente deixarem de lado o problema do pesado fardo do serviço militar. Grande parte da literatura daí decorrente não se restringe à perspectiva das relações entre o estado e as elites regionais, mas, antes, focaliza a experiência dos homens livres pobres ou particularmente dos homens de cor livres. De acordo com Kalina V. da Silva, que examinou as atividades das tropas auxiliares constituídas pelos "pobres do açúcar" em seu período de formação, entre a segunda metade do século XVII e o começo do seguinte, aqueles corpos militares eram amparados socialmente "menos por seu desempenho defensivo do que por sua natureza suntuária", uma vez que forneciam "postos e cargos honoríficos a grupos sociais que de outra forma estariam excluídos de papéis sociais respeitados". ${ }^{95}$ Quando combinado com conjunturas de estabilidade social, o caráter pomposo que revestia a atuação dos oficiais militares é ocasionalmente lido por analistas como indicativo da natureza "cerimonial" e "representativa" dos corpos militares não profissionais. ${ }^{96}$ Uma vez que examina um período permeado por guerras e ações militares, o argumento de Silva provavelmente tenha visado mais a ressaltar as oportunidades de visibilidade social oferecidas pelas atividades militares e menos descaracterizar as funções militares da segunda linha. Considere-se igualmente que o período em tela assistiu à lenta implantação dos corpos auxiliares na América portuguesa, de modo que, como observou Russell-Wood relativamente à segunda e terceira linhas, "era tamanha a semelhança dos deveres e funções dos soldados de ambos os grupos que a correspondência da época usa indiferentemente os termos milícia, ordenança e auxiliar". ${ }^{97} \mathrm{O}$ mesmo historiador atestou o papel vital desempenhado por negros livres nas funções de defesa interna e externa da América portuguesa. ${ }^{98}$ As abordagens atinentes às capitanias interioranas, como é o caso de Minas Gerais, tendem a ressaltar a importância das milícias negras para o patrulhamento de

\footnotetext{
94 SODRÉ, Nelson Werneck. História militar do Brasil. Rio de Janeiro: Civilização Brasileira, 1979, p. 45-50; LEONZO, Nanci. Defesa militar e controle social..., p. 352; PEREGALLI, Enrique. Recrutamento militar no Brasil colonial. Campinas: Editora da UNICAMP, 1986.

${ }^{95}$ SILVA, Kalina V. Paiva da. 'Nas solidões vastas e assustadoras'..., p. 151 e 162.

${ }^{96}$ Cotta se refere especificamente ao terço dos pretos, em Pernambuco e Bahia, denominado de Henrique Dias. COTTA, Francis Albert. Negros e mestiços nas milícias da América portuguesa. Belo Horizonte: Crisálida, 2010, p. 63.

${ }^{97}$ RUSSELL-WOOD, A. J. R. Escravos e libertos no Brasil colonial..., p. 131.

${ }^{98}$ RUSSELL-WOOD, A. J. R. Autoridades ambivalentes: o Estado do Brasil e a contribuição africana para a "boa ordem na república". In: SILVA, Maria Beatriz Nizza da (Org.). Brasil: Colonização e Escravidão. Rio de Janeiro: Nova Fronteira, 2000, p. 105-123.
} 
estradas rurais, perseguição a quilombolas, comunidades indígenas hostis, criminosos e contrabandistas em zonas de difícil acesso ${ }^{99}$; já aquelas que incidem sobre espaços urbanos ou importantes portos marítimos destacam sua atuação auxiliando as tropas regulares na vigia marítima bem como na guarda de prédios públicos e rondas no perímetro das cidades. ${ }^{100}$

Por fim, tais estudos problematizam uma função social não menos importante desempenhada pela milícia: a capacidade de disciplinar e subordinar seus integrantes, contribuindo assim para o exercício de controle social sobre vasta camada populacional. ${ }^{101}$ Essa faceta, aliás, era vista por representantes régios de alto escalão, a exemplo do vice-rei marquês do Lavradio, como a principal contribuição da milícia para a sociedade colonial e escravista. ${ }^{102}$ De acordo com o sugestivo argumento de Luiz Geraldo Silva, a possibilidade da inclusão de pardos e pretos na milícia e a decorrente atribuição de funções sociais associadas aos ideais de honra e prestígio eram resultantes de um processo mais amplo de assimilação e enraizamento social desses grupos, o qual era reforçado pela experiência desses segmentos na milícia. Essa, por sua vez, produziria na estrutura de personalidade individual e coletiva a assimilação das normas e padrões de conduta disseminados pelas elites luso-americanas. ${ }^{103}$

Desse breve balanço historiográfico nota-se que, se por um lado há interpretações contundentes acerca da natureza do serviço miliciano, por outro se carece de maior detalhamento empírico em torno de suas atividades e obrigações. Essas, por seu turno, não podem ser adequadamente compreendidas sem que se leve em conta algumas variantes, tais como o diferencial entre períodos/espaços de paz e períodos/espaços de guerras e enfrentamentos, a natureza rural ou urbana do espaço de atuação, a interdependência entre as três linhas que constituíam a estrutura militar e os contextos históricos. $\mathrm{O}$ exame que segue tem como objeto específico a emergente milícia parda de São Paulo ao longo das três primeiras décadas do século XIX, momento em que os corpos de segunda linha já estavam plenamente integrados na estrutura militar colonial e imperial bem como constituíam força militar numericamente muito superior à tropa de linha. Embora não tenha havido confrontos militares relevantes no território paulista, os anos finais da colônia e sobretudo o período de instalação da Corte lusitana no Brasil e da ulterior independência brasileira foram marcados por guerras

\footnotetext{
${ }^{99}$ COTTA, F. Albert. Negros e mestiços nas milícias da América portuguesa..., p. 64-90.

${ }^{100}$ KRAAY, Hendrik. Política racial, Estado e Forças Armadas..., p. 139-142.

${ }^{101}$ MELLO, Christiane F. Pagano de. Os Corpos de Auxiliares e de Ordenanças na Segunda Metade do Século XVIII. As Capitanias do Rio de Janeiro, São Paulo e Minas Gerais e a Manutenção do Império Português no Centro Sul América. Tese (doutorado em História). Niterói: ICHF, Universidade Federal Fluminense, 2002 , p. 158-170; COTTA, Francis Albert. Negros e mestiços nas milícias..., p. 64.

${ }^{102} C f$ : : Relatório do Marquês de Lavradio vice-rei do Rio de Janeiro, entregando o governo a Luiz de Vasconcellos e Sousa, que o sucedeu no vice-reinado. Rio de Janeiro, 19 de junho de 1779. RIHGB, tomo 4, 1863, p. 424-425.

${ }^{103}$ SILVA, Luiz Geraldo. Gênese das milícias de pardos e pretos..., p. 117-122.
} 
nas fronteiras, para as quais a capitania/província em tela esteve diretamente comprometida. É preciso, pois, ter em mente o quadro de confrontos e tensões externas e a participação dos corpos militares paulistas nele a fim de se compreender o papel e as atividades desempenhados por sua milícia.

Do mesmo modo, é preciso atentar para um conjunto de práticas culturais típicas do Antigo Regime que foram atualizadas no contexto de implantação do liberalismo por meio das quais se promovia modalidades de interação e aproximação entre a sociedade local e a Monarquia/Império e a Igreja. ${ }^{104}$ Ao lado de outras corporações, os corpos milicianos figuravam como elementos centrais nesse processo, quer pelo peso que o militarismo obtinha naquela sociedade, quer pela abrangência de seus tentáculos no seio da população em geral. Em cerimônias públicas, os milicianos manejavam as insígnias corporativas e monárquicas como legítimos representantes do Estado, cumprindo assim funções concretas e simbólicas estruturantes daquele universo. Como mostra o Quadro 3.1, uma espécie de calendário das obrigações atribuídas às praças de segunda linha que viviam na capital da província e nos seus arredores entre os anos de 1826 e $1827^{105}$, aqueles homens eram instados a dedicar-se às funções militares, anualmente, por um mínimo de 25 dias. Isto significa que eles passariam aproximadamente um dos doze meses do ano fardados, ocupados em celebrações religiosas, marchas e exercícios militares, bem como com serviços extraordinariamente requisitados.

${ }^{104}$ Para um exame da atuação das câmaras no processo de legitimação da figura imperial de D. Pedro I, ver SOUZA, Iara Lis Carvalho. A adesão das Câmaras e a figura do imperador. Revista Brasileira de História, v. 18, n. 36, p. 367-394, 1998.

105 Esse período foi escolhido para compor a amostra em função da qualidade dos dados presentes nas fontes consultadas. Os regimentos/batalhões milicianos referidos são o $1 .^{\circ}, 2^{\circ} .^{\circ}$ e $3 .^{\circ}$ regimentos de infantaria miliciana e o $1 .^{\circ}$ de cavalaria miliciana, também referidos a partir da nomenclatura estabelecida em 1824 , respectivamente $32 .^{\circ}, 33 .^{\circ}$ e $34 .^{\circ}$ batalhões de infantaria de $2 .^{a}$ linha do exército e $16 .^{\circ}$ batalhão de cavalaria de $2 .^{a}$ linha do exército. 


\section{QUADRO 3.1 - Calendário das atividades milicianas (1826-1827)}

\begin{tabular}{ll}
\hline Data & Descrição da atividade \\
\hline $1826 / 01 /$ a & Instrução militar mensal \\
$1826 / 01 / 13$ & Escolta de presos para a vila de Santos \\
& \\
$1826 / 01 / 22$ & Solenidade referente ao aniversário da imperatriz D. Leopoldina \\
$1826 / 01 / 27$ & Escolta de presos para a vila de Santos
\end{tabular}

1826/02/ Instrução militar mensal

1826/02/01 Escolta de presos para a vila de Santos

1826/03/ Instrução militar mensal

1826/03/ Guarda nas igrejas da cidade durante a semana santa

Participantes

Oficiais e soldados

6 soldados de cada

batalhão miliciano

Oficiais e soldados

De 6 a 10 soldados

de cada batalhão

miliciano

Oficiais e soldados

6 soldados de cada

batalhão miliciano

Oficiais e soldados

Destacamento de

oficiais e soldados

1826/03/11 Escolta de presos para a vila de Santos

4 soldados de cada

batalhão miliciano

1826/04/ Instrução militar mensal

Oficiais e soldados

1826/04/04 Funções militares relativas ao aniversário da princesa D. Maria da Oficiais e soldados Glória

1826/04/29 Festa militar

1826/05/ Instrução militar mensal

1826/06/ Instrução militar mensal

1826/07/ Instrução militar mensal

1826/07/26 Honras fúnebres a D. João VI

1826/08/ Instrução militar mensal

1826/09/ Instrução militar mensal

1826/09/05-07 Solenidade relativa ao dia da independência

1826/10/ Instrução militar mensal

1826/10/12 Funções militares em referência ao aniversário de D. Pedro I

1826/11/ Instrução militar mensal

1826/11/09 Cortejos militares para recepcionar o novo bispo

$1826 / 12 /$

Instrução militar mensal

1826/12/03-05 Cerimônias religiosas dedicadas ao imperador e ao império

$1827 / 01 /$

Instrução militar mensal

Oficiais e soldados

Oficiais e soldados

Oficiais e soldados

Oficiais e soldados

Oficiais, soldados e

oficiais reformados

Oficiais e soldados

Oficiais e soldados

Oficiais e soldados

Oficiais e soldados

Oficiais e soldados

Oficiais e soldados

Oficiais e soldados

Oficiais e soldados

Oficiais e soldados

Oficiais e soldados

1827/01/09 Descargas militares relativas ao falecimento da imperatriz D. Oficiais e soldados Leopoldina

1827/01/09 Solenidade religiosa relativa ao falecimento da imperatriz D. Oficiais

1827/02/ Instrução militar mensal

1827/02/09 Honras fúnebres a um coronel

1827/03/ Instrução militar mensal

1827/03/04 Honras fúnebres a um oficial do estado-maior do Exército

1827/03/25 Solenidade em memória ao juramento da constituição

1827/04/ Instrução militar mensal

1827/04/12-13 Guarda nas igrejas da cidade durante a semana santa

1827/05/ Instrução militar mensal

1827/06/ Instrução militar mensal

1827/06/14 Funções militares de Corpus Christi

1827/06/27-28 Exéquias à imperatriz D. Leopoldina

1827/07/ Instrução militar mensal

1827/07/11 Recepção honrosa ao presidente da província de Goiás

Oficiais e soldados

Oficiais e soldados

Oficiais e soldados

Oficiais e soldados

Oficiais e soldados

Oficiais e soldados

Destacamento de

oficiais e soldados

Oficiais e soldados

Oficiais e soldados

Oficiais e soldados

Oficiais e soldados

Oficiais e soldados

Oficiais e soldados 


\begin{tabular}{|c|c|c|}
\hline 1827/08/ & Instrução militar mensal & Oficiais e soldados \\
\hline $1827 / 08 / 07$ & Arrumação militar & Oficiais e soldados \\
\hline 1827/09/ & Instrução militar mensal & Oficiais e soldados \\
\hline $1827 / 09 / 07$ & Funções militares relativas ao dia da independência & Oficiais e soldados \\
\hline 1827/10/ & Instrução militar mensal & Oficiais e soldados \\
\hline 1827/10/12 & Funções militares relativas ao aniversário do imperador & Oficiais e soldados \\
\hline $1827 / 11 /$ & Instrução militar mensal & Oficiais e soldados \\
\hline $1827 / 12 /$ & Instrução militar mensal & Oficiais e soldados \\
\hline $1827 / 12 / 14$ & Funções militares relativas à entrada do novo bispo & Oficiais e soldados \\
\hline $1827 / 12 / 17$ & $\begin{array}{l}\text { Funções militares relativas à entrada do novo presidente da } \\
\text { província }\end{array}$ & Oficiais e soldados \\
\hline $1827 / 12 / 18$ & Posse do novo presidente da província & Oficiais \\
\hline
\end{tabular}

a As datas exatas dos exercícios mensais não constam dos livros de ordens do dia. No entanto, essa obrigação foi atestada pelo governador das armas em circular para os batalhões de 2 . $^{\text {a }}$ linha da província. $C f$ :: "Circular aos Corpos de 2. " Linha". São Paulo, 2 de março de 1826. APESP, ordem E00663, fl. 32v-33. Embora com interrupções, os exercícios mensais obrigatórios vinham de período anterior. Cf:: APESP, ordem C00264, doc. 32-252. São Paulo, 22 de junho de 1814.

Fonte: Compilação de ordens, circulares e ordens do dia. Cf:: APESP, ordens E00663, E00675 e E00698.

Um governador das armas tentou justificar o emprego de milicianos para auxiliar o transporte de presos ao longo da serra do mar, em 1826, alegando que tais "soldados não são ocupados com tanta efetividade, pois que apenas são obrigados a exercícios um dia em cada mês nas assembleias das companhias". ${ }^{106}$ Já se configuram aí dois compromissos frequentes aos integrantes da segunda linha: a prática de treinamento e instrução militar e o serviço de escolta. A ambos deve-se adicionar as revistas de inspeção aos regimentos com periodicidade anual ou semestral, bem como o fornecimento de praças para compor os destacamentos militares responsáveis pela guarda de ruas, igrejas e prédios públicos por ocasião de procissões, festas e outras celebrações religiosas - compromissos evidentemente ignorados na retórica da máxima autoridade militar da província, que então se via obrigada a ampliar o apelo ao serviço miliciano. Ademais, as milícias estavam igualmente presentes nas datas festivas do império, na recepção de autoridades, assim como eram mobilizadas para prestarem honras fúnebres aos membros da família real e às autoridades políticas, militares e religiosas locais. Mas, como se nota, em tais circunstâncias sua participação se devia menos à especialidade no patrulhamento e uso dos instrumentos de coerção e mais à capacidade em expressar publicamente, como corporação, seus vínculos com o Estado e o Império, o respeito às relações hierárquicas e aos valores sociais compartilhados. Algumas funções eram reservadas com exclusividade aos oficiais, como a presença em missas de ação de graças realizadas na catedral da Sé e a posse de

\footnotetext{
${ }^{106} C f$.: "Circular aos Corpos de 2. ${ }^{a}$ Linha”. São Paulo, 2 de março de 1826. APESP, ordem E00663, fls. 32 v-33.
} 
presidentes da província; no entanto, os soldados faziam parte de quase todas as reuniões da milícia.

Vale a pena observar de perto uma dessas solenidades públicas. Por ocasião do aniversário do imperador D. Pedro I, em 12 de outubro 1826, a tropa de linha se reuniu com os batalhões milicianos e mais alguns oficiais das ordenanças. Pela manhã, após a salva de tiros promovida pelo parque de artilharia ao nascer do sol, a primeira de três que seriam realizadas ao longo do dia, as tropas começaram a se reunir no quartel. Elas deveriam formar uma brigada resguardada por dois esquadrões, a qual marcharia ao Largo de São Gonçalo às 9 horas, local e horário escolhidos para o general governador das armas tomar o comando de toda a força militar disponível e conduzi-la em marcha para a "grande parada". Além disso, os corpos de infantaria miliciana da capital, dentre os quais se incluía o dos pardos, também forneceriam homens para a formação de uma guarda de honra. ${ }^{107}$ Nota-se, pois, que parte substancial da comemoração pública ao aniversário do imperador revestia-se com elementos provenientes do universo marcial e tomava a forma de uma grande parada militar. É pertinente sublinhar a presença dos oficiais e soldados pardos nesses atos solenes e os significados políticos mais amplos desse fenômeno: a visibilidade que seus integrantes, muitos dos quais membros da oficialidade, obtinham junto à sociedade civil; seu papel ativo na construção de identidade e senso de pertencimento ao corpo político em formação; a proximidade mantida por esses homens de baixa extração em relação aos núcleos de poder político, militar e religioso da província.

Até aqui a imagem construída a respeito do serviço miliciano destacou a atuação dos corpos militares nos cerimoniais por meio dos quais se exteriorizavam o poder, as hierarquias e os valores sociais. Nessa perspectiva, as corporações em questão se parecem mais instrumentos litúrgicos a serviço do estado do que propriamente forças militares capazes de executar as competências de policiamento interno e reserva para as campanhas de "guerra viva". Entretanto, como já anunciado em páginas anteriores, a capitania/província de São Paulo esteve diretamente envolvida nos confrontos luso-espanhóis travados na região da bacia do Prata, aspecto que impactou profundamente na sociedade local e em particular na experiência de seus habitantes inseridos nas milícias.

A América portuguesa foi significativamente afetada pelo quadro europeu de concorrências, alianças e disputas durante todo o século XVIII. Exemplos disso são as pontuais invasões francesas ao Rio de Janeiro, ocorridas em 1710-1711, e os confrontos intermitentes com espanhóis nas partes meridionais da América portuguesa, cujos fenômenos foram

${ }^{107} C f:$ : “Ordem do Dia”. São Paulo, 11 de outubro de 1826. APESP, ordem E00698, fls. 115-116. 
responsáveis por movimentar e reestruturar o sistema militar luso-americano. O século seguinte não foi diferente. Em realidade, a historiografia tem argumentado que os equilíbrios de poder e a concorrência estabelecida entre as metrópoles europeias determinavam o tipo de relações que as colônias ultramarinas constituíam entre si. Não havia política ou projeto de longo prazo que se desvencilhasse desse quadro competitivo mais amplo. ${ }^{108}$ Já em 1801, a Espanha, aliada da França napoleônica, declarou guerra a Portugal, que, por sua vez, mantinha-se entre a neutralidade e o apoio à Inglaterra. A invasão das fronteiras lusitanas, em meados daquele ano, caracterizou a guerra de curta duração entre os reinos ibéricos denominada Guerra das Laranjas. Sabedores da guerra com um atraso considerável, luso e hispano-americanos iniciaram as pelejas entre si nas fronteiras das capitanias do Rio Grande de São Pedro e do Mato Grosso quando a paz na Europa já estava firmada. ${ }^{109}$ Os confrontos de pequenas dimensões, comparativamente às guerras de meados do Setecentos, se encerraram formalmente logo que as notícias do Tratado de Badajoz chegaram a América. ${ }^{110} \mathrm{Na}$ prática, porém, persistiram as incursões e preparativos militares na região da bacia do Rio da Prata. Se na península Ibérica Portugal perdeu Olivença à Espanha, na América houve a assimilação lusitana de territórios missioneiros no Rio Grande e a expansão dos limites do Mato Grosso. ${ }^{111}$

Em 1807, mantendo-se aliada à França, a Espanha aceitou o ingresso em seu território das tropas napoleônicas que estavam em trânsito para Portugal e objetivavam empreender o bloqueio comercial à Inglaterra, em vigor desde novembro de 1806. Em fins de 1807, o avanço das tropas francesas na península Ibérica obrigou a Corte lusitana a abandonar o reino e se deslocar para o Brasil com o apoio inglês. Ao mesmo tempo, as forças militares francesas ocuparam paulatinamente as cidades da Espanha, forçaram a abdicação do rei Carlos IV, prenderam seu filho e sucessor Fernando VII - respectivamente pai e irmão de Carlota Joaquina, esposa do príncipe regente de Portugal D. João VI - e, finalmente, coroaram como rei da Espanha a José Bonaparte, irmão de Napoleão Bonaparte. Produziu-se um rompimento

\footnotetext{
108 SOUZA, J. A. Soares de. O Brasil e o Prata até 1828. In: HOLANDA, S. B. de (Dir.). História geral da civilização brasileira. Tomo II, 1. ${ }^{\circ}$ vol. São Paulo: Difusão Européia do Livro, 1962, p. 303; MENZ, Maximiliano M. Entre dois impérios: formação do Rio Grande na crise do antigo sistema colonial (1777-1822). Tese (doutorado em História). São Paulo: FFLCH, Universidade de São Paulo, 2006, p. 28-85.

${ }^{109}$ A capitania de São Paulo recebeu o decreto de 24 de maio de 1801, no qual Portugal declarou guerra à Espanha, somente em 30 de setembro daquele ano. $C f$.: "Carta para o ouvidor desta cidade". São Paulo, 30 de setembro de 1801. DIHCSP, vol. 93, p. 25.

${ }^{110}$ O anúncio da paz entre os reinos ibéricos ocorreu em São Paulo apenas em janeiro de 1802. $C f$.: "Carta para a câmara da cidade". São Paulo, 10 de janeiro de 1802. DIHCSP, vol. 93, p. 64. Já a declaração de paz com a França e a organização de festejos demoraram, ali, um pouco mais. Ocorreram tão somente em 2 de abril de 1802 . $C f$ :: "Para a câmara da cidade". São Paulo, 2 de abril de 1802. DIHCSP, vol. 93, p. 75.

111 CARVALHO, Francismar A. Lopes de. Lealdades negociadas: povos indígenas e a expansão dos impérios ibéricos nas regiões centrais da América do Sul (segunda metade do século XVIII). Tese (doutorado em História). São Paulo: FFLCH, Universidade de São Paulo, 2012; MENZ, Maximiliano M. Entre dois impérios..., p. 56-62.
} 
na aliança franco-espanhola. Uma vez instalada no Rio de Janeiro, a Monarquia portuguesa tratou de neutralizar e até mesmo revidar, na América, as agressões sofridas na Europa. Decorreu daí uma intensificação das movimentações diplomáticas e militares em torno de duas áreas fronteiriças: ao extremo norte do Brasil, conflitante com a Guiana Francesa, e ao extremo sul, confinante com o vice-reino espanhol do Rio da Prata. ${ }^{112}$

A capitania do Pará reuniu corpos militares destinados à conquista do território francês de Caiena, em um esforço de contenção ao possível avanço dos ideais revolucionários bem como de retaliação à recente invasão francesa sofrida por Portugal. E de fato, entre fins de 1808 e começo de 1809, as forças militares luso-americanas avançaram sobre o território e exigiram a capitulação da capital Caiena. A dominação empreendida por tropas reinóis e das capitanias do Pará e Pernambuco, igualmente auxiliadas por forças navais cedidas pela Inglaterra - em síntese, a "infantaria brasileira e marujada inglesa" -, perdurou por quase uma década. Com a queda de Napoleão e os vários acordos diplomáticos que se seguiram na Europa, determinouse entre 1814 e 1815 a devolução do território à França, o que se efetuou em fins de $1817 .{ }^{113}$

Por outro lado, a partir de 1808 houve concentração de tropas no Rio Grande de São Pedro e expedições de emissários luso-americanos que ofereceram a proteção joanina-carlotina aos territórios coloniais espanhóis que então viviam uma conjuntura marcada por vazio de poder: com o afastamento forçado da casa bourbônica e sua substituição pela dinastia bonapartista, carente de legitimidade, as colônias hispano-americanas tenderam a se alinhar às províncias espanholas reunidas em Junta como forma alternativa e de resistência aos usurpadores do trono. ${ }^{114}$ A recusa desconfiada de Buenos Aires, capital do vice-reino, quanto à ingerência da casa real de Bragança nos assuntos do Prata perdurou mesmo com a sequência de notícias peninsulares, como as da deposição de Fernando VII na Espanha, coroação de José Bonaparte e da nomeação de um novo vice-rei para o Prata. Entretanto, tais fenômenos resultaram em um rompimento da maior parte do mundo hispano-americano para com a Espanha. A Revolução de Maio de 1810 ocorrida em Buenos Aires revelar-se-ia a posteriori um ato irreversível de autonomização do vice-reino formatado na ocasião como junta provisória de governo. Contudo, Buenos Aires não teve força política e militar suficiente para impor seu

\footnotetext{
${ }^{112}$ SOUZA, J. A. Soares de. O Brasil e o Prata até 1828...; LINS, M. de L. Ferreira. A Legião de São Paulo no Rio Grande do Sul. Tese (doutorado em História). São Paulo: FFLCH, Universidade de São Paulo, 1976; MENZ, Maximiliano M. Entre dois impérios..., p. 28-85.

113 REIS, A. C. Ferreira. A ocupação de Caiena. In: HOLANDA, S. B. de (Dir.). História geral da civilização brasileira. Tomo II, 1. ${ }^{\circ}$ vol. São Paulo: Difusão Européia do Livro, 1962, p. 303; NOGUEIRA, S. M. Silva. "A soldadesca desenfreada": politização militar no Grão-Pará da Era da Independência (1790-1850). Tese (doutorado em História). Salvador: FFCH, Universidade Federal da Bahia, 2009, p. 182-195.

${ }^{114}$ A narrativa que segue tem como base SOUZA, J. A. Soares de. O Brasil e o Prata até 1828...; LINS, M. de L. Ferreira. A Legião de São Paulo...; MENZ, Maximiliano M. Entre dois impérios..., p. 28-85.
} 
projeto à Banda Oriental, que passou a abrigar o vice-rei nomeado pela Espanha, e ao Paraguai, que se independentizou. Esse processo de reconfiguração política foi marcado por grande movimentação militar. Nos conflitos com Buenos Aires, tanto Assunção como Montevidéu requisitaram apoio militar luso-americano, fornecendo assim condições para a intervenção direta da Coroa portuguesa na região e especialmente na Banda Oriental. Para além dos ideais imperialistas então em voga, certamente o apoio de D. João VI era motivado pela necessidade de conter o avanço revolucionário e republicano de modo análogo ao que se passava na fronteira norte do Brasil. Assim, em acordo firmado com o vice-rei do Prata, corpos militares estacionados no Rio Grande de São Pedro marcharam para o território uruguaio em meados de 1811 para fazerem frente às tropas de Buenos Aires, mas foram surpreendidos por um armistício firmado entre Montevidéu e Buenos Aires que implicou na retirada das tropas luso-brasileiras. O certo é que as diferentes províncias platinas, como de resto todos os demais territórios coloniais hispano-americanos, permaneceram sob uma atmosfera de tensões em torno a distintos projetos políticos subsidiados, no mais das vezes, por força militar.

Entre 1816 e 1817, D. João VI promoveu novo envio de tropas luso-americanas - o Exército Pacificador - para a Banda Oriental objetivando-se, com sucesso, o domínio provisório daquele território. A revolução liberal do Porto, a convocação das Cortes em Lisboa e o retorno de D. João VI a Portugal, em 1821, impactaram nos rumos da política no Prata. Numa tentativa de definir o estatuto da Banda Oriental, procedeu-se a uma eleição a partir de representantes locais, da qual resultou sua vinculação, como corpo político autônomo, ao reino unido de Portugal, Brasil e Algarves sob o nome de província Cisplatina. Pouco tempo depois, foi a independência do Brasil ${ }^{115}$ que desencadeou novo desequilíbrio, uma vez que, então, o governador de Montevidéu e segmentos das elites locais tomaram o partido de D. Pedro I ao passo que parte substancial do corpo militar que ocupava a Cisplatina permanecera leal a D. João VI e às Cortes lisboetas. Derrotadas, as tropas portuguesas retornaram à Europa e a Cisplatina uniu-se ao Império do Brasil como província, jurando a constituição e enviando deputados à Assembleia Geral. Por seu turno, a partir de 1822 o governo de Buenos Aires empreendeu esforço para romper a união frágil entre o império e a Cisplatina, no que obteve o apoio de líderes orientais. Gradualmente, à exceção de Montevidéu e da Colônia, todo o Uruguai ficou sob mãos de grupos que contestavam a vinculação ao Brasil. Foi só então, em dezembro de 1825, em resposta às agressões diplomáticas e das ações militares provenientes de Buenos Aires, que o império declarou guerra às Províncias Unidas. Conforme Souza, "essa

\footnotetext{
${ }^{115}$ Cuja problematização segue, mais oportunamente, na última parte desta tese.
} 
guerra não foi favorável ao Brasil. Foi uma guerra impopular que se arrastou até 1827". ${ }^{116}$ Após algumas tratativas, em agosto de 1828, reuniram-se representantes do Brasil e das Províncias Unidas e ambos reconheceram a independência da, a partir de então, República Oriental do Uruguai.

Como sucedera na guerra luso-espanhola de 1762-1777, a capitania e depois província de São Paulo comprometeu-se com os esforços de guerra na região meridional da América portuguesa de fins do século XVIII em diante. Na guerra de 1801, enviara um de seus dois regimentos de linha para complementar a guarnição de Santa Catarina - o Regimento de Santos, também conhecido como "de Mexia" - e era pressionada a preparar soldados destinados ao Mato Grosso, recrutas para o Rio de Janeiro assim como várias companhias de cavalaria, de linha e de milícias, para o Rio Grande do Sul. ${ }^{117}$ Como consequência do desfalque de tropas regulares, as milícias tiveram que assumir o papel de defesa de sua costa marítima e do centro político-administrativo da capitania. O Plano da distribuição das tropas para a defesa da marinha desta capitania de São Paulo ${ }^{118}$, de 1800, testemunha a adoção de medidas críticas: a Legião de São Paulo deslocou-se da capital para a região costeira e seu reduzido contingente permaneceria destacado nas principais fortalezas, já que as demais seriam guarnecidas por corpos milicianos, estes responsabilizados igualmente pelas vilas mais importantes da costa. Para Cananéia, São Sebastião, Ubatuba e Cunha determinou-se que "os corpos de ordenanças [...], com a escravatura de cada uma das ditas vilas, serão empregados na sua defesa". Das vilas de Itu e Sorocaba marchariam corpos de segunda linha para guarnecer a cidade de São Paulo. Os milicianos pardos, por sua vez, deveriam oferecer destacamentos para as fortalezas da Estacada, da Barra, o passo do Cubatão e a guarnição da cidade de São Paulo e das vilas de Santos, São Sebastião e Ubatuba. Há um detalhamento mais preciso da distribuição das tropas em serviço para o período de abril de 1801 a fevereiro de 1802. As localidades litorâneas continuavam a ser guarnecidas pela tropa de linha e também por um destacamento miliciano mensal constituído por 33 praças, entre oficiais e soldados, dos regimentos de Santos e dos Úteis. Já segurança da capital ficou completamente dependente das milícias, cujos regimentos tiveram que se revezar no fornecimento de 41 praças cada um. ${ }^{119}$ Assim, tanto o litoral como a

\footnotetext{
${ }^{116}$ SOUZA, J. A. Soares de. O Brasil e o Prata até $1828 \ldots$, p. 327.

${ }^{117}$ Cf:: "Para o mesmo vice-rei do Estado". São Paulo, 21 de agosto de 1801. DIHCSP, vol. 39, p. 86-92; LEONZO, Nanci. Defesa militar e controle social..., p. 174-175.

${ }^{118}$ Cf:: Plano da distribuição das Tropas para a defesa da marinha desta capitania de São Paulo. São Paulo, 28 de dezembro de 1800. AN, Secretaria de Estado do Brasil, códice 111 (Correspondência de São Paulo com o vice-rei do Brasil), p. 77-80.

${ }^{119} C f$ : : APESP, ordem C00444, livro 246, fls. 10-13v.
} 
cidade de São Paulo tornaram-se as áreas de atuação dos milicianos pardos no começo do século XIX. $^{120}$

Pouco tempo depois, na conjuntura das ações militares no Prata desencadeadas pela invasão francesa a Portugal de 1807, mais tropas paulistas marcharam para o Rio Grande do Sul - especificamente esquadrões da Legião de São Paulo. ${ }^{121}$ Em realidade, esse corpo militar permaneceu nos territórios beligerantes por grande parte do período compreendido entre os anos 1775 a 1828. ${ }^{122}$ Alguns números fragmentários são suficientes para que se obtenha uma ideia do impacto da guerra na sociedade local. Lins contabilizou que a Legião de São Paulo destacada no Sul recebeu um acréscimo de 855 recrutas paulistas entre os anos 1808-1812. ${ }^{123}$ O contingente era suficiente para a formação de um novo batalhão, o que permite dimensionar a alta demanda de homens destinados a preencher os vazios das fileiras. Pouco tempo depois, em 1814, a capitania enviou um reforço de 600 praças à Legião que servia no Sul, e, já em 1818, mais 800 homens pertencentes a dois regimentos de cavalaria. Uma estimativa da câmara da cidade de São Paulo apontou que a província enviara para o Sul, entre os anos 1809-1824, algo em torno de " 12.000 homens, em 14 expedições, sem falar nos 1.300 homens que seguiram para a Corte" em 1822. ${ }^{124}$ Tais números foram apresentados ao imperador por um órgão oficial de governo, de modo que, descontado algum possível exagero, deviam ser, em termos gerais, ao menos aceitáveis. Portanto, não cabe aqui um esforço mais preciso para quantificar os contingentes totais enviados de São Paulo para as guerras; basta apenas mencionar que, reforçadas continuamente com o envio de soldados, as tropas paulistas permaneceram nas campanhas sulinas até 1828 , quando do encerramento dos confrontos.

A historiografia tem aceitado de bom grado a noção de que São Paulo, a capitania notabilizada a partir do Seiscentos pela eficácia militar de seus habitantes sertanistas ${ }^{125}$, se

\footnotetext{
${ }^{120}$ Tendo passado as circunstâncias que exigiram essa mobilização militar emergencial, foram efetuadas mudanças na configuração de alguns corpos militares paulistas. Nesse contexto, as companhias litorâneas do Regimento dos Úteis foram extintas e substituídas por novas companhias formadas em vilas do planalto. Assim, o espaço de atuação da corporação em questão passou a ser, prioritariamente, a capital.

${ }^{121}$ LINS, M. de L. Ferreira. A Legião de São Paulo..., p. 292-450.

${ }^{122}$ LINS, M. de L. Ferreira. A Legião de São Paulo..., p. 386. Ver também a narrativa de Oliveira, que participou da campanha como oficial da Legião paulista, em OLIVEIRA, José Joaquim Machado de. Quadro Historico da Provincia de S. Paulo até o anno de 1822. São Paulo: Typografia Brasil de Carlos Gerke, 1897, p. 198-209, 219220, 222-228.

${ }^{123}$ LINS, M. de L. Ferreira. A Legião de São Paulo..., p. 330-331.

${ }^{124}$ HOLANDA, S. Buarque de. São Paulo. In: HOLANDA, S. B. de (Dir.). História geral da civilização brasileira. (t. II, $2^{\circ}$ vol.). São Paulo: Difusão Européia do Livro, 1967, p. 437-439. As estimativas em questão também foram reproduzidas e aceitas por LEONZO, N. Defesa militar e controle social..., p. 19. José J. Machado de Oliveira informou um número menor de paulistas enviados para o Sul, que corresponderia a 3.200 homens, sendo, no entanto, equivalente a 2/3 dos efetivos do Exército do Sul. OLIVEIRA, J. J. M. de. Quadro Historico da Provincia de S. Paulo..., p. 227-228.

${ }^{125}$ SOUZA, Laura de Mello e. O sol e a sombra: política e administração na América portuguesa do século XVIII. São Paulo: Companhia das Letras, 2006, p. 109-147; PUNTONI, Pedro. A guerra dos bárbaros. Povos indígenas
} 
comportou como uma barreira protetora ao território aurífero e diamantino desde o século XVIII. ${ }^{126}$ Mas é pertinente, igualmente, a perspectiva de acordo com a qual a partilha da função guerreira com o Rio Grande do Sul - um dos principais teatros das ações militares - fora fundamental para possibilitar a formação de um espaço pacificado em São Paulo - e, portanto, apto para o povoamento e para o desenvolvimento econômico. ${ }^{127}$ Embora São Paulo estivesse intensamente envolvida nas campanhas militares travadas nas fronteiras meridionais do Brasil entre a segunda metade do século XVIII e a primeira do seguinte, nesse mesmo período assistiuse a um desenvolvimento econômico extraordinário para os padrões da capitania/província: refere-se nomeadamente ao cultivo voltado para a exportação da cana-de-açúcar e posteriormente do café, à importação de escravos africanos e ao comércio interprovincial de bovinos e cavalares. $^{128}$

Ainda assim, a despeito do crescimento econômico, uma breve leitura aos ofícios dos governadores e depois presidentes da província, ou mesmo aos relatos de viajantes estrangeiros que passaram por São Paulo nas décadas de 1810 e 1820, revela de imediato expressões das consequências danosas da intensa militarização vivida localmente. Conforme expunham, a agricultura e o comércio eram áreas extremamente sensíveis às sangrias na população ocasionadas pelo recrutamento e envio de tropas para o Sul, bem como pelo fenômeno da deserção massiva de homens em idade e condições para servir nos corpos militares de linha. "A expedição portuguesa a Montevidéu", argumentaram os naturalistas alemães Spix e Martius, "havia custado grandes sacrifícios a São Paulo, pois não foram somente remetidas tropas regulares do exército, mas também um regimento de milícias, o que ocasionou sensível falta na

\footnotetext{
e a colonização do Sertão do Nordeste do Brasil, 1650-1720. São Paulo: Hucitec, 2002, p. 181-282. Em meados do século XVIII, cogitou-se o emprego de paulistas em corpos militares de Moçambique. Ver RODRIGUES, Maria Eugénia. Cipaios da Índia ou soldados da terra? Dilemas da naturalização do exército português em Moçambique no século XVIII. História Questões \& Debates, v. 24, n. 45, p. 57-95, jul./dez. 2006, p. 65.

${ }^{126}$ BELLOTTO, Heloísa Liberalli. Autoridade e conflito no Brasil colonial: o governo do Morgado de Mateus em São Paulo (1765-1775). São Paulo: Conselho Estadual de Artes e Ciências Humanas, 1979, p. 69-83.

${ }^{127}$ LINS, M. de L. Ferreira. A Legião de São Paulo..., p. 116-117 e 314-319; uma perspectiva sociológica sobre a espacialização da guerra, isto é, a definição móvel, no interior dos estados, de zonas pacificadas e fronteiras militarizadas, em TILLY, Charles. Coerção, Capital e Estados Europeus (990-1992). Trad. Geraldo Gerson de Souza. São Paulo: Edusp, 1996, p. 127.

${ }^{128}$ Para um panorama geral do quadro socioeconômico da província de São Paulo nas primeiras décadas do Oitocentos, ver HOLANDA, S. Buarque de. São Paulo...; LUNA, Francisco Vidal; KLEIN, Herbert S. Evolução da sociedade e economia escravista de São Paulo, de 1750 a 1850. São Paulo: EDUSP, 2006, especialmente p. 25-136; MEDICCI, A. P. De capitania a província: o lugar de São Paulo nos projetos de império, 1782-1822. In: COSTA, W. P.; OLIVEIRA, C. H. de S. (Orgs.). De um império a outro: estudos sobre a formação do Brasil, séculos XVIII e XIX. São Paulo: Aderaldo \& Rothschild: Fapesp, 2007, p. 241-260. Um quadro completo das dinâmicas populacionais paulistas conectadas às transformações econômicas em MARCÍLIO, Maria Luiza. Crescimento demográfico e evolução agrária paulista (1700-1836). São Paulo: Hucitec/EDUSP, 2000. A relação da capitania/província com o tráfico de transatlântico de escravos africanos é examinada em QUEIROZ, Suely Robles Reis de. Escravidão negra em São Paulo. Rio de Janeiro: José Olympio, 1977 e também em LUNA, F. V.; KLEIN, H. S. Evolução da sociedade e economia..., p. 137-196.
} 
classe dos trabalhadores e consequências funestas para muitas famílias". Ainda conforme as testemunhas coevas, a exaustão de uma longa guerra cuja causa era pouco compreendida ou aceita pela população e as inúmeras baixas ocorridas na marcha e nos confrontos, resultaram em "geral descontentamento na capitania inteira por esse empreendimento militar". "Por isso, uma grande parte de milicianos desertou das bandeiras antes de se pôr em marcha, e refugiouse às vezes com toda a família nas remotas matas da capitania de São Paulo ou de Minas Gerais [...]". ${ }^{129}$ Em síntese, a constatação macroscópica do crescimento econômico vivido por São Paulo desde fins do século não deve ocultar toda a perturbação social e econômica ocasionada pelo fenômeno de extração de recursos humanos e financeiros voltado a atender às demandas da guerra. Mesmo porque, desprovida de seus efetivos militares regulares, a capitania/província teve que recorrer a seus habitantes meio paisanos meio militares para o serviço ordinário de policiamento e tudo o mais que era atribuição da tropa paga. Assim, como será demonstrado adiante, o emprego intensivo da milícia nos destacamentos da cidade de São Paulo por toda a década da independência ${ }^{130}$ forneceu sua parcela de contribuição para o que as autoridades e observadores viam como uma crise no cultivo de alimentos e no giro dos negócios.

\footnotetext{
${ }^{129} C f$ : SPIX, Johann Baptist Von; MARTIUS, Car. Friedrich Philipp von. Viagem pelo Brasil: 1817-1820. (v. 1). Trad. Lúcia Furquim Lahmeyer. Belo Horizonte: Ed. Itatiaia; São Paulo: Ed. da Universidade de São Paulo, 1981, p. 130 .

${ }^{130} \mathrm{~A}$ escolha do período se deve tanto à disponibilidade de dados mais precisos e seriados quanto a uma ampliação das pressões sobre a milícia. Claro está que enfatizar esse contexto não implica reduzir a importância das milícias nos destacamentos obrigatórios ao longo das décadas anteriores.
} 
TABELA 3.3 - Destacamento miliciano mensal na cidade de São Paulo (1824-1829)

\begin{tabular}{|c|c|c|c|c|c|}
\hline Data & $\begin{array}{c}32 .^{\circ} \\
\text { Batalhão }\end{array}$ & $\begin{array}{c}33 .^{\circ} \\
\text { Batalhão }\end{array}$ & $\begin{array}{c}34 .^{\circ} \\
\text { Batalhão }\end{array}$ & $\begin{array}{c}16^{\circ} \\
\text { Batalhão }\end{array}$ & Total \\
\hline $1824 / 04$ & 63 & 60 & 69 & 30 & 222 \\
\hline $1824 / 05$ & 49 & 46 & 54 & 33 & 182 \\
\hline $1824 / 06$ & 54 & 43 & 51 & 34 & 182 \\
\hline $1824 / 07$ & 19 & 13 & 19 & 14 & 65 \\
\hline $1824 / 07 / 15-1824 / 08$ & 25 & 23 & 24 & 13 & 85 \\
\hline $1824 / 09$ & 25 & 26 & 25 & 13 & 89 \\
\hline $1824 / 10$ & 0 & 31 & 31 & 22 & 84 \\
\hline $1824 / 11$ & $?$ & $?$ & $?$ & ? & $?$ \\
\hline $1824 / 12$ & 38 & 27 & 35 & 22 & 122 \\
\hline $1825 / 01$ & 38 & 27 & 35 & 22 & 122 \\
\hline $1825 / 02$ & 32 & 23 & 19 & 16 & 90 \\
\hline $1825 / 03$ & 29 & 26 & 20 & 15 & 90 \\
\hline $1825 / 04$ & 29 & 26 & 20 & 15 & 90 \\
\hline $1825 / 05$ & 31 & 25 & 19 & 15 & 90 \\
\hline $1825 / 06$ & $?$ & $?$ & $?$ & $?$ & $?$ \\
\hline $1825 / 07$ & 20 & 21 & 16 & 13 & 70 \\
\hline $1825 / 08$ & 19 & 12 & 20 & 12 & 63 \\
\hline $1825 / 09$ & 10 & 6 & 9 & 5 & 30 \\
\hline $1825 / 10-1826 / 11$ & $?$ & $?$ & $?$ & $?$ & $?$ \\
\hline 1826/12 (S. Paulo, capital) & 47 & 51 & 39 & 27 & 164 \\
\hline 1826/12 (Santos) & 30 & 33 & 24 & 16 & 103 \\
\hline $1827 / 01$ & $?$ & $?$ & $?$ & $?$ & $?$ \\
\hline $1827 / 02$ & 50 & 36 & 46 & 32 & 164 \\
\hline $1827 / 03$ & 9 & 7 & 8 & 6 & 30 \\
\hline $1827 / 04$ & 30 & 0 & 0 & 0 & 30 \\
\hline $1827 / 05$ & 17 & 22 & 30 & 23 & 92 \\
\hline $1827 / 06$ & 26 & 19 & 27 & 20 & 92 \\
\hline $1827 / 07$ & 8 & 7 & 9 & 4 & 28 \\
\hline $1827 / 08$ & 8 & 7 & 9 & 4 & 28 \\
\hline $1827 / 09$ & 52 & 45 & 53 & 30 & 180 \\
\hline $1827 / 10-1828 / 02$ & $?$ & $?$ & ? & ? & $?$ \\
\hline $1828 / 03$ & 32 & 33 & 25 & 10 & 100 \\
\hline $1828 / 04-1828 / 05$ & ? & $?$ & $?$ & ? & $?$ \\
\hline $1828 / 06$ & 38 & 37 & 29 & 11 & 115 \\
\hline $1828 / 07$ & 87 & 61 & 44 & 17 & 209 \\
\hline $1828 / 08$ & 64 & 56 & 63 & 30 & 213 \\
\hline $1828 / 09$ & 86 & 47 & 60 & 20 & 213 \\
\hline $1828 / 10$ & 89 & 49 & 64 & 20 & 222 \\
\hline $1828 / 11$ & 79 & 47 & 71 & 15 & 212 \\
\hline $1828 / 12$ & 62 & 37 & 55 & 13 & 167 \\
\hline $1829 / 01$ & 22 & 14 & 18 & 6 & 60 \\
\hline $1829 / 02$ & 0 & 0 & 0 & 0 & 0 \\
\hline $1829 / 03 \mathrm{e} 04$ & 37 & 28 & 22 & 9 & 96 \\
\hline $1829 / 05$ & 41 & 29 & 26 & 10 & 106 \\
\hline $1829 / 06$ & 36 & 26 & 33 & 11 & 106 \\
\hline
\end{tabular}

Fonte: APESP, ordens E00675 e E00698. 
Um exame ao total de milicianos mensalmente requeridos pelo governo das armas da província de São Paulo entre os anos críticos de 1824 a 1829, durante os quais a capital permanecera desfalcada das tropas regulares habitualmente empregadas nos destacamentos, não deixa dúvidas quanto à importância militar atribuída às milícias (Tabela 3.3). Embora os números contemplem um curto período, é plausível afirmar que semelhante quadro se verificasse desde a passagem do século XVIII para o XIX e se mantivesse nas décadas seguintes, em cujo período o árduo trabalho da segunda linha podia ocasionalmente ser aliviado em função do regresso ou presença de corpos militares profissionais. Entre 1824-1829, porém, o governo pode dispensar os serviços da milícia em apenas uma ocasião e durante um único mês. ${ }^{131}$ A regra foi o emprego mensal de um mínimo de 28 e um máximo de 222 milicianos pertencentes aos três batalhões de infantaria e ao de cavalaria sediados na cidade de São Paulo. Em média, 112 milicianos das quatro corporações eram destacados a cada mês. Ampliando o nível de abstração, o $32 .^{\circ}$ e o $33 .^{\circ}$ batalhões de infantaria, identificados aos homens brancos, forneciam respectivamente uma média de 36,7 e 28,9 homens a cada mês; o 34. ${ }^{\circ}$, também de infantaria, mas reconhecido por ser composto por homens pardos, contribuía mensalmente com 31,3 homens ao passo que o $16^{\circ}$ batalhão, de cavalaria e constituído por brancos, responsabilizava-se por uma média bem inferior aos demais, mas, ainda assim, de 16,1 milicianos a cada 30 dias.

Uma vez que se pretenda compreender minimamente a atuação das milícias paulistas no período em tela, torna-se indispensável levar em conta o calendário anual de atividades - que incluía a presença em festas e celebrações públicas, os exercícios mensais de treinamento e instrução, as revistas de inspeção e a convocação extraordinária para tarefas específicas - assim como os contingentes mensais variáveis, mas perenes, requisitados para os destacamentos militares. Tomando-se como exemplo o mês de abril de 1824, aos 222 milicianos responsáveis pela guarda da cidade deve-se adicionar mais um total de 228 homens, provenientes da 1 . $^{\mathrm{a}}$ e 2 . $^{\mathrm{a}}$ linhas, requisitados para comporem guardas nas portas das igrejas durante os dias 15 e 16 daquele mês, quinta-feira de endoenças e sexta-feira santa. ${ }^{132}$ Antes da semana santa, porém, os milicianos já haviam sido instados a comparecer em três outros compromissos militares: o arrumamento em referência à posse de um novo presidente da província, no dia $1 .^{\circ}$ de abril; o arrumamento por ocasião do aniversário da princesa D. Maria da Glória, a 4 do mesmo mês,

\footnotetext{
131 Evidentemente, foram desconsiderados os períodos para os quais se dispõe de informações e que seguem identificados na Tabela 3.3 com um "?".

${ }^{132}$ Cf:: "Para o coronel comandante do 3. ${ }^{\circ}$ Regimento de Infantaria de 2. ${ }^{\text {a }}$ Linha desta cidade". São Paulo, 12 de abril de 1824. APESP, ordem E00675, fls. 2v-3.
} 
em cuja data a oficialidade deveria igualmente assistir ao Te Deum na Sé além de compor um cortejo até o palácio do governo; finalmente, entre os dias 6 e 7 ocorrera o juramento à constituição e ao imperador, na catedral, e a ratificação do ato, mediante assinaturas, na câmara da cidade. ${ }^{133}$ Os faltosos eram devidamente censurados e punidos. ${ }^{134}$

Como se vê, havia uma pesada carga de compromissos e responsabilidades recaindo sobre as milícias, a qual por sua vez gerava enorme mobilização da população masculina em idade produtiva inserida em tais corpos militares. Esse fenômeno salientou o já problemático quadro de desarranjo social e econômico decorrente da participação da capitania/província nas guerras sulinas. Em 1828 a situação foi discutida no Conselho da Presidência da Província de São Paulo, pois era encarada como o principal entrave para o progresso agrícola regional. De acordo com o projeto apresentado pelo conselheiro Antonio Bernardo Bueno da Veiga,

Sendo a agricultura a única fonte da riqueza e prosperidade desta província de São Paulo, infelizmente de longa data ela é atropelada [...]; pois que os braços de sua lavoura são ocupados em contínuo giro nas estradas, uns a virem destacar na cidade [de São Paulo] e vila de Santos, outros a regressarem dos destacamentos para voltarem logo com mui pouca folga; por isso que a carestia dos mantimentos de boca se torna de dia-a-dia mais pesada, e ainda mais aflitiva a pobreza, que os não pode comprar. Os lavradores menores são os que plantam os cereais indispensáveis para a vida; estes são os Milicianos, que se acham transformados ou reduzidos a $1^{\mathrm{a}}$ Linha, sendo que em todos os Estados cultos e providentes, ainda mesmo em tempo de guerra, os braços da agricultura sempre foram desocupados e privilegiados, porque sem ela não se sustenta a guerra, nem os Estados. ${ }^{135}$

O texto que abre o projeto de Bueno da Veiga oferece uma síntese precisa do argumento até aqui desenvolvido. Seria impreciso personificar o discurso ou encará-lo como mera retórica. Em novembro de 1828, quando da apresentação e discussão do projeto em questão, o fim das guerras no Sul tinha sido firmado havia pouco tempo e os corpos militares paulistas sequer tinham regressado integralmente à província. Foi o período mais duro para a milícia. Conforme os dados da Tabela 3.3, de meados de 1828 em diante a presença de milicianos nos destacamentos da capital se intensificou: em junho o contingente requisitado era de 115

\footnotetext{
${ }^{133}$ Cf:: Ordens do dia (31 de março e de 3 de abril de 1824). APESP, ordem E00698, fls. 36-37; "Para o tenente coronel José Olinto de Carvalho". São Paulo, 14 de abril de 1824. APESP, ordem E00700, fl. 12.

${ }^{134} C f$ : : APESP, ordem E00698, fls. 132v-133. São Paulo, 14 de junho de 1827.

135 Cf: : VEIGA, Antonio Bernardo Bueno da. "Expozição de Projecto". São Paulo, 5 de novembro de 1828. DIHCSP, vol. 86, 88. ${ }^{a}$ Sessão, p. 175-176. A discussão desse projeto nas p. 178-179. Karina da Silva examinou essa fonte na ótica dos recrutamentos militares efetuados em São Paulo para as tropas de $1 .^{\mathrm{a}}$ linha destinadas ao Rio Grande do Sul e à Cisplatina. SILVA, Karina da. Os recrutamentos militares e as relações sociedade-Estado na capitania/província de São Paulo (1765-1828). Dissertação (mestrado em História). Franca: FHDSS, Universidade Estadual Paulista, 2006, p. 112-113.
} 
homens, em julho elevou-se para 209, em agosto e setembro manteve-se em 213 milicianos, em outubro 222 e em novembro 212. Não por acaso vários milicianos foram processados por deserção já em agosto. Em dezembro daquele mesmo ano, quando o destacamento miliciano percebeu redução irrisória devendo ser integrado por 167 praças, os comandantes dos batalhões milicianos receberam ordem para punir os 38 homens, entre oficiais inferiores, cabos e soldados, que não se apresentaram para compor o destacamento. ${ }^{136}$

Em janeiro de 1829, mediante intervenção da presidência da província nos assuntos militares, resolveu-se pela diminuição da participação das praças de $2 .^{a}$ Linha no serviço ordinário da capital e se ordenou que o Batalhão de Caçadores N. 6 da $1 .{ }^{a}$ Linha "principie a fazer o serviço da guarnição [...] coadjuvado por um contingente de 40 soldados dos corpos de milícias". ${ }^{137}$ Finalmente, em fevereiro ocorreu o tão aguardado anúncio da dispensa dos milicianos do serviço da guarnição, em função do retorno do Corpo de Cavalaria de Milícias que até o momento estava na campanha do Sul. ${ }^{138}$ A ocasião ensejou elogios e louvores, da parte do governador das armas, à "conduta digna dos Milicianos, que têm há meses feito o serviço da guarnição com a maior prontidão e obediência, deixando suas casas e famílias porque o serviço público assim o exigia, dando neste procedimento provas do seu patriotismo". ${ }^{139}$ Pouco mais de um mês, porém, as palavras de Bueno da Veiga que lamentaram o vexame vivido pelos milicianos ao "regressarem dos destacamentos para voltarem logo com mui pouca folga" tornaram-se outra vez realidade. ${ }^{140}$ Em tom desditoso, o governador das armas expôs que "se vê na dura mas indispensável necessidade de chamar por algum tempo ao serviço da guarnição algumas praças dos Batalhões de Caçadores de 2. ${ }^{a}$ Linha para coadjuvarem o 6. ${ }^{\circ}$ Batalhão de Caçadores da 1. a Linha". ${ }^{141}$ Como se sabe (Tabela 3.3), tratava-se do retorno de 96 milicianos ao serviço nos meses de março e abril, cujo contingente aumentou para 106 homens nos meses seguintes.

\footnotetext{
136 Cf:: "Detalhe para o mês de setembro". São Paulo, 16 de agosto de 1828; "Ordem adicional à ordem do dia". São Paulo, 9 de dezembro de 1828. APESP, ordem E00698, fls. 164v e 176v-177.

${ }^{137}$ Cf:: APESP, ordem E00698, fls. 182-182v. São Paulo, 14 de janeiro de 1829. Até então, eram 60 os milicianos destacados.

${ }^{138} C f$ : APESP, ordem E00698, fl. 186. São Paulo, 4 de fevereiro de 1829.

${ }^{139} C f$ :: APESP, ordem E00698, fls. 182-182v. São Paulo, 14 de janeiro de 1829.

${ }^{140}$ Entre junho e setembro de 1825 se preparou a transição na composição do destacamento da capital entre a milícia, que fora despedida a 20 de setembro, e a tropa de linha, que reassumiria integralmente tais funções. Contudo, o alívio aos soldados de segunda linha durou pouco, já que a intensificação das tensões sulinas e o início da guerra entre o império do Brasil e as Províncias Unidas do Prata deixaram São Paulo de sobreaviso, de modo que os milicianos passaram os últimos meses de 1825 e os primeiros do ano seguinte ocupados com as guardas na costa litorânea e na capital da província. $C f$ :: "Para o capitão D. Antonio de Locio e Seilla". São Paulo, 16 de junho de 1825; "Para o capitão Joaquim Lopes Guimarães". São Paulo, 20 de setembro de 1825. APESP, ordem E00675, folhas sem numeração. Ver também a Tabela 9.

${ }^{141}$ Cf:: APESP, ordem E00698, fl. 193v. São Paulo, 11 de março de 1829.
} 
Em conjunto, esses dados matizam a perspectiva de acordo com a qual as milícias comportavam-se maiormente como corporações litúrgicas. A função simbólica desempenhada pelas corporações militares, pode-se afirmar melhor agora, era extremamente relevante e requisitada - tanto quanto sua capacidade de preencher as lacunas no serviço especificamente militar da capitania/província produzidas pela ausência da tropa regular. A rigor, a partir das funções militares assumidas pela capitania/província de São Paulo durante as três primeiras décadas do século XIX, parece impreciso pretender determinar rigidamente as diferenças entre os corpos militares profissionais e milicianos no tocante às suas obrigações e tarefas. Ambos se intercalaram no serviço interno de São Paulo e alguns corpos de segunda linha foram até mesmo enviados para a guerra. Pela mesma razão, é um tanto difícil distinguir entre períodos de paz e períodos de guerra, já que as tensões, ameaças e confrontos concretos se estenderam intermitentemente por todo o período. Por certo, a posição de São Paulo não pode ser definida como a de palco das guerras platinas, mas isso não deve ocultar o peso da extração de recursos a elas destinados e menos ainda sua face mais visível, a intensa militarização da capitania/província.

Não se pretende que esse quadro fosse exclusivo de São Paulo. A capitania do Rio de Janeiro passou por situação semelhante, no que diz respeito ao emprego da segunda linha para fazer as vezes da tropa regular, nas décadas de 1760 e 1770. Conforme o vice-rei, "esta capitania tem só três regimentos [pagos] e que além de se acharem diminutos estão divididos nos destacamentos que tenho na Colônia, Santa Catarina e Rio Grande, e que por esta causa fazem os auxiliares muita parte do serviço que só aos pagos competia". ${ }^{142}$ Em Minas Gerais, as milícias que "supriam as praças da 1. a linha" foram despedidas do serviço da guarnição da cidade de Ouro Preto em 1830, o que indica que, assim como na vizinha São Paulo, a 2. ${ }^{\text {a }}$ linha esteve efetiva e intensamente mobilizada até as vésperas de sua exclusão da estrutura militar imperial, ocorrida em 1831. ${ }^{143}$ Situação muito semelhante teve lugar na Bahia, já que as milícias desempenharam o serviço policial na capital até o retorno das tropas regulares ocupadas na campanha da Cisplatina. ${ }^{144}$ Como se vê, fontes históricas e relatos historiográficos referentes a outros espaços e também a diferentes temporalidades indicam o protagonismo da segunda linha

\footnotetext{
$142 C f$ :: "Ofício do vice-rei a Francisco Xavier Mendonça Furtado". Rio de Janeiro, 17 de agosto de 1767. AHU_ACL_CU_017, Cx. 87, doc. 7-g. Citado em MELLO, C. F. P. de. Os corpos de auxiliares e de ordenanças..., p. 164.

${ }^{143} C f$ :: "Bilhete ao tesoureiro das tropas informando que as milícias serão retiradas do serviço da guarnição desta cidade". Ouro Preto, 05 de outubro de 1830. BN/dm, Coleção Casa dos Contos. Disponível em: <http://objdigital.bn.br/objdigital2/acervo_digital/div_manuscritos/mss1436001_1448077/mss1446518.pdf>. Acesso em: 9 jun. 2016.

144 KRAAY, Hendrik. Política racial, Estado e Forças Armadas..., p. 320-322.
} 
diante do desfalque da tropa paga, mas para se chegar a qualquer conclusão mais abrangente, faz-se necessário um exame acurado a tais casos, inviável aqui. O que se pode sugerir a partir da atuação da milícia em São Paulo é que a formação da Guarda Nacional se relaciona mais com as percepções e concepções relativas à organização social que articulavam a noção de cidadania ao universo militar, então amplamente difundidas no Ocidente, do que com uma suposta inoperância das milícias como corpo policial e militar. A investigação minuciosa do comportamento e das atividades milicianas em outras capitanias/províncias da América portuguesa e do Brasil imperial possivelmente revele que, em algumas delas, a interdependência funcional entre tropas regulares e de segunda linha somada a um quadro de extensa demanda aos escassos corpos militares profissionais produziram experiências semelhantes à de São Paulo.

Todos esses anos, décadas até, em que oficiais e soldados milicianos foram convocados a compor a guarnição da cidade e de outros pontos carentes da presença militar, além obviamente de presenciarem as demais reuniões ordinárias de seus corpos militares, foram onerosos não apenas para os cofres públicos, como incessantemente lembravam os burocratas e administradores luso-brasileiros, mas especialmente para os próprios milicianos. Como é de se esperar, a persistente retirada de trabalhadores do exercício de seus ofícios e de "chefes de domicílio" de suas casas produziu impactos sociais significativos. A face mais conhecida desse fenômeno é constituída pelas dificuldades econômicas em termos de produção agrícola e comércio de gêneros diversos. Entretanto, a intensa militarização referida afetou até mesmo a estrutura de personalidade dos milicianos, chegando, em alguns casos, a constituir situaçõeslimite.

Em uma dessas circunstâncias, no dia 20 de abril de 1827, um soldado do Batalhão de 2. ${ }^{a}$ Linha n. ${ }^{\circ} 34$, o dos pardos, decidiu evadir-se de seu posto na guarnição da cidade não sem antes dirigir seu protesto, contrário à incumbência de tais obrigações militares, a um oficial superior. Com efeito, o soldado Joaquim Antonio Galvão fazia o serviço da patrulha noturna ou sentinela quando, por volta das 21 horas, manifestou-se, aos berros, "dizendo que o comandante da guarda lhe fizera injustiça e que ele não viera ali para ganhar dinheiro e que não era de 1. 'linha para se lhe castigar daquela maneira". Essa manifestação pública do soldado, que aos 42 anos de idade vivia do ofício de carpinteiro, revela grande insatisfação na realização do serviço para o qual era coagido e que - pode-se deduzir - o impedia de executar sua profissão habitual ou, ainda, levava-o à extrema exaustão no caso de que realizasse o trabalho mecânico conjuntamente ao miliciano. Em verdade, além de qualificar como "injustiça" e "castigo" as obrigações militares compartilhadas pela $1 .^{\mathrm{a}}$ e $2 .^{\mathrm{a}}$ linhas, o soldado-carpinteiro pardo foi 
acusado de abusar "não só dos artigos como da subordinação e respeito devida ao comandante da guarda", por cujo motivo foi preso e submetido a um conselho de investigação militar. No dia seguinte, quando questionado pelas autoridades competentes, Galvão se conteve, afirmando apenas que "nada se lembra tivesse dito, talvez por ter tomado alguma bebida". ${ }^{145}$ Essa triste realidade deve ser encarada ao menos em duas vias: se, por um lado, indica a debilidade do serviço de polícia da cidade de São Paulo na década da independência, pois confiado a homens sujeitos à embriaguez, complementarmente, de outro lado, sugere que os próprios milicianos eram submetidos a situações física e mentalmente estressantes, capazes inclusive de ampliar a tendência individual e coletiva ao alcoolismo.

Florestan Fernandes, em uma instigante resenha ao livro Palmares pelo avesso, de Paulo Duarte, chamou a atenção para o problema sociológico da transformação de civis em militares bem como para as implicações, nos níveis psíquico, corporativo e para o corpo social mais amplo, da assimilação das práticas, normas e ideais militares por parte de ex-paisanos. ${ }^{146} \mathrm{E}$, com efeito, argumenta-se aqui que a delegação de amplas funções militares aos milicianos, especificamente as de policiamento urbano, induziu a transformações no habitus individual e social da coletividade em tela. Os efeitos sociais da combinação das pressões e rigores das obrigações militares com a incorporação de valores associados à autoridade e honra variaram, evidentemente, de acordo com as pessoas e grupos envolvidos. Mas em algumas circunstâncias, como já mencionado, se produziu situações-limite.

Francisco Antonio de Paula, soldado pardo do Regimento dos Úteis, passou as festas de natal e ano-novo, na virada de 1817 para 1818, preso no quartel militar em razão de ter cometido abuso de poder e desproporção no emprego da força física enquanto cumpria a função militar de sentinela na cidade de São Paulo. De acordo com um oficial militar responsável pelo destacamento da capital, a 23 de dezembro de 1817 o soldado em questão estava de sentinela no chafariz da cidade, local onde tipicamente havia alguma aglomeração de pessoas ocupadas na coleta de água, e decidiu intervir na discussão travada entre duas escravas que disputavam a primazia no acesso à fonte. As coisas não saíram bem. Francisco Antonio de Paula "dera uma grande pancada com o coice da arma na barriga de uma preta que se achava prenhe, sem que esta desse outra causa mais que o diligenciar encher um pote de água para o serviço de seu

\footnotetext{
${ }^{145} C f$ :: "Conselho de investigação feito ao soldado Joaquim Galvão, do Batalhão número trinta e quatro de segunda linha, que se acha adido a este Batalhão de Caçadores da primeira linha do Exército". APESP, ordem C02406. São Paulo, 21 de abril de 1827. Os dados pessoais e militares do soldado podem ser encontrados no Livro Mestre, fl. $170 \mathrm{v}$.

${ }^{146}$ FERNANDES, Florestan. Uma evocação da Revolução Constitucionalista. In: FERNANDES, Florestan. Mudanças sociais no Brasil: aspectos do desenvolvimento da sociedade brasileira. São Paulo: Global Editora, 2013, p. 318-338.
} 
senhor primeiro que outra", argumentou o coronel ajudante de ordens. Ainda de acordo com esse oficial, da terrível agressão "resultou sair a preta com dores, e que sendo d'ali conduzida para a casa de seu senhor abortara o filho morto, ficando ela em perigo de vida". ${ }^{147}$ Sem dispor de dados complementares ou mesmo de competência teórico-metodológica, não é possível reconstituir os traços gerais da personalidade do soldado agressor no âmbito desta tese; mas pode-se, de outra parte, ler esse lamentável fenômeno como uma consequência, ao menos parcial, da extensa militarização vivida pela configuração social da capitania/província de São Paulo, cujo processo mobilizou milhares de indivíduos técnica, física e mentalmente despreparados para o manejo das armas.

Em 14 de janeiro de 1818, após permanecer vinte dias preso, o soldado pardo requereu a liberdade alegando ser "sumamente pobre, casado, [...] sem ter vintém para comer", mas principalmente "para poder ir tratar de sua casa e família". Francisco Antonio de Paula era casado, pai de uma filha e trabalhava em uma pequena roça e no corte de madeiras. ${ }^{148}$ Ingressou na milícia no ano de 1808 com apenas 14 anos de idade e vivia nas imediações dos bairros da Penha e da aldeia São Miguel, distante do quartel militar em cerca de 25 quilômetros. Não passava dos 25 anos de idade, portanto, quando agrediu a escrava gestante. De acordo com o requerimento,

vindo [...] uma preta encher o pote de água e querendo quebrar o das outras que estavam enchendo, foi o suplicante acudir o motim, de que passou a dita preta a desautorizar o suplicante com nomes injuriosos, estando o suplicante de sentinela, que por tal deu-lhe um empurrão, parecendo-lhe assim o devia fazer, por ser desautorizado, achando-se o suplicante de sentinela, que parecia dever ser respeitado durante aquelas duas horas por aqueles indivíduos a que se propunha sua sentinela. ${ }^{149}$

Conquanto delimitada por eventuais fórmulas presentes na composição do requerimento e pelo intrínseco interesse de livrar-se da prisão, a versão do miliciano pardo para os fatos interessa aqui na medida em que fornece uma leitura acerca dos significados do serviço e autoridade militares para pessoas de baixa extração que o vivenciavam a partir das posições hierárquicas mais diminutas. Ela revela que o pequeno agricultor, uma vez fardado e armado, assimilava prontamente os ideais de autoridade e honra militar. Nesse caso específico, o soldado exacerbou a defesa de sua posição de poder esquecendo-se de outros valores exigidos ao desempenho das funções militares, tais como os de disciplina e autocontrole, e reiterando o

\footnotetext{
${ }^{147}$ Cf:: APESP, ordem C00278, doc. 42-2-51.

${ }^{148} C f$ :: APESP, Maços de população, cidade de São Paulo, bairro Penha e São Miguel, 1818, fogo 54.

${ }^{149} C f$ : : APESP, ordem C00278, doc. 42-2-51.
} 
quadro social mais vasto marcado pelo exercício de violência às mulheres e especialmente àquelas submetidas ao cativeiro. ${ }^{150}$

Os oficiais milicianos eram incumbidos da tarefa de disciplinar e controlar os integrantes localizados mais abaixo na escala militar, além, é claro, das obrigações de instrução e comando. A postura do capitão pardo José Manoel da Costa Ribeiro diante das faltas cometidas por um soldado de sua companhia exemplifica esse aspecto bem como o interesse no resguardo aos pilares da instituição militar. Em meados de 1819, o capitão informou a seu coronel que o soldado Bento José Francisco "tem sido sempre muito insubordinado e remisso nas suas obrigações". Na lista de faltas cometidas pelo soldado pardo havia ausência prolongada sem obtenção de licença, faltas no destacamento da cidade e "nos manejos do natal e páscoa, e nas arrumações dos dias de anos de sua majestade". O capitão ainda argumentou que o soldado deveria ser punido "pela sua desobediência", porque do contrário trataria de bagatela "as ordens dos seus superiores; sendo a base principal da disciplina a subordinação, e logo que esta falte de nenhum modo se poderá fazer o serviço”. Por essas razões, foi preso na primeira ocasião em que se apresentou na assembleia da companhia. ${ }^{151}$

Nesses anos em que a capitania/província convertera-se em um imenso estabelecimento militar, a busca por recrutas chegou a pontos extremos. Como o filho de um soldado pardo, residente na vila interiorana de Itu, estivesse desaparecido, o governador e capitão-general ordenou ao capitão e ao tenente responsáveis pela companhia dos pardos naquela vila para que "façam aparecer o dito rapaz em oito dias, e quando assim o não cumpram, que se me venham apresentar estes dois oficiais". ${ }^{152}$ Em outros termos, os oficiais milicianos pardos deveriam responder pela fuga do filho de um soldado de sua companhia e regimento. Uma ordem de janeiro de 1829 determinou a proibição de os soldados destacados urinarem "nos cantos do mesmo Largo [da guarda], nem tampouco no corredor de dentro do Palácio" e responsabilizou aos comandantes dos corpos militares pelo eventual descumprimento dessas normas por parte dos subordinados. ${ }^{153}$ Como se vê, o serviço militar deveria funcionar como uma rede de controle social e propagação do processo civilizacional, cuja condução estaria, em boa medida, nas mãos da oficialidade das tropas profissionais e milicianas.

\footnotetext{
${ }^{150}$ A ordem para a prisão de outro soldado do Batalhão N. ${ }^{\circ}$ 34, antigo Regimento dos Úteis, que se achando destacado dera "umas bordoadas em Manoela Maria", sugere a reiteração do fenômeno. $C f$.: Ordem do dia 16 de feveireiro de 1828. APESP, ordem E00698, fls. 151.

${ }^{151} C f:$ : APESP, ordem, C00270, doc. 37-1-17.

${ }^{152} C f$ : "Para o capitão-mor de Itu". São Paulo, 4 de novembro de 1820. APESP, ordem C00413, livro 152, fl. 18v.

${ }^{153} C f$.: Ordem do dia 19 de janeiro de 1829. APESP, ordem E00698, fl. 183v.
} 
Em resumo, cumpre notar que o serviço militar, em geral, e o miliciano, em particular, requeriam o funcionamento de mecanismos de controle e disciplina que atravessassem toda a densa hierarquia de poder associada aos postos militares. Os diversos pontos dessa teia governadores e capitães-generais, posteriormente substituídos pelos cargos de presidentes de província e governadores das armas, comandantes dos destacamentos, coronéis de milícia, oficiais de estado-maior, capitães e demais oficiais de patente, oficiais inferiores, cabos-deesquadra e, finalmente, soldados - mantinham relações de interdependência funcional entre si, as quais tendiam a ser mais evidentes de acordo com a proximidade que um ponto dessa hierarquia guardava com os outros, de modo que se constituía uma enorme cadeia de sucessivas delegações de obrigações e tarefas, controle e autoridade. Vai daí que ascender na escala miliciana significaria - para além da potencial ampliação de estima social e do manejo dos signos e elementos simbólicos os mais diversos que acompanhavam e revestiam os postos militares - a designação concreta de autoridade e comando em esfera cada vez mais ampla; por conseguinte, o ocupante de um posto elevado perceberia o acréscimo de responsabilidade pelo desempenho de suas funções militares assim como pelas executadas por seus subordinados.

Ao investigar as funções militares desempenhadas por uma corporação militar formada e identificada a homens pardos nos quadros de uma sociedade escravista é inevitável levantar o problema dos mecanismos de diferenciação social com base na cor. Ora, é sabido que a sociedade colonial organizou-se e se pensou a si mesma a partir da distinção entre brancos, pardos e pretos, dentre outras modalidades de hierarquização, e legou ao Oitocentos a tarefa de lidar com a contradição presente a uma comunidade política que declarava formalmente a abolição do princípio da diferenciação pela cor, mas que mantinha a escravidão de africanos e crioulos, pretos e pardos. Como esse problema foi encarado no universo militar?

A distribuição das funções militares pelos diferentes corpos militares revela que a tropa regular obtinha proeminência em relação às milícias em ocasiões como a das guardas de honra, ao palácio do governo, às instituições e locais que exigiam maior eficiência no policiamento, bem como nas marchas festivas e cerimoniais. Contudo, como já visto, a escassez de contingentes profissionais frequentemente elevou a milícia ao exercício dessas tarefas e a ocupar as posições de destaque. Não há notícia de que o Regimento dos Úteis tenha sido isento ou excluído integralmente do desempenho de determinadas atividades militares em razão de ser constituído por homens pardos. Antes, sabe-se que seus oficiais pardos de alto escalão conduziram a tropa em atos cerimoniais, integraram o corpo dos conselheiros em processos ligados à justiça militar, formaram a guarda do palácio em determinadas circunstâncias e chefiaram o contingente miliciano nos destacamentos. Ademais, a corporação, em sua 
totalidade, devia observar as normas de continência militar. ${ }^{154}$ Todas essas eram situações em que brancos e pardos estabeleciam contato e eram obrigados a respeitar mutuamente a hierarquia e os postos militares, de forma que um oficial pardo mereceria as saudações e respeito de brancos ocupantes de postos inferiores tanto quanto inferiores pardos deviam reverência a superiores brancos.

São bem conhecidas as tensões que grassaram na América espanhola em torno da aplicação da etiqueta militar indistintamente a brancos, pardos e morenos. ${ }^{155}$ Entretanto, do volumoso corpo de fontes disponível para São Paulo não se infere a recorrência de situações conflituosas diante dessa questão e mesmo de outras inter-relacionadas ao exercício das atividades militares. Alguns indícios permitem sugerir que os pardos de São Paulo reconheciam sua posição naquela configuração social, em geral inferior à dos brancos. Ao mesmo tempo, a circunstancial presença dos oficiais milicianos pardos, e mesmo do conjunto da corporação, em posições de prestígio e honra contribuía para a manutenção do equilíbrio social. Um exemplo interessante de como a atribuição de funções militares atuava respeitando as posições sociais dos grupos encontra-se na distribuição dos corpos militares para a guarda das igrejas da capital por ocasião das celebrações religiosas da semana santa na década de 1820. Em 1824, os dois regimentos milicianos identificados aos brancos ficaram responsáveis pelas igrejas da Sé e do Carmo. A igreja de São Francisco foi guarnecida pela cavalaria de linha ao passo que a de São Bento o foi pela cavalaria miliciana. A artilharia de linha deveria montar sua guarda em frente à igreja de Santa Tereza e, finalmente, o 3. ${ }^{\circ}$ Regimento Miliciano, formado pelos pardos, foi designado para a igreja da Boa Morte. ${ }^{156}$ Como se vê, os milicianos pardos estavam presentes às funções cerimoniais, mas em uma posição adequada à qualidade ou status social do grupo e corpo militar. A guarda das mais prestigiadas igrejas da cidade de São Paulo era privilégio, nessa ordem, dos corpos militares de linha, da cavalaria miliciana e da infantaria miliciana constituída por brancos. Numa composição que se repetiu nos anos de 1827 e 1828, os pardos montaram sua guarda defronte à Boa Morte, onde, afinal, costumavam frequentar, e também na igreja de Santa Teresa, onde funcionava um recolhimento feminino sem o caráter "professo". 157 Em suma, estava em funcionamento um arranjo fundado na mescla de critérios tipicamente militares e de outros atinentes à hierarquização social em geral.

\footnotetext{
154 Cf:: APESP, ordem E00698, fls. 115-116, 124v-125; "Batalhão de Infantaria da 2. linha e guarnição desta cidade, roteiro das guardas da guarnição, em 21 de março de 1823”. APESP, ordem C02385, doc. sem número. 155 KUETHE, Allan J. The status of the free pardo in the disciplined militia of New Granada. The Journal of Negro History, v. 56, n. 2, p. 105-117, apr./1971.

${ }^{156} C f$ : APESP, ordem E00675, fls. 2v-3. São Paulo, 12 de abril de 1824.

${ }^{157} C f:$ : APESP, ordem E00698, fls. 126v e 154v. São Paulo, 11 de abril de 1827 e 2 de abril de 1828.
} 


\section{PARTE 2}




\section{Capítulo 4 - Origem social dos milicianos pardos de São Paulo. Condição SOCIAL, COR E FAMÍLIA}

\subsection{A cor parda dos milicianos: reiteração e transformação}

A variável "cor" era central na organização da estrutura militar das sociedades escravistas americanas. ${ }^{1}$ Como já se sabe, o Regimento Miliciano dos Úteis era identificado aos homens pardos. Os registros formais da corporação atestam que 1.107 homens foram nela matriculados entre os anos 1811 e 1831, havendo, dentre eles, dez oficiais militares brancos procedentes das tropas de linha. Como resultado, eram pardos os demais 1.097 milicianos que compunham a imensa maioria de integrantes do regimento. A implicação lógica dessa constatação é que, considerados pardos, eles não eram brancos, pretos e tampouco índios - ou seja, não cabiam adequadamente nas outras categorias de cor em que se pautava a organização das milícias. ${ }^{2}$ Contudo, esse tipo de inferência resulta pouco eficaz para a compreensão daqueles homens como atores sociais. Faz-se necessário e urgente, como destacado no início desta tese, problematizar os pardos a partir de "dentro", isto é, buscar caracterizá-los a partir de suas próprias dinâmicas e ações sociais, e, paralelamente, examiná-los em sua relação de interdependência para com os demais grupos. Afinal, o que a categoria "pardo" informa sobre as pessoas e a coletividade às quais ela era aplicada? O que ela eventualmente oculta? De modo mais preciso, qual a origem e a condição social dos homens a ela identificados? Antes de explorar os significados e implicações da categoria pardo, é preciso tecer um breve panorama das tendências historiográficas em torno do papel da cor na organização social.

\footnotetext{
${ }^{1}$ Uma interessante abordagem para o caso luso-brasileiro em KRAAY, Hendrik. Política racial, Estado e Forças Armadas na época da independência: Bahia, 1790-1850. Trad. Magda Lopes. São Paulo: Hucitec, 2011, p. 46-47. 2 É evidente que a categoria "índio" não se reduz a uma "cor". No entanto, nos recenseamentos paulistas, era nesse campo que os índios eram indicados, assim como o eram os brancos, pardos/mulatos e pretos/negros. Provavelmente, a mesma lógica era aplicada às milícias nas regiões em que existiam corporações de brancos, de índios, de pardos e de pretos. Mais adiante será abordada detalhadamente a categoria "cor" com referência ao Brasil colonial, os seus significados e as interpretações historiográficas mais recentes.
} 


\subsubsection{Os debates sobre a cor e sobre os pardos na historiografia}

Há algumas décadas que, no Brasil, a classificação da população que viveu entre os séculos XVI e XIX deixou de figurar primordialmente como instrumento analítico "neutro" e se tornou de fato objeto de estudos. Isto é, o emprego cientificamente seguro das diferentes categorias que organizavam a distribuição dos homens nos espaços físico e, sobretudo, social cedeu espaço ou passou a ser precedido pela reflexão em torno da construção e do papel social desempenhado por tais categorias. Esse movimento corresponde a transformações paradigmáticas mais amplas no seio da História e das Ciências Sociais em geral, cabendo aqui menção especial aos questionamentos que incidiram sobre os modelos estruturalistas vigentes até os anos 1970 e, como decorrência, ao surgimento de inúmeras propostas teóricometodológicas daí em diante. No campo historiográfico, vale citar, por exemplo, o advento da Nova História Inglesa e da Micro-História italiana, que buscaram estabelecer um diálogo mais estreito com a antropologia. ${ }^{3}$ A partir de então, os estudos históricos rapidamente perceberam transformações no modo como várias dimensões da realidade - tais como política, economia, cultura e sociedade - passaram a ser encaradas. Nesse novo paradigma, passou-se a evidenciar os limites do emprego de categorias de análise preestabelecidas, estáticas e alheias à realidade observada, por um lado, bem como a defender a pertinência do emprego de categorias manejadas no universo examinado, de outro lado. Tal postura implicaria levar em conta a construção e o papel social desempenhado pelas categorias utilizadas na observação e análise da realidade histórica, sejam elas científicas ou coevas à sociedade examinada. ${ }^{4}$ Desse modo, as noções relacionadas à "raça" e "cor" sofreram um processo de desconstrução, que se desenrola até hoje, semelhante ao qual passaram outros eixos ou categorias comumente empregados para se pensar a organização social, como é o caso da classe, gênero, escravidão, cultura e economia. ${ }^{5}$ Ao mesmo tempo, tem-se apostado na relevância da utilização de noções

\footnotetext{
${ }^{3}$ THOMPSON, E. P. Costumes em comum. São Paulo: Companhia das Letras, 1998. Quanto à micro-história, vários textos da seguinte coletânea tratam do contexto de formação desse método ou paradigma: OLIVEIRA, Mônica Ribeiro de; ALMEIDA, Carla Maria Carvalho de (Orgs.). Exercícios de micro-história. Rio de Janeiro: Editora FGV, 2009.

${ }^{4}$ Michel Certeau, por exemplo, alertou para o peso do "lugar social" do investigador, sugerindo que as opções científicas estão, elas próprias, imersas em relações de poder e que, portanto, não são isentas de parcialidade. CERTEAU, Michel de. A escrita da história. Trad. Maria de Lourdes Menezes. Rio de Janeiro: Forense Universitária, 1982, p. 23-119.

${ }^{5}$ Sobre classe, ver THOMPSON, Edward P. A formação da classe operária. (3 v.). Trad. Denise Bottmann. Rio de Janeiro: Paz e Terra, 1987. Sobre escravidão, ver KOPYTOFF, Igor; MIERS, Suzanne. African 'slavery' as an institution of marginality. In. MIERS, Suzanne; KOPYTOFF, Igor (Eds.). Slavery in Africa. Historical and anthropological perspectives. Madison: The University of Wisconsin Press, 1979, p. 12-20; PATTERSON, Orlando. Escravidão e morte social. São Paulo: Edusp, 2008, p. 350-354.
} 
pertencentes ao universo examinado. A disseminação do emprego do conceito "qualidade" para o estudo da sociedade escravista brasileira é exemplar dessa tendência. ${ }^{6}$

O ponto de partida para a compreensão dos significados, definições e usos da categoria "pardo" - como de qualquer outra referente à "cor" - é a sua desnaturalização, isto é, o reconhecimento de que as "cores", "raças", "qualidades", "etnias" ou "identidades" - enfim, os conjuntos mais amplos que lhe podem servir de referência - são construções sociais. Sendo um produto social, a categoria pardo é dotada de historicidade e está impregnada das relações de poder vigentes nos universos aos quais faz parte. A propósito, "pardo" será considerado aqui como uma cor. A cor como construção social é uma definição quase axiomática na literatura recente. Dela partilham inúmeros historiadores, os quais, contudo, como se verá adiante, apresentam perspectivas divergentes entre si no tocante à interpretação do processo de construção social das cores, de seus esquemas classificatórios e de suas definições ou significados.

Os fenômenos da construção social da cor e, particularmente, das categorias fundamentais empregadas no Brasil entre os séculos XVI e XIX, devem ser encarados em perspectiva abrangente. Sabe-se que a expansão ultramarina iniciada no século XV e o decorrente contato entre populações de diferentes territórios desempenharam papel decisivo na elaboração de quadros mentais genéricos referentes aos agrupamentos humanos envolvidos. Assim é que se tornou possível a construção e a imposição de uma perspectiva continental a espaços constituídos por territórios que outrora não eram percebidos como unidade. É o caso da invenção da Europa a partir do contraste com a África, primeiramente, e depois com o Oriente e com a América - territórios igualmente forjados por intermédio do contato e do contraste. ${ }^{7}$ Paralelamente, algo semelhante ocorreu no tocante à nação, à etnia e à cor. $\mathrm{O}$ heterogêneo contingente humano que vivia em terras americanas, reunido em inúmeras nações ou agrupamentos os mais diversos, jamais havia se percebido como indígena. Ao contrário de uma autoidentificação, essa categoria lhes foi imposta. Com efeito, índio é uma típica categoria colonial que sinalizava a diferença entre conquistado e conquistador e, implicitamente, o exercício de domínio por parte dos europeus brancos. ${ }^{8}$ Nesse mesmo sentido, a possibilidade de autoidentificação entre os brancos - ou melhor, a percepção de que compartilhavam uma

\footnotetext{
${ }^{6}$ PAIVA, Eduardo França. Dar nome ao novo: uma história lexical da Ibero-América entre os séculos XVI e XVIII (as dinâmicas de mestiçagens e o mundo do trabalho). Belo Horizonte: Autêntica Editora, 2015.

${ }^{7}$ TILLY, Charles. Coerção, Capital e Estados Europeus (990-1992). Trad. Geraldo Gerson de Souza. São Paulo: Edusp, 1996, p. 89-97.

${ }^{8}$ BATALLA, Guillermo Bonfil. El concepto de indio en América: una categoría de la situación colonial. In: BATALLA, G. B. Identidad y pluralismo cultural en América Latina. Puerto Rico: Fondo Editorial del CEHASS, 1992.
} 
realidade em comum capaz de, em certas circunstâncias, se sobrepor às diferenças existentes entre eles próprios - se deu necessariamente em função do contraste com os outros, ou seja, aqueles de cor preta, no caso das pessoas oriundas da África, e aos de cor parda ou vermelha, no caso dos habitantes da América. Nesse sentido, a variável cor remete a signos exteriores capazes de expressar a identidade de um grupo e ao mesmo tempo as máculas sociais imputadas aos demais grupos. Ela é um instrumento empregado para diferenciar e hierarquizar pessoas e grupos. Portanto, mesmo as gradações de cor de pele mais comuns passaram por processos de construção social e são dotadas de historicidade.

Acresce a esse quadro o fato de que o fenômeno da mestiçagem marcou profundamente as sociedades escravistas modernas, e notadamente as ibero-americanas. Se a classificação das pessoas por cor se mostrava viável no início da colonização tendo-se como base as categorias elementares branco, pardo e preto, com o passar do tempo o intercurso entre as populações complicou os esquemas classificatórios. Havia pretos que não eram tão pretos, brancos um pouco escuros e pardos disfarçados. Logo, a classificação com base na cor tendeu a expandirse para comportar a diversidade social produzida pela miscigenação. São bem conhecidos os quadros de castas produzidos na América espanhola que exemplificam o intento local em demarcar com precisão os tipos humanos resultantes daquilo que se entendia como mesclas de sangue africano com o de brancos, índios ou mestiços. ${ }^{9} \mathrm{Na}$ América portuguesa também houve uma profusão de categorias de cor referentes principalmente aos mestiços, mas essas não foram submetidas à rigidez e ao formalismo observados no caso hispano-americano. A esse respeito, o inglês Henry Koster, que viveu em Pernambuco nas primeiras décadas do século XIX, revelou-se surpreso pela relativamente pequena diferença lá existente entre pessoas de diferentes gradações de cor, "se eles são todos pobres ou se nasceram livres", em comparação a outros espaços coloniais e escravistas. "É surpreendente", prossegue ele, "porque nas colônias da Inglaterra, França e Holanda, as distinções são decididamente marcadas, e no meio dos Espanhóis as linhas estão estabelecidas entre as várias gradações da cor". ${ }^{10}$ Mulato, cabra, bode, mamaluco, caboclo, entre outros, foram termos cunhados ou utilizados extensamente na realidade colonial luso-americana. O emprego dessas categorias era difuso, pois dependia da região, da época e do lugar social de produção e enunciação do discurso ou representação. É de se notar que várias das categorias de cor referentes aos mestiços sequer aludiam a um "catálogo

\footnotetext{
${ }^{9}$ Sobre quadros de castas, ver CASTRO MORALES, Efraín. Los cuadros de castas de la Nueva España. Trad. Institute of Latin America Studies, University of London. Jahrbuch für Geschichte von Staat, Wirtschaft, und Gesellschaft Lateinamerikas, n. 20, 1983.

${ }^{10}$ Cf:: KOSTER, Henry. Viagens ao Nordeste do Brasil. Trad. Luiz da Camara Cascudo. São Paulo; Recife; Rio de Janeiro: Companhia Editora Nacional, 1942, p. 400.
} 
de cores", já que recorriam ao universo animal para classificar pessoas. Apesar de que os pardos eram assim identificados em função da semelhança existente entre sua cor e a do pardal ${ }^{11}$, para mulatos, cabras e bodes, na América portuguesa, e mulatos, lobos e coyotes, na hispanoAmérica, a justificativa era de natureza diferente, sendo a relação com os animais sempre de caráter depreciativo.

A harmonia que caracterizava a relação estabelecida entre os sistemas classificatórios coloniais fundados na diversidade de "cores" e a governabilidade (ou gestão das populações abrigadas sob o território estatal) passou a apresentar incompatibilidades da segunda metade do século XVIII em diante, em cujo período esteve em curso um processo tendente à homogeneização das categorias de cor empregadas pelos órgãos centrais de Estado. ${ }^{12} \mathrm{~A}$ intensa e persistente mestiçagem, por um lado, e a aplicação da racionalidade administrativa ilustrada, por outro, são componentes centrais desse processo. No que diz respeito à realidade da América espanhola, a historiografia se refere ao esfacelamento das castas em fins do Setecentos, isto é, a ineficácia das inúmeras categorias que visavam a demarcar com precisão e em perspectiva geracional os graus de sangue africano e de mestiçagem que constituíam cada indivíduo. Em decorrência da inviabilidade de se apreender por meio das categorias usuais a notável heterogeneidade populacional, os termos designativos de cor tenderam a ser cada vez mais genéricos. ${ }^{13}$ Já no caso da América portuguesa, alguns estudos indicam, de diferentes formas, a construção de um sistema de classificação de cores tripartite em fins do século XVIII. Hebe M. Mattos destacou o processo de crescente abrangência e consolidação da categoria genérica pardo livre, cuja função seria distinguir a população livre distanciada do cativeiro mas que ainda trazia as marcas desse passado - e para a qual não caberiam o termos preto ou branco. ${ }^{14}$ Por sua vez, Muriel Nazzari examinou uma reforma na confecção dos recenseamentos promovida em 1798 pelo ministro e secretário de Estado da Marinha e Domínios Ultramarinos, D. Rodrigo de Souza Coutinho, a qual padronizou as categorias descritoras de cor - sendo elas

\footnotetext{
${ }^{11}$ Cf:: BLUTEAU, Raphael. Vocabulário portuguez \& latino: aulico, anatômico, architectonico [...]. Coimbra: Collegio das Artes da Companhia de Jesus, 1712-1728. 8 v. Verbete "Pardo", Vol. 5, p. 265.

${ }^{12}$ MORSE, Richard. O espelho de próspero. São Paulo: Companhia das Letras, 2000, p. 76, 81; BLACKBURN, Robin. A construção do escravismo no Novo Mundo. Do barroco ao moderno (1492-1800). Rio de Janeiro: Record, 2003, p. 34-44.

${ }^{13}$ BELTRÁN, Aguirre. La población negra de México: estudio etno-historico. México: Fondo de Cultura Económica, 1989, p. 277-292. Um brevíssimo balanço dessa questão se encontra em MARCHENA FERNÁNDEZ, Juan; GARAVAGLIA, Juan Carlos. Mestizos y mulatos en la sociedad colonial. In.: MARCHENA FERNÁNDEZ, J.; GARAVAGLIA, J. C. America latina: de los orígenes a la independencia. (v. 2). Barcelona: Crítica, 2005, p. 355-359.

${ }^{14}$ MATTOS, Hebe. Escravidão e cidadania no Brasil monárquico. Rio de Janeiro: Jorge Zahar Editor, 2004, p. 16-18.
} 
branco, pardo e preto -, e explorou o impacto dessa medida em relação aos esquemas de classificação até então vigentes. ${ }^{15}$

Os pesquisadores reconhecem que nas sociedades escravistas modernas a classificação das pessoas com base na cor não se referia unicamente à cor de pele. Em determinadas circunstâncias, as cores revelavam muito sobre a origem, estima, posição e condição social das pessoas classificadas, de modo tão ou mais contundente do que o faziam as variáveis gênero, ocupação e religião, por exemplo. São significativos o testemunho setecentista de Domingos Loreto Couto e o relato oitocentista de Henry Koster. Ao escrever sobre a sociedade colonial pernambucana, Couto dividiu-a em "nobreza", de um lado, e "homens mecânicos" e demais "povo miúdo", de outro. Apesar de essa divisão primar pela simplificação ao considerar apenas dois grandes agrupamentos, ele expressou a dificuldade em reconhecer com precisão "quais sejam os homens da plebe: porque todo aquele que é branco na cor, entende estar fora da esfera vulgar". Para os brancos, portanto, "o mesmo é ser alvo que ser nobre”, e o exercício de ofícios mecânicos nem de longe abalaria essa percepção. A despeito de os pardos "mal se acomoda[rem] com as diferenças" e de os pretos sentirem-se "como os brancos" logo que obtivessem a liberdade, Couto aparentemente se deparou com menos estorvos para localizá-los em meio ao vulgo. ${ }^{16}$ Como se percebe, a descrição em questão trabalha com o entrelaçamento dos critérios de diferenciação social fundados na "nobreza" e na "cor" e enfatiza o modo como a justaposição dessas variáveis se exprimia informalmente, mas com notável vigor, nas percepções cotidianas. Tal era a importância da escravidão como elemento estruturador da sociedade colonial que as cores parda e preta, sendo encaradas como símbolos do cativeiro, estavam diretamente associadas à "esfera vulgar". Elas seriam incompatíveis com o ideal aristocrático.

Correlatamente, o escravismo produziu transformações significativas na própria percepção social estamental vigente no Brasil. Uma vez que a cor branca assumiu acepção diametralmente oposta à cor preta, não era raro que os indivíduos reconhecidos como alvos, precisamente por essa característica, se sentissem socialmente distanciados do universo vulgar compartilhado pela plebe, ainda que estivessem profundamente comprometidos com o trabalho manual e mesmo que não possuíssem quaisquer credenciais formais para arrogarem uma tal diferenciação. Nesses termos, a cor branca poderia acenar para a liberdade e, mais do que isso,

\footnotetext{
${ }^{15}$ NAZZARI, Muriel. Vanishing Indians: the social construction of race in colonial São Paulo. The Americas, v. 57, n. 4, p. 497-524, abr./2001.

${ }^{16}$ Cf:: COUTO, Domingos do Loreto. Desagravos do Brasil e Glória de Pernambuco. Rio de Janeiro: Officina Typographica da Biblioteca Nacional, 1904, p. 226-227.
} 
também sugerir proximidade ou pertencimento à nobreza. Uma faceta interessante da relação de interdependência recíproca estabelecida entre as cores, estando uma associada a posições sociais superiores em função da identificação das outras às posições sociais inferiores e viceversa, se expressa no famoso e já referido trecho do relato de Koster: "Conversando numa ocasião com um homem de cor que estava ao meu serviço, perguntei-lhe se certo Capitão-Mor era mulato. Respondeu-me: Era, porém já não é! E como lhe pedisse eu uma explicação, concluiu: - Pois Senhor, um Capitão-Mor pode ser Mulato?". ${ }^{17}$ Eis aí um significativo testemunho acerca da percepção social relativa à cor produzida pelo escravismo: foi um modesto trabalhador mulato quem afirmou que sua cor era incompatível com as posições sociais de prestígio para as quais a cor branca serviria adequadamente. Além da relação entre a cor e a condição social, esse excerto diz respeito igualmente ao fenômeno da mudança de cor. Como se verá adiante, essas duas temáticas estão presentes nas principais abordagens historiográficas sobre o tema.

Na historiografia brasileira, Hebe M. Mattos e Sheila de C. Faria propuseram de modo enfático a correlação entre cor e condição social e instigaram um debate interessantíssimo. ${ }^{18}$ Conforme argumentaram, tendencialmente "preto" e "negro" estariam diretamente associados à escravidão, tanto quanto, pode-se deduzir, "branco" ao universo da liberdade. Ademais, como a dinâmica de funcionamento do escravismo ibérico dava margem ao fenômeno das manumissões, fez-se preciso tornar identificável a condição jurídica dos libertos bem como os níveis de afastamento do cativeiro por parte dos descendentes de escravos nascidos livres e que não podiam ser considerados brancos e nem pretos. Essa - e não necessariamente a indicação de origem mestiça - constituiria a principal função assumida pela categoria "pardo livre" em fins do período colonial. ${ }^{19}$

\footnotetext{
${ }^{17}$ Cf:: KOSTER, Henry. Viagens ao Nordeste do Brasil. Trad. Luiz da Camara Cascudo. São Paulo; Recife; Rio de Janeiro: Companhia Editora Nacional, 1942, p. 480.

${ }^{18}$ MATTOS, Hebe. Escravidão e cidadania no Brasil monárquico. Rio de Janeiro: Jorge Zahar Editor, 2004, p. 16-18; MATTOS, Hebe. Racialização e cidadania no Império do Brasil. In: CARVALHO, José Murilo de; NEVES, Lúcia Maria Bastos Pereira das (Orgs.). Repensando o Brasil do Oitocentos: cidadania, política e liberdade. Rio de Janeiro: Civilização Brasileira, 2009, p. 356-357; FARIA, Sheila de Castro. A colônia em movimento: fortuna e família no cotidiano colonial. Rio de Janeiro: Ed. Nova Fronteira, 1998, p. 135-139; VIANA, Larissa. O idioma da mestiçagem: as irmandades de pardos na América portuguesa. Campinas: Editora da UNICAMP, 2007; GUEDES, Roberto. Egressos do cativeiro: trabalho, família, aliança e mobilidade social (Porto Feliz, São Paulo, c. 1798-c. 1850). Rio de Janeiro: Mauad X: FAPERJ, 2008, p. 17-28. Outros estudos que vão na mesma linha são os de MACHADO, Cacilda da Silva. A Trama das Vontades. Negros, pardos e brancos na produção da hierarquia social (São José dos Pinhais - Pr, passagem do XVIII para o XIX). Tese (doutorado em História). Rio de Janeiro: IFCS, Universidade Federal do Rio de Janeiro, 2006; LIBBY, Douglas Cole. A empiria e as cores: representações identitárias nas Minas Gerais dos séculos XVIII e XIX. In: PAIVA, E. F.; IVO, I. P.; MARTINS, I. C. (Orgs.). Escravidão, mestiçagens, populações e identidades culturais. São Paulo: Annablume; Belo Horizonte: PPGH-UFMG; Vitória da Conquista: Edições UESB, 2010.

${ }^{19}$ MATTOS, Hebe. Escravidão e cidadania..., p. 16-18.
} 
Igualmente amparado na formulação "cor/condição", isto é, na plena correspondência entre uma variável e outra, Roberto Guedes examinou trajetórias de famílias de pardos escravos, forros e livres entre fins do século XVIII e a primeira metade do XIX, na vila paulista de Porto Feliz. Seu estudo forneceu contribuições altamente sugestivas quanto à relação estabelecida entre mobilidade social e mudança de cor, notadamente ao demonstrar que processos ascensionais que culminavam na obtenção de um modo de vida senhorial, mediante a posse de escravos e o acesso às patentes militares, nobilitavam e, não raro, embranqueciam as famílias pardas. As mudanças de cor eram registradas nas listas nominativas e nos registros paroquiais locais. Embora evite restringir a cor preta à condição escrava e a cor parda à condição de pessoa liberta ou livre com vinculação geracional ao cativeiro, a correlação entre cor e condição social fica manifesta quando Guedes sugere a tendência de que, numa perspectiva “geracional/familiar", à condição nobre corresponderia a cor branca e, de modo implícito e complementar, que a cor parda seria incompatível com a nobreza. ${ }^{20}$

Enquanto vários historiadores subscreveram a hipótese de Hebe M. Mattos atinente ao amálgama entre cor e condição ${ }^{21}$, outros questionaram, direta ou indiretamente, os aspectos mais generalistas da formulação em questão. É o caso de Silvia H. Lara, que, assim como vários historiadores, têm recorrido ao argumento de A. J. Russell-Wood, conforme o qual o instrumento analítico da pirâmide social seria inadequado para a sociedade escravista brasileira, cuja compreensão exige modelos alternativos que comportem as inúmeras possibilidades de entrelaçamento entre os diversos fatores que constituíam a base de sua organização social fluída. ${ }^{22}$ Nessa linha, Lara argumenta que, em virtude da importância assumida pela escravidão na organização social da América portuguesa, a distinção básica entre nobres e povo comum ("peões", "plebeus", "mecânicos"), vigente na Europa de Antigo Regime e transplantada para a América, percebeu na colônia o incremento da diferenciação com base na cor - a qual, afinal, tornou-se o "critério [...] prevalente". ${ }^{23}$ A cor funcionaria como uma marca exposta publicamente pelas pessoas ao longo de suas vidas, e por onde quer que fossem, sugerindo aspectos relevantes para a localização dos indivíduos no continuum escravidão-liberdade. Se Lara reconheceu a centralidade da diferenciação com base na cor e na condição social, ela

${ }^{20}$ GUEDES, Roberto. Egressos do cativeiro..., p. 275.

${ }^{21}$ GUEDES, Roberto. Egressos do cativeiro...; MACHADO, Cacilda da Silva. A Trama das Vontades...; VIANA, Larissa. O idioma da mestiçagem...

22 RUSSELL-WOOD, A. J. R. Escravos e libertos no Brasil colonial. Trad. Maria Beatriz de Medina. Rio de Janeiro: Civilização Brasileira, 2005, p. 119; LARA, Silvia Hunold. Fragmentos setecentistas: escravidão, cultura e poder na América portuguesa. São Paulo: Companhia das Letras, 2007, p. 282-283; PESSOA, Raimundo Agnelo Soares. Gente sem sorte: os mulatos no Brasil colonial. Tese (doutorado em História). Franca: FHDSS, Universidade Estadual Paulista "Júlio de Mesquita Filho", 2007, p. 11-14.

${ }^{23}$ LARA, Silvia Hunold. Fragmentos setecentistas..., p. 102-103. Vide igualmente os capítulos 2 e 3 e a conclusão. 
também destacou o entrecruzamento de variáveis no estabelecimento da hierarquia social lusoamericana. Conforme expressou, "a correspondência entre cor e condição social não caminhava de modo direto, mas transversal, passando por zonas em que os dois aspectos se confundiam ou se afastavam, e em que critérios díspares de identificação social estavam superpostos". ${ }^{24}$

Assim como Lara, Jocélio Teles Santos dialoga implicitamente com o argumento da correlação entre cor e condição social, levado a efeito por Mattos, e, através de seu estudo de caso, fornece nuances interessantes para a questão. Santos examinou o que ele denomina "sistema de classificação racial" operante na Santa Casa de Misericórdia da cidade de Salvador entre os séculos XVIII e XIX. Esse sistema era composto por categorias básicas e recorrentes - branco, pardo e preto - e se complexificava extraordinariamente por intermédio da combinação entre essas e categorias ainda mais detalhistas, resultando em categorias múltiplas, a exemplo de "branco bastante moreno", "pardo claro" ou "pardo bastante trigueiro". A atribuição da "cor social" seria o resultado da percepção social quanto aos aspectos biológicos e sociais que constituíam cada indivíduo. O fabuloso leque de cores e suas combinações permitiu a Santos sugerir o caráter heterogêneo e multipolar desse "sistema de classificação racial". ${ }^{25}$

Por sua vez, Douglas Cole Libby fez ressalvas mais diretas à argumentação de Hebe M. Mattos - notadamente quanto à definição oferecida por ela à cor parda. Amparado em amplo e diversificado conjunto documental e circunscrito à paróquia mineira de São José do Rio das Mortes entre meados do Setecentos e meados do Oitocentos, chamou a atenção para a incidência de inúmeras variantes em torno dessa cor. Ela poderia ser aplicada tanto a indivíduos em situação de cativeiro quanto a libertos e livres. Ainda conforme Libby, apesar de que "tais representações poderiam se carregar de significados mais indicativos de posição social do que de identidade racial", deve-se considerar, no caso da cor parda, "a possibilidade de uma forte e persistente conotação de mestiçagem racial, a qual, ao final das contas, sempre denotou de maneira implícita alguma ascendência escrava", ${ }^{26}$

Em síntese, a desconstrução da "cor" como conceito ou representação naturalizada e estática conduziu os historiadores e cientistas sociais a aceitarem a noção de que a cor, construída socialmente, expressava muito mais do que a tonalidade de pele no universo colonial e escravista. Após a historiografia receber o impacto da instigante argumentação concernente à

\footnotetext{
${ }^{24}$ LARA, Silvia Hunold. Fragmentos setecentistas..., p. 131.

${ }^{25}$ SANTOS, Jocélio Teles. De pardos disfarçados a brancos pouco claros: classificações raciais no Brasil dos séculos XVIII-XIX. Afro-Ásia, 32 (2005), 115-137.

${ }^{26}$ LIBBY, Douglas Cole. A empiria e as cores..., p. 46-47.
} 
equivalência entre cor e condição social, verifica-se uma tendência à promoção de equilíbrio entre esse aspecto e a polissemia dos usos e significados das cores. Vai daí as ênfases concedidas aos processos de mestiçagem, à fluidez e diversidade da sociedade e também para o papel da cor na construção de identidades étnicas e "raciais".

Acrescente-se ainda a noção, absolutamente central no âmbito desta tese, de que as designações de cor funcionavam como um componente fundamental das relações estabelecidos/outsiders no universo colonial e escravista. ${ }^{27}$ Isto é, as cores faziam parte das disputas por poder e, dependendo da posição dos grupos na competição, podiam tomar a forma de um autoelogio ou de um estigma social. No caso em questão, a cor branca referia-se aos grupos detentores das maiores concentrações de poder, e, por essa razão, evocava uma gama elevada de virtudes e qualidades superiores; já as cores mais escuras, como é o caso da parda e da preta, correspondiam às pessoas de condição social inferior e desempenhavam a função de estigmas sociais capazes de revelar facilmente a origem escrava e/ou ameríndia de seus portadores, essa entendida como fonte de vícios e defeitos. De modo análogo, pardos consideravam-se superiores a pretos, assim como pretos crioulos a africanos, e livres ou libertos a escravos, o que demonstra que os estigmas sociais eram reconhecidos e mobilizados por todo o corpo social e que a sua constituição se assentava em múltiplas variáveis. Mudanças no modo como o espectro das cores era socialmente concebido configuram uma chave interessante para se perceber mudanças nos equilíbrios de poder entre os grupos interdependentes. Nesse sentido, o recurso empregado pelos milicianos pardos de São Paulo quando da formação do Regimento, ao associarem a sua cor ao ideário da utilidade à Monarquia, de certo modo até eclipsando-a, é aqui interpretado como um esforço no sentido da desestigmatização do grupo.

Após essa incursão historiográfica, é pertinente retomar as perguntas iniciais desse capítulo, que versam sobre a relação estabelecida entre os milicianos e a cor parda. Aqui o intuito passa a ser menos a busca por definição formal para a categoria pardo e mais a compreensão de seu processo de construção social a partir do caso de São Paulo, o qual, enfim, fornecerá elementos para um melhor entendimento tanto da origem como da experiência social dos pardos forros e livres em questão. Evidentemente, o foco estará nos integrantes das companhias Setecentistas de ordenanças e auxiliares dos pardos, mas principalmente nos milicianos do Regimento dos Úteis - para os quais os registros históricos produzidos e preservados são mais abundantes e generosos em informações.

\footnotetext{
${ }^{27}$ ELIAS, Norbert; SCOTSON, John L. Os estabelecidos e os outsiders. Sociologia das relações de poder a partir de uma pequena comunidade. Trad. Vera Ribeiro. Rio de Janeiro: Jorge Zahar Editor, 2000, p. 19-50.
} 


\subsubsection{Origem social e cor dos integrantes das companhias setecentistas de pardos e de pretos em São Paulo}

No alvorecer do século XIX, quase 50 mil pessoas de cor livres ou libertas, a maioria das quais parda, viviam na capitania de São Paulo. Mas, se, como já visto, a região vinculou-se ao tráfico transatlântico de escravos apenas nas décadas finais do século XVIII, como explicar a existência prévia de um segmento de pardos forros e livres já bem consolidado? A historiografia referente à São Paulo, de modo geral, relegou esse problema a um segundo plano. Dentre os poucos estudiosos que o encararam, Holanda interpretou que o alargamento pujante da presença de negros e mulatos no ramo do artesanato, verificado entre 1765 e 1822, seria um bom indicativo da crescente introdução de cativos na capitania. Logo, deduz-se que os pardos descenderiam diretamente dos cativos africanos recém-incorporados. ${ }^{28} \mathrm{Já}^{\mathrm{B}}$ Bastide e Fernandes sugeriram que a decadência da mineração em Minas Gerais, Goiás e Mato Grosso gerou um refluxo de população para a capitania paulista. Apesar de se referirem apenas aos escravos negros, é lícito supor que os sociólogos concordariam quanto à participação de pretos e pardos forros e livres, provavelmente em menor volume, naquele mesmo movimento migratório. ${ }^{29}$ Por sua vez, Luna e Klein apostaram nas elevadas taxas de manumissão, as quais incidiam mais comumente sobre mulheres, como fator explicativo para a formação da população parda livre de São Paulo. ${ }^{30}$

Por outro lado, a historiografia atenta ao universo social dos indígenas e seus descendentes mestiços tem revelado aspectos muito sugestivos acerca da incorporação desse vasto contingente à categoria dos pardos ou das pessoas livres de cor. Em primeiro lugar, demonstrou-se que os indígenas submetidos a trabalho compulsório sob a forma de administrados eram passíveis de transmissão a terceiros via inventários e de obterem alforria, como ocorria com os escravos. Ademais, verificou-se em São Paulo colonial a vigência dos casamentos mistos envolvendo pessoas de origem indígena e africana, cujas uniões eram estimuladas ou mesmo forçadas por proprietários de escravos visando-se à ampliação da mão de obra. Nesse caso, bem como quando o administrado conquistava alforria, era designado "forro". Esse termo tornou-se generalizado, conforme Goldschmidt, após a Lei de Liberdade

\footnotetext{
${ }^{28}$ HOLANDA, Sérgio Buarque de. Prefácio. In: QUEIROZ, S. R. R. de. Escravidão negra em São Paulo..., p. xiii.

${ }^{29}$ BASTIDE, R.; FERNANDES, F. Brancos e negros em São Paulo..., p. 42.

${ }^{30}$ LUNA, F. V.; KLEIN, H. S. Evolução da sociedade e economia..., p. 203-204.
} 
dos Índios, de $1755 .{ }^{31}$ As diferentes formas de vinculação dos indígenas ao universo da escravidão provavelmente tenha os conduzido a integrar o amplo conjunto dos pardos forros e livres existente já em meados do século XVIII. Esse, aliás, foi objeto de exame de Muriel Nazzari, a qual argumentou que para fins daquela centúria os indígenas e seus descendentes foram formalmente incorporados ao contingente de pardos na capitania de São Paulo. ${ }^{32}$

Em realidade, está-se diante de diferentes e parceladas hipóteses acerca da formação do grupo dos pardos livres em São Paulo: descendência direta dos escravos africanos aportados a partir de fins do século XVIII, migrações intracapitanias, manumissões referentes ao contingente de escravos crioulos, e assimilação de indígenas. Argumenta-se aqui que, em maior ou menor medida, todos esses fatores atuaram na composição daquele segmento social, uma vez que, isoladamente, nenhum deles seria capaz de explicar o fenômeno satisfatoriamente. Pode-se concluir, preliminarmente, que os integrantes das companhias de pardos existentes no Setecentos e, depois, os do Regimento dos Úteis seriam recrutados dentre uma população mestiça e vinculada a um passado, mais ou menos recente, marcado pela submissão a formas de trabalho compulsório e a marginalização delas decorrente.

O surgimento das primeiras companhias de ordenanças de pardos e de pretos em São Paulo apresenta características bem demarcadas, como visto anteriormente. Trata-se de corpos militares localizados em região litorânea e que assumiram papéis extremamente relevantes na defesa local em face de eventuais inimigos externos. Em 1712, a formação da Companhia de Pardos Obrigados na vila de Santos - a tropa de cor mais antiga de que se tem registro na capitania, composta e comandada por escravizados - foi justificada diante do problema crônico de falta de "gente necessária para sua defesa, assim de infantaria paga como de ordenança". ${ }^{33}$ Durante o meio século que se seguiu, essa companhia de pardos cativos conviveu com outros corpos militares que aos poucos, e exclusivamente nas regiões costeiras, foram sendo formados. Importa notar a composição ou identificação social dessas companhias: em Santos, além da dos Pardos Obrigados, havia uma outra referida, em 1726, como Companhia de Ordenança de Homens Pardos Livres. Em 1743, um preto forro aspirante a capitão da antiga companhia dos

31 GOLDSCHMIDT, E. R. Casamentos mistos... Sobre o emprego do termo forro aos indígenas e exadministrados, p. 15-16. Ver também MONTEIRO, J. M. Negros da terra..., p. 159-170 e SILVA, M. B. N. da (Org.). História de São Paulo colonial..., p. 113-119.

${ }^{32}$ NAZZARI, M. Vanishing Indians... Em perspectiva oposta, Marcílio argumentou que os descendentes de índios e brancos foram plenamente assimilados ao grupo dos brancos. MARCÍLIO, M. L. Crescimento demográfico..., p. 118.

${ }^{33} C f$ :: "Requerimento do capitão Teodoro Gonçalves Santiago, homem pardo, morador na vila de Santos, escravo do sargento-mor Manuel Gonçalves de Aguiar, pedindo a D. João V que, por alvará, mande o suplicado aceitar ume escravo que lhe oferece em troca da sua liberdade". AHU_CU_023-01, Cx. 8, D. 898. Santos, anterior a 4 de maio de 1733. 
Pardos Obrigados fez menção a ela como sendo uma Companhia de Homens Pretos Escravos e Libertos. Também na década de 1740, a Companhia de Mulatos da vila de São Vicente era comandada por um capitão pardo e integrada por "todos os mais pardos moradores nesta vila". Já a Companhia dos Homens Pardos, da vila de Itanhaém, outrora capitaneada por um escravo, passou a ser encabeçada por um pardo forro. ${ }^{34}$

Observa-se uma nítida tendência de que a formatação desses corpos militares acompanhasse os processos de transformação de status dos escravos em libertos e livres e o de formação das camadas de pardos e pretos forros e livres. ${ }^{35}$ À medida que os forros abundam, esses tendem a transformar e mesmo a suprimir os corpos militares inicialmente identificados aos escravos. O mesmo ocorre na relação entre livres e forros e entre pardos e pretos. Exceto quanto à condição jurídica de pardos e pretos, isto é, se eram escravos, forros ou livres, as fontes consultadas revelam pouco acerca das origens sociais desses soldados e oficiais da primeira metade do Setecentos.

Especialmente em função da guerra luso-castelhana de 1763-1777, na capitania paulista a trajetória dos corpos militares em questão foi marcada pela reforma das companhias litorâneas de pardos e pretos bem como por sua gradual difusão nas localidades do planalto segunda metade do século XVIII. Até o final desse período terá ocorrido o progressivo desmantelamento das companhias autônomas de escravos e até mesmo das de pretos forros e, inversamente, o predomínio das companhias de pardos forros e livres dentre os corpos militares formados pelos homens de cor. Em 1770, no curso, portanto, desse processo, ocorreu uma situação que fornece importantes vestígios sobre a origem social dos soldados e oficiais que integravam as companhias de pardos e de pretos paulistas daquele período. Quando um preto forro que pretendia o posto de capitão trabalhou para remobilizar a decadente Companhia dos Pretos Forros de Santos ele se deparou com sérios problemas para alistar a gente necessária. Conforme argumentou perante o governador de São Paulo, vários pretos forros estavam irregularmente alistados na companhia dos pardos de São Vicente, sendo provável que também o estivessem na de Santos, "e como estes são pessoas pelas suas cores que só pertencem ser alistados na lista do suplicante", assim o requereu. Instado a informar sobre o caso, o comandante da Praça de Santos revelou que os "forros" alistados nas companhias de pardos forros "são trigueiros quase

\footnotetext{
${ }^{34} C f:$ : APESP, ordem C00271, docs. 19, 32, 37 e 49; ordem C00361, livro 5. Registro de uma patente de Bernardino Correa Pais de Santa Rita, de capitão de infantaria de Ordenança. Santos, 7 de outubro de 1735.

35 KOPYTOFF, Igor; MIERS, Suzanne. African 'slavery' as an institution of marginality..., p. 12-20; PATTERSON, O. Escravidão e morte social..., p. 350-354.
} 
na forma de pretos [...]. Em uma palavra, todos são forros administrados carijó com tapanhunos". ${ }^{36}$

O caso em tela permite acompanhar a notável transformação operada nessa que na época era a única companhia identificada aos pretos de São Paulo, a qual era composta inicialmente por Pardos Obrigados, passando-se para Pretos Escravos e Libertos e, ao final, convertendose em uma companhia de Pretos Forros. A consolidação dos libertos e a exclusão dos escravos como membros da companhia sinaliza a crescente visibilidade social dos libertos e forros de cor preta. Contudo, relacionalmente, nota-se maior ampliação dos pardos enquanto grupo social, o que se expressa em ao menos dois sentidos. Em primeiro lugar, no poder de ingerência sob a camada de pretos forros e libertos exercido pelas companhias de pardos forros e por seus oficiais que fora exposto e contestado pelo capitão preto. Em segundo lugar, pela abrangência, flexibilidade ou capacidade de assimilação apresentada pela categoria "pardo". Nesse caso, ela incorporava pessoas de diferentes matizes de cor e de condição social debaixo do termo "pardo forro", conforme atestou o comandante da Praça de Santos. É extremamente interessante que, em meio à tamanha pluralidade, ela acene para a origem social comum a todos os seus integrantes. A escravidão e demais formas de trabalho compulsório, como é o caso da instituição da administração imposta aos indígenas, colocaram lado a lado índios, africanos e seus descendentes mestiços. Vai daí que a parcela livre ou liberta dessa população submetida ao cativeiro pudesse compor as companhias de ordenança de pardos forros.

$\mathrm{O}$ fato de que os índios e seus descendentes tenham sido associados à cor parda matiza uma noção tradicional conforme a qual pardo seria sinônimo de mulato e esse, por sua vez, identificaria, em regra, o mestiço de pessoas brancas com pessoas pretas. Apenas muito recentemente é que a historiografia vem incorporando a presença indígena às reflexões em torno do significado da categoria pardo e de sua experiência como grupo social. ${ }^{37}$ Em São Paulo, uma capitania periférica da América portuguesa até pelo menos meados do século XVIII, a presença indígena se fez sentir de inúmeras formas. Certamente uma delas diz respeito à constituição do grupo social de pardos livres, forros e libertos. Em 1722, um Registro do Regimento e forma em que se hão de governar as ordenanças, e das obrigações que tem os oficiais de guerra desta capitania expressou o peso demográfico dos "índios, de que se compõe a maior parte desta

\footnotetext{
${ }^{36} C f$ :: APESP, Ordem 270, doc. s.n. Santos, 23 de setembro de 1770.

${ }^{37}$ MATTOS, Hebe. Racialização e cidadania no Império do Brasil. In: CARVALHO, José Murilo de; NEVES, Lúcia Maria Bastos Pereira das (Orgs.). Repensando o Brasil do Oitocentos: cidadania, política e liberdade. Rio de Janeiro: Civilização Brasileira, 2009, p. 356-357; LIBBY, Douglas Cole. A empiria e as cores: representações identitárias nas Minas Gerais dos séculos XVIII e XIX. In: PAIVA, E. F.; IVO, I. P.; MARTINS, I. C. (Orgs.). Escravidão, mestiçagens, populações e identidades culturais. São Paulo: Annablume; Belo Horizonte: PPGHUFMG; Vitória da Conquista: Edições UESB, 2010, p. 47.
} 
capitania". ${ }^{38}$ Já bem adentrado o século XVIII, os indígenas mantinham-se como o segmento mais abundante da população paulista. ${ }^{39}$ Sua importância como trabalhadores e os meios pelos quais se dava sua integração à sociedade luso-americana são evidenciados em um requerimento que os oficiais do Senado da Câmara da cidade de São Paulo destinaram ao governador e capitão-general nesse mesmo período, por volta de 1725, no qual pediram "conservar-lhes a administração do gentio pardo e do mais que conquistarem dos bárbaros nos sertões". ${ }^{40}$ Já nesse período abundam as referências à entrada de cativos de origem africana na capitania com destino às áreas de mineração. De acordo com a historiografia, os paulistas retinham uma parcela, embora reduzida, desses escravizados. Igualmente nesse contexto, tornou-se comum em procedimentos administrativos - tais como o estabelecimento de ordens, proibições, gratificações ou punições - considerar "bastardo, índio ou preto forro" como parte de um mesmo segmento social e diferenciá-lo de "brancos" e ocasionalmente de "escravos". ${ }^{4}$

Essas evidências acenam para algo que se tornou, senão um 'elo perdido', certamente uma lacuna na história de São Paulo, isto é, a composição social da população forra, liberta e livre existente na capitania durante o período de transição entre a escravidão indígena e a escravidão africana. ${ }^{42}$ Ora, é amplamente reconhecida a forte presença indígena no conjunto da população, economia, cultura e sociedade paulista até as primeiras décadas do século XVIII, assim como é aceito o fenômeno do gradual ‘enegrecimento' de São Paulo desde que o acesso local ao tráfico de escravos africanos se viu ampliado, no final daquele século. Em meio a essas balizas é que tomou forma um segmento social forro, liberto ou livre que nos recenseamentos paulistas de fins do Setecentos em diante estava associado à cor parda e sobre o qual - suas origens e sua composição social - pouco se conhece. Duas indagações básicas ajudam a colocar o problema da gênese desse grupo social a partir do caso de São Paulo. Em primeiro lugar, como bem formulou M. Nazzari, o que teria ocorrido com a multidão de índios que conformava

\footnotetext{
${ }^{38} C f$ :: "Registro do Regimento e forma em que se hão de governar as ordenanças, e das obrigações que tem os oficiais de guerra desta capitania, que se mandou registrar em todas as câmaras das vilas deste governo". DIHCSP, vol. 12, p. 40-41.

${ }^{39}$ HOLANDA, Sérgio Buarque de. Movimentos de população de São Paulo no século XVIII. Revista do Instituto de Estudos Brasileiros, n. 1, p. 55-111, 1966, p. 82-84.

${ }^{40}$ Cf:: AHU_CU_023-01, Cx. 7, D. 750. São Paulo, ant. a 26 de outubro de 1725. O grifo é meu.

${ }^{41} C f$ : "Registro de um bando que se lançou na Vila de Itu e de Sorocaba, para acudirem todos para prenderem ou matarem Lourenço Leme da Silva e João Leme da Silva”. DIHCSP, vol. 12, p. 118. Ver, nesse mesmo volume, outras ordens emitidas pelo governador Rodrigo César de Menezes nas pp. 53-59, 72-73, 85, 96, 120-121. "Registro de um bando sobre as penas que se impõem aos negros, mulatos, bastardos e carijós que trouxerem baetas ou qualquer gênero de armas”. DIHCSP, vol. 22, p. 180-181. São Paulo, 25 de janeiro de 1743.

${ }^{42}$ Sobre o tema da transição da escravidão indígena para a africana, a referência é PORTELA, Bruna Marina. Gentio da terra, gentio da Guiné: a transição da mão de obra escrava e administrada indígena para escravidão africana (Capitania de São Paulo, 1697-1780). Tese (doutorado em História). Curitiba: SCHLA, Universidade Federal do Paraná, 2014; ver também MONTEIRO, J. M. Negros da terra..., p. 209-226.
} 
a maioria da população ainda na primeira metade do século XVIII? Em segundo, como explicar a existência de um vultoso contingente populacional formado por pessoas de cor livres antes mesmo do grande afluxo de escravos africanos na capitania? De partida, a constituição do grupo em questão deve ser concebida como um processo histórico complexo e que envolveu diversos fenômenos sociais, tais como escravidão africana, administração indígena, alforrias, migrações e casamentos forçados. Não há dúvida que na transição da escravidão indígena para a africana houve o convívio e decorrente mestiçagem cultural e biológica envolvendo índios, bastardos e carijós "forros", negros e mulatos libertos e livres, bem como os brancos, fossem eles pobres ou mesmo da classe de senhores e administradores de pessoas. Esses fatores estão na raiz da formação do grupo social dos pardos forros e livres.

Se nas vilas litorâneas da capitania as companhias de ordenanças dos pardos eram compostas por homens "trigueiros quase na forma de pretos" e por "forros administrados carijó com tapanhunos", igualmente heterogênea era a composição das companhias situadas no planalto ao longo da segunda metade do século XVIII, notadamente nas vilas mais próximas do sertão. A cidade de São Paulo não abrigava nenhum corpo militar específico para pardos ou pretos até 1775 , ano em que se formou uma Companhia de Mulatos forros. ${ }^{43}$ Alguns historiadores têm notado que, apesar de em certos usos pardo e mulato obterem quase que uma equivalência, em determinados contextos pardo assumia conotação positiva, oposta à carga pejorativa imposta a mulato. ${ }^{44}$ Ademais, enquanto o termo mulato poderia se referir diretamente aos filhos de pai branco e mãe preta, o termo pardo tendia a ser mais abrangente e a assimilar pessoas de diferentes matizes de cor, especialmente as mestiças. ${ }^{45}$ É possível, mas não necessariamente provável, que os "mulatos forros" em questão, da cidade de São Paulo, tivessem uma ancestralidade africana mais acentuadamente marcada. Não obstante a escassez de detalhamento acerca desses soldados de ordenança, é o que sugere a sua comparação com os "pardos" das vilas e localidades tipicamente rurais. Recorde-se do caso da Companhia dos Pardos que serviu no distante Presídio do Iguatemi na década de 1770, a qual fora criada a partir da reunião de duas companhias integradas por “mulatos, bastardos e carijós”, uma da vila

\footnotetext{
${ }^{43} C f$.: "Ordem para se formar nesta cidade uma Companhia de Mulatos forros”. DIHCSP, vol. 33, p. 180-181. São Paulo, 4 de janeiro de 1775 .

${ }^{44}$ PESSOA, Raimundo Agnelo Soares. Gente sem sorte: os mulatos no Brasil colonial. Tese (doutorado em História). Franca: FHDSS, Universidade Estadual Paulista "Júlio de Mesquita Filho", 2007; VIANA, Larissa. $O$ idioma da mestiçagem: as irmandades de pardos na América portuguesa. Campinas: Editora da UNICAMP, 2007. ${ }^{45}$ LIBBY, Douglas Cole. A empiria e as cores..., p. 46-48.
} 
de Jundiaí e outra de Mogi Mirim. ${ }^{46}$ Aqui mais uma vez as injunções da realidade colonial e escravista reuniram os mestiços de origem africana e indígena.

Essa aproximação de mulatos, bastardos e carijós não era um fenômeno promovido exclusivamente pelo Estado. Trata-se de um grupo social cuja origem e experiência, formação e enraizamento, estavam assentados na escravidão e em outras formas de dominação e de exploração incidentes sob pessoas forras, libertas e livres amplamente disseminadas naquela sociedade. Mas certamente a perspectiva generalista acerca dessa população que norteava as ações dos governadores e de autoridades locais influiu diretamente na consolidação do vasto grupo dos pardos forros e livres. Em 1774, quando Francisco Barreto Leme foi investido na função de "fundador e diretor da nova povoação das Campinas do Mato Grosso, distrito da vila de Jundiaí", ele recebeu ordem para convocar "para o dito efeito todos os forros, carijós e administrados de que tiver notícia andam vadios e não têm casa nem domicílio certo, nem são úteis à República, e os obrigue a ir povoar as ditas terras [...]" ${ }^{47}$ Juntos, "forros, carijós e administrados" eram vítimas do estigma da vadiagem e de ações de controle social extremamente arbitrárias. Quase meio século depois, em 1821, requisitou-se serventes para o Hospital Real da cidade de São Paulo, os quais deviam ser "tirados da classe dos índios, mulatos e pardos libertos". ${ }^{48}$ Conquanto haja reconhecimento de diferença entre esses três tipos sociais, note-se que eles podiam ser agrupados em uma só "classe", e o foram. As diferentes modalidades de reunião forçada dessa população livre, forra ou liberta apenas reiteravam a convivência já existente no universo do cativeiro, fosse ele legal ou disfarçado.

\subsubsection{Origem social dos milicianos pardos a partir da cor e tipo de cabelo (1810-1831)}

Pode-se, agora, indagar sobre quem eram os pardos que integravam o Regimento dos Úteis nas primeiras décadas do século XIX. Dentre as informações registradas continuamente no Livro Mestre da corporação, o tipo e a cor de cabelo dos milicianos são as que fornecem

\footnotetext{
${ }^{46} C f$ :: "Carta dos oficiais da Câmara de Mojimirim ao governador Luís Antonio de Sousa Botelho Mourão, remetendo lista dos mais capazes para servir na nova companhia de mulatos bastardos e carijós”. Mogi Mirim, 28 de junho de 1772. B.N./s.m., doc. I-30,22,11 n 5; "Ordem que foi ao sargento-mor de Jundiaí para formar uma Companhia de mulatos, bastardos e carijós". São Paulo, 11 de maio de 1772. DIHCSP, vol. 33, p. 60; "Ordens e instruções que se dirigiram ao tenente-coronel João Miz.' Barros e ao sargento-mor D. José de Macedo sobre o estabelecimento de Guatemy que novamente se dão por cópia ao capitão-mor regente José Gomes de Gouvêa com outras que juntamente lhe são expedidos por escrito e de palavras para em virtude dela fazer dar a sua devida e cabal execução. DIHCSP, vol. 7, p. 16-1630; São Paulo, 11 de janeiro de 1773.

${ }^{47} C f$ :: "Para Francisco Barreto Leme ser fundador e diretor da nova Povoação das Campinas do Mato Grosso, distrito da vila de Jundiaí”. São Paulo, 27 de maio de 1774. DIHCSP, vol. 33, p. 160.

${ }^{48}$ Cf:: "Para o capitão Manoel de F. Costa e Cintra". São Paulo, 7 de abril de 1821. DIHCSP, vol. 37, p. 101-102.
} 
uma visão mais aproximada acerca do fenótipo daqueles homens. O principal motivo para que essas informações sobre os cabelos dos milicianos figurassem nos registros militares é a necessidade de identificação individual. Era através de descrições físicas e de referências familiares e geográficas que se tentava identificar as centenas de homens que integravam o Regimento dos Úteis e aplicar a eles o controle e a disciplina militar. ${ }^{49}$ Aqui, para melhor visualizar os milicianos pardos, os oficiais brancos do estado-maior foram isolados e excluídos das amostragens. Como se vê na tabela 4.1, a descrição dos 1.097 milicianos pardos comporta uma variedade de tipos e cores de cabelos. Os registros tiveram como base seis cores de cabelo (branco, castanho, loiro, preto, preto com pintas brancas e ruivo), cinco tipos de cabelo (corredio, crespo, grenho, liso e solto), bem como as combinações entre essas variáveis.

Identifica-se de imediato a heterogeneidade resultante da descrição dos milicianos pardos, ainda que a observação esteja restrita às variáveis tipo e cor de cabelo. A maior parte dos milicianos (776 homens) foi descrita a partir dessas duas variáveis, mas para alguns deles (111 homens) apenas se notou a cor e para outros (206 homens) somente o tipo de cabelo. Além disso, para uma minoria (quatro) não consta qualquer descrição a esse respeito - o que pode ser lido como falha no registro ou mesmo como ocultação proposital. A cor de cabelo predominante entre os milicianos pardos era o preto, o que corresponde a cerca de $80,13 \%$ dos milicianos cuja cor de cabelo foi registrada. Em um distante segundo lugar estavam os cabelos castanhos, que descreveram 15,57\%. Esses tons mais escuros estão plenamente de acordo com o que se poderia esperar em se tratando de homens pardos. No entanto, havia também 30 milicianos ruivos (ou $3,38 \%$ ) e oito loiros, o que indica uma interessante variedade fenotípica ou mesmo genética presente a esse conjunto de mais de um milhar de homens pardos.

\footnotetext{
${ }^{49}$ Sobre os desafios e os métodos atinentes à identificação individual vigentes até a 'descoberta' das impressões digitais, ver GINZBURG, Carlo. Sinais: raízes de um paradigma indiciário. In: GINZBURG, Carlo. Mitos, emblemas, sinais: morfologia e história. Trad. Federico Carotti. São Paulo: Companhia das Letras, 1989, p. 173177.
} 
TABELA 4.1 - Tipo e cor de cabelo de oficiais e soldados pardos (1810-1831)

\begin{tabular}{llccc}
\hline Tipo de cabelo & Cor de cabelo & Oficiais & Soldados & Total \\
\hline Corredio & & 3 & 11 & 14 \\
Corredio & Castanho & 7 & 49 & 56 \\
Corredio & Loiro & & 1 & 1 \\
Corredio & Preto & 26 & 142 & 168 \\
Corredio & Ruivo & 3 & 3 & 6 \\
Crespo & & 31 & 124 & 155 \\
Crespo & Castanho & 13 & 42 & 55 \\
Crespo & Loiro & & 3 & 3 \\
Crespo & Preto & 75 & 295 & 370 \\
Crespo & Ruivo & 1 & 7 & 8 \\
Grenho & & 4 & 19 & 23 \\
Grenho & Castanho & & 1 & 1 \\
Grenho & Preto & 1 & 9 & 10 \\
Liso & & 1 & & 1 \\
Liso & Ruivo & & 1 & 1 \\
Solto & & & 14 & 14 \\
Solto & Castanho & 5 & 7 & 12 \\
Solto & Preto & 8 & 66 & 74 \\
Solto & Ruivo & 3 & 8 & 11 \\
& Castanho & 5 & 9 & 14 \\
& Loiro & 4 & & 4 \\
& Preto & 18 & 67 & 85 \\
& Preto com pintas brancas & 1 & 2 & 3 \\
Sem indicação & Ruivo & 211 & 4 & 4 \\
\hline TOTAIS & Sem indicação & & 2 & 4097 \\
\hline
\end{tabular}

Fonte: Livro Mestre.

Mas o que mais importa lançar luz, aqui, é para o universo social. E uma análise à cor e ao tipo de cabelo pode constituir uma entrada relevante para o conhecimento da origem e da experiência social do grupo de pardos forros e livres de São Paulo, sobretudo na medida em que os dados possam ser cruzados e complementados por outras informações. De imediato, nota-se que a variável tipo de cabelo permite inferências ainda mais pertinentes do que a cor. A tabela 4.2, que é uma derivação da tabela anterior, enfatiza a relação analítica entre os tipos de cabelo e a alocação dos milicianos nos principais grupos funcionais e hierárquicos do Regimento. Deixando claro que se trabalha aqui apenas com tendências, buscou-se extrair dos 
tipos de cabelo alguns indícios - mesmo que superficiais e genéricos - da herança genética ${ }^{50}$ e, em decorrência, da origem social dos milicianos pardos. Os cabelos crespos e grenhos ${ }^{51}$ sinalizariam uma forte presença de antepassados oriundos do continente africano. Já os cabelos corredios - típicos do "gentio do cabelo corredio" - acenariam prioritariamente para a ascendência indígena. Finalmente, os cabelos lisos e soltos, que foram reunidos em um mesmo grupo, poderiam indicar descendência indígena e europeia. Está claro que essa associação entre tipo de cabelo e origem deve considerar, obrigatoriamente, o fenômeno da mestiçagem, que, aliás, marcava no âmago o grupo dos pardos. Por isso, é pertinente reiterar que os termos tendências e predominâncias são aqui decisivos.

TABELA 4.2 - Tipo de cabelo dos milicianos pardos por posição hierárquica (1810-1831)

\begin{tabular}{lccccr}
\hline $\begin{array}{l}\text { Tipo de cabelo / Posição } \\
\text { hierárquica }\end{array}$ & $\begin{array}{c}\text { Estado } \\
\text { Maior }\end{array}$ & $\begin{array}{c}\text { Oficiais de } \\
\text { patente }\end{array}$ & $\begin{array}{c}\text { Baixa } \\
\text { oficialidade }\end{array}$ & Soldados & Total \\
\hline Corredio & & 6 & 33 & 206 & 245 \\
Crespo & 5 & 24 & 91 & 471 & 591 \\
Grenho & & & 5 & 29 & 34 \\
Liso/Solto & & 6 & 11 & 96 & 113 \\
Apenas descrição de cor & 1 & 7 & 20 & 82 & 110 \\
Sem indicação & 2 & & & 2 & 4 \\
\hline Total & 8 & 43 & 160 & 886 & 1097 \\
\hline
\end{tabular}

Fonte: Livro Mestre.

Dos 983 milicianos cujo tipo de cabelo foi registrado, a ordem de predominância é a seguinte: crespo $(60,12 \%)$, corredio $(24,92 \%)$, liso/solto $(11,5 \%)$ e grenho $(3,46 \%)$. É possível imaginar que o Regimento dos Úteis, devidamente postado nas situações de mostras e exercícios militares, seria formado por uma maioria de homens pardos com cabelos crespos e pretos, os quais expressariam, mesmo que involuntariamente, seus vínculos antigos ou recentes com o cativeiro. Chamaria a atenção, igualmente, um número considerável de milicianos pardos cujos cabelos pretos de aspecto corredio, e mesmo liso ou solto, evocariam a ancestralidade

\footnotetext{
${ }^{50}$ PELLICER, Luis Felipe. Entre el honor y la pasión: familia, matrimonio y sistema de valores en Venezuela durante la crisis del orden hispánico: 1778-1820. Caracas: Fondo Editorial de la Facultad de Humanidades y Educación; Universidad Central de Venezuela, 2005, p. 68-69.

${ }^{51}$ Conforme a definição tardo-setecentista de Antonio de Moraes e Silva, "grenha, de ordinário se toma por cabelo embaraçado". Cf.: SILVA, Antonio de Moraes. Diccionario da Lingua Portugueza composto pelo padre D. Rafael Bluteau, reformado e accrescentado por Antonio de Moraes Silva natural do Rio de Janeiro. Tomo Primeiro. Lisboa: Officina de Simão Thaddeo Ferreira, 1789, p. 670.
} 
indígena e os rigores do sistema de dominação e exploração que a instituição administração impôs. Em conjunto, esses homens também expressariam o retrato de uma população heterogênea resultante de processos de forte e intensa mestiçagem. Ainda de acordo com os dados da tabela 4.2, não se percebem variações significativas na composição dos quadros funcionais do Regimento no tocante ao tipo de cabelo e, portanto, à origem pronunciadamente afrodescendente ou indígena dos milicianos. De fato, a proporção entre homens de cabelos crespos e os de cabelos corredios/lisos/soltos se mantém sem grandes desvios na oficialidade de patente, na baixa oficialidade e dentre os soldados - exceto entre os sete milicianos pardos do estado-maior. As pessoas com cabelos grenhos, porém, enfrentaram extrema dificuldade para acessar os postos superiores da corporação e permaneceram nas posições mais baixas da hierarquia miliciana.

\section{Tabela 4.3 - Tipo de cabelo de soldados por Companhia (em n. ${ }^{\text {os }}$ absolutos) e área citadina ou interiorana (em percentagem), 1810-1831}

\begin{tabular}{|c|c|c|c|c|c|c|c|c|c|c|c|c|}
\hline \multirow[b]{2}{*}{ Tipo de cabelo } & \multicolumn{5}{|c|}{ Companhias da Cidade de São Paulo } & \multirow[b]{2}{*}{$\begin{array}{r}\text { Total da } \\
\text { Cidade } \\
(\%)\end{array}$} & \multicolumn{5}{|c|}{ Companhias de vilas interioranas } & \multirow[b]{2}{*}{$\begin{array}{r}\text { Total d } \\
\text { Interio } \\
(\%\end{array}$} \\
\hline & Gran. & Caç. & $\begin{array}{l}1 .^{\mathrm{a}} \\
\text { Fuz. }\end{array}$ & $\begin{array}{l}2 .^{\mathrm{a}} \\
\text { Fuz. }\end{array}$ & $\begin{array}{l}3 .^{a} \\
\text { Fuz. }\end{array}$ & & Atibaia & Jundiaí & Parnaíba & Itu & Sorocaba & \\
\hline Corredio & 14 & 9 & 2 & 4 & 13 & 10,5 & 43 & 44 & 6 & 35 & 36 & 33,9 \\
\hline Crespo & 57 & 47 & 41 & 34 & 22 & 50,1 & 50 & 50 & 71 & 39 & 60 & 55,7 \\
\hline Grenho & 4 & 8 & 1 & 0 & 5 & 4,5 & 0 & 0 & 11 & 0 & 0 & 2,2 \\
\hline Liso/Solto & 17 & 16 & 15 & 27 & 6 & 20,2 & 6 & 5 & 2 & 1 & 1 & 3,1 \\
\hline Apenas cor & 4 & 12 & 3 & 4 & 35 & 14,5 & 6 & 1 & 4 & 9 & 4 & 5 \\
\hline Sem indicação & 0 & 1 & 0 & 0 & 0 & 0,2 & 0 & 0 & 1 & 0 & 0 & 0,1 \\
\hline TOTAL & 96 & 93 & 62 & 69 & 81 & 100 & 105 & 100 & 95 & 84 & 101 & 100 \\
\hline
\end{tabular}

Fonte: Livro Mestre.

É possível examinar a distribuição dos soldados ${ }^{52}$ de acordo com os tipos de cabelo em meio às dez companhias que formavam o Regimento dos Úteis. Como se vê na tabela 4.3, havia mais soldados alocados nas companhias aquarteladas nas vilas interioranas de São Paulo (Atibaia, Jundiaí, Parnaíba, Itu e Sorocaba) que nas da cidade (companhias de Granadeiros, Caçadores, 1. ${ }^{\mathrm{a}}, 2$. $^{\mathrm{a}}$ e $3 .^{\mathrm{a}}$ de Fuzileiros). Para que se possa comparar as macrorregiões entre si, fez-se necessário mencionar os percentuais referentes ao conjunto das companhias da cidade de

\footnotetext{
${ }^{52}$ A amostra que está expressa na Tabela 12 se refere apenas aos soldados, estando excluídos, portanto, todos os integrantes da oficialidade. Como não há variações relevantes quanto à questão do tipo de cabelo entre soldados e oficiais, entende-se não haver prejuízo analítico.
} 
São Paulo assim como ao conjunto das companhias das vilas do interior, além dos números absolutos referentes à cada companhia. Percebe-se uma constância na presença numericamente dominante de soldados de cabelo crespo em todas as companhias e nos espaços urbanos e rurais. Por outro lado, ao passo que os soldados de cabelo corredio eram pouco representativos nas companhias da cidade, seu número era significativo nas vilas. O inverso ocorreu com os milicianos de cabelo liso ou solto, que eram abundantes na cidade e rarefeitos no interior. Entretanto, se agrupados os de cabelo corredio, liso e solto, se obterá proporções semelhantes na cidade e nas vilas rurais.

Há duas situações de desvio que servem de alerta para as eventuais limitações dos dados em fornecer perspectivas mais aproximadas da realidade. A primeira é o caso da $3 .^{a}$ companhia de fuzileiros, na qual havia menor contingente de milicianos com cabelo crespo e o maior de conjunto de referências exclusivas à cor de cabelo. A segunda é o caso da companhia de Parnaíba, na qual houve a maior desproporção entre cabelos crespos e corredios. Provavelmente, em ambos os casos, os registros lacunares ou baseados em critérios dispares é o que melhor explica tamanhas variações. Em função disso, tais dados parecem pouco seguros, por si sós, para se precisar a composição da camada de pardos forros e livres nas diferentes regiões paulistas na fase final da transição entre a escravidão indígena e a africana. O certo é que o abrangente grupo dos pardos reunia mestiços e pessoas com notória ascendência indígena e africana em todas as regiões da capitania/província de São Paulo, tal como revela este exame aos tipos de cabelo. A esse respeito, mesmo as regiões com maior potencial de atração e retenção de mão de obra escrava de origem africana - como a cidade de São Paulo, centro político e econômico paulista, e a vila de Itu, centro da produção açucareira e importadora de escravos africanos - não destoavam das outras localidades.

\subsubsection{A cor dos milicianos pardos nos recenseamentos: atribuição, mudança, branqueamento e mobilidade social}

É evidente que os homens alistados em um corpo militar privativo aos pardos fossem socialmente reconhecidos como tendo essa cor. Assume-se aqui que essas corporações, associadas às cores, incorporavam pessoas dotadas de cores previamente definidas e também reiteravam as cores de seus integrantes de acordo com a identificação coletiva. Assim, ao mesmo tempo em que era preciso ser considerado pardo para ingressar no Regimento dos Úteis, a identificação à cor parda obteria reforço após o alistamento. Para testar essa hipótese, 
considerou-se pertinente comparar a cor disseminada pela milícia e a cor em outros âmbitos sociais. As listas nominativas confeccionadas em São Paulo quase que ininterruptamente entre os anos 1765 e 1831 permitem que se examine a cor dos milicianos pardos sob a ótica dos recenseadores, os quais eram oficiais das ordenanças. Portanto, as listas fornecem uma perspectiva oriunda de diferente instituição social em relação à milícia bem como expressam a atribuição de cor socialmente aceita a cada indivíduo. Durante o período de 1765 a 1797, as listas nominativas não informavam com regularidade a cor dos integrantes dos domicílios paulistas. Em algumas delas se indicava apenas a cor dos chefes dos fogos, e em outras não há menção alguma a essa variável. De 1798 em diante, após as instruções de D. Rodrigo de Souza Coutinho, os recenseamentos foram padronizados e toda a população, tanto livre como escrava, passou a ser compreendida em alguma das cores branca, parda e preta. Esse é exatamente o momento de atividade do Regimento dos Úteis, o que viabiliza a comparação entre a cor estabelecida pela milícia e a cor atribuída nos recenseamentos.

Não é tarefa fácil localizar nominalmente os milicianos nas listas de população. As dificuldades estão relacionadas ao elevado número de localidades em que residiam os milicianos, às eventuais mudanças de residência, às discrepâncias existentes entre os nomes registrados na milícia e os nomes escritos pelos recenseadores e finalmente ao grande contingente de soldados e oficiais. Ademais, dois importantes obstáculos se impuseram para a localização de milicianos das cinco companhias aquarteladas na capital: um deles é a rotatividade das pessoas, que muitas vezes se estabeleciam temporariamente na cidade de São Paulo e em seguida mudavam para outras localidades, e o outro é a quantidade de freguesias e bairros mais ou menos próximos de São Paulo que forneciam soldados para o Regimento dos Úteis. Diante disso, tornou-se necessário estabelecer recortes e amostras, de modo que foram localizados nas listas nominativas os seguintes milicianos pardos: oficiais de patente do estadomaior do Regimento (coronel, tenente-coronel, tenente quartel-mestre e tenentes secretários) e oficiais de patente das cinco companhias aquarteladas na cidade de São Paulo (capitães, tenentes e alferes); soldados residentes nas freguesias de Penha de França, São Miguel, Nossa Senhora do Ó, Santana, Pinheiros e Cotia, todas situadas nos arrabaldes da cidade de São Paulo; e os integrantes das companhias de Atibaia e de Santana de Parnaíba, incluindo oficiais de patente, a baixa oficialidade (sargentos, furriéis, cabos) e soldados. Assim, foram selecionadas duas companhias interioranas completas além de todos os oficiais de patente das companhias da cidade e os soldados dessas companhias que residiam nas regiões suburbanas indicadas.

As amostragens presentes nas tabelas 4.4, 4.5 e 4.6 se referem aos milicianos localizados nas listas de população ao menos duas vezes. Esse procedimento permite perceber a reiteração 
da cor parda ou a variação de cor entre os milicianos identificados. Pardo é considerado didaticamente como o padrão, já que corresponde à cor à qual o corpo militar dos Úteis era associado, e a identificação de milicianos como brancos, negros/pretos ou índios no campo cor das listas nominativas é entendida como mudança de cor em relação à cor parda. A incidência de variação de cor dos indivíduos que compõem a amostra foi computada mesmo que ocorresse em uma única listagem.

\section{TABELA 4.4 - Cores dos milicianos pardos das cinco companhias da cidade de São Paulo nas listas nominativas (em números absolutos), 1798-1836}

\begin{tabular}{|c|c|c|c|c|c|c|}
\hline \multirow{2}{*}{$\begin{array}{l}\text { Localidades } \\
\text { ou posições } \\
\text { hierárquicas }\end{array}$} & \multirow[b]{2}{*}{ Amostra } & \multicolumn{3}{|c|}{ Cor } & \multicolumn{2}{|c|}{ Mudanças de cor $^{\mathrm{a}}$} \\
\hline & & Pardos & Brancos & $\begin{array}{l}\text { Negros e } \\
\text { índios }\end{array}$ & $\begin{array}{c}\text { Fora do período de } \\
\text { pertencimento aos Úteis }\end{array}$ & $\begin{array}{c}\text { Pertencendo aos } \\
\text { Úteis }\end{array}$ \\
\hline Oficiais ${ }^{b}$ & 26 & 22 & 4 & 0 & 1 & 3 \\
\hline Penha & 37 & 34 & 3 & 0 & 0 & 3 \\
\hline N. S. do Ó & 28 & 24 & 2 & 2 & 3 & 1 \\
\hline Santana & 11 & 9 & 2 & 0 & 1 & 1 \\
\hline Pinheiros & 8 & 1 & 4 & 3 & 2 & 5 \\
\hline Cotia & 25 & 24 & 1 & 0 & 0 & 1 \\
\hline Totais & 135 & 114 & 16 & 5 & 7 & 14 \\
\hline
\end{tabular}

Fonte: APESP, Maços de População. Companhias da Capital e Companhias de Cotia.

${ }^{a}$ Considerando apenas brancos e negros.

${ }^{\mathrm{b}}$ Considerando apenas os oficiais de patente (capitães, tenentes e alferes) das cinco companhias aquarteladas na cidade de São Paulo.

\section{TABELA 4.5 - Cores dos milicianos pardos da Companhia de Atibaia nas listas nominativas (em números absolutos), 1798-1830}

\begin{tabular}{|c|c|c|c|c|c|c|c|}
\hline \multirow{2}{*}{$\begin{array}{l}\text { Posições } \\
\text { hierárquicas }\end{array}$} & \multirow{2}{*}{$\begin{array}{c}\text { Total } \\
\text { da } \\
\text { Cia. }\end{array}$} & \multirow[b]{2}{*}{ Amostra } & \multicolumn{3}{|c|}{ Cor } & \multicolumn{2}{|c|}{ Mudanças de cor ${ }^{a}$} \\
\hline & & & Pardos & Brancos & Negros & $\begin{array}{c}\text { Fora do período de } \\
\text { pertencimento aos Úteis }\end{array}$ & $\begin{array}{c}\text { Pertencendo aos } \\
\text { Úteis } \\
\end{array}$ \\
\hline Oficiais ${ }^{b}$ & 17 & 12 & 9 & 3 & 0 & 0 & 3 \\
\hline Soldados & 105 & 69 & 51 & 16 & 2 & 8 & 10 \\
\hline Totais & 122 & 81 & 60 & 19 & 2 & 8 & 13 \\
\hline
\end{tabular}

Fonte: APESP, Maços de População. Companhias de Atibaia.

${ }^{a}$ Considerando apenas brancos e negros.

${ }^{\mathrm{b}}$ Incluindo os oficiais de patente (capitães, tenentes e alferes) e a baixa oficialidade (sargentos, furriéis e cabos). 


\section{TABELA 4.6 - Cores dos milicianos pardos da Companhia de Santana de Parnaíba nas listas nominativas (em números absolutos), 1806-1828}

\begin{tabular}{|c|c|c|c|c|c|c|c|}
\hline \multirow{2}{*}{$\begin{array}{l}\text { Posições } \\
\text { hierárquicas }\end{array}$} & \multirow{2}{*}{$\begin{array}{c}\text { Total } \\
\text { da } \\
\text { Cia. }\end{array}$} & \multirow[b]{2}{*}{ Amostra } & \multicolumn{3}{|c|}{ Cor } & \multicolumn{2}{|c|}{ Mudanças de cor $^{a}$} \\
\hline & & & Pardos & Brancos & Negros & $\begin{array}{c}\text { Fora do período de } \\
\text { pertencimento aos Úteis }\end{array}$ & $\begin{array}{l}\text { Pertencendo } \\
\text { aos Úteis }\end{array}$ \\
\hline Oficiais ${ }^{b}$ & 20 & 17 & 15 & 2 & 0 & 1 & 1 \\
\hline Soldados & 95 & 66 & 62 & 3 & 1 & 2 & 2 \\
\hline Totais & 115 & 83 & 77 & 5 & 1 & 3 & 3 \\
\hline
\end{tabular}

Fonte: APESP, Maços de População. Companhias de Parnaíba/São Roque, listas de 1806, 1812, 1816, $1822,1828$.

${ }^{a}$ Considerando apenas brancos e negros.

${ }^{\mathrm{b}}$ Incluindo os oficiais de patente (capitães, tenentes e alferes) e a baixa oficialidade (sargentos, furriéis e cabos).

Um exame às listas nominativas de habitantes revela que a maioria dos milicianos pardos tinha essa cor reiterada pelos oficiais das ordenanças que realizavam os recenseamentos. Entre os oficiais da cidade e os soldados residentes nas freguesias próximas a ela, $85 \%$ foram identificados exclusivamente como pardos. Aproximadamente $74 \%$ dos oficiais e soldados da companhia de Atibaia, residentes nessa vila e na vizinha Bragança, foram registrados como pardos em todas as listagens em que foram identificados. Em Parnaíba eles perfizeram 93\% da amostra. A reprodução da cor em diferentes âmbitos sugere que os indivíduos em tela eram socialmente reconhecidos como pardos. Assim como os demais corpos militares estruturados com base na variável cor, o Regimento dos Úteis incorporava indivíduos cuja cor estava estabelecida de antemão e contribuía decisivamente para reafirmar essa faceta da identidade social de seus integrantes.

No entanto, uma parcela significativa - embora minoritária - dos milicianos do Regimento dos Úteis cuja presença nas listas nominativas fora identificada por duas ou mais vezes alterou a cor em pelo menos uma ocasião. Isto é, aproximadamente $15 \%$ dos milicianos da cidade, $25 \%$ da companhia de Atibaia e $7 \%$ da de Parnaíba foram reputados brancos, negros ou índios nas listagens. No interior desse contingente de milicianos que não foram notados exclusivamente como pardos, verifica-se a predominância dos registrados com a cor branca e uma pequena quantidade de milicianos notados como negros/pretos ou índios. Essa constatação conduz aos problemas mais gerais da construção social e à mudança de cor. Ela evoca, em particular, questões caras à historiografia recente e que giram em torno dos significados e definições da cor parda e do fenômeno do branqueamento social na sociedade colonial e imperial brasileira. Como explicar que milicianos aceitos como pardos pudessem ser notados com diferentes cores nas listas? Essas variações de cor se relacionam com fenômenos de 
mobilidade social? Comecemos pelos casos de milicianos registrados como negros e como índios nas listas nominativas de população.

Um desses milicianos pardos notados como negro foi Faustino Carneiro, alistado na $1 .^{\mathrm{a}}$ Companhia de Fuzileiros da cidade. Nos anos de 1808, 1809 e 1810, quando ele residia na casa da proprietária de sua esposa escravizada, localizada na freguesia de Nossa Senhora do Ó, o casal foi notado como pardo. A partir de 1811, eles não foram mais encontrados nas listas daquela freguesia, pois, com a morte da antiga senhora, "saíram em ação de partilha". Eles voltaram a revelar-se no recenseamento de 1822 e no de 1825 , mas agora morando na cidade de São Paulo, em casa própria, e a esposa Eufrásia estando livre do cativeiro. ${ }^{53} \mathrm{Na}$ realidade, no ano da independência do Brasil eles foram notados em duas casas, pertencentes a diferentes companhias de ordenança: no fogo localizado no Pateo da Sé, o casal tinha a cor parda e Faustino trabalhava como sapateiro; já no fogo pertencente à $9 .{ }^{a}$ Companhia, próximo ao bairro do Tatuapé, eles foram notados como negros que viviam "de suas agências". É presumível que no endereço mais central funcionasse a oficina artesanal do miliciano e que sua casa fosse a estabelecida em bairro mais distante. Em 1825, porém, eles moravam em outro endereço na cidade, Faustino continuava com a profissão, e estavam identificados exclusivamente como pardos. Em que medida a alteração pontual de cor significaria um descenso social? O “enegrecimento" poderia ter se manifestado como sendo um resquício do passado recente da esposa atrelado à escravidão. Mas, assumindo essa perspectiva, não deixa de ser paradoxal que, durante o cativeiro de Eufrásia, ambos tenham sido sempre notados como pardos e que a cor negra tenha surgido após Faustino se estabelecer com uma profissão especializada para logo em seguida retornar à cor parda. Nesse caso, embora a condição de liberta da esposa, por evocar o cativeiro recente, possa ter dado ensejo à atribuição da cor negra ao casal, parece mais provável a ocorrência de um equívoco semelhante ou decorrente ao da duplicação do registro na lista daquele ano.

Em direção semelhante, os registros de cor de Silvestre de Lima, um soldado de Atibaia, acenam para as instabilidades que configuravam o processamento de ascensão social de libertos e também revelam os riscos de se encarar a fluidez nas atribuições de cor como evidências seguras acerca das variações na estima social das pessoas cuja cor estava sendo definida. Silvestre nasceu escravo, em 1794, e, em 1807, na primeira ocasião em foi encontrado nas listas, tinha doze anos e era pardo. Todos os integrantes do núcleo familiar estavam livres do cativeiro. Na mesma ocasião, seu pai, Domingos de Lima, era branco, e sua mãe, Maria, parda. Em 1810,

\footnotetext{
${ }^{53}$ Cf:: Livro Mestre, fl. 113; APESP, Maços de População, N.S.Ó: (1808) fogo 35; (1809) fogo 24; (1810) fogo 84; Capital: (1822) 5. ${ }^{\mathrm{a}}$, Pateo da Sé, fogo 22 e (1822) 9. ${ }^{\mathrm{a}}$, fogo 113; (1825) 3. a , Rua da Esperança, fogo 1.
} 
todos os integrantes da família estavam pardos, e, no ano seguinte, negros. Recém-casado, o liberto Silvestre de Lima se manteve como negro em 1812, enquanto sua esposa Maria estava parda. Ele mudou novamente a cor em 1815, tornando-se pardo, e a manteve em 1818. Em 1821, foi alistado no Regimento dos Úteis e permaneceu como miliciano e possivelmente pardo até a sua morte, em 1823. ${ }^{54}$ Percebe-se aqui que as cores que caracterizavam as pessoas poderiam mudar radicalmente em um curtíssimo espaço de tempo. Se a alternância entre as cores parda e negra encontrava justificativa no fenótipo daquelas pessoas e especialmente na perpetuação social das máculas da escravidão, é difícil conceber que o pobre chefe de família Domingos de Lima fosse realmente considerado branco pela comunidade e em poucos anos transitasse para pardo e em seguida negro. Não havia escravos nos domicílios dessa família formada por pessoas oriundas do cativeiro, um dos quais, aliás, tendo sido descrito em 1807 com a frase "não tem nada". Seja como for, acredita-se aqui que o ingresso nos Úteis tenha contribuído para solidificar a percepção social de Silvestre como um homem pardo.

Inácio Gabriel, matriculado na Companhia de Granadeiros no ano de 1821, foi outro miliciano registrado como negro nas listas de Nossa Senhora do Ó. Ele também passou de negro para pardo. Entre 1804 e 1809, quando criança, ele foi descrito como negro, assim como seu pai, um homem "preto forro" e "congo", e sua mãe, natural da vila paulista de Santana de Parnaíba. De 1810 para frente, o crioulo Inácio, que tinha apenas 10 ou 11 anos, já não morava mais no lar paterno. É provável que ele tenha sido enviado a um mestre alfaiate para aprender o ofício que desempenharia quando adulto. Após uma década, esse filho de um ex-escravizado negro foi alistado no Regimento dos Úteis, o que indica que ele era aceito socialmente como pardo ou tornou-se a partir de então. ${ }^{55}$ Esse caso e o do soldado atibaiense reforçam o papel desempenhado pela corporação na atribuição de cor a seus integrantes, sendo possível tanto reconhecer uma situação social preestabelecida como alterá-la. ${ }^{56}$

Mas a realidade é que poucos milicianos dos Úteis foram, em algum momento, registrados como negros. Na amostra, eles perfizeram o número de cinco soldados. Quatro dos quais tinham os cabelos crespos, o que remete para uma condição fenotípica associada ao passado geracional africano e, logo, escravo, o que poderia catalisar a atribuição de cor negra

\footnotetext{
${ }^{54}$ Cf.: Livro Mestre, fl. 261; ACMSP, D.M. 4173, fl. 36; APESP, Maços de População, Atibaia: (1807) M.D., fogo 116; (1810) M.D., fogo 10; (1811) M.D., fogo 29; (1812) M.D.,I., fogo 80; (1815) M.D.,I., fogo s.n., 01402_82; (1818) C.L.,C., fogo 99.

${ }^{55}$ Cf:: Livro Mestre, fl. 22v; APESP, Maços de População, Capital: (1804) N.S.Ó, fogo 34; (1805) N.S.Ó, fogo 14; (1808) N.S.Ó, fogo 11; (1809) N.S.Ó, fogo 31.

${ }^{56}$ Cf:: Livro Mestre, fls. 256 e 261; APESP, Maços de População, Atibaia: (1807) M.D., fogo 116; (1810) M.D., fogo 10; (1812) M.D.,I., fogos 44 e 80; (1815) M.D.,I., fogos s.n., 01402_82; (1818) M.D.,B.V., fogo 86; (1818) C.L.,C., fogo 99; (1829) R.Ab., fogo 8.
} 
ou preta a eles. ${ }^{57}$ Igualmente em reduzido número estavam os milicianos cujas identificações no campo cor das listas intercalavam entre pardo e índio. Os três soldados viviam na aldeia de Pinheiros, bastante próxima à cidade de São Paulo, e se chamavam Manoel José (pardo em 1804, 1811, 1822 e 1825 e índio em 1814, 1816 e 1818), Joaquim Marques (pardo em 1804, 1805, 1807, 1808, 1811, 1816 e 1822 e índio em 1783, 1814, 1818 e 1825) e Joaquim José Aranha (pardo em 1811, 1822 e 1825 e índio em 1814). ${ }^{58}$ Tratava-se, evidentemente dos já então raros remanescentes de índios aldeados na capitania, para os quais era plenamente cabível a descrição da condição indígena ou da cor parda. Aqui a influência do Regimento dos Úteis não se mostrou decisiva na atribuição de cor, já que tais alterações ocorreram independentemente de os homens em questão estarem ou não alistados na corporação. Nos anos 1804, 1811, 1822 e 1825 houve a tendência de descrever os habitantes da aldeia como pardos, ao passo que em 1814 e 1818 optou-se por registrá-los como índios. Nesse caso, as “cores” se alteraram de modo coordenado, correspondendo mais aos critérios adotados pelos recenseadores e menos a quaisquer modalidades de negociação das cores ou qualidades em termos individuais ou familiares.

A maior parte dos milicianos que mudaram de cor ao serem registrados nas listas de população alternou entre a cor parda e a branca. Esses 39 milicianos correspondem a 13\% do total da amostra (tabelas 4.4, 4.5, 4.6). O diferencial existente entre o conjunto mais vasto de indivíduos que alternaram entre as cores parda e branca e o reduzido agrupamento formado pelos que transitaram pelas cores parda e negra sugere que os milicianos dos Úteis estavam mais próximos do universo dos brancos do que ao dos negros ou pretos. A reduzida incidência de pardos que também foram registrados como negros ou pretos pode significar que a maior parte dos milicianos pardos se encontrava em posição intermediária, mas ascendente, no continuum escravidão-liberdade. Quanto àqueles que foram registrados ora como pardos e ora como brancos, cabe indagar se essa ocorrência da mudança de cor indicaria índices elevados de fluidez ou até mesmo uma transitoriedade inerente à cor parda e, não menos importante, se o fenômeno estava atrelado à mobilidade social ascendente.

\footnotetext{
${ }^{57}$ Cf:: Livro Mestre, fls. 22v, 113, 256, 261 e 338v; APESP, Maços de População, Capital: N.S.Ó (1804) fogo 34; (1805) fogo 14; (1808) fogos 11 e 35; (1809) fogos 24 e 31; (1810) fogo 84; Capital (1822) 5. a , Pateo da Sé, fogo 22; (1822) 9. ${ }^{\mathrm{a}}$, fogo 113; (1825) 3. ${ }^{\mathrm{a}}$, Rua da Esperança, fogo 1; Atibaia: (1807) M.D., fogo 116; (1810) M.D., fogo 10; (1812) M.D.,I., fogos 44 e 80; (1815) M.D.,I., fogos s.n., 01402_82; (1818) M.D.,B.V., fogo 86; (1818) C.L.,C., fogo 99; (1829) R.Ab., fogo 8; Parnaíba: (1822) 4. ${ }^{\text {a }, \text { fogo }} 40$ e (1828) 4. a, fogo 37.

${ }^{58}$ Cf:: Livro Mestre, fls. 35v, 36, 157; APESP, Maços de População, Capital: (1804) 2. a , fogos 332 e 337; (1805) 2. ${ }^{a}$, fogo 327; (1807) 2..$^{a}$, fogo 352; (1808) 2. ${ }^{a}$, fogos 316 e 321; (1811) 2. ${ }^{a}$, fogos 304 e 313; (1814) 2. ${ }^{a}$, fogos 460, 461 e 462; (1816) 2. a, Pinheiros, fogos 3, 4 e 15; (1818) 8. ${ }^{a}$, fogos 90, 100 e 101; (1822) 8. ${ }^{a}$, fogos 93,94 e 100 ; (1825) 8. ${ }^{a}$, fogos 9,14 e 15.
} 
As referências ao branqueamento social estão presentes no pensamento social brasileiro desde pelo menos as obras clássicas de Gilberto Freyre e de Caio Prado Júnior. Elas perpassaram nossa historiografia e têm continuado abundantes nas primeiras décadas do século XXI, sem, no entanto, receberem definições precisas acerca de seus sentidos e significados. ${ }^{59}$ Não está completamente claro o que os diversos autores pensaram e ainda pensam sobre o embranquecimento social. Em geral, o embranquecimento tem sido associado à mobilidade social ascendente e, conforme vários autores, uma de suas expressões típicas seria o aparecimento de indivíduos e famílias costumeiramente reputadas pardas ou mulatas como tendo a cor branca nas listagens de população. Os estudos referenciais nessa linha são os de Roberto Guedes, os quais evidenciam a importância desempenhada pela ascensão social e pelas relações pessoais na mudança de cor entre fins do século XVIII e a primeira metade do século XIX. ${ }^{60}$ Mas, afinal, esse fenômeno diz respeito aos casos de indivíduos de cor parda, mulata e/ou preta que, sem alterarem a cor socialmente reconhecida, conseguiram acessar funções honorárias e obter capitais sociais tipicamente associados às pessoas de cor branca? A identificação de pessoas "de cor" como brancas, nos recenseamentos e em circunstâncias equivalentes, mesmo que não acompanhada de mudanças sociais ascendentes verificáveis em outras esferas, já seria suficiente para caracterizar o embranquecimento? Não há resposta objetiva a essas questões na literatura. Por outro lado, sem necessariamente negarem a possibilidade de negociação da cor entre recenseador e recenseados, historiadores têm chamado a atenção para as eventuais arbitrariedades presentes à atribuição de cor às pessoas e para a dificuldade em reconhecer padrões classificatórios. Nesse sentido, as mudanças de cor poderiam ocorrer tanto por negociação quanto por aplicação de critérios díspares e variáveis ou até mesmo por negligência dos funcionários responsáveis. Pode-se identificar o que melhor caracteriza as mudanças de cor experimentadas pelos milicianos pardos?

\footnotetext{
${ }^{59}$ FREYRE, Gilberto. Sobrados e mucambos: decadência do patriarcado rural e desenvolvimento do urbano. São Paulo: Global, 15a ed., 2004 (1 $1^{\mathrm{a}}$ ed. 1936); PRADO JÚNIOR, Caio. Formação do Brasil contemporâneo. $23^{\mathrm{a}}$ ed. (1. ${ }^{a}$ ed. 1942). São Paulo: Editora Brasiliense, 1994, p. 274-275; FAORO, Raymundo. Os donos do poder. Formação do patronato político brasileiro. Rio de Janeiro: Globo, 2001, capítulo VI; MARCÍLIO, Maria Luiza. Crescimento Demográfico e evolução agrária paulista: 1700-1836. São Paulo: Hucitec/Edusp, 2000, p. 117; RICCI, Magda Maria de Oliveira. "Nas fronteiras da independência”: um estudo sobre os significados da liberdade na região de Itu (1779-1822). Dissertação (mestrado em História). Campinas: IFCH, Universidade Estadual de Campinas, 1993, p. 125-128.

${ }^{60}$ GUEDES, Roberto. Egressos do cativeiro: trabalho, família, aliança e mobilidade social (Porto Feliz, São Paulo, c. 1798-c. 1850). Rio de Janeiro: Mauad X: FAPERJ, 2008. Outros estudos que vão na mesma linha são os de MACHADO, Cacilda da Silva. A Trama das Vontades. Negros, pardos e brancos na produção da hierarquia social (São José dos Pinhais - Pr, passagem do XVIII para o XIX). Tese (doutorado em História). Rio de Janeiro: IFCS, Universidade Federal do Rio de Janeiro, 2006; LIBBY, Douglas Cole. A empiria e as cores: representações identitárias nas Minas Gerais dos séculos XVIII e XIX. In: PAIVA, E. F.; IVO, I. P.; MARTINS, I. C. (Orgs.). Escravidão, mestiçagens, populações e identidades culturais. São Paulo: Annablume; Belo Horizonte: PPGHUFMG; Vitória da Conquista: Edições UESB, 2010.
} 
Dentre os milicianos pardos que surgiram notados como brancos nas listas nominativas, houve alta incidência de homens costumeiramente referidos como pardos nos mesmos recenseamentos, mas que obtiveram uma única e isolada referência como brancos. Eles perfizeram cerca de $70 \%$ do total dos registrados brancos. Esse embranquecimento estaria associado a uma ascensão social? Seria precipitado e imprudente extrair conclusões a partir dos casos mais pobres em vestígios, ou seja, daqueles em que os milicianos foram localizados nas listas em apenas duas ou três situações e que, em ao menos uma delas, foram notados como brancos. No entanto, trabalha-se com a hipótese de que em tais casos não havia correlação entre experimentar uma melhoria social e parecer branco. Cabe analisar os dados da amostra à luz de informações mais fartas e abrangentes. Em primeiro lugar, percebeu-se a tendência de elevação da incidência de brancos em algumas listagens em particular, como ocorreu na de Bragança e na de Atibaia nos anos de 1829 e 1830, assim como em alguns dos recenseamentos já referidos da aldeia de Pinheiros. Dos 39 milicianos pardos-brancos localizados, oito foram registrados como brancos na listas atibaienses e bragantinas de 1829 e $1830 .{ }^{61}$ É o caso de José Joaquim Cardoso, soldado entre os anos 1811 e 1821, que fora reputado pardo nas listas de 1808, 1812, 1815 e 1822 e branco na de $1829 .{ }^{62}$ Entre outros fatores, talvez o incremento da população africana escravizada nessas regiões tenha alterado a percepção local sobre as cores em fins da década de 1820, possibilitando então que pardos mais claros fossem referidos como brancos. ${ }^{63}$

Em segundo lugar, ademais, boa parte dos registros isolados pode ter ocorrido acidentalmente. O caso do soldado João Ivo, morador na região de Cotia, é exemplar. Entre os anos 1809 e 1829, considerando-se todas as listas disponíveis, ele fora registrado como pardo em treze ocasiões, tendo surgido como branco apenas em 1823 e tornando logo a ser visto como pardo. ${ }^{64}$ Ao longo desses vinte anos, João Ivo foi descrito como pobre, pequeno agricultor e camarada de tropas, isto é, viajante condutor, nos caminhos de Santos e do Rio de Janeiro. Jamais foi proprietário de escravos e tampouco ascendeu na escala hierárquica do Regimento

\footnotetext{
${ }^{61}$ Cf:: Livro Mestre, fls. 232, 233, 234v, 236, 244v, 247v, 249, 250; APESP, Maços de População, Atibaia: (1829) I.,R.Ac., fogos 125 e 134; Bragança: (1829) 2. ${ }^{a}$, fogos 13, 61, 105 e 204; (1829) 4. ${ }^{a}$, fogos 102 e 103; (1830) 2. ${ }^{a}$, fogos 70 e 180 .

${ }^{62}$ Cf.: Livro Mestre, fl. 247v; APESP, Maços de População, Bragança: (1808) 1. a, fogo 178; (1812) 1. ${ }^{\mathrm{a}}$, fogo 180; (1815) 1..$^{a}$, fogo 302; (1822) 2. ${ }^{\mathrm{a}}$, fogo 60; (1829) 2.. , fogo 105.

${ }^{63}$ GUEDES, Roberto. Egressos do cativeiro... p. 102-108; MACHADO, Cacilda. A escravidão e a cor dos escravos e dos livres (Freguesia de São José dos Pinhais - PR, passagem do XVIII para o XIX). In: SANTOS, A. C. de A.; DORÉ, A. (Orgs.). Temas setecentistas: governos e populações no império português. Curitiba: UFPRSCHLA/Fundação Araucária, 2008, p. 429-442.

${ }^{64}$ Cf:: Livro Mestre, fl. 196; APESP, Maços de População, Cotia: (1809) 1.a , fogo 113; (1810) 1. a, fogo 103; (1811)

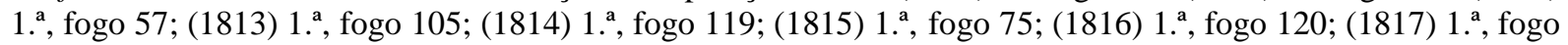
131; (1818) 1. ${ }^{\mathrm{a}}$, fogo 127; (1822) 1. ${ }^{\mathrm{a}}$, fogo 121; (1823) 1. ${ }^{\mathrm{a}}$, fogo 156; (1825) 1. ${ }^{\mathrm{a}}$, fogo 92; (1827) 1. ${ }^{\mathrm{a}}$, fogo 133 ; (1829) $1 .^{\mathrm{a}}$, fogo 136
} 
desde a sua matrícula, em 1811. Não há indícios de que a mutação pontual da cor fosse fruto de negociação ou indicasse alteração substantiva nas suas condições de vida. Em terceiro lugar, deixando-se de lado os oficiais, que serão examinados mais adiante, nenhum dos 31 soldados registrados pelo menos uma vez como brancos foram identificados como proprietários de escravos. Soma-se a essa limitada projeção socioeconômica dos soldados pardos-brancos o fato de que, como não ascenderam na hierarquia, eles não ocuparam funções sociais de prestígio na milícia capazes de modificar sua situação social.

Um quarto dado relevante é que a maioria das variações de cor, tanto de negro para pardo e vice-versa como de pardo para branco e vice-versa, ocorreu durante o período em que os indivíduos estavam alistados no Regimento dos pardos, como se vê nas tabelas 4.4, 4.5 e 4.6. Isso sucedeu com Francisco Rodrigues Pereira, soldado da 3. ${ }^{a}$ Companhia de Fuzileiros desde 1811 até a extinção da corporação, e com a sua esposa Josefa Maria, moradores no bairro de São Miguel. Nas listas eles foram descritos recorrentemente como pardos até 1818, mas em 1822, 1825 e 1829, quando Francisco ainda estava entre os milicianos pardos, surgiram como brancos. ${ }^{65}$ Essa situação ilustra uma vez mais a questão da cor como uma atribuição social e a sua capacidade de manifestar-se de diferentes modos em âmbitos sociais distintos - não obstante, cumpre lembrar, a maior parte dos milicianos pardos tivesse a cor parda reiterada nas listas. É possível aventar que, em casos como esse, os indivíduos e famílias que consolidassem a cor branca após a desvinculação do Regimento desfrutariam das vantagens em termos de estima social que eram acessíveis a brancos pobres. Certamente, dava-se um passo adiante no distanciamento do passado escravo, administrado ou forro. Entretanto, não se infere daí que tais indivíduos ou famílias caminhassem, no curto prazo, na direção da adoção de um modo de vida aristocrático para o qual a classificação como brancos cairia bem.

Costumeiramente, as listas nominativas de habitantes eram acompanhadas de tabulações que continham o total da população recenseada. A partir da ordem régia de 21 de outubro de 1797, esses quadros estatísticos foram organizados de acordo com os eixos cor (branco, pardo/mulato e negro/preto), condição jurídica (livre e escravo), gênero (homens e mulheres), estado civil (solteiro, casado e viúvo) e idade (em faixas etárias por década). ${ }^{66}$ Mesmo que seus dados sejam aproximados, e que as tabulações e listas faltem para alguns anos, é possível acompanhar as variações gerais da população de acordo com esses documentos. Interessa aqui

\footnotetext{
${ }^{65}$ Cf:: Livro Mestre, fl. 206; APESP, Maços de População, Capital: Penha de França e São Miguel (1811) fogo 136; (1815) fogo 108; (1817) fogo 109; (1818) fogo 101; (1822) fogo 109; (1825) fogo 84; (1829) fogo 169.

${ }^{66}$ MARCÍlIO, Maria Luiza. Crescimento Demográfico..., p. 39-40. Esses quadros podem ser examinados em vários dos recenseamentos paulistas.
} 
atentar para a correlação ou interdependência existente entre as populações branca e parda livre em algumas das regiões que fizeram parte da amostra. Foram selecionadas listas da companhia de ordenança de Penha de França e São Miguel, da companhia de Santana, das da vila de Atibaia e das duas companhias de ordenança da vila de Santana de Parnaíba, todas situadas nas três primeiras décadas do século XIX.

Como demonstram os gráficos abaixo, era comum que variações significativas no contingente de pessoas brancas fossem acompanhadas de alterações inversamente proporcionais no grupo das pardas - e sem que houvesse influência significativa dos demais segmentos. ${ }^{67} \mathrm{Em}$ geral, o tamanho das populações das localidades em questão sofreu oscilações pouco pronunciadas. A estabilidade marcou a dinâmica demográfica dos bairros Penha de França e São Miguel e Santana e o crescimento populacional caracterizou as vilas de Atibaia e Parnaíba. Por outro lado, a variação entre os contingentes populacionais das cores branca e parda, em particular, podia ocorrer de forma abrupta, independentemente dos ritmos e dinâmicas demográficas locais. Em Penha de França e São Miguel, as curvas de brancos e pardos livres são extremamente oscilantes. Em Santana, o predomínio relativamente estável dos brancos durante os anos 1805 a 1820-1823 foi sucedido por um súbito equilíbrio entre brancos e pardos a partir de 1825. Em Santana de Parnaíba, o declínio dos pardos entre 1812 e 1816 foi inversamente proporcional ao crescimento dos brancos no mesmo período. Finalmente, a variação mais saliente na trajetória de crescimento dos pardos de Atibaia, ocorrida entre 1815 e 1822, foi acompanhada de um significativo declínio dos brancos.

\footnotetext{
${ }^{67}$ Cacilda Machado detectou o mesmo para a população do atual Paraná no mesmo período e em particular para as vilas de Curitiba, Paranaguá e para a freguesia de São José dos Pinhais. Ver MACHADO, Cacilda da Silva. $A$ Trama das Vontades..., p. 218-222; MACHADO, Cacilda. A escravidão e a cor dos escravos e dos livres..., p. 438439.
} 


\section{GRÁFICO 4.1 - População das freguesias Penha de França e São Miguel por cor e condição jurídica (em números absolutos), 1804-1827}

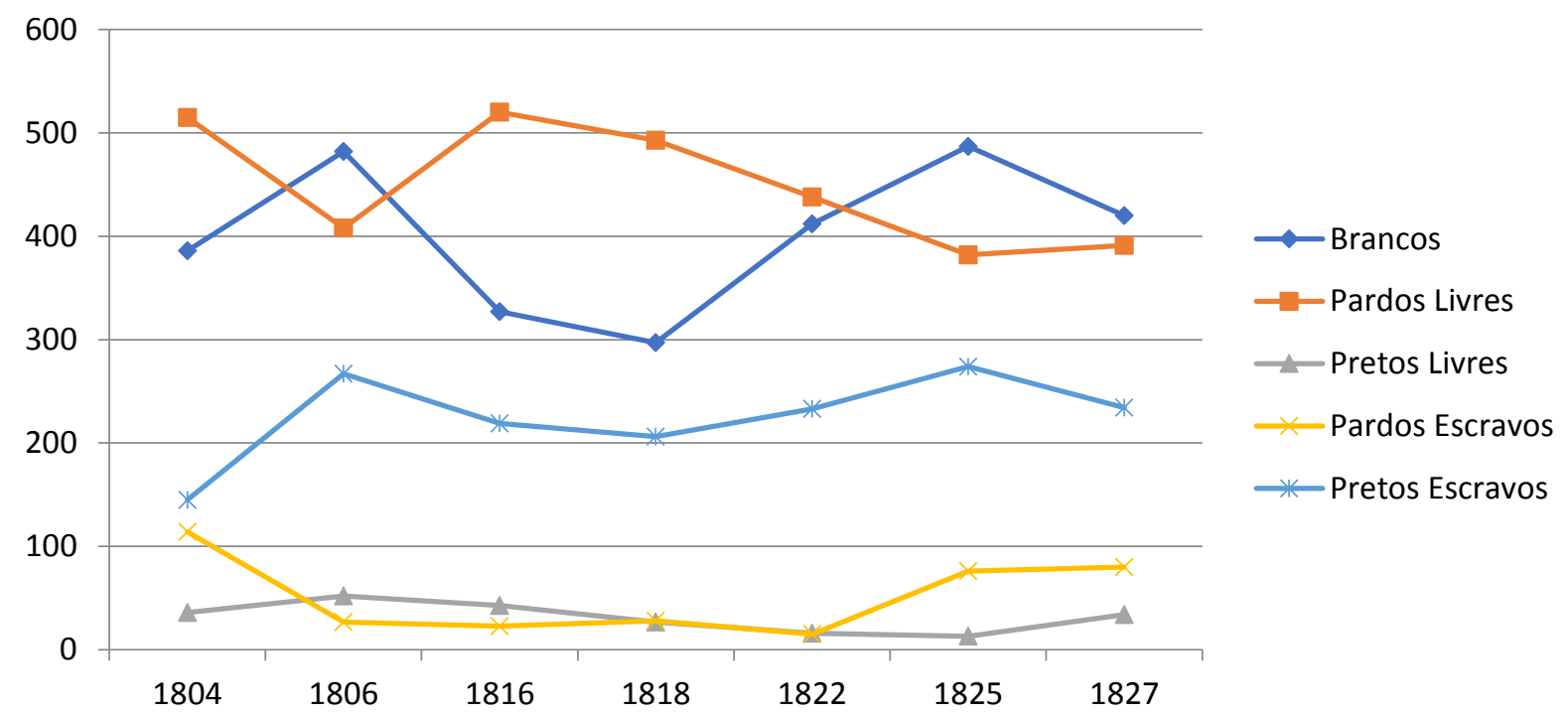

Fonte: APESP, Maços de População. Capital, Cia. Penha de França, Latas 33A-37. Observação: há um equívoco na organização do documento na forma como está publicado no site do APESP. As páginas referentes a essa Companhia são 03321_037, 03321_038, 03321_003, 03321_004, 03321_005, 03321_036.

GRÁFICO 4.2 - População da freguesia Santana por cor e condição jurídica (em números absolutos), 1805-1829

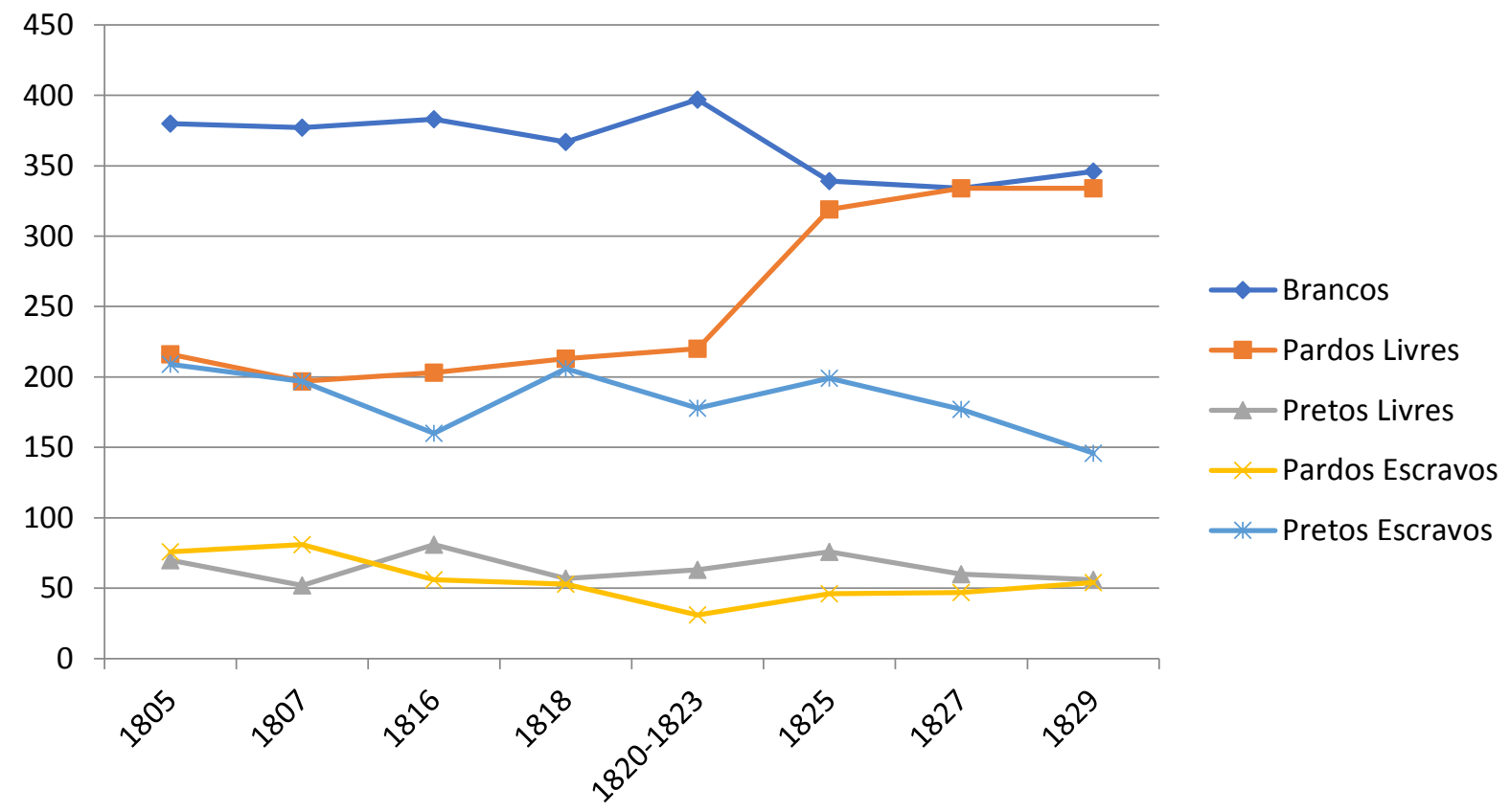

Fonte: APESP, Maços de População, Capital, Cia. Santana, Latas 33A-37. 
GRÁFICO 4.3 - População da vila de Santana de Parnaíba por cor e condição jurídica (em números absolutos), 1806-1822

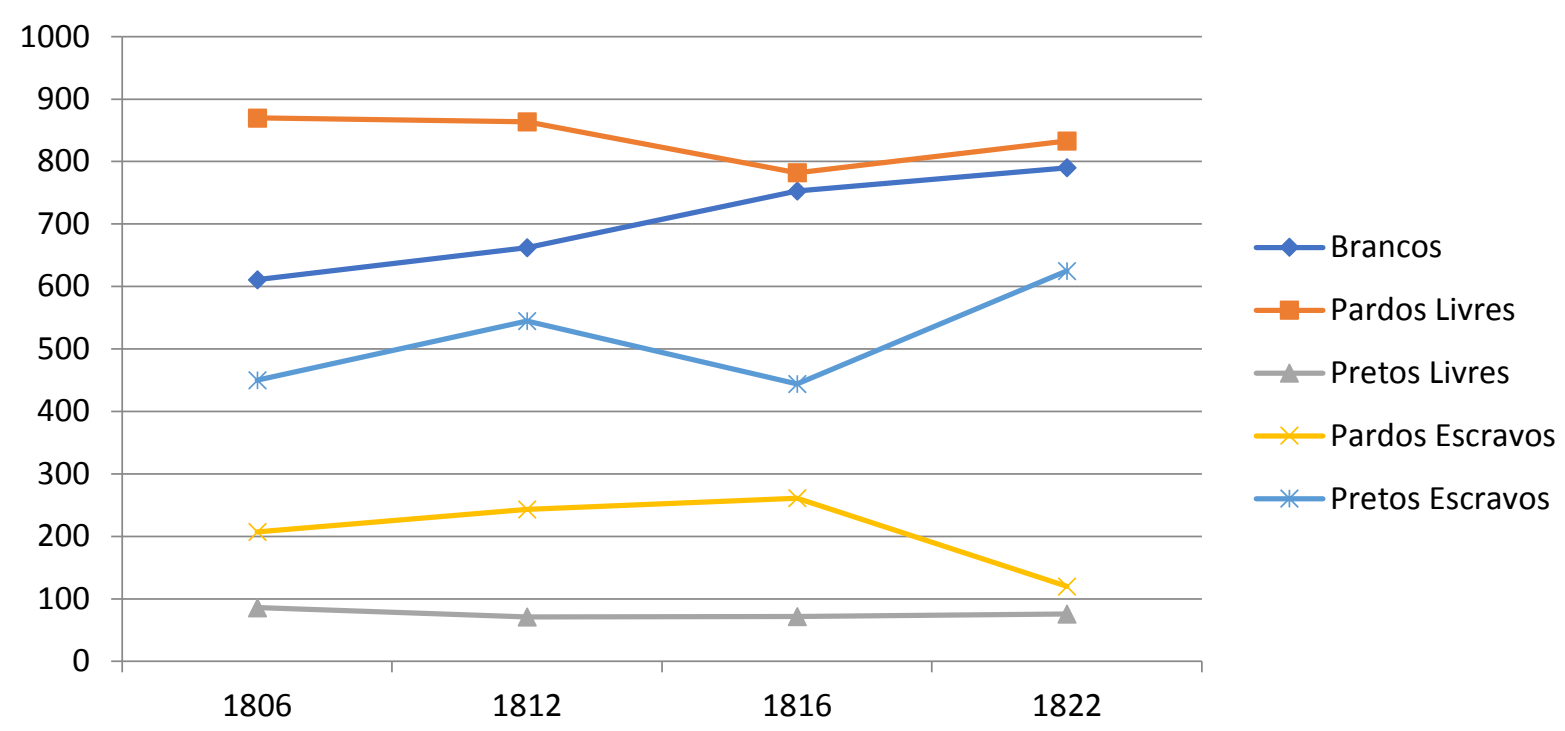

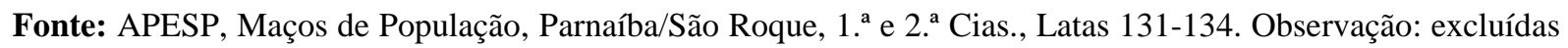
as companhias das freguesias de Araçariguama e São Roque, cujas tabulações estão incompletas.

\section{GRÁFICO 4.4 - População da vila de Atibaia por cor e condição jurídica (em números absolutos), 1805-1828}

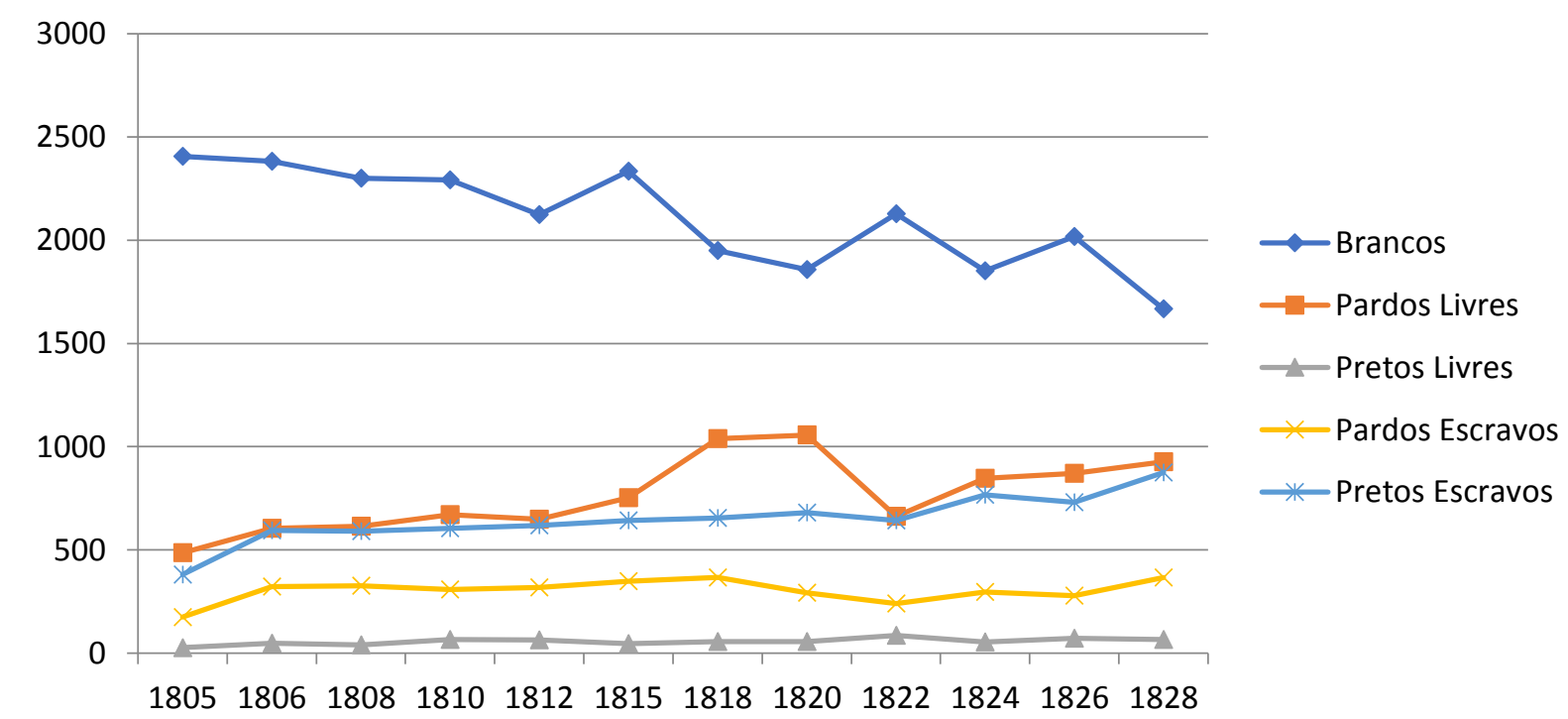

Fonte: APESP, Maços de População, Atibaia, Latas 12-16. Observação: excluídas as companhias da freguesia de Nazaré, que não forneciam soldados ao Regimento dos Úteis. 
Percebe-se que a variação de cor era um componente estrutural das listagens. Isso se devia fundamentalmente: 1) às dinâmicas demográficas e sociais dos grupos (alforrias, nascimentos, mortes, migrações e imigrações) que afetavam seu crescimento ou encolhimento; 2) à existência de setores da população recenseada que se localizavam nas zonas de intersecção entre as três categorias de cor genéricas, e que por isso em algumas listas assumiam uma cor e alteravam-na em outras; 3 ) aos critérios e percepções mutantes dos funcionários responsáveis pelo recenseamento da população e 4) em menor medida ao fenômeno da ascensão social acompanhada da negociação e mudança de cor. Certamente a maioria dos soldados pardosbrancos era parte desse contingente cuja cor variava de recenseamento para recenseamento em função dos três primeiros fatores elencados acima. E quanto aos nove oficiais que foram notados como brancos por pelo menos uma vez nas listas nominativas (tabelas 4.4, 4.5 e 4.6)?

Sempre que mudaram de cor, os oficiais pardos foram registrados como brancos. Nenhum, portanto, intercalou a cor parda com a negra. A princípio, esse dado é compatível com os relatos anteriormente evocados de Domingos Loreto Couto e de Henry Koster, os quais expressaram noções difundidas pelo corpo social a respeito da correspondência existente entre as cores e as condições sociais. De acordo com tais percepções, as cores parda e preta remetiam à esfera vulgar, à plebe e ao universo da escravidão, ao passo que a branca era associada à liberdade, a um distanciamento do povo comum e a uma aproximação à nobreza. É possível entrever nelas a ideia de que as cores parda e preta eram incompatíveis com o ideal nobre. Mas o "embranquecimento" de alguns dos oficiais do Regimento dos Úteis parece não caminhar nessa direção. Em primeiro lugar, porque oito dos nove oficiais foram referidos como brancos enquanto serviam no Regimento dos pardos. E, como afirmou o inspetor geral das milícias de São Paulo, José Arouche de Toledo Rendon, matricular-se nesse corpo militar implicaria o reconhecimento público e a perpetuação da cor parda. ${ }^{68} \mathrm{Em}$ segundo lugar, esses oficiais não apenas assumiam a cor parda, mas se beneficiavam dessa circunstância para lograrem acesso aos postos e as patentes da milícia separada por cor. Como será visto em capítulo adiante, os oficiais pardos não reuniam as condições sociais necessárias para concorrerem aos postos superiores dos regimentos identificados aos brancos. Mas isso jamais impediu que, formalmente, a nobreza da patente de um capitão pardo ou preto fosse equivalente à de um capitão branco. Esse, aliás, foi o caso de Joaquim Barbosa Neves ${ }^{69}$, que, após servir como

\footnotetext{
${ }^{68}$ Cf:: "Projeto de Plano para o Melhoramento das tropas Milicianas de São Paulo". APESP, Ordem C00265, doc. 24. São Paulo, 5 de setembro de 1815.

${ }^{69}$ GUEDES, R. De ex-escravo a elite escravista: a trajetória de ascensão social do pardo alferes Joaquim Barbosa Neves (Porto Feliz, São Paulo, século XIX). In: FRAGOSO, J.; ALMEIDA, C.; SAMPAIO, A. (Orgs.).
} 
soldado por anos a fio em corpos militares de brancos, e sem qualquer perspectiva de promoção, mobilizou suas redes pessoais para ser incorporado ao Regimento dos Úteis. Foi-lhe preciso reconhecer a cor parda para ascender repentinamente ao posto de sargento e ser reformado como alferes, desfrutando, assim, da nobreza da sua patente.

$\mathrm{Na}$ realidade, a milícia parda ou preta constitui uma via muito específica de acesso a funções sociais de prestígio, das quais emanavam honras, privilégios e graus de nobreza. É apenas aparente a contradição entre o que se processa entre a oficialidade miliciana assumidamente parda e preta, que goza da nobreza de suas patentes, e o mulato que se transforma em branco após ascender ao posto de capitão-mor referido por Koster. É que se trata de instituições ou corporações militares diferentes. O capitão-mor em questão comandava um terço ou uma companhia de ordenanças, a qual, presumivelmente, não estava organizada com base na cor. O inverso ocorria nas milícias de pardos e de pretos, onde o reconhecimento social das cores era um pré-requisito para que os oficiais de patente assumissem suas posições e a nobreza delas derivada. Desse modo, o eventual embranquecimento de oficiais milicianos pardos nas listas nominativas dificilmente decorreria de negociação entre eles e os recenseadores. Enquanto mantivessem o capital social e simbólico atrelado às patentes, eles pouco se interessariam em tornarem-se brancos e em colocarem em risco as suas posições.

Ninguém menos que o tenente-coronel do Regimento, Manoel José da Costa Ribeiro, filho do antigo coronel pardo Manoel José Ribeiro, surgiu como branco na lista de 1826, após ser sucessivamente registrado como pardo em quinze recenseamentos no período compreendido entre os anos 1802 e $1822 .{ }^{70}$ Como a listagem de 1826 foi a última em que esse oficial foi localizado $^{71}$, não se sabe se a cor branca caracterizou-o novamente nos recenseamentos seguintes. Embora a segunda esposa do tenente-coronel Ribeiro fosse registrada como branca desde o casamento, ocorrido em 1812, e esse fator pudesse pesar para embranquecer a família no médio e longo prazo, não é crível que fosse esse o caso em 1826. Ora, entre as décadas de 1810 e 1820, Manoel José da Costa Ribeiro tornou-se um líder influente entre os pardos de São Paulo. Por mais de uma vez ele suplicou ao rei D. João VI e depois ao imperador D. Pedro I a

Conquistadores e negociantes: histórias de elites no Antigo Regime nos trópicos, América lusa, séculos XVI a XVIII. Rio de Janeiro: Civilização Brasileira, 2007, p. 337-376.

${ }^{70} C f$ :: APESP, Maços de População, Capital: cidade de São Paulo (1802) 1. a , fogo 139; (1804) 1. a , fogo 140; (1805) 1. a , Rua do Rosário, fogo 127; (1807) 1. a, Rua do Rosário, fogo 137; (1808) 1. a, Rua do Rosário, fogo 134; (1809) 1. a , Rua do Rosário, fogo 29; (1810) 1. a, Rua do Rosário, fogo 105; (1811) 1. a, Rua do Rosário, fogo 118; (1813) 1. a , Rua do Rosário, fogo 29; (1814) 1. a, Rua do Rosário, fogo 29; (1815) 1. a , Rua do Rosário, fogo 29; (1816) 1. a, Rua do Rosário, fogo 29; (1817) 1. a , Rua do Rosário, fogo 107; (1818) 4. a, Rua do Rosário, fogo 29; (1822) 4. a, Rua do Rosário, fogo 29; (1826) 5. a, Tv. Jogo da Bola, fogo s.n.

${ }^{71}$ Partes das listas nominativas subsequentes se perderam ou não foram confeccionadas. A partir dos anos 1830, a feitura das listas tornou-se rara. 
proteção do trono para si próprio e a "todos os mais da sua cor". ${ }^{72} \mathrm{O}$ Regimento dos Úteis e a identificação à cor parda eram, em parte, um patrimônio familiar, de modo que Ribeiro não necessitava valer-se de um ardil tal como a mudança de cor na lista nominativa para que fosse aceito em sua posição honrosa e de prestígio.

Já o miliciano Joaquim Antonio Rodrigues, alistado na companhia de Atibaia, seguiu um caminho diferente. Ele ingressou no Regimento dos pardos em 1819 e já no ano seguinte ascendeu ao posto de $2 .^{\circ}$ sargento. Embora mantivesse o posto e a identificação implícita com os pardos, ele foi notado como branco nas três ocasiões em que foi localizado nas listas, em 1822, 1824 e 1825. Sua esposa e seus filhos, porém, eram pardos. Joaquim ausentou-se da vila e da assembleia de sua companhia entre os anos de 1826 e 1827 sem o consentimento dos superiores e sem se justificar, razão pela qual foi punido com a perda do posto, retornando, então, a simples soldado. Contrariado com a nova situação, esse miliciano solicitou a transferência para um regimento de brancos já em 1828 e foi atendido. ${ }^{73}$ Esse exemplo é significativo das diferentes vias possíveis para se buscar o melhoramento social na sociedade escravista: o branco Joaquim Antonio Rodrigues manteve-se como miliciano pardo enquanto durou a sua expectativa em se tornar oficial de patente. Uma vez decaído na hierarquia militar e vendo seu projeto de momento se esvair, Joaquim decidiu desvincular-se do Regimento dos pardos para passar a ser definitivamente associado à cor branca.

Chegado a esse ponto de um exaustivo exame do tipo de cabelo e da cor dos milicianos que integraram o Regimento dos Úteis nas três primeiras décadas do século XIX, três aspectos devem ser ressaltados. Primeiro, a corporação era composta por homens que expressavam uma fabulosa diversidade fenotípica, a qual, contudo, convergia para a origem comum assentada na mestiçagem processada entre africanos, indígenas, europeus e seus descendentes. Segundo, a cor parda atribuída ou reforçada pelo Regimento era reiterada na maior parte dos registros dos milicianos nos recenseamentos paulistas. Ela era arbitrária, como qualquer outra. Em alguns casos, ela convivia, em um mesmo indivíduo, com as cores negra ou branca. Os poucos milicianos pardos-negros tinham em comum uma proximidade com a situação de cativeiro, fosse ela vivenciada pelos pais, esposas ou pelos próprios soldados. Se alguns deles foram, inicialmente, notados como negros, o ingresso no Regimento dos Úteis implicou-lhes a atribuição de cor parda. Outros, porém, foram referidos como negros quando já eram

\footnotetext{
${ }^{72}$ Cf:: "Requerimento do sargento-mor graduado Manoel José da Costa Ribeiro pedindo a efetividade, digo, ser agregado no seu posto". APESP, ordem C00439, livro 229, sem paginação e sem data.

${ }^{73}$ Cf:: Livro Mestre, fl. 224v; APESP, Maços de População, Atibaia: (1822) V.,C., fogo s.n., 01501_066; (1824)

V.,C., fogo 19; (1825) C.,V., fogo 103.
} 
socialmente aceitos como pardos, aspecto que sinaliza tanto para a constituição fenotípica das pessoas quanto para as dificuldades em apagarem as marcas da escravidão. Já a alternância entre as cores parda e branca, para esses milicianos, dificilmente poderia ser encarada como o coroamento de trajetórias de ascensão social. De um lado, porque os soldados não reuniam capital simbólico e material suficiente para justificar uma alteração em sua localização estamental. De outro lado, os oficiais que possuíam escravos e patentes estavam atados àquela instituição militar e vivenciavam as coerções e implicações dessa vinculação ao Regimento dos pardos.

Embebido dos ideais ilustrados e levando adiante a missão de aperfeiçoar os vínculos entre súditos, o rei e o Estado por meio da extinção de corporações que, a seu ver, impunham obstáculos a essa relação, o inspetor Rendon argumentava, nas primeiras décadas do século XIX, que as aldeias construíam os índios assim como os regimentos milicianos separados por cor criavam os pardos e pretos. Aldeias e regimentos de pardos e pretos persistiam na reprodução de tipos sociais maculados, os quais poderiam apagar os estigmas e embranquecer caso fossem integrados socialmente de outro modo. Em sua perspectiva, do ponto de vista do Estado, essas corporações impediam a formação de uma concepção de direito homogênea e aplicável indistintamente a todos os vassalos; já do ponto de vista dos seus próprios membros, elas perpetuavam as “prevenções”, ou preconceitos, aos indígenas em função da barbárie a eles associada e aos milicianos em razão do mulatismo que lhes era imputado. Em síntese, esse funcionário de alto escalão da capitania e província de São Paulo, pouco afeito ao Regimento dos Úteis, exaltou o processo de embranquecimento social experimentado por famílias que escaparam das teias e dos registros de aldeias e daquelas milícias. ${ }^{74}$

E, com efeito, essa era uma via possível de integração social. Quanto aos milicianos pardos, e especialmente para os soldados, embora o embranquecimento nas listas não tenha significado o ápice de trajetórias de mobilidade social ascendentes, não se pode descartar a hipótese de que os sujeitos em questão estivessem iniciando uma inserção social por essa via. ${ }^{75}$

\footnotetext{
${ }^{74}$ Sobre as concepções ilustradas de organização social e suas implicações nas relações entre súditos, corporações e Estado, ver GUERRA, F. X. Modernidad e independencias: ensayos sobre las revoluciones hispânicas. Madrid: Editorial Mapfre, 1992, p. 23. Para a perspectiva de Rendon a respeito das aldeias e dos regimentos milicianos de pardos e pretos, ver DIHCSP, vol. 44, p. 114-115 e APESP, Ordem C00265, doc. 24.

${ }^{75}$ Ben Vinson III argumenta que os milicianos pardos da Nova Espanha que se casaram com mulheres tidas como brancas ou espanholas ao longo do século XVIII não estariam necessária e imediatamente embranquecendo, visto que esse processo se desenrolava intergeracionalmente e podia ou não se concretizar. Ver VINSON III, Ben. Bearing arms for his majesty: the free-colored militia in colonial Mexico. Stanford: Stanford University Press, 2001, p. 128-130. Essa perspectiva também é compatível com a sugestão de I. Kopytoff, S. Miers e O. Patterson conforme a qual a passagem da escravidão para a condição de liberto não demarcava o fim de um processo, mas o final de uma etapa e o começo de outra no sentido do distanciamento de um passado atrelado à situação de
} 
Talvez, para eles, serem eventualmente considerados brancos, mesmo que pobres, fosse mais benéfico do que serem pardos. Assim, embora a atribuição de cor branca em períodos mais ou menos curtos e de modo intercalado com a cor parda não fosse resultante de ascensão social, ela poderia significar mudanças benéficas em longo prazo - notadamente o apagamento das origens escrava ou indígena. As milícias de pardos e pretos, por sua vez, ofereciam um caminho diferente. Elas reiteravam as cores e a origem social de seus integrantes, mas, no entanto, ofereciam a algumas dezenas de homens o acesso a funções sociais de prestígio e honra que jamais ocupariam enquanto brancos pobres. Não é por acaso que os pedidos de transferência para regimentos de brancos, examinados em momento anterior, partiam quase que exclusivamente de soldados. Os oficiais mantinham grande interesse na dinâmica de promoção interna ao Regimento dos pardos. Como evidenciam algumas pesquisas recentes, a crescente presença de pardos e pretos nos postos mais elevados de suas milícias, ao longo do Setecentos e da primeira metade do Oitocentos, implicou em processos de contestação de sua posição de inferioridade em relação aos brancos em diferentes pontos das Américas portuguesa e espanhola. ${ }^{76}$ Enobrecidos por suas patentes, esses homens relativizaram a percepção social vigente conforme a qual as cores parda e preta eram incompatíveis com a nobreza.

\subsection{Origem social dos milicianos pardos de São Paulo: escravidão negra, administração indígena e mestiçagens na formação familiar (século XVIII e primeira metade do século XIX)}

A investigação sobre a cor e tipo de cabelo dos milicianos pardos sugeriu que a mestiçagem envolvendo africanos, indígenas, europeus e seus descendentes é componente fundamental do grupo em tela. Já o exame relativo à cor dos milicianos expressa nas listas nominativas revelou que a cor parda era reforçada e reiterada na maioria dos casos. Em boa parte dos casos eventuais de embranquecimento, tratava-se de registros momentâneos e isolados, os quais não foram considerados como manifestação de reconhecimento a trajetórias de elevação social em estágio avançado. Entretanto, como afirma L. F. Pellicer, as variáveis textura de cabelo e cor de pele não eram as mais seguras para indicar a qualidade das pessoas

cativeiro. Vide KOPYTOFF, Igor; MIERS, Suzanne. African 'slavery' as an institution of marginality..., p. 1220; PATTERSON, O. Escravidão e morte social..., p. 350-354

${ }^{76}$ SOUZA, Priscila de Lima. "Sem que lhes obste a diferença de cor": a habilitação dos pardos na América portuguesa e no Caribe espanhol (c. 1750-1808). Tese (doutorado em História). São Paulo: FFLCH, Universidade de São Paulo, 2017. 
nas sociedades escravistas coloniais. A oitiva de testemunhas e principalmente a consulta às atas de batismo forneciam os mais elevados níveis de confiabilidade possíveis a esse respeito. ${ }^{77}$

A questão a partir de agora é adensar a explicação em torno da origem social dos milicianos pardos e da reprodução ou transformação dessa base social. Em um primeiro momento, os milicianos pardos estarão em foco na ocasião de seu nascimento, ou melhor, do nascimento para a vida social e religiosa, tal como ratificava a Igreja católica, mediante o sacramento do batismo. A formatação de suas famílias nesse momento poderá servir como um termômetro para indicar as condições de maior ou menor estabilidade social em que vieram ao mundo os futuros milicianos pardos e em que se processou a constituição do grupo social em questão. Por ocasião desse rito, é igualmente possível examinar a condição jurídica dos batizandos e a de seus pais. A reunião de um conjunto de registros referentes aos milicianos pardos fornece subsídios necessários para se encarar questões centrais à compreensão desse grupo social e da organização interna da milícia. Em que medida os milicianos e suas famílias estavam próximos ou já distanciados do cativeiro? Quanto esse aspecto influía na composição da oficialidade miliciana?

Em um segundo momento, os milicianos pardos serão contemplados em sua participação mais efetiva na formação de novas famílias e, consequentemente, na reprodução do grupo social ao qual faziam parte. O sacramento religioso do matrimônio, precedido pelas averiguações de praxe quanto à legalidade da união pretendida, resultava na confecção de registros que, por sua vez, fornecem um segundo conjunto de informações acerca dos milicianos pardos. Eles revelam eventuais transformações na condição jurídica dos milicianos pardos quando em idade adulta e também informam a condição das noivas, a qual determinava se os frutos das novas famílias, os seus filhos, nasceriam livres ou escravizados. Ademais, não era raro que os funcionários eclesiásticos incluíssem nos registros matrimoniais informações diversas acerca da origem e da condição social dos milicianos, de suas noivas, pais e sogros, as quais ora complementam e ora contrastam com os dados constantes nos registros batismais. Ao fim do capítulo, os milicianos pardos e seu grupo social estarão caracterizados por meio de análise aos registros provenientes de diferentes instituições (milícia, ordenanças, igreja católica) em diferentes etapas de suas vidas (batismo, alistamento, casamento e recenseamento).

Aqui também se impõe a necessidade de estabelecer recortes sobre o contingente de mais de um milhar de milicianos pardos e de recorrer às amostras. Assim, as análises e

\footnotetext{
77 PELLICER, Luis Felipe. Entre el honor y la pasión: familia, matrimonio y sistema de valores en Venezuela durante la crisis del orden hispánico: 1778-1820. Caracas: Fondo Editorial de la Facultad de Humanidades y Educación; Universidad Central de Venezuela, 2005, p. 68-69.
} 
conclusões terão como base as informações referentes aos oficiais de patente das cinco companhias aquarteladas na cidade de São Paulo e ao conjunto das companhias interioranas de Atibaia e de Santana de Parnaíba. Em tese, a amostra deveria compreender 265 milicianos pardos, o que se aproximaria à quarta parte do total de milicianos matriculados, mas os embaraços eventualmente encontrados na tarefa de localizar com exatidão esses homens nas fontes militares e paroquiais obrigaram a diminuições nesse total, como se verá adiante. À medida que os dados se avolumam e que o seu cruzamento torna-se crescentemente complexo, a integridade dos conjuntos documentais e a qualidade das informações disponíveis tornam-se critérios essenciais para a confecção dos recortes. Afortunadamente, tanto as listas nominativas como as diversas modalidades de registros paroquiais estão completos e bem preservados para as vilas de Atibaia, Bragança Paulista e Santana de Parnaíba. Não menos importante, as paróquias que atendiam essas vilas eram chefiadas por padres bastante diligentes em se tratando do registro de informações dos fiéis. Esses dados complementam as informações extraídas do Livro Mestre e das listas de população. ${ }^{78}$

\subsubsection{Condição social e jurídica dos milicianos pardos no batismo e no casamento}

Os milicianos alistados no Regimento dos Úteis durante as três primeiras décadas do século XIX eram todos livres ou libertos. Nesse contexto em que a estrutura militar lusoamericana já se encontrava consideravelmente institucionalizada, o ingresso de escravos na segunda linha era impedido formalmente. Apesar disso, em determinadas circunstâncias nas quais a mobilização militar assumiu caráter emergencial, escravizados foram admitidos em corpos militares, como, aliás, demonstram fartamente os trabalhos referentes às guerras de independência na Bahia e às guerras travadas nas fronteiras platinas nesse mesmo período. ${ }^{79}$

\footnotetext{
${ }^{78}$ Carlos de A. P. Bacellar, especialista em demografia histórica e no manejo às fontes paroquiais e nominativas, testemunhou o quão dificultosa - e eventualmente infrutífera - é a tarefa de rastreamento e identificação de indivíduos e famílias escravas, libertas e pobres por meio do cruzamento dessas fontes. Sua constatação decorreu de pesquisa relativa à vila paulista de Itu, que também abrigava uma companhia pertencente à milícia dos pardos. Ver BACELLAR, Carlos de Almeida Prado. O matrimônio entre escravos e libertos em São Paulo, Brasil, séculos XVIII e XIX. In: GHIRARDI, Mónica; SCOTT, Ana S. V. (Coords.). Familias históricas: interpretaciones desde perspectivas Iberoamericanas a través de los casos de Argentina, Brasil, Costa Rica, España, Paraguay y Uruguay. Red de Investigación Formación, comportamientos y representaciones de la Familia en Latinoamerica. São Leopoldo: Oikos; Editora Unisinos, 2015, p. 217-238. Em um investimento preliminar nas fontes ituanas, também me deparei com extrema dificuldade para identificar os milicianos pardos. Evidentemente, esses aspectos pesaram na delimitação das localidades e amostras a serem observadas com mais rigor.

${ }^{79}$ KRAAY, Hendrik. "Em outra coisa não falavam os pardos, cabras, e crioulos": o recrutamento de escravos na guerra da independência na Bahia. Revista brasileira de história, v. 22, n. 43, p. 109-126, 2002; ALADRÉN,
} 
Exceto o caso dos escravos residentes nas vilas litorâneas de São Sebastião e de Ubatuba, arrolados em meio à "gente capaz de pegar em armas" - "em caso urgente" - pertencente às companhias de ordenança locais, em $1819^{80}$, esse fenômeno não teve lugar em São Paulo, de modo que na extensa documentação consultada não há uma única referência a escravos alistados irregularmente no Regimento dos Úteis. Já foi evidenciado que esses milicianos pardos, livres e libertos, apresentavam traços evidentes de mestiçagem e em geral eram identificados socialmente à cor parda. O que os dados anteriores não revelam é o quão vinculados ao universo do cativeiro aqueles homens estavam. Para entender um pouco mais sobre esses milicianos pardos, é pertinente examinar a condição em que eles nasceram para a vida social.

Ao mesmo tempo em que o batismo era um sacramento religioso dos mais importantes para a cristandade, na medida em que previa o apagamento do pecado original e o recebimento do Espírito Santo, ele era um rito carregado de implicações institucionais. Os assentos batismais registravam pela primeira vez os nomes e o sexo dos batizandos, identificavam seus pais e padrinhos e formalizavam a condição social a quem o sacramento era ministrado. A tabela 4.7 condensa informações sobre os futuros milicianos pardos quando do batismo. Embora uma boa parte dos milicianos tenha sido excluída da amostra, em função tanto da não localização de seus registros quanto da indisponibilidade de informações seguras em relação a eles ${ }^{81}$, ainda assim há dados precisos para um contingente expressivo formado por 175 homens, o qual representa aproximadamente $16 \%$ de todos os matriculados no Livro Mestre. Há uma predominância dos nascidos livres em todos os cenários: entre os oficiais de patente que comandavam o estadomaior e as companhias da capital de São Paulo, bem como entre os oficiais, oficiais inferiores e soldados das companhias de Atibaia e Santana de Parnaíba. Dentre os livres, havia ainda 17 indígenas nascidos em aldeias da capitania além de dez expostos ou enjeitados, isto é, crianças abandonadas ou doadas a outrem por pais anônimos. Juntos, livres, expostos e índios formam $90 \%$ da amostra. No outro extremo, 14 meninos nasceram escravos, o que perfazia $8 \%$ do

Gabriel. Experiências de liberdade em tempos de guerra: escravos e libertos nas Guerras Cisplatinas (1811-1828). Estudos Históricos, Rio de Janeiro, vol. 22, n. 44, p. 439-458, jul./dez. 2009.

${ }^{80} C f$ : : APESP, Ordem C00265, docs. 33-2-39 e 33-2-41. São Sebastião, 27 de novembro de 1819 e Ubatuba, 15 de novembro de 1819 .

${ }^{81}$ A identificação nominal dos milicianos em diferentes corpos documentais é tarefa árdua. Partiu-se dos assentos do Livro Mestre - os quais indicam nome, nome paterno, idade, profissão e localidades de nascimento e residência - e se tentou localizá-los nas listas nominativas de habitantes. Através dos nomes dos pais dos milicianos, deles próprios e de suas esposas, extraídos dos recenseamentos, buscou-se localizar seus registros de casamento e os processos do fundo "Dispensas Matrimoniais e Casamentos", onde constam seus batismos. A travessia de um tipo documental a outro ora acrescenta dados riquíssimos e ora embaralha as referências. Nesse último caso, há fatores que obstaculizam a identificação dos milicianos, tais como a incidência de nomes invertidos, incompletos e variáveis para a mesma pessoa, idades díspares, ocorrência de homônimos, mudança de residência, entre outros. 
contingente considerado. E, na fronteira entre a liberdade e a escravidão, dois meninos eram administrados e dois foram alforriados na pia batismal.

TABELA 4.7 - Condição dos milicianos pardos ao serem batizados, 1752-1808

\begin{tabular}{lcccccccc}
\hline & LIVRES & EXPO & ÍNDIOS & ADM & ALF & ESCR & S.INFO & TOTAL \\
\hline Of. Pat. S. Paulo & 12 & 1 & 0 & 0 & 0 & 4 & 11 & 28 \\
Of. Atibaia & 6 & 0 & 3 & 0 & 1 & 1 & 6 & 17 \\
Of. Parnaíba & 9 & 0 & 1 & 0 & 1 & 1 & 8 & 20 \\
Sold. Atibaia & 53 & 7 & 4 & 1 & 0 & 4 & 36 & 105 \\
Sold. Parnaíba & 50 & 2 & 9 & 1 & 0 & 4 & 29 & 95 \\
\hline TOTAL & 130 & 10 & 17 & 2 & 2 & 14 & 91 & 265 \\
\hline
\end{tabular}

Legenda: $\mathrm{EXPO}=$ Expostos; $\mathrm{ADM}=$ Administrados; $\mathrm{ALF}=$ Alforriados no batismo; ESCR = Escravos; S.INFO = Sem informação precisa.

Fonte: Livro Mestre; Livros de Casamento (Atibaia, Bragança, Santana de Parnaíba e São Paulo); Dispensas Matrimoniais; Maços de População (Capital, Santana de Parnaíba, Atibaia, Bragança).

Alguns aspectos desses dados merecem ser destacados. Somados os índios e os administrados, tem-se que cerca de $11 \%$ dos milicianos pardos da amostra tinham origem expressamente indígena. ${ }^{82}$ Mesmo com o avanço no processo de desestruturação dos aldeamentos promovidos pelo Estado e geridos inicialmente por jesuítas e, depois da expulsão desses, em 1757, por administradores civis, havia nas redondezas de São Paulo grupos significativos de pessoas integradas à sociedade e reconhecidas como índios. As referências à instituição da administração indígena nos anos de 1790, após décadas de sua extinção formal, sugerem a persistência da dominação que incidia sobre os nativos da América e da exploração de seu trabalho, sobretudo em regiões rurais não muito distantes da capital paulista.

Um desses batizandos referidos como administrado era Pedro Domingues de Siqueira, que assentou praça no Regimento dos Úteis em 1821. Em seu batismo, ocorrido em 1795, ele foi identificado apenas como "filho de Tereza, muda, solteira, agregada a João de Siqueira de Alvarenga". Muito já se discutiu na historiografia sobre os agregados, desde o seu perfil demográfico até o potencial de ação política em meio às teias da dominação. ${ }^{83}$ Em geral,

\footnotetext{
${ }^{82} \mathrm{Na}$ composição do grupo composto por pessoas de "origem expressamente indígena" estão sendo levados em conta apenas as pessoas nascidas em aldeamentos indígenas e também as pessoas que eram administradas. Já a presença indígena no contingente mais vasto de milicianos batizados na condição de livres e sem outras referências mais específicas sobre sua origem será avaliada mais detidamente ao longo do texto.

${ }^{83}$ SAMARA, Eni de Mesquita. Lavoura canavieira, trabalho livre e cotidiano. Itu, 1780-1830. São Paulo: EDUSP, 2005, p. 55-179; FRANCO, Maria Sylvia de Carvalho. Homens livres na ordem escravocrata. $4^{\mathrm{a}}$ ed. São
} 
admite-se que o agregado, ou seja, aquele que morava de favor em uma residência que originalmente não era de sua propriedade, era incorporado aos fogos por ser familiar ou amigo dos chefes de domicílio, por caridade e especialmente por representar um acréscimo em termos de mão de obra. Desse modo, a relação entre proprietários e agregados era resultante de uma complementação de interesses: os agregados, em situação de vulnerabilidade econômica e social, decorrente tanto de desestruturação familiar quanto da falta de terras e propriedades em função da concentração latifundiária, recorriam à proteção e ao favor de famílias melhor estabelecidas; já os proprietários mantinham vivo interesse em alargar os seus conjuntos de trabalhadores e de dependentes, o que lhes proporcionava maior projeção econômica e social. No caso de Pedro e de sua mãe, Tereza, são os autos de casamento do futuro miliciano, onde consta a cópia da ata do batismo, que revelam a condição do agregado "Pedro Domingues de Siqueira, filho de Tereza Domingues e pai incógnito, administrado de dona Maria Cardosa de Oliveira, viúva do falecido João de Siqueira de Alvarenga". ${ }^{84}$ O que se vê aí é a perpetuação da dominação sofrida pela família, exposta de modo mais ou menos disfarçado. O termo agregado, nesse caso, fora empregado como uma adaptação à condição de administrado, formalmente extinta, mas vigente na prática, como revelado pelo padre.

É de modo igualmente sutil que se indicou a condição administrada, ou os resquícios dessa condição, na família de Antonio José, nascido na freguesia de Araçariguama, em 1790, e soldado da companhia de Santana de Parnaíba desde 1811. Ao ser batizado, Antonio foi referido como "filho de pai incógnito e de Petronila, solteira, filha de Maria Delgada, agregadas de Manoel de Morais de Brito". Não era de praxe indicar em tais registros a vinculação do batizando a pessoas que não faziam parte diretamente de sua família. Limitava-se a nomear os pais e, no caso de mães solteiras, havia referência aos avôs maternos. Aqui, a ausência paterna fora suprida pela indicação da avó materna. Então a inclusão de Manoel de Morais de Brito no assento de batismo do pardo Antonio José pode sugerir que havia entre todos eles um vínculo antigo fundado na prática da administração, hipótese que é reforçada pelo fato de o registro em questão estar localizado no livro referente aos escravos, e não, como deveria, no dos livres. Ademais, não é improvável que a menção ao proprietário tivesse a função de revelar, nas entrelinhas, a paternidade considerada ilegítima aos olhos da Igreja. ${ }^{85}$ Seguramente, os casos acima configuram exemplos pontuais das relações escravistas tipicamente estabelecidas na

Paulo: Fundação Editora da UNESP, 1997; COSTA, Iraci Del Nero. Arraia-miúda: um estudo sobre os nãoproprietários de escravos no Brasil. São Paulo: MSGP, 1992.

${ }^{84}$ Cf:: Livro Mestre, fl. 256; 1795/03/14, ACMSP/DMC 4165, fl. 3. O grifo é meu.

${ }^{85}$ Cf.: Livro Mestre, fl. 328; 1790/03/28, L.B.B.E. Araçariguama 1783-1806, fl. 113v. 
capitania paulista durante o século XVIII e sintetizadas pelo governador Morgado de Mateus, em 1767, ao discorrer sobre os problemas enfrentados por sua administração para a fundação de "povoações civis". Os povos, divididos na argumentação do governador em dois grupos de acordo com os seus potenciais de retenção de poder, se opunham a tais estabelecimentos: "os pequenos porque querem viver na liberdade, na dissolução e nos vícios, livres de todo o governo e justiça; e os maiores porque querem servir-se daqueles mesmos debaixo do nome de administrados e tê-los como verdadeiros escravos". ${ }^{86}$ A tensão entre liberdade e escravidão surge como elemento central na configuração da condição social dos administrados.

A maior incidência de índios na companhia de Santana de Parnaíba se deve principalmente à proximidade existente entre essa vila e a Aldeia de Barueri. Alguns milicianos pardos de origem indígena também nasceram na freguesia de Araçariguama. Quando Auguste de Saint-Hilaire percorreu o caminho entre a cidade de São Paulo e a vila de Itu, em fins de 1819, ele observou atentamente os povoados paulistas historicamente associados aos índios, muitos dos quais originados de aldeamentos e antigas fazendas movidas pelo trabalho forçado daquelas pessoas, e notou grande presença de mestiços entre essa população. E, com efeito, as aldeias ou freguesias de Pinheiros, Carapicuíba, Cotia, Embu, Itapecerica, Barueri e Araçariguama, próximas ou pertencentes ao caminho pelo qual passou o viajante, forneciam soldados ao Regimento dos pardos. ${ }^{87}$ Mas em Atibaia e Bragança não havia aldeias ou aldeamentos tão próximos, e assim mesmo havia alguns milicianos referidos como índios, o que sugere que a presença dessas pessoas era difundida para além dos aldeamentos formais. Esses homens integraram o Regimento dos Úteis e eram referidos como pardos nas listas nominativas.

Entretanto, a localização desses índios e administrados na hierarquia miliciana atesta que seu potencial de retenção de poder entre os demais milicianos pardos era reduzido. Nenhum miliciano com origem indígena tão pronunciada foi localizado entre os oficiais de patente pertencentes ao estado-maior do Regimento e às cinco companhias sediadas na capital. Três índios de Atibaia e Bragança fizeram parte apenas da oficialidade inferior daquela companhia, pois não ultrapassaram o posto de cabo de esquadra. ${ }^{88} \mathrm{O}$ mesmo sucedeu ao único índio que integrou o corpo de oficiais em Santana de Parnaíba. ${ }^{89}$ Por outro lado, o inverso ocorreu com

\footnotetext{
${ }^{86} C f$ : "Para o mesmo Conde Vice Rei. Sobre dificuldades de fundar povoações e limites da Capitania ao Sul". São Paulo, 7 de julho de 1767. DIHCSP, vol. 23, p. 204-206.

${ }^{87}$ Cf:: SAINT-HILAIRE, A. de. Viagem à província de São Paulo. Belo Horizonte: Ed. Itatiaia; São Paulo: Ed. da Universidade de São Paulo, 1976, p. 158-162.

${ }^{88}$ Cf:: Livro Mestre, fls. 225v, 226, 227, 237v, 240v; 1783/05/15, ACMSP/DMC 3248, fl. 23; 1807/08/12, L.C. Atibaia $\mathrm{n}^{\circ}$ 5, fl. $138 \mathrm{v}$; L.C. Bragança $\mathrm{n}^{\circ} 2$, fl. 58v.

${ }^{89}$ Cf:: Livro Mestre, fl. 308; 1791/02/19, ACMSP/DMC 3205, fl. 46.
} 
os nascidos escravos, todos luso-americanos e predominantemente paulistas, aspecto que acentua a ideia de que, comparativamente, os índios manejavam recursos limitados e frágeis na competição pelas posições mais relevantes da milícia e da sociedade mais ampla. A despeito do fato de que nas companhias de Atibaia e Santana de Parnaíba os nascidos em cativeiro permaneceram na oficialidade inferior ${ }^{90}$, entre os oficiais de patente do estado-maior e das companhias citadinas, havia quatro indivíduos diretamente marcados pela escravidão. ${ }^{91}$ Essa mácula não impediu a Manoel José Ribeiro chegar ao prestigiado posto de coronel. É significativo, pois, que o único pardo a ocupar essa posição na capitania/província de São Paulo tivesse nascido de ventre cativo.

As fontes consultadas não informam as condições em que se deram as alforrias de todos os quinze milicianos pardos nascidos em situação de escravizados constantes da amostra. Alguns deles obtiveram-na após a morte de seus proprietários. Isso ocorreu, por exemplo, com a família dos irmãos Amador e Silvestre de Lima, que era escravizada por Antonio da Rocha Lima até o falecimento deste, em 1805, e que persistiu em cativeiro sob o senhorio da viúva Inácia Antunes de Siqueira. Após o falecimento da proprietária, os integrantes da família surgiram livres e em unidade domiciliar autônoma na lista nominativa de 1807. Não surpreende, entretanto, que a produção agrícola dessa família recém-emancipada tenha sido resumida com a singela expressão "não têm nada". ${ }^{92}$ Havia também quem obtivesse a alforria enquanto o proprietário estivesse vivo, a exemplo de José Joaquim Teodoro, batizado como escravo de José de Siqueira Franco, em 1789. Quando esse se tornou capitão-mor da vila de Atibaia, em 1803, aquele já não estava mais vinculado a qualquer senzala. Desconhecendo-se se a alforria fora gratuita, condicional ou completamente paga, não é possível avaliar em que medida relações de tipo paternalista estabelecidas entre o poderoso ex-proprietário e o pardo liberto fundamentaram tanto a conquista da liberdade quanto a ascensão de Teodoro na milícia, que passou de soldado, em 1808, para alferes, em $1824 .^{93}$

Além disso, os dois milicianos que obtiveram a alforria no batismo - em cujos rituais apagaram-se não apenas as manchas do pecado original como também as marcas individuais do cativeiro - ascenderam na hierarquia do Regimento. Um deles tornou-se cabo de esquadra

\footnotetext{
${ }^{90}$ Cf:: Livro Mestre, fls. 224, 309, 333; 1774/12/09, ACMSP/DMC 3512, fl. 8; 1789/09/24, ACMSP/DMC 3730, fl. 17.

${ }^{91}$ Cf:: Livro Mestre, fls. 1-1v, 12, 13, 58-58v, 140, 141, 142v, 143 e 225; 1752/10/12, ACMSP/DMC 1355, fl. 42; 1780/10/30, ACMSP/DMC 3320, fl. 14; 1789/11/15, ACMSP/DMC 3575, fl. 30; Maços de População, Capital: (1808), $1 .{ }^{\mathrm{a}}$, fogo 335.

92 Cf:: Maços de População, Atibaia: (1804) M.D., fogo 66; (1806) M.D., fogo 24; (1807) M.D., fogo 116; 1805/09/28 e 1807/05/05, L.O. Atibaia no 3, fls. 88 e 100.

${ }^{93}$ Cf:: Livro Mestre, fls. 141, 142v, 143 e 225; 1789/11/15, ACMSP/DMC 3575, fls. 29-30.
} 
em Parnaíba e o outro alferes em Atibaia. ${ }^{94}$ Por comparação, a ascensão destes homens alforriados em pia batismal reitera a ideia de que os índios estavam entre os mais frágeis competidores pelos postos da milícia dos pardos. Já os expostos não tinham sorte muito diferente da dos índios na carreira militar, pois, dos dez pardos expostos, quase todos permaneceram como soldados - exceto Manoel Eugênio Barbosa, alferes da 2. ${ }^{a}$ companhia de Fuzileiros da cidade de São Paulo. ${ }^{95}$ Os indivíduos nascidos livres, por sua vez, constituíam a maior parte dos soldados, mas também eram os principais candidatos aos postos superiores daquela corporação. De certo modo, a constatação de que a oficialidade miliciana era composta majoritariamente por pardos nascidos livres - em detrimento dos indígenas, dos expostos e dos oriundos do cativeiro, esses últimos teoricamente bastante atados aos (não tão) antigos senhores - atenua uma hipótese implícita na literatura de acordo com a qual os oficiais milicianos pardos poderiam ser uma espécie de representantes dos interesses das elites senhoriais brancas no Regimento. Como as posições de autoridade e comando eram ocupadas prioritariamente por homens enraizados no trabalho artesanal e urbano, em cujo ambiente social as relações de tipo clientelar, ainda que vigentes, eram menos rígidas do que nas configurações sociais rurais, pode-se argumentar que o serviço militar prestado pela corporação atendia primeiramente aos interesses dos próprios pardos e aos do Estado.

Alguns dos principais teóricos que pensaram a escravidão como um processo de mudança de status alertaram para a pertinência da distinção entre a condição jurídica formal de escravos e libertos e duas outras dimensões estruturantes da vida social daquelas pessoas, a do afeto informal e a da realização mundana e do sucesso. ${ }^{96}$ Ou seja, além da condição jurídica formal havia outros fatores que definiam a direção e o ritmo daquilo que Kopytoff e Miers denominam como processo de desmarginalização dos escravos e seus descendentes. A transição da situação de escravidão para a de liberdade era marcada, na maior parte das sociedades escravistas, por um estágio intermediário no qual os libertos e seus descendentes eram permanentemente lembrados, por parte da coletividade ao seu redor, do passado cativo vivenciado por eles próprios ou por seus familiares. Esse era um modo de diferenciar os antigos escravos da população livre e estabelecida. Como demonstraram Elias e Scotson, lançar mão

\footnotetext{
${ }^{94}$ Cf:: Livro Mestre, fls. 223, 224v e 307v; 1787/10/14, ACMSP/DMC 4513, fl. 9; 1791/05/30, ACMSP/DMC 3764, fl. 10.

${ }^{95}$ Cf:: Livro Mestre, fls. 141, 231, 231v, 233, 236, 254, 326 e 331; 1785/07/17, ACMSP/DMC 3695, fl. 41; 1786/05/02, ACMSP/DMC 3217, fl. 8; 1786/05/13, ACMSP/DMC 3485, fl. 8; 1792/05/13, L.C. Atibaia no 5 , fl. 13; 1793/10/10, L.C. Nazaré no 4, fl. 156v; 1801/05/04, ACMSP/DMC 5072, fl. 3; 1805/12/12, L.C. Sorocaba n ${ }^{\circ}$ 8, fl. 12v; 1820/12/16, L.C. Parnaíba 1790-1821, fl. 143v.

${ }^{96}$ KOPYTOFF, Igor; MIERS, Suzanne. African 'slavery' as an institution of marginality..., p. 12-20; PATTERSON, O. Escravidão e morte social..., p. 350-354.
} 
da atribuição de estigmas é um recurso amplamente difundido e verificável nas diversas situações de disputa de poder entre grupos rivais. ${ }^{97}$ As sociedades escravistas, evidentemente, não fogem à regra. Na realidade da América portuguesa, dispunha-se de um vasto repertório de estigmas dirigidos às pessoas e grupos vinculados à escravidão, bem como a outros setores e grupos os mais diversos. Após examinar o tipo de cabelo, a cor e a condição jurídica de nascimento dos milicianos pardos, a observação incidirá sobre outras categorias empregadas nas fontes paroquiais para descrever esses homens.

O matrimônio era ocasião extremamente importante para todos os envolvidos. Do ponto de vista dos noivos, a formação da nova família poderia significar a obtenção de maior autonomia em relação ao poder paterno e, no caso dos escravos, um alento face às durezas do cativeiro. Embora pouco se saiba sobre os sentimentos afetivos que conduziam aos casamentos nos séculos XVIII e XIX, era comum que os contraentes se referissem à solidariedade e à proteção mútua, no plano terreno, e à salvação de suas almas, no plano espiritual, como elementos motivadores das uniões. Para as famílias ou proprietários dos noivos, os casamentos implicavam o estabelecimento de alianças e o acréscimo ou diminuição da mão de obra disponível. Do ponto de vista do Estado e da Igreja, o matrimônio católico era um aspecto chave para o exercício de controle à população. Significava a formação de famílias aptas à procriação e, consequentemente, à expansão dos fiéis e dos súditos. Além disso, como observou E. R. Goldschmidt, os elevados valores desembolsados pelos contraentes durante o cumprimento dos trâmites burocráticos tornavam os casamentos bastante lucrativos para os funcionários eclesiásticos. $^{98}$

Uma vez que os noivos acertassem o casamento entre si e entre os demais envolvidos familiares e proprietários, no caso de escravizados - eles deviam iniciar os preparativos junto à Igreja. Não cabe aqui tratar desses procedimentos em pormenor, o que, aliás, foi realizado exemplarmente por Goldschmidt ${ }^{99}$, mas tão somente fornecer um apanhado dos pré-requisitos para a realização do sacramento religioso e do detalhado conjunto de informações acerca dos noivos que então se recolhia. Os nubentes deviam provar suas identidades e estarem livres e desimpedidos para unirem-se em casamento. Entre outros requisitos, deviam ser católicos, solteiros ou viúvos, não terem feito votos religiosos ou promessa de casamento a outrem, não terem graus de parentesco próximos e, no caso dos homens, não terem raptado as noivas. As

\footnotetext{
${ }^{97}$ ELIAS, Norbert; SCOTSON, John L. Os estabelecidos e os outsiders. Sociologia das relações de poder a partir de uma pequena comunidade. Trad. Vera Ribeiro. Rio de Janeiro: Jorge Zahar Editor, 2000.

${ }^{98}$ GOLDSCHMIDT, Eliana Rea. Casamentos mistos: liberdade e escravidão em São Paulo colonial. São Paulo: Annablume; Fapesp, 2004, p. 88-99.

${ }^{99}$ GOLDSCHMIDT, Eliana Rea. Casamentos mistos...
} 
cópias das atas de batismo anexadas ao processo permitiriam conhecer o nome, a naturalidade e a condição jurídica dos noivos e dos pais, bem como comprovariam serem eles católicos. Por meio dos proclamas, a intenção de se casar era publicizada em editais afixados na porta das igrejas frequentadas pelos noivos, de modo que a comunidade era formalmente coagida a denunciar eventuais impedimentos. Ademais, os párocos deviam atestar sobre o cumprimento das obrigações religiosas anuais e sobre as residências dos contraentes, assim como deviam relatar ao juízo eclesiástico caso tivessem conhecimento de envolvimento dos contraentes em atividade sexual ilícita.

Como se nota, o conhecimento que os padres tinham acerca dos contraentes era vasto e resultava da consulta a documentos formais, da observação cotidiana sobre a vida dos fiéis, e dos relatos, confissões e inquirições obtidos junto aos noivos e à comunidade. Uma análise aos autos de Dispensas matrimoniais e casamentos e principalmente aos assentos dos matrimônios dos milicianos pardos possibilita a comparação entre a condição jurídica extraída dos seus batismos e a maneira pela qual aqueles homens, já adultos e todos livres ou libertos, eram socialmente reputados conforme a perspectiva dos padres. É preciso considerar que alguns milicianos mantiveram-se solteiros ao longo suas vidas e que os registros de dezenas de outros oficiais e soldados pardos não puderam ser localizados. Além disso, para o que interessa aqui, cabe lembrar que em vários desses documentos informa-se pouco mais que a cor parda dos nubentes e em muitos outros apenas seus nomes e filiações. Contudo, foram identificados 46 assentos ou autos de dispensas matrimoniais e casamentos referentes a milicianos de Atibaia e Santana de Parnaíba cuja condição jurídica de nascimento é conhecida, os quais revelam informações mais detalhadas acerca dos homens em questão.

Os onze milicianos nascidos escravos, ao contraírem matrimônio, estavam referidos como forros ou libertos, o que acena para uma mudança significativa em sua condição jurídica e também no status relativo ao continuum escravidão-liberdade. ${ }^{100}$ Curiosamente, porém, muitos dos milicianos pardos que indubitavelmente nasceram livres foram descritos como "pardos forros", "libertos" e até mesmo "forro liberto" nos assentos de seus casamentos. Isso ocorreu com três oficiais e mais dez soldados da companhia de Santana de Parnaíba. Além desses, a expressão "pardo forro" foi aplicada a três soldados índios da mesma companhia. Da

\footnotetext{
${ }^{100}$ Cf:: Livro Mestre, fls. 224, 230, 258, 259, 260, 261, 309, 314v, 319v, 323, 326v e 333; L.B. Atibaia ${ }^{\circ}$ 7, fl. 46; L.C. Araçariguama 1783-1817, fl. 94; ACMSP/DMC 2707, fl. 12; ACMSP/DMC 2996, fl. 37; ACMSP/DMC 3512, fl. 8; ACMSP/DMC 3645, fl. 31; ACMSP/DMC 3730, fl. 17; ACMSP/DMC 4173, fl. 36; ACMSP/DMC 4214, fl. 4; ACMSP/DMC 5400, fl. 3; ACMSP/DMC 5403, fl. 27. Ver também KOPYTOFF, Igor; MIERS, Suzanne. African 'slavery' as an institution of marginality..., p. 12-20; PATTERSON, O. Escravidão e morte social..., p. 350-354.
} 
companhia de Atibaia, cinco soldados nascidos livres também foram assim identificados na ocasião dos seus casamentos, bem como o foram um soldado batizado como índio e outro como exposto. Douglas C. Libby notou a prática da "imposição do termo por mais de uma geração", embora a condição jurídica daqueles que se encontravam em um estágio intermediário entre a escravidão e a liberdade não pudesse ser formalmente transmitida de pais para filhos no Brasil escravista. Ele supõe que esse procedimento visava "à identificação de vínculos ascendentes com a escravidão". ${ }^{101} \mathrm{Ou}$ seja, não era raro que pessoas jamais alforriadas ou libertadas, uma vez que nasceram livres, fossem identificadas a ex-escravos. Esses, na realidade, eram tão somente pais ou avós. Mais adiante serão examinados os vínculos geracionais desses milicianos pardos, nascidos livres mas referidos como forros ou libertos, com a situação de escravidão. Mas cumpre notar que essa designação recaía até mesmo aos índios, que não poderiam ter sido escravizados, e aos expostos, cuja ascendência era desconhecida e, consequentemente, não havia como relacioná-los diretamente ao cativeiro.

Seria impreciso, portanto, estabelecer uma relação direta entre a forte presença de pardos forros e libertos nos assentos de matrimônio das vilas em questão e a suposição de elevadas taxas de alforria nas três primeiras décadas do século XIX - já que uma parte considerável dos forros e libertos havia nascido livre. Diante dessa constatação, faz-se preciso, pois, distinguir claramente nas fontes históricas o uso dos termos forro/liberto significando literalmente a condição jurídica dos indivíduos emancipados do cativeiro e o emprego menos formal e mais flexível que, sem primar por um rigor institucional, remetia essas pessoas livres ao universo da escravidão. Munidos de um conjunto extenso de informações sobre os fiéis, não há dúvidas de que os párocos de Atibaia e Santana de Parnaíba se valiam desse uso informal, já que eles próprios constatavam nos assentos batismais o nascimento livre dos noivos "forros" ou "libertos". Tratava-se da perpetuação das marcas da escravidão nos libertos e seus descendentes livres, um aspecto compartilhado por todas as sociedades escravistas. Nunca é demais lembrar da função social desempenhada pelos estigmas como instrumento de dominação de grupos estabelecidos sobre grupos outsiders em quaisquer relações sociais em que haja diferenciais de poder. De fato, aqui se está diante de um caso desse tipo. Não condizente com a condição jurídica de vários dos milicianos pardos, o designativo forro/liberto decorria da atribuição do estigma da escravidão para um conjunto significativo de pessoas, as quais, em virtude de seu

${ }^{101}$ LIBBY, Douglas Cole. A empiria e as cores..., p. 42-45. Ver também FARIA, Sheila de Castro. A colônia em movimento..., p. 135-139. 
pequeno potencial de retenção de poder comparativamente aos padres e ao establishment que eles representavam, acabavam assimilando essa mácula social e conferindo-lhe legitimidade. ${ }^{102}$

Havia outro estigma lançado a pardos livres, especialmente os adscritos na paróquia de São João Batista de Atibaia, o qual, no entanto, se referia menos a um passado escravo e mais à ascendência indígena dos milicianos. Dez soldados nascidos livres e um enjeitado foram descritos através do termo "bastardo". As definições fornecidas pelos dicionários de época apontam para diferentes origens e significados possíveis para o termo. ${ }^{103} \mathrm{Um}$ dos significados seria o de pessoa cujo nascimento é ilegítimo, exterior ao matrimônio. Essa acepção é inadequada para o caso, uma vez que, exceto o miliciano que fora exposto, todos os demais bastardos eram frutos legítimos de uniões sancionadas pela Igreja católica. ${ }^{104}$ Em outra definição corrente, bastardo dizia respeito aos "animais gerados por pais com alguma diferença na casta". ${ }^{105}$ De fato, conforme argumentou John M. Monteiro, na configuração social paulista do século XVII o termo descrevia "a prole de pai branco e mãe indígena" não reconhecida publicamente, sendo esse o traço que o diferenciava da expressão mamaluco, que era adotada para se referir aos filhos legitimados e localizados social e culturalmente mais próximos dos pais. Ainda de acordo com Monteiro, “já no século XVIII, o termo mamaluco caiu em desuso, enquanto bastardo passava a designar, genericamente, qualquer um de descendência indígena". ${ }^{106}$ Essa, portanto, parece ser a acepção que mais se compatibiliza ao emprego da expressão por parte dos párocos de Atibaia. Somados os bastardos, índios e administrados, eles compõem uma porção significativa dos milicianos pardos identificados.

Então temos aqui, mediante o exame às máculas e estigmas imputados aos milicianos pardos, a percepção de que, em fins do século XVIII e começos do XIX, o termo pardo abarcava tanto indivíduos com origem escrava como com origem indígena. É preciso escavar mais camadas para se conhecer a origem social dessas pessoas. Investigar a origem e condição social de seus pais pode melhor iluminar o tipo de vinculação dos milicianos com a escravidão e com

\footnotetext{
102 ELIAS, Norbert; SCOTSON, John L. Os estabelecidos e os outsiders...

${ }^{103}$ Cf:: BLUTEAU, Raphael. Vocabulário portuguez \& latino: aulico, anatômico, architectonico [...]. Coimbra: Collegio das Artes da Companhia de Jesus, 1712-1728. 8 v. Verbetes "Bastardia" e "Bastardo". Vol. 2, p. 63-64; SILVA, Antonio de Moraes. Diccionario da lingua portugueza composto pelo padre D. Rafael Bluteau, reformado, e accrescentado por Antonio de Moraes Silva natural do Rio de Janeiro. Lisboa: Officina de Simão Thaddeo Ferreira, 1789. 2 v. Verbete "Bastardear", "Bastardia" e "Bastardo", Vol. 1, p. 171.

${ }^{104}$ Cf:: Livro Mestre, fls. 229, 229v, 231v, 232, 233, 234v, 235v, 244, 252v, 256, 260v; L.B.E.B. Atibaia $\mathrm{n}^{\circ} 4$, fl. 35; L.C. Atibaia, $n^{\circ}$ 5, fls. 18, 125v, 130 e 135v-136; L.C. Atibaia $n^{\circ}$ 6, fls. 28v, 29 e 42v; L.C. Atibaia, $n^{\circ} 7$, fls. 8 e 35v; L.C. Atibaia, $n^{\circ} 8$, fl. 15v. Os livros de casamentos da paróquia de Atibaia estão repletos desses casos. ${ }^{105}$ Cf.: BLUTEAU, Raphael. Vocabulário portuguez \& latino..., verbetes "Bastardia" e "Bastardo". Vol. 2, p. 6364; SILVA, Antonio de Moraes. Diccionario da lingua portugueza..., verbetes "Bastardear", "Bastardia" e "Bastardo", Vol. 1, p. 171.

${ }^{106}$ MONTEIRO, J. M. Negros da terra..., p. 166-167; NAZZARI, M. Vanishing indians..., p. 505.
} 
o universo indígena, a formatação familiar na qual foram concebidos e, finalmente, a natureza do grupo social formado por pardos livres na capitania/província de São Paulo.

\subsubsection{Famílias pardas: condição social e jurídica dos pais e das mães de milicianos pardos}

Um primeiro aspecto que se evidencia a respeito das formações familiares das quais os milicianos pardos eram oriundos é o predomínio de famílias legitimamente constituídas seguido de um elevado número de famílias ou uniões não sancionadas pela Igreja. No cômputo geral, cerca de $61 \%$ dos milicianos eram filhos de casais legítimos, mas outros 36,5\% eram filhos naturais, ilegítimos ou expostos/enjeitados e pairavam dúvidas ou irregularidades quanto à paternidade dos 2,5\% restantes. Famílias pardas adequadas às normas impostas pela Igreja e pela Monarquia eram majoritárias às demais, o que sugere que uma grande parte desse contingente populacional existente em São Paulo aproximadamente entre os anos de 1750 a 1820 havia assimilado e conferido sentido a tais normas e práticas ao longo de seu processo de enraizamento na sociedade local.

Contudo, os índices de ilegitimidade entre os milicianos pardos também eram significativos. Isso não quer dizer, necessariamente, que todos os milicianos indicados no registro militar como "filho de pai incógnito" desconhecessem os pais, não fossem assistidos por eles ou não mantivessem vínculos de parentesco. Como a historiografia vem demonstrando mais recentemente, o recurso a uniões alternativas - a exemplo da "família fragmentada" - era bastante comum no mundo colonial e atendia às mais diversas necessidades de pessoas e grupos. ${ }^{107}$ Ocorre, em tais circunstâncias, que as famílias não correspondiam ao ideal difundido pelo establishment. Todos os milicianos foram batizados, mas a Igreja não reconhecia formalmente a paternidade nos casos de frutos de uniões não sacramentadas. É provável que alguns milicianos tivessem nascido de relações de concubinato posteriormente regularizadas via matrimônio. Mas nesse caso eles seriam legitimados ${ }^{108}$ e a paternidade seria mencionada nos assentos militares. A maioria desses filhos ilegítimos foi gerada a partir de arranjos familiares jamais formalizados e/ou por encontros sexuais casuais e fortuitos que não contaram com a união estável entre os genitores. Os altos índices de ilegitimidade entre os milicianos

\footnotetext{
107 CERCEAU NETTO, Rangel. Um em casa do outro. São Paulo: Annablume; Belo Horizonte: PPGH/UFMG, 2008, p. 66-67.

108 CASTRO, José Luiz de. Transgressão, controle social e Igreja Católica no Brasil colonial: Goiás, século XVIII. Tese (doutorado em História). Franca: FHDSS, Universidade Estadual Paulista, 2009, p. 184.
} 
pardos devem ser tributários, em alguma medida, da prostituição, que era um recurso de sobrevivência tipicamente acessado por mulheres pertencentes aos grupos em situação de maior vulnerabilidade social. Com a paternidade desconhecida - não necessariamente pela comunidade coeva, que observava curiosa e atentamente os relacionamentos humanos que se estabeleciam em seu seio, mas certamente de nós, historiadores - para dois quintos dos milicianos pardos, é impossível mensurar a participação dentre os pais incógnitos de antigos senhores, de homens com famílias já estabelecidas ou mesmo de escravos. Esse traço tão marcante também constituiu obstáculo para a localização dos milicianos nas fontes paroquiais e nos recenseamentos. Finalmente, cumpre lembrar que esses filhos de pais incógnitos não devem ser confundidos com os "bastardos" referidos acima.

TABELA 4.8 - Filiação dos milicianos pardos

\begin{tabular}{|c|c|c|c|c|c|c|c|c|}
\hline & \multicolumn{8}{|c|}{$\begin{array}{r}\text { Filiação } \\
\end{array}$} \\
\hline & \multicolumn{2}{|c|}{ Legítima } & \multicolumn{2}{|c|}{ Pai Incógnito } & \multicolumn{2}{|c|}{ Ambas $^{\text {a }}$} & \multicolumn{2}{|c|}{ Total } \\
\hline & $\mathrm{N}$ & $\%$ & $\mathrm{~N}$ & $\%$ & $\mathrm{~N}$ & $\%$ & $\mathrm{~N}$ & $\%$ \\
\hline Estado-Maior & 4 & 60 & 3 & 40 & 0 & 0 & 7 & 100 \\
\hline Oficiais de patente ${ }^{b}$ & 20 & 47 & 22 & 51 & 1 & 2 & 43 & 100 \\
\hline Baixa oficialidade $^{c}$ & 83 & 52 & 73 & 45 & 5 & 3 & 161 & 100 \\
\hline Cia. Granadeiros ${ }^{\mathrm{d}}$ & 52 & 54 & 41 & 43 & 3 & 3 & 96 & 100 \\
\hline Cia. Caçadores & 64 & 69 & 29 & 31 & 0 & 0 & 93 & 100 \\
\hline 1. ${ }^{\mathrm{a}}$ Cia. Fuzileiros & 40 & 64 & 20 & 32 & 2 & 4 & 62 & 100 \\
\hline 2. ${ }^{a}$ Cia. Fuzileiros & 44 & 64 & 22 & 32 & 3 & 4 & 69 & 100 \\
\hline 3. ${ }^{\mathrm{a}}$ Cia. Fuzileiros & 45 & 55 & 34 & 42 & 2 & 3 & 81 & 100 \\
\hline Cia. Atibaia & 69 & 66 & 32 & 30 & 4 & 4 & 105 & 100 \\
\hline Cia. Jundiaí & 67 & 67 & 33 & 33 & 0 & 0 & 100 & 100 \\
\hline Cia. Sant. Parnaíba & 71 & 75 & 19 & 20 & 5 & 5 & 95 & 100 \\
\hline Cia. Itu & 41 & 49 & 40 & 48 & 3 & 3 & 84 & 100 \\
\hline Cia. Sorocaba & 66 & 66 & 32 & 32 & 3 & 3 & 101 & 100 \\
\hline Total & 666 & $\begin{array}{c}61 \\
\text { (média) }\end{array}$ & 400 & $\begin{array}{c}36,5 \\
\text { (média) }\end{array}$ & 31 & $\begin{array}{c}2,5 \\
\text { (média) }\end{array}$ & 1097 & 100 \\
\hline
\end{tabular}

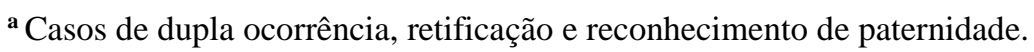

${ }^{\mathbf{b}}$ De todas as dez companhias do Regimento. Incluem-se capitães, tenentes e alferes.

${ }^{\mathbf{c}}$ De todas as dez companhias do Regimento. Incluem-se sargentos, furriéis, porta-bandeiras, cabos.

${ }^{\mathrm{d}}$ Assim como para as demais companhias, incluem-se os soldados, tambores e pífanos.

Fonte: Livro Mestre.

Essa proporção de milicianos pardos que eram filhos ilegítimos é a mesma encontrada por Maria Luiza Marcílio ao examinar 11.586 assentos de batismos referentes à população livre 
da Sé da cidade de São Paulo entre os anos 1771-1815, em cujos marcos temporais nasceram os homens que se tornaram milicianos do Regimento dos Úteis. ${ }^{109}$ Então a grande quantidade de filhos de "pai incógnito" dentre os milicianos pardos não era exclusividade de seus integrantes, mas, antes, uma característica compartilhada no universo das pessoas livres que viviam na cidade de São Paulo e em suas circunvizinhanças, a qual adquiria ainda maior vulto em outros espaços luso-americanos, tais como Minas Gerais e Goiás. ${ }^{110}$ Por outro lado, os dados levantados por Iraci del Nero da Costa a partir das listas nominativas de várias vilas paulistas fornecem proporções bastante diferentes. Conforme constatou, havia considerável predomínio das crianças de até 14 anos de idade cujo nascimento era legítimo em relação às nascidas ilegitimamente. Entre as famílias mais pobres, que não possuíam escravos, aproximadamente $80 \%$ das crianças eram filhos legítimos, e esse índice ampliava-se para mais de $90 \%$ quando se tratava de famílias paulistas que possuíam escravos. ${ }^{111}$ Assume-se aqui que os recenseadores não tinham o mesmo rigor dos padres para anotar a paternidade ilegítima ou as pessoas enjeitadas, e, como decorrência, que as informações das listas nominativas possivelmente subestimem a presença dos filhos naturais e dos expostos. Por isso, nesse particular, optou-se por conferir maior crédito aos dados levantados por Marcílio. ${ }^{112}$

Seja qual for a natureza da discrepância entre os dados de Marcílio e os de Costa, uma constatação desse historiador é altamente pertinente: no que concerne à legitimidade ou ilegitimidade dos nascimentos, havia uma diferença modestamente pronunciada entre famílias mais ricas e famílias mais pobres. ${ }^{113}$ As últimas apresentaram índices mais elevados de filhos naturais e esse aspecto sugere que, quanto mais pobres e socialmente vulneráveis, mais as famílias tendiam a ser instáveis e irregulares conforme o ponto de vista do Estado e da Igreja. Inversamente, as famílias mais bem estabelecidas socialmente buscavam se estruturar de tal forma que se preservasse ou mesmo ampliasse suas posições. Diante de eventuais desvios de conduta, elas acionavam mecanismos para ocultá-los e assim evitar sanções sociais. Não

\footnotetext{
109 MARCíliO, Maria Luiza. A cidade de São Paulo: povoamento e população, 1750-1850, com base nos registros paroquiais e nos recenseamentos antigos. São Paulo: Pioneira; Ed. da Universidade de São Paulo, 1973, p. 157-161.

${ }^{110}$ Para Minas Gerais, ver COSTA, Iraci Del Nero. Arraia-miúda..., cap. 4; para Goiás, ver CASTRO, José Luiz de. Transgressão, controle social e Igreja Católica..., p. 188 e 193.

${ }^{111}$ COSTA, Iraci Del Nero. Arraia-miúda..., cap. 4.

${ }^{112}$ Alguns fatores podem explicar essa discrepância entre os dados de Marcílio e Costa. Em primeiro lugar, a maior proporção de filhos legítimos extraída das listas poderia resultar da combinação de maiores índices de mortalidade entre as crianças de nascimento ilegítimo com a regularização, através do matrimônio, de famílias concubinadas - o que não poderia ser apreendido via assentos batismais. Em segundo lugar, e principalmente, as listas nominativas fornecem retratos anuais extremamente ricos acerca das variáveis demográficas, mas os dados extraídos dos assentos batismais, por sua própria natureza, produzem uma perspectiva mais precisa em torno da questão.

${ }^{113}$ COSTA, Iraci Del Nero. Arraia-miúda..., cap. 4.
} 
surpreende que os maiores índices de ilegitimidade correspondam aos filhos de mães escravizadas. ${ }^{114}$ Apesar de não haver concessões formais por parte do Estado e da Igreja quanto ao matrimônio, a opção dos indivíduos em se casar - e gerar filhos legítimos - dependia de fatores sentimentais, culturais e sociais. Não obstante, essa variável pode servir como um índice da organização, enraizamento e estabilidade social dos grupos.

Comparativamente, nota-se que os milicianos pardos das localidades interioranas apresentavam maiores índices de filiação legítima do que seus pares naturais ou habitantes da cidade de São Paulo e de seus bairros mais próximos. Uma hipótese pertinente sugere que a expansão agrícola motivada pelo cultivo da cana-de-açúcar a partir do último quartel do século XVIII expulsou inúmeras famílias das regiões rurais e gerou desequilíbrios na formatação familiar. Enquanto muitos homens migraram para regiões de fronteira, em busca de novas terras, grande quantidade de mulheres solteiras se estabeleceram nos pequenos centros urbanos das vilas e igualmente na cidade de São Paulo. Essas mulheres "mostravam maior propensão a terem filhos ilegítimos do que as do meio rural". 115

$\mathrm{O}$ aspecto mais surpreendente se deve à localização das maiores taxas de ilegitimidade em meio à estrutura funcional do Regimento dos Úteis. Ter nascido em família plenamente constituída segundo os padrões sociais vigentes, de acordo com uma hipótese inicial desta pesquisa, se configuraria vantajoso aos (futuros) milicianos, já que, presumivelmente, tais unidades domésticas seriam caracterizadas por maior estabilidade e capacidade econômica em relação aos lares chefiados por mulheres solteiras. Ao contrário do que se poderia esperar, não era no setor dos soldados que se encontravam os maiores percentuais de filhos naturais, mas no topo da hierarquia miliciana, entre os oficiais de patente das dez companhias. Mais uma vez, o desconhecimento dos pais de muitos desses milicianos impossibilita que se avalie o seu papel na ascensão experimentada pelos filhos. De fato, não seria extemporâneo pensar que, ao menos em alguns casos, a intervenção de pais naturais dotados de concentrações significativas de capital social e econômico possa ter contribuído para alavancar a carreira dos filhos ilegítimos. Por outro lado, atribuir demasiada importância a esse fator implicaria subestimar a importância desempenhada por outros fatores tão ou mais diretamente associados à movimentação dos milicianos pardos na teia social, tais como sua inserção no mundo do trabalho, seus vínculos pessoais e seus méritos militares. O que se pode afirmar com segurança é que o ambiente

\footnotetext{
${ }^{114}$ MACHADO, Cacilda da Silva. A Trama das Vontades..., p. 236.

115 METCALF, Alida C. Family and frontier in colonial Brazil, Santana de Parnaíba, 1580-1822. Berkeley: University of California Press, 1992, p. 143 e ss; LUNA, F. V.; KLEIN, H. S. Evolução da sociedade e economia..., p. 210-211.
} 
urbano, notadamente o da cidade de São Paulo, gerava mais crianças pardas ilegítimas e ao mesmo tempo propiciava a esses homens, quando adultos, maiores chances de progredirem nos degraus da hierarquia miliciana.

Em contrapartida à considerável dificuldade para se mapear a presença de homens brancos como pais daqueles se tornaram milicianos pardos, a participação de indígenas, de escravizados negros e de pessoas provenientes de diversos grupos mestiços na composição das famílias pardas se evidencia a partir de análise à condição de nascimento e/ou batismo dos pais e mães dos integrantes do Regimento dos Úteis. Mantém-se o recorte que considera os oficiais de patente do estado-maior e das cinco companhias da cidade de São Paulo bem como os oficiais e soldados das companhias de Atibaia e de Santana de Parnaíba. Como visto acima, a localização de centenas de milicianos em outros universos documentais, tais como listas nominativas e fontes paroquiais, é tarefa árdua e penosa, e essas características se potencializam quando da busca dos seus progenitores. O método mais viável para essa busca consiste, em primeiro lugar, na localização dos assentos matrimoniais dos próprios milicianos, os quais informam os nomes de seus pais. Em seguida, após conferir a exatidão das informações por meio da comparação com os dados contidos nas listas nominativas e no registro individual do Livro Mestre, parte-se para a localização dos assentos matrimoniais dos pais e dos autos de dispensas matrimoniais e casamentos a eles concernentes. Por fim, o terceiro passo é consultar as cópias dos assentos de batismo dos noivos (pais dos milicianos) contidos nos autos de dispensa. Esse procedimento apresenta o inconveniente de excluir da amostra as mães solteiras. Uma alternativa seria a consulta direta aos livros de assentos de batismo. Mas a exigência de um largo período de tempo para o processamento dos dados e as características das informações ${ }^{116}$ tornaram essa possibilidade completamente inviável.

\footnotetext{
${ }^{116}$ As mães não eram mencionadas no Livro Mestre. Para identificá-las, deve-se recorrer aos assentos de batismo, matrimônio e, eventualmente, de óbito referentes aos filhos milicianos. Em alguns casos elas também podem ser localizadas nas listas nominativas, mas sempre associadas aos filhos milicianos. Entretanto, não era raro que as inúmeras Marias Gertrudes ou Escolásticas Marias surgissem com seus nomes invertidos nos assentos de batismo de seus outros filhos e também nos recenseamentos. Além disso, como essas mulheres eram pobres e solteiras, os sobrenomes, que poderiam auxiliar na busca, são grosseiramente referidos nas fontes. A maior dificuldade é localizar os assentos de batismo dessas mães pardas. Nessas fontes, os batizandos não eram mencionados com os sobrenomes que portariam quando adultos, e, como a historiografia já evidenciou, a atribuição de sobrenomes não obedecia a uma lógica única. Por isso, ainda que munido de rigor metodológico, o pesquisador não está imune aos sérios obstáculos que se impõem à identificação de crianças sem sobrenome a partir, exclusivamente, dos sobrenomes dos pais. Sobre o repasse, trocas e abando de sobrenomes na realidade colonial luso-brasileira, ver HAMEISTER, Martha Daisson. Uma contribuição ao estudo da onomástica no período colonial: os nomes e o povoamento do Extremo Sul da Colônia (Continente do Rio Grande de São Pedro, c. 1735-c. 1777). In: SANTOS, A. C. de A.; DORÉ, A. (Orgs.). Temas setecentistas: governos e populações no império português. Curitiba: UFPR-SCHLA/Fundação Araucária, 2008, p. 459-478. Sobre a árdua tarefa de busca nominal de escravos, forros e livres pobres nas fontes em questão, ver, uma vez mais, BACELLAR, C. A. P. O matrimônio entre escravos e libertos...
} 
Considerando-se o conjunto formado pelos 266 milicianos que compõem a base da amostra, foram localizados os assentos de batismo referentes a 86 pais e a 102 mães de oficiais e soldados pardos, conforme se vê na tabela 4.9. Desconhecem-se completamente as características da estrutura familiar e a condição social dos pais e mães de 88 milicianos (P? + M?) cujos assentos de batismo e matrimônio não foram localizados, além dos seis casos de milicianos expostos $(\mathrm{PI}+\mathrm{MI})$ para os quais igualmente se ignora a condição dos pais. Em relação a outros 60 (PI + M?), sabe-se apenas que eram filhos de "pai incógnito", já que as informações sobre suas mães solteiras são precárias e escassas. Entretanto, pôde-se identificar a origem social de 16 mães de milicianos nessas circunstâncias (PI + ML, PI + MIND e PI + ME). Excluídos os 82 pais incógnitos da amostra ideal de 266 homens, tem-se que os 86 pais identificados correspondem a 47\% dos possíveis de serem localizados. Quanto à parte materna, excluídas da amostra ideal composta por 266 mulheres as seis não identificáveis, cujos filhos foram expostos, resulta que a amostra real de 102 pessoas contempla pouco mais de $39 \%$ das mães.

Trabalha-se, portanto, com dados expressivos, os quais, se não dão conta da totalidade do conjunto observado, por outro lado permitem que se observem tendências relativas à composição familiar e à origem social dos milicianos pardos, e, de um modo mais geral, à própria formação do grupo social de pardos livres em São Paulo. A opção em surpreender os pais no momento do batismo - e não no do matrimônio, em período mais próximo à concepção dos filhos - permite que se lance luz sobre as raízes mais profundas das famílias - sua vinculação à escravidão, à instituição da administração, às aldeias indígenas, e daí por diante. Descontados os casais cuja origem social se desconhece (P? + M? e PI + M?) e o elevado número de pais incógnitos, analisado anteriormente, um dos aspectos que mais chama a atenção é a alta incidência de pais e mães indígenas e de pais e mães nascidos em cativeiro, cujas proporções guardam pouca ou nenhuma diferença em relação aos pais e mães nascidos livres. Das 102 mães identificadas, 37 nasceram livres ou foram expostas, sem outra identificação de condição ou qualidade, 33 nasceram escravas e 32 eram índias. E dentre os 86 pais cujos batismos foram localizados, 29 provinham de ventres livres ou eram enjeitados, 21 nasceram sob cativeiro e 36 foram identificados como índios. 
TABELA 4.9 - Estrutura familiar de acordo com a condição de nascimento/batismo de pais e mães de milicianos dos Úteis, c.1730 - c.1800

\begin{tabular}{|c|c|c|c|c|c|c|c|c|}
\hline $\begin{array}{l}\text { Condição } \\
\text { dos pais }\end{array}$ & $\begin{array}{c}\text { Of. Pat. } \\
\text { São Paulo }\end{array}$ & $\begin{array}{l}\text { Of. Pat. } \\
\text { Atibaia }\end{array}$ & $\begin{array}{l}\text { Of. Pat. } \\
\text { Parnaíba }\end{array}$ & $\begin{array}{l}\text { B. Of. } \\
\text { Atibaia }\end{array}$ & $\begin{array}{c}\text { B. Of. } \\
\text { Parnaíba }\end{array}$ & $\begin{array}{c}\text { Sold. } \\
\text { Atibaia }\end{array}$ & $\begin{array}{c}\text { Sold. } \\
\text { Parnaíba }\end{array}$ & Total \\
\hline $\mathrm{PL}+\mathrm{ML}$ & 2 & & & & & 7 & 7 & 16 \\
\hline PL + MIND & & & & & 1 & 1 & 1 & 3 \\
\hline $\mathrm{PL}+\mathrm{ME}$ & 3 & & 2 & & 2 & & & 7 \\
\hline $\mathrm{PL}+\mathrm{M} ?$ & & & & & & 1 & 2 & 3 \\
\hline PIND + MIND & & & & 1 & 1 & 9 & 11 & 22 \\
\hline PIND + ML & & & & 1 & & 1 & 8 & 10 \\
\hline PIND + ME & & & & & & 1 & 1 & 2 \\
\hline PIND + M? & & & & & & 2 & & 2 \\
\hline $\mathrm{PE}+\mathrm{ME}$ & 2 & & & 1 & & 2 & 7 & 12 \\
\hline $\mathrm{PE}+\mathrm{ML}$ & & & & & & 2 & 1 & 3 \\
\hline PE + MIND & & & & & & 1 & & 1 \\
\hline $\mathrm{PE}+\mathrm{M} ?$ & & & & & & 2 & 3 & 5 \\
\hline $\mathrm{PI}+\mathrm{ML}$ & & 1 & & & & & & 1 \\
\hline PI + MIND & & & & & & 1 & 3 & 4 \\
\hline $\mathrm{PI}+\mathrm{ME}$ & 3 & 1 & & 2 & 2 & 3 & & 11 \\
\hline $\mathrm{PI}+\mathrm{MI}$ & 2 & & & & & 3 & 1 & 6 \\
\hline $\mathrm{PI}+\mathrm{M} ?$ & 8 & 1 & 2 & 1 & 5 & 26 & 17 & 59 \\
\hline $\mathrm{P} ?+\mathrm{ML}$ & 2 & & & 1 & & & 4 & 7 \\
\hline P? + MIND & & & & & & 2 & & 2 \\
\hline $\mathrm{P} ?+\mathrm{ME}$ & 1 & & & & & & & 1 \\
\hline $\mathrm{P} ?+\mathrm{M} ?$ & 6 & 1 & 1 & 6 & 4 & 41 & 29 & 88 \\
\hline Total & 29 & 4 & 5 & 13 & 15 & 105 & 95 & 266 \\
\hline
\end{tabular}

* Legenda: Casal = Pai + Mãe; PL = pai livre (inclui expostos) PIND = pai índio (inclui administrados); PE = pai escravo; PI = pai incógnito; P? = sem informações acerca do pai; o mesmo para as mães, substituindo-se a letra inicial "P" por "M".

Fonte: Livro Mestre; Dispensas Matrimoniais; Livros de Batismo e Casamento (Atibaia, Araçariguama, Bragança, Santana de Parnaíba, São Paulo e São Roque).

O fato de estarem plenamente livres por ocasião do batismo cerca de um terço dos pais e um terço das mães cuja condição de nascimento fora identificada sugere, inicialmente, a existência de um contingente igualmente proporcional de milicianos pardos distantes da escravidão em pelo menos duas gerações. Mas isso está longe de corresponder à realidade. Havia tantos casais constituídos por indivíduos que tiveram a mesma condição social ou qualidade no batismo, quanto havia casais mestiços e formados pela combinação dos tipos sintetizados na tabela 4.9, os quais potencializavam a participação de cativos nas famílias. Em relação aos casais formados por pessoas de mesma condição ou qualidade, os indígenas tenderam a se relacionar predominantemente entre si, advindo daí as 22 famílias indígenas. Mas eles também compuseram outros tipos de arranjos, sendo notável sua pequena disposição para 
se unirem com pessoas nascidas escravas em comparação com a preferência pelos cônjuges livres. A presença de administrados entre os indígenas é outro fator que amplia a vinculação dos milicianos pardos com o universo da escravidão, ainda que essa fosse uma modalidade disfarçada.

Quanto aos nascidos e batizados como escravizados, houve maior "abertura" em termos dos modelos das famílias formadas. Em contraste com a tendência apresentada pelos casais progenitores de milicianos identificados como indígenas, os pais e mães nascidos em cativeiro se relacionavam tanto com pessoas nascidas escravas como de outras condições sociais. Foram identificados 12 casais em que marido e esposa nasceram escravizados, além de nove constituídos por marido nascido no cativeiro e esposa com outra condição ou condição desconhecida, e 21 famílias nas quais apenas a mulher era diretamente marcada pela escravidão. $\mathrm{O}$ fato de homens e mulheres que vivenciaram o cativeiro se casarem com pessoas nascidas em diferentes condições pode ser lido como uma busca por melhorias nas condições de vida e por afastamento gradual do universo escravo. Por outro lado, a situação de seus cônjuges originários de ventre livre ou indígena não devia ser muito diferente da servidão que lhes era imposta. Como sugerem Marchena Fernández e Garavaglia, nesses casos a mestiçagem é prévia às uniões sexuais: as pessoas envolvidas compartilham entre si condições de vida mais ou menos comuns, e a afetividade estabelecida entre elas resulta da convivência preexistente. ${ }^{117} \mathrm{Em}$ se tratando de outro modelo familiar, a maior presença de mulheres nascidas cativas dentre aquelas que geraram filhos de pais incógnitos é um indicativo da vulnerabilidade social que caracterizava as pessoas submetidas aos rigores da escravidão.

Já os pais e mães de milicianos pardos nascidos livres estavam em melhor situação que os escravos e é provável que também o estivessem em relação aos indígenas. Afinal, apesar de serem pardos e reputados como tendo condição social inferior à dos brancos, a liberdade certamente minimizava o alcance das máculas associadas à escravidão e à gentilidade dos antepassados. Em dezesseis casais da amostra, marido e mulher haviam nascido em liberdade. Alguns homens livres se uniram a mulheres escravas e, menos frequentemente, a indígenas. Com as mulheres livres que não se casaram com homens nascidos livres se processou o inverso, já que foi mais comum elas se unirem a índios do que a nascidos escravos. Esse aspecto particular sugere que, entre os pardos, as mulheres livres eram dotadas de maior capacidade de

\footnotetext{
${ }^{117}$ MARCHENA FERNÁNDEZ, Juan; GARAVAGLIA, Juan Carlos. Mestizos y mulatos en la sociedad colonial. In.: MARCHENA FERNÁNDEZ, J.; GARAVAGLIA, J. C. America latina: de los orígenes a la independencia. (v. 2). Barcelona: Crítica, 2005, p. 355-359.
} 
escolha no mercado matrimonial do que os homens nascidos em liberdade, já que uma maior proporção de homens estabeleceu relações com mulheres nascidas em escravidão.

Não deve escapar à vista o reduzido número de casais cujos membros haviam nascido plenamente livres e, consequentemente, o pequeno contingente de milicianos pardos que estavam distanciados das senzalas e das aldeias por duas ou mais gerações. Mas nem mesmo esse maior afastamento era suficiente para livrá-los dos estigmas sociais imputados a essa classe de gente, uma vez que muitos desses pardos livres eram referidos como forros, libertos e bastardos em ocasiões formais, como visto mais acima. Na realidade, a multiplicidade de arranjos e relações a partir dos quais os milicianos pardos foram gerados revela que o grupo mais vasto em questão estava profundamente enraizado na sociedade paulista e marcado pelas relações de dominação típicas do escravismo. E isso não se deve exclusivamente ao papel de pais e mães nascidos escravos, já que pouco mais da metade dos índios da amostra havia nascido em aldeias ou bairros rurais redutos de indígenas e a outra parte era formada por índios administrados por particulares e, portanto, submetidos a trabalho compulsório. Eis aí a razão para a distinção efetuada entre as pessoas nascidas livres e os índios e administrados. Nessa situação se encontravam 15 homens e 14 mulheres, sendo que quatro casais foram formados unicamente por administrados e os demais se uniram a pessoas nascidas livres e escravas. Como a instituição da administração foi abolida pelos decretos pombalinos da década de 1750, é provável que mais famílias vivenciassem de fato o que era proibido na lei. Os casos de dois milicianos pardos nascidos nos anos de 1790 que foram identificados como administrados corroboram essa afirmação.

Assim como ocorreu com os escravos, as pessoas subjugadas sob a administração indígena também foram estigmatizadas e as marcas da dominação permaneceram mesmo após elas serem declaradas plenamente livres. No assento de batismo de Ângelo Rodrigues Ferreira, soldado da companhia de Santana de Parnaíba residente na freguesia de Araçariguama e nascido em 1776, seus pais João Leme de Alvarenga e Leonor Rodrigues foram notados como "pardos forros". ${ }^{118}$ Ao verificar a origem dessa condição social, vê-se que o pai, natural da vila de Itu, ao se casar foi referido como "administrado que foi do tenente Francisco Leme de Alvarenga", assim como a mãe, natural de Araçariguama e "administrada que foi de Agostinha Rodrigues". ${ }^{119}$ Nem sempre ficam suficientemente claros os motivos para o emprego da designação "forro": em certos casos, se referia a pessoas que obtiveram a libertação do cativeiro, mas em outros funcionava como uma manobra diante do fato de que os administrados

\footnotetext{
${ }^{118}$ Cf:: Livro Mestre, fl. 327v; ACMSP/DMC 4179, fl. 4.
}

${ }^{119} C f:$ : ACMSP/DMC 688, fls. 52 e 53. 
não eram juridicamente escravos mas também não eram plenamente livres. A observação sugere que essa modalidade de utilização do termo se generalizou após a proibição do cativeiro e da administração indígenas, de modo que os antigos administrados eram tão forros quanto as pessoas emancipadas da escravidão. Como a parte mais fraca da relação de administração, essas pessoas herdaram não apenas os sobrenomes dos administradores como também os sinais da dominação.

O adjetivo "bastardo" faz parte desse mesmo universo, e não se mostrou incompatível ou excludente em relação a "forro" ou "administrado". O casal Bento José de Lima e Maria Lopes gerou dois filhos que se serviram como milicianos pardos na companhia de Atibaia, a saber, Felisberto José de Lima e José de Lima. Em 1807, no registro de casamento desse último, noivos e familiares foram descritos como sendo "todos bastardos". Novamente os batismos dos pais esclarecem a origem familiar. A mãe recebera o sacramento em 1762, período em que a administração indígena já era considerada ilegal, e talvez por isso o padre que o ministrou decidiu registrar no assento que "a inocente Maria" era "filha de Serafino e de Joana, administrados, ou agregados, de Joana Pereira". No mesmo ano ocorreu o batismo do pai, Bento, o qual foi referido como filho de "carijós forros". ${ }^{120}$ Isso reforça o argumento de que uma das razões para a perpetuação e persistência dessas máculas sociais em pessoas mais ou menos distanciadas da escravidão pode estar vinculada à proximidade familiar em relação à administração indígena.

Uma das principais características do grupo social formado pelos pardos livres em São Paulo, no interior do qual se recrutou homens para o Regimento dos Úteis, é a presença igualmente importante de pais e mães de origem escrava, indígena e nascidos livres. Não há africanos entre pais e mães escravizados bem como não há referência às nações de procedência dos índios e administrados. Os escravizados são crioulos e os indígenas são mencionados tão somente a partir de termos genéricos e homogeneizantes como "índio", "bastardo" e "carijó". 121 Parece claro que se trata de pessoas que estavam integradas àquela sociedade - embora a partir das formas mais difíceis e cruéis - havia pelo menos uma geração. Muitos dos pais de milicianos eram eles próprios frutos de mestiçagem biológica e cultural.

Além do reconhecimento dos diferentes grupos sociais que constituíram os pardos livres de São Paulo, uma das principais decorrências dessa constatação, derivada de amostra referente

${ }^{120}$ Cf.: Livro Mestre, fls. 234, 235v; 1807/02/09, L.C. Atibaia n ${ }^{\circ}$ 5, fls. 135v-136; ACMSP/DMC 1512, fls. 8 e 10.

${ }^{121}$ Discussão em torno do significado dessas categorias e sua transformação ao longo do tempo em MONTEIRO, J. M. Negros da terra..., p. 165-167; NAZZARI, M. Vanishing indians..., p. 503-509; PORTELA, B. M. Gentio da terra, gentio da Guiné..., p. 32-41. 
aos milicianos pardos, é a compreensão de que os elementos constitutivos do grupo dos pardos livres e forros estavam enraizados na sociedade paulista antes mesmo de sua consolidação institucional, em fins do século XVIII, a qual refletiu a homogeneização ilustrada implementada principalmente a partir dos recenseamentos. Nesse momento, a categoria pardo deixou de ser empregada ao gosto das instituições, das localidades e das pessoas, como em boa medida fora até então, e passou a estruturar definitivamente a notação de cor e qualidade nos recenseamentos, nos livros paroquiais e nos documentos judiciais. Muriel Nazzari demonstrou brilhantemente a importância desempenhada pela transformação no sistema classificatório da cor para a conformação de um abrangente grupo de pardos livres em São Paulo. ${ }^{122}$ Pardo então abarcará um universo de pessoas cujas origens mais remotas eram diversas, mas que foram unidas mediante a experiência comum da escravidão e do trabalho em geral. ${ }^{123}$ Em São Paulo, a convivência mais estreita entre índios e afrodescendentes se deu ao longo do século XVIII, período em que um contingente indígena declinante se amalgamou a um número crescente de pessoas africanas e seus descendentes imediatos. ${ }^{124}$ A mestiçagem biológica, cultural e social na qual a maior parte dessas pessoas se envolveu - contando, ainda, com a presença quase sempre velada de homens brancos - culminou, em fins daquele século, na consolidação da categoria pardo. É em meio a esse processo que, nas listas nominativas de Atibaia de inícios do século XIX, a categoria pardo eclipsou a distinção outrora vigente entre bastardos, carijós, oriundos e mulatos. Por outro lado, a vigorosa persistência dos modelos de referência locais exemplificada pelo repertório de termos empregados pelos padres de Atibaia nos registros paroquiais - expressa não apenas a pertinência das formas de distinção específicas para a dinâmica social regional, mas revela igualmente a característica abrangente e homogeneizante da categoria pardo.

Desse modo, a vigorosa camada de pardos livres que se fez notar na capitania já em fins do século XVIII, revela-se concomitante, mas não tributária, à vinculação paulista ao mercado

\footnotetext{
122 NAZZARI, Muriel. Vanishing indians...

${ }^{123}$ PAIVA, Eduardo França. Dar nome ao novo: uma história lexical da Ibero-América entre os séculos XVI e XVIII (as dinâmicas de mestiçagens e o mundo do trabalho). Belo Horizonte: Autêntica Editora, 2015, p. 49-121. ${ }^{124}$ Diversos autores têm demonstrado empiricamente aspectos dessa ordem que compuseram a transição entre a escravidão indígena e a africana em São Paulo colonial. MACHADO, Cacilda da Silva. A Trama das Vontades...; GODOY, Silvana Alves de. A vila de Itu e os negros da terra - séculos XVII e XVIII. Texto apresentado no XXIV Simpósio Nacional de História. São Leopoldo, Rio Grande do Sul, jul. 2007; BACELLAR, C. A. P. O matrimônio entre escravos e libertos...; BACELLAR, C. A. P. Famílias cativas em São Paulo colonial: a escravidão de indígenas e africanos através dos registros paroquiais (vila de Itu, capitania de São Paulo, primeira metade do século XVIII). Trabalho apresentado no XVIII Encontro Nacional de Estudos Populacionais, ABEP. São Paulo, nov. 2012; PORTELA, B. M. Gentio da terra, gentio da guiné...
} 
transatlântico de escravos negros ocorrida a partir do último quartel daquele século. ${ }^{125} \mathrm{Um}$ dos meios pelo qual o grupo social conformado pelas famílias ricas, tradicionais e bem estabelecidas em São Paulo deu-se a conhecer foi através das genealogias. A recuperação do passado familiar serviu mesmo como um monumento aos paulistas da elite, especificamente em um momento no qual São Paulo assumia funções militares de relevo no conjunto da América portuguesa, estreitava os laços com a Monarquia portuguesa e a economia local apresentava sinais de dinamismo e crescimento. ${ }^{126} \mathrm{O}$ relativamente abundante conhecimento acerca dos principais "troncos paulistas" contrasta com a invisibilidade a que foram relegados os setores populares. Apesar de estarmos longe de aspirar a algo como a construção da genealogia do grupo dos pardos, um exame a algumas árvores genealógicas dos milicianos pardos permite que se observe com mais clareza os diversos componentes dessas famílias e do grupo social em tela. O foco em períodos intermediários e até recuados do século XVIII surpreende uma dinâmica social específica e condizente ao quadro econômico paulista, voltado prioritariamente para o abastecimento interno e das regiões mineradoras do interior; diferente, portanto, do momento posterior, caracterizado pelo grande aquecimento da economia, em cujo período esteve em atividade o Regimento dos Úteis.

A família Rocha Lima, entranhada na vila de Atibaia, já é conhecida aqui. Ela foi mencionada quando se examinou a questão da variação de cor e também o foi relativamente ao tema da obtenção de alforria. E, com efeito, se trata de uma família profundamente marcada pela escravidão. Esse grupo familiar teve origem a partir do casamento de Domingos e Maria, ocorrido em 1781, os quais compartilhavam a situação de escravidão sob o poder de um mesmo senhor. Ambos eram escravos crioulos, nascidos na vila de Atibaia, filhos de pais incógnitos e mães cativas. Eles também legaram a seus filhos a condição escrava. Três deles interessam diretamente: Amador da Rocha Lima e Silvestre de Lima, que foram incorporados ao Regimento dos Úteis no ano de 1821, e Catarina de Lima, que se casou com o também miliciano Pedro Domingues. Como visto anteriormente, essa família obteve a liberdade após o falecimento do casal de proprietários, Antonio da Rocha Lima e Inácia Antunes de Siqueira. Em 1807 eles já se apresentavam com os sobrenomes adquiridos Rocha Lima e Siqueira, mas, para além desse patrimônio simbólico, conforme o recenseador eles não possuíam mais nada naquele ano.

\footnotetext{
125 A relação entre o robustecimento da participação paulista no tráfico de escravos africanos e o aumento da população livre de cor foi sugerida por Sérgio Buarque de Holanda em prefácio à obra de QUEIROZ, Suely Robles Reis de. Escravidão negra em São Paulo. Rio de Janeiro: José Olympio, 1977, p. viii-xviii.

${ }^{126}$ Sobre os genealogistas paulistas e suas obras, ver SOUZA, Laura de Mello e. O sol e a sombra: política e administração na América portuguesa do século XVIII. São Paulo: Companhia das Letras, 2006, p. 137-147.
} 


\section{DIAGRAMA 4.1}

Genealogia de Amador da Rocha Lima, Silvestre de Lima e Pedro Domingues

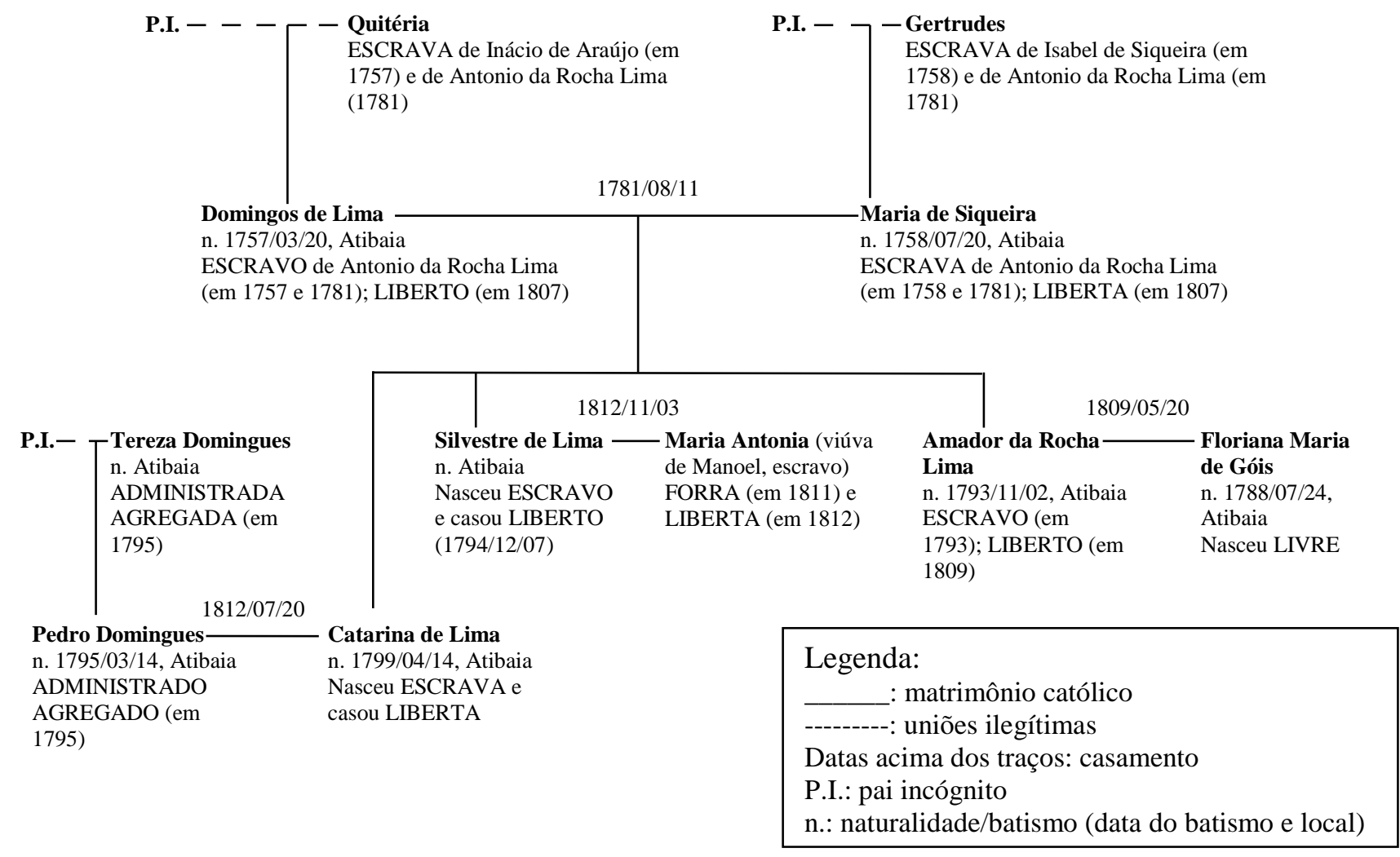

Domingos de Lima, pai e sogro de milicianos pardos, foi um dos indivíduos que mais abruptamente mudou a cor nas listas nominativas. Quando escravo, em 1804 e 1806, foi notado como pardo. Recém-emancipado, em 1807, tornou-se branco. Voltou a ser referido como pardo, em 1810, e nos anos seguintes passou a ser identificado como negro. Em 1815 estava branco e em 1818 pardo. Exceto pelo ano de 1807, Maria de Siqueira acompanhou a flutuação de cores do marido. Os três filhos também intercambiaram as cores, mas apenas entre pardo e negro, e antes que se vinculassem ao Regimento dos pardos. Examinando o Diagrama 4.1, nota-se as fortes ligações que essa família tinha com o universo da escravidão. As cores variáveis que caracterizaram o casal de pais parecem estar associadas mais à perspectiva dos recenseadores quanto aos seus fenótipos do que a percepções em torno da posição ou condição social da família. Ora, observando-se sua posição na esfera socioeconômica, nota-se que todos os homens integrantes dessa família eram pequenos agricultores que também se dedicavam a todo tipo de 
trabalho miúdo no campo como jornaleiros. Nenhum deles era senhor de escravizados e, pelo contrário, cada um de seus domicílios foi descrito, por pelo menos uma vez, como não possuindo absolutamente nada. É certo que a cor branca surgiu logo após a conquista da alforria, mas ela não contemplou a todos e tampouco foi duradoura. Não é improvável que os avôs incógnitos dos milicianos fizessem parte do grupo de proprietários das avós escravas e que Domingos e Maria fossem mestiços amulatados - decorrendo daí sua característica camaleônica.

Os três filhos casaram-se pouco tempo depois de libertos, entre os anos 1809 e 1812, e a condição social dos novos membros da família indica que, mesmo na tentativa de progredir no processo de desvinculação do passado escravo, esse se fazia presente tanto na medula da família quanto na do grupo social ao qual ela fazia parte e tecia relações. Entre as noras e genro de Domingos de Lima e Maria de Siqueira não havia escravos, mas, dos três filhos, apenas Amador da Rocha Lima se arranjou com um cônjuge plenamente livre. Catarina contraiu matrimônio com o também miliciano Pedro Domingues, o qual vivenciou a continuidade da alienação pessoal imposta pelo regime de administração então dissimulado pela referência ao agregamento, e Silvestre de Lima se casou com Maria, possivelmente nascida escrava, já que, além de ser referida como forra e liberta, era também viúva de um cativo. ${ }^{127}$

A genealogia do pardo Jacinto Leite Pedroso, representada no Diagrama 4.2, ilumina a junção de dois troncos familiares que durante todo o século XVIII experimentaram a exploração e a dominação social a partir das posições menos favorecidas, mas sob regimes diferentes: o da escravidão e o da administração. Jacinto nasceu livre em 1796, na vila de Santana de Parnaíba, mas em uma mão ele levava as chagas da escravidão a que foram submetidos os avós, as bisavós e a tataravó solteiras, e em outra mão as marcas da administração particular imputada aos familiares remotos, descendentes de indígenas, e inclusive ao seu pai. Considerado o conjunto das gerações, a liberdade com a qual o miliciano nasceu, lograda, aliás, pelos avós maternos, que se casaram na condição de libertos, e o matrimônio efetuado com cônjuge igualmente pardo e livre se assemelham à ponta visível de um iceberg. Ela dá a impressão de um afastamento contínuo e seguro da escravidão. Entretanto, nas profundezas há uma linhagem imersa no cativeiro e na servidão. A lembrança estava muito próxima a Jacinto, em seu próprio pai, João Leite Pedroso, nascido administrado.

${ }^{127} C f$ : L.C. Atibaia no 4, fl. 89v; L.C. Atibaia no 6, fls. 18, 46v, 50; ACMSP/DMC 1421; ACMSP/DMC 3645; ACMSP/DMC 4165; ACMSP/DMC 4173; Maços de População, Atibaia: (1804) M.D., fogo 66; (1806) M.D., fogo 24; (1807) M.D., fogo 116; (1810) M.D., fogo 10; (1811) M.D., fogo 29; (1812) M.D.,I., fogos 44 e 80 ; (1815) M.D.,I., fogos s.n., 01402_70 e 01402_82; (1818) C.L.,C., fogo 99; (1818) M.D.,B.V., fogos 84, 85 e 86; (1824) R.Ab., fogo 114; (1825) R.Ab., fogo 10; (1829) R.Ab., fogos 8 e 114. 
Mais dois aspectos dessa família merecem destaque. $\mathrm{O}$ primeiro diz respeito à grande mobilidade geográfica que caracterizou a população colonial e que, portanto, está na raiz do grupo social dos pardos. Do lado paterno, uma parte da família de administrados estava arraigada à vila de Parnaíba e outra era proveniente de Goiás. Já do lado materno destacam-se as trajetórias das bisavó e tataravó escravas do miliciano pardo, uma delas proveniente da Costa da Mina e conduzida a Minas Gerais e a outra já nascida na América, no Rio de Janeiro. Presume-se que o estabelecimento dessas pessoas e de seus descendentes na vila de Santana de Parnaíba esteja diretamente relacionado ao papel desempenhado pelas localidades paulistas como centros abastecedores das áreas mineradoras no século XVIII.

O segundo aspecto diz respeito à formatação das famílias como indicativo de enraizamento social. Como se vê no Diagrama 4.2, há um corte nítido entre as primeiras gerações da família de Jacinto Leite Pedroso e a de seus avós em diante quanto à formalização e estabilidade das relações conjugais via matrimônio. Os antepassados mais recuados são constituídos, sem exceção, por mulheres escravizadas e administradas e por pais incógnitos ou naturais. Independentemente se os parceiros tinham a mesma condição social delas ou se eram seus proprietários e administradores, esse tipo de relação denota ainda maior instabilidade e vulnerabilidade social às mães solteiras. Por outro lado, os integrantes das gerações mais recentes - incluídos os casais de avós, os pais e o próprio miliciano pardo - casaram-se todos na vila de Santana de Parnaíba. Para além do enraizamento ao território, a formação sucessiva de famílias consolidadas contrasta com as características originárias dessa linhagem e parece revelar um esforço coletivo em prol de estabilidade social. 
DIAGRAMA 4.2

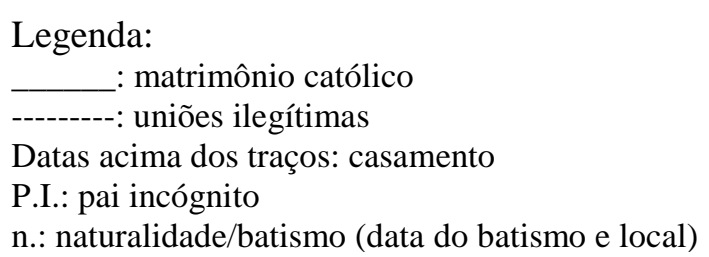

Datas acima dos traços: casamento

P.I.: pai incógnito

n.: naturalidade/batismo (data do batismo e local)

\section{Genealogia de Jacinto Leite Pedroso}

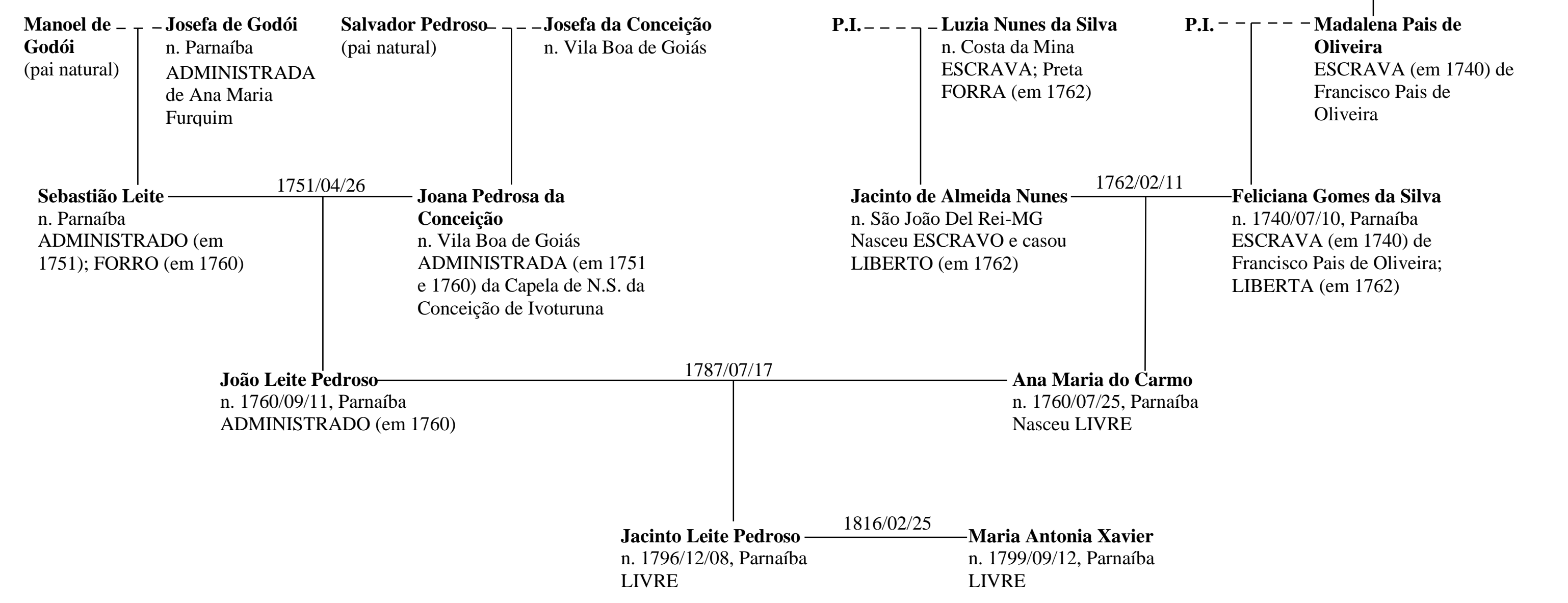




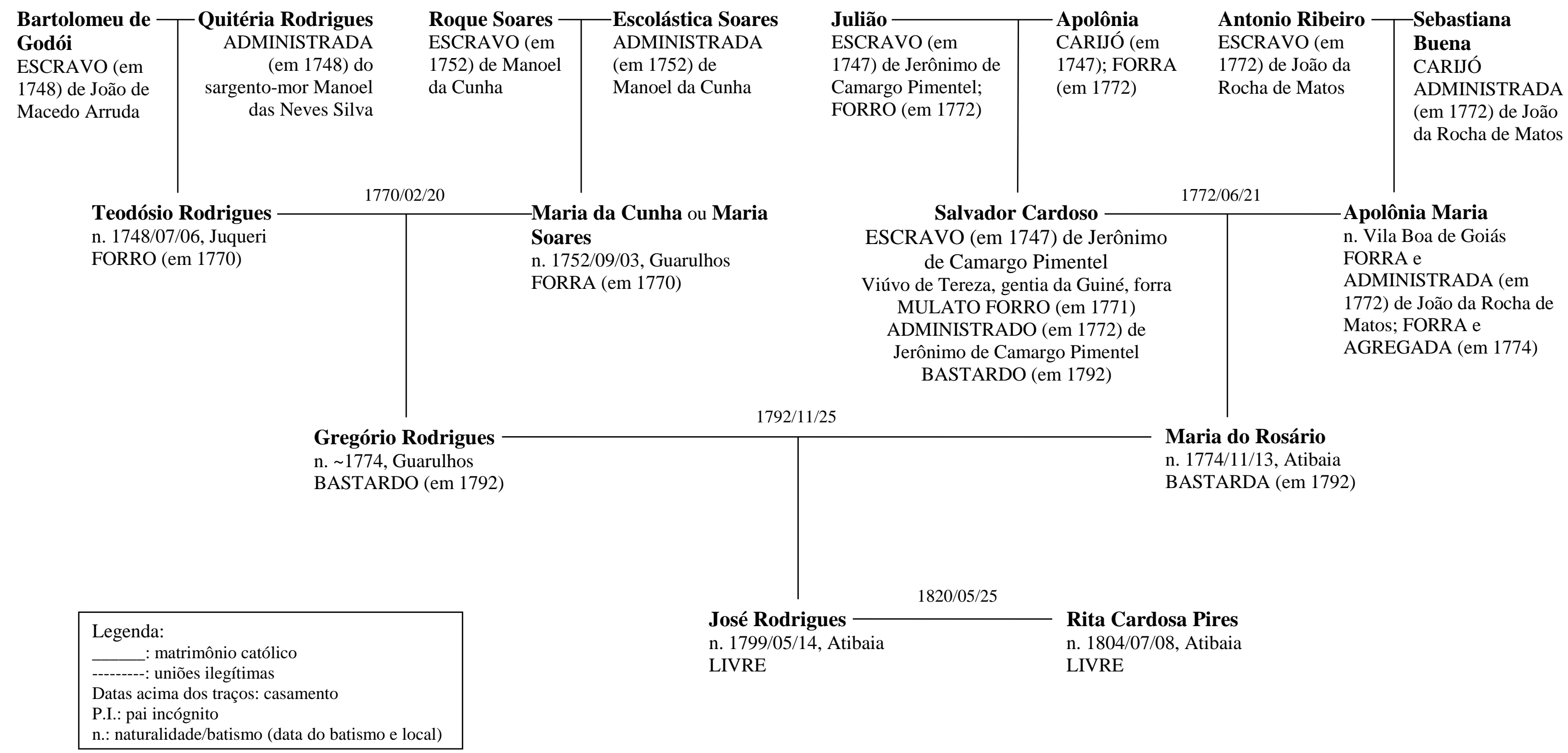




\section{DIAGRAMA 4.4}

Genealogia de José Rodrigues Batista, Joaquim Rodrigues

Legenda: matrimônio católico uniões ilegítimas

Datas acima dos traços: casamento

P.I.: pai incógnito

n.: naturalidade/batismo (data do batismo e local)

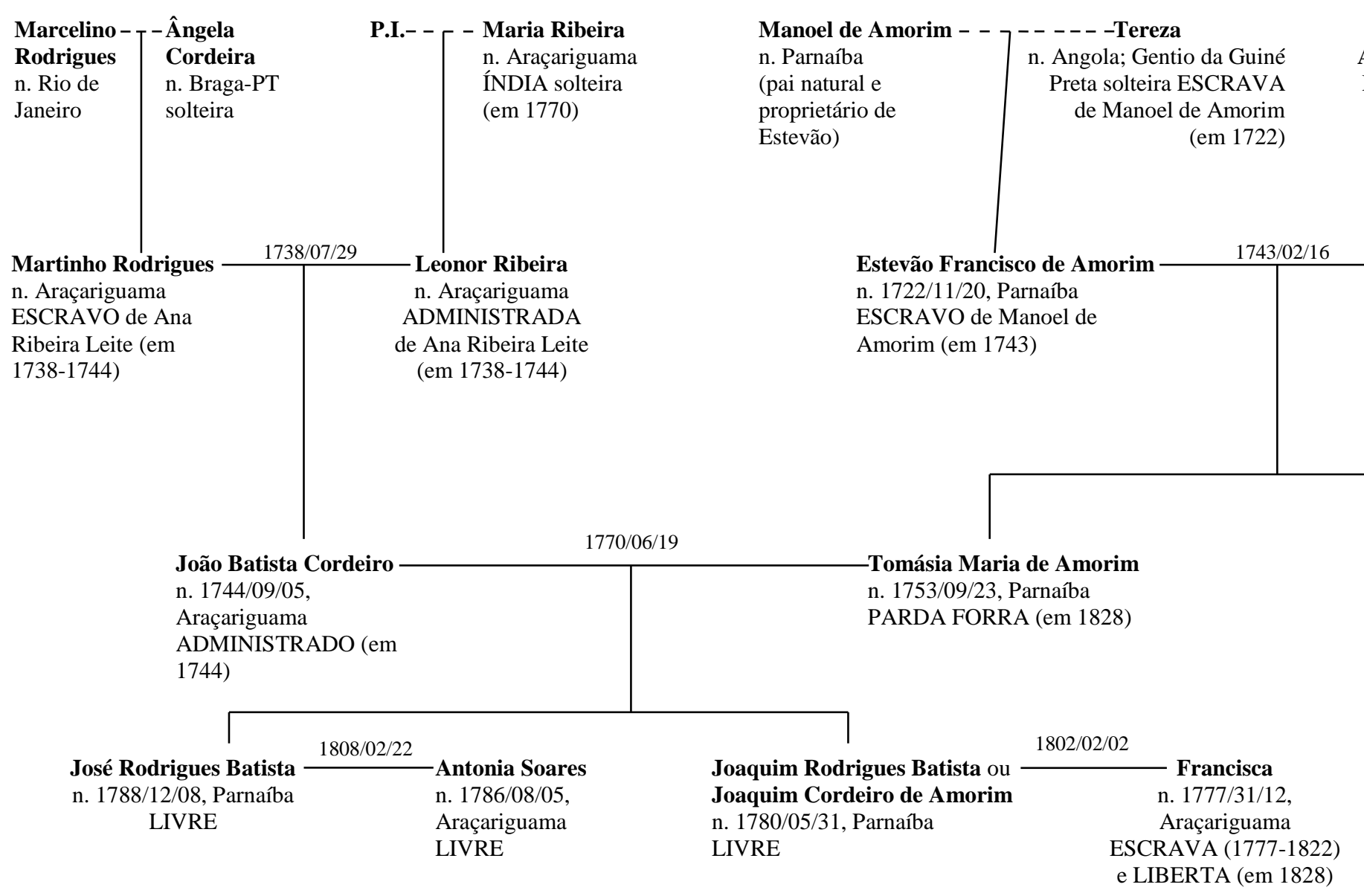

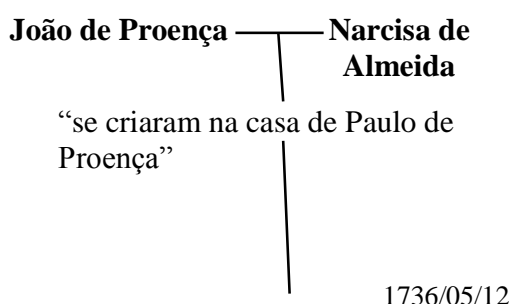

Cosme de $\frac{1736 / 05 / 12}{1}$

Almeida Cabral

Mulato FORRO

(em 1743)

\begin{tabular}{|c|}
\hline \\
\hline \\
\hline 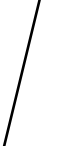 \\
\hline
\end{tabular}

Arcang

n. Parnaíba

ADMINISTRADA

(em 1729); Mulata

FORRA (em 1743)

Antonia

LIBERTOS (em 1736) "que se

criaram em casa de Jorge Moreira"

Garcia
Arcângela Moreira

\section{Joana Moreira}

. 1729/09/08, Parnaíb

ADMINISTRADA (em 1729);

FERT e Mulata FORRA (em

1743)
ESCRAVOS de Manoel Correi Penteado e de Fernando Pais de

1750

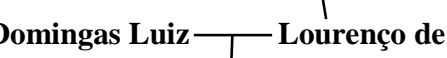
FORRA, "da Carvalho

casa de Pascoal n. Araçariguam ESCRAVO Fernando Pais de Barros (em 1750) e de Pascoal Fernandes de

Sampaio (em 1755)

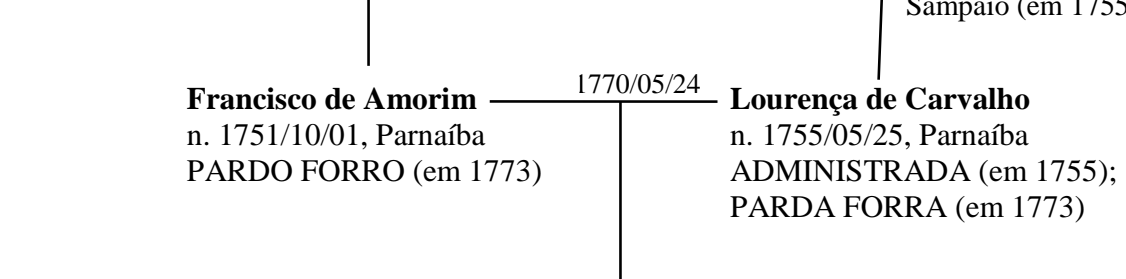

\begin{tabular}{|c|c|c|c|}
\hline \multicolumn{2}{|c|}{ 1817/11/02 } & $1811 / 0$ & \\
\hline $\begin{array}{l}\text { Cabo Manoel de } \\
\text { Amorim } \\
\text { n. 1773/12/15, } \\
\text { Araçariguama } \\
\text { LIVRE }\end{array}$ & $\begin{array}{l}\text { Matilde de Lacerda } \\
\text { n. 1803/08/14, Jundiaí } \\
\text { ESCRAVA (em 1803); } \\
\text { LIBERTA (em 1817) }\end{array}$ & $\begin{array}{l}\text { Antonio } \\
\text { Francisco de } \\
\text { Amorim } \\
\text { n. } \sim 1777 \text {, } \\
\text { Araçariguama } \\
\text { LIVRE }\end{array}$ & $\begin{array}{l}\text { Maria } \\
\text { Gertrudes } \\
\text { n. 1794/08/10 } \\
\text { Araçariguama } \\
\text { LIVRE }\end{array}$ \\
\hline
\end{tabular}


A linhagem dos milicianos pardos Gregório Rodrigues e seu filho José Rodrigues, de Atibaia, é outro caso extremamente instigante (Diagrama 4.3).

${ }^{128}$ Diferentemente da família de Jacinto Leite Pedroso, vista acima, cujos alicerces estão conformados pela ilegitimidade, os Rodrigues eram todos filhos legítimos, frutos de uniões endossadas pela Igreja até onde se pôde "escavar". Entretanto, um aspecto dessa árvore genealógica chama a atenção de imediato: na primeira geração, a dos avós de Gregório e bisavós de José Rodrigues, todos os casais foram formados por homens escravizados e mulheres administradas. Há na historiografia a percepção de que esses arranjos familiares nem sempre resultavam da afinidade e do acordo entre os contraentes, já que não são raros os casos em que senhores de escravos literalmente forçaram o casamento de seus cativos com administradas em seu poder ou de outrem, e mesmo com indígenas aldeadas. Essa prática social teria sido típica da primeira metade do século XVIII, período no qual a economia paulista viu-se carente de mão de obra barata em função da escassez de índios e da difícil concorrência por escravos africanos travada com as localidades mineradoras. ${ }^{129}$ Em virtude das normas eclesiásticas que prezavam pela inseparabilidade do casal e do fato de que o escravo permaneceria atado ao proprietário após o casamento, do ponto de vista dos proprietários de escravos esse mecanismo geralmente visava à retenção de mão de obra em seus plantéis, já que induzia a incorporação da esposa indígena ou administrada e também de seus filhos - que se tornavam servos ou administrados - ao grupo de trabalhadores ao qual os maridos e pais pertenciam. ${ }^{130}$

Em que pese a impossibilidade de se afirmar taxativamente que os quatro pares de avós e bisavós desses milicianos foram formados mais sob coação e menos por suas livres vontades, é fato que os proprietários e administradores consentiam nessas uniões e não era raro que até mesmo arcassem com as despesas delas decorrentes. ${ }^{131}$ Em dois desses casais é evidente o pertencimento a um mesmo senhorio e pairam poucas dúvidas quanto a Apolônia, esposa de Julião, ser administrada do proprietário do marido. Mas Bartolomeu e Quitéria viviam em lares separados. Se esse último exemplo não se enquadra na ideia dos casamentos mistos como forma de ampliação do contingente de trabalhadores, ele revela, em sentido complementar, a composição resultante de uma provável queda de braços entre o proprietário do noivo e o

\footnotetext{
${ }^{128}$ Cf.: L.C. Guarulhos n ${ }^{\circ}$ 2, fl. 97v; L.C. Atibaia n $\mathrm{n}^{\circ}$, fl. 24; L.C. Atibaia $\mathrm{n}^{\circ}$ 4, fls. 5v-6; L.C. Atibaia ${ }^{\circ}$ 5, fl. 17v; L.C. Atibaia nº 7, fl. 34; ACMSP/DMC 919; ACMSP/DMC 978; ACMSP/DMC 4989.

129 MONTEIRO, J. M. Negros da terra..., p. 169-170; GOLDSCHMIDT, E. R. Casamentos mistos...; BACELLAR, C. A. P. Famílias cativas em São Paulo colonial...

${ }^{130}$ Ao se deparar com vários casos de casais legítimos formados por um membro livre ou liberto e outro escravo que viviam em residências separadas, Bacellar encontrou indícios que matizam essa afirmação mais geral quanto à estratégia senhorial de retenção de mão de obra. BACELLAR, C. A. P. Famílias cativas em São Paulo colonial... ${ }^{131}$ GOLDSCHMIDT, E. R. Casamentos mistos..., p. 129-154.
} 
administrador da noiva: como ambos não abriram mão de seus subordinados, coube a eles viverem apartados, em desrespeito às normas da Igreja.

E qual a condição dos filhos de pai escravo e mãe administrada? Goldschmidt demonstra que o termo "servo" podia ser aplicado em tais circunstâncias. ${ }^{132}$ Todavia, os batismos de Teodósio e Maria, pais de Gregório e avós de José Rodrigues, elaborados por vigários de paróquias diferentes, não informam a designação de suas condições, e os assentos de Salvador e Apolônia não foram localizados. A resposta somente pode ser encontrada a partir de seus matrimônios e dos seus filhos, em período posterior ao Diretório dos Índios, e portanto ocultando a referência à servidão ou à administração. O que há em comum entre todos os filhos de pai escravo e mãe administrada é o termo "forro", que nesse caso parece acenar para a condição posterior à administração. O casal formado por Salvador Cardoso e Apolônia Maria foi caracterizado por uma variedade incrível de categorias ao longo do tempo. Em 1747, quando se casou pela primeira vez, então com uma escravizada, gentia da Guiné, Salvador foi notado como escravo de Jerônimo de Camargo Pimentel. Quando a esposa faleceu, em 1771, ele era um "mulato forro". Contudo, surpreendentemente, em suas segundas núpcias, no ano seguinte, Salvador e Apolônia foram referidos como administrados de diferentes senhores ou administradores. Finalmente, quando do casamento da filha Maria do Rosário com o futuro miliciano Gregório Rodrigues, em 1792, todos foram descritos como bastardos. Após esse longo percurso, a partir da última década do Setecentos, os membros remanescentes da família foram todos incluídos na generosa categoria pardo.

Com esse exemplo, avança-se em termos da compreensão da terminologia da época e quanto às múltiplas características que estão na raiz do grupo social dos pardos de São Paulo. Já foi visto que a categoria bastardo, conforme dela se valiam os vigários de Atibaia da segunda metade do século XVIII em diante, não se referia à filiação ilegítima, mas acenava para animais e pessoas originárias de pais de diferentes "castas" e genericamente para "qualquer um de descendência indígena". Para o caso de São Paulo, é comum associar exclusivamente os mamelucos - filhos de homens brancos e mulheres nativas - à descendência mestiça de índios. No entanto, conforme se pôde observar nos exemplos acima, havia "bastardos" longe de uma ascendência branca direta ou de corresponder sinonimamente a mameluco. E dessas relações mais ou menos frequentes entre escravos e administrados, se conclui que, nos quadros da “eliminação progressiva do índio pelo negro na organização do trabalho escravo" em São Paulo,

${ }^{132}$ GOLDSCHMIDT, E. R. Casamentos mistos..., p. 148-150. 
conforme formularam Fernandes e Bastide, houve espaço suficiente para a convivência e a mestiçagem entre esses grupos. ${ }^{133}$

Como no caso analisado acima, o de Jacinto Leite Pedroso, Gregório Rodrigues e José Rodrigues eram livres e se casaram com mulheres livres. Ambas, entretanto, eram igualmente filhas de pais nascidos escravos e mães forras e libertas. Ter em vista o passado familiar dessas pessoas, profundamente impregnado pela situação de sujeição imposta a escravos e administrados, auxilia a compreender a importância, para todos eles, da condição de livres e o relacionamento com pessoas igualmente livres.

Finalmente, o Diagrama 4.4 se refere a uma família de milicianos estabelecida na vila de Santana de Parnaíba e na freguesia de Araçariguama e se presta a vários propósitos. ${ }^{134}$ Em primeiro lugar, a presença de escravos, administrados e forros na composição da extensa rede familiar em tela, tecida ao longo do Setecentos, guarda semelhança considerável à de Gregório e José Rodrigues, de Atibaia, examinada acima. A recorrência da ligação conjugal de escravos e administrados em diferentes vilas da capitania de São Paulo é um indicativo seguro de que a formação histórica do grupo social integrado pelos pardos forros e livres é tributária desse relacionamento entre descendentes de indígenas e de africanos, catalisado pelas condições de vida comuns e não raro pela vinculação a um mesmo senhor. É claro que uma parcela significativa dos milicianos pardos devia ser composta por mulatos originados de pais brancos e de mães pretas, mulatas, índias ou mestiças de todos os tipos - uma realidade que a dissimulação dos pais somada ao estado de solteiro das mães impede de ser constada e que se mensure sua envergadura em face do conjunto dos pardos. Entretanto, sublinhar essa modalidade de relacionamento entre as camadas mais baixas da população visa a indicar que, não obstante suas diferenças jurídicas, étnicas ou fenotípicas, eles compartilhavam condições sociais comuns como trabalhadores forçados e dependentes que eram. Diante dos vários exemplos aqui reunidos, resulta impreciso afirmar que "insignificantes eram as proporções de

\footnotetext{
133 BASTIDE, Roger; FERNANDES, Florestan. Brancos e negros em São Paulo: ensaio sociológico sobre aspectos da formação, manifestações atuais e efeitos do preconceito de cor na sociedade paulistana [1955]. (4. ${ }^{\mathrm{a}}$ ed.). São Paulo: Global, 2008, p. 27-53.

${ }^{134}$ Cf:: L.C. Parnaíba 1722-1759, fls. 70 e 112v; L.C. Parnaíba 1758-1790, fls. 83v-84; L.C.E. Parnaíba, fl. 77v; L.C. Parnaíba 1790-1821, fls. 73v-74, 130; L.O. Parnaíba 1797-1830, fl. 185v; L.C. Araçariguama 1721-1750, fl. 66v; L.C. Araçariguama 1751-1783, fl. 102v; L.C. Araçariguama 1783-1817, fl. 98; ACMSP/DMC 118; ACMSP/DMC 301; ACMSP/DMC 881; ACMSP/DMC 903; ACMSP/DMC 2731; ACMSP/DMC 3598; ACMSP/DMC 3939; ACMSP/DMC 4681; Maços de População, Parnaíba: (1806) 2. a , fogos 45 e 53; 4. ${ }^{a}$, fogo 71; (1812) 2..$^{a}$, fogo $71 ; 3 .{ }^{a}$, fogo 41; (1816) 2. ${ }^{a}$, fogo $96 ; 3 .{ }^{a}$, fogos 37 e 42; (1822) 1. ${ }^{a}$, fogo 174; 3. ${ }^{a}$, fogo 45; (1828) $1 .^{\mathrm{a}}$, fogo 177 .
} 
indivíduos frutos de cruzamentos de índios com negros” em São Paulo. ${ }^{135}$ Diferentemente de outras configurações sociais caracterizadas por uma vinculação mais antiga, sólida ou abrangente ao tráfico transatlântico de escravos, em que abundavam os mulatos entre as pessoas livres, em São Paulo o grupo dos pardos forros e livres bebeu o leite de muita escrava crioula e também de muita índia administrada e de toda sorte de mestiças ao longo do século XVIII.

Esse tópico vem sendo repisado à exaustão, mas não despropositadamente. É preciso que se tenha em mente o caráter relativamente tardio da transição da escravidão indígena para a africana nessa região marginal da América portuguesa bem como a mestiçagem cultural, social e enfim biológica que envolveu negros, índios e as inúmeras variantes resultantes para que se possa pensar adequadamente o grupo dos pardos em São Paulo. Nesses termos, aplicar de modo generalizante as categorias "negro" e "afrodescendente" aos pardos forros e livres dessa capitania/província implicaria conferir destaque especial a um de seus componentes e relegar um outro, de igual importância, a uma posição secundária e marginal. Ademais, em meio à heterogeneidade de arranjos familiares que vieram à tona e à decorrente mestiçagem, resulta dificultoso e mesmo improdutivo aplicar aqui as noções clássicas de endogamia e exogamia. Afinal, como delimitar e definir o endógeno e o exógeno em um grupo social que é fruto do relacionamento entre negros, índios, brancos, bastardos, mulatos, livres, forros e escravos?

Uma outra constatação relevante do Diagrama 4.4 é a influência que o pertencimento a um mesmo plantel de escravos e administrados tinha para a formação dos casais. Em 1769, o governador e capitão-general de São Paulo, morgado de Mateus, escreveu ao ministro de Estado conde de Oeiras que "vão-se fazendo tantos casamentos de negros e negras e povoações nas fazendas e lavras particulares, que já multiplicam muito nas mesmas terras [os escravos], sem que precisem vir de fora, e além de se ir povoando o Estado de má gente". ${ }^{136}$ Essa comunicação entre funcionários de alto escalão do Estado português, que sem qualquer embaraço reproduz os estigmas sociais imputados aos negros, indígenas e mestiços, no entanto dá conta do crescimento natural existente entre a população escrava paulista. $\mathrm{O}$ morgado de Mateus não mencionou a presença dos ex-administrados nessas uniões e também deixou de lado o papel desempenhado pelos proprietários na promoção dos casamentos entre essa população, interessados que estavam na multiplicação de sua mão de obra.

\footnotetext{
${ }^{135}$ Essa é a leitura de Marcílio aos dados referentes a casamentos mistos entre indígenas e escravos ocorridos entre os anos 1728 e 1822, auferidos por E. R. Goldschmidt, em Casamentos mistos... Ver MARCÍLIO, Maria Luiza. Crescimento demográfico..., p. 118.

${ }^{136} C f$ :: "Carta ao mesmo conde [de Oeiras] remetendo-lhe a lista dos escravos e rendimentos da capitania de S. Paulo". DIHCSP, vol. 19, p. 282-287. São Paulo, 22 de fevereiro de 1769.
} 
Nas gerações de avós, bisavós e tataravós dos milicianos das famílias Batista e Amorim há vários casos de casamentos ocorridos a partir da convivência em uma mesma unidade produtiva e quiçá estimulados pelos proprietários e administradores. Ao centro da árvore genealógica está o ponto nodal entre as famílias de milicianos, o casal formado por Estevão Francisco de Amorim e Joana Moreira, nascidos na década de 1720 e casados no ano de 1743. Estevão, que se tornou avô de quatro milicianos do Regimento dos Úteis, era escravo de seu próprio pai. Esse aparentemente levou às últimas consequências a ambição por manter e se possível ampliar o grupo de escravos e subjugados, já que manteve o filho como escravo até pelo menos o tempo de ele se casar. Já a esposa Joana Moreira havia nascido como administrada, mas casou-se sendo registrada como "liberta" e "mulata forra".

Esse casal gerou, entre outros filhos, Francisco de Amorim e Tomásia Maria de Amorim, notados como pardos forros em diferentes ocasiões. Os irmãos Francisco e Tomásia contraíram matrimônio, em 1770, com pessoas que nasceram na condição de administrados e que, assim como eles, posteriormente seriam identificados como pardos forros. Cada casal gerou dois filhos que seriam incorporados ao Regimento dos pardos. Esse exemplo esclarece que entre os milicianos devia haver inúmeras modalidades de solidariedade e camaradagem as quais também conviviam com situações conflituosas. Além de serem pardos, vizinhos e se relacionarem em função da atividade miliciana, muitos desses homens eram parentes - irmãos e primos, como os Batistas e Amorins, pais e filhos, como os Rodrigues da vila de Atibaia, e também tios, sobrinhos, compadres, afilhados, cunhados e daí por diante - mas essa dimensão dificilmente se revela de modo espontâneo nas fontes. $\mathrm{O}$ que mais merece a atenção é o comportamento dos milicianos provenientes de um mesmo tronco familiar no mercado matrimonial. Vale esclarecer que o pressuposto aqui é o de que a obtenção de um consórcio com noiva nascida livre, da qual resultaria uma prole também livre, significaria um passo adiante no afastamento da escravidão e do regime da administração. Desses quatro homens nascidos livres, mas que emergiram do cativeiro e da administração, dois primos conseguiram se casar com mulheres também nascidas em liberdade e outros dois primos receberam como esposas mulheres nascidas escravas, sendo que uma delas havia sido libertada antes do casamento e a outra conseguiu esse feito muitos anos após o matrimônio. A constatação de que pessoas oriundas de um mesmo grupo familiar pudessem construir arranjos matrimoniais bastante diferentes entre si no tocante à condição das noivas sugere que, em termos gerais, se tratava de um grupo social heterogêneo mas com uma base comum vinculada à escravidão. Mesmo para forros e nascidos livres, esse passado familiar que também marcava a totalidade do grupo social em tela constituía um verdadeiro atoleiro, o qual podia ser mais facilmente 
vencido por alguns poucos habilidosos, extremamente esforçados, disciplinados e com um pouco de sorte, mas que retinha por um longo tempo a vasta maioria dos envolvidos.

A análise das famílias em meio às quais vieram ao mundo os homens que integraram as fileiras do Regimento dos Úteis objetivou, por um lado, estabelecer relações entre a configuração familiar e a trajetória dos indivíduos na hierarquia miliciana e, por outro, discutir o processo de formação do grupo social dos pardos forros e livres em São Paulo. Constatou-se, de partida, que a maior parte dos milicianos (3/5 deles) eram frutos de uniões sacramentadas pela Igreja, ao passo que um contingente menor, mas significativo (os $2 / 5$ restantes), eram filhos de pais incógnitos. Esse predomínio das famílias constituídas conforme as normas vigentes e teoricamente estáveis foi interpretado como um indicativo de enraizamento social. Já os altos índices de ilegitimidade acenariam tendencialmente para situações de vulnerabilidade e instabilidade social vivenciadas pelas famílias em questão. Mas eles não eram exclusividade dos pardos forros e livres, se acentuavam nas cidades em comparação com as regiões rurais, e, surpreendentemente, tinham ocorrência mais frequente entre a oficialidade. Como é extremamente difícil identificar os inúmeros pais incógnitos e a sua eventual contribuição para a ascensão dos filhos na hierarquia do Regimento, a explicação mais segura para a elevada participação de homens nascidos ilegitimamente nos postos de comando apela para a dinâmica das cidades e para o leque de oportunidades econômicas e institucionais que elas ofereciam às pessoas pobres, tais como as mulheres pardas solteiras e os seus filhos.

Apesar de ser uma tarefa árdua, a identificação dos registros batismais e matrimoniais dos pais dos milicianos pardos revelou aspectos importantíssimos acerca do grupo social em tela e permitiu o entrelaçamento de perspectivas centradas em indivíduos, famílias e grupos sociais mais vastos. Conforme os dados da amostra, havia equilíbrio na proporção de pais e mães quanto à condição de nascimento/batizado, já que eles estavam distribuídos com certa equivalência entre livres, escravos e indígenas (administrados e aldeados). Além disso, a configuração dos casais de pais de milicianos não levava em conta, necessariamente, a correspondência entre a condição de nascimento/batizado, de modo que poucos milicianos provinham de pai e mãe plenamente livres. Isso significa que os soldados e oficiais pardos estavam situados, na maior parte, entre a segunda e a terceira geração de liberdade. Decorre daí a permanência da atribuição de estigmas sociais aos pardos. Ademais, o termo "forro" se generalizou após a abolição da administração indígena, e não por acaso era aplicado a homens e mulheres que jamais haviam vivenciado pessoalmente a escravidão ou a administração. 


\subsubsection{A reprodução das famílias pardas: milicianos pardos, noivas e matrimônio}

Até aqui a atenção foi destinada para a origem social dos milicianos, isto é, para a condição social e jurídica que tanto eles como seus pais portavam quando foram apresentados à sociedade por meio do sacramento católico do batismo. O esforço mais pontual de reconstrução de árvores genealógicas de soldados pardos também recuperou a condição de membros de gerações anteriores. Em conjunto, esses elementos dizem respeito não apenas à formação familiar dos milicianos, mas à própria construção do grupo social dos pardos livres e forros durante o século XVIII e o começo do XIX. A partir desse ponto, a análise se desdobra para uma etapa seguinte da construção das famílias e do grupo em questão, passando-se a examinar os casamentos dos milicianos pardos. A escolha do cônjuge é vista como um fator revelador acerca da capacidade de afastamento ou não do universo da escravidão por parte desses homens e se reveste de extrema importância por determinar a condição jurídica de nascimento dos filhos.

O casamento era uma etapa importante na vida dos indivíduos, das famílias e da comunidade. Como bem observou Bacellar, ele "é um ato profundamente submisso a imperativos de ordem social, econômica e cultural que o direcionam em qualquer comunidade analisada". ${ }^{137}$ No universo colonial e escravista em questão, há fartos exemplos de que o critério condição social e qualidade era observado quando da formação das famílias mediante o matrimônio, especialmente em se tratando do grupo social dos brancos. As Ordenações Filipinas asseguravam aos pais o direito de deserdarem as filhas que se casassem sem o seu consentimento e, indiretamente, também continham cláusulas capazes de fazer valer a vontade paterna perante os filhos homens. ${ }^{138}$ Uma expressão vigorosa dos ideais que norteavam a proibição dos matrimônios desiguais se encontra na Real Pragmática de Matrimonios outorgada aos territórios espanhóis em 1776, a qual reiterava o poder paterno na condução dos destinos das famílias e visava prioritariamente a preservar as barreiras entre a nobreza e a plebe. ${ }^{139}$ Ao longo do Setecentos e ainda no século seguinte, oficiais de câmaras municipais e

\footnotetext{
${ }^{137}$ BACELLAR, Carlos de Almeida Prado. Viver e sobreviver em uma vila colonial: Sorocaba, séculos XVIII e XIX. São Paulo: Annablume/Fapesp, 2001, p. 73.

${ }^{138}$ SAMARA, Eni de Mesquita. Casamento e papéis familiares em São Paulo no séc. XIX. Cad. Pesq., São Paulo, 37, p. 17-25, maio/1981.

${ }^{139}$ Cf:: "Pragmatica sancion para evitar el abuso de contraer matrimonios desiguales". In: KONETZKE, Richard. Colección de Documentos para la historia de la formación social de Hispanoamérica, 1493-1810. Vol. III, Tomo 1. Madrid: Consejo Superior de Investigaciones Cientificas, 1962, p. 406-413. El Pardo, 23 de março de 1776. Essa Pragmática foi estendida para as Índias, em 1778, com adaptações à realidade colonial. Apesar de excluir, por definição, as castas, isto é, os mestiços com algum grau de ascendência africana, ela incluiu a todos os milicianos pardos e morenos. "Real Cedula que extiende a Indias la Real Pragmática sobre matrimonios de 23 de marzo de 1776”. In: AYALA, Manuel José de. Cedulario Índico. Tomo LI. Madri, 1788, fls. 263v-267.
} 
até mesmo de postos administrativos mais elevados, a exemplo de um governador de Minas Gerais, exerceram fortes pressões junto à Coroa para que mulatos e brancos casados com mulatas não fossem admitidos nos postos da governança local. ${ }^{140} \mathrm{O}$ Diretório pombalino que proibiu a escravidão indígena e aboliu a instituição da administração buscou incentivar os casamentos entre brancos e índios e desterrar "as prejudicialíssimas imaginações dos moradores deste Estado, que sempre reputaram por infâmia semelhantes matrimônios". ${ }^{141}$ Entretanto, vários autores observaram atentamente que negros, mulatos, pardos e pretos da América portuguesa não foram contemplados com semelhante equiparação. ${ }^{142}$ Após a independência do Brasil, nem mesmo a retirada dos entraves legais para a realização de uniões entre desiguais, preservando-se, porém o papel do consentimento paterno, alterou a percepção social sobre a questão. ${ }^{143}$ Desse modo, as relações amorosas entre brancos e pessoas consideradas de inferior condição ou qualidade foram mais comumente mantidas na esfera da informalidade.

Em contraste, entre os setores mais pobres da sociedade ocorriam uniões entre pessoas de condição social e qualidade diversas, como visto nas páginas precedentes. Pessoas escravizadas se casavam com administradas, mulatos com bastardos, pardos forros com pardos livres e assim por diante. Os casamentos significavam a formação de novas famílias e consequentemente de novas unidades produtivas. Para os setores sociais aqui em consideração, tratava-se do estabelecimento de parceria e cumplicidade entre os cônjuges visando à sobrevivência do casal e dos filhos. Mas também implicava a aliança entre famílias, e por isso elas acompanhavam atentamente a escolha dos futuros parentes e ocasionalmente intervinham no sentido de impedir a realização de matrimônios considerados desiguais. Significativamente, a manifestação de pais e mães contrários às uniões desejadas pelos filhos sugere a vigência de

\footnotetext{
${ }^{140} C f$ :: "Representação dos oficiais da Câmara de Vila do Príncipe contra os casamentos dos brancos com os mulatos e vice-versa, solicitando ordem regia sobre este assunto". Vila do Príncipe, 28 de abril de 1762. AHU_CU_011, Cx. 80, D. 6618; "Representação que fazem os oficiais da Câmara da vila de Nossa Senhora do Bom Sucesso ao governador, pedindo que destitua dois oficiais que foram eleitos para servirem na Câmara no ano de 1806, por não terem as qualidades necessárias para os ditos cargos, visto que são casados com mulheres pardas, o que os impedem de servir, conforme a Lei de 27/01/1726". Vila de Bom Sucesso, 27 de dezembro de 1805. Arquivo Público Mineiro, SG, Cx. 66, Doc. 37.

${ }^{141} C f:$ : "Directorio, que se deve observar nas Povoações dos Indios do Pará, e Maranhão em quanto Sua Magestade não mandar o contrario". Pará, 17 de agosto de 1758. In: SILVA, Antonio Delgado da. Collecção da Legislação Portugueza desde a ultima compilação das Ordenações. Legislação de 1750 a 1762. Lisboa: Typografia Maigrense, 1830, p. 507-530.

${ }^{142}$ DEGLER, Carl N. Nem preto nem branco: escravidão e relações raciais no Brasil e nos Estados Unidos. Rio de Janeiro: Labor do Brasil, 1976, p. 222; LARA, S. H. Fragmentos setecentistas..., p. 264-269. A análise mais completa sobre a questão em LIMA, Priscila de. De libertos a habilitados. Interpretações populares dos alvarás anti-escravistas na América portuguesa (1761-1810). Dissertação (mestrado em História). Curitiba: SCHLA, Universidade Federal do Paraná, 2011, p. 13-43.

${ }^{143}$ SAMARA, Eni de Mesquita. Casamento e papéis familiares...
} 
coerções sociais e de mecanismos de distinção refinados entre esses segmentos oriundos da escravidão.

A maioria dos milicianos pardos constituiu família e a regularizou através do matrimônio. Como se vê na Tabela 4.10, ao menos 138 homens receberam as bênçãos nupciais - o que é o mesmo que $52 \%$ da amostra. Esse número em realidade pode ser maior, considerando-se tanto os elevados índices de casados entre a população livre ${ }^{144}$ quanto o fato de que vários milicianos foram identificados nas listas nominativas no estado de casados mas cujos assentos de casamento e/ou processos de matrimônio movidos junto ao juízo eclesiástico não foram localizados. Esses últimos figuram no conjunto formado por 111 milicianos relativamente aos quais nenhuma informação precisa foi encontrada ou que ainda se mantém alguma dúvida a respeito do seu estado civil. Apenas 17 homens, ou pouco mais de $6 \%$ da amostra, seguramente permaneceram solteiros durante o período de atuação do Regimento dos Úteis ou faleceram em estado celibatário.

TABELA 4.10 - Estado civil dos milicianos e condição das esposas no batismo

\begin{tabular}{|c|c|c|c|c|c|c|c|c|}
\hline \multirow[t]{2}{*}{ Companhia } & \multirow{2}{*}{$\begin{array}{c}\text { Total de } \\
\text { Milicianos }\end{array}$} & \multicolumn{3}{|c|}{$\begin{array}{c}\text { Estado Civil } \\
\text { dos Milicianos }\end{array}$} & \multicolumn{4}{|c|}{ Esposas } \\
\hline & & $S$ & $?$ & $\mathrm{C}$ & Livres & Expostas & Escravas & Índias \\
\hline Of. Patente SP & 29 & 6 & 13 & 10 & 7 & & 3 & \\
\hline Of. Atibaia & 17 & & 7 & 10 & 8 & & 2 & \\
\hline Of. Parnaíba & 20 & 3 & 9 & 8 & 4 & & 2 & 2 \\
\hline Sold. Atibaia & 105 & 2 & 42 & 61 & 49 & 3 & 8 & 1 \\
\hline Sold. Parnaíba & 95 & 6 & 40 & 49 & 31 & 3 & 14 & 1 \\
\hline TOTAL & 266 & 17 & 111 & 138 & 99 & 6 & 29 & 4 \\
\hline
\end{tabular}

Fonte: Livro Mestre; Dispensas Matrimoniais; Livros de Batismo e Casamento (Atibaia, Araçariguama, Bragança, Santana de Parnaíba, São Paulo, São Roque).

O que interessa diretamente é examinar a condição social das mulheres que formaram família com os milicianos pardos, os quais estavam todos livres ou libertos quando se casaram. É preciso esclarecer que os dados da Tabela 4.10 referente às esposas dizem respeito exclusivamente às consortes de primeiras núpcias dos milicianos e informam a condição em que elas foram batizadas. Como demonstrado no caso dos próprios milicianos, a condição de

\footnotetext{
144 Vide REIS, Déborah Oliveira Martins dos. Cinturão Paulistano: economia e demografia nas vizinhanças da capital de São Paulo (c. 1798 - c.1830). São Paulo: FFLCH/USP, 2013, p. 34-37, 66-69, 94-98.
} 
batismo revela de modo mais efetivo o grau de proximidade ou distanciamento dos indivíduos quanto à escravidão e ao universo indígena. Apesar da importância dos casos duvidosos ou sem informação relativos aos milicianos - pouco mais de $41 \%$ da amostra - e de seu potencial de produzir alterações e desvios, a análise incidirá sobre um contingente significativo de pessoas, de modo que os resultados da observação terão caráter aproximativo.

Nitidamente, a maior parte dos milicianos pardos se casou com mulheres nascidas livres. Poucos deles contraíram matrimônio com mulheres que foram expostas ou que nasceram em aldeias, as quais também podem ser englobadas ao conjunto das livres, e um contingente significativo desses homens recebeu como esposas mulheres diretamente marcadas pela escravidão. A proporção de casamentos de milicianos pardos com esposas nascidas livres chega a $79 \%$ da amostra caso se inclua as mulheres expostas e índias nesse conjunto. Isso significa que os frutos dessas relações vieram ao mundo completamente livres do cativeiro. Ademais, a condição de liberdade possibilitaria às famílias optarem por mudar o local de residência com relativa autonomia e gerirem os proventos de seu trabalho da maneira como lhes conviesse, sem a preocupação de acumular pecúlio para destiná-lo à aquisição da alforria de familiares próximos. $^{145}$

Embora minoritária, pode ser considerada expressiva a proporção de esposas nascidas na situação de escravizadas, todas crioulas, correspondente a $21 \%$ da amostra. Recuperando os dados da Tabela 4.7, vê-se que, de 175 milicianos cuja condição no momento do batismo é conhecida, apenas 14 eram escravos, ao passo que 28 mulheres nasceram em cativeiro em um universo formado por 138 esposas. Esse diferencial significa que vários milicianos nascidos livres constituíram família com mulheres escravas ou libertas. É realmente surpreendente o fato de que, entre os milicianos que se casaram com nascidas escravas, apenas dois tivessem nascido em cativeiro e um sob o regime da administração. Trata-se de dois oficiais de patente residentes da cidade de São Paulo e de um soldado de Atibaia. ${ }^{146}$ Para além desses, e de um oficial de Atibaia que foi alforriado na pia batismal e de outro oficial da mesma companhia nascido índio, todos os demais milicianos casados com esposas nascidas escravas (um oficial de patente da Cidade de São Paulo, dois oficiais inferiores e 14 soldados da companhia de Santana de Parnaíba além de oito soldados da companhia de Atibaia) haviam nascido indubitavelmente

\footnotetext{
${ }^{145}$ Para uma perspectiva mais realista da questão relacionada ao peso da compra de alforria, seria ainda necessário considerar a condição de outros integrantes também muito próximos, como os pais, sogros, irmãos e cunhados.

$146 C f$ : Livro Mestre, fls. 1-1v, 141, 142v, 143, 225, 256; ACMSP/DMC 1355; ACMSP/DMC 3575; ACMSP/DMC 4165.
} 
livres da escravidão. ${ }^{147}$ Ou seja, enquanto a maior parcela dos milicianos batizados como escravos encontrou noivas nascidas livres, uma boa parte de soldados nascidos em plena liberdade constituiu laços com mulheres pessoalmente marcadas pela escravidão. Os significados mais amplos dessa constatação acenam para duas situações complementares, inerentes ao grupo dos pardos livres e forros em construção: enquanto uma maioria se encaminhava no sentido do distanciamento do passado escravo, muitos milicianos ainda permaneciam muito próximos a esse universo - seja em função do seu próprio nascimento, seja pela condição dos pais ou a dos cônjuges.

Para tentar melhor compreender a afinidade existente entre esses homens nascidos livres e as esposas nascidas escravas, pessoas de diferentes condições sociais, portanto, vale a pena recuperar a origem social dos milicianos em questão. Atendo-se aos quatorze soldados da companhia de Santana de Parnaíba que vivenciaram essa circunstância, se percebe rapidamente que, apesar de livres desde o nascimento, eles estavam muito próximos da realidade social das esposas e que a sua liberdade não era mais que incipiente. Três deles eram filhos de pais nascidos escravos e mães identificadas apenas como forras, e dois soldados, irmãos, eram filhos de um casal de escravos. Também havia dois irmãos milicianos que eram filhos de antigos administrados e um soldado originário de pai administrado e mãe nascida em liberdade. Além deles, três eram filhos de pais e mães indígenas e um miliciano fora originado de pai incógnito e mãe índia. Por fim, não foi possível identificar a condição dos pais de dois milicianos cujas esposas nasceram em cativeiro. ${ }^{148}$ Filhos de casais indígenas, administrados e escravos, sem muita diferença, se entrelaçaram com mulheres nascidas em cativeiro e com elas formaram família.

Os dados disponíveis sugerem, pois, que os milicianos pardos nascidos livres compartilhavam condições de vida bastante comuns com as esposas batizadas como cativas, da mesma maneira com que os nascidos escravos eram plenamente compatíveis com as esposas livres desde o nascimento. Uma visão mais precisa sobre a atuação dos homens aqui em questão no mercado matrimonial é fornecida a partir da análise sobre a condição das noivas quando do

\footnotetext{
${ }^{147}$ Cf:: Livro Mestre, fls. 98, 223, 224v, 225v, 229, 231, 236v, 237v, 242, 242v, 253v, 255, 308v, 309v, 310v, 311, 314, 318, 319, 322, 325, 325v, 326v, 330, 330v, 334v, 339, 341, 341v; L.C. Atibaia no 5, fl. 13; ACMSP/DMC 1896; ACMSP/DMC 2543; ACMSP/DMC 2641; ACMSP/DMC 2731; ACMSP/DMC 2976; ACMSP/DMC 3267; ACMSP/DMC 3274; ACMSP/DMC 3332; ACMSP/DMC 3396; ACMSP/DMC 3454; ACMSP/DMC 3764; ACMSP/DMC 3806; ACMSP/DMC 3901; ACMSP/DMC 3921; ACMSP/DMC 4132; ACMSP/DMC 4405; ACMSP/DMC 4483; ACMSP/DMC 4634; ACMSP/DMC 4681; ACMSP/DMC 4702; ACMSP/DMC 4718; ACMSP/DMC 4775; ACMSP/DMC 5140; ACMSP/DMC 5493.

${ }^{148} C f .:$ ACMSP/DMC 578, fl. 3; ACMSP/DMC 903, fls. 9-10; ACMSP/DMC 1603, fls. 18 e 20; ACMSP/DMC 1896, fl. 12; ACMSP/DMC 2976, fl. 4; ACMSP/DMC 3396, fl. 3; ACMSP/DMC 4405, fl. 10; ACMSP/DMC 4702, fl. 8; ACMSP/DMC 5140, fl. 27; L.C. Parnaíba 1790-1821, fl. 19.
} 
casamento. As mulheres nascidas livres evidentemente permaneceram como tais enquanto adultas, mas entre as batizadas como escravas houve mudanças expressivas. Das 29 mulheres nessa situação, apenas dez se casaram na condição de cativas, ao passo que as 19 restantes obtiveram a alforria entre a infância e a idade adulta e portanto constituíram família já como libertas. Os oficiais de patente da cidade de São Paulo e os oficiais das companhias de Atibaia e de Parnaíba estabeleceram laços com mulheres nascidas escravas, mas todas elas estavam alforriadas quando se casaram. Apenas os soldados das companhias interioranas é que efetivamente se uniram a escravas. ${ }^{149}$ Essas evidências mostram um corte interessante entre oficiais e soldados milicianos no tocante à ligação com o cativeiro: quanto aos oficiais, no que dependia deles próprios, buscavam evitar o estabelecimento de relações tão próximas a escravos, as quais poderiam comprometer as posições de prestígio alcançadas na corporação militar e na vida social mais ampla; essa tendência se verificava igualmente entre os soldados, pois a maior parte deles desposou mulheres livres. Entretanto, alguns deles não se importaram com as consequências advindas da união com escrava, talvez porque não visualizassem melhores opções ou porque as diferenças entre as suas experiências de vida fossem, na prática, irrelevantes, ou, ainda, por razões sentimentais capazes de se sobrepor a quaisquer outras.

Em observância a uma provisão expedida por um vigário geral, alguns matrimônios envolvendo milicianos pardos livres ou forros e mulheres escravas da paróquia de Santana de Parnaíba foram precedidos pela adesão dos noivos a um termo de obrigação, pelo qual o marido "por si e de vontade própria" se comprometia "a seguir a sua mesma mulher em qualquer estado que permitir o seu cativeiro". ${ }^{150} \mathrm{Em}$ parte, o termo servia de alerta aos envolvidos quanto às consequências atinentes a esse tipo de união, mas, do ponto de vista senhorial, uma de suas funções primordiais era a de formalizar a vinculação do noivo à propriedade do senhor da noiva escravizada. Enquanto perdurasse o casamento e/ou o cativeiro da família, os proprietários contariam com a mão de obra desses agregados e veriam ampliadas as chances de reprodução natural de seu plantel de escravos. E, com efeito, uma vez casados, os seis soldados pardos daquela vila cujas esposas permaneceram em cativeiro passaram a residir como agregados nos domicílios dos proprietários, que também eram senhores dos seus filhos. ${ }^{151} \mathrm{O}$ mesmo ocorreu

\footnotetext{
149 As referências são as mesmas das notas de rodapé 146, 147 e 148 acima.

${ }^{150}$ Cf.: L.C.E. Parnaíba 1759-1886, fl. 76.

${ }^{151}$ Cf:: Livro Mestre, fls. 310v, 311, 330, 334v, 339 e 341; Maços de População, Santana de Parnaíba: (1806) 1. fogo 86; (1806) 2..$^{\mathrm{a}}$, fogo 53; (1812) 1. ${ }^{\mathrm{a}}$, fogo 82; (1812) 2. ${ }^{\mathrm{a}}$, fogos 71, 77, 88, 89 e 90; (1816) 2. ${ }^{\mathrm{a}}$, fogos 83, 85, 87, 93 e 96; (1822) 1.a , fogos 88, 167 e 174; (1822) 2. , fogo 9; (1828) 1. , fogos 138, 163 e 177.
} 
com três dos quatro milicianos de Atibaia unidos a escravas. ${ }^{152}$ Todos esses matrimônios ocorreram no intervalo entre os anos de 1792 e 1817.

Pelo menos no que toca a essa dezena de casamentos mistos de homens livres ou forros e mulheres escravas, nas vilas de Santana de Parnaíba e Atibaia se observa tendência oposta à observada por Bacellar para a vila de Itu, onde "encontrar casais mistos dentro de mesmo domicílio foi mais difícil do que os encontrar separados". ${ }^{153}$ Isso denota que os poucos milicianos pardos que se submeteram a tal situação enfrentavam sérias dificuldades para se desvencilhar do universo do cativeiro e de suas múltiplas ramificações. Outro dado interessante é que a maior parte desses homens e de suas famílias estava enraizada nas comunidades em que viviam as futuras esposas. Desse modo, salvo exceções, a ocorrência desses casamentos mistos não se explica pela necessidade de homens forasteiros, dotados de reduzida estima e capital social, se integrarem rapidamente à comunidade, mesmo que para isso tivessem que se valer de casamento com mulheres escravas - a qual foi verificada por Machado para a freguesia paulista de São José dos Pinhais. ${ }^{154}$

Então o casamento de pardos nascidos livres com esposas escravas crioulas, ambos integrantes de uma mesma comunidade, somado ao estabelecimento da família junto da propriedade senhorial indicam veementemente a proximidade em termos das condições de vida e de sociabilidade entre esses setores pobres da população paulista. A penúria que configurava a vida de muitos pardos da capitania de São Paulo e que era subjacente às suas uniões foi limpidamente expressa em um auto de dispensa matrimonial relativo a um futuro miliciano, em 1807. Os noivos Rafael de Oliveira e Isabel Francisca da Conceição, moradores em Santana de Parnaíba, nascidos livres, requereram à câmara episcopal dispensa do impedimento de quarto grau de consanguinidade para que pudessem casar. Em seus testemunhos, quando perguntados “pelos teres e haveres dele e dela oradores", Rafael afirmou "que ele não tinha mais que a roupa do corpo e as suas lavouras, com que se alimenta e à sua mãe, e que a oradora nada tem, senão o que lhe dá a sua benfeitora" - uma senhora que se responsabilizou por Isabel quando esta ficou órfã. A noiva, por sua vez, “dos teres e haveres disse não ter ela nada, e que o orador só tem a sua agilidade". ${ }^{155}$ Não obstante as fórmulas inerentes a esses pedidos de dispensa, as quais

\footnotetext{
${ }^{152}$ Desses quatro milicianos, um foi localizado nas listas nominativas apenas quando estava casado pela segunda vez, então com mulher nascida livre. Cf:: Livro Mestre, fls. 231, 236v, 242v e 255; Maços de População, Atibaia: (1807) M.D., fogo 88; (1810) B.V., fogo 116; (1810) M.D., fogo 3; (1811) R.Ab., fogo 37; (1812) M.D.,I., fogos 11 e 114; (1815) M.D.,I., fogo s.n., 01402_080; (1815) R.Ab., fogo 136; (1818) I.,R.Ac., fogo 92; (1818) M.D.,B.V., fogos 27 e 28.

${ }^{153}$ BACELLAR, C. A. P. O matrimônio entre escravos e libertos..., p. 226.

${ }^{154}$ MACHADO, Cacilda da Silva. A Trama das Vontades..., p. 245.

${ }^{155}$ Cf.: Livro Mestre, fl. 332; ACMSP/DMC 3477, fls. 11, 13-14.
} 
tipicamente apelavam para a pobreza e vulnerabilidade das mulheres e para o potencial protetor e mantenedor dos homens, que também foram incorporadas a esse processo, o pauperismo do casal parece ser indiscutível. Vários casais formados por milicianos pardos requereram dispensa do pagamento das custas dos autos de dispensa e casamento pela razão de serem sumamente pobres. ${ }^{156}$ Provavelmente essa era também a situação do casal formado em 1822 pelo miliciano pardo Francisco Antonio de Santa Bárbara e a esposa Ana Maria Xavier, cuja liberdade estava em litígio. O vigário de Santana de Parnaíba observou que "neste estado, ou de cativeiro, foi vontade do contraído a receber por mulher". ${ }^{157}$ Francisco Antonio estava comprometido com Ana Maria, e nesses termos ele era indiferente à condição jurídica da esposa.

As coerções sociais, vigentes notadamente nas camadas mais elevadas, que atuavam impedindo o considerado envilecedor matrimônio de livres com escravos, não pareciam ter a última palavra ali, entre as pessoas menos favorecidas. Contudo, o grupo dos pardos era heterogêneo, e mesmo entre as pessoas mais ou menos próximas do cativeiro e de outras formas de dominação e alienação pessoal havia fortes anseios de distinção, os quais se manifestavam ora indiretamente e ora mais expressamente. Lourenço Miguel de Siqueira, futuro capitão pardo em Atibaia, estava tratado para se casar com uma escrava, em 1788, mas eles desfizeram o acordo e Lourenço acabou casando com uma mulher liberta ou livre naquele mesmo ano. ${ }^{158} \mathrm{~A}$ despeito do desconhecimento das causas desse desquite de compromisso, o que é certo é que o casamento efetivado consistiu em situação socialmente mais vantajosa a Lourenço.

Por outro lado, há as situações em que famílias inteiras se mobilizavam na tentativa de obstruir a celebração de matrimônios em função da desigualdade de condição ou qualidade existente entre os cônjuges. Apesar de raros, tais exemplos revelam que as alianças efetuadas por ocasião dos casamentos ultrapassavam a esfera dos noivos e afetavam o cerne das famílias, ciosas de sua posição social, por mais diminuta que fosse. Em 1807, estavam proclamados para se casar os pardos José de Lima e Custódia Maria, ele morador na freguesia Juqueri e ela na vila vizinha de Atibaia. No entanto, durante o tempo em que se processaram as três canônicas denunciações, em janeiro daquele ano, o pai do noivo, um “carijó forro" casado com uma exadministrada, se apresentou ao padre local e manifestou "não ser sua vontade casar-se seu filho com aquela mulher", que nascera em condição de plena liberdade. Como resultado, em meados de fevereiro, o promotor da câmara episcopal emitiu o seguinte despacho: "Não se pode deferir

\footnotetext{
${ }^{156}$ Ver, por exemplo, Livro Mestre, fls. 231, 334v, 338; ACMSP/DMC 3454; ACMSP/DMC 4662; ACMSP/DMC 5714.

${ }^{157}$ Cf.: Livro Mestre, fl. 330v; ACMSP/DMC 5140.

${ }^{158}$ Cf.: Livro Mestre, fls. 221, 222; L.C. Sé-SP nº 4, fl. 142; ACMSP/DMC 1831.
} 
a pretensão dos contraentes, porque o pai do contraente impede o casamento". Trata-se dos mesmos ideais presentes nas Ordenações Filipinas e que alicerçaram a Real Pragmática de Matrimonios espanhola três décadas atrás, ou seja, o respeito incontestável ao poder paterno e a seu zelo pela condução da família, componentes centrais da organização social de Antigo Regime. ${ }^{159}$ Mas a questão já havia sido resolvida localmente, pois o pai do miliciano pardo mudou sua opinião e retirou o impedimento, de modo que as núpcias ocorreram ainda em fevereiro. ${ }^{160}$

Em 1804, foi a vez de Isidoro Dias e Ângela, moradores de Santana de Parnaíba, sofrerem a tentativa de obstrução do matrimônio. Ele nascera na aldeia de Barueri, filho de um casal de índios, e a noiva era uma escrava crioula, natural da vila. Estando o processo em andamento, o vigário local foi abordado pela mãe de Isidoro, que tentou impedir seu prosseguimento, "participando-me não levava a bem o casamento dele com escrava, e que portanto não o proclamasse". O padre, contudo, contrariou o requerimento materno sob a alegação de que o contraente "há muitos anos se não acha debaixo de seu poder", era adulto, “vivia concubinado e já tinha dado princípio e feito despesa com os papéis da Dispensa". Finalmente, considerou impróprio que a mãe - que "suposto [índia] da freguesia de Barueri, constava ser filha de um escravo" - por sua qualidade tentasse impedir o casamento. E assim foi. O matrimônio foi celebrado em fevereiro daquele ano. ${ }^{161}$

É evidente que mesmo em meio à situação de calamitosa pobreza, havia uma enorme distância social entre escravos, libertos e livres. Mas, ainda assim, não se pode exagerar na avaliação da estima social desfrutada pelos pardos livres. Ora, de modo análogo aos milicianos, percebeu-se que as esposas pardas eram vítimas dos estigmas sociais. Restringindo-se a observação às cônjuges de soldados nascidas livres - excetuando-se as expostas e índias -, cinco mulheres foram identificadas como pardas libertas ou forras, uma como "liberta e bastarda escura" e doze como bastardas em Atibaia e Bragança; em Santana de Parnaíba, sete esposas nascidas livres foram referidas como pardas libertas ou forras quando se casaram. ${ }^{162}$ Não é preciso voltar a esse ponto, já discutido amplamente em páginas anteriores, bastando apenas sublinhar aquilo que vem sendo dito. A camada social dos pardos livres de São Paulo,

\footnotetext{
${ }^{159}$ HESPANHA, António Manuel. Carne de uma só carne: para uma compreensão dos fundamentos históricoantropológicos da família na época moderna. Análise Social, vol. 28 (123-124), p. 951-973, 1993. Para a análise de um caso semelhante, ver GUEDES, R. Egressos do cativeiro..., p. 89-91.

${ }^{160}$ Cf.: Livro Mestre, fl. 235v; L.C. Atibaia n ${ }^{\circ}$ 5, fls. 135v-136; ACMSP/DMC 3437, fls. 46 e 48.

${ }_{161}$ Cf.: Livro Mestre, fl. 339; L.C.E. Parnaíba, fls. 80v-81; ACMSP/DMC 2976, fl. 3.

162 ACMSP/DMC 2309, fl. 38; ACMSP/DMC 2996, fl. 38; L.C. Araçariguama 1818-1896, fl. 8v; L.C. Atibaia, $\mathrm{n}^{\circ}$ 5, fls. 17v, 55v, 72-72v, 101v, 124, 130 e 135v-136; L.C. Atibaia no 6, fls. 16-16v, 22, 23v-24, 28v, 29, 51, 89 e 92; L.C. Atibaia $n^{\circ}$ 7, fls. 23 e 35v; L.C. Bragança ${ }^{\circ}$ 2, fl. 241v; L.C. Bragança no 4, fl. 92v; L.C. Parnaíba 17901821 , fls. 28v, 39, 73v-74 e 144-144v; L.C. Parnaíba 1821-1864, fls. 8v e 23v.
} 
berço dos milicianos do Regimento dos Úteis, é tributária da intensa mestiçagem ocorrida em diferentes níveis entre negros, índios e brancos ao longo do século XVIII. Mais do que a questão biológica, revelada de antemão por fontes de natureza qualitativa e pelo exame à textura de cabelo dos milicianos, o interesse aqui foi direcionado para a origem social dos soldados pardos e para o encaminhamento que eles forneceram a esse grupo social mediante a escolha dos cônjuges e a decorrente reprodução do grupo. Nesse sentido, uns mais proximamente do que outros, o certo é que todos eles estavam vinculados à escravidão, à administração, às aldeias ou a todas essas realidades, e havia poderosos mecanismos sociais em funcionamento para expor essas raízes. Consequentemente, apesar de os milicianos, na maior parte, terem nascido em liberdade, o alcance dessa condição era constantemente relativizado - em função tanto do relacionamento com mulheres diretamente marcadas pela escravidão quanto pelos labéus imputados a essa população.

Em síntese, nesse exame à construção de famílias pardas e à decorrente reprodução do grupo, recuperou-se a importância dos laços matrimoniais na cultura de Antigo Regime no tocante ao estabelecimento de alianças entre as famílias envolvidas. Os casos de mobilização de familiares visando ao dissenso matrimonial, isto é, a impedir que um dos seus se unisse a uma pessoa considerada de condição ou qualidade inferior, ilustram bem esse aspecto. Mas eles são raros. Em geral, os casamentos propiciavam alianças e certa proximidade entre as famílias dos noivos. No caso dos pardos de São Paulo, a parceria e a cumplicidade entre os cônjuges giravam em torno, entre outros fatores, do auxílio mútuo voltado à sobrevivência. Um dado essencial é que a instituição do matrimônio era também uma imposição da Igreja e da Monarquia, e não por acaso, entre os milicianos pardos, os casados e viúvos predominavam em relação aos solteiros e aos aderentes a modelos familiares alternativos. Coube, então, investigar a condição das esposas desses milicianos em dois momentos de suas vidas: no batismo e no matrimônio, ou seja, logo após o nascimento e ao ingressarem na vida adulta. Constatou-se o amplo predomínio de nascidas livres entre as esposas dos milicianos pardos e a tendência de que os frutos dessas uniões viessem ao mundo sem vínculos diretos com a escravidão e a administração. Não obstante esse significativo aceno em direção à liberdade por parte do grupo social constituído pelos milicianos pardos, percebeu-se que na composição de suas famílias havia proporcionalmente mais mulheres nascidas em cativeiro do que homens, significando que vários homens nascidos em liberdade se casaram com mulheres nascidas em situação de escravidão. Porém, aproximando-se o foco, verificou-se que tais milicianos, na verdade, tinham origem social não muito diferente da de seus cônjuges, já que muitos dos seus pais e avós haviam vivido situações de alienação pessoal. Além disso, a maior parte dessas mulheres 
nascidas escravas havia conquistado a liberdade antes de se casarem com milicianos pardos. Os dados da amostra revelaram uma relevante diferenciação social existente entre oficiais e soldados pardos: embora tanto uns como outros tenham se casado com mulheres nascidas em cativeiro, apenas aqueles que ocupavam posições inferiores na hierarquia miliciana se uniram a mulheres que permaneceram escravizadas. Nesses casos, o contraente livre passava a residir com a esposa, tornando-se agregado de um senhor de escravos. Evidentemente, a proximidade com a escravidão e com a administração indígena era característica a todos esses homens e mulheres pardos, tanto livres como libertos e escravos, e a abrangência do emprego de estigmas sociais - tais como "forros", "libertos" e "bastardos" - em documentos públicos visava a consagrar a distância social existente entre brancos e pardos. 


\section{CAPÍtulo 5 - Condição socioeconômica dos milicianos Pardos de São Paulo: TRABALHO, RIQUEZA E POSSE DE ESCRAVOS}

A segunda metade do século XVIII representou para a capitania de São Paulo uma ruptura em relação aos dois séculos anteriores e inaugurou um quadro de profundas transformações, em boa medida já anunciado pelos descobrimentos de ouro e diamantes nos sertões da América portuguesa. Em todos os âmbitos, as mudanças se farão sentir. A população experimentará um crescimento significativo, o território paulista se expandirá e dará margem ao surgimento de novas vilas e povoações, toda a estrutura organizacional do Estado também se ampliará e refinará, dezenas de corpos militares serão criados e institucionalizados, o processo civilizador progressivamente transformará os hábitos, costumes, gostos e comportamentos dos paulistas, os vínculos entre seus habitantes e a Monarquia portuguesa se reforçarão. ${ }^{1}$ Essas tendências não são propriamente particularidades de São Paulo. Antes, se trata de transformações que acometem os vários pontos da América portuguesa e mesmo de boa parte do mundo colonial americano. Elas, no entanto, alterarão significativamente as bases sociais, administrativas, demográficas, econômicas e culturais sobre as quais os paulistas estavam até então apoiados, produzindo um nítido contraste entre um e outro período de sua história. De configuração social marginal ou periférica², São Paulo passará a se integrar mais proximamente ao centro político do Estado do Brasil, atuará decisivamente nos confrontos militares travados na região sulina e se conectará definitivamente à economia de mercado.

O âmbito da economia é um dos que melhor expressam a mutação vivida por São Paulo, e pode até ser considerado o seu carro-chefe. A agricultura destinada ao consumo interno e movida pelo trabalho indígena, que estava diretamente associada às expedições bandeirantes de apresamento e procura de ouro, características de fins do século XVI e inícios do XVIII, sofreu alterações a partir da descoberta dos metais preciosos em Minas Gerais, Goiás e Mato Grosso. Os centros mineradores demandaram suprimentos e São Paulo se converteu em um dos seus

\footnotetext{
${ }^{1}$ Sobre aspectos demográficos de São Paulo, ver MARCÍLIO, Maria Luiza. Crescimento demográfico e evolução agrária paulista: 1700-1836. São Paulo: Hucitec, Edusp, 2000; panoramas acerca da expansão territorial, formação de vilas e da evolução da estrutura administrativa em São Paulo em QUEIROZ, Suely Robles Reis de. São Paulo. Madrid: Editorial MAPFRE, 1992, p. 81-158 e SILVA, Maria Beatriz Nizza da (Org.). História de São Paulo colonial. São Paulo: Editora Unesp, 2009; sobre o processo civilizador em São Paulo entre os séculos XVII e XIX, ver SOUZA, Fernando Prestes de. Milicianos pardos em São Paulo. Cor, identidade e política (17651831). Dissertação (mestrado em História). Curitiba: SCHLA, Universidade Federal do Paraná, 2011, p. 14-31. 2 SCHWARTZ, Stuart B. Brasil colonial: plantaciones y periferias, 1580-1750. In: BETHELL, Leslie (Ed.). Historia de América Latina. (Vol. 3 - América Latina colonial: economía). Barcelona: Editorial Crítica, 1990, p. 229-236; LUNA, Francisco Vidal; KLEIN, Herbert S. Evolução da sociedade e economia escravista de São Paulo, de 1750 a 1850. São Paulo: EDUSP, 2006, p. 25-53.
} 
principais abastecedores durante os períodos intermediários do Setecentos, função que também assumiria em relação à cidade do Rio de Janeiro, transformada em capital do Estado do Brasil, em 1763, e Corte imperial em 1808.

De 1765 em diante, quando os sucessivos governadores aplicaram medidas de incentivo ao desenvolvimento econômico da capitania, na linha do renascimento agrícola planejado para o Brasil pela metrópole portuguesa, São Paulo já contava com uma acumulação de capital capaz de viabilizar investimentos de mais longo alcance e dispunha minimamente da infraestrutura necessária. Estava conectada com as regiões mineradoras através de caminhos e redes fluviais, com as localidades platinas através de seus portos marítimos e do caminho do Viamão e, finalmente, tinha no porto de Santos a principal zona de escoamento e comunicação com o Rio de Janeiro, com as cidades costeiras mais ao norte e à Europa. A crise mundial em termos da produção e distribuição do açúcar, desencadeada notadamente pela revolução de Saint Domingue, iniciada em 1791, favoreceu o ingresso de São Paulo nesse circuito, o qual estava diretamente associado ao tráfico transatlântico de escravos africanos que, afinal, fornecia os trabalhadores para as grandes fazendas e engenhos. Paralela e complementarmente, a economia paulista era dinamizada por um pujante setor agropecuário voltado ao consumo interno à capitania/província. ${ }^{3}$

Uma vez que a atividade militar não era habitualmente considerada como uma ocupação exclusiva e capaz de fornecer o sustento dos milicianos e de suas famílias, as questões que se colocam são: quais ocupações e atividades esses homens se dedicavam na maior parte do tempo? Qual a posição ocupada por soldados e oficiais pardos na cada vez mais próspera economia de São Paulo? Qual a capacidade desses homens, mais ou menos distanciados da escravidão, em competir pelo acesso a escravos? Em que medida as atividades ocupacionais e os diferenciais em termos de riqueza intervieram na conformação da estrutura de comando do Regimento dos Úteis?

\footnotetext{
${ }^{3}$ LUNA, F. V.; KLEIN, H. S. Evolução da sociedade e economia...; EISENBERG, Peter L. Homens Esquecidos: escravos e trabalhadores livres no Brasil - séculos XVIII e XIX. Campinas: Editora da UNICAMP, 1989, p. 317367.
} 


\subsection{Composição socioprofissional dos milicianos pardos de São Paulo}

O passo inicial é o exame da composição socioprofissional dos milicianos pardos de São Paulo. O Regimento dos Úteis era formado por 10 companhias e um estado-maior, devendo contar com 800 milicianos ativos entre oficiais e soldados. Porém, como era comum a todos os demais corpos militares, na prática seu contingente ativo oscilava. Uma amostragem mais abrangente, decorrente do levantamento dos dados referentes a todos os milicianos matriculados no Regimento durante o período de 1810 a 1831 e contidos no Livro Mestre ${ }^{4}$, fornece uma perspectiva que supera as constantes variações na composição da corporação e apreende um contingente mais elevado de integrantes em um período maior de tempo. Essa amostragem revela que 1.107 homens foram alistados, sendo que 220 desses milicianos ascenderam aos postos como oficiais inferiores ou oficiais de patente e os 887 restantes permaneceram na condição de soldados. Como uma corporação militar privativa a homens pardos, todos os postos das companhias eram providos em pessoas dessa cor ou condição social. No entanto, os postos do alto escalão hierárquico do Regimento - o estado-maior - foram ocupados hegemonicamente por homens brancos provenientes da tropa de linha e apenas de modo restrito providos em oficiais pardos.

Apesar de associado diretamente à sede do quartel militar na cidade de São Paulo, o Regimento dos pardos era composto por cinco companhias situadas na cidade e em freguesias rurais adjacentes e por mais cinco unidades localizadas em vilas do interior. Esse caráter disperso das companhias constitutivas do Regimento não era exclusividade dos Úteis, uma vez que se verificava em quase todos os demais regimentos milicianos paulistas. ${ }^{5}$ Ademais, o amplo espectro geográfico no qual se espraiava a corporação dotava-a de um caráter ao mesmo tempo urbano e rural, e esse aspecto se reflete diretamente na composição socioprofissional ${ }^{6}$ do Regimento dos Úteis.

\footnotetext{
${ }^{4} C f:$ : APESP, ordem C00446.

${ }^{5} C f:$ : APESP, ordem C00263. Ver os mapas da oficialidade dos regimentos de Sorocaba, Sertanejos e $1 .{ }^{\circ}$ e $2 .^{\circ} \mathrm{de}$ Infantaria da cidade de São Paulo, onde constam as sedes de suas companhias.

${ }^{6}$ No Livro Mestre se descrevia a atividade ocupacional dos milicianos listando apenas uma ocupação, tida como principal, e raramente se dava conta das alterações experimentadas pelos oficiais e soldados nesse âmbito particular. Considerando-se que os milicianos mudavam de ofício ou profissão com certa frequência e, principalmente, que exerciam diversas atividades, há algumas restrições associadas à natureza dos dados semelhantes às observadas por especialistas quanto às listas nominativas. Por outro lado, é digno de nota o fato de que a vasta maioria dos alistados declarou a atividade principal à qual se dedicava, de modo que a totalidade da corporação segue contemplada na amostra.
} 
TABELA 5.1 - Milicianos pardos por ofício e companhias, 1811-1831

\begin{tabular}{|c|c|c|c|c|c|c|c|c|c|c|c|c|}
\hline \multirow{2}{*}{ Ofícios } & \multirow{2}{*}{$\begin{array}{c}\text { Estado } \\
\text { maior }\end{array}$} & \multicolumn{10}{|c|}{ Companhias } & \multirow{2}{*}{ Total } \\
\hline & & Gran. & Caç. & $1 .^{\mathrm{a}}$ & $2 .^{a}$ & $3 .^{a}$ & Atib. & Jund. & Parn. & Itu & Soro. & \\
\hline Alfaiate & 1 & 14 & 13 & 18 & 21 & 17 & 12 & 7 & 6 & 14 & 6 & 129 \\
\hline Arrieiro & & 1 & 1 & & & & & 1 & & & & 3 \\
\hline Barbeiro & & & & & 2 & & & & & 1 & & 3 \\
\hline Cabeleireiro & & & & & 1 & & & & & & & 1 \\
\hline Camarada $^{\mathbf{a}}$ & & & & & & & & & 1 & & & 1 \\
\hline Cangalheiro & & & & & & & & 1 & & & & 1 \\
\hline Carniceiro & & & & & & & & & & & 1 & 1 \\
\hline Carpinteiro & 2 & 14 & 8 & 9 & 7 & 6 & 7 & 2 & 7 & 15 & 3 & 80 \\
\hline Carreiro & & & 3 & & & 1 & & & & & 1 & 5 \\
\hline Cirurgião & 1 & & & & & & & & & & & 1 \\
\hline Entalhador & & & & & & 1 & & & & & & 1 \\
\hline Ferreiro & & 3 & 1 & 2 & & 2 & 4 & 3 & 2 & 1 & & 18 \\
\hline Funileiro & & & & & & & & & 1 & & & 1 \\
\hline Imaginário & & & 2 & & & & & & & & & 2 \\
\hline Latoeiro & & 1 & & & & & & & 1 & & & 2 \\
\hline Lavrador & & 47 & 60 & 21 & 34 & 57 & 89 & 93 & 84 & 42 & 88 & 615 \\
\hline Madeireiro & & 1 & & & & & & & & & & 1 \\
\hline Marceneiro & 2 & 3 & 2 & 2 & 1 & 5 & & & & 1 & & 16 \\
\hline Músico & & & & 1 & & & & 1 & & 2 & & 4 \\
\hline Negociante & & 3 & & 3 & 1 & 2 & & 1 & 1 & 3 & 1 & 15 \\
\hline Oleiro & & & & & & & & & & 1 & & 1 \\
\hline Ourives & & 3 & & 3 & 6 & 3 & & 2 & & 6 & 8 & 31 \\
\hline Pedreiro & & 1 & & 1 & & & 1 & & & & & 3 \\
\hline Pescador & & & & & 1 & & & & & & & 1 \\
\hline Pintor & & 1 & 1 & 5 & & & & & & 1 & & 8 \\
\hline Relojoeiro & & & & 1 & & & & & & & & 1 \\
\hline Sapateiro & & 20 & 7 & 12 & 11 & 7 & 6 & 3 & 6 & 9 & 9 & 90 \\
\hline Seleiro & & 1 & 2 & 3 & 1 & 1 & 1 & & & & & 9 \\
\hline Sem ofício & & 2 & 0 & & & & & & 1 & & & 3 \\
\hline Serrador & & 0 & 3 & & & & 1 & & & & & 4 \\
\hline Tecelão & & 1 & 2 & & & & & & & & 1 & 4 \\
\hline Telheiro & & 2 & 0 & & 1 & & 1 & & & & & 4 \\
\hline Tropeiro & & 2 & 1 & 2 & 1 & & & 2 & 1 & 1 & & 10 \\
\hline Vive s. agências ${ }^{\mathbf{b}}$ & & 1 & 1 & & & & & & & & & 2 \\
\hline Não declarou & 11 & 1 & 7 & 3 & 4 & 1 & & 1 & 4 & 4 & & 36 \\
\hline Total & 17 & 122 & 114 & 86 & 92 & 103 & 122 & 117 & 115 & 101 & 118 & 1107 \\
\hline
\end{tabular}

${ }^{\text {a }}$ Camarada $=$ Camarada de tropas

${ }^{\text {b }}$ Vive s. agências = Vive de suas agências

Fonte: Livro Mestre. 
A Tabela 5.1 relaciona os milicianos pardos de acordo com as companhias às quais estavam inscritos e conforme as atividades ocupacionais a que se dedicavam. Essas atividades estão listadas conforme os termos originais mediante os quais foram referidas no Livro Mestre. Efetivamente, 406 milicianos pardos se dedicavam ao trabalho manual especializado ${ }^{7}$, o que equivale a 36,6\% de todos os integrantes daquela corporação. Apesar da importância do artesanato urbano, era no campo que se localizava a maior parte dos milicianos do Regimento. Os 615 homens descritos apenas como lavradores representavam 55,5\% do total de inscritos no Livro Mestre, o que leva a considerar o mundo rural como um pilar da instituição em questão. Para além de artesãos e lavradores, 47 milicianos, ou pouco mais de 4,2\% do total, declararam trabalhar em outras atividades. Dezesseis deles lidavam com a venda de bestas e muares e com serviço de transporte (tropeiros, camaradas de tropa e carreiros), 15 eram negociantes, 13 se ocupavam das artes liberais (música, pintura e cirurgia), dois viviam de suas agências e apenas um soldado se identificou como pescador. Para finalizar esse apanhado mais geral, se desconhece a ocupação de um contingente pouco expressivo de milicianos, os quais correspondem a cerca de 3,5\% da amostra: os três que declararam não ter ofício e ainda os 36 que não informaram nada a esse respeito. Portanto, a maioria dos oficiais e soldados pardos intercalava os treinamentos e serviços concernentes à vida militar ao trabalho em pequenas unidades agrícolas e em modestas oficinas artesanais - aspecto que reforça a natureza simultaneamente urbana e rural do Regimento.

A hegemonia dos agricultores entre os milicianos pardos está conforme aos padrões de distribuição dos domicílios na capitania de acordo com a principal atividade econômica desempenhada pelos chefes familiares, pois se estimou que 59\% dos domicílios paulistas dedicavam-se à lavoura no ano de 1798 e 75\% em 1829. ${ }^{8}$ Nas primeiras décadas do século XIX, São Paulo era uma configuração social marcadamente agrícola, como era, de resto, a quase totalidade das capitanias/províncias brasileiras. No entanto, a configuração socioprofissional do Regimento revela-se mais complexa quando se considera a divisão hierárquica do Regimento, simplificada pelo corte entre oficiais e soldados. ${ }^{9}$ A partir desses termos, vê-se que 589

\footnotetext{
${ }^{7}$ Alfaiates, arrieiros, barbeiros, cabeleireiro, cangalheiros, carniceiro, carpinteiros, entalhador, ferreiros, funileiro, imaginários, latoeiros, madeireiro, marceneiro, oleiro, ourives, pedreiros, relojoeiro, sapateiros, seleiros, serradores, tecelões e telheiros.

${ }^{8}$ RABELLO, Elisabeth Darwiche. Os ofícios mecânicos e artesanais em São Paulo na segunda metade do século XVIII. Revista de História, n. 55, v. 112, p. 575-588, 1977, p. 575; LUNA, F. V.; KLEIN, H. S. Evolução da sociedade e economia..., p. 24.

${ }^{9} \mathrm{O}$ conjunto dos oficiais inclui oficiais do estado-maior do Regimento (coronéis, tenentes-coronéis, sargentosmores, ajudantes, quartéis-mestres, secretários, cirurgião-mor e tambor-mor), oficiais de patente (capitães, tenentes e alferes) e oficiais inferiores (sargentos, furriéis, porta-bandeiras e cabos). O conjunto dos soldados inclui os próprios soldados além dos tambores, cornetas e pífanos.
} 
lavradores compunham uma maioria entre os soldados - a qual representava em torno de 66,5\% desse setor inferior da hierarquia miliciana e contrastava com os 252 artesãos, que correspondiam a $29 \%$ do conjunto dos soldados - mas não obtinham a mesma representatividade no segmento conformado pela oficialidade miliciana. Nesse outro setor, a dimensão dos lavradores encolheu, já que os 26 homens identificados aos trabalhos agrícolas perfaziam tão somente $12 \%$ dos oficiais, em nítida discrepância aos 154 milicianos artesãos ou oficiais mecânicos que representavam cerca de $70 \%$ dos oficiais investidos nas posições de autoridade e comando da corporação.

\section{FIGURA 5.1 - Proporções de ocupações entre soldados e oficiais pardos}

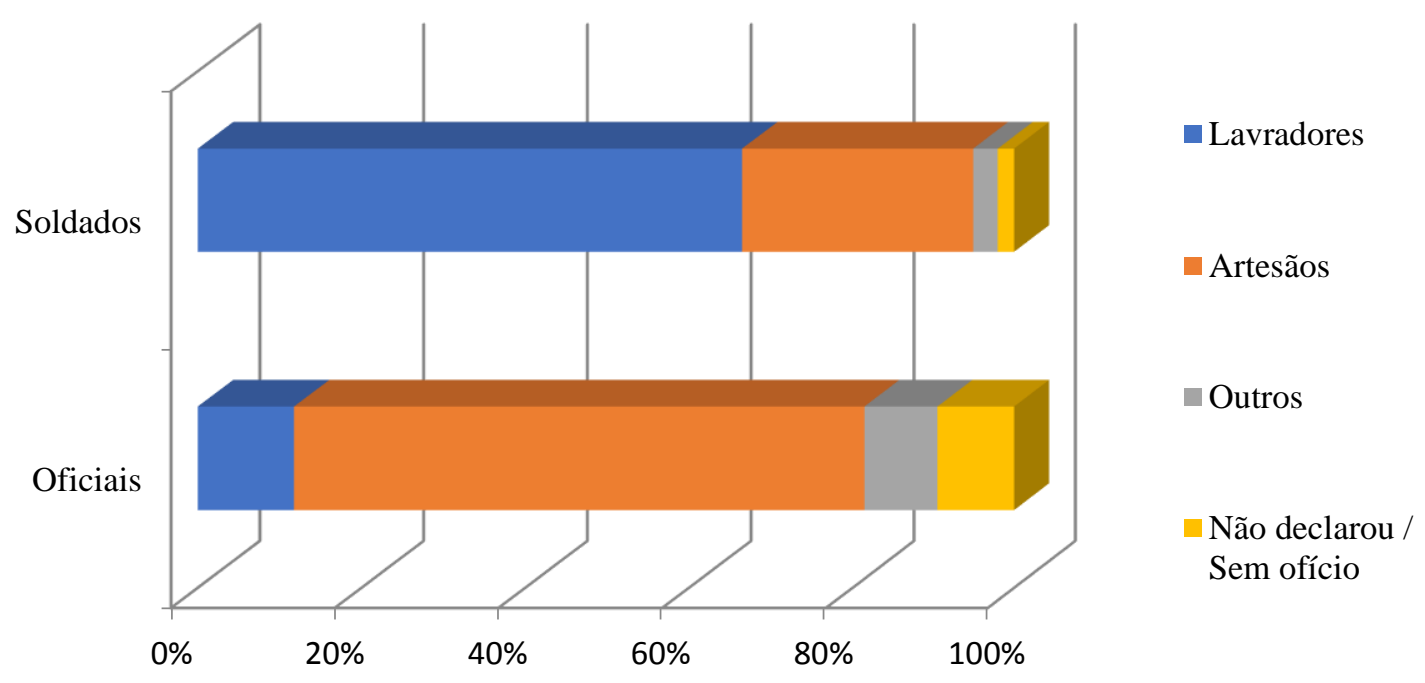

Fonte: Livro Mestre.

Sob tais parâmetros, pode-se dizer que o Regimento dos pardos estava estruturado no equilíbrio existente entre soldados-agricultores e oficiais-artesãos - como expressa visualmente a Figura 5.1. Enquanto o campo fornecia o grosso das fileiras de soldados, a maior concentração de poder interna ao Regimento estava associada aos ambientes urbanos - especialmente a cidade de São Paulo e imediações, onde residiam aproximadamente 63\% dos artesãos dos Úteis, mas também nos pequenos núcleos urbanizados das vilas interioranas, que abrigavam os $37 \%$ restantes. Em face de sua representatividade numérica e, mais notadamente, da sua importância em termos das relações de poder para a organização dos milicianos pardos, o setor artesanal merece um exame detalhado. Ele era constituído por um conjunto muito diversificado de 
atividades, as quais envolviam a produção, corte e costura de tecidos, o beneficiamento de couros, o corte de madeiras e sua transformação em casas, móveis e outros bens, a forja e moldagem de metais como o ferro e o ouro, o trabalho de dar forma ao barro e à argila, o serviço de corte de cabelos e barba e a prática de sangrias curativas.

As ocupações mais comuns entre os milicianos artesãos eram aquelas tipicamente reguladas em moldes corporativos pelas câmaras locais, tais como a alfaiataria, sapataria, carpintaria, ourivesaria, ferraria e marcenaria. Em ordem decrescente de representatividade, 129 oficiais e soldados pardos dedicavam-se ao ofício de alfaiate, 90 deles eram sapateiros, 80 carpinteiros, 31 ourives, 18 ferreiros, 16 marceneiros e 42 homens exerciam outras especialidades menos representativas numericamente. Essa distribuição dos ofícios artesanais conforme ordem de predomínio se reproduzia nos segmentos específicos dos soldados (soldados e músicos militares), oficiais inferiores (de cabo a sargento) e de patente (de alferes a coronel), alterando-se ligeiramente apenas no caso dos ourives e marceneiros, que ganham maior expressão entre a oficialidade: 51 oficiais milicianos eram alfaiates, 29 sapateiros, 24 ourives, 23 carpinteiros e 15 marceneiros, sendo que 12 trabalhavam em outros ofícios mecânicos.

Os números em questão revelam uma primazia de alfaiates, sapateiros e carpinteiros no conjunto dos artesãos pardos integrados à milícia e estão exatamente de acordo com o que sugere a historiografia: desde fins do século XVIII os homens pardos dominavam estes segmentos do artesanato na cidade de São Paulo e nas localidades essencialmente rurais. ${ }^{10}$ Eles estavam bem distribuídos entre soldados e oficiais. Por outro lado, nota-se que a ourivesaria e marcenaria eram especialidades típicas da oficialidade miliciana, uma vez que, dos 31 ourives pertencentes à corporação, 24 eram oficiais, e 15 dos 16 marceneiros também o eram. Esses dados sugerem que determinados ofícios artesanais eram mais valorizados que outros e desse modo tendiam a elevar grande parte de seus executores pardos aos postos de prestígio e autoridade na milícia. Não obstante essa peculiaridade dos ourives e marceneiros, nenhum deles chegou ao prestigiado posto de capitão, tipicamente ocupado por alfaiates e alguns comerciantes e agricultores.

\footnotetext{
${ }^{10}$ FLEXOR, M. H. O. Ofícios, manufaturas e comércio. In: SZMRECSÁNYI, T. (Org.). História econômica do período colonial. (2. ed.). São Paulo: Hucitec, 2002, p. 179-180; RABELLO, E. D. Os ofícios mecânicos e artesanais..., p. 587; RABELLO, E. D. A cidade de São Paulo e sua estrutura profissional: 1804-1825. In: COSTA, I. del N. da. Brasil: História econômica de demográfica. São Paulo: USP; FEA/IPE, 1986, p. 223-244; LUNA, F. V.; KLEIN, H. S. Evolução da sociedade e economia..., p. 223-245.
} 


\section{TABELA 5.2 - Artesãos de diferentes ofícios pertencentes ao Regimento dos Úteis (1810-1831) e habitantes da província de São Paulo (1836)}

\begin{tabular}{|c|c|c|c|c|c|c|c|c|}
\hline \multirow[b]{2}{*}{ OFÍCIOS } & \multirow[b]{2}{*}{ AMOSTRAS } & \multicolumn{6}{|c|}{ LOCALIDADES } & \multirow[b]{2}{*}{ TOTAL } \\
\hline & & Cidade & $\begin{array}{l}\text { Atibaia e } \\
\text { Bragança }\end{array}$ & Jundiaí & Parnaíba & Itu & Sorocaba & \\
\hline \multirow{2}{*}{ Alfaiate } & Úteis & 82 & 12 & 7 & 6 & 14 & 6 & 127 \\
\hline & 1836 & 51 & 15 & 5 & 7 & 22 & 4 & 104 \\
\hline \multirow{2}{*}{ Carpinteiro } & Úteis & 46 & 7 & 2 & 7 & 15 & 3 & 80 \\
\hline & 1836 & 79 & 55 & 14 & 14 & 44 & 16 & 222 \\
\hline \multirow{2}{*}{ Ferreiro } & Úteis & 8 & 4 & 3 & 2 & 1 & 0 & 18 \\
\hline & 1836 & 58 & 13 & 6 & 3 & 1 & 16 & 97 \\
\hline \multirow{2}{*}{ Marceneiro } & Úteis & 15 & 0 & 0 & 0 & 1 & 0 & 16 \\
\hline & 1836 & 28 & 0 & 0 & 0 & 6 & 3 & 37 \\
\hline \multirow{2}{*}{ Ourives } & Úteis & 15 & 0 & 2 & 0 & 6 & 8 & 31 \\
\hline & 1836 & 30 & 1 & 1 & 0 & 10 & 26 & 68 \\
\hline \multirow{2}{*}{ Sapateiro } & Úteis & 57 & 6 & 3 & 6 & 9 & 9 & 90 \\
\hline & 1836 & 71 & 43 & 20 & 6 & 21 & 15 & 176 \\
\hline
\end{tabular}

Fonte: Livro Mestre; MÜLLER, Daniel Pedro (Org.). Ensaio d'um Quadro Estatístico da Província de São Paulo. São Paulo: Reedição Literal Secção de Obras d'O Estado de São Paulo, 1923, p. 241-244.

A significativa participação dos milicianos pardos no mundo do trabalho artesanal da capitania/província de São Paulo fica evidente ao se cotejar os dados do Livro Mestre com os números do recenseamento de 1836 (Tabela 5.2). Esse procedimento fornece uma perspectiva aproximada, não obstante as restrições decorrentes da natureza distinta dos dados. ${ }^{11}$ Ao longo do período compreendido pelos anos de 1810 e 1831, havia 129 milicianos pardos trabalhando como alfaiates na cidade de São Paulo e nas vilas interioranas que serviam de quartel a companhias do Regimento dos Úteis. No ano de 1836, nessas mesmas localidades, 104 homens se dedicavam a esse ofício. Esses números nos informam, indiretamente, que os milicianos pardos sobressaíam nesse ramo específico, quase que monopolizando o seu exercício. É certo que nem todos os alfaiates de 1836 eram ex-milicianos pardos. Uma parcela desses homens deve ter abandonado o ofício, uns por falecerem e outros por trocarem de profissão, e decerto havia alguns homens brancos e pretos exercendo a ocupação em questão. Contudo, presume-se que muitos dos antigos milicianos pardos permaneceram na alfaiataria após a desmobilização dos corpos milicianos, bem como se aventa que eles introduziram filhos e demais aprendizes

\footnotetext{
${ }^{11} \mathrm{O}$ Livro Mestre registrou milicianos pardos que atuaram em ocupações artesanais em algum momento situado entre os anos 1810 e 1831 ou por todo esse período. Já os números fornecidos por Müller dizem respeito aos artesãos de toda a província de São Paulo, mas se referem exclusivamente ao ano de 1836. Para tornar possível a comparação entre os dados, da lista de 1836 foram selecionadas apenas as localidades que correspondiam às já antigas companhias do Regimento dos Úteis.
} 
nessa atividade especializada. Embora não estivesse entre as mais rentáveis atividades econômicas do Brasil escravista, a confecção de roupas sob medida fornecia aos trabalhadores uma condição de vida no mínimo modesta, capaz de distingui-los em meio à massa de pardos livres e libertos. De fato, a formação de clientelas compostas por pessoas de posses somada ao atendimento ao lucrativo setor de confecção de fardas e uniformes militares contribuiu decisivamente para a elevação de vários alfaiates ao topo da hierarquia dos milicianos pardos.

A participação dos milicianos pardos no conjunto dos demais ofícios artesanais listados foi bastante significativa, mesmo que não tenha atingido os níveis semimonopolistas da alfaiataria. Não é exagero afirmar que boa parte dos carpinteiros, ferreiros, marceneiros, ourives e sapateiros atuantes na capitania/província durante a primeira metade do Oitocentos eram pardos vinculados ao Regimento dos Úteis.

Resta examinar a composição socioprofissional dos demais corpos milicianos de São Paulo e colocar em perspectiva o caso dos pardos. Ao iniciar o século XIX, São Paulo contava com 11 regimentos milicianos distribuídos por boa parte de seu território e encarregados de auxiliar a reduzida tropa de linha ali existente. Oito deles eram corpos militares de infantaria ou artilharia e apenas três de cavalaria. À exceção do Regimento dos Úteis, formado por pardos livres, todos os demais eram identificados como corporações de homens brancos. ${ }^{12}$ Entendendo-se ser suficiente restringir a comparação aos regimentos, depois denominados batalhões, de infantaria ou artilharia, um retrato da composição profissional dos oficiais milicianos de São Paulo, entre os anos 1826-1830, segue na Tabela 5.3.

No quesito profissão, o Regimento dos Úteis, então denominado 34. ${ }^{\circ}$ Batalhão, amplificava a sua peculiaridade, previamente estabelecida por ser o único composto por homens pardos, em comparação com os demais regimentos milicianos de São Paulo. Oficiais pertencentes aos batalhões fincados em zonas comerciais expressivas, como eram os portos marítimos de Santos e Paranaguá e o animado mercado de gado situado na vila de Sorocaba, eram recrutados predominantemente entre a classe mercantil. Trata-se de homens abonados, extremamente influentes na dinâmica local e conectados a circuitos comerciais de longo alcance. Mas, nessas mesmas localidades, a camada mais próspera do setor agrícola também se fazia presente na oficialidade miliciana com importância destacada. Nas vilas tipicamente voltadas para a produção comercial do açúcar, situadas no Vale do Paraíba e no Oeste Paulista, senhores de engenho exerceram amplo domínio sobre os principais postos milicianos e

\footnotetext{
${ }^{12}$ Cf:: CABRAL, J. A. T. A estatística da imperial província de São Paulo. [1827]. Tomo I. São Paulo: EDUSP,
} 2009, p. 123-126. 
deixaram pouco espaço para comerciantes ou funcionários públicos. ${ }^{13}$ Já na cidade de São Paulo, e particularmente nos dois batalhões identificados a homens brancos, a distribuição dos postos da oficialidade de acordo com a atividade ocupacional contou com relativo equilíbrio entre agricultores e comerciantes.

TABELA 5.3 - Oficiais milicianos por batalhão e área profissional (1826-1830)

\begin{tabular}{cccccccc}
\hline Batalhão & Quartel & Agricultor & $\begin{array}{c}\text { Comerciante } \\
\text { ou negociante }\end{array}$ & $\begin{array}{c}\text { Oficial } \\
\text { mecânico }\end{array}$ & Outros & $\begin{array}{c}\text { Não } \\
\text { declarado }\end{array}$ & TOTAL \\
\hline $32 .^{\circ}$ & São Paulo & $39,5 \%$ & $30,5 \%$ & $6 \%$ & $10,5 \%$ & $13,5 \%$ & $100 \%$ \\
& & $(26)$ & $(20)$ & $(4)$ & $(7)$ & $(9)$ & $(66)$ \\
$33 .^{\circ}$ & São Paulo & $26 \%$ & $34,5 \%$ & $14 \%$ & $22,5 \%$ & $3,5 \%$ & $100,5 \%$ \\
& & $(15)$ & $(20)$ & $(8)$ & $(13)$ & $(2)$ & $(58)$ \\
$34 .^{\circ}$ & São Paulo & $8 \%$ & $9,5 \%$ & $65 \%$ & $16 \%$ & $1,5 \%$ & $100 \%$ \\
& & $(5)$ & $(6)$ & $(41)$ & $(10)$ & $(1)$ & $(63)$ \\
$35 .^{\circ}$ & Itu & $54 \%$ & $19 \%$ & & $23 \%$ & $4 \%$ & $100 \%$ \\
& & $(26)$ & $(9)$ & & $(11)$ & $(2)$ & $(48)$ \\
$36 .^{\circ}$ & Sorocaba & $33,5 \%$ & $37 \%$ & $7 \%$ & $17,5 \%$ & $5 \%$ & $100 \%$ \\
& & $(19)$ & $(21)$ & $(4)$ & $(10)$ & $(3)$ & $(57)$ \\
$37 .^{\circ}$ & Cunha & $57,5 \%$ & $18,5 \%$ & $2,5 \%$ & $14,5 \%$ & $6,5 \%$ & $99,5 \%$ \\
$38 .^{\circ}$ & \multirow{2}{*}{ Santos } & $(43)$ & $(14)$ & $(2)$ & $(11)$ & $(5)$ & $(75)$ \\
& & $35 \%$ & $41,5 \%$ & $12,5 \%$ & $11 \%$ & & $100 \%$ \\
$39 .^{\circ}$ & Paranaguá & $(23)$ & $(27)$ & $(8)$ & $(7)$ & & $(65)$ \\
& & $(22)$ & $42,5 \%$ & $7 \%$ & $10 \%$ & $3,5 \%$ & $100 \%$ \\
& & $(25)$ & $(4)$ & $(6)$ & $(2)$ & $(59)$ \\
\hline
\end{tabular}

Fonte: Mapas semestrais da oficialidade miliciana dos Batalhões N. ${ }^{\circ} 32,33,34,35,36,37,38$ e 39 , respectivamente, em APESP (ordens e datas): C02364 (31/12/1830); C02365 (30/06/1829); C02366 (01/07/1828); C02367 (01/07/1826); C02369 (31/12/1826); C02371 (01/07/1829); C02372 (31/12/1828) e C02375 (01/01/1830).

A realidade do Regimento dos Úteis, o $34 .^{\circ}$ Batalhão, era deveras distinta dos demais. Com efeito, nenhum outro batalhão miliciano possuía a sua predominância característica de artesãos ou trabalhadores manuais na oficialidade. Em 1828, 65\% dos oficiais do batalhão dos pardos eram artesãos e o batalhão que mais se aproximou desse perfil, o $33 .^{\circ}$, contava em seus postos mais elevados com apenas $14 \%$ de artesãos. Em sentido contrário, a oficialidade de todos os mais batalhões era composta por agricultores e comerciantes de porte elevado, muitos dos quais associavam seus negócios privados e os postos na milícia aos cargos que ocupavam na governança de suas vilas e da capitania/província. De modo que em quase todos aqueles corpos

\footnotetext{
13 Também apontam nessa direção os dados coligidos por Déborah Reis nas listas nominativas referentes à vila de Jundiaí no período em questão. REIS, D. O. M.. Cinturão Paulistano: economia e demografia..., p. 198-200.
} 
milicianos a expectativa dos artesãos ascenderem aos postos de comando era extremamente reduzida.

Muito além do retrato circunscrito a São Paulo, exposto acima, o acúmulo de dados empíricos atesta que a qualidade mecânica da oficialidade miliciana era aspecto recorrente, no tempo e no espaço, a várias corporações congêneres de pardos e pretos. Ora, as informações fragmentárias relativas à oficialidade das companhias avulsas de pardos atuantes na capitania de São Paulo durante o século XVIII já indicam a presença constante, se não predominante, de sapateiros e alfaiates em postos de comando. ${ }^{14}$ Em iguais circunstâncias estariam boa parte dos oficiais das milícias de pardos e pretos de outras configurações sociais do Estado do Brasil, como se tem demonstrado para os casos de Salvador, na Bahia, e Recife e Olinda, em Pernambuco. ${ }^{15}$ A preponderância de artesãos em meio a oficiais e soldados de cor também foi constatada em espaços hispano-americanos, a exemplo de Santiago, no Chile, Cartagena de Índias, em Nova Granada, Havana, em Cuba, e em diferentes localidades da Nova Espanha, tais como a Cidade do México, Puebla, Zacatecas, Patzcuaro, Valladolid e Orizaba. ${ }^{16}$

\footnotetext{
${ }^{14} C f$ : Listas gerais dos moradores da capitania de São Paulo, referentes ao ano 1772. AHU, códice 2098, doc. 168; AHU, códice 2105.

${ }^{15}$ KRAAY, Hendrik. Política racial, Estado e Forças Armadas na época da independência: Bahia, 1790-1850. Trad. Magda Lopes. São Paulo: Hucitec, 2011, p. 142-154; SILVA, Luiz Geraldo. Aspirações barrocas e radicalismo ilustrado. Raça e nação em Pernambuco no tempo da independência (1817-1823). In: JANCSÓ, István (Org.). Independência: história e historiografia. São Paulo: Hucitec, 2005, p. 915-934.

${ }^{16}$ MÚNERA, A. El fracaso de la nación. Región, clase y raza en el Caribe colombiano (1717-1821). Bogotá: Planeta Colombiana, 2008; SOLANO D., Sergio Paolo; BOLÍVAR, Roicer Flórez. "Artilleros pardos y morenos artistas": artesanos, raza, milicias y reconocimiento social en el Nuevo Reino de Granada, 1770-1812. Historia critica, Bogotá, n. 48, p. 11-37, sep./dic. 2012; SOLANO D., Sergio Paolo. Las vías para la inclusión social. Artesanos, raza, Estado y liberalismo en el Caribe colombiano, 1770-1850. Del Caribe, Santiago de Cuba, n. 59, p. 23-41, 2013; CRUCES, H. C. Oficios, milicias y cofradías. Éxito económico, prestigio y redes sociales afromestizas en Santiago de Chile, 1780-1820. Revista de Historia Social y de las Mentalidades, Santiago de Chile, v. 17, n. 2, 2013, p. 43-74; DELGADO, María del Refugio M. Artesanos en armas. Del gremio de oficios a las milicias en Zacatecas, 1758-1820. In: TOLEDO, S. P.; GRIJALVA, M .M.; PEÑAFLORES, R. A. (Coords.). El mundo del trabajo urbano. Trabajadores, cultura y prácticas laborales. Zacatecas; México D.F.: Universidad Autónoma de Zacatecas; El Colegio de México, 2012, p. 127-165; VINSON III, Ben. Bearing Arms for his majesty: the free-colored militia in Colonial Mexico. Standford, California: Standford University Press, 2001, p. 103-122. Quanto a alguns corpos milicianos mexicanos formados por homens de cor nos quais os artesãos tinham representatividade mínima, Vinson III esclarece que não se tratou de imposição de desprestígio ou preterição aos artesãos. Antes, o fenômeno se deve à total rarefação desses ofícios nas localidades que abrigavam os corpos militares. KUETHE, Allan J. Cuba, 1753-1815: Crown, military, and society. Knoxville: The University of Tennessee Press, 1986, p. 74. Apesar de não mencionar o grau de participação dos artesãos na oficialidade e entre os soldados do Batalhão de Pardos de Cuba y Bayamo, entranhado na parte oriental da ilha de Cuba, José L. Belmonte Postigo revela a importância do setor agropecuário entre esses milicianos. Ao lado de modestos camponeses, milicianos pardos dedicavam-se à produção de tabaco e açúcar em fazendas com seus próprios escravos. O autor frisa a diferença na configuração socioeconômica entre as cidades de Havana e Santiago de Cuba, uma como grande centro comercial atlântico e outra atrelada mais diretamente à produção agrícola, o que é lido aqui como um aspecto fundamental na diferenciação entre as respectivas oficialidades milicianas de cor. BELMONTE POSTIGO, José Luís. El color de los fusiles. Las milicias de pardos en Santiago de Cuba en los albores de la Revolución Haitiana. In: CHUST, Manuel; MARCHENA, Juan (Eds.). Las armas de la nación. Independencia y ciudadanía en Hispanoamérica (1750-1850). Madrid: Iberoamericana/Vervuert, 2007, p. 37-51.
} 
Em Havana, na capitania geral de Cuba, tanto a oficialidade do batalhão de pardos como a do batalhão de morenos estavam completamente abarrotadas de artesãos entre os anos 1760 e 1810. É o que revelam as folhas de serviço de seus capitães, tenentes, subtenentes e sargentos em três períodos: entre os anos 1760 e 1769, os artesãos representavam 88\% da oficialidade dos morenos e $90 \%$ da dos pardos; sua participação chegou às incríveis cifras de $95 \%$ entre os morenos e de $100 \%$ entre oficiais pardos na década de 1790; finalmente, entre 1800 e 1810 eles perfizeram $95 \%$ e $85 \%$ entre morenos e pardos, respectivamente. ${ }^{17}$ Lamentavelmente, documentação análoga referente aos corpos militares cubanos formados por homens brancos não informa os ofícios ou profissões no campo “cualidad”, como ocorreu no caso de pardos e morenos. ${ }^{18}$ Assim mesmo, pode-se afirmar com segurança que em Cuba as dificuldades eram consideravelmente maiores para que os trabalhadores manuais pudessem penetrar a oficialidade nos batalhões e regimentos identificados aos brancos. De modo especialmente sugestivo, carpinteiros, alfaiates e sapateiros eram, de longe, os ofícios mais comuns entre oficiais milicianos pardos e morenos cubanos, assim como ocorria entre os milicianos pardos de São Paulo.

Portanto, é altamente significativo que, por intermédio da relação entre milícia e trabalho, os homens pardos de São Paulo apresentassem maiores semelhanças a seus pares de diferentes configurações sociais, que aos oficiais milicianos brancos, seus conterrâneos, de qualquer dos 10 regimentos existentes em sua própria configuração social. Esse padrão, que tende a aglutinar elementos complexos da vida social dos sujeitos em questão ao trio de categorias pardos livres, oficiais milicianos e artesãos, certamente está relacionado a aspectos estruturais das sociedades ibero-americanas. Parte da explicação repousa nas origens sociais e na conformação dos grupos sociais de pardos e de pretos, livres e libertos, nas sociedades coloniais e escravistas luso e hispano-americanas. A origem humilde, no mais das vezes associada a um passado escravo, pesava substantivamente ao conferir moderadas chances de sucesso material e estima social a essas pessoas. Elas, em geral, herdavam de seus pais pouquíssimos bens materiais comparativamente às famílias brancas bem estabelecidas. Exceto uns poucos indivíduos favorecidos por pais naturais ricos e alguns cuja prosperidade adquirida ao longo da vida os distinguiu de seus pares, a vasta maioria dos pardos e pretos sofria em condições marcadas pela pobreza e por isso movia seus maiores esforços numa luta cotidiana pela sobrevivência. A herança da escravidão, que fazia com que a vasta maioria dos libertos e

\footnotetext{
${ }^{17} C f:$ : Archivo General de Indias - Sevilla (AGI), Santo Domingo, legajos 1225 e 2093; AGI, Cuba, legajos 1491A, 1770 e 1770B; Archivo General de Simancas - Valladolid (AGS), Guerra Moderna, legajos 7259 e 7262. ${ }^{18}$ Cf:: AGI, Cuba, legajo 1771B; AGS, Guerra Moderna, legajos 7262 e 7265.
} 
seus descendentes começassem a vida livre ou adulta com níveis reduzidos de riqueza, impunha a eles poderosas limitações à obtenção de terras, escravos ou crédito necessários para o investimento na agricultura comercial, em negócios de maior vulto ou em atividades rentistas.

Para essas pessoas, naturalmente expelidas dos setores mais rentáveis da economia, os ofícios especializados do ramo artesanal figuravam entre as melhores oportunidades disponíveis de obtenção de estabilidade social e econômica. Diferentemente das configurações sociais escravistas dos Estados Unidos, onde a dura e desigual competição com os brancos tornava rarefeitas as oportunidades de as pessoas livres de cor se inserirem no mercado $\operatorname{artesanal}^{19}$, nas sociedades ibero-americanas, com seus centros urbanos em expansão, os libertos e seus descendentes encontravam nichos específicos para exercerem os ofícios mecânicos. A percepção acerca do trabalho - e notadamente do trabalho manual - como atividade desonrosa, que provinha da antiguidade e que persistiu na mentalidade ocidental por todo o tempo em que serviu para distinguir os nobres da plebe, obteve nessas sociedades escravistas um novo vigor. São inúmeros os cronistas que atestam o pejo que homens brancos e até mesmo mulatos tinham em empregar-se em tais ofícios, ainda que estivessem longe de ostentar quaisquer graus de nobreza. As autoridades do governo ou membros da burocracia colonial viam o fenômeno com certa preocupação, uma vez que, numa terra destinada à produção, inúmeros homens com forças e capacidade se tornavam ociosos em virtude das coerções sociais por distinção. Mas certamente os descendentes de africanos e de indígenas, como era o caso dos pardos forros e livres, tinham menos condições do que os brancos para recusar oportunidades de trabalho. Por isso, ainda que fosse notória a presença de homens brancos entre os artesãos qualificados, não há dúvidas de que o preconceito em torno do trabalho manual catalisou a absorção de pardos e pretos, livres, libertos ou escravos, em diversas especialidades dos ofícios mecânicos.

Para resumir a situação dos milicianos-pardos-artesãos, os pardos livres de São Paulo encontravam no artesanato possibilidades de enraizamento social e um meio estável de prover o sustento familiar. Com alguma frequência, eles articularam esse heterogêneo ramo ocupacional e o pequeno comércio, e somente em raros casos de ascensão e de estabilidade financeira o artesanato foi substituído por outro ramo de atividade. Assim como seus pares residentes nas mais diversas localidades escravistas hispano e luso americanas, eles chegaram a dominar determinados ofícios mecânicos e fizeram com que o exercício destes ofícios qualificados alçasse parte de seus executores aos principais postos da milícia. Para que se tenha

${ }^{19}$ PATTERSON, Orlando. Escravidão e morte social. São Paulo: Edusp, 2008, p. 358-359, 365-366. 
uma visão mais completa sobre a condição socioprofissional desses homens, é preciso ainda examinar duas variáveis ou fenômenos sociais relacionados ao mundo do trabalho: a mudança ou diversidade ocupacional dos milicianos em relação à ocupação discriminada no Livro Mestre e a posse de escravos.

\subsection{Diversidade ocupacional, mudança de ofício e riqueza}

Ao cotejar o Livro Mestre e os recenseamentos paulistas, fica claro o fenômeno da mudança ou diversidade ocupacional. Inúmeros milicianos foram identificados permanentemente no exercício das mesmas atividades profissionais mencionadas em seus registros militares, denotando estabilidade nas condições sociais e econômicas. Entretanto, uma parcela significativa de oficiais e soldados surgiu nas listas nominativas associada a mais de um ofício ou alternando atividades ao longo dos anos. Trata-se de um aspecto congruente à sociedade colonial e escravista, de base agropecuária, na qual a elevada complexificação das funções sociais e a segmentação do processo produtivo não eram a regra. Os mesmos indivíduos que se dedicavam à lavoura também pescavam, caçavam e criavam animais. Construíam casas e benfeitorias, podiam trabalhar no transporte de cargas e de pessoas e também dominar os fundamentos básicos de artes, como a música e pintura, e dos ofícios mecânicos. Os artesãos fincados no mundo urbano eventualmente aproveitavam o espaço de suas oficinas e lojas para comerciar secos, molhados e produtos mais associados às tabernas. $\mathrm{O}$ grau de envolvimento e dedicação a cada uma das múltiplas tarefas desempenhadas podia mudar no decorrer dos anos e se refletir nas anotações dos recenseadores. Além disso, deve-se sempre recordar que a origem social dos milicianos pardos impunha-lhes sérias limitações à conquista de sucesso material, de modo que as mudanças ou variações de atividade profissional certamente se relacionam, a um só tempo, à instabilidade social e econômica imposta a esse grupo e à ânsia de seus indivíduos em melhorarem suas condições de vida.

Um fenômeno tipicamente vivenciado por oficiais pardos diz respeito ao convívio entre oficinas artesanais e pequenos estabelecimentos comerciais. ${ }^{20}$ Os casos de oficiais da $2 .^{\text {a }}$

\footnotetext{
${ }^{20}$ Para um exame dos diferentes tipos de estabelecimentos comerciais existentes na cidade de São Paulo na primeira metade do século XIX, seus proprietários, produtos e demais características, ver ARAÚJO, Maria Lucília Viveiros. Lojas e armazéns das casas de morada paulistas. Revista de História, 160 (1 semestre de 2009), 285322.
} 
Companhia de Fuzileiros, aquartelada na cidade de São Paulo, o ilustram perfeitamente. José Inácio de Loiola, capitão, foi matriculado no Regimento como alfaiate. Na lista nominativa de 1804 ele se manteve no ofício, passou a ter negócio de venda em 1808, voltou a ser associado à alfaiataria em 1811 e, três anos depois, suas ocupações eram "alfaiate e negócio de venda". ${ }^{21}$ Já Francisco de Paula e Oliveira, tenente dessa companhia, era reconhecido como sapateiro no assento da milícia. Na lista de 1802, ele vivia de "tecer panos e venda de efeitos da terra", e deve ter sido introduzido nos mistérios da sapataria por esses mesmos anos, ofício que exercia em 1804, 1808, 1811 e 1818. Na lista de 1822 ele apareceu dedicando-se a uma "venda", e, em 1825 , as suas atividades foram descritas como "negócio de venda e sapateiro". ${ }^{22} \mathrm{O}$ também tenente da companhia, Pedro Antonio Ferreira, foi inscrito como alfaiate, mas nas listas as suas ocupações eram "negócio de venda", em 1808, e "negócio de molhados", em 1811. ${ }^{23}$ Manoel

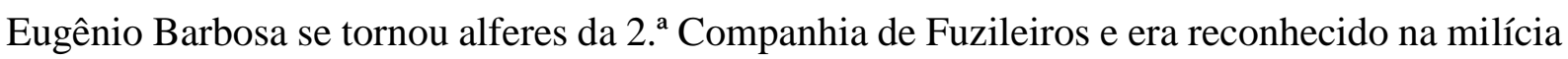
como ourives. Entretanto, em 1811, quando era sargento, ele tinha "negócio de molhados". Após ascender a alferes, ele passou a estar sempre associado à ourivesaria, como se vê nas listagens de 1818, 1822 e $1825 .^{24}$ Finalmente, o alferes Joaquim José Teodoro vivia de "seus negócios" de venda, em Atibaia, entre os anos 1811 e 1814. Ao mudar-se para a cidade de São Paulo, progrediu na hierarquia, aprendeu o ofício de alfaiate e assumiu definitivamente essa ocupação - conforme as listas de 1825 e $1836 .{ }^{25}$

Componente característico dos milicianos de cor, o trabalho mecânico não era atributo da oficialidade miliciana branca, como visto anteriormente. É presumível, então, que os oficiais pardos de São Paulo se dedicassem à produção artesanal e paralelamente aos negócios de venda não apenas como forma de ampliar a receita familiar, mas como resposta às coerções sociais impostas pela disparidade existente entre a posição ocupada no universo do trabalho e o desempenho das funções sociais de honra e prestígio na milícia. A pressão social se encaminhava no sentido de os oficiais milicianos abandonarem o trabalho manual a fim de se dedicarem exclusivamente a atividades menos comprometedoras socialmente, a exemplo o

\footnotetext{
${ }^{21}$ Cf:: Livro Mestre, fl. 139; Maços de População, Capital: (1804) 1. ${ }^{a}$, Rua da Quitanda, fogo 205; (1808) 2. ${ }^{a}$, fogo 105; (1811) 1. a , fogo s.n. entre 319-320; (1814) 2. a , Rua do Piques, fogo 257 e (1814) 1. a , Jogo da Bola, fogo 6.

${ }^{22}$ Cf.: Livro Mestre, fl. 140; Maços de População, Capital: (1802) 1. a , fogo 286; (1804) 1. a , fogo 334; (1808) 1.a, fogo 388; (1811) 2. a, Piques, fogo 172; (1818) 1. a , Rua do Príncipe, fogo 16; (1822) 7. a, Rua do Hospital, fogo 13.114; (1825) 7. a, S.Ef., fogo 51.

${ }^{23}$ Cf:: Livro Mestre, fls. 58-58v, 140; Maços de População, Capital: (1808) 1. a, fogo 251; (1811) 1. a, fogo 337; (1818) 6. ${ }^{a}$, Pátio de São Francisco e Casa Santa, fogo 10; (1825) 6. ${ }^{a}$, Jogo da Bola, fogo 10 (estava ausente).

${ }^{24}$ Cf:: Livro Mestre, fl. 141; Maços de População, Capital: (1811) 1. a, fogo 321; (1818) 1. ${ }^{a}$, Rua do Comércio, fogo 10; (1822) 1. a , Rua do Príncipe, fogo 6.111; (1825) 1. a, Rua do Comércio, fogo 13.

${ }^{25}$ Cf:: Livro Mestre, fls. 141, 142v, 143, 225; Maços de População, Atibaia: (1810) Vila, fogo 14; (1811) V.,C.,C., fogo 15; (1813) V.,C.,C., fogo 49; (1814) V.,C.,C., fogo 40; Capital: (1825) 7. , S.Ef., fogo 69; (1836) Sé D.S., 4. ${ }^{\circ}$ Quarteirão, fogo 12.
} 
comércio. Todavia, poucos milicianos pardos conseguiram completar essa transição das atividades ocupacionais. Vários artesãos que chegaram a acenar para essa mudança, ao deixarem de ser reconhecidos como oficiais mecânicos e ao assumirem a função de comerciantes nas listas nominativas, não mantiveram a nova posição por muito tempo. Em geral, nos anos imediatamente seguintes, eles voltavam a ser associados ao artesanato e ao comércio.

Ademais, não havia uma relação direta entre a mudança de atividade ocupacional e a ascensão nos postos da milícia, como se depreende dos exemplos acima. Os poucos oficiais que se desvencilharam do artesanato somente o fizeram quando suas posições no topo da hierarquia já estavam consolidadas. Sem abandonarem os ofícios especializados, o capitão e alfaiate José Inácio de Loiola e o tenente e sapateiro Francisco de Paula e Oliveira aparentemente conciliaram as lojas artesanais a pequenos empreendimentos comerciais. Já os alferes Manoel Eugênio Barbosa e Joaquim José Teodoro apostaram no sentido inverso: trocaram seus "negócios" de venda e de molhados pelo exercício de atividades artesanais, o que não os impediu de ocuparem postos de patente na milícia e de se manterem em tais posições de honra e prestígio. Nota-se, pois, que, a despeito da pressão social externa, que denunciava a incompatibilidade dos ofícios mecânicos com a nobreza das patentes milicianas, o sistema de promoções interno aos corpos milicianos de pardos e de pretos valorizava ou, no limite, era indiferente, à vinculação de seus integrantes ao artesanato.

Deslocando a observação para a outra ponta da hierarquia miliciana, entre os soldados que foram referidos genericamente como lavradores no Livro Mestre se constata uma diversidade de ocupações coexistentes, substitutas ou melhor definidas nas listas de população. A maior parte desses lavradores plantava "para o seu sustento", "para o seu passar" e "para comer". Vários deles eram registrados como lavradores em algumas listas e em outras informava-se que viviam "de suas agências", como "jornaleiro" ou "de jornais", uns poucos de "lavrar madeira" e alguns foram ocasionalmente notados como "pobres". São tantas as famílias que viveram essas circunstâncias que referenciá-las extensivamente, conforme foram rastreadas nas inúmeras e seriadas listas nominativas, seria um trabalho árduo e de pouca utilidade. ${ }^{26}$

\footnotetext{
${ }^{26}$ Cf:: Livro Mestre. As listas consultadas estão guardadas no APESP, no fundo Maços de População, e correspondem às seguintes localidades e a companhias de ordenança: Atibaia (anos 1798 a 1831), Bragança (anos 1798 a 1830), Capital (Companhias da Capital, Freguesia do Ó, Nossa Senhora da Penha, Santana, Santa Efigênia, Sé Distrito Norte, Sé Distrito Sul - anos 1798 a 1836, conforme o caso), Cotia (anos 1798 a 1829), Guarulhos (1807, 1815 e 1822), Itu (1801, 1803, 1809, 1813, 1815, 1818, 1822, 1825, 1830), Jundiaí (1808, 1811, 1813, 1822, 1824 e 1829), Juqueri (1807, 1811, 1813 e 1818), Santana de Parnaíba (1806, 1812, 1816, 1822 e 1828), Santo Amaro (1813, 1814, 1818), Sorocaba (1807, 1816-1817, 1818, 1823).
} 
As condições de vida desses pobres agricultores, que faziam de tudo um pouco para sobreviver, em parte eram semelhantes e compartilhadas por todos, como uma herança persistente da marginalização social imposta ao grupo desde suas raízes, e em parte obtinham contornos específicos de acordo com as localidades em que viviam. Milicianos provenientes de famílias radicadas em aldeias e mesmo das que se mantinham em sua órbita comumente eram registrados na milícia como lavradores e nos recenseamentos como louceiros. ${ }^{27}$ Essa era, efetivamente, uma especialidade dos indígenas, e chegou a causar boa impressão em um viajante inglês que conheceu os produtos: "Nos arredores da cidade, vive certo número de índios crioulos, que fabricam louça de barro para a cozinha, grandes jarros para água e uma variedade de outros utensílios, ornamentados com algum gosto". ${ }^{28}$ Embora fosse frequente a associação entre a fabricação de louças, imagens e utensílios de barro e o cultivo de pequenas roças, a pobreza local incitava os moradores das aldeias a ampliarem o leque de ocupações. $\mathrm{O}$ soldado Manoel José, da aldeia de Pinheiros, que foi matriculado como lavrador, foi referido em ocupações diferentes nas três vezes em que foi localizado nas listas nominativas: fazia louça em 1814, lavrava madeira em 1818, e era trabalhador jornaleiro em $1822 .{ }^{29}$ Morador da mesma aldeia e igualmente registrado como lavrador na milícia dos pardos, o soldado Joaquim José Aranha fazia louça em 1814, era ourives em 1818, trabalhava como condutor de carros em 1822 e beneficiava couros em $1825 .{ }^{30}$ Por sua vez, o soldado pardo José Plácido, residente em Embu, figurava como sapateiro no Livro Mestre, jornaleiro nas listas de 1822 e 1825, oleiro em 1823, camarada de tropas em 1827 e músico em $1829 .{ }^{31}$ A troca constante de ocupação ou a mudança periódica de ênfase entre as múltiplas atividades desempenhadas por esses homens indica que eles realmente viviam em condições de instabilidade econômica e por isso se viam forçados a procurar as melhores oportunidades. Nesse esforço, eles revelaram enorme versatilidade profissional.

\footnotetext{
${ }^{27}$ Ver, por exemplo, os soldados Manoel do Espírito Santo, Antonio João, Camilo Soares e Joaquim da Cunha, da freguesia de Penha e aldeia de São Miguel, e Salvador Dias, morador na freguesia da Cotia e imediações da aldeia de Embu. Livro Mestre, fls. 204v, 205, 206v, 207v, 208; APESP, Maços de População, Capital: Penha de França e São Miguel, (1808) fogo s.n. 03405_199; (1811) fogos 206, 212 e 216; (1815) fogos 174, 192 e 196-197; (1817) fogos 172 e 193; (1818) fogos 160, 164, 174 e 178; (1822) fogos 159 e 175; (1825) fogos 154 , 156 e 162; (1829) fogo 121; Cotia: (1814) 2. ${ }^{\mathrm{a}}$, fogo 89; (1815) 2. ${ }^{\mathrm{a}}$, fogo 87; (1816) 2. ${ }^{\mathrm{a}}$, fogo 85; (1817) 2..$^{\mathrm{a}}$, fogo 81; (1818) 2. ${ }^{\mathrm{a}}$, fogo 78; (1827) 3. $.^{\mathrm{a}}, 3 .^{\mathrm{a}}$ esq., b. Cotia.

${ }^{28}$ MAWE, John. Viagens ao interior do Brasil. Trad. Selena Benevides Viana. Belo Horizonte: Ed. Itatiaia; São Paulo: EDUSP, 1978, p. 64.

${ }^{29}$ Cf:: Livro Mestre, fl. 35v; Maços de População, Capital: (1814) 2. ${ }^{a}$, fogo 462; (1818) 8. ${ }^{a}$, fogo 90; (1822) 8. ${ }^{a}$, fogo 93.

${ }^{30}$ Cf:: Livro Mestre, fl. 157; Maços de População, Capital: (1814) 2. ${ }^{a}$, fogo 461; (1818) 8. ${ }^{a}$, fogo 100; (1822) 8. ${ }^{a}$, fogo 100; (1825) 8. a, fogo 15.

${ }^{31}$ Cf:: Livro Mestre, fl. 132; Maços de População, Cotia: (1822) 1. ${ }^{\mathrm{a}}$, fogo 133; (1823) 1. ${ }^{\mathrm{a}}$, fogo 163; (1825) 1. ${ }^{\mathrm{a}}$, Embu, fogo 100; (1827) 1. ${ }^{\text {a }}$, fogo 141; (1829) 1. ${ }^{\mathrm{a}}$, fogo 142.
} 
Havia também milicianos pardos que se dedicaram tanto à agricultura como a ofícios mecânicos. Joaquim José dos Santos, morador no bairro de Santana, foi inscrito como lavrador, mas na lista que compreende os anos de 1820 a 1823 foi notado como sapateiro e, em 1827 , recebeu a descrição "sapateiro e planta para comer". ${ }^{32}$ Já João de Crasto, da freguesia da Penha de França, era conhecido na milícia como sapateiro e essa especialização foi de fato registrada nas listas nominativas de 1807, 1808 e 1811. Contudo, em 1815, 1817 e 1818 ele mudou para roceiro, e, em 1822, para pescador. ${ }^{33}$ Os casos desses dois milicianos, que viviam e trabalhavam em localidades rurais das cercanias da cidade de São Paulo, retratam a inviabilidade de manterem o ofício artesanal em caráter de exclusividade nessas regiões relativamente afastadas dos núcleos urbanos, onde se situavam os centros comerciais e as oficinas concorrentes. João de Crasto se obrigou a desistir do ofício e Joaquim José dos Santos teve que conciliar o trabalho de sapateiro com a roça, que ao menos garantia a alimentação da família. Nesse aspecto, há um corte evidente entre a realidade mais próspera dos oficiais milicianos, residentes nos espaços urbanos, que eventualmente associavam o artesanato a pequenas vendas, e os soldados do campo e das aldeias, que em tudo trabalhavam para sobreviver.

Em todas as vilas e freguesias alcançadas pelos tentáculos do Regimento dos Úteis havia milicianos registrados como lavradores mas que também prestavam serviço de transporte de cargas em geral com seus próprios carros de bois. Nas localidades mais intensamente envolvidas com a organização das tropas, um número maior de milicianos pardos deixava as pequenas roças aos cuidados da família e partia para longas viagens como camaradas de tropa. Vários milicianos da vila de Jundiaí trabalhavam nos caminhos de Minas Gerais e Goiás e mais do que uma dezena de soldados de Santana de Parnaíba percorriam de tempos em tempos o caminho de Santos. ${ }^{34}$ Esses homens transportavam desde os pequenos excedentes agrícolas

\footnotetext{
${ }^{32}$ Cf:: Livro Mestre, fl. 22; Maços de População, Capital: Santana (1820-1823) fogo 30; (1827) fogo 30.

${ }^{33}$ Cf:: Livro Mestre, fl. 110; Maços de População, Capital: Penha e São Miguel (1808) fogo s.n. 03405_175; (1811) fogo 22; (1815) fogo 9; (1817) fogo 8; (1818) fogo 8; (1822) fogo 4.

${ }^{34}$ Cf:: Livro Mestre, fls. 274v, 275, 277, 278, 279v, 280, 281v, 282v, 283v, 285, 285v, 287v, 288, 293v, 315, 322, $322 v, 324,325 v, 328 v, 329 v, 331,333 v, 334,334 v, 335 v, 336 v$ e 338; Maços de População, Jundiaí: (1808) 1. a , R.Ab., fogo 66; (1811) 1. ${ }^{a}$, fogos 136 e 275; (1811) 2. ${ }^{a}$, fogo 31; (1811) 3. ${ }^{a}$, fogos 71, 105, 111 e 133; (1813) 1. ${ }^{a}$,

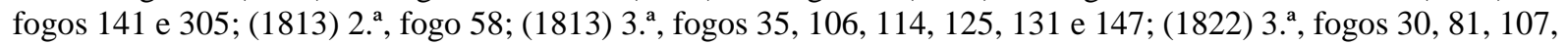
131 e 143; (1824) 2..$^{a}$, fogos 35, 66 e 78; (1829) 3. ${ }^{a}$, fogo 46; Maços de População, Parnaíba: (1806) $1 .^{\mathrm{a}}$, fogos 111 e 116; (1806) 4. a , fogo 95; (1812) 1. a , fogo 116, 128, 137, 138 e 195; (1812) 2..$^{\text {, }}$, fogo 89; (1816) 1. ${ }^{\mathrm{a}}$, fogos 139, 146, 148 e 150; (1816) 2. ${ }^{\mathrm{a}}$, fogo 85; (1816) 3. ${ }^{\mathrm{a}}$, fogo 41; (1816) 4. ${ }^{\mathrm{a}}$, fogos 44, 74 e 77; (1822) 2. ${ }^{\mathrm{a}}$, fogos $69,86 \mathrm{e}$

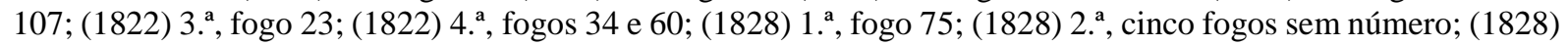
3. ${ }^{\text {, }}$, dois fogos sem número; (1828) 4. a , fogos 106, 109 e 111; ACMSP/DMC 5714, fl. 9v. Embora os dados acessados nesta pesquisa concernentes às vilas de Itu e Sorocaba, provenientes das listas nominativas de habitantes, não se refiram extensamente à vinculação dos milicianos pardos ao setor do transporte e mais especificamente como camaradas de tropa, é lícito supor que eles ocupavam esses nichos nas primeiras décadas do século XIX. Tais localidades necessitavam de trabalhadores para o escoamento do açúcar, no caso de Itu, e para a condução das tropas que afluíam ao mercado de Sorocaba. Bacellar constatou o descompasso entre o profundo envolvimento da população sorocabana com o comércio de animais e a escassez de referências a tais atividades nas listas
} 
locais, muitos dos quais direcionados ao abastecimento da cidade de São Paulo, até o grosso da produção agrícola destinada à exportação e enviada ao porto de Santos, para daí regressarem com cargas de sal e de produtos importados da Europa. Eles também participavam da condução de tropas de muares e de produtos diversos ao longo do caminho do Sul bem como transportavam às capitanias/províncias interioranas parte da produção agropecuária local, os animais comercializados em Sorocaba e as importações desembarcadas no litoral. ${ }^{35}$

Para completar um apanhado razoável das ocupações dos milicianos pardos, resta mencionar os quinze homens registrados no Livro Mestre como negociantes e recordar dos vários oficiais mecânicos que, de modo intermitente, também se dedicavam ao comércio. Não há informação abundante relativa ao que se vendia, às dimensões dos empreendimentos e ao lucro neles auferido. ${ }^{36}$ No entanto, vários indícios dispersos sugerem se tratar de modestas lojas e armazéns. Entre eles está o fato de que uma parcela significativa das vendas compartilhava o espaço de lojas de sapateiros e alfaiates. A referência mais comum a esses comerciantes, nas listas de população, associava-os ao "negócio de molhados", isto é, comercialização de alimentos importados ou beneficiados localmente, e vai no mesmo sentido. Seu potencial de investimento comercial estava muito distante do dos comerciantes de grosso trato e eles não possuíam inúmeras características típicas do grupo mercantil mais elevado, como o serviço de caixeiros, a prática de arrematação de contratos e valor avultado de bens. Como adverte M. B. Nizza da Silva, é preciso ter em vista que as listas nominativas - e pode-se acrescentar os

nominativas. Ele sugeriu que o principal motivo para isso se relaciona à natureza dos recenseamentos, que estava imbuída de inspiração fisiocrática, e por isso tendia a destacar a produção agropecuária e não o seu transporte. BACELLAR, Carlos de Almeida Prado. Viver e sobreviver em uma vila colonial..., p. 26-28. Por outro lado, o naturalista francês A. de Saint-Hilaire atestou que muitos dos camaradas de tropa da vila de Itu eram mulatos, o que vem ao encontro dos dados referentes à Jundiaí e Santana de Parnaíba. Ele associou o exercício dessa ocupação a uma suposta escassez de casamentos entre os mulatos - algo que vai em sentido contrário aos dados reunidos para outras vilas da região e atinentes exclusivamente aos milicianos. Sua narrativa detalhada acerca da atividade dos camaradas de tropa e a organização das viagens em SAINT-HILAIRE, A. de. Viagem à província de São Paulo. Belo Horizonte: Ed. Itatiaia; São Paulo: Ed. da Universidade de São Paulo, 1976, p. 106, 117, 132-133.

${ }^{35}$ LUNA, F. V.; KLEIN, H. S. Evolução da sociedade e economia..., p. 234. Para uma análise ampla do mercado de animais em Sorocaba e sobre o papel das mulas para o funcionamento da economia regional no século XIX, ver KLEIN, Herbert S. A oferta de muares no Brasil central: o mercado de Sorocaba, 1825-1880. Estudos econômicos, São Paulo, v. 19, $\mathrm{n}^{\circ}$ 2, p. 347-372, maio/ago. 1989. Um exame aos tropeiros em termos de seu potencial de reprodução ou contestação das relações de dominação vigentes na sociedade escravista em FRANCO, M. S. de C. Homens livres na ordem escravocrata. $4^{a}$ ed. São Paulo: Fundação Editora da UNESP, 1997, p. 65114.

${ }^{36}$ Maria L. V. Araújo examinou os estabelecimentos comerciais da capital e atestou a dificuldade em precisar genericamente as suas características, já que se vendia de tudo em lojas pertencentes tanto a pessoas mais aquinhoadas como a segmentos economicamente mais modestos e nem sempre se seguia à risca as divisões funcionais entre importador, distribuidor, atacadista, varejista, comerciantes de grosso trato, de fazendas secas, de molhados e simples taberneiros. ARAÚJO, Maria Lucília Viveiros. Lojas e armazéns das casas de morada paulistas... 
registros da milícia - não distinguiam entre simples vendeiros e negociantes matriculados na Real Junta do Comércio. ${ }^{37}$

Ainda assim, alguns desses milicianos, e sobretudo entre os que faziam parte do corpo da oficialidade, conseguiam se destacar de seus pares através de seus negócios. O coronel Manoel José Ribeiro foi um dos poucos milicianos pardos da cidade de São Paulo que efetuou a transição entre o artesanato e o comércio. Até a década de 1790 ele era conhecido como alfaiate, mas de 1802 em diante as listas nominativas informavam que ele vivia de "negócio de fazenda seca que traz do Rio de Janeiro". Ribeiro, além disso, estava entre os raros milicianos pardos que comercializavam fazenda seca - todos, aliás, oficiais de patente egressos do artesanato - mas se diferenciava deles pela estabilidade de seu empreendimento e por ser o único pardo cuja vinculação direta à praça comercial do Rio de Janeiro fora explicitada. ${ }^{38}$

A despeito do fato de que vários milicianos pardos trabalhavam com tropas de animais, como condutores, arrieiros, seleiros e camaradas, pouquíssimos puderam investir no ramo dos negócios com muares. O capitão da 3. ${ }^{a}$ Companhia de Fuzileiros, Joaquim Manoel Gomes, matriculado no Livro Mestre como lavrador e assim permanecendo nas listas concernentes ao período de 1804 a 1825, em realidade vivia numa chácara situada na freguesia de Nossa Senhora do Ó e pertencente a Francisco Pinto do Rego e fez dela espaço de lavoura e de criação de animais de tropa para a venda. A avaliação de seus bens, levada a efeito em 1843 por ocasião de seu inventário, computou oito escravos, 39 cabeças de gado entre vacas e crias, 10 mulas de carga e 17 cavalares entre crias, animais adultos e velhos, além de chácaras, utensílios de cobre, ferro e prata, roupas e móveis. Anteriormente, ele já havia transmitido a dois de seus filhos, em dote, um total de três escravos, 30 éguas e 12 bestas - cujo valor certamente era superior ao dos bens possuídos pela maior parte dos milicianos pardos. ${ }^{39}$ Seu irmão, o sargento pardo Domiciano Zacarias, também tinha negócios de tropa. Em seu testamento, lavrado em 1841, declarou possuir, "além de vários móveis e trastes", uma "fazenda com duas casas de morada [...], cuja fazenda contém em si para mais de 200 cabeças de gado vacum, além de 200 éguas mais ou menos, das quais metade pertence ao coronel Antonio da Silva Prado, conforme a

\footnotetext{
${ }^{37}$ SILVA, Maria B. Nizza da (Org.). História de São Paulo colonial..., p. 190-197.

${ }^{38}$ Cf:: Livro Mestre, fl. 1-1v; Maços de População, Capital: Rua do Rosário (1794) 1. a , fogo 254; (1795) 1. a , fogo 237; (1797) 1. a , fogo 89; (1798) 1. , fogo s.n; (1802) 1. ${ }^{\mathrm{a}}$, fogo 139; (1804) 1. a , fogo 140; (1805) 1.a, fogo 127; (1807) 1. a, fogo 137; (1808) 1. , fogo 134; (1809) 1. , fogo 29; (1810) 1. a, fogo 105; (1811) 1. a, fogo 118; (1813)

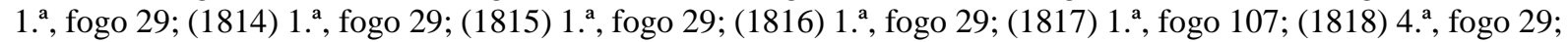
(1822) 4. ${ }^{a}$, fogo 29; (1836) Sé D.N., 5. ${ }^{\circ}$ Quarteirão, fogo 31; para os demais oficiais pardos, ver Livro Mestre, fls. $263,344,345,346,347$ e 349v.

${ }^{39}$ Cf.: Livro Mestre, fl. 180; Maços de População, N.S.Ó: (1804) fogo 33; (1805) fogo 19; (1808) fogo 53; (1810) fogo 78; (1814) fogo 123; (1818) fogo 108; (1822) fogo 93; (1825) fogo 123; (1829) fogo 99; (1836) 3. ${ }^{\circ}$ Quarteirão, fogo 14; TJESP, 2. ${ }^{a}$ Vara da Família, processo $n^{\circ} 1369$, ano 1843.
} 
sociedade que nelas formamos". Domiciano advertiu, porém, que "o casco da fazenda é somente meu", e afirmou ser proprietário de 16 pessoas escravizadas, entre adultos e crianças. ${ }^{40}$ Mesmo sem computar o valor desses bens e sem descontar as dívidas, os bens adquiridos e administrados por esses milicianos pardos atestam que eles seguramente se destacavam economicamente entre seus pares.

A posição ocupada pelos milicianos pardos em meio à próspera economia paulista, entre finais do século XVIII e a primeira metade do XIX, pode ser avaliada em função do valor dos bens acumulados informados em tabulações relativas à carreira, comportamento e demais dados pessoais dos integrantes da oficialidade miliciana que eram enviadas semestralmente ao governo. ${ }^{41}$ Embora, por uma série de razões, esses dados não mereçam demasiada confiança, eles fornecem uma certa noção da rentabilidade dos diferentes ofícios, da relação entre atividade ocupacional, acúmulo de bens e capital e a conformação da hierarquia miliciana. ${ }^{42}$ Eles se referem exclusivamente à oficialidade miliciana dos três batalhões de infantaria aquartelados na cidade de São Paulo - o 32..$^{\circ}$ e o $33 .^{\circ}$, integrados por brancos, e o $34 .^{\circ}$, que era o antigo Regimento dos Úteis - e se restringem ao período de 1828 a 1830. Presume-se que o corpo de oficiais, tomado em bloco, represente o setor mais bem-sucedido em termos socioeconômicos dos regimentos ou batalhões. A tabela 5.4 permite observar o papel desempenhado pela variável riqueza na estruturação da hierarquia bem como comparar diferentes batalhões milicianos acerca desse aspecto.

\footnotetext{
${ }^{40}$ Cf.: Livro Mestre, fls. 18v, 306v; Maços de População, Capital: N.S.Ó (1804) fogo 33; (1805) fogo 19; (1808) fogo 53; (1810) fogo 81; (1814) fogo 123; (1818) fogo 108; (1822) fogo 93; (1825) fogo 123; (1829) fogo 99; TJESP, $1 .^{\mathrm{a}}$ Vara da Família, processo $\mathrm{n}^{\circ} 1381$, ano 1841.

${ }^{41}$ Durante a pesquisa, não foram localizados modelos para a confecção desses Mapas Semestrais e tampouco foram identificados os critérios empregados para o preenchimento do item "bens que possui".

${ }^{42} \mathrm{Em}$ face da prática comum de o Estado requerer contribuições pecuniárias junto às pessoas mais abastadas da capitania/província e aos oficiais militares, é de se supor que os milicianos pardos, como os demais oficiais brancos, evitassem declarar o valor exato de seus bens. Por outro lado, os valores informados nos mapas semestrais da oficialidade miliciana parda não variaram no período de 1828 a 1830, de modo que tais informações parecem resultar de exames ou declarações não mais que superficiais e genéricos. Entretanto, como essas informações eram registradas em documentos públicos, os milicianos que porventura informassem valores muito inferiores aos reais podiam obter contestações quanto à sua capacidade e independência para manterem-se em suas posições por parte de concorrentes aos postos. Vale também lembrar que as modalidades de participação política desde o Primeiro Reinado eram estruturadas a partir de critérios censitários. Havia pressões em todos os sentidos. Embora seja impossível saber se os valores informados correspondiam de fato ao valor dos bens acumulados pelos milicianos, o que é certo é que, com o registro formal desses dados nos relatórios da milícia, eles assumiam publicamente a condição material declarada.
} 
TABELA 5.4 - Riqueza de oficiais milicianos de diferentes batalhões (São Paulo, 1828-1830)

\begin{tabular}{|c|c|c|c|c|c|c|c|}
\hline \multirow[b]{2}{*}{$\begin{array}{l}\text { Valor dos Bens } \\
\text { (em réis) }\end{array}$} & \multicolumn{2}{|c|}{ Batalhão 32} & \multicolumn{2}{|c|}{ Batalhão 33} & \multicolumn{2}{|c|}{ Batalhão 34} & \multirow[b]{2}{*}{ Total } \\
\hline & $\begin{array}{c}\text { Of. } \\
\text { Patente }\end{array}$ & $\begin{array}{l}\text { Baixa } \\
\text { Of. }\end{array}$ & $\begin{array}{c}\text { Of. } \\
\text { Patente }\end{array}$ & $\begin{array}{l}\text { Baixa } \\
\text { Of. }\end{array}$ & $\begin{array}{c}\text { Of. } \\
\text { Patente }\end{array}$ & $\begin{array}{l}\text { Baixa } \\
\text { Of. }\end{array}$ & \\
\hline Inferior a $100 \$ 000$ & & & & & 1 & 2 & 3 \\
\hline $100 \$$ a $499 \$$ & & 8 & 1 & 3 & 8 & 10 & 30 \\
\hline $500 \$$ a $999 \$$ & & 4 & & 1 & 7 & 4 & 16 \\
\hline $1: 000 \$$ a $1: 999 \$$ & & 9 & 6 & 5 & 5 & 1 & 26 \\
\hline 2:000\$ a 4:999\$ & 4 & 3 & 17 & 4 & 2 & & 30 \\
\hline 5:000\$ a 9:999\$ & 10 & & 4 & 1 & 1 & & 16 \\
\hline Superior a 10:000\$ & 6 & & & & 1 & & 7 \\
\hline Totais & 20 & 24 & 28 & 14 & 25 & 17 & 128 \\
\hline Total por batalhão & \multicolumn{2}{|c|}{44} & \multicolumn{2}{|c|}{42} & \multicolumn{2}{|c|}{42} & \\
\hline Média de Riqueza & \multicolumn{2}{|c|}{$7: 295 \$ 454$} & \multicolumn{2}{|c|}{$2: 461 \$ 904$} & \multicolumn{2}{|c|}{$1: 022 \$ 00$} & \\
\hline
\end{tabular}

Fonte: Mapas semestrais da oficialidade miliciana dos Batalhões N. ${ }^{\circ} 32,33$ e 34, respectivamente, em APESP (ordens e datas): C02364 (31/12/1830); C02365 (30/06/1829); C02366 (01/07/1828).

Complementarmente ao que foi examinado em relação à ocupação dos oficiais milicianos, tanto o critério da distribuição dos oficiais dos três batalhões em faixas de riqueza quanto o cálculo da média de riqueza que cabia a cada integrante contabilizado indicam uma rígida hierarquização desses corpos militares. O $32 .^{\circ}$ Batalhão era o velho $1 .^{\circ}$ Regimento de Infantaria Miliciana, o mais antigo de São Paulo e aquele que incorporava algumas das figuras mais proeminentes da sociedade paulista. Os seus oficiais de patente eram os mais ricos milicianos dos três batalhões em tela e esse aspecto fica evidente pela elevada média de riqueza, consideravelmente superior a dos demais batalhões considerados. Os cinco oficiais mais abastados dessa corporação eram negociantes e possuíam valor em bens estimado, em ordem crescente, em 16:000\$000 réis, 24:000\$000 réis, 25:000\$000 réis, 50:000\$000 réis e 60:000\$000 réis. Daí para baixo, negociantes de fazendas e lavradores se dividiam entre os oficiais com maiores posses. Já o Batalhão n. ${ }^{\circ} 33$, o antigo $2 .^{\circ}$ Regimento de Infantaria, ocupava posição intermediária no quesito riqueza. A concentração de riqueza atinente aos cinco oficiais mais abastados dentre aqueles que informaram o valor de seus bens era significativamente inferior à verificada para o 32. ${ }^{\circ}$ Batalhão, assim como o era a média de riqueza contabilizada para todos os oficiais declarantes: também em ordem crescente, dois oficiais possuíam 5:000\$000 réis cada, um oficial dispunha de 6:000\$000 réis, outros dois de 8:000\$000 réis. Quatro deles eram lavradores e o coronel do batalhão mencionou como profissão apenas o exercício de seu posto. O restante dos oficiais ganhava a vida a partir "dos giros de seus 
negócios”, de empregos públicos e das suas lavouras. Um pequeno contingente era formado por artesãos.

Como era de se esperar, os oficiais pardos detinham os níveis mais inferiores de riqueza relativamente aos oficiais brancos. A riqueza média dos oficiais não atingia a metade do valor médio dos bens da oficialidade do $33 .^{\circ}$ Batalhão e essa desigualdade era ainda mais acentuada em relação ao 32..$^{\circ}$ Dos cinco oficiais mais ricos, três eram negociantes de fazenda seca, um era alfaiate e tinha negócio de molhados e outro era lavrador em 1828. O valor estimado de seus bens era de 1:200\$000 réis, 2:000\$000 réis, 2:600\$000 réis, 5:000\$000 réis e 16:000\$000 réis. Se as distinções entre os batalhões saltam aos olhos considerando-se a riqueza dos oficiais mais abonados, elas ficam ainda mais nítidas quando se observa o segmento da oficialidade que obtinha as menores riquezas. Levando-se em conta o conjunto de oficiais cujo valor dos bens não ultrapassava os 1:999\$000 réis, vê-se que nele não se incluíam os oficiais de patente $32{ }^{\circ}$ Batalhão e também a maior parte dos do 33. ․ No Batalhão dos pardos, por outro lado, quase todos os oficiais de patente e todos os inferiores estavam incluídos nessa faixa de riqueza. $\mathrm{Na}$ realidade, nesse corpo militar os oficiais milicianos se concentravam nos cortes inferiores, ocorrendo até mesmo presença de um oficial de patente no grupo econômico mais precário. Daí se infere que o peso que a variável riqueza assumia na conformação da hierarquia miliciana era mais acentuado nos batalhões $32 .^{\circ}$ e $33 .^{\circ}$. A nítida diferenciação observada no $32 .^{\circ}$ Batalhão, entre oficiais de patente nas faixas superiores de riqueza e a baixa oficialidade nas faixas inferiores, desconfigura-se parcialmente no $33 .^{\circ}$ Batalhão e se torna praticamente opaca no batalhão n. ${ }^{\circ}$ 34. A posse e concentração de bens também influía entre os oficiais pardos, mas como as distinções socioeconômicas vigentes entre eles eram menos pronunciadas, havia espaço para outros elementos atuarem na alocação dos indivíduos na hierarquia.

A relação entre o tipo de atividade econômica desenvolvida e os níveis de concentração de riqueza entre os oficiais pardos revela que os negociantes de fazenda seca oriundos do mundo artesanal estavam entre os mais abastados, com bens avaliados em valores superiores a 1:000\$000 réis. Esse dado corrobora o que se disse acerca do empenho dos milicianos pardos em conciliarem a especialidade artesanal ao pequeno comércio e, se possível, efetivarem a transição entre esses ramos de atividade. A faixa de renda entre $500 \$ 000$ réis e $1.000 \$ 000$ réis compreende um militar branco e um cirurgião da tropa de linha, três ourives, três pintores, um marceneiro, um carpinteiro, um lavrador de madeiras e quatro indivíduos que se dedicavam a mais de um ofício: um requerente e um marceneiro que tinham negócio de molhados, um alfaiate-agricultor-tabelião e um músico-ourives. É exatamente nas faixas inferiores de riqueza - abaixo dos 500\$00 réis - que se situava a maior parte dos oficiais mecânicos. Nela constavam 
sete alfaiates, dois sapateiros, dois carpinteiros, um ourives, um ourives e artista, um seleiro, um arrieiro, um lavrador e camarada de tropas, um lavrador e curtidor de couros, um músico, um escrevente, um lavrador, um carpinteiro com negócio de loja e um alfaiate com venda. As atividades artesanais típicas dos homens de cor, quando exercidas em caráter de exclusividade, tendiam a ser pouco rentáveis, assim como o trabalho com couros e na área do transporte. Independentemente da rentabilidade, o trabalho na confecção de roupas sob medida, fabricação de sapatos e móveis e no beneficiamento de madeira jamais bloqueou o acesso dos pardos aos postos de prestígio nas companhias do Regimento.

\subsection{Milicianos pardos e a posse de escravos}

Uma sondagem à condição socioeconômica dos milicianos pardos não poderia deixar de incorporar a variável posse de escravos, que apesar de ser uma derivação da questão anterior - a dos "bens que possui" - extrapola e muito esse âmbito em função do impacto social da condição senhorial. Na realidade, a posse de escravos representava aos proprietários concentração de poder tanto do ponto de vista material como simbólico. A riqueza, de modo geral, era uma variável poderosamente atuante na alocação social dos indivíduos e famílias, e seu papel na organização da hierarquia miliciana o comprova. Ora, os oficiais milicianos de patente eram investidos de autoridade sobre os subordinados, desfrutavam da nobreza inerente a seus postos e eram recrutados entre os homens mais abastados das suas corporações. $\mathrm{Na}$ sociedade escravista brasileira, organizada sob a perspectiva aristocrática que valorizava as distinções oriundas do nascimento, da honra e da prosperidade econômica, a condição senhorial era praticamente um pressuposto à oficialidade. Os cativos, na América, substituíam os criados na prestação de serviços pessoais às pessoas que aspiravam ou eram constrangidas a viver "à lei da nobreza". Cabe indagar em que medida isso se verifica em relação aos oficiais milicianos pardos, notadamente mais pobres que os brancos, e também qual o grau de acesso dos soldados pardos a essa fonte de dinheiro e prestígio social que era representada pelos cativos. Os resultados dessa investigação fornecerão elementos ainda mais precisos para que se avalie a importância da posse de escravos na organização da hierarquia miliciana dos pardos e igualmente para que se conheça o papel desempenhado pelo grupo dos pardos livres e forros nessa fase especial em que se encontrava a economia paulista. 
Para a capitania e província de São Paulo, há excelentes estudos que fornecem quadros densos e completos acerca da demografia e economia para o período de funcionamento do Regimento dos Úteis. Esses trabalhos revelam as tendências e padrões atinentes ao crescimento populacional e à distribuição de famílias quanto a atividades ocupacionais e a posse de escravos, por exemplo. ${ }^{43}$ Conforme o levantamento realizado por F. V. Luna e H. S. Klein nas listas nominativas de habitantes, a população total de São Paulo cresceu extraordinariamente entre os anos 1777, 1804 e 1829, passando de pouco mais de 113 mil pessoas no primeiro período, para 191 mil no seguinte e para aproximadamente 269 mil almas no ano de 1829. Nesse meio século, o número de seus habitantes mais do que dobrou, e isso se deve tanto ao crescimento verificado entre as pessoas livres como ao ingresso de escravos africanos. O contingente de escravos, que incluía africanos e nascidos no Brasil, triplicou no mesmo período: dos cerca de 25 mil cativos estimados para o ano de 1777, chegou-se a perto de 44 mil em 1804 e a 76 mil escravos em 1829. Nesse intervalo de tempo, durante o qual a configuração econômica de São Paulo mudou significativamente de feição, a proporção do grupo de escravizados em relação ao total da população paulista, que era de $22 \%$, ampliou-se para $28 \%$. Apesar de o número absoluto de proprietários de escravos também aumentar, acompanhando o crescimento dos grupos de livres e escravos, a proporção de unidades domiciliares ou de produção que tinham acesso à mão de obra escrava permaneceu constante. Observando a capitania/província como um todo e suprimindo as variações regionais, de 20 a $25 \%$ dos fogos dispunham de escravos, o que, de acordo com Luna e Klein, segue um padrão generalizado no Brasil e nos Estados Unidos. ${ }^{44}$ Conjuntamente, esses dados sugerem um processo gradual de concentração de escravos e de riqueza, sobretudo no âmbito das localidades ligadas à produção de gêneros agrícolas destinados à exportação, como era o caso do açúcar.

A importância dos escravos para o sucesso da economia colonial foi traduzida em sua essência, no começo do século XVIII, pelo padre jesuíta João Antonio Andreoni, conhecido pelo pseudônimo André João Antonil. Conforme suas palavras, “os escravos são as mãos e os

\footnotetext{
${ }^{43}$ MARCÍLIO, Maria Luiza. A cidade de São Paulo: povoamento e população, 1750-1850, com base nos registros paroquiais e nos recenseamentos antigos. São Paulo: Pioneira; Ed. da Universidade de São Paulo, 1973; MARCÍLIO, Maria Luiza. Crescimento demográfico e evolução agrária paulista...; RABELLO, Elisabeth Darwiche. As elites na sociedade paulista na segunda metade do século XVIII. São Paulo: Comercial Safady, 1980; COSTA, Iraci Del Nero. Arraia-miúda: um estudo sobre os não-proprietários de escravos no Brasil. São Paulo: MSGP, 1992; LUNA, F. V.; KLEIN, H. S. Evolução da sociedade e economia...; REIS, Déborah Oliveira Martins dos. Cinturão Paulistano: economia e demografia nas vizinhanças da capital de São Paulo (c.1798 c. 1830). São Paulo: FFLCH/USP, 2013.

${ }^{44}$ LUNA, F. V.; KLEIN, H. S. Evolução da sociedade e economia..., p. 137-141, 165; LUNA, Francisco Vidal. São Paulo: população, atividades e posse de escravos em vinte e cinco localidades (1777-1829). In: LUNA, F. V.; COSTA, I. del N.; KLEIN, H. S. Escravismo em São Paulo e Minas Gerais. São Paulo: EDUSP/Imprensa Oficial do Estado de São Paulo, 2009, p. 396 e 399.
} 
pés do senhor de engenho, porque sem eles no Brasil não é possível fazer, conservar e aumentar fazenda, nem ter engenho corrente". ${ }^{45}$ Conduzidos coercitivamente pelos proprietários, os cativos foram os grandes responsáveis pela próspera economia açucareira e depois cafeeira paulista. E longe de se restringir ao universo dos canaviais e engenhos, o trabalho escravo gerou riqueza aos proprietários nos mais diversos ramos de atividade econômica. Em todos os lugares os cativos foram abundantemente empregados no cultivo de inúmeros gêneros alimentícios, voltados ou não para o comércio exterior, na mineração, na criação de gado, no trabalho artesanal, no transporte, no pequeno comércio, nos serviços domésticos e também como força armada, entre tantas outras atividades. Certamente eles também forneceram imensurável apoio como trabalhadores aos milicianos pardos que conseguiram se incluir no estreito grupo dos proprietários de escravos. Cumpre examinar o grau de acesso à mão de obra escrava apresentado pelos milicianos, o seu potencial de retenção dessa mão de obra, as atividades ocupacionais em que os cativos eram empregados e o perfil dos plantéis.

Tomando como base os 1.097 milicianos pardos registrados no Livro Mestre, tanto oficiais do estado-maior como oficiais e soldados das dez companhias que integravam o Regimento dos Úteis, procedeu-se ao trabalho de rastreamento nominal desses homens nas listas nominativas de habitantes durante o período compreendido entre anos 1798 e $1836 .{ }^{46}$ As listas oferecem uma perspectiva temporal diferenciada em relação aos inventários e testamentos: enquanto esses geralmente retratam de modo mais congelado os estágios finais da vida dos indivíduos, aquelas informam as mutações nas condições materiais e sociais ao longo dos anos. ${ }^{47}$ Um total de 777 milicianos foram identificados por pelo menos uma vez nas listas. Eles correspondem a aproximadamente $72 \%$ de todos os milicianos pardos daquele corpo militar. A metodologia empregada para a localização dessas pessoas nos recenseamentos é a mesma aludida em páginas anteriores, quando se abordou a cor dos milicianos e a formação de famílias. Ela consistiu no cruzamento criterioso de informações diversas ${ }^{48}$ contidas no Livro Mestre, em fontes paroquiais (assentos de batismo, casamento, óbito e autos de dispensas matrimoniais e casamentos) e nas listas nominativas de habitantes, e por isso forneceu bastante segurança à composição da amostra.

\footnotetext{
${ }^{45}$ Cf:: ANTONIL, André João. Cultura e opulência do Brasil, por suas drogas e minas. Rio de Janeiro: Typ. Imp. e Const. De J. Villeneuve e Ca., 1837, p. 31.

${ }^{46}$ Desconsidera-se os dez oficiais brancos do estado-maior. As listas consultadas são as mesmas da nota de rodapé 26 do capítulo 5 .

${ }^{47}$ Desde que, evidentemente, os indivíduos sejam localizados em diferentes anos nas listas nominativas.

48 Tais como o nome e sobrenome dos milicianos, de seus pais, irmãos e de suas esposas; a idade; cor; local de nascimento, batismo, residência, casamento e óbito; ocupação; referências ao pertencimento à milícia e ao posto ocupado; cronologia articulada dos principais eventos observáveis (nascimento, batismo, alistamento na milícia, casamento, batismo de filhos, compadrio, progressão na milícia, mudança de residência, óbitos).
} 
Como era de se esperar, por se tratar de um grupo social oriundo dos degraus mais baixos da sociedade colonial, a maior parte desses milicianos jamais obteve acesso a escravos ao longo do período analisado. Aqui é preciso esclarecer algo sobre os dados obtidos: enquanto alguns milicianos foram rastreados em anos seguidos durante um intervalo de tempo bastante abrangente, contemplando-se diferentes momentos e circunstâncias de suas vidas, outros puderam ser identificados nas listagens apenas uma, duas ou três vezes, resultando daí, no que se refere aos últimos, uma perspectiva apenas parcial acerca de sua capacidade de adquirir e manter cativos. Surpreendentemente, 104 milicianos foram senhores de escravos, alguns diretamente, como proprietários formais, e outros indiretamente, exercendo domínio cotidiano aos cativos pertencentes aos pais ou aos compartilhados entre irmãos. Juntos, esses proprietários representam pouco mais de $13 \%$ de toda a amostra, e mesmo que se considere os 1.097 que formavam a totalidade dos milicianos pardos matriculados no Livro Mestre a proporção de escravistas não deixa de ser significativa, já que chega a quase 9,4\% de seus integrantes.

Graças aos inúmeros trabalhos que abordam a população, sociedade e economia de São Paulo por meio do tratamento estatístico das listas nominativas, é possível colocar em perspectiva a situação dos milicianos pardos em relação ao padrão de posse de escravos vigente entre a população de cor da capitania/província em geral. ${ }^{49}$ Conforme Luna e Klein, nas três primeiras décadas do século XIX a população livre de São Paulo estava dividida entre um vasto grupo de pessoas reputadas brancas, que abrigava de um quarto a um terço dos habitantes livres, e um segmento considerável, mas minoritário, de pessoas livres de cor, que atingia de um terço a um quarto do total dos não escravos, a depender do período e das localidades. O diferencial entre brancos, de um lado, e pardos e pretos, de outro, dilata-se ainda mais quando se considera a posse de escravos. Nesse quesito, os brancos compunham a imensa maioria dos proprietários, perfazendo um total de $94 \%$ deles, enquanto os outros $6 \%$ eram formados quase que integralmente por pessoas pardas. Além disso, como os proprietários pardos geralmente dispunham de um pequeno número de escravos, a maior concentração de cativos estava reservada aos brancos, os quais, além dos pequenos e médios plantéis, controlavam os grandes conjuntos de trabalhadores escravos. ${ }^{50} \mathrm{Ou}$ seja, em relação aos escravistas brancos, os escravistas pardos estavam em dupla desvantagem: não apenas eram minoritários no que se refere à quantidade de proprietários, como também controlavam grupos menores de cativos.

\footnotetext{
49 As obras em questão estão listadas na nota 43. Em termos do recorte espacial, alguns desses trabalhos desenvolvem perspectiva regional e outros mais abrangente. Além de ser um dos estudos mais atualizados, os textos de Luna e Klein são os mais englobantes em termos dos dados empregados e da territorialidade considerada, e por essa razão constituem, aqui, a referência fundamental sobre a questão da posse de escravos em São Paulo.

${ }^{50}$ LUNA, F. V.; KLEIN, H. S. Evolução da sociedade e economia..., p. 137-165, 197-222.
} 
Uma condição essencial para se compreender a posição ocupada pelos milicianos pardos no conjunto da capitania/província é analisar o que representava a sua participação como proprietários de escravos em relação ao grupo social mais amplo constituído por pardos e pretos livres e libertos. Segundo os dados de 1829, referentes a um momento em que o fluxo de escravos para São Paulo estava plenamente consolidado mas que a forte demanda da economia açucareira elevou o custo de sua aquisição, apenas $6 \%$ das residências chefiadas por pessoas de cor eram escravistas. Como revelaram Luna e Klein, a participação dos homens livres de cor como proprietários de escravos diferia muito entre São Paulo e Minas Gerais. Se entre os paulistas ela era diminuta, entre os mineiros ela alcançou a importância de 30\% de todos os senhores de escravos, em 1831. ${ }^{51}$ Além do fato de Minas Gerais ter se tornado a configuração social com maior população de cor livre e liberta da América, ainda no século XVIII, e ter desenvolvido uma economia tão próspera a ponto de fornecer melhores oportunidades de ascensão social a essa população de cor do que em várias outras capitanias luso-americanas, a trajetória histórica dos seus grupos de pardos, pretos e de mestiços foi marcada por lutas visando o melhoramento de suas condições sociais e a consolidação de privilégios. ${ }^{52}$ Em São Paulo, as características da formação do grupo dos pardos livres e libertos - destacando-se a temporalidade mais tardia, o quadro econômico do Setecentos, tipicamente marcado pelas atividades de subsistência e pelo comércio interno, a pequena dimensão do grupo em relação ao dos brancos e a sua localização acentuadamente rural - delimitaram, em termos gerais, a sua posição social. A maioria dos seus pardos e pretos mantinha-se, pois, completamente alijada da condição senhorial.

Esse padrão também se verificava entre os milicianos pardos, não surpreendendo que, considerados apenas os chefes de domicílios escravistas, a proporção de proprietários fosse muito semelhante à verificada para o total da população parda e preta livre ou liberta de São Paulo. Entre os 104 milicianos pardos associados à propriedade escrava, 55 eram chefes de domicílio e proprietários diretos, nove compartilhavam a condição senhorial com irmãos e 40 somente tiveram acesso a escravizados enquanto residiam na casa de seus pais, deixando de exercer esse tipo de domínio tão logo passassem a chefiar seus próprios domicílios. Isso

\footnotetext{
${ }^{51}$ LUNA, F. V.; KLEIN, H. S. Evolução da sociedade e economia..., p. 143-144; 205-209; LUNA, F. V. São Paulo: população, atividades e posse de escravos..., p. 350-351.

52 RUSSELL-WOOD, A. J. R. Escravos e libertos no Brasil colonial. Trad. Maria Beatriz de Medina. Rio de Janeiro: Civilização Brasileira, 2005, p. 157-187; SILVEIRA, Marco Antonio. Soberania e luta social: negros e mestiços libertos na Capitania de Minas Gerais (1709-1763). In: CHAVES, C. M. das G.; SILVEIRA, M. A. (Orgs.). Território, conflito e identidade. Belo Horizonte: Argumentum, 2007; SILVEIRA, Marco Antonio. Acumulando forças: luta pela alforria e demandas políticas na capitania de Minas Gerais (1750-1808). Revista de História, n. 158, p. 131-156, 2008; SILVEIRA, Marco Antonio. Narrativas de contestação. Os Capítulos do crioulo José Inácio Marçal Coutinho (Minas Gerais, 1755-1765). História social, n. 17, p. 285-307, 2009.
} 
significa que apenas 5\% de todos os 1.097 milicianos pardos matriculados no Livro Mestre e aproximadamente 7\% dos 777 milicianos da amostra eram efetivamente senhores de escravos. Os milicianos que dividiam a posse de escravos com irmãos ou que desfrutaram dos serviços dos cativos de seus pais certamente possuíam uma mentalidade escravista pronunciada. Presumivelmente, muitos deles, tão logo tenham podido, adquiriram seus próprios escravos em período posterior ao recorte considerado.

TABELA 5.5 - Modalidade de posse de escravos entre soldados e oficiais milicianos pardos (em percentuais e números absolutos de proprietários), 1798-1836

\begin{tabular}{|c|c|c|c|c|c|c|}
\hline Modalidade & \multicolumn{2}{|c|}{ Oficiais } & \multicolumn{2}{|c|}{ Soldados } & \multicolumn{2}{|c|}{ Total } \\
\hline Chefes de domicílio & $41,3 \%$ & (43) & $10,6 \%$ & (11) & $51,9 \%$ & $(54)$ \\
\hline Compartilhada com irmãos & $6,7 \%$ & $(7)$ & $2,9 \%$ & (3) & $9,6 \%$ & (10) \\
\hline Residindo com os pais & $26 \%$ & $(27)$ & $12,5 \%$ & (13) & $38,5 \%$ & $(40)$ \\
\hline Totais parciais & $74 \%$ & $(77)$ & $26 \%$ & $(27)$ & $100 \%$ & (104) \\
\hline
\end{tabular}

Fontes: Livro Mestre; APESP, Maços de População (Atibaia, latas 9-16; Bragança, latas 17-24A; Capital, latas 30-37A; Cotia, latas 38-40; Itu, latas 71-79; Jundiaí, latas 90-94; Juqueri, latas 95A-96; Parnaíba/São Roque, latas 131-133; Santo Amaro, latas 149-150; Sorocaba, latas 171-173A).

A predominância dos pequenos plantéis, de até cinco escravos, é outra componente típica do perfil escravocrata dos milicianos pardos, a qual, aliás, era extensiva ao grupo de pardos livres e mesmo à sociedade paulista em geral. ${ }^{53}$ Observando-se o grupo mais amplo de milicianos que vivenciou a condição senhorial, direta ou indiretamente, em algum momento de suas vidas entre os anos 1798 e 1836, se evidencia que a posse de cativos, para eles, era praticamente restrita a pequenos grupos senão a um único escravo. Essa é a principal razão para que uma boa parte desses milicianos tenham podido explorar o trabalho de escravos e o status senhorial somente durante o período em que viveram debaixo do poder paterno ou materno. Quando eles decidiam morar em suas próprias casas ou a isso eram impelidos, não podiam levar consigo os poucos ou únicos cativos que serviam aos pais e também não tinham condições financeiras para adquirir os seus próprios escravos. Talvez essa acanhada posse de escravos e de bens também explique o fato de muitos oficiais milicianos pardos permanecerem na residência familiar depois de adultos e alguns mesmo depois de casados, um meio encontrado para não deixarem de pertencer ao grupo senhorial e desfrutarem da estima social a ele atrelada.

\footnotetext{
${ }^{53}$ LUNA, F. V.; KLEIN, H. S. Evolução da sociedade e economia..., p. 137-165; REIS, D. O. M. Cinturão Paulistano..., p. 18-189.
} 


\section{TABELA 5.6 - Tamanho de plantéis de escravos entre oficiais e soldados milicianos pardos (em percentuais e números absolutos de proprietários), 1798-1836}

\begin{tabular}{|c|c|c|c|c|c|c|}
\hline Tamanho do plantel & \multicolumn{2}{|c|}{ Oficiais } & \multicolumn{2}{|c|}{ Soldados } & \multicolumn{2}{|c|}{ Total } \\
\hline 01 a 05 & $59,5 \%$ & (62) & $25 \%$ & (26) & $84,5 \%$ & (88) \\
\hline 06 a 10 & $11,5 \%$ & (12) & $1 \%$ & (1) & $12,5 \%$ & (13) \\
\hline 11 ou mais & $3 \%$ & (3) & & & $3 \%$ & (3) \\
\hline Total & $74 \%$ & (77) & $26 \%$ & (27) & $100 \%$ & (104) \\
\hline
\end{tabular}

Fonte: Livro Mestre; APESP, Maços de População (Atibaia, latas 9-16; Bragança, latas 17-24A; Capital, latas 3037A; Cotia, latas 38-40; Itu, latas 71-79; Jundiaí, latas 90-94; Juqueri, latas 95A-96; Parnaíba/São Roque, latas 131-133; Santo Amaro, latas 149-150; Sorocaba, latas 171-173A).

Pouco mais de $15 \%$ dos milicianos pardos escravistas se situavam nas duas maiores faixas de número de escravos por proprietário e esses casos merecem alguma atenção para que se evite superestimar o potencial de retenção de mão de obra escrava daqueles homens. Dentre os milicianos que chegaram a dispor de 6 a 10 escravos, quatro eram membros da família Ribeiro, radicada na capital, a qual dominou parte dos principais postos do Regimento dos Úteis. O coronel Manoel José Ribeiro, seus dois filhos, o tenente-coronel Manoel José da Costa Ribeiro e o capitão José Manoel da Costa Ribeiro, e o neto, sargento-mor Antonio Joaquim da Costa Ribeiro, viveram a maior parte do tempo na mesma residência, onde funcionava uma antiga oficina artesanal convertida em loja de fazenda seca. O filho mais velho, Manoel, permaneceu no lar paterno até pelo menos o ano de 1822, depois de casado, assim como seu irmão e sobrinho solteiros. Eles detinham um número variável mas crescente de escravos ao longo das décadas de 1790 e 1820, o qual chegou ao ápice de dez pessoas no ano de 1822. A dinâmica de formação do plantel indica que ele era alimentado por compra e venda de cativos e, portanto, decorria diretamente do acúmulo de capital por parte da família. No entanto, com o sucessivo desmembramento da família em novas residências, o contingente escravo também se fragmentou e diminuiu. Em 1826, o tenente-coronel Manoel José da Costa Ribeiro, então chefe de seu próprio domicílio, era senhor de dois escravos. Já o coronel patriarca dispunha de quatro escravizados em 1836, quando seus filhos e neto homens não mais coabitavam a sua casa. ${ }^{54}$ A estratégia dos Ribeiros parece ter sido a de concentrarem recursos e manterem-se

\footnotetext{
${ }^{54}$ Cf:: Livro Mestre, fls. 1-2, 3-3v, 11-12, 56; Maços de População, Capital, Rua do Rosário (1794) 1.a, fogo 254; (1795) $1 .^{\mathrm{a}}$, fogo 237; (1797) 1.a, fogo 89; (1798) 1. , fogo s.n. 03220_022; (1802) 1. a, fogo 139; (1804) 1..$^{\mathrm{a}}$, fogo 140; (1805) 1. , fogo 127; (1807) 1. ${ }^{\mathrm{a}}$, fogo 137; (1808) 1. , fogo 134; (1809) 1. , fogo 29; (1810) $1 .^{\mathrm{a}}$, fogo 105 ; (1811) $1 .^{\mathrm{a}}$, fogo 118; (1813) $1 .^{\mathrm{a}}$, fogo $29 ;(1814) 1 .^{\mathrm{a}}$, fogo $29 ;(1815) 1 .^{\mathrm{a}}$, fogo $29 ;(1816) 1 .^{\mathrm{a}}$, fogo $29 ;(1817) 1 .^{\mathrm{a}}$, fogo 107; (1818) 4. a, fogo 29; (1822) 4. a , fogo 29; (1826) 5. a , Tv. Jogo da Bola, fogo s.n. 03639_011; (1836) Sé D.N., 5. ${ }^{\circ}$ Quarteirão, fogo 31
} 
unidos até onde fosse possível a fim de se evitar o risco de fracionamento de seu capital material e social e assim preservarem a visibilidade de seu poder.

Ainda nesse grupo de proprietários constam dois irmãos pardos da cidade de São Paulo, sendo um oficial e outro soldado, que compartilhavam a posse de quatro escravos em 1822, seis em 1825 e quatro em 1836. Eles eram filhos naturais do capitão Antonio Álvares dos Reis, um negociante com loja, branco e nascido em Portugal, que legitimou os filhos em seu testamento. Com grande probabilidade, os escravos sob o poder dos irmãos pardos na década de 1820 eram provenientes da satisfação das disposições testamentárias paternas e da conclusão do inventário correspondente, o que não exclui a possibilidade de aquisição de parte deles através de seus próprios pecúlios. ${ }^{55}$

Entre os maiores escravistas no conjunto dos milicianos pardos de São Paulo estão o capitão Joaquim Manoel Gomes e o sargento Domiciano Zacarias da Rocha, dois irmãos residentes na freguesia rural de Nossa Senhora do Ó, adjacente à cidade, e o sargento Joaquim Barbosa Neves, da vila de Porto Feliz e matriculado na companhia de Itu. Os primeiros foram aludidos mais acima e ilustraram os raros casos de milicianos que se tornaram prósperos com o negócio de tropas, já que a maior parte dos que trabalhavam com animais ficava atada às funções de prestação de serviços como condutores e arrieiros. Os irmãos em questão, pelo contrário, trabalharam juntos como agricultores e criadores de gado por todo o período de atividade no Regimento dos Úteis e, em 1829, compartilhavam a posse de 14 escravos. Ambos formaram família após a extinção das milícias e passaram a morar em residência separada. No começo dos anos 1840, quando ambos faleceram, foram avaliados oito cativos de Joaquim e 16 escravos e Domiciano - um caso em que a fragmentação familiar não implicou a diminuição do tamanho do plantel de escravos. ${ }^{56}$

Mas nenhum miliciano pardo chegou próximo do vulto adquirido por Joaquim Barbosa Neves como senhor de escravos. Como já mencionado, esse homem não fez propriamente a carreira no Regimento dos Úteis. Antes, ele serviu como simples soldado por alguns anos na tropa de linha e por uma década no Regimento Miliciano de Sorocaba, onde não teve progressão

\footnotetext{
${ }^{55}$ Cf:: Livro Mestre, fls. 145v, 151v; Maços de População, Capital: (1802) 2. ${ }^{\text {a }}$, fogo 126; (1804) 2. ${ }^{\text {a }}$, fogo 175; (1808) 1. . , Boa Vista, fogo 113; (1810) 2. ${ }^{a}$, Ponte do Anhangabaú, fogo 170; (1814) 2. ${ }^{a}$, S.Ef., Ponte do Marechal, fogo 355; (1816) 2. ${ }^{a}$, S.Ef., Ponte do Marechal, fogo 13; (1822) 7. ${ }^{a}$, Rua do Hospital, fogo 10.111; (1825) 7. . , S.Ef., fogo 53; (1836) S.Ef., $1 .^{\circ}$ Q., fogo 60. Breve referência à legitimação dos irmãos, filhos naturais, em ARAÚJO, Maria Lucília Viveiros. As práticas testamentárias paulistanas da primeira metade do século XIX. História Hoje - Revista Eletrônica de história. ANPUH, vol. 3, nº 9, abr. 2006, p. 10.

${ }^{56}$ Cf:: Livro Mestre, fls. 18v, 180 e 306v; Maços de População, N.S.Ó: (1804) fogo 33; (1805) fogo 19; (1808) fogo 53; (1810) fogos 78 e 81; (1814) fogo 123; (1818) fogo 108; (1822) fogo 93; (1825) fogo 123; (1829) fogo 99; (1836) 3. ${ }^{\circ}$ Quarteirão, fogo 14; TJESP, 1. ${ }^{a}$ Vara da Família, processo no 1381 , ano 1841 e TJESP, 2. ${ }^{a}$ Vara da Família, processo n ${ }^{\circ} 1369$, ano 1843.
} 
na hierarquia em razão da sua cor. Em função disso, ele mobilizou suas redes com as elites locais e obteve intercessão junto ao governador e, por ordem deste, o coronel Ribeiro admitiuo logo a sargento, em 1818. Neves apenas se tornou oficial de patente quando obteve a sua reforma, em alferes, pouco mais de um ano após o ingresso no corpo militar dos pardos. Ele, portanto, ostentou a patente mas não chegou a comandar os subordinados nessa posição. Em 1818, tinha negócio de fazenda seca e dispunha de sete escravos africanos adultos. Entretanto, como demonstrou Roberto Guedes, Neves teve uma trajetória marcada pelo trabalho artesanal, pela posterior conversão a negociante de fazenda seca e estava a meio caminho de se assentar como senhor de engenho quando faleceu, em 1828. Nesse momento, dez anos após sua passagem pelo Regimento, ele tinha nada menos que 41 escravos. ${ }^{57}$

Guedes não encontrou indícios de que o pardo em questão tenha sido favorecido com heranças, sendo provável que a formação desse grande plantel, o maior e notadamente destoante em relação aos milicianos pardos, tenha sido fruto de seu trabalho e de seus investimentos. Após a sua morte, um casal de escravos foi libertado e mais 15 foram vendidos para a quitação de dívidas. Os demais devem ter sido distribuídos entre os herdeiros - a esposa e os sete filhos legítimos. Nem mesmo essa diminuição da concentração familiar de escravos ocasionada pela morte do chefe do domicílio e a instabilidade da manutenção do grande plantel ofuscam a projeção socioeconômica lograda por esse pardo que, quando faleceu, possuía uma fortuna de 15:911\$614 réis, já descontadas as dívidas.

Vários trabalhos historiográficos têm alertado para a pertinência de se traçar perfis dos escravos a fim de melhor avaliar questões como a capacidade produtiva, as funções ocupacionais desempenhadas e o comportamento dos proprietários no mercado de pessoas. Afinal, o preço de escravos em plena idade produtiva que dominavam atividades especializadas era consideravelmente maior que o de escravos crianças, idosos ou doentes, por exemplo. Como não é o caso, aqui, de rastrear os cativos de uma centena de pessoas no intervalo de aproximadamente três décadas, é suficiente examinar o perfil dos escravos pertencentes aos 34 proprietários que dispuseram de apenas um cativo.

Em primeiro lugar, deve-se esclarecer que 17 proprietários eram os próprios milicianos, 15 somente tiveram acesso aos cativos pertencentes aos pais e dois dividiam a propriedade com irmãos. Em segundo lugar, é notável a volatilidade da posse de escravos para a maioria desses

\footnotetext{
${ }^{57}$ Cf.: Livro Mestre, fl. 347; GUEDES, Roberto. Egressos do cativeiro..., p. 267-278; GUEDES, Roberto. De exescravo a elite escravista: a trajetória de ascensão social do pardo alferes Joaquim Barbosa Neves (Porto Feliz, São Paulo, século XIX). In: FRAGOSO, J.; ALMEIDA, C.; SAMPAIO, A. (Orgs.). Conquistadores e negociantes: histórias de elites no Antigo Regime nos trópicos, América lusa, séculos XVI a XVIII. Rio de Janeiro: Civilização Brasileira, 2007, p. 337-376.
} 
milicianos. Em parte ela é decorrente do fato de que a experiência de vários deles como senhores se deu apenas nos marcos da infância e juventude, acompanhados dos pais. Mas a modesta condição socioeconômica desses homens também jogou um papel fundamental como limitador de sua capacidade de aquisição e manutenção de mão de obra cativa. Casos como os do capitão Lourenço Miguel de Siqueira e de seu filho, o soldado Benedito Alexandre de Siqueira, que exerceram domínio sobre a escrava Zuzana, de nação benguela, na vila de Atibaia por aproximadamente trinta anos - entre 1803 e 1829, pelo menos, até quando as listas nominativas da vila estão completas - são menos comuns. ${ }^{58} \mathrm{O}$ alferes Ezequiel de Morais Santos, por exemplo, não tinha escravos entre os anos 1808 e 1814, enquanto morava com a mãe. Ele foi encontrado novamente na lista nominativa de 1825 , então como proprietário do escravo africano Benedito, de 14 anos de idade. Entretanto, em 1836 já não dispunha de nenhum cativo. ${ }^{59}$ Já o capitão Francisco de Paula Leite Prestes, que serviu no Regimento dos Úteis por quase todo o seu período de funcionamento, isto é, entre os anos 1798 e 1831, dispôs de um escravo somente entre os anos de 1802 e 1803. Em 1801 ele morava em Itu e no ano seguinte se mudou para a capital, talvez levando consigo um escravo. Como em pouco tempo esse falecera, Francisco de Paula ficou sem o escravo e, até 1836, jamais conseguiu ou se interessou em adquirir outro. ${ }^{60}$

Os exemplos acima revelam a dificuldade enfrentada por capitães e alferes, oficiais de patente socialmente coagidos a expressarem compatibilidade com a distinção honorífica atrelada às patentes, em adquirirem e manterem escravos, os quais eram encarados tanto como mão de obra para o trabalho quanto um bem suntuário. Nos casos de milicianos pardos que se converteram em proprietários de um número maior de cativos, a instabilidade de seus plantéis era ainda mais acentuada. O tenente Francisco de Paula e Oliveira, por exemplo, era proprietário de um cativo entre os anos 1802 e 1808. Em 1811 ele surgiu nas listas acompanhado de quatro

\footnotetext{
${ }^{58}$ Cf:: Livro Mestre, fls. 221, 222, 229; Maços de População, Atibaia: (1803) Vila, fogo 18; (1806) Caioçara, fogo 7; (1807) Vila, fogo 35; (1810) Vila, fogo 25; (1811) V.,C.,C., fogo 24; (1812) V.,C.,C., fogo 27; (1813) V.,C.,C., fogo 37; (1814) V.,C.,C., fogo 25; (1815) Vila, fogo s.n.; (1818) V.,C., fogo 66; (1820) V.,C., fogo 72; (1822) Vila, fogo s.n. 01501_066; (1824) V.,C., fogo 44; (1829) V.,C.,C., fogo 40.

${ }^{59}$ Cf:: Livro Mestre, fls. 306-306v; Maços de População, Capital: (1808) 1. ${ }^{\mathrm{a}}$, fogo 220; (1811) 1. ${ }^{\mathrm{a}}$, fogo entre 8687 ou (1811) 2. ${ }^{a}$, fogo 49; (1814) 2. ${ }^{a}$, Rua nova de São José, fogo 144; (1825) 3. ${ }^{a}$, Rua do Quartel, fogo 15; (1836) Sé D.S., 9. ${ }^{\circ}$ Quarteirão, fogo 3.

${ }^{60}$ Cf:: Livro Mestre, fl. 97; Maços de População, Itu: (1801) 1. ${ }^{a}$, fogo 19; Capital: (1804) 3. ${ }^{a}$, fogo 107; (1808) 3. ${ }^{a}$, fogo 115; (1811) 3. ${ }^{a}$, Rua das Flores, fogo 42; (1818) 3. ${ }^{a}$, fogo 42; (1823) 3. ${ }^{a}$, Rua das Flores, fogo 42.158; (1825) 3. ${ }^{\mathrm{a}}$, Rua das Flores, fogo 47; (1836) Sé D.N., 6. ${ }^{\circ}$ Q., fogo 52.
} 
escravos, mas, por razões desconhecidas, sua situação não se manteve favorável por muito tempo. Nas listas de 1818, 1822 e 1825 ele já não dispunha de escravos. ${ }^{61}$

Exceto alguns casos isolados, não é possível identificar as condições de aquisição dos cativos através das listas nominativas. No entanto, elas revelam o gênero, a idade, o estado civil, a cor e a procedência. Os 34 escravos dos pequenos proprietários em tela eram predominantemente mulheres, havendo apenas doze homens. Esse aspecto já estabelece um corte interessante. Uma vez que as escravas eram comercializadas por valores inferiores aos cativos homens, decerto eram um investimento mais viável às pessoas de cor livres. Mas essa é apenas uma parte da questão. Dois terços desses proprietários viviam na cidade de São Paulo e o restante nos setores urbanos das vilas rurais, e empregavam os parcos escravos em atividades artesanais, domésticas e talvez no auxílio às suas pequenas lojas e vendas. Além disso, inúmeras pardas, mães de milicianos, dedicavam-se à fiação, à costura e à venda de alimentos. ${ }^{62}$ Desse modo, o predomínio de mulheres entre os escravos surge como uma adaptação aos escassos recursos das famílias pardas bem como às atividades ocupacionais levadas a efeito por mães, esposas e aos próprios milicianos.

A nação, procedência ou o porto de embarque dos cativos não era informada com absoluta regularidade, mas das 22 pessoas para as quais consta essa informação, 15 eram africanos (seis "Benguelas", quatro de "nação", três "africanos", um "Moçambique" e um referido ora como "Rebolo" e ora como "Monjolo") e sete "brasileiros" ou "crioulos". Essa distribuição é indicativa da vinculação entre a região Centro-Sul do Brasil com as praças negreiras angolanas e também atestam que o boom escravista em São Paulo, de fins do século XVIII em diante, também tocou algumas famílias pardas. Exceto uma parda, todos os demais escravos foram identificados como negros ou pretos. Isso se deve à predominância de africanos e secundariamente à tendência, observada pela historiografia, de a sociedade escravista retratar os cativos homogeneamente como negros e pretos. ${ }^{63}$ Quase todos esses cativos eram solteiros, salvo uma crioula viúva, mas, através dos dados disponíveis, pouco se pode discutir sobre o seu status de desmarginalização, visto que a ausência de casamentos referendados pela Igreja

\footnotetext{
${ }^{61}$ Cf:: Livro Mestre, fl. 140; Maços de População, Capital: (1802) 1. a, fogo 286; (1804) 1. a , fogo 334; (1808) 1. ${ }^{\mathrm{a}}$, fogo 388; (1811) 2. a , Piques, fogo 172; (1818) 1. a, Rua do Príncipe, fogo 16; (1822) 7. a, Rua do Hospital, fogo 13.114; (1825) 7., , S.Ef., fogo 51.

${ }^{62}$ Maria Odila Dias deslindou esse setor ocupado por mulheres, muitas das quais solteiras, na cidade de São Paulo. DIAS, Maria Odila Leite da Silva. Quotidiano e poder em São Paulo no século XIX. Ana Gertrudes de Jesus. São Paulo: Brasiliense, 1984; sobre a importância das costureiras entre os pequenos proprietários de escravos na capitania/província e a sua predileção por escravas, ver LUNA, F. V.; KLEIN, H. S. Evolução da sociedade e economia..., p. 233-234.

${ }^{63}$ MATTOS, Hebe. Escravidão e cidadania no Brasil monárquico. Rio de Janeiro: Jorge Zahar Editor, 2004 , p. 16-18.
} 
católica não deve ser diretamente interpretada como ausência de relacionamentos pessoais e afetivos estáveis. Finalmente, a idade de 33 desses cativos revelou que se tratava de pessoas pertencentes às faixas etárias consideradas mais produtivas. Havia quatro crianças ou adolescentes, abaixo de 15 anos, quatro adultos ou idosos com 40 anos ou mais e 25 escravos entre 16 e 39 anos de idade. Como esses escravistas pardos tinham que lidar com a escassez de recursos a eles característica, a inversão de boa parte de seu capital em um único escravo deveria ser certeira. Vai daí privilegiarem cativos potencialmente mais produtivos e duradouros.

Os milicianos pardos que se beneficiaram do trabalho de escravos geralmente moravam na cidade de São Paulo e nos centros urbanizados das vilas do interior. Não surpreende, portanto, a presença dominante de artesãos, comerciantes, músicos, pintores e escrivães entre os proprietários. Com efeito, mesmo que os lavradores e populações residentes em áreas rurais compusessem a maior parte dos milicianos pardos, havia entre eles poucos agricultores e criadores escravistas. Esse quadro reitera a perspectiva de que as atividades da referida multidão de roceiros - que cultivava cereais, hortaliças e frutas bem como criava animais - eram voltadas para seu próprio sustento e, no limite, para a comercialização dos eventuais excedentes na própria localidade. Tinha-se como base o trabalho familiar executado, conforme se presume, em pequenas extensões de terras comparativamente às fazendas escravistas.

Por outro lado, esses dados sugerem que as melhores oportunidades para as famílias pardas, tanto as forras como as livres há mais de uma geração, estavam situadas nas cidades. Indicadores mais abrangentes em relação à população paulista apontam para uma hierarquização entre os diferentes ramos ocupacionais em termos de rentabilidade. Grandes fazendeiros, criadores e negociantes estariam entre os setores mais ricos, os profissionais liberais e burocratas e comerciantes de médio porte conformariam um setor intermediário e pequenos vendeiros, lavradores e oficiais mecânicos estariam no conjunto mais pobre da população. Em geral, os milicianos pardos pertenciam ao grupo economicamente menos favorecido da população livre, mas, em seu interior, os trabalhadores especializados, muitos dos quais com potencial de investimento no setor comercial, se destacavam em relação aos modestos agricultores, condutores, jornaleiros e pessoas que buscavam de tudo para sobreviver. Os três maiores proprietários de escravos, aludidos anteriormente, com suas grandes fazendas de criação ou beneficiamento da cana-de-açúcar configuram uma exceção no conjunto dos milicianos. Os escravistas eram tipicamente artesãos, artesãos-comerciantes e negociantes. Enquanto os artesãos se destacavam entre os proprietários de um ou dois cativos, à medida que as faixas de posse de escravos aumentam, cresce também a participação dos negociantes. 
TABELA 5.7 - Posse de escravos por faixas de quantidade e atividades econômicas dos milicianos pardos (1798-1836)

\begin{tabular}{|c|c|c|c|c|c|}
\hline \multirow[t]{2}{*}{ Atividades econômicas } & \multicolumn{5}{|c|}{ Faixas de posse de escravos } \\
\hline & Um & Dois & 3 a 5 & 6 a 10 & 11 ou mais \\
\hline Alfaiataria & 7 & 3 & 1 & & \\
\hline Carpintaria & 2 & 4 & & 1 & \\
\hline Marcenaria & 1 & 2 & 2 & & \\
\hline Ourivesaria & 4 & 1 & 1 & 2 & \\
\hline Sapataria & 2 & 5 & 2 & 1 & \\
\hline Artesanato e agricultura & 1 & & 2 & & \\
\hline Artesanato e negócios & 5 & 7 & 3 & 3 & \\
\hline Negociantes & 4 & & 2 & 4 & \\
\hline Agricultura & 3 & 3 & 2 & 1 & \\
\hline Agricultura e negócios & & & & 1 & 3 \\
\hline Pintura & & 1 & & & \\
\hline Música & 1 & 1 & & & \\
\hline $\begin{array}{l}\text { Artes liberais e } \\
\text { artesanato ou negócios }\end{array}$ & & 3 & & & \\
\hline Tropeirismo & 1 & & 2 & & \\
\hline Outros $^{\mathbf{a}}$ & 2 & & 4 & & \\
\hline Não Declarado & & & 3 & & \\
\hline TOTAL & 36 & 32 & 28 & 13 & 3 \\
\hline
\end{tabular}

a Inclui um escrivão, um alfaiate e feitor, um ferreiro, dois seleiros e um alfaiata, tabelião e agricultor.

Fonte: Livro Mestre; APESP, Maços de População (Atibaia, latas 9-16; Bragança, latas 17-24A; Capital, latas 3037A; Cotia, latas 38-40; Itu, latas 71-79; Jundiaí, latas 90-94; Juqueri, latas 95A-96; Parnaíba/São Roque, latas 131-133; Santo Amaro, latas 149-150; Sorocaba, latas 171-173A).

Esse perfil dos escravistas não por acaso se assemelha ao perfil ocupacional da oficialidade miliciana, já que $74 \%$ dos proprietários milicianos faziam parte do corpo de oficiais. Além disso, quase a metade dos soldados proprietários tinha familiares ocupando os postos superiores do Regimento dos Úteis e seu acesso aos escravos era muitas vezes partilhado com esses pais e irmãos que já haviam progredido na hierarquia. Esse quadro sugere que a posse de escravos, conjuntamente a outras variáveis socioeconômicas, tais como a ocupação e a riqueza em forma de bens possuídos, eram componentes estruturadores da organização interna da milícia dos pardos. Entretanto, essa relação entre condição material e a ocupação dos postos milicianos não se processava de maneira direta ou absoluta, o que leva a reconhecer a importância de outros fatores no estabelecimento da hierarquia, tais como critérios técnicos atrelados ao desempenho das funções militares e a estima social que os indivíduos desfrutavam na comunidade e entre os superiores da milícia, por exemplo. Os $26 \%$ de milicianos vinculados de algum modo à propriedade escrava que não evoluíram na hierarquia o comprovam, assim 
como o fazem os 91 oficiais milicianos rastreados nas listas nominativas de habitantes que jamais se tornaram senhores de cativos, dentre os quais se incluem oito oficiais de patente. ${ }^{64}$

É extremamente instigante o fato de que as normas que regiam a progressão na hierarquia miliciana - ao menos entre os pardos - não se dobravam completamente à pressão socioeconômica. Talvez a melhor demonstração desse aspecto advenha da comparação entre o maior proprietário de escravos entre os milicianos pardos e o oficial com a menor renda declarada nos anos 1828-1830. Mencionado acima, o sargento Joaquim Barbosa Neves, que chegou a possuir 41 escravos e uma das maiores riquezas entre os integrantes do Regimento, obteve reforma como alferes. Já o sapateiro Antonio Joaquim de Almeida, que era sargento quando Neves ingressou nos Úteis, ascendeu a alferes em 1820 e a tenente em 1824. Ele era proprietário de dois escravos em 1822, mas não conseguiu mantê-los até 1825, quando não possuía nenhum, e, finalmente, tinha bens avaliados em meros 50\$000 mil réis. Apesar da relativa pobreza material (vide as tabelas 5.4 e 5.7), na milícia Almeida conseguiu acessar uma posição superior à alcançada por Neves.

Feitas essas considerações que afastam a possibilidade de estabelecimento de relação determinista entre a condição socioeconômica e a projeção na hierarquia miliciana, um olhar de sobrevoo a esse tema revela que, de fato, havia a tendência de que homens residentes na cidade de São Paulo ou nos centros das vilas interioranas, artesãos pendentes ao comércio e proprietários de escravos ocupassem os postos de maior prestígio e autoridade da corporação dos pardos. Em fins da década de 1820, os milicianos mais ricos do Batalhão N. 34 ocupavam postos de patente. Entretanto, diante da condição socioeconômica mais geral do grupo, não havia entre os pardos grandes escravistas ou detentores de grandes fortunas se apresentando como candidatos à oficialidade. Assim, boa parte dos postos foram providos em pequenos artesãos que levavam uma vida modesta e humilde. Nem mesmo o nascimento em cativeiro obstou o acesso ao topo daquela hierarquia.

Apesar da heterogeneidade existente no interior do grupo dos pardos livres e libertos de São Paulo, e em particular no dos milicianos do Regimento dos Úteis, está evidente a posição que eles ocupavam em meio à economia e sociedade paulista de finais do século XVIII e a primeira metade do XIX. Oriundos da escravidão negra, da administração e das aldeias

\footnotetext{
${ }^{64}$ Não convém citar as inúmeras ocasiões em que esses milicianos não proprietários foram localizados nas diversas listas nominativas. De qualquer modo, pode-se rastreá-los a partir de seus registros no Livro Mestre, fls. 10, 14$17 \mathrm{v}, 29 \mathrm{v}, 31 \mathrm{v}, 46,50,58 \mathrm{v}-62 \mathrm{v}, 63 \mathrm{v}, 68 \mathrm{v}, 70,77,88 \mathrm{v}, 97 \mathrm{v}-98,99,100-100 \mathrm{v}, 101-102 \mathrm{v}, 103 \mathrm{v}, 106,107 \mathrm{v}, 108 \mathrm{v}$, $109 \mathrm{v}, 111 \mathrm{v}, 113 \mathrm{v}-114,118 \mathrm{v}, 121,124,125-125 \mathrm{v}, 126 \mathrm{v}, 129,131-131 \mathrm{v}, 141,142-144 \mathrm{v}, 146,149,156,163 \mathrm{v}, 167$, $177 \mathrm{v}, 181,182,183 \mathrm{v}-184,185-185 \mathrm{v}, 186 \mathrm{v}, 193,199 \mathrm{v}, 208,210,215,224 \mathrm{v}-226 \mathrm{v}, 227 \mathrm{v}, 229 \mathrm{v}, 237 \mathrm{v}, 240 \mathrm{v}, 260 \mathrm{v}$, 265-268v, 274, 275v, 279-279v, 282v, 303, 305, 306-309v, 314, 323v, 333, 338, 343, 347-347v, 348v, 349v-350v, $374,377-377 v, 381 v-382,388-389,392 v, 401 v$.
} 
indígenas, e quase sempre de processos de mestiçagem, esses homens e suas famílias se integraram à dinâmica econômica local nos setores de prestação de serviços e de produção de gêneros agropecuários de subsistência e abastecimento interno. Foram raros os milicianos pardos que transcenderam esses limites e se integraram aos setores mais prósperos do comércio e da agricultura.

Essa era uma realidade inescapável e vinha à tona em todas as vezes em que os regimentos ou batalhões milicianos se enfileiravam nas ruas e praças para prestar serviços militares e participar de mostras ou cerimoniais. Talvez a diferença de condições materiais de sobrevivência não fosse extremamente pronunciada entre soldados brancos e soldados pardos, não obstante o fato de que os primeiros pudessem de partida se considerar em posição socialmente superior aos últimos em função dos estigmas imputados às pessoas de cor. No entanto, o contraste maior se produzia entre a oficialidade parda e a dos demais regimentos ou batalhões. Se entre os oficiais brancos vigia certa harmonia quanto à relação entre condição social e as funções sociais de prestígio, tanto a origem social quanto as condições socioeconômicas dos pardos denunciavam o descompasso existente entre esses âmbitos e as posições de honra e nobreza que ocupavam na milícia. Levando em conta o material aqui examinado e a produção historiográfica relativa a outros espaços ibero-americanos, fica claro que a imensa maioria dos oficiais de cor não detinha capital social mínimo para competir abertamente com oficiais brancos caso não existisse essa via específica de inserção no serviço militar que eram os corpos milicianos formados privativamente por pardos e pretos. Tais instituições apresentavam, pois, um caráter paradoxal: por um lado, reproduziram e amplificaram as distinções e estigmas sociais fundados na cor; por outro, constituíram as principais vias de acesso da população de cor às honras e graus de nobreza inerentes às patentes militares. 
PARTE 3 


\section{CAPÍtulo 6 - Milicianos PARdos EM UM CAMPO de TENSÕes (I): MONARQuia, REFORMADORES, OFICIAIS DE LINHA E SOLDADOS PARDOS}

\subsection{Introdução}

O período compreendido pelos finais do século XVIII e as três primeiras décadas do século XIX constitui o ápice do longo processo de formação da estrutura militar luso-americana e brasileira. A grande concentração de efetivos militares dispostos nas diferentes capitanias/províncias e o tipo de equilíbrio vigente entre a tropa regular e a milícia não se repetirão após iniciar-se a década de 1830. Desse período em diante, houve grande desconfiança tanto em relação à militarização em geral - representada fundamentalmente pela tropa regular - quanto ao papel desempenhado pelas milícias - como atores corporativos e como porta-vozes de segmentos sociais mais amplos - na vida social e política da América portuguesa e por todo o Primeiro Reinado. Por isso, a extinção das milícias e das ordenanças seguida pela criação da Guarda Nacional, de um lado, e a diminuição dos efetivos da Tropa de Linha remanescente, de outro lado, foram medidas implementadas já nos primeiros anos da Regência. Tais ações revelam igualmente que a estrutura militar oriunda do período colonial atingira sua extensão máxima. Nem as finanças do Estado eram capazes de sustentá-la e nem a dinâmica econômica e social brasileira apresentava propensão a manter um Exército de tamanha dimensão. Durante a maior parte da década de 1830 , a $1 .^{a}$ Linha fora formada por um contingente inferior a dez mil homens e a Guarda Nacional apresentara efetivos ainda menores. ${ }^{1}$

Tudo isso contrasta com os mais de 14 mil soldados de linha e os quase 91 mil milicianos em serviço ativo nas várias regiões da América portuguesa na década de 1800, e aos mais de 26 mil homens da tropa paga e os cerca de 109 mil integrantes das milícias mobilizados em todo o Império do Brasil nos anos de $1820 .^{2}$ Tratava-se pois de uma estrutura militar correspondente a uma conjuntura marcada de cabo a rabo por tensões e abalos nos equilíbrios de poder vigentes no mundo ocidental e pela ocorrência, de tempos em tempos, da guerra. Nesse sentido, como já indicado, a Guerra dos Sete Anos (1756-1763) constituiu um ponto de inflexão em termos da militarização tanto da Europa como da América - um capítulo específico do longo processo de construção do exército moderno. É nessa vaga que as milícias se proliferam e

\footnotetext{
${ }^{1}$ CASTRO, Jeanne Berrance de. A milícia cidadã: a Guarda Nacional de 1831 a 1850. 2. ed. São Paulo: Companhia Editora Nacional, 1979, p. 62-102.

${ }^{2}$ Vide os capítulos 1 e 2 desta tese.
} 
dispersam sobre os territórios portugueses e espanhóis na América em um ritmo e intensidade inéditos, o que inclui, evidentemente, os terços, regimentos ou batalhões de pardos e de pretos. De fato, o mapeamento desses corpos militares revelou que a profusão das milícias de pardos e de pretos marcou o século XVIII, e mais especificamente a sua segunda metade. Durante o período anterior, isto é, a segunda metade do Seiscentos e a primeira metade do Setecentos, inúmeras companhias de ordenanças formadas por pardos e pretos atuavam no Estado do Brasil, mas, em contraste, eram raras e restritas ao Nordeste açucareiro as formações mais robustas, como os terços, integradas por essa população. As reformas empreendidas a partir da década de 1760 resultaram na criação de vinte terços auxiliares, depois convertidos em regimentos milicianos, em diferentes localidades, a maioria deles sendo identificada aos pardos.

Como era de se esperar, os efeitos dessa expansão militar, e em particular das milícias de pardos e de pretos, cujo ápice se localiza precisamente na virada do século XVIII para o XIX, não se restringiram aos aspectos quantitativos da mobilização bélica. Antes, esse fenômeno histórico estava impregnado de considerações e consequências políticas. Uma parte delas já foi preliminarmente explorada quando se considerou que a dimensão que as milícias de brancos, pardos, pretos e índios assumiam em cada capitania ou configuração social não correspondia necessariamente à disponibilidade de população de cada uma dessas classes. $\mathrm{Ou}$ seja, embora a existência de grupos sociais de pardos e de pretos livres fosse um requisito à formação de corpos militares privativos a eles, de um lado, e que houvesse a tendência de que as configurações sociais com maior população de pessoas de cor livres abrigassem o maior número de milícias de pardos e de pretos, de outro lado, percebe-se que essa relação entre população e milícia não era diretamente proporcional e nem se processava de modo determinista. Certos casos nos quais tanto o número como as características daqueles corpos militares destoavam sensivelmente em relação ao vulto demográfico e social das camadas mais amplas de pessoas de cor livres - o que ocorria, nomeadamente, nas capitanias da Bahia e de Goiás - acenam para a importância desempenhada por outras variáveis na definição de aspectos atinentes às milícias de cor. Previamente examinados, os diferentes níveis de envolvimento das localidades com a guerra conformam uma dessas variáveis.

Resta, daqui em diante, abordar mais detidamente a face política da existência e da atuação das milícias de pardos e de pretos nesse ponto alto de sua trajetória histórica, prolongado até o ano de 1831, tomando-se como fio condutor o Regimento dos Úteis de São Paulo. Neste e no capítulo seguinte, serão examinados os temas referentes à oficialidade de cor, às diferentes dimensões da competição pelo acesso aos postos, às tensões inerentes ao equilíbrio 
de poder interno à milícia dos pardos, à participação do Regimento dos Úteis na independência do Brasil e à trajetória de uma família parda na milícia como forma de nobilitação.

Esses diferentes temas estão organizados em seções específicas, mas, a despeito dessa separação didática, constituem dimensões entrelaçadas de um mesmo fenômeno histórico, que é a imersão da milícia de cor em relações de poder de múltiplos níveis e notadamente no âmbito do Estado. A face política da experiência da milícia, portanto, resulta do entendimento de que a sua expressão social não se restringia à esfera de uma instituição que cumpria funções específicas e vitais para o funcionamento da sociedade. Mais do que isso, esses corpos militares eram formados por um emaranhado de pessoas conectadas umas às outras, dotadas de visões de mundo particulares correspondentes às múltiplas funções sociais que desempenhavam a partir de posições sociais específicas. Cada regimento miliciano assumia a forma de uma configuração social, isto é, uma teia constituída por pessoas interdependentes umas em relação às outras e estruturada a partir de equilíbrios de poder mais ou menos estáveis. As distinções hierárquicas estruturavam institucionalmente as relações de poder entre seus componentes, e enquanto a execução do serviço previa a colaboração mútua entre oficiais e soldados, as pressões internas atinentes à imposição de autoridade e à disputa pelos postos imprimiam rivalidades em seu meio. Isso significa pensá-los como unidades sociais no interior das quais se estabelecem relações de cooperação e de competição além de inúmeras outras formas de expressão social entre os seus componentes.

Ao mesmo tempo, os corpos militares como configurações sociais não podem e nem devem ser vistos de modo isolado e estático, pois constituíam configurações sociais mais abrangentes e dinâmicas a partir da sua relação de interdependência com outros corpos militares e com o corpo social mais amplo ao qual faziam parte. Os corpos militares deviam realizar as atividades militares em sintonia uns com os outros e com o governo, mas não era raro que as exigências do serviço ou questões de precedência e de honorabilidade inerentes àquela sociedade escravista e com feições de Antigo Regime dessem margem a desentendimentos e disputas de poder mais explícitas entre as diferentes corporações e os oficiais régios responsáveis pelos assuntos militares. Quer dizer que as ações de uma dada instituição militar, encarada como configuração social, só podem ser compreendidas a partir tanto de seus movimentos internos quanto mediante a sua posição relativa a outras configurações sociais estabelecida no interior de unidades mais vastas. Isso ficará mais claro adiante.

Abordar as milícias de cor como configurações sociais que, por sua vez, formavam configurações sociais mais abrangentes com outros corpos militares e com diferentes dimensões da sociedade e do governo, permite que elas sejam pensadas a partir dos pertinentes modelos 
de jogos propostos por Norbert Elias. ${ }^{3}$ A noção de jogos remete à ideia de competição e, com efeito, conforme a sociologia processual e configuracional de Elias, os indivíduos e quaisquer tipos de atores sociais passam a medir forças uma vez que estabeleçam relações com outros. Dos entrelaçamentos entre pessoas e instituições que são dotados, cada um de seus componentes, de potenciais de retenção de força ou poder relativamente uns aos outros, se produzem equilíbrios de poder mais ou menos estáveis. O grau de estabilidade ou instabilidade dos campos de força, ou equilíbrios de poder, depende das mudanças em termos do potencial de poder que cada ator social experimenta. Se um indivíduo, um grupo ou uma corporação dispõe de grande poder relativamente a outros e consegue manter esse diferencial, então o equilíbrio de poder encontra-se estável. Quando este jogador se vê enfraquecido, porém, significa que há indivíduos, grupos ou corporações emergentes, aptos a diminuir as distâncias sociais ou os diferenciais em termos do potencial de poder, ampliando os recursos para desafiar a posição do ator prevalecente. Nesse caso, o equilíbrio de poder assume contornos de instabilidade. Esse tipo de relações também pode ser pensado a partir do modelo teórico eliasiano de estabelecidos e outsiders. ${ }^{4}$

Se a milícia estava envolta numa espécie de jogo, então é fundamental saber quais eram os jogadores e quais os objetos do desafio. A começar pelo último aspecto, a própria definição da função elementar da milícia como uma instituição integrante das forças armadas - a quem cabia o exercício legítimo da força física e da violência para assegurar a paz interna e proteger o território de invasões estrangeiras - induz a pensar que o jogo em questão se tratava de uma disputa no campo das armas e em termos de poderio militar. Vários governadores e burocratas coloniais expressaram a hipótese de que, em algum momento, os milicianos pardos e pretos poderiam vir a levantar as suas armas contra os brancos e, em decorrência, contra a ordem vigente, o que corroboraria essa primeira impressão. Entretanto, como ficará claro ao longo desta parte da tese, havia múltiplos objetos em disputa, a depender das dimensões do jogo e dos jogadores considerados, mas, em qualquer circunstância, o emprego da força física por parte dos pardos de São Paulo não seria mais do que uma opção remota. As competições pelo controle do Regimento dos Úteis e pelos bens simbólicos de Antigo Regime jamais poderiam ser simplificadas em termos do emprego de força física. Ao contrário do que qualquer perspectiva

\footnotetext{
${ }^{3}$ ELIAS, Norbert. Introdução à sociologia. Lisboa: Edições 70, 2008, p. 77-112.

${ }^{4}$ ELIAS, Norbert. Introdução à sociologia..., p. 77-112 e 133-145. Em linhas gerais, esse raciocínio é o mesmo subjacente ao modelo teórico de relações estabelecidos-outsiders. Ver ELIAS Norbert. Introdução. Ensaio teórico sobre as relações estabelecidos-outsiders. In: ELIAS, Norbert; SCOTSON, John L. Os estabelecidos e os outsiders. Sociologia das relações de poder a partir de uma pequena comunidade. Trad. Vera Ribeiro. Rio de Janeiro: Jorge Zahar Editor, 2000, p. 19-50.
} 
estática acerca da sociedade escravista brasileira pode fazer pensar, a supremacia social dos brancos e o seu distanciamento em relação a pardos, pretos, índios e toda a sorte de mestiços, fossem eles livres, libertos, administrados ou escravos, era construída, reiterada e questionada cotidianamente. A vigência da escravidão, dos critérios hierárquicos de tipo aristocrático e dos estigmas atribuídos às populações índio ou afrodescendentes durante quatro séculos sugere um elevado grau de estabilidade a esse equilíbrio de poder que pendia favoravelmente aos brancos. Mas mesmo uma tamanha estabilidade como essa decorria do funcionamento de uma complexa mecânica social. ${ }^{5}$ E reduzindo-se a escala de observação, nota-se que esse tipo de exercício de domínio vinha acompanhado de inúmeras expressões que lhe conferiam alguma instabilidade. Uma decorrência relevante desse raciocínio é o entendimento de que a condição estabelecida das famílias brancas tradicionais que viviam à lei da nobreza bem como a condição outsider de pardos e pretos descendentes de escravos não eram fenômenos inatos, mas decorrentes de processos históricos e sociais, e, portanto, passíveis de mudança.

As milícias pardas e pretas constituíam precisamente as principais vias de expressão social e política às pessoas de cor livres. ${ }^{6}$ Elas não apenas conformavam um grande veículo de ascensão social à disposição especialmente das oficialidades, mas se transformaram, por assim dizer, nos mais importantes jogadores a representar pardos e pretos em sua busca por concentrar poder relativamente aos grupos concorrentes e por minimizar o distanciamento social em relação aos brancos. Demonstrou-se extensamente que os pardos descendiam de escravos, administrados, índios e mestiços de toda sorte, viviam modestamente, a maioria sem dispor de escravos, e viam-se numa competição com brancos muito melhor situados socialmente. Tratava-se, em suma, de uma competição profundamente desigual, que somente poderia ter sido levada a cabo no universo específico da milícia. Assim, as disputas de poder que eram travadas no universo militar estavam diretamente vinculadas com a configuração da sociedade mais ampla. Mesmo no interior das configurações sociais correspondentes aos terços e regimentos, as disputas por postos e as tensões existentes entre aqueles que mandavam e aqueles que obedeciam adquiriam semelhante conotação. Essas são apenas algumas das dimensões do jogo, cujo objeto principal, para os oficiais militares e milicianos, era a aquisição de privilégios, honrarias, distinções, isenções, liberdades, garantias, e daí por diante, o que pode ser traduzido por obtenção de potencial de poder relativamente aos demais competidores. A competição em

\footnotetext{
${ }^{5}$ Para uma abordagem que considera a estabilidade do sistema escravista no Brasil a partir de perspectiva processual, ver MARQUESE, Rafael de Bivar. A dinâmica da escravidão no Brasil. Resistência, tráfico negreiro e alforrias, séculos XVII a XIX. Novos Estudos, n. 74, p. 107-123, 2006.

${ }^{6}$ RUSSELL-WOOD, A. J. R. Escravos e libertos no Brasil colonial. Trad. Maria Beatriz de Medina. Rio de Janeiro: Civilização Brasileira, 2005, p. 129-142, 289-290.
} 
questão se desdobrava em níveis tanto mais crescentes e complexos quanto o número de jogadores e de jogadas se via ampliado. Os participantes eram, essencialmente, os integrantes (oficiais e soldados) dos terços e regimentos pardos e pretos, a oficialidade branca tanto miliciana quanto oriunda da tropa regular, governadores e oficiais militares de alto escalão, e, finalmente, no nível mais elevado, a Coroa, representada pelos detentores diretos da soberania, pelo Conselho Ultramarino e pelos demais ministros que atuavam relativamente aos assuntos do Brasil.

Sugere-se aqui que as Coroas portuguesa e, após 1822, brasileira mantinham interesses de primeira ordem no seu relacionamento com os integrantes dos corpos militares lusobrasileiros: a) garantir a prestação de serviço militar eficaz, o que, sobretudo da segunda metade do século XVIII em diante, passava pelo incentivo aos quadros técnicos; b) impor-se aos poderes locais e controlar poderes concorrentes, advindo daí que a nomeação de oficiais da tropa de linha para as milícias brancas significaria, além da profissionalização do serviço militar, a retirada do comando militar das mãos das elites locais; c) promover a manutenção do equilíbrio social via controle social às populações livres pobres; isso implicaria o estabelecimento de relações específicas com tais grupos, a delegação de funções, o reconhecimento de seus nichos particulares de atuação e de suas lideranças, a reafirmação dos laços recíprocos de fidelidade, e o estímulo às divisões entre escravos e seus descendentes livres e libertos.

Todos os participantes dessa grande espécie de jogo estavam entrelaçados em relações de interdependência recíproca. Ao mesmo tempo em que todos atuavam conjuntamente visando à manutenção da paz interna e a defesa das fronteiras, eles também mediam forças entre si e buscavam ampliar as suas concentrações de poder relativamente aos demais. Como essa teia social incluía desde os simples soldados até os príncipes e reis, todos eles tornavam-se jogadores, diferenciando-se entre si sobretudo pela posição que ocupavam nos campos de força e pela concentração de poder de que dispunham. Mas em virtude do caráter móvel dessas posições e dos níveis de poder, todas as mudanças experimentadas por quaisquer dos participantes do jogo interferiam nos demais aos quais estavam vinculados. Portanto, a dinâmica do processo social - ou do jogo - é capaz de alterar os equilíbrios de poder, sendo que a competição entre os integrantes, que geralmente se manifesta de modo latente quando esse se encontra estável, tende a vir à tona com mais ênfase nas situações de instabilidade.

As relações estabelecidas entre os diversos atores sociais envolvidos com a milícia eram reguladas por leis e normas de comportamento que em geral respeitavam as posições institucionais e refletiam as distintas posições de poder de seus integrantes. No interior dos 
regimentos, os oficiais tinham precedência sobre os subordinados, de modo que determinados aspectos da competição entre ambos não podiam ser abertamente expressados. Era comum que oficiais mobilizassem os meios disciplinatórios e punitivos ao seu alcance sempre que tivessem queixas quanto ao comportamento dos soldados, ao passo que, do outro lado, os soldados encontravam sérias dificuldades para acusarem os seus superiores. Já as disputas de poder que marcavam as relações estabelecidas entre diferentes corpos militares ocorriam tipicamente de modo velado, uma vez que deviam se comportar harmoniosamente como aliados perante os governadores de capitanias, governadores de armas de províncias e principalmente com as instituições mais centrais do Estado. De sua parte, os representantes dessas instâncias superiores eram incumbidos de se portarem equanimemente nas questões concernentes às forças armadas, prezando prioritariamente pela justiça e pelo bem comum.

A descrição acima reflete melhor as relações vigentes em equilíbrios de poder estáveis. De modo oposto, nos capítulos e seções seguintes as milícias pardas e pretas, e notadamente o Regimento dos Úteis, serão examinados como campos de força de diferentes dimensões marcados por níveis elevados de tensão e instabilidade ao longo do período que vai da segunda metade do século XVIII às três primeiras décadas do XIX, no qual o processo de transformação histórica se acelera no sentido da desestruturação do Antigo Regime e do sistema colonial e da construção dos Estados-nação liberais e constitucionais.

\subsection{A legislação referente à existência das milícias de pardos e de pretos na América portuguesa e a regulamentação da oficialidade desses corpos militares}

Para que se possa adensar a perspectiva em torno da face política tanto da existência e da atuação das milícias de pardos e de pretos quanto do seu relacionamento com o Estado, é preciso começar pela desnaturalização dos fenômenos em questão. Significa demonstrar, primeiramente, que o estabelecimento e manutenção de corpos militares separados por cor, e, em segundo lugar, da oficialidade de patente composta por seus próprios integrantes, eram produtos de disputas, tensões e pressões vivenciados em vários níveis e decorridos em tempo longo - não se tratando, em síntese, de pontos pacíficos ou de aspectos inatos àqueles corpos militares. Acompanhar o encaminhamento dessa questão ao longo do tempo é deslindar um processo de mudança de status vivenciado não somente pelos milicianos pardos e pretos, mas igualmente por seus corpos militares como atores corporativos. Nessa linha, é fundamental ler 
o acesso aos postos superiores dos corpos militares como uma forma de habilitação nos termos do Antigo Regime, isto é, admissibilidade ao exercício de funções sociais ligadas à administração e a gestão estatal e das quais emanavam distinções, honrarias e privilégios. Por isso mesmo, um âmbito repleto de disputas e, no tocante aos pardos e pretos, de interdições. $\mathrm{O}$ que se segue, portanto, é um exame do processo de conformação dos corpos militares exclusivos a pardos e pretos na América portuguesa atrelado ao da legislação que regulou a presença dessas pessoas nos postos da oficialidade.

Ter em vista os traços gerais do processo de formação, institucionalização e difusão territorial das milícias de pardos e de pretos na América portuguesa é essencial para que se compreenda adequadamente os termos da legislação que buscou regular a sua existência e a da oficialidade de cor. Por sua vez, o conhecimento dessas normas implica dialogar com o contexto que as informa e com as etapas do processo de constituição das tropas e da configuração atingida pela oficialidade. A legislação, portanto, pode ser ao mesmo tempo resultante das práticas sociais previamente estabelecidas que procura normatizar e inauguradora de novos padrões de conduta e comportamento institucional. $\mathrm{O}$ exame empreendido anteriormente à criação das forças militares de segunda linha em meio à formação da estrutura militar portuguesa e luso-americana, em particular, permitiu visualizar o papel de destaque crescentemente assumido pelos auxiliares e depois pela milícia entre os séculos XVII e XIX bem como a natureza de sua importância, algo que dificilmente a visão cristalizada de uma estrutura militar formada por três linhas revela. Algo semelhante se verifica em relação ao fenômeno do acesso de pardos e pretos aos postos de autoridade e comando de suas milícias. Ora, a simples constatação da existência de oficialidades de cor em um dado momento pouco informa, por si só, sobre os processos históricos e sociais que levaram ao estabelecimento de tais instituições separadas por cor e que permitiram que pessoas oriundas dos níveis inferiores da sociedade fossem investidas em funções sociais de autoridade e prestígio. $\mathrm{O}$ breve percurso pela trajetória histórica das oficialidades parda e preta busca, enfim, fornecer os elementos fundamentais para que se possa melhor examinar o quadro de tensões sociais e políticas que a sua existência despertava, em fins do século XVIII e as primeiras décadas do XIX, envolvendo diretamente a Coroa, os governadores e membros do alto escalão do exército, e os oficiais milicianos pardos e pretos.

Uma primeira fase do processo em questão compreende o período secular que vai dos anos 1630 a 1730. Esse é o momento histórico de formação das primeiras companhias de pretos, pardos e índios no Nordeste açucareiro no calor das guerras luso-holandesas, cujos corpos militares, conforme Luiz Geraldo Silva, não passavam de bandos nos períodos mais recuados, 
e de seu posterior emprego nas guerras de Palmares e "dos Bárbaros" e paulatino enraizamento na sociedade local. Ele marca, igualmente, a difusão dessas companhias pela região Centro-Sul da América portuguesa desde finais do século XVII e notadamente após as descobertas de ouro em Minas Gerais, Goiás e Mato Grosso. Enquanto as tropas de Henrique Dias, dos Pardos e dos índios de Felipe Camarão, em Pernambuco, e os Henriques, na Bahia, foram assimilados definitivamente à estrutura militar, tomando a forma de terços, nas demais regiões aquelas forças militares não passavam de companhias avulsas ou agregadas a terços e regimentos identificados às pessoas brancas ou aos distritos de atuação. Não houve, por todo esse momento, uma definição clara por parte da Coroa quanto ao status dessas tropas. Assim como elas surgiam de modo relativamente espontâneo, em resposta tanto às necessidades da guerra quanto ao interesse dos homens de cor, ou, melhor dizendo, em meio às dinâmicas próprias do mundo colonial, a sua evolução foi ocorrendo mais por intermédio das interações entre práticas locais e o encaminhamento de demandas junto ao Estado do que por ações deliberadas antecipadamente pela Monarquia europeia. Em realidade, no que se refere a esse período, inexistem regulamentos específicos para as tropas auxiliares coloniais, fossem elas brancas ou de cor, e esse é um traço compartilhado pelas Monarquias ibéricas. ${ }^{7}$ Esta é, pois, uma fase de formação e institucionalização dos primeiros terços e companhias de pardos e de pretos, a qual fora já marcada pela conquista de privilégios, tais como o provimento dos postos da oficialidade em seus próprios integrantes e a obtenção de soldo para os oficiais do estado-maior. ${ }^{8}$

O curto período compreendido pelos anos de 1730 a 1766 corresponde a uma segunda fase desse processo de constituição dos corpos militares de pardos, pretos e indígenas e de formatação de suas oficialidades. O aspecto inaugurador dessa etapa, e que ao fim e ao cabo a caracteriza, é a primeira grande intervenção régia no desenvolvimento até então relativamente autônomo dos corpos militares em questão, a qual se encaminhou no sentido da destituição das respectivas oficialidades e da desintegração dos corpos militares separados por cor.

Com efeito, por Carta de 14 de janeiro de 1731, enviada separadamente a todas as capitanias da América portuguesa, o rei lusitano expressou as mais recentes deliberações do Conselho Ultramarino acerca daquelas tropas. Os ministros viram com preocupação o fato de

\footnotetext{
${ }^{7}$ SILVA, Luiz Geraldo. Gênese das milícias de pardos e pretos na América portuguesa: Pernambuco e Minas Gerais, séculos XVII e XVIII. Revista de História, São Paulo, n. 169, p. 112-144, jul./dez. 2013. Para espaços hispano-americanos, ver CAMPBELL, Leon G. The changing racial and administrative structure of the peruvian military under the later bourbons. The Americas, v. 32, n. 1, p. 117-133, 1975; VINSON III, Ben. Articular el espacio: el establecimiento militar de gente de color libre en el México colonial de la conquista hasta la independencia. Callaloo, v. 27, n. 1, p. 331-354, 2004; MARCHENA FERNÁNDEZ, Juan (Coord.). El ejército de América antes de la independencia. Ejército regular y milicias americanas, 1750-1815 - Hojas de servicio y uniformes. Madrid: Fundación Mapfre Tavera, CD-Rom, s./data, p. 103-106.

${ }^{8}$ SILVA, Luiz Geraldo. Gênese das milícias...
} 
que "nesse Estado haja Corpos de Infantaria da Ordenança separados de pardos e bastardos, o que pode ser em grande prejuízo desse Estado e muito contra a quietação e sossego desses povos, o que se faz digno de todo o cuidado e atenção". Diante dessas considerações de ordem política, a Coroa estabeleceu

que o mais conveniente será não separar esta gente, dando-lhes oficiais e cabos que os governem separadamente, e que parece mais acertado que todos os moradores de um distrito sejam agregados àquela Companhia, ou Companhias, que houver naquele distrito, sem que haja Corpos separados de pardos e bastardos, com oficiais privativos, e que assim o deveis executar conformando-vos com o Regimento das Ordenanças, que assim o dispõe. ${ }^{9}$

Dois anos após essa medida contundente, expediu-se nova ordem relativamente aos corpos militares coloniais formados pela gente de cor, reiterando-se o disposto para os pardos e incorporando os pretos em seus termos. A existência de "corpos de Infantaria da Ordenança de pardos separados nesse Estado" foi novamente considerada prejudicial à Coroa e uma vez mais se recomendou que eles fossem incorporados às companhias dos brancos e que, assim que os postos da oficialidade das "Companhias dos pardos forem vagando, se não provam mais, por ser escusada esta separação e fiar dos pardos me sirvam como brancos”. Quanto aos pretos, a ordem foi para que "se extingam" seus corpos de Ordenança "na mesma forma que mando praticar com os pardos, ficando os negros forros alistados em companhias sujeitos aos capitãesmores das freguesias ou aos coronéis das Ordenanças". ${ }^{10}$ Como na capitania de Pernambuco ainda se preservava a figura do capitão e governador dos índios - um resquício do terço de D. Antonio Felipe Camarão - a Carta régia que dispôs a abolição dos corpos e oficialidades militares específicas para pardos e pretos foi extensiva a eles. Determinou-se que "cada Aldeia seja governada por um capitão dos mesmos Índios, como era, e do seu missionário [...], e que para o militar fiquem sujeitos ao capitão-mor do distrito". ${ }^{11}$

Após quase um século de funcionamento desses corpos militares coloniais chancelados por governadores locais e pelo poder régio, os quais, afinal, proviam os postos e confirmavam

\footnotetext{
${ }^{9} C f$ :: "Proibindo a existência de corpos separados de pardos e bastardos". DIHCSP, vol. 24, p. 43-44. Esta cópia é a que foi remetia a São Paulo. Para a cópia referente à Pernambuco, ver AHU_CU_015, Cx. 42, D. 3797. Recife, 10 de março de 1732. Para o Maranhão, ver AHU_ACL_CU_009, Cx. 18, D. 1917. São Luís do Maranhão, 29 de junho de 1731. Para Minas Gerais, ver Arquivo Público Mineiro, SG-Cx.29-Doc.136.

${ }^{10}$ Cf:: AHU_ACL_CU_005, Cx. 45, D. 4011. Bahia, 13 de abril de 1733.

${ }^{11}$ Cf:: AHU_CU_015, Cx. 42, D. 3797. Recife, 10 de março de 1732; “Consulta do Conselho Ultramarino n. ${ }^{\circ} 61$ ". DH, vol. 100 , p. $92-94$. Lisboa, 31 de outubro de 1732. Sobre a desestruturação do governo militar dos índios de Pernambuco e em particular da crise de prestígio e autoridade da família Camarão, ver RAMINELLI, Ronald. Privilegios y malogros de la familia Camarão. Nuevo Mundo Mundos Nuevos [Online], Colóquios, posto online no dia 17 de março de 2008. URL: http://nuevomundo.revues.org/27802.
} 
as patentes correspondentes, a Coroa portuguesa interveio enfaticamente pondo fim aos terços e companhias de pardos, pretos e índios. Tratava-se de uma imposição do modelo reinol das Ordenanças à organização militar desenvolvida na colônia, a qual, se bem que espelhada nas ordenanças, assumia contornos próprios. Tais medidas implicariam, por um lado, um duro golpe na autogestão desses grupos e, por outro, e complementarmente, sua subordinação aos capitães-mores brancos.

A explicação para essa interferência súbita da Coroa na organização dos corpos militares de pardos, pretos e indígenas, que, de fato, ocorreu em um contexto caracterizado por intensificação da participação régia nos assuntos coloniais, não se restringe, porém, à observância de aspectos técnicos do Regimento das Ordenanças. Em uma instigante interpretação, Silva sugeriu que todo o processo de "gênese das milícias de pardos e de pretos" se deu em "um campo de disputas e tensões, no interior do qual indivíduos interdependentes, situados em diferentes níveis, tentavam impor seus pontos de vista através de relações marcadas por um enorme diferencial de retenção de poder". Ao passo que ministros de Estado, governadores e burocratas coloniais, ao examinarem as diferentes configurações sociais com as quais lidavam, tinham em vista as múltiplas questões atreladas à administração do Império, os milicianos de cor, que também batalhavam pela manutenção da ordem, demandavam diferentes tipos de retribuição à sua lealdade, todos, evidentemente, inseridos nas lógicas de distinção de Antigo Regime. A gestão das questões atinentes a esses corpos militares e aos seus integrantes fazia parte, na verdade, de "um jogo dotado de regras, de estrutura, mas que ninguém, nem no nível mais alto e muito menos no nível mais baixo, conseguia enxergar em seu conjunto ou controlar. Tratava-se, portanto, de um processo social não planejado, mas dotado de coerência e estrutura $[\ldots]]^{\prime 12}$

As ordens régias em questão veiculavam o argumento de que aquelas companhias e terços poderiam gerar "grande prejuízo" ao Estado, pois concorriam "contra a quietação e sossego desses povos, o que se faz digno de todo o cuidado e atenção". Essa retórica parece acenar para uma atitude de precaução relativa a eventuais perigos à segurança pública e a distúrbios inerentes a prática de se armar populações de baixa condição e de se permitir que elas fossem comandadas por seus próprios integrantes. Em certo sentido, pardos, pretos e índios surgem como alvos da desconfiança monárquica. ${ }^{13}$ Entretanto, o acúmulo de pressões exercidas

\footnotetext{
${ }^{12}$ SILVA, Luiz Geraldo. Gênese das milícias..., p. 130-136. Grifos no original.

${ }^{13}$ A primeira metade do século XVIII assiste a fenomenal emergência do grupo de pardos, pretos e mestiços livres em Minas Gerais que em pouco tempo se transformaria no maior grupo de pessoas de cor livres e libertas das Américas. Não era incomum que as autoridades vissem essa coletividade como ameaçadora em vários sentidos. A esse respeito, ver "Carta do Conde das Galveias, governador das Minas, para D. João V, em cumprimento da
} 
por pardos e pretos integrantes de corpos militares privativos às suas cores junto ao centro de poder monárquico, e tudo o que isso significava do ponto de vista da manutenção do diferencial de poder existente entre brancos e "outros" no qual repousavam as diferentes capitanias lusoamericanas, foi o que certamente desencadeou a pronta intervenção régia. O desequilíbrio social resultante da produção e reprodução de elites entre as pessoas de cor, que, da baixeza de suas origens e condições materiais, ascendiam a posições associadas à nobreza, isso sim, era o que mais alarmava o establishment. Ora, não há quaisquer vestígios nas fontes consultadas que indiquem a incidência de admoestações a oficiais pardos e pretos por comportamento inadequado na execução do serviço e que oferecessem ameaças à ordem. ${ }^{14}$ Em sentido oposto, o cerceamento a tais oficialidades surge associado diretamente à apresentação de demandas, justificadas e dentro dos parâmetros vigentes, para a formação de corporações e provimento de postos.

Em 1728, quando Francisco Gil de Andrade procurou confirmar a sua patente de capitão dos homens pardos e bastardos forros de Vila Real, passada pelo governador de Minas Gerais havia dez anos, foi surpreendido com uma negativa do Conselho Ultramarino e da Coroa. ${ }^{15}$ As deliberações sobre esse caso anteciparam as medidas mais gerais ordenadas em 1731 e 1733, sendo que a primeira fez referência ao caso de um outro capitão pardo, Antonio Telles de Albuquerque, em tudo semelhante à situação de Andrade. Por esses mesmos anos, precisamente em 1729, os capitães, alferes e mais oficiais das companhias de pardos de Salvador requereram ao rei a formação de um regimento de pardos, pois até então serviam agregados aos terços das ordenanças, a cujos oficiais eram subordinados. Eles objetivavam erigir um corpo militar cujas dimensões institucional e simbólica ultrapassavam e muito o das simples companhias. Essa

provisão de 20.05.1732, dando o seu parecer sobre os inconvenientes de haver negros forros naquela Capitania e sobre a frequência da concessão da alforria”. AHU_CU_011, Cx. 22, D. 1776. Consultar, igualmente, RUSSELLWOOD, A. J. R. Escravos e libertos..., p. 129-142 e SILVEIRA, Marco Antonio. Soberania e luta social: negros e mestiços libertos na Capitania de Minas Gerais (1709-1763). In: CHAVES, C. M. das G.; SILVEIRA, M. A. (Orgs.). Território, conflito e identidade. Belo Horizonte: Argumentum, 2007. Quanto aos índios, o governador de Pernambuco Duarte Sodré Pereira Tibão expressou a opinião de que o grupo, liderado por governador e capitãomor próprio, era dado a insolências "como bárbaros" e propenso a se associar facilmente a "inimigos da Europa". Ver "Carta do governador da capitania de Pernambuco, Duarte Sodré Pereira Tibão, ao rei D. João V informando não haver necessidade de Corpos separados de pardos e negros, sugerindo a extinção dos postos de mestre-decampo e sargento-mor dos mesmos, assim como o de governador dos índios”. AHU_CU_015, Cx. 42, D. 3797. Recife, 10 de março de 1732.

${ }^{14}$ Sobre o comprometimento de pardos e de pretos com a ordem, mediante discursos e práticas de controle social vigentes no universo das irmandades religiosas, ver SOUZA, Fernando Prestes de; LIMA, Priscila de. "Que haja paz e quietação": controle social e irmandades negras na América portuguesa, século XVIII. Revista Ágora, Vitória, n. 11, 2010, p. 1-22.

${ }^{15}$ Cf:: "Requerimento de Francisco Gil de Andrade, solicitando a mercê de o confirmar no posto de capitão da Ordenança dos homens pardos e bastardos forros da Vila Real de Nossa Senhora da Conceição do Sabará". Anterior a 27 de maio de 1728. AHU_CU_011, Cx. 12, D. 1027; APMG, SG-Cx. 29, doc. 75. Lisboa, 28 de janeiro de 1728 . 
demanda foi precedida de duas representações, nas quais os pardos baianos reiteraram os bons serviços prestados à Monarquia e requereram providências quanto aos atritos provocados pelos militares brancos. Estes se davam por duas vias: pelo desrespeito à honra dos oficiais pardos, já que os brancos se negavam a prestar-lhes as continências militares devidas, e pela desconsideração à sua autoridade, uma vez que buscavam imiscuir-se nos assuntos internos às companhias ao recrutar soldados pardos para os corpos militares de brancos. ${ }^{16}$ Está claro, então, que essa investida que acometeu pardos, pretos e índios em suas posições de comando tinha como objetivo precípuo a contenção das principais fontes de projeção social acessíveis a tais segmentos, de modo a brecar o processo mais amplo de transformação de status dessas coletividades.

A recepção a esse conjunto de reformas variou conforme a capitania. O governador de Pernambuco, Duarte Sodré Pereira Tibão, foi o grande entusiasta da abolição das companhias de pardos e do atrofiamento de sua oficialidade, tanto assim que a sugestão para que determinasse o mesmo aos pretos e índios partiu de seu gabinete. Em resposta à Carta régia de 1731, Tibão expôs que considerava "injurioso que a um preto, sem mais merecimento que de algum ofício mecânico, se lhe mande passar uma patente de mestre-de-campo e outra de sargento-mor". Tais eram as razões para que, antes mesmo da intervenção régia, ele cessasse, por conta própria, o provimento daqueles postos. ${ }^{17}$ No Rio de Janeiro, o governador Gomes Freire de Andrade também deu cumprimento às determinações, extinguindo as companhias de pardos e de pretos e reinserindo seus ex-integrantes nos terços de ordenanças. ${ }^{18}$

Em Minas Gerais, por outro lado, o governador Martinho de Mendonça de Pina e Proença não tardou a manifestar a $\mathrm{D}$. João $\mathrm{V}$ a impertinência das novas determinações. Expressando elementos diferentes, mas complementares, em relação aos critérios de distinção social evocados por Tibão, Pina e Proença alegou que a mescla de soldados brancos e de cor nos corpos militares "neste país causaria horror aos moradores, envileceria o exercício das

\footnotetext{
${ }^{16} C f:$ :"Carta do Rei de Portugal ao Vice-Rei do Brasil pedindo informações e parecer sobre uma petição dos Capitães, Alferes e mais oficiais de Infantaria da Ordenança das Companhias dos Homens Pardos Livres, dos Regimentos da cidade da Bahia, que solicitam separação das suas Companhias dos Regimentos aos quais se acham agregados, fazendo-lhes um regimento separado na forma que relatam na dita petição, melhor e mais convenientemente ao Serviço Real, e mandando passar Patente de Coronel do mesmo regimento ao Capitão Miguel Mendes de Vasconcelos". Lisboa, 22 de março de 1729. Arquivo Público do Estado da Bahia, Ordens Régias, vol. 25, Doc. 33; AHU_ACL_CU_005, Cx. 27, D. 2433 e D. 2436. Bahia, anterior a 25 de junho de 1726 e anterior a 28 de junho de 1726.

${ }^{17}$ Cf:: AHU_CU_015, Cx. 42, D. 3797. Recife, 10 de março de 1732. Ver também SILVA, L. G. Gênese das milícias..., p. 130-136.

${ }^{18}$ BARBOSA, Francielly Giachini. Tropas de homens de cor mobilizando e conectando capitanias: Bahia e Rio de Janeiro (1638-1763). Monografia de graduação. Curitiba: DEHIS, Universidade Federal do Paraná, 2014, p. $35-42$.
} 
ordenanças e faria que sem grande violência e indignação não concorressem a eles os brancos”. Vê-se aqui que a existência de corpos militares separados por cor cumpria uma função social concreta, a de demarcar rigidamente a diferença de cor e qualidade. Diante dessa demanda, a solução provisoriamente encontrada fora a de abolir as referidas companhias, mas conservar pretos, pardos e demais gente de cor em esquadras separadas dos brancos. ${ }^{19} \mathrm{O}$ Estado do Maranhão foi igualmente contemplado pelas medidas regidas de 1731, não obstante o fato de lá inexistirem tais corpos militares, como esclareceu o seu governador e capitão-general. $\mathrm{Na}$ ocasião, Alexandre de Sousa Freire ainda lembrou da existência dos terços pernambucanos de Henrique Dias e Felipe Camarão "sem que nem um e outro resultasse a Vossa Majestade algum desserviço, antes utilidade, pela glória que estes dois Regimentos de Pardos, de Índios e negros, granjearam em grande parte na restauração de Pernambuco". ${ }^{20}$ Em São Paulo, como visto anteriormente, as patentes de oficiais pardos e pretos continuaram a ser providas com normalidade na década de 1730 .

Finalmente, a resposta singela e apressada que o vice-rei Conde de Sabugosa forneceu em 1733 - "com as companhias dos pardos e com as dos pretos forros praticarei o que Vossa Majestade me ordena" - não expressa adequadamente a ebulição social provocada pela extinção da separação por cor nas ordenanças na Bahia. Com efeito, em 1735, os integrantes do terço dos pretos Henriques apresentaram-lhe uma petição com o objetivo de permanecerem, com sua corporação, no real serviço, "oferecendo novamente as vidas como fiéis vassalos que sempre souberam ser". Eles argumentaram ainda que o rei lusitano "foi servido mandar extinguir este terço [...] sem os suplicantes delinquirem em coisa alguma". Sabugosa reconsiderou a questão, atestou favoravelmente à causa dos pretos, e anuiu à conservação do terço. ${ }^{21} \mathrm{O}$ reconhecimento quanto à importância dos militares de cor baianos e a conquista da manutenção de seu terço serviu de exemplo aos pretos de Pernambuco, que, articulando a obtenção de documentos comprobatórios junto ao vice-rei, Conde das Galveias, requereram ao sucessor de Tibão a restauração do terço. Além da brecha oferecida pelo caso da Bahia, um dos argumentos de que se valeram os pretos pernambucanos indicava a repugnância dos brancos em aceitá-los em seus corpos militares, fato atestado pelo governador Henrique Luís Pereira Freire de Andrada. O

\footnotetext{
${ }^{19}$ Cf:: "Carta de Martinho de Mendonça de Pina e Proença, governador das Minas, para D. João V, dando conta da situação em que se encontram as ordenanças daquela Capitania e sugere um método para acabar com a desordem". Vila Rica, 18 de dezembro de 1736. AHU_CU_011, Cx. 32, D. 2609.

${ }^{20} C f$ :: "Carta em resposta à provisão sobre o pedido de António Teles de Alenquer, para sua confirmação no posto de capitão dos Pardos e Bastardos da passagem morro e outras vizinhas à vila do Carmo". São Luís do Maranhão, 29 de junho de 1731. AHU_ACL_CU_009, Cx. 18, D. 1917.

${ }^{21} C f$.: "Petição que fizeram os oficiais do terço da gente preta desta cidade ao excelentíssimo senhor conde vicerei”. $D H$, vol. 76, p. 345-348. Ver, ainda, as análises de SILVA, L. G. Gênese das milícias..., p. 130-136, e BARBOSA, F. G. Tropas de homens de cor..., p. 35-42.
} 
resultado dessas demandas foi um acordo entre o governador de Pernambuco, o vice-rei na Bahia e os pretos, que lograram a restituição de seu patrimônio institucional. ${ }^{22}$

A extinção das companhias e dos terços formados por pardos e pretos, bem como a descaracterização de suas oficialidades, revelaram-se medidas inviáveis na América portuguesa já na primeira metade do século XVIII. O Estado necessitava do serviço militar que esses homens podiam oferecer, mas concebeu como ideal o seu enquadramento junto aos brancos e sendo por eles comandados - e não através de corpos militares relativamente autônomos, separados por cor. Entretanto, em todas as capitanias o desprezo que os brancos devotavam às pessoas de cor configurou-se em poderoso obstáculo à implementação das medidas propostas pela Coroa, e nem mesmo como meros soldados os pardos e pretos foram admitidos nos corpos de ordenança identificados a brancos. Ademais, em configurações sociais mais antigas, como Pernambuco e Bahia, pardos e pretos retinham um capital social que não podia ser simplesmente desprezado, o qual decorria tanto da memória de sua atuação nas guerras lusoholandesas quanto de sua posição nos equilíbrios instáveis de poder relativamente aos brancos. As pressões não tardaram a surgir. Embora poucos corpos militares de pardos e de pretos tenham sido formados nas décadas seguintes, nessas capitanias os terços em questão foram integralmente restituídos à organização anterior a 1731. Em relação à fase anterior, o período compreendido entre 1728 e 1763 iniciou com um sensível abalo nas bases dos corpos militares de pardos e pretos. Mas a imediata reafirmação dessas corporações - mesmo que não tenha sido acompanhada de avanços em termos do conjunto de privilégios - reforçou o seu enraizamento na sociedade colonial, e esse aspecto, enfim, caracteriza o segundo momento histórico das milícias de pardos e de pretos luso-americanas.

O envolvimento de Portugal na Guerra dos Sete Anos, e especialmente a extensão da guerra aos espaços americanos, configuram uma nova fase na trajetória dos corpos militares de pardos e de pretos na América portuguesa, para a qual a Carta Régia de 22 de março de 1766 serviu como instrumento principal. ${ }^{23}$ Como visto no capítulo 1 , mais do que estipular padrões institucionais ou inovações técnicas, essa Carta estimulou uma formidável expansão e difusão dos corpos militares de auxiliares e de ordenanças na América portuguesa. Estabelecendo como carro-chefe a diretiva de se promover o alistamento de "todos os moradores [...] que se acharem em estado de poderem servir nas tropas auxiliares, sem exceção de nobres, plebeus, brancos, mestiços, pretos, ingênuos e libertos”, essa orientação régia incitou a formação de duas dezenas de terços de auxiliares compostos por pardos e pretos além de inúmeras companhias de segunda

\footnotetext{
${ }^{22}$ SILVA, L. G. Gênese das milícias..., p. 135-136.

${ }^{23}$ Cf:: AHU_CU_023-01, Cx. 24, D. 2352.
} 
e terceira linhas. Nessa conjuntura específica, foram suplantadas tanto as diretrizes de 1731 e 1733, analisadas acima, como a restrição da área de atuação dos corpos auxiliares aos principais portos marítimos do Brasil, estabelecida pela Provisão de 21 de abril de $1739 .{ }^{24}$ Além disso, mediante um processo silencioso que se completou em 1796, muitos dos corpos militares formados por homens de cor até então enquadrados no modelo das ordenanças transitaram para o das tropas auxiliares - o que implicou em ampliação dos privilégios e mudança de status.

Quanto à oficialidade de auxiliares e ordenanças, pouco se inovou. A determinação para que cada tropa fosse disciplinada por sargento-mor "escolhido entre os oficiais das Tropas pagas" e o aceno no sentido de que "os serviços que fizerem os mesmo oficiais, desde o posto de alferes até o de mestre-de-campo inclusivamente, sejam despachados como os dos oficiais das Tropas pagas" apenas reiteraram disposições já estabelecidas. ${ }^{25}$ Essa Carta não interveio na oficialidade de cor, senão por reafirmar a figura do sargento-mor proveniente da Tropa de Linha para a generalidade dos corpos militares de segunda e terceira linhas. Para pardos e pretos, essa cláusula podia ser lida menos como significando a intervenção de militares profissionais em sua organização interna e mais como estabelecendo uma incômoda presença de oficial branco em suas corporações. Essa questão foi resolvida por meio de Consulta do Conselho Ultramarino, a qual fora realizada em 1767, após o governador de Pernambuco, Conde de Vila Flor, ter manifestado as suas dúvidas na execução do serviço. Dispôs-se, na ocasião, que os sargentos-mores e os ajudantes responsáveis por disciplinar auxiliares e ordenanças deveriam realmente ser oriundos da Tropa de Linha e como tais remunerados. Contudo,

pelo que toca aos dois Regimentos dos Henriques e Pardos: ordena o mesmo Senhor que Vossa Excelência mande exercitar os oficiais dos mesmos Regimentos que lhe parecerem mais aptos para exercitarem os seus Corpos; tendo os sargentos-mores e os ajudantes o mesmo soldo, graduação e honras que têm os dos outros Regimentos. Não sendo isto novo nesta capitania, porque Henrique Dias e Antonio Felipe Camarão rolavam com todos os oficiais brancos que havia na mesma capitania e nas Tropas que os auxiliavam, sem que ninguém lhes disputasse a igualdade, como estão bem cheias as histórias. ${ }^{26}$

\footnotetext{
${ }^{24}$ Cf:: Provisão de 21 de abril de 1739. In: COELHO E SOUZA, José Roberto Monteiro de Campos (Org.). Systema, ou Collecção dos Regimentos Reaes. Tomo 4. Lisboa: Officina de Simão Thaddeo Ferreira, 1785, p. 536537.

${ }^{25}$ Cf:: "Carta Régia de 22 de março de 1766". AHU_CU_023-01, Cx. 24, D. 2352; "Carta Régia de 7 de janeiro de 1645. Criação de Soldados Auxiliares". In: SILVA, José Justino de Andrade e. Collecção Chronologica da legislação portugueza (1640-1647). Lisboa: Impensa de F. X. de Souza, 1856, p. 271-272; “Alvará sobre os privilégios dos Auxiliares". Monte Mór o Novo, 24 de novembro de 1645. In: Systema, ou collecçã dos regimentos reaes. (Tomo 5). Lisboa: Officina Patriarcal de Francisco Luiz Ameno, 1789, p. 228-229.

${ }^{26}$ Cf:: AHU_CU_015, Cx. 176, D. 12334. Palácio de Nossa Senhora da Ajuda, 30 de maio de 1767.
} 
Por meio dessa resolução, pardos e pretos livraram-se da ingerência direta de oficiais brancos em seus corpos militares e, mais do que isso, foram admitidos eles próprios aos postos de sargentos-mores e ajudantes com a garantia de soldo equivalente ao dos oficiais de linha sem que a ninguém coubesse questionar essa igualdade. Entretanto, como era de praxe na administração colonial, em cujo universo as capitanias, apesar de conectadas e interdependentes, guardavam relativa autonomia entre si, as medidas válidas para algumas nem sempre eram extensivas a outras. No caso em questão, trava-se de um conjunto de privilégios que, formalmente, permaneceram exclusivos aos pardos e pretos pernambucanos por três décadas. $^{27}$

Essas novidades geraram inúmeras controvérsias e, na prática, o pagamento do soldo aos oficiais de cor foi postergado por governadores pernambucanos. Apesar disso, é preciso demarcar os significados atrelados à ordem em si, independentemente de sua aplicação, e um exemplo relativo às milícias da América espanhola, pelo contraste, auxilia a visualizá-los. Na capitania de Santo Domingo, os oficiais milicianos recebiam soldos quando prestavam serviços militares, e o valor do pagamento mensal era diferente para os inscritos nas companhias de brancos e nas de morenos, de modo que esse aspecto frisava as desigualdades sociais vigentes entre esses grupos. Os capitães, tenentes e subtenentes brancos recebiam, respectivamente, 34 , 20 e 16 pesos, ao passo que os morenos, ocupantes de postos equivalentes, percebiam apenas 10,7 e 5 pesos, nessa ordem. ${ }^{28}$ É evidente que havia diferenças, no tocante às relações envolvendo os grupos de brancos, pardos e pretos ou morenos, entre as realidades hispano e luso-americanas e mesmo no interior de cada configuração social particular pertencente a tais territórios. No entanto, todas as sociedades escravistas americanas preservaram distinções baseadas na cor. Os valores de soldos referentes a Santo Domingo fornecem como que uma ordem de grandeza para se pensar os significados da equiparação entre oficiais brancos, pardos e pretos promovida na América portuguesa em 1767.

Entre as décadas de 1760 e 1790, a realidade dos auxiliares pardos e pretos variou de capitania para capitania, muito em função da perspectiva dos governadores coloniais acerca do peso que os grupos formados pelas pessoas de cor representavam na balança de poder em cada uma delas. Outros fatores, de igual importância, diziam respeito à trajetória histórica dos corpos

\footnotetext{
${ }^{27}$ Sobre a autonomia relativa das capitanias e como isso se refletiu em diferenças em suas organizações militares, ver SILVA, L. G. Gênese das milícias...

${ }^{28}$ Cf:: Archivo General Militar, Madrid. Ministerio de la Guerra, Santo Domingo, sig. 5664.12. "N." 180. El gobernador de Santo Domingo satisface a la Real Orden por la que se le pide razón de si convendrá en aquella Isla reducir a la clase de Urbanas las Milicias Disciplinadas a ejemplo de lo practicado con las del Nuevo Reyno de Granada". Santo Domingo, 25 de abril de 1790.
} 
militares em questão e aos níveis, maiores ou menores, de coesão social efetivamente existentes entre os pardos e pretos das diferentes configurações sociais. Na Bahia, em cuja configuração social os pretos Henriques lutaram com sucesso pela conservação do seu corpo militar nos anos 1730 e, quatro décadas mais tarde, os pardos lograram criar, enfim, a sua própria corporação, os terços de homens de cor contavam com estado-maior consolidado. Os seus postos - a saber, mestre-de-campo, sargento-mor e ajudantes, ou, a depender da formatação assumida pelas corporações, coronel, tenente-coronel, sargento-mor e ajudantes - eram providos entre seus próprios integrantes, na mesma linha estabelecida para seus pares de Pernambuco. ${ }^{29}$

No Rio de Janeiro, entretanto, o vice-rei Marquês do Lavradio (1769-1778) estabeleceu um padrão, mantido por seus sucessores, que consistiu na desfiguração dos estados-maiores dos recém-formados terços de pardos e de pretos Henriques. Os primeiros eram comandados por sargento-mor branco e disciplinados por ajudantes igualmente brancos, os quais eram retirados da tropa de linha. ${ }^{30}$ Nesse quesito, procedeu-se ignorando o precedente aberto pelos pernambucanos e seguido por baianos, buscando, ao contrário, seguir as determinações da Carta Régia de 1766, mas até certo ponto, já que ela não previa a exclusão do posto de mestre-decampo. Os Henriques, por sua vez, permaneceram por todo esse tempo sob o comando de um capitão-mandante, isto é, um capitão de companhia que, sem deixar de sê-lo, acumulava uma primazia em relação às demais companhias. ${ }^{31}$ De modo que a projeção social de pardos e pretos fluminenses nos corpos militares estava limitada ao exercício dos postos da oficialidade das companhias, não tendo eles acesso às funções superiores do estado-maior.

Essa diferença existente entre os oficiais pardos e pretos fluminenses, por um lado, e baianos e pernambucanos, de outro, pode ser explicada por alguns fatores através do recurso à comparação. Embora a camada de pessoas de cor livres no Rio de Janeiro fosse avultada já na segunda metade do século XVIII, suas dimensões não se aproximavam das dimensões do grupo dos brancos ou da participação de pardos e pretos livres e libertos nas capitanias do Nordeste açucareiro. Mais importante ainda é a trajetória histórica de serviços prestados à Coroa, os níveis de coesão corporativa e a diferente temporalidade de constituição dos terços nas distintas localidades. Ora, baianos e pernambucanos retinham um capital social e simbólico de valor imensurável correspondente à participação de seus ancestrais nas guerras do açúcar, Palmares

\footnotetext{
${ }^{29} C f:$ : AHU_ACL_CU_005, Cx. 206, D. 14735.

${ }^{30} C f:$ : "Relatório do marquês de Lavradio, vice-rei do Rio de Janeiro, entregando o governo a Luiz de Vasconcelos e Souza, que o sucedeu no vice-reinado". RIHGB, t. 4, n. 16, p. 419-425 e 436.

${ }^{31}$ MARTA, M. M. Em busca de honras, isenções e liberdades: as milícias de homens pretos forros na cidade do Rio de Janeiro (meados do século XVIII e início do XIX). Dissertação (mestrado em História). Niterói: ICHF, Universidade Federal Fluminense, 2013, p. 26-71.
} 
e dos Bárbaros. Seus corpos militares eram antigos e ostentavam uma densa folha de serviços prestados à Monarquia. Ambos conseguiram reaver os seus corpos militares e sua oficialidade pouco tempo após os abalos instaurados em 1731 e 1733. Diferentemente, durante a primeira metade do século XVIII os militares pardos e pretos do Rio de Janeiro estavam reunidos em um par de companhias de formação recente e aparentemente não conseguiram oferecer resistência capaz de mantê-las após a década de 1730. Seus terços foram criados nos anos de 1760 em diante, mas permaneceram desfigurados quanto à oficialidade maior. Apesar de reiterarem sua importância no sistema defensivo local, não podiam evocar serviços semelhantes aos de seus pares baianos e pernambucanos. Somente na década de 1790, quando o enraizamento de seus terços conferiu-lhes maior coesão, puderam pressionar à Coroa por obterem status semelhante ao dos pardos e pretos de Pernambuco e Bahia. Cumpre lembrar que na capitania de São Paulo a experiência militar de pardos e pretos era restrita, à época, ao âmbito das companhias. Questões envolvendo o acesso ao estado-maior virão à tona apenas a partir da década de 1790 .

Essa fase de expansão dos corpos de ordenança e de auxiliares formados por pardos e pretos se estendeu até finais do século XVIII, mas, já em 1787, a Coroa demonstrou preocupação com as dimensões apresentadas pela estrutura militar colonial. Por meio de uma provisão, todos os governadores foram incumbidos da tarefa de vistoriarem os terços e regimentos com a finalidade de identificarem e depois extinguirem os corpos militares que não transpunham para a realidade a organização e formação expostas no papel. A expansão da oficialidade, e notadamente a dos postos remunerados, foi alvo de igual cuidado. ${ }^{32}$

Por vários motivos, os anos finais da década de 1790 constituem um novo marco na trajetória das milícias de cor da América portuguesa e da oficialidade parda e preta. Em primeiro lugar, deve-se considerar a promulgação do Decreto de 7 de agosto de 1796 - que converteu os terços de auxiliares em regimentos milicianos - como um esforço para adequar as forças militares de segunda linha ao modelo da tropa regular europeia. Entre outras transformações, ele ampliou o estado-maior das corporações - que passou a ser constituído por coronel, tenentecoronel, sargento-mor, dois ajudantes, um quartel-mestre e um tambor-mor - inaugurando a disputa por mais duas vagas de alto escalão. ${ }^{33} \mathrm{Um}$ segundo aspecto diz respeito ao lugar que

\footnotetext{
${ }^{32} C f$ :: "Cópia da Carta Régia sobre corpos de Auxiliares e ordenanças". Lisboa, 2 de novembro de 1787. "Carta Régia sobre o provimento de Postos". Lisboa, 26 de maio de 1791. DIHCSP, vol. 25, p. 97-100 e 105-106.

${ }^{33}$ Cf:: "Decreto de 7 de Agosto de 1796. Regulando os Corpos Auxiliares do Exército, denominando-os para os futuros Regimentos de Milícias". In: SILVA, António Delgado da. Collecção da Legislação Portugueza Legislação de 1791 a 1801. Lisboa: Typografia Maigrense, 1828, p. 295-297. A partir de 1811, o estado-maior dos regimentos milicianos deveria contar também com um secretário, "para fazer a escrituração geral dos Corpos". Ver o "Decreto de 17 de dezembro de 1811". In: Collecção das Leis do Brazil de 1811. Rio de Janeiro: Imprensa Nacional, 1890, p. 148.
} 
esse momento ocupa na história das milícias de pardos e de pretos. É na última década do século XVIII que a obra não planejada de difusão dos corpos militares de pardos e pretos pelas várias capitanias luso-americanas se completa e atinge seu ápice. Não obstante ocorra a formação de companhias de pequenas dimensões em capitanias como o Pará, os terços ou regimentos atuantes no período que se segue são todos provenientes das fases anteriores, e principalmente da segunda metade do Setecentos. Nesse contexto, tais corpos militares se apresentam mais vigorosos e as demandas decorrentes de seu funcionamento se avolumam nos gabinetes de governadores coloniais e ministros portugueses.

Há, ainda, duas medidas emanadas da metrópole a se levar em conta. Antes, porém, cumpre ter em vista o quadro de transformações instaurado pela ilustração que incidiu sobre a organização social e impactou profundamente a estrutura militar. Como demonstrado pela historiografia, em Portugal o movimento intelectual do iluminismo esteve em boa medida associado às matérias de governo. Isso decorreu não somente do controle à produção literária e científica exercido pela censura régia, mas deveu muito à própria receptividade demonstrada pelo poder central, notadamente quanto aos estudos e projetos que se debruçavam sobre a questão do desenvolvimento econômico do reino e das colônias. ${ }^{34}$

Além da preocupação com a economia, a ilustração pautou diversas ações administrativas em matérias da organização da sociedade, a maioria das quais voltadas a reforçar o processo de centralização do poder monárquico em curso. De acordo com a concepção organicista da sociedade - representação típica da sociedade de corpos, ainda vigente em meados do século XVIII -, esta era estruturada em órgãos interdependentes mas relativamente autônomos entre si, de modo que o rei, como cabeça do corpo social, dirigia as suas ações permanentemente sob a dependência das demais partes constitutivas. ${ }^{35}$ Assim, as partes estruturavam o poder monárquico, mas também conferiam limites ao seu campo de ações e, em certo sentido, se apresentavam como forças concorrentes. Em contraste a esse ideário, o iluminismo forneceu embasamento à perspectiva de que somente um governo forte e centralizado seria capaz de romper as amarras e levar adiante um projeto reformista voltado a reerguer Portugal no quadro das nações europeias, o que alimentou o ímpeto do poder central em sobrepor-se aos demais. Em poucas palavras, estabeleceu-se a relação entre o poder central, a ilustração e as reformas econômicas e sociais.

\footnotetext{
${ }^{34}$ NOVAIS, Fernando Antonio. O reformismo ilustrado luso-brasileiro: alguns aspectos. Revista Brasileira de História, São Paulo, n. 7, p. 105-118, 1984.

35 HESPANHA, António Manuel; XAVIER, Angela Barreto. A representação da sociedade e do poder. In: MATTOSO, José (Org.). História de Portugal. O Antigo Regime (1620-1807). v. 4. Lisboa: Editorial Estampa, 1993.
} 
A cruzada movida pelo Estado contra os jesuítas, a qual não foi exclusiva de Portugal, é apenas um exemplo da ação centralizadora diante de poderes concorrentes. Várias reformas sociais alteraram o status de corporações e de grupos visando-se tanto a relativizar o poder da nobreza quanto a imprimir um modelo de relação mais direto e homogêneo entre o monarca e os súditos. ${ }^{36}$ Dentre tantas medidas, merecem destaque a equiparação de indígenas da América portuguesa aos brancos (1755 e 1758), dos cristãos indianos e asiáticos aos portugueses (1761), a extinção dos estigmas que atribuíam impureza de sangue aos cristãos-novos (1773) e a habilitação dos libertos residentes no Reino para todas as honras civis, militares e eclesiásticas (1773). ${ }^{37}$ Ao mesmo tempo, uma série de outras intervenções em corporações se processaram nesse período, tais como a crescente interferência régia nos processos de confirmação dos hábitos militares e na estruturação das irmandades religiosas. ${ }^{38}$ Foi ainda com a ilustração que se afirmou a não depreciação social dos lavradores e dos comerciantes de grosso trato e que se produziu a homogeneização das categorias de cor nos recenseamentos. ${ }^{39}$

As várias reformas sociais implementadas retiraram máculas e habilitaram setores até então estigmatizados no mundo português. As honras, privilégios e a condição de nascimento eram precisamente uma parte dos principais elementos que concorriam para a manutenção dos diferenciais entre setores da nobreza e os da plebe - incluindo-se aí a diversidade de grupos que constituíam os vassalos do rei português nos quatro cantos do mundo. Por isso todo esse movimento de elevação social dos grupos outsiders não podia deixar de ser encarado como um

\footnotetext{
${ }^{36}$ GUERRA, François-Xavier. Modernidad e independencia. Ensayos sobre las revoluciones hispánicas. Mexico: Fondo de Cultura Económica, 1993, p. 23; LIMA, Priscila de. De libertos a habilitados. Interpretações populares dos alvarás anti-escravistas pombalinos na América portuguesa (1761-1810). Dissertação (mestrado em História). Curitiba: SCHLA, Universidade Federal do Paraná, 2011, p. 13-43.

${ }^{37}$ LIMA, Priscila de. De libertos a habilitados..., p. 20-30.

${ }^{38}$ A paulatina sobreposição régia à autonomia da Mesa de Consciência e Ordens é abordada em SILVA, Maria Beatriz Nizza da. Ser nobre na colônia. São Paulo: Editora Unesp, 2005, p. 175-322. Já a crescente intervenção do poder central nas irmandades religiosas, moldando os compromissos que as regiam e alterando certos critérios de admissão foi tratada em vários estudos e com diferentes matizes. Ver, por exemplo, SCARANO, Julita. Devoção e escravidão: a Irmandade de Nossa Senhora do Rosário dos Pretos no Distrito Diamantino no século XVIII. São Paulo: Comp. Ed. Nacional: Secretaria de Estado da Cultura, Ciência e Tecnologia, 1976, p. 19-24; BOSCHI, Caio C. Os leigos e o poder. Irmandades leigas e política colonizadora em Minas Gerais. São Paulo: Ática, 1986, p. 118-119; SOARES, Mariza de Carvalho. Devotos da cor: identidade étnica, religiosidade e escravidão no Rio de Janeiro, século XVIII. Rio de Janeiro: Civilização Brasileira, 2000, p. 195-196; MATTOS, Regiane Augusto de. De cassange, mina, benguela a gentio da Guiné. Grupos étnicos e formação de identidades africanas na cidade de São Paulo (1800- 1850). Dissertação (mestrado em História). São Paulo: FFLCH, Universidade de São Paulo, 2006, p. 154; VIANA, Larissa. O idioma da mestiçagem: as irmandades de pardos na América portuguesa. Campinas: Editora da Unicamp, 2007, p. 148-149.

39 SILVA, Maria Beatriz Nizza da. Ser nobre na colônia..., p. 11, 23-24, 175-191, 204, 295-305. Sobre os recenseamentos, ver MARCÍLIO, Maria Luiza. Crescimento demográfico e evolução agrária paulista (17001836). São Paulo: Hucitec/EDUSP, 2000, p. 29-49 e NAZZARI, Muriel. Vanishing Indians: the social construction of race in colonial São Paulo. The Americas, v. 57, n. 4, p. 497-524, abr./2001.
} 
ataque aos privilégios aristocráticos. Cabe indagar de que forma esse processo afetou os corpos militares.

A reforma militar encomendada pelo Conde de Oeiras, o futuro Marquês de Pombal, e realizada pelo Conde de Lippe, buscou aparelhar o exército português aos das maiores potências militares europeias. Como demonstram Gouveia e Monteiro, a rigidez dos critérios estamentais tornou-se, então, obstáculo à profissionalização dos corpos militares no Reino. A diretriz que recomendava que os principais postos da milícia fossem providos entre os homens que melhor dominassem as teorias e práticas militares se chocou e buscou impor-se à prática tradicional vigente, que provinha da Idade Média, de atribuir os postos de comando aos membros da alta nobreza. ${ }^{40}$ É preciso acompanhar mais detidamente o que se processou no universo colonial luso-americano nesse contexto de transição ou embate entre as formas de organização social corporativa e ilustrada.

Na América portuguesa, em meio ao referencial corporativo, havia uma profusão de corpos militares que se distinguiam uns dos outros espelhando a condição social de seus integrantes. Ou seja, havia companhias ou terços denominados "da nobreza", "dos privilegiados", “dos familiares do Santo Ofício", "dos Dragões", “dos mercadores", “dos forasteiros" e também havia de "brancos" em geral, de "índios", de "pardos" e de "pretos". ${ }^{4}$ São vários os exemplos que atestam o zelo dos indivíduos, notadamente daqueles pertencentes aos setores mais elevados da sociedade, em servirem nos corpos que correspondessem à sua condição e status e, ao mesmo tempo, impedirem o ingresso de estranhos. Era assim nas demais instituições sociais, a exemplo das confrarias e irmandades. ${ }^{42}$ Os critérios de admissibilidade ou exclusão visavam a reiterar as coisas como elas eram, com sua diversidade e principalmente desigualdade concebidas como naturais. Em um tal estado de coisas, pode-se pensar que o establishment não levava completamente a sério as patentes de tenentes ou capitães de pardos e pretos, por exemplo. Simplesmente não se concebia como equivalentes os capitães "dos nobres", cujos postos eram ocupados por figuras das mais poderosas na esfera local, e os capitães pardos e pretos, muitos dos quais forros e consideravelmente próximos ao cativeiro,

\footnotetext{
40 GOUVEIA, António Camões; MONTEIRO, Nuno G. A milícia. In: MATTOSO, José (Dir.). História de Portugal. vol. 4. Lisboa: Ed. Estampa, 1998, p. 202-203.

${ }^{41}$ Uma interpretação acerca da criação de companhias de "privilegiados", "moedeiros" e de "familiares do Santo Ofício" e sua agregação ao "Regimento ou Terço da Nobreza ou dos Privilegiados", no Rio de Janeiro, entre finais do século XVII e começos do XVIII, em MELLO, Christiane Figueiredo Pagano de. O Rio de Janeiro: uma praça desfalcada “dos melhores soldados e oficiais” (séculos XVII e XVIII). História, São Paulo, v. 31, n. 1, p. 210-232, jan./jun. 2012, especialmente em p. 219-220.

42 Sobre critérios exclusivistas nas Santas Casas de Misericórdia, RUSSELL-WOOD, A. J. R. Escravos e libertos..., p. 202-204; SILVA, Luiz Geraldo. Religião e identidade étnica. Africanos, crioulos e irmandades na América portuguesa. Cahiers des Amériques Latines, v. 44, p. 77-96, 2003.
} 
por exemplo. Se, munidos de chuços e arcos e flechas, esses últimos eram militarmente úteis, por outro lado as suas técnicas marciais eram reputadas bárbaras e distantes do ideário nobiliárquico que revestia a teoria e prática bélica de matriz europeia. Priorizava-se, antes, o estabelecimento de fronteiras entre as corporações e, logo, entre os diferentes e desiguais grupos sociais.

São inúmeras as expressões do pejo que os brancos sentiam em servir em corpos militares ao lado de negros - as quais, como visto anteriormente, contribuíram para o malogro da separação por cores estabelecida entre 1731 e 1733. Há, contudo, exemplos de que comandantes militares brancos recrutavam pardos para o preenchimento de suas fileiras. Nesses casos, a aceitação das pessoas de cor em corpos militares de brancos é instrumental. Ela é um requisito para o pleno exercício de poder por parte do comando militar formado por brancos, o qual não raro atribuía aos corpos militares os nomes pessoais de seus capitães e mestres-decampo, personificando as instituições. Em tais circunstâncias, a diferença entre o alto escalão da oficialidade branca e os reles soldados de cor estava plenamente assegurada pelas patentes militares. Provavelmente também havia mecanismos internos para separar e hierarquizar os soldados de acordo com a cor. Contudo, sempre que os corpos militares podiam manter rigorosamente as diferenças, fechando suas portas a segmentos sociais considerados inferiores, eles o faziam.

As reformas ilustradas impostas pela Monarquia aspirante a concentrar em si própria a maior parcela possível de poder incidem diretamente sobre essas inúmeras distinções. Como visto, a perspectiva centralizadora ou, o que é o mesmo, a imposição da vontade e do poder régio diretamente sobre a sociedade e os súditos, esbarrava nesses espaços sociais amuralhados que eram as corporações. A força e autonomia corporativa, com sua autogestão e seus privilégios e foros específicos, passou a ser encarada como um obstáculo ao poder central e ao seu ímpeto reformador e racionalista. Vai daí o estabelecimento, por parte do Estado, das várias medidas referidas que visaram a enfraquecer a autonomia dos corpos sociais a partir de meados do século XVIII. Esse ataque às corporações incidiu diretamente sobre a nobreza mas também impactou na vida social de grupos outsiders. ${ }^{43}$

\footnotetext{
${ }^{43}$ Pardos e pretos, em suas corporações, também foram alvo da empresa homogeneizante movida na atmosfera da ilustração. Sobre o ataque ao catolicismo barroco dos negros, escorado nas irmandades, ver SILVA, Luiz Geraldo. Da festa barroca à intolerância ilustrada. Irmandades católicas e religiosidade negra na América portuguesa (17501815). In: SALLES-REESE, Verónica (Org.). Repensando el pasado, recuperando el futuro. Nuevos aportes interdisciplinarios para el estudio de la América colonial. Bogotá: Editorial Pontificia Universidad Javeriana, 2005, p. 270-287.
} 
No terreno militar, e particularmente no mundo luso-americano, se nota o gradual desaparecimento daquela faceta dos corpos militares que tendia a reafirmar a identidade coletiva no âmbito local. Para o Estado, o que mais interessava era a identificação dos corpos militares às técnicas e ao armamento bélico, ou, ainda, ao espaço territorial de sua atuação. Por isso, as distinções outrora vigentes no universo militar entre corpos de "nobres", "dragões", "mercadores", "forasteiros" e outros serão duramente censuradas. Um episódio referente a Minas Gerais ilustra essa tendência. Diante da proliferação de Regimentos da Nobreza naquela capitania, o ministro de Estado Martinho de Melo e Castro estranhou que por lá existissem tantos nobres em 1775. Ele advertiu ao governador local que "semelhantes distinções" eram "geralmente muito nocivas ao serviço". Antes, "parece mais conforme a ele que as pessoas mais abonadas e de maior estimação e crédito (que pode ser que sejam os denominados Nobres) se empreguem, segundo os seus merecimentos, nos postos dos Auxiliares, sem ser preciso fazerem-se corpos separados, com a estranha e incompetente distinção, quanto a serviço, de Nobres e Plebeus". ${ }^{44}$ E mesmo as tentativas de distinção mais rasteiras, entre os soldados, foram incisivamente reprimidas. Em 1776, o governador de São Paulo esclareceu a um capitão da vila de Itu que os "clamores dos alistados, de que entre eles está alistado um filho de um mulato, são inatendíveis e dignos de castigo". Ele prosseguiu afirmando que "por Santa Lei novíssima de El Rey Nosso Senhor estão os mulatos forros habilitados para todas as honras civis, militares e eclesiásticas" - uma interpretação controversa, sem dúvida, do alvará de 16 de janeiro de $1773 .^{45}$

Contudo, os regimentos milicianos de pardos e de pretos - assim como as companhias e terços de ordenanças, que, diante do status que a segunda linha alcança, paulatinamente perdem parte de sua expressão social ${ }^{46}$ - permanecem intocados. Extinguem-se várias distinções até então preservadas pelas camadas superiores da sociedade, mas mantêm-se as distinções elementares referentes ao nível mais baixo. Até esse ponto, não há comoção social:

\footnotetext{
${ }^{44} C f$ :: "Instrução" [para o governador e capitão-general de Minas Gerais, D. Antônio de Noronha]. Salvaterra de Magos, 24 de janeiro de 1775. In: MENDONÇA, Marcos Carneiro (Org.). Século XVIII, século pombalino do Brasil. Rio de Janeiro: Xerox do Brasil, 1989, p. 626-627. Destaque no original. Por lapso, na obra em questão esse documento é associado ao governador e capitão-general de São Paulo, Martim Lopes Lobo de Saldanha.

${ }^{45}$ Cf:: "Para o capitão Romualdo José de Pinho e Azevedo da Vila de Itu". São Paulo, 15 de agosto de 1776. DIHCSP, vol. 76, p. 37-38. Para a recepção desse alvará na América portuguesa, consultar SILVA, L. G. Esperança de liberdade... e LIMA, Priscila de. De libertos a habilitados...

${ }^{46}$ Em 1813, o Ministério da Guerra impediu a criação de nove companhias de ordenanças na capitania de São Paulo sob a alegação de que os regimentos de milícias, "que constituem a maior força militar do Brasil”, careciam de soldados e de oficiais, não convindo, desse modo, que esses fossem destinados às ordenanças. APESP, C00416, livro 160, fl. s./n. Rio de Janeiro, 20 de março de 1813. A tese da progressiva decadência das ordenanças em LEONZO, Nanci. As companhias de ordenanças na capitania de São Paulo. Das origens ao governo do Morgado de Mateus. Dissertação (mestrado em História). São Paulo: FFLCH, Universidade de São Paulo, 1975.
} 
a separação entre regimentos de brancos, pardos e pretos obedece aos mesmos critérios que organizavam as irmandades religiosas, os recenseamentos populacionais e os registros paroquiais, os quais eram reconhecidos pelos grupos sociais envolvidos. Todavia, essa reorganização luso-americana dos corpos militares que suplantou critérios distintivos locais em prol dos interesses do poder central gerou confrontos e tensões por estabelecer cláusulas específicas a pardos e pretos, na contramão do movimento mais geral de supressão de privilégios e imunidades corporativas. As determinações específicas às milícias de cor estão presentes na Provisão de 26 de julho de 1797 e no Alvará de 17 de dezembro de 1802 e versam sobre a oficialidade parda e preta.

A Provisão de 1797 representou nada mais e nada menos do que a extensão para toda a América portuguesa da Provisão de 30 de maio de 1767, aludida atrás, que determinou que os sargentos-mores e os ajudantes dos corpos militares de pardos e pretos fossem remunerados e providos entre os seus próprios integrantes - não obstante as disposições em contrário referentes às milícias dos brancos. Em uma época em que determinados elementos e espaços distintivos dos milicianos brancos estavam sendo suprimidos, os milicianos de cor conquistavam a formalização de privilégios e imunidades. Para completar, por meio dessa provisão se afirmou a igualdade entre os oficiais brancos e os de cor em termos de "soldos, graduação e honras". Numa palavra, a Coroa fixou a prevalência das patentes e postos militares sobre a condição ou qualidade de seus ocupantes. ${ }^{47}$

Já o Alvará de 1802 consistiu no maior esforço régio voltado a regular o sistema de promoções na milícia colonial. Os seus 23 parágrafos tratam dos procedimentos a serem observados nas várias etapas desse sistema: os critérios e requisitos para a ocupação dos postos, a formulação de propostas, os exames teóricos e práticos e as reformas. Estabeleceu-se que todos os postos do estado-maior dos regimentos milicianos - coronel, tenente-coronel, sargento-mor e ajudantes - deveriam ser providos preferencialmente em oficiais oriundos da tropa de linha. A ascensão de oficiais milicianos a tais postos configuraria uma exceção, justificada somente para os casos em que não houvesse candidatos da tropa regular. Em relação às normas pregressas, o alvará em questão não apenas reiterou a ingerência de militares profissionais nas milícias, mas a ampliou. A esses militares estariam reservados todos os postos de alto escalão dos regimentos e, na passagem da primeira para a segunda linha, eles obteriam progressão relativamente às suas posições originais, conforme o caso, em termos de posto ou

\footnotetext{
${ }^{47}$ Cf:: "Provisão de 26 de julho de 1797". AHU_CU_010, Cx. 35, D. 1819.
} 
graduação. Isso significou, por outro lado, a imposição de uma pesada limitação às aspirações dos milicianos, que se viram praticamente confinados à oficialidade de suas companhias. ${ }^{48}$

O alvará em questão tocou também na delicada questão da oficialidade parda e preta, que se arrastava desde a primeira metade do século XVIII. O simples fato de esse ponto específico das milícias coloniais ter sido objeto de apreciação régia nos anos de 1731, 1733, 1767, 1797 e 1802 indica de modo cristalino as dificuldades encontradas pela Coroa em exercer a função de engenharia social sobre um tema que absolutamente não se dobrava às soluções propostas. Se a extinção dos corpos militares de pardos e pretos e das respectivas oficialidades revelou-se inviável, a preservação do estado-maior dos seus terços e regimentos bem como dos privilégios a ele inerentes não foram objeto de menor impasse. Por isso, dois parágrafos do Alvará de 1802 dedicaram-se exclusivamente a essas milícias. Após esclarecer as normas para o provimento do estado-maior das milícias, dispõe-se que

XVI. Desta generalidade não será excetuado Regimento algum de homens brancos. Sendo, porém, muito conveniente ao Meu Real Serviço, e inteiramente conforme aos princípios da Razão e Direito natural, que Eu procure, como Pai comum de todos os Meus Vassalos, desterrar de seus ânimos a odiosa preocupação com que muitos ainda consideram a diferença das cores como um princípio de que devem resultar diversos direitos entre aqueles em que se não dá a uniformidade deste acidente; e querendo por outra parte dar a todos os Meus Vassalos Pretos e Pardos uma prova irrefragável de que os Considero habilitados para todas as Honras e Empregos Militares, a que serão efetivamente elevados segundo o seu pessoal merecimento: Sou Servido Ordenar que, para os Postos de Coronéis, Tenentes-Coronéis, Majores e Ajudantes dos Regimentos Milicianos de homens pretos, denominados de Henriques, e igualmente para os de homens pardos, que atualmente existem ou para o futuro existirem em qualquer Capitania do Brasil, sejam sempre atendidos de preferência os Oficiais de suas próprias cores, quando neles concorram as precisas circunstâncias para o desempenho dos mesmos Postos, na conformidade do que Fui Servido Ordenar a respeito dos Regimentos de homens pardos das Cidades do Rio de Janeiro e Bahia de Todos os Santos, pela Minha Resolução de vinte e três de julho próximo passado, tomada em Consulta do Conselho Ultramarino de treze de janeiro de mil oitocentos e de vinte de maio do corrente ano.

XVII. E porque nos Meus Domínios do Brasil não há Regimentos de Linha de homens pretos ou pardos, dos quais possam ser tirados os Oficiais Superiores e Ajudantes dos Regimentos Milicianos destas duas cores, o Provimento dos referidos Postos se fará sempre por oposição entre os Oficiais dos respectivos Regimentos, como fica determinado a respeito dos Regimentos de brancos no $\S \mathrm{XV}$. Quando, porém, aconteça que entre os Oficiais dos Regimentos de pretos ou pardos se não encontrem tantos dignos de ocupar os Postos Superiores e de Ajudantes quantos sejam necessários, nesse caso os ditos Postos se porão a Concurso por Editais e se proverão em Oficiais brancos tirados da Tropa de Linha, pela mesma forma que fica ordenado acerca dos Regimentos de homens brancos.

\footnotetext{
${ }^{48} C f .:$ “Alvará de 17 de dezembro de 1802”. Lisboa: Regia Officina Typografica, 1803.
} 
Esses parágrafos representam o ponto alto na trajetória das milícias de pardos e pretos na América portuguesa e na sua relação com a Monarquia. A Coroa não apenas reforçou a manutenção da separação por cores nas milícias coloniais, mas igualmente acenou para a sua existência futura, através da formação de corpos milicianos congêneres. Mais relevante, porém, é a garantia do acesso aos postos superiores dos regimentos, cuja conquista se deve em boa medida à intensa pressão exercida na Corte por milicianos de diferentes corporações e de várias capitanias, a qual foi acolhida nas consultas do Conselho Ultramarino e resolvida pelo príncipe regente.

Esse ponto, que já demandava a atenção dos funcionários régios, tornou-se particularmente problemático a partir de então. O que era regra para as milícias de homens brancos constituía exceção para pardos e pretos: para uns se determinou a intromissão de militares da tropa de linha, para outros se concedeu a prioridade no acesso aos postos superiores. Contudo, um parágrafo em particular, referente à oficialidade de patente das companhias, e não, portanto, ao estado-maior, estabeleceu critérios vagos para o provimento dos postos e forneceu algum grau de instabilidade à oficialidade de cor. Sua intenção era evitar o "inconveniente de ser promovido ao Posto de Capitão oficial [...] que não tenha os precisos meios para manter o decoro de um posto tão autorizado". Insistindo na questão, mas sem fixar quais ou quantos seriam os "precisos meios", proibiu-se o acesso aos postos de patente (capitão, tenente e alferes) a quem "não possua bens ou rendas suficientes para se manter com a decência conveniente". 49 Como se verá adiante, a oficialidade miliciana se converteu em um campo de batalha no qual estiveram envolvidos indivíduos e grupos, representantes de diferentes âmbitos, corporações e condições sociais.

As disposições de 1802 foram lidas pela historiografia, adequadamente, como um esforço no sentido de profissionalizar a segunda linha. Pode-se acrescentar, porém, que esse intuito estava presente já por ocasião da formação dos auxiliares, em 1645, tendo sido reiterado em sucessivas regulamentações no século XVIII e constituído o mote principal do Decreto de 1796. Quanto às medidas voltadas especificamente às milícias de cor, historiadores como A. J. R. Russell-Wood e Hendrik Kraay notaram a ambiguidade presente na postura da Coroa, a qual se dava fundamentalmente em função do duplo aceno em relação aos ocupantes preferenciais dos postos do estado-maior, que tanto podiam ser pretos e pardos como oficiais da primeira

\footnotetext{
${ }^{49}$ Cf:: “Alvará de 17 de dezembro de 1802", § XIX.
} 
linha. Haveria, pois, um misto de confiança e desconfiança quanto àqueles milicianos. ${ }^{50}$ Há pelo menos três aspectos a se considerar acerca dessa questão.

O primeiro deles se refere ao contexto de transição entre perspectivas de governo e de organização social assentadas em referenciais corporativos, de um lado, e ilustrados, por outro, aspecto assente já nas primeiras frases do parágrafo XVI. O príncipe regente, na qualidade de "pai comum de todos os Meus Vassalos", expressou a intenção de desterrar os preconceitos em torno da cor - afirmando tratar-se de mero acidente - dos quais resultariam "diversos direitos". O combate a esses múltiplos diretos era, pois, uma bandeira da ilustração, que afinal produziu uma perspectiva mais homogeneizante da sociedade. Conforme esses princípios, portanto, a cor não deveria ser justificativa para o estabelecimento de diferentes privilégios e graus de honorabilidade. Em correspondência a tais princípios, formulou-se o intento de fornecer "a todos os Meus Vassalos Pretos e Pardos uma prova irrefragável de que os Considero habilitados para todas as Honras e Empregos Militares" conforme os seus merecimentos. Contudo, a forma encontrada para desterrar as prevenções e habilitar pardos e pretos às honras e empregos militares foi justamente a preservação da separação por cores e a manutenção dos "diversos direitos", notadamente a prerrogativa de os milicianos de cor ascenderem aos postos superiores de seus regimentos. Tais contradições são próprias desse momento histórico de transição e acabam também por revelar o difícil estabelecimento de arranjos e compromissos entre os diferentes grupos pertencentes a uma sociedade escravista e desigual.

Daí procede um segundo aspecto a se ter em vista, a postura flexível da Coroa na determinação das regras e procedimentos atinentes às promoções na milícia. A acirrada competição pelos postos envolvia militares da tropa regular, oficiais milicianos brancos e oficiais pardos e pretos, de modo que o equacionamento dessas tensões, visando sempre à estabilidade do equilíbrio social, deveria ocorrer na realidade local, que é onde havia maior sensibilidade às condições específicas do jogo de forças. Decorrem desse cuidado as brechas para que os oficiais milicianos dos regimentos de homens brancos concorressem aos postos superiores de suas corporações quando não houvesse militares de linha dispostos a eles, bem como a possibilidade de oficiais de linha ocuparem os postos das milícias de pardos e pretos caso não existisse, entre esses, oficiais capazes. Também por respeitar as condições específicas de cada configuração social, a norma não foi taxativa quanto ao valor dos bens e da riqueza que se considerava compatível e equivalente aos postos de patente.

\footnotetext{
${ }^{50}$ RUSSELL-WOOD, A. J. R. Escravos e libertos..., p. 141-142; KRAAY, Hendrik. Política racial, Estado e forças armadas na época da independência: Bahia, 1790-1850. Trad. Magda Lopes. São Paulo: Hucitec, 2011 , p. 159-160.
} 
Finalmente, não se pode deixar de assinalar o ganho de status proporcionado às milícias de cor com a consolidação do reconhecimento régio à oficialidade parda e preta e a sua equiparação com o corpo de oficiais com experiência na tropa regular. Ainda que existisse um fosso entre as normas e as práticas sociais e que houvesse ocasião para a intromissão de oficiais da tropa de linha, a formalização da tradição vigente em algumas capitanias e a sua extensão para a generalidade dos corpos milicianos de cor representou um capital imensurável àqueles grupos, tanto mais quando se tem em vista a situação dos oficiais milicianos brancos, praticamente apartados do acesso ao estado-maior de seus próprios regimentos. A Provisão de 1797 e sobretudo o Alvará de 1802 assinalam definitivamente a dependência colonial com relação ao serviço militar prestado pelos vassalos de cor. Tais disposições, vigentes até 1831, significam, igualmente, um estreitamento dos laços entre as elites pardas e pretas e o Estado em uma conjuntura caracterizada pela deflagração de guerras e agitações sociais e políticas associadas à Era das Revoluções.

\subsection{Milícias de pardos e de pretos e o reformismo ilustrado: projetos e embates}

Na América portuguesa, a virada do século XVIII para o XIX assistiu a um momento único na história das milícias formadas por homens pretos e pardos. A expansão da quantidade desses corpos militares e a sua disseminação pelas diferentes capitanias luso-americanas foram acompanhadas de ampliação em termos de status e consolidação de privilégios. De fato, várias medidas emanadas da metrópole ao longo da segunda metade do Setecentos - debatidas pelo Conselho Ultramarino e estabelecidas formalmente pela Coroa - reconheceram a equiparação dos oficiais pardos e pretos relativamente aos brancos, fossem eles da tropa auxiliar ou da regular. Através desse princípio mais geral, as milícias de cor deveriam ser contempladas com o mesmo soldo, privilégios e honras dos demais corpos militares, em um processo gradual de ganho de autonomia e ascensão de status corporativo. Vale a pena lembrar que a provisão de 1797 garantiu a igualdade dos oficiais pardos e pretos relativamente aos brancos quanto às honras, soldos e graduações militares, e o alvará de 1802 dispôs a eles o acesso preferencial aos postos do estado-maior de seus regimentos, o que era vetado às milícias brancas. A compreensão que a burocracia régia situada na Corte manifestava acerca da situação social das milícias de cor da América decorria de um esforço caracteristicamente conciliador de tensões, somente possível a partir de uma perspectiva distanciada. Para aqueles funcionários que 
vivenciavam de perto o constante medir forças interno ao universo militar colonial, e especificamente os confrontos, latentes ou plenamente expressos, entre brancos, pardos e pretos, o panorama podia ser lido de modo bastante diferente. A perspectiva de governadores e de oficiais militares de alto escalão a respeito das milícias de pardos e de pretos, entre os anos 1790 e 1820, é objeto da apreciação que se segue. De que modo os seus projetos de reforma para as milícias se relacionavam com o momento histórico caracterizado pela elevação social de soldados e oficiais pardos e pretos?

Todos os pontos da América pertencentes aos impérios coloniais europeus sofreram em maior ou menor medida os impactos da Guerra dos Sete Anos. Um de seus efeitos mais notáveis foi a crescente militarização dos espaços coloniais à medida que as tensões passaram a atravessar o Atlântico com maior intensidade. As Américas portuguesa e espanhola equiparamse defensivamente com tropas profissionais e, principalmente, criaram inúmeros corpos milicianos. Entretanto, se tais forças militares configuravam uma solução do ponto de vista da segurança externa, o apogeu das milícias produziu consequências sociais e econômicas. A manutenção dessas sociedades “em pé de guerra", com seus exércitos de dimensões até então inimagináveis permanentemente mobilizados, era difícil de sustentar. Afetava as finanças do Estado e a produção agrícola e o comércio de seus habitantes. Com o ápice das milícias, governadores coloniais e burocratas ligados às forças armadas se debruçaram mais detidamente sobre o tema da eficácia das estruturas militares locais. O desafio era estabelecer sistemas defensivos eficientes comprometendo a menor quantidade de recursos humanos e financeiros possíveis.

A significativa dependência que as Coroas portuguesa e espanhola desenvolveram para com as milícias coloniais de pardos e pretos/morenos, contudo, produziu questões de outra ordem. Na medida em que esses corpos militares foram assumindo funções de relevo, eles ampliaram seus contingentes e igualmente a sua dimensão social. Para além dos soldos a que tinham direito a receber quando mobilizados, a principal remuneração dos milicianos de cor dizia respeito ao conjunto de privilégios, honrarias e distinções que poderiam desfrutar. Por sua vez, a concentração de recursos sociais, políticos e simbólicos propiciada pela milícia foi o principal meio encontrado pelos homens de cor livres para encurtarem as distâncias que os separavam do nível mais alto da sociedade, em geral associado às pessoas de cor branca. As transformações experimentadas pelos pardos e pretos responsáveis por ampliar o seu peso nas balanças de poder - tanto as balanças de dimensões mais amplas, como os impérios coloniais, quanto as de dimensões mais reduzidas, como as configurações sociais internas às capitanias e vice-reinos - afetaram os grupos constituídos por brancos, uma vez que os diversos grupos 
sociais competidores mantinham relações de interdependência entre si. Desse modo, a elevação social de milicianos pardos e pretos em uma dada configuração social frequentemente era encarada como sinal de desprestígio aos brancos dessa mesma configuração. Cabe indagar de que modo a tensão existente entre milicianos brancos e milicianos pardos e pretos esteve presente nos projetos que visaram à reforma dos corpos militares.

\subsubsection{América espanhola: vice-reino de Nueva España}

Na realidade da América espanhola, os programas reformistas de fins do século XVIII contemplaram as milícias de pardos e morenos e afetaram a sua configuração institucional em diversas localidades. São relativamente bem conhecidos os casos do Peru, de Nova Granada, de Cuba e de Nova Espanha. ${ }^{51}$ Embora não seja o caso de retomá-los, todos, ponto a ponto, é pertinente aludir sucintamente à trajetória dos corpos milicianos na Nova Espanha para, por um lado, alargar a visão em torno da incidência do fenômeno do reformismo ilustrado sobre as milícias, e, por outro, para pôr em perspectiva os casos do Brasil e, em particular, o de São Paulo.

A trajetória histórica das milícias de cor do vice-reino da Nova Espanha pode ser dividida em três fases bem delineadas considerando-se o grau de autonomia e a gama de privilégios por elas conquistados, de acordo com o historiador Ben Vinson III. ${ }^{52}$ A primeira fase vai da criação das primeiras companhias de pardos e morenos livres, em 1550, até aproximadamente 1670. Esse período é caracterizado pela formação e enraizamento de diferentes tipos desses corpos militares na sociedade colonial. Lentamente, conforme os homens de cor livres conseguiram fornecer provas de lealdade à Coroa espanhola e afastar

\footnotetext{
${ }^{51}$ CAMPBELL, Leon G. Black power in colonial Peru: the 1779 tax rebellion of Lambayeque. Phylon, v. 33, n. 2, p. 140-152, 1972; CAMPBELL, Leon G. The changing racial and administrative structure of the peruvian military under the later bourbons. The Americas, v. 32, n. 1, p. 117-133, 1975; KUETHE, Allan J. The status of the free pardo in the disciplined militia of New Granada. The Journal of Negro History, v. 56, n. 2, p. 105-117, apr./1971; KUETHE, Allan J. The military reform in the Viceroyalty of New Granada, 1773-1796. Tese de doutorado. Flórida: Universidade da Flórida, 1967; KUETHE, Allan J. Cuba, 1753-1815: Crown, military, and society. Knoxville: University of Tennessee Press, 1986; BELMONTE POSTIGO, José Luís. El color de los fusiles. Las milicias de pardos en Santiago de Cuba en los albores de la Revolución Haitiana. In: CHUST, Manuel; MARCHENA, Juan (Eds.). Las armas de la nación. Independencia y ciudadanía en Hispanoamérica (1750-1850). Madrid: Iberoamericana/Vervuert, 2007, p. 37-51; ARCHER, Christon I. Pardos, Indians, and the Army of New Spain. Inter-relationships and conflicts. Journal of Latin American Studies, Vol. 6, No. 2, p. 231-255, nov. 1974; VINSON III, Ben. Los milicianos pardos y la relación estatal durante el siglo XVIII en México. In: ESCAMILLA, Juan Ortiz (Coord.). Fuerzas militares en Iberoamérica, siglos XVIII y XIX. México: El Colegio de México, Centro de Estudios Historicos; Zamora, Michoacán, México, El Colegio de Michoacán; Veracruz, México: Universidad Veracruzana, 2005, p. 47-60.

${ }^{52}$ VINSON III, Ben. Los milicianos pardos y la relación estatal...; VINSON III, Ben. Articular el espacio...
} 
eventuais desconfianças quanto ao seu papel no desempenho de funções militares, seus corpos milicianos foram adquirindo delineamentos institucionais mais precisos até a consolidação de corporações específicas para pardos e para morenos.

$\mathrm{O}$ advento da segunda fase foi precipitado após o vice-reino sofrer um ataque exitoso, empreendido em 1683 pelo pirata Lorencillo, ao porto marítimo de Veracruz, a principal conexão da Cidade do México com o Atlântico. Esse assalto atestou a vulnerabilidade defensiva daquela colônia e desencadeou um processo de militarização local baseado nas milícias. Entre os anos 1670-1760, houve expansão numérica das milícias de pardos e morenos, "crescente autonomia" e "mudanças significativas na estrutura de mando que lhes permitiram o acesso aos postos de mais alto escalão". ${ }^{53}$ Nomeadamente, foi nesse período que os milicianos pardos e morenos conquistaram isenções tributárias e que obtiveram a nomeação do primeiro coronel pardo, com jurisdição sobre várias unidades, as quais cobriam um vasto território.

Nova e ainda mais abrangente reestruturação militar teve lugar na Nova Espanha após a comoção em torno da queda de Havana, em 1762, no bojo dos confrontos excitados pela Guerra dos Sete Anos. Esse período deu início a uma terceira fase na trajetória histórica das milícias de pardos e morenos novo-hispânicas, a qual se caracterizou por uma perda de autonomia da oficialidade e por um combate à própria preservação desses corpos militares. ${ }^{54}$ Esse é o período mais interessante para a reflexão proposta nesta seção e por isso será abordado mais detalhadamente.

A obra de reestruturação militar da Nova Espanha tem como marco principal o ano de 1764, em que o tenente-general Juan de Villalba y Angulo recebeu da Coroa a comissão de inspetor geral dos corpos regulares e milicianos do vice-reino e uma densa documentação instrutiva para organizar a tropa regular e formar as milícias provinciais. Essas deveriam estar vinculadas mais diretamente aos poderes centrais e alcançar os níveis mais elevados de disciplina e treinamento militar, não obstante fossem constituídas por habitantes locais que não faziam parte do exército profissional. Por isso esses corpos militares foram também denominados milícias regladas, isto é, reguladas, e disciplinadas, e se diferenciavam da milícia que não havia passado por esse processo, em geral as corporações situadas em áreas secundárias do ponto de vista estratégico-militar, chamadas milícias urbanas. Um aspecto relevante da diferenciação entre essas milícias é que, assim como as obrigações da milícia provincial eram,

\footnotetext{
${ }^{53}$ VINSON III, Ben. Los milicianos pardos y la relación estatal..., p. 50. Tradução livre.

${ }^{54}$ VINSON III, Ben. Los milicianos pardos y la relación estatal..., p. 52-54.
} 
em geral, mais sisudas, seus privilégios eram maiores. ${ }^{55} \mathrm{Um}$ contingente significativo de companhias de milícias urbanas formado por pardos e morenos, ainda não mapeado pela historiografia, se difundiu em diversas regiões novo-hispânicas. O foco aqui, todavia, recairá exclusivamente nas milícias provinciais, menos por esse inconveniente ao estudo das urbanas e mais em função do status diferenciado adquirido pela provincial, fator que amplificou a confrontação social entre pardos e brancos no universo militar.

Nas instruções de 1764, determinou-se, a respeito das milicias provinciais, "el modo de combinar, en la formación, las diferentes especies de Españoles, Mulatos, Mestizos, y demás que componen aquellos naturales", por certo um "punto de los que piden mayor reflexión". A orientação a Villalba foi explícita no sentido de conceder preferência à formação de corpos militares integrados conjuntamente por homens de todas as cores, pois, "exceptuando los absolutamente Negros, se considera conveniente la admisión indistinta de todos los naturales, de cualquier color que sean", advertindo-se, porém, que "se procurará tener una tercera parte de estos en cada Compañía". No entanto, previa-se que "si en la práctica si tocasen inconvenientes, o fuese repugnante a los blancos la mezcla con otros colores: dejo a vuestro concepto la libertad de formar el pie de Milicias con separación". ${ }^{56}$ Com efeito, a formação de regimentos separados entre brancos, pardos e morenos foi um recurso efetivamente empregado na Nova Espanha, assim como nos demais territórios coloniais espanhóis. Em 1766, as milícias disciplinadas daquele vice-reino eram constituídas por seis Regimentos, três Batalhões e duas Companhias de Infantaria e ainda por um Regimento de Cavalaria e um Corpo de Lanceros, os quais abrigavam, conjuntamente, pouco mais de nove mil homens. Desse conjunto, dois Batalhões eram integrados por homens pardos e duas Companhias avulsas por pardos e morenos, sendo o restante da milícia disciplinada identificado a brancos de diferentes localidades.

Essa configuração mais geral das forças militares pouco se alterou nas décadas seguintes, especialmente pelo pequeno crédito que os vice-reis depositavam nas milícias. ${ }^{57} \mathrm{O}$ que houve, na realidade, foi uma ampliação das milícias provinciais de pardos quanto ao número das companhias soltas, isto é, que não formavam batalhões ou regimentos. Em 1780, além do batalhão sediado na Cidade do México e das sete companhias de Puebla, havia mais onze companhias de infantaria formadas por pardos nas regiões de Guadalajara (5), Valladolid

\footnotetext{
55 SUAREZ, Santiago-Gerardo. Las milicias. Instituciones militares hispanoamericanas. Caracas: Academia Nacional de la Historia, 1984.

${ }^{56}$ Cf:: AGI, Mexico, leg. 2422. "Instrucción de D. Julian de Arriaga al Señor Villalba". San Ildefonso, 1 de agosto de 1764.

${ }^{57}$ MARCHENA FERNÁNDEZ, Juan (Coord.). El ejército de América..., p. 158-161.
} 
(2), Córdoba e Orizaba (1), Pátzcuaro (1), Veracruz (1) e Xalapa (1). Em Guanajuato, mestiços e pardos também serviam na Legión del Príncipe, formando seis e oito companhias de cavalaria, respectivamente. Por fim, existia uma companhia de milícia provincial integrada por morenos em Veracruz. Juntamente com as milícias brancas e as tropas regulares, esses corpos militares formados por pardos e por uma parcela menor de mestiços e morenos claramente estavam posicionados em rotas estratégicas que partiam tanto do Golfo do México quanto da costa oeste e que forneciam acesso à capital. Em função do seu importante papel em meio à estrutura militar novohispana, o projeto para a arrumação dos corpos militares proposto por de Croix, em 1771, previu a manutenção das milícias provinciais de pardos. Esse mesmo projeto reiterou o que já se praticava a respeito da oficialidade dos corpos militares dos homens de cor: "el mando de los Cuerpos de Pardos debe precisamente darse a oficiales veteranos, nombrando subinspectores, ayudantes y garzones según la útil practica que se observa en la Isla de Cuba". 58

Apesar de as milícias de pardos serem consideradas úteis e necessárias para a defesa da Nova Espanha, foram-lhes aplicados mecanismos de controle quanto à sua expressão militar, social e política - o que se depreende menos pela limitação numérica de seus corpos militares em comparação com os de brancos e mais pela subordinação das companhias a oficiais veteranos brancos. Um quadro que resumia o "estado de força da tropa veterana e milícias" referente a 1779 não menciona as companhias de pardos dispersas pelo território, mas, por outro lado, revela a estrutura da oficialidade dos batalhões de pardos da Cidade do México e de Puebla, bem como das companhias de pardos e de morenos de Veracruz. O exercício de mando em cada um dos batalhões estava assentado em uma "plana mayor veterana", constituída por um subinspetor com graduação de sargento-mor, dois ajudantes-mores, um tambor-mor e dois pífanos, todos oriundos das tropas profissionais e brancos, à exceção dos músicos. Somente após essa plana-maior é que, na cadeia hierárquica das corporações em questão, estava situada a "plana mayor miliciana", constituída por um coronel - exclusivamente no caso do Batalhão do México - e dois ajudantes e abandeirados. Na sequência, no interior das companhias, havia sargentos brancos compondo o "pie de oficiales y tropa veterana", e, então, o restante da hierarquia dos pardos, formada por capitães, tenentes, subtenentes, sargentos, cabos, tambores e soldados. Embora a oficialidade parda e morena persistisse nas companhias e no pequeno

\footnotetext{
${ }^{58}$ Cf:: AGI, México, leg. 2422. "Dictamen del Brigadier Caballero de Croix, inspector general interino de las tropas del Reyno de la Nueva España, sobre el fijo establecimiento, arreglo, y subsistencia de los Regimientos Provinciales de Infantería y Caballería". México, 20 de setembro de 1771.
} 
estado-maior miliciano, os corpos militares estavam não somente sob a supervisão como também sob o comando efetivo de militares da tropa profissional.

A ingerência da oficialidade branca foi uma inovação promovida pela reestruturação da década de 1760. Nos períodos anteriores, ao contrário, se verificava o autogoverno nos corpos militares de cor, já que os coronéis empossados a partir dos anos 1720 eram a autoridade máxima dos batalhões, e abaixo deles vinham os demais oficiais da própria cor. A partir das reformas, a pequena plana-maior parda tornou-se completamente subordinada à plana-maior veterana e, no âmbito das companhias, os capitães, tenentes e subtenentes pardos perderam parte significativa de sua autonomia para os sargentos veteranos. Os problemas relacionados à delimitação das competências dos vários postos não tardaram a surgir e, na realidade, logo se transformaram em enfrentamentos nos quais se opuseram mutuamente a oficialidade veterana branca e a oficialidade miliciana parda. Ademais, a presença dos experientes militares profissionais acabou tornando "redundante", como expressou Vinson III, o posto de coronel ocupado por um miliciano pardo. Propostas visando à sua extinção surgiram já nos anos $1770 .{ }^{59}$

A confecção de projetos de arreglo ou reforma das milícias provinciais ou disciplinadas persistiram no decênio seguinte, assim como as discussões concernentes a essa temática ${ }^{60}$, e não tardou para chegar-se ao ponto de se propor a extinção das milícias de pardos. Isso ocorreu nos anos 1790, sob o governo do vice-rei Conde de Revillagigedo, em meio a um conjunto de disposições que tratavam de repensar as dimensões da estrutura militar erigida durante três décadas e especialmente buscavam desvincular uma parte da receita até então comprometida com a manutenção do sistema defensivo. Em toda a América espanhola, nos espaços interioranos de difícil acesso e apartados da costa marítima, notadamente nos vice-reinos do Peru, Nova Granada e Nova Espanha, esteve em curso ao longo das últimas décadas do século XVIII um processo de transformação de milícias provinciais em milícias urbanas. Objetivavase reduzir a folha salarial gasta com a oficialidade veterana bem como os custos de manutenção das armas e uniformes das milícias provinciais arcados pelo Real Erário. ${ }^{61}$

\footnotetext{
${ }^{59}$ VINSON III, Ben. Bearing arms for his majesty: the free-colored militia in colonial Mexico. Stanford: Stanford University Press, 2001, p. 74-78. Tradução livre.

${ }^{60}$ Cf: : AGI, México, leg. 2418. "Proyecto formado en el año de 1784 sobre el mejor arreglo y establecimiento del Estado de Nueva España. De Bonilla". 1784; "Informe del Inspector Ezpeleta sobre el Proyecto". México, 24 de outubro de 1785.

${ }^{61}$ KUETHE, Allan J. The military reform in the Viceroyalty of New Granada..., p. 211-247; KUETHE, Allan J. Las milicias disciplinadas: ¿fracaso o éxito? In: ESCAMILLA, Juan Ortiz (Coord.). Fuerzas militares en Iberoamérica, siglos XVIII y XIX. México: El Colegio de México, Centro de Estudios Históricos; Zamora, Michoacán, México: El Colegio de Michoacán; Veracruz, México: Universidad Veracruzana, 2005, p. 19-26; CAMPBELL, Leon G. The changing racial and administrative...; MARCHENA FERNÁNDEZ, Juan (Coord.). El ejército de América..., p. 155-172.
} 
Alguns indícios exteriores a tais projetos reformistas, no entanto, acenam para uma dimensão diferente quando se trata das milícias de cor: o intento de diminuir o status adquirido pelos milicianos pardos após grande mobilização bélica levada a cabo ao longo dos anos anteriores. Algumas medidas que transcendiam o âmbito específico do vice-reino ecoavam em seu interior, a exemplo da ordem de 3 de setembro de 1789 sobre as honras e distinções assinaladas ao comandante e oficiais pardos das milícias, estabelecidos primeiramente para a Província de Caracas, que "privó inmediatamente a los Oficiales Pardos de este reino el distintivo de banda con que se presentaron". Como se recomendou às autoridades da Nova Espanha que analisassem a viabilidade de aplicação dessa ordem em sua configuração social, "atendidas las circunstancias y disgusto que pueda ocasionarles [aos oficiais pardos] la resolución", o vice-rei Revillagigedo informou ao rei, em 1793, que "no se advirtió en ellos alteración alguna". ${ }^{62}$ Apesar de aparentemente apresentar-se como uma medida de pequeno significado ou de conteúdo pouco relevante, esse foi um passo, entre outros, no sentido da desestruturação das milícias de cor, as quais, no caso da Nova Espanha, já estavam extintas há um ano.

De fato, em 1792, o subinspetor geral Pedro Gorostiza enviou ao vice-rei Revillagigedo seu projeto destinado à supressão das milícias de pardos da Cidade do México e de Puebla. Em sua narrativa, afirmou que aqueles corpos militares haviam sido criados nos anos 1760 sob a suposição de que eram capazes de fazer o serviço como se fossem corpos veteranos, o que, em sua interpretação, não passava de um equívoco. Propôs, então, que as milícias de pardos fossem completamente abolidas nas localidades do interior e que as milícias em geral compreendessem "solo los Blancos de Casta limpia, sin necesidad de incluir a los tributarios". Quanto às “jurisdicciones de las Costas y en las de Frontera, la falta de aquella gente y la precisión de formar un competente número de milicia capaz de defender y rechazar los primeros insultos, obligarán a comprender por necesidad los Pardos, aunque con oficiales blancos y comandantes veteranos". ${ }^{63}$ É, pois, dessa época a extinção das companhias de milícias de pardos e morenos existentes em Veracruz e a readmissão de seus integrantes em um corpo militar de primeira linha ${ }^{64} \mathrm{E}$, com efeito, essa transformação se justificou pela falta de homens brancos disponíveis para a defesa desse sítio costeiro tão importante do ponto de vista

\footnotetext{
${ }^{62} C f$ : AGI, México, leg. 1437, doc. 794. "El Virrey de Nueva España, conde de Revillagigedo, en satisfacción de la real orden de 18 de octubre último sobre honores y distinciones al comandante y oficiales Pardos de Milicias de esta clase, incluye copia de lo informado por el subinspector general, Don Pedro Gorostiza". México, 31 de janeiro de 1793.

${ }^{63}$ Cf:: Archivo General de la Nación - México, leg. 197B (Indiferente de Guerra). Pedro Gorostiza ao Conde de Revillagigedo. México, 2 de janeiro de 1792.

${ }^{64} C f$ : AGI, México, leg. 1437, doc. 875.
} 
econômico, e por isso mesmo exposto a ataques estrangeiros. ${ }^{65}$ Diferente sorte obtiveram os milicianos pardos dos batalhões da Cidade do México e de Puebla, os quais foram efetivamente desmobilizados.

Assim, no caso novo-hispânico, a extinção e reforma das milícias de pardos foi justificada através de três linhas de argumentação: a primeira sugeria que esses corpos militares eram dispensáveis, já que, além da tropa veterana, "habrá suficiente milicia en la clase de Provincial y Urbana" composta dos "blancos de casta limpia"; a segunda considerava os batalhões "gravosos", ou onerosos, uma vez que, para além dos soldos da oficialidade, todos os seus soldados eram isentos do pagamento de tributos; a terceira argumentação reputava os pardos como um elemento "perjudicial a la causa pública, porque siendo en general la gente más viciosa de ambas poblaciones, dan infinito que hacer a la superioridad con la multitud de causas y competencias que se promueven a la sombra del fuero que gozan". ${ }^{66}$ Ao final da súbita reforma dos Batalhões do México e de Puebla, completada poucos meses após a aprovação do projeto correspondente, as explicações para o procedimento convergiram simplesmente para "el fin de economizar a la Real Hacienda los gastos (...) en la subsistencia de los Batallones de Pardos libres (...) y aumentar el apreciable ramo de tributos". ${ }^{67}$

A situação dos milicianos reformados dependeu de qual posto ocupavam na milícia, do tempo de serviço e da ausência ou presença de notas ou faltas em termos de disciplina militar. Alguns oficiais continuaram recebendo soldo, desfrutando do foro militar e dispensados do pagamento de impostos, um grupo um pouco maior foi declarado apenas isento quanto aos tributos, mas a maior parte dos soldados experimentou essa espécie de rebaixamento social que era a condição de tributários. ${ }^{68}$ A oficialidade do México e de Puebla reagiu ao duro golpe

\footnotetext{
${ }^{65}$ ARCHER, Christon I. Pardos, Indians, and the Army os New Spain..., p. 240-244; GONZÁLEZ DE LA VARA, Martín. El rey Revillagigedo y la defensa del puerto de Veracruz, 1789-1794. Relaciones. Estudios de historia y sociedad, Zamora-México, vol. XXVIII, núm. 110, 2007, p. 69-93; SERNA H., Juan M. de la. Integración e identidad, pardos y morenos en las milicias y cuerpo de lanceros de Veracruz en el siglo XVIII. In: ESCAMILLA, Juan Ortiz (Coord.). Fuerzas militares en Iberoamérica, siglos XVIII y XIX. México: El Colegio de México, Centro de Estudios Historicos; Zamora, Michoacán, México, El Colegio de Michoacán; Veracruz, México: Universidad Veracruzana, 2005. p. 61-74. Como se lê na historiografía, as crises epidêmicas associadas à febre amarela devastaram parte considerável da população estabelecida em Veracruz entre finais do século XVIII e inícios do XIX. As populações de cor revelaram maior resistência à doença em comparação aos brancos, e em função disso foram amplamente requisitadas para compor a defesa local.

${ }^{66}$ Cf:: AGN-Mx, leg. 197B (Indiferente de Guerra). Pedro Gorostiza ao Conde de Revillagigedo. México, 2 de janeiro de 1792. A argumentação que embasou o projeto de Gorostiza foi reproduzida por Revillagigedo quando informou à Coroa a implementação da reforma. Ver AGN-Mx, Correspondencia de los Virreyes, serie 1, vol. 167, fls. 130-131. "N. 602. El Virrey de N. E., Conde de Revillagigedo. Da cuenta con testimonio de expediente de haber reformado los dos Batallones de Pardos Libres de México y Puebla, por las ventajas que refiere en favor del Real Erario y causa pública". México, 30 de junho de 1792.

${ }^{67}$ Cf:: AGN-Mx, leg. 197B (Indiferente de Guerra). Vice-rei Revillagigedo ao senhor Intendente de Puebla. México, 29 de março de 1792.

${ }^{68}$ Cf:: AGN-Mx, leg. 197B (Indiferente de Guerra). Pedro Gorostiza ao Conde de Revillagigedo. México, 16 de março e 25 e 29 de outubro de 1792.
} 
sofrido pela corporação e encaminhou ao trono representações e requerimentos com a finalidade de restituir as suas corporações no estado imediatamente anterior à reforma. Eles alegavam, por um lado, a antiguidade dos corpos militares e os inúmeros serviços prestados ao longo de mais de dois séculos de existência, aspectos que avalizavam sua utilidade e fidelidade à Coroa; por outro lado, expressavam o desgosto e o abatimento por não servirem mais e por decaírem à condição desprestigiada de tributários. ${ }^{69}$

Diante da insistente pressão exercida pelos já antigos oficiais pardos, em abril de 1794 a Coroa espanhola encarregou o novo vice-rei, Marquês de Branciforte, de informar sobre as consequências da reforma. A sua aprovação definitiva, então, ficou à mercê da avaliação relativa ao impacto social das medidas, especificamente quanto ao seu potencial de ocasionar “cualesquiera novedad contrária a la quietud pública o al mejor servicio de S. M.". ${ }^{70}$ Em fins de setembro de 1794, Branciforte manifestou os seus conceitos acerca do trabalho de seu antecessor a respeito dos batalhões de pardos, considerando a reforma "bien hecha, sin que pueda causar recelo o descontento de consideración". Embora ela tenha dado ensejo aos requerimentos dos milicianos, o vice-rei argumentou que "estas demostraciones no pueden causar el más leve recelo según el estado actual de las cosas en este Reyno". ${ }^{71}$ Conforme a avaliação das principais autoridades da Nova Espanha, as tensões sociais desencadeadas pela abolição das milícias pardas eram insignificantes e em nada comprometiam o equilíbrio social. Mesmo com uma empreitada de Branciforte para restabelecer as milícias provinciais recentemente extintas por Revillagigedo, levada a efeito no mesmo ano de 1794, tais corporações dos homens de cor permaneceram definitivamente aniquiladas. ${ }^{72}$

A trajetória das milícias de pardos da Nova Espanha não pode ser encarada como um padrão que se possa atribuir aos corpos congêneres de outros espaços da América espanhola. Em verdade, cada batalhão, regimento ou companhia tinha a sua própria história e foi afetado de forma particular pelas reformas empreendidas entre fins do século XVIII e começo do XIX,

\footnotetext{
${ }^{69} C f:$ : AGN-Mx, leg. 197B (Indiferente de Guerra). Requerimento dos capitães e subalternos do Batalhão de Pardos da cidade do México ao vice-rei Branciforte. Cidade do México, [1795]; Requerimento de José Arellano, José Zambrano, José Moreno, José Ricardo e Ramon Riveros, capitães do antigo Batalhão de Pardos de Puebla, ao vice-rei Revillagigedo. Puebla, 3 de julho de 1794. Requerimento do capitão José Zambrano e do subtenente Joaquim de Medina, em nome dos demais oficiais do Regimento de Milícias dos Pardos de Puebla, ao rei. Puebla, post. 1792.

${ }^{70}$ Cf:: AGN-Mx, leg. 197B (Indiferente de Guerra). Ofício do vice-rei Branciforte a Bonilla. México, 14 de julho de 1794.

${ }^{71} C f$ :: AGI, México, leg. 1438, doc. N. 66. "El Virrey de N.E., Marqués de Branciforte, en cumplimiento de las reales ordenes de 22 y 27 de abril último manifiesta sus conceptos sobre la reforma de los dos Batallones de Pardos Libres de México y Puebla ejecutada por su antecesor, y la considera bien hecha, sin que pueda causar recelo o descontento de consideración". México, 30 de setembro de 1794.

${ }^{72} C f$ :: AGI, México, leg. 1438, docs. N. 134. México, 3 e 5 de dezembro de 1794.
} 
como revela a literatura especializada. ${ }^{73}$ No entanto, a observação dos elementos compartilhados em toda a Hispano-América e igualmente das especificidades mexicanas serve muito bem para colocar em perspectiva a história das milícias pardas e pretas da América portuguesa. A arregimentação de descendentes de escravos e de sua progênie mestiça foi prática corriqueira nos impérios coloniais português e espanhol desde muito cedo. Sobretudo onde o escravismo foi mais intenso, essa população compôs uma parte significativa dos sistemas defensivos locais e os seus corpos militares foram se estabelecendo ao longo do tempo e conforme os confrontos militares, internos e externos, ocorriam. De fato, os ataques holandeses à Bahia e Pernambuco, na América portuguesa, e os dos piratas comandados por Lorencillo, na Nova Espanha, ocorridos no século XVII, foram marcos importantes na configuração das milícias de cor ibero-americanas e no acesso a privilégios e honrarias por parte das próprias corporações e de seus integrantes. As mobilizações militares internas, frente a grupos indígenas e de quilombolas, reforçaram o importante papel das milícias de pardos, pretos e morenos.

Quando as milícias de pardos mexicanas consolidaram sua elevação em termos de status, mediante a obtenção de um coronelato entre seus integrantes, entre as décadas de 1720 e 1730, pardos e pretos da América portuguesa, que também haviam atingido um grau significativo de autonomia atrelado à oficialidade de cor, sofreram com a extinção de seus terços e companhias, mas logo se reestruturaram. A década de 1760 significou, em ambos os espaços, um processo de militarização de grandes proporções. As milícias formadas por homens de cor expandiram-se e foram reguladas por governadores locais e por oficiais militares comissionados. Nesse processo, enquanto as milícias de pardos e morenos de todos os espaços hispano-americanos receberam a ingerência direta de um conjunto de oficiais brancos provenientes das tropas regulares, no Estado do Brasil elas conseguiram lutar para manter a exclusividade do mando em suas mãos, o que de fato foi obtido em várias capitanias. Finalmente, o ocaso dos batalhões de milícia provincial de pardos na Nova Espanha, na década de 1790, contrasta integralmente com o prestígio obtido por pardos e pretos diante da Coroa portuguesa. O exemplo novo-hispânico atesta o impacto que os projetos reformistas ilustrados atinentes às milícias tiveram ou puderam vir a ter para pardos e pretos. Faz-se necessário, pois, examinar os principais planos de reforma das milícias apresentados em diferentes configurações sociais brasileiras para que se visualize de que forma as altas autoridades militares lidaram com

\footnotetext{
${ }^{73}$ CAMPBELL, Leon G. Black power in colonial Peru...; KUETHE, Allan J. The status of the free pardo...; BELMONTE POSTIGO, José Luís. El color de los fusiles...; VINSON III, Ben. Los milicianos pardos y la relación estatal...; CRUCES, Hugo Contreras. Artesanos mulatos y soldados beneméritos. El Batallón de Infantes de la Patria en la Guerra de Independencia de Chile, 1795-1820. Historia, Santiago, v. 44, n. 1, p. 51-89, ene./jun. 2011.
} 
o status elevado dos milicianos de cor na virada do século XVIII para o XIX. Assim como o caso hispano ilumina as características do luso-americano, a análise às configurações sociais baiana, pernambucana e fluminense permitirá que melhor se compreenda o que se passou com o Regimento dos Úteis em São Paulo.

\subsubsection{América portuguesa: Pernambuco, Rio de Janeiro e Bahia}

Poucos anos depois de firmada a paz com a Espanha, em 1777, governadores coloniais da América portuguesa se depararam com uma estrutura militar colossal, a qual, a exemplo dos vizinhos hispano-americanos, comprometia as finanças públicas. Em 1781, o governador de Pernambuco, José César de Menezes, recebeu ordens da rainha transmitidas pelo Marquês de Angeja, presidente do Real Erário, para proceder novo alistamento de praças para compor os terços existentes naquela capitania e em seguida informar "da redução que neles se poderá fazer em utilidade da Fazenda Real e desse Estado, e sem vexame dos moradores dele”. Na resposta, formulada no ano seguinte, Menezes justificou os motivos pelos quais suspendeu o pagamento de soldo aos ajudantes pardos e deixou de prover os postos de sargento-mor e ajudante vacantes nos terços de pardos e de pretos, fato que redundou na ida de alguns desses oficiais para a Corte, em Lisboa, a reclamar o que achavam justo. Também argumentou que os terços pernambucanos estavam todos faltos de soldados e plenos de oficiais, e que a "esta Praça lhe bastam só um Terço de Brancos, outro de Pardos e outro de Henriques: porém, para serem bem disciplinados e úteis ao Real serviço, devem os seus oficiais maiores de mestre-de-campo, sargento-mor e ajudante ser brancos, pois só assim se pode conservar nos soldados a disciplina". A opção pela oficialidade branca, para Pardos e Henriques, baseava-se em três pontos: em primeiro lugar, nas características pessoais e nas práticas atribuídas aos oficiais pardos e pretos, que "vivem com pouca honra, utilizando-se dos soldados, que fazem valer até a desesperação para os seus interesses particulares"; em segundo e terceiro, nos exemplos pretensamente exitosos tanto das Companhias indianas de Sipais e dos Migueletes - "que correspondem aos Pardos e Pretos nesta capitania, sempre os seus capitães são brancos e tirados da Tropa" - quanto das ações "louváveis" do Marquês do Lavradio no Rio de Janeiro - que "fizera os oficiais maiores dos corpos em questão homens brancos, de cuja honra se pudesse fiar". ${ }^{74}$

\footnotetext{
${ }^{74} C f$ :: AHU_CU_015, Cx. 144, D. 10544. Lisboa, 23 de novembro de 1781 e Recife, 13 de abril de 1782. Ver também SILVA, Luiz Geraldo. Sobre a "etnia crioula": o Terço dos Henriques e seus critérios de exclusão na América portuguesa do século XVIII. In: VENÂNCIO, R. P.; GONÇALVES, A. L.; CHAVES, C. M. das G.
} 
A encomendada e projetada redução dos terços, assim como a suspensão da oficialidade de cor, não tiveram efeito. Como visto nos capítulos 1 e 2, Pernambuco era uma das capitanias brasileiras com contingente miliciano mais elevado no começo do século XIX. O que mais interessa notar, no entanto, é o fato de Menezes recorrer ao modelo de formatação dos corpos militares de pardos e de pretos instaurado por Lavradio no Rio de Janeiro na década anterior, ao passo que, na mesma época, o modelo pernambucano era energicamente reivindicado pelos auxiliares de cor da Bahia, como já visto. Enquanto as autoridades coloniais pressionavam por moldar as tropas de pardos e pretos em um sentido, os homens de cor despendiam esforços no sentido contrário.

O paradigma vigente no Rio de Janeiro também serviu de inspiração a D. Fernando José de Portugal, governador da Bahia entre os anos 1788 e 1801 e vice-rei do Estado do Brasil de 1801 a 1806, ao ponto de implementá-lo por sua própria iniciativa em 1796. Em maio desse ano, ele encaminhou às instâncias superiores no Reino uma lista de oficiais das tropas de linha e de auxiliares que estavam em condições de se retirarem do serviço, fosse por idade ou por moléstias, a qual recebeu aprovação em agosto. Em um segundo ofício, Portugal expressou a dúvida de como proceder no pagamento dos soldos desses oficiais reformados, pois seria muito oneroso às câmaras das cidades e vilas arcarem com o pagamento de sargentos-mores ativos e também dos reformados. Mas essa era somente uma parte da questão, pois entre tais oficiais havia um sargento-mor pardo. Na sequência, o governador representou à Coroa para que se observasse em Pernambuco aquilo que praticou Lavradio no Rio de Janeiro, isto é, que os terços de cor fossem comandados por um sargento-mor branco, da tropa regular, e não pardo ou preto, como garantiu a resolução de 1767. Além disso, solicitou que os postos de coronel e tenentecoronel desses corpos militares, superiores na hierarquia ao de sargento-mor, fossem abolidos. Complementarmente, pediu a reforma do ajudante pardo e a sua substituição por um ajudante com a graduação de capitão. Isso tudo "para que estes oficiais" brancos "nunca sejam comandados por homens pardos". ${ }^{75}$

A sequência de acontecimentos posteriores - a reação imediata dos milicianos pardos e a postura cautelosa dos ministros na Europa - se assemelha ao que ocorreu na Nova Espanha entre 1792 e 1794, mas, em virtude das especificidades da sociedade escravista luso-americana e das configurações sociais internas às suas capitanias, os desdobramentos das medidas relativas às milícias de pardos e pretos tomaram um sentido diferente. Com efeito, a oficialidade parda

(Orgs.). Administrando impérios. Portugal e Brasil nos séculos XVIII e XIX. Belo Horizonte: Fino Traço, 2012, p. 71-96.

${ }^{75}$ Cf: AHU_CU_005-01, Cx. 85, D. 16.642, 16.647-16.649. Bahia, 24 e 25 de maio e 15 de julho de 1796. 
do 4. ${ }^{\circ}$ Regimento de Salvador - a única diretamente afetada, já que a dos pretos Henriques permaneceu intocada - se mobilizou e expôs a sua situação à Coroa tão logo se efetivou o pacote de reformas militares que incluiu sua oficialidade maior. Como era de praxe, buscaram demonstrar a pertinência dos serviços militares prestados pela milícia parda, seu asseio e a fidelidade devotada à Coroa, para em seguida implorarem para que os postos fossem providos entre homens da sua própria cor, uma vez que corriam boatos - evidentemente bem fundamentados - de que D. Fernando José de Portugal pretendia investir um oficial branco da tropa regular no comando do Regimento. Em consulta relativa aos requerimentos apresentados pelos oficiais pardos, realizada em 1797, os ministros do Conselho Ultramarino instaram o governador Portugal a fornecer informações sobre o caso. A primeira manifestação do Conselho considerou que, entre os vários assuntos levantados pelos pardos, havia um artigo para o qual “pode ser perigosa a sua dilação". Era precisamente a inovação proposta na formatação do estado-maior do Regimento. Conforme o parecer, "o direito dos suplicantes nesta parte é notório e firmado desde a criação deste Regimento, na dita real ordem de 30 de maio de 1767. A sua posse, aprovada e titulada, não sofre alteração sem justíssimas causas”. Recomendou-se, então, que até que Portugal prestasse a sua informação e o rei decidisse a questão, não deveria haver inovação alguma e que "se acautelem os seus contingentes efeitos quanto for possível". ${ }^{76}$

O governador Portugal encaminhou dois informes ao Conselho Ultramarino, em fevereiro e abril de 1798. Neles, expôs que já havia concretizado o seu projeto, mediante a reforma dos oficiais pardos, da extinção dos postos de coronel e tenente-coronel, e da nomeação de sargento-mor e ajudantes brancos egressos da tropa de linha, em virtude da aprovação régia de agosto do ano pretérito. Acrescentou que seria "sumamente dificultoso fazer um bom sargento-mor de um oficial Preto ou Pardo, que jamais serviu na Tropa Regular" e que, após a transformação, o Regimento dos Pardos passou a estar "em bom pé e disciplinado, quando antecedentemente estava na última decadência". ${ }^{77}$ O governador e capitão-general também respondeu sobre os demais artigos constantes dos requerimentos dos oficiais pardos - questões atinentes ao foro e à etiqueta militar - mas nada expôs sobre o problema central apontado pelos ministros régios, relativo ao impacto social da descaracterização da oficialidade parda. A matéria era, de fato, delicada. Os reformadores argumentavam que os exércitos aumentavam, diminuíam ou se transformavam prioritariamente de acordo com o planejamento técnicomilitar. Entretanto, os ministros, mais distanciados, ponderavam a questão pela ótica do objetivo principal de manutenção da estabilidade do equilíbrio social mediante o controle dos

\footnotetext{
${ }^{76} C f$ : : AHU_ACL_CU_005, Cx. 206, D. 14735. Lisboa, 28 de junho de 1797.

77 Cf: AHU_ACL_CU_005, Cx. 216, D. 15168. Bahia, 21 de fevereiro e 18 de abril de 1798.
} 
diversos grupos e corpos. Como o acesso às funções honoríficas e de autoridade da milícia eram encarados como privilégios concedidos pela Coroa, ele se converteu desde muito cedo em uma via de estreitamento dos laços entre os vassalos pardos e pretos e a Monarquia. Ademais, esse vínculo se espraiava por todo o corpo social: em cada terço ou regimento, os comandantes pardos e pretos exerciam influência pessoal sobre centenas de milicianos subordinados, os quais, por sua vez, tinham pais, esposas e filhos. Portanto, alterar qualquer aspecto constitutivo das bases dessa relação poderia significar o mesmo que mexer em um vespeiro.

De fato, as insatisfações de militares pardos da tropa de linha e de um grupo menor de milicianos, relativas à desigualdade de tratamento dispensada a eles relativamente aos brancos, vieram à tona em pasquins afixados em Salvador em agosto de 1798. Como chamou a atenção Maria B. N. da Silva, o movimento social conhecido como Revolta dos Alfaiates pode ser melhor entendido ao se reconhecer o predomínio de militares entre os envolvidos e a centralidade das questões internas à organização da hierarquia militar colonial em sua estruturação. Ora, a liberdade e igualdade perseguidas pelo movimento pouco afetariam a vida dos escravos. Tratava-se, antes de tudo, da noção conforme a qual "qualquer homem, fosse qual fosse a sua cor, ascenderia no futuro governo às funções militares e políticas se tivesse méritos para isso". 78

Bem se vê que o ímpeto do governador e capitão-general D. Fernando José de Portugal em alterar a configuração da oficialidade miliciana parda ia frontalmente de encontro às demandas efervescentes de grupos organizados de militares de cor. A nomeação do sargentomor e dos ajudantes brancos para o $4 .^{\circ}$ Regimento miliciano foi assunto tratado entre os sediciosos. Tal era a gravidade da matéria, que ela não passou despercebida por aqueles que pensavam e refletiam sobre o equilíbrio social. O professor Luís dos Santos Vilhena, como atento observador, considerou imprudente a reforma empreendida por Portugal e também as descomposturas praticadas pelos oficiais brancos recém-empossados aos subordinados pardos. ${ }^{79}$ Já o provedor da moeda, José Venâncio de Seixas, ao comentar sobre a "associação sediciosa de mulatos" a D. Rodrigo de Souza Coutinho, secretário de Estado da Marinha e do Ultramar, afirmou enfaticamente que a Coroa havia se equivocado quando incentivou a ascensão das milícias de cor e permitiu que seus oficiais desfrutassem de privilégios e honras. De acordo com suas palavras, "a carta régia de 1766 foi [...] um erro de política em

\footnotetext{
${ }^{78}$ SILVA, Maria Beatriz Nizza da. Conflitos raciais e sociais na sedição de 1798 na Bahia. In: ARAÚJO, U. C.; TAVARES, L. H. D.; SILVA, M. B. N.; JANCSÓ, I.; MOREL, Marco (Orgs.). II Centenário da Sedição de 1798 na Bahia. Salvador: Academia de Letras da Bahia; Brasília: MINC, 1999, p. 38.

${ }^{79}$ SILVA, Maria Beatriz Nizza da. Conflitos raciais e sociais na sedição de 1798 na Bahia..., p. 42-44.
} 
administração de colônias, porque mandando formar corpos milicianos desta qualidade de indivíduos [, pardos e pretos] se viram condecorados com postos de coronéis e outros semelhantes". Chegado a esse ponto, "esta gente, naturalmente persuadida, adiantou consideravelmente as suas ideias vaidosas, o que, junto ao espírito do século, os faz romper em toda a qualidade de excessos" ${ }^{80}$

Havia, pois, um campo de debates e de ações concretas marcado por posições antagônicas em janeiro de 1800, quando baixou nova resolução do Conselho Ultramarino. Sem menoscabarem as razões do governador da Bahia, os ministros entenderam que o $4 .^{\circ}$ Regimento deveria retornar ao estado inicial, com estado-maior completo e constituído por homens pardos. Os postos, dali em diante, deveriam ser providos mediante concurso e exames públicos aos quais poderiam se submeter os pardos que já houvessem servido na tropa regular. Esse parecer estava respaldado numa interpretação que conferiu coesão e coerência aos seguidos posicionamentos da Coroa perante os oficiais milicianos pardos e pretos ao longo de toda a segunda metade daquele século. Os conselheiros lembraram ao príncipe regente, D. João, que seu avô D. José I foi servido

[...] igualar os terços dos Pardos e Pretos com os Brancos quanto às suas honras, regalias e soldos, não admitindo as oposições e as instâncias que obstaram largos tempos aquela mercê, tendo ela por objeto o bem do mesmo serviço, pois que este meio era o mais fácil, o mais justo e o mais político para lhes influir e radicar nos seus corações o amor e a fidelidade que devem conceber e conservar ao seu Soberano e à sua Pátria.

Estes mesmos sentimentos da piedade, próprios efeitos da indefectível Justiça do Trono, são os que V.A.R. fez há pouco cumprir, deferindo aos sargentos-mores e ajudantes dos Pretos de Pernambuco quanto à igualdade dos seus soldos, e até pelos mesmos régios efeitos de grandeza e piedade, foi V.A.R. servido mandar ampliar esta graça, estabelecendo-a em regra para todos os outros Pretos ocupados naqueles postos nos Regimentos ou Terços de todo o Estado do Brasil.

V.A.R., pela sua superior e iluminada compreensão, há de conhecer melhor que este Conselho a necessidade que há de não alterar nos nossos domínios - e menos na presente época - a um ramo da Tropa que é utilíssimo àquele Estado, composto de indivíduos que se honram e gloriam com a igualdade que lhes é devida em postos do real serviço [...]. ${ }^{81}$

Ainda em 1800, D. Fernando José de Portugal respondeu à resolução do Conselho, dando prosseguimento ao debate que já durava quatro anos e demonstrando uma certa irritação

\footnotetext{
${ }^{80} C f$ :: "Carta de José Venâncio de Seixas para D. Rodrigo de Sousa Coutinho, em que lhe participa ter chegado à Bahia e ter tomado posse do lugar de Provedor da Casa da Moeda, referindo-se a diversos assuntos de serviço público e especialmente à descoberta de uma associação sediciosa de mulatos". Bahia, 20 de outubro de 1798 . Doc. 18.431 - 18.432. In: Anais da Biblioteca Nacional, v. 36, 1914, p. 42-43.

${ }^{81}$ Cf:: AHU_ACL_CU_005, Cx. 216, D. 15168. Lisboa, 13 de janeiro de 1800.
} 
por ver seu projeto contrariado. Portugal reiterou o seu posicionamento quanto à pertinência da nomeação de oficiais brancos da tropa paga e se remeteu novamente ao exemplo da formatação imposta por Lavradio aos terços de cor no Rio de Janeiro. Ele acrescentou um elemento diferente ao debate quando discordou que os pardos seriam "pouco atendidos" a partir da ingerência da oficialidade branca, uma vez que continuariam a ser "promovidos até os postos de capitães, quando a maior parte destes homens é destituída de bens e vive de ofícios mecânicos". No transcurso do tempo, quando ficou claro que as justificativas técnicas não eram suficientes para convencer os ministros acerca da reforma, vieram à tona aspectos mais vinculados à perspectiva nobiliárquica dos governadores coloniais e dos militares de alto escalão, os quais denunciavam a incompatibilidade existente entre as condições de nascimento e vida dos oficiais pardos e pretos e as posições de honra e prestígio que ocupavam na milícia. Finalmente, com desvelada ironia, afirmou que, no caso de o interesse da Coroa quanto àqueles corpos militares residir somente "em os não desgostar e descontentar, mas antes em os animar e os elevar, e em sustentar o seu capricho e a sua vaidade", então se poderia retornar ao antigo estado daquele Regimento. ${ }^{82}$

A resolução formal para o caso da milícia dos pardos de Salvador foi acenada no parecer do Conselho Ultramarino datado de 20 de maio de 1802 e confirmada na Provisão de 26 de agosto do mesmo ano. Determinou-se na ocasião que o $4 .^{\circ}$ Regimento retornasse à organização anterior às alterações promovidas em $1796^{83}$, com estado-maior completo e formado por homens pardos, preferencialmente oriundos da tropa regular e alternativamente pelos próprios milicianos, desde que aprovados nos exames militares. Em último caso, na ausência de pardos beneméritos e com merecimentos, os postos seriam providos em brancos da tropa paga. Ademais, essa medida transcendeu o âmbito baiano e se tornou extensiva para o Rio de Janeiro, para onde D. Fernando José de Portugal se transferira havia pouco tempo como vice-rei. Desse modo, o modelo instaurado por Lavradio para as tropas pardas e pretas, o qual embasou os projetos de reforma de governadores de Pernambuco e Bahia, foi enfim suplantado. ${ }^{84}$

Como visto, a implementação da reforma na oficialidade parda de Salvador deu início a um longo debate entre o governador da Bahia, os oficiais milicianos pardos e os representantes das altas instâncias administrativas da Coroa relativamente ao Ultramar que é do maior interesse

\footnotetext{
${ }^{82}$ Cf:: AHU_ACL_CU_005, Cx. 225, D. 15603. Bahia, 17 de setembro de 1800.

${ }^{83}$ As alterações em questão dizem respeito especificamente à deposição da oficialidade maior parda e não à transformação dos terços auxiliares em regimentos de milícias instigada pelo decreto de mesmo ano.

${ }^{84}$ Cf:: AHU_ACL_CU_005, Cx. 226, D. 15603. Lisboa, 20 de maio de 1802; AHU_ACL_CU_005, Cx. 226, D. 15669. Lisboa, 26 de agosto de 1802. Conferir também as análises de RUSSELL-WOOD, A. J. R. Escravos e libertos..., p. 138-142; e KRAAY, Hendrik. Política racial, Estado e Forças Armadas..., p. 154-164.
} 
para a história das milícias de cor luso-americanas. Nesse embate, todos os envolvidos recuperaram diferentes aspectos da trajetória e da natureza daqueles corpos militares, e o dado mais significativo é que a resolução desse caso antecipou os termos que seriam empregados especificamente a pardos e pretos no Alvará de 1802. Vistas a partir dessa perspectiva, tais disposições podem ser lidas menos pelo aspecto da "ambiguidade" e preferencialmente como significando a vitória do modelo defendido pelos pardos e pretos da América portuguesa após uma acirrada investida de governadores e vice-reis no sentido contrário. Trata-se, como vem sendo afirmado, do auge do processo de elevação social dos milicianos pardos e pretos, que se traduziu na ampliação do número desses corpos militares, de seus privilégios e honrarias e na formalização institucional de garantias.

Na prática, porém, o imbróglio em torno do provimento dos postos mais elevados dos regimentos de pardos persistiu: no Rio de Janeiro pelo menos até 1804 e em Salvador até 1808. ${ }^{85}$ A competição entre brancos, de um lado, e pardos e pretos, de outro, pelo capital simbólico disponível na milícia converteu-se em conflito aberto. Se até 1802 os administradores reformistas miravam a destituição das oficialidades de cor e acionavam critérios técnicos em suas argumentações, a partir daí eles formularão em seus projetos a aniquilação das corporações de pretos e pardos e apelarão cada vez mais para elementos exteriores, apenas aparentemente, ao universo militar. Daqui em diante, a manifestação de governadores e oficiais militares de alto escalão será o principal objeto de exame, deixando para analisar na próxima seção as expressões igualmente relevantes dos milicianos pardos e pretos acerca da questão.

$\mathrm{Na}$ Bahia, a adequação às normas impostas pela Coroa obrigou a elaboração de uma proposta para o provimento dos postos vagos no Regimento dos pardos, a qual ficou a cargo do marechal Florêncio José Correia de Mello. Nessa ocasião, o militar designado para a tarefa não se ateve a apontar o que ele considerava falta de merecimentos de cada um dos indivíduos que se apresentaram ao concurso para os postos, pois exprimiu espontaneamente reflexões mais abrangentes acerca daquele corpo militar. Dois pontos do seu texto merecem destaque: em primeiro lugar, um questionamento incisivo aos oficiais pardos tendo-se como fundamento a sua condição socioprofissional. Conforme expressou, "eu não sei escolher um coronel entre homens que vivem de ofícios mecânicos, sem educação alguma nem meios suficientes de sustentar dignamente a autoridade daquele posto, igualado hoje nas honras com os outros coronéis das tropas pagas". Em segundo lugar, propôs que se abolisse o "Regimento Miliciano de Mulatos, e que o referido Regimento fosse organizado, como são os outros corpos milicianos

\footnotetext{
${ }^{85}$ Sobre o Rio de Janeiro, ver AHU_ACL_CU_017, Cx. 220, D. 15152. Rio de Janeiro, ant. 31 de julho de 1804. Para a milícia parda de Salvador, KRAAY, Hendrik. Política racial, Estado e Forças Armadas..., p. 163.
} 
desta capitania, de cidadãos livres, sem distinção alguma de cores". ${ }^{86}$ Como se vê, governadores e militares brancos de alta patente em serviço na Bahia mantiveram o ataque à milícia parda mesmo diante das mais recentes considerações em sentido contrário advindas do Conselho Ultramarino e da própria Coroa.

Já as reflexões visando à reforma das milícias esboçadas em 1806 por Caetano Pinto de Miranda Montenegro, governador de Pernambuco, primavam pela adequação das forças militares locais às normas metropolitanas. Cabia diminuir os efetivos onde excedessem e aumentar onde não atingissem o estipulado pelo Decreto de 1796. Porém, em se tratando dos Regimentos de pardos e de pretos, as ideias foram dotadas de um tom acentuadamente político. Antes de qualquer coisa, Montenegro examinou as "três espécies de habitantes" mais numerosas da capitania, ou seja, brancos, mestiços e pretos, estabeleceu proporções entre elas e compartilhou com o Visconde de Anadia, secretário de estado da Marinha e do Ultramar, as decorrências atinentes ao equilíbrio social extraídas de seu raciocínio. Como quem coloca as cartas na mesa, afirmou que os mestiços contavam já a metade da população pernambucana e que, "ajuntando-se os pardos aos pretos, virão a fazer o duplo, o triplo ou o quádruplo dos brancos". Em seguida, traçou um resumo do quadro social seguido da configuração do campo de forças local. Conforme Montenegro, "os brancos são os possuidores das terras e das riquezas. Os pardos e pretos em geral são pobres e vivem do seu trabalho e indústria". Apesar de destituídos de recursos materiais abundantes, os homens de cor estavam "em muito maior número e mais robustos nestes climas", dispondo de maior concentração de "força física da sua parte". Consequentemente, cravou que "a força moral e de opinião deve estar a favor dos brancos", pois, do contrário, estes veriam os negros e mestiços a exclamar "ide-vos embora, também queremos possuir: já basta de obedecer, também queremos mandar”. São esses os termos, pois, que introduzem suas considerações acerca das milícias pardas e pretas, denotando claramente que a gestão dessas populações e de seus corpos militares era assunto estratégico e que demandava uma visão precisa dos equilíbrios de poder internos à capitania de Pernambuco. ${ }^{87}$

Em um segundo momento, o governador Montenegro examinou a legislação atinente àqueles corpos militares destacando a inversão operada no tratamento a pardos e pretos e colocando o status atingido por suas milícias em começos do século XIX como um problema político. Ele considerou que as Provisões de 1731 e 1733, ao excluírem completamente os pardos e pretos dos postos de autoridade e honra, buscavam reduzir a sua força física e ao

\footnotetext{
${ }^{86}$ Cf:: AHU_CU_005-01, Cx. 131, D. 25.845. Bahia, 25 de fevereiro de 1803.

${ }^{87}$ Cf:: AHU_CU_015, Cx. 259, D. 17405. Recife, 24 de março de 1806.
} 
mesmo tempo aumentar a força moral dos brancos. No entanto, a proliferação dos corpos de auxiliares e de ordenanças, que constituiu o mote da Carta Régia de 1766, mudou os rumos das relações de força entre brancos, de um lado, e pardos e pretos, de outro. Daí em diante, "nomearam-se Oficiais, até mesmo Superiores, tirados dos ofícios mecânicos e sem poderem manter a decência e independência dos postos".

O terceiro ponto do ofício encaminhado ao Visconde de Anadia trata mais diretamente da postura adotada em Pernambuco quanto aos oficiais pardos e pretos, diante do processo evolutivo de suas milícias que afinal era respaldado pela Coroa:

É mais fácil evitar abusos, do que arrancá-los depois de introduzidos. Agora os pobres pretos e pardos, apesar de que largando a espada vão pegar na agulha, no picão e na sovela, de boa mente não se veriam privados do acesso dos postos e das honras de oficiais pagos que a sobredita Carta Régia lhes concedeu; sendo necessário contemporizar e lançar mão de meios indiretos, porque uma reforma direta e muito austera poderia fazer grande concussão em ânimos acostumados a diversa ordem de coisas. Se o § 19 do Alvará de 17 de dezembro de 1802 se pusesse em execução com os que já são Oficiais, bem poucos estariam nas circunstâncias de ser compreendidos na disposição do $\S 16^{88}$

Após essas considerações, Montenegro expôs no que consistiria a reforma aos 16 regimentos milicianos da capitania que governava: o ajustamento às disposições da Carta Régia de 1787, que buscou remover os corpos militares "fictícios" ou destituídos de praças, e do Decreto de 1796, que estabeleceu o formato exato dos regimentos milicianos. Os regimentos de pardos e de pretos estavam no centro de suas preocupações - basta notar que, nesse ofício, o governador pouco se ocupou dos corpos militares formados por homens brancos - mas essas não diziam respeito a problemas ou estorvos na realização do serviço militar. Antes, toda a narrativa se concentra nas relações de poder estabelecidas entre brancos e homens de cor livres intermediadas pela milícia, e converge, ao fim, para a oficialidade miliciana parda e preta caracteristicamente atada aos ofícios mecânicos. A questão, em síntese, era que "os pobres pretos e pardos", ao ocuparem os postos superiores da milícia, se elevavam da baixa condição de nascimento e de ocupação e alcançavam posições consideradas honradas e associadas à nobreza, as quais indubitavelmente amplificavam a "força moral" de seus grupos. Então por quais motivos Montenegro imprimiu o tom "contemporizador" ao final de seu discurso, diferenciando-o, nesse ponto, dos reformistas novo-hispânicos bem como de Lavradio, Menezes, Portugal e do marechal Mello?

${ }^{88}$ Cf.: AHU_CU_015, Cx. 259, D. 17405. Recife, 24 de março de 1806. 
Em primeiro lugar, além de assegurar garantias específicas para os oficiais pardos e pretos, o Alvará de 1802 alterou os termos do debate. Os proponentes dos projetos de reforma evitavam remeter-se aos estigmas relacionados à escravidão e à cor de pardos e pretos, e tal postura foi acentuada após o alvará em questão declarar aqueles vassalos habilitados para todas as honras e postos militares. Em períodos mais recuados, os reformistas apelaram para as desordens e indisciplinas praticadas nas atividades militares como forma de desmobilizar a oficialidade de cor; após 1802, tenderam a explorar o parágrafo daquele alvará que estabeleceu, de modo vago, a necessidade de os candidatos aos postos possuírem bens ou rendas suficientes para se manterem com a decência exigida. A partir dessa brecha, atingiram um ponto sensível da vida social de pardos e pretos, como visto no capítulo 5. Ademais, é presumível que Montenegro adotasse uma postura cautelosa também para evitar as repreensões sofridas por D. Fernando José de Portugal após alterar a configuração das milícias negras da Bahia.

Mais importante, porém, foi sua a perspectiva em torno do jogo de forças que se desenrolava em um equilíbrio de poder instável. Em relação aos pardos e pretos, Montenegro agiu como estrategista: analisou os contingentes demográficos, suas expressões sociais e a evolução das milícias de pardos e pretos. Não se pode esquecer que o governo pernambucano estava rodeado por regimentos de pardos e de pretos convertidos em uma espécie de grupos de pressão. ${ }^{89}$ Os cinco corpos militares dessa natureza perfaziam a metade dos regimentos milicianos alocados na cidade de Olinda e na vila do Recife. Tratava-se de uma força militar e social significativa. Além disso, tais corpos militares ostentavam sua enorme tradição e capital simbólico - cujas origens remontavam à participação dos antepassados na guerra lusoholandesa do século XVII - e serviam de modelo aos demais regimentos formados por pessoas de cor na América portuguesa. Afora o aspecto quantitativo, pardos e pretos de Pernambuco apresentavam níveis elevados de enraizamento e coesão social. O inglês Henry Koster, que testemunhou o interesse de milicianos pardos e pretos da capitania quanto ao rumores da nomeação de coronéis brancos para seus respectivos regimentos, considerou que "se for verdade, muito desagradáveis serão as consequências que poderão ser esperadas desse procedimento". ${ }^{90}$ Não por acaso, como reconheceu Montenegro, qualquer reforma que incidisse sobre esses corpos militares deveria necessariamente ocorrer por "meios indiretos".

\footnotetext{
${ }^{89}$ Sobre a utilização do conceito grupos de pressão, ver o capítulo 3, nota de rodapé 18.

${ }^{90}$ Cf:: KOSTER, Henry. Viagens ao Nordeste do Brasil. Trad. Luiz da Camara Cascudo. São Paulo: Companhia Editora Nacional, 1942, p. 491, nota de rodapé n 16 . Ver também SILVA, Luiz Geraldo. Aspirações barrocas e radicalismo ilustrado. Raça e nação em Pernambuco no tempo da independência (1817-1823). In: JANCSÓ, István (Org.). Independência: história e historiografia. São Paulo: Hucitec, 2005, p. 931.
} 
Quase uma década depois, e já no âmbito do Reino Unido de Portugal, Brasil e Algarves, as milícias de pardos e de pretos foram objeto central de outro projeto de reestruturação das forças armadas - que bem poderia ser encarado, na linha das reflexões propostas por Montenegro, como um projeto de engenharia social. Nele o tenente-general Vicente Antonio de Oliveira considerou particularmente a realidade da capitania do Rio de Janeiro, capital do Reino Unido, em 1815, buscando aperfeiçoar a estrutura militar "a fim de que esta não somente seja a máxima possível em defesa do país, mas também a menos perigosa em seus efeitos”. Entretanto, a "perfeita semelhança que se observa tanto no físico como no moral de todos os Povos do Estado do Brasil, [...] faz que estas reflexões se possam identicamente aplicar à instituição da Força Armada em cada uma das componentes capitanias do dito Estado". ${ }^{91}$ Tratase, então, da proposta reformista mais abrangente relativamente ao espaço de atuação das milícias de cor, a qual fora encaminhada diretamente na Corte.

O ponto inicial é também o exame do quadro populacional e da expressão social de suas diferentes partes. Considera-se que a população local era composta por homens livres e escravos, e que, embora os últimos fossem em maior número, tratava-se de uma "classe [...] judiciosamente degradada do honroso serviço militar". Entre os homens livres, os brancos tinham predileção para ocuparem os empregos públicos e as atividades honrosas além de estarem comprometidos com a "agricultura, fábricas e comércio". Restando um pequeno número deles para o preenchimento dos corpos militares, tornava-se necessária a admissão de "homens livres de cor parda e preta para o serviço das Armas". Contudo, segundo o tenentegeneral, era perigoso armar tão grande número de homens de cor dotado de potencial conspirador, já que havia uma intrínseca tensão social e psicológica entre eles: os pretos seriam dotados de "um caráter rebelde e vingativo", os pardos "engenhosos e todos vaidosos e altivos" e os brancos "persuadidos de serem, por diferença de cor, superiores". Ademais, os pardos “consideram-se como filhos legítimos do país, e [...] olham os brancos vindos de Portugal como estrangeiros". Daí resultaria “que jamais virão tempos em que os homens destas três diferentes cores se olhem e amem como uma mesma família".

O problema estava posto:

Sendo, pois, de absoluta necessidade compor a Força Armada de homens brancos, pardos e pretos, homens, torno a dizer, rivais uns dos outros pela poderosa força das diferentes opiniões que os senhoreiam; fica evidente a outra precisão indispensável que há, de que sendo a classe dos homens brancos aquela em que o Estado deve basificar toda a confiança de segura

\footnotetext{
${ }^{91} C f$ : OLIVEIRA, Vicente Antonio. Força Armada no Rio de Janeiro. BN/dm, doc. 5,1,41. Rio de Janeiro, 1815.
} 
defesa interna e externa do País, esta classe seja a mais ponderante em seus efeitos sobre a maior força em número das duas outras.

É uma verdade comprovada pela constante experiência de todos os muitos séculos que têm decorrido desde o estabelecimento das Sociedades Civilizadas, que a estável conservação destas está pendente da diferença em consideração que se deve praticar com as diferentes classes de Cidadãos, que como partes formam estes grandes todos sociais. Este axioma político nos é ensinado pela sábia natureza no inato respeito - diga-o assim - que todo o homem tem àquele outro que lhe deu o ser $\left[\ldots . .{ }^{92}\right.$

Está claro que, para o estrategista, os perigos que envolviam a montagem de uma estrutura militar de tamanhas proporções giravam em torno, notadamente, da inclusão de pardos e de pretos em suas engrenagens, algo que a insuficiência de homens brancos obrigava. Tendo em vista essa determinante, o tenente-general Oliveira projetou que a aplicação do referido "axioma político" se daria por meio da "mistura de cores no mesmo Batalhão", conservandose, porém, as bases da organização assentada na diferença de cor. Os batalhões de homens brancos permaneceriam como tais, preservando-se as fronteiras sociais entre eles e as pessoas de cor; nos batalhões de homens pardos, no entanto, toda a oficialidade, incluindo-se os cabos de esquadra, seriam homens de cor branca, e os tambores e pífanos homens pretos; já nos batalhões de pretos a oficialidade de patente seria composta por homens brancos e a oficialidade inferior por homens pardos, restando aos pretos a simples praça de soldado. Haveria, pois, um fracionamento no interior dos batalhões de pardos e pretos estruturado a partir dos diferentes setores da hierarquia (oficiais de patente, baixa oficialidade e soldados) e das diferenças de cores (brancos, pardos e pretos). Os pardos passariam a ser excluídos dos postos de patente, os quais caberiam apenas aos brancos, enquanto os pretos ver-se-iam completamente afastados das funções de mando. $\mathrm{O}$ arranjo proposto merece algumas reflexões adicionais.

Tanto Caetano Pinto de Miranda Montenegro, referindo-se a Pernambuco, quanto Vicente Antonio de Oliveira, aludindo em particular ao Rio de Janeiro e ao Estado do Brasil no geral, vincularam indiretamente as proporções existentes entre as massas de população segmentadas por cor - ou seja, entre as "partes" que formam "estes grandes todos sociais" - e as oficialidades milicianas. Ambos destacaram especificamente a significativa participação das pessoas de cor na população total e nos corpos militares e definiram esse aspecto como configurador de ameaça ao grupo dos brancos, ao qual se identificavam e representavam, e igualmente à ordem social como um todo. Em 1806, quando Montenegro escreveu o seu projeto, a Revolução Haitiana era conhecida em todo o Ocidente e tanto mais em configurações

${ }^{92} C f .:$ OLIVEIRA, Vicente Antonio. Força Armada no Rio de Janeiro... 
sociais como a capitania de Pernambuco, onde o escravismo era tão presente. É possível que, em 1815, Oliveira tivesse notícias do papel político e militar desempenhado pelos milicianos pardos na Era das Revoluções em outros espaços do mundo atlântico, a exemplo daqueles que precipitaram a independência de Cartagena de Índias frente à Espanha. ${ }^{93}$ A nenhum dos dois devia ter escapado o espectro do movimento político ocorrido na cidade de Salvador, em 1798, e protagonizado por militares pardos. Não eram infundados, portanto, seus cuidados em relação ao potencial de mobilização armada das massas populares, em geral integradas por pessoas negras e mestiças.

Entretanto, esses dois reformistas não propuseram o afastamento de pardos e pretos das funções militares. Antes, ao apontarem as soluções para os problemas que abrem e justificam os seus projetos, ambos se concentraram no intento de restringir o acesso dos homens de cor à oficialidade miliciana. Esta, efetivamente, era a grande questão. A imagem depreciativa das pessoas de cor como excessivamente orgulhosas e rebeldes embasava a tese veiculada de que os seus grupos apresentavam potencial de mobilização contra os brancos. É certo que tais formulações podem expressar cálculos preventivos e estratégicos quanto aos riscos que corriam os integrantes do establishment em sociedades escravistas, mas não se pode perder de vista a sua faceta como recurso empregado em uma competição cujo objeto eram as funções sociais associadas à honra e ao prestígio. Nessa ótica, as manifestações de desconfiança para com os milicianos pardos e pretos serviam para atacar os oficiais de cor naquilo que constituía o seu principal trunfo: a fidelidade devotada à Monarquia e ao Estado. Perante a Coroa, pardos e pretos nunca ocultaram o desprezo que os brancos lhes impunham, mas tampouco manifestaram expressões de ódio como retribuição. Acima das questões atinentes ao relacionamento entre os grupos, eles buscavam estabelecer vínculos diretos com o rei e independentes da intermediação de brancos e da burocracia local, e, de fato, como no Alvará de 1802, lograram obter formalmente a proteção do trono. É significativo que os discursos que remetiam os oficiais de cor a uma espécie de "guerra racial" ${ }^{94}$, os quais eram proferidos por indivíduos defensores da exclusividade das funções e posições honoríficas, tenham sido mais comuns justamente após a elevação do status das milícias pardas e pretas ocorridas entre fins do século XVIII e começos do XIX.

\footnotetext{
${ }^{93}$ MÚNERA, Alfonso. El fracaso de la nación. Región, clase y raza en el Caribe colombiano (1717-1821). Bogotá: Editorial Planeta Colombiana, 2008, p. 173-215.

94 LASSO, Marixa. Guerra racial e nação na Gran Colômbia caribenha, Cartagena, 1810-1832. Estudos IberoAmericanos, Porto Alegre, vol. 36, n. ${ }^{\circ}$ 2, p. 179-207, jul./dez. 2010.
} 
Esses aspectos do exclusivismo e da reiteração da desigualdade social são parcialmente revelados pelo tenente-general Oliveira ao comentar as vantagens do arranjo peculiar sugerido para as milícias. Em primeiro lugar, com a estrutura dos corpos milicianos proposta, "se evita aquele desgosto e natural repugnância com os que os homens de cor branca servem, vendo-se de mistura na mesma fileira com aqueles que foram escravos de seus avós, pais ou parentes". Em segundo, e complementarmente, conseguir-se-ia "fazer reviver aquele antigo respeito que os homens de cor parda ou preta prestavam à classe dos brancos", e se combateria mais eficazmente aquela "perigosa máxima de igualdade com que os frenéticos filósofos buscam aniquilar totalmente as sociedades civilizadas". A etapa final de sua proposta de reforma das milícias de pardos e de pretos desembocaria na completa extinção dos seus oficiais de patente. Isso, porém, ocorreria gradualmente, "para evitar-se aquela perigosa impressão que em todas as Nações causa toda a mudança dos seus recebidos costumes", e mediante o recurso das reformas. Estas se dariam sob três diferentes justificativas: "uns debaixo do pretexto de se acharem já em idade avançada, outros por falta da necessária aptidão para o inteiro desempenho do exercício dos seus cargos, e finalmente outros por falta de meios de viverem com aquela decência que anda anexa à nobreza dos mesmos Postos". Vicente Antonio de Oliveira, enfim, demonstrou otimismo em "conseguir reintegrar a classe dos homens brancos naquela distinta consideração de que por um erro impolítico tem decaído". ${ }^{95}$

\subsubsection{São Paulo}

O surgimento do Regimento dos Úteis, em 1797, portanto, se deu em meio ao ponto alto de um processo de elevação do status das milícias de pardos e pretos no Brasil referendado pela Coroa portuguesa, mas igualmente sob uma atmosfera marcada pela agudização dos conflitos estabelecidos entre os grupos sociais concorrentes, os quais eram alicerçados em diferenças como as de nascimento, cor, riqueza e coesão social. Os vários projetos de reforma das milícias apresentados por governadores e capitães-generais e demais oficiais militares de alto escalão que, quer fossem reinóis ou luso-americanos, certamente eram todos brancos e representantes das elites escravistas - constituíram uma das expressões mais acintosas àquelas milícias formadas por pessoas de baixa extração. Em realidade, essa campanha contrária também teve

${ }^{95} C f$ : OLIVEIRA, Vicente Antonio. Força Armada no Rio de Janeiro... 
lugar em São Paulo e percorreu todo o período de existência dos Úteis. Por isso se torna elemento essencial para a compreensão da história social e política daqueles milicianos pardos.

Em fins de 1797, quando enviou a Lisboa notícias da reestruturação militar empreendida na capitania de São Paulo, o governador Antonio Manoel de Melo Castro e Mendonça (1797-1802) mencionou a criação do Regimento dos Úteis. Nessa ocasião, esclareceu que esse corpo militar estava "disciplinado como tropa de linha", ou seja, que os oficiais do estado-maior encarregados de treinar e disciplinar a corporação eram militares profissionais. Como se tratava de um regimento recém-constituído, carente de instrução e organização militar, essa presença de oficiais brancos aparentemente não gerou descontentamentos ou distúrbios significativos entre os integrantes pardos das dez companhias. Mesmo porque a imposição desse mecanismo de controle social e disciplinarização não era exclusiva aos pardos livres e forros, já que Castro e Mendonça pediu autorização para nomear coronéis oriundos das tropas pagas para quatro outros regimentos paulistas. ${ }^{96} \mathrm{Na}$ circunstância de formalização de um regimento miliciano a partir de companhias dispersas e avulsas, os milicianos pardos estavam satisfeitos com o novo status adquirido pela corporação e especialmente com o acesso aos postos da oficialidade de patente. Embora o alto escalão fosse integrado por homens brancos, os pardos dispunham, em cada uma das dez companhias, de uma vaga para capitão, uma para tenente e outra para alferes. De imediato, o Regimento oferecia a possibilidade para que trinta deles desfrutassem das honras e privilégios inerentes às patentes bem como incutia em mais uma centena de oficiais inferiores a expectativa de ocuparem tais postos assim que eles vagassem.

Não demorou para que o regimento dos pardos de São Paulo se tornasse alvo de projetos de reforma e, desse modo, se integrasse à dinâmica conflituosa que configurava a existência de milícias de pardos e de pretos em diferentes espaços americanos entre finais do século XVIII e começos do XIX. Já na gestão de Antonio José da Franca e Horta (1802-1808), o sucessor de Castro e Mendonça, a corporação sofreu duros ataques. Em 1804, ao indicar um indivíduo branco para o posto vacante de $1 .^{\circ}$ ajudante pertencente ao estado-maior do Regimento, o governador sugeriu que este fosse "sempre graduado com a patente de capitão" - e jamais com patentes inferiores, como as de tenente e alferes - "porque sendo os oficiais deste Corpo mulatos, nenhum oficial de honra nele quer servir para não ser mandado por um deles na falta dos respectivos oficiais maiores". ${ }^{97}$ Afigura-se aí a condição inferiorizada atribuída às pessoas de cor parda ou preta nas sociedades escravistas americanas. Franca e Horta cuidou em evitar

\footnotetext{
${ }^{96} C f:$ : AHU_CU_023-01, Cx. 44, D. 3507. São Paulo, 19 de novembro de 1797.

${ }^{97} C f$ :: "Ofício ao Visconde de Anadia". DIHCSP, vol. 94, p. 131. São Paulo, 30 de junho de 1804.
} 
que oficiais militares brancos e "honrados", como afinal se reputavam e eram aceitos socialmente, fossem expostos ao constrangimento de se submeterem às ordens de oficiais pardos. Por isso demandou a patente de capitão para os ajudantes: assim eles ocupariam as primeiras posições em termos da sucessão de mando em quaisquer ocasiões em que o coronel, tenente-coronel e o sargento-mor do Regimento não estivessem presentes, e se resguardariam da ameaça oferecida por capitães pardos.

Como se vê, em São Paulo não se fez valer a prioridade do acesso aos postos superiores da milícia a pardos e pretos concedida pela Coroa e consagrada no Alvará de 1802. O monopólio exercido por homens brancos aos postos do estado-maior vinha desde 1797, quando esses foram providos pela primeira vez, mas, por essa época, a provisão de julho do mesmo ano que equiparou os oficiais pretos aos brancos em honras, soldos e privilégios não estava plenamente difundida. Entretanto, de 1802 em diante, a opção por manter os brancos naqueles postos e, ao mesmo tempo, vetar a primazia do acesso aos pardos, deveria ser adequadamente embasada e justificada. Essa necessidade estimulou tanto os governadores e capitães-generais como os oficiais militares de alto escalão responsáveis pela milícia a formularem discursos complexos e sofisticados para sustentarem a oposição aos milicianos pardos sempre que esse fosse o caso.

Em 1806, Franca e Horta recusou-se a elaborar e a submeter a proposta de promoção relativa ao Regimento dos Úteis, "por me persuadir que nele se devia fazer a mudança que passo a expor" - conforme escreveu ao Visconde de Anadia. Iniciou situando o secretário de estado de que se tratava de um corpo formado por "mulatos forros", aprovado pela Coroa e dotado de oficiais com patentes confirmadas. Apesar dessa regularidade institucional da corporação, Franca e Horta representou que não lhe parecia "conforme a boa razão que homens abjetos e de uma tão inferior qualidade, como são os daqui, cinjam uma banda e entrem na roda da mais oficialidade, quando há homens brancos em quem se podem prover os postos de alferes, tenentes e capitães, do mesmo modo que sempre o foram os oficiais superiores do dito Regimento". ${ }^{98}$ O governador de São Paulo revelou-se um importante porta-voz do preconceito coletivo fundado na contraposição entre o ideal aristocrático e as origens e condições de vida “inferiores" dos homens pardos que remontavam à escravidão. E nesses termos pretendeu não apenas a exclusão dos pardos dos principais postos do Regimento como também de toda a oficialidade de patente - algo que os governadores da Bahia e de Pernambuco sequer ousaram propor. Nesse aspecto, Franca e Horta antecipou a proposta mais extrema elaborada pelo tenente-general Oliveira para o Rio de Janeiro e o Estado do Brasil em geral.

\footnotetext{
${ }^{98} C f .:$ "Para o Excelentíssimo Senhor Visconde de Anadia". DIHCSP, vol. 94, p. 169-170. São Paulo, 25 de junho
} de 1806. 
Diante do amparo legal conferido à oficialidade parda e preta, o reformista se valeu dos termos do próprio Alvará de 1802 para fundamentar a sua proposta de mudanças. Numa referência indireta ao parágrafo XIX daquele texto, o qual estipulou vagamente a necessidade da posse de "bens ou rendas suficientes" por parte dos ocupantes dos postos de patente, Franca e Horta esclareceu que tais medidas visavam a manter-se "a decência e o decoro da Tropa". 99 Argumentou que a equiparação entre a oficialidade parda e a branca provocava nos "homens de bem" não apenas repugnância, mas inclusive uma sensação de desestímulo e desprestígio. Ele denunciou o que era visto como uma incompatibilidade incontornável entre a função social honorífica na milícia e as condições sociais dos homens pardos e, nesse sentido, sintetizou o quadro familiar e socioprofissional examinado detalhadamente na Parte 2 da tese. De acordo com os seus termos,

Como pode, na verdade, lisonjear-se um homem de bem, que serve o Estado, de ser capitão e ainda tenente-coronel, se vê condecorado com igual patente e honras um mulato alfaiate ou sapateiro, outro que ele conheceu escravo, e finalmente outro que ainda que forro seja casado com uma negra cativa, como são de ordinário os que atualmente servem neste corpo? ${ }^{100}$

A retórica empregada fornece uma noção do campo de estigmas vigente no começo do século XIX. Ao longo do Setecentos, e especialmente a partir de sua segunda metade, os pardos luso-americanos passaram a combater a ideia conforme a qual a sua cor constituía um defeito da natureza que comprometia a sua essência humana. Nos inúmeros requerimentos enviados à Coroa, os quais tratavam notadamente de questões relativas à milícia, eles foram substituindo a noção de "defeito" pela de "acidente", sugerindo, pois, que a cor não influía na sua conduta moral. ${ }^{101}$ A presença do caráter acidental da cor no Alvará de 1802 endossou a assimilação dessa perspectiva por parte do poder monárquico e indubitavelmente constitui uma faceta do processo de elevação do status dos pardos como grupo social. Não havia, portanto, um campo fértil para o estigma da cor. Não por acaso, para demarcar a diferença existente entre brancos e pardos, Franca e Horta recorreu a elementos inerentes ao grupo dos últimos que fossem relacionados mas não confundíveis com a cor: a origem escrava, a proximidade social aos

\footnotetext{
${ }^{99}$ Cf:: "Alvará de 17 de dezembro de 1802". Lisboa: Regia Officina Typografica, 1803; "Para o Excelentíssimo Senhor Visconde de Anadia”. DIHCSP, vol. 94, p. 169-170. São Paulo, 25 de junho de 1806.

${ }^{100}$ Cf:: "Para o Excelentíssimo Senhor Visconde de Anadia". DIHCSP, vol. 94, p. 169-170. São Paulo, 25 de junho de 1806.

${ }^{101}$ SOUZA, Priscila de Lima. "Sem que lhes obste a diferença de cor": a habilitação dos pardos na América portuguesa e no Caribe espanhol (c. 1750-1808). Tese (doutorado em História). São Paulo: FFLCH, Universidade de São Paulo, 2017.
} 
cativos e o enraizamento de uma parcela considerável do grupo em questão ao universo do trabalho artesanal. Por fim, o governador traduziu de modo cristalino a indisposição cultivada tanto pela nobreza reinol destacada na colônia quanto pelos paulistas das famílias tradicionais e mais abastadas relativamente à magnífica elevação social dos pardos. A equiparação entre esses diferentes grupos, promovida pelas patentes militares, foi lida pelo grupo estabelecido como um claro sinal de desprestígio. ${ }^{102}$

Esse assunto foi recuperado, e em termos muito semelhantes, em fins de 1806, em cuja ocasião o governador de São Paulo informou ao Conselho Ultramarino sobre o requerimento de um oficial pardo e reiterou que havia suspendido as promoções para o Regimento dos Úteis enquanto aguardava a decisão da Coroa sobre os planos de substituir a oficialidade parda por homens brancos. A resposta régia foi proferida apenas em 1809, após a instalação da Corte portuguesa no Brasil e depois de manifestações contrárias à suspensão das promoções emergirem do interior da corporação ${ }^{103}$, e consistiu na determinação para que se efetuasse uma proposta para o provimento dos postos vagos. ${ }^{104}$ A sugestão de Franca e Horta foi cabalmente refutada no Rio de Janeiro sem maiores explicações e considerações. Apesar de obrigado a pôr em execução as determinações atinentes à proposta, nesse ato ele não deixou de expressar inúmeras reticências à oficialidade parda, no que contava com o apoio do inspetor geral das milícias, o paulista José Arouche de Toledo Rendon, quem levaria adiante e com um ímpeto ainda maior a causa da destituição dos oficiais pardos. Em fins de 1809, o governador encaminhou à Corte a lista dos indicados para os postos acompanhada de ofícios dele próprio e de Rendon. O recorrente argumento da inexistência de pardos abonados em São Paulo, capazes de manterem-se nos postos com a decência exigida, permaneceu como base de legitimação de seu projeto, mas, quanto à proposta geral para o Regimento, Franca e Horta radicalizou na sua cartada final. Conforme seus termos, "é o meu parecer que este Regimento seja inteiramente abolido - apesar de eu ter presente as contrárias ordens régias a este respeito - pois deste meu sistema certamente não se segue desvantagem alguma". ${ }^{105}$ Com essas palavras, ele passou o bastão ao inspetor geral das milícias, que daí em diante formularia uma série de densos e sofisticados projetos de remodelação das milícias paulistas, nos quais as reflexões acerca da milícia parda obtiveram significativo destaque.

\footnotetext{
${ }^{102}$ Esse processo foi detalhadamente examinado na seção antecedente.

${ }^{103}$ A posição dos milicianos pardos será examinada em uma seção adiante.

${ }^{104}$ Cf:: AHU_ACL_CU_023, Cx. 29, D. 1286. São Paulo, 22 de dezembro de 1806; APESP, Ordem C00415, Livro 158, fls. 13-14v. Rio de Janeiro, 21 de janeiro de 1809.

${ }^{105} C f$ : APESP, Ordem C00402, Livro 111, fls. 105v-106 e 106-106v. São Paulo, 25 de novembro de 1809.
} 
O primeiro projeto de Rendon estava atrelado à questão do provimento dos postos da milícia parda que se arrastava desde os primeiros anos do governo de Franca e Horta. Como inspetor das milícias, coube a esse oficial militar comentar a proposta elaborada pelo coronel do Regimento dos Úteis e dirigir esses documentos ao governador. Mas ao invés de examinar individualmente cada indicado, Rendon optou por estabelecer considerações gerais sobre aquele regimento e seus oficiais pardos. Essas foram organizadas em duas linhas de pensamento: em primeiro lugar, a pertinência da abolição da separação dos regimentos milicianos com base na cor; em segundo, o descompasso existente entre a condição social dos pardos e a condição nobre derivada das patentes milicianas. De cada um desses eixos decorriam propostas para o futuro da milícia parda: do primeiro, e preferencialmente, a sua extinção, e do segundo a troca da oficialidade parda pela branca.

Rendon formulou um discurso referente à história das milícias de pardos e de pretos no Brasil pautado, evidentemente, na versão da administração colonial, e esse olhar dirigido ao passado tinha como contrapartida a projeção de um futuro para aqueles corpos militares. Conforme argumentou genericamente, "os regimentos milicianos foram criados todos com homens brancos, não sendo admitidos os Pardos nem para a praça de soldados". Mas a exclusão de "toda esta classe de gente" contrariava "o sistema do nosso ministério, que sempre quis, e ainda quer, que no Brasil todo o homem capaz de pegar em armas seja alistado nos corpos milicianos; e para remediar esta falta lembrou em muitas capitanias, e depois nesta, o fazer regimentos de mulatos". ${ }^{106} \mathrm{Na}$ sua retórica, as milícias de cor eram um produto direto e exclusivo dos desígnios administrativos, pouco importando o seu relevante papel no sistema defensivo e no controle social dos homens sem senhor e a pressão que pardos e pretos impunham à Coroa no sentido da criação e manutenção das corporações. Tal perspectiva era conveniente ao seu intento, já que, analogamente, fazia crer que um simples decreto régio seria suficiente para abolir tais corporações ou ao menos afastar pardos e pretos das posições de poder e prestígio.

Deslocando o foco para o presente, argumentou que já não existiam razões para a separação por cores, uma vez que os mulatos já eram admitidos pelos brancos nos corpos milicianos e na tropa paga, onde podiam chegar até os postos de oficiais inferiores, sem patente e sem nobreza. E “o escrúpulo só reina quanto a passarem a oficiais; escrúpulo que terá de durar muitos tempos, visto que ele tem sua origem na escravidão". Concluindo essa articulação entre passado, presente e futuro, Rendon lembrou que, "além disto, ocorrem as felizes circunstâncias

${ }^{106}$ Cf:: APESP, Ordem C00277, doc. 41-1-97. São Paulo, 12 de novembro de 1809. 
de não ser hoje o Brasil uma colônia, e de se deverem lançar as linhas para o que há de vir a ser e não para o que ainda é presentemente". A exuberante mutação do status políticoadministrativo do Brasil durante a Era das Revoluções, momento em que ocorre uma aceleração do tempo histórico, aguçou em muitos atores sociais uma percepção de progressivo distanciamento da relação entre passado e futuro, isto é, de que aquele não ditava mais os rumos deste. ${ }^{107}$ Por sua vez, essa nova experiência com o processo histórico alimentou as propostas de reforma das milícias de cor, tornando-se possível projetar um rompimento com a tradição militar de Henriques e Pardos. O inspetor geral das milícias propôs, então, que "tais Regimentos se extinguissem", pois "se a utilidade foi quem lembrou a criação de tais corpos, ela mesma é quem lembra a sua extinção". De acordo com seus termos, os milicianos de cor deveriam ser reintegrados em posições subordinadas nos regimentos de brancos, e o problema do acesso à oficialidade, assim como o da persistência da escravidão, poderia ser lançado ao futuro: “ $\mathrm{O}$ tempo fará com que também se extinga os escrúpulos de passarem a oficias os mulatos de merecimento, e que saibam servir ao Estado; fim este que nunca se conseguirá enquanto existir a odiosa separação e distinção de corpos". ${ }^{108}$

O segundo eixo de sua argumentação se referia à hipótese de que a abolição das milícias de cor não fosse "admissível segundo o estado das coisas, e que seja da vontade de S.A.R. a existência dos corpos milicianos de homens pardos". Nesse caso, Rendon discursou em prol do afastamento da oficialidade parda e da sua substituição por oficiais brancos. Como vinha sendo feito pelos demais reformistas do começo do século XIX, o principal alvo dos questionamentos não era a qualidade do serviço estritamente militar prestado por pardos e pretos em suas unidades particulares, mas a sua condição social e econômica. Com efeito, os vínculos à escravidão e aos ofícios mecânicos eram tidos por governadores e oficiais militares de alto escalão como o calcanhar de Aquiles dos oficiais de cor. Rendon esclareceu que, em São Paulo, o estado-maior do Regimento dos Úteis era provido em homens brancos e os pardos somente ocupavam os postos das companhias por condescendência régia, o que se justificava "pela falta que há de mulatos abastados e que se possam tratar com decência" e que "estejam nas circunstâncias de gozar das honras de oficiais milicianos”. O cerne da argumentação dirigida ao governo da capitania não trazia novidades significativas em relação ao que Franca e Horta

${ }^{107}$ KOSELLECK, Reinhart. "Espaço de experiência" e "horizonte de expectativa": duas categorias históricas. In: KOSELLECK, R. Futuro passado. Contribuição à semântica dos tempos históricos. Trad. Wilma P. Maas, Carlos A. Pereira. Rio de Janeiro: Contraponto; Ed. PUC-Rio, 2006, p. 305-327.

108 Cf.: APESP, Ordem C00277, doc. 41-1-97. São Paulo, 12 de novembro de 1809. 
já havia exposto, mas, a despeito disso, os termos empregados merecem ser reproduzidos pois evidenciam o sentido e intensidade do ataque perpetrado à milícia parda:

S.A.R. quando põe a sua real assinatura na patente de um mulato, o honra e o põe na classe de homem nobre: mas por outra parte jamais se poderá combinar esta nobreza com o miserável estado do promovido. V.Exa. tem visto na sua guarda e nas ocasiões de beija-mão os sapateiros, os ferreiros, e os taverneiros de banda e gola, tendo andado no dia antecedente debaixo de um pobre capote. Esta cena toca ao sumo da indecência e tudo redunda em mau serviço de S.A.R.

[...]

Eu podia fazer uma miúda análise do estado de fortuna em que se acha a maior parte dos propostos, mas pedia isto muita extensão; e satisfaço o meu dever dizendo a V.Exa. que a maior parte deles são pobres que têm até hoje vivido de seus ofícios mecânicos e de tavernas. ${ }^{109}$

Munido dessas considerações, Rendon defendeu a incompatibilidade dos pardos paulistas para com as posições elevadas da milícia e propôs o seu definitivo afastamento da oficialidade das companhias.

Argumentou, obviamente, que nenhum dos indivíduos propostos para ocuparem os postos vagos atendia aos seus requisitos mínimos. Ademais, que apesar de haver milicianos pardos em melhores condições servindo fora dos Úteis, eles recusavam-se a ascender às posições superiores do regimento dos pardos, "porque estando alistados nos regimentos dos brancos lembra menos que eles são mulatos, quando, pelo contrário, estando no Regimento dos Úteis ainda com a honrosa patente de oficial trazem consigo a certidão de Pardos”. Então havia um dilema a se resolver quanto à indicação dos pardos para os postos de patente: ou se priorizava o critério da decência dos postos, arriscando-se a investir homens com níveis de riqueza sutilmente superiores aos demais embora carentes da devida experiência militar, ou escolhia-se entre os pardos "de gênio mais próprio ao serviço militar, mas que vivem nas circunstâncias de não largarem as ocupações mecânicas de que tiram a sua subsistência". Conforme Rendon, no caso de a Coroa determinar que os postos fossem providos nos próprios pardos, "então a escolha só deve ser a do merecimento pessoal, sem atenção ao seu pequeno estado de fortuna", porque seria pior premiarem-se como nobres aos pardos detentores de modestos bens do que àqueles que, a despeito de sua "indecência", eram ao menos úteis militarmente. Como se nota, o papel desempenhado pela origem e condição social dos pardos em meio ao entrelaçamento existente no universo miliciano - entre as altas instâncias administrativas luso-americanas, governadores coloniais, oficiais militares de alto escalão e

${ }^{109}$ Cf:: APESP, Ordem C00277, doc. 41-1-97. São Paulo, 12 de novembro de 1809. 
oficiais milicianos brancos e pardos aspirantes aos postos - contribuiu para inserir e afirmar a questão do "merecimento" individual no centro de um debate ainda dominado por visões de mundo aristocráticas.

A insistente, coesa e refinada argumentação do governador Franca e Horta e do inspetor Rendon não surtiu o efeito que esperavam, e, em agosto de 1810, um aviso do Ministério da Guerra e do Estrangeiro participou ter sido aprovada a proposta referente ao provimento dos postos do Regimento dos Úteis, ou seja, confirmando a progressão dos oficiais pardos nela indicados. ${ }^{110} \mathrm{Em}$ abril de 1812, por ocasião do encaminhamento de outra proposta para preenchimento dos postos vacantes, estabeleceu-se novo impasse. Diferentemente da proposta encaminhada em 1809, nessa circunstância o Regimento era comandado por um coronel pardo, o qual não impôs qualquer entrave à indicação de oficiais de sua cor. Mas, de sua parte, o inspetor Rendon voltou à carga reiterando que "não os julgava com posses para sustentarem com decência os postos, segundo dispõe o Alvará de 17 de dezembro de 1802”. A posição do novo governador, Marquês de Alegrete, foi a de evitar indispor-se aos desígnios régios e, "não querendo errar", suspendeu a aprovação à proposta enquanto aguardava a determinação superior. Contudo, ele observou que apesar de viverem "de seus ofícios", "os oficiais propostos em tudo o mais são muito dignos de continuarem a merecer de S.A.R. a graça de fazê-los subir aos postos", como, aliás, "se pratica nessa Corte e nas outras capitanias do Brasil". ${ }^{111}$ Dessa vez a resposta do príncipe regente não tardou, e veio por meio de um aviso do Ministério da Guerra, de outubro daquele ano. Não obstante ser presente à Coroa a impossibilidade dos propostos sustentarem-se "com decência, pela falta de posses", ordenou-se peremptoriamente que os oficiais fossem todos "tirados da classe dos pardos, na qual poucos há que sejam abastados", e que, dentre eles, fossem escolhidos aqueles que possuíssem "mais bens", ainda que "exerçam ofícios mecânicos". ${ }^{112}$ Essa determinação frustrou mais uma vez a expectativa de componentes dos setores mais elevados da sociedade paulista e de oficiais militares brancos que se opunham à oficialidade parda, ao mesmo tempo em que consolidou o reconhecimento de que a situação socioeconômica dos pardos não constituía óbice para que eles acessassem os postos superiores da milícia, de um lado, e que tais posições eram equivalentes às das milícias brancas, de outro.

Uma situação semelhante se repetiu entre 1815 e 1816, revelando que as tensões inerentes à escolha de milicianos pardos para os postos de patente ultrapassavam o âmbito interno do Regimento, marcado como era por competição entre os próprios pardos pelas

\footnotetext{
${ }^{110} C f$ : APESP, Ordem C00415, Livro 157, fl. 197. Rio de Janeiro, 13 de agosto de 1810.

${ }^{111} C f$ : : APESP, Ordem C00403, Livro 14, fls. 82v-83. São Paulo, 23 de abril de 1812.

112 Cf: APESP, Ordem C00416, Livro 159, fl. 107. Rio de janeiro, 8 de outubro de 1812.
} 
posições vacantes. Na realidade, essas questões extravasavam para a configuração social mais vasta justamente porque o fenômeno da milícia parda, com sua oficialidade própria, era dotado de implicações para as relações que os diferentes grupos societários estabeleciam entre si. Em 1815, o coronel pardo Manoel José Ribeiro indicou 14 milicianos para os postos de alferes, tenente e capitão e apenas raramente justificou a escolha com base na posse de bens. Antes, optou por acentuar as características mais diretamente vinculadas à prestação de serviço militar dos subordinados, tais como "merecimentos", "agilidade" e "forças para o serviço". Cumprindo o dever de prestar informação relativamente à proposta, o brigadeiro inspetor geral de milícias Rendon alterou a estratégia e, ao invés de estabelecer considerações mais gerais, comentou caso por caso os indicados. No conjunto, indicou que quase todos os propostos eram artesãos que não possuíam bens suficientes para se manterem dignamente nos postos. Em um trecho de seu informe, se percebe como a realidade material dos pardos livres e forros, analisada extensivamente atrás, pesava na sua relação com os grupos socialmente mais elevados daquela configuração social. Conforme Rendon, “eu não posso reputar capaz de ser oficial miliciano um homem só porque tem um ofício que lhe dá o que comer o dia que trabalha, sem ficar nada de resto para ajuntar um capital. Quando este oficial estiver doente não terá o que comer". ${ }^{113}$ Quase um ano depois, em outubro de 1816, as patentes dos propostos foram expedidas, o que indica claramente que os pardos saíram vitoriosos pela terceira vez consecutiva. ${ }^{114}$

Por esse tempo, José Arouche de Toledo Rendon já havia elaborado, sob encomenda do governo da capitania, um segundo projeto de reforma das milícias paulistas, datado de 5 de setembro de 1815 e intitulado Projeto de Plano para o Melhoramento das tropas Milicianas de São Paulo. ${ }^{115}$ Rendon tratou de três elementos estruturais referentes à organização daqueles corpos militares: 1) a necessidade de que as companhias convergissem e se concentrassem o mais próximo possível dos quartéis dos regimentos; 2) a redução dos efetivos de cavalaria miliciana; 3) a afirmação da infantaria e sobretudo dos caçadores como a força militar mais eficaz para o caso de São Paulo. Todos esses pontos eram justificados mediante o "pleno conhecimento do caráter dos Paulistas, do seu modo de vida, das suas habitações e sobretudo de todas as circunstâncias locais da Capitania" e embasaram uma proposta de reorganização dos corpos militares, com a extinção de uns e a readequação daqueles que persistiriam ou seriam criados. Entretanto, para além dessa abordagem geral às milícias paulistas, reflexões

\footnotetext{
${ }^{113}$ Cf:: APESP, Ordem C00285, doc. 48-3-37. São Paulo, 7 de dezembro de 1815.

${ }^{114} C f:$ : APESP, Ordem C00285, doc. 48-3-37. São Paulo, 9 de outubro de 1816.

${ }^{115}$ Cf: : APESP, Ordem C00286, doc. 33-2-24. São Paulo, 5 de setembro de 1815. Esse projeto já foi analisado por LEONZO, Nanci. Defesa militar e controle social na capitania de São Paulo: as milícias. Tese (doutorado em História). São Paulo: FFLCH, Universidade de São Paulo, 1979.
} 
particulares sobre o Regimento dos pardos ocuparam a primeira parte de sua explanação, de modo análogo ao projeto do tenente-general Oliveira, de mesmo ano, apresentado na Corte.

Rendon iniciou comentando entusiasticamente uma proposta que corria informalmente pelas secretarias de governo de São Paulo, a qual previa a redução do Regimento dos Úteis para um batalhão formado por quatro companhias e um total de 600 homens. Diminuir-se-iam os efetivos e notadamente a oficialidade parda. A retórica é a mesma expressada insistentemente nos anos anteriores: a falta de educação e sobretudo a pobreza generalizada dos pardos eram aspectos incompatíveis com "as honras de oficiais". "Daqui procede a indecência de se apresentarem na sala de Vossa Excelência e no batalhão homens de banda e gola, que dali a poucos instantes voltam para o triste estado de sapateiros ou taverneiros com o capote roto". Após tratar brevemente dessa alternativa, o inspetor geral das milícias retomou com maior ênfase a proposta de desmobilizar o Regimento dos Úteis.

É interessante notar a hábil assimilação da linguagem empregada pelos pardos e principalmente pela Coroa por parte desse oficial letrado em prol de uma argumentação diametralmente oposta às recentes determinações régias. Conforme seus termos, a abolição do Regimento dos pardos conviria ao Estado e seria desejada pelos próprios pardos. Em primeiro lugar, atenderia ao interesse da Coroa em promover o fim dos preconceitos relativos à cor, os quais, na linguagem de época, eram referidos como "prevenções". Apesar de não empregar o termo "acidente", está claro que o militar reformista operava nos termos propagados pelos pardos da América portuguesa no século XVIII visando desvencilharem-se da noção de que suas cores acusavam “defeito” em suas essências humanas, cuja retórica fora, afinal, aceita pela Coroa. Sem indicar como, Rendon argumentou que a junção de brancos e pardos nos mesmos corpos militares encerraria as prevenções e instituiria o "pessoal merecimento" como o critério fundamental na regulação da competição pelo acesso aos postos da milícia. Em segundo lugar, como "semelhantes Corpos se devem reputar perigosos ao Estado em certas circunstâncias", a extinção do Regimento dos Úteis faria cessar a "continuada rivalidade e inimizade à cor branca, que os despreza". Essa alusão aos perigos atinentes à existência dos corpos militares de pardos e de pretos foi feita igualmente de modo genérico e superficial - pois destituída de qualquer consideração técnica, estratégica ou histórica - e é a única referência dessa natureza para o caso paulista. Contrasta, portanto, com as considerações político-estratégicas referentes às milícias de cor e aos equilíbrios entre os grupos de brancos, de homens de cor livres e libertos e de escravos, tecidas por Caetano Pinto de Miranda Montenegro e por Vicente Antonio de Oliveira em Pernambuco e no Rio de Janeiro, respectivamente. 
Para os pardos, a abolição da separação por cores na milícia conviria principalmente porque, servindo "em Corpos separados", "o público [...] os reputa de uma Classe muito inferior". Ou seja, os Regimentos de pardos e de pretos perpetuariam as diferenças entre as cores e, consequentemente, os preconceitos. Rendon sugeriu que a inclusão dos homens de cor na estrutura militar por meio de corpos separados havia sido, no passado, um "passo político" - entendendo-se pela expressão "política" a justa manutenção do equilíbrio entre os grupos e os corpos constitutivos da Monarquia, realizada pelo rei -, pois o fenômeno era adequado aos níveis mais elevados de "prevenção do povo" quanto às cores parda e preta. Presumivelmente ele tenha se referido a um contexto como o da década de 1730, no qual se tornou manifesta a resistência que os auxiliares e ordenanças brancos ofereceram à admissão de pardos, bastardos e pretos em seus corpos militares, o que veio a contribuir para a manutenção da separação por cores nos terços e companhias. Contudo,

[...] parece que melhorando tanto o estado das coisas a este respeito, têm cessado os motivos daquela valiosa separação que ofende ao Estado, nutre a prevenção contra as cores, e faz desgraçados os próprios Pardos que se empregam no serviço de Sua Alteza Real, deixando seu nome escrito naqueles Livros Mestres, que serão eternos monumentos do mulatismo para os netos dos que neles juraram defender as bandeiras do Mesmo Augusto Senhor. É um fato não oculto que hoje em dia há famílias Nobres, que se reputam da classe dos Brancos, as quais estariam na Classe dos Pardos se os seus avós tivessem passado pela desgraça de ter os seus nomes naqueles arquivos. ${ }^{116}$

A linha de raciocínio proposta por Rendon estabelece um corte entre passado, presente e futuro. A separação por cores, que havia sido adequada em uma época recuada, não era mais bem-vinda no presente, e por isso cabia lançar as bases de um novo modelo de organização miliciana e de uma nova organização social. Rendon ocultou, nesse projeto, que a origem do preconceito de cor estava assentada na escravidão e que a milícia dos pardos e pretos era tão somente uma expressão das divisões sociais vigentes. A sua extinção minaria um dos veículos do preconceito, mas pouco afetaria o seu núcleo produtor e reprodutor. De modo análogo, ele não expôs a versão da oficialidade parda, a qual, sedenta por permanecer no exercício de suas funções sociais de prestígio, parecia não se importar em assumir a sua cor.

Por outro lado, o inspetor geral das milícias, assim como os reformistas que o antecederam ou que lhe foram contemporâneos, revelou, ainda que indiretamente, todo o incômodo causado ao nível superior da sociedade local pelo processo de ascensão social de

${ }^{116} C f$ : APESP, Ordem C00286, doc. 33-2-24. São Paulo, 5 de setembro de 1815. 
oficiais mecânicos e descendentes de escravos e de indígenas investidos em postos milicianos que culminou na equiparação entre os oficiais pardos e pretos e os oficiais brancos da milícia e da tropa de linha. Se, no passado, a divisão por cores fora defendida pelos brancos como forma de consolidar as barreiras que asseguravam e conferiam visibilidade à sua proeminência social, eles tenderam a mudar de abordagem em face do progressivo cerceamento às distinções de cunho aristocrático produzidas nos seus corpos militares e diante do reconhecimento de que a nobreza das patentes se sobrepunha às diferenças arraigadas e constantes na dinâmica local. Da segunda metade do século XVIII em diante, ou uma vez formalizada a igualdade entre os oficiais de sua cor e os pardos e pretos, a separação por cores deixou de ser prioritária para os brancos. Portanto, o corte estabelecido por Rendon entre o passado e o presente refletia menos a alegada predisposição social para a promoção de igualdade entre as diferentes cores, e mais esse novo estado das coisas, inaceitável para os oficiais militares mais bem situados econômica e socialmente, que se postavam como guardiães da nobreza - e, na realidade, de uma meramente civil ou política, reinante entre os coloniais e estatutariamente distante da alta nobreza hereditária. ${ }^{117}$ Vai daí a denúncia insistentemente propagada por governadores e oficiais militares superiores relativa ao descompasso existente entre a ínfima situação material dos pardos e pretos - para não se referir às suas origens e aos estigmas mais profundos que expunham na própria pele - e as altas posições sociais que ocupavam na milícia.

A atuação de Rendon no combate à oficialidade parda e ao seu regimento miliciano se deu por diferentes formas ao longo de todo o período em que inspecionou as milícias paulistas. Além de expor seu ponto de vista em cada uma das propostas para provimento dos postos vagos e nos projetos formais destinados à reforma dos corpos militares, suas ações mais ordinárias e cotidianas eram coerentes com seus princípios. Em fins de 1816, por exemplo, ele informou favoravelmente à pretensão de dois irmãos, soldados dos Úteis, que desejavam obter transferência do regimento sob a alegação de não serem pardos. Embora desconhecesse a veracidade da argumentação dos soldados, Rendon afirmou que "politicamente falando, devemse promover os meios de extinguir a lembrança do mulatismo por meios indiretos [...], visto que ainda não é possível, no estado das coisas, mudar a opinião pública a respeito dos mulatos". ${ }^{118}$ Não se pode deixar de notar que essa postura diante de tais requerimentos poderia estimular uma debandada dos soldados pardos em direção a regimentos milicianos de brancos, comprometendo o próprio funcionamento e existência da corporação - como alertaram os

\footnotetext{
${ }^{117}$ SILVA, Maria Beatriz Nizza da. Ser nobre na colônia. São Paulo: Editora Unesp, 2005.

${ }^{118} C f$ : APESP, Ordem C00265, doc. 33-1-57. São Paulo, 12 de dezembro de 1816.
} 
próprios oficiais pardos. ${ }^{119}$ Apesar de as propostas de abolição dos regimentos e oficialidades de pardos e pretos serem reiteradamente refutadas na Corte, isso não impedia que os gestores da estrutura militar local colocassem em funcionamento mecanismos indiretos para a obtenção de seu intento.

As propostas de reforma para o Regimento dos Úteis foram novamente postas à mesa no segundo semestre de 1821, quando se discutia em São Paulo as bases para a formulação de um projeto coeso a ser apresentado e defendido pelos deputados paulistas nas Cortes lisboetas. No mês de setembro de 1821, iniciaram-se os preparativos para os trabalhos de uma comissão militar responsável por "levantar o projeto para o novo Edifício Militar". ${ }^{120}$ Já em outubro os integrantes dessa comissão, todos oficiais militares de alto escalão, debateram os vários projetos de reforma para as milícias paulistas que puderam ser reunidos, e entre eles o Projeto de Plano de Rendon. No sumário elaborado pelo inspetor de milícias não constam as opiniões dos demais integrantes sobre o tema da milícia parda, mas se sabe ao menos que a ideia de extinguir-se o Regimento ou no mínimo reduzir seus efetivos e sua oficialidade foi novamente defendida. Em plena vigência da atmosfera constituinte, Rendon sentiu-se mais confortável para expor os seus sentimentos acerca das deliberações régias concernentes às milícias pardas e pretas. Segundo as suas palavras, "sempre me pareceu muito impolítico nesta parte o Alvará de 17 de dezembro de 1802". ${ }^{121}$ Cabe destacar que o destino dos Úteis estava em pauta nas vésperas da independência do Brasil. Em seção mais adiante desta tese, se discutirá em que medida o confronto entre a oficialidade parda e os entusiastas de sua desmobilização influenciou o posicionamento político dos primeiros nesse contexto.

Os trabalhos da comissão militar foram afetados pela turbulência política de finais de 1821 e do ano seguinte, e a resolução das questões que aqui mais interessam aparentemente foi postergada. De modo geral, pode-se afirmar que a intensa mobilização das milícias na composição dos destacamentos da capital ao longo de todo o restante da década de 1820, examinada atrás, impediu que debates mais aprofundados ou medidas concretas visando à desmobilização da milícia parda fossem estabelecidas. Cumpre ainda salientar que os milicianos pardos paulistas foram alvo constante de ataques perpetrados ao longo de todo o período compreendido entre os anos 1806 a 1821 por parte de indivíduos investidos em posições de poder significativamente elevadas, como eram governadores e brigadeiros. E, no fim das

\footnotetext{
119 Vide o capítulo 3.

${ }^{120}$ Cf:: "Para o inspetor geral das Milícias". DIHCSP, vol. 37, p. 163-164. São Paulo, 16 de agosto de 1821; "Para o Ilmo. e Exmo. Snr. João Carlos Augusto de Oeynhausen”. DIHCSP, vol. 37, p. 180. São Paulo, 3 de setembro de 1821.

${ }^{121} C f$ :: APESP, Ordem C00265, doc. 33-3-54. São Paulo, 24 de outubro de 1821.
} 
contas, o Regimento dos Úteis resistiu até 1831, quando todas as demais milícias brasileiras foram extintas. Apesar de exaustiva, a tarefa de acompanhar a cronologia dessas investidas, os seus termos, e, em seguida o posicionamento régio, é fundamental para a compreensão da dimensão do campo de tensões no qual as milícias pardas e pretas estavam inseridas.

6.3.4. Um balanço dos projetos de reforma para as milícias pardas e pretas na América Ibérica (segunda metade do século XVIII e primeiras décadas do XIX)

Chegado a esse ponto, é possível estabelecer considerações mais gerais sobre a expressão reformista nos diferentes casos examinados com o intuito de melhor compreender a realidade do Regimento dos Úteis. É indispensável notar, em primeiro lugar, a abrangência espacial do fenômeno do ataque às corporações milicianas de pardos e de pretos e às suas oficialidades, o qual pôde ser verificado em diferentes regiões da América onde se falava português ou o espanhol. Apesar de compartilharem esse aspecto em comum, há diferenças notáveis na configuração das reformas milicianas nas diferentes capitanias do Brasil e no caso novo-hispânico. Após a formulação de um projeto sucinto e sob o pretexto de redução de gastos com a tropa, ampliação da receita tributária e aperfeiçoamento militar, os dois batalhões milicianos formados por pardos livres da Nova Espanha foram imediatamente extintos pelo vice-rei. Esse ato de governo foi aprovado pela Coroa espanhola tão logo as autoridades locais asseguraram-na de que não havia qualquer preocupação de que a desmobilização da milícia parda desencadeasse tumultos sociais e políticos. Em contraste, apesar da irrupção de projetos em diversas configurações sociais luso-brasileiras, a Coroa portuguesa jamais permitiu a extinção de um único terço ou regimento de pardos ou pretos, desde o malogro das reformas da década de 1730. Governadores e oficiais militares reformistas se depararam com severos obstáculos até mesmo para intervirem na oficialidade daqueles corpos militares.

Outra diferença destacável na abordagem às milícias de cor em um e outro espaço colonial ibero-americano se refere à exaustiva remissão à condição socioprofissional de pardos e pretos nos projetos de reforma elaborados no âmbito do Brasil colonial e imperial, a qual praticamente inexiste nos casos hispano-americanos. Complementarmente, verifica-se que na realidade do Brasil não teve lugar o fenômeno da conformação de identidades coletivas firmadas na associação direta entre o serviço militar de pardos e pretos ao artesanato, tão 
marcante em espaços coloniais espanhóis. ${ }^{122}$ A contraposição que se fazia entre a vileza do exercício dos ofícios mecânicos e a honra inerente às patentes remetia à própria definição da nobreza, a qual não podia fugir do seu principal contraponto, representado pelos desonrados, a plebe ou os peões, faltos de dignidade, cujas origens estavam assentadas no trabalho manual. Com efeito, durante o Antigo Regime o ideário da nobreza sustentava uma verdadeira repulsa ao trabalho manual. Quanto aos milicianos de cor, não bastasse a ascendência escrava, eles estavam profundamente arraigados ao universo artesanal.

Contudo, essa concepção foi revista na segunda metade do século XVIII, no bojo do iluminismo espanhol. Tratados como os de Campomanes e de Perez y Lopez, atentos à necessidade de se promover a dinamização da economia, visavam recuperar a dignidade do trabalho, deslocando o foco das concepções pejorativas atinentes ao labor manual para uma perspectiva que ressaltava a utilidade, honra e honestidade dos trabalhadores. ${ }^{123}$ A real cédula de 18 de março de 1783 expressou perfeitamente essa mudança de paradigma e sua assimilação ao Estado espanhol. ${ }^{124}$ Em Portugal, apesar da circulação desse conjunto de ideias e da adoção de medidas vanguardistas em termos de reformas sociais, a tradicional percepção do trabalho mecânico como elemento envilecedor permaneceu formalmente intocada. Portanto, a diferença no modo como os estados ibéricos lidaram com a questão do trabalho manual certamente se refletiu nos discursos construídos sobre as milícias de cor nos territórios americanos, de modo que o estigma concernente ao artesanato encontrou maior expressão no caso luso-brasileiro, não obstante os ofícios mecânicos fossem igualmente presentes na vida social de pardos e pretos em ambos os impérios coloniais.

Deslocando a análise para o caso luso-brasileiro, entende-se que a explicação para a atitude da Coroa em relação às milícias de cor, desautorizando as advertências e notadamente o ímpeto reformista de governadores e militares brancos em prol da manutenção daquelas corporações, deve levar em conta ao menos três aspectos: as pressões exercidas por parte de pardos e pretos junto ao poder central; a projeção da escravidão nas estratégias de manutenção

\footnotetext{
122 SOLANO D., Sergio Paolo; BOLÍVAR, Roicer Flórez. “Artilleros pardos y morenos artistas": artesanos, raza, milicias y reconocimiento social en el Nuevo Reino de Granada, 1770-1812. Historia critica, Bogotá, n. 48, p. 1137, sep./dic. 2012; CRUCES, Hugo Contreras. Artesanos mulatos y soldados beneméritos. El Batallón de Infantes de la Patria en la Guerra de Independencia de Chile, 1795-1820. Historia, Santiago, v. 44, n. 1, p. 51-89, ene./jun. 2011; WOOD, James A. The burden of citizenship: artisans, elections, and the fuero militar in Santiago de Chile, 1822-1851. The Americas, v. 58, n. 3, p. 443-469, jan./2002.

${ }^{123}$ Cf: : CAMPOMANES, Pedro Rodríguez. Discurso acerca do modo de fomentar a industria do povo. Lisboa: Typografia Rollandiana, 1778; PEREZ Y LOPEZ, A. X. Discurso sobre la honra y deshonra legal. Madrid: Blas Roman, 1781.

${ }^{124}$ Cf:: Real cédula de 18 de março de 1783. Madrid: Imprenta de Don Pedro Marin, 1783.
} 
do equilíbrio social; o papel das milícias de cor como contrapeso à expressão social e política das elites brancas luso-americanas.

O primeiro aspecto tem sido amplamente discutido. A sociedade colonial legou ao Brasil do Reino Unido e do Primeiro Reinado uma elevada dependência de sua estrutura militar relativamente às milícias, e nesse quadro se inseriam os terços e regimentos específicos de pardos e de pretos. As movimentações bélicas estimularam a formação de corpos militares, mas, como visto, a manifestação de interesse dos homens de cor em constituírem corpos militares privativos e dotados de oficialidade própria estava na raiz da formação das milícias de cor e foi decisiva em sua história. Através da prestação de serviço militar esses homens expressavam fidelidade à Monarquia, demandavam honrarias e privilégios e consolidavam relações de mútuo interesse com a Coroa. Alterar as bases dessa relação e, principalmente, rompê-la no auge do processo de elevação social experimentado pelas milícias pardas e pretas, significava correr o risco de precipitar a emergência de turbulências e abalos à ordem social e política.

Do ponto de vista da Coroa portuguesa, era preferível estender seus tentáculos às amplas camadas populacionais compostas pelos livres e libertos de cor mediante as milícias, mesmo que esse tipo de relação desencadeasse pressões constantes por ampliação de status e privilégios - "pois que este meio era o mais fácil, mais justo e o mais político para lhes influir e radicar nos seus corações o amor e a fidelidade que devem conceber e conservar ao seu soberano e à sua pátria". ${ }^{125}$ Uma das expressões mais cristalinas da percepção metropolitana acerca da questão está presente em um ofício enviado em 1800 por D. Rodrigo de Souza Coutinho, em nome do príncipe regente, ao governador da Bahia, D. Fernando José de Portugal, cujo conteúdo se originou de uma reunião do Conselho Ultramarino na qual se discutiu um requerimento da oficialidade parda baiana. Portugal foi advertido para que tomasse "em consideração a necessidade que há, de uma parte, de não desanimar os oficiais pardos" negando-lhes o "acesso aos postos superiores", pois, do contrário, "se poderão até mostrar-se menos afeitos ao governo [...]; e, da outra parte, não os elevar tanto que possam vir a perturbar a tranquilidade pública, visto que esta gente, em todas as colônias, se tem sempre mostrado a mais inquieta". ${ }^{26}$

A Coroa apostou, decididamente, em manter as milícias de cor estreitando os laços com as oficialidades pardas e pretas do Brasil na contramão da percepção de burocratas e militares que, situados no centro dos equilíbrios instáveis de poder, consideravam tal postura como um

\footnotetext{
${ }^{125}$ Cf:: AHU_ACL_CU_005, Cx. 216, D. 15168. Lisboa, 13 de janeiro de 1800.

${ }^{126}$ Cf:: "Ofício de D. Rodrigo de Souza Coutinho, Secretário de Estado, para D. Fernando José de Portugal". Palácio de Queluz, 20 de abril de 1800. Arquivo Público do Estado da Bahia, Ordens Régias, vol. 91, Doc. 71.
} 
grave erro "político". É inevitável indagar sobre o peso que a escravidão impunha às considerações relativas aos corpos militares em questão, tanto as estabelecidas na metrópole quanto na América. Esse problema adquiriu algum relevo nos projetos referentes à Pernambuco e ao Rio de Janeiro, nos quais as estimativas atinentes à proporção dos diferentes grupos populacionais estavam no centro da argumentação - não por uma questão meramente estatística, mas porque, segundo pensavam os estrategistas da sociedade, as proporções dos grupos expressavam a sua posição nas relações de força estabelecidas entre grupos concorrentes e rivais. Do diferencial existente entre os brancos - que representavam aproximadamente $28,5 \%$ dos habitantes de Pernambuco e 33,6\% dos moradores do Rio de Janeiro na passagem do século XVIII para o XIX (vide a tabela 2.3) - e a maioria restante formada pelas pessoas de cor, tanto livres como libertas ou escravas, os reformistas extraíram justificativas para a contenção da projeção militar, social e política - ou "física" e "moral”, na linguagem de época - de pardos e pretos, o que passava inexoravelmente pela remodelagem da milícia.

Mas mesmo nos casos em que os escravos foram mencionados explicitamente, é frágil a conexão estabelecida entre o seu peso demográfico e o potencial de sublevação dos milicianos pardos e pretos, todos livres ou libertos. Alguns fatores permitem inferir que a projeção da escravidão nos projetos reformistas era, em parte, um recurso retórico. É verdade que, no período considerado, as cidades do Rio de Janeiro e Salvador e a vila do Recife eram os principais portos de desembarque e de destino de escravizados africanos, mas é preciso considerar que o controle sobre as ações dos escravos era confiado, em primeira instância, aos seus proprietários. Deve se levar em conta, igualmente, que as milícias de cor atuavam constantemente, desde muito tempo e em toda a parte, na repreensão a movimentos de resistência escrava que extrapolassem a alçada dos senhores de escravos. Ademais, as milícias pardas e pretas estavam supervisionadas por contingentes militares majoritários formados por milícias brancas e pela tropa de linha, de modo que era pouco factível tanto o seu entabulamento com grupos de cativos como a sua disposição e potencial para empreender isoladamente ações militares contrárias à ordem vigente. É esclarecedora a atitude tomada pela câmara de Itu ao negar o envio de tropas milicianas para o destacamento da capital, em 1822, em um contexto marcado por divisões políticas na província de São Paulo. Deve-se recordar que Itu era sede de uma das companhias do Regimento dos Úteis. Segundo os seus camaristas, a presença dos milicianos na vila era imprescindível em face da agitação dos escravos, somente contida mediante emprego da "força moral” e da "tropa física e militar deste distrito, sem a qual é muito 
de se temer alguma explosão daquela gente, que faz mais da metade da população". ${ }^{127}$ Essa retórica, que já havia sido explorada pelas câmaras mineiras durante a guerra luso-castelhana das décadas de 1760-1770, difere fundamentalmente daquela aplicada em Pernambuco e Rio de Janeiro por considerar os soldados pardos como esteios da ordem e um contrapeso aos escravos. $^{128}$

Mais recorrente na argumentação dos reformistas foi delimitar-se a comparação ao vulto demográfico de brancos, de um lado, e ao de pardos e pretos livres ou libertos, de outro excluindo-se, portanto, os escravos. Isso se deu na medida em que aos escravos eram impostos mecanismos eficazes de controle social, tanto por parte dos proprietários quanto do Estado, mas aos seus descendentes livres coube aplicar recursos mais refinados e indiretos, já que não contavam com a supervisão direta de senhores escravocratas. Diversos trabalhos trataram da preocupação assumida por governadores coloniais quanto ao exercício de domínio e contenção às expressões de tais populações. ${ }^{129}$ Armar esses homens, sob os quais recaíam estigmas que os associavam a pessoas tendencialmente revoltosas, orgulhosas e pouco confiáveis, podia ser encarado como uma opção extremamente perigosa, mas essa perspectiva se esvai rapidamente quando se considera o comportamento centenário dos milicianos pardos e pretos no serviço. Especialmente os integrantes da oficialidade miliciana expressavam ter assimilado em suas estruturas de personalidade formas refinadas de autocontrole, aspecto que se refletia na fidelidade devotada à Monarquia, por um lado, e no exercício de controle sobre as centenas de

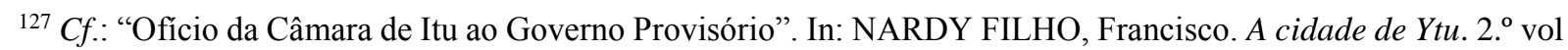
- Da acclamação de D. João VI à proclamação da Republica. A cooperação ytuana nos factos politicos desse periodo. São Paulo: Escolas Profissionais Salesianas, 1930, p. 73-74. Esse documento também foi examinado por RODRIGUES, Rejane M. Freitas. Representações políticas no Primeiro Império: a relação das Câmaras Municipais de Itu e Franca com o Governo Provincial. Dissertação (mestrado em História). Franca: FHDSS, Universidade Estadual Paulista, 2005, p. 56, e por RICCI, Magda M. de Oliveira. "Nas fronteiras da independência": um estudo sobre os significados da liberdade na região de Itu (1779-1822). Dissertação (mestrado em História). Campinas: IFCH, Universidade Estadual de Campinas, 1993, p. 259-260, sendo esse o trabalho referencial acerca das pressões exercidas pelos escravos de Itu em prol da liberdade no contexto aqui em questão.

${ }^{128}$ PAULA, Leandro Francisco de. Negros no campo das armas: homens de cor nos corpos militares das Minas Setecentistas. Dissertação (mestrado em História). Curitiba: SCHLA, Universidade Federal do Paraná, 2012, p. 46-51.

${ }^{129}$ Luiz Geraldo Silva atentou para a perspectiva ilustrada de governadores coloniais e de religiosos que conduziu o olhar dirigido às irmandades e festas dos negros livres em Pernambuco e notadamente o intento de cerceá-las. Ver SILVA, Luiz Geraldo. Da festa à sedição: sociabilidades, etnia e controle social na América portuguesa (17761814). História: Questões \& Debates, Curitiba, n. 30, p. 83-110, 1999; SILVA, Luiz Geraldo. Da festa barroca à intolerância ilustrada. Irmandades católicas e religiosidade negra na América portuguesa (1750-1815). In: SALLES-REESE, Verónica (Org.). Repensando el pasado, recuperando el futuro. Nuevos aportes interdisciplinarios para el estudio de la América colonial. Bogotá: Editorial Pontificia Universidad Javeriana, 2005, p. 270-287; Silvia H. Lara argumentou que o desenvolvimento da camada de homens de cor livres gerou um problema político de manutenção da ordem no Rio de Janeiro de fins do período colonial. LARA, Silvia Hunold. Fragmentos setecentistas: escravidão, cultura e poder na América portuguesa. São Paulo: Companhia das Letras, 2007. 
subordinados em cada terço ou regimento, por outro. ${ }^{130}$ Ainda assim, nos projetos reformistas a manutenção da concentração de "força moral" entre os brancos foi tratada como questão de primeira ordem. Se tratava menos de uma preocupação com a força física das milícias de cor ou, em outros termos, com o seu potencial de ação militar contra o establishment, e mais em preservar o exclusivismo dos brancos detentores de riquezas no tocante às posições elevadas e decisórias da sociedade. E as milícias de cor foram corretamente apontadas como corporações que desequilibravam esse monopólio, advindo daí o ímpeto em desestruturá-las. Desde o século XVIII que se denunciava a vinculação desses milicianos com o universo do cativeiro, com os ofícios mecânicos e seus níveis ínfimos de riqueza como fatores que conferiam incapacidade para viverem à lei da nobreza, tal como se requeria aos portadores de patentes milicianas. Governadores e militares reformistas demonstraram grande coesão em torno dessa retórica. Entretanto, apesar de o discurso ser comum, as propostas efetivas e o modo de se proceder diante das milícias de cor divergiram de acordo com os equilíbrios de poder internos às capitanias, o que ressalta as especificidades das configurações sociais luso-brasileiras.

No Rio de Janeiro, o Marquês do Lavradio implantou um modelo institucional peculiar para o terço de pardos, que consistiu em um estado-maior desfigurado e sob o comando de sargento-mor e ajudantes brancos retirados da tropa regular. Já os pretos Henriques sequer contavam com oficiais superiores, mas apenas com um capitão-mandante. Como visto, essa formatação inspirou governadores de Pernambuco e da Bahia, e provavelmente também tenha orientado a configuração das milícias de cor em outras capitanias, a exemplo de Goiás, onde a criação do terço dos pretos Henriques se arrastou por algumas décadas e em cujo período o seu comando foi subordinado ao do colossal terço e depois regimento dos pardos. Essa atrofia dos estados-maiores pardos e pretos foi possível nas configurações sociais em que a camada de livres de cor e principalmente os seus corpos militares eram mais recentes. No Rio de Janeiro e em Goiás, os terços já foram criados desse modo incompleto nas décadas de 1760 e 1770, e é presumível que, nesse momento inicial, a oficialidade das suas companhias auxiliares estivesse plenamente satisfeita com a ereção das corporações, acreditando ser questão de tempo a aquisição de tal complemento institucional. Já para pardos e pretos pernambucanos e baianos, situados em configurações sociais nas quais a escravidão era antiquíssima e a camada de homens de cor livres colhia os frutos de seu enraizamento social e da tradição de prestação de serviços militares à Coroa portuguesa havia muito tempo, a atrofia dos estados-maiores de seus terços e regimentos seria encarada como um fenômeno inaceitável. Isso justifica o fato de que

\footnotetext{
${ }^{130}$ SILVA, Luiz Geraldo. Gênese das milícias de pardos e pretos na América portuguesa: Pernambuco e Minas
} Gerais, séculos XVII e XVIII. Revista de História, São Paulo, n. 169, p. 112-144, jul./dez. 2013, p. 121-122. 
a opção pela abolição dos terços e regimentos foi praticamente desconsiderada para essas realidades.

O caso mexicano oferece um contraponto interessante. A vinculação da Nova Espanha com o tráfico transatlântico de escravos foi significativa entre os séculos XVI e XVII, mas sua capacidade de absorção de mão de obra africana decaiu sensivelmente no Setecentos. ${ }^{131}$ Daí resultou, desde muito cedo, a formação de um grupo social integrado por descendentes de escravos livres e libertos que afinal constituíram as milícias de pardos e de morenos. Contudo, a drástica redução na importação de cativos também impactou na reprodução do grupo social em tela. Ao contrário da América portuguesa, onde a categoria pardo tendeu a aglutinar os mestiços de todas as matizes, formando-se um grupo constantemente renovado e crescente, na realidade novo-hispânica vigia uma distinção rigorosa entre espanhóis, brancos criollos, índios, mestizos e os pardos, que integravam as castas. Estimou-se que, entre fins do século XVIII e começo do XIX, os pardos livres da Cidade do México representassem pouco mais de $7 \%$ da população total da capital do vice-reino. ${ }^{132}$ Tratava-se, então, de um grupo socialmente arraigado, mas envelhecido, que gradualmente perdia projeção social à medida que diminuía a sua capacidade de reprodução. Não é por acaso, pois, que a desmobilização dos seus batalhões milicianos tenha ocorrido tão rapidamente, demandando aos reformistas nada mais que um mínimo de esforços retóricos e políticos, e sem que daí se provocasse quaisquer abalos à ordem estabelecida como informaram sucessivos vice-reis.

Todos esses casos fornecem parâmetros pertinentes para se refletir sobre o que se passou em São Paulo. A julgar pela duração, intensidade e dimensões gerais do ataque imposto pelos reformistas ao Regimento dos Úteis, certamente essa corporação foi uma das que mais sofreu e duramente suportou o ímpeto das elites brancas que se pronunciavam como guardiãs da nobreza. Passados apenas nove anos desde a sua criação, o Regimento já era alvo de propostas direcionadas à suspensão da oficialidade parda, as quais em breve tempo evoluiriam no sentido da completa extinção daquele corpo militar. Durante aproximadamente metade do seu curto período de existência, as atividades do Regimento dos Úteis (1797-1831) foram realizadas sob a sombra do temor da desfiguração e da desmobilização. De fato, ao longo do período

\footnotetext{
131 SERNA H., Juan M. de la. Periodos, cifras y debates del comercio de esclavos novohispanos, 1540-1820. América Latina en la Historia Económica, vol. 11, n. 1, p. 46-58, jan./jun. 2004.

${ }^{132}$ HERNÁNDEZ Y SÁNCHES-BARBA, Mario. La población hispanoamericana y su distribución social en el siglo XVIII. Revista de Estudios Políticos, n. 78, p. 111-142, 1954, p. 127. Um cálculo para a jurisdição mais abrangente do México, para 1790, indicou que os mulatos perfaziam 5\% da população total, mas, somados à

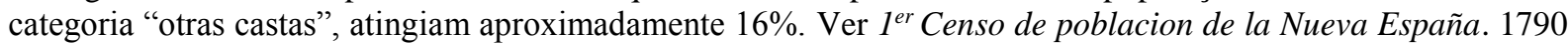
- Censo de Revillagigedo, "un censo condenado". México: Secretaria de Programacion y Pressupuesto de Direccion General de Estadistica, 1977, p. 144.
} 
compreendido pelos anos 1806 e 1821, o governador Franca e Horta e o inspetor geral das milícias, José Arouche de Toledo Rendon, insistiram junto à Coroa, por mais de uma dezena de vezes, para obterem autorização para a realização das reformas naquela milícia. E deve-se notar que em parte alguma do Brasil tais manifestações adquiriram os contornos de obstinação e foram extremamente ousadas em seus termos como em São Paulo. Lavradio recusou-se a prover os postos superiores dos terços que ele próprio criara no Rio de Janeiro, mas recomendou, ao sucessor, a manutenção desses corpos militares. ${ }^{133} \mathrm{Na}$ Bahia, D. Fernando José de Portugal investiu somente contra o estado-maior dos pardos, deixando intocados os antigos e tradicionais Henriques. Em Pernambuco, Caetano P. de M. Montenegro considerou prudente “contemporizar e lançar mão de meios indiretos", antevendo os riscos de "uma reforma direta e muito austera", razão pela qual não chegou a propor a substituição da oficialidade de cor e menos ainda a abolição dos seus regimentos. ${ }^{134}$ Novamente no Rio de Janeiro, o tenente-general Oliveira projetou o cerceamento aos oficiais pardos e pretos, em 1815, postergando para um futuro indefinido o fim da separação por cores na milícia.

São Paulo destoa das demais configurações sociais luso-brasileiras mencionadas porque, desde o início, os reformistas militaram pela completa extinção da oficialidade parda e, sobretudo, pela total supressão do Regimento dos Úteis. Ademais, não expressaram quaisquer receios de que a desmobilização dos pardos provocasse conflitos, tensões ou instabilidade ao equilíbrio de poder interno a capitania/província. Em realidade, a atitude intrépida dos reformistas em São Paulo faz lembrar a dos seus pares novo-hispânicos, não obstante tenham sido muito diferentes os destinos das milícias pardas nesses dois espaços. Acredita-se aqui que essa semelhança se deva ao fato de que os pardos ocupavam uma posição social relativamente frágil em tais configurações sociais. Acerca do caso mexicano já se fez menção acima, mas quanto aos paulistas é preciso retomar alguns dados dos capítulos anteriores. O pleno desenvolvimento de São Paulo como uma sociedade escravista remonta ao século XVII e à intensa exploração do trabalho indígena. A introdução mais significativa de cativos de origem africana na capitania ocorreu somente ao longo do século XVIII, na esteira da exploração aurífera nos sertões da América portuguesa. Em um primeiro momento, houve a mescla entre uma decadente escravidão indígena e uma incipiente e ainda modesta escravidão negra, originando-se daí contingentes expressivos de cativos crioulos. É dessa escravidão mais antiga que se originou o grupo dos pardos forros e livres que integrou o Regimento dos Úteis a partir

\footnotetext{
${ }^{133} C f$ :: "Relatório do marquês de Lavradio, vice-rei do Rio de Janeiro, entregando o governo a Luiz de Vasconcelos e Souza, que o sucedeu no vice-reinado". RIHGB, t. 4, n. 16, p. 419-425 e 436.

${ }^{134}$ Cf:: AHU_CU_015, Cx. 259, D. 17405. Recife, 24 de março de 1806.
} 
de finais do Setecentos. Desse modo, quando ocorreu o boom escravista na capitania incentivado pelo cultivo da cana-de-açúcar e se completou a transição da mão de obra indígena para a africana, o vigoroso grupo dos pardos livres já estava plenamente formado. Os reformistas tinham a clara percepção da dissociação reinante entre os grupos de pardos livres e o dos escravos africanos, bem como do amplo predomínio dos brancos em meio à população livre paulista durante o período considerado. Além disso, o fato de que havia um único regimento de pardos na capitania/província e de que esse estava rodeado por dez corpos milicianos identificados aos brancos, além de dois regimentos regulares, fornecia-lhes tamanha segurança a ponto de pouco se preocuparem com eventuais distúrbios relacionados aos ataques aos milicianos pardos.

Mas se o potencial e a disposição de ação dos milicianos pardos de São Paulo estavam longe de poderem afligir governadores e oficiais militares reformistas, cabe indagar os motivos pelos quais esses impuseram retoricamente a humilhação daqueles e por que pressionaram tão veementemente a Coroa portuguesa pela desmobilização do Regimento dos Úteis. Tamanho dispêndio de energia, variável de configuração social para configuração social, possivelmente era proporcional à síntese entre a sensação de incômodo que a existência dos milicianos pardos e pretos causava ao establishment e a capacidade de os grupos superiores da sociedade imporem sua dominação aos grupos inferiores. De fato, a projeção social que a milícia de cor adquiriu, sobretudo desde a segunda metade do século XVIII e com o respaldo da Coroa, afetou diretamente a milícia branca e aos grupos que se arrogavam os ares de nobreza. A ampliação de privilégios por parte de pardos e pretos ocorreu em um período em que a liberdade de ação dos milicianos brancos estava sendo tolhida pela Coroa. Tanto o cerceamento aos corpos de segunda linha específicos aos "nobres" quanto a intromissão da oficialidade de linha na milícia fragilizaram alguns dos principais mecanismos de distinção dos brancos. Pardos e pretos, ao contrário, perceberam a manutenção dos seus corpos militares, lograram obter a primazia no acesso aos postos superiores dos seus regimentos e, mais importante, conquistaram a equiparação de seus oficiais aos oficiais brancos de milícias e das tropas regulares.

A equivalência dos postos no universo da milícia, colocando pardos e pretos em pé de igualdade com brancos, subvertia o equilíbrio no qual repousavam as sociedades coloniais e escravistas americanas, como argutamente observaram Allan J. Kuethe e Santiago-Gerardo Suarez para a realidade hispano-americana. ${ }^{135}$ Tal situação amplificou imensamente o desconforto que brancos sentiam ao relacionar-se com pardos e pretos nas situações do serviço

\footnotetext{
${ }^{135}$ KUETHE, Allan J. The status of the free pardo...; SUAREZ, Santiago-Gerardo. Las milicias. Instituciones
} militares hispanoamericanas. Caracas: Academia Nacional de la Historia, 1984, p. 124-138. 
militar. Era intolerável, para senhores de engenho, ricos comerciantes e grandes escravistas pertencentes às famílias influentes de longa data nas localidades, o constrangimento de terem que prestar reverência a homens oriundos da escravidão, meros oficiais mecânicos e com poucas posses, todas as vezes em que as suas patentes fossem inferiores às desses. Por isso os projetos de reforma serviram como mensageiros desse setor e jamais deixaram de denunciar o descompasso existente entre a situação material e social de pardos e de pretos, externa à milícia, e a condição elevada que as patentes lhes atribuíam.

Recuperando a noção de que o universo da milícia se configurava como uma espécie de jogo, torna-se claro que os brancos percebiam o crescimento relativo dos pardos e pretos e, correlatamente, também se faziam cientes da gravidade de suas derrotas à medida que o processo social se desenrolava. No quadro mais geral, a Revolução Francesa, como epicentro da crise do Antigo Regime, desencadeou uma caça às monarquias europeias e ataques vorazes à nobreza e aos seus privilégios. Nesse contexto, a transferência da Corte portuguesa para a antiga colônia americana garantiu a imediata salvaguarda da família real e a sobrevida da nobreza cortesã. Por outro lado, no que diz respeito à sociedade luso-americana, um dos efeitos imediatos da instalação da Corte em seu seio foi um reforço da perspectiva aristocrática de mundo. Ora, a proximidade ao rei e às grandes famílias do reino exerceu imediata coerção sobre os diversos grupos sociais locais, mais notadamente sobre as elites coloniais, que sentiram a relativização de sua expressão social diante da nobreza europeia recém-chegada à América. Ao mesmo tempo, apesar de ainda preservarem uma segura distância social em relação aos modestos homens de cor na sociedade mais ampla, internamente ao universo militar as elites luso-brasileiras estavam acuadas entre fins do século XVIII e começos do XIX. É o que exprimiram os reformistas, os quais trataram de difamar a imagem da oficialidade parda e preta de um modo e intensidade inéditos e, ao mesmo tempo, de exaltar as virtudes das elites brancas luso-americanas. Na realidade, a oficialidade branca sentia que estava lentamente perdendo o controle do jogo: viu diminuir, ao longo do tempo, a sua capacidade de controlar os movimentos dos adversários, de induzir os seus comportamentos e de prever os rumos globais da competição. ${ }^{136}$ Ela própria estava sendo fortemente coagida a encontrar meios capazes de garantir a sua diferenciação social em relação a pardos e pretos após a consolidação da igualdade dos postos. ${ }^{137}$

\footnotetext{
${ }^{136}$ ELIAS, Norbert. Introdução à sociologia. Lisboa: Edições 70, 2008, p. 77-112.

137 Sobre a "diminuição dos contrastes" nos processos sociais mediante a imposição de "restrições crescentes à classe alta" a partir de "pressões crescentes a partir de baixo", vide ELIAS, Norbert. O processo civilizador. Vol. 2 - Formação do Estado e Civilização. Trad. Ruy Jungmann. Rio de Janeiro: Jorge Zahar Editor, 1993, p. 210225, 248-262.
} 
Nesse ponto, é preciso atentar para o fato de que a competição não envolvia apenas milicianos brancos, de um lado, e milicianos de cor, de outro. Ela ultrapassava o âmbito particular das capitanias e províncias - e, portanto, a alçada de governadores e de seus imediatos - e envolvia as instituições mais centrais do estado, as quais, afinal, concentravam a maior parcela de poder na figura régia. Examinado o processo por essa ótica, percebe-se logo que, assim como a ascensão das milícias pardas e pretas ocorreu em função de inúmeras variáveis, também o relativo cerceamento às milícias brancas se deveu a vários fatores. A interferência régia foi fundamental em ambos os casos. Sugere-se aqui, finalmente, que, apesar de confiar a defesa interna e externa do Brasil em grande medida às milícias, a Coroa buscou controlar tanto quanto possível a expressão social e política desse ramo das forças armadas. Um dos meios de que se valeu foi a manutenção de um equilíbrio tenso entre os diferentes corpos militares através da elevação relativa do status de uns e da limitação da projeção de outros. Essa diminuição de contrastes, aliás, era coerente com as políticas ilustradas que visavam, a um só tempo, conter os poderes concorrentes e promover a centralização monárquica. Algo semelhante se processou na América espanhola. No âmbito das milícias, oficiais peninsulares substituíram as elites criollas nas posições mais elevadas, com o que passaram a controlá-las em regiões como Nueva España e Nueva Granada. ${ }^{138}$ Nesse sentido, no Brasil, as milícias pardas e pretas surgem como leais à Coroa na prestação de serviço militar e no exercício de controle social sobre vastas populações egressas do cativeiro e, sem que o soubessem, como um contrapeso à expressão social e política das elites brancas alocadas nas milícias luso-brasileiras.

\footnotetext{
${ }^{138}$ Para um panorama geral das reformas bourbônicas nos campos administrativo, judiciário e religioso, vide BRADING, David A. A Espanha dos Bourbons e seu Império americano. In: BETHELL, Leslie (Org.). História da América Latina. Vol. 1 - América Latina colonial. São Paulo: Edusp; Brasília: Fundação Alexandre de Gusmão, 1997, p. 391-445. Acerca da relação entre peninsulares e criollos nas milícias coloniais e a perspectiva régia, ver MARCHENA FERNÁNDEZ, Juan (Coord.). El ejército de América antes de la independencia. Ejército regular y milicias americanas, 1750-1815 - Hojas de servicio y uniformes. Madrid: Fundación Mapfre Tavera, CD-Rom, s./data, p. 98-100, 120, 127-128, 179-193, 201-230, 243-247. Deve-se notar que em localidades específicas, como Cuba e o Peru, se processou um arranjo diferente mediante uma espécie de "pacto político-econômico-militar" entre as elites locais e a Coroa espanhola. Ver KUETHE, Allan. Las milicias disciplinadas: ¿fracaso o éxito? In: ESCAMILLA, Juan Ortiz (Coord.). Fuerzas militares en Iberoamérica, siglos XVIII y XIX. México: El Colegio de México, Centro de Estudios Históricos; Zamora, Michoacán, México: El Colegio de Michoacán; Veracruz, México: Universidad Veracruzana, 2005, p. 19-26; MARCHENA FERNÁNDEZ, Juan (Coord.). El ejército de América..., p. 98-99.
} 


\subsection{Disputa pelo comando da milícia parda: competição aberta entre pardos e brancos (São Paulo, 1797-1831)}

Na perspectiva que encara o universo militar como um campo de tensões, já se examinou duas das principais dimensões atinentes à existência das milícias pardas e pretas e à configuração de suas oficialidades - os posicionamentos do poder soberano, de um lado, e os de governadores e oficiais militares de alto escalão, de outro. Daqui em diante, o objetivo passa a ser examinar-se o processamento dos enfrentamentos entre pardos e brancos na competição pelos postos do Regimento dos Úteis em São Paulo, numa dimensão ainda mais próxima à da vivência cotidiana daquelas tensões. Em parte, tais enfrentamentos estavam estruturados pelas normas que regiam o relacionamento dos súditos com o soberano e notadamente pela legislação concernente às promoções dos postos militares. Como já visto, o Alvará de 1802 concedeu acesso preferencial ao estado-maior dos regimentos de pardos e de pretos aos próprios milicianos de cor, mas deixou aberta a possibilidade de que oficiais brancos ocupassem aquelas funções no caso de inexistir milicianos aptos. Esse aspecto da legislação, em particular, alimentou uma intensa competição entre os diferentes postulantes aos postos durante as três primeiras décadas do século XIX. Foi em meio a esse campo de embates que os pardos de São Paulo produziram argumentações refinadas para competir com militares da tropa regular pelo comando do Regimento dos Úteis e, ao mesmo tempo, para combater as proposições contrárias à sua existência social como oficiais milicianos que estavam contidas nos projetos de reforma. Em tais circunstâncias a oficialidade de cor se mobilizava e se expressava, interpretando as leis e o processo histórico, enriquecendo os significados de sua relação com o Estado e se posicionando quanto à importância da cor e da riqueza como delimitadores da sua posição na milícia e na sociedade, ou seja, aos temas estruturantes das relações sociais que mais lhes afetavam.

Por outra parte, a configuração social de São Paulo imprimiu contornos específicos a esse fenômeno da competição pelos postos, que pode ser definida como a busca pelas posições que concentravam as maiores honrarias, privilégios, autoridade e poder relativo. Os aspectos fundamentais dizem respeito, primeiramente, à posição ocupada e às funções desempenhadas por São Paulo no âmbito da Monarquia portuguesa e, depois, do império do Brasil; e, em segundo lugar, e não menos importante, à configuração das forças armadas na capitania/província. Ora, a economia paulista do Setecentos passou por profundas transformações: para além das atividades voltadas à subsistência e às pequenas trocas, São Paulo tornou-se um centro de convergência para o comércio de animais e um abastecedor de 
víveres para as localidades mineradoras do interior. Quando a produção de açúcar engrenou definitivamente, ampliando sua capacidade de importação de escravizados africanos, a capitania também se converteu em núcleo aprovisionador da Corte instalada no Rio de Janeiro. Já do ponto de vista militar, desde o século XVII, com as guerras “dos Bárbaros” e de Palmares, que os paulistas foram desempenhando um papel de relevo nas mobilizações armadas em solo luso-americano. Mas, ao longo do século seguinte e até bem avançado o XIX, foram os confrontos fronteiriços ao Sul, com os espanhóis, que exigiram maior participação de corpos militares da capitania. Em conjunto, esses vários aspectos complexificaram a busca por distinção social: a guerra e o dinheiro amplificaram as oportunidades, mas, em contrapartida, acirraram as disputas. Os militares da tropa paga retornavam das campanhas sedentos por mercês e encontravam nos prestigiados postos superiores dos corpos milicianos um pagamento adequado aos seus serviços. Ao mesmo tempo, o Regimento dos Úteis, o único corpo miliciano de pardos, rodeado por dez regimentos de brancos, executava relevantes funções militares internas à capitania/província, aspecto que igualmente emulava a sua oficialidade a buscar ascender ao estado-maior da corporação. Poucos postos à disposição de inúmeros competidores - tal é a visão elementar do jogo no qual se digladiaram militares brancos das tropas pagas e milicianos pardos.

Ao se formular o problema da disputa pelas patentes superiores da instituição em questão, confere-se visibilidade a um aspecto nem sempre notado na historiografia: o acesso de pessoas de baixa extração a tais postos e, por conseguinte, as suas possibilidades de ascensão social em meio à sociedade escravista, não eram pontos pacíficos ou dados estáveis e imutáveis; antes, eram o resultado de lutas, arranjos e de processos históricos complexos. A estrutura interna dos corpos militares constituídos por descendentes de escravos em diferentes impérios coloniais americanos já oferece uma aproximação a essa noção: enquanto nos territórios britânicos e franceses pesadas restrições eram impostas aos milicianos negros, impedindo-lhes o acesso aos postos mais elevados de suas corporações, os milicianos hispano e sobretudo os luso-americanos dispuseram de chances mais evidentes de exercerem a autoridade e desfrutarem do prestígio inerente às funções sociais mais relevantes da milícia. ${ }^{139}$ Mas mesmo a característica dessas configurações, mais ou menos abertas, não era dada de partida. O exame aqui empreendido acerca da trajetória histórica das milícias de cor revela que essas instituições não apenas encapsulavam equilíbrios internos de poder, mas elas próprias estavam inseridas e

${ }^{139}$ SILVA, Luiz Geraldo. Indivíduo e sociedade. Brás de Brito Souto e o processo de institucionalização das milícias de afrodescendentes livres e libertos na América portuguesa (1684-1768). Tempo, Niterói, vol. 23, n. ${ }^{\circ} 2$, p. 174-203, mai./ago. 2017. 
conectadas a campos de força mais abrangentes. Dessa maneira, a formulação de estratégias individuais ou familiares de elevação social por meio da milícia - a qual era a principal via de acesso de pardos e pretos a privilégios e honrarias associados à nobreza - estava subordinada à atuação desses grupos visando à formação, estruturação, institucionalização, manutenção e ampliação do status de seus corpos militares. É nesse sentido que a competição travada entre pardos e brancos pelos postos superiores ao longo do período que marca o fim da colonização portuguesa e a fundação do estado e da nação brasileira assume a feição de um capítulo decisivo tanto na história das milícias de cor quanto na do tensionamento aos limites impostos à projeção social dos grupos outsiders.

As promoções da milícia ocorriam de diferentes formas, a depender da posição dos postos na hierarquia militar. O provimento dos postos da baixa oficialidade, isto é, cabos, furriéis, porta-bandeiras e sargentos, era responsabilidade dos coronéis e, consequentemente, baseava-se em critérios e mecanismos internos aos corpos militares. Certamente havia competição pelo acesso a esses postos e mesmo ingerência de fatores externos à milícia, mas como as tensões resultantes eram resolvidas no âmbito dos próprios regimentos, não chegavam a induzir a produção de documentos que detalhassem tais práticas. No que respeita aos postos de alferes, tenente e capitão, distinguidos dos oficiais inferiores pelas patentes, a realidade era diversa. A competição tornava-se mais acirrada na medida em que se ampliava a autoridade, a honra, o prestígio e os privilégios associados às funções. Em razão disso, o sistema de promoções tornou-se cada vez mais complexo. Nas primeiras décadas do século XIX, os coronéis formulavam uma lista de indicados para os postos, chamada de proposta, a qual era submetida à apreciação dos governadores e capitães-generais e, após 1822, aos governadores das armas. Durante a década de 1810, enquanto existiu o cargo de inspetor geral das milícias, as propostas eram encaminhadas a esse funcionário para que fornecesse informações detalhadas sobre os indicados, e somente então os governadores aprovavam as promoções. Após isso, os oficiais promovidos eram obrigados a confirmarem as suas patentes sob pena de serem removidos dos postos, embora não raro se fizesse vistas grossas aos negligentes. Já o provimento dos postos de patente do estado-maior estava mais diretamente vinculado aos governos das capitanias e províncias e ao monarca, o que se devia à sua grande relevância em termos tanto de técnica militar como de concentração de poder. As propostas eram elaboradas no espaço das capitanias/províncias e a sua confirmação ocorria na Corte. Como visto, as promoções de coronéis, tenentes-coronéis, sargentos-mores e de ajudantes ocorriam mediante 
concurso ao qual se submetiam os postulantes, os quais deviam atender a inúmeros requisitos de antemão e também no decorrer dos exames. ${ }^{140}$

No regimento dos pardos de São Paulo, o provimento dos postos de patente da oficialidade das companhias (alferes, tenentes e capitães) constituiu-se em um campo de embates sobretudo na década de 1800, período em que o governador Antonio José da Franca e Horta (1802-1808) tentou colocar em prática o plano de desmobilizar os Úteis, principiando pela recusa em prover os postos vagos. Uma parte do problema foi resolvida através dos seguidos acenos da Coroa no sentido de manterem-se as promoções dos pardos e a existência do Regimento e a outra parte foi sanada com a ascensão de um pardo ao coronelato, em 1810. Daí em diante, os postos tornaram a ser regularmente preenchidos e a competição foi delimitada ao universo dos milicianos pardos. No âmbito da disputa pelas funções do estado-maior, porém, a concorrência era extremamente acirrada e extravasava os limites do Regimento. Nela se digladiavam militares da tropa de linha e milicianos, brancos e pardos.

Quando o Regimento dos Úteis foi criado, em 1797, pelo menos três fatores contribuíram para que o estado-maior fosse integrado por homens brancos. O primeiro deles é o fato de que os oficiais pardos não contavam com experiência no comando de corporações desse porte, já que atuavam somente na esfera das companhias, e entre eles eram raríssimos os egressos da tropa de linha que demonstravam capacidade técnica para gerir o Regimento. $\mathrm{O}$ segundo diz respeito à criação dos Úteis ter ocorrido anteriormente ao conhecimento da Provisão de 1797 e à publicação do Alvará de 1802, cujas peças normativas acenavam para a equiparação entre oficiais brancos e de cor e para a preferência concedida aos últimos no desempenho das funções de comando de seus corpos militares. Já o terceiro fator está associado à relação de interdependência existente entre os diversos setores do universo militar e notadamente à pressão exercida por oficiais veteranos da tropa de linha visando à progressão em suas carreiras mediante a transferência para a milícia.

De fato, entre 1797 e 1801, os postos de coronel, tenente-coronel, sargento-mor e ajudantes do regimento dos pardos de São Paulo foram sistematicamente providos em homens brancos, provenientes da tropa regular, através de nomeações passadas pelo governador Antonio Manoel de Melo Castro e Mendonça (1797-1802). O posto de coronel foi ocupado pelo então tenente-coronel Modesto Antonio Coelho Neto (1797) e depois pelo então sargento-mor José Joaquim Mariano da Silva César (1802). Já o posto de tenente-coronel foi marcado por maior rotatividade no período de formação do Regimento, tendo sido ocupado sucessivamente

${ }^{140} C f$ : “Alvará de 17 de dezembro de 1802”. Lisboa: Regia Officina Typografica, 1803. 
por quatro homens: capitão José Mendes da Costa (1797), capitão Francisco Gonçalves Cordeiro (1797), capitão José Florêncio de Oliveira (1798) e capitão José dos Santos Souza (1799). O sargento-mor nomeado foi o capitão Prudente Borges da Costa (1797), e havia ainda, como ajudantes, o alferes Vicente José Saul (1797) e o sargento Antonio de Pádua de Gusmão (1801). ${ }^{141}$ Durante o governo de Franca e Horta, como visto, houve uma espécie de congelamento na dinâmica das promoções na milícia, a qual somente se normalizou de 1808 em diante, após a instalação da Corte no Brasil e em um contexto de readequação da estrutura militar luso-brasileira visando-se as campanhas militares no Prata e na Guiana francesa. A partir daí, os postos superiores da milícia dos pardos figuraram constantemente como objeto de demandas dos militares profissionais, como está sintetizado no quadro 6.1.

\section{Quadro 6.1 - Militares brancos oriundos da $1 .^{\text {a }}$ linha que pleitearam postos no estado- maior do Regimento dos Úteis (1803-1828)}

\begin{tabular}{|c|c|c|c|c|c|}
\hline N. ${ }^{\circ}$ & Nome & $\begin{array}{l}\text { Data do } \\
\text { requerimento }\end{array}$ & Posto atual & $\begin{array}{l}\text { Posto } \\
\text { pretendido* }\end{array}$ & $\begin{array}{l}\text { Pleiteou Reg. } \\
\text { dos Úteis** }\end{array}$ \\
\hline 1 & $\begin{array}{l}\text { José Joaquim Mariano da } \\
\text { Silva César }\end{array}$ & ant. 1803/12/09 & $\begin{array}{l}\text { Coronel Reg. dos } \\
\text { Úteis (comissão) }\end{array}$ & Coronel efetivo & Sim \\
\hline 2 & $\begin{array}{l}\text { Antonio de Pádua de } \\
\text { Gusmão }\end{array}$ & $\begin{array}{c}\text { post. } \\
1803 / 09 / 03\end{array}$ & $\begin{array}{l}\text { Ajudante Reg. dos } \\
\text { Úteis (comissão) }\end{array}$ & Ajudante efetivo & Sim \\
\hline 3 & Antonio Pereira da Silva & ant. $1808 / 12 / 22$ & Sargento de linha & Ajudante Supra & Sim \\
\hline 4 & $\begin{array}{l}\text { Antonio de Pádua de } \\
\text { Gusmão }\end{array}$ & ant. $1808 / 12 / 22$ & Sargento de linha & $\underline{2{ }^{\circ} \text { ajudante }}$ & Sim \\
\hline 5 & $\begin{array}{l}\text { José Joaquim Mariano da } \\
\text { Silva César }\end{array}$ & $1808 / 07 / 23$ & $\begin{array}{c}\text { Sargento-mor de } 2 .^{a} \\
\text { linha }\end{array}$ & $\underline{\text { Coronel efetivo }}$ & Sim \\
\hline 6 & José da Silva Lisboa & $\begin{array}{l}\text { ant. } 1809 / 06 / 30 \text {; } \\
\text { ant. } 1811 / 02 / 28\end{array}$ & $\begin{array}{l}\text { Ajudante de } 2 .^{\mathrm{a}} \\
\text { linha }\end{array}$ & $\underline{\text { Sargento-mor }}$ & Sim \\
\hline 7 & Pedro José de Brito & ant. $1810 / 03 / 20$ & $\begin{array}{c}\text { Sargento-mor de } 2 .^{a} \\
\text { linha }\end{array}$ & $\underline{\text { Sargento-mor }}$ & Sim \\
\hline 8 & Antonio Pinto do Rego & ant. $1810 / 03 / 20$ & Tenente de linha & Sargento-mor & Sim \\
\hline 9 & $\begin{array}{l}\text { Antonio de Pádua de } \\
\text { Gusmão }\end{array}$ & ant. $1810 / 12 / 22$ & $\begin{array}{l}\text { 2. }{ }^{\circ} \text { Ajudante Reg. } \\
\text { dos Úteis }\end{array}$ & $\begin{array}{l}\text { 1. }{ }^{\circ} \text { Ajudante } \\
\text { Reg. dos Úteis }\end{array}$ & Sim \\
\hline 10 & José Manoel Monteiro & ant. $1811 / 07 / 01$ & Alferes de $2 .^{a}$ linha & Ajudante & Sim \\
\hline 11 & $?$ & $1813 / 05 / 12$ & $\begin{array}{l}\text { 1. } \\
\underset{\text { linha }}{\text { Ajudante de } 2 .^{a}}\end{array}$ & Sargento-mor & Sim \\
\hline 12 & $\begin{array}{l}\text { Antonio de Pádua de } \\
\text { Gusmão }\end{array}$ & ant. $1814 / 04 / 30$ & $\begin{array}{l}\text { 2. }{ }^{\circ} \text { Ajudante Reg. } \\
\text { dos Úteis }\end{array}$ & $\frac{1 .^{\circ} \text { Ajudante }}{\underline{\text { Reg. dos Úteis }}}$ & Sim \\
\hline
\end{tabular}

${ }^{141} C f:$ : APESP, Ordem C00407, Livro 130, fls. 20v-21, 24-24v, 31v-32, 34, 47v-48, 111v, 134v-135, $188 \mathrm{v}-189$. 


\begin{tabular}{|c|c|c|c|c|c|}
\hline 13 & Domingos Velho da Silva & ant. $1814 / 10 / 20$ & Tenente de linha & Sargento-mor & Não \\
\hline 14 & Manoel dos Santos Lima & ant. $1815 / 03 / 02$ & $\begin{array}{l}\text { Artífice de fogo de } \\
\text { linha }\end{array}$ & 2. Ajudante & Não \\
\hline 15 & José da Silva Lisboa & $1815 / 04 / 21$ & $\begin{array}{l}\text { Sargento-mor Reg. } \\
\text { dos Úteis }\end{array}$ & $\underline{\text { Tenente-coronel }}$ & Sim \\
\hline 16 & $\begin{array}{l}\text { Antonio de Pádua de } \\
\text { Gusmão }\end{array}$ & ant. $1816 / 04 / 20$ & $\begin{array}{l}\text { 1. Ajudante Reg. } \\
\text { dos Úteis }\end{array}$ & $\underline{\text { Sargento-mor }}$ & Sim \\
\hline 17 & Manoel dos Santos Lima & ant. $1817 / 03 / 16$ & $\begin{array}{l}\text { 2. Ajudante Reg. } \\
\text { dos Úteis }\end{array}$ & 1. Ajudante & Sim \\
\hline 18 & $\begin{array}{l}\text { Antonio de Pádua de } \\
\text { Gusmão }\end{array}$ & $1818 / 07 / 11$ & $\begin{array}{l}\text { Sargento-mor Reg. } \\
\text { dos Úteis }\end{array}$ & $\underline{\text { Tenente-coronel }}$ & Sim \\
\hline 19 & Luiz Pedroso da Silva & ant. $1818 / 10 / 24$ & $\begin{array}{c}\text { Cabo de esquadra } \\
\text { de linha }\end{array}$ & Ajudante & Não \\
\hline 20 & $\begin{array}{l}\text { José Joaquim César de } \\
\text { Cerqueira Leme }\end{array}$ & $1821 / 02 / 16$ & $\begin{array}{l}\text { Sargento-mor de } \\
\text { linha }\end{array}$ & Coronel & Sim \\
\hline 21 & Matias José da Silva & $1822 / 07 / 06$ & $\begin{array}{l}\text { Cirurgião-mor de } \\
\text { Leais Paulistanos }\end{array}$ & Cirurgião-mor & Sim \\
\hline 22 & Joaquim José da Fonseca & ant. $1822 / 08 / 27$ & Sargento de linha & Ajudante & Não \\
\hline 23 & Francisco de Lima & ant. $1822 / 08 / 20$ & Alferes de linha & Ajudante & Não \\
\hline 24 & $\begin{array}{l}\text { José Rodrigues da Silva e } \\
\text { Meneses }\end{array}$ & $\begin{array}{c}\text { 1822/11/11; ant. } \\
1825 / 09 / 30\end{array}$ & $\begin{array}{l}\text { 2. Ajudante de } 2 .^{\mathrm{a}} \\
\text { linha }\end{array}$ & 2. ${ }^{\circ}$ Ajudante & Sim \\
\hline 25 & Jerônimo Isidoro de Abreu & ant. 1822/12/04 & Capitão de linha & $\underline{\text { Sargento-mor }}$ & {$[?]$} \\
\hline 26 & $\begin{array}{l}\text { Antonio Mariano } \\
\text { Bittencourt }\end{array}$ & ant. $1822 / 12 / 06$ & Capitão de linha & Major agregado & Sim \\
\hline 27 & $\begin{array}{l}\text { João Homem Guedes } \\
\text { Portilho }\end{array}$ & ant. $1823 / 10 / 01$ & $\begin{array}{l}\text { Alferes graduado de } \\
\text { linha }\end{array}$ & Ajudante & Não \\
\hline 28 & Jerônimo Isidoro de Abreu & ant. $1826 / 06 / 27$ & $\begin{array}{l}\text { Sargento-mor de } 2 .^{\text {a }} \\
\text { linha }\end{array}$ & Tenente-coronel & Sim \\
\hline 29 & Antonio José dos Santos & $1828 / 02 / 04$ & Sargento de linha & Ajudante & Sim \\
\hline
\end{tabular}

* Sublinhados os que realmente obtiveram a promoção almejada no Regimento dos Úteis.

** Indica se o requerente pleiteou o posto explicitamente no Regimento dos Úteis ou não.

Fontes: AHU_ACL_CU_023, Cx. 26, D. 1198; AHU_ACL_CU_023, Cx. 21, D. 994; APESP, Ordem C00280, doc. 43-1-115; Ordem C00286, doc. 49-1-9; Ordem C00402, Livro 111, fls. 88v-89 e 134v-135; Ordem C00403, Livro 114, fls. 19-20, 55v, 121, 185-185v, 188v, 190 e 195v-196v; Ordem C00403, Livro 115, fls. 28v-30, 124124v, 143-143v, 241v-242, fl. s./n. ofício "N. . 42" e ofício "N. " 43"; Ordem C00405, Livro 122, fls. 4-4v, 11-13 e 19-20; Ordem C00415, Livro 157, fls. 220-220v; Ordem C00416, Livro 159, fls. 11v-12v, 21v-22 e 216-216v; Ordem C07776, Livro 327, fls. 7-7v, 58-58v, 193-193v e 294v-295; Ordem E00662, fls. 19v e 128v; Ordem E00890, fls. 51v-52v.

Ao menos vinte militares brancos aspiraram aos postos do estado-maior do Regimento dos Úteis entre os anos 1803 e 1828, alguns deles tendo sido propostos diretamente pelos governadores e capitães-generais. A maioria, contudo, demandou o acesso via requerimentos: 
uns solicitavam a promoção como uma mercê individual e outros requisitavam a admissão aos concursos - os quais somente se estabeleceram efetivamente como prática padrão do sistema de promoções na década de $1810 .{ }^{142} \mathrm{O}$ fato de que a maior parte desses aspirantes manifestava expressamente o desejo de servir no Regimento dos pardos merece algumas reflexões. Em primeiro lugar, indica claramente que a repulsa dos brancos já não dizia respeito, simplesmente, a serem alocados em um corpo militar identificado aos pardos, como ocorria em períodos mais recuados do século XVIII; se referia, antes, à possibilidade de terem que se subordinar a oficiais que descendiam de escravos e que eram modestos trabalhadores mecânicos. Por isso, como advertiu Franca e Horta, esses oficiais brancos exigiam que fossem elevados a capitães, pois desse modo tanto a graduação como o posto efetivamente ocupado na milícia seriam superiores aos dos oficiais pardos, resguardando-lhes, desse modo, a sua honra e distinção. ${ }^{143} \mathrm{Em}$ realidade, em segundo lugar, a transferência para a milícia dos pardos propiciava aos brancos uma progressão na carreira que dificilmente lograriam na tropa regular. Na tabela acima se vê que vários indivíduos ascenderam da baixa oficialidade ou da oficialidade de patente das companhias da tropa regular para o estado-maior miliciano. Alguns deles inclusive já vivenciavam - ou ao menos demandavam - uma sequência à promoção obtida na segunda linha, sendo esse o caso, por exemplo, de ajudantes que pleitearam o posto de sargento-mor.

Do ponto de vista da gestão do Estado, realocar os veteranos da tropa de linha cumpria as funções, primeiro, de imprimir uma espécie de profissionalização na milícia, que seria treinada e disciplinada por oficiais experientes, e, segundo, de atenuar as tensões referentes à competição pelos postos que se davam no universo da tropa de linha. É certo que houve uma ampliação na disponibilidade de postos a partir da intensificação da atuação militar paulista nas guerras do Sul, com o aumento das tropas e a atualização frequente das fileiras, mas, correlatamente, se verificou um acirramento da competição entre os postulantes. Ora, diante do fato cabal de que não havia vagas na oficialidade dos corpos regulares para todos os bons servidores da Monarquia, a transferência para a milícia se tornou uma opção adequada para os oficiais que buscavam progressão, mas que vislumbravam pouco espaço na primeira linha.

\footnotetext{
${ }^{142} C f$ :: APESP, Ordem C00264, doc. 32-2-43. São Paulo, 4 de maio de 1814.

${ }^{143}$ Cf:: DIHCSP, vol. 94, p. 132. São Paulo, 30 de agosto de 1804. Em 1825, um tenente branco oriundo da tropa regular e que ocupava o posto de ajudante no $3 .^{\circ}$ Batalhão miliciano - o antigo Regimento dos Úteis - requereu apenas a graduação de capitão, comprometendo-se a permanecer no posto de ajudante. A lógica do demandante foi a de evitar pleitear uma mudança mais substantiva no topo da cadeia hierárquica do Batalhão, e por isso mesmo mais dispendiosa e menos factível, e focar em algo avaliado como tangível, uma vez que essa mercê seria suficiente para equiparar a sua dignidade à de um tenente-coronel pardo que servia na mesma corporação - não obstante essa intenção não tenha sido mencionada no requerimento. APESP, Ordem C07776, Livro 327, fls. 193-193v. São Paulo, 30 de setembro de 1825 .
} 
Do outro lado, também os pardos de São Paulo lutaram pelo acesso a esses postos, como o fizeram os demais milicianos pardos e pretos luso-brasileiros entre os séculos XVII e XIX. Mas a verdade é que foram poucos os que ousaram enfrentar a dura competição com os oficiais brancos da tropa regular, medindo forças com eles, expondo os seus serviços militares e submetendo os seus merecimentos à comparação pública em relação aos rivais. Como se depreende do exame ao quadro 6.2, embora tenham sido encaminhados diversos requerimentos ao governo de São Paulo e à Corte solicitando-se postos e graduações superiores, essas demandas estavam associadas a apenas cinco milicianos pardos. Para ser exato, um número maior de homens pardos ocuparam postos no estado-maior do Regimento dos Úteis. Mas tratase de quartéis-mestres, secretários e tambores-mores, os quais eram responsáveis, respectivamente, pela guarda e distribuição de armas, escrita de documentos referentes ao Regimento e adestramento e comando dos seus tambores, pífanos e clarins. ${ }^{144}$ Uma vez que a natureza dessas funções não adquiria o mesmo prestígio ou o mesmo potencial de comando que os postos de capitão, ajudante, sargento-mor, tenente-coronel e coronel, elas não eram disputadas por oficiais brancos e nem mesmo pelos milicianos pardos que se sobressaíam em meio a oficialidade. A competição que merece destaque aqui, portanto, é a dos postos de ajudante para cima.

A pequena representatividade dos pardos na disputa pelos postos contrasta com a elevada participação dos militares brancos e constitui um problema instigante. Uma parte da explicação para esse fato certamente repousa nas características da formação do grupo social dos pardos livres e libertos na capitania de São Paulo e de seu corpo militar mais notável. Essas pessoas livres e pobres abundavam na região desde o século XVII, mas a percepção de que os mestiços de índios, negros, brancos e daí por diante constituíam um grupo - o dos pardos - era recente, uma construção do Setecentos. Nessa linha, a experiência dos milicianos pardos de São Paulo também remontava a um período histórico mais avançado, e a criação do Regimento dos Úteis representou a primeira vivência desses homens armados em corporação mais complexa do que as companhias. Correlatamente, a mobilização que marcou a configuração do regimento dos pardos - decidindo-se o seu nome e as suas funções - consistiu em um primeiro ensaio de construção de sua identidade e coesão coletivas. No período imediato de formação daquela corporação, os pardos paulistas não dispunham de suficiente experiência militar e, principalmente, acúmulo de poder para almejarem os postos superiores, que, aliás, já eram visados por oficiais veteranos da tropa paga. Não é por acaso que o comando do Regimento

${ }^{144}$ Cf.: Livro Mestre, fls. 6-7 e 10. 
tenha sido confiado a um tenente-coronel branco, e não ao então capitão Manoel José Ribeiro, o oficial pardo responsável pelo recrutamento dos milicianos e formação das companhias que deram vida aos Úteis. ${ }^{145}$

\section{Quadro 6.2 - Milicianos pardos que pleitearam postos no estado-maior do Regimento dos Úteis (1798-1830)}

\begin{tabular}{|c|c|c|c|c|}
\hline N. ${ }^{\circ}$ & Nome & $\begin{array}{c}\text { Data do } \\
\text { requerimento }\end{array}$ & Posto atual & Posto pretendido* \\
\hline 1 & Manoel José Ribeiro & ant. 1798/06/19 & Capitão & $\frac{\text { Capitão graduado }}{\text { tenente-coronel }}$ \\
\hline 2 & Manoel José Ribeiro & ant. $1810 / 08 / 21$ & $\begin{array}{l}\text { Capitão graduado } \\
\text { tenente-coronel }\end{array}$ & $\frac{\text { Tenente-coronel }}{\text { efetivo }}$ \\
\hline 3 & Manoel José da Costa Ribeiro & $1813 / 06 / 25$ & Capitão & Sargento-mor \\
\hline 4 & Manoel José Ribeiro & ant. $1814 / 09 / 26$ & $\begin{array}{l}\text { Tenente-coronel } \\
\text { graduado coronel }\end{array}$ & $\underline{\text { Coronel efetivo }}$ \\
\hline 5 & $\begin{array}{l}\text { Antonio Joaquim da Costa } \\
\text { Ribeiro }\end{array}$ & ant. $1814 / 10 / 01$ & Alferes & 2. ${ }^{\circ}$ Ajudante \\
\hline 6 & Manoel José da Costa Ribeiro & ant. $1814 / 12 / 10$ & Capitão & Tenente-coronel \\
\hline 7 & $\begin{array}{l}\text { Manoel José Ribeiro e } \\
\text { Manoel José da Costa Ribeiro }\end{array}$ & ant. $1815 / 04 / 21$ & Capitão & $\frac{\text { Sargento-mor }}{\text { graduado }}$ \\
\hline 8 & Manoel José da Costa Ribeiro & ant. $1816 / 01 / 23$ & $\begin{array}{l}\text { Sargento-mor } \\
\text { graduado }\end{array}$ & Sargento-mor efetivo \\
\hline 9 & Manoel José da Costa Ribeiro & ant. $1818 / 07 / 25$ & $\begin{array}{l}\text { Sargento-mor } \\
\text { graduado }\end{array}$ & $\frac{\text { Sargento-mor }}{\text { agregado }}$ \\
\hline 10 & $\begin{array}{l}\text { Antonio Joaquim da Costa } \\
\text { Ribeiro }\end{array}$ & ant. $1824 / 06 / 21$ & Capitão & Capitão de $1 .{ }^{\mathrm{a}}$ Linha \\
\hline 11 & $\begin{array}{l}\text { Antonio Joaquim da Costa } \\
\text { Ribeiro }\end{array}$ & ant. $1824 / 09 / 10$ & Capitão & $\frac{\text { Sargento-mor }}{\text { graduado }}$ \\
\hline 12 & Manoel José da Costa Ribeiro & ant. 1826/03/02 & $\begin{array}{l}\text { Sargento-mor } \\
\quad \text { efetivo }\end{array}$ & $\frac{\text { Tenente-coronel }}{\underline{\text { efetivo }}}$ \\
\hline 13 & Joaquim José Teodoro & [1825] & Alferes & $1 .^{\circ}$ ou $2 .^{\circ}$ Ajudante \\
\hline 14 & José Manoel da Costa Ribeiro & $\begin{array}{l}\text { ant. 1824/06/21; ant. } \\
1830 / 09 / 22\end{array}$ & Capitão & $\begin{array}{r}\text { Graduação de major } \\
\text { (sargento-mor) }\end{array}$ \\
\hline
\end{tabular}

* Sublinhados os que realmente obtiveram a promoção almejada no Regimento dos Úteis.

Fontes: AN, Registro Geral das Mercês, Cód. 137, Livro 12, fl. 77; APESP, Ordem C00286, doc. 49-1-1a; Ordem C00407, Livro 130, fls. 73v-74; Ordem C00416, Livro 159, fls. 160v-161, 189-190, 200, 201v-202, 217-218v; Ordem C00416, Livro 160, sem paginação; Ordem C00438, Livro 223; fls. 20v-21; Ordem C00439, Livro 226, sem paginação; Ordem C07776, Livro 327, fls. 252-253; Ordem E00891, fls. 68v-69, 82-82v, 91v-92; AHEx, requerimento de José Manoel da Costa Ribeiro, J-109-3252.

${ }^{145}$ Sobre o processo de criação do Regimento dos Úteis, ver capítulo 3. 
A elevação dos pardos na hierarquia da corporação foi gradual. No começo, os brancos monopolizavam os postos superiores, mas, na medida em que o tempo foi passando e os pardos foram se fortalecendo como grupo e acumulando experiências na milícia (tempo de serviço e conhecimentos técnicos), a desigualdade da competição diminuiu. Tornou-se viável a alguns dos milicianos pardos pleitearem aos postos em condições mais ou menos equivalentes às dos brancos da tropa regular. Além dos requerimentos individuais visando ao acesso aos postos, houve ações coletivas resultantes da mobilização da oficialidade parda. Esses movimentos, situados no tempo, revelam transformações nos níveis de coesão e no potencial competitivo dos pardos de São Paulo.

Se se considera a reunião dos pardos para a deliberação da formatação do Regimento dos Úteis, em 1797, como um primeiro movimento coletivo, a segunda dessas mobilizações diz respeito a um requerimento enviado à Corte pelos "oficiais e oficiais inferiores do Regimento dos Úteis", em 1808, queixando-se "do abatimento" em que se achavam durante a administração de Franca e Horta. Esse era o governador que suspendeu as promoções e projetou, em um primeiro momento, a substituição da oficialidade parda por militares brancos e, em uma segunda etapa, a abolição daquele Regimento. Especificamente, os milicianos pardos questionaram os motivos pelos quais os efetivos da corporação estavam reduzidos à metade de sua lotação original e também denunciaram o fato de que o governador lhes negava o acesso aos postos, "pondo em abandono o Alvará de 17 de dezembro de 1802, em que manda dar preferência aos oficiais das suas próprias cores, para pôr oficiais brancos no Regimento". ${ }^{146}$ Cumpre notar o impacto da instalação da Corte no Brasil na trajetória da milícia parda. No que concerne ao objeto específico em tela, a proximidade geográfica em relação ao centro do poder soberano estimulou aos pardos de São Paulo a exporem prontamente ao rei a situação daquela corporação miliciana.

Esse requerimento de 1808 marca uma etapa importante na organização política dos milicianos. Nessa ocasião eles se apresentaram como grupo coeso e, pela primeira vez, enfrentaram explicitamente as adversidades inerentes à relação tensa estabelecida com o grupo superior da sociedade paulista - personificada no governador Franca e Horta e exemplificada pela intromissão da oficialidade branca no Regimento - e demandaram um posicionamento régio para as questões prioritárias. Eram elas a manutenção da corporação e o acesso aos postos de patente das companhias. Como visto anteriormente, os milicianos foram atendidos: o plano de extinguir o Regimento foi rechaçado, ordenou-se a elaboração de uma proposta para o

${ }^{146} C f:$ APESP, Ordem C00405, Livro 122, fl. 25. Rio de Janeiro, 5 de setembro de 1808. 
provimento dos postos e também a admissão dos pardos, ainda que se tratasse de humildes oficiais mecânicos. A terceira manifestação dos pardos foi além, pois, em 1813, quinze oficiais de patente subscreveram um abaixo-assinado enviado à Coroa no qual solicitavam que o posto de sargento-mor do Regimento fosse provido em um pardo, o capitão Manoel José da Costa Ribeiro, filho do coronel pardo há pouco empossado, e não em um branco, como até então ocorria. A agressividade inscrita na retórica dos pardos revela a intensidade que a competição assumiu nas décadas de 1810 e 1820. Conforme os oficiais milicianos, "os majores de Tropa de Linha não servem melhor e nem com maior gosto e satisfação a S.A.R. do que este" - o capitão Ribeiro - "nem menos o Regimento faz tanto gosto servir como com este, por ser da própria cor, e não vivermos no total abatimento em que temos vivido". ${ }^{147}$ Essa nova circunstância expôs um grau ainda mais elevado de coesão entre os pardos, os quais se perceberam capazes de lutar abertamente pelos postos superiores após mais de quinze anos de vigência de uma hegemonia inconteste a favor dos brancos.

Embora seja evidente o processo de concentração de poder interno aos oficiais pardos, permanece o dado concreto de que apenas cinco deles ousaram disputar com os brancos os postos de ajudante, sargento-mor, tenente-coronel e coronel do Regimento. Dois desses postulantes pardos surgiram em ocasiões isoladas, na década de 1820, e sem obterem sucesso: Joaquim José Teodoro e José Manoel da Costa Ribeiro. Esse último fazia parte da família Ribeiro, a mesma dos três oficiais pardos que mais insistentemente demandaram acesso aos postos e graduações no curto período de existência da corporação (ver quadro 6.2). Eram eles Manoel José Ribeiro, seu pai e patriarca da família, Manoel José da Costa Ribeiro, seu irmão mais velho, e Antonio Joaquim da Costa Ribeiro, seu sobrinho e neto do patriarca Ribeiro. Isso significa que se formou em São Paulo um grupo diminuto de milicianos de cor dispostos a concorrer com os militares da tropa regular pelos postos, e que a base desse grupo correspondia a uma única família. Não se pode deixar de notar o enorme potencial de concentração de poder no âmbito desse núcleo familiar, evidenciado pelos postos, não apenas demandados, mas ocupados por seus integrantes. O patriarca alcançou a patente máxima, a de coronel. Seu filho primogênito tornou-se tenente-coronel e o caçula, que chegou a pleitear a graduação de sargento-mor, permaneceu como capitão. Já o neto conseguiu progredir até sargento-mor.

Para os oficiais brancos, a migração da tropa regular para a milícia funcionava como um trampolim alavancando as suas carreiras militares. Já para os pardos, o significado do acesso aos postos superiores do Regimento obviamente também passava pela aquisição de prestígio e

\footnotetext{
${ }^{147} C f$ : : APESP, Ordem C00416, Livro 160, sem paginação. Rio de Janeiro, em 20 de setembro de 1813.
} 
graus de nobreza inerentes a tão elevadas funções sociais, mas adquiria conotações específicas, que ultrapassavam a questão da ascensão social individual. Implicava manter o controle da corporação entre os próprios pardos, aspecto que contribuía para a legitimação do exercício de autoridade e liderança sobre uma vasta cadeia de pessoas que, afinal, tinham uma experiência social em muitos sentidos próxima à deles. Em outros termos, os oficiais pardos investidos nos postos superiores se distinguiam notavelmente dos seus pares, mas igualmente consolidavam a sua influência junto ao vasto grupo dos pardos livres e libertos, estendendo seus tentáculos às centenas de subordinados na milícia bem como, informalmente, aos familiares, amigos e vizinhos desses.

Como explicar a convergência dessa significativa concentração de poder em uma única família parda? O ponto de partida é a posição de líder militar ocupada pelo patriarca Manoel José Ribeiro em meio aos pardos de São Paulo. Ribeiro possuía experiência na tropa regular, onde fora soldado e fizera a campanha contra os espanhóis na década de 1770. Isso lhe valeu o acesso imediato ao posto de capitão quando as primeiras companhias de pardos foram formadas na cidade de São Paulo, entre fins da década de 1780 e começos dos anos 90, e um papel decisivo na formação do Regimento dos Úteis, em 1797. Sua dedicação e sua influência garantiram o respeito de governadores e de oficiais brancos. O segundo aspecto diz respeito à ascensão de Ribeiro ao posto de coronel, na década de 1810, às expectativas das demais lideranças pardas relativamente à milícia e ao arranjo de poder estabelecido entre esses integrantes. Ora, ao penetrar um espaço até então monopolizado pelos brancos, Manoel José Ribeiro não apenas expandiu o campo de possibilidades aos milicianos pardos, mas passou a coordenar o sistema de promoções intrínseco ao Regimento, um mecanismo chave na definição do seu equilíbrio de poder interno. Isso significava que ele tinha em mãos o poder de elaborar as propostas para os postos vagos, indicar os nomes de sua preferência e formar um vigoroso grupo de aliados. Não demorou para a família se beneficiar de sua posição: os filhos e o neto de Ribeiro encontraram facilidades para ascenderem na hierarquia e é elucidativo o exemplo acima evocado do primogênito Manoel José da Costa Ribeiro, que conseguiu mobilizar quase toda a oficialidade parda em seu favor no pleito com os brancos pelo posto de sargento-mor. Em terceiro lugar, os demais oficiais pardos nutriam pouco interesse pelos postos do estadomaior, preocupando-se mais em assegurar as suas posições de mando no âmbito das companhias. Em 1817, por exemplo, o coronel Ribeiro informou ao inspetor geral de milícias que, após anunciar a abertura de concurso para o posto de ajudante da corporação, os tenentes e alferes pardos unanimemente "responderam que não queriam" participar, "pois não estão nas 
circunstâncias de passarem por esse incômodo". ${ }^{148} \mathrm{O}$ ofício não revela quais seriam esses "incômodos", mas pode presumir-se que se tratava de uma constelação de fatores entrelaçados, dentre os quais as coerções atreladas à competição travada com oficiais brancos, os constrangimentos decorrentes da modesta condição socioeconômica dos artesãos pardos e as obrigações inerentes ao exercício do posto em questão - o qual, na ocasião, foi mais uma vez ocupado por um militar oriundo da tropa regular.

O resultado objetivo desse jogo no qual a milícia parda estava envolvida pode ser sintetizado em poucas palavras. O Regimento dos Úteis foi formado com um estado-maior integralmente dominado pelos militares brancos egressos da tropa regular. Nesse período inicial, o capitão pardo Manoel José Ribeiro obteve a graduação de tenente-coronel, mas sua expressão na milícia permaneceu restrita ao comando de uma companhia. Os postos vacantes não foram preenchidos durante boa parte da primeira década do século XIX, mas, assim que foram elaboradas propostas e abertos os concursos, vários oficiais brancos pleitearam os postos do Regimento. Na década de 1810, os pardos entraram em cena com mais força, e pela primeira vez conseguiram romper as barreiras impostas por governadores, oficiais militares de alto escalão e oficiais da tropa regular, vindo a alcançar postos do estado-maior. Eram membros de uma mesma família - cujas origens estavam vinculadas à escravidão e ao trabalho manual que aceitaram o desafio e competiram arduamente com os oficiais brancos ao longo de dois decênios, até a extinção das milícias brasileiras.

A chegada dos pardos às funções superiores da milícia não encerra a questão. $\mathrm{Na}$ realidade, esse aspecto inflamou o campo de embates existente em São Paulo que envolvia militares brancos e milicianos pardos, para o que também concorreram os fenômenos históricos referentes à instalação da Corte portuguesa no Brasil, às campanhas militares sulinas, à revolução constitucionalista e à independência. É nesse intervalo de tempo, entre 1810 e 1822, que os projetos de reforma mais consistentes são apresentados, que se avolumam os pleiteantes brancos e que os pardos se apresentam mais coesamente. Portanto, é da maior relevância examinar a trama dessa história, a estrutura da competição, os movimentos de um e de outro lado, as pressões e coerções recíprocas. Esse processo social deu vida a um debate sobre o papel da cor na estruturação das relações sociais, da vinculação dos súditos com o soberano, bem como sobre os critérios elementares que deviam subsidiar o sistema de progressões militares daí em diante.

${ }^{148} C f:$ : APESP, Ordem C00286, doc. 49-1-9. São Paulo, 26 de março de 1817. 
Em todo o Brasil, governadores e oficiais militares de alto escalão defendiam que o comando dos regimentos de cor fosse confiado a militares brancos. Como demonstrado, a publicação do Alvará de 1802 consolidou o ideário em torno da noção de honra como o principal argumento dos opositores àquelas milícias. ${ }^{149}$ Esses entendiam que somente os brancos eram capazes de se manterem "decentemente" nos postos, assegurando a sua autoridade e prestígio; e, inversamente, que os pardos e pretos, egressos da escravidão e fincados no universo artesanal, eram incapazes de viver à lei da nobreza. Cabe examinar a argumentação mobilizada pelos próprios competidores.

Os militares brancos da tropa regular que se voltaram para a milícia, ambicionado os postos do estado-maior, demandavam remuneração especialmente em função de longo tempo de serviço e de idade avançada, e complementavam os requerimentos com certidões e atestações de bom comportamento, serviços relevantes e tradição familiar. Ademais, o envolvimento paulista nas guerras do Sul do Brasil possibilitou que esses militares passassem a agregar nos requerimentos a sua participação em campanhas específicas como meio de obterem a mercê pretendida. ${ }^{150}$ Já os oficiais pardos que ansiavam por escalar a hierarquia superior do Regimento dos Úteis, por seu turno, fundamentavam o seu pleito especialmente nos bons serviços prestados no espaço da capitania/província enquanto supriam a falta da tropa regular enviada para as guerras no Sul. Eles, igualmente, não deixavam de buscar resguardo nas disposições régias que lhes concederam preferência no acesso aos postos. ${ }^{151} \mathrm{O}$ Alvará de 1802 figurou no centro do debate, mas a verdade é que os brancos empregaram com parcialidade a seu favor, valendo-se do amplo espaço para interpretação que essa peça deixou.

O requerimento de José Joaquim Mariano da Silva César, um oficial branco egresso da tropa regular que solicitou a efetividade do posto de coronel do Regimento, previamente ocupado por ele via comissão, exemplifica adequadamente o modo pelo qual os demais militares brancos empregaram os termos do Alvará de 1802 para fundamentarem o acesso aos postos do regimento dos pardos de São Paulo. Na ocasião, em 1803, Silva César argumentou que fora nomeado para comandar o Regimento dos Úteis após o falecimento do seu primeiro coronel, por "ser conforme as reais ordens [...] que se provam semelhantes corpos de chefes

\footnotetext{
${ }^{149}$ Mas a relação entre honra e riqueza não afetou somente os milicianos pardos e pretos. Vários candidatos brancos a postos de patente dos mais diversos regimentos foram preteridos em função dessa cláusula específica do Alvará de 1802. Ver APESP, Ordem C07776, Livro 328, ofício “N. ' 25”, fls. 35-36v. São Paulo, 11 de agosto de 1827; Idem, fls. sem paginação. São Paulo, 12 de março de 1828.

150 São os casos de Manoel dos Santos Lima, Domingos Velho da Silva, Luiz Pedroso da Silva, José Joaquim César de Cerqueira Leme, Joaquim José da Fonseca e Jerônimo Isidoro de Abreu. Ver também a folha de serviço dos oficiais brancos que serviram no Regimento dos Úteis em Livro Mestre, fls. 1-5v.

${ }^{151}$ Ver os requerimentos listados nos quadros 6.1 e 6.2 .
} 
tirados da tropa paga, como V.A.R. ultimamente se dignou mandar estabelecer para todos os seus domínios ultramarinos pelo Alvará de 17 de dezembro de 1802”. Contudo, como o recémchegado governador Franca e Horta (1802-1808) cancelou as comissões passadas pelo antecessor, o requerente foi obrigado "a deixar o posto de coronel, a que tinha o mais incontestável direito". Por isso, pedia que fosse restituído ao posto. ${ }^{152}$

Surpreendentemente, os ministros do Conselho Ultramarino, que por esses mesmos anos deliberavam favoravelmente às demandas dos milicianos pardos da Bahia que estimularam a formulação dos parágrafos especiais do referido Alvará, anuíram à pretensão do militar branco que desejava chefiar um corpo militar análogo. Assim, eles consideraram justo que se fizesse “a graça de o nomear coronel do Regimento dos Úteis da cidade de São Paulo, com o soldo de capitão de infantaria que lhe compete na forma do Alvará pelo qual V.A.R. houve por bem regular as promoções dos Corpos Milicianos do Brasil". ${ }^{153} \mathrm{O}$ fato de o requerente ocultar que se tratava de um regimento de pardos configura uma das possíveis razões para que, na ocasião, os ministros, desavisados, adotassem uma postura contraditória em relação a oficialidade dos regimentos milicianos de pardos e de pretos e desconsiderassem por completo as cláusulas específicas da legislação. Ironicamente, a decisão da oficialidade parda em suprimir a tradicional referência à cor de seus integrantes do nome do Regimento e optar por positivar a sua utilidade militar, em um ato inédito entre as milícias correlatas, se voltou contrariamente às pretensões de seus membros e favoreceu aos competidores brancos. ${ }^{154}$

Já dentre os competidores pardos, destacavam-se os integrantes da família Ribeiro, os quais pleitearam assiduamente os postos superiores do Regimento. Eles jamais puderam ser acusados de incorrer nas incapacidades apontadas pelo parágrafo XIX do Alvará de 1802, que condicionou a obtenção de patentes militares à posse de níveis suficientes de riqueza, pois faziam parte do segmento economicamente mais próspero do grupo dos pardos livres paulistas. ${ }^{155}$ Se o emprego que os brancos faziam do alvará em questão deixava de lado os parágrafos XVI e XVII, os requerimentos dos pardos confluíam exatamente para esse ponto. $\mathrm{O}$ requerimento de Antonio Joaquim da Costa Ribeiro, pelo qual suplicou ser promovido ao posto vago de 2. ${ }^{\circ}$ ajudante do Regimento, revela o teor mais geral da argumentação dos pardos. Ele inicia com a informação do tempo de serviço, que na ocasião contava cinco anos, e da trajetória na hierarquia: de soldado voluntário passou a porta-bandeira e em seguida a alferes, exercendo

\footnotetext{
152 Cf:: AHU_ACL_CU_023, Cx. 26, D. 1198. São Paulo, ant. a 9 de dezembro de 1803.

${ }^{153}$ Cf:: AHU_ACL_CU_023, Cx. 26, D. 1198. Lisboa, 23 de setembro de 1805.

${ }^{154}$ Sobre o processo de formação do Regimento dos Úteis e os significados desse nome, ver capítulo 3.

155 Veja-se o capítulo 5.
} 
ainda, interinamente, o posto de ajudante que afinal demandava. Um terceiro ponto é a alegação de ter prestado bons serviços ao soberano, "sempre com decente comportamento e aplicação nas suas obrigações". Em seguida, lembrou dos termos presentes no Alvará de 1802, conforme os quais "os homens pardos, nos seus respectivos Corpos, preferirão nos postos que fossem vagando quando dessem bastantes provas da sua conduta e inteligência militar". A cereja do bolo ficou por conta da alusão à origem familiar e à herança que, segundo considerava, lhe era devida. Antonio Joaquim da Costa Ribeiro esclareceu que era "neto do coronel graduado do Regimento [...] e legítimo filho e herdeiro dos serviços de Antonio Moreira, que serviu mais de 24 anos a V.A. nas Tropas de Linha, em serviço ativo e em campanha, tanto no Rio Grande como em Santa Catarina, na guerra de 1776”. Em função dos itens alegados, ele reputava-se “em circunstâncias próprias de merecer de V.A.R. a graça de promovê-lo ao referido posto de 2. ${ }^{\circ}$ ajudante". 156

Em geral, a formulação dos requerimentos, uma das principais armas na luta pelos postos, obedecia a padrões e a normas não declaradas formalmente. Como se percebe, havia a tendência de que cada qual buscasse valorizar ao máximo os seus serviços e méritos e ao mesmo tempo extorquir da letra da lei e de antecedentes da prática governamental tudo aquilo que lhes fosse favorável. Vigia uma espécie de regra moral que impedia que os oponentes se referissem uns aos outros, estabelecessem comparações e se detratassem mutuamente nas instâncias formais da competição. A avaliação justa e isenta cabia apenas ao rei e aos seus delegados. Contudo, o acirramento das tensões levou alguns jogadores a ousarem ultrapassar esses limites em certas ocasiões.

José da Silva Lisboa, um ajudante lotado em uma milícia branca com passagem pela tropa regular, solicitou em 1811 o posto de sargento-mor, vago no $2 .^{\circ}$ Regimento e no dos Úteis. Ele buscou amparo numa cláusula do Alvará de 1802 que permitia que oficiais da milícia concorressem aos postos excepcionalmente, mas, como era de praxe entre os brancos, omitiu o conteúdo dos parágrafos específicos para as milícias pardas e pretas. Mesmo assim, ele forneceu pistas sobre o problema social da convivência de oficiais pardos e brancos em uma mesma corporação. Conforme informou, um sargento-mor branco dos Úteis obteve progressão para tenente-coronel, deixando o posto vago, após a ascensão de Manoel José Ribeiro ao exercício do coronelato do Regimento, mas "passou a dar parte de doente" a fim de "não ficar servindo debaixo do comando" daquele. Lisboa não explicitou tratar-se da relação entre brancos e pardos; porém, com esse exemplo, construiu um contraponto a seu favor. Afirmou que "deseja

${ }^{156}$ Cf:: APESP, Ordem C00416, Livro 159, fls. 191-191v. Rio de Janeiro, 1. o de outubro de 1814. 
servir no referido Regimento de Úteis, [...] que todos os mais desprezam, acrescendo mais o ter-se já achado na Campanha" com Ribeiro. ${ }^{157}$ Nesse caso específico, o suplicante mencionou um oficial de linha desgostoso de servir no Regimento e também o novo comandante, com quem tinha afinidade e se dispunha a obedecer.

A harmonia que o veterano José da Silva Lisboa garantiu manter com o comandante pardo somente era possível em uma situação em que o equilíbrio de poder interno à corporação pendesse favoravelmente aos pardos, como era aquele. Apesar das duras investidas de governadores e do inspetor de milícias, a Coroa sustentou o Regimento dos Úteis e a sua oficialidade parda e artesã na década de 1810. Todavia, a década de 1820 assistiu a uma mudança no campo de forças que reincentivou as manifestações hostis aos pardos. As campanhas sulinas recentes deram vazão às demandas dos militares da tropa regular, os quais exigiam, como recompensa, a obtenção de progressão na milícia. Nesse contexto o Regimento passou para o comando de um coronel branco e vários militares pagos pleitearam os seus postos superiores. Esse é o caso de Jerônimo Isidoro de Abreu, que serviu por mais de 24 anos na primeira linha, até o posto de capitão, "sendo a maior parte deste serviço empregado desde o princípio da conquista da província Cisplatina, onde foi efetivo nas campanhas do Exército Pacificador, bem como nas que tiveram princípio desde o ano de 1816 até o de 1822 ”. Nesse ano, foi despachado em sargento-mor dos Úteis. A promoção, no entanto, não agradou completamente esse oficial veterano, justamente pelo fato de ele ser alocado em posição inferior a um pardo. Por isso, requereu entre 1825 e 1826 "a graça da graduação do posto de tenentecoronel, a fim de lhe ser mais suave servir no dito Regimento, onde o tenente-coronel efetivo" - o filho primogênito do já antigo coronel Ribeiro - "não só não tem os serviços do suplicante, como é inteiramente miliciano". ${ }^{158}$ Em outros termos, o militar branco almejava conseguir a mesma graduação do tenente-coronel pardo mencionado em sentido desabonador, o que já servia para isentá-lo da submissão ao superior, não obstante permanecesse desempenhando uma função inferior.

A legislação que regulava as promoções foi sensível ao fato de que pardos e pretos não eram admitidos como oficiais na tropa regular, e, portanto, reconhecia que eles estavam isentos da exigência de serviço prévio na primeira linha que normalmente se fazia para os postulantes aos postos superiores da milícia. Desse modo, não havia qualquer demérito ao tenente-coronel pardo cuja trajetória de serviços se dera na milícia. A despeito disso, como se observa, na prática não há novidade no ocultamento do fato de que se tratava de um corpo militar destinado aos

\footnotetext{
${ }^{157}$ Cf:: APESP, Ordem C00416, Livro 159, fls. 11v-12v. Rio de Janeiro, 28 de fevereiro de 1811.

${ }^{158} C f$ : : APESP, Ordem C07776, Livro 327, fls. 294v-295. São Paulo, 1. o de julho de 1826.
} 
pardos e tampouco na interpretação parcial do Alvará de 1802. Não surpreende, igualmente, que a demanda examinada acima recebesse o amparo do coronel branco do Regimento, também oriundo da tropa regular, e que Jerônimo Isidoro de Abreu não fosse admoestado por menosprezar os serviços militares e os méritos de um superior. ${ }^{159}$ É preciso notar, contudo, que o contrário não se verifica, pois em todas as circunstâncias em que os pardos atreveram-se a estabelecer comparações com os brancos em defesa de suas prerrogativas eles receberam fortes censuras. Ora, as regras desse jogo desigual buscavam, no fim das contas, a preservação do equilíbrio de poder favorável aos estabelecidos, e qualquer movimento dos outsiders em sentido contrário deveria ser duramente reprimido.

É o que ocorreu com a oficialidade parda que subscreveu, em 1813, um abaixo-assinado analisado atrás, no qual solicitaram que o pardo Manoel José da Costa Ribeiro fosse elevado ao posto de sargento-mor. A manifestação foi classificada como uma "ousadia" por dois motivos: em primeiro lugar, por não ser permitido "aos indivíduos de qualquer Corpo pedirem ao seu soberano a nomeação dos oficiais que nele devem servir", e, em segundo, "por pretenderem macular indistintamente a reputação de todos os majores brancos que têm servido no sobredito Regimento, declarando, vaga e incompetentemente, que eles não têm cumprido as suas funções com aquela honra e exação com que o deveriam fazer". Cuidou-se em resguardar a Coroa de pressões coletivas provenientes das corporações assim como em impedir que a posição dos oficiais brancos na milícia parda fosse desautorizada. Em virtude dessas considerações, o ministro interino da Guerra, Conde das Galveias, mandou repreender a todos aqueles oficiais pardos em nome do rei. ${ }^{160}$

Na década seguinte, as demandas do capitão pardo Antonio Joaquim da Costa Ribeiro provocaram grande agitação entre os militares paulistas. Com efeito, entre os anos de 1824 e 1826 ele requereu e obteve do imperador a graça da graduação de sargento-mor, mas com a ressalva de que os capitães mais antigos não seriam prejudicados. Desse modo, Ribeiro disporia da graduação mas permaneceria no posto de capitão, além de ter que respeitar a prioridade devida aos capitães mais antigos nos concursos para o posto de sargento-mor. Insatisfeito com a restrição, ele voltou à carga, argumentando que merecia integralmente a graça solicitada em função dos seus serviços e os de seu falecido pai, acrescentando, ainda, comparações aos demais capitães. Em primeiro lugar, conforme seus termos, os capitães mais antigos lotados no Regimento "não ocuparam, como o suplicante, todos os postos de subalternos"; em segundo

${ }^{159}$ C07776, Livro 327, fls. 294v-295. São Paulo, 1. ${ }^{\circ}$ de julho de 1826.

${ }^{160} C f$ :: APESP, Ordem C00416, Livro 159, fls. 160v-161 e 166v-167 e Ordem C00416, Livro 160, sem paginação. Rio de Janeiro, 20 de setembro de 1813. 
lugar, quanto à relevância do serviço prestado por uns e outros, "pesados que sejam na balança da justiça os do suplicante com os de cada um desses capitães, jamais poderão entrar em competência com o mesmo suplicante". Finalmente, e em terceiro lugar, formulou ser conforme as intenções soberanas que "o merecimento e distintos serviços prefiram e sempre prevaleçam às simples antiguidades". 161

Ocorre que o posto de sargento-mor era objeto de disputa não apenas entre os capitães pardos - os quais, aliás, sequer contestaram as alegações de Ribeiro e jamais pleitearam efetivamente o acesso àquela função - já que a competição incluía os oficiais advindos da tropa regular e igualmente oficiais milicianos, que desde a década de 1810 pressionavam para serem regularmente admitidos aos concursos. ${ }^{162}$ Portanto, a postura relativamente agressiva do sargento-mor branco Jerônimo Isidoro de Abreu - colocando em menoscabo a posição do tenente-coronel formado na milícia e, mesmo sem o mencionar claramente, sugerindo sentir-se inferiorizado por ter que se subordinar a um pardo -, vista acima, de modo algum se configura extemporânea. A década de 1820 assistiu a uma exasperação na competição pelos postos da milícia parda: enquanto ampliava-se o número dos oficiais brancos da tropa regular que regressavam da guerra sedentos por honrarias e acessos, também os integrantes da família Ribeiro acumulavam experiência na milícia, tempo de serviço e ocasiões de distinção.

Nesse quadro de tensões, a jogada enérgica de Antonio Joaquim da Costa Ribeiro irritou alguns capitães da milícia branca que se viram compreendidos na comparação proposta pelo pardo bem como prejudicados caso a demanda lograsse êxito. Eles prontamente reagiram, enviando um requerimento ao governo da província no qual consideraram a pressão exercida por Ribeiro como uma "obstinação" devida unicamente a "uma ambição sem limites e a um orgulho pueril", por cuja razão suplicaram que o imperador indeferisse a pretensão em questão. O texto do requerimento consiste basicamente em um esforço visando-se à depreciação dos méritos de Ribeiro. Os capitães brancos argumentaram que os serviços militares do sargentomor pardo "pouco ou nenhum preço têm", e que sua atuação nos destacamentos da cidade resultava somente do seu próprio interesse em "vencer o soldo da sua patente, que não é diminuto". Antonio Joaquim da Costa Ribeiro era o miliciano pardo mais rico no final daquela década, mas ainda assim os seus adversários afirmaram que não possuía "meios alguns de subsistência". Conforme os capitães brancos, esse mesmo motivo justificaria o fato de Ribeiro

\footnotetext{
${ }^{161} C f$ : APESP, Ordem C00438, Livro 223, fls. 32-32v. São Paulo, [1825].

162 Como visto, o alvará de 1802 admitia apenas excepcionalmente oficiais da milícia branca nos concursos para os postos do estado-maior dos diversos regimentos de segunda linha. A mobilização desses oficiais pode ser vista em APESP, Ordem C00415, Livro 157, fls. 218v-219v. Rio de Janeiro, 15 de dezembro de 1810; e Ordem C00403, Livro 114, fls. 226v-227v. São Paulo, 20 de janeiro de 1816.
} 
ter se oferecido voluntariamente para marchar em expedições militares que tinham como destino a Corte do Rio de Janeiro e a capital da província Cisplatina, Montevidéu. ${ }^{163}$

O governador das armas da província foi instado a fornecer sua informação para esses requerimentos. Ele, que havia sido bastante elogioso no que se refere aos merecimentos de Ribeiro na primeira ocasião, relativizou-os nessa segunda circunstância, em meados de 1825, considerando que Ribeiro, "um oficial de merecimento, [...] só pode ser deferido particularmente ao Regimento em que serve, visto que as suas circunstâncias são superiores aos demais capitães". Entretanto, advertiu que "nunca em relação aos oficiais de outros Corpos quando concorrer com eles em serviço, em razão de terem iguais e maiores serviços, e por cujo motivo se lhes não deve fazer injustiça". ${ }^{164}$ Na sequência desses movimentos, Antonio Joaquim da Costa Ribeiro formulou um terceiro requerimento no qual pediu que a antiguidade de sua graduação fosse reconhecida desde o dia do decreto que a concedeu. O que mais importa, no entanto, é a sua atitude no confronto com a oficialidade branca. Ribeiro reiterou o argumento de que seus merecimentos eram superiores aos demais capitães pardos e alegou mais que a inclusão de oficiais brancos na sua comparação resultara de leitura equivocada ao requerimento. Mas, como havia sido atacado, resolvera responder com um contra-ataque equivalente:

Ora, não tendo sido da intenção do suplicante mencionar coisa alguma relativa
a esses oficiais, agora, com efeito, se vê obrigado a dizer expressamente que
não divisa nesses Corpos de $2{ }^{\text {a }}$ Linha da sua província quais sejam esses que
o excedam em relevantes serviços, uma vez que fossem imparcialmente
pesados na balança da justiça; pois até poucos há que o igualem [...], e mesmo
com respeito à instrução militar; os conhecimentos do suplicante em nada são
inferiores aos mais distintos oficiais dos sobreditos Corpos, o que tão
eficazmente tem patenteado à face pública. ${ }^{165}$

Os termos de um e de outro lado revelam a intensidade da competição durante o Primeiro Reinado. E nisso há um nítido contraste em relação ao contexto da década de 1800 , período em que as expressões dos milicianos pardos eram ainda modestas diante do fato de que a oficialidade branca dominava o estado-maior do Regimento e em face das humilhações que o governador Franca e Horta impunha aos oficiais pardos. Porém, encarando esses dois marcos temporais como parte de um processo, é adequado formular que os pardos estavam aprendendo a jogar o jogo. Ao Estado eles demonstravam lealdade, já aos competidores eles expunham o

163 Cf: APESP, Ordem C00438, Livro 223, fl. sem paginação. São Paulo, ant. a 10 de julho de 1825. Sobre a posição socioeconômica de Antonio Joaquim da Costa Ribeiro em relação à oficialidade parda e aos oficiais milicianos brancos da cidade de São Paulo, ver o capítulo 5.

${ }^{164} C f$ : : APESP, Ordem E00892, fl. 42v. São Paulo, 10 de julho de 1825.

${ }^{165} C f$.: APESP, Ordem E00909, fls. 44v-46. Rio de Janeiro, 16 de janeiro de 1826. 
arsenal de recursos acumulados durante décadas de experiência na milícia. As respostas dos brancos e as tréplicas dos pardos também revelam que os jogadores estavam atentos aos movimentos de seus oponentes, e que as suas jogadas eram definidas durante o curso do jogo, de acordo com o modo pelo qual as jogadas iam se sucedendo. ${ }^{166}$ Isso implicava um acesso corriqueiro por parte desses milicianos à documentação que circulava nas secretarias do governo e é desnecessário dizer que os oficiais pardos, em razão dessa experiência, tinham uma visão privilegiada dos mecanismos e instâncias institucionais, algo que, enfim, lhes fornecia uma parcela de poder na relação com os demais integrantes do universo militar.

A competição pelos postos superiores da milícia tem sido examinada a partir do conjunto dos movimentos e percepções de brancos e de pardos, sintetizados nos Quadros 6.1 e 6.2. Esses quadros revelam a participação de Antonio de Pádua de Gusmão, um branco egresso da tropa regular, e de Manoel José da Costa Ribeiro, miliciano pardo, como os jogadores mais recorrentes no período considerado. Com efeito, eles foram os sujeitos que por mais vezes demandaram postos e graduações no Regimento dos Úteis. É extremamente interessante o entrelaçamento de suas carreiras em meio à competição que se desenrolava no universo militar, envolvendo-os em um duelo particular ao longo das décadas de 1810 e 1820. Essa disputa por postos condensa muito do que foi dito anteriormente e oferece o melhor exemplo para se pensar as tensões inerentes às relações de interdependências estabelecidas na milícia entre pardos e brancos.

Em 1800, quando o pardo Manoel José da Costa Ribeiro foi matriculado no Regimento dos Úteis, Antonio de Pádua de Gusmão já servia na tropa de linha paulista havia dez anos, período que correspondia aproximadamente à idade do jovem Ribeiro. Gusmão, então sargento de linha, recebeu em 1801, no contexto de formação da oficialidade do Regimento dos Úteis, uma comissão do governo para exercer o posto de ajudante na corporação dos pardos, transferindo-se desse modo para a milícia. Entretanto, essa comissão não foi confirmada pelo Conselho Ultramarino e, em 1803 , ele retornou para a $1 .^{a}$ linha a ocupar o posto anterior de sargento, não deixando, porém, de recorrer junto a Lisboa relativamente a esse retrocesso na carreira. Ribeiro, por sua vez, alcançou uma progressão importante após seis anos de serviço na milícia, saltando do posto de soldado para o de sargento, um oficial inferior. Já Gusmão obteve parecer favorável à sua antiga demanda e, em 1809, foi admitido como 2. ${ }^{\circ}$ ajudante dos

\footnotetext{
166 Tratava-se, assim, de um processo social dotado de dinâmica própria, pouco controlável pelos indivíduos e grupos mais diretamente envolvidos. Além do referencial eliasiano recorrentemente citado, é pertinente a leitura de BOURDIEU, Pierre. A ilusão biográfica. In: AMADO, J.; FERREIRA, M. de M. (Coords.). Usos \& abusos da história oral. Rio de Janeiro: Editora da Fundação Getúlio Vargas, p. 183-191.
} 
Úteis; no ano seguinte ele requereu o posto de $1 .^{\circ}$ ajudante como indenização aos prejuízos profissionais ocasionados pelo período em que permanecera afastado do posto, mas sem sucesso. Por esse mesmo período, o então sargento Ribeiro logrou pular para o posto de capitão mediante um decreto régio, cuja mercê lhe desobrigou de servir nas funções intermediárias de alferes e tenente. Já em 1813, o pardo ambicionou o elevado posto de sargento-mor com o respaldo de toda a oficialidade de cor paulista, cujo requerimento, como se sabe, foi não apenas malogrado como também repreendido pelo governo. ${ }^{167}$

No ano seguinte, 1814, as posições ocupadas na milícia pelo pardo Manoel José da Costa Ribeiro e pelo branco Antonio de Pádua de Gusmão se aproximaram, pois esse obteve promoção para $1 .^{\circ}$ ajudante, com a graduação de capitão, e aquele, que já era capitão, demandou, mas sem sucesso, o posto de tenente-coronel. Nesse momento, ambos dispunham da mesma graduação militar e, apesar de que Gusmão já estivesse enraizado no estado-maior do Regimento, os dois se mostraram igualmente ávidos por conquistarem progressões contínuas e em ritmo acelerado. Prova disso é que, já em 1815, Ribeiro, que não teve sucesso nos pleitos pelos postos de sargento-mor e tenente-coronel, apresentou nova demanda ao rei, solicitando que fosse graduado sargento-mor. Com a graduação, efetivamente obtida, ele estava plenamente habilitado a exercer a função de sargento-mor, mas permaneceria no posto de capitão até que conseguisse o acesso via concurso, nomeação ou graça régia. Mas foi em 1816 que os seus caminhos se cruzaram definitivamente, quando, após o governo paulista publicar a abertura de concurso para o posto de sargento-mor do Regimento dos Úteis, competiram entre si na condição de candidatos. ${ }^{168}$

Mais do que uma disputa envolvendo meros indivíduos, Ribeiro e Gusmão representavam famílias, grupos e setores sociais bastante diferentes e certamente materializaram projetos concorrentes para a milícia dos pardos. O primeiro era pardo, oriundo de uma família profundamente enraizada na escravidão, miliciano, e contava com o apoio dos oficiais de sua cor e notadamente de seu pai, que ocupava o posto de coronel do Regimento dos Úteis. Em realidade oposta, o segundo era branco, de cabelos ruivos e olhos azuis, fizera carreira na infantaria da Legião paulista e integrava o grupo de militares que buscavam a ascensão na milícia após longos anos de serviço e participação em campanhas. Nesse sentido, Ribeiro consubstanciava aquilo que alguns governadores e oficiais militares de alto escalão

\footnotetext{
${ }^{167}$ As fontes primárias são as mesmas referenciadas nos Quadros 6.1 e 6.2.

168 Cf:: "Edital pelo qual mandou o Ilmo. Exmo. Snr. General pôr a Concurso o posto de sargento-mor do Regimento dos Úteis". DIHCSP, vol. 90, p. 21-22. São Paulo, 18 de janeiro de 1826. As demais fontes primárias estão referenciadas nos Quadros 6.1 e 6.2.
} 
buscavam insistentemente evitar, isto é, que os pardos assumissem o controle de seus corpos militares mediante o acesso às posições mais elevadas. Gusmão, inversamente, representava tanto a garantia da ingerência dos militares brancos na milícia parda quanto uma válvula de escape para as tensões atreladas à competição existente na tropa regular.

Desafortunadamente, os requerimentos associados ao concurso não foram localizados nos arquivos. Em compensação, dispõe-se dos comentários do governador Conde de Palma atinentes ao desempenho obtido pelos competidores nos exames teórico e prático e também concernentes à avaliação de seus merecimentos mais gerais, os quais diziam respeito ao comportamento militar e ao tempo e tipo de serviço. Essas considerações constam de um ofício enviado pelo governador de São Paulo ao ministro ocupado com os negócios da guerra, Marquês de Aguiar - título obtido por D. Fernando José de Portugal, o mesmo que promovera as polêmicas reformas no regimento dos pardos de Salvador na década de 1790, quando ocupava o cargo de governador da Bahia (1788-1800) -, no qual informou a escolha do ajudante Antonio de Pádua de Gusmão para ascender ao posto de sargento-mor. Conforme a opinião do governador, os candidatos "satisfizeram a maior parte dos quesitos dos examinadores", demonstrando até algum "desembaraço" no exame prático. O pardo Ribeiro havia obtido melhores resultados nos exames - "o sargento-mor graduado apresentou mais conhecimentos no exame teórico; e no prático, se não excedeu, ao menos igualou ao outro concorrente" -, mas os serviços de Gusmão foram considerados superiores, o que, enfim, lhe valeu a promoção. Para o governador, foram decisivos os fatos de Ribeiro nunca ter servido na tropa de linha e de ter sido recentemente agraciado com a graduação de sargento-mor, ao passo que Gusmão contava com "largos anos de serviço" nos corpos profissionais e havia marchado com sua tropa para o Rio Grande do Sul logo após a chegada da Corte ao Brasil. ${ }^{169}$

Com a ascensão de Gusmão, o estado-maior do Regimento dos Úteis assumiu a seguinte configuração em fins da década de 1810: o coronel era Manoel José Ribeiro, o tenente-coronel era José da Silva Lisboa, o sargento-mor era Antonio de Pádua de Gusmão e os ajudantes eram Manoel dos Santos Lima e Luiz Pedroso da Silva. Exceto o coronel, todos os demais eram brancos egressos da tropa paga. Caso tivesse ocorrido, a promoção de Manoel José da Costa Ribeiro significaria um relevante acréscimo nos níveis de participação dos pardos nas funções decisórias e de comando, além, é claro, de situá-lo em posição privilegiada na linha sucessória do coronelato do Regimento. A escolha do militar branco em lugar do pardo fez parte dos arranjos complexos dirigidos pelo Estado visando-se à manutenção da estabilidade dos

\footnotetext{
${ }^{169} C f$ : APESP, Ordem C00403, Livro 115, fls. 28v-30. São Paulo, 20 de abril de 1816.
} 
equilíbrios sociais, bem como se insere nitidamente nas disputas por poder travadas no âmbito local entre indivíduos, famílias e grupos. Observando os critérios e procedimentos adotados no concurso de 1816, nota-se um desprezo flagrante às cláusulas do Alvará de 1802 que favoreciam a Ribeiro. Por se tratar de um regimento de pardos, esse oficial desfrutava da preferência para ocupar o posto e estava formalmente dispensado da exigência - aplicável somente às milícias de brancos - de ter servido em tropa regular. Ademais, outros aspectos o favoreciam na disputa: possuía bens para manter-se com decência, dispunha da graduação referente ao posto pleiteado e se saíra melhor que o concorrente nos exames. Ainda assim, fora preterido sob a alegação, carente de amparo legal, de ter pouco tempo de serviço. Possivelmente, a intensa mobilização de Rendon na capitania e igualmente a presença do Marquês de Aguiar na Secretaria dos Negócios Estrangeiros e da Guerra tenham pesado para a promoção do militar branco. ${ }^{170}$

A manobra realizada pelo governador de São Paulo provocou a indignação de Ribeiro, e, em 1818, ele encaminhou um requerimento ao rei requerendo que fosse elevado a sargentomor agregado com a garantia de ser efetivado no posto tão logo esse estivesse vacante. O que mais interessa, porém, são os termos empregados pelo capitão pardo para denunciar as irregularidades que marcaram aquele concurso e para sugerir que a gravidade desse fato afetaria a configuração das relações estabelecidas entre os pardos e a Coroa do Reino Unido. Ribeiro afirmou "ter dado bastantes provas da sua aplicação no real serviço e nas obrigações de major, tantas vezes por ele exercitadas na ocupação de mandante". Porém, "apesar do exame do suplicante, fora preterido pelo seu ajudante Antonio de Pádua de Gusmão, hoje sargento-mor, que nenhum direito tinha para preferir ao suplicante sem agravo da lei”. Referia-se explicitamente ao Alvará de 17 de dezembro de 1802 e aos parágrafos 16 e 17, que lhe conferiam "um direito inegável" ao posto. Ademais, o capitão pardo rechaçou duramente os argumentos evocados pelo governador na ocasião, considerando que aquela "interpretação parece incompatível a toda razão". ${ }^{171}$

De modo ainda mais enérgico, Manoel José da Costa Ribeiro tensionou as relações de reciprocidade existentes entre o monarca e os seus súditos pardos: conforme os termos empregados no requerimento, em referência à preterição por ele sofrida, "o suplicante vê-se por

\footnotetext{
${ }^{170}$ Cf:: Livro Mestre, fls. 1-10; APESP, Ordem C00403, Livro 115, fls. 28v-30. São Paulo, 20 de abril de 1816. Para uma análise acerca dos níveis de riqueza dos milicianos pardos e dos Ribeiros, em particular, ver o capítulo 5. Para uma visão de conjunto acerca dos projetos de reforma que tinham como objeto as milícias pardas e pretas, ver o capítulo 6.

${ }^{171} C f$ :: "Requerimento do sargento-mor graduado Manoel da Costa Ribeiro pedindo a efetividade, digo, ser agregado no seu posto". APESP, Ordem C00439, Livro 226, fls. sem paginação. Sem data.
} 
esta forma agravada a sua reputação, granjeada no centro da honra, e ultimamente abandonada aquela confiança irrefragável que ele suplicante e todos os mais da sua cor têm posto na proteção do trono". ${ }^{172}$ Ora, o compromisso de que o rei, como "pai comum de todos os [...] vassalos", zelaria pela habilitação dos "vassalos pretos e pardos" a todas as "honras e empregos militares" às quais seriam elevados conforme "o seu pessoal merecimento" estava presente precisamente no referido Alvará. ${ }^{173}$ Pisoteados, como foram, em São Paulo, os seus parágrafos 16 e 17, produziu-se abalos na confiança que os pardos depositavam na proteção régia. A retórica empregada por Ribeiro fora, no mínimo, ousada, mas jamais extemporânea; ela revela justamente uma agudização das tensões relativas à milícia dos pardos nesse período que precedeu o advento da revolução constitucionalista no mundo lusófono. Finalizando o requerimento, Ribeiro pediu a efetivação "na 1. a vaga que se ofereça no mesmo corpo, a fim de evitar outro semelhante sucesso de vir a ser preterido pelos ajudantes, que se saberão aproveitar deste exemplo novo". Com essa frase, ele mostrou que se preocupava tanto com os movimentos do adversário mais recente, que o ultrapassara na escala hierárquica, como com os dos demais eventuais competidores brancos. À luz desse caso, nota-se como o Alvará de 1802 simbolizou um alargamento do horizonte de expectativas dos oficiais milicianos pardos, mas também se evidencia que a concretização dos anseios e projetos daqueles homens chocava-se inevitavelmente com interesses divergentes e concorrentes espraiados pelo corpo social.

Manoel José da Costa Ribeiro finalmente obteve despacho favorável, em 1819, em ocasião na qual o governo paulista reconhecera que "ele já seria efetivo, na conformidade do Alvará de 17 de dezembro de 1802, pelo bom exame que fez". ${ }^{174}$ Mas antes de se tornar sargento-mor agregado, Ribeiro ainda viu o concorrente adquirir nova vantagem, já que, no ano anterior, o sargento-mor Antonio de Pádua de Gusmão obteve a graduação de tenentecoronel. ${ }^{175} \mathrm{O}$ comando do Regimento dos Úteis passou por transformações importantes entre os anos de 1820 e 1821, primeiramente com a reforma do tenente-coronel branco, José da Silva Lisboa, e posteriormente com a reforma do coronel pardo Manoel José Ribeiro e a ascensão, em seu lugar, do militar branco José Joaquim César de Cerqueira Leme, egresso da tropa regular e atuante nas recentes campanhas sulinas. No tocante à disputa particular entre Gusmão e Ribeiro pelos postos do estado-maior, essa reconfiguração significou que o primeiro ganhara

\footnotetext{
${ }^{172} C f$ :: "Requerimento do sargento-mor graduado Manoel da Costa Ribeiro pedindo a efetividade, digo, ser agregado no seu posto". APESP, Ordem C00439, Livro 226, fls. sem paginação. Sem data. Os grifos são meus.

${ }^{173}$ Cf:: “Alvará de 17 de dezembro de 1802". Lisboa: Regia Officina Typografica, 1803.

${ }^{174} C f$ :: APESP, Ordem C00440, Livro 233, fls. 17v-18. São Paulo, 22 de março de 1819.

175 Cf: : APESP, Ordem C00403, Livro 115, fls. 124-124v. São Paulo, 11 de julho de 1818; Livro Mestre, fls. 2 e 3.
} 
um aliado de peso situado no topo da hierarquia e que o segundo perdera seu principal apoio. Entre os anos de 1821 e 1822, a formatação do estado-maior do Regimento era a seguinte: como coronel, José Joaquim César de Cerqueira Leme; o posto de tenente-coronel estava vacante; Antonio de Pádua de Gusmão era graduado tenente-coronel, mas exercia o posto de sargentomor; Manoel José da Costa Ribeiro era sargento-mor agregado; e Manoel dos Santos Lima e Luiz Pedroso da Silva eram os ajudantes. ${ }^{176}$ Havia, portanto, apenas um pardo nas funções superiores do Regimento dos Úteis durante o tenso e dinâmico contexto da independência. Tais tensões foram vividas de modo específico nas configurações sociais internas à milícia parda e nos equilíbrios mais abrangentes que tinham lugar na província de São Paulo e por isso merecem exame pormenorizado.

Deixando para tratar dos embates entre milicianos pardos e militares brancos no contexto da independência em seção específica ${ }^{177}$, cumpre indicar as sucessivas posições ocupadas por Gusmão e Ribeiro e de modo mais geral a configuração da oficialidade do Regimento dos Úteis. ${ }^{178}$ Novo choque entre ambos os competidores ocorreu justamente entre os anos de 1822 e 1823, antes que o posto de tenente-coronel fosse provido em Gusmão, o que levou, por outro lado, a que Ribeiro se tornasse sargento-mor efetivo do Regimento. A acirrada competição entre ambos somente se encerrou em 1826, com o falecimento de Antonio de Pádua de Gusmão. ${ }^{179}$ Ribeiro requereu imediatamente o posto vago, alegando a antiguidade, bom comportamento e a preferência no acesso, remetendo-se novamente ao Alvará de 1802 e ao recente Decreto de 4 de dezembro de 1822, que também tratava do sistema de promoções. ${ }^{180}$ Ao findar-se o ano de 1826, o Regimento dos Úteis tinha o comando plenamente renovado em relação à década anterior. No topo da hierarquia estava o coronel César, seguido dos novos tenente-coronel Manoel José da Costa Ribeiro, sargento-mor Jerônimo Isidoro de Abreu oficial da tropa paga promovido ao posto -, sargento-mor agregado Antonio Joaquim da Costa Ribeiro - cuja trajetória fora examinada atrás - e ajudante José Rodrigues da Silva. ${ }^{181}$ Os

\footnotetext{
${ }^{176}$ Cf:: Livro Mestre, fls. 1-5v.

177 Veja-se, adiante, o capítulo 7, seção 7.1.

${ }^{178}$ O regimento dos pardos de São Paulo sofreu mudanças em sua nomenclatura. De Regimento dos Úteis (17971822), passou a ser denominado $3 .^{\circ}$ Regimento de milícias (1822-1824) e, depois, em virtude de uma reorganização das forças militares do império brasileiro, $34{ }^{\circ}$ Batalhão de $2{ }^{a}$ Linha do Exército (1824-1831). Adota-se aqui como critério de exposição a manutenção da referência a Regimento dos Úteis.

${ }^{179} C f$ : ACMSP, Paróquia da Sé (da cidade de São Paulo), Livro de Óbitos de Brancos, Libertos e Escravos n. ${ }^{\circ} 9$ (1823-1834), fls. 93; Livro Mestre, fl. 2.

180 Cf: APESP, Ordem C07776, Livro 327, fls. 252-253. São Paulo, 2 de março de 1826; "Decreto de 4 de dezembro de 1822. Determina que as promoções do Exército, até coronel inclusive, sejam gerais em cada Província e Arma". In: Collecção das Leis do Imperio do Brazil - 1822. Decretos, Cartas e Alvarás. Rio de Janeiro: Imprensa Nacional, 1887, p. 90-93.

${ }^{181}$ Cf:: Livro Mestre, fls. 1-5v.
} 
pardos, que haviam perdido o coronelato da corporação, passaram a contar, contudo, com dois integrantes no alto escalão, membros de uma mesma família, sendo um deles filho e outro neto de Manoel José Ribeiro. Essa formatação seguiu-se até a abolição da milícia, em 1831.

\section{QUADRO 6.3 - Coronéis e tenentes-coronéis do Regimento dos Úteis (1797-1831)}

\begin{tabular}{|c|c|c|}
\hline Períodos & Coronéis & Tenentes-Coronéis \\
\hline \multirow{4}{*}{$1797-1801$} & \multirow{4}{*}{ Modesto Antonio Coelho Neto } & José Mendes da Costa \\
\hline & & Francisco Gonçalves Cordeiro \\
\hline & & José Florêncio de Oliveira \\
\hline & & José dos Santos Souza \\
\hline $\begin{array}{l}1801-1803, \\
1808-1810\end{array}$ & José Joaquim Mariano da Silva César & $?$ \\
\hline \multirow{2}{*}{$1810-1821$} & \multirow{2}{*}{$\underline{\text { Manoel José Ribeiro }}$} & José da Silva Lisboa \\
\hline & & Antonio de Pádua de Gusmão \\
\hline \multirow{2}{*}{$1821-1831$} & \multirow{2}{*}{ José Joaquim César de Cerqueira Leme } & Antonio de Pádua de Gusmão \\
\hline & & Manoel José da Costa Ribeiro \\
\hline
\end{tabular}

Legenda: Fonte sublinhada para homens pardos, o restante para homens brancos.

Fontes: Vide os Quadros 6.1 e 6.2, acima; Livro Mestre, fls. 1-2v.

Como se percebe, o comando do Regimento dos Úteis era objeto de disputa entre indivíduos e grupos concorrentes: milicianos pardos, de um lado, e militares brancos oriundos da tropa regular, de outro. Igualmente interessante é o fato de que duas famílias surgiram intermediando a relação entre indivíduos e coletividades, o que se evidencia particularmente no âmbito da competição pelo posto de coronel, o qual concentrava a maior parcela de poder e prestígio no seio da corporação. Vejamos. O primeiro coronel do Regimento (1797-1801), Modesto Antonio Coelho Neto, era um militar branco reformado. Embora o estado-maior espelhasse a origem e condição social do coronel, durante a sua gestão ele indicou o pardo José Elias da Silva para o posto de tenente quartel-mestre. Alguns documentos fornecem indícios da vinculação pessoal entre o coronel Coelho Neto, o quartel-mestre em questão e o também pardo Manoel José Ribeiro, àquela altura capitão. Em 1798, o coronel branco aceitou ser fiador no processo matrimonial de sua afilhada Francisca de Paula, que vivia em sua companhia e sob sua proteção, e seu quartel-mestre. A noiva, além disso, fora batizada como sendo filha de pai incógnito e da forra Belizarda Pinta do Rego, também chamada Belizarda do Espírito Santo, 
certamente a esposa de Manoel José Ribeiro. Presume-se que este seja o pai oculto, pois Belizarda e Ribeiro se casaram apenas no ano seguinte ao nascimento de Francisca de Paula. Essa hipótese é reforçada pelo fato de que os membros do casal, admitidos aqui como avós, batizaram três filhos de José Elias da Silva e de Francisca de Paula. ${ }^{182}$ Portanto, embora os pardos estivessem afastados do comando direto do recém-criado Regimento dos Úteis, eles eram chefiados por um coronel em quem confiavam e com quem estabeleciam relações sociais de compadrio.

Quando Modesto Antonio Coelho Neto faleceu, assumiu o comando do Regimento José Joaquim Mariano da Silva César (1801-1803 e 1808-1810), também branco e proveniente da tropa paga. Ele foi nomeado por uma comissão especial, a qual foi cancelada em 1803, ficando o Regimento temporariamente sem alguns oficiais superiores até que, em 1808, sua patente foi confirmada - de modo idêntico ao ocorrido com Antonio de Pádua de Gusmão. Até onde se sabe, ao contrário de seu antecessor, César não estabelecera relações de proximidade para com os oficiais pardos. Na realidade, ele partilhava com o governador Franca e Horta a repulsa ao acesso de trabalhadores mecânicos aos postos da oficialidade miliciana. Entretanto, vendo-se acuado com a animosidade dos pardos, ele suplicou, em 1808, para que aquele governador não substituísse os oficiais das companhias (capitães, tenentes e alferes) por militares brancos, de modo a não perder a autoridade sobre os subordinados e o controle do Regimento. ${ }^{183}$

$\mathrm{O}$ adoecimento do coronel César provocou o seu afastamento das atividades militares e a ascensão do capitão Manoel José Ribeiro, graduado tenente-coronel em 1809, ao comando da corporação. Em 1810, Ribeiro obteve a nomeação de tenente-coronel efetivo com a graduação de coronel, e, em 1814, um decreto régio o tornou coronel efetivo. ${ }^{184} \mathrm{Ele}$, que no período formativo dos Úteis recrutou e criou companhias, mantendo relativa proximidade ao estadomaior da milícia por meio de relações clientelares com os superiores hierárquicos, logrou comandar os Úteis entre os anos de 1810 e 1821 . Durante sua gestão, ele procurou encaminhar a progressão dos seus filhos e neto nos postos da milícia, e o sucesso dessa família não foi maior sobretudo em função da competição oferecida pelos militares profissionais brancos. Nomeadamente, a esperança de alocar o filho Manoel José da Costa Ribeiro como imediato sucessor foi obstada pela aprovação de Antonio de Pádua de Gusmão no concurso de 1816, acima analisado. Gusmão, que na década de 1800 passara pelos mesmos percalços que o coronel

\footnotetext{
182 Cf:: ACMSP/DMC 1355, fls. 39-53 e ACMSP/DMC 2257, fls. 35-42; ACMSP, Paróquia da Sé (da cidade de São Paulo), Livro de Batizados de Brancos e Libertos no 9 (1799-1804), fl. 179 e no 10 (1804-1811), fl. 217.

183 Cf: APESP, Ordem C00415, Livro 158, fls. 13-14v. São Paulo, 12 de dezembro de 1808.

${ }^{184}$ Cf:: Livro Mestre, fls. 1-1v.
} 
César para ver confirmada a sua patente, ganhara, em 1821, um importante aliado no Regimento: como se sabe, José Joaquim César de Cerqueira Leme, filho do antigo coronel César, fora indicado para substituir Ribeiro no comando do Regimento dos Úteis. Entretanto, com o falecimento de Gusmão, em 1826, elevou-se Manoel José da Costa Ribeiro ao posto imediatamente inferior ao de coronel. Em 1831, enquanto os corpos milicianos lançavam seus últimos suspiros e antes que o processo histórico em tela recebesse uma guinada decisiva, o tenente-coronel Ribeiro, filho primogênito do velho coronel pardo, ansiava para que César deixasse o posto e ele, sua família e seu grupo social pudessem, enfim, reassumir o controle do Regimento.

A abordagem às minúcias da competição travada no seio do estado-maior do Regimento dos Úteis oferece uma perspectiva rica e aprofundada acerca dos jogadores e de seus movimentos, além de iluminar inúmeros aspectos do equilíbrio de poder formado pela milícia, assim como das configurações sociais mais abrangentes das quais ela fazia parte. Está claro que a construção de tipologias referentes às estratégias de ascensão hierárquica e o estabelecimento de estimativas das possibilidades de sucesso dos jogadores não compuseram os objetivos desse exame. Antes, buscou-se compreender a complexa imersão da milícia dos pardos em equilíbrios instáveis de poder e em fenômenos históricos tais como o reformismo ilustrado, as guerras travadas na bacia do Rio da Prata, e a independência e constituição do Estado brasileiro. De fato, tais fenômenos influenciaram diretamente as vivências dos militares, a conformação de alianças, o estabelecimento de objetivos e, de uma maneira geral, os rumos do jogo. Em meio à competição com os brancos da tropa regular ou mesmo das milícias, a oficialidade parda formulou e levou adiante argumentos que ressaltavam a lealdade, o mérito e os conhecimentos militares, aspectos que, para o sistema de progressão na milícia, se opunham a valores mais tradicionais, tais como o nascimento e a capacidade de viver à lei da nobreza. Contudo, os jogadores e os seus movimentos não estavam isolados de outros indivíduos e grupos sociais e tampouco dos processos históricos em curso. Por essa razão, os dois próximos capítulos versarão sobre as relações entre oficiais e soldados pardos em meio ao equilíbrio de poder interno ao Regimento dos Úteis e sobre a atuação dos milicianos pardos na conjuntura da independência. 


\subsection{Equilíbrio de poder interno ao grupo dos pardos livres: entre a milícia e o artesanato (São Paulo, 1810-1821)}

Após considerar as relações estabelecidas pelas milícias de cor com os órgãos mais centrais do Estado, com governadores e oficiais militares de alta patente e, finalmente, com oficiais militares brancos com carreira na tropa paga ou mesmo nas milícias, ou seja, em três dimensões distintas, mas articuladas, do jogo disputado em meio ao universo militar, cumpre ainda examinar o equilíbrio pendular de poder que configurava as relações sociais entre os pardos livres e forros no interior do Regimento dos Úteis. Privilegia-se o período de 1810 a 1821, no qual a milícia dos pardos esteve pela única vez sob o comando de um coronel cuja cor era a mesma dos subordinados, entendendo se tratar do momento mais apropriado para a visualização das relações de mando e obediência estabelecidas entre os homens de baixa extração na corporação. Com efeito, a gestão do coronel Manoel José Ribeiro foi marcada por uma espécie de pacto entre a oficialidade parda, que se manteve coesa e leal ao seu comandante, o que dificultou a ocorrência de situações de atrito entre esses milicianos e otimizou o exercício de controle sobre a multidão de soldados. Como a milícia era uma "tropa anfíbia", no sentido anteriormente explicitado, as relações de poder que nela tinham lugar extrapolavam o seu âmbito específico e alcançavam outros nichos de atuação social dos milicianos, a exemplo do mundo do trabalho; dadas as características ocupacionais dos oficiais e soldados, tais relações de poder se imiscuíam especialmente nas oficinas artesanais, locais de labuta de muitos deles. Então, o cumprimento das funções milicianas pouco se dissociava das demais atividades profissionais realizadas por aqueles homens, de modo que a autoridade investida nos oficiais milicianos era frequentemente exercida sobre os oficiais inferiores e sobretudo os soldados no âmbito civil. A milícia dos pardos surge, então, caracterizada como um centro de exercício de controle social ao vasto grupo dos pardos livres e forros existente na capitania/província de São Paulo entre finais do século XVIII e as três primeiras décadas do XIX. Interessa abordar as relações sociais mantidas pelos milicianos pardos de diferentes posições hierárquicas, dentro e fora do Regimento dos Úteis, como um equilíbrio de poder que tanto estruturava o funcionamento daquele corpo militar quanto, e à medida que as tensões internas a esse universo provocavam instabilidade, também o podiam desestruturar.

É comum na historiografia brasileira que se associe os postos superiores da milícia e das ordenanças diretamente às elites locais, homens bons, nobrezas da terra e daí por diante. Coronéis, mestres-de-campo, capitães-mores, sargentos-mores e mesmo oficiais de companhia munidos de patentes - a exemplo dos capitães, tenentes e alferes - são correntemente 
entendidos como indivíduos pertencentes a famílias e grupos detentores de prestígio social e de projeção econômica e política em vilas, cidades e capitanias/províncias. O fato de tais indivíduos estarem investidos nos principais postos militares da segunda e terceira linhas é lido como um reforço em suas posições de poder: eles estão entre os grandes produtores ou comerciantes, proprietários de terras e de cativos, e encabeçam enormes redes clientelares, nas quais os subordinados na milícia ou nas ordenanças apenas se somam à multidão de afilhados, dependentes, agregados e escravos. Contando com boa fundamentação, essa perspectiva também está presente na historiografia relativa à São Paulo dos séculos XVIII e XIX. ${ }^{185}$ Todavia, vários obstáculos se impõem à generalização de tal interpretação quando se leva em conta as milícias pardas e pretas e os seus oficiais, cujas origens remontavam à escravidão africana e à administração indígena e a realidade material assentava-se no artesanato e, quando muito, na pequena propriedade escrava. Se os comandantes pardos dificilmente poderiam ser encarados como "potentados locais", cumpre examinar as modalidades de relações estabelecidas com as centenas de subordinados na milícia. Como eles exerciam sua autoridade, influência e poder? Como se comportavam os soldados pardos diante da rigorosa interferência imposta pelos superiores ao conjunto de suas vidas? Em que medida a manutenção das posições dos superiores na hierarquia dependia da anuência dos inferiores? Argumenta-se que a abordagem da relação entre milícia e mundo do trabalho revela tensões internas ao grupo dos pardos livres cuja compreensão é essencial para uma revisão crítica acerca do lugar social ocupado pelos pardos e pretos livres na sociedade escravista brasileira e de sua atuação política na conjuntura da independência.

Nas Américas portuguesa e espanhola a dinâmica da escravidão moderna resultou na formação de um segmento social composto por pessoas livres que descendiam, imediatamente ou no intervalo de algumas gerações, de africanos escravizados ${ }^{186}$ e de indígenas administrados.

\footnotetext{
${ }^{185}$ LEONZO, Nanci. Defesa militar e controle social na capitania de São Paulo: as milícias. Tese (doutorado em História). São Paulo: FFLCH, Universidade de São Paulo, 1979, p. 187-217, 307-312; FERLINI, Vera Lucia Amaral. Uma capitania dos novos tempos: economia, sociedade e política na São Paulo restaurada (1765-1822). Anais do Museu Paulista, São Paulo, v. 17, n. 2, p. 237-250, jul./dez. 2009, p. 245; DELATORRE, Aparecida Vanessa. São Paulo à época da independência. Contribuição para o estudo do chamado movimento "bernardista", 1821/1823. Dissertação (mestrado em História). São Paulo: FFLCH, Universidade de São Paulo, 2003, p. 43; MEDICCI, Ana Paula. São Paulo en el movimiento de Independencia de Brasil (1820-1822). Nuevo Mundo Mundos Nuevos. Débats, 2013, nota de rodapé n. ${ }^{\circ}$ 12. URL: http://nuevomundo.revues.org/65314; DOI: 10.4000/nuevomundo.65314; REIS, Déborah Oliveira Martins dos. Cinturão Paulistano: economia e demografia nas vizinhanças da capital de São Paulo (c. 1798 - c. 1830). São Paulo: FFCLH/USP, 2013, p. 199.

${ }^{186}$ MARQUESE, R. de B. A dinâmica da escravidão no Brasil...
} 
Embora o peso demográfico e social desse grupo heterogêneo variasse de acordo com as especificidades das configurações sociais e dos processos mediante os quais ia se constituindo, ele foi se tornando o segmento populacional mais vultoso do Brasil nos séculos XVIII e XIX. ${ }^{187}$ Apesar disso, a compreensão de aspectos mais complexos da experiência social deste vasto agrupamento humano permaneceu (de)limitada, durante muito tempo, de um lado, pela preocupação em definir as classes sociais a priori a partir da posição ocupada pelos agentes nas relações de produção e, de outro, pelo modo em que se processou o debate em torno da questão racial no Brasil escravista. Como resultado, quer como classe social, destituída de funções específicas na relação de produção essencial senhor/escravo, quer como raça, ocupando uma posição incômoda ou um lugar de passagem entre pretos e brancos, os pardos - e também mulatos e pretos - livres e libertos foram entendidos como elementos "desajustados", "inadaptados" "vadios" e "ambíguos". ${ }^{188}$ Procurava-se, com a discussão daqueles temas, tocar diretamente no âmago da sociedade brasileira, de modo a decifrá-la em seus traços estruturais. Não obstante a indiscutível pertinência dessas tradições intelectuais, seu enraizamento no pensamento social brasileiro perpetuou a tendência nefasta de definir na negativa aquele vasto segmento populacional, ou seja, a partir do que ele "não era" e do que "lhe faltava".

Esta modalidade de pensamento também influenciou os estudos diretamente relacionados ao mundo do trabalho na sociedade escravista de Antigo Regime. Notadamente, a dilatação, em solo americano, da concepção ibérica que depreciava o trabalho mecânico e, seu corolário, a noção conforme a qual o trabalho era atribuição exclusiva de escravos, desestimulou a investigação do trabalho livre sob a vigência da escravidão. ${ }^{189}$ Foi a partir dos recém-formados programas de pós-graduação, na década de 1971, e sob o influxo da história demográfica ou institucional, que as interpretações ensaísticas de caráter geral ou predominantemente teórico foram dando lugar aos primeiros estudos monográficos relativos aos trabalhadores livres no ramo do artesanato no Brasil. ${ }^{190}$ Tais trabalhos expressam os esforços mais elementares de mapeamento geral do tema e organização de amplos corpus

\footnotetext{
${ }^{187}$ KLEIN, H. S. Os homens livres de cor...

${ }^{188}$ FREYRE, G. Sobrados e mucambos..., p. 710-815; PRADO Jr., C. Formação do Brasil contemporâneo..., p. 269-297; FRANCO, M. S. de C. Homens livres na ordem escravocrata..., p. 14; SCHWARZ, R. As idéias fora do lugar..., p. 153.

189 Aspecto notado particularmente por historiadores que se ocuparam da história social do trabalho no Brasil referente à segunda metade do século XIX e primeira metade do XX. LARA, S. H. Escravidão, cidadania e história do trabalho no Brasil. Projeto História, São Paulo, v. 16, p. 25-38, fev. 1998.

${ }^{190}$ RABELLO, E. D. Os ofícios mecânicos e artesanais em São Paulo na segunda metade do século XVIII. Revista de História, n. 55, v. 112, p. 575-588, 1977; BARROS, D. R. de M. Um século dos ofícios mecânicos na vila de São Paulo. Dissertação (mestrado em História). São Paulo: FFLCH, Universidade de São Paulo, 1982; FLEXOR, M. H. O. O trabalho livre em São Paulo no século XVIII. Tese (doutorado em História). São Paulo: FFLCH, Universidade de São Paulo, 1984.
} 
documentais visando à produção de narrativas científicas coesas. Decorre daí a carência de propostas interpretativas mais densas e abrangentes naqueles estudos, aspecto presentemente notado por alguns historiadores. ${ }^{191}$

Por outro lado, em fins dos anos 1960 os brasilianistas A. J. R. Russell-Wood e Herbert S. Klein, preocupados com a estrutura das relações sociais e "raciais" do Brasil escravista em comparação, direta ou indireta, com a realidade norte-americana, acenaram para a presença maciça de pardos e de pretos livres nas várias dimensões do trabalho manual. Contudo, sem dispor de bases empíricas sólidas e abrangentes, eles divergiram quanto ao grau de acesso dos negros livres ao topo da hierarquia profissional no artesanato. Klein sugeriu que o domínio quantitativo exercido por homens livres de cor aos ofícios mecânicos acenaria para processos de mobilidade social, o que estaria em conformidade com o caráter "aberto" daquela sociedade; em sentido oposto, Russell-Wood destacou os preconceitos e barreiras sociais a ela inerentes, argumentando que o peso da ancestralidade escrava influenciaria qualitativamente ao reduzir de forma drástica as possibilidades dos negros e mulatos livres chegarem ao topo da hierarquia dos ofícios artesanais. ${ }^{192}$ Alternativamente, os historiadores que têm se debruçado atualmente sobre o tema no período em tela vêm deslocando os problemas de análise a partir de fontes e métodos diversos. Assim, os artesãos são abordados a partir de sua relação com diferentes âmbitos da sociedade, tais como as irmandades religiosas, as milícias e redes de crédito, bem como com outros grupos sociais, nomeadamente as elites brancas vinculadas ao comércio e a propriedades agrícolas de grande porte. ${ }^{193}$

${ }^{191}$ LIBBY, D. C. Habilidades, artífices e ofícios na sociedade escravista do Brasil colonial. In: COLE, D. C.; FURTADO, J. F. (Orgs.). Trabalho livre, trabalho escravo: Brasil e Europa, séculos XVII e XIX. São Paulo: Annablume, 2006, p. 61-62.

${ }^{192}$ KLEIN, H. S. Os homens livres de cor..., p. 18-23; RUSSELL-WOOD, A. J. R. Escravos e libertos..., p. 9294.

193 BARRETO, Daniela Santos. A despeito do defeito: artesãos na cidade do Rio de Janeiro, c. 1690-c. 1750. Acervo, Rio de Janeiro, v. 15, $\mathrm{n}^{\circ}$ 2, p. 69-86, jul./dez. 2002; SILVA FILHO, G. Oficialato mecânico e escravidão urbana em Minas Gerais no século XVIII. São Paulo: Scortecci, 2008, p. 71-129; BONNET, Márcia C. Leão. Entre o artifício e a arte: pintores e entalhadores no Rio de Janeiro setecentista. Rio de Janeiro: Secretaria Municipal de Cultura: Arquivo Geral da Cidade do Rio de Janeiro, 2009; LUNA, F. V.; KLEIN, H. S. Evolução da sociedade e economia..., p. 223-245; PEREIRA, José Neilton. Além das formas, a bem dos rostos: faces mestiças da produção cultural barroca recifense - 1701-1789. Dissertação (mestrado em História). Recife: DLCH, Universidade Federal Rural de Pernambuco, 2009; PRECIOSO, Daniel. "Legítimos vassalos”: pardos livres e forros na Vila Rica colonial (1750-1803). Dissertação (mestrado em História). Franca: FHDSS, Universidade Estadual Paulista "Júlio de Mesquita Filho", 2010; SANTOS, Amália Cristovão dos. Em obras: os trabalhadores da cidade de São Paulo entre 1775 e 1809. Dissertação (mestrado em Arquitetura e Urbanismo). São Paulo: FAU, Universidade de São Paulo, 2013; SILVA, Fabiano Gomes da. Pedra e cal: os construtores de Vila Rica no século XVIII (1730-1800). Dissertação (mestrado em História). Belo Horizonte: FFCH, Universidade Federal de Minas Gerais, 2007; SILVA, Henrique Nelson. Trabalhadores de São José: artesãos do Recife no século XVIII. Dissertação (mestrado em História). Recife: CFCH, Universidade Federal de Pernambuco, 2010; SIQUEIRA, Mariana Nastari. Entre o signo da mudança e a força da tradição: o conflito entre a Irmandade de S. Crispim e S. Crispiniano dos sapateiros e a Câmara, Rio de Janeiro, c. 1764 - c. 1821. Dissertação (mestrado em História). Seropédica: ICHS, Universidade Federal Rural do Rio de Janeiro, 2011. 
Dois estudos recentes, mas referenciais, merecem nova atenção aqui porque articulam as dimensões trabalho, cor e milícia e auxiliam na explicitação dos problemas de análise enfrentados nesse capítulo. Guedes abordou processos de ascensão social vivenciados por famílias de ex-escravos entre 1790 e 1850 e concluiu que o trabalho artesanal, a estabilidade familiar e as relações de deferência para com as elites locais configuravam-se no tripé fundamental à elevação social de pardos libertos. O ápice do processo, nos termos de Antigo Regime, seria a transformação do forro em "rei dos forros". Alguns, com mais sorte ou melhor estratégia, conseguiriam romper as "barreiras da cor", tornando-se senhores de homens, portadores de patentes militares enobrecedoras e, finalmente, sendo reputados brancos. ${ }^{194} \mathrm{Nessa}$ abordagem, no entanto, não se considera a importância fundamental que as relações horizontais entre os pardos - para além das familiares - desempenhariam no processo de elevação social intragrupal. Ademais, a tese de que a nobreza proveniente das patentes militares implicaria, necessariamente, uma superação das "barreiras da cor" ignora as características das instituições militares coloniais, as quais eram organizadas a partir de divisões com base na cor e no pleno reconhecimento das posições de poder no interior de cada corporação.

Por sua vez, em um interessante exercício de comparação a respeito dos oficiais milicianos brancos, pardos e pretos da cidade de Salvador no período aqui em questão envolvendo as variáveis condição profissional, econômica e social -, Kraay concluiu que os brancos e pretos apresentavam uma coerência interna em termos da definição de seu lugar social. Já os oficiais milicianos pardos caracterizavam-se pela "ambiguidade", uma vez que suas ocupações e níveis de renda mantinham-se mal definidos entre brancos e pretos. Embora Kraay tenha sido enfático quanto à ambiguidade dos pardos, esse diagnóstico careceu de exame pormenorizado às relações de interdependência e aos equilíbrios de poder existentes entre os milicianos e artesãos pardos. Ainda conforme esse modelo, o caráter pouco coeso dos milicianos pardos teria consequências políticas importantes, de modo que reside aí o núcleo de sua explicação para a destituição da oficialidade miliciana parda de Salvador em fins do século XVIII. ${ }^{195}$ Uma interpretação contundente como esta naturalmente suscita algumas observações críticas: em primeiro lugar, a ideia de que a constatação de heterogeneidade do grupo dos pardos em termos culturais, ocupacionais e de níveis de riqueza não deve pressupor, a priori, ausência de coesão coletiva relativamente a um âmbito comum, como era o caso da milícia; em segundo lugar, mesmo que se admita reduzida coesão entre grupos mais ou menos abrangentes de milicianos pardos, restaria examinar a natureza e o grau de coesão implicitamente existente

\footnotetext{
${ }^{194}$ GUEDES, R. De ex-escravo a elite escravista...

195 KRAAY, H. Race, state, and armed forces..., p. 98-105.
} 
entre os grupos de milicianos brancos e pretos; em terceiro, a noção conforme a qual os níveis reduzidos de coesão vigentes entre os pardos acenariam mais para configurações específicas nos equilíbrios de poder intra e intergrupal do que para características essenciais de todo um grupo, como é o caso da atribuição de "ambiguidade".

Tendo em vista esse conjunto de questões, sugere-se aqui que um ponto de partida pertinente ao exame de aspectos que eram específicos e internos à coletividade dos pardos livres e libertos e, ao mesmo tempo, recorrentes aos vários grupos das sociedades escravistas é o foco nas instituições típicas da sociedade de corpos, as quais sobreviveram ao reformismo ilustrado e atrofiaram ou remodelaram-se completamente com a emergência do liberalismo. Segregadas por cor, como as irmandades e milícias, ou mais abrangentes em termos de composição social, como as corporações de ofício, elas constituíram-se em veículos para a formação de redes de relações sociais entre aquelas pessoas e para sua vinculação ao Estado, das quais decorriam solidariedades, hierarquias, conflitos e identidades. Numa palavra, as corporações contribuíram decisivamente para a definição e sedimentação do lugar social de pardos e pretos livres. Não é por acaso, portanto, que as mudanças de posição social vivenciadas individual ou coletivamente durante o Antigo Regime também estivessem diretamente atreladas às corporações. ${ }^{196}$

Há um bom tempo que os cientistas sociais esforçam-se para deslocar suas tradicionais categorias de análise em direção a uma perspectiva relacional. Buscando superar o tratamento reificado dispensado a conceitos como sociedade, classe, raça e indivíduo, tem-se sugerido a adoção de instrumentos e procedimentos teóricos mais adequados à abordagem das relações de interdependência entre os seres humanos a partir das quais se formam vínculos, redes e configurações sociais. ${ }^{197}$ Nessa linha, o desafio inscrito na abordagem das relações entre milícia, cor e artesanato passa por articular os dados "em forma de propriedades" ou "agregação máxima", provenientes de exame quantitativo, a fragmentos que revelem comportamentos, identidades coletivas, experiências sociais e relações de poder daí decorrentes. ${ }^{198}$ Em outros termos, uma vez constatado, através dos números, que o exercício do artesanato se constituía em elemento diferenciador no interior do grupo dos pardos livres, contribuindo para elevar seus

\footnotetext{
196 GUERRA, F.-X. De la política antigua a la política moderna...; HOLANDA, S. B. de. A herança colonial sua desagregação. In: HOLANDA, S. B. de (Dir.). História geral da civilização brasileira [1960]. (Tomo II, 1 . $^{\circ}$ vol.). 3. ${ }^{a}$ ed. São Paulo: Difusão Européia do Livro, 1970, p. 9-39; KUETHE, A. J. The status of the free pardo... ${ }^{197}$ ELIAS, N. A sociedade dos indivíduos...

${ }^{198}$ BOURDIEU, Pierre. Espaço social e génese das «classes». In: BOURDIEU, P. O poder simbólico. Lisboa; Rio de Janeiro: Difel; Editora Bertrand Brasil, 1989, p. 135; REVEL, Jacques. Microanálise e construção do social. In. REVEL, J. (Org.). Jogos de escalas: a experiência da microanálise. Rio de Janeiro: Editora FGV, 1998, p. 21.
} 
executores nos degraus da hierarquia miliciana ${ }^{199}$, é pertinente examinar o modo pelo qual as relações de poder na milícia e no mundo do trabalho se iluminavam reciprocamente.

No Brasil, como também nos espaços hispano-americanos, cujas estruturas sociais em construção compartilhavam, em linhas gerais, a mesma matriz ibérica e as injunções da condição colonial, as corporações de ofício não obtiveram a mesma formalidade e rigidez institucional que as caracterizavam na Europa. Isso se refletiu, por exemplo, na escassez, em várias regiões coloniais, de instituições de representação centralizadas como a Casa dos Vinte e Quatro que, em Portugal, aglutinava os vários ofícios mecânicos e procedia à eleição de um representante dos artesãos para os conselhos municipais - o juiz do povo. Em virtude desse mesmo fator, também foram raros na América portuguesa os estatutos destinados a organização das relações entre as corporações e o Estado, o público e os próprios trabalhadores. ${ }^{200}$ Por outro lado, alguns estudos sugerem que as características particulares assumidas pelas corporações de ofício no mundo colonial produziram um estreitamento das relações entre elas e as irmandades religiosas, de modo que as últimas passaram a suprir várias das funções sociais relacionadas ao mundo do trabalho artesanal. Assim, as irmandades vinculadas aos ofícios regulariam desde aspectos mais gerais, como as sociabilidades e identidades coletivas, até os mais específicos, como a qualidade e o preço dos produtos, os exames técnicos e todo o processo de aprendizagem. ${ }^{201}$ No entanto, não havia homogeneidade entre os espaços lusoamericanos neste e em inúmeros outros aspectos: nas capitanias/províncias de São Paulo e Minas Gerais, por exemplo, inexistia até $1824^{202}$ a relação direta entre corporações de ofício e irmandades religiosas verificada na Bahia e Rio de Janeiro. Antes, a historiografia sugere que os artesãos daquelas localidades se identificavam apenas à bandeira e ao santo protetor dos seus ofícios, devendo seu frágil aparato institucional exclusivamente às câmaras locais. Nesses

\footnotetext{
199 Vide a Parte 2 desta tese.

${ }^{200}$ A questão da existência de instituições de representação centralizadas no Brasil é controversa. De um lado, argumenta-se que Salvador foi um caso único de existência de instituição central aos artesãos do Estado do Brasil (FLEXOR, M. H. O. Ofícios, manufaturas e comércio..., p. 173-176), e, de outro, alguns estudos defendem a proliferação de tais instituições a partir, sobretudo, de referências ao juiz do povo no caso do Rio de Janeiro (CUNHA, L. A. O ensino de ofícios artesanais e manufaturas no Brasil escravocrata. São Paulo: Editora UNESP, Brasília, DF: Flacso, 2000, p. 47; MARTINS, M. de S. N. Entre a cruz e o capital: mestres, aprendizes e corporações de ofícios no Rio de Janeiro (1808-1824). Tese (doutorado em História). Rio de Janeiro: IFCS, Universidade Federal do Rio de Janeiro, 2007). Comparativamente, as corporações de ofícios, ou grêmios, parecem ter obtido níveis mais elevados de institucionalização e enraizamento em determinadas regiões do mundo hispano-americano. Ver: LUNA GARCÍA, Sandra Nancy. Trabajadores de origen africano en los gremios de la Ciudad de México, siglo XVIII. TOLEDO, S. P.; GRIJALVA, M .M.; PEÑAFLORES, R. A. (Coords.). El mundo del trabajo urbano. Trabajadores, cultura y prácticas laborales. Zacatecas; México D.F.: Universidad Autónoma de Zacatecas; El Colegio de México, 2012, p. 87-126; CALA, Mauricio Puentes. Artesanos y labriegos al servicio de la Corona: un acercamiento a las relaciones entre la raza, los oficios y el alistamiento miliciano en Santa Fe de Bogotá a finales del siglo XVIII. El Taller de la Historia, Cartagena de Indias, v. 5, n. 5, p. 173-210, 2013.

${ }^{201}$ CUNHA, L. A. O ensino de ofícios..., p. 49-51; MARTINS, M. de S. N. Entre a cruz e o capital...

${ }^{202}$ Ano em que as corporações de ofício foram extintas pela Constituição do Império do Brasil.
} 
termos, as corporações de ofício não obtiveram em São Paulo a robustez europeia e tampouco se verificou ali a ingerência decisiva das irmandades no trabalho artesanal, característica de outros espaços luso-americanos. Vai daí a pertinência de se atentar para os vínculos entre a esfera do trabalho e outros âmbitos do espaço social como meio de se compreender um pouco mais sobre a organização do trabalho artesanal paulista. Propõe-se aqui, precisamente, um exame à atuação de pardos livres nos ofícios mecânicos e nas milícias enfatizando que os vínculos e relações daí provenientes, nem sempre formais e explícitos, lançam luz a um vasto campo de tensões que caracterizou a organização interna da coletividade dos pardos.

Assim como as milícias, as corporações de ofício encerravam práticas e hierarquias reconhecidas por todo o corpo social: do aprendizado dos ofícios à participação nas festas públicas e eleições internas à corporação, levava-se em conta a diferenciação existente entre serventes ou jornaleiros, aprendizes, oficiais e mestres de cada ofício. A possibilidade de orientar aprendizes, ter loja própria e ser eleito escrivão ou juiz de cada ofício e assim examinar e representar seus pares era exclusividade dos mestres artesãos. Eles, de fato, ocupavam as posições mais elevadas naquele segmento profissional e não por acaso tendiam a desfrutar de maiores, embora limitadas, chances de adquirir escravos e ostentar relativo prestígio social diante dos demais artesãos.

Como visto, o grau de acesso dos pardos e pretos livres ao topo da hierarquia profissional da sociedade escravista brasileira deu margem a controvérsias na historiografia. ${ }^{203}$ A quantificação dos mestres artesãos dentre os milicianos pardos de São Paulo esbarra na precariedade e no caráter lacunar das fontes. ${ }^{204}$ Alternativamente, a constatação da predominância numérica dos pardos livres em segmentos específicos do artesanato, permite inferir que, neles, os homens livres de cor alcançavam a condição de mestres com uma frequência maior do que julgaria Russell-Wood. Viu-se aqui que no período de 1810-1831 havia cerca de 129 milicianos pardos trabalhando como alfaiates em São Paulo. Seu predomínio nesse ramo fica evidente quando se considera que, para o ano de 1836, contabilizou-se apenas 102 alfaiates atuantes nas localidades em que viviam dos milicianos pardos. Logo, a vasta maioria dos alfaiates, e inclusive os mestres, eram pardos. ${ }^{205}$ Tão ou mais importante é notar que a esse peso quantitativo correspondia o acesso dos pardos a posições de autoridade e representação

\footnotetext{
${ }^{203}$ KLEIN, H. S. Os homens livres de cor..., p. 18-23; RUSSELL-WOOD, A. J. R. Escravos e libertos..., p. 9294.

${ }^{204}$ Cf:: Registro Geral da Câmara Municipal de São Paulo - Publicação oficial do Arquivo Municipal de São Paulo. São Paulo: Typographia Piratininga, 1921-1923, volumes 13 ao 20, referentes ao período 1803-1830; APESP, Maços de População; Livro Mestre.

${ }^{205}$ Cf: MÜELLER, D. P. Ensaio d'um quadro estatístico da província de S. Paulo. São Paulo: Typographia de Costa Silveira, 1838, p. 241-244.
} 
institucionalizadas: com alguma assiduidade, milicianos pardos foram empossados juízes e escrivães dos ofícios alfaiate, sapateiro e carpinteiro como resultado das eleições anuais das quais participavam os mestres artesãos. ${ }^{206}$ Mas, se dentre os milicianos pardos havia alguns cuja trajetória de vida os alçara a uma condição de liderança e referência na comunidade artesanal, a maior parte desses homens deve ter despendido seu suor trabalhando exclusiva ou predominantemente a partir das posições inferiores de aprendiz, servente e oficial. Isso significa que tanto as oficinas laborais como o conjunto do universo artesanal eram espaços completamente estruturados por relações de poder estabelecidas entre mestres, oficiais e aprendizes. Para uma melhor compreensão da experiência social dos artesãos, deve-se considerar, portanto, alguns elementos da relação entre mestres e aprendizes.

O ensino dos ofícios artesanais deveria atender a determinadas normas, como as que se referiam ao período de treinamento, idade e quantidade dos aprendizes, mas elas podiam sofrer alterações no Brasil em relação às regras europeias e serem descumpridas com frequência. Os mestres não poderiam receber simultaneamente um número maior de aprendizes que variava de dois a quatro, e estes, com idade mínima de 12 anos, deveriam instruir-se por um período máximo de quatro a seis anos. ${ }^{207}$ No entanto, a ausência de regulamentos pormenorizados a esse respeito concedia aos mestres uma ampla margem de arbítrio sobre seus discípulos e aos processos e relações em que estavam imersos. "Aprendizes e mestres faziam um acordo pelo qual estes ensinavam àqueles o ofício em troca da prestação de serviços, remunerados ou não", sendo prática comum que os mestres acolhessem os principiantes em suas próprias casas. ${ }^{208} \mathrm{Em}$ decorrência, os laços estabelecidos entre mestre e aprendiz de ofício visando à transmissão dos mistérios e segredos profissionais devem ser compreendidos não apenas como relação de trabalho, mas como síntese de um emaranhado de relações sociais. Estas foram definidas por Martins como "relações patriarcais e de cunho autoritário". ${ }^{209}$ Ora, "o estatuto do aprendiz é de ampla dependência de seu Mestre, não apenas no ambiente de trabalho - a oficina - mas, de modo geral, na sua inserção no mundo da cidade". ${ }^{210}$ Desse modo, ao mestre artesão era incumbida a responsabilidade de introduzir o aprendiz nas técnicas profissionais e, não menos importante, formar um trabalhador disciplinado e vassalo útil. Vai daí o reconhecimento estatal

\footnotetext{
${ }^{206}$ Cf:: Atas da Câmara Municipal de São Paulo - Publicação oficial do Arquivo Histórico Municipal de São Paulo. São Paulo: Typographia Piratininga, 1921, v. 19 (1788-1796), p. 293 e v. 21 (1809-1815), p. 117-118, 206208 e $355-356$.

${ }^{207}$ CUNHA, L. A. O ensino de ofícios..., p. 44-51; MARTINS, M. S. N. Entre a cruz e o capital..., p. 113-114.

208 CUNHA, L. A. O ensino de ofícios..., p. 44.

${ }^{209}$ MARTINS, M. S. N. Entre a cruz e o capital..., p. 118.

${ }^{210}$ MENESES, José Newton Coelho. Educar na oficina: a aprendizagem do artesão no mundo português e as reformas pombalinas do ensino no final do século XVIII. In: FONSECA, Thais Nivia de Lima e (Org.). As reformas pombalinas no Brasil. Belo Horizonte: Mazza Edições, 2011, p. 252.
} 
ao papel desempenhado por corporações e mestres de ofício em termos de exercício de controle social sobre a população livre pobre.

No caso dos homens pardos, era possível que alguns deles ingressassem no mundo artesanal ainda na condição de escravos e sob as ordens de seus proprietários enquanto outros tantos o fizessem na condição de libertos ou mesmo livres. Embora fosse comum a transmissão e a continuidade dos ofícios entre pais e filhos, não era raro que os vários membros de suas famílias exercessem ocupações distintas entre si, aprendidas com diferentes mestres. A esse respeito, é exemplar o rumo tomado pelos milicianos pardos filhos de um casal de ex-escravos, entre o final do século XVIII e começo do XIX: o pai, Amaro Coelho Ayres, era mestre e juiz do ofício de alfaiate, cuja especialidade legou a dois de seus cinco filhos - um dos quais tornouse sargento e o outro cabo do Regimento dos Úteis. Os três restantes, todos cabos daquele Regimento, ocuparam-se como pintor, carpinteiro e sapateiro. ${ }^{211}$ É significativo que o mais bem posicionado na hierarquia miliciana tenha sido um dos filhos que herdou do pai a ocupação qualificada. Realidade análoga se processou na família do mestre e juiz carpinteiro Desidério da Assunção, igualmente miliciano pardo e morador na cidade de São Paulo: entre seus filhos, o alferes Joaquim José Soares seguiu a especialização paterna, tornando-se mestre carpinteiro, o sargento Anacleto Elias fez-se ourives e, finalmente, o cabo Manoel do Sacramento enveredou em direção ao ofício de sapateiro até conseguir converter-se em pequeno comerciante. $^{212}$

Já foi visto que a transição do trabalho artesanal para o comércio - tal como vivenciada por Manoel do Sacramento - era perseguida pelos pardos livres, mas pouco factível de se concretizar. Algo bastante evidente na trajetória daqueles que obtiveram sucesso nessa empreitada é a associação existente entre processos de elevação profissional e ascensão na hierarquia miliciana. Retome-se o caso do pardo Pedro Antonio Ferreira: enquanto era escravo, trabalhou como cabeleireiro até aprender o ofício de alfaiate, cujo exercício, provavelmente, forneceu-lhe capital material e social suficiente para conseguir a liberdade do cativeiro e logo ser incorporado ao Regimento dos Úteis, onde serviu de 1802 a 1831. Ferreira ascendeu rapidamente nas hierarquias do ofício e do Regimento, pois em 1808 o liberto exercia as funções de escrivão do ofício de alfaiate e de sargento miliciano. Em 1813 passou a dedicar-se ao seu próprio negócio comercial e três anos depois ascendeu ao posto de alferes, findando sua

\footnotetext{
${ }^{211}$ Cf:: Livro Mestre, fls. 101, 102v, 103, 130v, 156 e 185v; Atas da Câmara Municipal de São Paulo - Publicação oficial do Arquivo Histórico Municipal de São Paulo. São Paulo: Typographia Piratininga, 1921, v. 21 (18091815), fls. 117-118.

${ }^{212}$ Cf:: Livro Mestre, fls. 59v, 61v, 68v e 88v; Atas da Câmara Municipal de São Paulo..., v. 21 (1809-1815), fls. 355-356.
} 
passagem na milícia dos pardos como tenente. ${ }^{213}$ Outro caso que revela uma correlação entre a elevação na milícia, de um lado, e o exercício de ofícios artesanais e a ascensão na hierarquia laboral - mesmo que sucedida pela transição do artesanato para o comércio -, de outro, é o do liberto Manoel José Ribeiro. Este foi um veterano da guerra luso-castelhana de 1763-1777 - na qual atuou como soldado da tropa de linha - que dedicou parte de sua vida ao ofício de alfaiate, tornando-se mestre e chegando a ser eleito por seus pares juiz daquele ofício em 1790. Antes da criação do regimento miliciano dos pardos, em 1797, Ribeiro já se havia elevado a capitão, mas permanecia identificado como alfaiate. No entanto, a partir de 1802, quando obteve a graduação de tenente-coronel, passou a viver "de seu negócio de fazenda seca que traz do Rio de Janeiro". ${ }^{214}$ O título de nobreza com o qual foi condecorado bem como o acesso ao posto de coronel, obtidos em 1810, explicitam a singularidade da trajetória desse homem entre os pardos libertos de São Paulo. De fato, seus filhos e neto pertencentes ao regimento dos pardos jamais foram identificados como artesãos ou oficiais mecânicos. Apesar disso, como será visto adiante, o velho mestre e juiz dos alfaiates manteria por muito tempo, e sob outros moldes, a antiga atribuição de gerenciar aspectos centrais do exercício dos ofícios mecânicos. ${ }^{215}$

Antes, porém, é necessário retomar o caso das famílias pardas que se vinculavam ao artesanato a partir de distintas especializações, indagando quais os possíveis significados da submissão dos filhos de artesãos a outros mestres quando os próprios pais eram os profissionais mais capacitados dentre os alfaiates e carpinteiros, e, portanto, plenamente habilitados para instruí-los. Ora, mediante esse expediente os mestres artesãos pardos abriam mão de contar com o auxílio de seus filhos no trabalho realizado em suas tendas, e isso não era pouco para integrantes de grupo social cujo acesso à mão de obra escrava era severamente limitado. Como visto no capítulo 5, uma minoria dentre todos os milicianos pardos havia sido senhor de escravos em algum momento de suas vidas, ao longo dos anos 1798 e 1836, e entre eles predominavam os pequenos plantéis, compostos por um ou dois cativos. Sob tais circunstâncias, o recurso à mão de obra familiar era essencial para todos os agricultores e artesãos pardos. ${ }^{216}$ De fato, essa era a realidade dos núcleos familiares de Amaro Coelho Ayres e Desidério da Assunção. Apesar de o primeiro dispor de dois escravos em 1804, nos recenseamentos seguintes

\footnotetext{
${ }^{213}$ Cf: : APESP, ordem C00277, doc. 41-1-97; Livro Mestre, fls. 58 e 140.

${ }^{214}$ Cf:: Livro Mestre, fls. 1-1v; Atas da Câmara Municipal de São Paulo..., v. 19 (1788-1796), p. 148; APESP, Maços de População (cidade de São Paulo, 1798, 1. a companhia; 1802, 1. ${ }^{\text {a }}$ companhia, casa n. 139).

${ }^{215}$ CUNHA, L. A. O ensino de ofícios..., p. 51.

${ }^{216}$ Sobre a posse média de escravos por parte dos artesãos em São Paulo no período considerado, ver LUNA, F. V. São Paulo: população, atividades e posse de escravos em vinte e cinco localidades (1777-1829). In: COSTA, I. del N. da; LUNA, F. V.; KLEIN, H. S. (Eds.). Escravismo em São Paulo e Minas Gerais. São Paulo: Imprensa Oficial/EDUSP, 2009, p. 362-363. Sobre a posse de escravos entre os pardos livres, ver LUNA, F. V.; KLEIN, H. S. Evolução da sociedade e economia..., p. 143-144, 208-209.
} 
- 1808, 1811, 1816, 1818, 1822, 1825 - a família não mais possuía qualquer cativo. Já o segundo núcleo jamais contou com o trabalho escravo em sua oficina artesanal durante os anos de 1802 a $1825 .{ }^{217}$

A estrutura da sociedade escravista compelia um segmento importante dos descendentes de escravos, de índios administrados e de mestiços pobres à milícia e ao exercício de ofícios mecânicos, e as famílias desenvolviam estratégias conforme as avaliações que faziam do mercado profissional e das redes de relações humanas nas quais estavam imersos. Aparentemente, nos casos dos pardos livres Amaro e Desidério ${ }^{218}$, ao invés de concentrarem toda a mão de obra familiar em uma única especialização e tenda artesanal, eles optaram por diversificar os ramos de atividade mesmo estando no topo da hierarquia de seus ofícios, evitando-se assim futura concorrência entre os familiares e ampliando as chances de sucesso econômico. Com esse mesmo procedimento estabeleciam alianças com mestres de outros ofícios a quem confiavam o aprendizado dos jovens filhos, os quais eram, muitas vezes, seus companheiros na milícia, e assim solidificavam, com base em diferentes âmbitos, uma posição familiar privilegiada no interior do grupo dos pardos livres. Porém, como consequência das limitações no acesso à mão de obra escrava e de estratégias que nem sempre visavam à retenção da mão de obra familiar, os artesãos pardos defrontavam-se com o problema elementar do acesso a trabalhadores ajudantes. Já que um significativo segmento dos pardos vivia uma realidade em comum, marcada pela associação entre o mundo do trabalho a inserção familiar nos corpos militares, sugere-se que os vínculos entre milícia e artesanato iluminam as práticas sociais estabelecidas em um e outro âmbito, reciprocamente. É o caso da relação entre mestres e aprendizes pardos: muitas vezes o mestre artesão ocupava postos da oficialidade miliciana ao passo que seu aprendiz de ofício era também um soldado miliciano a ele subordinado. Em tais circunstâncias, as relações de poder consolidadas no universo militar reproduziam-se extrapolando suas fronteiras e alcançando diferentes âmbitos da sociedade. Para os pardos melhor situados nas hierarquias miliciana e laboral, esse tipo de relação, no limite, apresentavase como solução parcial a problemas na disponibilidade de mão de obra e sujeição dos soldados.

\footnotetext{
${ }^{217} C f$ : : APESP, Maços de População (cidade de São Paulo). Amaro Coelho: (1804) 3. Cia., fogo 2; (1808) 3. ${ }^{\mathrm{a}}$ Cia., fogo 38; (1811) 3. ${ }^{a}$ Cia., Rua do Carmo, fogo 40; (1816) 3. ${ }^{a}$ Cia., Rua do Carmo, fogo 3; (1818) 2. ${ }^{a}$ Cia., Rua de São Bento, fogo 43; (1825) 3. ${ }^{a}$ Cia., Rua das Flores, fogo 46; Desidério: (1802) 2. ${ }^{a}$ Cia., fogo 201; (1804) 2. ${ }^{a}$ Cia., fogo 205; (1805) 2. ${ }^{a}$ Cia., fogo 101; (1808) 2. ${ }^{a}$ Cia., fogo 92; (1811) 2. ${ }^{a}$ Cia., Piques, fogo 126; (1814) 2. ${ }^{a}$ Cia., Rua do Piques, fogo 249; (1816) 2. ${ }^{a}$ Cia., Rua do Piques, fogo 8; (1818) 8. ${ }^{a}$ Cia., Piques, fogo 6; (1822) 8. ${ }^{a}$ Cia., Piques, fogo 8.15; (1825) 8. ${ }^{\mathrm{a}}$ Cia., Piques, fogo 25.

218 Os quais, obviamente, não são tomados aqui como padrão em meio ao universo múltiplo e heterogêneo dos pardos livres.
} 
Em 1814, houve uma disputa entre o coronel pardo e os padrinhos de um jovem miliciano pela guarda do rapaz. Os familiares, que acolheram em seu lar o tambor pardo, argumentavam que dispunham do direito de governar o afilhado até sua emancipação adulta. Já o coronel, fundamentado no dever que os milicianos tinham de prestar o serviço militar fardados, asseados e submissos a seus comandantes, ordenara que o rapaz pardo deixasse aquela casa e fosse entregue a um alferes do Regimento, que era também mestre do ofício de alfaiate, a fim de que este ensinasse ao jovem o ofício, administrasse o soldo referente à atividade miliciana do aprendiz e mantivesse-o pronto para o serviço militar. ${ }^{219}$ Percebe-se claramente, aqui, uma íntima articulação entre as hierarquias miliciana e artesanal. Afinal, o coronel e o alferes, mestres alfaiates, faziam valer a autoridade militar sob um soldado-tambor e sua família, retirando-o de sua casa e transformando-o em aprendiz de um ofício mecânico. Essa devia ser uma prática recorrente, pois, conforme as palavras do coronel pardo, vinha fazendo o mesmo "a todos os mais, para não andarem furtando e embebedando-se". Como se vê, na retórica a favor dos oficiais milicianos-artesãos ela assumia contornos de exercício de controle social, na medida em que tinha em vista disciplinar e instruir descendentes de escravos fazendoos úteis ao Estado tanto no plano militar quanto na esfera socioeconômica - cuja aspiração estava explicitamente presente no nome do regimento dos pardos, ou “dos Úteis", nas diretrizes de governos de vice-reis do Brasil e na mente do último defensor das corporações de ofício no Brasil. ${ }^{220} \mathrm{O}$ próprio inspetor das milícias, José Arouche de Toledo Rendon, opositor ferrenho à existência do Regimento dos Úteis, procurava meios para obrigar os "vadios" ao trabalho, fossem eles índios, negros libertos e órfãos. Em certa ocasião, ele sugeriu que os "filhos sem pais" fossem "entregues a pessoas capazes de os aplicar ao serviço, sustentá-los, vesti-los e educá-los, fazendo-os ensinar a ler e a escrever. Os rapazes podem ser entregues a mestres de ofícios e as raparigas a senhoras graves". Assim, quando adultos, uns obteriam um "ofício e outros [estariam] pelo menos acostumados ao trabalho e com boa educação". ${ }^{221}$ As práticas levadas a efeito pelos oficiais pardos estavam em plena sintonia, portanto, com formas de controle social defendidas por autoridades de alto escalão ao longo da segunda metade do século XVIII e das primeiras décadas do seguinte.

\footnotetext{
${ }^{219} C f:$ APESP, ordem C00264, doc. 32-2-27.

${ }^{220} C f$ : : Relatório do Marquês de Lavradio vice-rei do Rio de Janeiro, entregando o governo a Luiz de Vasconcellos e Souza, que o sucedeu no vice-reinado [1779]. Revista do Instituto Histórico e Geográfico Brasileiro, t. 4, 1863, p. 419-425 e 436; HOLANDA, S. B. de. A herança colonial..., p. 26-29; LARA, S. H. Fragmentos Setecentistas..., p. $272-274$.

${ }^{221} C f:$ : "Reflexões sobre o estado em que se acha a agricultura na capitania de S. Paulo". DIHCSP, vol. 44, p. 200. Os grifos são meus.
} 
Ademais, esse tipo de relação autoritária combinava-se plenamente com elementos paternais. Os mestres artesãos, ao introduzirem seus soldados, ou melhor, aprendizes, nos mistérios do ofício, assumiam inúmeras responsabilidades para com os subordinados, tais como o fornecimento de hospedagem, alimentação, vestuário e proteção. Quando, em 1820, um soldado dos Úteis requereu liberdade da prisão militar em que se encontrava pelo motivo de não ter se apresentado com regularidade ao serviço miliciano, alegou que estava "aprendendo o ofício de funileiro, com Manoel Pereira Nunes [um oficial dos Úteis], desta mesma cidade, e vivendo muito pobre não se pôde fardar; e por isso teve algumas faltas tocantes às obrigações do serviço". Obtendo a liberdade, poderia "acabar de aprender o seu ofício" e "emendar-se de todas as faltas e ser pronto no serviço", para o que contaria com o auxílio de seu superior na milícia e mestre no trabalho, o qual, "por compaixão, promete fardá-lo com brevidade, uma vez que o mesmo suplicante se conservou em sua companhia". Fechando o ciclo de controle social que se iniciou com a prisão militar, a liberdade foi concedida pelo coronel Ribeiro tão logo se firmou o compromisso atinente à disciplina militar e civil do soldado-aprendiz. ${ }^{222}$

É de se presumir que os próprios mestres e oficiais artesãos passaram por processo de aprendizagem nos mesmos moldes e que parcela considerável deles aproveitou o processo como oportunidade para obtenção de estabilidade e enraizamento social, aspectos especialmente necessários para ex-escravos e seus descendentes, dos quais muitos sequer conheciam ou contavam com o auxílio paterno. ${ }^{223}$ Apesar da recorrência dessa relação no universo colonial e escravista, a desigualdade de forças e os interesses eventualmente divergentes entre as partes frequentemente geravam casos de conflito entre aprendizes e seus mestres artesãos. Relatou-se que o tambor pardo, referido acima, que fora compulsoriamente introduzido na casa e tenda de seu alferes, fugira do poder deste por não menos que sete vezes. Em uma outra situação, ocorrida em 1818, um cabo do regimento dos pardos moveu processo judicial contra seu tio, um mestre do ofício de alfaiate e também alferes dos Úteis, requerendo a parte que lhe cabia referente à herança legada por seus finados pais, a qual, como ele próprio, ficara sob a tutela do tio. Buscando demonstrar que sua conduta era honrada e seus protestos dignos, o cabo pardo argumentou que, embora tivesse começado a aprender o ofício com o tio, foi depois que mudou para Atibaia e passou a trabalhar com o tenente pardo e mestre alfaiate Lourenço Miguel de Siqueira é que de fato aprendeu o ofício, através do qual pôde adquirir um capote para si e se

${ }^{222} C f:$ : APESP, ordem C00279, doc. 42a-4-64.

${ }^{223}$ Cf:: Livro Mestre. Ver também o capítulo 4 desta tese. 
casar. ${ }^{224}$ Essas situações mostram que os aprendizes faziam valer a parcela reduzida de retenção de poder que lhes cabia na relação estabelecida com seus mestres e comandantes milicianos. ${ }^{225}$

De sua parte, em tais relações de poder os mestres e oficiais milicianos empregavam recursos mais abundantes e consistentes, pois eram amparados na simbiose entre as corporações. Em 1820, um porta-bandeira foi destituído do posto por seus superiores, tornandose simples soldado, sob a alegação de que se eximia do serviço militar e era extremamente insubordinado. Ao requerer a readmissão ao posto, o soldado instou o capitão e o coronel a apresentarem suas versões para o ocorrido, decorrendo daí a construção de um argumento que expressa nitidamente a coesão existente entre os oficiais pardos no tocante aos vínculos entre a milícia e as corporações de ofício, dois universos interligados por relações de poder. Conforme o argumento do capitão, que era respaldado pelo comandante do Regimento, o porta-bandeira decaído "foge muito com o corpo ao serviço" militar, "porque estando comigo aprendendo o ofício de alfaiate, de repente aborreceu-se, disse-me [...] que queria ser ourives", mas logo abandonou esse outro ofício "e por isso agora nem é alfaiate e nem ourives". ${ }^{226}$ O que salta aos olhos é a forma adotada para se demonstrar a insubordinação e fuga ao serviço militar imputadas ao subalterno, recorrendo-se exclusivamente à evasão do soldado ao aprendizado de ofícios, aspecto que não teria, formalmente, qualquer relação com o universo militar.

Entretanto, na dinâmica de funcionamento do Regimento dos Úteis, o controle que os oficiais exerciam sobre os subordinados não se restringia ao âmbito dos ofícios mecânicos, uma vez que envolvia outros setores de atividade. Em 1813, o coronel Manoel José Ribeiro conduziu um soldado pardo à prisão militar e justificou seu ato recorrendo ao comportamento do subordinado, o qual agia "muito libertinamente" e se atrevia a maldizê-lo publicamente. A versão do soldado era diferente. Conforme relatou, recebera bofetões do coronel e fora preso em razão de não lhe haver entregado uma carga de laranjas e farinha, como costumeira e gratuitamente fazia. Quanto ao recebimento desses alimentos, Ribeiro contra-argumentou indicando que eles eram o pagamento em espécie relativo a fazendas que o soldado comprara em sua loja. O mais importante, porém, é que testemunhas pertencentes ao Regimento confirmaram que o soldado preso trabalhara alguns dias em uma obra do coronel, e que essas jornadas e as cargas de alimentos eram uma espécie de pagamento para o "livrar do manejos dos dias Santos do natal passado" - esse um exercício rotineiro dos milicianos, como se pôde

\footnotetext{
${ }^{224} C f$ : : Arquivos Históricos do Centro de Memória - UNICAMP. TJESP, Comarca de Jundiaí, processo 0119.

${ }^{225}$ ELIAS, N. Introdução à sociologia. Lisboa: Edições 70, 2005, p. 80-96.

${ }^{226} C f:$ : APESP, ordem C00279, doc. 42a-4-11.
} 
ver no calendário da milícia. ${ }^{227}$ Portanto, evidencia-se que os oficiais do Regimento esforçavam-se em converter o capital social que manejavam na milícia em capital socioeconômico na esfera particular - em um relacionamento típico de estruturas sociais nas quais não havia completa dissociação entre público e privado. ${ }^{228}$ Os elementos estavam de tal modo imbricados que é dificultoso separar as relações entre credor e devedor, oficial miliciano e soldado, e o serviço miliciano das atividades econômicas em geral. Ora, nesse arranjo informal, a isenção do serviço miliciano podia ser obtida mediante pagamento ou prestação de serviço aos comandantes na esfera civil, mas, no caso de eventuais dívidas ou faltas no âmbito do trabalho, estas se reconvertiam, levando os subordinados à prisão militar.

Embora relações dessa natureza não fossem amparadas legalmente, como práticas de controle social elas eram amplamente reconhecidas e legitimadas, inclusive pelas autoridades das mais altas instâncias administrativas, podendo-se crer que eram vigentes, a depender das características das diferentes configurações sociais, em todo o mundo escravista iberoamericano até boa parte do século XIX. Contudo, em São Paulo, a pequena corte dos oficiais milicianos pardos, presidida por seu coronel - um homem liberto e portador de título de nobreza - e que tinha como base de sustentação centenas de soldados ou "súditos", como por vezes estes aparecem nas fontes ${ }^{229}$, não estava isolada do mundo. A partir do momento em que aqueles homens pertencentes à elite dos pardos livres, investidos em posições de autoridade e prestígio tanto na milícia como no universo artesanal, demonstravam incapacidade em gerenciar as tensões internas ao grupo e em impedir que estas transbordassem para fora de sua jurisdição, a autoridade neles investida passava a ser alvo de questionamentos incisivos. ${ }^{230}$ Como desafiantes à elite parda concentradora das frações mais expressivas de poder naquela configuração social específica, apresentavam-se indivíduos ou pequenos grupos hierarquicamente subordinados, dotados das menores parcelas de poder nas relações com os superiores, ou seja, oficiais inferiores e soldados, e, para além da milícia, aprendizes de ofícios e clientes/dependentes. Mas também os competidores alocados em níveis mais elevados da sociedade, a exemplo de oficiais

\footnotetext{
${ }^{227}$ Cf:: APESP, ordem C00264, pasta 2, docs. 27 e 36. Sobre o calendário ou cronograma das atividades da milícia, veja-se o capítulo 3 , item 3.3 .

${ }^{228}$ NOVAIS, F. A. Condições da privacidade na Colônia..., p. 13-39; FRANCO, M. S. de C. Homens livres na ordem escravocrata..., p. 111-162.

${ }^{229}$ Até mesmo os governadores coloniais referiam-se aos subordinados da milícia como "súditos" dos respectivos coronéis. Para exemplos, ver APESP, Ordem C00444, Livro 246, fl. 10; "Circular aos Coronéis de Milícias”. São Paulo, 24 de fevereiro de 1821. DIHCSP, vol. 37, p. 84-85.

${ }^{230}$ SILVA, Luiz Geraldo. Da festa à sedição: sociabilidades, etnia e controle social na América portuguesa (17761814). História: Questões \& Debates, Curitiba, n. 30, p. 83-110, 1999; SILVA, Luiz Geraldo. Governos e reinados negros. Conflito, hierarquia e poder entre crioulos e africanos (Pernambuco, 1750-1814). In: Ninth Internacional Congress Brazilian Studies Association (BRASA IX), 2008, New Orleans. New Orleans: Tulane University, 2008. v. 1 .
} 
militares brancos e governadores, estavam atentos à dinâmica social do universo dos pardos e aproveitavam as fissuras em sua estrutura de poder para nela estenderem sua própria influência.

A conjunção de aspectos corriqueiros da dinâmica de funcionamento da milícia - tais como a obtenção de licença das atividades militares para o desempenho dos ofícios mecânicos, solicitações de transferência para corpos militares de brancos e a convocação para o destacamento da cidade - eram capazes de desencadear crises de autoridade e contestações aos poderes estabelecidos. Em 1819, um cabo pardo obteve nove meses de licença para concluir seu trabalho de marcenaria na residência de Anastácio de Freitas Trancoso, um coronel branco de outro regimento. Findado esse período, o cabo foi chamado para servir na guarnição da cidade de São Paulo, mas, gozando da proteção do coronel branco, seu empregador, e desrespeitando a autoridade do coronel pardo, não se apresentou. Pouco tempo depois, requereu transferência para um regimento de homens brancos. Ao recorrer a essa prática, especialmente problemática no universo das milícias de cor, e ao desautorizar os seus comandantes, o cabo inflamou o rancor dos oficiais pardos.

Na ocasião, o seu capitão não consentiu à passagem pretendida e elencou como justificativa uma série de fatores: por ser pardo, deveria servir entre os pardos; era uma peça necessária ao Regimento em virtude de ser músico e estar fardado; inexistiam queixas da parte do suplicante que justificassem a sua saída da corporação; a transferência supostamente objetivaria a um abrandamento do serviço miliciano; e, por fim, abriria "caminho a toda a companhia para requererem o mesmo". ${ }^{231}$ A possibilidade de que o Regimento se atrofiasse mediante a migração constante de vários de seus soldados para outras tropas revela o entrelaçamento existente entre um caso pontual e todo o equilíbrio de poder vigente na configuração social formada no interior do Regimento dos Úteis, expressando claramente a preocupação da oficialidade parda com o funcionamento e manutenção dessa teia de poder.

Ao coronel Ribeiro coube ir ainda mais fundo na defesa de sua posição e do corpo militar que chefiava. Em primeiro lugar, ele denunciou que os comandantes dos outros corpos militares paulistas costumavam aliciar os melhores soldados pardos, aqueles que estavam fardados, disciplinados e hábeis, deixando para os Úteis apenas os "refugados", "só a fim deste Regimento nunca poder luzir". ${ }^{232}$ Tal aspecto está longe de constituir mera retórica. Em realidade, o afã dos oficiais pardos e pretos no sentido de elevarem os seus regimentos a merecedores do reconhecimento e da estima pública e governamental, tantas vezes mencionado

${ }^{231} C f$ : : APESP, ordem C00278, doc. 42-2-65. São Paulo, 16 de janeiro de 1819.

${ }^{232}$ Cf:: APESP, ordem C00278, doc. 42-2-65. São Paulo, 17 de janeiro de 1819. 
por observadores estrangeiros, fazia parte de uma competição travada com os demais corpos militares. Eles buscavam associar, para si próprios e para os grupos sociais outsiders aos quais pertenciam, o brio, honra e dignidade mais facilmente aceitos em seus corpos militares. ${ }^{233}$

Em segundo lugar, Ribeiro questionou asperamente a intromissão do coronel branco Trancoso, que, segundo a sua perspectiva, agiu fomentando a "insubordinação a um súdito de diferente Corpo" e sobrepondo-se à autoridade dos oficiais pardos. Para o coronel pardo, os seus adversários agiam "talvez julgando que, por serem brancos, são meus superiores; porém, enganam-se, que eu sou mais antigo e mais pronto para o serviço, e muito humilde para os meus superiores, porém nunca foi do meu gênio receber desfeitas de outros da minha graduação". ${ }^{234}$ Vê-se o ponto em que se obrigou a chegar o comandante pardo, reafirmando a noção de que a graduação e os méritos atinentes ao serviço militar eram preponderantes em relação à cor e defendendo a sua igualdade perante Trancoso e quaisquer outros coronéis brancos. Já desde a segunda metade do Setecentos que oficiais pardos, aqui e acolá, vinham construindo e reforçando tais argumentos com o sentido de promoverem uma equiparação social entre os da sua cor e os brancos através da milícia. ${ }^{235}$ Mas, para além dessa faceta, em São Paulo a retórica empregada e as ações sociais que lhe deram sentido são indicativos da crise de autoridade vivenciada pelos oficiais pardos em relação a seus subordinados; elas igualmente acenam para a abertura de espaços que possibilitavam que esses se livrassem do poder daqueles, tanto no universo militar como no artesanal, ainda que essa desvinculação significasse pouco mais que tornar-se "súdito" de outros senhores. Ela revela, finalmente, a articulação existente entre, de um lado, a competição pelas posições de autoridade e poder envolvendo governadores, altos oficiais militares, oficiais da tropa regular e oficias pardos, e, de outro, as disputas e tensões que se processavam no universo particular dos pardos livres e forros de São Paulo na transição do Antigo Regime para o liberalismo.

Nesse momento, era corrente entre as mais altas autoridades militares de São Paulo a noção de que "as necessidades do chefe e de muitos oficiais" pardos "obriga-os a um tratamento que lhes não podia competir", dando causa a "uma grande parte do clamor geral dos soldados". O brigadeiro inspetor geral das milícias era enfático quanto ao extravasamento dos conflitos

\footnotetext{
${ }^{233}$ KRAAY, Hendrik. Política racial..., p. 140-141; Orlando Patterson considera que a aquisição de estima social era um dos pilares da transformação de status dos libertos e de seus descendentes. Ver o seu livro Escravidão $e$ morte social. São Paulo: Edusp, 2008, p. 341-368.

${ }^{234}$ Cf:: APESP, ordem C00278, doc. 42-2-65. São Paulo, 17 de janeiro de 1819. O grifo é meu.

${ }^{235}$ Cf:: AHU_CU_015, Cx. 122, D. 9319. Recife, 20 de abril de 1776; AHU_CU_014, Cx. 29, D. 2141. Paraíba, ant. 19 de abril de 1785 . Ver também a perspectiva processual dos embates entre milicianos pardos e brancos na tese de Priscila de Lima Souza, "Sem que lhes obste a diferença de cor": a habilitação dos pardos livres na América portuguesa e no Caribe espanhol (c. 1750-1808). Tese (doutorado em História). São Paulo: FFLCH, Universidade de São Paulo, 2017.
} 
internos aos milicianos pardos, os quais chegavam até ele: “o certo é que este Regimento só tira-me mais tempo do que dez Regimentos de brancos". ${ }^{236}$ A gota d'água foi quando, em janeiro 1821, chegaram às mãos do governador de São Paulo duas cartas anônimas, as quais apresentavam denúncias contra o coronel pardo. Na primeira delas, “os infelizes indivíduos do Regimento dos Úteis" solicitaram a substituição do coronel sob a alegação de que Manoel José Ribeiro "vive à nossa custa e tem enriquecido com o nosso suor e trabalho; e, apesar de tantos sacrifícios, somos tratados piores que escravos". Já na segunda carta, assinada por "um militar", afirmava-se que o coronel dos pardos, estando na Corte do Rio de Janeiro, reunira documentação através da qual contestaria, perante o rei, a administração do governador e capitão-general de sua capitania, João Carlos Augusto de Oeynhausen. Sob tais circunstâncias, o governador revelou a seu interlocutor na Corte que, após muito contemporizar, tomou medidas para conter o excesso de poder exercido pelo referido coronel aos seus subalternos, o qual, a partir de então, tornara-se seu desafeto. ${ }^{237}$

A primeira dessas medidas consistiu em uma dura repreensão que teve lugar ainda em fins de janeiro de 1821. Por meio de um ofício, o governador censurou o coronel pardo por tratar "indecorosamente" aos "seus oficiais" e por "se ingerir [...] no pagamento dos tambores". Também o alertou acerca da vulnerabilidade de sua situação: "repare que, qualquer falta sua à execução desta ordem, o sujeitará (muito contra a minha vontade) às penas que traz consigo a insubordinação e desobediência, e muito particularmente se equivalem a qualquer dessas faltas e as agravam infinitamente". ${ }^{238}$ Essa crise não deve ser lida em termos estritamente pessoais, já que ela resultou na reconfiguração do equilíbrio de forças entre pardos e brancos no Regimento dos Úteis, o qual, agora, pendia ainda mais para os últimos. É que o governo paulista tomou rapidamente uma segunda e ainda mais drástica medida: providenciou a troca do comando do Regimento. Em fevereiro de 1821, o velho coronel Ribeiro obteve sua reforma, mas continuou gerindo a corporação até setembro daquele ano, quando entregou para o seu substituto o posto que ocupara por mais de uma década. No curto intervalo de tempo decorrido desde as denúncias até o seu definitivo afastamento, o coronel pardo recebeu outra grave admoestação, agora da parte do governo provisório, o que sugere que as tensões internas ao Regimento poderiam ter sido a principal causa de sua queda. Nesse segundo ofício, datado de julho de 1821, o coronel

\footnotetext{
${ }^{236} C f$ : APESP, ordem C00264, doc. 32-2-28 e doc. 32-2-29.

${ }^{237} C f::$ BN/dm, doc. ii-35,26,56.

${ }^{238} C f .:$ DIHCSP, vol. 37, p. 71. São Paulo, 29 de janeiro de 1821.
} 
pardo era instado a "abster-se de castigos arbitrários de que, sem interrupção, se queixam os oficiais e soldados do seu Regimento". 239

Algo muito semelhante ocorreu com o último coronel miliciano pardo da Cidade do México, deposto na segunda metade do Setecentos, o qual fora acusado de extorquir e corromper os subordinados de seu corpo militar, além de se ter envolvido em confrontos abertos com a oficialidade branca do batalhão, como bem examinou Ben Vinson III. ${ }^{240} \mathrm{Em}$ Pernambuco, o governador José César de Menezes (1774-1787) também acusou a oficialidade parda de impor arbitrariedades e ilicitudes aos soldados. ${ }^{241}$ Deve-se ter em mente, todavia, que todos os regimentos ou batalhões configuravam-se como equilíbrios de poder instáveis, e que certamente as colisões entre oficiais e soldados não eram exclusivas do universo dos pardos. ${ }^{242}$ No entanto, se a derrocada dos referidos coronéis pardos se relacionava diretamente com o rompimento de instabilidade nos setores intermediários da sociedade, a concorrência representada pelos oficiais brancos com carreira nas tropas profissionais complementou a já difícil situação daqueles comandantes milicianos. Em São Paulo, como em Salvador e na Cidade do México, militares brancos requeriam expressamente o acesso àqueles postos superiores, já que a graduação, privilégios e honras entre milícias e tropas pagas eram equivalentes e em nada eram comprometidas por se tratar de milícia de pardos ou de pretos. ${ }^{243}$ Não por acaso, pois, o substituto de Manoel José Ribeiro no coronelato do Regimento dos Úteis foi um branco egresso da tropa regular. ${ }^{244}$

\footnotetext{
${ }^{239}$ Cf:: DIHCSP, vol. 37, p. 139. São Paulo, 18 de julho de 1821.

${ }^{240}$ VINSON III, Ben. Bearing arms for his majesty..., p. 70-78.

${ }^{241}$ Cf:: AHU_CU_015, Cx. 144, D. 10544. Recife, 13 de abril de 1782.

${ }^{242}$ Vide, por exemplo, o caso de "despotismo" do coronel Policarpo Joaquim de Oliveira, ocorrido na capitania de São Paulo, em Nanci LEONZO. Defesa militar e controle social na capitania de São Paulo: as milícias. Tese de doutorado. São Paulo: PPGHS/FFLCH da Universidade de São Paulo, 1979, p. 95-106. Ademais, em duas ocasiões o governador Franca e Horta revelou preocupação com os abusos que os superiores perpetravam aos inferiores nos corpos militares paulistas. Ver, novamente, LEONZO, Nanci. Defesa militar..., p. 200 e p. 259-260, nota de rodapé $\mathrm{n}^{\circ}$ 427; APESP, Ordem C00422, Livro 176, fls. 44-45. São Paulo, 5 de setembro de 1807. Por fim, H. Kraay encontrou inúmeros vestígios de relações conflituosas, de semelhante natureza, no tocante às tropas pagas de Salvador. KRAAY, Hendrik. Política racial, Estado e Forças Armadas na época da independência: Bahia, 1790 1850. São Paulo: Hucitec, 2011, p. 113-114, 119-120.

${ }^{243}$ KRAAY, Hendrik. Política racial, Estado e Forças Armadas na época da independência: Bahia, 1790-1850. São Paulo: Hucitec, 2011, p. 134; VINSON III, Ben. Bearing arms for his majesty..., p. 70-78.

${ }^{244}$ Cf:: Livro Mestre, fls. 1-1v.
} 
A qualificação profissional contribuía decisivamente na elevação dos artesãos aos postos da milícia, aspecto que resultava na diferenciação entre a oficialidade parda e os oficiais de todos os demais corpos milicianos de homens brancos. Complementarmente, o aparato miliciano fornecia base recorrente no exercício de controle dos mestres sobre seus subordinados. De forma mais ampla, o vínculo entre a milícia e artesanato desempenhava funções sociais essenciais àquela sociedade: além de otimizar a organização da esfera do trabalho e da vida militar, funcionava como instrumento de controle social àquele vasto grupo humano. Os oficiais milicianos e mestres artesãos exerciam práticas caracterizadas por elementos autoritários e paternais, típicos da sociedade de Antigo Regime. Vai daí também a opacidade da fronteira entre público e privado que estava na base de tais relações e práticas sociais.

Além disso, o ensino e aprendizagem dos ofícios mecânicos no universo dos pardos livres deve ser pensado como relação de mão dupla. Do ponto de vista dos mestres artesãos, o esforço despendido na introdução dos aprendizes nos mistérios do ofício poderia ser parcialmente recompensado pelo auxílio prestado por estes nas tarefas diárias da tenda artesanal. A ampliação dos dependentes nas esferas conectadas do trabalho e na hierarquia miliciana poderia propiciar ao mestre artesão e oficial miliciano uma ampliação de sua visibilidade social e ganho de status. Da perspectiva dos aprendizes, a qualificação profissional significaria, no longo e médio prazo, oportunidades relevantes de estabilidade e reconhecimento social. Não por acaso, vários daqueles homens se tornariam figuras proeminentes na comunidade dos pardos livres. Mas, de imediato, obteriam apenas a instrução e proteção de seus mestres. Talvez os rigores e dificuldades das relações que vivenciavam a partir das posições inferiores acentuassem o quadro de tensões preexistentes. Seja como for, todos jogavam aquele jogo com os instrumentos que tinham à disposição.

Como fica claro, a ascensão e o reconhecimento social dos pardos livres e forros de São Paulo estavam assentados em uma vasta teia de poder que abrangia os milicianos, suas famílias e dependentes. Por um lado, promoveu-se a harmonização dos interesses dos eventuais concorrentes mediante as promoções dos postos da milícia e, por outro, a oficialidade parda, coesa, pôde estender seus tentáculos à soldadesca. As extensivas funções sociais desempenhadas pelo coronel pardo e pelos oficiais de patente dos Úteis, sob a batuta das autoridades brancas de São Paulo, acenam para a vigência de relações de poder complexas entre os próprios pardos. Elas indicam que os processos de ascensão social vivenciados por aqueles libertos ou descendentes de escravos e de administrados estavam assentados também na manutenção e reprodução da diferenciação em relação aos subordinados pardos. Esse equilíbrio 
de poder manteve-se estável por anos, até que o acúmulo de tensões extravasou os limites do Regimento e se tornou um problema para a administração dos governadores e capitães-generais da capitania e, ao mesmo tempo, uma oportunidade de ação para os oficiais brancos que almejavam os postos superiores do Regimento e àqueles que projetavam o fim da oficialidade parda ou mesmo de toda a corporação. 


\section{CAPÍTULO 7 - MILICIANOS PARDOS EM UM CAMPO DE TENSÕES (II): A INDEPENDÊNCIA DO BRASIL E A NOBILITAÇÃO DE OFICIAIS}

\subsection{O Regimento dos Úteis e seus integrantes pardos na independência do Brasil}

Entre os anos 1820 e 1822, o Reino Unido de Portugal, Brasil e Algarves esteve novamente às voltas com expressões e desdobramentos da Era das Revoluções. Pouco mais de uma década após a transferência da Corte portuguesa para a América, eclodiu a Revolução do Porto, em agosto de 1820, e daí em diante uma sucessão de fatos e processos alteraram completamente a sua organização política. Alguns dos mais importantes foram a formação de uma assembleia constitucional em Lisboa, a eleição de deputados europeus e americanos e a sua participação nos debates, a composição de juntas de governo nas províncias em substituição à estrutura colonial de governo das capitanias, o retorno do rei D. João VI a Portugal, a permanência do príncipe D. Pedro no Brasil, o acirramento das tensões envolvendo os projetos políticos apresentados nas Cortes, a abertura de uma assembleia constituinte no Brasil e a independência brasileira.

Enquanto isso, em São Paulo, a milícia dos pardos vivia os seus próprios problemas. Ela estava sendo recorrentemente requisitada para compor o destacamento da capital, grupos menores compostos de seus oficiais e soldados eram eventualmente deslocados para guarnecerem as regiões litorâneas e, em vilas interioranas marcadas por agitações escravas, como Itu, foram mobilizados para impor a ordem requisitada pelos proprietários dos canaviais. ${ }^{1}$ Entretanto, não foi somente o seu papel relevante na prestação de serviço militar em face da escassez de tropas regulares o que marcou o Regimento dos Úteis nesse contexto. Em meio à sua configuração social particular, ocorria, por esses anos, um reordenamento no exercício de poder provocado pelo acirramento das tensões entre oficiais pardos e oficiais brancos e entre os próprios oficiais e soldados pardos. As graves denúncias e acusações relativas ao coronel pardo que, em janeiro de 1821, chegaram anonimamente às mãos do governador e capitãogeneral Oeynhausen culminaram na sua substituição por um militar branco da primeira linha,

\footnotetext{
${ }^{1}$ Sobre a atuação dos milicianos pardos nos destacamentos da capital, ver o capítulo 3. A formação de rondas milicianas em Itu foi analisada por RICCI, Magda Maria de Oliveira. "Nas fronteiras da independência". Um estudo sobre os significados da liberdade na região de Itu (1779-1822). Dissertação (mestrado em História). Campinas: IFCH, Universidade Estadual de Campinas, 1993, p. 240-242. Já a participação dos milicianos pardos como sentinelas nas vilas costeiras é atestada nas folhas de serviço contidas no Livro Mestre. Ver, por exemplo, fls. $10-11$ v e 58 .
} 
cuja transição ocorreu ao longo do período compreendido entre fevereiro e setembro de $1821 .^{2}$ Essa circunstância provavelmente era lida pela oficialidade de cor como uma afronta à sua autonomia e dignidade e, ao mesmo tempo, uma demonstração de força por parte dos grupos que se opunham ao acesso dos pardos aos principais postos militares ou que simplesmente almejavam tais posições. Ademais, o projeto de extinguir a milícia parda fora novamente posto à mesa pelo inspetor geral de milícias, José Arouche de Toledo Rendon, no segundo semestre de 1821, no âmbito de uma comissão militar que deveria "formar o Plano da organização das Tropas desta Província". ${ }^{3}$ Simultaneamente à aquisição de um protagonismo na execução de tarefas militares, a milícia parda sofria os mais duros ataques entre os anos de 1820 e 1821.

O objetivo desta seção é justamente compreender as formas de inserção dos milicianos pardos no jogo político a partir do entrelaçamento entre essas duas dimensões aparentemente tão distantes uma da outra - o quadro de transformações políticas da Era das Revoluções e a configuração social específica do Regimento dos Úteis - nos anos de 1820 a 1824. Evidentemente, a resolução da questão elementar que versa sobre a participação dos milicianos pardos nos fatos e processos relacionados à independência do Brasil se ancora na perspectiva da milícia como um campo particular de competições - a exemplo do que tem sido feito até aqui. Isso implica dizer que muito do que os milicianos pardos sentiam, interpretavam, aspiravam e de como agiam naquela conjuntura pode ser compreendido mediante a consideração de sua posição em meio aos equilíbrios de poder nos quais eles estavam inseridos. Trocando em miúdos, significa reconhecer que aqueles homens tinham objetivos específicos em jogo, encaravam suas próprias lutas, e que, finalmente, reside aí, em parte, o fundamento dos seus movimentos. Consequentemente, o argumento conforme o qual os pardos vivenciaram as transformações políticas e sociais da década de 1820 a partir de sua imersão no universo da milícia permite matizar a ideia de que aqueles segmentos sociais foram politicamente vacilantes ou mobilizados em favor de interesses alheios aos seus por meio de práticas "populistas". ${ }^{4}$

Essa perspectiva tende a privilegiar o segmento específico constituído pela oficialidade miliciana, deixando em segundo plano a multidão de soldados. Isso decorre, de um lado, da natureza das fontes primárias e, de outro, do próprio equilíbrio de forças existente entre os

\footnotetext{
${ }^{2}$ Cf:: Livro Mestre, fls. 1-1v.

${ }^{3}$ Cf.: DIHCSP, vol. 37, p. 162-164, 180 e 202. São Paulo, 16 de agosto, 3 de setembro e 9 de outubro de 1821.

${ }^{4}$ Caio Prado Jr. ofereceu uma interpretação pessimista acerca da participação popular na independência do Brasil, caracterizando-a a partir da noção de falta de consciência política. PRADO Jr., Caio. Evolução política do Brasil. Colônia e Império. 15a ed. São Paulo: Editora Brasiliense, 1986. p. 65-68. A aplicação do conceito de populismo para o contexto em questão se encontra em MELLO, Evaldo Cabral de. A ferida de Narciso. Ensaio de História Regional. São Paulo: Ed. do SENAC, 2001, p. 69 e 85; e em KRAAY, Hendrik. Identidade racial na política, Bahia, 1790-1840: o caso dos Henriques. In: JANCSÓ, István (Org.). Brasil: formação do Estado e da nação. São Paulo/Ijuí: Hucitec/Unijuí/FAPESP, 2003, p. 536.
} 
milicianos. É que, pela posição hierárquica em que se encontravam, os oficiais apresentavam níveis mais elevados de coesão em relação aos soldados e dispunham de instrumentos e oportunidades de expressão mais abundantes e eficazes. Por essa razão, os vestígios da atuação social e política dos milicianos pardos na década de 1820, que já são escassos comparativamente aos referentes aos milicianos brancos, dizem respeito predominantemente à oficialidade.

Inúmeros trabalhos vêm, desde meados do século XIX, interpretando os fenômenos políticos que tiveram lugar em São Paulo na conjuntura constitucionalista que culminou na independência do Brasil. ${ }^{5}$ Destacam-se, neles, o interesse relativo à configuração das elites paulistas em meio a um equilíbrio de poder instável e a ênfase na atuação da província junto ao bloco de apoio ao regente D. Pedro e à causa da independência. É nessa linha que têm sido examinados os principais fatos históricos vividos localmente, a saber, a reação paulista à Revolução do Porto, a adesão às Cortes lisboetas e a formação de uma junta de governo conciliadora, a eleição e a atuação dos seus deputados em Lisboa, o apoio à permanência do príncipe regente no Brasil, o protagonismo político de José Bonifácio de Andrada e Silva, o envio de tropas para o Rio de Janeiro, as dissensões no interior da junta de governo, e a posição de sustentáculo ao projeto independentista encabeçado por D. Pedro.

\footnotetext{
${ }^{5}$ OLIVEIRA, José Joaquim Machado de. Quadro Historico da Provincia de S. Paulo até o anno de 1822. São Paulo: Typografia Brasil de Carlos Gerke, 1897; AQUINO E CASTRO, Olegario Herculano de. O conselheiro Manoel Joaquim do Amaral Gurgel. Elogio historico e noticia dos successos políticos que precederam e seguiramse á proclamação da independencia na província de S. Paulo. RIHGB, tomo 41, parte 2. Rio de Janeiro: Typ. de Pinheiro \& C., 1878, p. 237-376; PIZA, Antonio de Toledo. Martim Francisco e a Bernarda. RIHGSP, vol. 5, 1901, p. 48-78; PIZA, Antonio de Toledo. A Bernarda de Francisco Inacio - Suas causas e suas consequências. RIHGSP, vol. 10, 1906, p. 126-177; ROMEIRO, João Marcondes de Moura. De D. João VI à independência. In: Revista do Instituto Histórico e Geográfico Brasileiro. Tomo especial - Primeiro Congresso de História Nacional (7-16 de setembro de 1914). Parte 1. Rio de Janeiro: Imprensa Nacional, 1915, p. 1351-1507; HOLANDA, Sérgio Buarque de. São Paulo. In: HOLANDA, S. B. de (Dir.). História geral da civilização brasileira. (t. II, $2^{\circ}$ vol.). São Paulo: Difusão Européia do Livro, 1967, p. 415-472; WERNET, A. O processo de independência em São Paulo. In: MOTA, C. G. (Org.). 1822: Dimensões. São Paulo: Perspectiva, 1975, p. 340-354; LEONZO, Nanci. Defesa militar e controle social na capitania de São Paulo: as milícias. Tese (doutorado em História). São Paulo: FFLCH, Universidade de São Paulo, 1979, p. 344-352; DAMACENO, Daniel Tarifa. Os "facciosos" de São Paulo (Considerações acerca da Bernarda de Francisco Ignacio) 23.05.1822 - 25.08.1822. Dissertação (mestrado em História). São Paulo: FFLCH, Universidade de São Paulo, 1993; DELATORRE, Aparecida Vanessa. São Paulo à época da independência. Contribuição para o estudo do chamado movimento "bernardista", 1821/1823. Dissertação (mestrado em História). São Paulo: FFLCH, Universidade de São Paulo, 2003; DOLHNIKOFF, Miriam. São Paulo na independência. In: JANCSÓ, István (Org.). Independência: história e historiografia. São Paulo: Hucitec, 2005, p. 557-575; NEVES, Lúcia Maria Bastos P. das. São Paulo e a independência. In: SILVA, Maria Beatriz Nizza da (Org.). História de São Paulo colonial. São Paulo: Editora Unesp, 2009, p. 275-318; MEDICCI, Ana Paula. São Paulo en el movimiento de Independencia de Brasil (1820-1822). Nuevo Mundo Mundos Nuevos [Online], Debates, posto online em 11 abril 2013, consultado em 18 julho 2014. URL: http://nuevomundo.revues.org/65314; DOI: 10.4000/nuevomundo.65314; BORGES, Luiz Adriano. Aspectos econômicos da participação paulista no processo de independência. Almanack, Guarulhos, n.06, p. 61-80, 2. ${ }^{\circ}$ semestre de 2013.
} 
Praticamente restringindo o campo de observação aos grupos da elite, os historiadores pouco refletiram sobre o modo como os segmentos populares paulistas vivenciaram esses fenômenos ou parte deles, e, por conseguinte, não se atentou para a participação dos milicianos pardos, os quais, como visto, estavam permanentemente mobilizados como parte do destacamento militar que guarnecia a cidade e também como participantes das solenidades e cerimônias públicas. As narrativas tradicionais acerca da atuação das pessoas comuns naquele contexto politicamente turbulento foram produzidas nas décadas de 1960 e 1970, e tiveram como base fundamental a versão generalista de um viajante francês. Os relatos de Saint-Hilaire, conforme os quais a população paulista das áreas rurais era completamente "indiferente" às transformações políticas, mal sabendo o significado da palavra "constituição", tornaram-se argumentos de autoridade. ${ }^{6}$ Franco tomou-os como indicativo da "asfixia da consciência política" e da "incapacidade das camadas dominadas de se integrarem aos mecanismos de participação na vida política". ${ }^{7}$ De acordo com Wernet, a população rural, "inculta e atrasada", "mostrava-se, em sua maioria, alheia às teorias e aos movimentos, acompanhando passivamente os chefes locais". Retomando discussões de Caio Prado Jr. acerca da "ineficiência política das camadas inferiores da população brasileira" e de Emília Viotti da Costa sobre os limites ao desenvolvimento e à difusão da "consciência" e da "prática revolucionária", este mesmo historiador argumentou que não existiam na província "grandes cidades com população composta de muitos" artesãos "que eram facilmente contaminados pelos ideais revolucionários, como foram os casos de Rio de Janeiro e Salvador". Assim, foi possível a independência em São Paulo sem se "precisar recorrer à rebelião popular". 8

Alguns aspectos característicos dos milicianos pardos e de suas funções militares que foram ignorados por tais investigadores são suficientes, já de partida, para justificar uma revisão crítica das interpretações consolidadas e o intento de avançar nesse terreno pouco explorado. Refere-se tanto à composição profissional dos oficiais milicianos pardos, profundamente vinculados ao artesanato, como à relativa proximidade que eles mantinham para com os principais núcleos de poder político da província. Evidentemente, não se trata aqui de superestimar a participação dos homens pobres - e especialmente dos milicianos pardos - nas

\footnotetext{
${ }^{6}$ Cf:: SAINT-HILAIRE, A. de. Viagem à província de São Paulo. Belo Horizonte: Ed. Itatiaia; São Paulo: Ed. da Universidade de São Paulo, 1976, p. 48-50; SAINT-HILAIRE, A. de. Segunda viagem a São Paulo e quadro histórico da província de São Paulo. Brasília: Senado Federal, Conselho Editorial, 2002, p. 97-100.

${ }^{7}$ FRANCO, Maria S. de Carvalho. Homens livres na ordem escravocrata. $4^{\mathrm{a}}$ ed. São Paulo: Fundação Editora da UNESP, 1997, p. 82-84.

${ }^{8}$ WERNET, A. O processo de independência em São Paulo..., p. 340-354; PRADO Jr., C. Evolução política do Brasil. Colônia e Império [1933]. 15ª ed. São Paulo: Editora Brasiliense, 1986. p. 57-89; COSTA, Emília Viotti

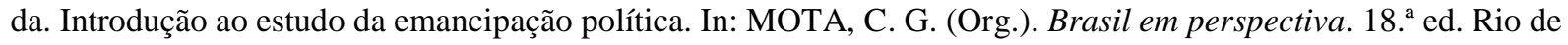
Janeiro: Ed. Bertrand Brasil, 1988, p. 90-101.
} 
decisões políticas da conjuntura da independência, mas, antes, de lançar luz sobre os seus objetivos, as suas opções, as suas perspectivas, para, enfim, compreender um pouco mais acerca dos seus comportamentos e atitudes militares e políticas.

Perspectivas historiográficas renovadas têm considerado dimensões específicas da participação dos milicianos pardos e pretos ibero-americanos nesse contexto transitório. Em primeiro lugar, conforme Garavaglia, o fenômeno das independências e da formação de Estados nacionais exigiu "o concurso de homens em armas". "Seja como votantes [...] ou como soldados milicianos, doravante o poder se basearia no número". Esse protagonismo dos homens armados “obrigou as elites a levar em consideração opiniões, desejos (e até exigências) dos setores populares anteriormente impensáveis". ${ }^{9}$ Assim, é pertinente identificar e buscar compreender as opiniões e anseios daqueles homens, os novos mecanismos formais ou institucionais de atuação política, bem como os enfrentamentos vivenciados por eles na qualidade de milicianos. Em segundo lugar, de acordo com Silva, os milicianos de cor encararam os desafios decorrentes daquela conjuntura a partir das tensões existentes entre, de um lado, as suas aspirações tradicionais por honras e mercês, e, de outro lado, o radicalismo político da ilustração e do liberalismo, que os colocava na condição de cidadãos, independentemente da cor parda ou preta. $^{10}$

A província de São Paulo atuou politicamente na conjuntura da independência "com uma influência que transcendia em muito sua importância econômica" nos quadros do Reino Unido de Portugal, Brasil e Algarves. ${ }^{11}$ Além das trocas e do abastecimento internos, São Paulo

\footnotetext{
${ }^{9}$ GARAVAGLIA, Juan C. Os primórdios do processo de independência hispano-americano. In: JANCSÓ, István (Org.). Independência: história e historiografia. São Paulo: Hucitec, 2005, p. 213. Grifos no original.

${ }^{10}$ SILVA, Luiz Geraldo. Aspirações barrocas e radicalismo ilustrado. Raça e nação em Pernambuco no tempo da independência (1817-1823). In: JANCSÓ, István (Org.). Independência: história e historiografia. São Paulo: Hucitec, 2005, p. 915-934. Sobre os debates acerca da inclusão de libertos e seus descendentes livres na condição de cidadãos, ver: BERBEL, Márcia Regina; MARQUESE, Rafael de Bivar. A ausência da raça: escravidão, cidadania e ideologia pró-escravista nas Cortes de Lisboa e na Assembléia Constituinte do Rio de Janeiro (18211824). In: CHAVES, C. M. das G.; SILVEIRA, M. A. (Orgs.). Território, conflito e identidade. Belo Horizonte: Argvmentvm; Brasília: CAPES, 2007, p. 63-88; SLEMIAN, A. Seriam todos cidadãos? Os impasses na construção da cidadania nos primórdios do constitucionalismo no Brasil (1823-1824). In: JANCSÓ, István (Org.). Independência: história e historiografia. São Paulo: Hucitec, 2005, p. 829-847. Acerca da relação entre cidadania e representação política no Brasil imperial, ver DOLHNIKOFF, Miriam. Representação política no Império. Anais do XXVI Simpósio Nacional de História - ANPUH. São Paulo, jul. 2011, p. 1-32.

${ }^{11}$ DOLHNIKOFF, Miriam. São Paulo na independência..., p. 557. Ver também semelhante afirmação em Oliveira Lima, que leu esse contexto como sendo o da emergência paulista na política imperial e depois republicana: LIMA, Oliveira. O movimento da independência. O Império brasileiro (1821-1889). 2. ${ }^{a}$ ed. São Paulo: Edições Melhoramentos, s.d., p. 100-101.
} 
redistribuía às capitanias/províncias circunvizinhas as tropas de muares vindas do Sul, provia Goiás e Mato Grosso de gêneros alimentícios, de escravos e de diversos produtos importados, e supria as demandas de víveres provenientes da Corte instalada no Rio de Janeiro. O açúcar tornara-se o seu principal produto de exportação, mas é preciso notar que, nas primeiras décadas do século XIX, a região ainda não havia atingido o seu ápice produtivo e portanto não figurava entre as grandes localidades açucareiras e escravistas. ${ }^{12}$ Embora São Paulo experimentasse um crescimento significativo, estava longe de figurar entre os maiores polos econômicos do Reino Unido. Apesar disso, é notável a importância desempenhada pela província na construção e manutenção do projeto político constituído em torno de um governo centralizado no Rio de Janeiro, cujo aspecto se evidenciou tanto na atuação dos deputados paulistas enviados às Cortes lisboetas quanto no apoio fornecido pelo governo local ao regente D. Pedro. ${ }^{13}$

Em agosto de 1820, a capitania era comandada pelo governador e capitão-general João Carlos Augusto de Oeynhausen, quando irrompeu em Portugal o movimento revolucionário do Porto, o qual desencadearia, em curto período de tempo, a formação de juntas provisórias para o governo das províncias europeias e das Cortes constituintes da nação portuguesa, essas reunidas em Lisboa a partir de janeiro do ano seguinte. As primeiras adesões de capitanias brasileiras ao movimento se deram entre janeiro e fevereiro de 1821, sendo esse o caso de Pará, Bahia, Piauí, Maranhão e Pernambuco, o que implicava, a cada uma delas, a transformação em província, o reconhecimento de subordinação política às Cortes e o dever de eleger e enviar deputados para a constituinte. ${ }^{14}$

Diferentemente, São Paulo aguardou um posicionamento formal do rei D. João VI e também uma espécie de acomodação dos interesses divergentes de suas elites para juntar-se ao movimento e jurar as bases da constituição, o que ocorreu em meados de março de $1821 .{ }^{15} \mathrm{Em}$

\footnotetext{
${ }^{12}$ Peter L. Einsenberg e Dauril Alden fornecem dados comparativos que permitem situar a produção paulista em relação à de outras localidades açucareiras, brasileiras ou não. Ver EINSENBERG, Peter L. Açúcar e mudança social no Brasil: Campinas, São Paulo, 1767-1830. In: EINSENBERG, Peter L. Homens esquecidos: escravos e trabalhadores livres no Brasil, séculos XVIII e XIX. Campinas: Editora da Unicamp, 1989, p. 343-344; ALDEN, Dauril. El Brasil colonial tardío, 1750-1808. In: BETHELL, Leslie (ed.) Historia de América Latina. (Vol. 3 América Latina colonial: economía). Barcelona: Editorial Crítica, 1990, p. 329-333.

${ }^{13}$ BERBEL, Márcia Regina. Os apelos nacionais nas cortes constituintes de Lisboa (1821/22). In: MALERBA, Jurandir (Org.). A independência brasileira. Rio de Janeiro: Editora FGV, 2006, p. 181-208.

${ }^{14} \mathrm{O}$ delineamento institucional da transformação das capitanias brasileiras em províncias é controverso na historiografia. Alguns autores, como Machado de Oliveira e Holanda a interpretaram como uma decorrência imediata da elevação do Brasil ao estatuto de reino, em 1815, e outros têm notado que a estrutura políticoadministrativa das capitanias perdurou até que elas aderissem às Cortes lisboetas, em 1821. Ver, por exemplo, OLIVEIRA, J. J. M. de. Quadro Historico da Provincia de S. Paulo..., p. 222; HOLANDA, S. B. de. São Paulo..., p. 438; BERBEL, M. R. Os apelos nacionais..., p. 185-186.

${ }_{15}$ WERNET, A. O processo de independência em São Paulo..., p. 346; NEVES, L. M. B. P. das. São Paulo e a independência..., p. 276-278. Pesquisas mais atuais têm matizado a ideia de que os paulistas devotavam completa fidelidade ao rei e vêm sugerindo que o seu comportamento político refletia interesses e condições específicos de
} 
abril, enquanto o rei se despedia do Brasil e regressava à Europa, apenas iniciavam-se os preparativos para a eleição dos deputados paulistas. Já a formação de uma junta governativa nos moldes das demais províncias se deu em junho, mediante a aclamação do "povo e tropa" conduzidos por José Bonifácio de Andrada e Silva, e em meio a um clima de agitação nas tropas de linha, que por duas vezes se amotinaram reclamando a equiparação de soldos em relação aos corpos militares lusitanos. ${ }^{16}$ Como demonstrou Leonzo, de tais quarteladas - e do decorrente escasseamento das forças militares regulares paulistas - resultou uma expressiva mobilização das milícias para o destacamento da capital ao longo de todo o segundo semestre de $1821 .{ }^{17}$ Alguns oficiais pardos, que presumivelmente presenciaram a aclamação dos membros da junta, fizeram questão de registrar em suas folhas de serviço a participação na guarnição durante esses meses, casos do capitão Antonio Joaquim da Costa Ribeiro e do alferes Pedro Antonio Ferreira. Ao fazê-lo, eles indicaram, indiretamente, que ao menos uma companhia completa do Regimento dos Úteis estava em serviço ativo e a par do que ocorria no terreno político. ${ }^{18}$

Uma vez formado o governo provisório paulista, a junta imediatamente reconheceu a autoridade do príncipe regente, no Rio de Janeiro, elegeu os deputados e elaborou um programa político a ser defendido nas cortes lisboetas, o qual fora sintetizado nas Lembranças e apontamentos do governo provisório de São Paulo para os seus deputados. ${ }^{19}$ Nesse mesmo ambiente de debate e de formulação de projetos para o futuro, que caracterizou o segundo semestre de 1821, é que se instalou a comissão militar destinada a reorganizar as forças militares, na qual se retomou a persistente ideia de abolir o Regimento dos Úteis. Entretanto, uma sucessão de acontecimentos nos dois lados do Atlântico atravessaram os trabalhos dessa comissão ao mesmo tempo em que reiteraram a importância dos milicianos pardos, comprometendo, assim, o ímpeto contrário à existência daquela milícia.

Enquanto a deputação paulista era formada e preparada, os trabalhos nas cortes iam avançando. Para se ter uma ideia, quando essa delegação chegou a Lisboa, em fevereiro de 1822, os constituintes europeus estavam reunidos havia mais de um ano e os primeiros deputados oriundos da América assumiram seus postos em agosto de $1821 .{ }^{20}$ Conforme Berbel, diferentes projetos políticos para a nação portuguesa eram discutidos nas cortes lisboetas, tendo

sua configuração social. Ver DAMACENO, D. T. Os "facciosos" de São Paulo...; DELATORRE, A. V. São Paulo à época da independência...; MEDICCI, A. P. São Paulo en el movimiento de Independencia..., §29.

16 OLIVEIRA, J. J. M. de. Quadro Historico da Provincia de S. Paulo..., p. 236; DAMACENO, D. T. Os "facciosos" de São Paulo..., p. 80-94; NEVES, L. M. B. P. das. São Paulo e a independência..., p. 279-282.

${ }^{17}$ LEONZO, Nanci. Defesa militar e controle social..., p. 344-345.

${ }^{18}$ Cf:: Livro Mestre, fls. 11v e 58.

${ }^{19}$ WERNET, A. O processo de independência em São Paulo..., p. 347-348; BERBEL, M. R. Os apelos nacionais..., p. 192-193; NEVES, L. M. B. P. das. São Paulo e a independência..., p. 285-286.

${ }^{20}$ BERBEL, M. R. Os apelos nacionais..., p. 188 e 192. 
sido dominante, no primeiro ano de atividades dos deputados, a perspectiva integracionista veiculada pelos líderes da Revolução do Porto. Essa defendia uma integração total das partes constituintes da nação, primando pela unidade e pela centralização das instâncias executivas, legislativas e judiciárias em Lisboa, e tinha consequências evidentes para a América:

Sinteticamente, a proposta estabelecia que: a) as capitanias do Brasil seriam transformadas em províncias; b) os governadores nomeados por $\mathrm{d}$. João estavam depostos, e juntas provinciais deveriam assumir o controle dos governos regionais; c) as juntas já formadas, como a da Bahia e a do Pará, eram reconhecidas como legítimos governos provinciais; d) estes teriam seus presidentes subordinados às cortes e ao rei; e) não teriam qualquer autoridade militar, e um governo de armas deveria ser formado em cada província, também submetido a Lisboa; f) todos os órgãos de governo formados no Rio de Janeiro depois da transferência da corte deveriam ser extintos; g) o príncipe regente deveria voltar para a Europa, retirando do Brasil o estatuto de uma unidade política como relativa autonomia. ${ }^{21}$

Todos esses itens constam da proposta de decreto discutida e aprovada entre os meses de agosto e setembro de 1821. A anuência de deputados pernambucanos e fluminenses revela, entre outras coisas, que a posição de D. Pedro como regente do Brasil era ainda bastante frágil e que a centralização política no Rio de Janeiro era indesejada em muitas províncias em face do anseio de autonomia que nelas já se esboçava. A defesa da autonomia provincial, no entanto, conflitava com a centralidade do integracionismo, o que contribuiu para acirrar ainda mais os ânimos entre os deputados. Havia, ainda, uma terceira proposta acerca do modo de integração do Brasil na nação portuguesa, a defendida pelo grupo dos liberais moderados. Em um primeiro momento, esses pressionaram pelo envio de tropas à América como meio de garantir a obediência das províncias, e especialmente de D. Pedro, às cortes; numa segunda etapa, entre janeiro e junho de 1822, passaram a defender uma forma diferente de relacionamento entre as partes da Monarquia, que preservasse a autonomia das províncias e promovesse a integração econômica. Tais propostas foram as "políticas predominantes no Congresso" durante o primeiro semestre de $1822 .{ }^{22}$ Contudo, a atuação dos deputados paulistas, pautados em projeto político específico, promoveu um desequilíbrio nos arranjos estabelecidos nas cortes.

O decreto de 29 de setembro de 1821, que determinou a formação das juntas de governo e o regresso do príncipe regente à Europa, chegou até São Paulo em finais do mês de dezembro, antes que os seus deputados partissem para Lisboa. A recepção local a tais medidas emanadas das cortes sensibilizou os representantes eleitos e certamente impactou na postura que eles

\footnotetext{
${ }^{21}$ BERBEL, M. R. Os apelos nacionais..., p. 188-189.

22 BERBEL, M. R. Os apelos nacionais..., p. 188-192.
} 
adotariam a partir de fevereiro de 1822. Em sintonia com o Rio de Janeiro e Minas Gerais, o governo de São Paulo, a câmara de vereadores da capital e o clero do bispado enviaram representações ao regente D. Pedro, nos últimos dias daquele ano, solicitando que ignorasse os apelos das cortes e permanecesse no Brasil. ${ }^{23}$ Através de termos ásperos, os membros do governo tentaram concitá-lo a zelar pela sua "dignidade de homem e de príncipe", bem como responsabilizá-lo pelo "rio de sangue que decerto vai correr pelo Brasil com a sua ausência". ${ }^{24}$ Os vereadores, por sua vez, lamentaram a ausência do rei D. João VI e lançaram ataques frontais à posição dos deputados eleitos em Portugal, os quais, "sem esperarem pelos do Brasil, começaram a discutir um projeto de constituição que [...] a cada página se descobre o maquiavelismo com que [...] se intenta escravizar este riquíssimo país e reduzi-lo à mera colônia". Um eventual retorno do regente deixaria "o reino do Brasil sem centro comum de governo e união $[\ldots]]^{\prime 25}$

Apesar da agressividade dos termos empregados pelos paulistas em sua tentativa de manter tanto o regente e como o centro de poder no Brasil, a separação em relação a Portugal não era desejada e sequer projetada. Ao contrário, as Lembranças e apontamentos, que sintetizavam seu projeto político e que norteariam a posição dos seus congressistas, primavam pela "integridade e indivisibilidade do Reino Unido", mas consideravam imprescindível a existência de Portugal e Brasil como reinos dotados, cada qual, de um poder executivo central e articulador das províncias. Já no tocante ao Brasil, defendiam expressamente a permanência do regente no Rio de Janeiro e o seu reconhecimento como chefe do executivo local. ${ }^{26}$ Tais propostas eram frontalmente contrárias ao centralismo europeu característico da vertente integracionista, e tanto os discursos dos deputados paulistas quanto as expressões do governo, da câmara e do clero local contribuíram para a configuração de um antagonismo em Lisboa entre os deputados portugueses e os brasileiros. ${ }^{27}$

\footnotetext{
${ }^{23}$ Essas manifestações foram analisadas em DAMACENO, D. T. Os "facciosos" de São Paulo..., p. 73-79; BERBEL, M. R. Os apelos nacionais..., p. 192-193 e em NEVES, L. M. B. P. das. São Paulo e a independência..., p. 286-289.

${ }^{24} C f$ :: "Representação ao Príncipe Regente pelo Governo Provisório de São Paulo, a 24 de dezembro de 1821". RIHGSP, vol. 7, 1902, p. 145-148.

${ }^{25} C f$ :: "Representação da Câmara de São Paulo ao Príncipe Regente, para que fique no Brasil, levada pelo marechal José Arouche Toledo Rendon". São Paulo, 31 de dezembro de 1821. RIHGSP, vol. 10, 1905, p. 303-306.

${ }^{26} C f$ :: Lembranças e apontamentos do Governo Provisório de São Paulo para os deputados da província (9 e 10 outubro e 3 novembro 1821). In: BONAVIDES, Paulo; AMARAL, Roberto (Orgs.). Textos políticos da história do Brasil. (Vol. 1). Brasília: Senado Federal, Conselho Editorial, 2002, p. 503-510. Esse documento expressa ainda o desejo de "que os laços indissolúveis que hão de prender as diferentes partes da Monarquia em ambos os hemisférios sejam eternos". NEVES, L. M. B. P. das. São Paulo e a independência..., p. 293-295.

${ }^{27}$ Detalhamento quanto à atuação dos deputados paulistas em Lisboa em BERBEL, M. R. Os apelos nacionais..., p. 192-206; e NEVES, L. M. B. P. das. São Paulo e a independência..., p. 289-303.
} 
A partir do entrelaçamento entre as dinâmicas das cortes e das províncias brasileiras, os deputados luso-americanos foram tecendo, paulatinamente, ao longo do primeiro semestre de 1822, um arranjo em torno do projeto inicial de São Paulo, que articulava unidade e autonomia. ${ }^{28}$ Alguns fatos desse processo, como a reação enérgica dos moderados portugueses manifestada no envio de tropas para assegurar o controle da Bahia, de Pernambuco e do Rio de Janeiro, de um lado, e a convocação de uma Constituinte para o Brasil, efetuada por D. Pedro em junho de 1822, de outro, estimularam um afastamento dos deputados brasileiros em relação aos portugueses e, ao mesmo tempo, um parcial desvanecimento da desconfiança dos congressistas brasileiros em relação ao poder central estabelecido no Rio de Janeiro. Para os deputados de Portugal, "a proposta tinha o significado de separação dos dois reinos e de fundação de uma outra nação no Brasil", motivo pelo qual votaram majoritariamente pela recusa ao ato adicional que reconhecia a constituinte brasileira e o poder central exercido pelo regente. ${ }^{29}$

Esse acirramento das tensões entre as delegações europeias e americanas não pode ser compreendido sem que se considere o posicionamento adotado pelo príncipe regente D. Pedro. Como visto, já em finais de 1821 as províncias do Rio de Janeiro, São Paulo e Minas Gerais formaram uma coalizão em torno da Corte brasileira e apelaram para que D. Pedro desobedecesse às determinações das cortes lisboetas e permanecesse no Brasil, mantendo um centro de poder e o estatuto de reino para o Brasil. A concordância do regente a tais pressões, tornada pública em 9 de janeiro de 1822, data conhecida como o Dia do Fico, foi celebrada por seus aliados, mas gerou atritos com a tropa portuguesa - a Divisão Auxiliadora, comandada pelo general Jorge de Avilez - que estava em serviço no Rio de Janeiro e obedecia às cortes de Lisboa. Como resultado, a cidade permaneceu por alguns dias dividida entre as áreas ocupadas pelas milícias locais e as controladas pela tropa europeia, todas de armas na mão e dispostas a agir uma contra a outra. Contudo, a Divisão Auxiliadora concordou em recolher-se no dia 13 de janeiro, mantendo-se relativamente afastada dos espaços centrais do governo, tendo sido obrigada a embarcar para Portugal a 15 de fevereiro. Além disso, entre 9 e 23 de março, uma esquadra proveniente de Lisboa com o fim de transportar o príncipe regente para Portugal estava estacionada no Rio de Janeiro. ${ }^{30}$

\footnotetext{
${ }^{28}$ DOLHNIKOFF, Miriam. São Paulo na independência..., p. 568-573.

${ }^{29}$ BERBEL, M. R. Os apelos nacionais..., p. 195.

${ }^{30}$ A exposição desses fatos se encontra em OLIVEIRA. J. J. M. de. Quadro Historico da Provincia de S. Paulo..., p. 245-251; LIMA, Oliveira. O movimento da independência..., p. 129-167; WERNET, A. O processo de independência em São Paulo..., p. 350.
} 
Nesse momento, uma parte do auxílio solicitado por D. Pedro no dia 12 de janeiro ${ }^{31}$ no calor dos enfrentamentos entre as tropas constitucionalistas e as milícias leais ao príncipe já havia chegado de São Paulo, precisamente em 5 de março de 1822. Tratava-se da brigada denominada de Leais Paulistanos que era constituída por 1.100 homens matriculados em diversos corpos militares paulistas, tanto nos de linha quanto nas milícias. ${ }^{32}$ De acordo com Machado de Oliveira, a parte deste contingente militar formada por milicianos "mereceu inteira confiança do príncipe regente, aquartelando-a no recinto do paço da Boa-Vista, e entregandolhe a guarda da sua pessoa e família". ${ }^{33}$ Ademais, durante o período de pouco mais de três meses de estadia no Rio de Janeiro, o corpo dos Leais Paulistanos eventualmente fez a guarda do Paço bem como participou de cerimoniais pomposos da família real, como o batismo da infanta Januária Maria. ${ }^{34} \mathrm{O}$ Regimento dos Úteis participou dessa marcha enviando 69 milicianos, os quais formavam uma companhia em meio aos Leais Paulistanos. Dois deles eram brancos, oficiais do estado-maior, e a maioria restante era composta por homens pardos, havendo sete oficiais de companhia, dois músicos e 58 soldados. ${ }^{35}$

Embora muitas famílias de milicianos-agricultores paulistas lamentassem o pesado fardo que lhes fora imposto nessa conjuntura de rápida transformação política - pois “outrora podíamos permanecer sossegados em nossas casas, agora somos forçados a deixar nossas mulheres e nossos filhos para ir restabelecer a paz no Rio de Janeiro [...]”, conforme ouviu e depois narrou Saint-Hilaire ${ }^{36}$-, oficiais milicianos pardos viram no auxílio a D. Pedro uma oportunidade para se acercar do centro de poder e demandar mercês. É o que revelam duas informações contidas nos assentos referentes aos sete oficiais pardos que marcharam com os Leais Paulistanos: todos eles se ofereceram voluntariamente e obtiveram progressão na hierarquia miliciana pouco tempo depois. ${ }^{37}$ Ora, os milicianos pardos, ou pelo menos os

\footnotetext{
${ }^{31} C f:$ : Carta régia ao Governo Provisório de S. Paulo e uma irmã ao de Minas Gerais. Rio de Janeiro, 12 de janeiro de 1822. Cartas, e mais peças oficiais dirigidas a Sua Majestade o senhor D. João VI pelo príncipe real, o senhor D. Pedro de Alcântara. Lisboa: Imprensa Nacional, 1822, p. 9-10.

${ }^{32}$ Cf:: "Ordem do dia de 18 de janeiro de 1822"; "Ordem do dia de 19 de janeiro de 1822 ". DIHCSP, vol. 1, p. 4446. São Paulo, 18 e 19 de janeiro de 1822; "Participação do Governo provisório da província de São Paulo ao príncipe regente, da marcha do auxilio militar pedido pelo príncipe". São Paulo, 18 de fevereiro de 1822. In: OLIVEIRA, J. J. M. de. Quadro Historico da Provincia de S. Paulo até o anno de 1822. São Paulo: Typografia Brasil de Carlos Gerke, 1897, p. 336-337.

${ }^{33}$ OLIVEIRA. J. J. M. de. Quadro Historico da Provincia de S. Paulo..., p. 268.

${ }^{34}$ Cf:: Gazeta do Rio de Janeiro. Rio de Janeiro: Impressão Régia. Suplemento à edição n. 35, de 21 de março de 1822.

${ }^{35}$ Cf:: Livro Mestre.

${ }^{36}$ Cf: : SAINT-HILAIRE, Auguste de. Viagem à província de São Paulo. Trad. Regina Regis Junqueira. Belo Horizonte: Ed. Itatiaia; São Paulo: Ed. da Universidade de São Paulo, 1976, p. 49.

${ }^{37}$ Cf:: Livro Mestre, fls. 11-11v, 12, 13, 14v, 58 e 59v. O único oficial que não alavancou a carreira no Regimento foi Manoel Gonçalves da Luz Tralhão, que não teve tempo hábil para tanto, uma vez que faleceu em 17 de abril de 1824. Ver as fls. 12 e 13 do Livro Mestre.
} 
integrantes da oficialidade, compreendiam a importância e a dimensão política daquele evento, de modo que, por serem igualmente sensíveis às regras que estruturavam a competição travada no interior do universo militar, projetaram a sua participação voluntária como uma ampliação das chances de promoção.

Ademais, era esperado que uma mobilização militar dessa magnitude, que compreendia mais de um milhar de paulistas e que atendia a um apelo feito pelo próprio príncipe regente em um contexto singular, resultasse na distribuição de mercês ainda mais avantajadas. Com efeito, os oficiais superiores da milícia que "pronta e animadamente saíram da província de São Paulo em defesa da causa do Brasil e da minha real pessoa", dizia o regente, foram condecorados com o hábito da Ordem de Cristo por decreto datado de 18 de maio de 1822. Atendia-se, outrossim, aos seus "patrióticos sentimentos [...] e para que esta honrosa distinção sirva de estímulo a outros em iguais circunstâncias". Entre os agraciados estavam o coronel branco que substituiu Manoel José Ribeiro, José Joaquim César de Cerqueira Leme, o qual comandou todo o batalhão de infantaria miliciana, além do capitão pardo Antonio Joaquim da Costa Ribeiro, responsável pela companhia formada pelos homens do Regimento dos Úteis. ${ }^{38}$ Fazendo valer o texto do decreto, na parte em que esse incitou aos demais militares a permanecerem estimulados, os oficiais subalternos que não haviam sido contemplados com o hábito, dentre os quais dois pardos dos Úteis, imediatamente demandaram a mesma mercê, mas sem obterem sucesso. ${ }^{39} \mathrm{De}$ fato, desde 1808 que tais honrarias pareciam mais acessíveis aos paulistas, uma vez que vários fatores contribuíam para que os seus serviços à Monarquia fossem reputados relevantes e merecedores de remuneração material e simbólica. As injunções do contexto colocaram São Paulo, uma capitania/província vizinha ao Rio de Janeiro, em posição de crescente influência política e militar. Para mais, como observou Holanda, os títulos e as insígnias nobiliárquicas receberam um novo impulso, no Brasil, com a trasladação da Corte portuguesa e a ulterior formação de uma nobreza brasileira, de certo modo se acomodando ao ambiente liberal em princípio avesso às expressões tipicamente herdadas de Antigo Regime. ${ }^{40}$

\footnotetext{
${ }^{38} C f$ :: "Decreto de 18 de maio de 1822" e "Relação dos oficiais do Batalhão de Infantaria e Esquadrão de Cavalaria da Segunda Linha dos Leais Paulistanos, a quem Sua Alteza Real faz mercê do Hábito da Ordem de Christo, e a que se refere o Decreto da data desta”. AN, Ministério do Império/Graças Honoríficas, Códice 15, vol. 9, fls. 128v129.

${ }^{39} C f$ :: "Representação a D. Pedro, príncipe regente, que fazem Luís Antonio de Sá Brasileiro e demais oficiais subalternos da 2. linha da província de São Paulo, os quais, como voluntários, participaram da marcha ao Rio de Janeiro por imposição da ordem pública, solicitando por razão de equidade, lhes fosse concedida 'a Mercê do Hábito de Cristo"'. BN/dm, doc. ii-35,24,23. Rio de Janeiro, 25 de maio de 1822; Livro Mestre, fls. 11, 11v, 12 e 13.

${ }^{40}$ HOLANDA, Sérgio Buarque de. A herança colonial - sua desagregação. In: HOLANDA, S. B. de (Dir.). História geral da civilização brasileira [1960]. (Tomo II, 1. ${ }^{\circ}$ vol.). 3. ${ }^{a}$ ed. São Paulo: Difusão Européia do Livro, 1970, p. 29-34.
} 
A permanência dos Leais Paulistanos na Corte, junto ao príncipe regente, foi interrompida em junho de 1822, em virtude de acontecimentos recentes ocorridos no bojo do governo provisório de São Paulo, os quais afinal eram suficientemente graves como para imporem o retorno dessa força armada à capital da província. Trata-se do movimento de recomposição da junta de governo paulista posteriormente conhecido como a Bernarda de Francisco Inácio.

Às 16 horas do dia 23 de maio de 1822, o quartel da guarnição da cidade de São Paulo foi ocupado por homens da tropa miliciana em estado de extrema tensão e agitação em razão do toque a rebate. Ao mesmo tempo, nas principais ruas da cidade ouvia-se o tanger dos tambores e o badalo dos sinos da cadeia, mediante os quais se conclamava o povo a comparecer, imediatamente, no largo de São Gonçalo. Diante dos membros do governo provisório da província, “Tropa e Povo" expressaram oposição à portaria de 10 daquele mês enviada pelo regente Pedro, a qual continha, a um só tempo, ordem para que o presidente da junta de governo, o ex-governador e capitão-general João Carlos Augusto de Oeynhausen, se dirigisse ao Rio de Janeiro, e nomeação do então vice-presidente da junta, Martim Francisco Ribeiro de Andrada, para o seu lugar. Ao contrário do disposto, "Tropa e Povo" exigiam a manutenção de Oeynhausen e a deposição de Martim Francisco e de Manoel Rodrigues Jordão. Ao fim daquela tarde conturbada, Martim Francisco e Jordão renunciaram aos seus cargos no governo, ao passo que Oeynhausen permaneceu interinamente como presidente e o coronel Francisco Inácio de Souza Queiróz, comandante da força miliciana destacada na cidade de São Paulo, recebeu a incumbência de conter quaisquer “ajuntamentos tumultuosos”. Essa é, resumidamente, a versão registrada nas Atas das Sessões do Governo Provisório, que contempla a perspectiva dos "bernardistas". 41

De outro lado, passados dois meses e já em ambiente de repressão à Bernarda, uma versão diferente dos fatos veio à tona por meio das narrativas das testemunhas ouvidas na devassa destinada à investigação daqueles acontecimentos. ${ }^{42}$ De acordo com elas, o quartel da

\footnotetext{
${ }^{41}$ Cf:: DIHCSP, vol. 2, p. 171-174.

42 A devassa em questão é um documento incompleto. Os testemunhos foram colhidos entre 16/09/1822 e 07/10/1822, sendo interrompidos quando do recebimento do decreto de 23/09/1822 que suspende o processo. Portanto, não há depoimentos dos acusados. A transcrição foi publicada em: Revista do Instituto Histórico e Geográfico de São Paulo (RIHGSP), v. 10, p. 393-480. O "Decreto de 23 de setembro de 1822. Faz cessar a devassa a que se mandou proceder na província de São Paulo, pondo em liberdade os que estiverem presos” está
} 
cidade fora ocupado por oficiais milicianos de alto escalão que não estavam em serviço no dia 23 de maio. Para tanto, tais comandantes militares empregaram violência e ameaças de toda ordem aos milicianos que faziam o serviço no quartel. Mediante a mesma violência, teriam os milicianos aquartelados assinado documentos cujo teor desconheciam ou não lhes importava. Ademais, relativamente ao dia 19 de julho, ou seja, quase dois meses após a tomada do quartel seguida da deposição dos dois membros do governo, descreveu-se a formação de um grande ajuntamento no interior do quartel diante das notícias de que tropas provenientes de Santos marchavam em direção à capital com ordens expressas do regente para invadi-la. Para esse ajuntamento haviam concorrido "militares, paisanos, negros e mulatos" ou "militares, paisanos e escravos", todos armados, sob as ordens do coronel Francisco Inácio de Souza Queiróz, do presidente Oeynhausen e do capitão Pedro Taques de Almeida Alvim, e "sustentados à carne, farinha, arroz e vinho". ${ }^{43}$

Assim, pois, a Bernarda foi um movimento de desobediência a uma ordem do regente, autorrepresentado como pronunciamento de "Tropa e Povo", sem derramamento de sangue, e que resultou, de imediato, em mudança de algumas peças do tabuleiro político da província. A “Junta Bernardista" recém-formada durou três meses e encontrou na cidade de São Paulo a sua principal base de sustentação, tendo sido energicamente contestada nas vilas pertencentes à comarca de Itu e, evidentemente, no Rio de Janeiro, onde o ministro José Bonifácio de Andrada e Silva exercia significativa influência junto ao próprio regente. ${ }^{44} \mathrm{~A}$ emergência desse fenômeno revelou as profundas fissuras no interior da junta de governo paulista que permaneciam ocultas, sob o véu da ação conciliatória de José Bonifácio, no segundo semestre de 1821. Os primeiros meses de 1822, entretanto, foram marcados por uma sucessão de fatos que configuraram a competição travada entre dois partidos: um deles orbitava a família Andrada e o outro era centralizado por Francisco Inácio, Oeynhausen e o ouvidor José da Costa Carvalho.

A historiografia vem, há muito tempo, se debruçando sobre as tensões presentes no universo das elites paulistas da década de 1820 e no episódio da Bernarda, em particular. Ao longo do período compreendido entre a segunda metade do século XIX e as primeiras décadas do XIX, as narrativas de observadores contemporâneos aos fatos foram sucedidas por versões

em: Decretos, cartas e alvarás, p. 49. In: Collecção das Leis do Imperio do Brazil de 1822. Rio de Janeiro: Imprensa Nacional, 1887.

${ }^{43}$ Cf:: "Devassa sobre a Bernarda de 23 de maio de 1822"..., p. 428-432. Depoimento das testemunhas $11 .^{\mathrm{a}}$ e $12 .^{\mathrm{a}}$. 44 DAMACENO, Daniel Tarifa. Os "facciosos” de São Paulo (Considerações acerca da Bernarda de Francisco Ignacio) 23.05.1822 - 25.08.1822. Dissertação (mestrado em História). São Paulo: FFLCH, Universidade de São Paulo, 1993. p. 137-220. 
não menos envolvidas da parte de descendentes diretos dos indivíduos e grupos sociais que protagonizaram a Bernarda. ${ }^{45}$ Essas continham uma tonalidade acentuadamente personalista, como era comum à narrativa historiográfica da época, além de pesarem a mão na caracterização dos antagonismos, decorrendo daí a definição do grupo andradista como brasileiro, constitucional e liberal e do grupo bernardista como português, absolutista e conservador. ${ }^{46}$ Mais tarde, entre as décadas de 1960 e 1970, e com maior distanciamento, historiadores complexificaram as interpretações. Sérgio Buarque de Holanda considerou que os embates em questão não se deviam "a antigas e arraigadas divergências de ordem ideológicas", mas a questões de "preponderância política" em âmbito local. ${ }^{47}$ Já Augustin Wernet retomou o argumento de que as divergências eram "de ordem ideológica" e "por motivos pessoais". ${ }^{48}$ Por sua vez, Nanci Leonzo destacou “os interesses comerciais” como aspecto de primeira ordem na competição entre os grupos de elite que compunham o governo provisório de São Paulo entre os anos de 1821 e $1822 .{ }^{49}$

Os caminhos propostos por Holanda e Leonzo têm sido seguidos em estudos mais recentes, de modo que as divisões entre as elites paulistas são vistas a partir da imbricação entre política e economia em meio a um cenário marcado pelo acirramento da competição entre grupos rivais. ${ }^{50}$ Basicamente, trata-se do enfrentamento de um grupo emergente - o dos Andradas - a um grupo estabelecido - o de Oeynhausen e Francisco Inácio - pelo acesso e controle dos principais cargos da estrutura administrativa e das milícias, assim como pela arrematação de contratos lucrativos junto ao governo e as câmaras paulistas. De acordo com Medicci, esses grupos constituíam redes de interesses que transcendiam o âmbito da capitania/província, alcançavam o governo no Rio de Janeiro e percorriam grande parte do Império lusófono numa "compleja relación existente entre política y negocios". ${ }^{51}$ Desse modo,

\footnotetext{
${ }^{45}$ Ver, entre outras obras, as de OLIVEIRA. J. J. M. de. Quadro Historico da Provincia de S. Paulo..., p. 229-292; AQUINO E CASTRO, O. H. de. O conselheiro Manoel Joaquim do Amaral Gurgel..., p. 256-265; PIZA, A. de T. Martim Francisco e a Bernarda...; PIZA, A. de T. A Bernarda de Francisco Inacio - Suas causas e suas conseqüências...; ROMEIRO, J. M. de M.. De D. João VI à independência...

${ }^{46}$ Para uma análise dessas narrativas, ver DELATORRE, A. V. São Paulo à época da independência..., p. 1-28.

${ }^{47}$ HOLANDA, Sérgio Buarque de. São Paulo. In: HOLANDA, S. B. de (Dir.). História geral da civilização brasileira. (t. II, $2^{\circ}$ vol.). São Paulo: Difusão Européia do Livro, 1967, p. 447-448.

${ }^{48}$ WERNET, A. O processo de independência em São Paulo..., p. 351.

${ }^{49}$ LEONZO, Nanci. Defesa militar e controle social..., p. 351-352.

50 DAMACENO, Daniel Tarifa. Os "facciosos” de São Paulo (Considerações acerca da Bernarda de Francisco Ignacio) 23.05.1822 - 25.08.1822. Dissertação (mestrado em História). São Paulo: FFLCH, Universidade de São Paulo, 1993; DELATORRE, A. V. São Paulo à época da independência...; MEDICCI, Ana Paula. São Paulo en el movimiento de Independencia de Brasil (1820-1822). Nuevo Mundo Mundos Nuevos [Online], Debates, posto online em 11 abril 2013, consultado em 18 julho 2014. URL: http://nuevomundo.revues.org/65314; DOI: 10.4000/nuevomundo.65314; BORGES, Luiz Adriano. Aspectos econômicos da participação paulista no processo de independência. Almanack, Guarulhos, n.06, p. 61-80, 2. ${ }^{\circ}$ semestre de 2013.

${ }^{51}$ MEDICCI, Ana Paula. São Paulo en el movimiento de Independencia..., §47.
} 
essa historiografia sugere que as elites paulistas poderiam estar mais preocupadas com as decorrências objetivas do processo político relativamente aos seus negócios - tanto para os efetuados no interior da província quanto em meio às redes mercantis mais amplas nas quais estavam inseridos - do que propriamente com projetos políticos e sociais abstratos. ${ }^{52}$

No que diz respeito à Bernarda, pode-se ler o movimento como a resultante de uma sucessão de jogadas promovidas por integrantes de grupos rivais e competidores arraigados no governo provisório da província de São Paulo no primeiro semestre de 1822. A fisionomia apaziguada da junta começou a romper já a partir de dezembro de 1821, por ocasião do envio de uma delegação paulista ao Rio de Janeiro dotada do intuito de pressionar pela permanência do regente no Brasil, da qual fazia parte o vice-presidente da junta, José Bonifácio de Andrada e Silva. Esse conquistou rapidamente um espaço de notória influência junto ao príncipe e se tornou ministro de Estado, o que, ao longo do tempo, promoveria um desequilíbrio de forças entre os grupos rivais que integravam a junta de São Paulo. Conforme Delatorre, José Bonifácio não demorou a "tentar conquistar a hegemonia política e comercial na província" através de “intervenções na Junta Provisória” chanceladas ou promovidas por D. Pedro. Desse modo, o grupo andradista visava "esfacelar o controle do comércio e das arrematações mais rendáveis da Província que há tempos estavam nas mãos de homens como Francisco Ignácio de Souza Queiróz". ${ }^{53}$ Paralelamente, no âmbito da província, o seu irmão Martim Francisco, que também era membro do governo paulista, passou a denunciar e a investigar as práticas monopolistas, de corrupção e de suborno atribuídas ao grupo rival. Até mesmo o recrutamento para formar a coluna de Leais Paulistanos foi alvo de suspeitas, as quais recaíram sobre o coronel Francisco Inácio de Souza Queiróz, responsável pela montagem desse corpo. Ele foi acusado de chefiar uma rede atuante em diversas localidades da província que recebeu propina para livrar inúmeros homens da marcha para o Rio de Janeiro. ${ }^{54}$

As jogadas mais agressivas do grupo dos Andradas foram realizadas em maio de 1822 e desencadearam, como contra-ataque, a Bernarda. A primeira delas foi concretizada no dia 10, data em que o príncipe regente convocou Oeynhausen para ir ao Rio de Janeiro "por motivo de serviço público", deixando em seu lugar, como presidente da Junta, Martim Francisco. No

\footnotetext{
52 DAMACENO, Daniel Tarifa. Os “facciosos” de São Paulo..., p. 95-107, 198-220; DELATORRE, Aparecida Vanessa. São Paulo à época da independência..., p. 29-47; MEDICCI, Ana Paula. São Paulo en el movimiento de Independencia..., §32; BORGES, Luiz Adriano. Aspectos econômicos da participação paulista... Evidentemente, tais historiadores não pressupõem um descolamento ou hierarquização entre as realidades política e econômica, mas, ao contrário, a íntima conexão entre ambas.

${ }^{53}$ DELATORRE, A. V. São Paulo à época da independência..., p. 87-88.

${ }^{54}$ NEVES, Lúcia M. B. P. das. São Paulo e a independência..., p. 306; DELATORRE, A. V. São Paulo à época da independência..., p. 86-89.
} 
mesmo dia, nomeou para governador das armas a José Arouche de Toledo Rendon, reputado pela historiografia como um "andradista". ${ }^{55}$ Ademais, em 21 de maio expediu-se, do Rio de Janeiro, mais duas portarias, as quais "determinavam a ida para o Rio de Janeiro de José da Costa Carvalho e Francisco Ignácio de Souza Queiróz”, ouvidor e coronel, respectivamente. ${ }^{56}$ Em síntese, sob a influência de José Bonifácio, D. Pedro interveio na configuração da junta provisória e no equilíbrio de poder interno à província, buscando enfraquecer as bases de um grupo e favorecer nitidamente ao outro. Vai daí, por outro lado, a resposta enérgica do grupo bernardista, que consistiu em uma mobilização militar capaz de forçar a permanência dos membros do governo convocados pelo regente e a saída de dois integrantes do grupo andradista.

Há quase dois séculos, portanto, que há veemente interesse pelos comportamentos e ações das elites paulistas na conjuntura independentista. Pouco se avançou, por outro lado, em termos da compreensão acerca da perspectiva de indivíduos e grupos sociais que também vivenciaram tais fenômenos e processos históricos, mas a partir de posições sociais menos privilegiadas. Já os relatos de época davam conta da participação popular, caracterizando esses atores sociais de duas maneiras, de acordo com a posição ocupada pelos formuladores do discurso no equilíbrio de poder em questão: como "tropa e povo", de um lado, ou de "militares, paisanos, negros e mulatos" acompanhados de "escravos", de outro. Seja qual for a forma de caracterizar os integrantes da Bernarda, está claro que esse grupo conseguiu o apoio e a adesão de um significativo contingente populacional urbano. Cumpre examinar como a historiografia interpretou essa participação popular.

Em uma narrativa temporalmente próxima aos eventos, José Joaquim Machado de Oliveira argumentou que os líderes bernardistas formaram "proselitismo, escorado pela força bruta popular, que é sempre pronta em acudir ao primeiro aceno da demagogia em ação, quando ostenta mais dinheiro do que mérito ou prestígio". Ele descreveu a sua versão para o modo como um milhar de pessoas, entre militares e civis, se juntaram na praça de São Gonçalo na tarde do dia 23 de maio de 1822: “Às trindades [refere-se aos três principais líderes] seguiram o povo e tropa para a praça de São Gonçalo [...]", sendo que "a maior parte [...] acudiu aos sinais sem saber para que fim o fazia". Em seguida, Machado de Oliveira, um militar e político liberal atuante por toda a primeira metade do século XIX, sintetizou a sua perspectiva em relação à inserção popular nos movimentos sociais e políticos: "É este as mais das vezes o

\footnotetext{
55 OLIVEIRA. J. J. M. de. Quadro Historico da Provincia de S. Paulo..., p. 254; ROMEIRO, J. M. de M. De D. João VI à independência..., p. 1455-1462; DELATORRE, A. V. São Paulo à época da independência..., p. 124, $127,136,160$.

${ }^{56}$ DELATORRE, A. V. São Paulo à época da independência..., p. 91-92.
} 
costume em que estão as massas: agitam-se, correm uns só por imitação de verem agitar-se, correr os outros sem moralizar a ação; e eis aí o que os astutos denominam 'movimento espontâneo e consciencioso do povo"". 57

Nos anos finais do Império, o magistrado e historiador Olegário Herculano Aquino e Castro veiculou uma interpretação semelhante à de Machado de Oliveira acerca da participação popular na Bernarda. Conforme narrou:

A 23 de maio de 1822 rebentou a revolta na capital; concitadas as turbas pelo vertiginoso espírito de partido, afagadas as ambições dos aventureiros e espertos especuladores, que em casos semelhantes soem vir à tona dos movimentos populares, em busca antes do ganho do que do triunfo de uma ideia, que muitas vezes não conhecem ou não compreendem, nem assim pôde a revolução tomar as proporções desejadas pelos seus autores. ${ }^{58}$

Martim Francisco, por outro lado, tinha "a seu lado os bons patriotas e o apoio franco da opinião sensata da população". ${ }^{59}$ É mais do que evidente o contraponto estabelecido entre as turbas revolucionárias e os bons patriotas, bem como a aversão dos autores aos "movimentos populares".

Antonio de Toledo Piza, escrevendo no começo do século XX e à luz dos depoimentos da devassa que acabara de encontrar e publicar, se via horrorizado com a participação de "mulatos" e "escravos" em negócio tão relevante como a deposição de membros do governo. Conforme entendeu Piza, "com um pessoal deste quilate a sedição passou além de popular, para se tornar plebéa!". ${ }^{60}$ Ele também desaprovou os meios empregados para a adesão daqueles homens: os banquetes regados à bebida e as ameaças físicas. ${ }^{61}$ Para aquele historiador, a arregimentação dos grupos populares revela a necessidade dos bernardistas por revestirem de legitimidade um movimento que era fruto de desobediência ao regente. Desse modo, foi-lhe suficiente indicar que a participação popular teria sido provocada e dirigida pelos comandantes da Bernarda, tanto para engrossar sua força armada como para conferir-lhe legitimidade.

Contemporâneo de Piza, o magistrado João Marcondes de Moura Romeiro igualmente condenou o movimento político da Bernarda, tanto em função dos ideais que ele supostamente representava quanto por escorar-se na "populaça inconsciente". Romeiro certamente tinha em

\footnotetext{
${ }^{57}$ OLIVEIRA. J. J. M. de. Quadro Historico da Provincia de S. Paulo..., p. 256-258.

${ }^{58}$ AQUINO E CASTRO, O. H. O conselheiro Manoel Joaquim do Amaral Gurgel..., p. 262-263.

${ }^{59}$ AQUINO E CASTRO, O. H. O conselheiro Manoel Joaquim do Amaral Gurgel..., p. 262-263.

${ }^{60}$ Cf:: RIHGSP, vol. 10, p. 407, nota de rodapé n. 1 . Grifos no original.

${ }^{61}$ Vejam-se seus comentários nas várias notas de rodapé anexas à transcrição da Devassa relativa à Bernarda. $C f$.:

RIHGSP, vol. 10, p. 393-480. Ver também RIHGSP, v. 5, p. 50.
} 
vista os movimentos sociais que eclodiram nos primeiros anos da República. Quanto à bernarda, ele esforçou-se por descaracterizar os seus integrantes, argumentando que não se tratava do "povo" e tampouco da "voz do povo" aquilo que se proferiu em praça pública. Citando o francês Gustave Le Bon e as ideias correntes entre fins do século XIX e começos do XX acerca da psicologia das massas, decompôs o "povo" em duas categorias distintas: a primeira, a dos "trabalhadores de toda sorte" que conformam "uma maioria que nunca faz revoluções" e, a segunda, a composta "de um resíduo social subversivo dominado por uma mentalidade criminosa. Degenerados pelo alcoolismo e pela miséria, ladrões, mendigos, indigentes, medíocres operários sem trabalho constituem o bloco perigoso dos exércitos insurrecionais". Esses últimos, "recrutados nas camadas mais baixas do povo", não tinham "a mais vaga ideia" dos motivos pelos quais agiam. Finalmente, conclui que "a esta categoria pertenciam os que, no dia 23 de maio, arrastados por Francisco Inácio, Costa Carvalho e Oeynhausen, derrotaram o partido liberal, conseguindo que o governo da Província passasse a ambiciosos estrangeiros". 62

Daí em diante, quando cessam ou ao menos diminuem os entreveros entre os intérpretes da bernarda, o envolvimento popular nas tensões políticas paulistas da década de 1820 também deixa de figurar como um dado relevante à historiografia. Como visto, Augustin Wernet analisou, em 1972, o processo de independência em São Paulo. Em sua perspectiva, a Bernarda revelou uma dissensão entre as elites paulistas que, no entanto, não teria causado "nenhum abalo" à província, sobretudo se comparado ao que se processou em outras províncias. É em função da tentativa de explicação dessa estabilidade social que marcou a independência em São Paulo que o historiador discorreu sobre o envolvimento popular na política. Caracterizou a população rural como "inculta e atrasada", indiferente ao debate político e conduzida pelos “chefes locais". A população urbana, por outro lado, teria seu potencial revolucionário tolhido por ser minguado o número de "pequenos artesãos e retalhistas", sendo possível a independência em São Paulo sem se "precisar recorrer à rebelião popular". ${ }^{63}$

Por fim, Daniel T. Damaceno problematizou, em sua dissertação de mestrado de 1993, as bases de apoio e de oposição à Bernarda entre os grupos sociais da capital paulista. Uma vez que o movimento foi autoproclamado como uma manifestação da "Tropa e Povo", coube-lhe, entre tantos outros aspectos, definir em qual categoria se incluiriam as pessoas de baixa extração. ${ }^{64}$ Damaceno recorreu a uma diferenciação entre "povo" e "populacho, populaça e

\footnotetext{
${ }^{62}$ ROMEIRO, J. M. de M. De D. João VI à independência...

${ }^{63}$ WERNET, A. O processo de independência em São Paulo..., p. 343-344.

${ }^{64}$ DAMACENO, D. T. Os “facciosos"..., p. 187-190.
} 
mesmo plebe" e a uma aproximação entre estas últimas e a categoria "desclassificados" sociais. ${ }^{65}$ Logo, era nesse bloco, composto por pessoas "sem condições de tomar parte em qualquer decisão que lhes pudesse alterar a condição", que se alocariam os "negros e mulatos" livres, além, obviamente, dos "escravos". Consequentemente, não era de natureza política o fator determinante para a adesão desse segmento à Bernarda: tratava-se principalmente da fome e da miséria, os males imediatos que acometiam os negros, passíveis de serem saciados por meio dos jantares e banquetes promovidos pelos bernardistas. ${ }^{66}$ As demais obras que versaram sobre a bernarda não se ocuparam do segmento social focalizado nesta tese. ${ }^{67}$

Propõe-se aqui um exame à atuação de segmentos populares na bernarda e no contexto mais amplo da independência em São Paulo a partir da perspectiva dos milicianos pardos. A historiografia perdeu inteiramente de vista essa via institucional de atuação social, muito provavelmente por uma combinação de fatores: o primeiro deles se deve a uma propensão dos analistas a contemplarem a imersão das pessoas livres pobres em relações clientelares, relegando a um segundo plano a sua inserção institucional em corporações, mediante as quais se vinculavam ao Estado; o segundo se refere ao fato de que a referência aos pardos é ocultada no nome do Regimento dos Úteis; o terceiro diz respeito a uma tendência dos historiadores a associarem as patentes militares exclusivamente aos integrantes das famílias tradicionais, poderosas e brancas, supondo a participação das pessoas de cor somente em meio à soldadesca; e o quarto está relacionado à indistinção com a qual os participantes "mulatos", "negros" e "escravos" foram retratados nas principais fontes primárias.

Sendo assim, defende-se a pertinência de se averiguar os motivos e as formas de sua participação a partir das perspectivas de Garavaglia, ou seja, a de que naquele contexto os milicianos eram necessários como homens em armas e como votantes, e a de Silva, conforme a qual militares pardos e pretos tinham motivações e leituras próprias acerca de sua inserção naquele processo. ${ }^{68}$ É preciso, pois, ir além dos mecanismos de dominação da elite branca sobre os homens de baixa extração ou da "ineficiência" revolucionária das camadas inferiores se se pretende entender um pouco mais acerca das circunstâncias e opiniões que moviam os milicianos pardos de São Paulo.

\footnotetext{
${ }^{65}$ SOUZA, Laura de Mello e. Desclassificados do ouro: a pobreza mineira no século XVIII. Rio de Janeiro: Edições Graal, 1982.

${ }^{66}$ DAMACENO, D. T. Os “facciosos"..., p. 187-190.

${ }^{67}$ DELATORRE, A. V. São Paulo à época da independência...; MEDICCI, A. P. São Paulo en el movimiento de Independencia...,; NEVES, L. M. B. P. das. São Paulo e a independência...

${ }^{68}$ GARAVAGLIA, J. C. Os primórdios do processo..., p. 213; SILVA, L. G. Aspirações barrocas...
} 
O foco na milícia parda apresenta limites evidentes, na medida em que restringe a análise a um segmento específico da população paulista e privilegia a perspectiva da oficialidade. Entretanto, ele também fornece inúmeras vantagens. Uma vez que a bernarda fora justamente uma proclamação militar, tem-se que esses homens protagonizaram os acontecimentos. Ademais, tal perspectiva possibilita a construção de uma interpretação distinta acerca do sentido da adesão dos pardos ao movimento. Não se trata, necessariamente, de descartar a capacidade das elites em angariar apoio popular mediante o emprego de vários instrumentos de dominação - o recurso à violência, os laços de interdependência desigual ou o apelo a um bom banquete -, mas, antes, de propor que a participação dos livres pobres e libertos na política pudesse ser dotada de significados mais complexos bem como relacionada à sua própria experiência social. Na linha do que tem sido proposto nesta tese, a milícia parda pode ser encarada simultaneamente como um jogador e um espaço de jogo em meio à competição mais ampla travada no universo militar e em vários aspectos transcendente ao corpo social como um todo. Esse jogo, por sua vez, informava as perspectivas, estratégias e objetivos dos milicianos pardos, o que permite matizar as versões veiculadas nas principais tradições interpretativas examinadas.

As milícias paulistas estavam em serviço ativo no mês de maio de 1822, fornecendo a maior parte dos efetivos que compunham a guarnição da capital. Ora, uma parte substancial da tropa de linha estava participando das campanhas sulinas e a outra fora destinada ao Rio de Janeiro. Ademais, a marcha para a Corte incluiu centenas de milicianos, sobrecarregando o serviço para os que permaneceram na província. Para se ter uma ideia da dimensão assumida pela mobilização da milícia naquele contexto, cada um dos três regimentos milicianos da capital foi inicialmente obrigado a disponibilizar 67 homens para o destacamento do mês de outubro de 1822, um contingente que pouco tempo depois seria ampliado para o número de cem milicianos. ${ }^{69}$

Essa disposição da força armada paulista colocou os milicianos pardos na posição de responsáveis pelo quartel da cidade de São Paulo e pelo armamento e munições da tropa na semana do dia 23 de maio de 1822, quando irrompeu a bernarda. Quem comandava o

\footnotetext{
${ }^{69} C f$ : APESP, ordem E00697, p. 26. São Paulo, 21 de outubro de 1822. Vale, ainda, consultar a seção 3.3 desta tese, na qual se examinam o calendário das obrigações cerimoniais da milícia e também os efetivos mensais requeridos para a guarnição da cidade na década de 1820.
} 
destacamento miliciano era o branco Antonio de Pádua de Gusmão, tenente-coronel dos Úteis responsável pelo Regimento na ausência do coronel César, o qual conduzia a infantaria de Leais Paulistanos. Já a guarda do quartel fora confiada a Francisco Manoel de Borja, um sargento pardo do Regimento. No momento em que o grupo bernardista tomou o controle do quartel, integrantes dos Úteis exerciam atividades corriqueiras na guarda: o cabo Inácio José Vieira, que conforme o recenseamento de 1822 "vivia no destacamento", estava limpando algumas armas, ao passo que o tambor-mor Jacinto José dormia "sobre a tarimba do corpo da guarda do quartel", 70

Na sequência, o referido tambor-mor conduziu os seus subordinados às ruas da cidade para, com o toque dos seus instrumentos, convocarem a população a se juntar à tropa em praça pública. Após as proclamações que definiram a manutenção de Oeynhausen e o afastamento de Martim Francisco e de Manoel Rodrigues Jordão do governo, “Tropa e Povo" se dirigiram à câmara da cidade, em cujo local assinaram a ata de vereação extraordinária. Importa destacar que os milicianos pardos atuaram na ocasião a partir tanto de sua posição institucional como força armada quanto mediante práticas políticas típicas do contexto constitucionalista, como era o caso das reuniões de "tropa e povo". Ou seja, compunham parte substantiva da tropa miliciana da cidade, detinham previamente o controle do quartel e participaram subscrevendo a ata de vereação. Portanto, as noções de acordo com as quais os segmentos populares foram simplesmente conduzidos à arena política pelas elites locais que competiam entre si ou até mesmo guiados por impulsos desprovidos de reflexão, não se enquadrando nas categorias “tropa" e "povo", não corresponde adequadamente à realidade.

Ora, na ata da vereação extraordinária que se realizou na câmara da cidade de São Paulo no dia 23 de maio de 1822, no calor dos fatos, há a assinatura de, ao menos, 14 oficiais do

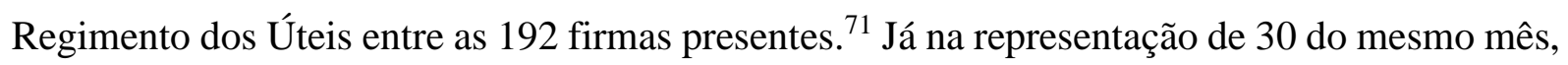
através da qual se informou ao regente os motivos para a deportação de Martim Francisco,

\footnotetext{
${ }^{70}$ Cf:: Livro Mestre, fls. 2, 3, 10, 104, 110, 186, 306-306v; APESP, Maços de População, Capital, 1822, Cia. Penha e São Miguel, fogo 19; "Devassa sobre a Bernarda de 23 de maio de 1822”. São Paulo, set./out. de 1822. RIHGSP, vol. 10, p. 425-432, 472-476. Testemunhas $10 .^{\mathrm{a}}, 11 .^{\mathrm{a}}, 12 .^{\mathrm{a}}$ e $21 .^{\mathrm{a}}$.

${ }^{71}$ Ao menos, pois os soldados geralmente não assinavam as atas de vereações extraordinárias. É possível que nesse caso alguns o tenham feito, mas sem indicar outra informação além do nome - o que inviabiliza a identificação dos soldados do Regimento dos Úteis. $C f$.: "Vereança extraordinaria de 23 de maio de 1822, feita a requerimento do povo e tropas da cidade de S. Paulo". RIHGSP, vol. 10, p. 342-347. O cruzamento das listagens que contêm as assinaturas, o Livro Mestre do Regimento dos Úteis e os recenseamentos referentes à cidade de São Paulo propiciam um nível elevado de confiabilidade à mensuração da participação dos pardos nos principais eventos políticos dos anos 1821 e 1822.
} 
dentre as 321 assinaturas, cerca de 56 eram de oficiais pardos. ${ }^{72}$ Ainda no âmbito da junta bernardista, três deles participaram da vereança extraordinária de 31 de julho, destinada a expor ao príncipe o estado de "pacífica paz" em que se encontrava a província, tendo rubricado a ata com mais 73 homens. ${ }^{73}$ Mas a presença da oficialidade parda não ocorreu exclusivamente na conjuntura da Bernarda. Antes mesmo, na reunião de "tropa e povo" promovida a 23 de junho de 1821, da qual resultou o juramento às bases da constituição, obediência à D. João VI e ao regente, e a instalação do governo provisório mediante aclamação de seus membros, ao menos 25 milicianos pardos figuraram entre as 447 assinaturas do termo de vereação. ${ }^{74}$ Novamente, em 31 de dezembro de 1821, quando a cidade de São Paulo manifestou o pedido para a permanência do regente, aproximadamente 25 pardos assinaram a representação. ${ }^{75}$ Por fim, das 170 rubricas referentes à sessão extraordinária de 28 de setembro de 1822, na qual se proclamou a D. Pedro imperador, doze são dos milicianos pardos. ${ }^{76}$

Os milicianos dos Úteis residentes na vila de Itu também registraram comparecimento nas sessões de vereações extraordinárias realizadas em meados de 1822, nas quais se deliberou o posicionamento da vila no tocante ao novo governo provisório paulista instalado após a bernarda. Como se sabe, Itu centralizou um bloco de oposição à junta reconfigurada, jurou lealdade ao regente, e articulou com vilas pertencentes à comarca a formação de uma junta governativa provisória. ${ }^{77}$ Os três oficiais de patente pertencentes à sétima companhia do Regimento dos Úteis, lá aquartelada, vivenciaram intensamente os debates políticos e os preparativos militares para a defesa em caso de um ataque proveniente da capital. De fato, o capitão José Leite de Cerqueira, o tenente Francisco de Paula do Espírito Santo e o alferes Francisco Antonio Romano, todos "filhos de pai incógnito", assinaram as atas dos dias 24 de junho, ocasião em que se decidiu pelo total rompimento com a junta de governo bernardista, e de 4 e 7 de agosto, quando se deliberou a formação de uma junta provisória no espaço da

\footnotetext{
${ }^{72}$ Além de alguns soldados e familiares. $C f$.: "Representação que o povo e tropa da cidade de S. Paulo levaram a sua alteza real, na corte do Rio de Janeiro, por meio da qual se dá a conta e os motivos por que depuzeram aos dous membros do Governo Provisório". RIHGSP, vol. 10, p. 332-342.

${ }^{73} C f$ :: "Vereança de 31 julho de 1822". RIHGSP, vol. 10, p. 353-356.

${ }^{74}$ Cf:: Atas da Câmara Municipal de São Paulo..., vol. 22, fls. 469-519. São Paulo, 23 de junho de 1821.

${ }^{75}$ Cf:: Cartas, e mais peças oficiais..., p. 37-44.

${ }^{76} C f$ : "Vereação extraordinária para tratar da conveniencia de poclamar D. Pedro imperador" [sic]. RIHGSP, vol. 10 , p. 357-360.

${ }^{77}$ A repercussão da bernarda, na vila de Itu, foi analisada em NARDY FILHO, Francisco. A cidade de Ytu. $2^{\mathbf{o}}$ vol - Da acclamação de D. João VI à proclamação da Republica. A cooperação ytuana nos factos políticos desse periodo. São Paulo: Escolas Profissionais Salesianas, 1930, p. 37-133; RODRIGUES, Rejane M. Freitas. Representações políticas no Primeiro Império: a relação das Câmaras Municipais de Itu e Franca com o Governo Provincial. Dissertação (mestrado em História). Franca: FHDSS, Universidade Estadual Paulista, 2005; RICCI, Magda M. de Oliveira. "Nas fronteiras da independência": um estudo sobre os significados da liberdade na região de Itu (1779-1822). Dissertação (mestrado em História). Campinas: IFCH, Universidade Estadual de Campinas, 1993.
} 
comarca de Itu. ${ }^{78}$ Como os milicianos pardos da capital, os seus pares ituanos participaram de outras sessões de vereança, como as que trataram da aclamação de D. Pedro imperador do Brasil e do juramento da constituição outorgada em $1824 .{ }^{79}$ Em todas essas circunstâncias, a milícia era fundamental na definição dos pardos como atores políticos, decorrendo daí o fato de que as patentes sempre precediam os nomes pessoais nas assinaturas.

A atuação dos milicianos pardos no processo histórico em tela está suficientemente documentada ao ponto de se saber que eles forneceram amplo apoio militar e político ao príncipe regente no Rio de Janeiro, à junta bernardista na cidade de São Paulo, e à vila interiorana de Itu. Por outro lado, não é tarefa simples compreender o quadro complexo de coerções, motivações e opções disponíveis àqueles homens, já que tais aspectos dificilmente se revelam nas fontes primárias. Apesar disso, pode-se notar a influência de duas variáveis significativas. Como milicianos, as suas percepções e o seu comprometimento fundamentavamse, em boa medida, nas posições ocupadas na hierarquia do Regimento e nas perspectivas de obtenção de recompensas. Isso pode ser visto nitidamente na atitude já referida de vários oficiais, que se ofereceram espontaneamente para a marcha ao Rio de Janeiro, a qual contrasta com a de soldados, que escassamente se voluntariaram e apresentaram uma incidência mais elevada de deserções. ${ }^{80}$ É evidente, pois, que os indivíduos que ocupavam as posições de maior destaque esperavam obter vantagens em troca de sua lealdade, ao passo que os homens investidos nas funções menos valorizadas não raro sentiam que tinham pouco a perder e nada a ganhar. Além disso, como os milicianos pardos residiam em diferentes regiões da província, afetou-os diretamente o modo como se vivenciou o turbulento contexto da independência e formação do Estado e da nação brasileira nas suas localidades. Exemplo disso é que, durante a junta bernardista, os milicianos pardos que moravam na capital permaneceram em posição oposta aos habitantes das vilas de Itu e Sorocaba.

Deve-se, ainda, levar em conta o caráter provisório de ações e representações elaboradas em contexto marcado por uma aceleração do tempo histórico, bem como as pressões e coerções que incidiam sobre indivíduos e grupos em função do seu posicionamento político em circunstâncias tão exaltadas quanto aquela. Embora não estejam suficientemente claras as perspectivas que nortearam a adesão dos milicianos pardos tanto à junta bernardista quanto à

\footnotetext{
${ }^{78}$ Cf: : Vereança extraordinária da Câmara Municipal de Itu. Itu, 4 de agosto de 1822. RIHGSP, v. 7, 1902, p. 178179; Livro Mestre, fls. 344, 345 e 346.

${ }^{79} C f$ : : NARDY FILHO, Francisco. A cidade de Ytu. $2^{\circ}$ vol - Da acclamação de D. João VI à proclamação da Republica. A cooperação ytuana nos factos políticos desse periodo. São Paulo: Escolas Profissionais Salesianas, 1930. p. 46-49, 54-57, 57-58, 102-105, 138-141. A paginação se refere às várias sessões.

${ }^{80}$ Cf.: Livro Mestre, fls. 47, 48, 72v, 82, 83v.
} 
coligação ituana, sabe-se que oficiais e soldados pardos da capital revelaram arrependimento por sua participação nos acontecimentos do dia 23 de maio de 1822. Quatro integrantes do Regimento dos Úteis declararam que foram coagidos pelos líderes do movimento - "com pistola no peito" e "socos nos tambores" - a tocarem rebate, entregarem o quartel, os seus postos e o armamento, para em seguida se dirigirem à praça e depois à câmara, onde assinaram a ata de vereação extraordinária. É impossível estabelecer qual a versão que corresponderia mais adequadamente ao envolvimento da generalidade dos milicianos pardos: se a dos homens que assinaram e conferiram legitimidade a um dos atos políticos mais relevantes na história da província, em maio, ou a das testemunhas visivelmente acuadas no ambiente de repressão à bernarda. O mais correto é considerar que ambas revelam posicionamentos distintos e mutáveis de acordo com os diferentes momentos do próprio movimento. Logo, é pouco proveitoso pressupor uma uniformidade ou rigidez de posicionamentos e de experiências entre os milicianos pardos. ${ }^{81}$

Uma excelente chave de leitura relativamente à atuação dos pardos nos enfrentamentos da década de 1820 é a das competições travadas no universo militar, a qual fornece inteligibilidade para a articulação entre as esferas miliciana e política. Nessa linha, cumpre retomar dois aspectos: os desafios enfrentados pela milícia parda diante dos projetos reformistas e as tensões que grassaram no âmbito do estado-maior do Regimento dos Úteis. De um lado, as tentativas de abolição daquele corpo militar e, de outro, a disputa aberta entre pardos e brancos pelos postos superiores. Essa resultou na troca de um coronel pardo por um branco e no prolongamento de um embate particular entre Manoel José da Costa Ribeiro - amparado inicialmente pelo pai, o coronel Manoel José Ribeiro - e Antonio de Pádua de Gusmão oriundo da tropa regular e aliado do novo coronel José Joaquim César de Cerqueira Leme, igualmente branco e com carreira na primeira linha. ${ }^{82} \mathrm{O}$ contexto político em questão forneceu uma roupagem inteiramente nova aos antigos desafios impostos à milícia parda, de modo que, na década de 1820, a disputa entre ambos esteve impregnada de conteúdo político. Entretanto, de forma semelhante ao que a historiografia vem sugerindo relativamente às elites paulistas, $o$ seu cerne era a competição por postos, privilégios e posições de poder.

\footnotetext{
${ }^{81}$ Cf:: "Devassa sobre a Bernarda de 23 de maio de 1822". São Paulo, set./out. de 1822. RIHGSP, vol. 10, p. 425$432,472-476$. Testemunhas $10 .^{\mathrm{a}}, 11 .^{\mathrm{a}}, 12 .^{\mathrm{a}} \mathrm{e} 21 .^{\mathrm{a}}$.

${ }^{82}$ Ver o item 6.4 desta tese.
} 
As dissensões políticas no seio da elite paulistana preocuparam ao regente D. Pedro a tal ponto de ele empreender uma viagem para a capital daquela província, entre agosto e setembro de 1822, a fim de pacificar os ânimos de seus importantes aliados. Com esse intuito, ele já havia ordenado a dissolução da junta bernardista e nesse momento determinou uma apuração judicial ao ocorrido. Então, em meados de setembro, foi aberta uma devassa, mas essa foi suspensa já em outubro, em função de um decreto que considerou novamente a questão da conciliação entre as elites provinciais e libertou os acusados. ${ }^{83}$ Ao ser encerrada a devassa, haviam sido interrogadas 23 testemunhas, mas nenhum acusado. Esses são conhecidos mediante uma "relação dos cidadãos mandados sair da capital em consequência dos sucessos de 23 de maio e de 19 de julho de 1822, com declaração dos destinos que tiveram". Talvez não se trate, precisamente, de uma deportação, mas de um procedimento dotado da finalidade de afastar os acusados do ambiente da investigação, resguardando-a de eventuais interferências. ${ }^{84}$ Entre os homens acusados, estava o sargento-mor do Regimento dos Úteis, Manoel José da Costa Ribeiro, o homem pardo melhor situado na hierarquia daquele corpo militar. ${ }^{85}$ Embora ele devesse se dirigir ao Rio de Janeiro, não foi localizado qualquer vestígio na documentação primária de que o tenha feito. Seja como for, o fato é que ele se beneficiou da suspensão da investigação em um primeiro momento.

Em 1823, porém, graves acusações tornaram a atingir o sargento-mor pardo. Em primeiro lugar, Costa Ribeiro foi reputado "insubordinado, intrigante e insolente" pelo coronel do Regimento em que servia. ${ }^{86}$ Para além de questões atinentes à disciplina militar, ele foi o único oficial do Regimento dos Úteis a ser apontado nos mapas semestrais atinentes à conduta da oficialidade miliciana como não tendo "adesão à causa do Brasil". ${ }^{87}$ Tais acusações foram elaboradas, em janeiro, pelo tenente-coronel Antonio de Pádua de Gusmão e reiteradas, em julho, pelo coronel José Joaquim César de Cerqueira Leme. Por essa época, a independência do Brasil em relação a Portugal já estava em vias de consolidação institucional, mas, por outro

\footnotetext{
${ }^{83} C f$ :: "Decreto de 25 de junho de 1822. Cria um Governo Provisório de eleição popular na Província de São Paulo" e "Decreto de 23 de setembro de 1822. Faz cessar a devassa a que se mandou proceder na província de São Paulo, pondo em liberdade os que estiverem presos". Decretos, cartas e alvarás, p. 25-26, 49. In: Collecção das Leis do Imperio do Brazil de 1822. Rio de Janeiro: Imprensa Nacional, 1887; "N. 109. Manda proceder a uma devassa na Província de São Paulo e conhecer dos sucessos do dia 23 de maio deste ano". São Paulo, 7 de setembro de 1822. Decisões do governo, p. 82-83. In: Collecção das decisões do governo do Império do Brazil de 1822. Rio de Janeiro: Imprensa Nacional, 1887.

${ }^{84}$ ROMEIRO, J. M. de M. De D. João VI à independência..., p. 1499.

${ }^{85}$ A transcrição dos nomes dos acusados foi publicada em AQUINO E CASTRO, O. H. de. O conselheiro Manoel Joaquim do Amaral Gurgel..., p. 348-349; FORJAZ, Djalma. O senador Vergueiro: sua vida e sua época (17781859). (Vol. 1). São Paulo: Officinas do Diario Official, 1924, p. 90 e 196-197. Ver também DAMACENO, D. T. Os "facciosos"..., p. 236.

${ }^{86}$ Cf:: APESP, Ordem E00891, p. 21v-23. São Paulo, 16 de março de 1823.

${ }^{87} C f$ : : APESP, Ordem C02366. São Paulo, $1 .^{\circ}$ de janeiro e $1 .^{\circ}$ de julho de 1823.
} 
lado, tratava-se de um período de afirmação do novo Estado, da construção da nação e da soberania imperial, no qual os enfrentamentos entre tropas brasileiras e lusitanas ainda perduravam na Bahia. Todos esses aspectos tornavam o conteúdo da denúncia algo extremamente grave. ${ }^{88}$

Durante o primeiro semestre de 1823, o coronel César ocupou interinamente a função de governador das armas da província de São Paulo e, a partir dessa posição elevada, deu prosseguimento às acusações a Costa Ribeiro, retomando o tema da sua participação na bernarda, não obstante as investigações estivessem, havia muito, suspensas por ordem de D. Pedro. Conforme o governador das armas, o sargento-mor pardo estava entre os "inimigos do soberano", de modo que as seguintes acusações dirigidas ao governo da província deveriam também ser apresentadas ao imperador. São elas: a) "tomou uma mui ativa e furiosa parte nos acontecimentos que tiveram lugar nesta cidade no dia 23 de maio do ano findo, e seguintes"; b) foi membro "da rejeitada guarda de honra, organizada nesta em semelhante tempo"; c) "é também pública a desafeição pelo suplicante patenteada a S.M.I., quando esteve nesta capital, e à causa deste império, proferindo em várias ocasiões as mais terríveis imprecações contra o mesmo senhor" ${ }^{89} \mathrm{O}$ caso foi de fato encaminhado à apreciação superior em abril de 1823, tanto pelo governo da província quanto pelo governador das armas. Em ofício enviado à Secretaria de Estado dos Negócios da Guerra, César voltou a apontar Costa Ribeiro como "um oficial notoriamente reconhecido inimigo da causa do Brasil, e corréu em todas as desordens desta capital de 23 de maio do ano passado em diante". Ademais, o governador das armas sugeriu que aquele oficial pardo fazia parte de um grupo de "demagogos e sectários das Cortes de Portugal, sendo a sua casa o ponto de reunião de homens que não gozam da opinião pública e de Clubs".90

Sem entrar no mérito de tais acusações, o fato é que elas revelam que a presença de D. Pedro e a suspensão da junta bernardista funcionaram como medidas paliativas, uma vez que o antagonismo estabelecido entre grupos rivais da província estava longe de acabar. Indicam, igualmente, que havia oficiais milicianos pardos plenamente inseridos nos debates políticos da Era das Revoluções e que possivelmente integravam os grandes grupos em competição pelo controle de funções sociais rentáveis e de poder.

\footnotetext{
${ }^{88}$ KRAAY, Hendrik. Política racial, Estado e Forças Armadas na época da independência: Bahia, 1790-1850. Trad. Magda Lopes. São Paulo: Hucitec, 2011, p. 165-212.

${ }^{89} C f$ : APESP, Ordem E00891, p. 21v-23. São Paulo, 16 de março de 1823.

${ }^{90} C f$ : APESP, Ordem C07776, Livro 327, fl. 24v; E00716, fls. 9-9v. São Paulo, 10 e 11 de abril de 1823.
} 
Em maio, expediu-se uma portaria pela Secretaria de Estado dos Negócios da Guerra pela qual se ordenou a formação de um conselho de averiguação para investigar tais acusações. ${ }^{91}$ Imediatamente, o governador das armas requisitou cópias de vários documentos referentes à dinâmica do Regimento dos Úteis na década de 1810 e às atividades particulares do sargento-mor Manoel José da Costa Ribeiro, com o intuito de formar uma espécie de dossiê acerca da conduta do oficial pardo. Entre os documentos recuperados estão, por exemplo, o abaixo-assinado de 1813, pelo qual a oficialidade parda requereu ao rei D. João VI a nomeação de Costa Ribeiro como sargento-mor do Regimento, e a ata de vereação extraordinária do dia 23 de maio de 1822, a fim de se provar o comprometimento daquele sargento-mor para com a bernarda. ${ }^{92}$

O resultado do conselho de averiguação foi divulgado a 20 de agosto de 1823 . Nesse processo, Manoel José da Costa Ribeiro respondeu a cinco artigos: pelo primeiro, era "acusado de insubordinação, por exigir um assinado de abonação, a seu benefício, dos oficiais do mesmo Regimento, e com ele requerer um despacho aos pés do trono"; pelo segundo, era "acusado de que seu pai, o coronel do Regimento Manoel José Ribeiro, assistia com fazendas da sua loja para vestir aos oficiais inferiores e tambores, de que se pagava nas ocasiões de pagamento"; pelo terceiro, era "acusado de ter parte na revolução urdida nesta cidade no dia 23 de maio" de 1822; pelo quarto, era "acusado de uma nota posta pelo mesmo autor na informação de condutas dos oficiais do Regimento, em que relata que o acusado não tem adesão à causa do Brasil”; e pelo quinto, fora "acusado de palavras incendiárias contra a augusta pessoa de S.M.I. quando esteve nesta cidade", por ter afirmado, especificamente, "que logo que o mesmo augusto senhor regressasse para a Corte do Rio de Janeiro, haveria efusão grande de sangue”. Os integrantes do referido conselho refutaram todos os artigos com base na oitiva de testemunhas. Notadamente, argumentaram que nenhuma testemunha da devassa relativa à bernarda mencionou o nome do sargento-mor pardo, nem mesmo o tenente-coronel Gusmão que ora o acusava; ademais, consideraram "suspeito todo e qualquer escrito ou dito do autor contra o acusado".93

Os cinco artigos de acusação presentes nos autos e, em especial, a suspeita evocada pelos membros do conselho de que haveria parcialidade na consideração do autor relativamente ao acusado remetem diretamente às tensões vigentes no equilíbrio de poder interno ao Regimento dos Úteis, sugerindo, pois, vinculação entre a competição na milícia e atuação

\footnotetext{
${ }^{91} C f$ :: APESP, Ordem E00721, páginas não numeradas. São Paulo, 24 de maio de 1823.

${ }^{92} C f$ :: APESP, Ordem E00716, fl. 15. São Paulo, 28 de maio de 1823.

${ }^{93} C f$ : APESP, Ordem C07776, Livro 327, fls. 42-43v. São Paulo, 20 de agosto de 1823.
} 
política. Ora, as questões relativas ao posicionamento político do sargento-mor pardo são precedidas por itens que retomam a acirrada competição entre milicianos pardos e militares brancos da tropa paga pelos postos do estado-maior do Regimento e as tensões que configuravam o relacionamento entre os oficiais e os soldados pardos em período anterior. Sendo assim, é pertinente reconstruir o quadro de tensões em que esses homens estavam envolvidos de modo a buscar uma compreensão adequada de sua atuação no contexto independentista.

Retomando alguns dados já examinados na tese, vê-se que Antonio de Pádua de Gusmão obteve transferência da tropa regular para o Regimento dos Úteis em 1801, passando do posto de sargento para o de ajudante. Em 1803, as comissões da milícia foram encerradas, e tanto ele como o coronel Joaquim José Mariano da Silva César foram retirados de suas funções no Regimento. Ambos recorreram ao rei e conseguiram retornar àquela milícia, nos mesmos postos, entre os anos de 1808 e 1809. É de se presumir que, desde esse período, Gusmão mantinha uma relação de aliança com a família César, tendo partilhado com o referido coronel o serviço na tropa de linha, a transferência para a milícia parda, o afastamento e a readmissão. Na década de 1810, o então ajudante graduado capitão Gusmão vivenciou a troca de comando no Regimento dos Úteis, que passou para as mãos do pardo Manoel José Ribeiro, e assistiu a progressiva ascensão do filho do coronel, Manoel José da Costa Ribeiro, que com ele disputaria o acesso aos postos de sargento-mor e de tenente-coronel. Em 1816, ambos prestaram concurso para o posto de sargento-mor e, mediante um resultado controverso, Gusmão saiu vitorioso. Costa Ribeiro, por sua vez, levou a questão aos pés do trono, alegando ter a preferência ao posto em virtude de ser pardo e de ter tido desempenho melhor que o concorrente nos exames. Ao ser atendido, em 1819, tornou-se sargento-mor agregado. Entretanto, nesse intervalo de tempo, Gusmão já havia ascendido ao posto vago de tenente-coronel. Em 1821, ocorreu a reforma do coronel Ribeiro, a qual estava relacionada tanto com as tensões entre os pardos como com as disputas mais amplas entre pardos e brancos pelo controle da milícia e aos ataques impostos ao Regimento e à sua oficialidade. Enquanto Costa Ribeiro perdeu a proteção oferecida por seu pai, Gusmão viu restabelecida a sua aliança com a família César, uma vez que o fillho do antigo coronel, José Joaquim César de Cerqueira Leme, foi promovido àquele posto.

A partir de então, Costa Ribeiro teve o seu raio de ação de certo modo tolhido. Exemplo disso é que, em janeiro de 1822, como os demais oficiais do seu Regimento, ele se voluntariou para marchar ao Rio de Janeiro integrando os Leais Paulistanos, a fim de "mostrar o seu patriotismo e amor ao melhor dos príncipes" e "ao sagrado da causa pública do Brasil”, mas foi recusado. O governo provisório paulista agradeceu o oferecimento, mas informou que a escolha 
dos oficiais que integrariam a marcha cabia aos comandantes dos corpos militares. Nesse caso, o sargento-mor pardo devia apresentar-se ao coronel César, "para que, se ele o quiser, oficie ao governo". ${ }^{94}$ Como revela o assento no Livro Mestre, Costa Ribeiro não foi incorporado aos Leais Paulistanos e, portanto, não foi aceito pelo coronel. César conhecia profundamente as regras que estruturavam formal e informalmente a carreira militar e sabia o que a participação naquela campanha poderia significar para um oficial militar. Em 1800, por exemplo, ele pediu transferência da tropa miliciana para a cavalaria de linha, "a fim de ter na Tropa efetiva mais ocasiões de se distinguir no real serviço". ${ }^{95}$ Ao deixar Costa Ribeiro de fora dessa relevante mobilização militar, César estava não apenas ferindo o prestígio como também cerceando as possibilidades de distinção do sargento-mor e, indiretamente, preservando a posição de Gusmão na competição em que ambos estavam envoltos. Como José Joaquim César de Cerqueira Leme foi designado para comandar toda a infantaria miliciana dos Leais Paulistanos, ele teve que passar o comando interino da milícia parda a um oficial de sua escolha e também indicar o oficial que comandaria a companhia formada pelos pardos na marcha para a Corte. O tenentecoronel Gusmão então assumiu o comando da corporação e o capitão Antonio Joaquim da Costa Ribeiro, sobrinho do sargento-mor pardo e hierarquicamente inferior a ele, conduziu a companhia parda. Esse, como se sabe, regressou do Rio de Janeiro com o hábito da Ordem de Cristo, também conferida ao coronel César. ${ }^{96}$

Impedidos de marchar para a Corte, um por assumir o comando do Regimento dos Úteis e o outro por ter sido preterido, Antonio de Pádua de Gusmão e Manoel José da Costa Ribeiro permaneceram na cidade de São Paulo durante o primeiro semestre de 1822 e se envolveram no movimento da Bernarda. Gusmão chefiava o destacamento no dia 23 de maio e, apesar de ter sido acusado de obrigar os seus subordinados a aderirem ao movimento, conforme depoimento de testemunhas da devassa, ele se livrou facilmente sob a alegação de ter agido forçado pelos líderes da ação. ${ }^{97}$ Já Manoel José da Costa Ribeiro enfrentou maiores dificuldades para se desvencilhar das acusações que lhe foram impostas, havendo a possibilidade de ele realmente ter aderido e se comprometido ao movimento que retirou do governo provisório dois

\footnotetext{
${ }^{94}$ Cf:: APESP, ordem C00280, doc. 43-2-6; ordem C00408, Livro [numeração não identificada], fl. 88v. São Paulo, 23 de janeiro de 1822.

${ }^{95}$ Cf:: APESP, ordem C00407, fl. 127v. São Paulo, 13 de setembro de 1800.

${ }^{96}$ Cf:: "Decreto de 18 de maio de 1822" e "Relação dos oficiais do Batalhão de Infantaria e Esquadrão de Cavalaria da Segunda Linha dos Leais Paulistanos, a quem Sua Alteza Real faz mercê do Hábito da Ordem de Christo, e a que se refere o Decreto da data desta". AN, Ministério do Império/Graças Honoríficas, Códice 15, vol. 9, fls. 128v129.

${ }^{97} C f$.: "Devassa sobre a Bernarda de 23 de maio de 1822”. São Paulo, set./out. de 1822. RIHGSP, vol. 10, p. 425432, 472-476. Testemunhas $10 .^{\mathrm{a}}, 11 .^{\mathrm{a}}, 12 .^{\mathrm{a}}$ e $21 .^{\mathrm{a}}$.
} 
integrantes do grupo andradista. Cumpre examinar os vestígios disponíveis e refletir sobre o sentido mais profundo de sua associação ao grupo bernardista.

Com efeito, Costa Ribeiro mantinha vínculos estreitos com um dos líderes do movimento, o coronel Francisco Inácio de Souza Queiróz. Eles tornaram-se compadres, em dezembro de 1823, por ocasião do batismo de Francisco, filho do sargento-mor pardo, o qual expressaria em seu nome, como era comum, homenagem eterna ao padrinho. ${ }^{98}$ Esse tipo de relação é normalmente interpretado pela historiografia como indicativo de estabelecimento de alianças entre os envolvidos. Apesar de serem altamente sugestivos, tais vínculos não explicam completamente a inclusão de Ribeiro entre os bernardistas. Ora, por um lado, tem-se que, em 1838, seu irmão, o capitão pardo José Manoel da Costa Ribeiro, levara como testemunha de seu casamento a Jaime da Silva Telles, também profundamente envolvido na bernarda; por outro lado, é fato que o pai dos Ribeiros, o coronel Manoel José Ribeiro, era considerado inimigo pessoal de Oeynhausen, outro líder da bernarda, em $1820 .{ }^{99}$ Ou seja, tais vínculos poderiam exemplificar tanto a adesão dos pardos à Bernarda como uma possível oposição. A hipótese aqui desenvolvida sugere que os indivíduos não definiam a priori as suas alianças com determinados grupos ou as suas posições políticas, mas o faziam de acordo com as pressões, coerções e oportunidades que se delineavam no curso do processo social. Em outros termos, acredita-se que a definição de posição de Manoel José da Costa Ribeiro - e eventualmente de outros oficiais pardos - se deu muito em função da configuração interna do Regimento dos Úteis e de como essa se relacionava com o equilíbrio de poder mais abrangente formado no âmbito capitania/província de São Paulo.

Desde meados do século XIX, historiadores têm buscado identificar os indivíduos proeminentes da sociedade paulista da década de 1820 a um dos grupos antagônicos, andradistas ou bernardistas. É bastante difundida a associação de José Arouche de Toledo Rendon e de José Joaquim César de Cerqueira Leme ao grupo andradista. ${ }^{100}$ Trata-se de dois indivíduos que representavam ameaças evidentes aos oficiais pardos e particularmente a Costa Ribeiro: o primeiro porque mobilizou amplos esforços para abolir o Regimento dos Úteis e a oficialidade de cor, tendo voltado à carga em 1821, e o segundo porque se tornara o oficial

\footnotetext{
${ }^{98}$ Cf:: ACMSP, Livro de Batizados - Paróquia da Sé (São Paulo), livro n. 12 (1819-1829), fl. 136.

${ }^{99}$ Cf:: ACMSP, Livro de Casamentos - Paróquia de Santa Efigênia (São Paulo), livro n. 2 (1841-1855), fl. 44; "Ofício de João Carlos Augusto de Oeynhausen a Thomás Antônio de Vilanova Portugal, ministro do império, acusando recebimento de uma carta assinada por 'Hum militar', avisando que o coronel dos pardos trama alguma empresa contra o ministro". São Paulo, 11 de janeiro de 1821. BN/dm, doc. ii-35,26,56.

100 OLIVEIRA, J. J. M. de. Quadro Historico da Provincia de S. Paulo..., p. 254; ROMEIRO, João Marcondes. De D. João VI à Independência..., p. 1455-1462; DELATORRE, A. V. São Paulo à época da independência ..., p. 124, 126-127, 136, 160.
} 
branco, oriundo da tropa paga, que substituiu um coronel pardo. Essa propensão de Rendon e César ao grupo andradista confere maior sentido à ideia de que Costa Ribeiro teria se posicionado em direção oposta aos seus adversários.

Tal perspectiva é reforçada pelo fato de que a historiografia recente tem acenado para o universo militar como um âmbito de primeira ordem na disputa entre os grupos rivais da elite paulista. Nesse sentido, argumenta-se que Francisco Inácio de Souza Queiróz detinha o controle institucional e afetivo da tropa miliciana da cidade, ao passo que Rendon, o antigo inspetor geral das milícias, não era bem quisto entre oficiais e soldados. ${ }^{101}$ Conforme Delatorre, nas cartas pessoais de Francisco Inácio, Rendon é retratado como um homem ansioso pelo cargo de governador das armas e diretamente associado a Martim Francisco, bem como alvo de impopularidade na capital em decorrência dos recrutamentos e envios de soldados para o Sul podendo-se acrescentar que também conquistara a antipatia dos milicianos pardos. ${ }^{102}$ Francisco Inácio também revelara privadamente a seu cunhado Estevão Rezende que Martim Francisco de Andrada tentara destituí-lo do comando da força armada com a finalidade de nomear ao posto outro indivíduo, "por motivos particulares". ${ }^{103}$ Na disputa pelo controle da força armada paulista, os Andradas deram um passo adiante em relação aos rivais, na medida em que conseguiram a nomeação de Rendon para o governo das armas da província, por decreto de 10 de maio de 1822. Para os oficiais pardos, o fato era visto com apreensão, uma vez que as reformas propostas para o Regimento dos Úteis poderiam finalmente ser levadas adiante. Contudo, a eclosão da bernarda criou obstáculos para que Rendon, que estava para regressar do Rio de Janeiro, tomasse posse da função.

Conforme as notícias relativas a São Paulo chegavam ao Rio de Janeiro, em junho de 1822, articulou-se uma represália à junta bernardista. Determinou-se que Rendon retornaria à capital paulista acompanhado da infantaria miliciana dos Leais Paulistanos - comandada por César - e, se necessário, de tropas provenientes de Santos, e assumiria o posto e consequentemente o controle da força armada. Os membros da junta interpretaram essa concentração de tropas nas proximidades da cidade como uma ameaça eminente e prepararam os contingentes militares para uma eventual resistência. Isso tudo na verdade não passou de uma demonstração de força de ambos os lados, com objetivos intimidatórios, e a questão foi resolvida com acordo entre as partes. Entretanto, segundo os relatos disponíveis, Rendon teria

101 OLIVEIRA, J. J. M. de. Quadro Historico da Provincia de S. Paulo..., p. 257; DAMACENO, D. T. Os “facciosos" de São Paulo..., p. 125; DELATORRE, A. V. São Paulo à época da independência..., p. 124-133.

102 DELATORRE, A. V. São Paulo à época da independência..., p. 101-105, 126-127.

${ }^{103}$ DELATORRE, A. V. São Paulo à época da independência..., p. 99. 
se convencido das inúmeras dificuldades que enfrentaria no relacionamento com a tropa e os líderes bernardistas e renunciou ao posto. Os Leais Paulistanos ingressaram pacificamente na cidade em 22 de junho de 1822, "no meio do geral aplauso de todas as classes do povo", e logo foram despedidos do serviço, retornando aos seus corpos militares de origem. ${ }^{104}$

Não demorou para o governo provisório bernardista deliberar acerca das recompensas aos integrantes daquela marcha, aludindo aos relevantes serviços prestados à causa do Brasil. O Regimento dos Úteis foi um dos corpos militares melhor atendidos, uma vez que seus integrantes receberam permissão para manter os signos distintivos usados durante a estadia na Corte - "os metais brancos" e farda tomada de empréstimo à tropa regular - e, principalmente, a corporação foi renomeada, passando a se chamar $3 .^{\circ}$ Regimento daí em diante. ${ }^{105}$ Essa alteração era dotada de significado profundo: a mensagem era a de que a distinção prevalecente no universo militar era a da antiguidade dos corpos, ficando em segundo plano a cor dos seus integrantes. Mediante esse afago, o governo provisório buscava recompensar o apoio logrado no dia 23 de maio e trazer para si os milicianos pardos que havia pouco regressaram à província. Também D. Pedro ofereceu recompensa aos milicianos pardos de São Paulo, pois dedicou uma composição musical intitulada Hino em homenagem àqueles homens. ${ }^{106}$

Em agosto de 1822, o príncipe regente viajou para a província, e a sua passagem pela capital gerou constrangimentos e perturbações ao sargento-mor pardo Manoel José da Costa Ribeiro. Em primeiro lugar, porque ele fez parte da guarda de honra enviada pela junta bernardista a fim de recepcionar a D. Pedro e a acompanhá-lo em sua estadia, a qual foi rejeitada pelo então príncipe regente, numa demonstração de desapreço aos integrantes do governo e aos seus apoiadores. Embora o alvo dessa decisão fosse impessoal, o fato foi lembrado e empregado para humilhar e desacreditar ao oficial pardo em 1823. ${ }^{107}$ Em segundo lugar, diante da renúncia de Rendon à função de governador das armas, José Joaquim César de Cerqueira Leme fora

\footnotetext{
$104 C f$ : “120." Sessão”. DIHCSP, vol. 2, p. 181. Palácio do governo de São Paulo, jun./ago. de 1822; "Congratulação do governo provisório ao corpo miliciano que marchara em auxilio ao Rio de Janeiro". São Paulo, 22 de julho de 1822. In: OLIVEIRA, J. J. M. de. Quadro Histórico..., p. 332-333; DAMACENO, D. T. Os "facciosos" de São Paulo..., p. 221-253; DELATORRE, A. V. São Paulo à época da independência..., p. 94-163. NEVES, L. M. B. P. das. São Paulo e a independência..., p. 304-318.

${ }^{105}$ Cf: : CABRAL, José Antônio Teixeira. A estatística da Imperial Província de São Paulo: com várias anotações do tenente-coronel José Antônio Teixeira Cabral, membro da mesma estatística. Tomo I, 1827. São Paulo: Editora da Universidade de São Paulo, 2009, p. 124-125.

106 BINDER, Fernando P. Bandas Militares no Brasil: difusão e organização entre 1808-1889. (Vol. 1). Dissertação (mestrado em Música). São Paulo: Instituto de Artes, Universidade Estadual Paulista, 2006, p. 32-33. 107 Cf: : APESP, Ordem E00891, p. 21v-23. São Paulo, 16 de março de 1823. Para uma narrativa detalhada acerca da viagem de D. Pedro, dos integrantes da sua comitiva em São Paulo e da recusa à guarda de honra cedida pelo governo bernardista, ver ROMEIRO, J. M. de M. De D. João VI à independência..., p. 1491-1507.
} 
nomeado interinamente em seu lugar. ${ }^{108}$ Para o sargento-mor pardo, essa elevação de seu desafeto a uma posição tão proeminente poderia significar riscos à sua posição na milícia e um prejuízo notável na competição pelos postos do Regimento.

Nessa conjuntura é que se processaram os maiores atritos entre Costa Ribeiro e os seus superiores brancos na milícia, o tenente-coronel Gusmão e o coronel licenciado César. Valendose de uma diretriz emitida pela Secretaria de Estado dos Negócios da Guerra, de 21 de junho de 1822, a qual recomendava que "os empregos e postos militares sejam ocupados por pessoas que, além de outras partes, tenham com especialidade os mais firmes sentimentos de adesão à causa do Brasil", o comandante interino do 3. Regimento, Antonio de Pádua de Gusmão, acusou a Costa Ribeiro de não ser adepto à causa do Estado em formação, em 1823. ${ }^{109}$ Aqui se está diante de um exemplo cristalino referente ao modo como o vocabulário político recente fora incorporado à competição no universo militar. Ora, em fevereiro de 1823, o próprio Antonio de Pádua de Gusmão requereu ao imperador "a mercê da sua efetividade" no posto de tenente-coronel, visto que até então era sargento-mor com graduação e exercício de tenentecoronel, e, portanto, não efetivo. A seu favor, alegava ter "reconhecida adesão à causa pública do Brasill". ${ }^{110}$ Era, pois, na sucessão e no entrelaçamento das jogadas dos dois competidores, agora em ambiente social e politicamente convulsionado, que as tensões no estado-maior do Regimento foram se agudizando e extrapolando o seu âmbito particular.

Ainda nesses primeiros meses de 1823, o coronel César estava licenciado da milícia e Gusmão, seu imediato, marchou em um destacamento para a praça de Santos em virtude dos receios de que a costa litorânea fosse atacada por tropas portuguesas, sendo necessário que se nomeasse, provisoriamente, um comandante para o 3..$^{\circ}$ Regimento. Como o sargento-mor Manoel José da Costa Ribeiro era o próximo na escala hierárquica, esperava que fosse incumbido dessa função. Entretanto, César, enquanto governador das armas interino, escolheu para o comando da corporação um oficial de outro regimento, novamente em menoscabo do pardo Costa Ribeiro. ${ }^{111}$ Esse, por sua vez, levou a questão às instâncias superiores, na Corte. Resultou daí a "imperial desaprovação" ao procedimento do governador das armas. O secretário de Estado dos Negócios da Guerra considerou que

\footnotetext{
${ }^{108}$ Cf:: APESP, Ordem C07746, Livro 205, fl. sem numeração. Rio de Janeiro, 30 de janeiro de 1823. Ver também ROMEIRO, J. M. de M. De D. João VI à independência..., p. 1499.

${ }^{109} C f$ : APESP, Ordem C00418, Livro 164, sem paginação Rio de Janeiro, 21 de junho de 1822; Ordem C02366, documentos não numerados. São Paulo, $1^{\circ}{ }^{\circ}$ de janeiro e $1 .^{\circ}$ de julho de 1823.

${ }^{110}$ Cf:: APESP, Ordem E00891, fl. 12. São Paulo, 12 de fevereiro de 1823.

${ }^{111} C f$ : : APESP, Ordem E00716, fls. 9-9v. São Paulo, 11 de abril de 1823; Livro Mestre, fl. 3.
} 
muito mal se houve aquele governador interino quando, arbitrariamente alterando a escala gradativa dos oficiais do $3 .^{\circ}$ Regimento, fez cair a nomeação de comandante deste em oficial de outro corpo, e sendo tal procedimento não somente um excesso de autoridade, mas uma ofensa aos beneméritos oficiais do 3. ${ }^{\circ}$ Regimento; não podendo finalmente servir de desculpa na presença de Sua Majestade Imperial as razões que o governador interino dá em desabono do major agregado. ${ }^{112}$

Determinou-se, ademais, que o comando deveria recair em um oficial da própria corporação, à exceção do sargento-mor Costa Ribeiro, que responderia ao conselho de averiguação em razão das graves acusações que lhe foram destinadas por César e Gusmão.

Esse caso expôs as lutas internas ao Regimento dos pardos e a sua instrumentalização política na Era das Revoluções. Para esses oficiais militares, fossem eles brancos ou pardos, o acesso às funções de poder e de prestígio, aspectos que lhes tocavam direta e pessoalmente, eram tão ou mais importantes que os diferentes projetos políticos e ideológicos existentes na conjuntura das independências. E nisso eles não se distinguiam da generalidade dos grupos dirigentes da província, os quais, como tem revelado a historiografia, articulavam com maestria as questões de natureza política aos seus interesses econômicos e simbólicos. O exame a essa intrincada rede social, na qual se processavam competições diversas, revela que os milicianos pardos, ou pelo menos os indivíduos melhor situados hierarquicamente, viam com acentuado interesse o processo político que transcorria no Brasil e na província de São Paulo em particular. Nesse sentido, as experiências sociais desses artesãos ou pequenos agricultores, descendentes de escravos negros, de indígenas administrados e de mestiços de vários matizes, afastam-se significativamente das perspectivas historiográficas tradicionais acerca da participação popular na conjuntura da independência do Brasil.

\subsection{Guerras, milícia, ofícios mecânicos e a nobilitação de uma família parda: estratégias e tensões vividas pelos Ribeiros (São Paulo, c. 1750 - c. 1830)}

Examinam-se aqui aspectos da trajetória de elevação social de uma família parda da capitania e depois província de São Paulo, a qual transitou do cativeiro para a ocupação de posições e obtenção de honrarias associados à nobreza ao longo do período compreendido entre os anos 1750 a 1830. Em decorrência desse processo ascensional, o grupo familiar em questão

${ }^{112} C f$ : : APESP, Ordem C07746, Livro 205, sem paginação. Rio de Janeiro, em 2 de março de 1823 
passou a ocupar posição central no equilíbrio instável de poder formado por pardos livres de São Paulo, situado em setor intermediário no espaço social daquela configuração, bem como estabeleceu relações de aliança e de competição com integrantes brancos dos grupos mais elevados. Ao mesmo tempo, a família Ribeiro buscou manter contato constante com o poder central, monárquico e depois imperial, via prestação de serviços militares e demandas por recompensas. Cabe esclarecer que a opção por abordar o fenômeno da nobilitação dos Ribeiros identificando as posições por eles ocupadas no espaço social ao longo do tempo e considerando as implicações das sucessivas mudanças nos equilíbrios instáveis de poder nos quais eles se inseriam visa a evitar aquilo que Pierre Bourdieu refere como o engodo da "história de vida" e igualmente o falso antagonismo, denunciado por Norbert Elias, entre indivíduo e sociedade. ${ }^{113}$

O núcleo familiar em questão era chefiado por Manoel José Ribeiro e Belizarda Pinto. Dentre as inúmeras afinidades que conduziram à formação desse casal, ambos compartilhavam a cor parda e a baixa origem. Os dois tinham pais incógnitos e nasceram de mães solteiras e escravizadas - ele na vila litorânea de São Sebastião, em 1752, e ela na cidade de São Paulo no ano seguinte. Em 1779, quando se casaram e estabeleceram domicílio em São Paulo, estavam já libertos do cativeiro - sem que se saiba quando e sob quais circunstâncias se deram suas alforrias. Sabe-se, porém, que Manoel José Ribeiro era liberto já em 1776, pois era soldado da tropa paga, em cujo posto permaneceu até 1779, ano em que obteve sua baixa. ${ }^{114}$ Após o casamento, o casal gerou cinco filhos, sendo três mulheres e dois homens, todos pardos e livres, mas Belizarda já era mãe de uma menina antes de se casar. Em virtude do fato de a concepção ter-se dado fora dos parâmetros exigidos pela Igreja, a filha foi registrada como tendo paternidade desconhecida e jamais residiu com o casal. ${ }^{115}$

$\mathrm{Na}$ sociedade colonial, a escolha dos nomes pessoais cumpria inúmeras funções, tais como a de busca de proteção sagrada e a de consolidação de vínculos pessoais. Por isso os nomes frequentemente homenageavam santos do dia ou de devoção, familiares, compadres, proprietários ou ex-proprietários no caso de escravos e libertos. Interessante notar que, na família Ribeiro, os filhos homens homenageavam, com seus nomes, o próprio pai: o primogênito se chamou Manoel José da Costa Ribeiro e o caçula José Manoel da Costa Ribeiro. Esse modo de proceder não era, absolutamente, discrepante com as lógicas sociais vigentes. ${ }^{116}$

\footnotetext{
${ }^{113}$ BOURDIEU, Pierre. A ilusão biográfica. In: AMADO, J.; FERREIRA, M. de M. (Coords.). Usos \& abusos da história oral. Rio de Janeiro: Editora da Fundação Getúlio Vargas, p. 183-191; ELIAS, Norbert. A sociedade dos indivíduos. Trad. Mário Matos. Lisboa: Dom Quixote, 1993.

${ }^{114} C f::$ ACMSP/DMC 5-60-1355, fls. 39-53. São Paulo, outubro de 1779.

${ }^{115}$ Cf:: ACMSP/DMC 6-60-2257, fls. 35-42. São Paulo, julho de 1798.

116 HAMEISTER, Martha D. Uma contribuição ao estudo da onomástica no período colonial: os nomes e o povoamento do Extremo Sul da Colônia (Continente do Rio Grande de São Pedro, c. 1735-1777). In: DORÉ, A.;
} 
Ao invés de acenar para pessoas ou entidades exteriores ao núcleo familiar, nesse caso a atribuição dos nomes aos filhos buscou realçar perante a comunidade local tanto o pertencimento como um índice elevado de coesão da unidade familiar, cuja característica veio efetivamente a se revelar constante com o decorrer dos anos.

Enquanto a família crescia, Manoel José Ribeiro dedicava-se a alfaiataria. Apesar da conotação negativa associada a esse ofício, que como os mais mecânicos era tido como oposto ao ideal de nobreza, tratava-se de profissão especializada com a qual Ribeiro, um egresso do cativeiro, pôde se estabelecer e prover o sustento familiar. ${ }^{117} \mathrm{O}$ grau de acesso dos negros livres ao topo das hierarquias profissionais gerou controvérsias na historiografia: enquanto Klein destacou a preponderância dos homens de cor livres no universo artesanal, Russell-Wood contra-argumentou sugerindo que esse predomínio ocorria apenas nas posições mais baixas. ${ }^{118}$ Em 1790, Ribeiro foi eleito por seus pares para ocupar o cargo anual de juiz dos alfaiates da cidade de São Paulo. ${ }^{119}$ Esse dado pode ser lido como atestação cabal da falta de limpeza de mãos, mas, por outro lado, indica também que o pardo era mestre de seu ofício e chegara ao topo daquela hierarquia. Como a historiografia vem demonstrando há algum tempo, determinadas especialidades artesanais eram tipicamente dominadas por pessoas de cor e essas pessoas alcançavam os postos de autoridade de suas corporações de ofício com uma frequência muito mais elevada do que supôs Russell-Wood para o período em tela. ${ }^{120}$

O antigo soldado da tropa paga foi readmitido ao serviço militar em 1794, mas então nas tropas de segunda linha. A experiência militar prévia pesou nessa circunstância, já que Ribeiro foi logo nomeado capitão de uma das três companhias auxiliares de pardos recémcriadas na cidade de São Paulo. ${ }^{121}$ A formação de um regimento miliciano destinado aos homens pardos da capitania, em 1797, consolidou a posição de Ribeiro como comandante da

SANTOS, A. C. de A. (Orgs.). Temas Setecentistas: governos e populações no Império Português. Curitiba: UFPR/SCHLA-Fundação Araucária, 2009, p. 459-478.

117 CUNHA, Luiz Antônio. O ensino de ofícios artesanais e manufaturas no Brasil escravocrata. São Paulo: Editora UNESP, Brasília, DF: Flacso, 2000, p. 7-25.

118 KLEIN, Herbert S. Os homens livres de cor na sociedade escravista brasileira. Dados - Revista de Ciências Sociais, n. 17, p. 3-27, 1978; RUSSELL-WOOD, A. J. R. Escravos e libertos no Brasil colonial. Rio de Janeiro: Civilização Brasileira, 2005, p. 92-94.

${ }^{119}$ Cf.: Atas da Câmara Municipal de São Paulo. (v. 19). São Paulo: Typographia Piratininga, 1921, p. 148.

${ }^{120}$ RABELLO, Elisabeth Darwiche. A cidade de São Paulo e sua estrutura profissional: 1804-1825. In: COSTA, Iraci del Nero da. Brasil: História econômica de demográfica. São Paulo: USP; FEA/IPE, 1986, p. 223-244; SILVA, Luiz Geraldo. Da festa à sedição: sociabilidades, etnia e controle social na América portuguesa (17761814). História: Questões \& Debates, Curitiba, n. 30, p. 83-110, 1999; FLEXOR, Maria Helena Ochi. Ofícios, manufaturas e comércio. In: SZMRECSÁNYI, T. (Org.). História econômica do período colonial. (2. ed.). São Paulo: Hucitec, 2002; LIBBY, Douglas Cole. Habilidades, artífices e ofícios na sociedade escravista do Brasil colonial. In: COLE, D. C.; FURTADO, J. F. (Orgs.). Trabalho livre, trabalho escravo: Brasil e Europa, séculos XVII e XIX. São Paulo: Annablume, 2006, p. 57-73.

${ }^{121}$ Cf:: Livro Mestre, fl. 1. 
companhia de granadeiros. Além disso, a sua participação ativa no recrutamento de soldados e na criação de companhias para a nova corporação rendeu-lhe a obtenção da graduação de tenente-coronel, uma mercê que fez jus às disposições da carta régia que criou as tropas auxiliares, em 1645, com a promessa de agraciar aos oficiais militares que formassem novos corpos de segunda linha. ${ }^{122}$ Essa conjunção de fatores permitiu-lhe aspirar aos postos superiores da milícia e certamente marcou um ponto de inflexão na estratégia familiar dos Ribeiros, os quais passariam a encarar o serviço militar como a melhor maneira para melhorar sua reputação social. Não por acaso Ribeiro tratou logo de alistar seus filhos na corporação: Manoel sentou praça de soldado em 1800, quando tinha apenas 11 anos de idade, e José em 1809, com 15 anos. Ademais, fosse de modo intencional ou por mera casualidade, a família ampliou seus vínculos com o universo militar. A filha que Belizarda teve no estado de solteira casou-se, em 1798, com o tenente quartel-mestre do Regimento, o pardo José Elias da Silva. Já a filha legítima Joaquina Ribeira Gomes contraiu matrimônio por volta de 1800 com o também pardo Antonio Moreira, um ex-companheiro de Manoel José Ribeiro na tropa paga. Com o falecimento do marido, Joaquina permaneceu na casa paterna junto com seu rebento, Antonio Joaquim da Costa Ribeiro. Este tinha tão somente 9 anos quando foi alistado na milícia pelo avô, em $1809 .{ }^{123}$

Na posição de capitão, Ribeiro almejava para seus filhos e neto um futuro melhor do que o de simples soldado na milícia. Tal perspectiva só fez aumentar com sua promoção a tenente-coronel efetivo, em 1810, e com o dado concreto de que, sem a nomeação de um coronel efetivo, o Regimento estava sob seu comando a partir de então. Observe-se a progressão vertiginosa de seus parentes na hierarquia miliciana: o genro José Elias da Silva, como visto, ascendera a tenente quartel-mestre em 1797 e permanecera no posto até sua reforma; Manoel, o filho primogênito, depois de cumprir seis anos no posto de soldado e quatro no de sargento, ocupou a partir de 1810 o posto de capitão de granadeiros que a ascensão de seu pai tornara vago. Em 1815, ele alcançou o posto de sargento-mor e, em 1826, o de tenente-coronel do Regimento dos pardos. Já o seu irmão, José, que havia sentado praça como soldado em 1809 e em menos de uma semana tornara-se cabo de esquadra, ascendera em 1810 a porta-bandeira e, no mesmo ano, a tenente. Ele permaneceu nesse posto até 1813, quando obteve promoção a capitão. Finalmente, o neto Antonio Joaquim também seguiu os passos do avô e dos tios. Após dois anos como soldado e mais dois como porta-bandeira, foi nomeado alferes em 1813 e

\footnotetext{
${ }^{122}$ Cf:: "Carta Régia de 7 de Janeiro de 1645. Criação de Soldados Auxiliares". In: SILVA, José Justino de Andrade e. Collecção Chronologica da Legislação Portugueza. Lisboa: Imprensa de J. J. A. Silva, 1854.

${ }^{123}$ Cf.: Livro Mestre, fls. 1-1v, 2, 3-3v, 11-12, 56; APESP, Maços de População, Capital: (1802) 1. ${ }^{a}$ Cia., fogo 139.
} 
tenente em 1816. Entre 1820 e 1825 ocupou o posto de capitão e, daí até 1831, quando da extinção das milícias no Império do Brasil, ele foi o sargento-mor do Batalhão. ${ }^{124}$

A recapitulação da ascensão dos Ribeiros na hierarquia miliciana é reveladora de como a formação de corpos milicianos destinados a pardos livres e o controle de tais unidades militares tornava possível a projeção de estratégias de ascensão individual e familiar. O forro Manoel José Ribeiro conhecia adequadamente os requisitos e trâmites legais que regiam as promoções militares, bem como seus atalhos, e valeu-se de sua posição para encaminhar filhos e neto na milícia desde muito cedo. Isso fez com que eles alcançassem o tempo de serviço necessário para pleitear acesso aos postos da oficialidade quando ainda jovens e para isso pesou decisivamente o fato de ele próprio, no exercício de coronel, realizar as indicações para as promoções. Como resultado, exceto o filho caçula, cuja ascensão estacionou no prestigiado posto de capitão de companhia, os demais integrantes dessa família chegaram aos postos superiores do Regimento.

Havia enorme concentração de poder ligada ao exercício dos postos. A cada capitão de companhia estavam subordinados os integrantes da oficialidade e cerca de 60 soldados; o coronel, por sua vez, comandava o estado-maior da corporação e tinha ascendência sobre os 800 homens que compunham os regimentos e batalhões, os quais, não raro, eram referidos como seus "súditos". Para além desse aspecto e da responsabilidade atinente ao comando militar, dos postos emanavam privilégios e distinções, os quais eram amplamente reconhecidos e perseguidos por todo o corpo social. Conforme escreveu um tratadista da nobreza portuguesa, em 1806, "é notório a todo o mundo que os postos militares enobrecem os sujeitos a quem forem conferidos" e que "o de capitão [de milícia] é suficiente para nobilitar". ${ }^{125}$ Não fora casual, portanto, o empenho dessa família egressa do cativeiro para abocanhar os principais postos do Regimento dos pardos.

Mas se a nobreza traz consigo honras e privilégios, ela implica, em contrapartida, "um fardo assaz pesado para aquele que a possui". ${ }^{126} \mathrm{O}$ portador dessa condição torna-se, então, refém de regras, práticas e pressões sociais para manter e defender sua honra e prestígio. ${ }^{127}$ Vai daí o empenho da família Ribeiro no sentido do abandono das atividades e sinais associados ao universo da plebe, que a caracterizaram no início, e da adoção gradual de práticas que os

\footnotetext{
${ }^{124}$ Cf:: Livro Mestre, fls. 1-1v, 2, 3-3v, 6, 11-12, 56.

${ }^{125}$ Cf:: OLIVEIRA, Luiz da Silva Pereira. Privilegios da nobreza, e fidalguia de Portugal. Lisboa: Oficina de João Rodrigues Neves, 1806, p. 41-50.

${ }^{126}$ Cf.: OLIVEIRA, Luiz da S. P. Privilegios da nobreza, e fidalguia de Portugal..., p. 7-8.

${ }^{127}$ ELIAS, N. A sociedade de corte: investigação sobre a sociologia da realeza e da aristocracia de corte. Rio de Janeiro: Jorge Zahar Ed., 2001.
} 
remetessem ao setor aristocrático e senhorial. Como já visto, Ribeiro estava profundamente comprometido com o mundo dos ofícios mecânicos na década de 1790. Em 1798, ele exercia o ofício de alfaiate e era capitão de milícia. Porém, a partir de 1802, Ribeiro passou a ser referido nos recenseamentos paulistas pela graduação militar obtida, a de tenente-coronel, e por viver do "negócio de fazenda seca que traz do Rio de Janeiro". De 1810 em diante, ele surge como “coronel Manoel José Ribeiro" e mantém-se, até 1815, com seu negócio de fazenda seca. A partir de 1818 as listas referem apenas que o coronel "vive de sua loja", a qual se situava, provavelmente, na parte térrea de seu sobrado. ${ }^{128} \mathrm{Com}$ a ascensão nos postos da milícia e a decorrente ampliação de honra e prestígio, Ribeiro buscou desvincular-se do artesanato e transitar para atividade socialmente menos comprometedora. Se bem que o comércio a retalho, que era o caso dos Ribeiros, não lograra obter a mesma reputação que os grandes comerciantes adquiriram a partir do ministério pombalino, o chefe da família conseguiu ao menos que os filhos e o neto jamais se dedicassem aos ofícios mecânicos. ${ }^{129}$

Outra variável relevante no sentido da transição pela qual passou a família de exescravos é exatamente a posse de cativos e a condição senhorial. Manoel José Ribeiro era proprietário de 2 escravizados enquanto se ocupava com a alfaiataria e era capitão. Mas, logo que obteve a graduação de tenente-coronel, mudou de profissão e ampliou o contingente de escravos. Entre os anos 1805 e 1810 houve variações no total de cativos, mas desse ano em diante, e enquanto Ribeiro exerceu o coronelato do Regimento, ele dispôs de 9 a 10 cativos para o trabalho na loja, para servi-lo em casa e possivelmente também para alugá-los a terceiros. ${ }^{130}$ O perfil econômico da capitania alterara-se significativamente desde o tempo em que Manoel José Ribeiro e sua esposa eram cativos, na década de 1750, até que o grupo familiar possuísse uma dezena de escravos, nos anos de 1810. O desenvolvimento da produção comercial do açúcar, a partir de fins do século XVIII, foi responsável por um alargamento da capacidade de aquisição de cativos naquela configuração social. No entanto, os maiores plantéis estavam sob o controle de proprietários brancos e vinculavam-se às grandes fazendas. Apenas $6 \%$ de todos os proprietários de escravos eram pardos, como os Ribeiros, e, em bem menor escala, pretos. Esse reduzido potencial de aquisição de escravos, característico dos grupos cuja origem se vinculava ao cativeiro, sugere que os pardos tinham maiores dificuldades que os brancos para

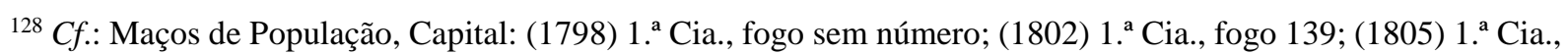
fogo 127; (1808) 1. ${ }^{a}$ Cia., fogo 134; (1810) 1. ${ }^{a}$ Cia., fogo 105; (1815) 1. ${ }^{a}$ Cia., fogo 29; (1818) 4. ${ }^{a}$ Cia., fogo 29.

129 SILVA, M. B. N. da. Ser nobre na Colônia. São Paulo: Ed. UNESP, 2005, p. 175-191; RAMINELLI, R. Nobreza e riqueza no Antigo Regime ibérico setecentista. Revista de História, São Paulo, n. 169, p. 83-110, jul./dez. 2013.

${ }^{130}$ Vide nota de rodapé 128 , acima.
} 
obter, acumular e investir pecúlio. ${ }^{131}$ Assim, Manoel José Ribeiro certamente figurava entre os pardos mais ricos de São Paulo. Seu empenho na aquisição de escravos atendia a interesses econômicos e, não menos importante, sociais: a família necessitava, por um lado, indicar o afastamento do baixo nascimento e da atividade mecânica e, por outro, manter-se "à lei da nobreza". Por isso, exceto o genro José Elias da Silva, todo o núcleo familiar permaneceu coabitando a mesma casa e compartilhando da condição social e econômica adquirida até pelo menos o ano de 1822. Trata-se, seguramente, de estratégia voltada à concentração da riqueza no núcleo familiar original. Como, além do chefe, os filhos e neto ocupavam postos de alto escalão na milícia, deveriam tratar-se todos ao modo aristocrático. A formação de novos núcleos familiares poderia significar a fragmentação da riqueza familiar e, dessa forma, pôr em risco a estabilidade e o reconhecimento social da posição nobre desfrutada por seus membros.

Vai daí que o filho primogênito, Manoel José da Costa Ribeiro, permaneceu no lar paterno mesmo após se casar. Ele contraiu matrimônio com uma mulher parda em 1805 e, após enviuvar, casou-se novamente em 1812, agora com uma jovem branca, natural de Lisboa. Quando do primeiro consórcio, Manoel ocupava o posto de sargento, sem patente, mas quando do segundo já era capitão. Como se vê, a posição prestigiada e honrosa pode ter sido decisiva para possibilitar a união entre um pardo e uma branca. Mas ler esse fato exclusivamente na ótica das estratégias de embranquecimento social pode ser um equívoco. Ora, desconsiderandose a esposa branca do filho Manoel, todos os integrantes da família foram reputados pardos durante o período examinado. A trajetória de ascensão não significou, para nenhum deles, tornar-se branco. Por outro lado, e inversamente, a posição na milícia alcançada pelo chefe, por seus filhos e neto, alterou substancialmente a condição da integrante branca da família, já que obrigou a que ela e as demais mulheres da família fossem reconhecidas socialmente como "donas".

As patentes militares enobreciam, como visto anteriormente. Contudo, elas correspondiam ao exercício de diferentes postos, os quais eram organizados hierarquicamente. Apesar de não existir diferença rigorosa entre os privilégios conferidos a um alferes e os desfrutados por um coronel, a autoridade e a honra dos postos variava consideravelmente de acordo com a posição na cadeia hierárquica. De 1796 em diante, previa-se para cada um dos regimentos e batalhões milicianos a existência de nada menos que 30 oficiais de patente distribuídos pelas companhias (capitão, tenente e alferes) e de mais seis integrantes do estadomaior - sem contar os oficiais reformados, os quais mantinham ou ampliavam as posições

${ }^{131}$ LUNA, F. V.; KLEIN, H. S. Evolução da sociedade e economia escravista de São Paulo, de 1750 a 1850. São Paulo: Edusp, 2005, p. 137-165, 208-209. 
adquiridas. ${ }^{132}$ Isso significa que, com o funcionamento ideal dos 11 corpos milicianos de São Paulo, os oficiais nobilitados pelas patentes militares alcançariam a cifra de 396 homens. Faziase necessário, pois, buscar e acumular outras fontes de honra e nobreza a fim de consolidar as posições e distinguir-se dentre os pares.

Na América portuguesa, e mesmo no Brasil imperial, não houve a formação ou consolidação da alta nobreza e da nobreza hereditária. Apesar da centralidade da família na organização social de Antigo Regime, a baixa nobreza por aqui era restrita ao âmbito individual. A riqueza e o "viver à lei da nobreza" não eram suficientes, por si só, para a obtenção formal dessa condição. Diante dessa realidade, o código honorífico exigia que os aspirantes acessassem uma ou mais fontes de nobreza, como era o caso do foro de fidalgo da Casa Real, da obtenção de comenda ou hábito de ordem militar, a instituição de morgado ou mesmo a ocupação de cargos nas Câmaras ou de postos militares. ${ }^{133}$ Durante duas décadas, entre 1810 e 1830, os Ribeiros buscaram incessantemente junto à Coroa e ao Império a obtenção de hábitos nas ordens militares, especialmente na Ordem de Cristo. As origens dessa ordem religiosa e militar medieval, que em Portugal sucedeu a Ordem do Templo, remontam ao começo do século XIV e ao fim das campanhas militares de reconquista frente aos califados muçulmanos. Ao longo do tempo, porém, as funções sociais das ordens militares se alteraram e elas tenderam a assumir a feição primordial de ordens honoríficas. Ao longo dos séculos XVI a XIX, a mercê de hábitos ou comendas das ordens de Cristo, Santiago e Aviz serviu como uma das mais importantes formas de remuneração régia aos serviços prestados pelos vassalos no reino e no ultramar, já que seu caráter predominantemente honorífico poupava recursos financeiros da Coroa para esse fim. A Ordem de Cristo era reputada mais prestigiosa do que as demais, por isso foi secularmente a mais demandada e a mais concedida. ${ }^{134}$

Até meados do século XVIII, a obtenção de hábitos ou comendas se dava após um processo extremamente rígido, cujas principais etapas se relacionavam com a conquista de despacho régio favorável e com a confirmação, por parte da Mesa de Consciência e Ordens, após as provanças. Como zeladora das prerrogativas da nobreza, a Mesa investigava se o habilitando possuía defeitos de raça (se era ou descendia de judeus, muçulmanos ou outras "raças infectas") ou de qualidade (se era ou descendia de oficiais mecânicos) e confirmava a mercê apenas após a constatação de inexistência de máculas ou de sua dispensa. Durante e após

\footnotetext{
132 Cf: : Decreto de 7 de Agosto de 1796. In: SILVA, A. D. da. Collecção da Legislação Portugueza - Legislação de 1791 a 1801. Lisboa: Typografia Maigrense, 1828.

${ }^{133}$ SILVA, M. B. N. da. Ser nobre na Colônia...; RAMINELLI, R. Nobreza e riqueza...

${ }^{134}$ SILVA, M. B. N. da. Ser nobre na Colônia..., p. 96-122, 198-212, 285-292.
} 
o ministério pombalino (1750-1777), houve uma espécie de atenuação nos procedimentos e atuação da Mesa, já que o trato mercantil deixou de ser encarado como atividade desonrosa e, por uma série de medidas, retirou-se as máculas de cristãos-novos, indianos, indígenas do Brasil e de pretos libertos residentes no reino. ${ }^{135}$ Daí em diante, ocorreu um processo de vulgarização das dispensas de impedimentos e até mesmo de provanças. Conforme Maria B. Nizza da Silva, a "liberalidade com que era concedida pelo monarca" fez com que a Ordem de Cristo tenha "perdido parte de seu prestígio" nos reinados de D. João VI e D. Pedro I. ${ }^{136}$ Se a expansão no contingente dos cavaleiros da Ordem de Cristo em solo luso-americano e brasileiro de certo modo inflacionou seu prestígio social entre fins do Setecentos e primeiras décadas do Oitocentos, formalmente não houve qualquer redução em seus privilégios e condição de nobreza. Por isso é notável o fato de que três gerações dos Ribeiros tenham alcançado tal honraria: em 1810, no reinado de D. João VI, o patriarca Manoel José Ribeiro; em 1822, sob a regência de Pedro, o neto Antonio Joaquim da Costa Ribeiro; e, em 1828, o filho Manoel José da Costa Ribeiro. ${ }^{137}$ As duas primeiras concessões serão examinadas a partir daqui.

Em 1810, o capitão pardo Manoel José Ribeiro licenciou-se das atividades milicianas e da administração de seu negócio para ir até a Corte no Rio de Janeiro. Lá ele apresentou várias demandas ao rei: pediu e obteve para si, via decreto régio, a efetividade do posto de tenentecoronel com graduação de coronel, e, para seu filho mais velho, o posto de capitão. Apesar da relativa proximidade, viajar até a Corte era um alto investimento para aqueles homens, e, valendo-se da ocasião, talvez até na forma de improviso, Ribeiro aproveitou para lançar sua carta mais alta: requereu o hábito de Cristo. Como ele não estava de posse dos documentos necessários para anexar e justificar os serviços pelos quais se julgava merecedor da honra, apresentou apenas "os que lhe foram possíveis" e que haviam sido preparados para pleitear a reforma como tenente-coronel. Na ausência do requerimento, as 12 atestações obtidas junto a um ex-governador, a um brigadeiro, a capitães-mores e a sargentos-mores fornecem uma perspectiva segura dos principais serviços e merecimentos de Ribeiro. ${ }^{138}$

Em primeiro lugar, ele realizou uma campanha militar quando ainda era soldado da tropa paga, em 1776. No calor das tensões entre luso e hispano-americanos na bacia do Prata, o

\footnotetext{
${ }^{135}$ LIMA, Priscila de. De libertos a habilitados. Interpretações populares dos alvarás antiescravistas na América portuguesa (1761-1810). Dissertação (mestrado em História). Curitiba: SCHLA, Universidade Federal do Paraná, 2011, p. 20-30.

136 SILVA, M. B. N. da. Ser nobre na Colônia..., p. 104; SILVA, M. B. N. da (Org.). História de São Paulo colonial. São Paulo: Editora Unesp, 2009, p. 235; HOLANDA, S. B. de. A herança colonial - sua desagregação. In: HOLANDA, S. B. de (Dir.). História geral da civilização brasileira [1960]. (Tomo II, 1. o vol.). 3. a ed. São Paulo: Difusão Européia do Livro, 1970, p. 29-34.

${ }^{137} C f:$ : AN, Decretos Gerais, Livro 2, fl. 63, 65; Livro 9, fl. 128v; Livro 11, fl. $148 \mathrm{v}$.

${ }^{138} C f:$ BN/dm, Col. Documentos Biográficos, doc. C.0360,017.
} 
regimento em que servia Manoel José Ribeiro foi destacado para o Rio Grande do Sul, onde o soldado pardo permaneceu por alguns meses transitando com sua corporação por diferentes pontos estratégicos da costa litorânea. Os merecimentos de Ribeiro foram exemplificados por um antigo tenente através de um relato episódico. Tendo ordens para pôr em execução ao anoitecer uma ronda com soldados de sua escolha, "a fim de impedir algum desembarque que os inimigos intentassem fazer naquelas praias, foi um dos soldados que me acompanharam Manoel José Ribeiro [...], o qual foi um dos primeiros que se me ofereceu para aquela diligência, na qual se distinguiu toda a noite com muito valor e honra, zelo e atividade". Em segundo lugar, em 1797, já como capitão de milícia, Ribeiro percorreu diversas vilas paulistas a fim de recrutar homens e criar as companhias de pardos que comporiam o Regimento Miliciano dos Úteis conforme atestaram um ex-governador e mais oficiais das ordenanças de São Paulo. Nessa diligência, o capitão pardo gastou mais de três meses, portando-se "sem nota e nem defeito" e “com limpeza de mãos", e durante todo esse tempo arcou com as suas despesas e as de mais quatro milicianos que o acompanharam. O decreto fazendo-lhe mercê do hábito da Ordem de Cristo não poderia vir em data mais festiva: o 12 de outubro, aniversário do príncipe da Beira, o futuro imperador do Brasil D. Pedro I, era também o dia em que fazia anos Manoel José Ribeiro. O agraciado obteve ainda a dispensa das provanças, habilitações e apresentação de documentos para receber e professar o hábito na catedral da cidade do Rio de Janeiro. ${ }^{139}$

Já o neto, Antonio Joaquim da Costa Ribeiro, tornou-se cavaleiro professo na Ordem de Cristo em 1822, sem a intercessão direta do avô, que já estava reformado. No entanto, todo o empenho do patriarca em alistar prematuramente os filhos e o neto na milícia, garantindo-lhes a progressão nas fileiras, surtiu efeito quando, no contexto das fissuras que foram abalando a união entre Portugal e o Brasil, o regente Pedro obrigou-se a recorrer às forças militares de São Paulo e Minas Gerais em seu auxílio. Diante da recusa de Pedro em regressar à Europa, tal qual deliberado nas Cortes de Lisboa, as tropas reinóis estacionadas no Rio de Janeiro puseram-se em armas. Por essa razão, 1.100 milicianos dos vários regimentos da província marcharam à Corte em fevereiro de 1822, reunidos em um corpo denominado Leais Paulistanos. O então capitão Antonio Joaquim da Costa Ribeiro, lembrando-se de como a participação de seu avô em guerra fora recompensada, ofereceu-se voluntariamente para a marcha. Até o regresso dos Leais Paulistanos à cidade de São Paulo, em junho daquele ano, ele comandou uma companhia

${ }^{139} C f:$ AN, Decretos Gerais, Livro 2, fl. 65. 
formada pelos 66 milicianos pardos de seu Regimento que participaram daquela campanha. ${ }^{140}$ Ainda na Corte, Antonio Joaquim e mais oito oficiais que integravam os Leais foram agraciados com a mercê do hábito da Ordem de Cristo e doze mil réis de tença efetiva. O decreto de 18 de maio justificou a concessão remetendo-se aos "patrióticos sentimentos dos oficiais declarados [...], os quais, pronta e animadamente, saíram da Província de São Paulo em defesa da causa do Brasil e da Minha Real Pessoa" e "para que esta honrosa distinção sirva de estímulo a outros em iguais circunstâncias". ${ }^{141}$ A imediata mobilização de 12 oficiais subalternos daquele corpo visando à obtenção de semelhante mercê mostra que aquele hábito manteve-se valorizado na década de $1820 .{ }^{142}$

A concessão do hábito da Ordem de Cristo aos pardos Manoel José Ribeiro e Antonio Joaquim da Costa Ribeiro é indicativa da importância da atividade militar como mecanismo de elevação social. Talvez essa fosse a única fonte de nobreza realmente acessível a homens como eles, cujas origens assentavam-se na escravidão. Ambos tinham em comum a participação em campanhas militares. Como se sabe, entre os séculos XVIII e XIX, a capitania e depois província de São Paulo permaneceu diretamente envolvida nos esforços de guerra realizados na bacia do Prata. ${ }^{143} \mathrm{Na}$ esteira da descoberta do ouro, o Brasil percebeu o deslocamento de seu eixo político-econômico da região Nordeste para a Centro-Sul, e essa viu ampliar sua posição na hierarquia dos espaços de guerra. Tal processo se consolidou com a instalação da sede do vice-reino e depois da Corte no Rio de Janeiro. A partir daí as atividades militares em solo americano passaram a ser mais valorizadas pelo poder central ao mesmo tempo em que a relativa proximidade da Corte estimulou as demandas por mercês. ${ }^{144}$

A historiografia especializada em temáticas atinentes à nobreza e nobilitação sugere, consensualmente, que as já parcas possibilidades de acesso aos hábitos das Ordens Militares portuguesas por parte de ex-escravos e seus descendentes tenderam a se esvair completamente entre finais do século XVII e começo do XVIII. A relativa pacificação dos territórios ultramarinos, o alargamento do contingente de escravos africanos e, por fim, a inclusão do "mulatismo" no rol das "raças infectas" são alguns dos fatores que teriam contribuído para esse

\footnotetext{
${ }^{140}$ Os milicianos pardos que fizeram parte da marcha são indicados no Livro mestre. Para mais detalhes, ver SOUZA, Fernando Prestes de. Milicianos pardos em São Paulo. Cor, identidade e política (1765-1831). Dissertação (mestrado em História); Curitiba: SCHLA, Universidade Federal do Paraná, 2011, p. 134-150.

${ }^{141} C f:$ AN, Decretos Gerais, Livro 9, fl. 128v.

${ }^{142} C f:: \mathrm{BN} / \mathrm{dm}$, doc. ii-35,24,23.

${ }^{143}$ LINS, M. de L. Ferreira. A Legião de São Paulo no Rio Grande do Sul. Tese (doutorado em História). São Paulo: FFLCH, Universidade de São Paulo, 1976.

${ }^{144} \mathrm{O}$ aumento progressivo no número dos lançamentos de hábitos no Brasil, entre os séculos XVII e XVIII, é atestado em SILVA, M. B. N. da. Ser nobre na Colônia..., p. 113.
} 
fenômeno. ${ }^{145}$ Em face da escassez de estudos, seria necessário averiguar, para o período subsequente, quais as tendências no comportamento da Coroa e da Mesa diante dos processos de habilitação a fim de que se tenha uma ideia mais precisa acerca dos significados da obtenção do hábito de Cristo por parte dos três milicianos pardos aqui em questão. Seja como for, não há dúvida de que eles se beneficiaram do relativo relaxamento em torno das confirmações e da liberalidade régia ocorridos desde a segunda metade do Setecentos e especialmente nos reinados de D. João VI e de D. Pedro I. Esse quadro, por sua vez, vincula-se diretamente ao impacto social das reformas ilustradas, à transmutação da Corte e a perene escassez de forças militares que toda e qualquer conjuntura de guerra punha a lume.

A sucessiva conquista dos hábitos por membros da mesma família e corporação miliciana representou aos Ribeiros uma concentração de poder sem igual entre os pardos de São Paulo. O conjunto dessa elevação no espaço social posicionou-os no centro gravitacional da configuração social específica formada pelos pardos livres e libertos. Por certo um equilíbrio de poder instável, sujeito a rearranjos, como já visto. Ademais, o exercício parcial de controle aos postos do estado-maior do Regimento dos pardos ensejou a concorrência direta entre os Ribeiros e os oficiais brancos provenientes da tropa de linha. Como se vê, esse processo de ascensão social e nobilitação não se restringiu à relação estabelecida entre indivíduos e o rei. Ele implicou a ampliação de autoridade e responsabilidade perante uma multidão de subordinados bem como acirrou a relação de competição entre rivais.

O fato de os Ribeiros terem ocupado parte das principais posições do Regimento entre 1810 e 1831 significou, logicamente, a frustração de outros pardos concorrentes àquelas vagas. Porém, a família de Manoel José Ribeiro conquistou relativa aceitação e legitimação por parte da oficialidade parda. É o que sugere a mobilização de capitães, tenentes e alferes subscrevendo um requerimento de Manoel José da Costa Ribeiro enviado ao rei, no qual pedia ser promovido ao posto de sargento-mor. ${ }^{146}$ Eles provavelmente reconheciam, como o fez a própria Coroa, o papel desempenhado por Manoel José Ribeiro na formação e institucionalização do Regimento: além de recrutar e criar as companhias, em 1797, após assumir o comando da corporação Ribeiro dotou-a de ferramentas necessárias ao seu funcionamento - tais como bandeiras,

\footnotetext{
${ }^{145}$ SILVA, M. B. N. da. Ser nobre na Colônia..., p. 119; MATTOS, Hebe. "Black Troops" and hierarchies of color in the Portuguese Atlantic World: The case of Henrique Dias and his Black Regiment. Luso-Brazilian Review, v. 45, n.1, p. 6-29, 2008; RAMINELLI, R. "Los límites del honor”. Nobles y jerarquías de Brasil, Nueva España y Perú, siglos XVII y XVIII. Revista Complutense de Historia de América, Madri, v. 40, 2014, p. 55-59. Já Dutra destaca a maior recorrência das dispensas para o impedimento de ser mulato em relação aos impedimentos de mecânica e impureza de sangue. Ver DUTRA, Francis A. Ser mulato em Portugal nos primórdios da época moderna. Tempo, Rio de Janeiro, n. 30, p. 101-114, 2010.

${ }^{146} C f:$ : APESP, ordem C00416, Livro 160, fl. sem numeração.
} 
instrumentos de música, livro de registro e treinamento especializado aos músicos. Ademais, os integrantes da oficialidade parda concordavam que a existência do Regimento propiciavalhes ganhos sociais, desde que tivessem acesso aos postos. Ao longo da década de 1810, enquanto o coronel Ribeiro encaminhava seus familiares na hierarquia militar, ele firmou alianças e harmonizou interesses junto a um grupo de pardos influentes que ele próprio indicou para a oficialidade miliciana. ${ }^{147}$ Nesse processo de desafogamento das tensões internas ao universo dos pardos, é significativo que vários oficiais residentes na cidade de São Paulo, sem esperança de ascensão imediata nos postos, tenham sido promovidos a postos em companhias situadas em vilas distantes da capital. ${ }^{148}$

Contudo, a pacificação entre os pardos não significou imunidade aos assédios dos oficiais das tropas regulares, que retornavam das campanhas sulinas sedentos por honrarias e mercês. Em 1810, na ocasião em que Manoel José Ribeiro assumiu o controle do Regimento dos Úteis, ele substituíra no posto a José Joaquim Mariano da Silva César, um coronel branco. Como visto, ele procurou conduzir seus familiares em direção ao topo da escala hierárquica. Nessa linha, Ribeiro via a possibilidade de seu filho primogênito, o então capitão Manoel, suceder-lhe na chefia da milícia dos pardos. Mas havia quem igualmente almejasse os postos superiores. Então, a partir de 1815, pai e filho se uniram para competir com Antonio de Pádua de Gusmão, um ajudante branco oriundo da tropa paga, numa corrida acirrada pelos postos de sargento-mor e depois tenente-coronel do Regimento que perduraria uma década. Manoel José da Costa Ribeiro realizou os exames teóricos e práticos necessários diante do governador e capitão-general e demais oficiais militares e obteve rendimento idêntico ao de Gusmão. No entanto, em razão da necessidade de premiar a antiguidade do oficial branco, Ribeiro foi preterido. Os Ribeiros recorreram, suplicando a graça régia, para que não houvesse prejuízo ao jovem Manoel, mas não obtiveram o resultado esperado. Isso significou que o filho do coronel pardo permaneceria em posição inferior a seu concorrente também na disputa ao posto de tenente-coronel, que vagara em $1820 .^{149}$

Com a reforma - ou queda - de Manoel José Ribeiro, em 1821, seu filho não apenas perdeu um importante aliado como viu seu concorrente lograr o apoio do novo coronel, José Joaquim César de Cerqueira Leme. Esse recebeu a nomeação de coronel como progressão na carreira após servir na tropa de linha e realizar campanhas de guerra-viva no Sul, na década de

\footnotetext{
${ }^{147} C f:$ : APESP, ordem C00285, Pasta 3, doc. 37.

${ }^{148}$ Cf:: Livro Mestre.

${ }^{149}$ Esse caso foi examinado com mais detalhes em SOUZA, F. P. de. Milicianos pardos em São Paulo..., p. 113126 e 134-161, onde estão disponíveis as referências às fontes primárias utilizadas daqui em diante.
} 
1810. Ademais, e não menos importante, César era filho do antigo coronel ao qual Manoel José Ribeiro sucedeu. Nota-se, portanto, um quadro de disputa pelo controle da corporação que, longe de se restringir ao âmbito individual, opunha famílias e grupos, pardos e brancos. Já como sargento-mor, Manoel José da Costa Ribeiro teve seu raio de ação cerceado pelos superiores brancos: em primeiro lugar, ele viu ser negado seu oferecimento voluntário para marchar ao Rio de Janeiro com sua tropa, em 1822, junto dos Leais Paulistanos - de cuja campanha, como visto, seu sobrinho regressara com o hábito da Ordem de Cristo; em segundo, fora acusado, no mesmo ano, de centralizar um grupo político contrário à permanência de $\mathrm{D}$. Pedro e, portanto, favorável a Portugal, o que motivou sua deportação temporária da província. Nada foi efetivamente provado a respeito de tais acusações. Finalmente, todo esse quadro não impediu que Manoel, o filho, conquistasse o acesso a tenente-coronel, em 1826, após o falecimento de seu principal adversário, e o hábito da Ordem de Cristo, em 1828.

A trajetória percorrida pelos integrantes da família Ribeiro é excepcional quando se leva em conta a generalidade dos milicianos pardos de São Paulo - e talvez até das demais capitanias e províncias do Brasil - entre finais do século XVIII e começos do XIX. Capitaneado pelo patriarca Manoel José Ribeiro, o núcleo familiar em questão afastou-se do cativeiro, do exercício de ofícios mecânicos, elevou-se à condição senhorial e nobilitou-se através dos postos superiores da milícia e da obtenção de hábitos da Ordem de Cristo. Esse processo ascensional ocorreu gradualmente: em parte ele pôde ser planejado, pois os tais indivíduos conheciam as normas que regiam a progressão na milícia e a importância do serviço das armas na consideração régia; por outro lado, a relação de interdependência que os Ribeiros mantinham com oficiais e soldados pardos, além da relação tensa estabelecida com a oficialidade militar branca, forneciam um quadro de imprevisibilidade à implementação de suas estratégias bem como à sua manutenção como centro gravitacional do equilíbrio instável de poder conformado pelo Regimento dos Úteis. 


\section{CONSIDERAÇÕES FINAIS}

Esta investigação acerca dos milicianos pardos da capitania e depois província de São Paulo partiu de uma constatação que logo se converteu em um conjunto de questionamentos. Afinal, tanto como indivíduos quanto como grupo, os pardos foram comumente entendidos como intermediários em relação a setores sociais estruturantes situados em pontos opostos da escala social. Relativamente aos milicianos pardos, certos indicadores - como a profissão e os níveis de riqueza - corroboram essa percepção, mas outros igualmente aplicáveis a eles - à exemplo da nobreza atrelada às patentes - comprometem a generalização. Esse, no entanto, não é o principal ponto. A questão fundamental diz respeito ao modo como esse caráter intermediário tem sido interpretado ao longo do tempo e às decorrências dessas interpretações para a compreensão dos pardos, seja como um grupo social específico ou pertencente a grupos mais abrangentes. Tipicamente, grupos intermediários da sociedade colonial e escravista brasileira foram adjetivados e descritos a partir, sobretudo, da comparação com os grupos sociais entendidos como estruturantes, preterindo-se muitas vezes a sua caracterização por meio da observação de aspectos de sua própria estrutura e dinâmica. Desse modo, argumentou-se na tese que determinadas categorias - como desajustamento e ambiguidade - frequentemente impuseram um ponto final na questão, cristalizando possibilidades de interpretações referentes aos pardos e de certo modo inibindo investigações mais detalhadas sobre esse grupo. Esse estado de coisas motivou e também justificou um esforço voltado à reunião, análise e exposição dos dados empíricos que perpassa todo este trabalho e que, no fim das contas, forneceu subsídios abundantes para caracterizar, sob diferentes vieses, a experiência social dos milicianos pardos de São Paulo de finais do período colonial até o fim do Primeiro Reinado.

Ao invés de iniciar este exame pela localização da milícia na estrutura militar tripartite vigente no período estudado, optou-se por reconstruir as linhas gerais do processo de formação da estrutura militar colonial, a qual era parte constitutiva da estrutura militar reinol, sendo esta, por sua vez, tributária de um processo formativo mais amplo vivenciado pela Europa. Evidenciou-se a natureza da segunda linha - os Auxiliares e depois as Milícias - como uma força militar intermediária entre as Tropas Profissionais, que se vinculavam diretamente ao poder central, e as Ordenanças, que representavam tipicamente as forças locais. A emergência das milícias significou uma expansão dos tentáculos do poder central nas localidades e, como força militar, ela complementou e não raro fez as vezes da primeira linha particularmente onde esta era escassa. Ademais, a tese revelou como a milícia demarcou uma diferença essencial existente entre as estruturas militares reinol e colonial durante o século XVIII e as primeiras 
décadas do XIX: enquanto o território europeu de Portugal, apesar da débil capacidade defensiva, sempre dispôs de mais tropa paga do que milícia, a segurança da América portuguesa esteve a cargo prioritariamente dos corpos militares milicianos. Nesse último espaço, o arranjo estabelecido primava pela complementaridade entre as tropas regulares e as milicianas das capitanias e províncias, já que algumas dispunham de contingentes de tropa paga e pouca milícia e outras viviam situação oposta. Em um universo no qual a milícia tornara-se reconhecidamente fundamental para a manutenção da ordem interna e para a defesa de eventuais ataques externos, a disponibilidade de honrarias e de privilégios aos seus integrantes foi uma decorrência natural, sob certo ponto de vista, mas que, por outro lado, deu margem a um quadro de crescentes tensões sociais e políticas ao longo do tempo, o qual, enfim, matiza a "naturalidade" da retribuição régia aos serviços prestados por milicianos.

Uma vez clarificado o papel relevante desempenhado pela milícia na organização militar luso-americana em finais do século XVIII e nas décadas seguintes, tornou-se pertinente situar os corpos militares de segunda linha formados por pardos e por pretos nessa estrutura. Para tanto, considerou-se necessário reconstruir alguns traços do processo de formação desses terços, regimentos e depois batalhões. Esse investimento revelou que havia uma correlação entre a dinamização da economia regional, o aumento de visibilidade das localidades no mapa internacional da guerra, o tráfico de escravos africanos, a formação de uma camada populacional composta por descendentes de escravos e mestiços livres, e, finalmente, a criação de corpos militares destinados a pardos e a pretos. Essas tropas originaram-se no Nordeste açucareiro a partir da primeira metade do século XVII, se difundiram para a região Centro-Sul desde finais desse mesmo século, com o boom minerador, e foram formadas no Norte somente na segunda metade do século XVIII, numa conjuntura marcada por uma espécie de renascimento agrícola. Mas um fenômeno histórico em particular foi decisivo para um verdadeiro alargamento da presença dos terços de pardos e de pretos nas várias regiões do Estado do Brasil: a guerra luso-castelhana de 1762-1777, uma decorrência da Guerra dos Sete Anos e das disputas coloniais entre Portugal e Espanha pela região da bacia do Rio da Prata. Daí em diante, houve uma significativa proliferação das tropas de pardos, e estas tornaram-se majoritárias em relação às de pretos.

Ao final desse exame, chegou-se a um dado pleno de significados merecedores de atenção ao longo de toda a tese: apesar de as companhias avulsas de pretos e de pardos, em São Paulo, remontarem ao início do século XVIII, a criação do Regimento Miliciano dos Úteis, em 1797, fez dessa corporação a última milícia parda a ser formada no Brasil. Foi inevitável indagar sobre o caráter tardio do regimento de pardos paulistas. Evidentemente, esse fenômeno é dotado 
de historicidade. Ele se inscreve em um contexto de crescimento econômico de São Paulo, simbolizado pelo advento das grandes fazendas de cana-de-açúcar movidas pelo trabalho de escravos de origem africana, bem como da ampliação de sua importância política e militar nos quadros da América portuguesa. Entretanto, ao se observar a distribuição da população paulista sob o critério "cor" no momento de criação dos Úteis, verificou-se a presença de um vasto contingente de pardos livres e libertos, suficiente para integrar mais de um regimento miliciano. Para compreender os motivos pelos quais a disponibilidade de população não se refletiu proporcionalmente na existência de regimentos de pardos e até mesmo por que os Úteis surgiram apenas em fins do Setecentos, os contingentes populacionais e militares das várias capitanias luso-americanas foram comparados. Algumas tendências relevantes foram reveladas: em primeiro lugar, as milícias de pardos e de pretos geralmente estavam concentradas nas regiões em que essas populações eram mais abundantes; em segundo, o número de terços, regimentos ou batalhões de pardos e de pretos jamais ultrapassou o de brancos em quaisquer capitanias, nem mesmo onde a população branca era minoritária. Juntos, esses dados sugerem que a distribuição da milícia entre as cores branca, parda e preta obedecia primordialmente a imperativos de ordem política, não havendo uma correlação direta entre as proporções de população fisicamente apta a servir na milícia e a existência de corporações separadas de acordo com a cor de seus integrantes.

A análise do processo de formação do Regimento dos Úteis evidenciou que a criação desse tipo de corporação militar, exclusiva aos pardos, não decorria unicamente da disponibilidade de população e das necessidades militares regionais, uma vez que o fenômeno foi marcado por uma negociação entre oficiais pardos e a principal autoridade da capitania. Nesse momento, os vários atores definiram aspectos fundamentais para a instituição e para a coletividade, tais como o nome do regimento - que evocava a utilidade dos serviços oferecidos pelos pardos à Coroa ao mesmo tempo em que refutava o estigma da vadiagem -, o seu enquadramento institucional - ou seja, a escolha pelo modelo miliciano e o rechaço ao dos pedestres - e, consequentemente, as suas funções. Trata-se de um momento de definição de identidade social e de pactuação política, que pressupõe um nível significativo de coesão social entre os milicianos pardos. Portanto, embora São Paulo já abrigasse uma significativa população masculina parda em meados do século XVIII, a formação de um regimento somente ocorreu depois de os pardos acumularem um longo período de prestação de serviço militar por meio de companhias avulsas, obterem maior coesão e potencial de retenção de poder.

Uma vez formado o Regimento dos Úteis, o desempenho de suas funções dependia das relações estabelecidas entre oficiais pardos e as autoridades paulistas tanto quanto das relações 
mantidas entre oficiais e soldados pardos. De fato, aspectos fundamentais da dinâmica de funcionamento da corporação - tais como o ingresso, a permanência e a saída dos seus integrantes - estavam sob a responsabilidade dos oficiais. Alocados em funções sociais de comando, esses homens carregavam o peso das obrigações do serviço, mas, em compensação, também exerciam grande influência sobre vários aspectos da vida dos subalternos. A eles competia recrutar, atestar sobre o estado físico e sobre o comportamento dos subordinados, e igualmente se posicionar quanto aos pedidos de licenciamento, transferência ou baixa que lhes eram encaminhados. Tornou-se evidente que na cidade de São Paulo - capital da capitania/província e sede do quartel do Regimento - havia maior eficácia dos dispositivos internos de controle e coerção, ao passo que nas localidades interioranas era elevada a incidência de práticas informais por parte dos milicianos - a exemplo das ausências não consentidas.

Para melhor compreender sobre o funcionamento do Regimento dos Úteis também foi extremamente profícuo analisar as funções efetivamente desempenhadas pelos milicianos, o que passou por detalhar quais as atividades realizadas e qual a frequência com que aqueles homens eram obrigados a deixar os seus afazeres cotidianos para prestar serviço militar. Observando inicialmente uma espécie de calendário das atividades milicianas referente à década de 1820, concluiu-se que, anualmente, os milicianos eram convocados por dezenas de vezes para participarem de solenidades diversas e para as reuniões de instrução militar. Mas, além destas ocasiões pontuais, os regimentos milicianos paulistas também assumiram a guarnição da capital enquanto boa parte das tropas regulares participava de campanhas militares. Não há dúvida de que, a partir da milícia, os pardos de São Paulo vivenciaram intensamente alguns dos fenômenos históricos mais decisivos na história paulista e brasileira, tais como os decorrentes da instalação da Corte no Brasil e da independência.

Após reconstruir as linhas gerais da estrutura militar luso-americana, situando nela e na trajetória histórica das milícias de pardos e de pretos o Regimento dos Úteis, e também após sistematizar os traços gerais do funcionamento do corpo militar em questão, coube lançar luz sobre os pardos que lhe deram vida. O primeiro passo nesse sentido consistiu na problematização da cor parda - que caracterizava o Regimento dos Úteis, diferenciando-o dos demais corpos milicianos paulistas - e na tentativa de extrair desse exercício elementos que auxiliassem a compreensão da origem social dos milicianos pardos. A historiografia brasileira mais recente tem promovido um debate interessante sobre os significados da cor na sociedade escravista. Atualmente se admite que a variável "cor" não dizia respeito exclusivamente à tonalidade da pele, tendo implicações relevantes na definição da condição social dos indivíduos. 
Enquanto algumas perspectivas defendem uma correspondência entre cor e condição jurídica, outras privilegiam a relação da cor com os processos de mestiçagem e ainda há outras que buscam um equilíbrio entre as tendências anteriores. Por intermédio dessas abordagens, os pardos podem ser compreendidos como um setor social alocado entre brancos e pretos e entre livres e escravos. A cor parda indicaria, portanto, a condição de liberta e a característica mestiça dessa população. Entretanto, considerou-se aqui extremamente pertinente ir além da mera constatação de que os pardos faziam parte de um segmento intermediário, a qual, como visto, tem redundado em diversas interpretações que atribuem ao grupo características como ambiguidade e inadequação social. Fez-se necessário buscar elementos para caracterizar os pardos de São Paulo, e a relevância dessa tarefa ampliou-se ainda mais quando se teve em vista a existência de um fosso na história paulista: afinal, se aceita de bom grado as imagens de uma sociedade profundamente marcada pela presença indígena até finais do século XVII e de uma sociedade marcada pela escravidão africana já no alvorecer do século XIX, mas pouco se sabe sobre a formação do grupo social dos pardos que já era significativo em meados do século XVIII. Como as histórias dos administrados indígenas e dos escravos de origem africana se cruzou em São Paulo?

Analisando as companhias militares paulistas setecentistas, notou-se que da convivência entre tropas de pardos e de pretos, típica da primeira metade do século XVIII, passou-se, na metade seguinte, para o predomínio absoluto dos pardos. As escassas informações sobre essas tropas foram suficientes para caracterizar os pardos como um grupo heterogêneo, formado tanto por descendentes de "carijós" como de "tapanhunos". Essa heterogeneidade se manteve quando os milicianos pardos do Regimento dos Úteis foram objeto de exame. Ora, entre eles predominavam homens de cabelo crespo e grenho, mas também era numericamente significativo o contingente de pardos cujos cabelos eram corredios ou lisos. Ou seja, esses milicianos eram mestiços, sendo que a fisionomia de alguns revelava origem africana mais acentuada enquanto a de outros acenava para a ancestralidade indígena. Todos, no entanto, eram reconhecidos como pardos. Uma questão instigante decorreu do cotejamento dos dados contidos no registro militar e nos recenseamentos paulistas, já que a maior parte dos milicianos teve a cor parda reiterada nas listagens de população, mas um segmento menor alterou a cor em diferentes listagens, passando de pardo para branco - o que tem sido lido pela historiografia como um processo de branqueamento social, ou seja, mudança de condição e ascensão social. No caso dos milicianos, pôde-se notar um padrão: aqueles que alternaram as cores eram predominantemente soldados e notavelmente pobres, enquanto que os oficiais do Regimento, que eram investidos da nobreza das patentes e estavam melhor situados economicamente, 
raramente mudavam de cor. Essa constatação permitiu afirmar que não há uma relação direta entre cor e condição social/jurídica. O Regimento dos Úteis reiterava a cor parda e, apesar dos estigmas sociais associados a ela, fornecia as melhores oportunidades de obtenção de visibilidade social aos pardos de São Paulo.

Para obter uma visão mais completa sobre a origem social dos milicianos pardos de São Paulo, investigou-se a configuração de suas famílias: a condição social e jurídica dos pais e eventualmente dos ancestrais mais antigos, a condição em que nasceram os futuros milicianos e também a que suas noivas portavam por ocasião do matrimônio. Desse modo, obteve-se uma perspectiva singular sobre os milicianos pardos, a qual articulou as dimensões individual, familiar e grupal, lançando luz, portanto, à própria formação histórica do grupo social dos pardos forros e livres paulistas. A maior parte dos milicianos pardos havia nascido e sido batizada livre, mas havia também um segmento minoritário formado pelos que haviam sido batizados como índios, escravos, expostos, administrados e alforriados na pia batismal. Entre os milicianos também predominavam aqueles que tinham filiação legítima, mas o número de oficiais e soldados cujos pais eram incógnitos era bastante elevado. $\mathrm{O}$ curioso é que muitos dos milicianos pardos oriundos de famílias regulamentadas pela Igreja foram denominados "bastardos" e vários dos nascidos em liberdade foram referidos como "libertos" ou "forros" quando se casaram. Esses adjetivos funcionavam como estigmas sociais e eram empregados para demarcar a posição social inferiorizada dessas pessoas, de modo que a origem social familiar fosse sempre lembrada.

E, de fato, quando a condição de nascimento/batismo dos pais dos milicianos pardos foi examinada, tornou-se clara a vinculação dessas pessoas às formas compulsórias de trabalho e alienação pessoal. As proporções de pais e de mães livres, escravizados e índios/administrados eram praticamente equivalentes entre si, de modo que se pode afirmar que, embora boa parte dos milicianos pardos tenha nascido livre, eles estavam geracionalmente muito próximos da escravidão e da administração. Vai daí a persistência dos estigmas mencionados acima. Ademais, a reconstrução de árvores genealógicas de milicianos - tão incomum no que se refere a essa população - revelou a intensa mestiçagem que está na raiz do grupo dos pardos paulistas. Para obter uma indicação do papel desses milicianos pardos na reprodução ou transformação do seu próprio grupo social, foram examinados os seus casamentos e particularmente a escolha dos cônjuges. A maior parte dos milicianos em questão era casada e formara família com mulheres nascidas livres, o que indica que os seus filhos nasceriam igualmente livres e que a unidade familiar gradativamente se afastava do passado cativo ou administrado. Entretanto, a 
quantidade minoritária, mas expressiva, de esposas nascidas na situação de escravizadas atesta como era difícil para tais milicianos pardos se distanciarem do universo do cativeiro.

O período de atuação do Regimento dos Úteis (1797-1831) se insere em uma conjuntura marcada por profundas transformações em São Paulo. Do ponto de vista econômico, a capitania se inseriu no mercado atlântico com a importação de escravizados africanos e a exportação de açúcar, deixando para trás a característica de região marginal na economia luso-americana. Qual a posição dos milicianos pardos nessa economia em aquecimento? O que faziam esses homens quando não estavam fardados? Mais da metade dos integrantes do Regimento dos Úteis vivia da agricultura, mas também era muito expressivo o contingente de artesãos de diversas especialidades. Efetivamente, a corporação estava assentada tanto no campo quanto nas regiões urbanas e nessa divisão se espelhava a organização de sua hierarquia, já que os oficiais milicianos pardos eram tipicamente artesãos enquanto os soldados eram lavradores. Milicianos pardos dominavam a alfaiataria paulista e boa parte dos capitães do Regimento dos Úteis exercia esse ramo profissional. Nesse sentido, os oficiais pardos se diferenciavam completamente dos oficiais brancos dos demais regimentos milicianos da capitania/província que se dedicavam comumente a negócios comerciais e agrícolas - e viviam uma realidade bastante semelhante à de oficiais milicianos pardos de diferentes espaços luso e hispanoamericanos. Todos esses oficiais pardos estavam caracteristicamente ligados ao universo do trabalho manual urbano e igualmente marcados por uma origem vinculada à escravidão.

É verdade que alguns desses pardos que portavam patentes tentaram conciliar o artesanato e o comércio, mas foram raros aqueles que conseguiram efetuar a transição de um ofício para outro. Muitos soldados também intercalavam o plantio em pequenas roças com ocupações diversas, certamente como forma de ampliar as possibilidades de sobrevivência. Todos esses homens enfrentavam inúmeras dificuldades herdadas da escravidão e da administração. Uma simples comparação entre os oficiais milicianos de São Paulo no quesito faixas de riqueza indicou que os pardos ocupavam as posições inferiores, estando, portanto, próximos e/ou vivenciando situação de absoluta pobreza. Ou seja, além de estarem atrelados ao mundo do trabalho manual, eles também se distinguiam dos oficiais brancos pela modesta condição econômica.

Junto com a ocupação e a riqueza, a posse de escravos foi uma variável relevante para caracterizar a posição socioeconômica dos milicianos pardos de São Paulo. Além de disporem de mão de obra, os proprietários ostentavam a condição senhorial. Está nítido que, entre os anos 1798 e 1836, a maior parte dos integrantes do Regimento dos Úteis jamais obteve acesso a escravizados. No entanto, aqueles que dispuseram de cativos em algum momento de suas vidas 
correspondem a aproximadamente $10 \%$ de todos os milicianos. Metade desses milicianos eram os proprietários diretos e a outra metade compartilhava escravos com pais e irmãos. Quase todos, porém, eram oficiais milicianos ou eram deles aparentados, o que reforça a noção de que a oficialidade era composta por homens que se destacavam tanto técnica quanto socialmente dos demais. O que caracteriza a posse de escravizados por parte desses milicianos pardos é a predominância de pequeníssimos plantéis, o diminuto potencial de retenção e de reposição de cativos, a alta incidência de mulheres africanas e o emprego dessa mão de obra em atividades artesanais realizadas nos centros urbanos das vilas e da cidade. Todos esses índices fornecem uma boa imagem acerca da posição ocupada pelos milicianos pardos na próspera economia paulista entre finais do século XVIII e a primeira metade do XIX. Em geral, essas pessoas não possuíam recursos para se envolver diretamente com a economia agroexportadora baseada no trabalho escravo e com atividades comerciais de grande porte: enquanto a maioria dos soldados realizava atividades de subsistência no campo, um conjunto significativo de oficiais vivia modestamente da prestação de serviços no ambiente urbano.

A investigação acerca das relações de poder vigentes na milícia parda foi orientada pela noção de que a dinâmica social é conduzida por competições de vários níveis, as quais podem ser pensadas através dos modelos de jogos. O ponto de partida consistiu no exame ao relacionamento dos corpos militares de pardos e de pretos com a monarquia portuguesa a partir da articulação entre a trajetória histórica dessas corporações e a legislação a elas referente, chegando-se à distinção de quatro momentos. O primeiro deles marca a formação e institucionalização das primeiras companhias e terços, assim como a conquista de privilégios, tais como o acesso aos postos da oficialidade e a obtenção de soldo para os oficiais do estadomaior. O segundo período é caracterizado por uma intervenção abrupta da Coroa no sentido de impor o modelo reinol das ordenanças e de desmobilizar as tropas em questão, cujas medidas rapidamente se mostraram inviáveis. A argumentação desenvolvida na tese elenca, como o principal motivo para as mudanças propostas, especificamente o significado que a exuberante ascensão disponível aos outsiders em seus corpos militares tinha para a hierarquia social e para o establishment. Já o terceiro momento se relaciona diretamente com os efeitos, na colônia, da Guerra dos Sete Anos (1756-1763), que conduziram a uma formidável expansão dos contingentes militares de segunda e terceira linhas, resultando, no tocante a pardos e pretos, na formação de vinte corpos militares de auxiliares. Nesse contexto, a margem de poder mobilizável pelos oficiais de cor viu-se ampliada ao ponto de pardos e pretos baianos e pernambucanos conseguirem reverter, exclusivamente no tocante aos seus corpos militares, a diretriz régia que indicava oficiais de linha, brancos, para o comando das tropas auxiliares. 
Enquanto isso, seus pares fluminenses, que não dispunham do mesmo cabedal de status, viviam realidade diferente, com corpos militares destituídos de oficialidade superior parda ou preta. A quarta e última fase marca a máxima extensão atingida pela estrutura militar luso-americana e a conquista de significativos privilégios por parte das milícias pardas e pretas. Nesse momento de transição entre formas de organização social e de centralização monárquica, as reformas sociais que promoveram a equiparação entre diversos grupos sociais impactaram significativamente na milícia. Enquanto certas distinções elitistas em corpos militares foram cerceadas, pardos e pretos obtiveram preferência no acesso aos postos de seus regimentos e uma abrangente equiparação em relação aos brancos. Essa configuração se manteve até a extinção das milícias no Brasil.

No entanto, inúmeros projetos de reforma redigidos por governadores de capitanias/províncias e por autoridades militares de alto escalão confrontaram as oficialidades pardas e pretas e defenderam até mesmo a abolição dos corpos militares separados por cor. Esses documentos expressam as perspectivas daqueles que viam de perto as tensões existentes entre oficiais brancos de linha e de milícia e a oficialidade de cor, e os termos empregados, assim como o alcance das propostas, permitiram refletir sobre os níveis de coesão social de pardos e pretos em cada configuração social observada. O caso do reformismo levado a cabo na Nova Espanha, que resultou na completa desmobilização da milícia parda em fins do século XVIII, contrastou vivamente com o processo transcorrido em solo luso-americano, uma vez que, em seu território, nenhuma proposta de abolição de oficialidades ou de corporações vingou. Isso porque em determinadas configurações sociais do Brasil, notadamente Pernambuco e Bahia, as populações pardas e pretas dispunham de um capital político, fruto da lealdade e da centenária prestação de serviço militar à monarquia, que não podia ser desprezado. Além disso, do ponto de vista da Coroa lusitana e depois brasileira, as oficialidades pardas e pretas constituíam um contrapeso à expressão social das elites locais brancas. Mais do que no primeiro, é nesse segundo ponto que reside a explicação para o caso de São Paulo. Ora, até mesmo o Regimento dos Úteis - uma corporação jovem, com modesta folha de serviços manteve-se em pé quando se chocou com a onda reformista. É significativo o fato de a Coroa ter rechaçado o repertório coeso de estigmas sociais mobilizados pelos opositores dessa milícia, os quais destacavam a origem escrava dos oficiais pardos e principalmente a sua pobreza e vinculação ao mundo do trabalho artesanal.

Como o apoio fornecido pela Coroa direcionava-se mais à manutenção da corporação e da oficialidade das companhias, o acesso aos postos do estado-maior do Regimento tornou-se objeto de disputas entre milicianos pardos e oficiais veteranos brancos da tropa paga durante as 
três primeiras décadas do século XIX - não obstante as disposições régias que concediam prioridade aos primeiros. Na medida em que os pardos foram acumulando serviços e tornandose mais coesos, eles se capacitaram para competir pelos postos de comando; por outro lado, com o passar o tempo as propostas de reforma também se acumulavam, assim como a quantidade de oficiais brancos que retornavam das guerras no Sul sedentos pela obtenção de progressão. Em síntese, a competição pelos postos do estado-maior dos Úteis opôs uma minoria de pardos - quase todos pertencentes à família Ribeiro - a uma minoria de brancos. Assim mesmo, os pardos paulistas chegaram a ocupar os postos de maior visibilidade, tais como os de coronel, tenente-coronel e sargento-mor. Algo que merece destaque, e que decorreu da intensidade da competição em questão, é a construção e a afirmação de um discurso, por parte dos pardos, que punha em primeiro plano os merecimentos, o conhecimento técnico, a utilidade e a lealdade, deixando para trás a importância dos estigmas atrelados à cor e à origem como critérios para a ocupação dos postos.

Outra dimensão do campo de tensões que a milícia formava se refere às relações internas ao Regimento dos Úteis, estabelecidas entre oficiais e soldados pardos. Na busca por compreender como se estruturavam as relações de mando e de obediência, surpreendentemente uma componente típica da realidade social dos pardos - e que, a priori, pouco tinha a ver com o universo militar - veio à tona: o mundo do trabalho e especificamente do ramo artesanal. Em realidade, se verificou um entrelaçamento entre milícia e trabalho, uma vez que os oficiais da milícia geralmente eram mestres de ofícios mecânicos, ao passo que vários dos soldados milicianos eram artesãos aprendizes. Em consequência disso, os oficiais milicianos pardos multiplicavam os seus instrumentos de controle e dominação sobre os subordinados, sendo comum que esses sofressem penas militares quando descumprissem algo no âmbito do trabalho. Mas os soldados/aprendizes também faziam valer a sua pequena margem de poder, e sobretudo quando se acentuou a competição entre oficiais pardos e brancos pelo controle do Regimento. Nesse momento, várias queixas quanto aos abusos praticados pela oficialidade parda chegaram ao governo da capitania e resultaram na deposição do coronel Ribeiro e na nomeação de um branco, egresso da tropa de linha, como seu substituto.

Esse momento, no qual o equilíbrio de poder interno ao Regimento dos Úteis se alterou a favor dos oficiais brancos, foi igualmente um contexto marcado por transformações políticas significativas nos âmbitos tanto da capitania/província como, e notoriamente, da relação entre Brasil e Portugal. Por essa razão, argumentou-se nesta tese que o envolvimento dos milicianos pardos nos fenômenos históricos atrelados ao processo de independência do Brasil estava em boa medida relacionado com a competição entre oficiais pardos e brancos pelo controle do 
regimento e também com a onda de ataques sofridas pela corporação. São esses os fatores que explicam o posicionamento do sargento-mor pardo Manoel José da Costa Ribeiro junto ao grupo bernardista e as sérias denúncias oferecidas por integrantes do grupo andradista e rivais na milícia que lhe atingiam diretamente. Ademais, ficou claro o quão fundamental foi recuperar os temas da importância da milícia na estrutura militar luso-americana e da contribuição imensurável dos milicianos pardos na guarnição da cidade e na representação e legitimação do poder. Com o desfalque das tropas regulares, os milicianos - incluindo-se aí os pardos estiveram presentes, com maior ou menor centralidade, em todos os principais acontecimentos do período. Além de marcharem para a Corte em apoio ao regente, eles estiveram presentes em reuniões de deliberação política e também se envolveram nas dissensões entre as elites paulistas, no episódio da bernarda.

Fecha a tese um exame à trajetória da mais poderosa família parda que vivia em São Paulo no período considerado, precisamente a do coronel Manoel José Ribeiro. Sua trajetória revela o ponto máximo a que os pardos de São Paulo puderam chegar na escala social por meio do serviço miliciano e em um contex to histórico específico, marcado por intensas mobilizações militares, por agitações políticas de grande importância e pelo protagonismo da milícia. Ora, trata-se de uma família cuja origem se situava no universo do cativeiro e que chegou a controlar o Regimento dos Úteis e a exercer influência sobre a vida de aproximadamente 800 homens. Com efeito, os Ribeiros transitaram da vileza associada ao exercício dos ofícios mecânicos - o patriarca Manoel José Ribeiro havia sido juiz do ofício de alfaiate - e se estabeleceram como comerciantes, proprietários de uma dezena de escravos e de um sobrado localizado na capital paulista. O mais impressionante, porém, é o fato de que integrantes de três gerações dessa família, todos radicados na milícia parda, obtiveram, em curto espaço de tempo, hábitos da Ordem de Cristo. Tais concessões expressam a importância dos milicianos como apoio da ordem e permitem matizar algumas afirmações correntes na historiografia. Uma delas sugere que as ordens militares haviam definitivamente fechado as suas portas para descendentes de escravos e oficiais mecânicos entre fins do século XVII e princípios do século XVIII. A outra propõe uma associação entre nobilitação - através da aquisição da condição senhorial, de patentes militares e de honrarias - e o difuso conceito de branqueamento social. O caso dos Ribeiros mostra, em primeiro lugar, como o contexto histórico da segunda metade do século XVIII e das primeiras décadas do século XIX transformou a relação entre a Coroa, a Mesa de Consciência e Ordens e os habilitandos pardos; em segundo lugar, revela que a milícia separada por cores propiciava formas específicas de relação entre súditos e o rei. 
Argumentou-se nesta tese que cada regimento miliciano formava uma configuração social específica e que a interação entre os integrantes dos diversos corpos militares e dos membros das diversas instâncias governamentais produzia um campo de tensões bastante abrangente. No tocante aos milicianos pardos, suas possibilidades de elevação social e de controle ao Regimento dos Úteis - que inclui tanto o acesso aos principais postos como o exercício de influência sobre a multidão de subordinados - estavam no centro das disputas e dos "jogos". Foi no decorrer da competição travada na milícia que se estabeleceram as alianças entre os membros da oficialidade parda, as quais lhes possibilitaram controlar os mais diversos âmbitos da vida dos soldados e oficiais inferiores por quase uma década. Em meio a esta competição é que a família Ribeiro acumulou a maior parte do seu capital simbólico e material. Mas igualmente aí é que se produziram inúmeras situações de atrito entre a oficialidade parda, radicada na milícia, e a oficialidade branca, oriunda da tropa regular. As campanhas militares no Sul inflamaram ainda mais as disputas pelos postos no Regimento, pois então os serviços dos milicianos, executados na zona relativamente pacífica da capitania/província, foram contrapostos aos serviços prestados na guerra pelos veteranos brancos. Um dos resultados mais significativos da vivência nesse campo de tensões foi o esforço retórico movido pelos oficiais pardos - e com a chancela da Coroa - no sentido de afirmar a prevalência da meritocracia e da graduação militar em relação às variáveis supostamente naturais que compunham os principais estigmas sociais com os quais tinham que lidar: os critérios estamentais que atribuíam uma origem vil àqueles homens. Assim, a milícia parda serviu como um esteio da ordem tanto quanto como um fator de sua transformação - notadamente no combate a determinados estigmas sociais, tais como o trabalho mecânico, a origem escrava ou servil e o "defeito da cor".

A abolição da milícia parda, em 1831, juntamente com o restante das milícias e das ordenanças, significou uma abrupta desestruturação desse universo institucional que servia de base para o estabelecimento de relações de poder em diversos níveis e para os jogos aqui examinados. Subitamente, práticas de controle social, exercício de autoridade e mecanismos de obtenção de visibilidade social vigentes havia décadas entre os pardos de São Paulo deixaram de existir, já que a antiga oficialidade miliciana parda jamais alcançou posições semelhantes na guarda nacional estruturada conforme as premissas do liberalismo político. Na realidade, pesquisas preliminares em listagens das companhias da guarda nacional e em atas de eleições para juízes, vereadores e juízes de paz referentes às localidades que abrigavam companhias do Regimento dos Úteis - guardadas respectivamente no APESP e no AHM-SP - revelam a tímida presença de oficiais pardos entre os votados. As transformações institucionais e sociais ocorridas já em fins do primeiro reinado e principalmente durante o período regencial retiraram 
o protagonismo militar dos pardos, e desde então a expressão política desses indivíduos passou a ser condizente à sua posição social e econômica. Mas ao contrário de localidades como Salvador, onde as insatisfações decorrentes da desarticulação da milícia preta e parda foram expressadas em movimentos políticos de grande vulto - a exemplo da Sabinada -, a província de São Paulo parece não ter sofrido abalos após e em virtude da desfuncionalização da oficialidade parda.

Ao chegar nessas linhas finais da tese, as várias hipóteses e argumentos esboçados nos seus diversos capítulos adquirem uma densidade e consistência maiores. E não é para menos. A análise, por definição, separa aquilo que está intimamente entrelaçado com a finalidade de compreender partes específicas. Em parte, é o que se executou aqui mediante a divisão didática das três partes que compõem a tese entre os universos militar, social e político. Entretanto, uma vez que se atinja esse ponto e se mantenha uma visão de conjunto, percebe-se o quanto essas realidades estavam de fato amalgamadas em processos históricos e em configurações sociais complexas. A reconstrução da história dos milicianos pardos de São Paulo revelou-se como uma oportunidade para reconhecer o papel de relevo desempenhado por esses homens na estrutura militar luso-americana e depois brasileira. Ela também oportunizou um mergulho nos meandros da formação do grupo social dos pardos paulistas, ocorrida no bojo da transição entre a administração indígena e a escravidão africana, e uma caracterização de sua realidade socioeconômica. Finalmente, permitiu revelar o complexo entrelaçamento existente entre os pardos - oficiais e soldados - e a monarquia, as mais altas autoridades militares, e os oficiais brancos da tropa regular e da milícia, e, a partir daí, interpretar a participação dos milicianos pardos no contexto da independência do Brasil e as suas possibilidades de nobilitação. 


\section{FONTES}

\section{Dicionários}

BLUTEAU, Raphael. Vocabulario portuguez \& latino: aulico, anatomico, architectonico ... Coimbra: Collegio das Artes da Companhia de Jesus, 1712 - 1728. 8v.

SILVA, Antonio de Moraes. Diccionario da lingua portugueza composto pelo padre D. Rafael Bluteau, reformado, e accrescentado por Antonio de Moraes Silva natural do Rio de Janeiro. Lisboa: Officina de Simão Thaddeo Ferreira, 1789. 2 v.

\section{Legislação}

Collecção das leis do Imperio do Brazil [1808-1831]. Rio de Janeiro: Imprensa Nacional e Tipografia Nacional, 1878-1891. (séries: Cartas de Lei, Alvarás, Decretos e Cartas Régias; Decretos e Cartas Imperiaes e Alvarás; Atos do Poder Legislativo; Atos do Poder Executivo; Leis das Cortes Gerais Extraordinárias e Constituintes da Nação Portuguesa; Leis do Império do Brazil; Constituição Política do Império do Brazil)

Collecção das decisões do Governo do Brazil [1808-1831]. Rio de Janeiro: Imprensa Nacional e Tipografia Nacional, 1875-1891.

SILVA, António Delgado da. Collecção da Legislação Portugueza desde a última compilação das Ordenações - Legislação de 1763 a 1774. Lisboa: Typografia Maigrense, 1829.

SILVA, António Delgado da. Collecção da Legislação Portugueza desde a última compilação das Ordenações - Legislação de 1791 a 1801. Lisboa: Typografia Maigrense, 1828.

SILVA, José Justino de Andrade e. Collecção Chronologica da Legislação Portugueza. Lisboa: Imprensa de J. J. A. Silva, 1854.

\section{Fontes impressas}

ATAS da Câmara Municipal de São Paulo. São Paulo: Tipografia Piratininga, 1921-1923. Volumes: XIX (1788-1796); XX (1797-1809); XXI (1809-1815); XXII (1815-1822); XXIII (1822-1826); XXIV (1826-1829); XXV (1829-1830); XXVI (1831-1832).

BARRIGA, Luis Alvares. Propuesta de las advertencias, que de necessidad forçada, se deven justamente descursar, sobre la seguridad y certeza con que se deve recuperar el puerto de Pernambuco, defenderse y conservarse el Estado del Brasil. Anais da Biblioteca Nacional. (vol. 69). Rio de Janeiro: Departamento de Imprensa Nacional, 1950. p. 232-311.

BEYER, Gustavo. Ligeiras notas de viagem do Rio de Janeiro à capitania de São Paulo, no Brasil, no verão de 1813, com algumas notícias sobre a cidade de Bahia e a ilha Tristão da Cunha, entre o Cabo e o Brasil e que há pouco foi ocupada. In: Revista do Instituto Histórico e Geográfico de São Paulo (RIHGSP), v. 12. São Paulo: Typografia do Diario Official, 1907, p. 275-311.

CABRAL, José Antônio Teixeira. A estatística da Imperial Província de São Paulo: com várias anotações do tenente-coronel José Antônio Teixeira Cabral, membro da mesma estatística. 
Tomo I, 1827. Organização, transcrição e notas paleográficas Cristina Antunes. São Paulo: EDUSP, 2009.

CAMPOMANES, Pedro Rodríguez. Discurso acerca do modo de fomentar a industria do povo. Lisboa: Typografia Rollandiana, 1778.

D’ALINCOURT, Luiz. Resultado dos trabalhos e indagações estatísticas da província de Mato Grosso. Anais da Biblioteca Nacional. (vol. 8). Rio de Janeiro: Typographia Nacional, 18801881. p. 39-142.

DOCUMENTOS INTERESSANTES para a história e costumes de São Paulo. São Paulo, Edições Arquivo do Estado, 1895-1990. Volumes: 1 a 95.

KOSTER, Henry. Viagens ao Nordeste do Brasil. Trad. Luiz da Camara Cascudo. São Paulo: Companhia Editora Nacional, 1942.

LAVRADIO, Marquês de. Relatório do Marquês de Lavradio vice-rei do Rio de Janeiro, entregando o governo a Luiz de Vasconcellos e Sousa, que o sucedeu no vice-reinado. Rio de Janeiro, 19 de junho de 1779. RIHGB, Rio de Janeiro, tomo 4, n. 16, p. 409-486, 1863.

MATTOS, Raymundo José da Cunha. Chorographia histórica da província de Goyaz. Arraial de Traíras, 31 de dezembro de 1824. RIHGB, Rio de Janeiro, tomo 38, parte 1, 1875, p. 5-150.

MENDONÇA, Marcos Carneiro de. Século XVIII, século pombalino do Brasil. Rio de Janeiro: Xérox, 1989.

MENEZES, Luiz Barba Alado de. Memoria sobre a capitania do Ceará. Rio de Janeiro, 18 de abril de 1814. RIHGB, Rio de Janeiro, tomo 34, parte 1, p. 255-286, 1871.

MIRALES, D. José de. Historia militar do Brazil. Desde o anno de mil quinhentos quarenta e nove, em q' teve principio a fund. ${ }^{\mathrm{am}}$ da Cid. ${ }^{\mathrm{e}}$ de S. Salv. ${ }^{\text {or }}$ Bahia de todos os Santos até o de 1762. Anais da Biblioteca Nacional. (vol. 22). Rio de Janeiro: Typographia Leuzinger, 1900. p. 3-238.

ORBIGNY, Alcide Dessalines d'. Viagem pitoresca através do Brasil (1826-1833). São PauloBelo Horizonte: Edusp-Itatiaia, 1976.

PEREZ Y LOPEZ, A. X. Discurso sobre la honra y deshonra legal. Madrid: Blas Roman, 1781.

REGISTRO Geral da Câmara Municipal de São Paulo (RGCMSP). São Paulo: Tipografia Piratininga, 1920-1922. Volumes: XI (1764-1795); XIV (1808-1813); XV (1814-1819); XVI (1820-1822); XVIII (1824-1826); XIX (1826-1828);

Relaçam verdadeira e breve da tomada da Villa de Olinda, e lugar do Recife na costa do Brazil pellos rebeldes de Olanda, tirada de uma carta que escreveo hum Religioso de muyta authoridade, \& que foy testemunha de vista de quase todo o socedido: \& assi o affirma, \& jura; $\&$ do mais que depois disso socedeo te os dezoito de Abril deste prezente, \& fatal anno de 1630. Anais da Biblioteca Nacional. (vol. 20). Rio de Janeiro: Typografia Leuzinger, 1899. p. 125132.

SAINT-HILAIRE, Auguste de. Segunda viagem a São Paulo e quadro histórico da província de São Paulo. Trad. Afonso de E. Taunay. Brasília: Senado Federal, Conselho Editorial, 2002.

SAINT-HILAIRE, Auguste de. Viagem à província de São Paulo. Trad. Regina Regis Junqueira. Belo Horizonte: Ed. Itatiaia; São Paulo: Ed. da Universidade de São Paulo, 1976.

SAINT-HILAIRE, Auguste. Viagem pela comarca de Curitiba. Curitiba: Fundação Cultural de Curitiba, 1995. 
SPIX, Johann Baptist von. Viagem pelo Brasil: 1817-1820. (v. 1). Trad. Lúcia Furquim Lahmeyer. Belo Horizonte: Ed. Itatiaia; São Paulo: Ed. da Universidade de São Paulo, 1981.

SPIX, Johann Baptist Von; MARTIUS, Car. Friedrich Philipp von. Viagem pelo Brasil: 18171820. (v. 1). Trad. Lúcia Furquim Lahmeyer. Belo Horizonte: Ed. Itatiaia; São Paulo: Ed. da Universidade de São Paulo, 1981.

\section{Fontes manuscritas}

Arquivo da Cúria Diocesana de Bragança Paulista

Atibaia - paróquia São João Batista

Livro n. 1, Batizados (1719-1752)

Livro n. 2, Batizados (1752-1767)

Livro n. 3, Batizados (1760-1782)

1-2-42 L.B. Atibaia n. ${ }^{\circ} 1$

$1-2-51$ L.B. Atibaia n. ${ }^{\circ} 2$

$1-2-26$ L.B. Atibaia n. ${ }^{\circ} 3$

Livro n. 4, Batizados de Escravos e Bastardos (1772-1787) $\quad$ 1-2-48 $\quad$ L.B.E.B. Atibaia n. ${ }^{\circ} 4$

Livro n. 5, Batizados de Libertos (1782-1807)

1-1-57 L.B.L. Atibaia n. ${ }^{\circ} 5$

Livro n. 6, Batizados de Escravos, Bastardos e Índios

1-2-45 L.B.E.B.I. Atibaia n. ${ }^{\circ} 6$

(1787-1799)

Livro n. 7, Batizados (1799-1810)

1-1-44 L.B. Atibaia n. ${ }^{\circ} 7$

Livro n. 9, Batizados (1811-1818)

1-2-39 L.B. Atibaia n. ${ }^{\circ} 9$

Livro n. 10, Batizados de Libertos e Cativos (1818-1826)

1-3-56 L.B.L.C. Atibaia n. ${ }^{\circ} 10$

Livro n. 11, Batizados (1826-1854)

1-1-38 L.B. Atibaia n. ${ }^{\circ} 11$

Livro n. 1, Casamentos (1720-1738)

1-2-50 L.C. Atibaia ${ }^{\circ} 1$

Livro n. 2, Casamentos (1742-1756)

1-1-49 L.C. Atibaia n 2

Livro n. 3, Casamentos (1758-1763)

1-2-22 L.C. Atibaia n 3

Livro n. 4, Casamentos (1772-1790)

1-2-55 L.C. Atibaia no 4

Livro n. 5, Casamentos (1790-1807)

1-1-26 L.C. Atibaia ${ }^{\circ} 5$

Livro n. 6, Casamentos (1807-1818)

1-1-47 L.C. Atibaia n ${ }^{\circ} 6$

Livro n. 7, Casamentos de Brancos, Forros e Escravos

$1-1-37$

L.C.B.F.E. Atibaia $n^{\circ} 7$

(1818-1827)

Livro n. 8, Casamentos de Brancos, Libertos e Escravos

1-1-17 L.C.B.L.E. Atibaia $n^{\circ} 8$

(1827-1883)

Livro n. 1, Óbitos (1720-1754)

Livro n. 2, Óbitos (1757-1796)

1-2-52 L.O. Atibaia $n^{\circ} 1$

1-2-27 L.O. Atibaia ${ }^{\circ} 2$

1-1-43 L.O. Atibaia $\mathrm{n}^{\mathrm{o}} 3$

Livro n. 3, Óbitos (1796-1816)

1-1-10 L.O. Atibaia no 4

Livro n. 4, Óbitos (1816-1854)

Bragança (atual Bragança Paulista) - paróquia Nossa Senhora da Conceição

Livros n. 2 e n. 3, Batizados de Livres (1779-1782) e

12-2-31 L.B.L.E. Bragança n ${ }^{\circ} 2$ e 3

Escravos (1780-1806)

Livro n. 4, Batizados (1782-1785)

Livro n. 1, Casamentos (1765-1789)

12-2-30 L.B. Bragança $n^{\circ} 4$

L.C. Bragança $\mathrm{n}^{\circ} 1$

Livro n. 2, Casamentos (1790-1806)

12-2-8 L.C. Bragança $\mathrm{n}^{\circ} 2$

Livro n. 4, Casamentos (1806-1810)

12-2-15 L.C. Bragança $n^{\circ} 4$

Livro n. 5, Casamentos (1810-1819)

12-2-11 L.C. Bragança $\mathrm{n}^{\circ} 5$

Livro n. 6, Casamentos (1819-1824)

Livro n. 7, Casamentos (1824-1827)

12-3-39 L.C. Bragança ${ }^{\circ} 6$

12-3-41 L.C. Bragança $\mathrm{n}^{\circ} 7$

Livro n. 9, Casamentos (1827-1836)

12-3-19 L.C. Bragança n ${ }^{\circ} 9$

$\underline{\text { Juqueri (atual Mairiporã) - paróquia Nossa Senhora do Desterro }}$ 
Livro n. 1, Casamentos (1801-1817)

6-3-28 L.C. Juqueri $\mathrm{n}^{\circ} 1$

Livro n. 2, Casamentos (1817-1835)

6-3-49 L.C. Juqueri ${ }^{\circ} 2$

Nazaré (atual Nazaré Paulista) - paróquia Nossa Senhora de Nazaré

Livro n. 4, Casamentos (1778-1807)

2-2-15 L.C. Nazaré n. ${ }^{\circ} 4$

\section{Arquivo da Cúria Diocesana de Guarulhos}

Guarulhos - paróquia Nossa Senhora da Conceição dos Guarulhos

Livro n. 1, Casamentos (1734-1754)

Livro n. 2, Casamentos (1749-1777)

Livro n. 3, Casamentos (1771-1802)

Livro n. 4, Casamentos (1802-1872)

Livro n. 5, Casamentos de Escravos (1828-1883)
1-2-53 L.C. Guarulhos n. ${ }^{\circ} 1$

1-1-55 L.C. Guarulhos n. ${ }^{\circ} 2$

1-2-41 L.C. Guarulhos n. 3

1-2-15 L.C. Guarulhos n. ${ }^{\circ} 4$

1-2-13 L.C.E. Guarulhos n. ${ }^{\circ} 5$

\section{Arquivo da Cúria Diocesana de Jundiaí}

Araçariguama - paróquia Nossa Senhora da Penha

Livro n. 1, Batizados (1712-1721)

Livro n. 2, Batizados (1721-1737)

Livro s./n., Batizados (1737-1765)

Livro s./n., Batizados (1766-1782)

Livro s./n., Batizados de Brancos e Escravos (1783-1806)

Livro s./n., Batizados de Brancos, Libertos e Cativos

(1799-1823)

Livro s./n., Casamentos (1721-1750)

Livro s./n., Casamentos (1751-1783)

Livro s./n., Casamentos de Brancos e Escravos (1783-

1817)

Livro s./n., Casamentos de Livres e Escravos (1818-1896)

Livro s./n., Óbitos (1816-1898)

L.B. Araçariguama $\mathrm{n}^{\circ} 1$

L.B. Araçariguama $\mathrm{n}^{\mathrm{o}} 2$

L.B. Araçariguama 1737-1765

L.B. Araçariguama 1766-1782

L.B.B.E. Araçariguama 17831806

L.B.B.L.C. Araçariguama 1799-1823

L.C. Araçariguama 1721-1750

L.C. Araçariguama 1751-1783

L.C.B.E. Araçariguama 1783-

1817

L.C.L.E. Araçariguama 18181896

L.O. Araçariguama 1816-1898

$\underline{\text { Itu - paróquia Nossa Senhora da Candelária }}$

Livro n. 1, Casamentos de Brancos (1703-1728)

Livro n. 2, Casamentos (1728-1741)

Livro n. 3, Casamentos (1742-1763)

Livro n. 4, Casamentos (1744-1791)

Livro n. 5, Casamentos (1764-1776)

Livro n. 6, Casamentos (1776-1789)

Livro n. 7, Casamentos (1790-1804)

Livro n. 8, Casamentos de Brancos (1804-1815)

Livro n. 9, Casamentos de Brancos (1828-1834)

Livro n. 10, Casamentos de Brancos e Forros (1834-1856)

Livro n. 1, Casamentos de Escravos (1723-1743)

Livro n. 2, Casamentos de Escravos (1791-1809)

Livro n. 3, Casamentos de Escravos (1810-1830)

Livro n. 10, Batizados e Casamentos (1815-1819)

Livro n. 12, Batizados e Casamentos (1819-1828)

Livro n. 34, Batizados (1747-1892) e Casamentos (1740-

L.C.B. Itu $\mathrm{n}^{\mathrm{o}} 1$

L.C.B. Itu $\mathrm{n}^{\circ} 2$

L.C. Itu $\mathrm{n}^{\circ} 3$

L.C. Itu $\mathrm{n}^{\circ} 4$

L.C. Itu $\mathrm{n}^{\circ} 5$

L.C. Itu $\mathrm{n}^{\circ} 6$

L.C. Itu ${ }^{\circ} 7$

L.C.B. Itu $\mathrm{n}^{\circ} 8$

L.C.B. Itu $\mathrm{n}^{\circ} 9$

L.C.B.F. Itu $\mathrm{n}^{\circ} 10$

L.C.E. Itu $\mathrm{n}^{\circ} 1$

L.C.E. Itu $\mathrm{n}^{\mathrm{o}} 2$

L.C.E. Itu $\mathrm{n}^{\circ} 3$

L.B.C. Itu $\mathrm{n}^{\circ} 10$

L.B.C. Itu $\mathrm{n}^{\mathrm{o}} 12$

L.B.C. Itu $\mathrm{n}^{\circ} 34$ 
Livro n. 5, Óbitos de Brancos (1810-1828)

Livro n. 6, Óbitos de Brancos (1828-1837)

Jundiaí - paróquia Nossa Senhora do Desterro

Livro s./n., Batizados de Brancos e Libertos (1802-1860)

Livro s./n., Batizados de Brancos, Libertos e Cativos (1828-1850)

Livro s./n., Batizados de Brancos e Libertos (1833-1838 e 1840)

Livro s./n., Batizados (1838-1842)

Livro s./n., Batizados de Brancos e Cativos (1842-1847)

Livro s./n., Casamentos de Escravos e Administrados

(1739-1863)

Livro s./n., Casamentos de Brancos e Forros (1802-1810)

Livro s./n., Casamentos de Livres e Escravos (1814-1841)

Livro s./n., Casamentos de Brancos e Cativos (1841-1851)

Livro s./n., Óbitos de Brancos e Cativos (1836-1842)

Livro s./n., Óbitos de Brancos e Cativos (1842-1849)

Santana de Parnaíba - paróquia Santa Ana

Livro s./n., Batizados (1722-1764)

Livro s./n., Batizados de Livres e Escravos (1754-1795)

Livro s./n., Batizados de Livres (1764-1786)

Livro s./n., Batizados de Livres (1786-1809)

Livro s./n., Batizados de Escravos (1797-1871)

Livro s./n., Batizados (1798-1832)

Livro s./n., Casamentos (1722-1759)

Livro s./n., Casamentos (1758-1790)

Livro s./n., Casamentos Escravo (1759-1886)

Livro s./n., Casamentos (1790-1821)

Livro s./n., Casamentos (1821-1864)

Livro s./n., Óbitos (1778-1818)

Livro s./n., Óbitos dos Brancos e Libertos (1797-1811 e 1818-1830)

Livro s./n., Óbitos dos Brancos e Libertos (1830-1842)
L.O.B. Itu $\mathrm{n}^{\circ} 5$

L.O.B. Itu $n^{\circ} 6$

L.B.B.L. Jundiaí 1802-1860

L.B.B.L.C. Jundiaí 1828-1850

L.B.B.L. Jundiaí 1833-1838 e 1840

L.B. Jundiaí 1838-1842

L.B.B.C. Jundiaí 1842-1847

L.C.E.A. Jundiaí 1739-1863

L.C.B.F. Jundiaí 1802-1810

L.C.L.E. Jundiaí 1814-1841

L.C.B.C. Jundiaí 1841-1851

L.O.B.C. Jundiaí 1836-1842

L.O.B.C. Jundiaí 1842-1849

L.B. Parnaíba 1722-1764

L.B.L.E. Parnaíba 1754-1795

L.B.L. Parnaíba 1764-1786

L.B.L. Parnaíba 1786-1809

L.B.E. Parnaíba 1797-1871

L.B. Parnaíba 1798-1832

L.C. Parnaíba 1722-1759

L.C. Parnaíba 1758-1790

L.C.E. Parnaíba 1759-1886

L.C. Parnaíba 1790-1821

L.C. Parnaíba 1821-1864

L.O. Parnaíba 1778-1818

L.O.B.L. Parnaíba 1797-1811 e 1818-1830

L.O.B.L. Parnaíba 1830-1842

\section{Arquivo da Cúria Metropolitana de São Paulo}

Dispensas Matrimoniais e Casamentos

$118 ; 301 ; 578 ; 688 ; 881 ; 903 ; 919 ; 978 ; 1355 ; 1421 ; 1512 ; 1603 ; 1831 ; 1896 ; 2257 ; 2309$;

$2543 ; 2641 ; 2707 ; 2731 ; 2976 ; 2996 ; 3205 ; 3217 ; 3248 ; 3267 ; 3274 ; 3320 ; 3332 ; 3396 ; 3437$; $3454 ; 3477 ; 3485 ; 3512 ; 3575 ; 3598 ; 3645 ; 3695 ; 3730 ; 3764 ; 3806 ; 3901 ; 3921 ; 3939 ; 4132$; $4165 ; 4173 ; 4179 ; 4214 ; 4405 ; 4483 ; 4513 ; 4634 ; 4662 ; 4681 ; 4702 ; 4718 ; 4775 ; 4989 ;$;072; $5140 ; 5400 ; 5403 ; 5493 ; 5714$.

Igreja Nossa Senhora da Assunção - paróquia da Sé Livro n. 5, Batizados (1780-1784)

Livro n. 9, Batizados Brancos e Libertos (1799-1804)

Livro n. 10, Batizados Brancos e Libertos (1804-1811)

Livro n. 11, Batizados Brancos e Libertos (1811-1817)

Livro n. 12, Batizados Brancos e Libertos (1819-1829)

Livro n. 1, Casamentos de Escravos (1768-1826)

$\begin{array}{cl}\text { 2-2-40 } & \text { L.B. Sé n. } 5 \\ \text { 2-1-22 } & \text { L.B.B.L. Sé no } 9 \\ 3-2-16 & \text { L.B.B.L. Sé no } 10 \\ 3-2-11 & \text { L.B.B.L. Sé no } 11 \\ 3-2-9 & \text { L.B.B.L. Sé n }{ }^{\circ} 12 \\ \text { 2-3-45 } & \text { L.C.E. Sé n }{ }^{\circ} 1\end{array}$


Livro n. 3, Casamentos de Brancos e Libertos (1768-1782) 2-2-22

Livro n. 4, Casamentos de Brancos e Libertos (1782-1794)

Livro n. 5, Casamentos de Brancos e Libertos (1794-1812)

Livro n. 6, Casamentos de Brancos e Libertos (1812-1833)

Livro n. 7, Casamentos de Brancos e Libertos (1833-1862)

Livro n. 7, Óbitos de Livres (1810-1820)

Livro n. 8 Óbitos Brancos, Libertos e Escravos (18201823)

Livro n. 9 Óbitos Brancos, Libertos e Escravos (18231834)

Livro n. 10 Óbitos Brancos, Libertos e Escravos (1834-

1844)

Livro n. 11 Óbitos (1844-1853)

Livro n. 12 Óbitos Livres (1853-1860)
L.C.B.L. Sé $\mathrm{n}^{\circ} 3$

L.C.B.L. Sé $n^{\circ} 4$

1-2-17 L.C.B.L. Sé ${ }^{\circ} 5$

2-2-30 L.C.B.L. Sé $\mathrm{n}^{\circ} 6$

1-1-1 L.C.B.L. Sé $\mathrm{n}^{\circ} 7$

2-2-31 L.O.L. Sé $\mathrm{n}^{\circ} 7$

3-1-38 L.O.B.L.E. Sé $n^{\circ} 8$

3-1-36 L.O.B.L.E. Sé $n^{\circ} 9$

3-1-34 L.O.B.L.E. Sé $n^{\circ} 10$

3-2-7 L.O. Sé no 11

3-1-25 L.O. Sé no 12

Igreja Nossa Senhora da Conceição de Santa Efigênia - paróquia Santa Efigênia

Livro n. 1, Casamentos (1809-1841)

Livro n. 2, Casamentos (1841-1855)

10-2-43 LC. S.Ef. $n^{\circ} 1$

10-2-33 LC. S.Ef. $\mathrm{n}^{\mathrm{o}} 2$

Livro s./n., Óbitos (1809-1834)

L.O. S.Ef. 1809-1834

Livro s./n., Óbitos (1834-1840)

L.O. S.Ef. $1834-1840$

Livro s./n., Óbitos (1840-1852)

L.O. S.Ef. $1840-1852$

Igreja Nossa Senhora da Expectação - paróquia de Nossa Senhora do Ó

Livro s./n., Casamentos de Brancos, Libertos e Escravos,

$11-2-8$

L.C.B.L.E. N.S.Ó 1801-1871

(1801-1871)

Igreja Nossa Senhora da Penha - paróquia da Penha Livro n. 1, Batizados (1801-1822) e Casamentos (18011826)

Livro n. 2, Batizados (1822-1840), Casamentos (18261856) e Óbitos (1829-1852)

Igreja de Santo Amaro - paróquia de Santo Amaro

Livro n. 1, Batizados de Escravos (1726-1802)

Livro n. 2, Batizados de Brancos (1725-1766)

Livro n. 3, Batizados (1766-1788)

Livro n. 5, Batizados de Brancos (1788-1801)

Livro n. 6, Batizados de Brancos e Forros (1801-1806)

Livro n. 1, Batizados, Casamentos e Óbitos (1686-1828)

2-2-6 L.B.C.O Penha ${ }^{\circ} 1$

Livro n. 1, Casamentos (1707-1752)

Livro n. 2, Casamentos (1752-1770)

2-2-17 L.B.C.O Penha ${ }^{\circ} 2$

Livro n. 3, Casamentos (1770-1785)

Livro n. 4, Casamentos (1785-1806)

Livro n. 5, Casamentos de Brancos (1806-1814)

4-2-24 L.B.E. Santo Amaro $n^{\circ} 1$

4-2-17 L.B.B. Santo Amaro ${ }^{\circ} 2$

4-2-23 L.B. Santo Amaro $n^{\circ} 3$

4-2-21 L.B.B. Santo Amaro ${ }^{\circ} 5$

4-2-22 L.B.B.F. Santo Amaro $n^{\circ} 6$

4-2-25 L.B.C.O. Santo Amaro $n^{\circ} 1$

4-2-29 L.C. Santo Amaro $\mathrm{n}^{\circ} 1$

4-2-33 L.C. Santo Amaro $n^{\circ} 2$

4-2-37 L.C. Santo Amaro ${ }^{\circ} 3$

5-2-10 L.C. Santo Amaro $n^{\circ} 4$

4-2-36 L.C. Santo Amaro ${ }^{\circ} 5$

Livro n. 6, Casamentos (1814-1822)

5-2-15 L.C. Santo Amaro $n^{\circ} 6$

Livro n. 7, Casamentos (1822-1834)

5-2-5 L.C. Santo Amaro no 7

Livro n. 8, Casamentos (1834-1841)

5-2-11 L.C. Santo Amaro ${ }^{\circ} 8$ 
Arquivo da Cúria Arquidiocesana de Sorocaba

Sorocaba - paróquia Nossa Senhora da Ponte

Livro n. 8, Casamentos de Escravos, Administrados,

Libertos e Brancos (1804-1819)

L.C. Sorocaba $n^{\circ} 8$

Archivo General de Indias

Santo Domingo, legajos: 1225, 2093;

Cuba, legajos: 1491A, 1770 e 1770B; 1771B

México, legajos: 1413, 1437, 1438, 2418, 2422.

Archivo General de la Nación - México

Legajos: 197B; 1438.

Correspondencia de los Virreyes, serie 1, vol. 167.

Archivo General de Simancas

Secretaría del Despacho de Guerra, legajos: 7259, 7262, 7265.

Arquivo Histórico do Exército

Fundo: Requerimentos (1811-1905)

Arquivo Histórico Ultramarino

AHU - Bahia (Avulsos) (1604-1828)

AHU - Bahia (Eduardo de Castro e Almeida) (1613-1807)

AHU - Ceará (1618-1832)

AHU - Códices do Fundo do Conselho Ultramarino relativos ao Brasil

AHU - Goiás (1731-1822)

AHU - Mato Grosso (1720-1827)

AHU - Minas Gerais (1680-1832)

AHU - Paraíba (1593-1826)

AHU - Pernambuco (1590-1825)

AHU - São Paulo (Alfredo Mendes Gouveia) (1618-1823)

AHU - São Paulo (Avulsos) (1644-1830)

AHU - Rio de Janeiro (Avulsos) (1614-1826)

AHU - Rio de Janeiro (Eduardo de Castro e Almeida) (1614-1757) 
Arquivo Nacional-Brasil

Secretaria de Estado do Brasil, Códice 111.

Decretos Gerais, Livros 2, 9 e 11.

Registro Geral das Mercês, Códice 137, Livro 12.

Arquivo Público do Estado de São Paulo

$\underline{\text { Ordem }}-\underline{\text { Título }}$

C00263 - Militares. Legião de Voluntários Reais. Cavalarias Ligeiras e Auxiliares dos Batalhões de 2. ${ }^{a}$ Linha e Condutas (1793-1818).

C00264 - Militares - Inspetor Geral - General Arouche (1733-1815).

C00265 - Militares - General Arouche (1816-1821).

C00270 - Militares. Requerimentos de Caçadores - Informações - Requerimentos (1819-1822).

C00271 - Requerimentos (1721-1749).

C00273 - Militares. Requerimentos de oficiais e praças (1770-1784).

C00276 - Militares. Requerimentos de oficiais e praças (1797-1799).

C00277 - Militares - Oficiais - Praças. Requerimentos (1800-1816).

C00278 - Militares. Requerimentos solicitando Patentes (1817-1820).

C00279 - Militares. Requerimentos solicitando Patentes (1817-1820).

C00280 - Militares. Requerimentos de Oficiais e Praças (1821-1822).

C00285 - Ordenanças. Propostas para Capitães e Oficiais do Corpo de Segunda Linha (18091817).

C00286 - Ordenanças. Propostas para Capitães e Oficiais do Corpo de Segunda Linha (18181821).

C00361 - Sesmarias - Patentes - Provisões. Livros 4, 5 (1727-1734).

C00365 - Sesmarias - Patentes - Provisões. Livros 14, 15 e 16 (1752-1770).

C00366 - Sesmarias - Patentes - Provisões. Livros 17 e 18 (1765-1771).

C00370 - Sesmarias - Patentes - Provisões. Livros 27 e 28 (1795-1802).

C00371 - Sesmarias - Patentes - Provisões. Livros 29 e 30 (1797-1802).

C00372 - Sesmarias - Patentes - Provisões. Livros 31 e 32 (1802-1807).

C00379 - Sesmarias, Provisões, Cartas e Instruções Régias. Livros 51, 52 e 53 (1759-1778).

C00402 - Ofícios dos generais aos vice-reis e ministros. Livros 110, 111 e 112 (1804-1816).

C00403 - Ofícios dos generais aos vice-reis e ministros. Livros 113, 114 e 115 (1808-1822).

C00405 - Ofícios dos generais de S. Paulo aos tribunais régios e aos outros generais. Livros 122, 123 e 124 (1808-1831).

C00407 - Patentes. Portarias, bandos e provisões. Livros 127, 128, 129 e 130 (1744-1802).

C00408 - Portarias, bandos de generais do governo provisório - Proclamação de M. Francisco e J. Bonifácio. Livros 131, 132 e 133 (1811-1822).

C00413 - Registro de ofícios para estradas no governo do general João C. A. de Oeynhausen e governo provisório. Livros 125, 153 e 154 (1820-1822).

C00415 - Avisos do Ministério da Guerra e do Estrangeiro. Livros 157 e 158 (1808-1810).

C00416 - Avisos do Ministério da Guerra. Livros 159 e 160 (1811-1816).

C00417 - Avisos do Ministério da Guerra. Livros 161, 162 e 163 (1815-1819).

C00418 - Avisos dos Ministérios da Guerra e da Marinha. Livros 164 e 165 (1808-1822).

C00422 - Avisos, Cartas Régias e Real Erário. Livros 175, 176 e 177 (1801-1814).

C00438 - Registros de Informações, Requerimentos e Prestações. Livros 221, 222, 223 e 224 (1727-1827). 
C00439 - Registros de Atestações, Despachos do Conselho Supremo Militar, Vacinas, Protocolo, Cartas e Ofícios da Sala de Ordens (1797-1831). Livro 229.

C00440 - Registros de Recibos da Sala de Ordens e Trem Bélico. Títulos de Professores. Informação Cons. Supremo Militar. Livros 230, 231, 232 e 233 (1800-1824).

C00444 - Ordens, Legião e Tropa Paga, do Dia ref., Guarda Ajudantes, Casa da Pólvora, Sala de Ordens. Livros 246-252 (1797-1822).

C00445 - Ajudante de Ordens. Ordem do Dia. Secretaria do Governo e Diário de Expediente. Livros 253, 254, 259, 260 e 261 (1721-1824).

C00446 - Regimento da Infantaria dos Úteis - Sertanejos de Itu. Livros Mestres (1794-1822).

C02364 - Ofícios e relatórios do comandante do Batalhão da Província de São Paulo (18231831).

C02365 - Of. e Relatórios dos Comandantes do Batalhão n. 33 da Cidade de São Paulo (18231831).

C02366 - Comandantes do Batalhão 34. Ofícios - Relatórios (1823-1831).

C02367 - Ofícios e relatórios do comandante do Batalhão N. 35 de Itu (1823-1826).

C02369 - Ofícios e relatórios do comandante do Batalhão N. 36 de Sorocaba (1822-1826).

C02371 - Ofícios e relatórios do comandante do Batalhão N. 37 de Cunha (1823-1831).

C02372 - Ofícios e relatórios do comandante do Batalhão N. 38 de Santos (1822-1828).

C02375 - Ofícios e relatórios do comandante da Infantaria e Artilharia da vila de Paranaguá N. 39 (1827-1831).

C02385 - Ofícios ao governador geral das armas de São Paulo (1822-1823).

C02406 - Ofícios ao comandante geral das armas (1822-1831)

C07743 - Guerra. Vindos. Livros 198 e 199 (1824-1833 e 1854-1858).

C07746 - Guerra. Vindos (1822-1824). Livro 205.

C07776 - Marinha. Idos. Livros 324, 325 e 326 (1873, 1876 e 1884); Guerra Idos. Livros 327 e 328 (1822-1826 e 1827-1850).

E00662 - Tropas de Primeira e Segunda Linha. Correspondência do Governador das Armas ao Presidente da Província e outras autoridades (1825).

E00663 - Tropas de Primeira e Segunda Linha. Correspondência do Governador das Armas com autoridades subalternas (1826).

E00675 - Governo. Correspondência com comandantes de Segunda Linha (1824-1828).

E00697 - Tropas de Primeira e Segunda Linha. Registro das ordens, portarias e passaportes expedidos pelo Governador das Armas aos oficiais (1822-1824).

E00698 - Tropas de Primeira e Segunda Linha. Ordens do dia do Ajudante de Ordens do Governo das Armas (1822-1829).

E00700 - Tropas de Primeira e Segunda Linha. Ordens expedidas pelo Governador das Armas (1824-1825).

E00716 - Tropas de Primeira e Segunda Linha. Correspondência do Governador das Armas ao Presidente da Província e Ministros (1822-1826).

E00721 - Governo. Portarias (1823-1824).

E00890 - Tropas de Primeira e Segunda Linha. Propostas do Governador das Armas ao Governo para promoção e reforma de militares (1823-1829).

E00891 - Governo. Despachos sobre requerimentos de militares (1822-1824).

E00892 - Governo. Despachos sobre requerimentos de militares (1824-1829).

E00909 - Governo. Registro de requerimento de militares e dos respectivos despachos emitidos pelo Governo Imperial (1822-1830). 
Maços de População (APESP)

\begin{tabular}{|c|c|c|}
\hline Lata/Ordem & $\underline{\text { Localidade }}$ & $\underline{\text { Ano }}$ \\
\hline$\overline{\mathrm{C} 00007}$ & $\overline{\text { Atibaia }}$ & $\overline{1777}-1778$ \\
\hline C00007-A & Atibaia & $1779-1781$ \\
\hline C00008 & Atibaia & $1782-1783$ \\
\hline C00008-A & Atibaia & 1785 \\
\hline C00009 & Atibaia & $1787-1793$ \\
\hline C00010 & Atibaia & $1794-1796$ \\
\hline C00011 & Atibaia & $1797-1798$ \\
\hline C00011-A & Atibaia & $1799-1803$ \\
\hline C00012 & Atibaia & $1804-1805$ \\
\hline $\mathrm{C} 00013$ & Atibaia & $1809-1814$ \\
\hline $\mathrm{C} 00014$ & Atibaia & $1815-1820$ \\
\hline $\mathrm{C} 00015$ & Atibaia & $1822-1827$ \\
\hline C00016 & Atibaia & $1828-1850$ \\
\hline C00017 & Bragança & $1798-1801$ \\
\hline C00018 & Bragança & $1802-1804$ \\
\hline $\mathrm{C} 00019$ & Bragança & $1805-1808$ \\
\hline $\mathrm{C} 00020$ & Bragança & $1809-1812$ \\
\hline $\mathrm{C} 00021$ & Bragança & $1813-1816$ \\
\hline $\mathrm{C} 00022$ & Bragança & $1817-1822$ \\
\hline $\mathrm{C} 00023$ & Bragança & $1824-1826$ \\
\hline C00024 & Bragança & 1827 \\
\hline C00024-A & Bragança & $1830-1847$ \\
\hline C00030 & Capital e bairros & $1765-1778$ \\
\hline $\mathrm{C} 00031$ & Capital e bairros & $1779-1785$ \\
\hline C00032 & Capital e bairros & $1786-1794$ \\
\hline C00032-A & Capital e bairros & $1795-1799$ \\
\hline $\mathrm{C} 00033$ & Capital e bairros & $1801-1803$ \\
\hline C00033-A & Capital e bairros & $1804-1806$ \\
\hline C00034 & Capital e bairros & $1807-1811$ \\
\hline $\mathrm{C} 00035$ & Capital e bairros & $1813-1817$ \\
\hline $\mathrm{C} 00036$ & Capital e bairros & $1817-1822$ \\
\hline C00037 & Capital e bairros & $1829-1832$ \\
\hline C00037-A & Capital e bairros & $1836-1847$ \\
\hline $\mathrm{C} 00038$ & Cotia & $1765-1784$ \\
\hline C00039 & Cotia & $1785-1811$ \\
\hline $\mathrm{C} 00040$ & Cotia & $1813-1847$ \\
\hline C00057 & Guarulhos & $1802-1846$ \\
\hline C00074 & Itu & $1800-1803$ \\
\hline $\mathrm{C} 00075$ & Itu & $1804-1806$ \\
\hline C00075-A & Itu & 1807 \\
\hline C00076 & Itu & $1808-1809$ \\
\hline C00076-A & Itu & $1810-1811$ \\
\hline C00077 & Itu & $1812-1816$ \\
\hline C00078 & Itu & $1817-1818$ \\
\hline C00078-A & Itu & $1822-1824$ \\
\hline C00079 & Itu & $1825-1836$ \\
\hline C00091 & Jundiaí & $1806-1809$ \\
\hline
\end{tabular}




$\begin{array}{lll}\text { C00092 } & \text { Jundiaí } & 1810-1813 \\ \text { C00093 } & \text { Jundiaí } & 1818-1824 \\ \text { C00094 } & \text { Jundiaí } & 1825-1829 \\ \text { C00095-A } & \text { Juqueri } & 1802-1808 \\ \text { C00096 } & \text { Juqueri } & 1810-1820 \\ \text { C00127 } & \text { Santana de Parnaíba } & 1792-1798 \\ \text { C00129 } & \text { Santana de Parnaíba } & 1804-1806 \\ \text { C00131 } & \text { Santana de Parnaíba } & 1811-1814 \\ \text { C00132 } & \text { Santana de Parnaíba } & 1816-1818 \\ \text { C00133 } & \text { Santana de Parnaíba } & 1820-1825 \\ \text { C00134 } & \text { Santana de Parnaíba } & 1827-1829 \\ \text { C00149 } & \text { Santo Amaro } & 1804-1815 \\ \text { C00150 } & \text { Santo Amaro } & 1816-1847 \\ \text { C00172 } & \text { Sorocaba } & 1815-1818 \\ \text { C00173 } & \text { Sorocaba } & 1818-1822\end{array}$

Biblioteca Nacional - Brasil

Divisão de Manuscritos

Documentos: doc. 5,1,41; doc. 7,3,026; doc. 9,1,3; doc. C.0360,017; doc. i-30,12,17 n. 40; doc. i-30,13,12 n.16; doc. i-30,27,004; doc. ii-30,28,1; doc. ii-35,24,23; doc. ii-35,26,56. 


\section{BIBLIOGRAFIA}

AIDAR, Bruno. Novo imposto, nova ordem: poderes locais e fiscalidade na capitania de São Paulo, 1765-1775. In: CARRARA, A. A.; SANTIRÓ, E. S. (Coords). Guerra e fiscalidade na Ibero-América colonial (séculos XVII-XIX). Juiz de Fora: Ed. UFJF, 2012, p. 301-333.

ALADRÉN, Gabriel. Experiências de liberdade em tempos de guerra: escravos e libertos nas Guerras Cisplatinas (1811-1828). Estudos Históricos, Rio de Janeiro, vol. 22, n. 44, p. 439-458, jul./dez. 2009.

ALDEN, Dauril. El Brasil colonial tardío, 1750-1808. In: BETHELL, Leslie (Ed.) Historia de América Latina. (Vol. 3 - América Latina colonial: economía). Barcelona: Editorial Crítica, 1990, p. 306-352.

ALDEN, Dauril. The population of Brazil in the late eighteenth century: a preliminary study. The Hispanic American Historical Review, v. 43, n. 2, maio/1963.

ALZATE, Jorge H. González. Las milicias y la preservación del dominio español en los altos de Guatemala, 1673-1821. Boletín de la Asociación para el Fomento de los Estudios Históricos en Centroamérica, n. 26, nov./2006.

AQUINO E CASTRO, Olegario Herculano de. O conselheiro Manoel Joaquim do Amaral Gurgel. Elogio historico e noticia dos successos políticos que precederam e seguiram-se á proclamação da independencia na província de S. Paulo. RIHGB, tomo 41, parte 2 . Rio de Janeiro: Typ. de Pinheiro \& C., 1878, p. 237-376.

ARAUJO, Luiz Antônio Silva. Contratos, comércio e fiscalidade na América portuguesa (16411730). In: CARRARA, A. A.; SANTIRÓ, E. S. (Coords). Guerra e fiscalidade na IberoAmérica colonial (séculos XVII-XIX). Juiz de Fora: Ed. UFJF, 2012, p. 249-263.

ARAÚJO, Ubiratan de C.; TAVARES, Luís H. D.; SILVA, Maria B. N. da; et al. Segundo centenário da sedição de 1798 na Bahia. Salvador: Academia de Letras da Bahia; Secretaria da Cultura e Turismo, 1999.

ARCHER, Christon I. Pardos, Indians, and the Army of New Spain. Inter-relationships and conflicts. Journal of Latin American Studies, Vol. 6, No. 2, p. 231-255, nov. 1974.

ARCHER, Christon I. The Army in Bourbon Mexico, 1760-1810. Albuquerque: University of New Mexico, 1977.

AZEVEDO, Celia Maria Marinho de. A recusa da "raça": anti-racismo e cidadania no Brasil dos anos 1830. Horizontes Antropológicos, Porto Alegre, ano 11, n. 24, p. 297-320, jul./dez. 2005.

BACELLAR, Carlos de Almeida Prado. Famílias cativas em São Paulo colonial: a escravidão de indígenas e africanos através dos registros paroquiais (vila de Itu, capitania de São Paulo, primeira metade do século XVIII). Trabalho apresentado no XVIII Encontro Nacional de Estudos Populacionais, ABEP. São Paulo, nov. 2012.

BACELLAR, Carlos de Almeida Prado. O matrimônio entre escravos e libertos em São Paulo, Brasil, séculos XVIII e XIX. In: GHIRARDI, Mónica; SCOTT, Ana S. V. (Coords.). Familias históricas: interpretaciones desde perspectivas Iberoamericanas a través de los casos de Argentina, Brasil, Costa Rica, España, Paraguay y Uruguay. Red de Investigación Formación, comportamientos y representaciones de la Familia en Latinoamerica. São Leopoldo: Oikos; Editora Unisinos, 2015, p. 217-238. 
BACELLAR, Carlos de Almeida Prado. Viver e sobreviver em uma vila colonial: Sorocaba, séculos XVIII e XIX. São Paulo: Annablume/Fapesp, 2001.

BAECHLER, Jean. Grupos e sociabilidade. In: BOUDON, Raymond. Tratado de sociologia. Rio de Janeiro: Jorge Zahar Ed., 1995, p. 65-106.

BALHANA, Altiva Pilatti; WESTPHALEN, Cecília Maria. Negros, gentios da terra, ou negros d'África? Revista da SBPH, Curitiba, n. 17, p. 17-23, 2000.

BARBOSA, Francielly G. Tropas de homens de cor mobilizando e conectando capitanias: Bahia e Rio de Janeiro (1638-1763). Monografia de graduação. Curitiba: DEHIS, Universidade Federal do Paraná, 2014.

BARRETO, Daniela Santos. A despeito do defeito: artesãos na cidade do Rio de Janeiro, c. 1690-c. 1750. Acervo, Rio de Janeiro, v. 15, nº 2, p. 69-86, jul./dez. 2002.

BARROS, Daisy Ribeiro de Morais. Um século dos ofícios mecânicos na vila de São Paulo. Dissertação (mestrado em História). São Paulo: FFLCH, Universidade de São Paulo, 1982.

BARZOTTO, Luis Fernando. Justiça Social - Gênese, estrutura e aplicação de um conceito. Revista Jurídica Virtual, Brasília, v. 5, n. 48, maio/2003.

BASTIDE, Roger; FERNANDES, Florestan. Brancos e negros em São Paulo: ensaio sociológico sobre aspectos da formação, manifestações atuais e efeitos do preconceito de cor na sociedade paulistana [1955]. (4. ${ }^{\text {a }}$ ed.). São Paulo: Global, 2008.

BATALLA, Guillermo Bonfil. El concepto de indio en América: una categoría de la situación colonial. In: BATALLA, G. B. Identidad y pluralismo cultural en América Latina. Puerto Rico: Fondo Editorial del CEHASS, 1992.

BELLOTTO, Heloísa Liberalli. Autoridade e conflito no Brasil colonial: o governo do Morgado de Mateus em São Paulo (1765-1775). São Paulo: Conselho Estadual de Artes e Ciências Humanas, 1979.

BELMONTE POSTIGO, José Luís. El color de los fusiles. Las milicias de pardos en Santiago de Cuba en los albores de la Revolución Haitiana. In: CHUST, Manuel; MARCHENA, Juan (Eds.). Las armas de la nación. Independencia y ciudadanía en Hispanoamérica (1750-1850). Madrid: Iberoamericana/Vervuert, 2007, p. 37-51.

BELTRÁN, Aguirre. La población negra de México: estudio etno-historico. México: Fondo de Cultura Económica, 1989.

BERBEL, Márcia Regina. Os apelos nacionais nas cortes constituintes de Lisboa (1821/22). In: MALERBA, Jurandir (Org.). A independência brasileira. Rio de Janeiro: Editora FGV, 2006, p. 181-208.

BERBEL, Márcia Regina; MARQUESE, Rafael de Bivar. A ausência da raça: escravidão, cidadania e ideologia pró-escravista nas Cortes de Lisboa e na Assembléia Constituinte do Rio de Janeiro (1821-1824). In: CHAVES, C. M. das G.; SILVEIRA, M. A. (Orgs.). Território, conflito e identidade. Belo Horizonte: Argvmentvm; Brasília: CAPES, 2007, p. 63-88.

BETHENCOURT, Francisco. A administração da coroa. In: BETHENCOURT, Francisco \& CHAUDHURI, Kirti (Orgs.). História da Expansão Portuguesa. (Vol. 1). Lisboa: Círculo de Leitores, 1998.

BINDER, Fernando P. Bandas Militares no Brasil: difusão e organização entre 1808-1889. (Vol. 1). Dissertação (mestrado em Música). São Paulo: Instituto de Artes, Universidade Estadual Paulista, 2006. 
BLACKBURN, R. A construção do escravismo no Novo Mundo. Do barroco ao moderno (1492-1800). Rio de Janeiro: Record, 2003.

BLAJ, Ilana. A trama das tensões: o processo de mercantilização de São Paulo colonial (16811721). São Paulo: Humanitas/FFLCH/USP, 2002.

BOBBIO, Norberto; MATTEUCCI, Nicola; PASQUINO, Gianfranco. Dicionário de política. (1.a Ed.). Brasília: Editora Universidade de Brasília, 1998.

BONNET, Márcia C. Leão. Entre o artifício e a arte: pintores e entalhadores no Rio de Janeiro setecentista. Rio de Janeiro: Secretaria Municipal de Cultura: Arquivo Geral da Cidade do Rio de Janeiro, 2009.

BORGES, Luiz Adriano. Aspectos econômicos da participação paulista no processo de independência. Almanack, Guarulhos, n.06, p. 61-80, 2. ${ }^{\circ}$ semestre de 2013.

BORREGO, Maria Aparecida de Menezes. A teia mercantil: negócios e poderes em São Paulo colonial (1711-1745). Tese (doutorado em História). São Paulo: FFLCH, Universidade de São Paulo, 2006.

BOSCHI, Caio C. Os leigos e o poder. Irmandades leigas e política colonizadora em Minas Gerais. São Paulo: Ática, 1986.

BOURDIEU, P. O poder simbólico. Lisboa; Rio de Janeiro: Difel; Editora Bertrand Brasil, 1989.

BOURDIEU, Pierre. A ilusão biográfica. In: AMADO, J.; FERREIRA, M. de M. (Coords.). Usos \& abusos da história oral. Rio de Janeiro: Editora da Fundação Getúlio Vargas, p. 183191.

BOXER, Charles R. Relações raciais no império colonial português, 1415-1825. (1. a ed. 1963). Porto: Edições Afrontamento, 1988.

BRADING, David A. A Espanha dos Bourbons e seu império americano. In: BETHELL, L. (Org.). História da América Latina. São Paulo: Edusp; Brasília: Fundação Alexandre Gusmão, 1997.

CABRAL, Dilma (Org.). Dicionário da Administração Pública brasileira Online-Período colonial. Disponível em: 〈http://linux.an.gov.br/mapa/?p=4768>.

CALA, Mauricio Puentes. Artesanos y labriegos al servicio de la Corona: un acercamiento a las relaciones entre la raza, los oficios y el alistamiento miliciano en Santa Fe de Bogotá a finales del siglo XVIII. El Taller de la Historia, Cartagena de Indias, v. 5, n. 5, p. 173-210, 2013.

CAMPBELL, Leon G. Black power in colonial Peru: the 1779 tax rebellion of Lambayeque. Phylon, v. 33, n. 2, p. 140-152, 1972.

CAMPBELL, Leon $\mathrm{G}$. The changing racial and administrative structure of the peruvian military under the later bourbons. The Americas, v. 32, n. 1, p. 117-133, 1975.

CAMPOS, Pedro Dias. O Espírito Militar Paulista. Revista do Instituto Histórico e Geográfico de São Paulo, v. 22, 1923, p. 129-175.

CARVALHO, Francismar A. Lopes de. Lealdades negociadas: povos indígenas e a expansão dos impérios ibéricos nas regiões centrais da América do Sul (segunda metade do século XVIII). Tese (doutorado em História). São Paulo: FFLCH, Universidade de São Paulo, 2012. 
CARVALHO, Marcus J. M. de. Os negros armados pelos brancos e suas independências no Nordeste (1817-1848). In: JANCSÓ, István (Org.). Independência: história e historiografia. São Paulo: Hucitec, 2005, p. 881-914.

CASTRO MORALES, Efraín. Los cuadros de castas de la Nueva España. Trad. Institute of Latin America Studies, University of London. Jahrbuch für Geschichte von Staat, Wirtschaft, und Gesellschaft Lateinamerikas, n. 20, 1983.

CASTRO, Celso; IZECKSOHN, Vitor; KRAAY, Hendrik (Orgs.). Nova história militar brasileira. Rio de Janeiro: Editora FGV, 2004.

CASTRO, Jeanne Berrance de. A milícia cidadã: a Guarda Nacional de 1831 a 1850. 2. ${ }^{\mathrm{a}}$ ed. São Paulo: Companhia Editora Nacional, 1979.

CASTRO, José Luiz de. Transgressão, controle social e Igreja Católica no Brasil colonial: Goiás, século XVIII. Tese (doutorado em História). Franca: FHDSS, Universidade Estadual Paulista, 2009.

CERCEAU NETTO, Rangel. Um em casa do outro. São Paulo: Annablume; Belo Horizonte: PPGH/UFMG, 2008.

CERTEAU, Michel de. A escrita da história. Trad. Maria de Lourdes Menezes. Rio de Janeiro: Forense Universitária, 1982.

COSTA, Ana Paula Pereira. Militares pardos e pretos e sua "utilidade" para o bom governo da região de Serro Frio: notas de pesquisa. Estudos Ibero-Americanos, Porto Alegre, v. 42, n. 2, p. 560-581, mai./ago. 2016.

COSTA, André Alexandre da Silva. La milicia, el Rey y la guerra: la corona de Portugal y el caso del Brasil meridional (siglos XVI-XVIII). In: RUIZ IBÁÑEZ, José Javier (Coord.). Las milicias del rey de España. Sociedad, política e identidad en las Monarquías Ibéricas. Madrid: FCE, Red Columnaria, 2009, p. 162-191.

COSTA, Emília Viotti da. Introdução ao estudo da emancipação política. In: MOTA, Carlos Guilherme (Org.). Brasil em perspectiva. 18. ${ }^{a}$ ed. Rio de Janeiro: Ed. Bertrand Brasil, 1988.

COSTA, Fernando Dores. Os problemas do recrutamento militar no final do século XVIII e as questões da construção do Estado e da nação. Análise social, v. 30 (130), p. 121-155, 1995.

COSTA, Iraci Del Nero. Arraia-miúda: um estudo sobre os não-proprietários de escravos no Brasil. São Paulo: MSGP, 1992.

COSTA, Sérgio. A construção sociológica da raça no Brasil. Estudos Afro-Asiáticos, ano 24, $\mathrm{n}^{\mathrm{o}} 1$, p. 35-61, 2002.

COTTA, Francis Albert. Negros e mestiços nas milícias da América portuguesa. Belo Horizonte: Crisálida, 2010.

CRISPIN, Ana Carolina Teixeira. Além do acidente pardo: os oficiais das milícias pardas de Pernambuco e Minas Gerais (1766-1807). Dissertação (mestrado em História). Niterói: ICHF, Universidade Federal Fluminense, 2011.

CRUCES, Hugo Contreras. Artesanos mulatos y soldados beneméritos. El Batallón de Infantes de la Patria en la Guerra de Independencia de Chile, 1795-1820. Historia, Santiago, v. 44, n. 1, p. 51-89, ene./jun. 2011.

CRUCES, Hugo Contreras. Oficios, milicias y cofradías. Éxito económico, prestigio y redes sociales afromestizas en Santiago de Chile, 1780-1820. Revista de Historia Social y de las Mentalidades, Santiago de Chile, v. 17, n. 2, 2013, p. 43-74. 
CUNHA, Luiz Antônio. O ensino de ofícios artesanais e manufaturas no Brasil escravocrata. São Paulo: Editora UNESP, Brasília, DF: Flacso, 2000.

CUNHA, Pedro Octávio Carneiro da. Política e administração de 1640 a 1763. In: HOLANDA, S. B. de (Dir.). História geral da civilização brasileira. (v. 2, t. 1). São Paulo: Difel, 1985, p. 19-41.

DAMACENO, Daniel Tarifa. Os "facciosos" de São Paulo (Considerações acerca da Bernarda de Francisco Ignacio) 23.05.1822 - 25.08.1822. Dissertação (mestrado em História). São Paulo: FFLCH, Universidade de São Paulo, 1993.

DEGLER, Carl N. Nem preto nem branco: escravidão e relações raciais no Brasil e nos Estados Unidos. Rio de Janeiro: Labor do Brasil, 1976.

DELATORRE, Aparecida Vanessa. São Paulo à época da independência. Contribuição para $o$ estudo do chamado movimento "bernardista", 1821/1823. Dissertação (mestrado em História). São Paulo: FFLCH, Universidade de São Paulo, 2003.

DELGADO, María del Refugio M. Artesanos en armas. Del gremio de oficios a las milicias en Zacatecas, 1758-1820. In: TOLEDO, S. P.; GRIJALVA, M .M.; PEÑAFLORES, R. A. (Coords.). El mundo del trabajo urbano. Trabajadores, cultura y prácticas laborales. Zacatecas; México D.F.: Universidad Autónoma de Zacatecas; El Colegio de México, 2012, p.127-165.

DESCHAMPS CHAPEAUX, Pedro. Los batallones de pardos y morenos libres. La Habana: Instituto Cubano del Libro, 1976.

DOLHNIKOFF, Miriam. Representação política no Império. Anais do XXVI Simpósio Nacional de História - ANPUH. São Paulo, jul. 2011, p. 1-32.

DOLHNIKOFF, Miriam. São Paulo na independência. In: JANCSÓ, István (Org.). Independência: história e historiografia. São Paulo: Hucitec, 2005, p. 557-575.

DONGHI, Tulio Halperín. Reforma y disolución de los imperios ibéricos 1750-1850. Madrid: Alianza Editorial, 1985.

DUTRA, Francis A. A hard-fought struggle for recognition: Manuel Gonçalves Dória, first Afro-Brazilian to become a Knight of Santiago. The Americas, v. 56, n. 1, p. 92-113, 1999.

DUTRA, Francis A. Ser mulato em Portugal nos primórdios da época moderna. Tempo, Rio de Janeiro, n. 30, p. 101-114, 2010.

EINSENBERG, Peter L. Açúcar e mudança social no Brasil: Campinas, São Paulo, 1767-1830. In: EINSENBERG, Peter L. Homens esquecidos: escravos e trabalhadores livres no Brasil, séculos XVIII e XIX. Campinas: Editora da Unicamp, 1989.

EINSENBERG, Peter L. Homens esquecidos: escravos e trabalhadores livres no Brasil, séculos XVIII e XIX. Campinas: Editora da Unicamp, 1989.

ELIAS, Norbert. A sociedade de corte: investigação sobre a sociologia da realeza e da aristocracia de corte. Rio de Janeiro: Jorge Zahar Ed., 2001.

ELIAS, Norbert. A sociedade dos indivíduos. Trad. Mário Matos. Lisboa: Dom Quixote, 1993.

ELIAS, Norbert. Envolvimento e distanciamento. Estudos sobre sociologia do conhecimento. Trad. Maria Luísa Cabaços Mélico. Lisboa: Publicações Dom Quixote, 1997.

ELIAS, Norbert. Introdução à sociologia. Trad. Maria Luísa Ribeiro Ferreira. Lisboa: Edições 70, 2008.

ELIAS, Norbert. Mozart, sociologia de um gênio. Rio de Janeiro: Jorge Zahar Editor, 1995. 
ELIAS, Norbert. O processo civilizador. Formação do Estado e Civilização. (v. 2). Trad. Ruy Jungmann. Rio de Janeiro: Jorge Zahar Editor, 1993.

ELIAS, Norbert. O processo civilizador. Uma história dos costumes. (v. 1). Trad. Ruy Jungmann. Rio de Janeiro: Jorge Zahar Editor, 1990.

ELIAS, Norbert; SCOTSON, John L. Os estabelecidos e os outsiders. Sociologia das relações de poder a partir de uma pequena comunidade. Trad. Vera Ribeiro. Rio de Janeiro: Jorge Zahar Editor, 2000.

ELLIS JÚNIOR, Alfredo. O ouro e a Paulistânia. Boletim História da Civilização Brasileira, São Paulo, n. 8, 1948.

FAORO, Raymundo. Os donos do poder. Formação do patronato político brasileiro. Rio de Janeiro: Globo, 2001.

FARIA, Sheila de Castro. A colônia em movimento: fortuna e família no cotidiano colonial. Rio de Janeiro: Ed. Nova Fronteira, 1998.

FERNANDES, Florestan. Uma evocação da Revolução Constitucionalista. In: FERNANDES, Florestan. Mudanças sociais no Brasil: aspectos do desenvolvimento da sociedade brasileira. São Paulo: Global Editora, 2013, p. 318-338.

FLEXOR, Maria Helena Ochi. O trabalho livre em São Paulo no século XVIII. Tese (doutorado em História). São Paulo: FFLCH, Universidade de São Paulo, 1984.

FLEXOR, Maria Helena Ochi. Ofícios, manufaturas e comércio. In: SZMRECSÁNYI, T. (Org.). História econômica do período colonial. (2ª ed.). São Paulo: Hucitec, 2002.

FORJAZ, Djalma. O senador Vergueiro: sua vida e sua época (1778-1859). (Vol. 1). São Paulo: Officinas do Diario Official, 1924.

FRANCO, Maria S. de Carvalho. Homens livres na ordem escravocrata. $4^{\mathrm{a}}$ ed. São Paulo: Fundação Editora da UNESP, 1997.

FREYRE, Gilberto. Casa-grande \& senzala. (12 ${ }^{\mathrm{a}}$ ed.). Brasília: Editora Universidade de Brasília, 1963.

FREYRE, Gilberto. Sobrados e mucambos: decadência do patriarcado rural e desenvolvimento do urbano. (15 ${ }^{\mathrm{a}}$ ed.). São Paulo: Global, 2004.

GARAVAGLIA, Juan C. Os primórdios do processo de independência hispano-americano. In: JANCSÓ, István (Org.). Independência: história e historiografia. São Paulo: Hucitec, 2005.

GINZBURG, Carlo. Mitos, emblemas, sinais: morfologia e história. Trad. Federico Carotti. São Paulo: Companhia das Letras, 1989.

GODOY, Silvana Alves de. A vila de Itu e os negros da terra - séculos XVII e XVIII. Texto apresentado no XXIV Simpósio Nacional de História. São Leopoldo, Rio Grande do Sul, jul. 2007.

GOLDSCHMIDT, Eliana Rea. Casamentos mistos: liberdade e escravidão em São Paulo colonial. São Paulo: Annablume; Fapesp, 2004.

GONZÁLEZ DE LA VARA, Martín. El rey Revillagigedo y la defensa del puerto de Veracruz, 1789-1794. Relaciones. Estudios de historia y sociedad, Zamora-México, vol. XXVIII, núm. 110, 2007, p. 69-93.

GOUVEIA, António Camões; MONTEIRO, Nuno G. A milícia. In: MATTOSO, José (Dir.). História de Portugal. (v. 4). Lisboa: Ed. Estampa, 1998, p. 197-203. 
GUEDES, Roberto. De ex-escravo a elite escravista: a trajetória de ascensão social do pardo alferes Joaquim Barbosa Neves (Porto Feliz, São Paulo, século XIX). In: FRAGOSO, J.; ALMEIDA, C.; SAMPAIO, A. (Orgs.). Conquistadores e negociantes: histórias de elites no Antigo Regime nos trópicos, América lusa, séculos XVI a XVIII. Rio de Janeiro: Civilização Brasileira, 2007, pp. 337-376.

GUEDES, Roberto. Egressos do cativeiro: trabalho, família, aliança e mobilidade social (Porto Feliz, São Paulo, c. 1798-c. 1850). Rio de Janeiro: Mauad X: FAPERJ, 2008.

GUERRA, François-Xavier. De la política antigua a la política moderna. La revolución de la soberanía. In: GUERRA, François-Xavier; LEMPÉRIÉRE, Annick (Coords.). Los espacios públicos en Iberoamérica: ambigüedades y problemas, siglos XVIII y XIX. México: Centro Francés de Estudios Mexicanos y Centroamericanos; Fondo de Cultura Económica, 1998.

GUERRA, François-Xavier. Modernidad e independencias: ensayos sobre las revoluciones hispânicas. Madrid: Editorial Mapfre, 1992.

GUIMARÃES, Antonio Sérgio Alfredo. Como trabalhar com "raça" em sociologia. Educação e pesquisa, São Paulo, v. 29, n. 1, p. 93-107, jan./jun. 2003.

GUTIÉRREZ, Horacio. Crioulos e africanos no Paraná, 1798-1830. Revista Brasileira de História, v. 8, n. 16, p. 161-188, mar./ago. 2008.

HAMEISTER, Martha Daisson. Uma contribuição ao estudo da onomástica no período colonial: os nomes e o povoamento do Extremo Sul da Colônia (Continente do Rio Grande de São Pedro, c. 1735-c. 1777). In: SANTOS, A. C. de A.; DORÉ, A. (Orgs.). Temas setecentistas: governos e populações no império português. Curitiba: UFPR-SCHLA/Fundação Araucária, 2008, p. 459-478.

HERNÁNDEZ Y SÁNCHES-BARBA, Mario. La población hispanoamericana y su distribución social en el siglo XVIII. Revista de Estudios Políticos, n. 78, p. 111-142, 1954.

HESPANHA, António Manuel. Carne de uma só carne: para uma compreensão dos fundamentos histórico-antropológicos da família na época moderna. Análise Social, vol. 28 (123-124), p. 951-973, 1993.

HESPANHA, António Manuel; XAVIER, Angela Barreto. A representação da sociedade e do poder. In: MATTOSO, José (Org.). História de Portugal. O Antigo Regime (1620-1807). v. 4. Lisboa: Editorial Estampa, 1993.

HOLANDA, Sérgio Buarque de. A Colônia do Sacramento e a expansão no extremo sul. In: HOLANDA, S. B. de (Dir.). História geral da civilização brasileira. (v. 1, t. 1). São Paulo: Difel, 1972, p. 322-363.

HOLANDA, Sérgio Buarque de. A herança colonial - sua desagregação. In: HOLANDA, S. B. de (Dir.). História geral da civilização brasileira [1960]. (Tomo II, 1. ${ }^{\circ}$ vol.). 3. a ed. São Paulo: Difusão Européia do Livro, 1970, p. 9-39.

HOLANDA, Sérgio Buarque de. Movimentos de população de São Paulo no século XVIII. Revista do Instituto de Estudos Brasileiros, n. 1, p. 55-111, 1966.

HOLANDA, Sérgio Buarque de. Raízes do Brasil. São Paulo: Companhia das Letras, 1995.

HOLANDA, Sérgio Buarque de. São Paulo. In: HOLANDA, S. B. de (Dir.). História geral da civilização brasileira. (t. II, $2^{\circ}$ vol.). São Paulo: Difusão Européia do Livro, 1967, p. 415-472.

IZECKSOHN, Vitor. Milícias. In: Anais do XXVI Simpósio Nacional de História - ANPUH. São Paulo, jul. 2011. 
JANCSÓ, István. Na Bahia, contra o império: história do ensaio da sedição de 1798. São Paulo: Hucitec, 1996.

JANCSÓ, István; PIMENTA, João Paulo Garrido. Peças de um mosaico (ou apontamentos para o estudo da emergência da identidade nacional brasileira). In: MOTA, Carlos Guilherme (Org.). Viagem incompleta 1500-2000 - A experiência brasileira. (Vol. 1). São Paulo: Senac São Paulo Editora, 2000.

KLEIN, Herbert S. A oferta de muares no Brasil central: o mercado de Sorocaba, 1825-1880. Estudos econômicos, São Paulo, v. 19, nº 2, p. 347-372, maio/ago. 1989.

KLEIN, Herbert S. Os homens livres de cor na sociedade escravista brasileira. Dados - Revista de Ciências Sociais, n. 17, p. 3-27, 1978.

KLEIN, Herbert S. The colored militia of Cuba: 1568-1868. Caribbean Studies, v. 6, n. 2, p. 17-27, 1969.

KOK, Maria da Glória Porto. O sertão itinerante: expedições da capitania de São Paulo no século XVIII. Tese (doutorado em História). São Paulo: FFLCH, Universidade de São Paulo, 1998.

KOPYTOFF, Igor. Slavery. Annual Review of Antropology, v. 11, p. 207-230, 1982.

KOPYTOFF, Igor; MIERS, Suzanne. African 'slavery' as an institution of marginality. In. MIERS, Suzanne; KOPYTOFF, Igor (Eds.). Slavery in Africa. Historical and anthropological perspectives. Madison: The University of Wisconsin Press, 1979.

KOSELLECK, Reinhart. "Espaço de experiência" e "horizonte de expectativa": duas categorias históricas. In: KOSELLECK, R. Futuro passado. Contribuição à semântica dos tempos históricos. Trad. Wilma P. Maas, Carlos A. Pereira. Rio de Janeiro: Contraponto; Ed. PUC-Rio, 2006, p. 305-327.

KRAAY, Hendrik. 'Tão assustadora quanto inesperada': A Sabinada baiana, 1837-1838. In: DANTAS, M. D. (Org.). Revoltas, motins, revoluções: homens livres pobres e libertos no Brasil do século XIX. São Paulo: Alameda, 2011. p. 263-294.

KRAAY, Hendrik. "Em outra coisa não falavam os pardos, cabras, e crioulos": o "recrutamento" de escravos na guerra da independência na Bahia. Revista brasileira de história, São Paulo, v. 22, n. 43, p. 109-126, 2002.

KRAAY, Hendrik. Identidade racial na política, Bahia, 1790-1840: o caso dos Henriques. In: JANCSÓ, István (Org.). Brasil: formação do Estado e da nação. São Paulo/Ijuí: Hucitec/Unijuí/FAPESP, 2003, p. 521-546.

KRAAY, Hendrik. Política racial, Estado e Forças Armadas na época da independência: Bahia, 1790-1850. Trad. Magda Lopes. São Paulo: Hucitec, 2011.

KRAAY, Hendrik. Race, state, and armed forces in independence-era Brazil: Bahia, 1790s1840s. California: Stanford University Press, 2001.

KUETHE, Allan J. Cuba, 1753-1815: Crown, military, and society. Knoxville: University of Tennessee Press, 1986.

KUETHE, Allan J. Las milicias disciplinadas: ¿fracaso o éxito? In: ESCAMILLA, Juan Ortiz (Coord.). Fuerzas militares en Iberoamérica, siglos XVIII y XIX. México: El Colegio de México, Centro de Estudios Históricos; Zamora, Michoacán, México: El Colegio de Michoacán; Veracruz, México: Universidad Veracruzana, 2005, p. 19-26. 
KUETHE, Allan J. The military reform in the Viceroyalty of New Granada, 1773-1796. Tese de doutorado. Flórida: Universidade da Flórida, 1967.

KUETHE, Allan J. The status of the free pardo in the disciplined militia of New Granada. The Journal of Negro History, v. 56, n. 2, p. 105-117, apr./1971.

KÜHN, Fábio. A fronteira em movimento: relações luso-castelhanas na segunda metade do século XVIII. Estudos Ibero-Americanos, v. 25, n.2, p. 91-112, dez./1999.

LARA, Silvia Hunold. Escravidão, cidadania e história do trabalho no Brasil. Projeto História, São Paulo, v. 16, p. 25-38, fev. 1998.

LARA, Silvia Hunold. Fragmentos setecentistas: escravidão, cultura e poder na América portuguesa. São Paulo: Companhia das Letras, 2007.

LASSO, Marixa. Guerra racial e nação na Gran Colômbia caribenha, Cartagena, 1810-1832. Estudos Ibero-Americanos, Porto Alegre, vol. 36, n. ${ }^{\circ}$ 2, p. 179-207, jul./dez. 2010.

LEONZO, Nanci. As companhias de ordenanças na capitania de São Paulo. Das origens ao governo do Morgado de Mateus. Dissertação (mestrado em História). São Paulo: FFLCH, Universidade de São Paulo, 1975.

LEONZO, Nanci. Defesa militar e controle social na capitania de São Paulo: as milícias. Tese (doutorado em História). São Paulo: FFLCH, Universidade de São Paulo, 1979.

LIBBY, Douglas Cole. A empiria e as cores: representações identitárias nas Minas Gerais dos séculos XVIII e XIX. In: PAIVA, E. F.; IVO, I. P.; MARTINS, I. C. (Orgs.). Escravidão, mestiçagens, populações e identidades culturais. São Paulo: Annablume; Belo Horizonte: PPGH-UFMG; Vitória da Conquista: Edições UESB, 2010.

LIBBY, Douglas Cole. Habilidades, artífices e ofícios na sociedade escravista do Brasil colonial. In: COLE, D. C.; FURTADO, J. F. (Orgs.). Trabalho livre, trabalho escravo: Brasil e Europa, séculos XVII e XIX. São Paulo: Annablume, 2006, p. 57-73.

LIMA, Carlos A. M. Escravos de peleja: a instrumentalização da violência escrava na América portuguesa (1580-1850). Revista de Sociologia e Política, Curitiba, n. 18, p. 131-152, jun. 2002.

LIMA, Oliveira. O movimento da independência. O Império brasileiro (1821-1889). 2. ${ }^{\text {a }}$ ed. São Paulo: Edições Melhoramentos, s.d.

LIMA, Priscila de. De libertos a habilitados. Interpretações populares dos alvarás antiescravistas na América portuguesa (1761-1810). Dissertação (mestrado em História). Curitiba: SCHLA, Universidade Federal do Paraná, 2011.

LINS, Maria de L. Ferreira. A Legião de São Paulo no Rio Grande do Sul. Tese (doutorado em História). São Paulo: FFLCH, Universidade de São Paulo, 1976.

LINS, Maria de L. Ferreira. Martim Lopes Lobo de Saldanha: a presença de São Paulo nas guerras do Sul. In: Anais do simpósio comemorativo do bicentenário da restauração do Rio Grande (1776-1976). (vol. 1). RJ: Instituto Histórico e Geográfico Brasileiro, 1979.

LOIOLA, Maria L. Defeito ou acidente? Mulatos e pardos na produção da hierarquia social em Goiás colonial. In: Anais do III Seminário de Pesquisa e Pós-graduação em História UFG/PUC Goiás, 2010.

LUNA GARCÍA, Sandra Nancy. Trabajadores de origen africano en los gremios de la Ciudad de México, siglo XVIII. TOLEDO, S. P.; GRIJALVA, M .M.; PEÑAFLORES, R. A. (Coords.). El mundo del trabajo urbano. Trabajadores, cultura y prácticas laborales. Zacatecas; México D.F.: Universidad Autónoma de Zacatecas; El Colegio de México, 2012, p. 87-126. 
LUNA, Francisco Vidal; COSTA, Iraci del Nero; KLEIN, Herbert S. Escravismo em São Paulo e Minas Gerais. São Paulo: Imprensa Oficial/Edusp, 2009.

LUNA, Francisco Vidal; KLEIN, Herbert S. Características da população em São Paulo no início do século XIX. In: LUNA, Francisco Vidal; COSTA, Iraci del Nero; KLEIN, Herbert S. Escravismo em São Paulo e Minas Gerais. São Paulo: Imprensa Oficial/Edusp, 2009.

LUNA, Francisco Vidal; KLEIN, Herbert S. Evolução da sociedade e economia escravista de São Paulo, de 1750 a 1850. São Paulo: EDUSP, 2006.

MACHADO, Cacilda da Silva. A Trama das Vontades. Negros, pardos e brancos na produção da hierarquia social (São José dos Pinhais - Pr, passagem do XVIII para o XIX). Tese (doutorado em História). Rio de Janeiro: IFCS, Universidade Federal do Rio de Janeiro, 2006.

MACHADO, Cacilda. A escravidão e a cor dos escravos e dos livres (Freguesia de São José dos Pinhais - PR, passagem do XVIII para o XIX). In: SANTOS, A. C. de A.; DORÉ, A. (Orgs.). Temas setecentistas: governos e populações no império português. Curitiba: UFPRSCHLA/Fundação Araucária, 2008, p. 429-442.

MALAQUIAS, Carlos de Oliveira. Militares negros e pardos na freguesia de São José do Rio das Mortes em fins do século XVIII. Temporalidades. Revista Discente do Programa de PósGraduação em História da UFMG, v. 2, n. 1, jan./jul. 2010, p. 130-137.

MARCHENA FERNÁNDEZ, Juan (Coord.). El ejército de América antes de la independencia. Ejército regular y milicias americanas, 1750-1815 - Hojas de servicio y uniformes. Madrid: Fundación Mapfre Tavera, CD-Rom, s./data.

MARCHENA FERNÁNDEZ, Juan. Ejército y milícias en el mundo colonial americano. Madrid: Editorial MAPFRE, 1992.

MARCHENA FERNÁNDEZ, Juan; GARAVAGLIA, Juan Carlos. Mestizos y mulatos en la sociedad colonial. In.: MARCHENA FERNÁNDEZ, J.; GARAVAGLIA, J. C. America latina: de los orígenes a la independencia. (v. 2). Barcelona: Crítica, 2005, p. 353-367.

MARCÍLIO, Maria Luiza. A cidade de São Paulo: povoamento e população, 1750-1850, com base nos registros paroquiais e nos recenseamentos antigos. São Paulo: Pioneira; Ed. da Universidade de São Paulo, 1973.

MARCÍLIO, Maria Luiza. A população do Brasil colonial. In: BETHELL, Leslie (Org.). História da América Latina: A América Latina Colonial. (vol. 2). São Paulo: EDUSP; Brasília, DF: Fundação Alexandre de Gusmão, 1999.

MARCÍLIO, Maria Luiza. Crescimento demográfico e evolução agrária paulista: 1700-1836. São Paulo: Hucitec, Edusp, 2000.

MARQUESE, Rafael de Bivar. A dinâmica da escravidão no Brasil. Resistência, tráfico negreiro e alforrias, séculos XVII a XIX. Novos Estudos, n. 74, p. 107-123, 2006.

MARTA, Michel Mendes. Em busca de honras, isenções e liberdades: as milícias de homens pretos forros na cidade do Rio de Janeiro (meados do século XVIII e início do XIX). Dissertação (mestrado em História). Niterói: ICHF, Universidade Federal Fluminense, 2013.

MARTINS, Mônica de Souza Nunes. Entre a cruz e o capital: mestres, aprendizes e corporações de ofícios no Rio de Janeiro (1808-1824). Tese (doutorado em História). Rio de Janeiro: IFCS, Universidade Federal do Rio de Janeiro, 2007.

MATTOS, Hebe Maria. Escravidão e cidadania no Brasil monárquico. Rio de Janeiro: Jorge Zahar Ed., 2004. 
MATTOS, Hebe. "Black Troops" and hierarchies of color in the Portuguese Atlantic World: The case of Henrique Dias and his Black Regiment. Luso-Brazilian Review, v. 45, n.1, p. 6-29, 2008.

MATTOS, Hebe. Racialização e cidadania no Império do Brasil. In: CARVALHO, José Murilo de; NEVES, Lúcia Maria Bastos Pereira das (Orgs.). Repensando o Brasil do Oitocentos: cidadania, política e liberdade. Rio de Janeiro: Civilização Brasileira, 2009, p. 356-357.

MATTOS, Regiane Augusto de. De cassange, mina, benguela a gentio da Guiné. Grupos étnicos e formação de identidades africanas na cidade de São Paulo (1800-1850). Dissertação (mestrado em História). São Paulo: FFLCH, Universidade de São Paulo, 2006.

MAXWELL, Kenneth. Marquês de Pombal: paradoxo do iluminismo. Rio de Janeiro: Paz e Terra, 1997.

McALISTER, Lyle N. The "fuero militar" in New Spain (1764-1800). Gainesville: University of Florida Press, 1957.

MEDICCI, Ana Paula. De capitania a província: o lugar de São Paulo nos projetos de império, 1782-1822. In: COSTA, Wilma Peres; OLIVEIRA, Cecília Helena de Salles (Orgs.). De um império a outro: estudos sobre a formação do Brasil, séculos XVIII e XIX. São Paulo: Aderaldo \& Rothschild: Fapesp, 2007, p. 241-260.

MEDICCI, Ana Paula. São Paulo en el movimiento de Independencia de Brasil (1820-1822). Nuevo Mundo Mundos Nuevos [Online], Debates, posto online em 11 abril 2013, consultado em 18 julho 2014. URL: http://nuevomundo.revues.org/65314; DOI: 10.4000/nuevomundo.65314.

MELLO, Christiane Figueiredo Pagano de. "Fazer soldados, poder tremendo! Não os fazer, maior ainda". In: SANTOS, A. C. de A.; DORÉ, A. (Orgs.). Temas setecentistas: governos e populações no império português. Curitiba: UFPR-SCHLA/Fundação Araucária, 2008, p. 3743.

MELLO, Christiane Figueiredo Pagano de. Forças militares no Brasil colonial: corpos de Auxiliares e de Ordenanças na Segunda Metade do Século XVIII. Rio de Janeiro: E-Papers, 2009.

MELLO, Christiane Figueiredo Pagano de. O Rio de Janeiro: uma praça desfalcada "dos melhores soldados e oficiais" (séculos XVII e XVIII). História, São Paulo, v. 31, n. 1, p. 210232, jan./jun. 2012.

MELLO, Christiane Figueiredo Pagano de. Os Corpos de Auxiliares e de Ordenanças na Segunda Metade do Século XVIII. As Capitanias do Rio de Janeiro, São Paulo e Minas Gerais e a Manutenção do Império Português no Centro Sul América. Tese (doutorado em História). Niterói: ICHF, Universidade Federal Fluminense, 2002.

MELLO, Evaldo Cabral de. A ferida de Narciso. Ensaio de História Regional. São Paulo: Ed. do SENAC, 2001.

MELLO, Evaldo Cabral de. Olinda restaurada: guerra e açúcar no Nordeste, 1630-1654. $2^{\mathrm{a}}$ ed. Rio de Janeiro: Topbooks, 1998.

MELLO, José Antônio Gonsalves de. Henrique Dias: governador dos pretos, crioulos e mulatos do Estado do Brasil. Recife: Universidade do Recife, 1954.

MELO, Edilberto de Oliveira. Raízes do militarismo paulista. São Paulo: Imprensa Oficial do Estado, 1982. 
MENDES, Fábio Faria. Encargos, privilégios e direitos: o recrutamento militar no Brasil nos séculos XVIII e XIX. In: CASTRO, C.; IZECKSOHN, V.; KRAAY, H. (Orgs.). Nova história militar brasileira. Rio de Janeiro: Editora FGV, 2004, p. 111-138.

MENESES, José Newton Coelho. Educar na oficina: a aprendizagem do artesão no mundo português e as reformas pombalinas do ensino no final do século XVIII. In: FONSECA, Thais Nivia de Lima e (Org.). As reformas pombalinas no Brasil. Belo Horizonte: Mazza Edições, 2011, p. 245-270.

MENZ, Maximiliano M. Entre dois impérios: formação do Rio Grande na crise do antigo sistema colonial (1777-1822). Tese (doutorado em História). São Paulo: FFLCH, Universidade de São Paulo, 2006.

METCALF, Alida C. Family and frontier in colonial Brazil, Santana de Parnaíba, 1580-1822. Berkeley: University of California Press, 1992.

MONTEIRO, John Manuel. Negros da terra: índios e bandeirantes nas origens de São Paulo. São Paulo: Companhia das Letras, 1994.

MORSE, Richard. O espelho de próspero. São Paulo: Companhia das Letras, 2000.

MOTA, Celio de Souza. A face parda da "Conspiração dos Alfaiates": homens de cor, corporações militares e ascensão social em Salvador no final do século XVIII. Dissertação (mestrado em História). Feira de Santana: Universidade Estadual de Feira de Santana, 2010.

MOTA, Celio de Souza. Os Regimentos de Milícias de pretos e pardos em Salvador: trajetórias e mobilidade social em sociedade do Antigo Regime no final do século XVIII. In: CHAMBOULEYRON, R.; ARENZ, K.-H. (Orgs.). Anais do IV Encontro Internacional de História Colonial. Dinâmica imperial no Antigo Regime português: séculos XVI-XVIII. Belém: Editora Açaí, volume 6, 2014, p. 57-71.

MÚNERA, Alfonso. El fracaso de la nación. Región, clase y raza en el Caribe colombiano (1717-1821). Bogotá: Editorial Planeta Colombiana, 2008.

NARDY FILHO, Francisco. A cidade de Ytu. $2^{\circ}$ vol - Da acclamação de D. João VI à proclamação da Republica. A cooperação ytuana nos factos políticos desse periodo. São Paulo: Escolas Profissionais Salesianas, 1930.

NAZZARI, Muriel. Vanishing Indians: the social construction of race in colonial São Paulo. The Américas, v. 57, n. 4, p. 497-524, abr./2001.

NEVES, Lúcia Maria Bastos P. das. São Paulo e a independência. In: SILVA, Maria Beatriz Nizza da (Org.). História de São Paulo colonial. São Paulo: Editora Unesp, 2009, p. 275-318.

NOGUEIRA, Shirley Maria Silva. "A soldadesca desenfreada”: politização militar no GrãoPará da Era da Independência (1790-1850). Tese (doutorado em História). Salvador: FFCH, Universidade Federal de Salvador, 2009.

NOVAIS, Fernando A. Condições da privacidade na Colônia. In: NOVAIS, Fernando A. (Org.). História da vida privada no Brasil [v. 1, SOUZA, Laura de Mello e (Org.). Cotidiano e vida privada na América portuguesa]. São Paulo: Companhia das Letras, 1997, p. 13-39.

NOVAIS, Fernando Antonio. O reformismo ilustrado luso-brasileiro: alguns aspectos. Revista Brasileira de História, São Paulo, n. 7, p. 105-118, 1984.

NOVAIS, Fernando Antonio. Portugal e Brasil na crise do Antigo Sistema Colonial (17771808). (5. ${ }^{a}$ ed). São Paulo: Editora HUCITEC, 1989. 
OLIVEIRA, José Joaquim Machado de. Quadro Historico da Provincia de S. Paulo até o anno de 1822. São Paulo: Typografia Brasil de Carlos Gerke, 1897.

OLIVEIRA, Mônica Ribeiro de; ALMEIDA, Carla Maria Carvalho de (Orgs.). Exercícios de micro-história. Rio de Janeiro: Editora FGV, 2009.

ORLANDO, Arthur. S. Paulo versus Alexandre VI. Rio de Janeiro: Typ. do Jornal do Commercio, $1910 . \quad$ Consulta online em: URL: http://www.brasiliana.usp.br/handle/1918/01969480.

PAIVA, Eduardo França. Dar nome ao novo: uma história lexical da Ibero-América entre os séculos XVI e XVIII (as dinâmicas de mestiçagens e o mundo do trabalho). Belo Horizonte: Autêntica Editora, 2015.

PAIVA, Eduardo França. De corpo fechado: gênero masculino, milícias e trânsito de culturas entre a África dos mandingas e as Minas Gerais da América, no início do século XVIII. In: LIBBY, Douglas Cole; FURTADO, Júnia Ferreira. (Org.). Trabalho livre, trabalho escravo. Brasil e Europa, séculos XVIII e XIX. São Paulo/Belo Horizonte: Annablume/PPGH-UFMG, 2006, p. 113-129.

PATTERSON, Orlando. Escravidão e morte social. São Paulo: Edusp, 2008.

PAULA, Leandro Francisco de. Negros no campo das armas: homens de cor nos corpos militares das minas setecentistas. Dissertação (mestrado em História). Curitiba: SCHLA, Universidade Federal do Paraná, 2012.

PELLICER, Luis Felipe. Entre el honor y la pasión: familia, matrimonio y sistema de valores en Venezuela durante la crisis del orden hispánico: 1778-1820. Caracas: Fondo Editorial de la Facultad de Humanidades y Educación; Universidad Central de Venezuela, 2005.

PEREGALLI, Enrique. Recrutamento militar no Brasil colonial. Campinas: Editora da UNICAMP, 1986.

PEREIRA, José Neilton. Além das formas, a bem dos rostos: faces mestiças da produção cultural barroca recifense - 1701-1789. Dissertação (mestrado em História). Recife: DLCH, Universidade Federal Rural de Pernambuco, 2009.

PESSOA, Raimundo Agnelo Soares. Gente sem sorte: os mulatos no Brasil colonial. Tese (doutorado em História). Franca: FHDSS, Universidade Estadual Paulista "Júlio de Mesquita Filho", 2007.

PETRONE, Maria Thereza Schorer. A lavoura canavieira em São Paulo - expansão e declínio (1765-1815). São Paulo: Difel, 1968.

PIERSON, Donald. Ascenção social do mulato brasileiro. Revista do Arquivo Municipal, São Paulo, ano 7, v. 87, p. 107-119, dez. 1942.

PINHEIRO, J. C. Fernandes. Henrique Dias. Biographia dos brasileiros illustres, por armas, virtudes, etc. Revista do Instituto Histórico e Geográfico Brasileiro (RIHGB), Rio de Janeiro, tomo XXI, parte 1, p. 365-383, 1868.

PIZA, Antonio de Toledo. A Bernarda de Francisco Inacio - Suas causas e suas consequências. RIHGSP, vol. 10, 1906, p. 126-177.

PIZA, Antonio de Toledo. Martim Francisco e a Bernarda. RIHGSP, vol. 5, 1901, p. 48-78.

PORTELA, Bruna Marina. Gentio da terra, gentio da Guiné: a transição da mão de obra escrava e administrada indígena para escravidão africana (Capitania de São Paulo, 16971780). Tese (doutorado em História). Curitiba: SCHLA, Universidade Federal do Paraná, 2014. 
PRADO JÚNIOR, Caio. Evolução política do Brasil. Colônia e Império. (1ª ed. 1933). São Paulo: Editora Brasiliense, 1986.

PRADO JÚNIOR, Caio. Formação do Brasil contemporâneo. São Paulo: Editora Brasiliense, 1994.

PRADO JÚNIOR, Caio. História econômica do Brasil. [1ª ed. 1945]. São Paulo: Brasiliense, 1994.

PRECIOSO, Daniel. "Legítimos vassalos": pardos livres e forros na Vila Rica colonial (17501803). Dissertação (mestrado em História). Franca: FHDSS, Universidade Estadual Paulista "Júlio de Mesquita Filho", 2010.

PUNTONI, Pedro. A arte da guerra no Brasil. Tecnologia e estratégia militar na expansão da fronteira da América portuguesa, 1550-1700. Novos Estudos. CEBRAP, n. 53, p. 189-204, 1999.

PUNTONI, Pedro. A guerra dos bárbaros. Povos indígenas e a colonização do Sertão do Nordeste do Brasil, 1650-1720. São Paulo: Hucitec, 2002.

QUEIROZ, Suely Robles Reis de. Escravidão negra em São Paulo. Rio de Janeiro: José Olympio, 1977.

RABELLO, Elisabeth Darwiche. A cidade de São Paulo e sua estrutura profissional: 18041825. In: COSTA, Iraci del Nero da. Brasil: História econômica de demográfica. São Paulo: USP; FEA/IPE, 1986, p. 223-244.

RABELLO, Elisabeth Darwiche. As elites na sociedade paulista na segunda metade do século XVIII. São Paulo: Comercial Safady, 1980.

RABELLO, Elisabeth Darwiche. Os ofícios mecânicos e artesanais em São Paulo na segunda metade do século XVIII. Revista de História, n. 55, v. 112, p. 575-588, 1977.

RAMINELLI, Ronald. "Los límites del honor”. Nobles y jerarquías de Brasil, Nueva España y Perú, siglos XVII y XVIII. Revista Complutense de Historia de América, Madri, v. 40, 2014, p. 55-59.

RAMINELLI, Ronald. Élite negra en sociedad esclavista: Recife (Brasil) c. 1654-1744. Nuevo Mundo Mundos Nuevos [Online], Debates, posto online no dia 30 de novembro de 2011, consultado em 30 de maio de 2013. URL: http://nuevomundo.revues.org/62216

RAMINELLI, Ronald. Impedimentos da cor. Mulatos no Brasil e em Portugal, c. 1640-1750. Varia Historia, Belo Horizonte, vol. 28, nº 48, p. 699-723, jun./dez. 2012.

RAMINELLI, Ronald. Nobreza e riqueza no Antigo Regime ibérico setecentista. Revista de História, São Paulo, n. 169, p. 83-110, jul./dez. 2013.

RAMINELLI, Ronald. Privilegios y malogros de la familia Camarão. Nuevo Mundo Mundos Nuevos [Online], Colóquios, posto online no dia 17 de março de 2008. URL: http://nuevomundo.revues.org/27802.

REICHEL, H. J.; GUTFREIND, I. Fronteiras e guerras no Prata. São Paulo: Atual, 1995.

REIS, A. C. Ferreira. A ocupação de Caiena. In: HOLANDA, S. B. de (Dir.). História geral da civilização brasileira. Tomo II, 1. ${ }^{\circ}$ vol. São Paulo: Difusão Européia do Livro, 1962, p. 278 299.

REIS, Déborah Oliveira Martins dos. Cinturão Paulistano: economia e demografia nas vizinhanças da capital de São Paulo (c. 1798 - c.1830). São Paulo: FFLCH/USP, 2013. 
REIS, João José. O jogo duro do Dois de Julho: o "partido negro" na independência da Bahia. In: REIS, João José; SILVA, Eduardo. Negociação e conflito: a resistência negra no Brasil escravista. São Paulo: Companhia das Letras, 1989, p. 79-98.

REVEL, Jacques. Microanálise e construção do social. In. REVEL, J. (Org.). Jogos de escalas: a experiência da microanálise. Rio de Janeiro: Editora FGV, 1998, p. 15-38.

RICARDO, Cassiano. Marcha para Oeste: A Influência da Bandeira na Formação Social e Política do Brasil. Rio de Janeiro: Livraria José Olympio Editora, 1940.

RICCI, Magda Maria de Oliveira. "Nas fronteiras da independência”. Um estudo sobre os significados da liberdade na região de Itu (1779-1822). Dissertação (mestrado em História). Campinas: IFCH, Universidade Estadual de Campinas, 1993.

RODRIGUES, José Washt. Tropas paulistas de outrora. São Paulo: Governo do Estado, 1978.

RODRIGUES, Maria Eugénia. Cipaios da Índia ou soldados da terra? Dilemas da naturalização do exército português em Moçambique no século XVIII. História Questões \& Debates, v. 24, n. 45, p. 57-95, jul./dez. 2006.

RODRIGUES, Vitor Luís Gaspar. A Acção reformadora dos filipes no seio da estrutura militar do Estado da Índia: a persistência do modelo tradicional de organização dos homens de armas (1584-1622). In: Separata das Actas do IX Colóquio «Os militares na sociedade portuguesa». Lisboa: Comissão Portuguesa de História Militar, 1999.

RODRIGUES, Vitor Luís Gaspar; SANTOS, Catarina Madeira. Fazer a guerra nos trópicos: aprendizagens e apropriações. Estado da Índia e Angola, séculos XVI e XVIII. In: PEREIRA, Magnus Roberto de Mello, et al (Eds.). VI Jornada Setecentista: conferências e comunicações. Curitiba: Aos Quatro Ventos, CEDOPE, 2006, p. 57-66.

ROMEIRO, João Marcondes de Moura. De D. João VI à independência. In: Revista do Instituto Histórico e Geográfico Brasileiro. Tomo especial - Primeiro Congresso de História Nacional (7-16 de setembro de 1914). Parte 1. Rio de Janeiro: Imprensa Nacional, 1915, p. 1351-1507.

RUIZ IBÁÑEZ, José Javier. Introducción: las milicias y el Rey de España. In: RUIZ IBÁÑEZ, José Javier (Coord.). Las milicias del Rey de España. Sociedad, política e identidad en las Monarquías Ibéricas. Madrid: Red Columnaria; Fondo de Cultura Económica, 2009, p. 9-21.

RUSSELL-WOOD, A. J. R. Autoridades ambivalentes: o Estado do Brasil e a contribuição africana para a "boa ordem na república". In: SILVA, Maria Beatriz Nizza da (Org.). Brasil: Colonização e Escravidão. Rio de Janeiro: Nova Fronteira, 2000. p. 105-123.

RUSSELL-WOOD, A. J. R. Escravos e libertos no Brasil colonial. Trad. Maria Beatriz de Medina. Rio de Janeiro: Civilização Brasileira, 2005.

SAMARA, Eni de Mesquita. Casamento e papéis familiares em São Paulo no séc. XIX. Cad. Pesq., São Paulo, 37, p. 17-25, maio/1981.

SAMARA, Eni de Mesquita. Lavoura canavieira, trabalho livre e cotidiano. Itu, 1780-1830. São Paulo: EDUSP, 2005.

SANTOS, Amália Cristovão dos. Em obras: os trabalhadores da cidade de São Paulo entre 1775 e 1809. Dissertação (mestrado em Arquitetura e Urbanismo). São Paulo: FAU, Universidade de São Paulo, 2013.

SANTOS, Jocélio Teles. De pardos disfarçados a brancos pouco claros: classificações raciais no Brasil dos séculos XVIII-XIX. Afro-Ásia, 32 (2005), 115-137. 
SCARANO, Julita. Devoção e escravidão: a Irmandade de Nossa Senhora do Rosário dos Pretos no Distrito Diamantino no século XVIII. São Paulo: Comp. Ed. Nacional: Secretaria de Estado da Cultura, Ciência e Tecnologia, 1976.

SCHWARTZ, Stuart B. Brasil colonial: plantaciones y periferias, 1580-1750. In: BETHELL, Leslie (Ed.). Historia de América Latina. (Vol. 3 - América Latina colonial: economía). Barcelona: Editorial Crítica, 1990, p. 229-236.

SCHWARTZ, Stuart B. Segredos internos: engenhos e escravos na sociedade colonial, 15501835. São Paulo: Companhia das Letras, 1988.

SCHWARZ, Roberto. As idéias fora do lugar. Estudos CEBRAP, São Paulo, n. 3, p. 149-161, jan. 1973.

SERNA H., Juan M. de la. Integración e identidad, pardos y morenos en las milicias y cuerpo de lanceros de Veracruz en el siglo XVIII. In: ESCAMILLA, Juan Ortiz (Coord.). Fuerzas militares en Iberoamérica, siglos XVIII y XIX. México: El Colegio de México, Centro de Estudios Historicos; Zamora, Michoacán, México, El Colegio de Michoacán; Veracruz, México: Universidad Veracruzana, 2005. p. 61-74.

SERNA H., Juan M. de la. Periodos, cifras y debates del comercio de esclavos novohispanos, 1540-1820. América Latina en la Historia Económica, vol. 11, n. 1, p. 46-58, jan./jun. 2004.

SILVA FILHO, Geraldo. Oficialato mecânico e escravidão urbana em Minas Gerais no século XVIII. São Paulo: Scortecci, 2008.

SILVA, Ana Rosa Cloclet da. Apropriações do Constitucionalismo nas Minas Gerais (182022). In: BERBEL, Márcia; OLIVEIRA, Cecília Helena de Salles (Orgs.). A experiência constitucional de Cádis: Espanha, Portugal e Brasil. São Paulo: Alameda, 2012, p. 137-166.

SILVA, Fabiano Gomes da. Pedra e cal: os construtores de Vila Rica no século XVIII (17301800). Dissertação (mestrado em História). Belo Horizonte: FFCH, Universidade Federal de Minas Gerais, 2007.

SILVA, Henrique Nelson. Trabalhadores de São José: artesãos do Recife no século XVIII. Dissertação (mestrado em História). Recife: CFCH, Universidade Federal de Pernambuco, 2010.

SILVA, Kalina Vanderlei Paiva da. 'Nas solidões vastas e assustadoras'. Os pobres do açúcar e a conquista do sertão de Pernambuco nos séculos XVII e XVIII. Tese (doutorado em História). Recife: CFCH, Universidade Federal de Pernambuco, 2003.

SILVA, Kalina Vanderlei. Os Henriques nas Vilas Açucareiras do Estado do Brasil: Tropas de Homens Negros em Pernambuco, séculos XVII e XVIII. Estudos de História, Franca, v. 9, n.2, p. 145-194, 2002.

SILVA, Karina da. Os recrutamentos militares e as relações sociedade-Estado na capitania/província de São Paulo (1765-1828). Dissertação (mestrado em História). Franca: FHDSS, Universidade Estadual Paulista, 2006.

SILVA, Luiz Geraldo. Aspirações barrocas e radicalismo ilustrado. Raça e nação em Pernambuco no tempo da independência (1817-1823). In: JANCSÓ, István (Org.). Independência: história e historiografia. São Paulo: Hucitec, 2005, p. 915-934.

SILVA, Luiz Geraldo. Da festa à sedição: sociabilidades, etnia e controle social na América portuguesa (1776-1814). História: Questões \& Debates, Curitiba, n. 30, p. 83-110, 1999.

SILVA, Luiz Geraldo. Da festa barroca à intolerância ilustrada. Irmandades católicas e religiosidade negra na América portuguesa (1750-1815). In: SALLES-REESE, Verónica 
(Org.). Repensando el pasado, recuperando el futuro. Nuevos aportes interdisciplinarios para el estudio de la América colonial. Bogotá: Editorial Pontificia Universidad Javeriana, 2005, p. 270-287.

SILVA, Luiz Geraldo. Gênese das milícias de pardos e pretos na América portuguesa: Pernambuco e Minas Gerais, séculos XVII e XVIII. Revista de História, São Paulo, n. 169, p. 112-144, jul./dez. 2013.

SILVA, Luiz Geraldo. Governos e reinados negros. Conflito, hierarquia e poder entre crioulos e africanos (Pernambuco, 1750-1814). In: Ninth Internacional Congress Brazilian Studies Association (BRASA IX), 2008, New Orleans. New Orleans: Tulane University, 2008. v. 1.

SILVA, Luiz Geraldo. Indivíduo e sociedade. Brás de Brito Souto e o processo de institucionalização das milícias de afrodescendentes livres e libertos na América portuguesa

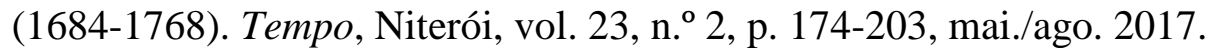

SILVA, Luiz Geraldo. Negros de Cartagena y Pernambuco en la era de las revoluciones atlánticas: trayectorias y estructuras (1750-1840). Anuário Colombiano de Historia Social y de la Cultura, vol. 40, n. ${ }^{\circ}$ 2, p. 211-240, jul./dez. 2013.

SILVA, Luiz Geraldo. Negros patriotas. Raça e identidade social na formação do Estado-nação (Pernambuco, 1770-1830). In: JANCSÓ, István (Org.). Brasil: formação do Estado e da nação. São Paulo: Hucitec; Ijuí: Unijuí, 2003.

SILVA, Luiz Geraldo. O avesso da independência: Pernambuco (1817-24). In: MALERBA, Jurandir (Org.). A independência brasileira: novas dimensões. Rio de Janeiro: Editora FGV, 2006, p. 343-384.

SILVA, Luiz Geraldo. Religião e identidade étnica. Africanos, crioulos e irmandades na América portuguesa. Cahiers des Amériques Latines, v. 44, p. 77-96, 2003.

SILVA, Luiz Geraldo. Sobre a "etnia crioula": o Terço dos Henriques e seus critérios de exclusão na América portuguesa do século XVIII. In: VENÂNCIO, R. P.; GONÇALVES, Andréa L.; CHAVES, Cláudia M. das G. (Orgs.). Administrando impérios. Portugal e Brasil nos séculos XVIII e XIX. Belo Horizonte: Fino Traço, 2012, p. 71-96.

SILVA, Luiz Geraldo; SOUZA, Fernando Prestes de. Negros apoyos. Milicianos afrodescendientes, transición política y cambio de estatus en la era de las independencias (capitanías de São Paulo y Pernambuco, Brasil, 1790-1830). Nuevo Mundo Mundos Nuevos [Online], Debates, posto online no dia 14 Dezembro 2014, consultado em 29 Julho 2017. URL: http://nuevomundo.revues.org/67529; DOI: 10.4000/nuevomundo.67529.

SILVA, Luiz Geraldo; SOUZA, Fernando Prestes de; PAULA, Leandro Francisco de. A guerra luso-castelhana e o recrutamento de pardos e pretos: uma análise comparativa (Minas Gerais, São Paulo e Pernambuco, 1775-1777). In: SANTOS, A. C. de A.; DORÉ, A. (Orgs.). Temas setecentistas: governos e populações no império português. Curitiba: UFPR-SCHLA/Fundação Araucária, 2008, p. 67-83.

SILVA, Maria Beatriz Nizza da (Org.). História de São Paulo colonial. São Paulo: Editora Unesp, 2009.

SILVA, Maria Beatriz Nizza da. Conflitos raciais e sociais na sedição de 1798 na Bahia. In: ARAÚJO, U. C.; TAVARES, L. H. D.; SILVA, M. B. N.; JANCSÓ, I.; MOREL, Marco (Orgs.). II Centenário da Sedição de 1798 na Bahia. Salvador: Academia de Letras da Bahia; Brasília: MINC, 1999.

SILVA, Maria Beatriz Nizza da. Ser nobre na Colônia. São Paulo: Ed. UNESP, 2005. 
SILVEIRA, Marco Antonio. Acumulando forças: luta pela alforria e demandas políticas na capitania de Minas Gerais (1750-1808). Revista de História, n. 158, p. 131-156, 2008.

SILVEIRA, Marco Antonio. Narrativas de contestação. Os Capítulos do crioulo José Inácio Marçal Coutinho (Minas Gerais, 1755-1765). História social, n. 17, p. 285-307, 2009.

SILVEIRA, Marco Antônio. $O$ universo do indistinto. Estado e sociedade nas Minas setecentistas (1735-1808). São Paulo: Editora Hucitec, 1997.

SILVEIRA, Marco Antonio. Soberania e luta social: negros e mestiços libertos na Capitania de Minas Gerais (1709-1763). In: CHAVES, C. M. das G.; SILVEIRA, M. A. (Orgs.). Território, conflito e identidade. Belo Horizonte: Argumentum, 2007.

SIQUEIRA, Mariana Nastari. Entre o signo da mudança e a força da tradição: o conflito entre a Irmandade de S. Crispim e S. Crispiniano dos sapateiros e a Câmara, Rio de Janeiro, c. 1764 - c. 1821. Dissertação (mestrado em História). Seropédica: ICHS, Universidade Federal Rural do Rio de Janeiro, 2011.

SLEMIAN, Andréa. Seriam todos cidadãos? Os impasses na construção da cidadania nos primórdios do constitucionalismo no Brasil (1823-1824). In: JANCSÓ, István (Org.). Independência: história e historiografia. São Paulo: Hucitec, 2005, p. 829-847.

SOARES, Márcio de Souza. Pretos e pardos na fronteira do Império: hierarquias e mobilidade social de libertos na capitania de Goiás (século XVIII). In: IV Seminário de Pesquisa do ESR, 2011, Campos dos Goytacazes, 2011. Anais do IV Seminário de Pesquisa do ESR.

SOARES, Mariza de Carvalho. Devotos da cor: identidade étnica, religiosidade e escravidão no Rio de Janeiro, século XVIII. Rio de Janeiro: Civilização Brasileira, 2000.

SODRÉ, Nelson Werneck. História militar do Brasil. Rio de Janeiro: Civilização Brasileira, 1979.

SOLANO D., Sergio Paolo. Las vías para la inclusión social. Artesanos, raza, Estado y liberalismo en el Caribe colombiano, 1770-1850. Del Caribe, Santiago de Cuba, n. 59, p. 2341, 2013.

SOLANO D., Sergio Paolo; BOLÍVAR, Roicer Flórez. "Artilleros pardos y morenos artistas": artesanos, raza, milicias y reconocimiento social en el Nuevo Reino de Granada, 1770-1812. Historia critica, Bogotá, n. 48, p. 11-37, sep./dic. 2012.

SOUZA, Fernando Prestes de. Milicianos pardos em São Paulo. Cor, identidade e política (1765-1831). Dissertação (mestrado em História). Curitiba: SCHLA, Universidade Federal do Paraná, 2011.

SOUZA, Fernando Prestes de; LIMA, Priscila de. "Que haja paz e quietação": controle social e irmandades negras na América portuguesa, século XVIII. Revista Ágora, Vitória, n. 11, 2010, p. $1-22$.

SOUZA, Iara Lis Carvalho. A adesão das Câmaras e a figura do imperador. Revista Brasileira de História, v. 18, n. 36, p. 367-394, 1998.

SOUZA, J. A. Soares de. O Brasil e o Prata até 1828. In: HOLANDA, S. B. de (Dir.). História geral da civilização brasileira. Tomo II, 1. ํ vol. São Paulo: Difusão Européia do Livro, 1962, p. 300-328.

SOUZA, Laura de Mello e. Desclassificados do ouro: a pobreza mineira no século XVIII. Rio de Janeiro: Edições Graal, 1990. 
SOUZA, Laura de Mello e. O sol e a sombra: política e administração na América portuguesa do século XVIII. São Paulo: Companhia das Letras, 2006.

SOUZA, Priscila de Lima. "Sem que lhes obste a diferença de cor": a habilitação dos pardos na América portuguesa e no Caribe espanhol (c. 1750-1808). Tese (doutorado em História). São Paulo: FFLCH, Universidade de São Paulo, 2017.

SUAREZ, Santiago-Gerardo. Las milicias. Instituciones militares hispanoamericanas. Caracas: Academia Nacional de la Historia, 1984.

TANNENBAUM, Frank. El negro en las Americas: esclavo e ciudadano. (1. a ed. 1944). Buenos Aires: Paidos, 1968.

TAVEIRA, Alfredo Pereira. A defeza de Portugal. Summario histórico (1640-1815). Lisboa: Typ. Da Cooperativa Militar, 1906.

THOMPSON, Edward Palmer. A formação da classe operária. (3 v.). Trad. Denise Bottmann. Rio de Janeiro: Paz e Terra, 1987.

THOMPSON, Edward Palmer. Costumes em comum. São Paulo: Companhia das Letras, 1998.

TILLY, Charles. Coerção, Capital e Estados Europeus (990-1992). Trad. Geraldo Gerson de Souza. São Paulo: Edusp, 1996.

VEIGA, A. Botelho da Costa. Organização militar do Oriente. In: BAIÃO, António; CIDADE, Hernani; MÚRIAS, Manoel. História da expansão portuguesa no mundo. Lisboa: Editorial Ática, 1939, p. 85-92.

VIANA, Larissa. O idioma da mestiçagem: as irmandades de pardos na América portuguesa. Campinas: Editora da UNICAMP, 2007.

VINSON III, Ben. Articular el espacio: el establecimiento militar de gente de color libre en el México colonial de la conquista hasta la independencia. Callaloo, v. 27, n. 1, p. 331-354, 2004.

VINSON III, Ben. Bearing arms for his majesty: the free-colored militia in colonial Mexico. Stanford: Stanford University Press, 2001.

VINSON III, Ben. Los milicianos pardos y la relación estatal durante el siglo XVIII en México. In: ESCAMILLA, Juan Ortiz (Coord.). Fuerzas militares en Iberoamérica, siglos XVIII y XIX. México: El Colegio de México, Centro de Estudios Historicos; Zamora, Michoacán, México, El Colegio de Michoacán; Veracruz, México: Universidad Veracruzana, 2005, p. 47-60.

WERNET, Augustin. O processo de independência em São Paulo. In: MOTA, C. G. (Org.). 1822: Dimensões. São Paulo: Perspectiva, 1975, p. 340-354.

WESTPHALEN, Cecília Maria. A milícia na comarca de Paranaguá e Curitiba: a vila de Nossa Senhora da Luz dos Pinhais. Revista da SBPH, n. 16, p. 31-49, 1999.

WOOD, James A. The burden of citizenship: artisans, elections, and the fuero militar in Santiago de Chile, 1822-1851. The Americas, v. 58, n. 3, p. 443-469, jan./2002.

ZEMELLA, Mafalda. O abastecimento da capitania de Minas Gerais. 2. ${ }^{\text {a }}$ ed. São Paulo: Hucitec/Edusp, 1990. 